\section{Pacific Northwest}

National Laboratory

Operated by Battelle for the

U.S. Department of Energy

\title{
Hanford Site Groundwater Monitoring for Fiscal Year 2006
}

\section{Editors}

\author{
M. J. Hartman \\ L. F. Morasch \\ W. D. Webber
}

March 2007

Prepared for Fluor Hanford, Inc. and the U.S. Department of Energy under Contract DE-AC05-76RL01830 


\title{
DISCLAIMER
}

This report was prepared as an account of work sponsored by an agency of the United States Government. Neither the United States Government nor any agency thereof, nor Battelle Memorial Institute, nor any of their employees, makes any warranty, express or implied, or assumes any legal liability or responsibility for the accuracy, completeness, or usefulness of any information, apparatus, product, or process disclosed, or represents that its use would not infringe privately owned rights. Reference herein to any specific commercial product, process, or service by trade name, trademark, manufacturer, or otherwise does not necessarily constitute or imply its endorsement, recommendation, or favoring by the United States Government or any agency thereof, or Battelle Memorial Institute. The views and

opinions of authors expressed herein do not necessarily state or reflect those of the United States Government or any agency thereof.

\author{
PACIFIC NORTHWEST NATIONAL LABORATORY \\ operated by \\ BATTELLE \\ for the \\ UNITED STATES DEPARTMENT OF ENERGY \\ under Contract DE-AC05-76RL01830
}

Printed in the United States of America

Available to DOE and DOE contractors from the

Office of Scientific and Technical Information,

P.O. Box 62, Oak Ridge, TN 37831-0062;

ph: (865) 576-8401

fax: (865) 576-5728

email: reports@adonis.osti.gov

\author{
Available to the public from the National Technical Information Service, \\ U.S. Department of Commerce, 5285 Port Royal Rd., Springfield, VA 22161 \\ ph: (800) 553-6847 \\ fax: $(703) 605-6900$ \\ email: orders@ntis.fedworld.gov \\ online ordering: http://www.ntis.gov/ordering.htm
}

This document was printed on recycled paper. 


\title{
Hanford Site Groundwater Monitoring for Fiscal Year 2006
}

\section{Editors}

\author{
M. J. Hartman \\ L. F. Morasch \\ W. D. Webber
}

March 2007

Prepared for Fluor Hanford, Inc. and the U.S. Department of Energy by Pacific Northwest National Laboratory under Contract DE-AC05-76RL01830, with contributions from CH2M HILL Hanford, Inc.; Fluor Hanford, Inc.; Vista Engineering Technologies, LLC; and Washington Closure Hanford, LLC

Pacific Northwest National Laboratory Richland, Washington 99352 


\section{Abstract}

This report presents the results of groundwater monitoring for fiscal year (FY) 2006 on the U.S. Department of Energy's (DOE's) Hanford Site in southeast Washington. Results of groundwater remediation and vadose zone studies are summarized.

Contaminant plumes occupy an area of $\sim 200$ square kilometers at levels exceeding one or more drinking water standards, compared to the total area (1,517 square kilometers) of the Hanford Site. The most extensive contaminant plumes in groundwater are tritium, iodine-129, and nitrate. These contaminants originated from multiple sources and are very mobile in groundwater. The largest portions of these plumes are migrating from the central Hanford Site to the southeast, toward the Columbia River, and concentrations generally are declining. Carbon tetrachloride and associated organic constituents form a relatively large plume beneath the west-central part of the Hanford Site. Hexavalent chromium is present in plumes beneath the reactor areas along the river and beneath the central part of the site. Strontium- 90 concentrations exceed drinking water standards beneath portions of all but one of the reactor areas. Technetium-99 and uranium plumes exceeding standards are present in the 200 Areas. A uranium plume exceeding standards also underlies part of the 300 Area. Small contaminant plumes with concentrations greater than standards include carbon-14, cesium-137, cis-1,2-dichloroethene, cyanide, fluoride, plutonium, and trichloroethene.

Levels of some contaminants exceed drinking water standards in water samples collected from aquifer sampling tubes along the river shore. The most significant exceedances were strontium-90 in the 100-N Area, chromium in the 100-D Area, and uranium in the 300 Area. Uranium also exceeded the drinking water standard in a riverbank spring in the 300 Area. Tritium exceeded the drinking water standard in a spring at the former Hanford town site.

Monitoring for the Comprehensive Environmental Response, Compensation, and Liability Act (CERCLA) is conducted in 11 groundwater operable units. The purpose of this monitoring is to define and track plumes and to monitor the effectiveness of interim remedial actions. Interim groundwater remediation in the $100-\mathrm{K}, 100-\mathrm{D}$, and $100-\mathrm{H}$ Areas, using a combination of pump-and-treat and in situ methods, continued to reduce the amount of chromium reaching the Columbia River. A pump-and-treat system for strontium-90 in the 100-N Area was put on standby in FY 2006, while an alternative, in situ remediation method is tested. A pumpand-treat system and a soil-gas extraction system in the northern half of the 200 West Area continued to be used to decrease the spread of the carbon tetrachloride plume. A rebound study was conducted in FY 2006 at the site of a former pump-and-treat system for technetium-99 and uranium in the south part of the 200 West Area. Concentrations remained below remedial action goals in FY 2006.

Resource Conservation and Recovery Act (RCRA) groundwater monitoring continued at 25 waste management areas during FY 2006:

- 15 under interim or final status detection programs, with the objective of determining whether or not they are adversely affecting groundwater

- 8 under interim status groundwater quality assessment programs to assess contamination

- 2 under final status corrective-action programs

During calendar year 2006, drillers completed 62 new wells for monitoring, remediation, or characterization. Eighty-two unneeded wells were decommissioned (filled with grout).

This report is available on the Internet through the Hanford Groundwater Performance Assessment Project (http://groundwater.pnl.gov/) and the Hanford Site Groundwater Remediation Project (http://www.hanford.gov/cp/gpp). Inquiries regarding this report may be directed to Ms. Mary J. Hartman, Pacific Northwest National Laboratory, P.O. Box 999, Richland, Washington 99352 or by electronic mail to mary.hartman@pnl.gov. 


\section{Acknowledgements}

This report represents the efforts of dozens of individuals who contribute to the Groundwater Performance Assessment Project: planners, schedulers, samplers, laboratory technicians, data management staff, site scientists, editors, text processors, and staff in graphics and duplicating.

John Fruchter and Stuart Luttrell manage the Groundwater Performance Assessment Project and the Groundwater Monitoring Task, respectively. Dot Stewart manages the monumental tasks of sampling and analysis, quality control, and data management.

Most of the graphics for this report were generated by Mickie Chamness and Chris Newbill, who put in many hours to meet our tight schedule. John McDonald, David Lanigan, and Shannon Neely also assisted with graphics. JoAnne Rieger retrieved and formatted data for maps and tables.

Thanks to Marcel Bergeron for providing a peer review and to many other reviewers whose comments and suggestions helped us improve this report. As usual, our team of editors and text processors worked tirelessly to produce a clear, polished document in a format that works in paper or electronic form. Thanks to Kathy Neiderhiser for her tremendous dedication, efficiency, and attention to detail.

Mary Hartman

Launa Morasch

Bill Webber 


\section{Report Contributors}

The production of the Hanford Site Groundwater Monitoring for Fiscal Year 2006 requires the knowledge, skill, expertise, and cooperation of many people and several organizations. The contributions and cooperation, often under demanding time constraints, of the following authors are gratefully acknowledged. The authors' names are listed on their respective sections of the report.

CH2M HILL Hanford, Inc.

D. A. Myers

Fluor Hanford, Inc.
B. J. Dixon
R. O. Mahood
V. J. Rohay
D. B. Erb
R. McCain
A. F. Shattuck
R. J. Fabre
B. B. Nelson-Maki
G. S. Thomas
G. G. Kelty
R. F. Raidl

Vista Engineering Technologies, LLC

W. Bratton K. Moser

\section{Washington Closure Hanford, LLC}
D. A. St. John
R. L. Weiss

Pacific Northwest National Laboratory
D. B. Barnett
S. M. Narbutovskih
M. D. Sweeney
M. A. Chamness
C. A. Newbill
C. J. Thompson
C. J. Chou
D. R. Newcomer
E. C. Thornton
P. E. Dresel
M. Oostrom
M. M. Valenta
M. J. Fayer
R. E. Peterson
A. L. Ward
H. Hampt
J. T. Rieger
M. D. White
D. G. Horton
R. J. Serne
B. A. Williams
J. M. Keller
D. S. Sklarew
Z. F. Zhang
J. W. Lindberg
R. M. Smith
J. P. McDonald
D. L. Stewart 


\section{Summary}

\section{Introduction}

The Hanford Site, a facility in the U.S. Department of Energy (DOE) nuclear weapons complex, encompasses $~ 1,517$ square kilometers northwest of the city of Richland along the Columbia River in southeast Washington State. The federal government acquired the site in 1943, and until the 1980s, it was dedicated primarily to the production of plutonium for national defense. Management of waste associated with plutonium production has been a major activity throughout Hanford's history and continues today at a much reduced scale. Beginning in the 1990s, DOE has focused on cleaning up the site.

DOE is committed to protecting the Columbia River from being impacted by contaminated groundwater and returning groundwater to its beneficial use where practicable. The Hanford Site Groundwater Strategy, developed collaboratively by DOE, the Washington State Department of Ecology (Ecology), and the U.S. Environmental Protection Agency (EPA),

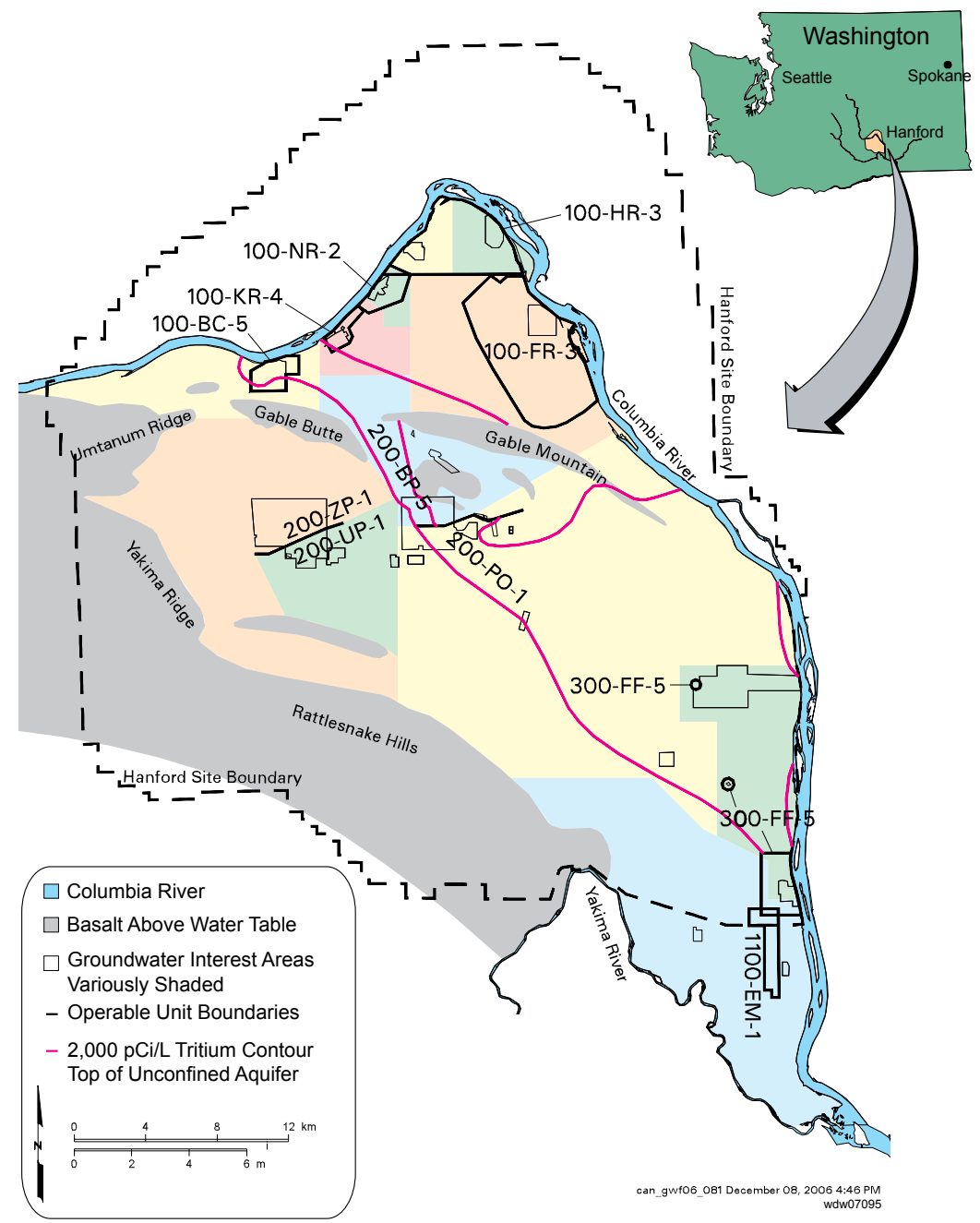

Hanford Site groundwater monitoring is organized by areas of interest, which are informally named after the groundwater operable units. The areas of interest are useful for planning and scheduling groundwater monitoring and interpreting data.
The Hanford Site

Groundwater

Strategy focuses

on three key areas:

groundwater

protection,

groundwater

monitoring, and

remediation of

contaminated

groundwater. 


\section{DOE sampled}

778 wells

during FY 2006.

Chromium, nitrate,

and tritium are

constituents

most frequently

analyzed. presents a means for multiple regulatory authorities and government agencies to protect and restore groundwater at the Hanford Site. The strategy focuses on three key areas: groundwater protection, groundwater monitoring, and remediation of contaminated groundwater.

DOE monitors groundwater at the Hanford Site to fulfill a variety of state and federal regulations, including the Atomic Energy Act (AEA), the Resource Conservation and Recovery Act (RCRA), the Comprehensive Environmental Response, Compensation, and Liability Act (CERCLA), and Washington Administrative Code (WAC).

The groundwater monitoring requirements for Hanford's RCRA units fall into one of two categories: interim status or final status. A permitted RCRA unit requires final status groundwater monitoring as specified in WAC 173-303-645. RCRA units that have not yet been incorporated into permits require interim-status groundwater monitoring as specified in WAC 173-303-400, which invokes 40 CFR 265.

RCRA groundwater monitoring is conducted under one of three possible phases:

- Indicator Parameter (or final status detection). Initially, a detection program is developed using groundwater monitoring data collected from the facility network wells to determine and monitor the impact, if any, of facility operations on the groundwater.

- Assessment (or final status compliance). If the detection monitoring results indicate a statistically significant increase in the concentration of dangerous waste constituents or chemical parameters in the groundwater beneath the regulated units, then an assessment or compliance phase of monitoring and investigation is initiated.

- Corrective Action (via administrative order for interim status sites or during final status). If the source of the contamination is determined to be the RCRA unit and the concentration exceeds the concentration limits as defined in the monitoring plan or permit, then Ecology may require a groundwater monitoring corrective action program to determine the effectiveness of the corrective action to reduce the contaminant hazards to the public and environment.

Some contaminants reached the Columbia River by moving downward from waste sites, primarily liquid discharge sites, through the vadose zone, into the groundwater, and then

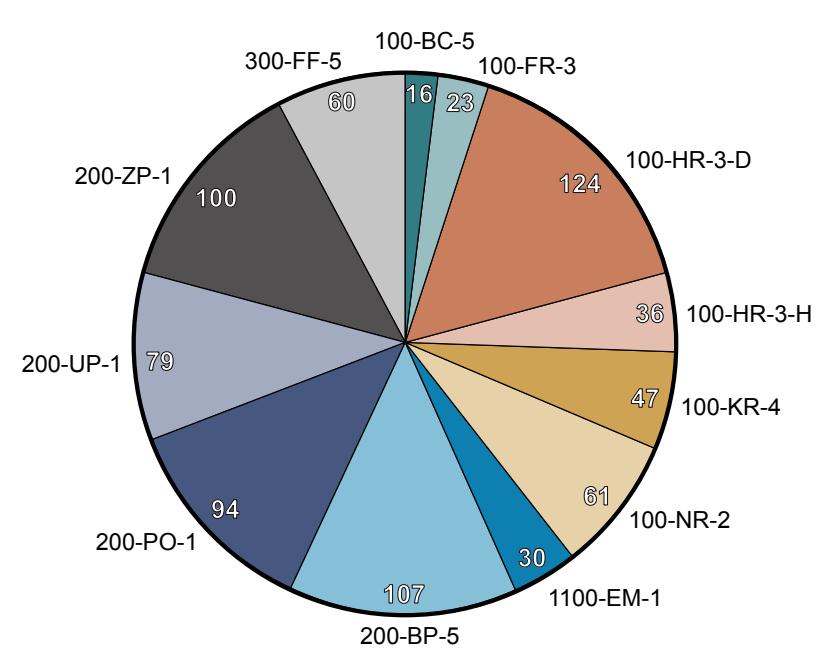

sbn07001

This chart shows the number of wells sampled in each groundwater interest area in FY 2006.

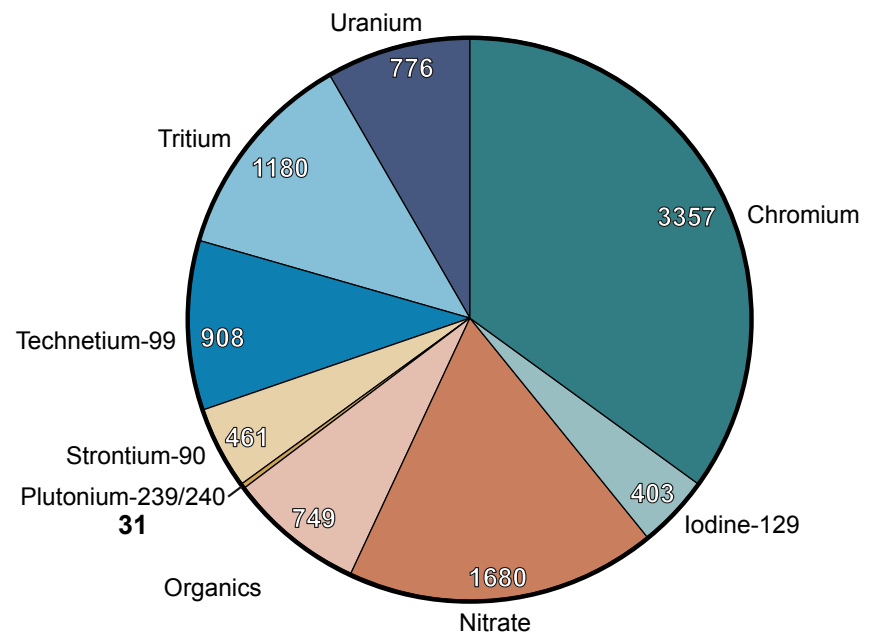

sbn07002

The groundwater project requests specific laboratory analyses based on the well's location, historical contaminant trends, and regulatory requirements. This graph shows the number of analyses for the most common constituents during FY 2006. 
into the river. The analysis of groundwater samples provides data that help characterize the nature, potential fate, and transport of contaminants in the environment. DOE works with regulatory agencies such as the EPA and Ecology to make cleanup decisions based on sound technical information and the technical capabilities available.

In fiscal year (FY) 2006, workers sampled 778 monitoring wells and 247 shoreline aquifer tubes to determine the distribution and movement of contaminants. This was an increase from the previous fiscal year of more than 100 wells and 75 aquifer tubes. Many of the wells were sampled multiple times during the year for a total of 1,919 sampling trips.

A total of 3,357 samples of Hanford groundwater were analyzed for chromium, 1,680 for nitrate, and 1,180 for tritium. Other constituents frequently analyzed include technetium-99 (908), uranium (776), and carbon tetrachloride (749). These totals include results for routinely sampled groundwater wells, pump-and-treat operational samples, and aquifer tube samples.

\section{Emerging Items of Interest}

This section briefly describes some of the high-priority groundwater topics for FY 2006. The groundwater chapter of the full report contains additional details.

KW Reactor Chromium Plume. In 1998, chromium concentrations in groundwater near the KW Reactor began to rise. Design and construction of a new pump-and-treat system to remediate this chromium plume began during FY 2006. Four new wells were installed, and two existing wells will be incorporated into the network. New well 199-K-137 had chromium concentrations over 2,000 $\mathrm{gg} / \mathrm{L}$ in early FY 2007. The pump-and-treat system will begin to operate in FY 2007.

100-N Pump-and-Treat Alternatives. The 100-N Area pump-and-treat system was placed on standby (pumps shut off) in March 2006 and an alternative remediation method is being tested. Apatite-forming chemicals were injected into two wells along the $100-\mathrm{N}$ shoreline (one in June and the other in September 2006), and the concentrations of strontium-90 and other parameters are being monitored around the injection sites. DOE plans to install a 90-meter apatite barrier in FY 2007.

100-H Area Pump-and-Treat. Concentrations of hexavalent chromium in 100-H Area groundwater have declined since 1997 when a pump-and-treat system was initiated as an interim action. The decline, due to remediation and natural processes, continued in FY 2006. In September 2006, concentrations in compliance wells were all below the remedial action goal of $22 \mu \mathrm{g} / \mathrm{L}$.

Vertical Distribution of Carbon Tetrachloride in 200 West Area. In recent years, depth-discrete sampling in existing wells, and sampling during drilling of new wells, have provided new information on how carbon tetrachloride concentrations change with depth in the unconfined aquifer. The results of a new study in FY 2006 created a conceptual model of the plume geometry. The extent of carbon tetrachloride contamination deeper in the aquifer indicates that a significantly greater mass of carbon tetrachloride is present in the unconfined aquifer than previously calculated.

Technetium-99 at Waste Management Area T. Technetium-99 concentrations in wells east of Waste Management Area T, in the 200 West Area, continued to increase. The highest concentrations in the technetium-99 plume downgradient of the south part of the waste management area are near the water table, while the highest concentrations downgradient of the north part are at about 10 meters below the water table.

Trichloroethene in 300-FF-5 Operable Unit. During the limited field investigation in the 300 Area, volatile organic compounds were found in water samples collected during the drilling of four characterization boreholes. Samples collected from a relatively fine-grained

\section{The analysis of groundwater samples provides data that help characterize the nature, potential fate, and transport of contaminants in the environment.}

DOE continued to study strontium-90 sequestration by apatite. Field tests were initiated in FY 2006. 
unit within the upper portion of the Ringold Formation at a depth other than typical screened intervals unexpectedly detected some high concentrations of trichloroethene.

CERCLA Five-Year Review. The second 5-year review of records of decision for remedial actions under CERCLA underwent public review in FY 2006 and a revised document was published in early FY 2007. DOE conducted the review in coordination with the EPA, which is responsible for certifying the review. More information on the 5-year review is available at: www.hanford.gov, "CERCLA Five-Year Review." The purpose of the review is to evaluate the implementation and performance of the remedies in order to determine if they are protective of human health and the environment.

\begin{tabular}{|c|c|}
\hline \multicolumn{2}{|r|}{ CERCLA 2006 Five-Year Review Conclusions Regarding Groundwater } \\
\hline \multirow[b]{2}{*}{100 Areas } & Most of the groundwater interim actions are meeting remedial action objectives. \\
\hline & $\begin{array}{l}\text { The interim action for the } 100-\mathrm{N} \text { strontium- } 90 \text { plume is not meeting objectives and an } \\
\text { alternative technology is being tested. }\end{array}$ \\
\hline \multirow{3}{*}{200 Areas } & $\begin{array}{l}\text { The } 200-\mathrm{ZP}-1 \text { interim action is being expanded to address additional portions of the carbon } \\
\text { tetrachloride plume. }\end{array}$ \\
\hline & The vapor extraction system has proven to be effective and will continue operation. \\
\hline & The $200-U P-1$ interim action has met remedial action objectives. \\
\hline 300 Area & $\begin{array}{l}\text { Monitored natural attenuation of uranium has not achieved remedial action objectives and } \\
\text { additional treatability studies are underway. }\end{array}$ \\
\hline 1100 Area & $\begin{array}{l}\text { The final remedies selected for this area met the remedial action objectives and the remedy } \\
\text { remains protective. }\end{array}$ \\
\hline
\end{tabular}

\section{Hanford} groundwater flows into the Columbia River, which is used for recreation, drinking water, agriculture, and wildlife habitat. Therefore, DOE is focusing remediation efforts on activities
that protect the
Columbia River.

EM-22 Technology Proposals. In FY 2006, the U.S. Congress authorized 10 million dollars for "...analyzing contaminant migration to the Columbia River, and for the introduction of new technology approaches to solving contamination migration issues." These funds will be administered through DOE's Office of Environmental Management (EM-22). It is anticipated that these funds will be spent in FY 2006, 2007, and part of FY 2008. Nine proposals have been funded after addressing comments from a peer review panel. The funded proposals include

- Five pertaining to hexavalent chromium in 100-K and 100-D Areas

- Two pertaining to strontium-90 in 100-N Area

- One pertaining to carbon tetrachloride in 200 West Area

- One pertaining to uranium in the 300 Area

Nine additional proposals are being considered for funding. More information on the EM-22 proposals is available at www.hanford.gov/cp/gpp/science/em21.cfm.

\section{Groundwater Flow}

Groundwater in the unconfined aquifer generally flows from west to east across the Hanford Site to discharge areas north and east along the Columbia River. The direction of groundwater flow is inferred from water-table elevations, barriers to flow (e.g., basalt or mud units at the water table), and the distribution of contaminants.

General directions of groundwater flow are illustrated on the water-table map for April 2006. Groundwater enters the unconfined aquifer from recharge areas to the west and eventually discharges to the Columbia River. Additional water infiltrates through the vadose zone beneath the Hanford Site. Hydrologists estimate that the total discharge of groundwater from the Hanford Site aquifer to the Columbia River is in the range 1.1 to 2.5 cubic 
meters/second. This rate of discharge is very small compared to the average flow of the river, $\sim 3,400$ cubic meters/second.

In the part of the site north of Gable Mountain and Gable Butte, unconfined groundwater flows generally toward the river. The water table beneath the 200 East Area is relatively flat because of the presence of highly permeable sediment of the Hanford formation at the water table. Groundwater enters the vicinity of the 200 East Area from the west and divides, with some migrating to the north through Gable Gap and some moving southeast toward the central part of the site. In the south part of the Hanford Site, groundwater converges on the 300 Area from the northwest, west, and southwest.

The natural pattern of groundwater flow was altered during the Hanford Site's operating years by water-table mounds. The mounds were created by the discharge of large volumes of wastewater to the ground and were present in each reactor area and beneath the 200 Areas. Since effluent disposal decreased significantly in the 1990s, these mounds have dissipated in the reactor areas and have declined considerably in the 200 Areas. Currently, wastewater is discharged to the ground at the StateApproved Land Disposal Site, north of the 200 West Area, affecting groundwater flow locally.

Groundwater flow in the unconfined aquifer is currently altered where extraction or injection wells are used for pumpand-treat systems. Extraction wells in the 100-K, 100-D, $100-\mathrm{H}$, and 200 West Areas capture contaminated water from the surrounding areas. Water flows away from injection wells, which are located upgradient of the contaminant plumes so the injection increases the hydraulic gradient toward the extraction wells.

A confined aquifer occurs within sand and gravel of the lowest sedimentary unit of the Ringold Formation. It is confined below by basalt and above by the lower mud unit. East of the 200 East Area there is no unconfined aquifer, and groundwater in the Ringold confined aquifer is still influenced by a residual recharge mound.

\section{Groundwater Monitoring and Remediation}

DOE has developed a plan to clean up Hanford's groundwater, which will return it to its beneficial use where practicable or will at least prevent further degradation. Under the plan DOE will (a) remediate high-risk waste sites, (b) shrink the contaminated area, (c) reduce natural and artificial recharge, (d) remediate groundwater, and (e) monitor groundwater. The maps on the following pages show the distribution of nine principal groundwater contaminant plumes.

Of the radionuclide plumes, tritium and iodine-129 have the largest areas with concentrations above drinking water standards. The dominant plumes had sources in the 200 East Area and extend toward the east and southeast. Less extensive tritium and iodine-129 plumes are also present in 200 West Area. Technetium-99 exceeds standards in plumes within both the 200 East and 200 West Areas. One technetium-99 plume has moved northward from the 200 East Area. Uranium is less mobile than tritium, iodine-129, or technetium-99; plumes containing uranium are found in the 200 East, 200 West, and 300 Areas. Strontium-90 exceeds standards in the 100 Areas, the 200 East Area, and beneath the former Gable Mountain Pond. Cesium-137, cobalt-60, and plutonium exceed drinking water standards in only a few wells in the 200 East Area.
DOE's cleanup plan includes the following elements: (a) remediate highrisk waste sites,

(b) shrink the contaminated area, (c) reduce recharge, (d) remediate groundwater, and (e) monitor groundwater. 


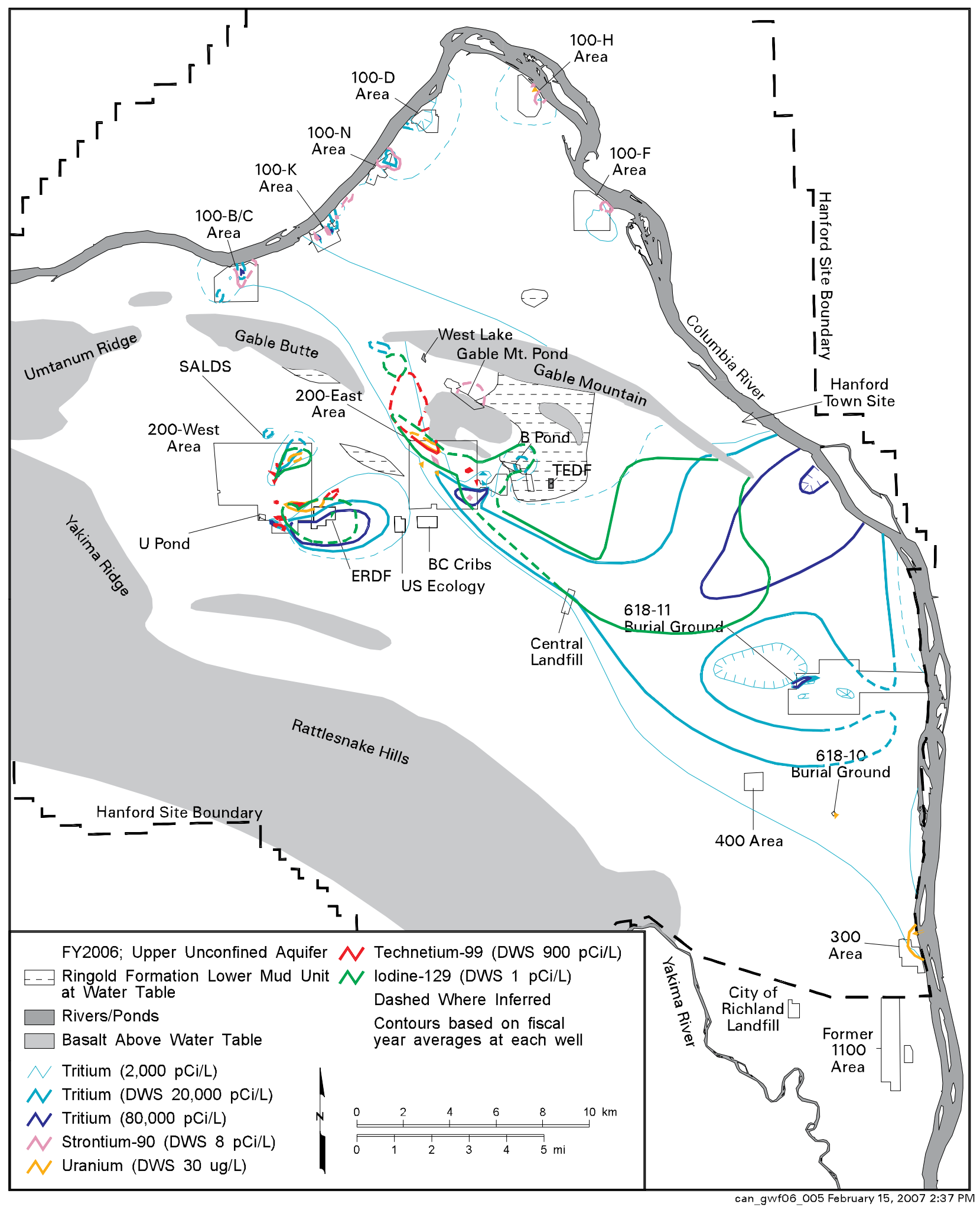

This map shows the distribution of radionuclides in groundwater at concentrations above drinking water standards during FY 2006 in the upper part of the unconfined aquifer. 


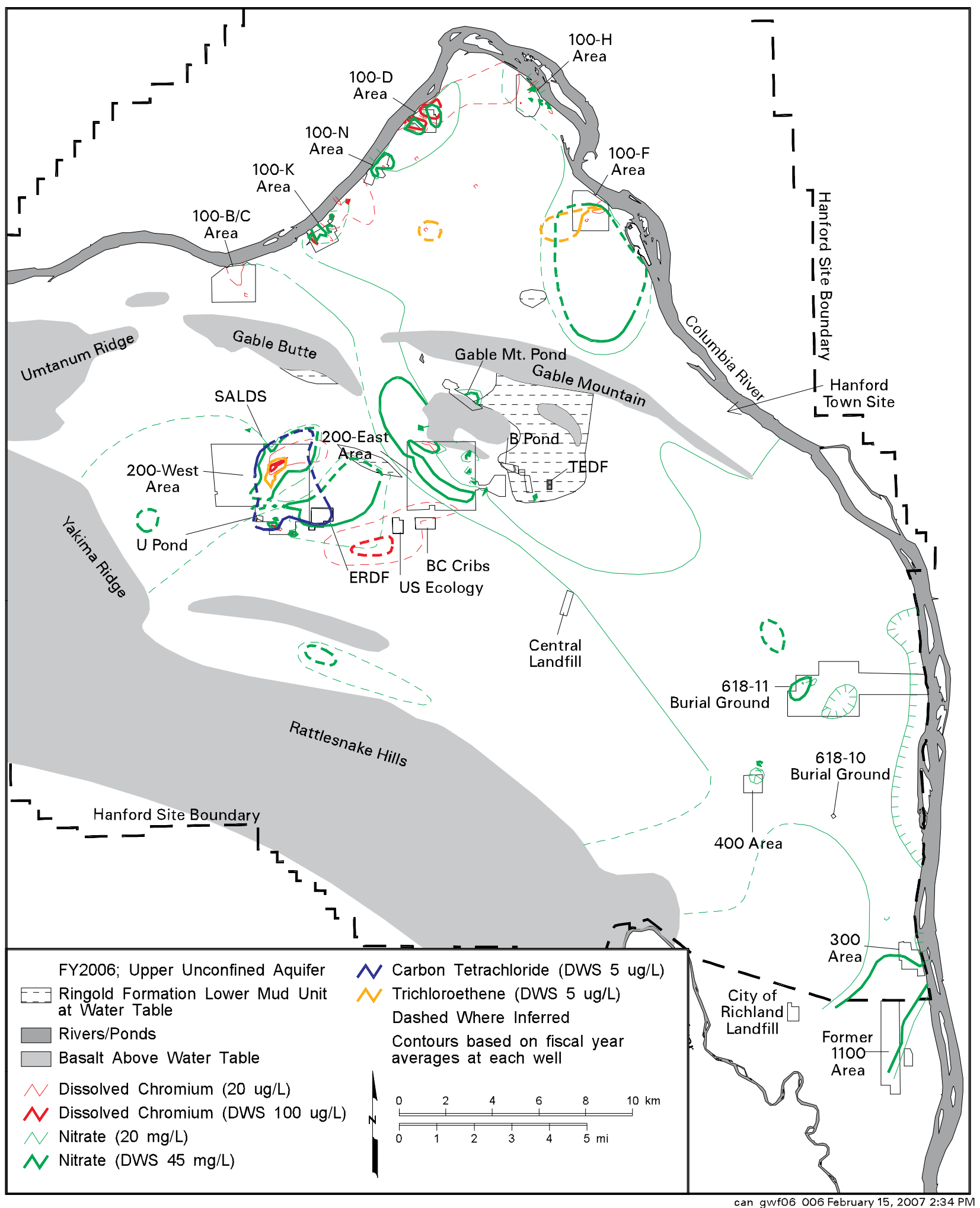

This map shows the distribution of hazardous chemicals in groundwater at concentrations above drinking water standards during FY 2006 in the upper part of the unconfined aquifer. 


\begin{tabular}{|c|c|c|}
\hline \multicolumn{3}{|c|}{ Groundwater Remediation } \\
\hline Remedial Action Site & Startup Date & Progress From Startup to September 2006 \\
\hline 100-K Area - 100-KR-4 Pump-and-Treat & 1997 & Decreases chromium to river; 291 kilograms removed. \\
\hline 100-N Area - 100-NR-2 Pump-and-Treat & 1995 & $\begin{array}{l}1.8 \text { curies of strontium-90 removed. Extraction ceased March } \\
\text { 2006. Testing alternative remediation methods. }\end{array}$ \\
\hline 100-D Area - 100-HR-3 Pump-and-Treat & 1997 & Decreases chromium to river; 243 kilograms removed. \\
\hline 100-D Area - DR-5 Pump-and-Treat & 2004 & Decreases chromium to river; 105 kilograms removed. \\
\hline 100-D Area - 100-HR-3 In Situ Redox & 1999 & Decreases chromium concentrations downgradient of barrier. \\
\hline 100-H Area - 100-HR-3 Pump-and-Treat & 1997 & Decreases chromium to river; 47 kilograms removed. \\
\hline 200 West Area - 200-ZP-1 Pump-and-Treat & 1994 & $\begin{array}{l}\text { Prevents high-concentration portion of carbon tetrachloride } \\
\text { plume from spreading; } 10,197 \text { kilograms removed. }\end{array}$ \\
\hline 200 West Area - Soil-Vapor Extraction & 1992 & $\begin{array}{l}\text { Reduces carbon tetrachloride movement to groundwater; } \\
78,900 \text { kilograms removed. }\end{array}$ \\
\hline 200 West Area - 200-UP-1 Pump-and-Treat & 1994 & $\begin{array}{l}\text { Decreases lateral migration of contaminants; } 119 \text { grams } \\
\text { technetium-99 ( } 2.02 \text { curies) and } 212 \text { kilograms uranium } \\
\text { removed through January 2005. No extraction FY } 2006 .\end{array}$ \\
\hline $\begin{array}{l}\text { Waste Management Area S-SX- } \\
\text { Well 299-W23-19 Pump-and-Treat }\end{array}$ & 2003 & $\begin{array}{l}\text { Decreased technetium- } 99 \text { concentrations; } 0.27 \text { grams } \\
(0.0046 \text { curie }) \text { of technetium- } 99 \text { removed. }\end{array}$ \\
\hline 300 Area - 300-FF-5 Natural Attenuation & Not applicable & $\begin{array}{l}\text { Average trichloroethene concentrations below target level in } \\
\text { wells; uranium concentrations above target level. }\end{array}$ \\
\hline 1100-EM-1 - Natural Attenuation & Not applicable & $\begin{array}{l}\text { Average trichloroethene concentrations below } 5 \mu \mathrm{g} / \mathrm{L} \text { since } \\
2001 \text {. }\end{array}$ \\
\hline
\end{tabular}

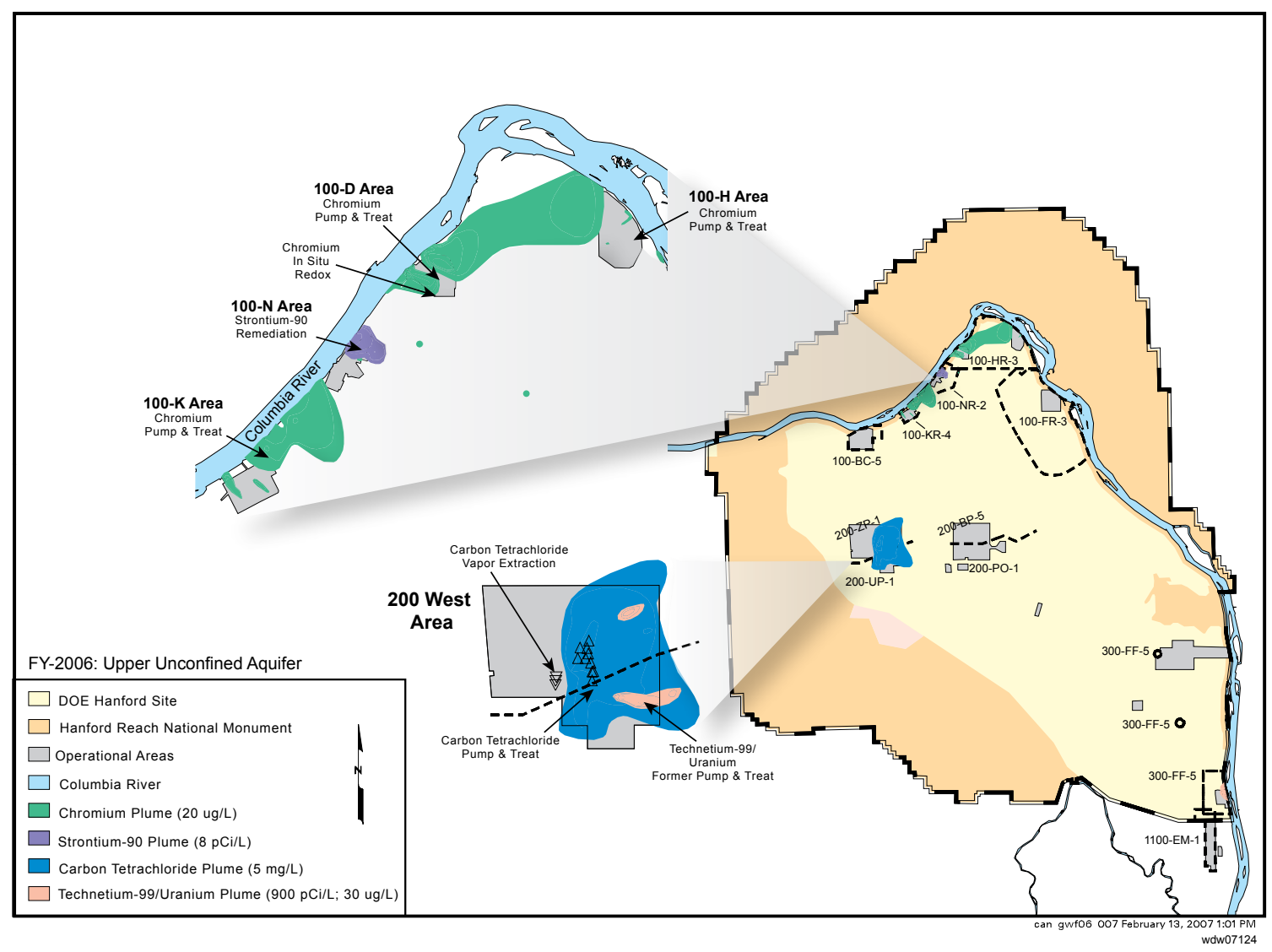

DOE operates groundwater and vadose zone remediation systems to remove contaminants and limit their movement in groundwater and the vadose zone. 
Nitrate is a widespread chemical contaminant in Hanford Site groundwater; plumes originate from the 100 and 200 Areas and from offsite industry and agriculture. Carbon tetrachloride, the most widespread organic contaminant on the Hanford Site, forms a large plume beneath the 200 West Area. Other organic contaminants include chloroform, found in 200 West Area, and trichloroethene. Trichloroethene plumes that exceed the drinking water standard are found in the 100-K, 100-F, and 200 West Areas. New wells in the 300 Area detected trichloroethene at levels above the drinking water standard at depth in the aquifer. Chromium at levels above the $100-\mu \mathrm{g} / \mathrm{L}$ drinking water standard underlies portions of the $100-\mathrm{K}$ and $100-\mathrm{D}$ Areas. Chromium exceeds the state's aquatic standard $(10 \mu \mathrm{g} / \mathrm{L})$ in these areas and portions of the $100-\mathrm{B} / \mathrm{C}, 100-\mathrm{H}$, and 100-F Areas. Local plumes of chromium contamination also are present in the 200 Areas, particularly the north part of 200 West Area.

The following text discusses groundwater contamination, monitoring, and remediation for each of the 11 groundwater operable units and in the confined aquifers.

\begin{tabular}{|c|c|c|c|}
\hline \multicolumn{4}{|c|}{$\begin{array}{l}\text { Area of Contaminant Plumes at Levels Above Drinking Water } \\
\text { Standards (square kilometers) }\end{array}$} \\
\hline $\begin{array}{l}\text { Constituent } \\
\text { (drinking water standard) }\end{array}$ & $\begin{array}{l}\text { Fiscal Year } \\
\quad 2000\end{array}$ & $\begin{array}{l}\text { Fiscal Year } \\
\quad 2005\end{array}$ & $\begin{array}{l}\text { Fiscal Year } \\
\quad 2006\end{array}$ \\
\hline Carbon tetrachloride $(5 \mu \mathrm{g} / \mathrm{L})$ & 9.8 & 10.8 & 9.8 \\
\hline Chromium (100 $\mu \mathrm{g} / \mathrm{L})$ & 2.8 & 2.0 & 2.0 \\
\hline lodine-129 (1 pCi/L) & 89.7 & 75.4 & 67.0 \\
\hline Nitrate (45 mg/L) & 36.3 & 43.3 & $40.0^{(\mathrm{a})}$ \\
\hline Strontium-90 (8 pCi/L) & 2.8 & 2.4 & 2.4 \\
\hline Technetium-99 (900 pCi/L) & 2.3 & 2.5 & $3.9^{(b)}$ \\
\hline Trichloroethene (5 $\mu \mathrm{g} / \mathrm{L})$ & 4.2 & 3.8 & 3.0 \\
\hline Tritium $(20,000$ pCi/L) & 176 & 135.5 & 121.2 \\
\hline Uranium $(20 / 30 \mu \mathrm{g} / \mathrm{L})^{(\mathrm{c})}$ & 2.0 & 1.4 & 1.6 \\
\hline Combined Plumes $^{(0)}$ & 232 & 199 & $186^{(a)}$ \\
\hline \multicolumn{4}{|c|}{$\begin{array}{l}\text { (a) Excludes } 1100-E M-1 \text { plume from offsite sources. } \\
\text { (b) Increase is the result of changing interpretation of plume size in } 200-B P-5 \\
\text { interest area due to data from a new well. } \\
\text { (c) Area of uranium plume based on } 20 \mu \mathrm{g} / \mathrm{L} \text { standard in } 2000 \text { and } 30 \mu \mathrm{g} / \mathrm{L} \\
\text { standard in subsequent years. } \\
\text { (d) Area with one or more constituent above drinking water standards. }\end{array}$} \\
\hline
\end{tabular}

\section{0-BC-5 Operable Unit}

A complete discussion of the 100-BC-5 Operable Unit can be found in Section 2.2. This operable unit includes the groundwater beneath the 100-B/C Area, located in the northwest Hanford Site. Most of the groundwater contamination is found in the north portion of the area, beneath former waste trenches and retention basins. Tritium and strontium-90 exceeded drinking water standards in several wells. Tritium concentrations in two wells in the northeast $100-\mathrm{B} / \mathrm{C}$ Area spiked in recent years, but the reason for the variability is not known. Tritium also exceeds the drinking water standard in a well near a burial ground where tritium was recently found at elevated levels in the vadose zone. Nitrate and chromium continued to be below drinking water standards in recent years in the $100-\mathrm{B} / \mathrm{C}$ Area, but chromium exceeds the $10-\mu \mathrm{g} / \mathrm{L}$ aquatic standard.

A record of decision has not yet been developed for the 100-BC-5 Operable Unit, and no active remediation of groundwater is underway. Monitoring contaminant conditions has continued since the initial remedial investigation and while waste site remedial actions are being conducted. Draft B of a pilot project risk assessment were published in FY 2006, which will serve as a prototype for risk assessments in the other reactor areas. The pilot risk assessment characterized the potential risks to human health and the environment under the cleanup standards implemented in remedial actions performed to date.

\section{0-KR-4 Operable Unit}

A complete discussion of the 100-KR-4 Operable Unit can be found in Section 2.3. The principal groundwater issues in this operable unit include (a) remediation of chromiumcontaminated groundwater; (b) tracking plumes from past-practices sites; and (c) monitoring groundwater near the KE and KW Basins. Interim remedial action involves a pump-and-treat system that removes chromium from groundwater and injects the treated water upgradient of the plume.

\section{Tritium levels are variable in two wells in the northeast 100-B/C} Area. 

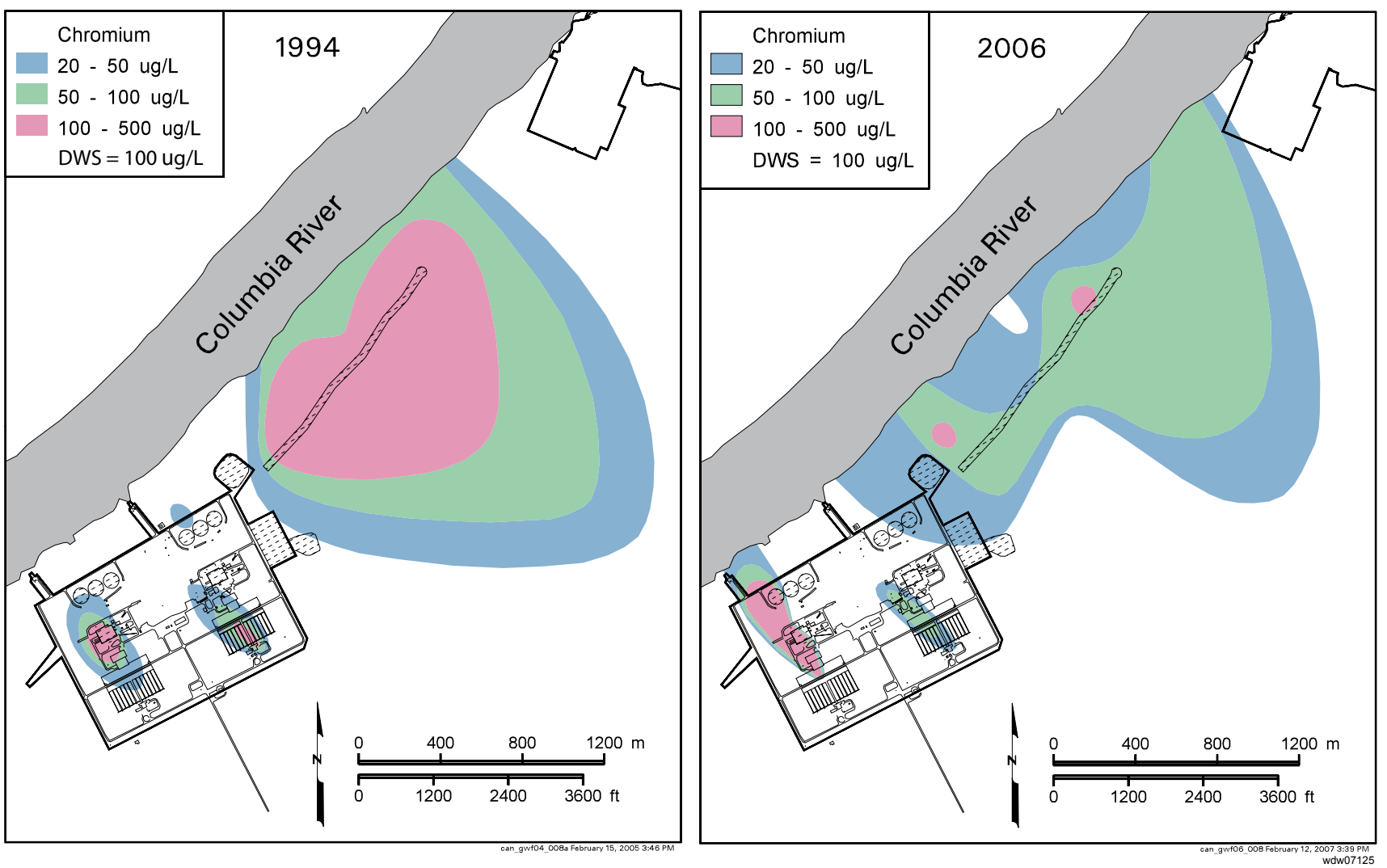

These maps show chromium in the upper part of the unconfined aquifer in the 100-K Area. A pump-and-treat system reduces the amount of chromium entering the Columbia River. Concentrations decreased in most areas since 1994.

The 100-K Area

pump-and-treat

system is being

expanded.
Interim Remedial Action. A pump-and-treat system is being used to remove hexavalent chromium from the aquifer beneath the 116-K-2 infiltration trench. Approximately 291 kilograms of chromium have been removed since startup in 1997. Although the mapped extent of contamination has remained fairly constant during the past 10 years, the area of highest concentrations $(>100 \mu \mathrm{g} / \mathrm{L})$ has decreased markedly. The concentration goal for the interim remedial action is $22 \mu \mathrm{g} / \mathrm{L}$ in groundwater near the Columbia River.

In 1998, chromium concentrations in groundwater near the KW Reactor began to rise. Although an exact source for this chromium has not been identified, it is most likely related to past sodium dichromate handling. In FY 2006, chromium concentrations continued to increase in a well between the reactor building and the river. Four extraction wells were installed for use in a new pump-and-treat system that is planned to begin operating in FY 2007.

The four wells installed in 2005 northeast of the 100-K Area to perform a treatability test using calcium polysulfide were sampled monthly throughout FY 2006. This test evaluated the practicality of treating chromium in the groundwater as an alternative to pump-andtreat systems. During the test, hexavalent chromium concentrations dropped to levels near to or below detection limits in the wells used to monitor the effectiveness and longevity of the treatment.

Monitoring Past-Practice Waste Sites. Other contaminants of potential concern in the operable unit are carbon-14, nitrate, strontium-90, trichloroethene, and tritium. These contaminants are associated with waste disposal and facility operations that occurred during the reactor operating years (1955 to 1971). While levels remain above drinking water standards, risks to the river ecosystem are deemed low, so decisions regarding remedial 

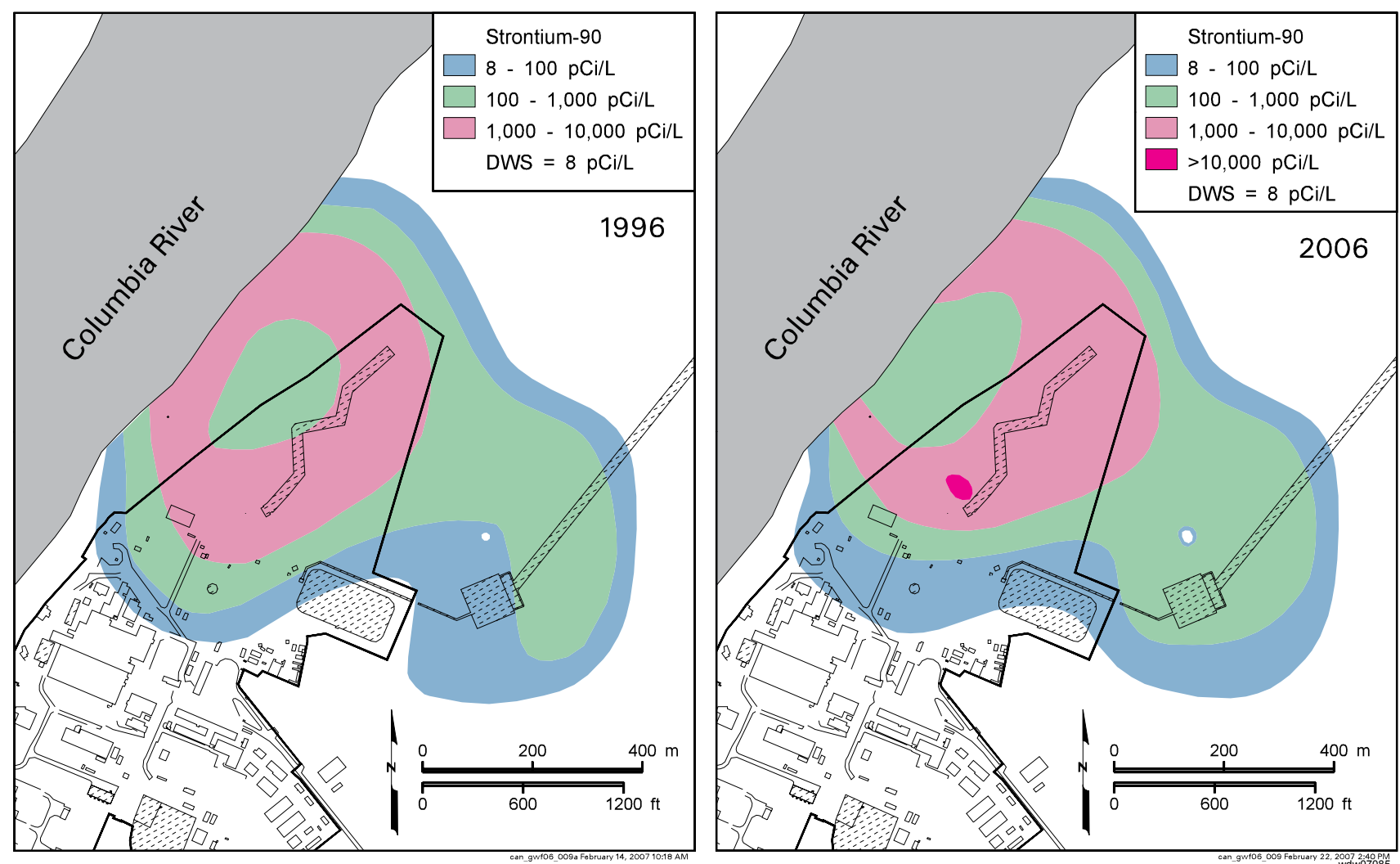

The overall shape of the 100-N strontium-90 plume at the 8-pCi/L level has not changed in many years, despite the operation of the pump-and-treat system from 1995 until March 2006.

actions have been deferred until remedial actions of source areas are complete. Some recent variability in tritium concentrations near KW Reactor is believed to be the result of remobilization of contaminants held in the vadose zone.

K Basins. The KE and KW Basins are integral parts of each reactor building. Since the late 1970s, they have been used to store irradiated fuel from the last run of N Reactor, as well as miscellaneous fuel fragments recovered from cleanup at other reactor areas. DOE has removed the fuel and is nearly finished removing radioactive sludge from KE Basin. Following sludge removal, basin interior concrete surfaces will be decontaminated, shielding water will be removed, and the basin will be demolished.

\section{0-NR-2 Operable Unit}

A complete discussion of activities in the 100-NR-2 Operable Unit can be found in Section 2.4. The primary groundwater contaminant plume in the 100-N Area is strontium-90, which originated at two liquid waste disposal cribs. A tritium plume also originated at the 100-N Area cribs. Tritium concentrations in groundwater are declining, and the plume is shrinking. Nitrate, sulfate, and petroleum hydrocarbons also are present in 100-N Area groundwater.

Interim Remedial Action. A pump-and-treat system for strontium-90, which operated as a CERCLA interim action, was put on standby in FY 2006. DOE continued to evaluate an alternative treatment method, apatite sequestration. Twenty-nine wells were installed along the shoreline in FY 2006 to support this technology. Apatite-forming chemicals were injected into two test wells during the year, and the concentrations of strontium- 90 and other parameters are monitored in surrounding wells and aquifer tubes. The goal is to create a permeable, reactive barrier near the shoreline that will capture strontium-90 as groundwater 

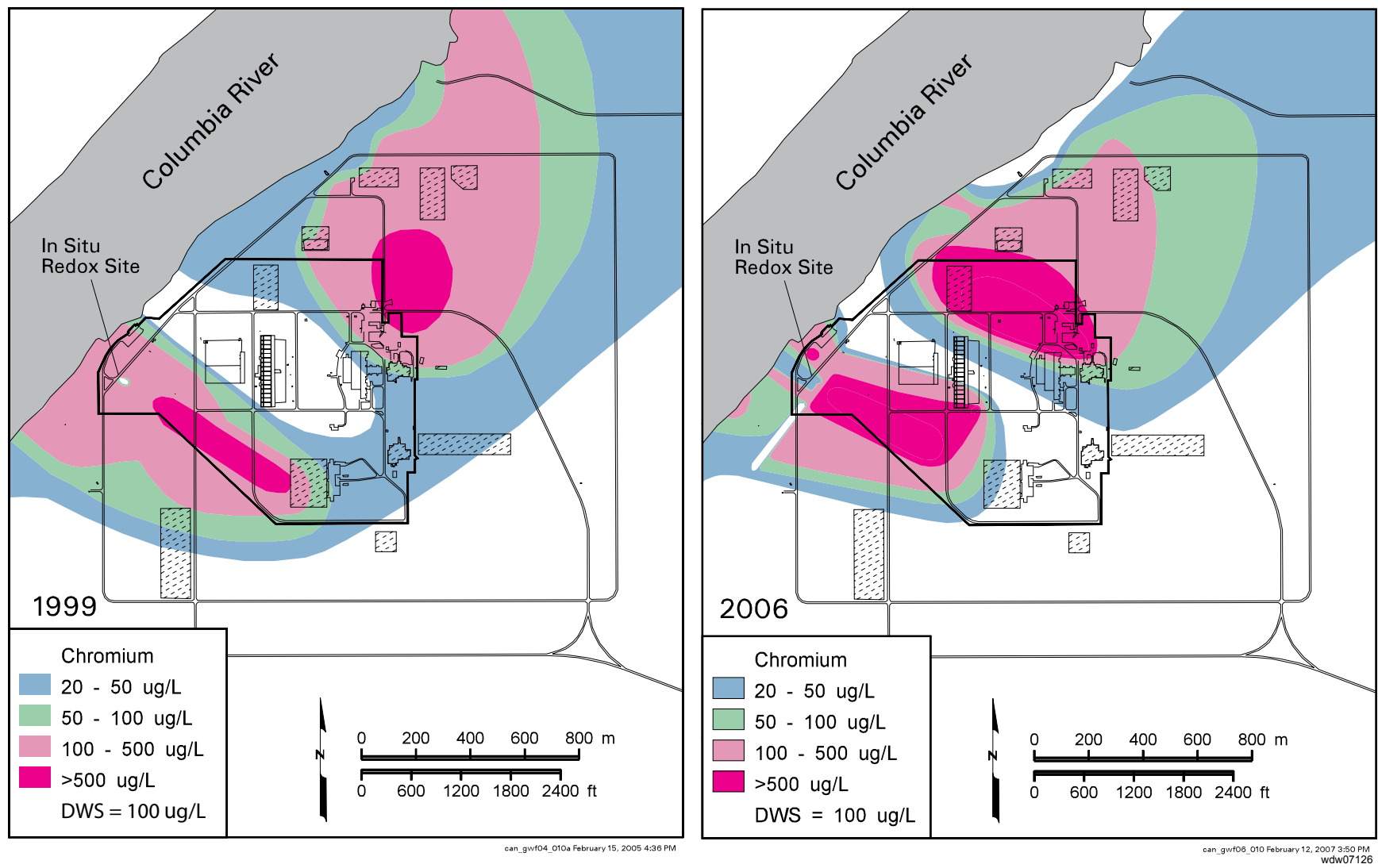

These maps show chromium plumes in the upper part of the aquifer in the 100-D Area. To reduce the amount of chromium entering the Columbia River, DOE operates two pump-and-treat systems in the north and an in situ treatment system in the south.

\section{Chromium}

concentrations

in 100-D Area

groundwater are

the highest on

the Hanford Site.

Three remediation

systems operate to

reduce the amount

of chromium

reaching the

Columbia River. flows through it to the river. DOE is also researching phytoremediation using Coyote Willows to remove shallow groundwater and soil contamination adjacent to the river.

$116-\mathrm{N}-1,116-\mathrm{N}-3,120-\mathrm{N}-1$, and 120-N-2 (1301-N, 1325-N, 1324-N/NA) Facilities. Four RCRA units are located in the 100-N Area. During FY 2006, the sites remained in detection monitoring programs. AEA and CERCLA monitoring continued to track strontium-90 and tritium plumes from the $116-\mathrm{N}-1$ and $116-\mathrm{N}-3$ facilities and sulfate from the $120-\mathrm{N}-1$ pond.

\section{0-HR-3-D Operable Unit}

The 100-HR-3 Operable Unit underlies the 100-D and 100-H Areas and the region between. Hexavalent chromium is the primary contaminant of concern in groundwater beneath the 100-D Area, which comprises the west part of the operable unit (100-HR-3-D; described in Section 2.5). A principal cause for this contamination was the routine discharge of reactor coolant, which contained sodium dichromate as a corrosion inhibitor, to disposal facilities, such as trenches. A second cause was periodic spillage and leakage of sodium dichromate stock solution to the ground. Chromium is distributed in north and southwest plumes and other contaminant plumes include tritium, nitrate, and sulfate exist in the same general area.

Interim Remedial Actions. The north chromium plume is the target of a pump-and-treat system, which is designed to reduce the amount of chromium entering the Columbia River. A second pump-and-treat system intercepts groundwater in the central 100-D Area near the shoreline. FY 2006, chromium concentrations remained above the remediation goal ( $22 \mu \mathrm{g} / \mathrm{L})$ 

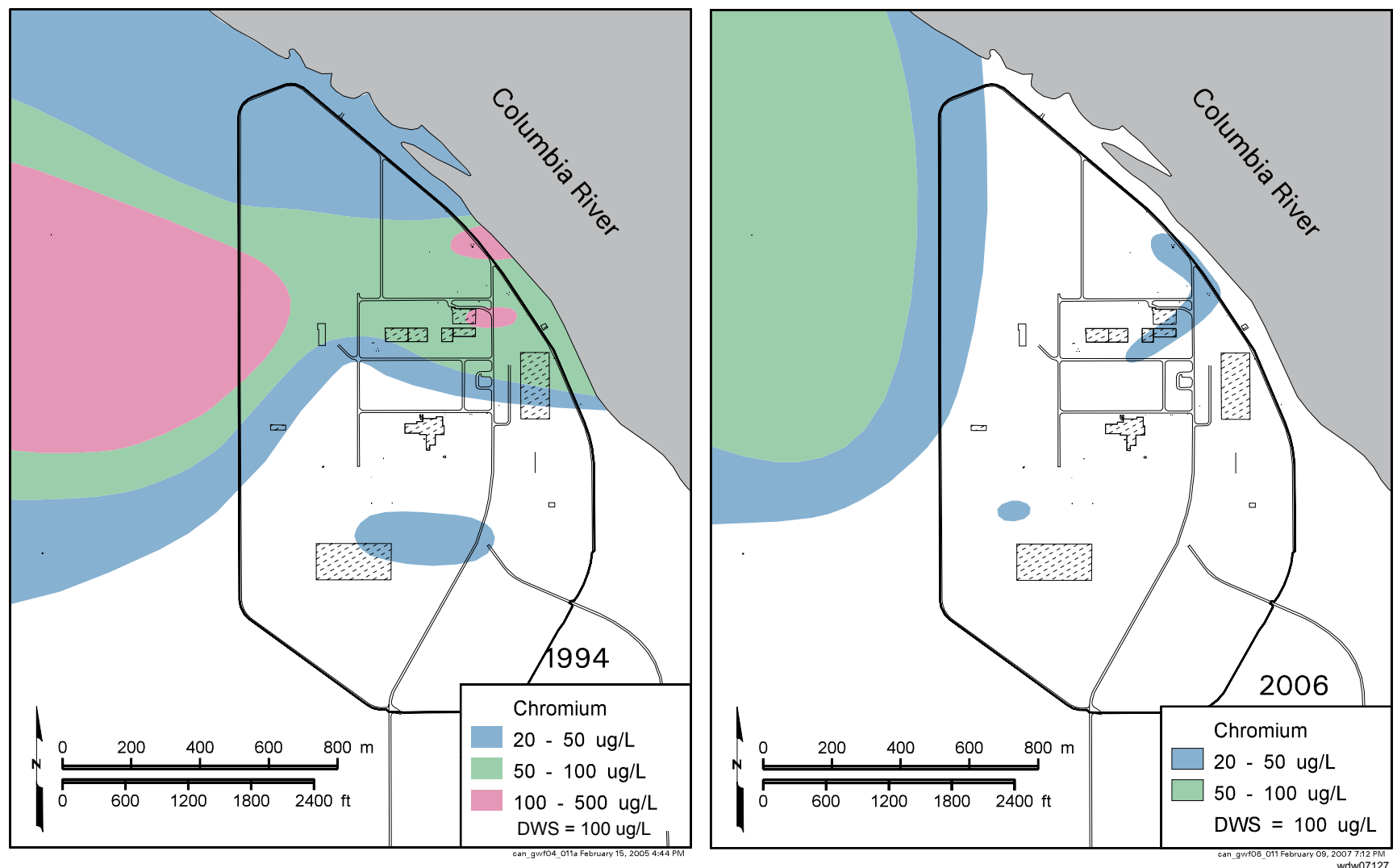

A pump-and-treat system in the 100-H Area has reduced the amount of chromium entering the Columbia River. Between 1994 and 2006, concentrations decreased through most of the plume.

in compliance wells. The two extraction systems have removed 348 kilograms of chromium from the aquifer since 1997. The southwest chromium plume is being remediated with a permeable barrier that immobilizes chromium in the aquifer. Data from recent years indicate that chromium is breaking through the barrier. At the end of FY 2006, concentrations in barrier wells ranged from below detection limits to $380 \mu \mathrm{g} / \mathrm{L}$, with concentrations in $\sim 66 \%$ of the wells below the remedial action goal of $20 \mu \mathrm{g} / \mathrm{L}$. Most of the elevated concentrations are in the northeast half of the barrier. Downgradient of the barrier, the $20-\mu \mathrm{g} / \mathrm{L}$ goal was met at two of the seven compliance wells.

\section{0-HR-3-H Operable Unit}

A complete discussion of the east part of the 100-HR-3 Operable Unit (100-HR-3-H), which underlies the 100-H Area, can be found in Section 2.6. Hexavalent chromium is the primary contaminant of concern in this area, but the plume is smaller and concentrations are lower than in the 100-D Area. Nitrate also is elevated, but concentrations have declined from their peak historical levels. Strontium- 90 exceeds the drinking water standard $(8 \mathrm{pCi} / \mathrm{L})$ beneath former retention basins, and technetium-99 and uranium are elevated in a small area.

Interim Remedial Action. The chromium plume in the 100- $\mathrm{H}$ Area is the target of a pump-and-treat system. The remediation of the plume has removed 47 kilograms of hexavalent chromium from the aquifer since 1997. Hexavalent chromium concentrations continued to decline in FY 2006 in the one remaining compliance well and in former compliance wells that have been converted to extraction wells. In September 2006, concentrations in all of those wells were below the $22 \mu \mathrm{g} / \mathrm{L}$ remedial action goal. 

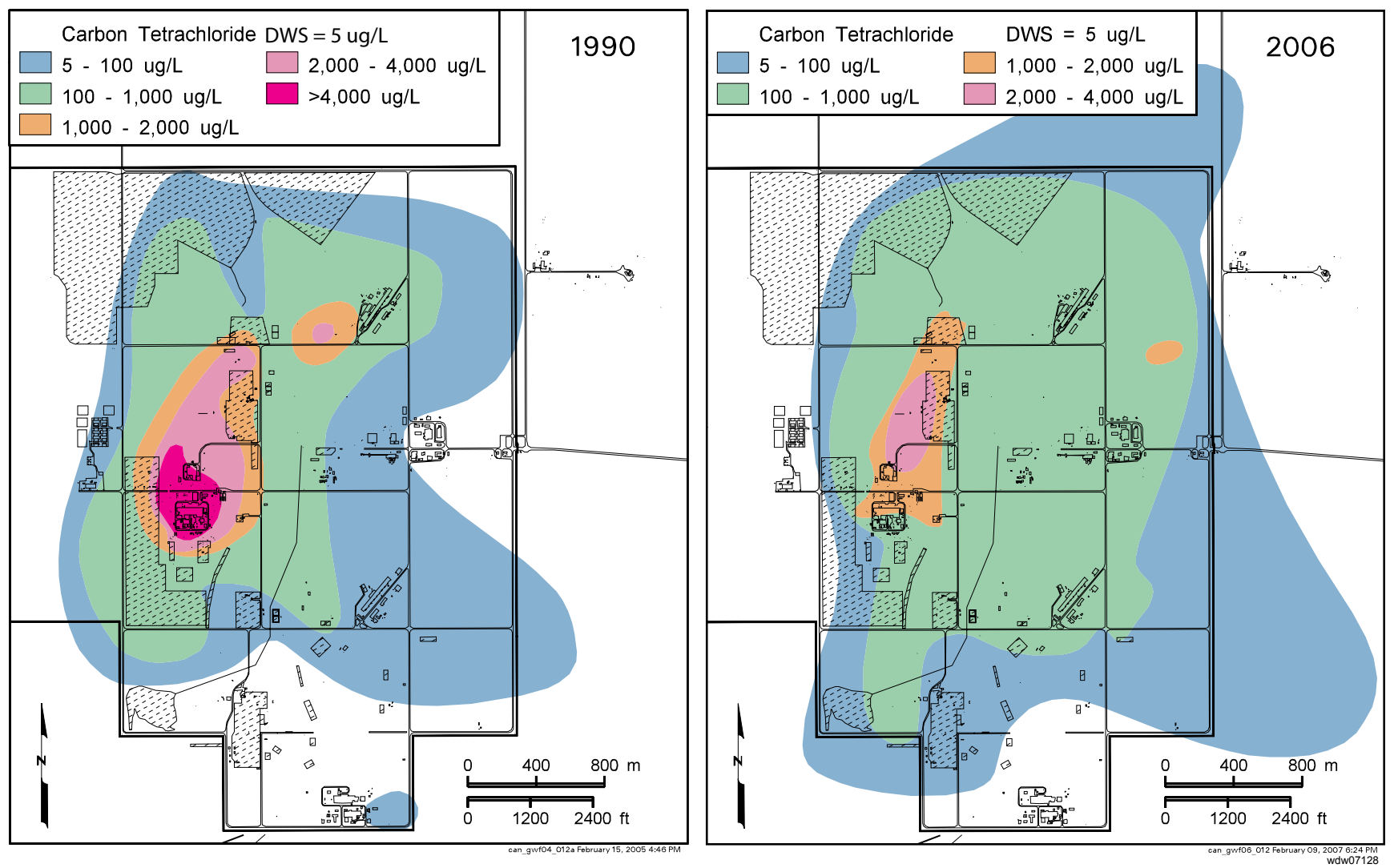

These maps show the carbon tetrachloride plume beneath the 200 West Area in the upper part of the unconfined aquifer. The edges of the plume spread between 1990 and 2006. Since 1996, a pump-and-treat system in the 200-ZP-1 Operable Unit is helping prevent further spreading of the core of the plume, shown here in pink and red.

DOE expanded the

pump-and-treat

system for carbon

tetrachloride in the

200 West Area to

capture a portion of

the plume beyond

the reach of the

former system.
116-H-6 (183-H) Evaporation Basins. These former basins comprise the only RCRA site in the 100-H Area. Leakage from the basins contaminated groundwater with chromium, nitrate, technetium-99, and uranium. The site is monitored during the post-closure period to track contaminant trends during the operation of the CERCLA interim action for chromium.

\section{0-FR-3 Operable Unit}

A complete discussion of the 100-FR-3 Operable Unit can be found in Section 2.7. Nitrate concentrations in groundwater exceed the drinking water standard beneath much of the 100-F Area and the downgradient region. Other groundwater contaminants include strontium-90 and trichloroethene. Chromium exceeds the $10-\mu \mathrm{g} / \mathrm{L}$ aquatic standard in some wells.

A record of decision has not yet been developed for the 100-FR-3 Operable Unit and no active remediation of groundwater is underway. Monitoring contaminant conditions has continued since the initial remedial investigation and while waste site remedial actions are conducted.

\section{0-ZP-1 Operable Unit}

A complete discussion of the 200-ZP-1 Operable Unit can be found in Section 2.8. This operable unit encompasses the north portion of the 200 West Area. The primary contaminant of concern is carbon tetrachloride, which forms the largest plume of chlorinated hydrocarbons on the Hanford Site. The carbon tetrachloride contamination had sources associated with waste disposal from the Plutonium Finishing Plant, where organic chemicals 
were used to process plutonium. Trichloroethene and chloroform also are associated with this plume. Other contaminants in the 200-ZP-1 Operable Unit include tritium, nitrate, chromium, fluoride, iodine-129, technetium-99, and uranium.

Work on the feasibility study for the 200-ZP-1 groundwater Operable Unit is ongoing. In FY 2006, potential remediation methods for the 200-ZP-1 Operable Unit were screened. The screening considered the eight major contaminants and used a generalized conceptual model of the lateral extent and depth of contamination.

The distribution of carbon tetrachloride is complex because of its potential to migrate as a dense, non-aqueous phase liquid, in the gaseous state, and dissolved in water. Depth-discrete data for 19 wells were evaluated in the 200-ZP-1 remedial investigation report in FY 2006. The results were integrated with geologic information to form a conceptual model of the plume geometry. The plume extends to the top of the Ringold lower mud unit where the mud is present and to the top of basalt where the mud is absent. The contamination occurs at increasing depth to the east of the known source areas. Relatively low concentrations are seen at the water table in the east-central part of the 200 West Area. The extent of carbon tetrachloride contamination deeper in the aquifer indicates that a significantly greater mass of carbon tetrachloride is present in the unconfined aquifer than previously estimated.

The 200-ZP-1 interest area contains one CERCLA interim action for groundwater, one remediation system for the vadose zone, four facilities monitored under RCRA (in conjunction with CERCLA and AEA), and one state-permitted unit.

Interim Remedial Action. Since 1994, DOE has operated an interim action pump-andtreat system to prevent carbon tetrachloride in the upper part of the aquifer from spreading. The remediation system was extended to the north in late FY 2005 to capture carbon tetrachloride contamination at levels above $2,000 \mu \mathrm{g} / \mathrm{L}$ extending beyond the capture zone of the former system. An additional monitoring well was converted to an extraction well in September 2006.

Soil-Vapor Extraction. Soil vapor is extracted from the vadose zone and treated to remove carbon tetrachloride. As of the end of September 2006, 78,900 kilograms of carbon tetrachloride have been removed from the vadose zone since extraction operations started in 1991.

Low-Level Burial Grounds Waste Management Areas 3 and 4. RCRA groundwater monitoring continued under interim status requirements in FY 2006. Three new monitoring wells were installed at Low-Level Waste Management Area 3 and one at Low-Level Waste Management Area 4. The changing flow direction has left Low-Level Waste Management Area 3 without any upgradient wells. Until new upgradient wells are installed and background conditions are established, statistical evaluations have been suspended.

Waste Management Area T. RCRA assessment monitoring continued in FY 2006 under a revised assessment plan. The waste management area has introduced technetium-99 and other tank waste contaminants to the uppermost aquifer in the area. Two new wells were installed in FY 2006. The highest concentrations of technetium-99 downgradient of the south part of the waste management area are near the water table, while the highest concentrations downgradient of the north part are at about 10 meters below the water table.

Waste Management Area TX-TY. RCRA assessment monitoring continued in FY 2006. Sources in the waste management area have contaminated groundwater with chromium, technetium-99, and other tank waste constituents. Other nearby sources of contamination make source determinations uncertain for some contaminants. Nitrate concentrations increased sharply in three wells. The highest chromium concentrations are observed at depths near the water table. Groundwater flow beneath Waste Management Area TX-TY is changing due to the operation of the 200-ZP-1 pump-and-treat remediation system. Extraction wells operate south and west of the waste management area. Because of the change in flow direction, the monitoring network no longer performs as originally designed.
The extent of carbon tetrachloride contamination deeper in the aquifer indicates that a significantly greater mass of carbon tetrachloride is present in the unconfined aquifer than previously estimated.

\section{Data collected} in recent years have helped define vertical distribution of contaminants around Waste Management Areas T and TX-TY. 
A groundwater

pump-and-treat

system operated

near U Plant

to contain the

technetium-99 and

uranium plumes

there. Rebound

monitoring

continued in

FY 2006 and

contaminant

concentrations

remained below

remedial action

goals.
State-Approved Land Disposal Site. This active disposal facility is regulated under a state waste discharge permit. Groundwater is monitored for tritium and 15 other constituents. Concentrations of all constituents considered in the permit did not exceed enforcement limits during FY 2006.

\section{0-UP-1 Operable Unit}

A complete discussion of the 200-UP-1 Operable Unit can be found in Section 2.9. This operable unit underlies the south portion of 200 West Area. The primary contaminants of concern are technetium-99 and uranium. Tritium, chromium, iodine-129, and nitrate plumes also have sources in this operable unit. Carbon tetrachloride in the 200-UP-1 Operable Unit originated from sources in the 200-ZP-1 Operable Unit. Six wells were drilled in this operable unit in FY 2006.

A study of vertical contaminant distribution in the 216-U-1,2 crib plume showed that in most areas, the highest technetium-99 concentrations are near the water table. In three wells, concentrations were higher 19 to 33 meters below the water table. Uranium was limited to the portion of the aquifer near the water table.

Four facilities are being monitored under RCRA (in conjunction with CERCLA and AEA), one CERCLA interim action, and a CERCLA disposal site in the 200-UP-1 Operable Unit. Monitoring activities are summarized in the following paragraphs.

Interim Remedial Action. A groundwater pump-and-treat system operated near U Plant to contain the technetium-99 and uranium plumes located in this area. In January 2005, groundwater extraction ceased and a rebound study was initiated to determine if contaminant concentrations will remain below the remedial action goal under natural groundwater flow conditions. The rebound study concluded in January 2006. For the remainder of FY 2006, semi-annual groundwater monitoring around the baseline plume area continued. Ecology is currently preparing an Explanation of Significant Difference which may revise the remedial action objective for uranium. After the Explanation of Significant Difference is issued, a decision will be made on whether or not to restart the pump-and-treat system.

The results of the rebound study and semiannual groundwater sampling indicate that enough technetium-99 and uranium was removed from the aquifer that concentrations of both constituents remained below their respective remedial action goals at all wells for FY 2006.
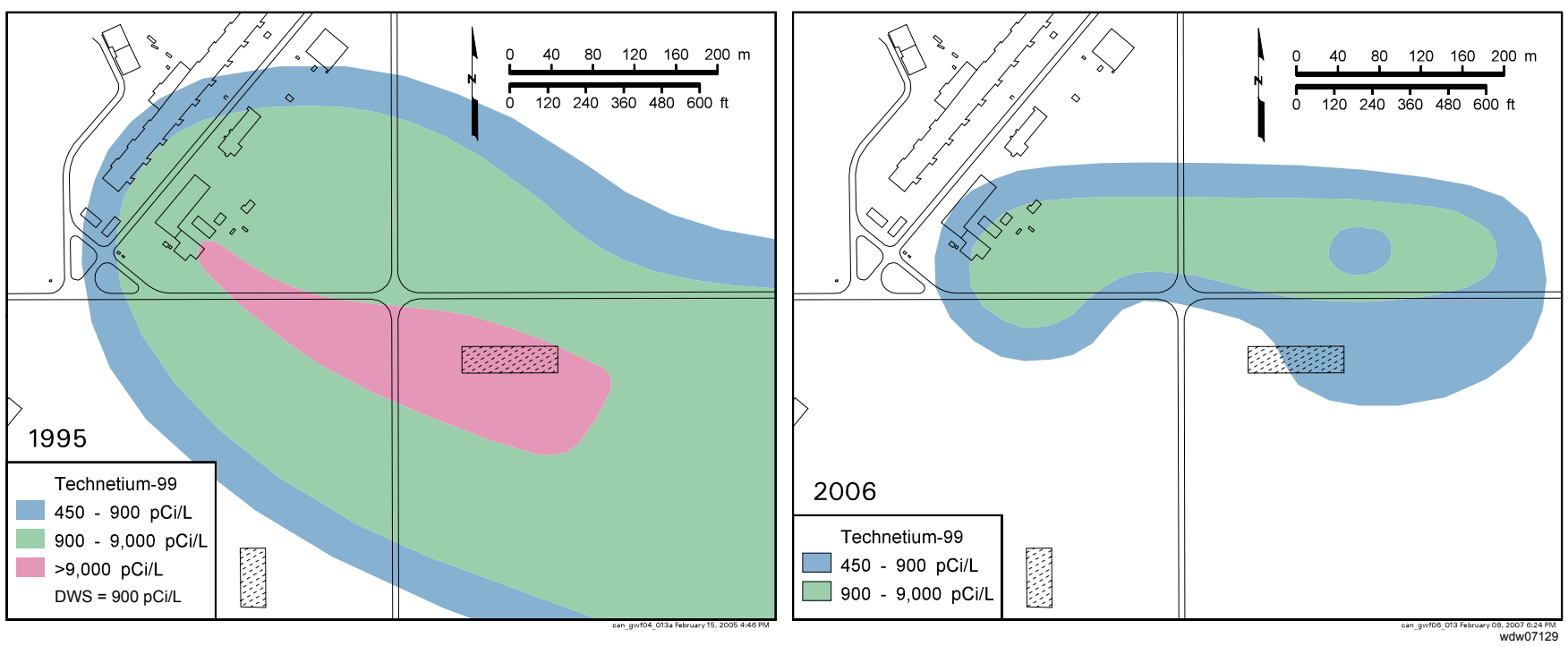

A pump-and-treat system at the 200-UP-1 Operable Unit (200 West Area) has decreased the size of the technetium-99 plume in the upper part of the aquifer. The system began to operate in fall 1995 and was shut down in January 2005, when DOE began to conduct a rebound study. 

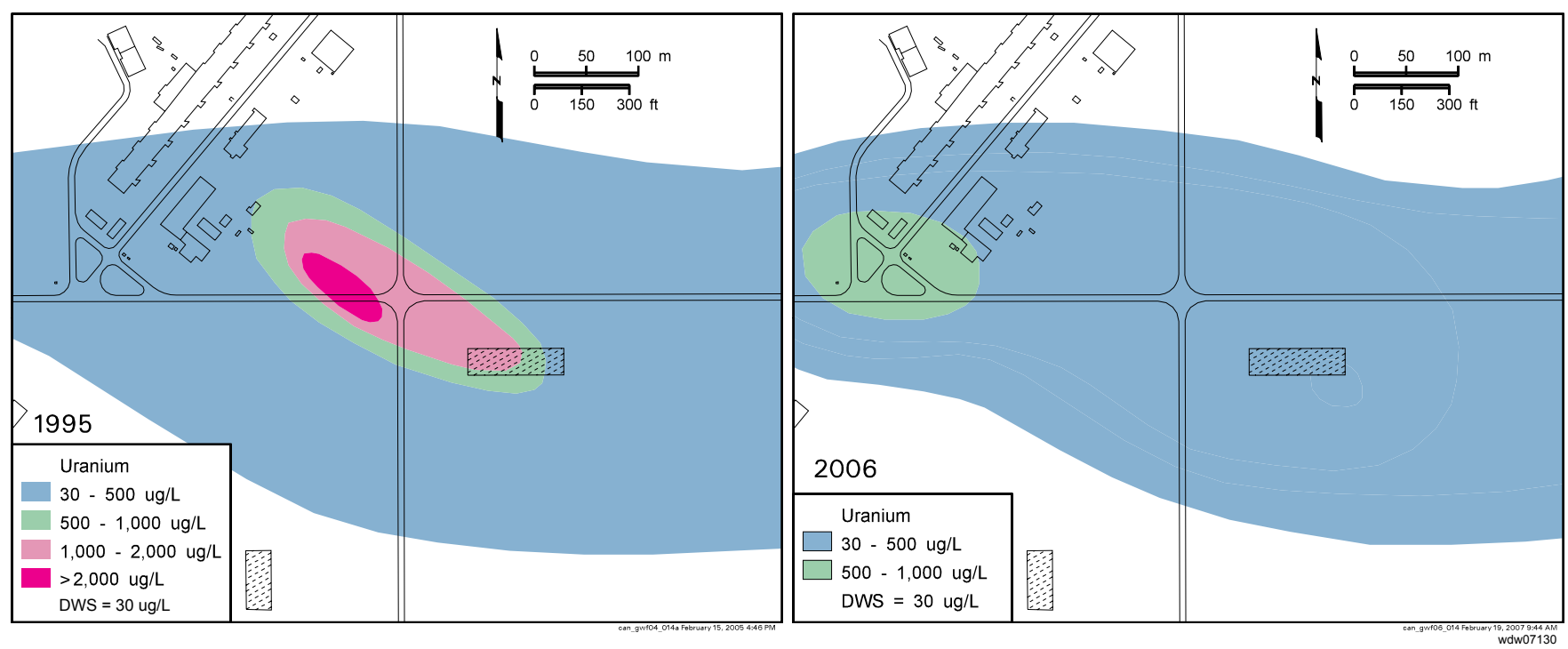

Uranium contamination in the 200-UP-1 Operable Unit (200 West Area), although now below the remedial action goal, did not respond to the pump-and-treat system as quickly as the technetium-99. Unlike technetium-99, uranium interacts with sediment grains, slowing its movement and response to remediation.

Waste Management Area S-SX. RCRA assessment monitoring continued in FY 2006. Groundwater beneath this waste management area is contaminated with tank waste constituents, which include nitrate, hexavalent chromium, and technetium-99 attributed to two general source areas within the waste management area. The south plume represents a growing contamination issue. Data from new wells indicate that both plumes extend farther downgradient than previously interpreted.

Waste Management Area U. RCRA assessment monitoring continued in FY 2006. The waste management area has been identified as the source of groundwater contamination that is limited to the downgradient (east) side of the site. Plume constituents of interest include nitrate and technetium-99.

216-U-12 Crib. RCRA assessment monitoring continued in FY 2006. The crib is one of several sources that have contributed to a nitrate plume in the area. Closure of the crib will be coordinated between RCRA and CERCLA. The monitoring plan was revised in FY 2006 to incorporate a new upgradient well.

216-S-10 Pond and Ditch. The 216-S-10 facility continued to be monitored under a RCRA interim status detection program in FY 2006. The current RCRA monitoring network consists of only two shallow downgradient wells and one deeper downgradient well, because other wells have gone dry. Three new wells are planned for installation in 2008.

Environmental Restoration Disposal Facility. This facility is a low-level, mixed waste facility where waste from surface remedial actions on the Hanford Site is disposed. The site is designed to meet RCRA standards, although it is not permitted as a RCRA unit. Results of groundwater monitoring continued to indicate that the facility has not adversely impacted groundwater quality.

\begin{tabular}{|c|c|c|c|c|}
\hline \multicolumn{5}{|c|}{ Dry Monitoring Wells } \\
\hline \multicolumn{5}{|c|}{$\begin{array}{l}\text { Some wells that were formerly sampled for the groundwater project have gone } \\
\text { dry as the water table declined. Most of the wells are in the 200 Areas. }\end{array}$} \\
\hline Fiscal Year & 200 West & 200 East & Other Areas & Total \\
\hline 1999 & 12 & 1 & 1 & 14 \\
\hline 2000 & 8 & 2 & 1 & 11 \\
\hline 2001 & 11 & 0 & 2 & 13 \\
\hline 2002 & 9 & 2 & 1 & 12 \\
\hline 2003 & 9 & 1 & 3 & 13 \\
\hline 2004 & 6 & 1 & 2 & 9 \\
\hline 2005 & 3 & 6 & 0 & 9 \\
\hline 2006 & 4 & 0 & 0 & 4 \\
\hline Total & $\mathbf{6 2}$ & $\mathbf{1 3}$ & $\mathbf{1 0}$ & $\mathbf{8 5}$ \\
\hline
\end{tabular}




\section{A uranium plume}

continues to reside

below the B-BX-BY

tank farms and

has spread to the

northwest.

\section{0-BP-5 Operable Unit}

A complete discussion of the 200-BP-5 Operable Unit can be found in Section 2.10. This operable unit includes groundwater beneath the north 200 East Area. Technetium-99 and tritium plumes extend northward between Gable Mountain and Gable Butte. Uranium forms a narrow plume that extends northwest of the 200 East Area. Nitrate forms a plume that extends to the north and probably originated from multiple sources within the 200 East Area. Other contaminants include cesium-137, cobalt-60, cyanide, iodine-129, nitrate, nitrite, plutonium, strontium-90, sulfate, and uranium.

Groundwater monitoring under CERCLA continued in FY 2006. No active groundwater remediation is being undertaken in this operable unit, and final remediation decisions are yet to be made.

Five facilities in the 200-BP-5 Operable Unit are monitored under RCRA in conjunction with CERCLA and AEA. Monitoring activities are summarized in the following paragraphs.

Waste Management Area B-BX-BY. RCRA assessment monitoring continued at this site in FY 2006. Contaminants include uranium, technetium-99, and nitrate. Concentrations of these contaminants continued to increase to new maximum levels in FY 2006.

Waste Management Area C. This site continued to be monitored under an interim status RCRA detection program in FY 2006, but is sampled quarterly at Ecology's request. RCRA indicator parameters did not exceed critical mean values. However, nitrate, technetium-99, and sulfate are elevated in the groundwater near the waste management area. Concentrations of sulfate in upgradient wells indicate an upgradient source. Although high levels of technetium-99 have been observed upgradient in the past, the plume is currently
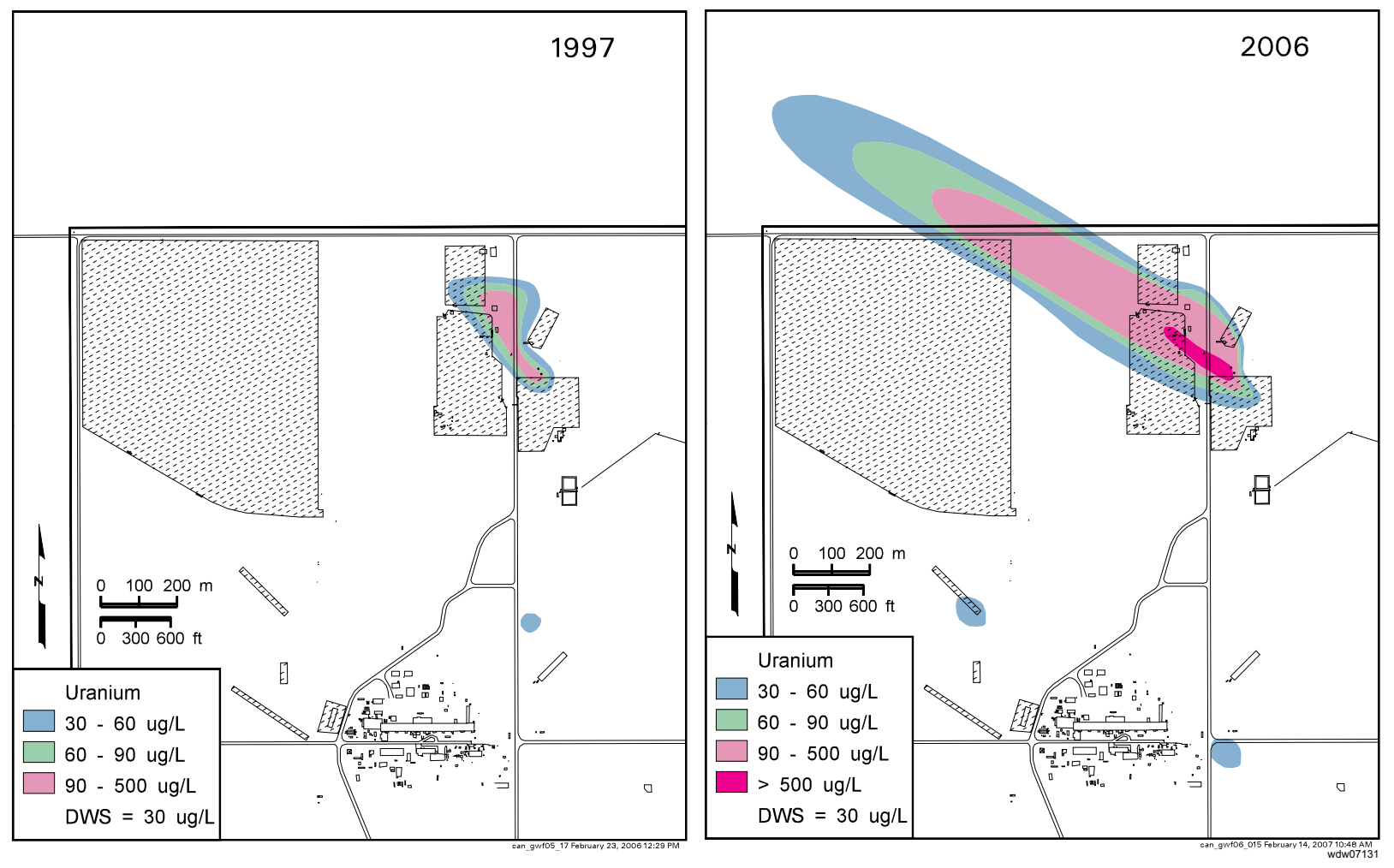

A uranium plume has developed in the northwest corner of the 200 East Area. The plume appears to have sources in Waste Management Area B-BX-BY. 
affecting only downgradient wells at levels above the drinking water standard $(900 \mathrm{pCi} / \mathrm{L})$. Cyanide, a tank waste constituent, continued to be detected in an upgradient well at levels below the drinking water standard.

216-B-63 Trench. This RCRA site continued to be monitored under an interim status detection monitoring program.

Low-Level Waste Management Area 1. This site continued to be monitored under RCRA interim status requirements. Specific conductance continued to exceed its critical mean value but exceedances were reported previously and do not appear to indicate contamination from the waste management area. Specific conductance and major ions increased sharply in one well. The transient nature of these changes suggests that the well is near a localized plume.

Low-Level Waste Management Area 2. This site continued to be monitored under RCRA interim status requirements. Two more wells in this area went dry in early FY 2006. Most wells in the north part of the waste management area are dry, and the water table has dropped below the top of basalt bedrock surface.

Liquid Effluent Retention Facility. The water table has dropped below the top of basalt in all but two monitoring wells. A 2001 letter from Ecology directed DOE to discontinue RCRA statistical evaluation of groundwater sample results. DOE has continued to sample the two remaining wells but is not conducting statistical analyses of the results. DOE and Ecology are pursuing an agreement for permit conditions for environmental monitoring.

\section{0-PO-1 Operable Unit}

A complete discussion of the 200-PO-1 Operable Unit can be found in Section 2.11. This operable unit encompasses the south portion of the 200 East Area and a large portion of the Hanford Site extending to the east and southeast that is contaminated with plumes of tritium, nitrate, and iodine-129 that exceed drinking water standards. Concentrations of tritium continued to decline as the plume attenuates naturally due to radioactive decay and dispersion. Other contaminants include strontium-90 and technetium-99, but these are limited to very small areas near cribs or tank farms.

CERCLA groundwater monitoring continued in FY 2006 under a revised sampling and analysis plan. Currently, no active groundwater remediation is occurring in this operable unit and final remediation decisions are yet to be made.

Groundwater is monitored at eight regulated units in the 200-PO-1 Operable Unit. Water supply wells in the 400 Area, which falls within the footprint of the 200-PO-1 Operable Unit, also are monitored.

Integrated Disposal Facility. This facility will be an expandable, lined, RCRA-compliant landfill. The facility is scheduled to receive its first waste in 2010. Background monitoring was completed in FY 2006. Until the facility begins to operate, results from semi-annual monitoring will be added to the background data set.

PUREX Cribs. Three cribs (216-A-10, 216-A-36B, and 216-A-37-1) are monitored jointly under a RCRA interim status assessment program, CERCLA, and AEA. The cribs have contributed to widespread contaminant plumes in the area, including nitrate, tritium, and iodine-129. The nitrate and tritium plumes are generally attenuating throughout most of their area. A revised monitoring plan was implemented in FY 2006.

Waste Management Area A-AX. RCRA assessment monitoring continued in FY 2006. Technetium-99 concentrations increased in FY 2006 and now exceeds the drinking water standard $(900 \mathrm{pCi} / \mathrm{L})$ in two wells.

216-A-29 Ditch. The groundwater beneath this site continued to be monitored as required by RCRA interim status detection regulations. Except for specific conductance, RCRA indicator parameters in downgradient wells did not exceed critical mean values in FY 2006. Specific conductance continued to exceed its critical mean value in downgradient

\section{Nitrate, technetium-99, and sulfate are elevated near \\ Waste Management}

Area C.

\author{
The PUREX \\ cribs contributed \\ to plumes of \\ iodine-129, nitrate, \\ and tritium. \\ Nitrate and tritium \\ concentrations are \\ generally declining.
}



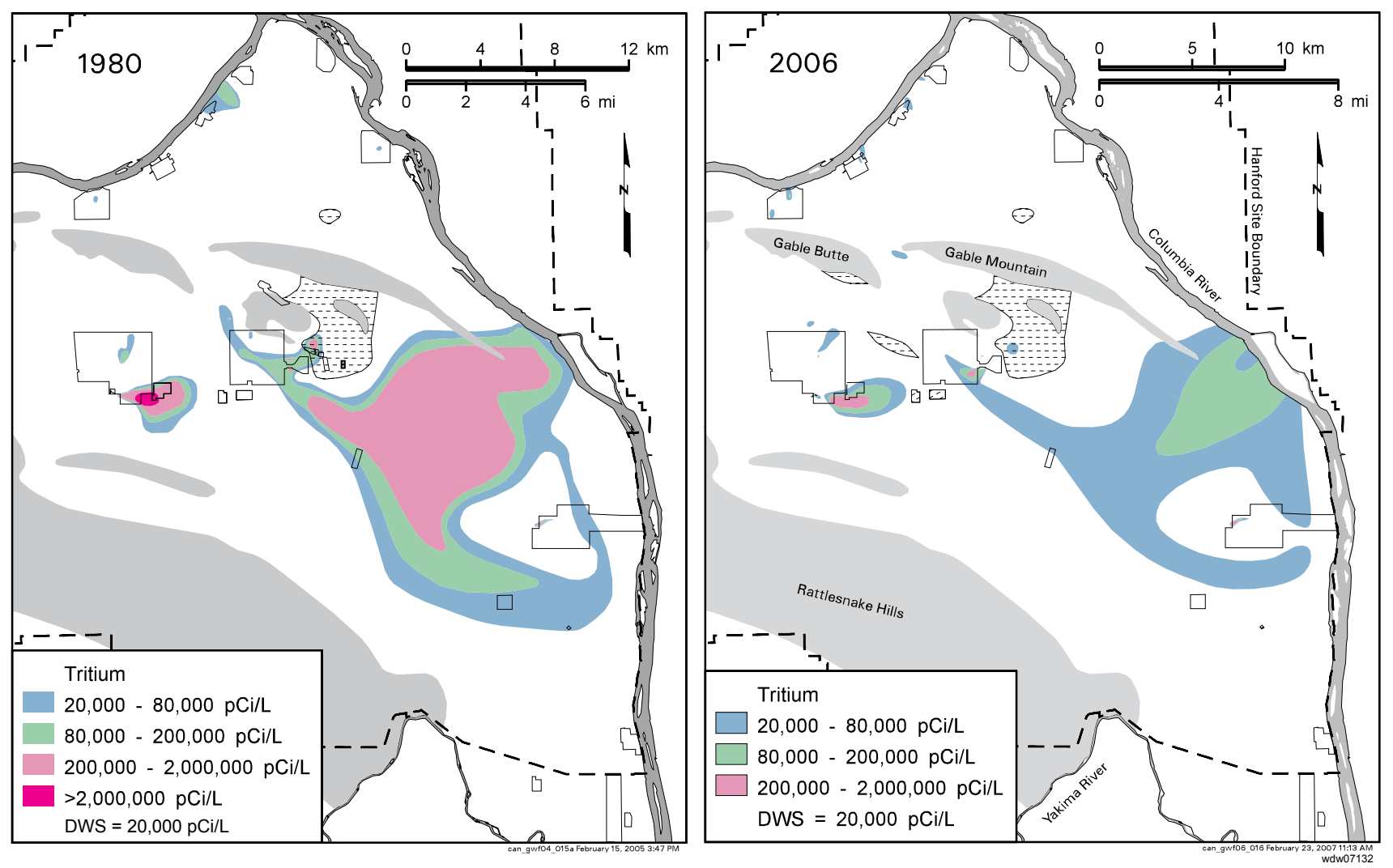

These maps show site-wide tritium plumes in the upper part of the unconfined aquifer in 1980 and 2006. Concentrations in the core of the plume have decreased over the years; the south margin has ceased its southward migration.

wells as groundwater quality returns to ambient conditions in response to the cessation of effluent disposal at B Pond. Groundwater quality beneath the ditch closely resembles regional patterns.

216-B-3 Pond. The groundwater beneath this site continued to be monitored as required by RCRA interim status detection regulations.

200 Area Treated Effluent Disposal Facility. A state waste discharge permit governs groundwater sampling and analysis in the three monitoring wells at this facility. No permit criteria for constituents in groundwater were exceeded in FY 2006. The groundwater monitoring network continues to show that effluent from the facility is not taking a direct route to the uppermost aquifer, which is confined.

Nonradioactive Dangerous Waste Landfill. This RCRA site is located in the 600 Area, within the footprint of the 200-PO-1 regional plume. Interim status detection monitoring continued FY 2006.

Solid Waste Landfill. This facility is adjacent to the Nonradioactive Dangerous Waste Landfill and is regulated under state solid waste regulations. As in previous years, some downgradient wells showed higher chemical oxygen demand, chloride, coliform bacteria, specific conductance, and sulfate, and lower $\mathrm{pH}$ than upgradient wells. Some of these constituents may be related to past disposal of sewage materials to the Solid Waste Landfill.

400 Area Water Supply Wells. Three water supply wells provide drinking water and emergency supply water for the 400 Area. Because the 400 Area lies in the path of the sitewide tritium plume, the wells are routinely monitored for tritium. The main water supply well is completed deep in the unconfined aquifer and has low tritium values. Two backup 

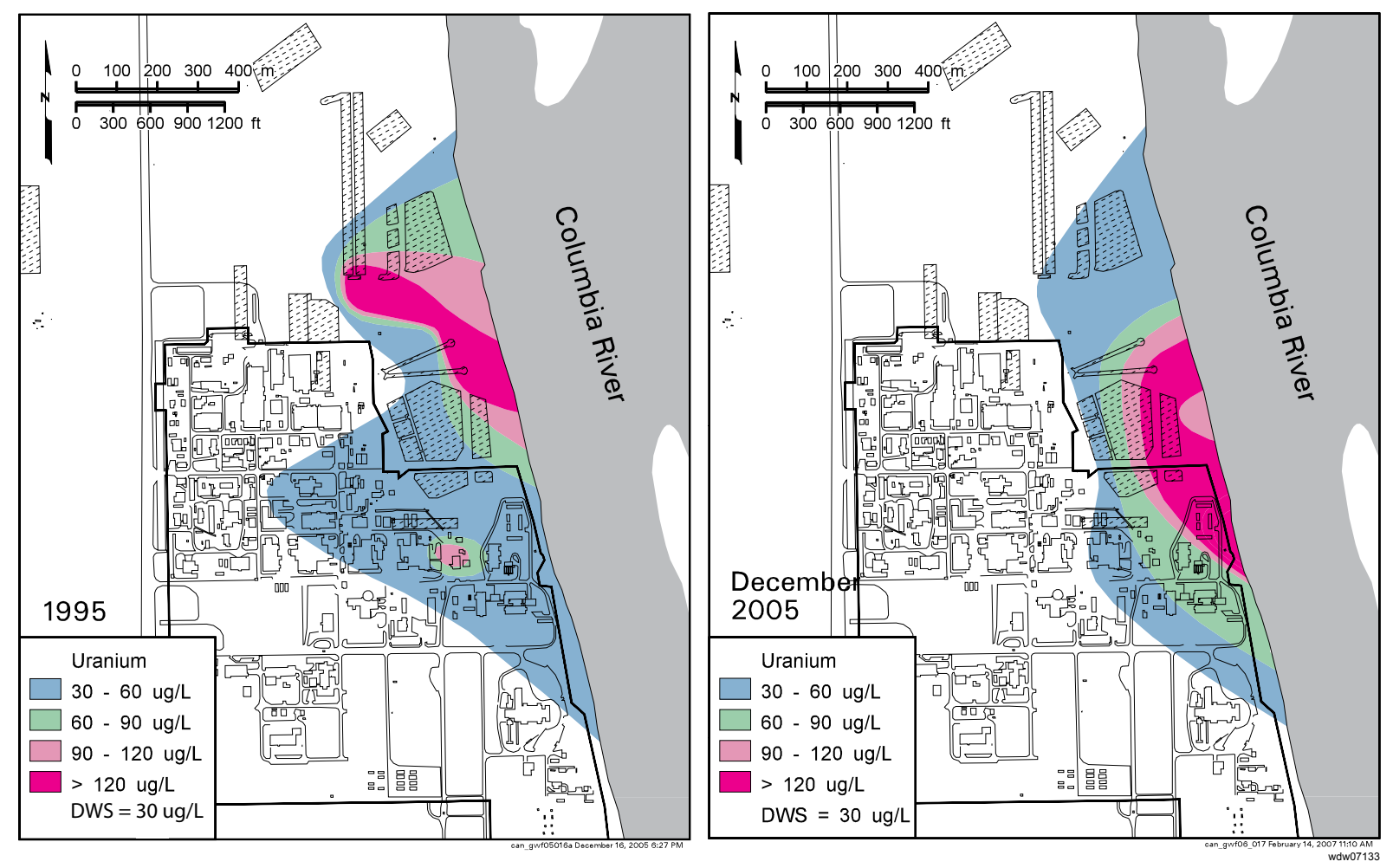

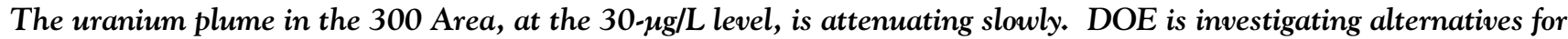
more rapid remediation.

wells are shallower and have higher tritium levels, but tritium concentrations in all samples were below the drinking water standard in FY 2006.

\section{0-FF-5 Operable Unit}

A complete discussion of the 300-FF-5 Operable Unit can be found in Section 2.12. This operable unit includes three geographic subregions: the 300 Area, the 618-11 burial ground subregion, and the $316-4$ cribs/618-10 burial ground subregion. The operable unit is currently regulated under a record of decision that calls for continued monitoring of groundwater conditions and institutional controls on the use of groundwater as an interim action, until source remedial actions are complete. The operable unit includes groundwater associated with a former liquid waste disposal site regulated under a RCRA final status, corrective action monitoring program. In FY 2006, DOE installed 13 new wells for a uranium treatability test or aquifer characterization.

Contaminants of concern in 300 Area groundwater are uranium, trichloroethene, and cis-1,2-dichloroethene. Monitoring and plume characterization activities indicate relatively constant or gradually decreasing levels for these contaminants. Uranium is the primary contaminant of concern and remains above the drinking water standard $(30 \mu \mathrm{g} / \mathrm{L})$ beneath part of the 300 Area.

$D O E$ is

investigating

remediation

methods for

uranium in the

300 Area.

Trichloroethene continued to be below the $5-\mu \mathrm{g} / \mathrm{L}$ drinking water standard in groundwater samples. However, during drilling of four characterization boreholes for the limited field investigation in the 300 Area, trichloroethene was found at unexpectedly high concentrations in water samples at a different depth than is routinely monitored by existing wells. The highest concentration was $630 \mu \mathrm{g} / \mathrm{L}$ in a deep sample from a well adjacent to the south side of 316-3 process trench. All of the samples with high concentrations came from a relatively fine-grained unit within the upper portion of the Ringold Formation. 


\section{Groundwater} characterization in the 300 Area found unexpectedly high levels of trichloroethene.

\section{In the 1100-EM-1 Operable Unit, trichloroethene concentrations continued to be below the cleanup level.}

Groundwater downgradient of the 618-11 burial ground is still contaminated by a high-concentration tritium plume, whose origin is believed to be irradiated material in the burial ground. Concentrations at a well adjacent to the burial ground have decreased from $>8$ million pCi/L in 2000 to $996,000 \mathrm{pCi} / \mathrm{L}$ in June 2006.

At the 316-4 cribs and 618-10 burial ground waste sites, uranium and tributyl phosphate are contaminants of potential concern. Both contaminants are associated with the 316-4 cribs, which were removed in 2004. Tributyl phosphate concentrations were elevated for a brief period in early 2004, along with uranium, during the period when crib removal actions were underway. Since then, concentrations have remained very low.

During excavation of the 618-2 burial ground in 2006, plutonium and other radiological contamination was detected unexpectedly. Some contamination was measured in a test pit excavated to the water table, leading to concerns about previously undetected impacts to groundwater. Increased monitoring was conducted at the nearest monitoring well (399-1-2) and no evidence for plutonium was uncovered to date. Previous measurements at other wells in the vicinity have not revealed detectable plutonium.

300-FF-5 Operable Unit Phase III Feasibility Study. Because the uranium plume beneath the 300 Area has not decreased in concentration as rapidly as predicted by earlier remedial investigations, DOE continued a detailed investigation of the natural processes that cause the plume to persist and the residual sources that may supply uranium to the plume. Key aspects of the Phase III feasibility study that continued during FY 2006 included a limited field investigation, three-dimensional computer modeling of groundwater flow and uranium transport, laboratory studies associated with potential remedial action technologies, and an updated risk assessment. During FY 2006, DOE assembled an inventory of potential remedial action technologies for reducing the level of uranium contamination in groundwater. Promising technologies include in situ methods to permanently sequester or reduce the mobility of uranium in the environment. Preliminary screening of these technologies was completed for two of three criteria — applicability and effectiveness. Screening for the third criterion, relative cost, will continue during 2007. A treatability test to immobilize uranium in the aquifer by injecting polyphosphate began in FY 2006.

316-5 Process Trenches. This former liquid waste disposal site was the last in the 300 Area to receive uranium-bearing effluent, with discharges ending in the early 1990s. The site, which has been remediated, is regulated under RCRA in conjunction with CERCLA and the AEA. Uranium currently exceeds the drinking water standard in wells downgradient from the waste site, although concentrations appear to be decreasing with time. Cis-1,2,dichloroethene concentrations exceed the standard at only one downgradient well that is completed near the bottom of the aquifer.

\section{0-EM-1 Operable Unit}

A complete discussion of the 1100-EM-1 Operable Unit, located in the south part of the Hanford Site, can be found in Section 2.13. Trichloroethene was the primary contaminant of concern. Contaminants also flow into the area from off-site sources (e.g., nitrate from agriculture and industry).

The final remedy selected for 1100-EM-1 Operable Unit groundwater is monitored natural attenuation of volatile organic compounds. Concentrations of trichloroethene have remained below the drinking water standard since FY 2001.

Wells in the city of Richland well field are monitored frequently to detect any changes in Hanford contaminants near these wells. The tritium plume originating from sources in the 200 East Area has not been detected in these wells. Low levels of tritium, similar to Columbia River water, continued to be detected.

Uranium concentrations in wells downgradient of DOE's inactive Horn Rapids Landfill have been increasing since 1996, but remained below the 30- $\mu \mathrm{g} / \mathrm{L}$ drinking water standard in FY 2006. 


\section{Confined Aquifers}

A complete discussion of the confined aquifers can be found in Section 2.14. Although most of Hanford's groundwater contamination is in the unconfined aquifer, DOE monitors wells in deeper aquifers because of the potential for downward migration of contamination and the potential migration of contamination offsite through the basalt-confined aquifer. No evidence of offsite migration via the confined aquifer has been detected.

The Ringold Formation confined aquifer occurs within fluvial sand and gravel comprising the lowest sedimentary unit of the Ringold Formation. It is confined below by basalt and above by the lower mud unit. Groundwater in this aquifer flows generally west to east in the vicinity of the 200 West Area. In the central portion of the aquifer, flow appears to converge into the 200 East Area from the west, south, and east. Groundwater likely discharges from the confined aquifer to the overlying unconfined aquifer where the confining mud unit has been removed by erosion.

While effluent disposal was occurring at the B Pond system, mounding within the unconfined aquifer in this area forced groundwater a limited distance into the Ringold Formation confined aquifer. During FY 2006, four wells were sampled that are completed in the Ringold Formation confined aquifer. Iodine-129 in a single well was the only contaminant present at concentrations above the drinking water standard.

Within the upper basalt-confined aquifer system, groundwater occurs within basalt fractures and joints, interflow contacts, and sedimentary interbeds. Groundwater in the upper basalt-confined aquifer generally flows from west to east across the Hanford Site, up through fractures or other pathways in the confining layers, into the unconfined aquifer, and into the Columbia River. Vertical gradients between the basalt-confined aquifer and the unconfined aquifer are upward on most of the Hanford Site. Downward gradients are measured in the west portion of the Hanford Site, near B Pond, and north and east of the Columbia River.

Tritium continued to be detected at low levels in some basalt-confined wells. One elevated tritium concentration near the 200 East Area is associated with intercommunication between the upper basalt-confined aquifer and the overlying unconfined aquifer (see Section 2.14). Iodine-129, strontium-90, gamma-emitting isotopes, and uranium isotopes were not detected above the minimum detection limits in the upper basalt-confined aquifer. Cyanide, nitrate, and technetium-99 were elevated in an upper basalt-confined aquifer well in the northwest part of the 200 East Area. Migration of high-salt waste from the vadose zone or unconfined aquifer via the well bore during well construction is responsible for this contamination.

\section{Shoreline Monitoring}

DOE monitors groundwater near the Columbia River via aquifer tubes, which are smalldiameter, flexible tubes that are implanted in the shallow aquifer and natural seepage points or springs. Results are discussed in the following paragraphs and along with other groundwater monitoring data in the applicable sections of this report.

Concentrations of strontium- 90 continued to exceed the $8-\mathrm{pCi} / \mathrm{L}$ drinking water standard in aquifer tubes in the 100-BC-5 and 100-NR-2 interest areas. Levels exceed the 1,000-pCi/L derived concentration guide in 100-N Area tubes.

Tritium concentrations exceeded the $20,000-\mathrm{pCi} / \mathrm{L}$ drinking water standard in springs at the Hanford town site, but were below the standard in aquifer tube samples.

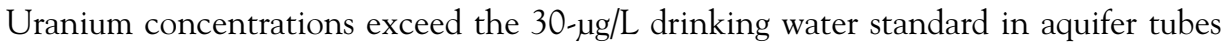
and springs in the 300 Area.

Hexavalent chromium concentrations exceeded the $100-\mu \mathrm{g} / \mathrm{L}$ drinking water standard in 100-D Area aquifer tubes. Concentrations in aquifer tubes or springs exceeded the $10 \mu \mathrm{g} / \mathrm{L}$ aquatic standard in the 100-B/C, 100-K, 100-D, 100-H, and 100-F Areas.

\section{Cyanide, nitrate, and technetium-99 were elevated in only one basalt- confined well. Contaminant migration via the well bore during well construction is suspected.}




\begin{tabular}{|c|c|}
\hline \multicolumn{2}{|c|}{ Wells Installed in 2006} \\
\hline Interest Area or RCRA Site & $\begin{array}{c}\text { Number of New Wells } \\
\text { FY } 2006\end{array}$ \\
\hline $100-K R-4$ & 4 \\
\hline 100-NR-2 & 29 \\
\hline 100-HR-3-H & 2 \\
\hline $200-Z P-1$ vadose characterization & 2 \\
\hline 200-UP-1 & 6 \\
\hline $300-F F-5$ & 4 \\
\hline Low-Level Waste Management Areas 3 and 4 & 4 \\
\hline Waste Management Area T & 2 \\
\hline Total & 53 \\
\hline
\end{tabular}

Nitrate concentrations exceed the 45-mg/L drinking water standard in aquifer tubes at the 100-K, 100-D, $100-\mathrm{H}$, and 300 Areas. Levels have exceeded the standard in a tube downgradient of the 100-F Area in the past, but the tube was not sampled in FY 2006. Levels and springs were below the standard.

Trichloroethene is detected in several aquifer tubes in the 300 Area. Most results were below the $5-\mu g / L$ drinking water standard, but one sample from September 2006 detected $96 \mu \mathrm{g} / \mathrm{L}$ in the deepest tube at site AT-3-3.

\section{Well Installation, Maintenance, and Decommissioning}

A complete discussion of the well installation, maintenance, and decommissioning can be found in Chapter 4. DOE installs new wells when needed for monitoring or characterization, maintains wells to repair problems, and decommissions wells that are no longer needed. Ecology, EPA, and DOE worked together to develop a prioritized list of new wells needed to meet requirements of various groundwater monitoring regulations. Fifty-three new wells were installed during FY 2006. These include monitoring wells and wells to support tests of new technologies for groundwater remediation.

Approximately 7,544 unique well identification numbers have been identified within the Hanford Site. These include all wells, characterization boreholes, aquifer tubes, soil gas probes, piezometers, or other subsurface installations. To date, a total of 3,094 (41\%) have been either administratively removed from the well inventory or decommissioned (sealed with grout) because they were no longer needed, were in poor condition, were in

During FY 2006,

82 unneeded wells

were physically

decommissioned

and filled with

grout; 2,934 wells

remain in use. the path of intended remediation or construction activities, or posed an environmental, safety, or public health hazard. DOE maintains a list of wells that are candidates for decommissioning. All candidate wells must be reviewed and approved by potential well users prior to decommissioning. During FY 2006, a total 2,934 wells were in use and 82 vadose zone wells were physically decommissioned (filled with grout).

\section{Vadose Zone}

Subsurface source characterization, vadose zone monitoring, soil-vapor monitoring, and sediment sampling were conducted in FY 2006. The complete discussion of these activities can be found in Chapter 3.

Leachate Monitoring at Environmental Restoration Disposal Facility. This facility is used for disposal of radioactive and mixed waste generated during waste management and remediation activities at the Hanford Site. The facility is lined, and there is no evidence of impacts to groundwater.

Leachate and Soil-Gas Monitoring at Solid Waste Landfill. Leachate is sampled and tested quarterly. Concentrations in the past year were similar to previous concentrations and did not identify any areas of concern. Soil gas is monitored quarterly to determine concentrations of oxygen, carbon dioxide, methane, and several key volatile organic compounds. Results were consistent with previous years. Contaminants of concern were near or below detection limits.

Soil-Vapor Extraction. This remedial action is being used to remove carbon tetrachloride from the vadose zone in the 200 West Area. As of September 2006, 78,900 kilograms of carbon tetrachloride have been removed from the vadose zone since extraction operations started in 1991. 
Tank Farms Investigations. DOE conducted a series of sampling efforts inside tank farms during FY 2006. To accomplish the work, a recently developed version of direct push technology was used. This direct push approach, the Hydraulic Hammer Unit, was demonstrated in several areas both inside and outside of the tank farms. The Hydraulic Hammer Unit provides optimal mobility for operating in the tank farm environment where infrastructure precludes access by many larger pieces of drilling equipment. Rates of advancement are as high as a few meters per minute.

In FY 2006, DOE conducted investigations of the T and S Tank Farms and surrounding areas for subsurface contamination using electrical resistivity methods. The primary objective of this investigation was to demonstrate the ability to map subsurface contamination in and around the tank farms using electrical resistivity methods. The results show that the demonstration was successful and that technical challenges associated with deploying these methods in a tank farm environment can be managed by a combined analysis of data acquired from both surface electrodes and steel-cased wells. Additionally, the method provides a basis for defining regions that are free from contamination.

Hanford scientists performed detailed analyses on vadose zone sediments from C Tank Farm. In FY 2006, a report was published containing all the geologic, geochemical, and selected physiochemical characterization data collected on vadose zone sediment recovered from two boreholes. Results indicated there is no similarity between the present or past groundwater contamination and current pore water compositions from the contaminated borehole sediments.

Borehole Geophysics. Radiation measurements by borehole geophysical methods have been performed since the early days of the Hanford Site to detect manmade radionuclides in the subsurface. During 2006, DOE logged 128 boreholes. Of these, eight were classified as baseline logging. Sixty-nine, or more than half, were logged in support of the well decommissioning program. Another 29 boreholes were logged in support of remedial investigation efforts, and 22 groundwater wells were logged.

Tank Farm Interim Cover Test. The largest known Hanford Site tank leak occurred from the T-106 tank in 1973. Many of the contaminants from that leak still reside within the vadose zone beneath the T Tank Farm. DOE seeks to minimize movement of this residual contamination by placing an interim cover on the surface. In FY 2006, two instrument nests were installed to monitor the future cover. Each instrument nest contains a neutron probe access tube, five sensors to measure water content, four heat-dissipation units to measure water potential, and a drain gauge to measure soil water flux.

\section{Continued Monitoring}

DOE will continue to monitor groundwater to meet the requirements of AEA, CERCLA, RCRA, and DOE Orders. During ongoing groundwater remediation, the groundwater project will monitor, assess, and report on activities at groundwater operable units. Both the unconfined and upper-confined aquifers are monitored and data are maintained and managed in a centralized database. Monitoring well locations, frequencies, and analytical constituents will continue to be documented each year. Water-level monitoring will continue to be performed to characterize groundwater flow and to determine the impact of Hanford Site operations on the flow system.

As such, groundwater monitoring remains a part of the Hanford Site baseline throughout the cleanup mission and will remain a component of long-term stewardship after remediation is completed.

Details about the Hanford Site Groundwater Remediation Project can be found online at http://www.hanford.gov/cp/gpp/. 


\section{Contents}

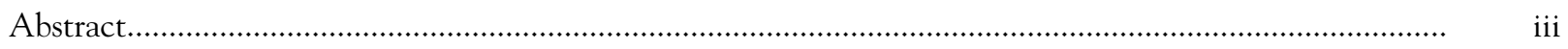

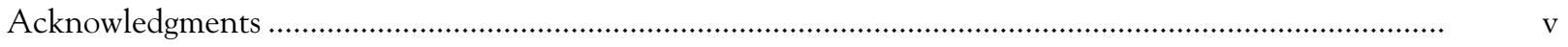

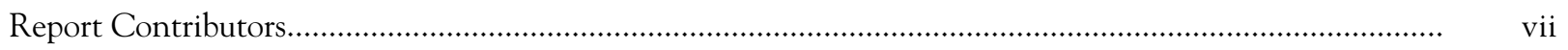

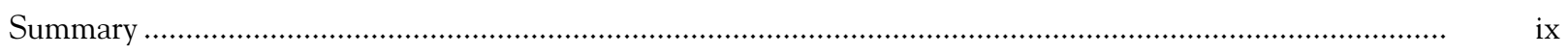

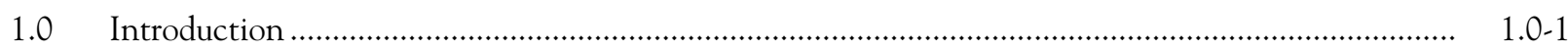

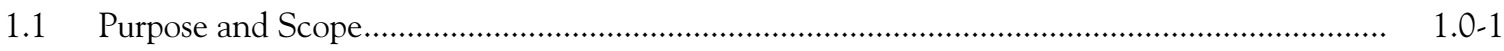

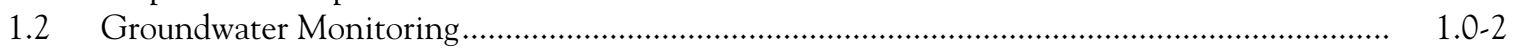

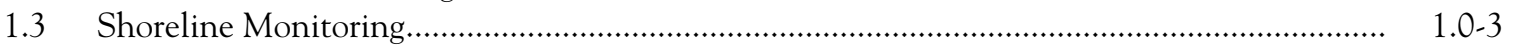

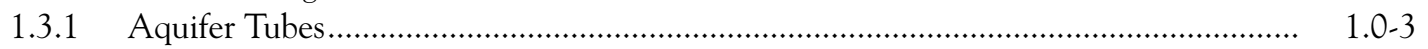

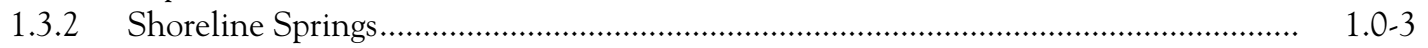

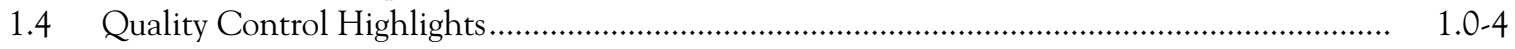

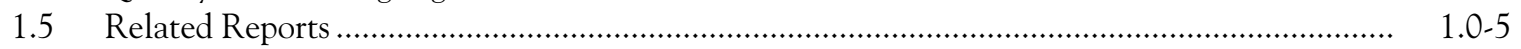

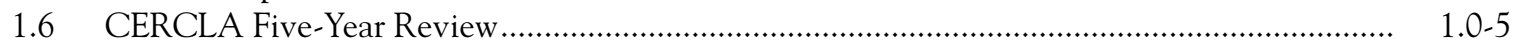

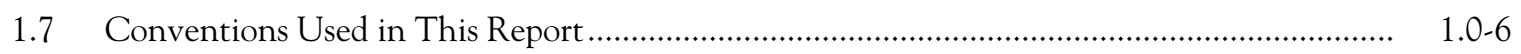

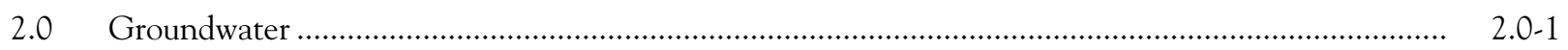

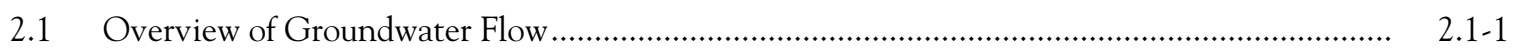

2.1.1 Water-Table Interpretation for April/May 2006 ............................................... 2.1-1

2.1.2 Water-Table Change from FY 2005 ......................................................................... 2.1 2.3

2.1.3 Fluctuations in the 200 East Area Water-Table Elevation..................................... 2.1-4

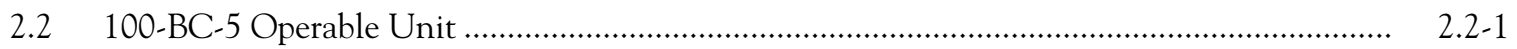

2.2.1 Groundwater Contaminants..................................................................... 2.2-1

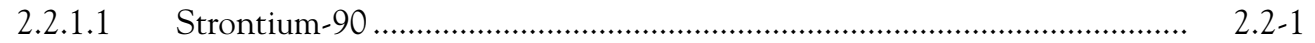

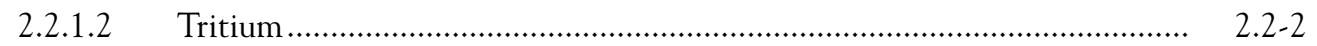

2.2.1.3 Chromium ............................................................................... 2... 2.2

2.2.1.4 Nitrate .......................................................................................... $2.2-3$

2.2.2 Operable Unit Monitoring and Risk Assessment ............................................... 2.2-3

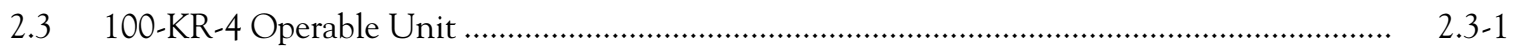

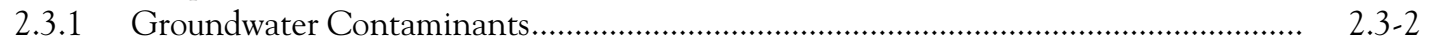

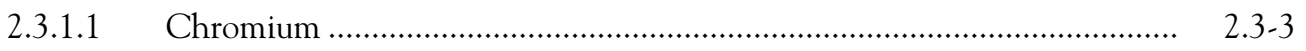

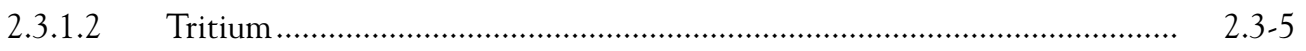

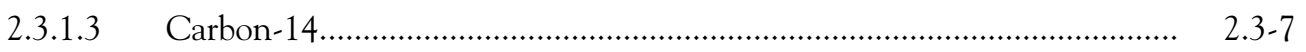

2.3.1.4 Strontium-90 .................................................................................. 2... 2.

2.3.1.5 Other Constituents ........................................................................... 2... 2.8

2.3.2 Interim Remedial Action for Chromium in Groundwater ........................................ 2.3-9

2.3.2.1 Progress During FY 2006 ..................................................................... 2... 2.3 10

2.3.2.2 Influence on Aquifer Conditions ........................................................ 2... 2.3-10

2.3.2.3 New Pump-and-Treat System Near KW Reactor .................................. 2.. 2-11

2.3.3 Facility Monitoring $-\mathrm{K}$ Basins ........................................................................ 2.3 2.11

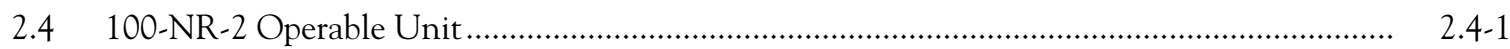

2.4.1 Groundwater Contaminants............................................................................ 2... 2.

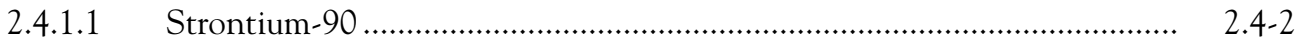

2.4.1.2 Tritium ...................................................................................... 2.4.3

2.4.1.3 Nitrate ...................................................................................... $2.4-4$

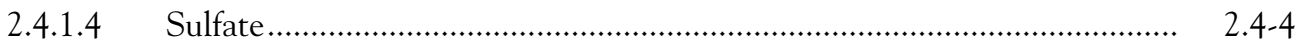

2.4.1.5 Petroleum Hydrocarbons ................................................................ 2.4 
2.4.1.6 Manganese and Iron ............................................................................. 2... 2.5

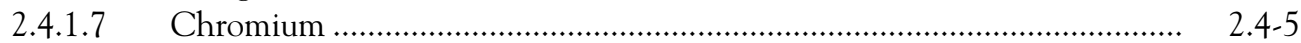

2.4.2 Interim Groundwater Remediation for Strontium-90 ........................................... 2... 2.5

2.4.2.1 Pump-and-Treat System ...................................................................... 2... 2.6

2.4.2.2 Permeable Reactive Barrier ....................................................................... 2... 2.4

2.4.2.3 Phytoremedition .................................................................................. 2...

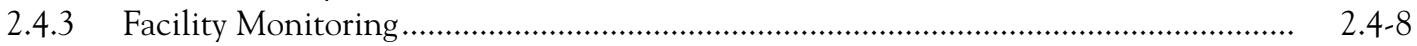

2.4.3.1 116-N-1 Liquid Waste Disposal Facility ................................................ 2.. 2.4-8

2.4.3.2 120-N-1 Percolation Pond and 120-N-2 Surface Impoundment .............. 2.. 2.4-9

2.4.3.3 116-N-3 Liquid Waste Disposal Facility ...................................................... 2.. 2.4-9

2.4.4 Geophysical Investigation ……....................................................................... 2... 2.4-10

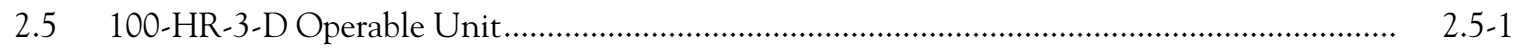

2.5.1 Groundwater Contaminants......................................................................... 2.... 2.1

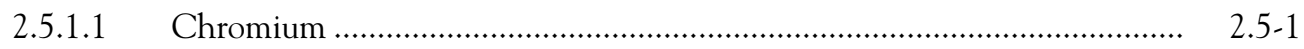

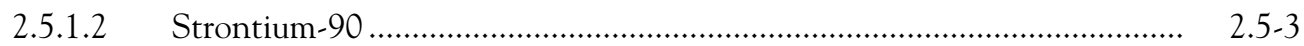

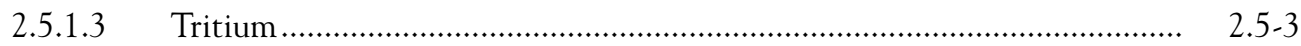

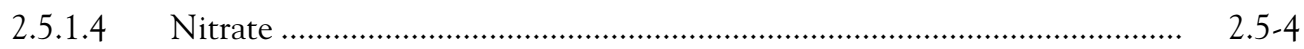

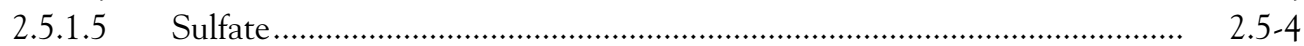

2.5.1.6 Gross Beta............................................................................. 2... 2.5

2.5.2 Interim Groundwater Remediation for Chromium................................................... 2.. 2.5-4

2.5.2.1 Pump-and-Treat Systems................................................................... 2... 2.5-4

2.5.2.2 In Situ Redox Manipulation System....................................................... 2... 2.5-5

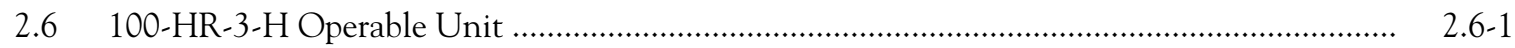

2.6.1 Groundwater Contaminants.............................................................................. 2. $2.6-1$

2.6.1.1 Chromium ................................................................................... 2.6.

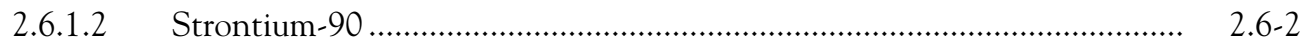

2.6.1.3 Technetium-99 and Uranium............................................................. 2..6-2

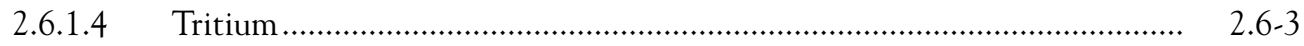

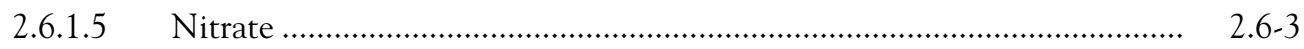

2.6.2 Interim Groundwater Remediation for Chromium.................................................... 2.. 2.6-3

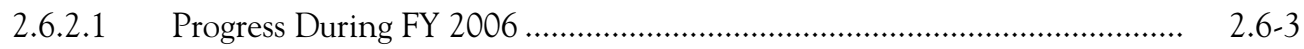

2.6.2.2 Influence on Aquifer Conditions ...................................................... 2... 2.6-4

2.6.3 Facility Monitoring - 116-H-6 Evaporation Basins ..................................................... 2.. 2.6-5

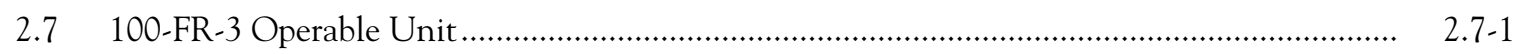

2.7.1 Groundwater Contaminants............................................................................... 2.7

2.7.1.1 Nitrate ……............................................................................. $2.7-1$

2.7.1.2 Strontium-90 ............................................................................... $2.7-2$

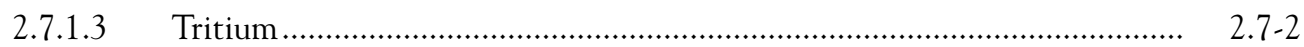

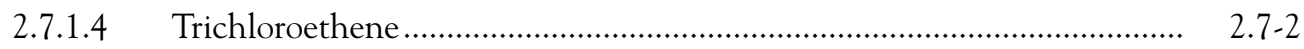

2.7.1.5 Uranium and Gross Alpha ..................................................................... 2... 2.2

2.7.1.6 Hexavalent Chromium …………….................................................... 2... 2.7-3

2.7.1.7 Other Constituents ........................................................................... 2... 2.7-3

2.7.2 Operable Unit Monitoring ………........................................................................... $2.7-3$

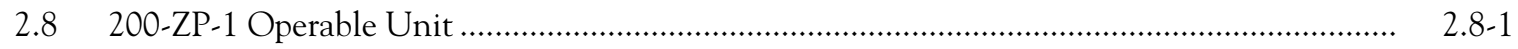

2.8.1 Groundwater Contaminants......................................................................... 2... 2.8

2.8.1.1 Carbon Tetrachloride ................................................................... 2... 2.8

2.8.1.2 Trichloroethene .................................................................................. 2.. 2.8-4

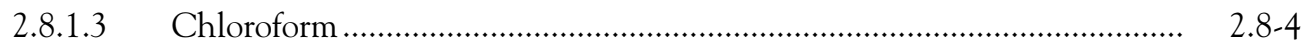

2.8.1.4 Nitrate ….................................................................................. 2.. 2.8-4

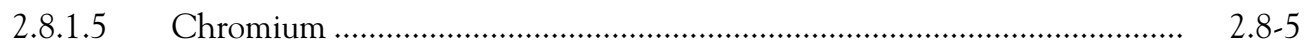

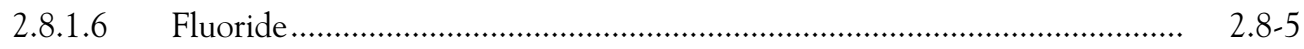




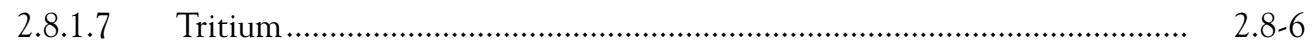

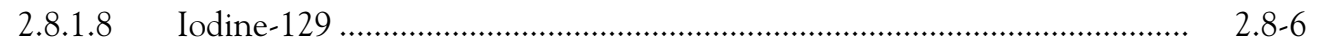

2.8.1.9 Technetium-99 .......................................................................... 2.8

2.8.1.10 Uranium ........................................................................................ 2.8.

2.8.1.11 Other Contaminants of Concern............................................................ 2.. 2.8-7

2.8.2 CERCLA Investigations and Interim Groundwater Remediation for Carbon

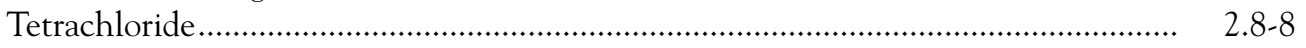

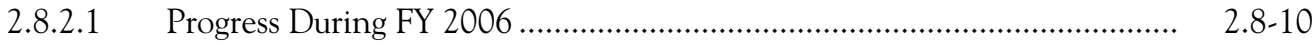

2.8.2.2 Influence on Aquifer Conditions ............................................................. 2... 2.8-11

2.8.3 Facility Monitoring ......................................................................................... $2.8-12$

2.8.3.1 Low-Level Waste Management Area 3 ..................................................... 2... 2.8-12

2.8.3.2 Low-Level Waste Management Area 4.................................................. 2... 2.8-13

2.8.3.3 Waste Management Area T ..................................................................... 2... 2.8-15

2.8.3.4 Waste Management Area TX-TY ............................................................ 2.. 2.8-18

2.8.3.5 Groundwater Monitoring for the State-Approved Land Disposal Site..... 2. 2.8-20

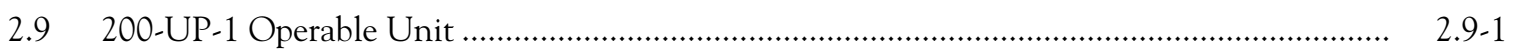

2.9.1 Groundwater Contaminants.................................................................................... 2.. 2.9-2

2.9.1.1 Technetium-99 ..................................................................... $2.9-3$

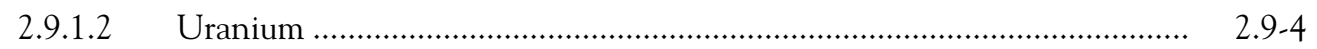

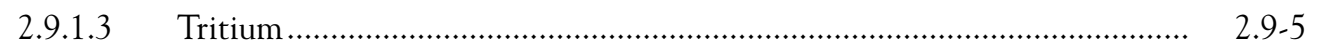

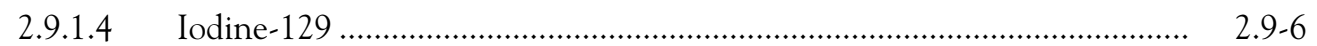

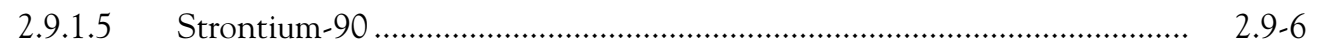

2.9.1.6 Chlorinated Hydrocarbons........................................................................ 2.9.7

2.9.1.7 Chromium …................................................................................ 2.9.7

2.9.1.8 Nitrate ……................................................................................... 2.9.

2.9.1.9 Other Constituents ................................................................................. 2.. 2.9

2.9.2 Interim Groundwater Remediation for Technetium-99 and Uranium ...................... 2.9-10

2.9.2.1 Progress During FY 2006 .................................................................... 2.9-11

2.9.2.2 Influence on Aquifer Conditions ............................................................ 2..9-12

2.9.3 Facility Monitoring ............................................................................................... 2.9. 2.9

2.9.3.1 Single-Shell Tank Waste Management Area U ......................................... 2... 2.9-13

2.9.3.2 Single-Shell Tank Waste Management Area S-SX ……………............... 2... 2.9-14

2.9.3.3 216-S-10 Pond and Ditch .................................................................... 2...9-16

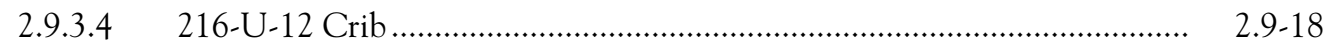

2.9.3.5 Environmental Restoration Disposal Facility …………............................ 2.. 2.9-19

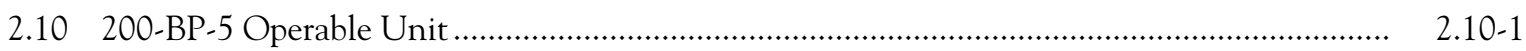

2.10.1 Groundwater Contaminants................................................................................. 2.. 2.10-2

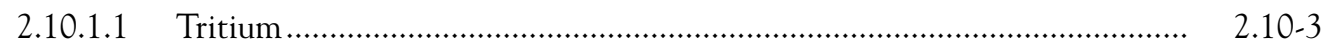

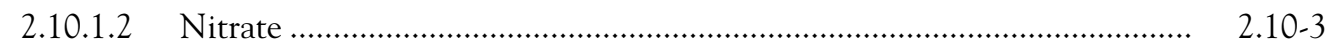

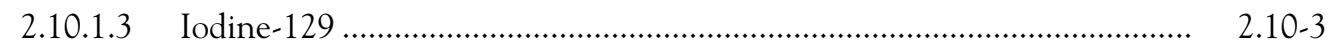

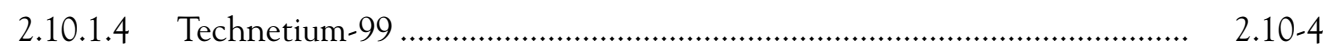

2.10.1.5 Cobalt-60 and Cyanide ….......................................................... 2.10-4

2.10.1.6 Uranium ......................................................................... $2.10-5$

2.10.1.7 Cesium-137 and Strontium-90 _...................................................... 2.10-6

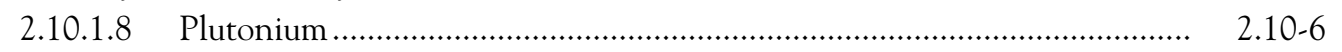

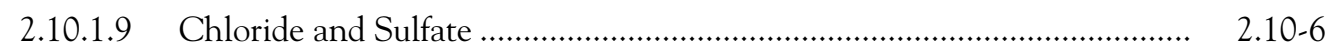

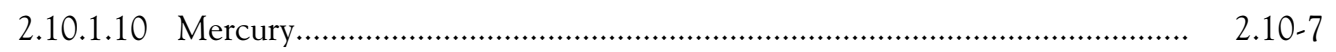

2.10.2 Operable Unit Monitoring ……........................................................................ 2... 2.10-7

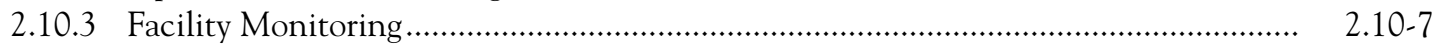

2.10.3.1 Waste Management Area B-BX-BY......................................................... 2... 2.10-8

2.10.3.2 216-B-63 Trench ................................................................................ 2.10-13

2.10.3.3 Low-Level Waste Management Area 1....................................................... 2.10-13 
2.10.3.4 Low-Level Waste Management Area 2 ....................................................... 2.10-16

2.10.3.5 Liquid Effluent Retention Facility......................................................... 2.10-18

2.10.3.6 Waste Management Area C................................................................. 2.10-18

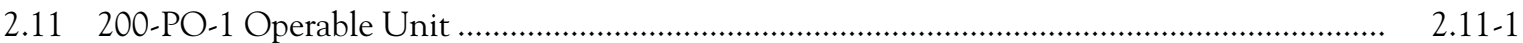

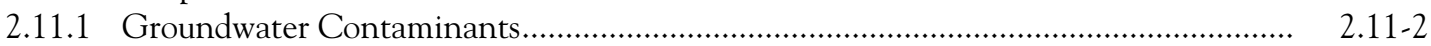

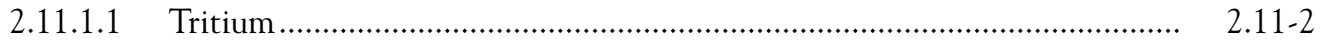

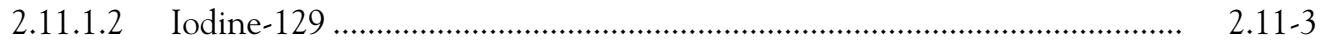

2.11.1.3 Nitrate …............................................................................................ 2.11-3

2.11.1.4 Strontium-90 ...................................................................................... 2.11-4

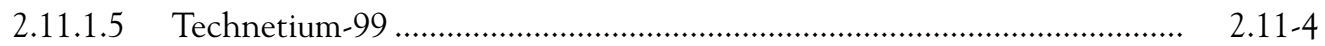

2.11.1.6 Other Constituents ................................................................................... 2... 2.11-5

2.11.2 Operable Unit Monitoring ................................................................................ 2.11-6

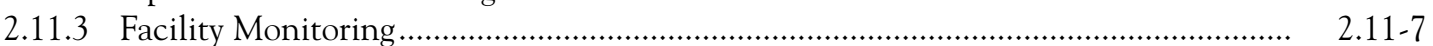

2.11.3.1 Integrated Disposal Facility ................................................................. 2.11-8

2.11.3.2 RCRA PUREX Cribs ......................................................................... 2.11-9

2.11.3.3 Single-Shell Tank Waste Management Area A-AX ……......................... 2. 2.11-10

2.11.3.4 216-A-29 Ditch .................................................................................... 2.11-12

2.11.3.5 216-B-3 Pond Facility …………………................................................ 2... 2.11-12

2.11.3.6 200 Area Treated Effluent Disposal Facility.............................................. 2... 2.11-13

2.11.3.7 Nonradioactive Dangerous Waste Landfill .............................................. 2... 2.11-14

2.11.3.8 Solid Waste Landfill .......................................................................... 2.11-14

2.11.3.9 400 Area Water Supply Wells............................................................... 2... 2.11-17

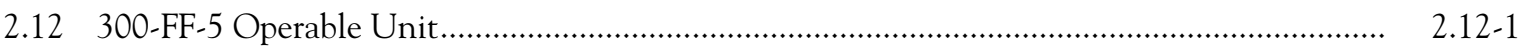

2.12.1 Groundwater Contaminants......................................................................... 2... $2.12-2$

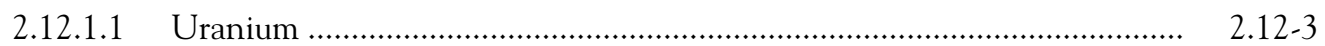

2.12.1.2 Volatile Organic Compounds............................................................... 2... 2.12-5

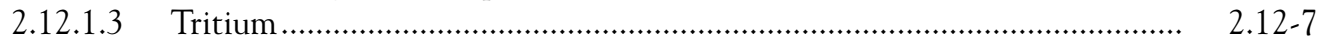

2.12.1.4 Other Constituents .................................................................................. 2.12-7

2.12.2 Operable Unit Interim Remedial Action.................................................................. 2... 2.12-9

2.12.2.1 Five-Year Reviews of Record of Decision................................................. 2... 2.12-9

2.12.2.2 Interim Remedial Action Monitoring ……………………………........... 2... 2.12-10

2.12.3 Phase III Feasibility Study …………...................................................................... 2..12-11

2.12.3.1 Evaluation of Remedial Action Alternatives for 300 Area Uranium ....... 2.12-11

2.12.3.2 Limited Field Investigation Drilling Project, 300 Area ............................. 2.12-11

2.12.3.3 Simulation of Groundwater Flow and Transport .................................... 2.12-13

2.12.3.4 Research Activities Involving the 300 Area Uranium Plume ................. 2. 2.12-13

2.12.3.5 Update to Human Health and Ecological Risk Assessment...................... . 2.12-14

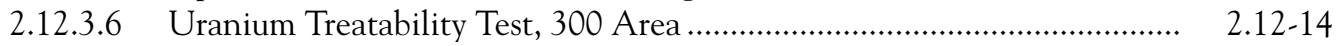

2.12.4 Facility Monitoring: RCRA Compliance at 300 Area Process Trenches ................... 2.12-15

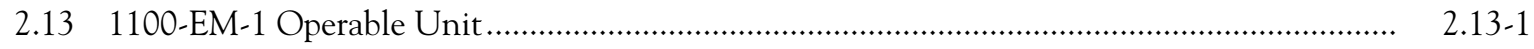

2.13.1 Groundwater Contaminants.................................................................................... 2... 2.13-1

2.13.1.1 Chlorinated Hydrocarbons............................................................. 2.13-2

2.13.1.2 Tritium ............................................................................. $2.13-3$

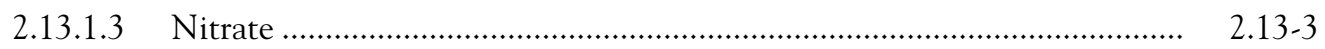

2.13.1.4 Gross Alpha and Uranium ................................................................. 2... 2.13-4

2.13.1.5 Other Constituents ............................................................................... 2... 2.13-4

2.13.2 Operable Unit Monitoring ………….................................................................. 2... 2.13-4

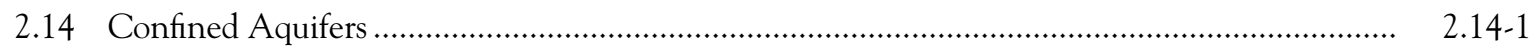

2.14.1 Ringold Formation Confined Aquifer .................................................................. 2.14-1

2.14.1.1 Groundwater Flow in the Ringold Formation Confined Aquifer............. 2.14-1

2.14.1.2 Groundwater Quality in the Ringold Formation Confined Aquifer ......... 2.14-2 
2.14.2 Upper Basalt-Confined Aquifer.

2.14.2.1 Groundwater Flow in the Upper Basalt-Confined Aquifer ....................... 2.14-3

2.14.2.2 Groundwater Quality in the Upper Basalt-Confined Aquifer................... 2.14-4

3.0 Vadose Zone Monitoring, Characterization, and Special Studies..................................................... 3.0-1

3.1 Vadose Zone Monitoring...................................................................................................

3.1.1 Leachate Monitoring at the Environmental Restoration Disposal Facility ................ 3.1-1

3.1.2 Leachate and Soil-Gas Monitoring at the Solid Waste Landfill .................................. 3.1-2

3.1.3 Carbon Tetrachloride Monitoring and Remediation .................................................... 3.. 3.1-3

3.1.3.1 Soil-Vapor Extraction................................................................. 3.1.

3.1.3.2 Monitoring at Off-Line Wells and Probes............................................... 3.1-4

3.1.3.3 Passive Soil-Vapor Extraction ..................................................................... 3.1-5

3.2 Selected Vadose Zone Characterization Studies...................................................................... 3.2-1

3.2.1 Application of Direct Push Technology in Tank Farms........................................... 3... 3.2

3.2.2 Hanford Geophysical Logging ................................................................................. 3.2.

3.2.2.1 Logging Systems in Use at Hanford ............................................................ 3... 3.2-2

3.2.2.2 Detection of Manmade Uranium ............................................................... 3.2.

3.2.2.3 Detection of Uranium in the Vadose Zone at 200-BP-5 Groundwater Operable Unit ................................................................................. $3.2-4$

3.2.3 Plutonium/Organic-Rich Group Operable Unit Characterization .............................. 3.2-4

3.3 Vadose Zone Studies.............................................................................................................. 3..

3.3.1 Assessment of the Chloride Mass Balance Technique: Accounting for Gravel

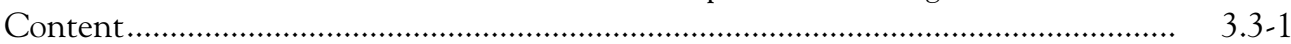

3.3.2 T Tank Farm Interim Cover Test.............................................................................. $\quad 3.3-2$

3.3.3 Estimation of Recharge from Well 699-S20-E10 Using Chloride Mass Balance ........ 3. 3.3-3

3.3.4 Extension of the Tensorial Connectivity-Tortuosity Concept to Multifluid Systems in Porous Media ........................................................................................... 3.. 3-4

3.4 Related Vadose Zone Studies Published in Fiscal Year 2006 .................................................. 3... 3-1

3.4.1 Subsurface Geophysical Exploration of T Tank Farm at the Hanford Site ................. 3.4-1

3.4.2 Surface Geophysical Exploration of S Tank Farm at the Hanford Site ....................... 3.4.5

3.4.3 Characterization of Vadose Zone Sediments Below the C Tank Farm ........................ 3.4-7

3.4.4 Vadose Zone Transport Field Study ………........................................................... 3.4.

3.4.5 Development of Analytical Methods for Anionic Fission Products and Application to Sediment and Groundwater Samples from Tank Farm Waste Management Areas............................................................................................. 3... 3-11

3.4.6 Vadose Zone Hydrogeology Data Package for Hanford Assessments............................ 3.. 3.4-12

3.4.7 Continued Development of a Prototype Borehole Geologic Database ....................... 3.4.13

3.4.8 Low-Flux Measurements in Desert Settings Using Water Fluxmeters......................... 3.. 3.14

4.0 Well Installation, Maintenance, and Decommissioning ............................................................... $4.0-1$

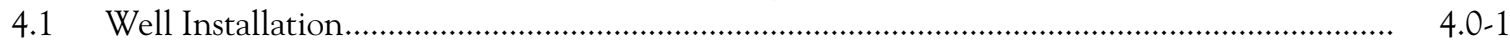

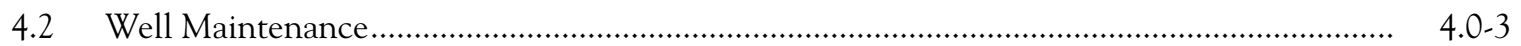

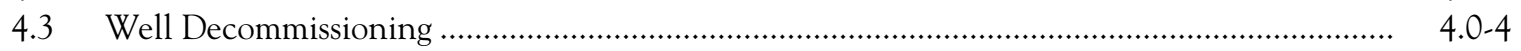

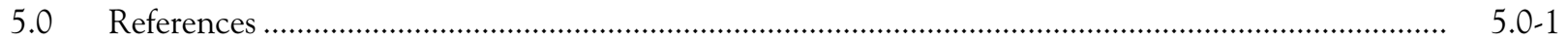

Appendix A - Supporting Information for CERCLA Groundwater Operable Units ................................... A.1

Appendix B - Supporting Information for Monitored Facilities................................................................ B. B.

Appendix C - Quality Assurance and Quality Control ............................................................................... C.1 


\section{Tables}

1.0-1 Reporting Requirements for Groundwater Monitoring ….................................................... 1.0-8

1.0-2 Number of Groundwater Analyses by Groundwater Interest Area, FY 2006 ............................. 1.0-9

1.0-3 Maximum Concentrations of Selected Groundwater Contaminants in Groundwater Interest Areas, FY 2006

1.0-4 Drinking Water Standards.

1.0-5 Derived Concentration Guides and 4-mrem Effective Dose Equivalent Concentrations for Drinking Water .....

2.3-1 Issues and Actions for 100-K Area Groundwater in Second CERCLA Five-Year Review..............

2.5-1 Issues and Actions for 100-D Area Groundwater in Second CERCLA Five-Year Review............

2.8-1 Contaminants of Concern in all Wells in the 200-ZP-1 Groundwater Interest Area, FY 2006 .

2.8-2 Contaminants of Concern for Risk Evaluation in the Feasibility Study .....

2.9-1 Quantity of Treated Groundwater and Technetium-99 Mass Removed from the Aquifer during Extended Purging at Well 299-W23-19, FY 2006

2.11-1 Ranges of Reported Chlorinated Hydrocarbon Concentrations in Solid Waste Landfill Wells, FY 2006.

2.14-1 Potential Contaminants of Interest in Ringold Formation Confined Aquifer, FY 2004 through FY 2006 .

2.14-2 Potential Contaminants of Interest in Upper Basalt-Confined Aquifer, FY 2004 through 2006 ...

3.1-1 Solid Waste Landfill Leachate Monitoring Results - Key Constituents....................................... 3.1-6

3.1-2 Carbon Tetrachloride Inventory Removed by Vapor Extraction from Primary Disposal Sites ..... 3.1-7

3.2-1 Direct Push Summary Table ................................................................................................ $3.2-10$

3.2-2 Hanford Geophysical Logging Project Logging Systems ......................................................... $\quad 3.2-10$

3.2-3 Number of Samples Collected as Part of 200-PW-1 Operable Unit Remedial Investigation ....... 3.2-11

3.3-1 Percent Gravel, Sand, Silt, and Clay of Core Samples ............................................................. 3... 3-6

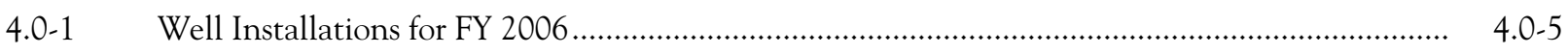

4.0-2 Characterization Boreholes, Soil-Gas Probes, and Push Technology Installation for FY 2006.

4.0-3 Well Maintenance Summary for FY 2006 ........................................................................... 4.0-9

4.0-4 Vadose Zone Wells Decommissioned during FY 2006 ............................................................. $\quad 4.0-10$ 


\section{Figures}

1.0-1 Groundwater Operable Units and Groundwater Interest Areas on the Hanford Site ................. 1.0-14

1.0-2 Average FY 2006 Tritium Concentrations on the Hanford Site, Upper Part of Unconfined Aquifer.

1.0-3 Average FY 2006 Nitrate Concentrations on the Hanford Site, Upper Part of Unconfined Aquifer.

1.0-4 Average FY 2006 Iodine-129 Concentrations on the Hanford Site, Upper Part of Unconfined Aquifer.

1.0-5 Maximum Dissolved Chromium in Aquifer Tubes, FY 2006 …................................................ 1.0-18

2.1-1 Groundwater Monitoring Wells on the Hanford Site.

2.1-2 Hanford Site and Outlying Areas Water-Table Map, April/May 2006 ....................................... 2.1-9

2.1-3 Water Levels in Well 299-E33-32, Northwest 200 East Area.....

2.1-4 Water-Level Elevations in Well 299-E33-32 and Monthly Effluent Discharge Volumes at the 200 Area Treated Effluent Disposal Facility.

2.1-5 Average Monthly Discharge in the Columbia River.

2.2-3 Strontium-90 Concentrations Near the 116-B-11 Retention Basin

2.2-4 Sample Elevations and Strontium-90 Concentrations in Wells and Aquifer Tubes in 100-B/C Area.

2.2-5 Average Tritium Concentrations in 100-B/C Area, Upper Part of Unconfined Aquifer.......

2.2-9 Sample Elevations and Chromium Concentrations in Wells and Aquifer Tubes in 100-B/C Area.

2.3-1 Location Map for 100-K Area Monitoring Wells, Shoreline Monitoring Sites, Waste Sites, and Facilities.

2.3-2 Chromium Concentrations in Upper Part of Unconfined Aquifer Beneath 100-K Area, Average Values for FY 2005 and $2006 .$.

2.3-3 Chromium Concentrations at Aquifer Tube Sites Along the 100-K Shoreline Adjacent to the Reactors, February/March 2006

2.3-4 Chromium Concentrations at Aquifer Tube Sites Along the 100-K Shoreline Adjacent to the Former 100-K Trench, February/March 2006.

2.3-5 Chromium Concentrations at Wells Located at the Southwest Edge of the 100-K Trench Plume...

2.3-6 Chromium Concentrations at Wells Located in the Central Portion of the 100-K Trench Plume.

2.3-7 Chromium Concentrations at Wells Located at the Northeast Edge of the 100-K Trench Plume......

2.3-8 Chromium Concentrations in Groundwater Near KE Water Treatment Plant Basins................ 2. 2.3-20

2.3-9 Chromium Concentrations in Groundwater Near KW Reactor Building …............................... 2.3-20

2.3-10 Chromium Concentrations in Groundwater Downgradient of the KW Reactor Building ........... 2.3-21 
2.3-11 Tritium Concentrations in Upper Part of Unconfined Aquifer Beneath 100-K Area, Average Values for FY 2005 and 2006.

2.3-12 Tritium and Carbon-14 Concentrations in Groundwater Near Former KE Condensate Crib.

2.3-13 Tritium Concentrations in Groundwater Near KE Basin

2.3-14 Tritium and Carbon-14 Concentrations in Groundwater Near Former KW Condensate Crib

2.3-15 Tritium Concentrations in Groundwater Near KW Basin

2.3-16 Tritium Concentrations in Groundwater Near 100-K Burial Ground.

2.3-17 Tritium Concentrations at Wells Downgradient of the Injection Site for Treated Effluent from 100-K Trench Pump-and-Treat System

2.3-18 Carbon-14 and Tritium Plumes Between Former KW and KE Condensate Cribs and the Columbia River

2.3-19 Strontium-90 Concentrations and Water-Table Elevation Near KE Basin

2.3-20 Chromium Concentration Trends at Aquifer Tube Sites Along Central Portion of 100-K Trench Plume.

2.3-21 Chromium Concentration Trends at Aquifer Tube Sites Along North Portion of 100-K Trench Plume......

2.4-1 Groundwater Monitoring Wells in 100-N Area

2.4-2 Aquifer Tubes, Seep Wells, and Monitoring Wells on 100-N Shoreline...

2.4-3 100-N Area Water-Table Map, April 2006

2.4-4 Water Levels in 100-N Area Monitoring Wells and the Columbia River..

Stratigraphy and Vertical Strontium-90 Distribution at 100-N Area Shoreline in the Center of Strontium-90 Plume.

2.4-9 Strontium-90 Concentrations in Vertical Profile Aquifer Tubes at 100-N Area, June $2006 .$.

2.4-10 Strontium-90 Concentrations and Water Level Near 116-N-1 Facility.

2.4-11 Strontium-90 Concentrations in Former Extraction Wells in 100-N Area

2.4-12 Gross Beta Concentrations in Vertical Profile Aquifer Tubes with Daily Average River Stage at $100-\mathrm{N}$ Area

2.4-13 Tritium Concentrations Near the 116-N-1 and 116-N-3 Facilities.

2.4-14 Average Nitrate Concentrations in 100-N Area, Upper Part of Unconfined Aquifer..

2.4-15 Nitrate Concentrations Near 116-N-1 Facility.

2.4-16 Nitrate Concentrations Near 116-N-3 Facility

2.4-17 Nitrate Concentrations Near 120-N-1 Percolation Pond in South 100-N Area..

2.4-18 Dissolved Chromium in Well 199-N-64

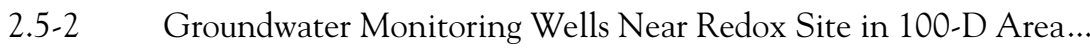

2.5-3 100-D Area Water-Table Map, April 2006

2.5-4 Dissolved Chromium Concentrations in 100-D and 100-H Areas, Upper Part of Unconfined Aquifer. 
2.5-6 Dissolved Chromium Concentrations at Selected Aquifer Tube Sites at 100-D Area

2.5-7 Cross-Section Parallel to Shoreline in 100-D Area Showing Aquifer Tube Depths, Projected Well Screen Intervals, and Dissolved Chromium Concentrations

2.5-8 Chromium Concentrations in Wells Near Former D Reactor

2.5-9 Dissolved Chromium Concentrations and Water Levels in Compliance Wells for 100-HR-3 Pump-and-Treat System at 100-D Area

2.5.10 Dissolved Chromium Concentrations in Central 100-D Area.

$2.5-18$

2.5-11 Dissolved Chromium Concentrations Southeast of 182-D Reservoir.....

$2.5-18$

2.5-12 Dissolved Chromium Concentrations in Compliance Wells Downgradient of Redox Barrier.....

2.5-13 Dissolved Chromium Concentrations in Aquifer Tubes Downgradient of Redox Barrier .............

Tritium Concentrations in South 100-D Area.

$2.5-19$

$2.5-20$

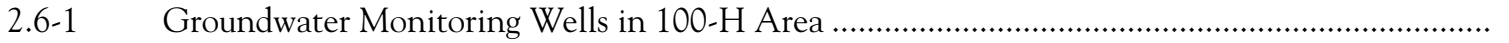

2.6-3 Chromium Concentrations East of 116-H-6 Evaporation Basins

2.6-4 Chromium Concentrations in Extraction Wells for 100-HR-3 Pump-and-Treat System at $100-\mathrm{H}$ Area

2.6-5 Chromium Concentrations Upgradient of 100-H Area .....

2.6-6 Sample Elevations and Chromium Concentrations in Wells and Aquifer Tubes in 100-H Area

2.6-7 Chromium Concentrations in Aquifer Tubes South of 100-H Area

2.6-10

2.6-8 Technetium-99, Uranium, Chromium, and Nitrate Concentrations East of 116-H-6 Evaporation Basins

$2.6-11$

2.6-9 Technetium-99 Concentrations Northeast of 116-H-6 Evaporation Basins ................................ 2.6-13

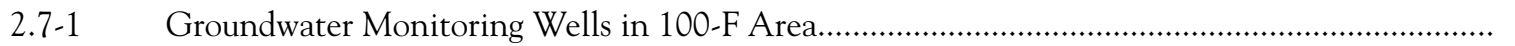

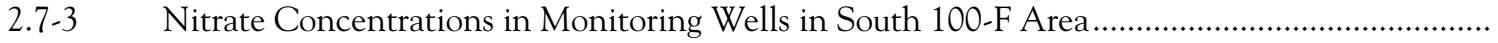

2.7-6 Sample Elevations and Strontium-90 Concentrations in Wells and Aquifer Tubes in 100-F Area

2.7-7 Tritium Concentrations Near 118-F-6 Burial Ground.....

2.7-9 Uranium and Gross Alpha Concentrations in Well 199-F5-46, West of 116-F-14

Retention Basins

2.7-10 Dissolved Chromium Concentrations in Well 199-F5-6 in Northeast 100-F Area

2.7-11 Sample Elevations and Chromium Concentrations in Wells and Aquifer Tubes in 100-F Area

2.7-12 Gross Beta and Tritium Concentrations Near 118-F-6 Burial Ground ........................................ 2.. 2-11

2.8-1 Groundwater Monitoring Wells in 200 West Area....................................................................... 2.. 2.8-27

2.8-2 200 West Area Water-Table Map, April/May 2006

2.8-3 Average Carbon Tetrachloride Concentrations in 200 West Area, Upper Part of Unconfined Aquifer

2.8-4 Carbon Tetrachloride Concentrations at Well 699-48-71, Northeast of the 200 West Area....... 
2.8-5 Hydrogeologic Cross Section for Wells with Depth-Discrete Carbon Tetrachloride Concentration Data, Northwest to Southeast.....

2.8-6 Hydrogeologic Cross Section for Wells with Depth-Discrete Carbon Tetrachloride Concentration Data, Southwest to Northeast

2.8-7 Average Trichloroethene Concentrations in Central and North 200 West Area, Upper Part of Unconfined Aquifer.

2.8-8 Average Nitrate Concentrations in Central and North 200 West Area, Upper Part of Unconfined Aquifer.

2.8-9 Average Dissolved Chromium Concentrations Near Waste Management Areas T and TX-TY, Upper Part of Unconfined Aquifer

2.8-10 Average Fluoride Concentrations Near Waste Management Area T in North 200 West Area, Upper Part of Unconfined Aquifer.

2.8-11 Average Tritium Concentrations in North 200 West Area, Upper Part of Unconfined Aquifer.

2.8-12 Tritium Concentrations versus Time in Wells 299-W14-12 and 299-W14-13, Waste Management Area TX-TY

2.8-13 Average Iodine-129 Concentrations in North 200 West Area, Upper Part of Unconfined Aquifer.

2.8-14 Average Technetium-99 Concentrations in North 200 West Area, Upper Part of Unconfined Aquifer.

2.8-15 Technetium-99 Concentrations in Selected Downgradient Water-Table Wells at Waste Management Area T

2.8-16 Technetium-99 Concentrations in Wells Screened Below Water Table at Waste Management Area T

2.8-17 Depth Distribution of Technetium-99 at Well 299-W11-47.

2.8-18 Nitrate Concentrations at Well 299-W11-47

2.8-19 Technetium-99/Nitrate Concentration Ratio for Groundwater at Waste Management Area T

2.8-20 Technetium-99 Concentration Versus Time for Four Wells at Waste Management Area TX-TY Influenced by the 200-ZP-1 Pump-and-Treat System

2.8-21 Tritium Concentrations in Wells Monitoring the State-Approved Land Disposal Site ........

2.9-1 Facilities and Groundwater Monitoring Wells in 200-UP-1 Groundwater Interest Area .............

2.9-2 Average Technetium-99 Concentrations in 200-UP-1 Groundwater Interest Area, Upper Part of Unconfined Aquifer.

2.9-3 Chromium and Technetium-99 Concentrations in Well 299-W23-19 Near a Source Area Within the South Portion of Waste Management Area S-SX

2.9-4 Depth-Discrete Sampling Results for Technetium-99 and Uranium in Northern Part of 200-UP-1 Groundwater Interest Area

2.9-5 Depth-Discrete Sampling Results for Technetium-99 and Uranium in Southern Part of 200-UP-1 Groundwater Interest Area.

2.9-6 Average Uranium Concentrations in 200-UP-1 Groundwater Interest Area, Upper Part of Unconfined Aquifer.

2.9-7 Uranium Concentrations in Well 299-W19-18 Near 216-U-1,2 Cribs

2.9-8 Average Tritium Concentrations in 200-UP-1 Groundwater Interest Area, Upper Part of Unconfined Aquifer. 
2.9-9 Average Iodine-129 Concentrations in 200-UP-1 Groundwater Interest Area, Upper Part of Unconfined Aquifer

2.9-10 Average Nitrate Concentrations in 200-UP-1 Groundwater Interest Area, Upper Part of Unconfined Aquifer.

2.9-11 Depth-Discrete Sampling Results for Nitrate at New Well 299-W19-107 at the Pump-andTreat Area

2.9-12 1,4-Dioxane Concentrations in Well 299-W22-20 Near 216-S-20 Crib

$2.9-41$

2.9-13 Average Technetium-99 Concentrations in 200-UP-1 Pump-and-Treat Area, Upper Part of Unconfined Aquifer.

$2.9-42$

2.9-14 Average Uranium Concentrations in 200-UP-1 Pump-and-Treat Area, Upper Part of Unconfined Aquifer.

2.9-15 Technetium-99 Concentrations in Selected Wells at 200-UP-1 Pump-and-Treat Area............... 2.9-44

2.9-16 Uranium Concentrations in Selected Wells at 200-UP-1 Pump-and-Treat Area........................ 2.9.44

2.9-17 Nitrate Concentrations in Selected Wells at 200-UP-1 Pump-and-Treat Area......

2.9-18 Average Nitrate and Technetium-99 Concentrations at Waste Management Area U, Upper Part of Unconfined Aquifer

$2.9-46$

2.9-19 Average Nitrate Concentrations at Waste Management Area S-SX, Upper Part of Unconfined Aquifer

2.9-20 Average Chromium Concentrations at Waste Management Area S-SX, Upper Part of Unconfined Aquifer.

2.9-21 Average Technetium-99 Concentrations at Waste Management Area S-SX, Upper Part of Unconfined Aquifer

2.9-22 Chromium and Technetium-99 Concentrations in Well 299-W22-50 Near the Middle of a Plume Emanating from the South Portion of Waste Management Area S-SX

2.10-1 Groundwater Monitoring Wells in 200 East Area

2.10-2 Groundwater Monitoring Wells Located in 600 Area Associated with the 200-BP-5 Operable Unit

2.10-3 200 East Area Water-Table Map, July 2006

$2.10-25$

2.10-4 Average Tritium Concentrations in 200 East Area, Upper Part of Unconfined Aquifer.....

$2.10-27$

2.10-5 Tritium Concentrations in Wells Located in Gable Gap Area...

2.10-29

2.10-6 Average Nitrate Concentrations in 200 East Area, Upper Part of Unconfined Aquifer

$2.10-31$

2.10-7 Nitrate Concentrations in Wells 699-53-47A and 699-53-48A at Gable Mountain Pond..........

$2.10-33$

2.10-8 Average Iodine-129 Concentrations in 200 East Area, Upper Part of Unconfined Aquifer

2.10-9 Average Technetium-99 Concentrations in North 200 East Area, Upper Part of Unconfined Aquifer

2.10-10 Technetium-99 Concentrations in Wells 299-E33-7 and 299-E33-38 at the BY Cribs and Well 699-49-57A North of 200 East Area

2.10-11 Cyanide Concentrations in North 200 East Area, Upper Part of Unconfined Aquifer.....

2.10-12 Average Uranium Concentrations in Northwest 200 East Area, Upper Part of Unconfined Aquifer.

2.10-13 Uranium Concentrations in Wells in Northwest 200 East Area....

2-10-14 Strontium-90 Concentrations in Wells 299-E28-23 and 299-E28-25 at the 216-B-5 Injection Well Site 
2.10-15 Strontium-90 Concentrations in Wells 699-53-47A and 699-53-48A at

Gable Mountain Pond...

$2.10-42$

2.10-16 Chloride Concentrations in Selected Wells in 200-BP-5 Operable Unit.

$2.10-43$

2.10-17 Sulfate Concentrations in Selected Wells in 200-BP-5 Operable Unit

$2.10-43$

2.10-18 Nitrate Concentrations on South Side of Waste Management Area B-BX-BY.

$2.10-44$

2.10-19 Technetium-99 Concentrations on South Side of Waste Management Area B-BX-BY.

$2.10-45$

2.10-20 Uranium Concentrations on South Side of Waste Management Area B-BX-BY...

$2.10-46$

2.10-21 Groundwater Flow Directions Near Waste Management Area B-BX-BY from 1999 to 2001 ......

$2.10-47$

2.10-22 Groundwater Flow Directions Near Waste Management Area B-BX-BY from 1991 to 2005 .......

$2.10-47$

2.10-23 Nitrate and Cyanide Concentrations Beneath BY Cribs.

$2.10-48$

2.10-24 Nitrate Concentrations in Central Waste Management Area B-BX-BY ...

$2.10-49$

2.10-25 Technetium-99 Concentrations Beneath and South of BY Cribs ...

$2.10-50$

2.10-26 Uranium Concentrations at Waste Management Area B-BX-BY...

$2.10-51$

2.10-27 Stiff Diagrams for Wells at Waste Management Area B-BX-BY ..

$2.10-52$

2.10-28 Cross Plots of Uranium Isotopes from Spectral Gamma Log Data ...

$2.10-53$

2.10-29 October 2005 Barometric Pressure, Total Head, and Total Head Corrected for Barometric Effects in Low-Level Waste Management Area 1 Well 299-E32-6

$2.10-54$

2.10-30 Specific Conductance in Well 299-E33-34 Near Northeast Corner of Low-Level Waste Management Area 1

$2.10-54$

2.10-31 Mercury Concentrations in Well 299-E33-34 Near Northeast Corner of Low-Level Waste Management Area 1

$2.10-55$

2.10-32 Technetium-99 Concentrations in Well 299-E33-34 Near Northeast Corner of Low-Level Waste Management Area 1.

$2.10-55$

2.10-33 Nitrate Concentrations in Low-Level Waste Management Area 2 Wells.

$2.10-56$

2.10-34 Groundwater Flow Directions from 1990 to 2003 at C Tank Farm.

2.10-56

2.10-35 Nitrate Concentrations at Waste Management Area C, June 2005 and June 2006 .......

$2.10-57$

2.10-36 Technetium-99 Concentrations at Waste Management Area C

$2.10-57$

2.10-37 Technetium-99 Concentrations at Waste Management Area C, June 2002, June 2005, and June 2006

2.11-1 Facilities and Groundwater Monitoring Wells in North Portion of 200-PO-1 Operable Unit.

2.11-2 200-PO-1 Operable Unit Boundaries, Far-Field Monitoring Wells, and Transects......................

2.11-3 Tritium Concentrations in Well 299-E17-14 at 216-A-36B Crib.

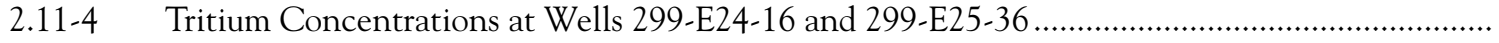

2.11-5 Iodine-129 Concentrations in Well 299-E17-14 at 216-A-36B Crib.

2.11-6 Nitrate Concentrations in Wells 299-E24-16 at the 216-A-10 Crib, 299-E24-18 Upgradient of the 216-A-10 Crib, and 299-E15-17 at the 216-A-37-1 Crib

2.11-7 Strontium-90 Concentrations in Well 299-E17-14 at 216-A-36B Crib.

2.11-8 Technetium-99 Concentrations in Wells 299-E25-93 and 299-E24-33 at Waste Management Area A-AX.

2.11-9 Groundwater Flow Directions at the A and AX Tank Farms from 1990 to 2003

2.11-10 Nitrate Concentrations in Groundwater at Waste Management Area A-AX, June 2006............

2.11-11 Nitrate Concentrations in Groundwater at Waste Management Area A-AX...

2.11-12 Technetium-99 Concentrations in Groundwater at Waste Management Area A-AX 
2.11-13 Technetium-99 Concentrations in Groundwater at Waste Management Area A-AX, June 2006

2.11-14 Sulfate Concentrations in Groundwater at Waste Management Area A-AX ............................. 2.11-29

2.11-15 Sulfate Concentrations in Groundwater at Waste Management Area A-AX, June 2006 ............ 2.11-30

2.11-16 Tritium Concentrations in 400 Area Water Supply Wells ............................................................ 2.11-31

2.12-1 Operable Units Defined for the 300 National Priorities List Site................................................. 2.12-16

2.12-2 Groundwater Monitoring Wells in 300 Area............................................................................ 2.12-17

2.12-3 Groundwater Monitoring Wells in 300-FF-5 North Subregion.................................................. 2.12-18

2.12-4 Water-Table Map for 300-FF-5 Operable Unit, April 2006........................................................ 2.12-19

2.12-5 Uranium Concentrations in Upper Part of Unconfined Aquifer Beneath 300 Area,

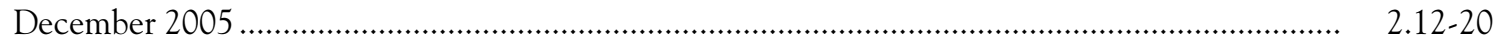

2.12-6 Uranium Concentrations in Upper Part of Unconfined Aquifer Beneath 300 Area, June 2006

2.12-7 Uranium Trends in RCRA Monitoring Wells Downgradient from Former 300 Area Process Trenches

2.12-8 Correlation Between Uranium Concentrations and Water-Table Elevation at Well Close to Columbia River

2.12-9 Correlation Between Uranium Concentrations and Water-Table Elevation at Well Near Waste Site

2.12-10 Uranium Concentrations at Aquifer Tube Sites Along 300 Area Shoreline

2.12-11 Cross Section Showing Uranium Concentrations at Multiple Depths in Aquifer Tubes Along 300 Area Shoreline.

2.12-12 Cross Section Showing Relationship Between Aquifer Tube, Near-River Wells, and Hydrostratigraphy at 300 Area Shoreline ....

2.12-13 Uranium Concentrations at Wells Near 316-4 Cribs Remedial Action Site..

2.12-14 Concentrations of cis-1,2-Dichloroethene at Well 399-1-16B Near Former 300 Area Process Trenches

2.12-15 Average Trichloroethene Concentrations in the Vicinity of 300 Area, Upper Part of Unconfined Aquifer

2.12-16 Trichloroethene in Samples Collected during Limited Field Investigation Drilling, May 2006

2.12-17 Average Tritium Concentrations in 300-FF-5 Operable Unit, Upper Part of Unconfined Aquifer

2.12-18 Average Tritium Concentrations at 618-11 Burial Ground, Upper Part of Unconfined Aquifer.

2.12-19 Tritium Concentration in Wells Near 618-11 Burial Ground.

2.12-20 Average Nitrate Concentrations in 300-FF-5 Operable Unit, Upper Part of Unconfined Aquifer

2.13-1 Groundwater Monitoring Wells and Facilities in 1100-EM-1 and 300 Areas.

2.13-2 Water-Table Map for 1100-EM-1 and 300 Areas, April 2006

2.13-3 Average Trichloroethene Concentrations in 1100-EM-1 Area Groundwater, Upper Part of Unconfined Aquifer.

2.13-4 Trichloroethene Concentrations Near the U.S. Department of Energy's Inactive Horn Rapids Landfill. 
2.13-5 Average Tritium Concentrations in 300 and 1100-EM-1 Areas, Upper Part of Unconfined Aquifer.

2.13-6 Tritium Concentrations in Selected Wells in 1100-EM-1 Groundwater Interest Area...

2.13-7 Average Nitrate Concentrations in 1100-EM-1 Area, Upper Part of Unconfined Aquifer.

2.13-8 Nitrate Concentrations in Selected Wells in 1100-EM-1 Groundwater Interest Area

2.13-9 Uranium Concentrations in 1100-EM-1 and 300 Areas, Upper Part of Unconfined Aquifer, 2006

2.13-10 Uranium Concentrations in the Near the U.S. Department of Energy's Inactive Horn Rapids Landfill.

2.14-1 Potentiometric Surface Map of Ringold Formation Confined Aquifer, Central Hanford Site, April/May 2006

2.14-2 Water-Level Elevation in Wells Monitoring Different Depths of the Unconfined Aquifer Near 200 East Area

2.14-3 Groundwater Monitoring Wells Sampled in Ringold Formation Confined and Upper Basalt-Confined Aquifers, FY 2004 through 2006

2.14-4 Potentiometric Surface Map of Upper Basalt-Confined Aquifer System, April/May 2006

2.14-5 Comparison of Observed Heads for Upper Basalt-Confined Aquifer and Overlying Unconfined Aquifer.

2.14-6 Distribution of Chemical and Radiological Constituents in Upper Basalt-Confined Aquifer, FY 2004 through 2006

2.14-7 Tritium Concentrations in Wells 699-42-40C and 699-43-41E

2.14-8 Technetium-99 Concentrations in Wells 299-E33-12 and 299-E33-13 .......

2.14-9 Cyanide and Nitrate Concentrations in Well 299-E33-12.

3.1-1 Leachate Collection Volumes at the Solid Waste Landfill

3.1-2 Locations of Carbon Tetrachloride Vapor-Extraction Wells at 216-Z-1A/216-Z-12/ 216-Z-18 and 216-Z-9 Well Fields.

3.1-3 Time Series Concentrations and Mass of Carbon Tetrachloride in Soil Vapor Extracted from 216-Z-1A/216-Z-12/216-Z-18 and 216-Z-9 Well Fields

3.2-1 Demonstration of Hydraulic Hammer Unit in Non-Vertical Mode.

3.2-2 Uranium-238 Decay Series

3.2-3 Build In of Gamma-Emitting Daughters in the Uranium-238 Decay Series...

3.2-4 Vadose Zone Uranium at 200-BP-5 Groundwater Operable Unit.

3.2-5 Locations of Past-Practice Disposal Facilities in 200-PW-1 Operable Unit, 200 West Area........

3.3-1 Field Gravimetric Moisture Content Profile Measured from Subsamples Taken from Homogenized Core Material.

3.3-2 Soil Pore-Water Chloride Concentration Profile for the $<2 \mathrm{~mm},>2 \mathrm{~mm}$, and Bulk Core Subsamples.....

3.3-3 Soil Pore-Water Chloride Concentration Profile from the Bulk Subsample and the Gravel Corrected $<2 \mathrm{~mm}$ Subsample

3.3-4 Cumulative Water Content and Cumulative Chloride Concentration with Increasing Depth. 
3.3-5 Pore-Water Chloride Profile and Groundwater Chloride Concentration for Well 699-S20-E10.

3.3-6 Cumulative Water Content and Cumulative Chloride with Increasing Depth ........................... 3.3-9

3.3-7 Matric Potential Profile for Well 699-S20-E10 ....................................................................... 3.3-10

3.3-8 NAPL Permeability of Anisotropic Heterogeneous Soils with $\sigma_{Y}{ }^{2}=2.0$ and Different Anisotropy for $\mathrm{h}_{\mathrm{w}}=-0.2 \mathrm{~m}$

3.4-1 Well-to-Well Inversion of Drywells in and Around T Tank Farm ...... $3.4-15$

3.4-2 Resistivity Data Beneath the Northeast Trenches and Western Cribs ......................................... 3.4-15

3.4-3 Well-to-Well Inversion of Groundwater Wells in and Around the T Tank Farm $3.4-16$

3.4-4 Views of Pre- and Post-LEAK Surface Inversion Results for the 1-2 ohm-m Level Plan View, Side View, and Three-Dimensional View....

3.4-5 Direct Comparison of WTW Inversion with Surface Inversion, with WTW Opacity of 1-14 ohm-meters and Surface Opacity of 1-1.5 ohm-meters

4.0-1 Categorization of Unique Well Identification Numbers ............................................................. 4. 4.0-12

4.0-2 Hanford Site and Surrounding Area Depicting Various Geographic Regions, Richland, Washington

4.0-3 Groundwater Monitoring Wells and Aquifer Tubes Installed in FY 2006 .................................. 4.0 4.0 14

4.0-4 Vadose Zone Monitoring Wells Decommissioned during FY 2006 


\subsection{Introduction}

\section{J. Hartman and C. J. Thompson}

The U.S. Department of Energy (DOE) has committed to protect the Columbia River from contaminated groundwater resulting from past, present, and future operations at its Hanford Site, and to protect and remediate groundwater. Hanford Site Groundwater Strategy (DOE/RL-2002-59) focuses on three key areas: groundwater protection, groundwater monitoring, and remediation of contaminated groundwater.

One of the implementing documents for the groundwater strategy is Hanford's Groundwater Management Plan: Accelerated Cleanup and Protection (DOE/RL-2002-68). DOE established the Groundwater Remediation Project, managed by Fluor Hanford, Inc., to implement the accelerated plan. Protection of Hanford's groundwater requires an aggressive plan to limit and control the continued migration of contaminants already in the soil and the groundwater. To do this, the Groundwater Remediation Project performs the following tasks:

- Prevent degradation of groundwater by (a) remediating high-risk waste sites, (b) shrinking the contaminated area, and (c) reducing natural and artificial recharge.

- Remediate groundwater.

- Monitor groundwater.

DOE monitors groundwater at the Hanford Site to fulfill a variety of state and federal regulations, including the Atomic Energy Act (AEA), the Resource Conservation and Recovery Act (RCRA), the Comprehensive Environmental Response, Compensation, and Liability Act (CERCLA), and Washington Administrative Code (WAC). DOE manages these activities through the Groundwater Performance Assessment Project (groundwater project), which in fiscal year (FY) 2006 was conducted by Pacific Northwest National Laboratory (PNNL). The groundwater project is under the umbrella of the Groundwater Remediation Project.

\subsection{Purpose and Scope}

This document presents results of groundwater monitoring to meet the requirements of the AEA, RCRA, and those CERCLA groundwater operable units where cleanup decisions have not yet been made (Table 1.0-1). This report also summarizes groundwater remediation, vadose zone monitoring and characterization, and well installation activities. Monitoring results primarily rely on data from samples collected in FY 2006, i.e., October 1, 2005 through September 30, 2006. Appendix A lists supporting information for CERCLA operable unit monitoring. Appendix B contains tables and figures that support RCRA and other facility monitoring.

This report is designed to meet the following objectives:

- Provide a comprehensive report of groundwater conditions on the Hanford Site.

- Fulfill the reporting requirements of RCRA, CERCLA (for operable units where cleanup decisions have not yet been made), DOE Orders, and Washington Administrative Code.

- Summarize the results of groundwater monitoring conducted to assess the effects of interim remedial actions conducted under CERCLA.

- Describe the results of monitoring, characterization, and studies associated with the vadose zone.

- Summarize the installation, maintenance, and decommissioning of Hanford Site monitoring wells. 


\section{During FY 2006, staff sampled 778 wells and 247 aquifer tubes for radiological and chemical constituents.}

Tritium, nitrate, and iodine-129

are the most

widespread

contaminants on

the Hanford Site.
Background information, including descriptions of regulatory requirements, waste sites, analytical methods, regional geology, and statistics is included in a separately published companion volume, Hanford Site Groundwater: Settings, Sources, and Methods (PNNL-13080), and in the most recent update, which was provided in PNNL-13788, Appendix C. Those changes have been incorporated into the electronic version of PNNL-13080, provided with this groundwater monitoring report.

\subsection{Groundwater Monitoring}

For remedial action and environmental restoration, waste sites are grouped into source operable units, and the groundwater beneath the sites is divided into groundwater operable units. The concept of operable units is to group the numerous waste sites (primarily by geographic area) into manageable components for investigation and response action and to prioritize the cleanup work to be done at the Hanford Site. The regulatory-defined groundwater operable units do not cover groundwater beneath the entire Hanford Site. Therefore, to provide scheduling, data review, and interpretation for the entire Hanford Site, groundwater staff have defined informal "groundwater interest areas" that include the groundwater operable units and intervening regions. Figure 1.0-1 illustrates these interest areas and the operable unit boundaries.

During FY 2006, Hanford Site staff sampled 778 wells and 247 aquifer tubes for radiological and chemical constituents. Many of the wells were sampled multiple times, for a total of 1,919 sampling trips. An additional 126 well trips scheduled for FY 2006 were delayed until FY 2007 or cancelled. Many of these delays were caused by samplers being restricted to established roads because of extreme fire hazard during the summer. Purge water truck availability, limited staff to perform groundwater sampling, and vapor monitoring at each well prior to the sampling event also affected the sampling schedule.

Chromium (total or hexavalent) was the most frequently analyzed constituent. Anions, tritium, iodine-129, metals, technetium-99, strontium-90, and volatile organic compounds were other commonly analyzed constituents (Table 1.0-2).

Tritium, nitrate, and iodine-129 are the most widespread contaminants associated with past Hanford Site operations. Their distribution in the unconfined aquifer is shown in Figures 1.0-2, 1.0-3, and 1.0-4, respectively. The most prominent portions of these plumes originated at waste sites in the 200 Areas and spread toward the southeast. Nitrate and tritium also had significant sources in the 100 Areas.

Table 1.0-3 lists maximum concentrations of selected groundwater contaminants in each of the groundwater interest areas, and refers to the sections in this report where they are discussed. Analytical results including FY 2006 and historical data are included in the data files accompanying this report.

Groundwater monitoring objectives of RCRA, CERCLA, and the AEA often differ slightly, and the contaminants monitored are not always the same. For RCRA-regulated units, monitoring focuses on non-radioactive dangerous waste constituents. Radionuclides (source, special nuclear and by-product materials) may be monitored in some RCRA unit wells to support objectives of monitoring under AEA and/or CERCLA. Please note that pursuant to RCRA, the source, special nuclear, and by-product material components of radioactive mixed waste are not regulated under RCRA and are regulated by the DOE acting pursuant to its AEA authority. Therefore, while this report may be used to satisfy RCRA reporting requirements, the inclusion of information on radionuclides in such a context is for information only and may not be used to create conditions or other restrictions set forth in any RCRA permit. 


\subsection{Shoreline Monitoring}

Monitoring groundwater quality along the river is accomplished by collecting samples from aquifer tubes and riverbank springs. Hydrologists estimate that the total discharge of groundwater from the Hanford Site aquifer to the Columbia River is in the range 1.1 to 2.5 cubic meters/second (PNNL-13447; PNNL-14753). This rate of discharge is very small compared to the average flow of the Columbia River, $~ 3,400$ cubic meters/second.

\subsubsection{Aquifer Tubes}

Monitoring groundwater near the Columbia River is done via aquifer tubes, which are small-diameter, flexible tubes that are implanted in the shallow aquifer. Representatives from the U.S. Environmental Protection Agency (EPA) and Washington State Department of Ecology (Ecology) meet annually with DOE and its contractors to plan the annual sampling event, which usually occurs during the fall months (DOE/RL-2000-59). The individual operable unit sections of this report discuss aquifer tube results and include location maps. Maximum contaminant concentrations in samples collected from aquifer tubes sampled in FY 2006 are listed in Table 1.0-3.

Concentrations of strontium-90 exceed the $8-\mathrm{pCi} / \mathrm{L}$ drinking water standard in aquifer tubes in the 100-BC-5 and 100-NR-2 interest areas. Levels exceed the 1,000-pCi/L DOE derived concentration guide in 100-N Area tubes.

Uranium concentrations exceed the $30-\mu \mathrm{g} / \mathrm{L}$ drinking water standard in most of the aquifer tubes at the 300 Area.

Hexavalent chromium exceeded the 100- $\mathrm{\mu g} / \mathrm{L}$ drinking water standard in 100-D Area aquifer tubes, and exceeded the $10-\mu \mathrm{g} / \mathrm{L}$ aquatic standard (WAC 173-201A) in the $100-\mathrm{B} / \mathrm{C}$, 100-K, 100-D, and 100-H Areas (Figure 1.0-5).

Nitrate concentrations exceed the $45-\mathrm{mg} / \mathrm{L}$ drinking water standard in aquifer tubes at the $100-\mathrm{K}, 100-\mathrm{D}, 100-\mathrm{H}$, and 300 Areas. Levels have exceeded the standard in a tube downgradient of the 100-F Area in the past, but the tube was not sampled in FY 2006.

Trichloroethene is detected in several aquifer tubes in the 300 Area. Most results were

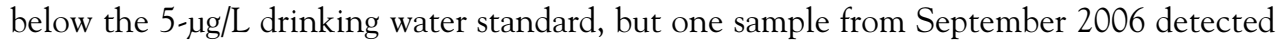
$96 \mu \mathrm{g} / \mathrm{L}$ in the deepest tube at site AT-3-3.

\subsubsection{Shoreline Springs}

Columbia River springs are sampled each autumn by the Surface Environmental Surveillance Project, which is part of DOE's Public Safety and Resource Protection Program. In recent years, some springs are sampled to support monitoring and characterization activities under CERCLA operable unit requirements. Analytical results for riverbank springs samples, along with results for adjacent nearshore river water, are published in the annual Hanford Site Environmental Report (PNNL-15892). Contaminant concentrations are typically much lower in spring water than in groundwater samples from wells and aquifer tubes.

Dissolved chromium concentrations in springs were all below the $100-\mu \mathrm{g} / \mathrm{L}$ drinking water standard, but exceeded the 10- $\mathrm{\mu g} / \mathrm{L}$ aquatic standard (WAC 173-201A) in the 100-K, 100-D, 100-H, and 100-F Areas. The maximum concentration was $57 \mu \mathrm{g} / \mathrm{L}$ in a 100-D Area spring.

Gross beta and strontium-90 exceeded drinking water standards $(50$ and $8 \mathrm{pCi} / \mathrm{L}$, respectively) in seep wells in the 100-N Area (seep wells are shallow casings open on the bottom that facilitate collecting samples of riverbank springs in the 100-N Area). The highest strontium-90 concentration was $178 \mathrm{pCi} / \mathrm{L}$ in seep well NS-3, in the heart of the 100-N strontium-90 plume.

Tritium exceeded the 20,000-pCi/L drinking water standard in springs at the Hanford town site. The maximum concentration in FY 2006 was 38,600 pCi/L.

\author{
Monitoring \\ groundwater \\ quality along \\ the river is \\ accomplished by \\ collecting samples \\ from aquifer tubes \\ and riverbank \\ springs.
}




\section{Evaluation of the groundwater project quality assurance program indicates that the majority of data for FY 2006 are reliable and defensible.}

Uranium exceeded the 30- $\mu \mathrm{g} / \mathrm{L}$ drinking water standard in 300 Area springs. The highest concentration was $145 \mu \mathrm{g} / \mathrm{L}$ (total uranium, converted from isotopic data).

\subsection{Quality Control Highlights}

Groundwater data quality is assessed and enhanced by a multifaceted quality assurance/ quality control program. Major components of the program include performance evaluation studies, field quality control samples, blind standards, laboratory quality control samples, and laboratory audits. Overall evaluation of these components indicates that the data for FY 2006 are reliable and defensible. Specific data values that are associated with out-of-limits quality control results are flagged in the Hanford Environmental Information System (HEIS) so that users can be circumspect when using them for interpretation. Details of the quality control program for FY 2006 are included in Appendix C. Highlights include the following:

- During FY 2006, 93\% of the groundwater monitoring data was considered complete, i.e., not rejected, suspect, associated with a missed holding time, or out-of-limit quality control criteria. The groundwater project is attempting to improve completeness by working with the laboratories to reduce laboratory blank contamination.

- Most analytical services were performed by four offsite contract laboratories. All four laboratories participated in three or more national performance evaluation studies. Overall, the percentage of acceptable results for FY 2006 was 97\%; the percentages for the individual laboratories ranged from $92 \%$ to $97 \%$.

- Field quality control samples include three types of field blanks (full trip, field transfer, and equipment blanks), field duplicates, and split samples. Greater than $97 \%$ of field blank and field duplicate results for FY 2006 were acceptable, indicating little problem with contamination and good precision overall.

- A comparison of Severn Trent Laboratories, Incorporated, St. Louis, Missouri's inductively coupled plasma-optical emission spectroscopy (ICP-OES) and inductively coupled plasma-mass spectrometry (ICP-MS) methods for aluminum analyses showed reasonable agreement between the two methods, but the ICP-OES method appears to generate some false-positive results for Hanford groundwater samples.

- Recommended holding times were met for $95 \%$ of non-radiological sample analysis requests for both long-term and interim-action monitoring. In general, the missed holding times should not have a significant impact on the data.

- Laboratory performance on blind standards was good overall - $85 \%$ of the results were acceptable.

- Approximately $98 \%$ of the laboratory quality control results for FY 2006 were within the acceptance limits, suggesting that the analyses were in control and reliable data were generated. Specifically, $98 \%$ of method blanks, $99 \%$ of the laboratory control samples, $97 \%$ of the matrix spikes, $98 \%$ of the matrix duplicates, and $98 \%$ of the surrogates were within the acceptance limits.

- Audits of the commercial laboratories were conducted by DOE and its contractors. Several minor findings and observations were identified along with a number of proficiencies. Corrective actions have been accepted for all of the audits. 


\subsection{Related Reports}

Other reports and databases relating to Hanford Site groundwater include the following:

- Calendar Year 2005 Annual Summary Report for the 100-HR-3, 100-KR-4, and 100-NR-2 Operable Unit Pumpand-Treat Operations (DOE/RL-2006-08) - This report evaluates the performance of groundwater remediation systems in the 100-K, 100-N, 100-D, and 100-H Areas.

- Fiscal Year 2005 Annual Summary Report for the In Situ Redox Manipulation Operations (DOE/RL-2005-97) This report describes activities related to the remediation system in the southwest 100-D Area.

- Fiscal Year 2005 Annual Summary Report for the 200-UP-1 and 200-ZP-1 Pump-and-Treat Operations (DOE/RL2005-91) - This report evaluates the performance of groundwater remediation systems in the 200 West Area.

- Performance Evaluation Report for Soil Vapor Extraction Operations at the 200-PW-1 Carbon Tetrachloride Site, Fiscal Year 2005 (WMP-30426) - This report describes activities related to vadose zone remediation in the 200 West Area.

- Initial Single-Shell Tank System Performance Assessment for the Hanford Site (DOE/ORP. 2005-01) - This report, which analyzed the long-term impacts of residual waste remaining after retrieval of tank waste and closure of the single-shell tank farms, was released for review in FY 2006. Past releases to the soil, most of which occurred during tank farm operations, were shown to have groundwater impacts significantly above most performance objectives at the waste management area fence lines. In the reference case, only Waste Management Area C did not impact groundwater at levels over performance objectives.

- Quarterly RCRA data transmittals - DOE transmits informal reports quarterly via e-mail to the Washington State Department of Ecology after groundwater data have been verified and evaluated (PNNL-15685, PNNL-15797, PNNL-15953, PNNL-16191). These reports describe changes or highlights of the quarter with reference to HEIS for the analytical results.

- Hanford Environmental Information System (HEIS) - This is the main environmental database for the Hanford Site that stores groundwater chemistry data, as well as other environmental data (e.g., soil chemistry, survey data).

- Hanford Site Environmental Report for Calendar Year 2005 (PNNL-15892) - This annual report summarizes environmental data, including riverbank springs and river water. It also describes environmental management performance and reports the status of compliance with environmental regulations.

\subsection{CERCLA Five-Year Review}

Whenever contaminants remain in the environment following a remedial action decision, CERCLA regulations require that the cognizant regulatory agency conduct a review of the decision at least every five years. DOE released The Second CERCLA Five-Year Review Report for the Hanford Site (DOE/RL-2006-20) in November 2006. The review identified 20 issues and associated corrective actions that are recommended such that the selected remedies

\section{Websites}

Documents relating to Hanford Site groundwater are available Tri-Party Agreement Administrative Record and Public Information DOE Public Reading Room - http://reading-room.pnl.gov/ DOE Information Bridge - http://www.osti.gov/bridge/ Hanford Technical Library - http://libraryweb.pnl.gov/

\section{DOE released the} second CERCLA five-year review in 2006. The review recommended corrective actions to protect human health and the environment. 
remain protective of human health and the environment. Actions that pertain to individual groundwater operable units are discussed in the applicable sections of this report. Two actions pertain to the river corridor, and thus cut across operable unit boundaries:

- Issue 1: Additional risk assessment information is needed to evaluate the interim actions prescribed within the records of decision and to develop final cleanup decisions.

- Action 1-1: Submit Draft A of the River Corridor Baseline Risk Assessment Report (due date June 2007).

- Action 1-2: Submit draft sampling and analysis plan for Inter-Areas Shoreline Assessment (transmitted August 2006 ${ }^{(a)}$ ).

- Issue 2: A strategy has not been developed and agreed upon to obtain the final records of decision and integrate the waste sites, deep vadose zone, and groundwater.

- Action 2-1: Submit Draft A of the River Corridor Strategy for Achieving Final Cleanup Decision in the River Corridor. The document will identify issues for integration and provide alternatives for future discussion between the Tri-Parties on milestones for final records of decision in the river corridor.

\subsection{Conventions Used in This Report}

Contaminant plume maps in this report, unless specified otherwise, are based on average results for samples collected in FY 2006 for each well, excluding data that appear unrepresentative. ${ }^{(\mathrm{b})}$ Averaging data allows the maps to include wells that were sampled at different times and at different frequencies. In some locations, it is advantageous to construct maps based on data from a single sampling event (e.g., uranium in the 300 Area in June 2006).

Mapped data are rounded to two significant digits. The maps are interpretations by project staff using current and historical data, source knowledge, and groundwater flow directions. Staff use data from FY 2004 and 2005 if there were no new data for a well in FY 2006. These older data, and data from aquifer tubes along the Columbia River, are given less weight than the current well data when the maps are contoured. The maps show data from wells completed in the upper part of the unconfined aquifer (generally the top $\sim 10$ meters).

Results less than detection limits (flagged "U" in HEIS) are treated in one of two ways when constructing maps:

- For chemical constituents (including uranium), U-flagged values represent analytical detection limits. These values are treated as zeroes and included in the data to be averaged. If all results (or the only result) for the fiscal year were undetected, a $U$ is plotted on the map. If the data represent a mixture of detected and undetected results, the average is plotted on the map, followed by an asterisk.

- For radiological parameters, if the counting error is greater than the result, the result is flagged $U$. Other factors also may result in values being flagged U. For plotting on

(a) Letter 06-AMRC-0317 from JR Franco (U.S. Department of Energy, Richland Operations Office) to N Ceto (U.S. Environmental Protection Agency) and J Hedges (Washington State Department of Ecology), "Transmittal of the Sampling and Analysis Plan for the Inter-Areas Shoreline Assessment," dated August 2, 2006.

(b) A table of data excluded from the plume maps, and the rationale for exclusion, is included in the electronic files that accompany this report. The excluded data have been deemed unrepresentative of upper aquifer conditions for reasons such as laboratory error or unusual sampling conditions (e.g., samples collected during drilling or using a method not comparable to routine monitoring). 
maps, all of the results for the fiscal year are averaged, whether U-flagged or not, because the reported values are statistically significant. The average values are plotted on the map, followed by $U$ (if all results for the fiscal year were undetected) or an asterisk (if the data represent a mixture of detected and undetected values). Note that the laboratories correct results for background radiation. In some cases, background corrected values are negative.

Conventions for handling undetected values do not adversely affect data interpretation for most constituents because the contour intervals are far above detection limits. A notable exception is iodine- 129 that is contoured at $1 \mathrm{pCi} / \mathrm{L}$ (the drinking water standard), which in some cases is less than the laboratory's detection limit. This problem is exacerbated in samples that contain significant concentrations of technetium-99. Those samples are filtered to remove the technetium-99 prior to iodine-129 analyses (see Section C.6.1 of PNNL-15070). Despite this practice, some values $>1 \mathrm{pCi} / \mathrm{L}$ were reported as undetected. The laboratory requires that both primary and secondary energy peaks are present before they consider iodine-129 detected. Requiring the secondary (less sensitive) energy peak adds conservatism to the laboratory's report (i.e., they do not report a detection unless they are very sure of it). However, many of the U-flagged values are believed to be real detections, and they are contoured as such. The contour lines are dashed to show that the distribution of iodine-129 at levels near the drinking water standard is less certain than other contaminants.

Trend plots generally include all analytical results, even those that appear to be erroneous if they do not distort or obscure the scale and data trends. If the outlying data distort the figure, they are not plotted. All of the data, with appropriate data quality flags, are included in the data files that accompany this report and are available in the HEIS database. Trend plots in this report use open symbols to show values so low the laboratory could not detect them. These results are typically reported and plotted as values that represent the detection limit for chemical parameters, and reported values for radiological parameters.

This report uses the following conventions for chemical results:

- Text, figures, and tables express nitrate and nitrite as the $\mathrm{NO}_{3}^{-}$and $\mathrm{NO}_{2}^{-}$ions, respectively.

- Figures showing chromium include total chromium in filtered samples and hexavalent chromium in filtered or unfiltered samples. Dissolved chromium in Hanford Site groundwater is virtually all hexavalent (WHC-SD-EN-TI-302), so filtered, total chromium data effectively represent hexavalent chromium.

- Contaminant concentrations are compared with state or federally enforceable drinking water standards (Table 1.0-4). Although Hanford Site groundwater is not generally used for drinking, these levels provide perspective on contaminant concentrations. Radionuclide concentrations also are compared with DOE derived concentration guides (Table 1.0-5). 
Table 1.0-1. Reporting Requirements for Groundwater Monitoring

\begin{tabular}{|c|c|c|}
\hline Operable Unit or Facility & Formal Report & Supplemental Reports or Summaries \\
\hline \multicolumn{3}{|c|}{ CERCLA } \\
\hline $\begin{array}{l}\text { Operable units without RODs } \\
\text { (100-BC-5, 100-FR-3, 200-BP-5, } \\
200-P O-1)\end{array}$ & This report & Unit manager's meeting presentations \\
\hline $\begin{array}{l}\text { Operable units with interim action RODs } \\
\text { managed by FHI (100-KR-4, 100-NR-2, } \\
100-H R-3,200-U P-1,200-Z P-1)\end{array}$ & $\begin{array}{l}\text { Interim action annual reports } \\
\text { (summarized in this report) }\end{array}$ & $\begin{array}{l}\text { Unit manager's meeting presentations; } \\
\text { this report }\end{array}$ \\
\hline $\begin{array}{l}\text { Operable unit with interim action ROD } \\
\text { managed by PNNL ( } 300-F F-5)\end{array}$ & This report & $\begin{array}{l}\text { Unit manager's meeting presentations; } \\
\text { this report }\end{array}$ \\
\hline $\begin{array}{l}\text { Operable unit with final ROD managed } \\
\text { by PNNL (1100-EM-1) }\end{array}$ & This report & None \\
\hline ERDF & $\begin{array}{l}\text { Separate annual report covers } \\
\text { groundwater and leachate (summarized } \\
\text { in this report) }\end{array}$ & This report \\
\hline \multicolumn{3}{|c|}{ RCRA Units } \\
\hline $\begin{array}{l}\text { Indicator evaluation or detection sites } \\
\text { (116-N-1 and }-3,120-\mathrm{N}-1 \text { and }-2 \text {, } \\
216-\mathrm{A}-29,216-\mathrm{B}-63,216-\mathrm{S}-10, \mathrm{~B} \text { Pond, } \\
\text { IDF, LERF, LLBG, NRDWL, WMA C) }\end{array}$ & This report & Informal quarterly reports \\
\hline $\begin{array}{l}\text { Assessment sites (216-U-12; PUREX } \\
\text { cribs; WMA A-AX, B-BX-BY, S-SX, T, } \\
\text { TX-TY, and U) }\end{array}$ & $\begin{array}{l}\text { This report; also occasional assessment } \\
\text { reports }\end{array}$ & Informal quarterly reports \\
\hline Corrective action sites $(116-\mathrm{H}-6,316-5)$ & $\begin{array}{l}\text { Semiannual letter reports to Ecology; this } \\
\text { report }\end{array}$ & Informal quarterly reports \\
\hline \multicolumn{3}{|c|}{ Other Facilities } \\
\hline $\begin{array}{l}\text { AEA sites (K Basins, } 400 \text { Area water } \\
\text { supply wells) }\end{array}$ & This report & $\begin{array}{l}\text { Quarterly K Basins reports to facility } \\
\text { operators and DOE }\end{array}$ \\
\hline SALDS (WAC 173-216) & Separate annual report & This report \\
\hline TEDF (WAC 173-216) & This report & None \\
\hline SWL (WAC 173-304) & $\begin{array}{l}\text { This report for groundwater; separate } \\
\text { report for leachate and soil gas }\end{array}$ & None \\
\hline $\begin{array}{l}\text { AEA = Atomic Energy Act. } \\
\text { CERCLA = Comprehensive Environment } \\
\text { DOE = U.S. Department of Energy. } \\
\text { Ecology = Washington State Department } \\
\text { ERDF = Environmental Restoration Disp } \\
\text { FHI = Fluor Hanford, Inc. } \\
\text { IDF = Integrated Disposal Facility (planne } \\
\text { LERF = Liquid Effluent Retention Facility } \\
\text { LLBG = Low-level burial grounds. } \\
\text { NRDWL = Nonradioactive Dangerous We } \\
\text { PNNL = Pacific Northwest National Labol } \\
\text { PUREX = Plutonium-Uranium Extraction } \\
\text { RCRA = Resource Conservation and Rec } \\
\text { ROD = Record of decision. } \\
\text { SALDS = State-Approved Land Disposal } \\
\text { SWL = Solid Waste Landfill. } \\
\text { TEDF = Treated Effluent Disposal Facility } \\
\text { WAC = Washington Administrative Code } . \\
\text { WMA = Waste management area. }\end{array}$ & $\begin{array}{l}\text { Response, Compensation, and Liability Ac } \\
\text { f Ecology. } \\
\text { al Facility. } \\
\text { I). }\end{array}$ & \\
\hline
\end{tabular}


Table 1.0-2. Number of Groundwater Analyses by Groundwater Interest Area, ${ }^{(a)}$ FY 2006

\begin{tabular}{|c|c|c|c|c|c|c|c|c|c|c|c|c|c|}
\hline Constituent & $\begin{array}{l}\text { Site } \\
\text { Total }\end{array}$ & $100-B C-5$ & 100-KR-4 & 100-NR-2 & 100-HR-3-D & 100-HR-3-H & 100-FR-3 & 200-ZP-1 & 200-UP-1 & 200-BP-5 & 200-PO-1 & $300-F F-5$ & 1100-EM-1 \\
\hline $\begin{array}{l}\text { Chromium (total and } \\
\text { hexavalent) }\end{array}$ & 3,357 & 49 & 354 & 155 & 1,304 & 465 & 55 & 247 & 154 & 242 & 229 & 100 & 3 \\
\hline lodine-129 & 403 & 0 & 0 & 0 & 0 & 0 & 0 & 150 & 84 & 81 & 84 & 1 & 3 \\
\hline Nitrate & 1,680 & 20 & 94 & 153 & 108 & 53 & 33 & 323 & 238 & 255 & 253 & 122 & 28 \\
\hline $\begin{array}{l}\text { Organics (carbon } \\
\text { tetrachloride, } \\
\text { trichloroethene) }\end{array}$ & 749 & 0 & 2 & 0 & 0 & 0 & 9 & 336 & 147 & 5 & 64 & 166 & 20 \\
\hline Plutonium-239/240 & 31 & 0 & 0 & 0 & 0 & 0 & 0 & 4 & 0 & 23 & 0 & 4 & 0 \\
\hline Strontium-90 & 461 & 23 & 53 & 143 & 17 & 26 & 17 & 68 & 14 & 34 & 60 & 6 & 0 \\
\hline Technetium-99 & 908 & 3 & 33 & 0 & 8 & 29 & 1 & 268 & 245 & 247 & 55 & 17 & 2 \\
\hline Tritium & 1,180 & 31 & 130 & 137 & 53 & 31 & 21 & 268 & 89 & 214 & 93 & 79 & 34 \\
\hline Uranium & 776 & 0 & 2 & 0 & 40 & 29 & 3 & 86 & 171 & 227 & 41 & 171 & 6 \\
\hline
\end{tabular}


Table 1.0-3. Maximum Concentrations of Selected Groundwater Contaminants in Groundwater Interest Areas, FY 2006 (Figure 1.0-1)

\begin{tabular}{|c|c|c|c|c|c|c|c|c|c|c|c|c|c|}
\hline \multirow[b]{2}{*}{$\begin{array}{l}\text { Contaminant, units } \\
\text { (alphabetical order) }\end{array}$} & \multirow[b]{2}{*}{$\begin{array}{l}\text { DWS } \\
(\text { DCG })^{(a)}\end{array}$} & \multicolumn{2}{|c|}{$100-B C-5$} & \multicolumn{2}{|c|}{ 100-KR-4 } & \multicolumn{2}{|c|}{ 100-NR-2 } & \multicolumn{2}{|c|}{ 100-HR-3-D } & \multicolumn{2}{|c|}{ 100-HR-3-H } & \multicolumn{2}{|c|}{ 100-FR-3 } \\
\hline & & Wells & $\begin{array}{l}\text { Aquifer } \\
\text { Tubes }\end{array}$ & Wells & $\begin{array}{l}\text { Aquifer } \\
\text { Tubes }\end{array}$ & Wells & $\begin{array}{l}\text { Aquifer } \\
\text { Tubes }\end{array}$ & Wells & $\begin{array}{l}\text { Aquifer } \\
\text { Tubes }\end{array}$ & Wells & $\begin{array}{l}\text { Aquifer } \\
\text { Tubes }\end{array}$ & Wells & $\begin{array}{l}\text { Aquifer } \\
\text { Tubes }\end{array}$ \\
\hline Antimony (filtered), $\mu \mathrm{g} / \mathrm{L}^{(\mathrm{b})}$ & 6 & & & & & & & & & 34.1 & & & \\
\hline Arsenic (filtered), $\mu \mathrm{g} / \mathrm{L}$ & 10 & & & & 2.4 & & & 6.1 & & & & & \\
\hline Carbon tetrachloride, $\mu \mathrm{g} / \mathrm{L}$ & 5 & & & & & & & & & & & & \\
\hline Carbon-14, pCi/L & $2,000(70,000)$ & & & 16,300 & 519 & & & & & & & & \\
\hline Cesium-137, pCi/L & $200(3,000)$ & & & & & & & & & & & & \\
\hline Chloroform, $\mu \mathrm{g} / \mathrm{L}$ & 100 & & & 0.74 & & & & & & & & 0.58 & \\
\hline Chromium (dissolved), $\mu \mathrm{g} / \mathrm{L}$ & 100 & 40 & 48 & 515 & 80 & 163 & 57 & 2,360 & 393 & 106 & 43 & 83.3 & 8 \\
\hline cis-1,2-Dichloroethene, $\mu \mathrm{g} / \mathrm{L}$ & 70 & & & & & & & & & & & & \\
\hline Cobalt-60, pCi/L & $100(5,000)$ & & & & & & & & & & & & \\
\hline Cyanide, $\mu \mathrm{g} / \mathrm{L}$ & 200 & & & & & & & & & & & & \\
\hline Fluoride, mg/L & 4 & 0.26 & 0.18 & 0.33 & 0.26 & 1.0 & 0.29 & 0.56 & 0.2 & 0.59 & 0.17 & 0.9 & 0.15 \\
\hline Gross alpha, pCi/L & 15 & 1.74 & 1.02 & 6.11 & & 8.83 & 2.15 & 3.51 & & 9.64 & & 9.05 & \\
\hline Gross beta, $\mathrm{pCi} / \mathrm{L}$ & 50 & 54.1 & 27.7 & $\mathbf{4 , 4 8 0}$ & 4.05 & 34,100 & 6,650 & 200 & & 76.9 & 19.3 & 99.1 & \\
\hline lodine-129, pCi/L & $1(500)$ & & & & & & & & & & & & \\
\hline Mercury, $\mu \mathrm{g} / \mathrm{l}$ & 2 & & & 0.1 & & & & & & & & & \\
\hline Nitrate, $\mathrm{mg} / \mathrm{L}$ & 45 & 25.2 & 28.8 & 160 & 48.3 & 410 & 26.1 & 77 & 41.6 & 253 & 47.4 & 124 & 31 \\
\hline Nitrite, $\mathrm{mg} / \mathrm{L}$ & 3.3 & & 0.174 & 1.58 & & $4.6^{(c)}$ & 0.125 & 3.28 & & & & 0.099 & \\
\hline Plutonium-239/240, pCi/L ${ }^{(d)}$ & NA (30) & & & & & & & & & & & & \\
\hline Strontium-90, pCi/L & $8(1,000)$ & 41.9 & 11.5 & 3,140 & 1.03 & 16,300 & 3,620 & $\mathbf{9}$ & & 40 & 6.83 & 48.6 & 2.5 \\
\hline Technetium-99, pCi/L & $900(100,000)$ & & 116 & 130 & & & & & & 870 & 35.4 & & \\
\hline Tetrachloroethene, $\mu \mathrm{g} / \mathrm{L}$ & 5 & & & & & & & & & & & & \\
\hline Trichloroethene, $\mu \mathrm{g} / \mathrm{L}$ & 5 & & & 2.9 & & & & & & & & 14 & \\
\hline Tritium, pCi/L & $20,000(2,000,000)$ & 125,000 & 19,200 & 669,000 & 4,750 & 26,500 & 7,840 & 32,500 & 10,900 & 6,030 & & 19,800 & \\
\hline Uranium, $\mu \mathrm{g} / \mathrm{L}$ & 30 & & & 6.49 & & & & 5.08 & & 85.5 & 1.17 & 14.5 & \\
\hline
\end{tabular}


Table 1.0-3. (contd)

\begin{tabular}{|c|c|c|c|c|c|c|c|c|c|}
\hline \multirow[b]{2}{*}{$\begin{array}{l}\text { Contaminant, units } \\
\text { (alphabetical order) }\end{array}$} & \multirow[b]{2}{*}{$\begin{array}{l}\text { DWS } \\
\text { (DCG) }^{(a)}\end{array}$} & \multirow{2}{*}{$\begin{array}{c}\text { 200-ZP-1 } \\
\text { Wells }\end{array}$} & \multirow{2}{*}{$\begin{array}{c}\text { 200-UP-1 } \\
\text { Wells }\end{array}$} & \multirow{2}{*}{$\begin{array}{c}\text { 200-BP-5 } \\
\text { Wells }\end{array}$} & \multicolumn{2}{|c|}{ 200-PO-1 } & \multicolumn{2}{|c|}{$300-F F-5$} & \multirow{2}{*}{$\frac{1100-E M-1}{\text { Wells }}$} \\
\hline & & & & & Wells & $\begin{array}{l}\text { Aquifer } \\
\text { Tubes }\end{array}$ & Wells & $\begin{array}{l}\text { Aquifer } \\
\text { Tubes }\end{array}$ & \\
\hline Antimony (filtered), $\mu \mathrm{g} / \mathrm{L}^{(\mathrm{b})}$ & 6 & $44.3^{(c)}$ & & & & & & & \\
\hline Arsenic (filtered), $\mu \mathrm{g} / \mathrm{L}$ & 10 & 10.8 & 7.3 & 6.1 & 10.5 & & & & \\
\hline Carbon tetrachloride, $\mu \mathrm{g} / \mathrm{L}$ & 5 & 4,400 & 610 & & 0.44 & & 0.65 & 0.19 & 0.27 \\
\hline Carbon-14, pCi/L & $2,000(70,000)$ & 165 & & & & & & & \\
\hline Cesium-137, pCi/L & $200(3,000)$ & & & 902 & & & & & \\
\hline Chloroform, $\mu \mathrm{g} / \mathrm{L}$ & 100 & 144 & 16 & 0.45 & 0.62 & & 1.5 & 0.46 & 0.39 \\
\hline Chromium (dissolved), $\mu \mathrm{g} / \mathrm{L}$ & 100 & 782 & 1,750 & 58.3 & 41.1 & & 23 & 4.3 & \\
\hline cis-1,2-Dichloroethene, $\mu \mathrm{g} / \mathrm{L}$ & 70 & 0.68 & & & & & 160 & 2 & \\
\hline Cobalt-60, pCi/L & $100(5,000)$ & 23.6 & & 290 & & & & & \\
\hline Cyanide, $\mu \mathrm{g} / \mathrm{L}$ & 200 & & & 1,470 & & & & & \\
\hline Fluoride, mg/L & 4 & 4.1 & 0.75 & 0.83 & 7.3 & 0.21 & 1.4 & 0.33 & 0.88 \\
\hline Gross alpha, pCi/L & 15 & 8.66 & 10.8 & 476 & 33.5 & & 74.2 & & 2.44 \\
\hline Gross beta, pCi/L & 50 & 22,900 & 20,700 & 10,700 & 2,020 & 3.27 & 86.2 & & 9.76 \\
\hline lodine-129, pCi/L & $1(500)$ & 42.7 & 30.6 & 4.57 & 9.11 & & & & \\
\hline Mercury, $\mu \mathrm{g} / \mathrm{L}$ & 2 & 0.13 & 0.05 & 3.1 & 0.09 & & & & \\
\hline Nitrate, $\mathrm{mg} / \mathrm{L}$ & 45 & 3,230 & 1,740 & 3,150 & 127 & 5.75 & 133 & 49.6 & $253^{(e)}$ \\
\hline Nitrite, mg/L & 3.3 & 3.02 & 1.61 & $6.24^{(\mathrm{c})}$ & 1.05 & & $2.89^{(\mathrm{c})}$ & 0.135 & \\
\hline Plutonium-239/240, pCi// ${ }^{(\mathrm{c})}$ & NA (30) & & & 19.7 & & & & & \\
\hline Strontium-90, pCi/L & $8(1,000)$ & 2.8 & 26.8 & 3,390 & 20.6 & & 3.32 & & \\
\hline Technetium-99, pCi/L & $900(100,000)$ & 63,200 & 89,900 & 42,900 & 7,740 & & 241 & & \\
\hline Tetrachloroethene, $\mu \mathrm{g} / \mathrm{L}$ & 5 & 6.4 & 2 & & 1.7 & & 0.44 & 1.1 & \\
\hline Trichloroethene, $\mu \mathrm{g} / \mathrm{L}$ & 5 & 27 & 6.9 & & 0.81 & & 4.7 & 96 & 2.3 \\
\hline Tritium, pCi/L & $20,000(2,000,000)$ & $1,820,000$ & $1,020,000$ & 95,500 & 571,000 & 3,790 & $1,470,000$ & 7,730 & 258 \\
\hline Uranium, $\mu \mathrm{g} / \mathrm{L}$ & 30 & 129 & 461 & 804 & 27.2 & & 192 & $394^{(\mathrm{c})}$ & 8.76 \\
\hline \multicolumn{10}{|c|}{$\begin{array}{l}\text { Note: Table lists highest concentration for FY } 2006 \text { in each ground } \\
\text { italic exceed DOE derived concentration guides. Blank space ind } \\
\text { (a) DWS = Drinking water standard; DCG = DOE derived concent } \\
\text { (b) Detection limit is higher than DWS. Not a known contaminant } \\
\text { (c) Suspected error. } \\
\text { (d) There is no drinking water standard for plutonium-239/240. } \\
\text { (e) From offsite contaminant sources. } \\
\text { DOE = U.S. Department of Energy. }\end{array}$} \\
\hline
\end{tabular}


Table 1.0-4. Drinking Water Standards

\begin{tabular}{|c|c|c|c|}
\hline Constituent & \multicolumn{2}{|c|}{ DWS } & \multirow{2}{*}{$\begin{array}{c}\text { Agency }^{(a)} \\
\text { EPA, DOP }\end{array}$} \\
\hline Aluminum & 50 to 200 & $\mu \mathrm{g} / \mathrm{L}^{(\mathrm{b})}$ & \\
\hline Antimony & 6 & $\mu g / L$ & EPA, DOH \\
\hline Arsenic & 10 & $\mu \mathrm{g} / \mathrm{L}^{(\mathrm{c})}$ & EPA, DOH \\
\hline Barium & 2,000 & $\mu \mathrm{g} / \mathrm{L}$ & EPA, DOH \\
\hline Cadmium & 5 & $\mu \mathrm{g} / \mathrm{L}$ & EPA \\
\hline Carbon tetrachloride & 5 & $\mu \mathrm{g} / \mathrm{L}$ & EPA, DOH \\
\hline Chloride & 250 & $\mathrm{mg} / \mathrm{L}^{(\mathrm{b})}$ & EPA, DOH \\
\hline Chloroform (THM) $)^{(\mathrm{d})}$ & 80 & $\mu \mathrm{g} / \mathrm{L}$ & EPA \\
\hline Chromium & 100 & $\mu g / L$ & EPA, DOH \\
\hline cis-1,2-Dichloroethene & 70 & $\mu \mathrm{g} / \mathrm{L}$ & EPA, DOH \\
\hline \multirow[t]{2}{*}{ Copper } & 1,300 & $\mu \mathrm{g} / \mathrm{L}$ & EPA \\
\hline & 1,000 & $\mu g / L^{(b)}$ & EPA, DOH \\
\hline Cyanide & 200 & $\mu \mathrm{g} / \mathrm{L}$ & EPA, DOH \\
\hline 1,4-Dichlorobenzene & 75 & $\mu \mathrm{g} / \mathrm{L}$ & EPA \\
\hline \multirow[t]{2}{*}{ Fluoride } & 4 & $\mathrm{mg} / \mathrm{L}$ & EPA, DOH \\
\hline & 2 & $\mathrm{mg} / \mathrm{L}^{(\mathrm{b})}$ & EPA, DOH \\
\hline Iron & 300 & $\mu \mathrm{g} / \mathrm{L}^{(\mathrm{b})}$ & EPA, DOH \\
\hline Lead & 15 & $\mu \mathrm{g} / \mathrm{L}$ & EPA \\
\hline Manganese & 50 & $\mu g / L^{(b)}$ & EPA, DOH \\
\hline Mercury (inorganic) & 2 & $\mu \mathrm{g} / \mathrm{L}$ & EPA, DOH \\
\hline Methylene chloride & 5 & $\mu \mathrm{g} / \mathrm{L}$ & EPA, DOH \\
\hline Nitrate, as $\mathrm{NO}_{3}^{-}$ & 45 & $\mathrm{mg} / \mathrm{L}$ & EPA, DOH \\
\hline Nitrite, as $\mathrm{NO}_{2}^{-}$ & 3.3 & $\mathrm{mg} / \mathrm{L}$ & EPA, DOH \\
\hline Pentachlorophenol & 1 & $\mu \mathrm{g} / \mathrm{L}$ & EPA, DOH \\
\hline $\mathrm{pH}$ & 6.5 to & $8.5^{(\mathrm{b})}$ & EPA \\
\hline Selenium & 50 & $\mu \mathrm{g} / \mathrm{L}$ & EPA, DOH \\
\hline Silver & 100 & $\mu g / L^{(b)}$ & EPA, DOH \\
\hline Sulfate & 250 & $\mathrm{mg} / \mathrm{L}^{(\mathrm{b})}$ & EPA, DOH \\
\hline Tetrachloroethene & 5 & $\mu \mathrm{g} / \mathrm{L}$ & EPA, DOH \\
\hline Thallium & 2 & $\mu \mathrm{g} / \mathrm{L}$ & EPA, DOH \\
\hline Total dissolved solids & 500 & $\mathrm{mg} / \mathrm{L}^{(\mathrm{b})}$ & EPA \\
\hline 1,1,1-Trichloroethane & 200 & $\mu g / L$ & EPA, DOH \\
\hline Trichloroethene & 5 & $\mu \mathrm{g} / \mathrm{L}$ & EPA, DOH \\
\hline Zinc & 5,000 & $\mu g / L^{(b)}$ & EPA, DOH \\
\hline Antimony-125 & 300 & $\mathrm{pCi} / \mathrm{L}^{(\mathrm{e})}$ & EPA \\
\hline Beta particle and photon activity & 4 & $\mathrm{mrem} / \mathrm{yr}^{(\mathrm{f})}$ & EPA, DOH \\
\hline Carbon-14 & 2,000 & $\mathrm{pCi} / \mathrm{L}^{(e)}$ & EPA \\
\hline Cesium-137 & 200 & $\mathrm{pCi} / \mathrm{L}^{(\mathrm{e})}$ & EPA \\
\hline Cobalt-60 & 100 & $\mathrm{pCi} / \mathrm{L}^{(\mathrm{e})}$ & EPA \\
\hline lodine-129 & 1 & $\mathrm{pCi} / \mathrm{L}^{(e)}$ & EPA \\
\hline Ruthenium-106 & 30 & $\mathrm{pCi} / \mathrm{L}^{(\mathrm{e})}$ & EPA \\
\hline Strontium-90 & 8 & $\mathrm{pCi} / \mathrm{L}^{(\mathrm{e})}$ & EPA, DOH \\
\hline Technetium-99 & 900 & $\mathrm{pCi} / \mathrm{L}^{(\mathrm{e})}$ & EPA \\
\hline Total alpha (excluding uranium) & 15 & $\mathrm{pCi} / \mathrm{L}^{(\mathrm{e})}$ & EPA, DOH \\
\hline Tritium & 20,000 & $\mathrm{pCi} / \mathrm{L}^{(\mathrm{e})}$ & EPA, DOH \\
\hline Uranium & 30 & $\mu \mathrm{g} / \mathrm{L}$ & EPA, DOH \\
\hline
\end{tabular}

(a) $\mathrm{DOH}=$ Washington State Department of Health at WAC 246-290; EPA = U.S. Environmental Protection Agency at 40 CFR 141, 40 CFR 143, and EPA 822-R-96-001.

(b) Secondary standards are not associated with health effects, but with taste, odor, staining, or other aesthetic qualities.

(c) Effective January 23, 2006.

(d) Standard is for total trihalomethanes (THM)

(e) EPA drinking water standards for radionuclides were derived based on a 4-mrem/yr dose standard using maximum permissible concentrations in water specified in National Bureau of Standards Handbook 69 (U.S. Department of Commerce, as amended August 1963).

(f) Beta and gamma radioactivity from anthropogenic radionuclides. Annual average concentration shall not produce an annual dose from anthropogenic radionuclides equivalent to the total body or any internal organ dose $>4 \mathrm{mrem} / \mathrm{yr}$. If two or more radionuclides are present, the sum of their annual dose equivalents shall not exceed $4 \mathrm{mrem} / \mathrm{yr}$. Compliance may be assumed if annual average concentrations of total beta, tritium, and strontium- 90 are $<50,20,000$, and $8 \mathrm{pCi} / \mathrm{L}$, respectively.

DWS = Drinking water standard (maximum contaminant level for drinking water supplies). 
Table 1.0-5. Derived Concentration Guides ${ }^{(a, b, c)}$ and 4-mrem Effective Dose Equivalent Concentrations for Drinking Water ${ }^{(\mathrm{d})}$

\begin{tabular}{|c|c|c|}
\hline Radionuclide & $\begin{array}{l}\text { Derived Concentration } \\
\text { Guide, } \mathrm{pCi} / \mathrm{L}\end{array}$ & $\begin{array}{l}\text { 4-mrem Effective Dose } \\
\text { Equivalent, pCi/L }\end{array}$ \\
\hline Tritium & $2,000,000$ & 80,000 \\
\hline Carbon-14 & 70,000 & 2,800 \\
\hline Cobalt-60 & 5,000 & 200 \\
\hline Strontium-90 & 1,000 & 40 \\
\hline Technetium-99 & 100,000 & 4,000 \\
\hline Ruthenium-103 & 50,000 & 2,000 \\
\hline Ruthenium-106 & 6,000 & 240 \\
\hline Antimony-125 & 60,000 & 2,400 \\
\hline lodine-129 & 500 & 20 \\
\hline lodine-131 & 3,000 & 120 \\
\hline Cesium-134 & 2,000 & 80 \\
\hline Cesium-137 & 3,000 & 120 \\
\hline Uranium-234 & 500 & 20 \\
\hline Uranium-235 & 600 & 24 \\
\hline Uranium-238 & 600 & 24 \\
\hline Plutonium-238 & 40 & 1.6 \\
\hline Plutonium-239 & 30 & 1.2 \\
\hline Plutonium-240 & 30 & 1.2 \\
\hline Americium-241 & 30 & 1.2 \\
\hline
\end{tabular}

(a) Concentration of a specific radionuclide in water that could be continuously consumed at average annual rates and not exceed an effective dose equivalent of $100 \mathrm{mrem} / \mathrm{yr}$.

(b) Values in this table represent the lowest, most conservative derived concentration guides considered potentially applicable to Hanford Site operations, and may be adjusted upward (larger) if accurate solubility information is available.

(c) From DOE Order 5400.5.

(d) Concentration of a specific radionuclide in water that would produce an effective dose equivalent of $4 \mathrm{mrem} / \mathrm{yr}$ if consumed at average annual rates. EPA drinking water standards for radionuclides listed in Table 1.0-4 were derived based on a 4-mrem/yr dose standard using maximum permissible concentrations in water specified in National Bureau of Standards Handbook 69 (U.S. Department of Commerce, as amended August 1963). The 4-mrem/yr dose standard listed in this table was calculated using a more recent dosimetry system adopted by DOE and other regulatory agencies (as implemented in DOE Order 5400.5 in 1993). DOE $=$ U.S. Department of Energy.

$E P A=$ U.S. Environmental Protection Agency.

For additional information on contaminants that are found at the Hanford Site, see "Summary Fact Sheets for Selected Environmental Contaminants to Support Health Risk Analysis" (Peterson et al. 2002), available on the web site of Environmental Assessment Division, Argonne National Laboratory (http://www.ead.anl.gov). Click on "publications" and search for the title. 


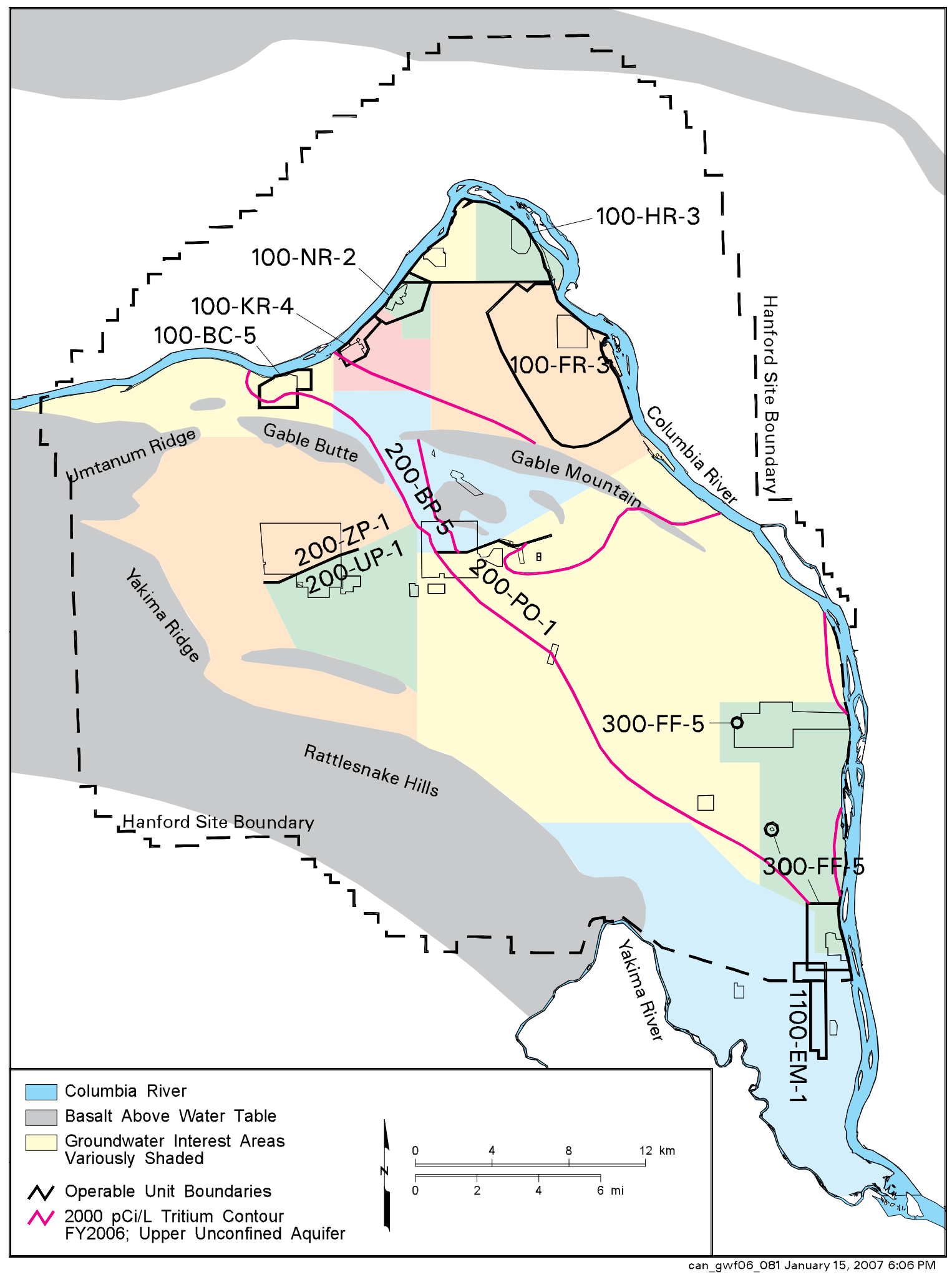

Figure 1.0-1. Groundwater Operable Units and Groundwater Interest Areas on the Hanford Site 


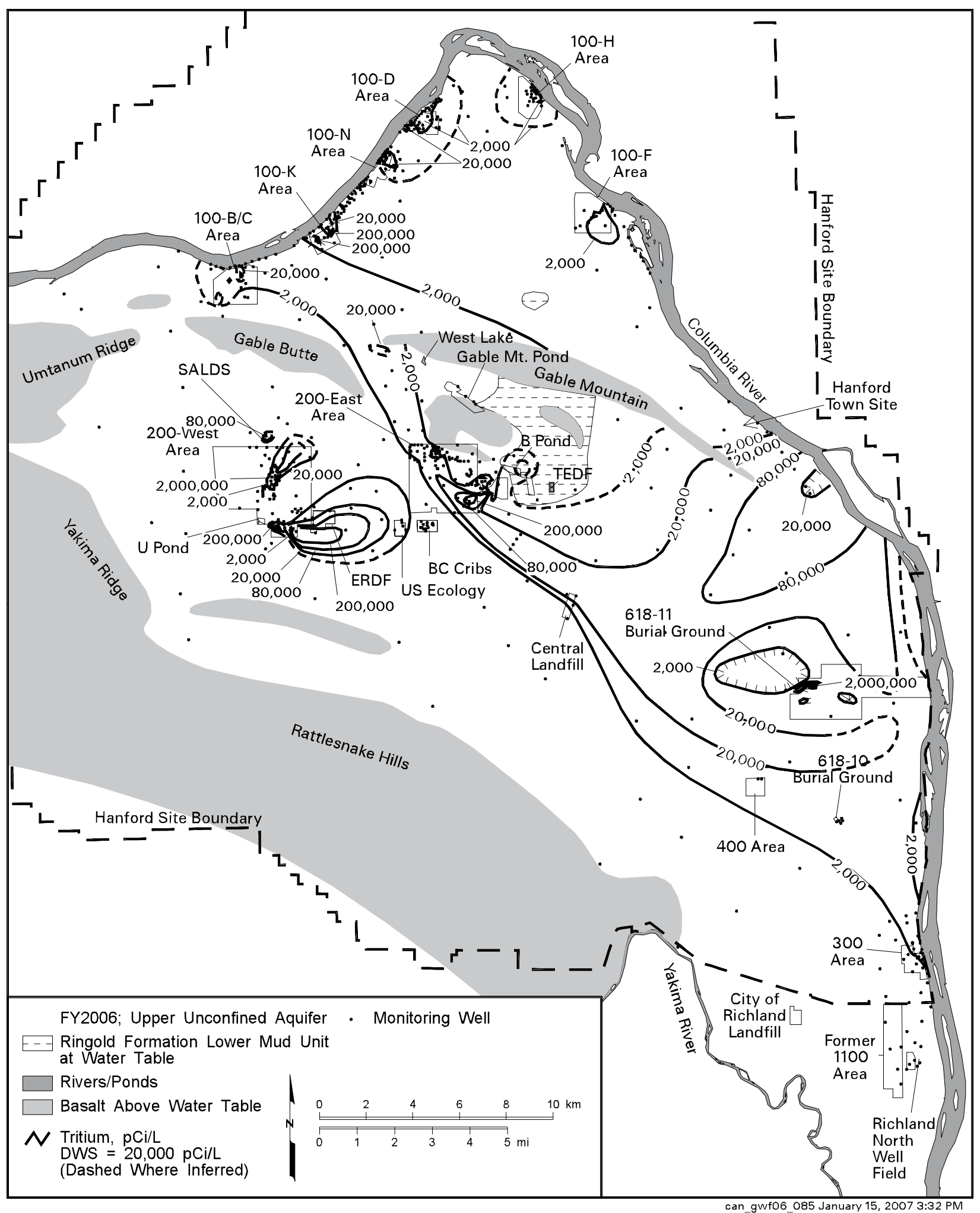

Figure 1.0-2. Average FY 2006 Tritium Concentrations on the Hanford Site, Upper Part of Unconfined Aquifer 


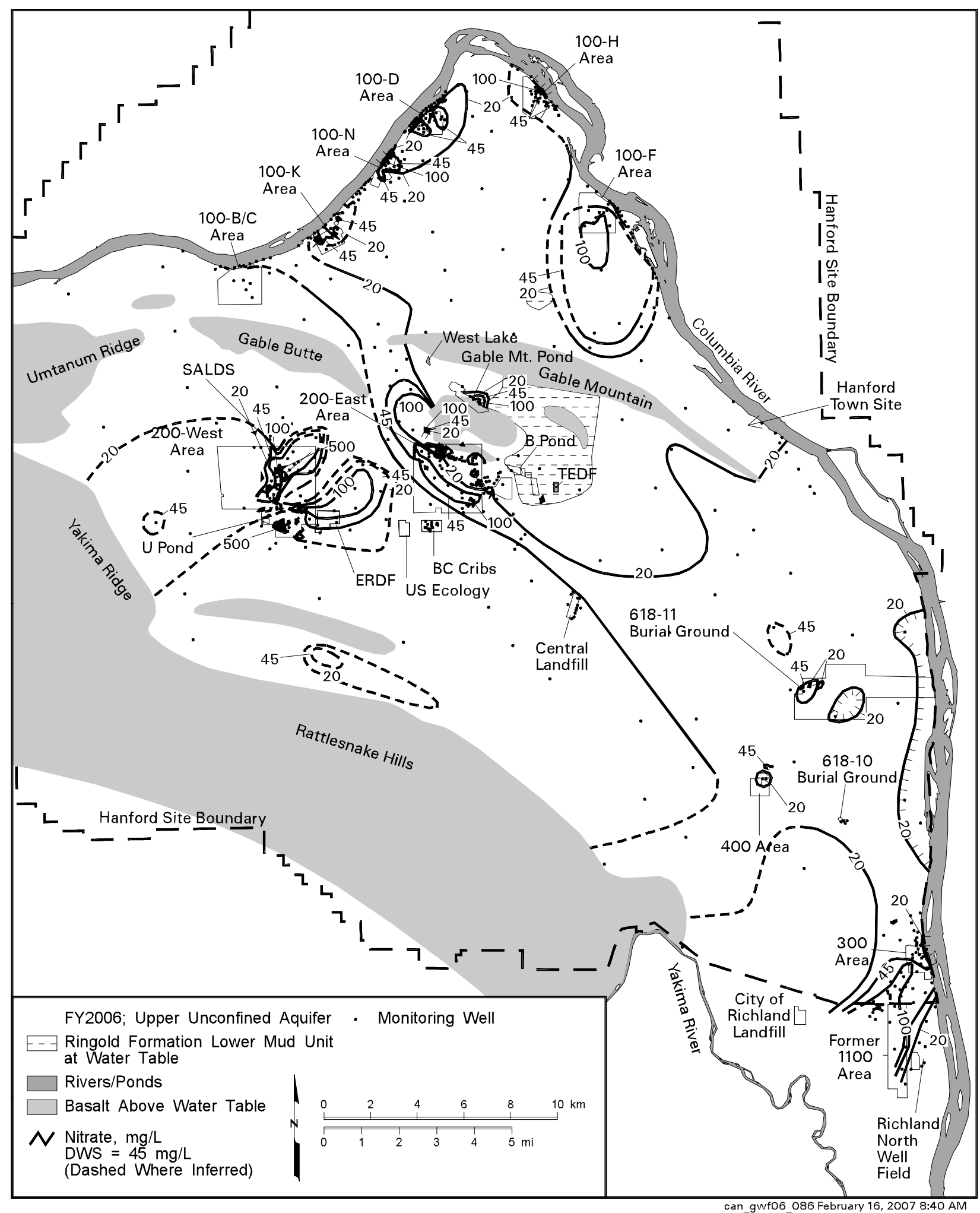

Figure 1.0-3. Average FY 2006 Nitrate Concentrations on the Hanford Site, Upper Part of Unconfined Aquifer 


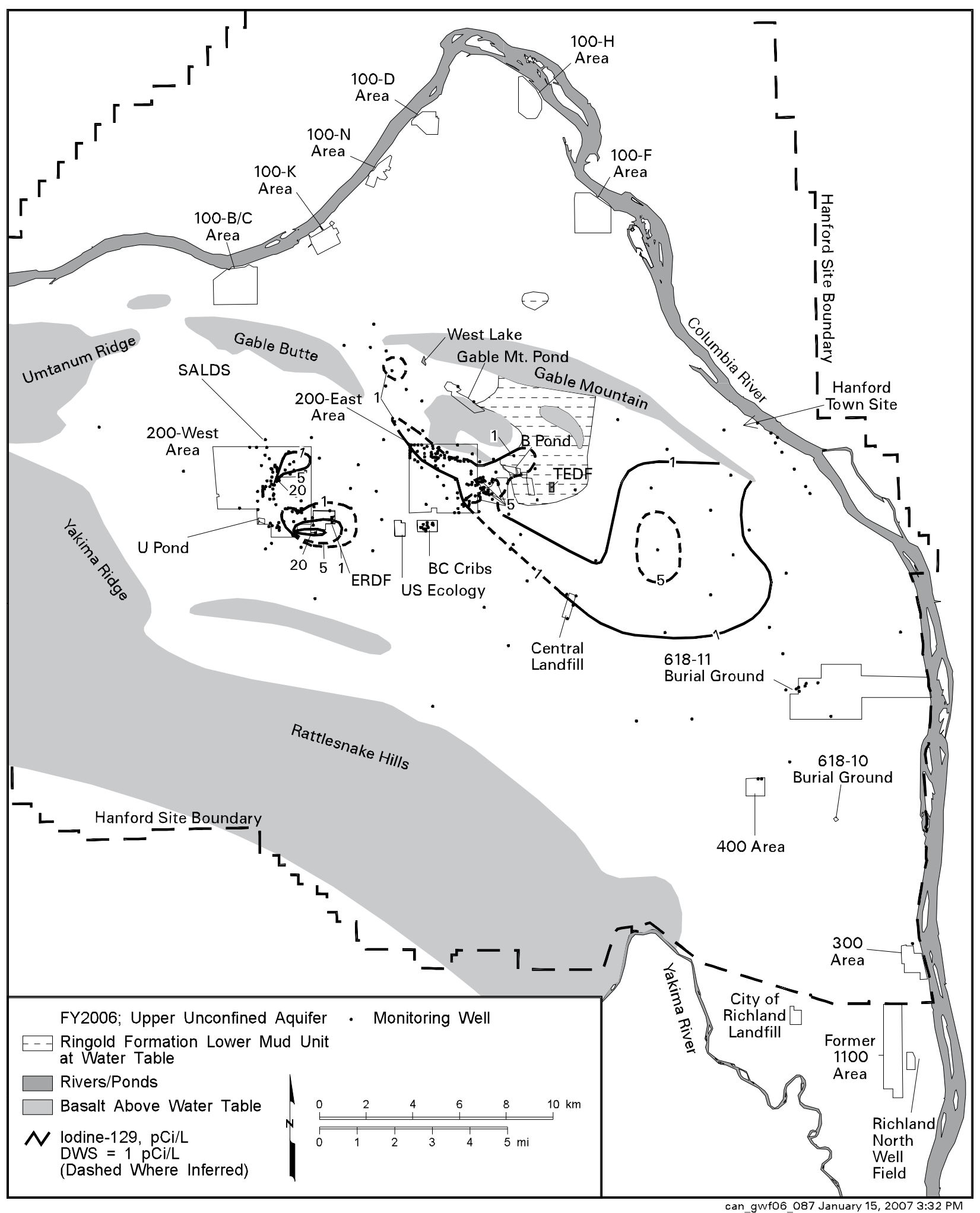

Figure 1.0-4. Average FY 2006 Iodine-129 Concentrations on the Hanford Site, Upper Part of Unconfined Aquifer 


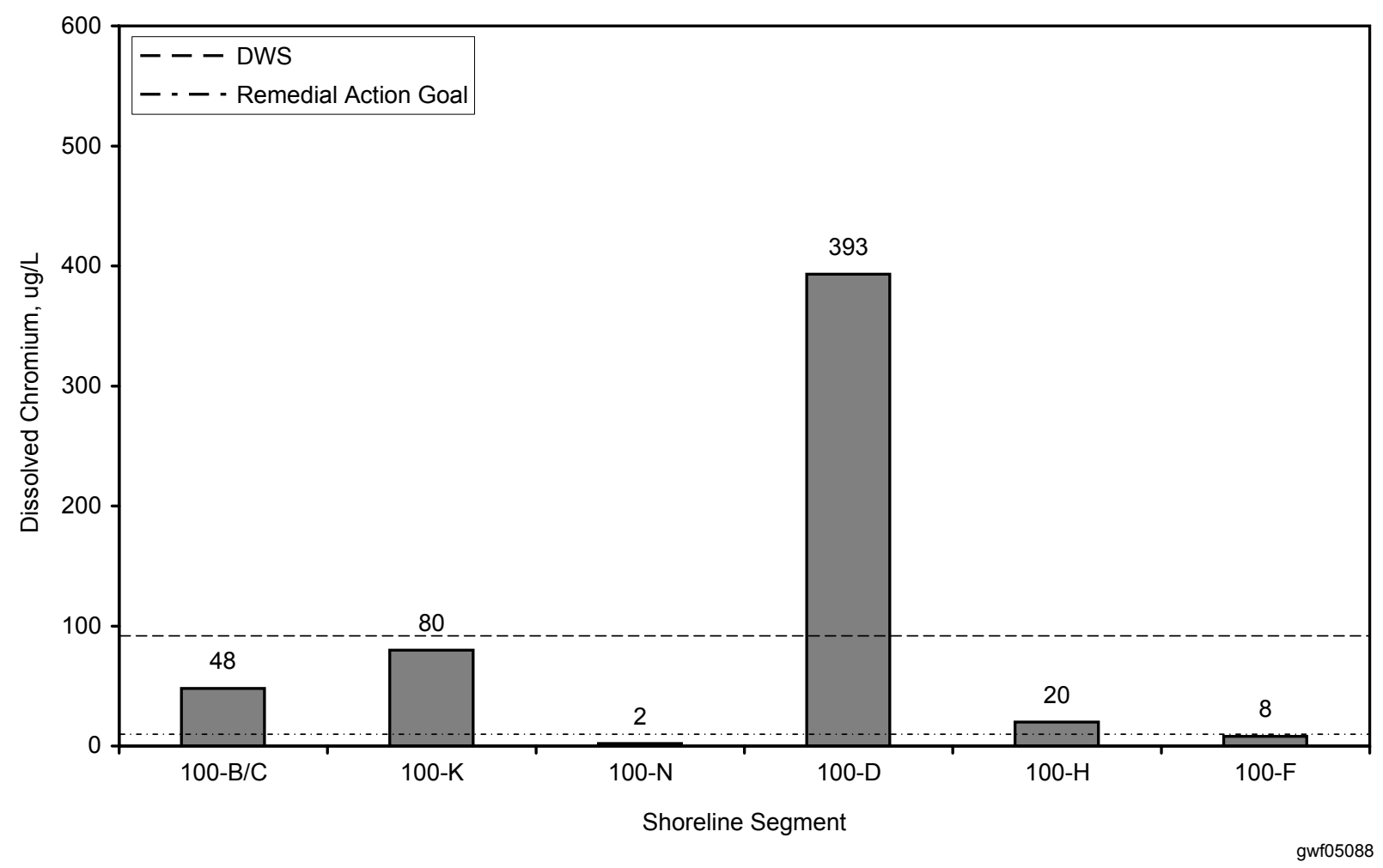

Figure 1.0-5. Maximum Dissolved Chromium in Aquifer Tubes, FY 2006 


\subsection{Groundwater}

This section discusses groundwater flow and chemistry on the Hanford Site. Section 2.1 gives a general overview of site-wide flow. Sections 2.2 through 2.13 describe groundwater for each of the groundwater interest areas/operable units. These regions are presented in geographic order (north to south, west to east). Monitoring of specific units under the Comprehensive Environmental Response, Compensation, and Liability Act; Resource Conservation and Recovery Act; Atomic Energy Act; or Washington Administrative Code are discussed within relevant sections. Section 2.14 describes groundwater flow and chemistry in the confined aquifers.

Waste sites, hydrogeology, and methods of sampling and analysis are described in Hanford Site Groundwater: Settings, Sources, and Methods (PNNL-13080). 


\subsection{Overview of Groundwater Flow}

\section{J. P. McDonald}

This section provides a broad picture of groundwater flow beneath the Hanford Site. The uppermost aquifer beneath most of the Hanford Site is unconfined and is composed of unconsolidated to semiconsolidated sediment of the Hanford and Ringold Formations, which was deposited on the basalt bedrock. In some areas, deeper parts of the aquifer are confined locally by layers of silt and clay. Deeper confined aquifers also occur within the underlying basalt and associated sedimentary interbeds. Well location maps for each geographic region are included in Sections 2.2 through 2.14. Wells in the 600 Area, which cover portions of the Hanford Site other than the former operational areas, are shown in Figure 2.1-1.

Each year during March, water-level measurements are normally collected from more than 800 wells monitoring the unconfined aquifer system and the underlying confined aquifers beneath the Hanford Site. During fiscal year (FY) 2006, the number of wells monitored was reduced to offset increased costs associated with vapor monitoring at the well heads, which was augmented in response to a safety concern expressed by field personnel. Because of the additional safety monitoring, the field work was delayed and most of the water-level measurements were collected during April and May.

A total of 542 water-level measurements were collected between March 29 and May 26, 2006, out of the 890 measurements originally scheduled. Wells not measured included all those in the lower basalt-confined aquifers and other wells not directly used to prepare contour maps. Several measurements to support mapping the water table also were cancelled, with the largest reductions made in areas having a relatively flat water table (i.e., 200 East Area) or where wells are closely spaced. Only limited reductions were made in areas experiencing active groundwater remediation. This approach, along with relying on the water-table interpretation from previous years, minimized the uncertainty in the FY 2006 water-table map caused by these reductions.

The water-level data were used to (1) prepare contour maps that indicate the general direction of groundwater movement within an aquifer; (2) determine hydraulic gradients, which in conjunction with the hydraulic properties of the aquifer, are used to estimate groundwater flow velocities; (3) support conceptual and numerical groundwater model development, modification, and maintenance; and (4) interpret sampling results. This section describes the results of a regional-scale analysis of these data for the unconfined aquifer, which is the aquifer most affected by Hanford operations. Local groundwater flow in each groundwater operable unit is described in Sections 2.2 through 2.13. Flow characteristics in the confined aquifers present in the lower Ringold Formation and in the upper basalt aquifer system are discussed in Section 2.14.

\subsubsection{Water-Table Interpretation for April/May 2006}

Figure 2.1-2 presents the Hanford Site water-table map representative of April/May 2006 conditions. Groundwater in the unconfined aquifer generally flows from upland areas in the west toward the regional discharge area north and east along the Columbia River. Steep gradients occur in the west, east, and north regions of the site. Shallow gradients occur southeast of the 100-F Area and in a broad arc extending from west of the 100-B/C Area to the southeast between Gable Butte and Gable Mountain (Gable Gap), and through the 200 East Area into the central portion of the site. The steep gradients in the west and east are due to the presence of the relatively low permeability sediment of the Ringold Formation at the water table, while the low gradients are associated with areas where the highly permeable sand and gravel of the Hanford formation is present at the water table. 


\section{Groundwater in}

the unconfined

aquifer generally

flows west to

east beneath the

Hanford Site and

discharges to the

Columbia River.
North of Gable Butte and Gable Mountain, groundwater flow directions vary from northwest to east depending on the location. Groundwater enters this region through the gaps between Gable Mountain, Gable Butte, and Umtanum Ridge. The Columbia River also recharges the unconfined aquifer west of the 100-B/C Area. Groundwater flow patterns suggest that Gable Gap is the dominant source of recharge. Recent estimates indicate that discharge northward through Gable Gap ranges between $3.1 \times 10^{9}$ and $9.6 \times 10^{9}$ liters per year (PNNL-SA-49780). This water spreads out and flows north-northwest toward the Columbia River, as well as toward the northeast and east along the north side of Gable Mountain. Recharge water from the Columbia River and the gap between Umtanum Ridge and Gable Butte is thought to flow east toward the 100-B/C Area and discharge to the river. In the 100 Areas, the local groundwater flow is generally toward the Columbia River, although this pattern is altered to varying degrees by pump-and-treat remediation systems in the $100-\mathrm{K}$, 100-D, and 100-H Areas. A pump-and-treat system in the 100-N Area was shut down during the year to begin a field test of a permeable reactive barrier.

An apparent groundwater mound exists $~ 2$ kilometers north of Gable Mountain and is associated with low conductivity Ringold Formation mud at the water table. This mound is contoured as if it were part of the unconfined aquifer (Figure 2.1-2), but it could also represent a perched water table above the regional water table. There is insufficient information to distinguish between these alternatives. Water-level elevations indicate that groundwater moving east along Gable Mountain flows around this apparent mound.

South of Gable Butte and Gable Mountain, recharge to the aquifer comes from the Cold Creek Valley, Dry Creek Valley, Rattlesnake Hills, Yakima River, and infiltrating precipitation, and groundwater generally flows from west to east. Past effluent discharges at U Pond and other facilities caused a groundwater mound to form beneath the 200 West Area that significantly affected regional flow patterns in the past. These discharges largely ceased by the mid-1990s, but a remnant mound remains, which is apparent from the shape of the water-table contours passing through the 200 West Area. Currently, the watertable elevation is $\sim 12$ meters above an estimated water-table elevation prior to the start of Hanford operations. ${ }^{(a)}$ When equilibrium conditions are once again established in the aquifer after dissipation of the mounding caused by artificial recharge, computer simulations suggest that the water table may still be $\sim 5$ to $\sim 7$ meters higher than the pre-Hanford water table (PNNL-14753). This may be due to modeling uncertainties, recent artificial recharge generated by increased irrigation activities to the region west of the Hanford Site, or the fact that Columbia River conditions are different than in pre-Hanford times due to the construction of hydroelectric dams. The water table beneath the 200 West Area is locally perturbed by discharges from the State-Approved Land Disposal Site, as well as by operation of a groundwater pump-and-treat remediation system at the 200-ZP-1 Operable Unit.

Groundwater flow in the central portion of the Hanford Site, encompassing the 200 East Area, is significantly affected by the presence of a buried flood channel, which lies in a northwest to southeast orientation (PNNL-12261). The water table in this area is very flat (i.e., the hydraulic gradient is estimated to be $\sim 10^{-5}$ ) due to the high permeability of the Hanford formation. Groundwater flow in this region is significantly affected by the presence of low permeability sediment of the Ringold Formation at the water table east and northeast of the 200 East Area, as well as basalt above the water table. These features constitute barriers to groundwater flow. The extent of the basalt units above the water table continues to increase slowly due to the declining water table, resulting in an even greater effect on groundwater flow in this area. The water table beneath the 200 East Area

(a) Based on the April 2006 water-level elevation in well 299-W18-15 (136.7 meters NAVD88) and the pre-Hanford water-table elevation at the location of this well estimated from BNWL-B-360 ( 125.1 meters NAVD88). The peak historical water-level elevation within the 200 West Area occurred at well 299-W18-15 in 1984 (149.1 meters NAVD88). 
is $\sim 2$ meters higher than estimated pre-Hanford conditions. ${ }^{\text {(b) }}$ Simulations of equilibrium conditions after site closure suggest that the water table in the 200 East Area will be near its pre-Hanford elevation (PNNL-14753).

The flat nature of the water table (i.e., very low hydraulic gradient) in the 200 East Area and vicinity makes determination of the flow direction difficult. This is because the uncertainty in the water-level elevation measurements is greater than the actual relief present on the water table. Therefore, determining the groundwater flow direction based on these data is problematic, so other evidence is used to infer flow directions. Water enters the 200 East Area and vicinity from the west and southwest, as well as from beneath the mud units to the east and from the underlying aquifers where the confining units have been removed or thinned by erosion. The flow of water divides, with some migrating to the north through Gable Gap and some moving southeast toward the central part of the site. The specific location of the groundwater flow divide is currently not known. It is known that groundwater flows north through Gable Gap, because the hydraulic gradient is steep enough to be determined using water-level-elevation data (the gradient averages $1.5 \times 10^{-4}$ along a north flow direction). Groundwater is known to flow southeast within the region between the 200 East Area and the Central Landfill, because the average water-level elevation at the landfill (121.96 meters NAVD88 for May 2006) is 0.13 meter less than the average elevation in the 200 East Area (122.09 meters NAVD88 for April 2006). This yields a regional hydraulic gradient ranging from $1 \times 10^{-5}$ to $2 \times 10^{-5}$. Efforts are underway to improve the accuracy of the water-level measurements so that hydraulic gradients can be determined for the 200 East Area (see Section 2.10).

Between the area southeast of the Central Landfill to the 300 Area, the highly permeable sediments of the Hanford formation occur above the water table. These sediments intercept the water table again at the 300 Area. For this reason, the hydraulic gradient in the 300 Area is also very low. Groundwater flow converges on the 300 Area from the northwest, west, and southwest, then generally moves along a southeast flow path and discharges to the Columbia River (PNNL-15127).

In addition to the Hanford Site water table, Figure 2.1-2 depicts the water table north and east of the Columbia River (using a 50-meter-contour interval), based on water-level measurements collected during March 2005. The offsite water table is heavily influenced by irrigation practices, and its configuration is significantly controlled by topography. Many of the contour flexures and mounds coincide with topographic valleys and higher plateau areas. Hydraulic heads north and east of the Columbia River are significantly higher than on the Hanford Site, as evidenced by the proximity of the 150-meter contour to the Columbia River. Therefore, it is unlikely that groundwater contaminants from the Hanford Site would migrate underneath the Columbia River to these offsite areas. PNL-8122 contains a more complete discussion of the offsite water table.

\subsubsection{Water-Table Change from FY 2005}

The water-table elevation continued to decline over much of the site from March 2005 to April/May 2006. The decline is a result of the curtailment of effluent discharges to ground during the 1980s and 1990s. The largest, widespread decline occurred in the 200 West Area, where the water table declined by an average of 0.31 meter (in those areas not influenced by the 200-ZP-1 pump-and-treat system) from March 2005 to April 2006. The water-table elevation increased in a few areas, such as in Dry Creek Valley, along the Yakima River, and

Over much of
the Hanford
Site, the water
table continued
to decline. The
declining water
table caused some
monitoring wells to
go dry; new wells
are being installed.

Over much of

the Hanford

Site, the water

table continued

declining water

table caused some

monitoring wells to

are being installed.

(b) Based on the average water-level elevation measured in 19 wells within the 200 East Area during March 2005, all of which have been corrected for deviations of the boreholes from vertical (122.1 meters NAVD88), and the pre-Hanford water-table elevation for the 200 East Area estimated from BNWL-B-360 ( 120 meters NAVD88). 
Beginning in 2002, the rate of watertable elevation decline in the 200 East Area and vicinity slowed significantly. Effluent releases to the $\mathbf{2 0 0}$ Area Treated Effluent Disposal Facility were a factor in the observed watertable fluctuation. at the North Richland Well Field and Recharge Ponds, signifying increased recharge to the aquifer from these areas. The water-table elevation was locally perturbed in the $100-\mathrm{H}$ and 200 West Areas due to reconfiguration of the 100-HR-3 and 200-ZP-1 groundwater pumpand-treat systems, and in the 100-N Area due to cessation of groundwater extraction and injection at the 100-NR-2 pump-and-treat system. The season spring runoff of the Columbia River during 2006 started earlier, and reached higher levels, than in the previous several years. The impact of the high river conditions is not apparent in the water-table map shown in Figure 2.1-2 because the water-level measurements along the river were completed prior to the increase in river stage.

In the 200 East Area, the elevation of the water table declined by an average of 0.07 meter from March 2005 to April 2006. This is less than the previous annual decline (0.13 meter from March 2004 to March 2005, PNNL-15670), and is below the average rate of decline observed from June 1997 to March 2002 (0.17 meter per year). Section 2.1.3 discusses water-table fluctuations in the 200 East Area in greater detail.

\subsubsection{Fluctuations in the 200 East Area Water-Table Elevation}

Beginning in the fall of 2002, the rate of water-table elevation decline in the 200 East Area and vicinity slowed significantly with water levels actually increasing in some wells. This change is evident in a graph of water levels in well 299-E33-32, located in the northwest 200 East Area (Figure 2.1-3). An investigation into the cause of this fluctuation was completed during FY 2006, and the results are described in PNNL-SA-49780. The region affected by this smaller than normal decline correlated with the highly permeable Hanford formation sediment of the buried flood channel extending from north of Gable Gap through the 200 East Area to the Central Landfill. This fluctuation indicated that there was additional water stored in the aquifer above that expected if the water table had continued to decline normally. For March 2003, the unconfined aquifer in the highly permeable sediments extending from Gable Gap through the 200 East Area to the Central Landfill was estimated to contain between $1.1 \times 10^{9}$ and $2.3 \times 10^{9}$ liters of extra water in storage. This water could be accounted for by either an increase in recharge to the study area, a decrease in discharge from the study area, or both. Using a water balance approach, several hypotheses that may account for the additional water were evaluated. The investigation considered the potential effects of increased natural recharge (through the vadose zone or from the Rattlesnake Hills), increased artificial recharge from a variety of sources (i.e., the 200 Area Treated Effluent Disposal Facility, the Waste Treatment Plant construction site, or a water line leak in the 200 East Area during November 2002), and decreased discharge from the highly permeable sediments due to high stage in the Columbia River.

Several of these hypotheses were either shown not to be causes of the fluctuation or were deemed unlikely causes (PNNL-SA-49780). The travel time for natural recharge to reach the water table in the 200 East Area was estimated to be decades. This long travel time would result in a relatively constant recharge rate at the water table, thus making increased natural recharge from the vadose zone unlikely. Increased recharge from the Rattlesnake Hills (estimated to be $\sim 1.0 \times 10^{7}$ liters) and potential recharge from the water line leak $\left(\sim 1.3 \times 10^{5}\right.$ liters $)$ were both too small to account for the estimated storage change. Water use at the Waste Treatment Plant construction site is not measured, but examination of aerial photographs of the site did not reveal any large-scale use of water that might impact the water table. Thus, while the construction site may be a possible source of recharge, this alternative was deemed unlikely.

The remaining hypotheses, namely increased discharges to the 200 Area Treated Effluent Disposal Facility and decreased discharge from the study area due to a high river stage, appeared to be feasible. The 200 East Area water-table elevation appears to temporarily 
increase in response to large discharges at the 200 Area Treated Effluent Disposal Facility, as reflected by well 299-E33-32 (Figure 2.1-4). Similar responses are seen in wells throughout the 200 East Area and vicinity, including those closer to the 200 Area Treated Effluent Disposal Facility. Discharges to this facility were $7.0 \times 10^{8}$ liters above average during the period from April 2002 to March 2003, which accounted for 30\% to 65\% of the extra water in storage. Thus, increased discharges from the facility was interpreted to be one cause of the observed fluctuation, but the data suggested that another factor also affected the water table.

Discharge in the Columbia River was higher than normal from April to July 2002 (Figure 2.1-5), which resulted in a higher than normal river stage. Application of an analytical equation that describes the water-table response to changes in river stage (Ferris 1952) demonstrated it is theoretically possible that the water table beneath the 200 East Area may respond to changes in river stage, even though the 200 East Area is $~ 10$ kilometers from the river. This is possible because of the high transmissivity associated with the Hanford formation sediments that extend from north of Gable Gap into the central part of the site. Thus, the hypothesis that high stage in the Columbia River affects the water table in the 200 East Area and vicinity appears to be feasible, because (1) the water-table fluctuation temporally coincides with increased discharge in the river, (2) it is theoretically possible for the river to affect the water table in the 200 East Area and vicinity, and (3) the extra water in aquifer storage cannot be fully accounted for by increased discharges to the 200 Area Treated Effluent Disposal Facility and no other likely explanation could be identified. However, there were insufficient data to demonstrate a cause-and-effect relationship between the 200 East Area water table and the river.

During the spring of 2006, discharge in the Columbia River was again higher than normal (Figure 2.1-5). The collection of additional water-level measurements was implemented in Gable Gap to assess the possible effects of the increased river stage on the water table. This study is in progress and the results will be described in the next annual report. 


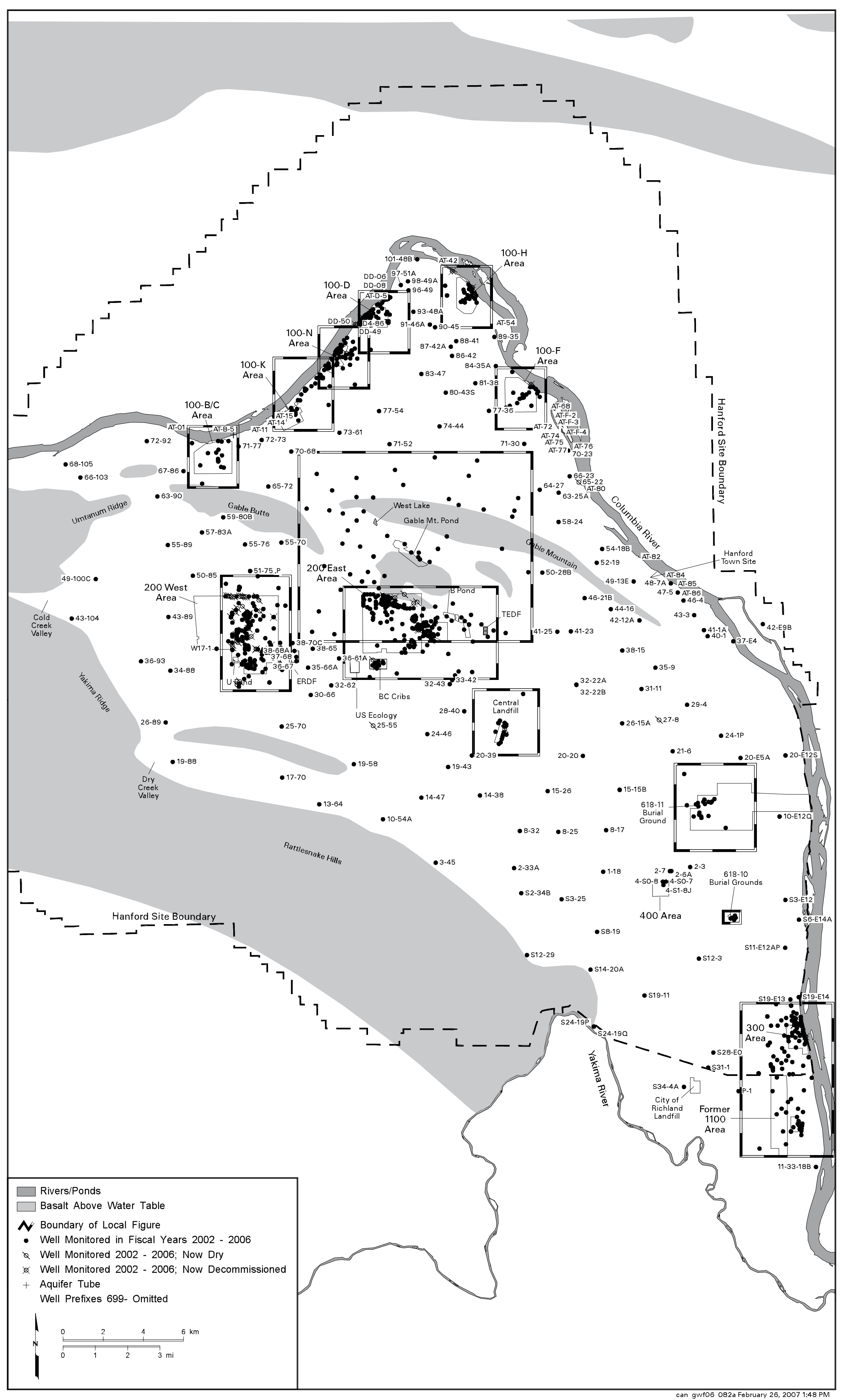

Figure 2.1-1. Groundwater Monitoring Wells on the Hanford Site 


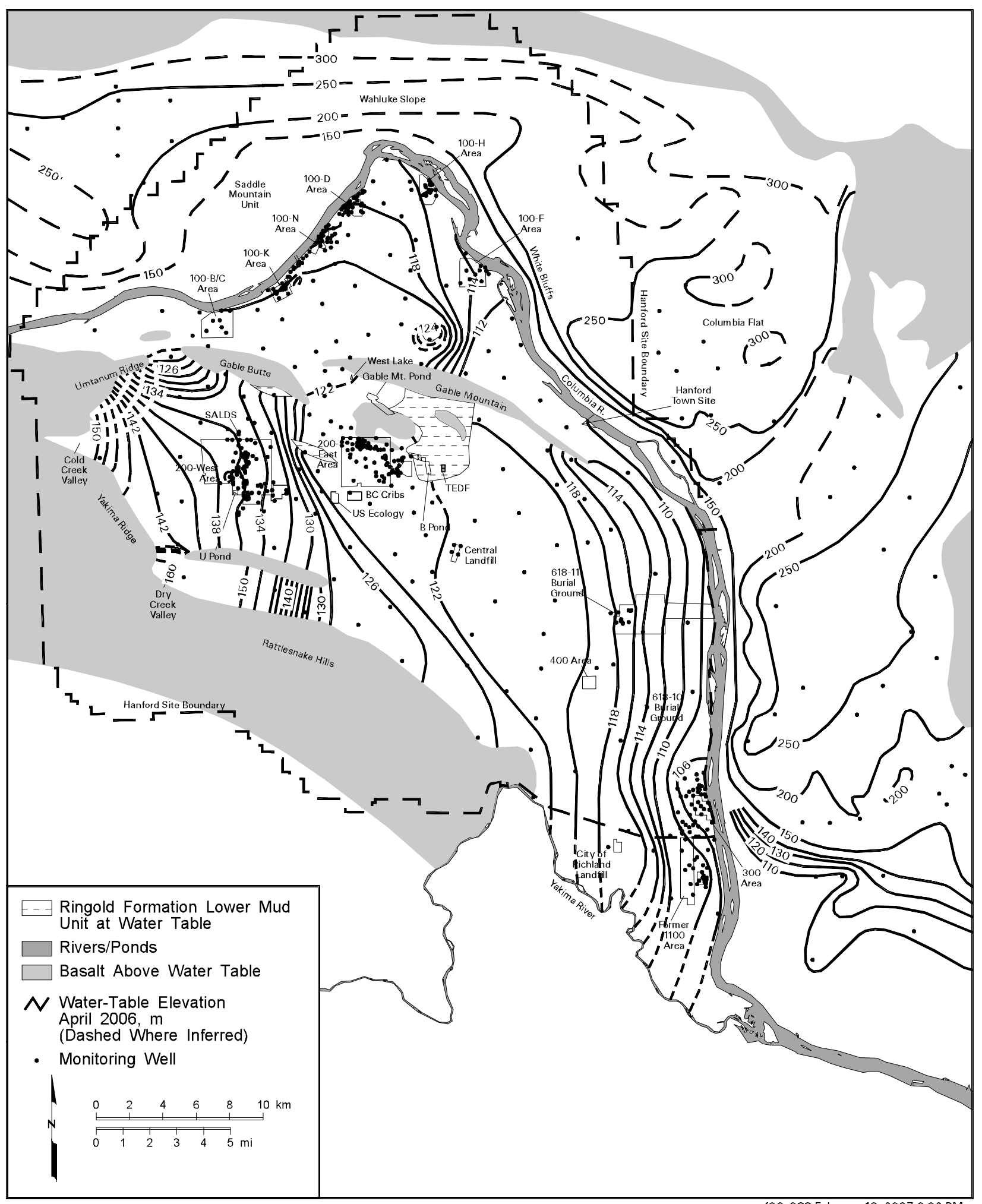

can gwf06 083 February 13, 2007 2:02 PM

Figure 2.1-2. Hanford Site and Outlying Areas Water-Table Map, April/May 2006 


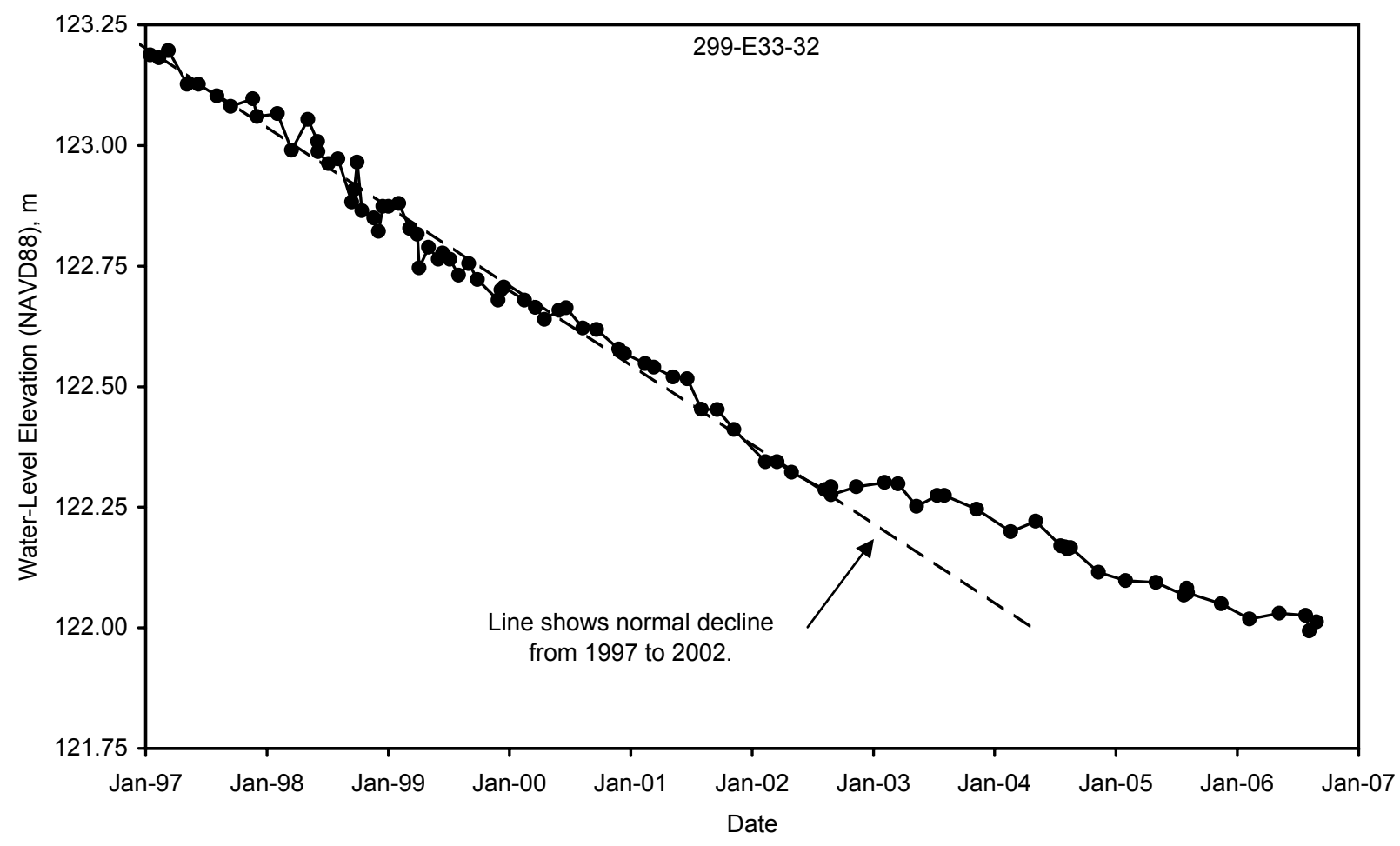

Figure 2.1-3. Water Levels in Well 299-E33-32, Northwest 200 East Area

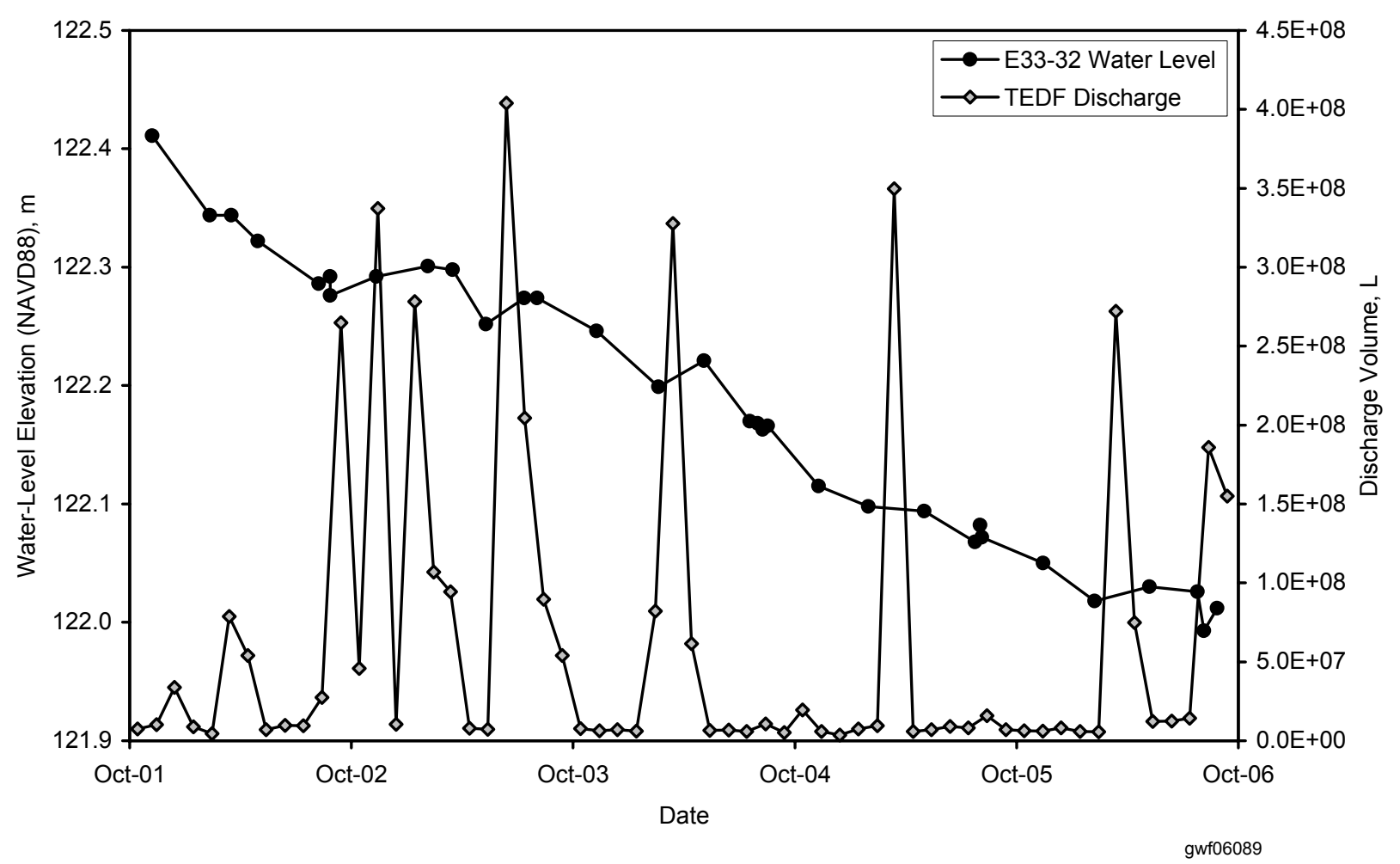

Figure 2.1-4. Water-Level Elevations in Well 299-E33-32 and Monthly Effluent Discharge Volumes at the 200 Area Treated Effluent Disposal Facility 


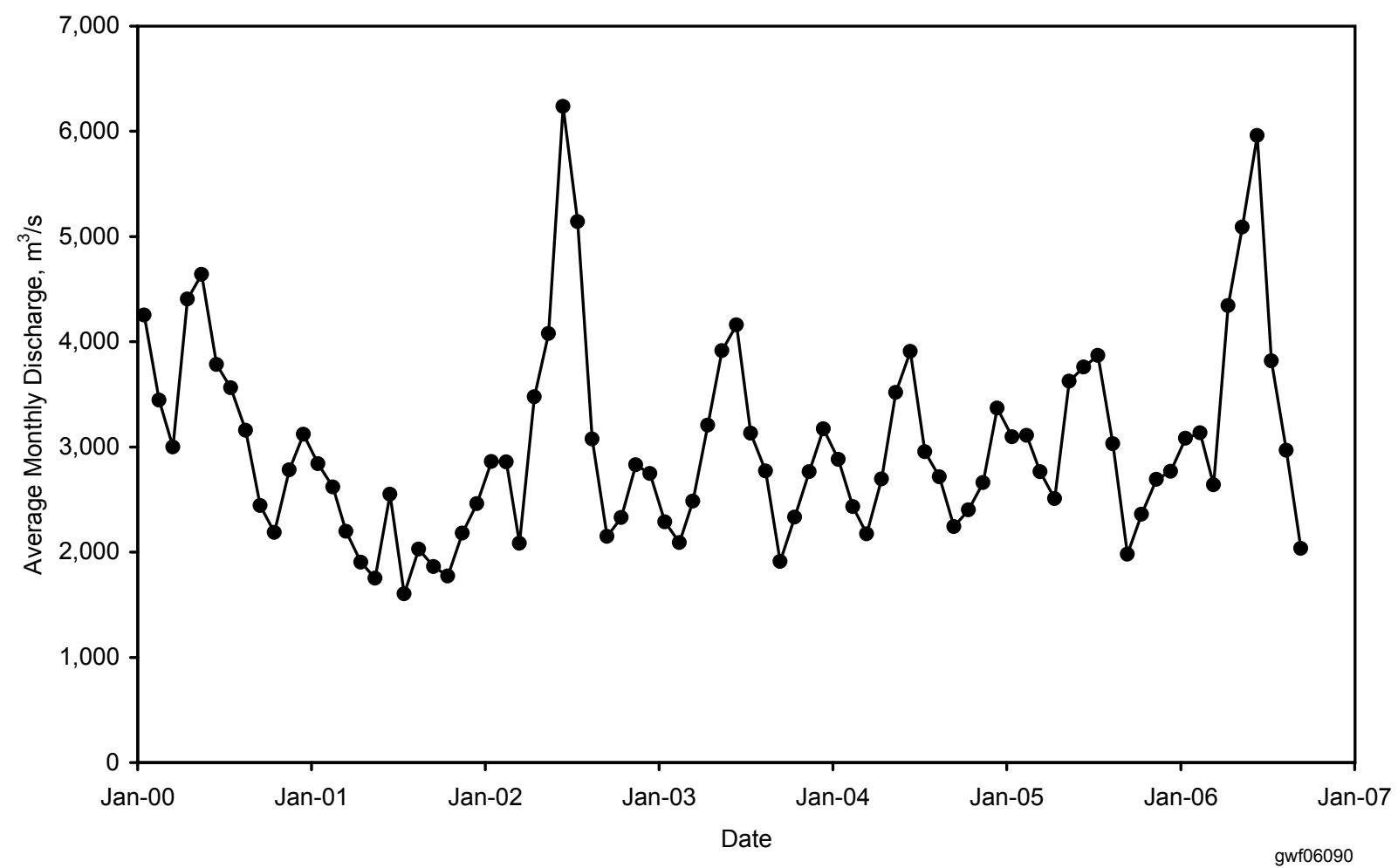

Figure 2.1-5. Average Monthly Discharge in the Columbia River (from USGS Station 12472800 South of Priest Rapids Dam) 


\subsection{0-BC-5 Operable Unit}

\section{J. Hartman}

The scope of this section is the $100-\mathrm{BC}-5$ groundwater interest area, which includes the 100-BC-5 Operable Unit (see Figure 1.0-1 in Section 1.0). The "groundwater interest areas" are informal designations to facilitate scheduling, data review, and interpretation. Figure 2.2-1 shows facilities, wells, and shoreline monitoring sites in the 100-B/C Area.

Groundwater enters the 100-B/C Area from upstream areas along the Columbia River and the gaps between Umtanum Ridge, Gable Butte, and Gable Mountain (see Figure 2.1-2 in Section 2.1). Groundwater flows primarily to the north beneath the 100-B/C Area and discharges to the Columbia River (Figure 2.2-2). The hydraulic gradient is very flat in the south 100-B/C Area and in the west part of the interest area (see Figure 2.1-2 in Section 2.1).

The remainder of this section describes contaminant plumes and concentration trends for the contaminants of concern under the Comprehensive Environmental Response, Compensation, and Liability Act (CERCLA). Groundwater monitoring for the requirements of the Atomic Energy Act (AEA) are completely integrated with CERCLA monitoring. There are no active waste disposal facilities or Resource Conservation and Recovery Act (RCRA) sites in the $100-\mathrm{B} / \mathrm{C}$ Area.

\subsubsection{Groundwater Contaminants}

Wells in the 100-BC-5 Operable Unit are sampled annually to biennially for the contaminants of concern based on results of the data quality objectives process (PNNL-14287): strontium-90, tritium, and hexavalent chromium. This section describes distribution and trends of the groundwater contaminants of concern and nitrate beneath the 100-BC-5 groundwater interest area.

\subsubsection{Strontium-90}

Strontium-90 concentrations in 100-B/C Area groundwater did not change significantly between fiscal years (FY) 2005 and 2006. The highest concentrations in FY 2006 were $\sim 40 \mathrm{pCi} / \mathrm{L}$ in well 199-B3-46 near the 116-C-1 trench and well 199-B3-1 near the 116-B-1 trench.

The strontium-90 plume beneath the 100-B/C Area is wedge-shaped, with an apex in the central 100-B/C Area, extending and spreading north toward the Columbia River (see Figure 2.2-3 in PNNL-15670). The plume has not changed significantly in over 10 years.

In December 2006, two wells in the 100-B/C Area were sampled with the "Spyder" sampling device to collect samples from discrete depths in the screened portion of the wells. Samples were analyzed for strontium-90 and hexavalent chromium. Strontium-90 results from the Spyder sampling did not show any vertical stratification. In well 199-B3-46,

\section{Strontium-90 and tritium exceeded drinking water standards in groundwater at the 100-BC-5 Operable Unit during FY 2006.}

Groundwater monitoring in the 100-BC-5 groundwater interest area includes integrated CERCLA and AEA monitoring:

- Wells are sampled annually or biennially.

- All of the scheduled wells were sampled in FY 2006.

- Fourteen aquifer tube sites and two seeps are scheduled for sampling annually. One tube and one seep were not sampled in FY 2006 (see Appendix A). 


\section{Tritium \\ concentrations \\ increased sharply \\ in one well in the \\ central 100-B/C}

Area. The cause of

this and previous

spikes in tritium

concentrations is

unknown. strontium-90 ranged from 29.2 to $30.5 \mathrm{pCi} / \mathrm{L}$, all in trend with recent results from routine sampling. In well 199-B3-47, strontium-90 ranged from 26.1 to $28.7 \mathrm{pCi} / \mathrm{L}$, all in trend with recent results from routine sampling (Figure 2.2-3).

Strontium-90 does show vertical stratification in the only shallow/deep well pair in $100-\mathrm{B} / \mathrm{C}$ Area and in multi-depth aquifer tubes, which monitor a broader range of depths than the screened intervals of wells 199-B3-46 and -47 (Figure 2.2-4). Deep well 199-B2-12 consistently has no detectable strontium-90, while its shallow counterpart, 199-B3-47, has levels above the drinking water standard. Similarly, deep aquifer tubes have only low to undetectable strontium-90 concentrations while their shallow counterparts had concentrations ranging from 6.8 to $12 \mathrm{pCi} / \mathrm{L}$ in $\mathrm{FY} 2006$ (e.g., see AT-5 and AT-B-3 in Figure 2.2-4).

\subsubsection{Tritium}

The upper part of the unconfined aquifer beneath the 100-B/C Area is contaminated with tritium, which exceeds the drinking water standard $(20,000 \mathrm{pCi} / \mathrm{L})$ in several wells. Figure 2.2-5 shows tritium distribution in FY 2006. The plume with concentrations above the drinking water standard extends from the 116-B-5 crib to the Columbia River, covering a slightly larger area than in FY 2005. Concentrations also exceeded the standard in well 199-B8-6, located near the 118-B-1 burial ground. Tritium was recently found in the vadose zone beneath this former burial ground. Additional characterization of the sediment and groundwater is planned.

Well 199-B5-1, in the west-central 100-B/C Area, has had very low tritium concentrations and specific conductance in recent years. This may be caused by dilution of groundwater with fresh water. A fire hydrant leak was discovered and repaired during the fiscal year.

The highest tritium concentration in the 100-B/C Area in FY 2006 was 125,000 pCi/L in well 199-B5-2 (Figure 2.2-6). This represented a decline after a spike in 2005. The well is located downgradient of the reactors and upgradient of the retention basins. The cause of tritium variability is unknown.

Tritium rose sharply in well 199-B4-1, located near the former 116-B-5 crib (Figure 2.2-7), exceeding the drinking water standard for the first time since 1989. As discussed above, tritium increased to a much higher level last year in well 199-B5-2, located relatively near (but downgradient) of well 199-B4-1, perhaps due to a common cause.

Tritium concentrations are elevated in samples from aquifer tubes in the $100-\mathrm{B} / \mathrm{C}$ Area. Tube AT-06-D, located within the main tritium plume in the north 100-B/C Area, had the highest concentration in FY 2006, 16,000 pCi/L. This was a slight decrease from the previous year.

The most recent data from tube sites AT-B-5 and AT-B-7, located just east of the 100-B/C Area, were slightly below the drinking water standard $(\sim 19,000 \mathrm{pCi} / \mathrm{L})$. Tritium east of the $100-\mathrm{B} / \mathrm{C}$ Area is believed to represent a plume from the 200 Areas that migrated northward. Elevated tritium also is observed in well 699-72-73, east of the 100-B/C Area (see Figure 2.1-1 in Section 2.1 for well location). The FY 2006 result was 17,700 pCi/L.

\subsubsection{Chromium}

Hexavalent chromium is of potential concern to salmon or other aquatic life. Fall Chinook salmon and steelhead spawning areas have been recorded just downstream and toward the center of the river channel, but not in areas along the 100-B/C Area shoreline. Shoreline areas provide rearing habitat for young salmon and steelhead, as well as for many of the other species of fish in the Columbia River (DOE/RL-2005-40). The aquatic standard for hexavalent chromium is $10 \mu \mathrm{g} / \mathrm{L}$.

Dissolved chromium concentrations continued to be below the drinking water standard $(100 \mu \mathrm{g} / \mathrm{L})$, but exceeded $10 \mu \mathrm{g} / \mathrm{L}$ in wells and aquifer tubes in the north 100-B/C Area. 
The highest concentration in a well was $40 \mu \mathrm{g} / \mathrm{L}$ in well 199-B3-47, downgradient of the 116-B-11 retention basin (Figure 2.2-8). Nearby aquifer tube AT-06-M had a slightly higher concentration, $48 \mu \mathrm{g} / \mathrm{L}$.

Discrete-depth samples from wells 199-B3-46 and 199-B3-47, collected with the Spyder sampling device, showed no significant vertical stratification of chromium (Figure 2.2-9). Concentrations ranged from 7 to $14.6 \mu \mathrm{g} / \mathrm{L}$ in well 199-B3-46. Hexavalent chromium results in well 199-B3-47 ranged from 26 to $30 \mu \mathrm{g} / \mathrm{L}$ and a single total chromium result was slightly higher $(40 \mu \mathrm{g} / \mathrm{L})$. Concentrations in shallow aquifer tubes generally are lower than middepth or deep tubes because of dilution with river water. Deep monitoring well 199-B2-12 has no detectable chromium.

\subsubsection{Nitrate}

The 100-B/C Pilot Project Risk Assessment Report (DOE/RL-2005-40) identified nitrate as a contaminant of concern based on its exceedance of the $45-\mathrm{mg} / \mathrm{L}$ drinking water standard in well 199-B3-47 in 1998 and 1999. Concentrations subsequently decreased, and the result in FY 2005 was $23.5 \mathrm{mg} / \mathrm{L}$. Although nitrate is not listed as a contaminant of concern in the groundwater sampling and analysis plan (DOE/RL-2003-38), it is monitored routinely in well 199-B3-47 and most of the other wells as a supporting parameter.

Well 699-72-73, located between 100-B/C and 100-K Areas, had a nitrate concentration of $25.2 \mathrm{mg} / \mathrm{L}$ in January 2005. Aquifer tube 14-D, also located east of the main 100-B/C Area, had a nitrate concentration of $28.8 \mathrm{mg} / \mathrm{L}$ in FY 2006. Like tritium, the source of this nitrate is believed to be the 200 East Area.

\subsubsection{Operable Unit Monitoring and Risk Assessment}

The groundwater sampling and analysis plan (DOE/RL-2003-38) specified annual sampling of 9 wells, 14 aquifer tube sites, and 2 seeps and biennial sampling of 14 wells (Appendix A). Of these, 16 wells and all of the aquifer tube sites and seeps were scheduled for sampling in FY 2006. All of the wells and all but one of the aquifer tubes were sampled as scheduled. Tube AT-12-D, located between 100-B/C and 100-K Areas, has not been sampled since 1997. Tubes on either side of it (AT-11 and AT-14) were sampled in FY 2006. One of two springs was sampled.

DOE and regulatory agencies are required to conduct reviews of the status of CERCLA response actions at least every five years. In November 2006, DOE released a five-year review report (DOE/RL-2006-20). The review identified no issues or actions for the 100-BC-5 Operable Unit.

Draft B of the 100-B/C Pilot Project Risk Assessment was published in FY 2006 (DOE/RL-2005-40). The purpose of the pilot risk assessment was to develop and apply a process to evaluate the protectiveness of remedial actions performed for the 100-BC-5 Operable Unit, with the intent that lessons learned would be applied to subsequent risk assessments performed for other locations within the Columbia River Corridor. The pilot project risk assessment characterized the potential risks to human health and the environment under the cleanup standards implemented in remedial actions performed to date. Conceptual exposure models were developed for the 100-B/C Area to describe the possible movement of contaminants to human and ecological receptors. Analytical data evaluated for the risk assessment included shallow-zone soil, deep-zone soil, surface sediment, riverbank seep water, surface water from the Columbia River, aquifer tube water, groundwater, and biota tissues.

The risk assessment identified five contaminants of concern for groundwater: strontium-90, tritium, antimony, hexavalent chromium, and nitrate. Antimony was identified based on two apparent detections in well 199-B2-12 in 1997 and 1999. Both of these results were associated with duplicate samples with no detectable antimony; however, the antimony detection limit is greater than the $6-\mu \mathrm{g} / \mathrm{L}$ drinking water standard. Antimony is part of a
Tritium, nitrate, and technetium-99 are detected in wells and aquifer tubes east of the 100-B/C Area. This contamination most likely migrated from the 200 East Area. 
metals suite monitored under the groundwater sampling and analysis plan (DOE/RL-2003-38). As discussed in Section 2.2.1.4, nitrate the risk assessment identified nitrate as a contaminant of concern based on two exceedances of the drinking water standard, and levels have declined. Chromium, strontium-90, and tritium are all contaminants of concern in the groundwater sampling and analysis plan and monitoring results were discussed in Section 2.2.1. 


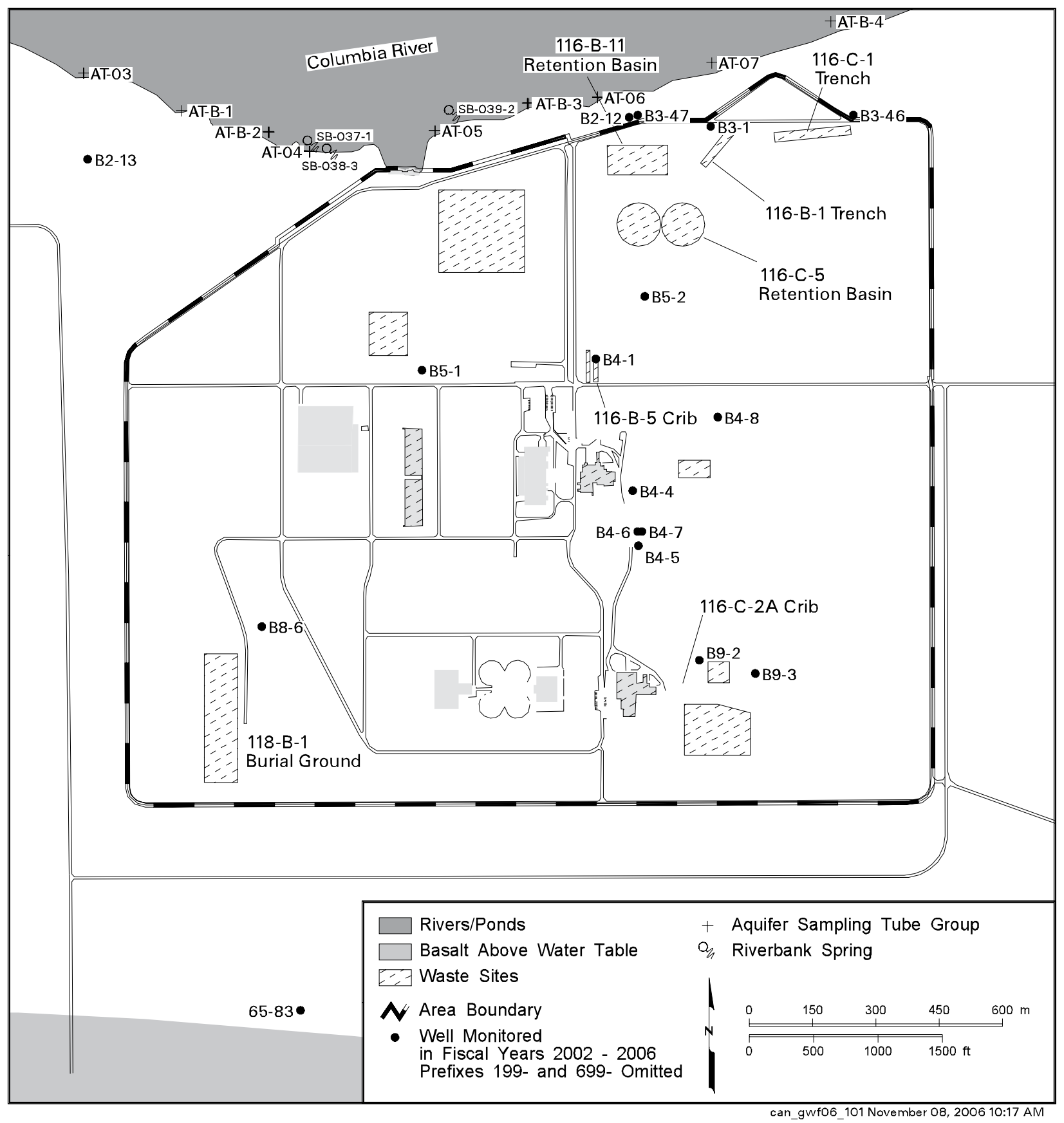

Figure 2.2-1. Groundwater Monitoring Wells in 100-B/C Area 


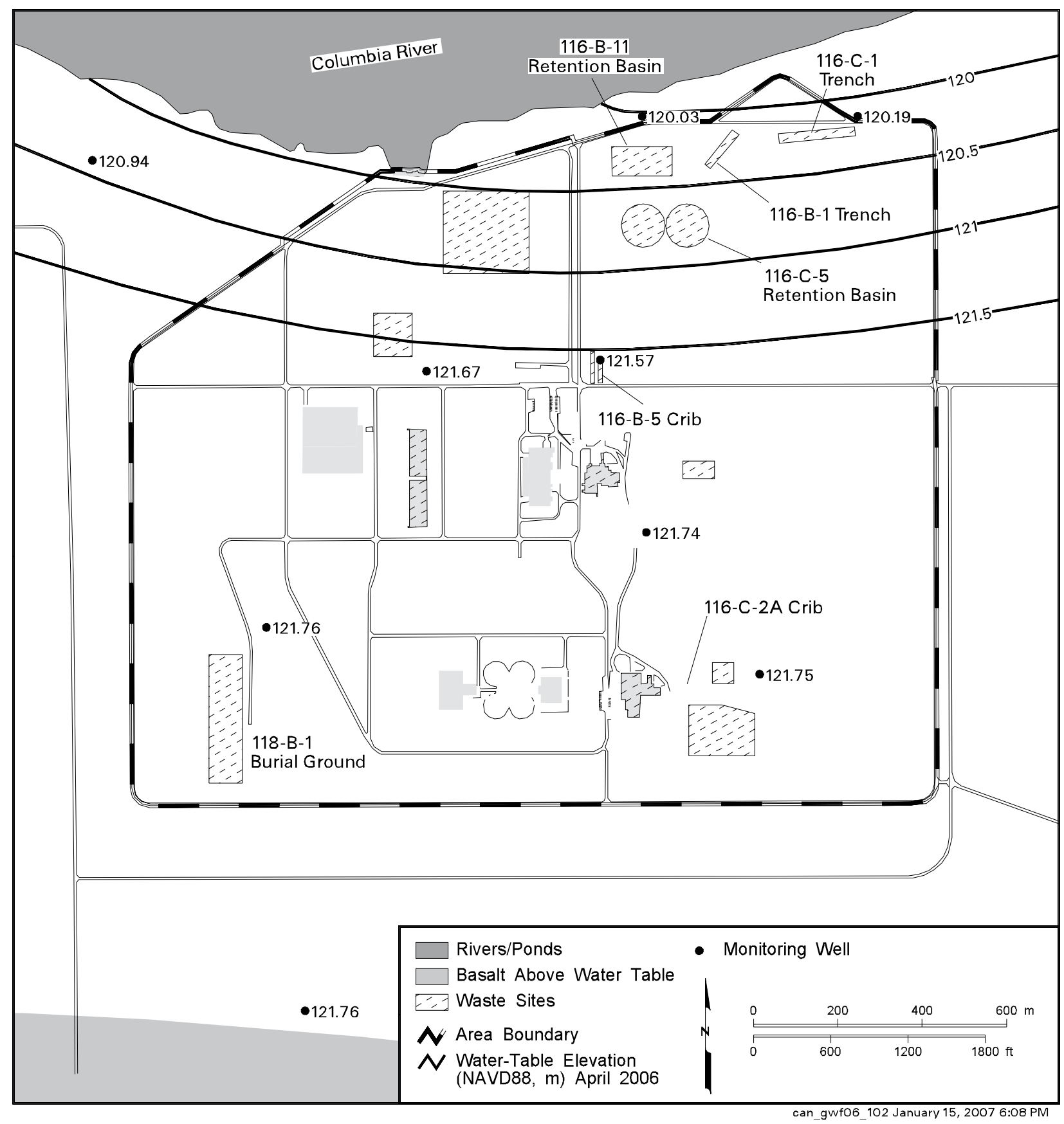

Figure 2.2-2. 100-B/C Area Water-Table Map, April 2006 


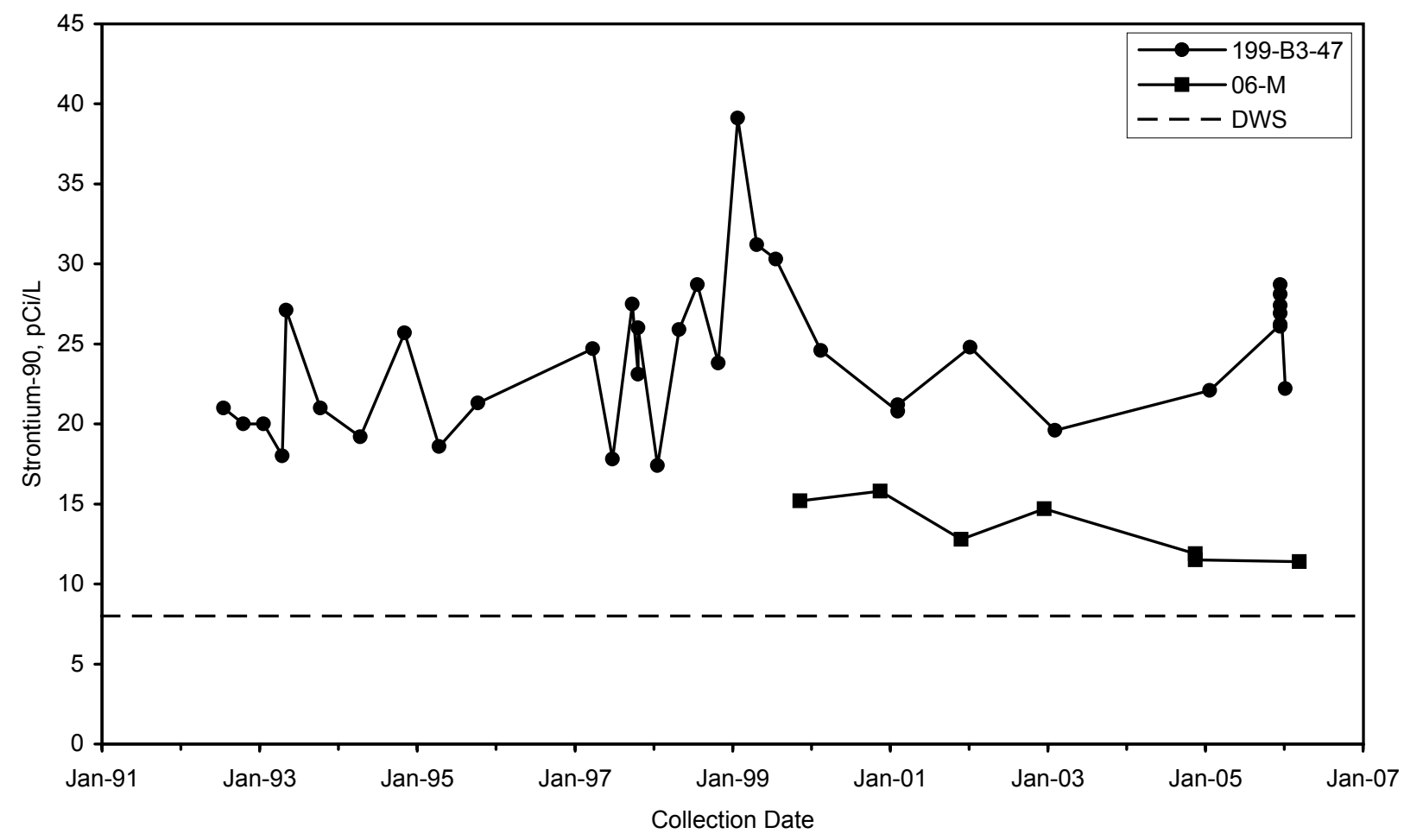

gwf06103

Figure 2.2-3. Strontium-90 Concentrations Near the 116-B-11 Retention Basin

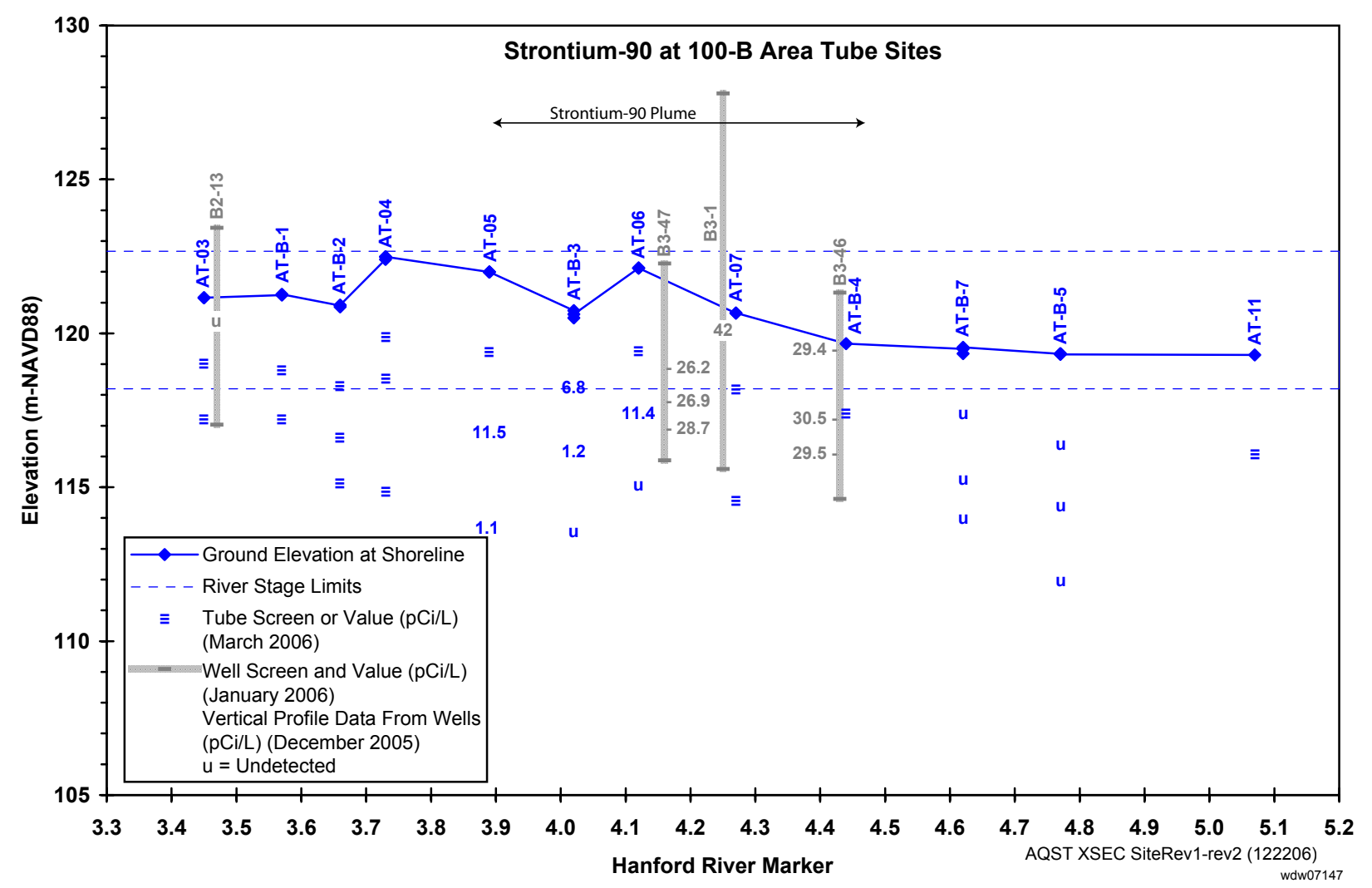

Figure 2.2.4. Sample Elevations and Strontium-90 Concentrations in Wells and Aquifer Tubes in 100-B/C Area 


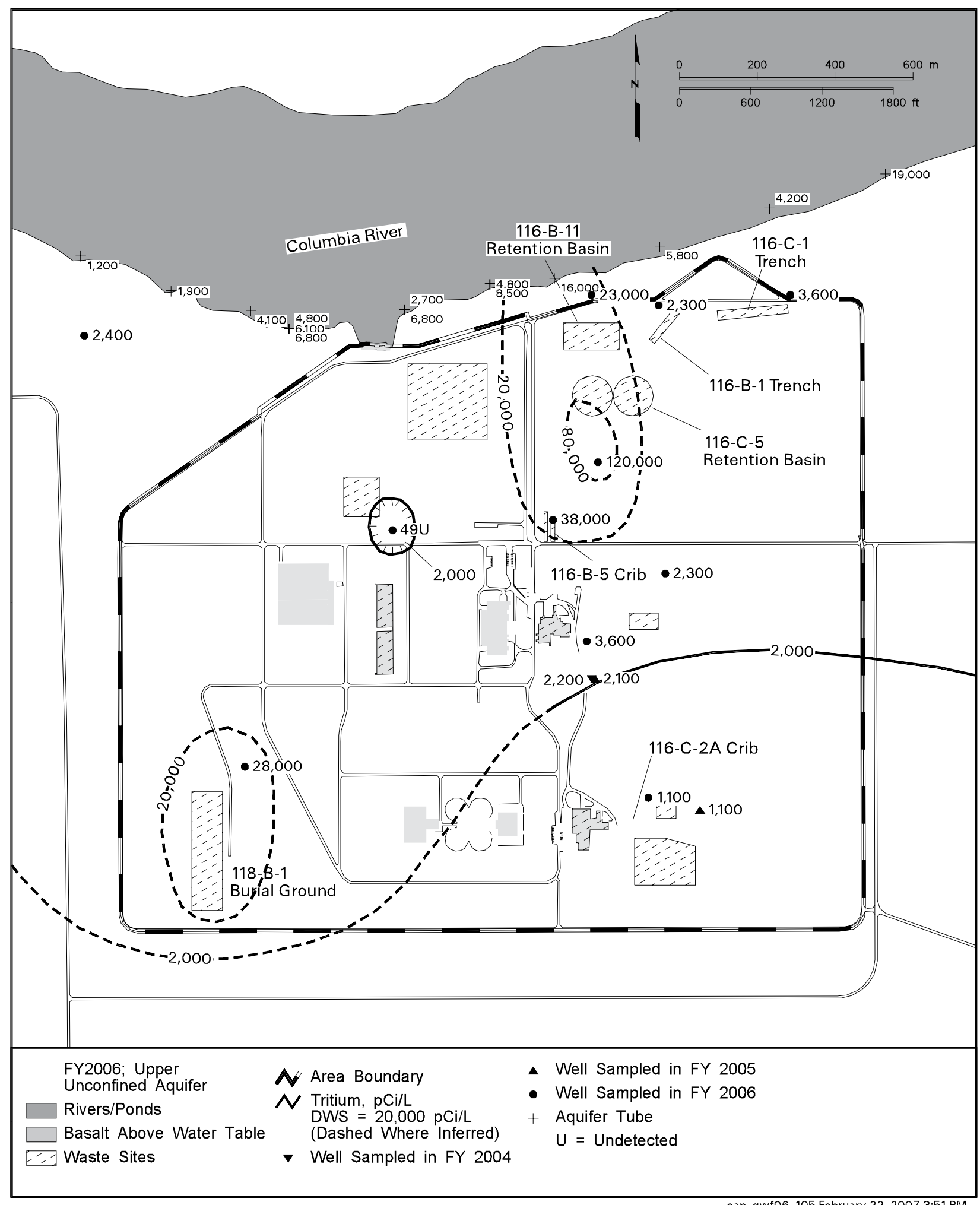

Figure 2.2-5. Average Tritium Concentrations in 100-B/C Area, Upper Part of Unconfined Aquifer 


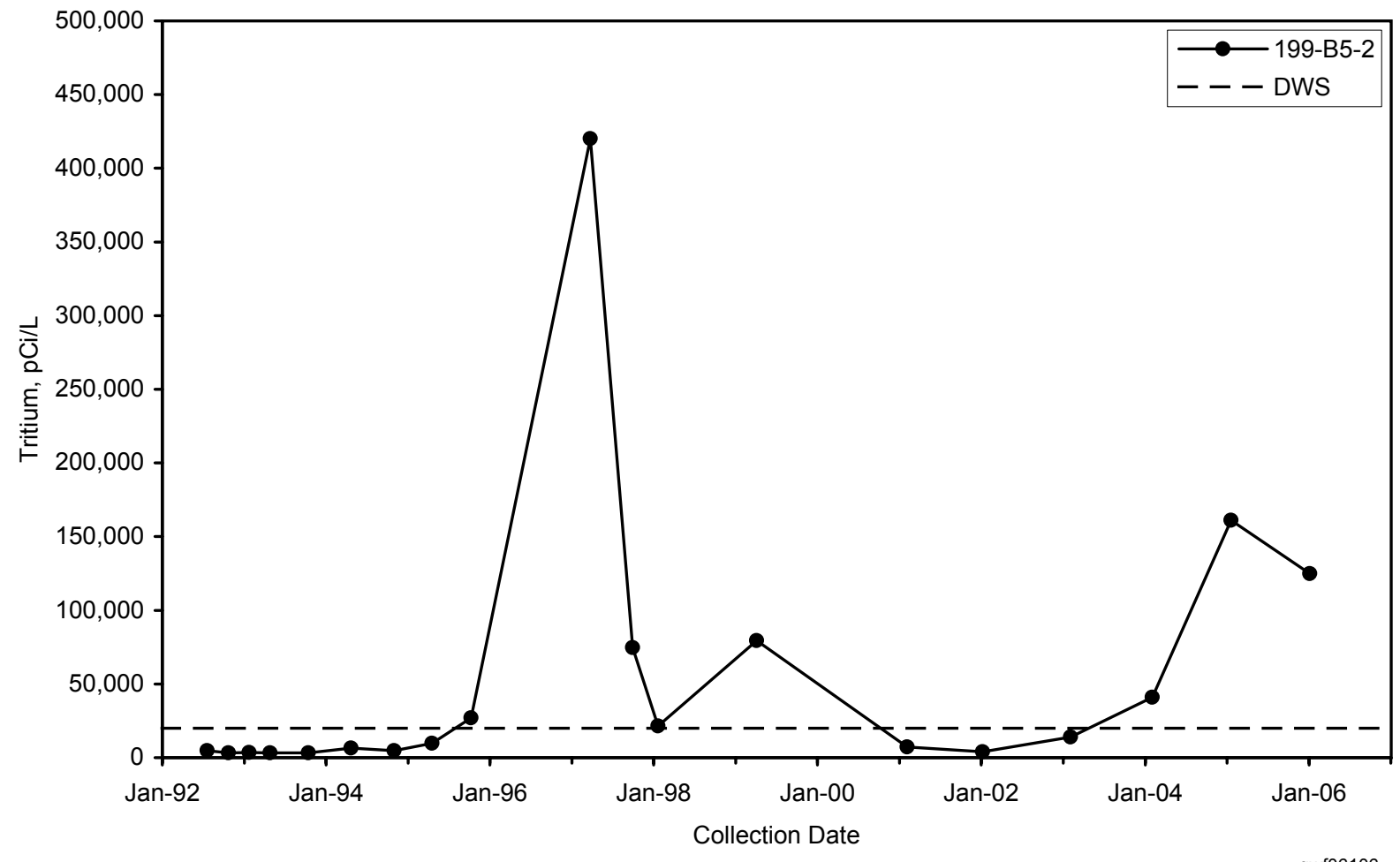

Figure 2.2-6. Tritium Concentrations Upgradient of 116-C-5 Retention Basin

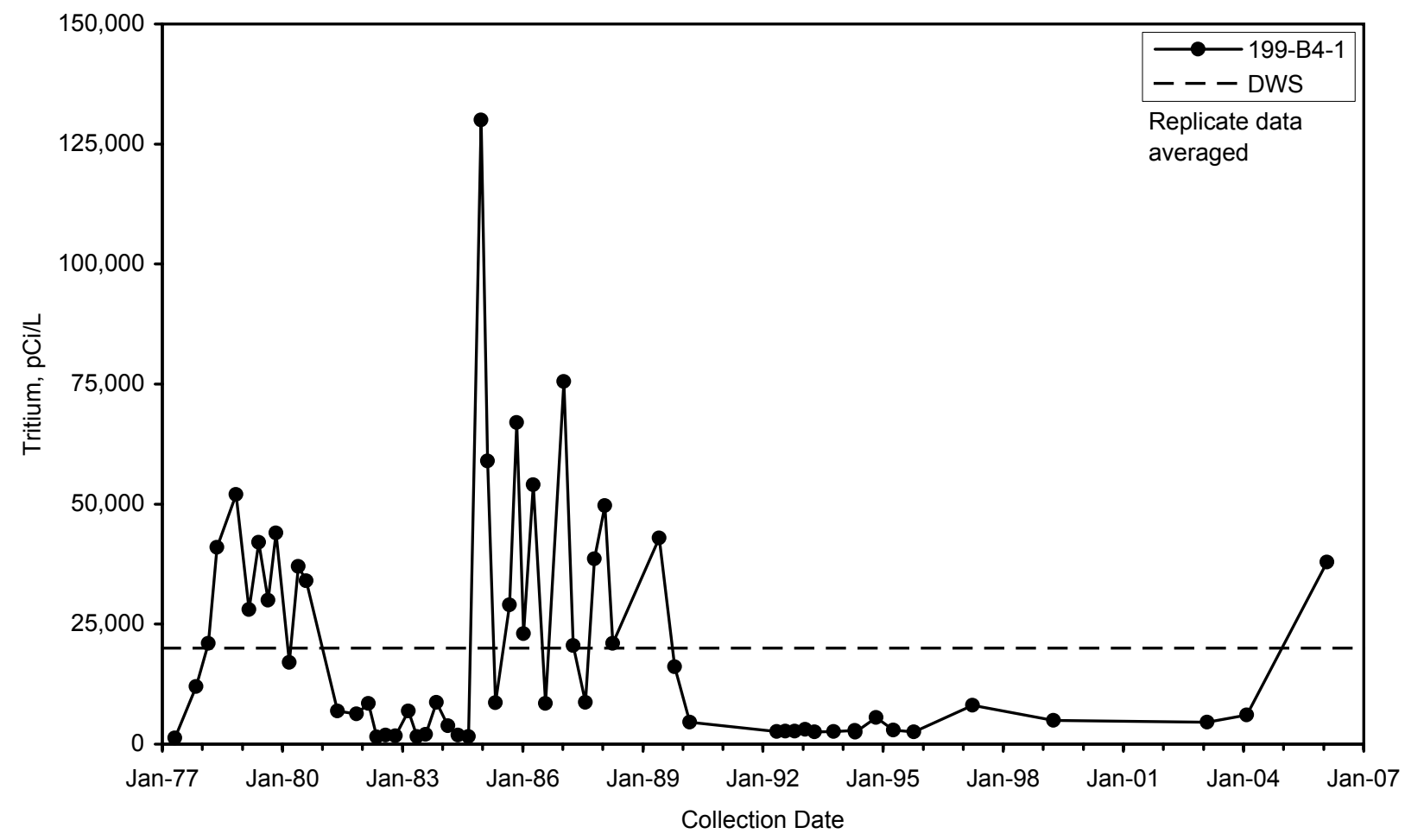

gwf06107

Figure 2.2-7. Tritium Concentrations Near the 116-B-5 Crib 


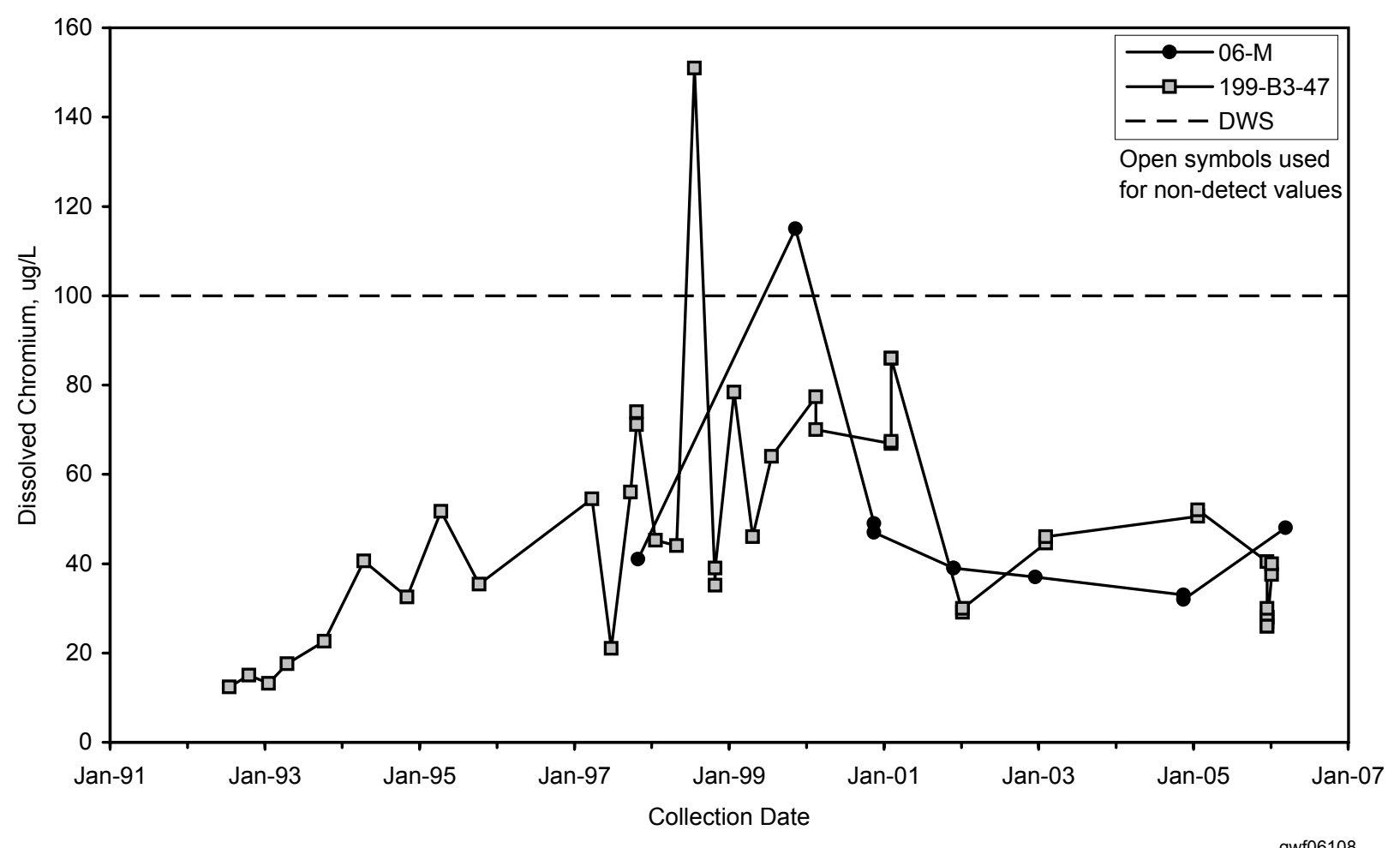

Figure 2.2-8. Chromium Concentrations Near the 116-B-11 Retention Basin

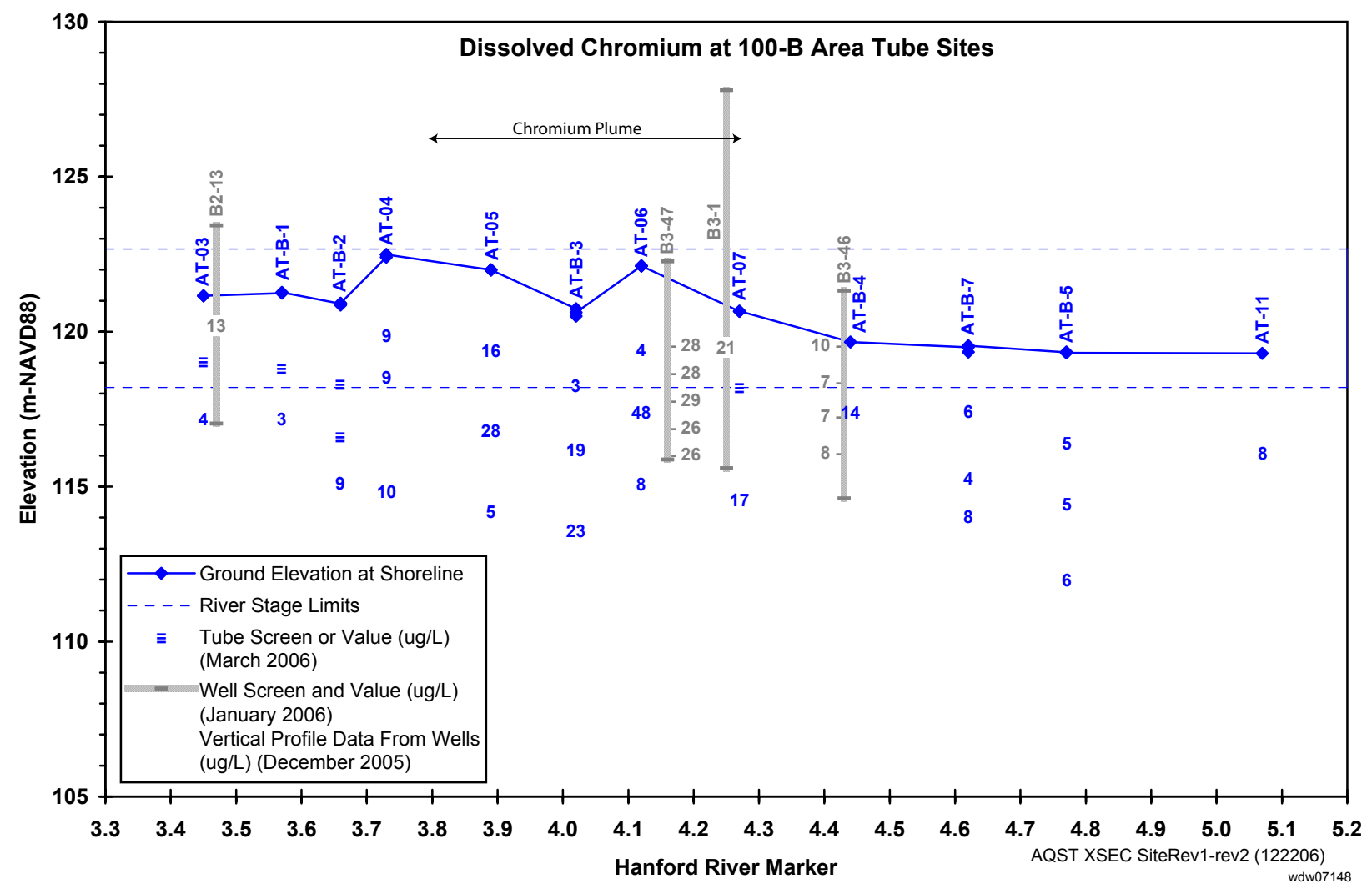

Figure 2.2-9. Sample Elevations and Chromium Concentrations in Wells and Aquifer Tubes in 100-B/C Area 


\subsection{0-KR-4 Operable Unit}

\section{R. E. Peterson and R. F. Raidl}

The 100-KR-4 Operable Unit includes groundwater impacted by contaminant releases from facilities and waste sites within the $100-\mathrm{K}$ Area. Most of the facilities and waste sites are associated with former operation of the KE and KW Reactors and their support facilities. Descriptions of $100-\mathrm{K}$ Area facilities, reactor operations, and designated waste sites are presented in a technical baseline report (WHC-SD-EN-TI-239), which is the primary source for historical information presented in the following sections. The operable unit lies within a larger groundwater interest area, informally defined to facilitate scheduling, data review, and interpretation (see Figure 1.0-1 in Section 1.0). Figure 2.3-1 is a location map showing 100-K Area monitoring wells, shoreline monitoring sites, waste sites, and facilities.

Principal groundwater issues for the 100-KR-4 Operable Unit involve (a) a large chromium plume created by past disposal to an infiltration trench located near the Columbia River, (b) localized chromium plumes of uncertain origin near the KE and KW Reactors, (c) radiological contamination associated with past discharges to the ground near the KE and KW Reactor buildings, and (d) loss of shielding water from the fuel storage basins associated with each reactor building and resulting impacts on groundwater. Groundwater remedial action to address the large chromium plume continued during fiscal year (FY) 2006, and action began to address the plume near KW Reactor. Waste site remedial actions included (a) excavation and backfilling of the former $100-\mathrm{K}$ trench, (b) excavation of materials in the $100-\mathrm{K}$ burial ground, (c) removing contaminated sludge from the KE fuel storage basin, and (d) planning for demolition and removal of the highly contaminated KE and KW fuel storage basins themselves, a remedial action that has some potential to impact groundwater.

Groundwater monitoring in the $100-\mathrm{K}$ Area is conducted under two regulatory drivers: the Comprehensive Environmental Response, Compensation, and Liability Act (CERCLA) governs

\section{Chromium is}

the contaminant

of concern in

groundwater

currently being

targeted by interim

remedial action

using pump-and-

treat systems.

Groundwater monitoring in the 100-KR-4 groundwater interest area includes the following activities:

\section{CERCLA Long-Term Monitoring}

- Wells are sampled at various frequencies from monthly to biennially for contaminants of concern and constituents of interest.

- Riverbank springs (three locations) and aquifer tubes (sixteen locations) are sampled annually along the 100-K Area river shore.

- During FY 2006, all wells were sampled as scheduled; several aquifer tube sites and riverbank springs that were scheduled did not produce water for samples.

CERCLA Interim Remedial Action Performance Evaluation

- Compliance wells and extraction wells are sampled monthly to monitor hexavalent chromium.

- Additional wells are sampled monthly or semiannually to track changes in chromium and co-contaminant concentrations.

- During FY 2006, one monthly sample was missed (see Appendix A).

Facility Monitoring

- Wells are sampled quarterly to semiannually to detect potential shielding water loss to the ground from the KW and KE Basins.

- Selected wells were also sampled monthly during basin cleanout.

- Riverbank springs (two locations) and aquifer tubes (six locations) are sampled annually to monitor conditions at the rivershore.

- In FY 2006, wells were sampled as scheduled except for missing several monthly samples because of well access issues. 


\section{Groundwater movement is generally to the northwest, toward the Columbia} River. the 100-KR-4 Operable Unit, while the Atomic Energy Act provides the basis for monitoring the fuel storage basins at each reactor building (i.e., $\mathrm{K}$ Basins). CERCLA requirements are further subdivided into monitoring conducted to (a) characterize and track all contaminants of concern or potential concern in the operable unit, and (b) evaluate the performance of the pump-and-treat system that removes hexavalent chromium from groundwater contaminated by past disposal to the former $100-\mathrm{K}$ trench (116-K-2 waste site). During FY 2006, essentially all sampling and analysis activities, as described in monitoring plans approved by regulatory agencies, were implemented. Deviations from schedules presented in the plans were caused by minor adjustments to the extraction/injection network associated with the pump-andtreat system, by maintenance problems at several wells, and by minor changes to scheduling dates and analysis suites in response to new information that became available during the year (see Appendices A and B).

Groundwater movement beneath the $100-\mathrm{K}$ Area is generally toward the northwest, as inferred from water-table contours (Figure 2.3-1; flow direction is approximately perpendicular to contours). Average rates of flow toward the Columbia River are in the range 0.1 to 0.3 meter/day, as estimated from hydraulic gradients, and from migration rates of plumes (PNNL-14031). The best-supported estimate for groundwater flow rate between the KE Reactor and the river is 0.12 meter/day and is based on the migration of a plume created by a leak from the KE Basin in 1993. This suggests a 10- to 12-year travel time for tritium and other dissolved waste constituents to travel from the vicinity of the KE Reactor to the river. Waste constituents that interact with sediment, such as strontium-90 and carbon-14, travel more slowly.

The current movement of contaminant plumes beneath most of the $100-\mathrm{K}$ Area is controlled by the flow of groundwater under natural conditions. However, in the region to the northeast of the KE Reactor, treated effluent from the interim remedial action pump-and-treatment system is injected back into the aquifer. A mound has formed on the water table, causing a radial flow pattern to develop around the injection sites (DOE/RL2006-08; Figure 2.3-1). Localized disruptions in the natural flow system also occur around the groundwater extraction wells.
Plume areas (square kilometers) at the 100-KR-4 Operable Unit:

Carbon-14, 2,000 pCi/L -0.10 Chromium, $100 \mu \mathrm{g} / \mathrm{L}-0.09$

Chromium, $20 \mu \mathrm{g} / \mathrm{L}-2.7$

Nitrate, $45 \mathrm{mg} / \mathrm{L}-0.33$

Strontium-90, 8 pCi/L -0.14

Tritium, 20,000 $\mathrm{pCi} / \mathrm{L}-0.20$

Near the Columbia River, the groundwater system is influenced by fluctuations in river stage (i.e., elevation), which is controlled by releases from Priest Rapids Dam. The pattern of movement and the rate at which groundwater discharges to the river are affected by these fluctuations. Because river water infiltrates the banks during periods of high river stage, contaminants carried by groundwater may become diluted prior to their eventual release to the river through riverbed sediment and via riverbank springs.

The river stage also affects the elevation of the water table beneath the $100-\mathrm{K}$ Area. During periods of prolonged high river conditions, the elevated water table may cause remobilization of contaminants held in the normally unsaturated lower vadose zone. A good example of this phenomenon occurred during the seasonal high river conditions in 1996 and 1997, when higher than typical contaminant concentrations were observed at some locations associated with former liquid waste disposal sites. Water-table conditions during FY 2006, which were higher than the preceding several years, also produced increased concentrations of contaminants at some locations.

\subsubsection{Groundwater Contaminants}

Chromium has been identified as a contaminant of concern that warrants interim remedial action in the 100-KR-4 Operable Unit (ROD 1996a). The primary risk driver is ecological health, although concentrations in groundwater do exceed the drinking water standard at some wells. Where groundwater containing chromium discharges into the river environment, there exists a potential risk of harm to aquatic life that uses the zone where 
groundwater meets river water as habitat. Other contaminants of potential concern in the operable unit include carbon-14, nitrate, strontium-90, technetium-99, trichloroethene, and tritium. These constituents are of concern primarily because their concentrations exceed drinking water standards. They are being monitored while waste sites are being remediated, and while facilities are being decontaminated and decommissioned.

The following descriptions of contaminants in 100-K Area groundwater refer to conditions at wells that monitor the uppermost hydrologic unit. The $100-\mathrm{K}$ Area contains only one well (199-K-32B) that is completed to monitor conditions below the uppermost aquifer, and groundwater at that deep well is essentially free of contamination from past operations.

\subsubsection{Chromium}

Sodium dichromate was used in large quantities as a corrosion inhibitor at the KE and KW Reactors during their years of operation (1955 through 1971). The chemical was added to reactor coolant in amounts that resulted in a concentration of $\sim 700 \mu \mathrm{g} / \mathrm{L}$ of hexavalent chromium. The hexavalent form of chromium is fully soluble in water and is toxic to aquatic organisms and humans. The relevant Washington State standards are $10 \mu \mathrm{g} / \mathrm{L}$ for chronic exposure for aquatic organisms (measured as hexavalent chromium) and $100 \mu \mathrm{g} / \mathrm{L}$ for drinking water supplies (measured as total chromium in an unfiltered water sample).

The extent of chromium contamination in groundwater beneath the $100-\mathrm{K}$ Area during 2006 is shown in Figure 2.3-2. The contour shapes reflect the concentrations observed during routine monitoring, the locations of various waste-site sources, and the direction of plume migration inferred from water-table elevation contours. Where information is lacking or uncertain, contours are shown as dashed lines.

The distribution of chromium with depth in the aquifer near the Columbia River is illustrated in Figures 2.3-3 and 2.3-4, which are cross sections drawn along the 100-K Area shoreline. The concentrations shown are for samples collected during February and March 2006 from aquifer tubes. The variability in observed concentrations is the result of several factors, including vertical distribution of contamination in the groundwater plume, dilution of contaminants by river water at some tubes, and heterogeneity in aquifer characteristics.

Chromium Beneath the 100-K Trench. The largest area of chromium contamination is associated with the former $100-\mathrm{K}$ trench (116-K-2 waste site), which received large volumes of reactor coolant. The interpretation shown in Figure 2.3-2 assumes that chromium detected at well 699-78-62, which is east of the $100-\mathrm{K}$ Area, was pushed inland by radial flow around the large groundwater mound that was present beneath the $100-\mathrm{K}$ trench during the operating years (HW-77170). The trench plume is the target of interim remedial action intended to protect aquatic receptors in the Columbia River from exposure to chromium in groundwater that discharges through the riverbed (see Section 2.3.2).

Concentrations at wells that monitor the trench plume are typically $<100 \mu \mathrm{g} / \mathrm{L}$ (the drinking water standard) and appear to be decreasing with time or remaining nearly constant, with exceptions at several locations. The overall decrease in the level of contamination is a combined consequence of the pump-and-treat operation (a chromium mass removal action) and dispersion. Figures 2.3-5, 2.3-6, and 2.3-7 illustrate concentration trends for southwest, central, and northeast groups of monitoring wells, respectively, within this plume area.

At the southwest edge of the plume, an exception to the generally decreasing trends occurs. Concentrations at well 199-K-18 have been increasing during recent years, although results for FY 2006 suggest that peak values may have been reached (Figure 2.3-5). The start of the increasing trend at this location correlates with the startup of the pump-and-treat system in October 1997, suggesting a relationship to the changes in groundwater movement patterns because of the extraction and injection of groundwater. Chromium concentrations are also relatively higher at nearby aquifer tube site AT-K-3, compared to conditions immediately upstream and downstream along this segment of shoreline (Figure 2.3-3). Historical aerial photos of this area in 1965 reveal extensive overland runoff of effluent from the head end

\section{The largest area of chromium contamination is associated with the former $100-K$ trench. A pump- and-treat system is reducing the mass of chromium in that plume.}




\section{Concentrations in}

the plume targeted

for remedial action

are gradually

decreasing.

\section{The chromium}

plume in the

vicinity of

KW Reactor will be

remediated using

a pump-and-treat

system. (i.e., southwest end) of the $100-\mathrm{K}$ trench, and it is possible that the vadose zone in this area is still contaminated and contributing to groundwater contamination. Alternatively, based on groundwater flow directions, an area of elevated chromium in groundwater may be present in the region immediately south of well 199-K-18, although the absence of wells in this area precludes confirmation.

In the central portion of the plume, between the trench and the river, concentration trends show the most evidence for a reduction in the level of contamination as a result of the groundwater extraction activities. While coverage by aquifer tubes at the shoreline is somewhat sparse for this segment of shoreline, samples from this area typically show relatively low concentrations (Figure 2.3-4). The broad, cobbly shoreline along this segment also suggests significant exchange with river water, such that contaminants carried by groundwater are diluted by the time they reach the tube sites. This is confirmed by relatively low specific conductance values (compared to groundwater inland from the river) for samples from tube sites AT-21, AT-22, AT-K-4, and AT-23, and also from near-river wells 199-K-114A and 199-K-117A.

At the northeast end of the trench, chromium concentrations are gradually decreasing, though conditions at wells $199-\mathrm{K}-37$ and $199-\mathrm{K}-130$ reveal variable trends for the past several years (Figure 2.3-7). Also, concentrations at well 199-K-131 ( 75 to $80 \mu \mathrm{g} / \mathrm{L})$, which is located $\sim 300$ meters northeast of well 199-K-130, provide evidence to extend the plume boundaries farther to the northeast than previously mapped. Results from aquifer tubes for this part of the shoreline confirm the presence of the plume at this location (Figure 2.3-4). As at the southwest end of the trench, aerial photos during operations (1965) reveal extensive overland runoff extending from the northeast end of the trench. Vadose zone contamination could be continuing to supply chromium to the aquifer in this area.

Chromium Near KE and KW Reactors. Two additional areas contain elevated concentrations of chromium, although the extent of each is poorly defined. Near KE Reactor, a plume is present that extends from the southeast side of the water treatment plant basins downgradient to the southwest corner of the reactor building. The source is likely to be contaminated soil in the vicinity of a former sodium dichromate storage tank and railcar transfer station (WHC-SD-EN-TI-239). Periodic events appear to have remobilized chromium in the past and create concentration changes in groundwater, as seen at well 199-K-36 (Figure 2.3-8). Leakage of clean water from the water treatment plant basins may have provided a remobilization mechanism to explain earlier trends. Migration downgradient beyond the KE Reactor appears to be slow. The travel time for groundwater to move from well 199-K-36 to the nearest downgradient well, i.e., 199-K-23, is $\sim 9$ years, based on an assumed migration rate of 0.12 meter/day. So the "pulse" of chromium seen at well 199-K-36 during 1994 to 1996 should have arrived at well $199-\mathrm{K}-23$ by 2005 , and the second pulse in 2001 should arrive by $\sim 2010$. The trend at 199-K-23 has remained relatively constant and does not show evidence for the earlier pulse, suggesting that the plume has either dissipated sufficiently to be unobservable at well 199-K-23, or has followed a path that bypasses the well.

Near KW Reactor, chromium concentrations are elevated above the drinking water standard at several wells, including new wells recently installed as part of a new pump-andtreat system. The suspected source for this chromium is sodium dichromate in the vadose zone at as yet unidentified locations. Candidate locations include the storage tank and transfer station at the southeast side of the KW Water Treatment Plant (same as at KE), and also the underground piping associated with the system used to add sodium dichromate to coolant water. Figure 2.3-9 shows concentration trends for wells located within this plume. (Note: The abrupt drop in concentrations at well 199-K-108A in 1999 was caused by groundwater being diluted by clean water from an unknown source, which stopped in 2005.) This chromium plume has migrated downgradient of the KW Reactor, and its presence at well 199-K-132 is revealed by concentrations that approached $\sim 200 \mu \mathrm{g} / \mathrm{L}$ during FY 2006 (Figure 2.3-10). 
Contrary to what was described in the annual report for FY 2005 (PNNL-15670, Section 2.3), subsequent data from aquifer tubes at the Columbia River have not revealed conclusive evidence for the arrival of this plume. Chromium concentrations at these tube sites have dropped back to earlier levels during FY 2006 (Figure 2.3-3, tubes 17-D and AT-K-1). However, the groundwater travel time from 199-K-107A to the shoreline is estimated at $\sim 9$ years (assumed rate of 0.12 meter/day), so the leading edge of the plume that passed well 199-K-107A in 1998 should be close to the river by now. A new pump-and-treat system has been designed to remediate this plume, and four new wells were installed during FY 2006 as part of this system. Chromium concentrations in samples collected during drilling at one of these new wells were much higher than concentrations observed in the routine monitoring wells. The interim remedial action is discussed further in Section 2.3.2.

\subsubsection{Tritium}

Tritium was common in liquid effluent discharged to the ground during $100-\mathrm{K}$ Reactor operations. However, some of the tritium currently observed in groundwater was introduced after the shutdown of the reactors in 1971. Current sources and potential sources for providing tritium to groundwater include loss of shielding water from the KE and KW Basins, the soil columns beneath the former reactor atmosphere gas condensate cribs located to the east of each reactor building, and possibly irradiated materials contained in the $100-\mathrm{K}$ burial ground (118-K-1 waste site). Tritium has a radioactive decay half-life of 12.3 years. The drinking water standard for this radionuclide is $20,000 \mathrm{pCi} / \mathrm{L}$.

The distribution of tritium in groundwater beneath the 100-K Area during FY 2006 is shown in Figure 2.3-11. The areas of contamination outlined by contours reflect concentrations observed at monitoring wells, several past and present known source locations, and the direction of plume migration as inferred from water-table elevations. The highest tritium concentrations are associated with locations immediately downgradient of the former KE and KW condensate cribs (116-KE-1 and 116-KW-1, respectively) at each reactor. During operating years, the cribs received liquid effluent containing high concentrations of tritium and carbon-14. These waste sites were excavated and backfilled with clean material during the period December 2003 to March 2004. Some contaminated soil remained at the bottom of the excavations.

Because high concentrations of tritium are present in the shielding water of each fuel storage basin, tritium in groundwater is closely monitored for evidence of shielding water loss to the ground (PNNL-14033). Also, evidence exists to suggest that tritium is being released from materials in the $100-\mathrm{K}$ burial ground and may be impacting groundwater in the area north of the burial ground. Finally, the treated effluent from the interim action pump-and-treat system contains tritium at concentrations that remained well below the drinking water standard during FY 2006. This causes a zone around the injection wells of tritium concentrations that are greater than background levels.

Tritium Near KE Reactor. The plume shown in Figure 2.3-11 near KE Reactor has been formed by tritium from past disposal to the former KE condensate crib; leaks to the ground from KE Basin (1976 to 1979, and again in 1993); and possible remobilization of contamination from the vadose zone beneath the KE drain field and associated catch tank (100-K-68 "D-sump"). The tritium distribution pattern reflects a coalescing of plumes from these sources and the timing of release from each source. The concentration trend for tritium, along with that for co-contaminant carbon-14, at well 199-K-30 located near the core of this plume is shown in Figure 2.3-12.

Tritium concentration trends at wells immediately downgradient of the KE Reactor are shown in Figure 2.3-13. Wells 199-K-27 and 199-K-109A are the wells most likely to detect loss of basin water to the ground. The increases at those wells that started in early 2003 remain unexplained, although there is no evidence from facility operations suggesting a significant loss of shielding water, which had a tritium concentration of 2.25 million $\mathrm{pCi} / \mathrm{L}$
The highest tritium concentrations beneath 100-K Area are downgradient of the former $\mathrm{KE}$ and $K W$ condensate cribs.
The cause for recent variability in tritium concentrations observed near each reactor building is not clear. 
in June 2006. Technetium-99, a second indicator of shielding water, has not been detected at these wells. Since mid-2004, tritium concentrations have generally declined and are approaching pre-2003 levels.

The tritium trend at well 199-K-29 also showed an increase that started in January 2001 (Figure 2.3-13). This well is located off to the side of the flow path directly beneath the KE Basin. The trend most likely reflects downgradient migration and lateral spread of the plume associated with the former KE condensate crib, rather than water loss from the KE Basin.

Tritium Near KW Reactor. The tritium plume mapped near the KW Reactor is most likely to be associated with effluent disposed during the operating years to the former $\mathrm{KW}$ condensate crib. An unexplained increase in tritium concentrations at well 199-K-106A, located downgradient of the crib, began in 2001, peaked sharply in 2003 and early 2005, and has remained elevated during FY 2006 (Figure 2.3-14). Other constituents showing a similar trend include chloride, nitrate, and possibly technetium-99. Carbon-14, which was disposed to the crib but is less mobile than tritium, does not follow the tritium trend. The cause for the trends at well $199-\mathrm{K}-106 \mathrm{~A}$ is presumed to be remobilization of contaminants associated with the crib and underlying soil column, although a driving mechanism has not been positively identified. The presence of very low concentrations of technetium- 99 at this well is also unexplained. Soil samples collected during the excavation of the crib in early 2004 did not reveal the presence of technetium-99. Technetium-99 does migrate into the region between 100-B and 100-K Areas from sources in 200 East Area. However, there is no direct evidence to relate that plume to the technetium-99 observed at well 199-K-106A.

There is also no evidence in groundwater monitoring data to suggest water loss to the ground from the KW Basin in recent years. Tritium concentrations in wells most likely to detect shielding water are shown in Figure 2.3-15. The groundwater concentrations are significantly lower than concentrations in $\mathrm{KW}$ Basin shielding water, which contained 1.8 million $\mathrm{pCi} / \mathrm{L}$ in June 2006. The change in concentrations at well 199-K-34 that began in late 2003 has no obvious explanation, but trend changes of this magnitude have occurred in the past.

Tritium Near the 118-K-1 Burial Ground. Tritium concentrations at well 199-K-111A, located at the northwest corner of the burial ground, began rising abruptly in mid-2000 to a peak value of $98,200 \mathrm{pCi} / \mathrm{L}$ in April 2002 (Figure 2.3-16). Since that time, concentrations declined to a level of $\sim 14,000 \mathrm{pCi} / \mathrm{L}$ by mid-2004, remained constant until early 2006 , and have since declined to $\sim 6,500$ in fall 2006. No monitoring wells exist along the direct downgradient flow path to the river. However, the nearest well just to the side of that flow path is well 199-K-18, located $\sim 450$ meters to the north of well 199-K-111A. Assuming a plume migration rate of 0.12 meter/day, the "pulse" of tritium that passed by well 199-K-111A starting in 2001 might possibly be detected at well 199-K-18 in 10 years, i.e., 2011.

The source for tritium in groundwater near the burial ground was the subject of a multifaceted investigation during 2002 (PNNL-14031). A subsequent soil-gas survey was conducted along the north perimeter of the burial ground in 2003 (PNNL-14548) during which soil gas was analyzed for helium isotopes (helium-3 is a decay product of tritium). An excess of helium-3 was measured at all sites and indicated the nearby presence of tritium. The pattern of isotope ratios suggests the likelihood of a tritium source in the burial ground, along with an underlying groundwater plume. This burial ground has undergone some remedial action during FY 2006, although the particular buried structures suspected of containing tritium-releasing materials have not yet been excavated.

Tritium Near the 100-K Trench. Groundwater downgradient of the trench typically contains low concentrations of tritium, i.e., $<2,000 \mathrm{pCi} / \mathrm{L}$. The exception occurs at the southwest end of the trench, where average concentrations during FY 2006 are $~ 37,900$ and $38,500 \mathrm{pCi} / \mathrm{L}$ at wells $199-\mathrm{K}-18$ and 199-K-120A (a pump-and-treat system extraction well), respectively (Figure 2.3-11). The source for tritium at this location is uncertain; it may 
represent past disposal to the $100-\mathrm{K}$ crib $(116-\mathrm{K}-1)$ or $100-\mathrm{K}$ trench $(116-\mathrm{K}-2)$, or possibly tritium from a source farther inland, such as the $100-\mathrm{K}$ burial ground $(118-\mathrm{K}-1)$.

Tritium is being re-introduced to the aquifer via injection of the effluent from the pumpand-treat system (see Figure 2.3-1 for location of injection wells). Semiannual measurements of tritium in effluent were 7,200 and $6,200 \mathrm{pCi} / \mathrm{L}$ during $\mathrm{FY} 2006$, and most of that tritium comes from extraction well 199-K-120A, where concentrations averaged $\sim 38,500 \mathrm{pCi} / \mathrm{L}$ during 2006. Injected effluent appears to have arrived at downgradient well 199-K-125A as early as 1999, as shown by increasing tritium concentrations at that and nearby wells (Figure 2.3-17). Increasing trends are also present at nearby wells 199-K-20, 199-K-116A, and $199-\mathrm{K}-127$.

\subsubsection{Carbon-14}

Condensate from gas circulated through the KE and KW Reactors contained carbon-14 (along with tritium) and was discharged to infiltration cribs at the east side of each reactor building. Release of carbon-14 from the cribs, which were excavated and backfilled during 2004 , is the source for the two carbon-14 plumes near each reactor. The drinking water standard is 2,000 pCi/L, which continued to be exceeded during FY 2006 at several wells that monitor these plumes. The half-life for carbon-14 is 5,730 years. This radionuclide exchanges with carbon in carbonate minerals, and so its movement is more restricted and variable than a non-exchanging constituent like tritium.

The two plumes are positioned between the crib source locations and the Columbia River (Figure 2.3-18). Current concentrations of carbon-14 in groundwater at wells immediately downgradient of each crib are shown in Figures 2.3-12 and 2.3-14. Near the KE condensate crib (116-KE-1), recent results at well 199-K-30 indicate a concentration of 5,660 pCi/L. Concentrations observed farther downgradient from this crib along the rivershore are very low and likely to be representative of background levels. Near the KW condensate crib (116-KW-1), a recent result at well $199-\mathrm{K}-106 \mathrm{~A}$ is $13,500 \mathrm{pCi} / \mathrm{L}$. There is evidence that the plume front in this region has reached the river, but at levels well below the drinking water standard. A 2006 sample from aquifer tube 17-D revealed a concentration of $519 \mathrm{pCi} / \mathrm{L}$, which is above background levels.

Carbon-14 has also been detected at well 199-K-108A in an area upgradient of the $\mathrm{KW}$ condensate crib. Concentrations exceeded the drinking water standard $(2,000 \mathrm{pCi} / \mathrm{L})$ during the mid-1990s, with monitoring results typically falling in the range $\sim 3,000$ to $4,000 \mathrm{pCi} / \mathrm{L}$. During the period 2000 to 2004, groundwater at this location was diluted by clean water from an unknown source, and contamination indicators were dramatically reduced in concentration. In 2005, dilution by clean water stopped, and monitoring results for FY 2006 indicate a return to pre-diluted conditions for many constituents, with carbon-14 concentrations rising to $1,670 \mathrm{pCi} / \mathrm{L}$.

\subsubsection{Strontium-90}

Strontium-90 was released to the environment at $100-\mathrm{K}$ Area primarily via used reactor coolant. It may also have been present in fuel storage basin shielding water, which was discharged to nearby drain fields and injection wells during the reactor operating period. Strontium-90 continues to be present at relatively high concentrations in the shielding water at $\mathrm{KE}$ and KW Basins, i.e., 1.1 million and 320,000 pCi/L, respectively, during June 2006. The radionuclide is moderately mobile in the environment and has a half-life of $\sim 29$ years. The drinking water standard is $8 \mathrm{pCi} / \mathrm{L}$, which is based on radiological exposure from beta emissions. If strontium-90 is the only beta-emitting radionuclide present in a groundwater sample, the gross beta concentration for the sample will be approximately twice the value for strontium-90. The doubled value is caused by yttrium-90, a short-lived strontium-90 decay product and also a beta emitter.

Strontium-90 Near the KE and KW Reactors. The highest concentrations in 100-K Area groundwater have been observed near the northwest corner of the KE Reactor, at

\section{Carbon-14 concentrations exceed the drinking water standard at several wells downgradient of former reactor atmosphere gas condensate cribs near KE and KW Reactors.}


At 100-K Area,

the highest concentration

of strontium-90

in groundwater

samples occurs

near the northwest

corner of the

KE Reactor.

Nitrate

concentrations

exceed drinking

water standards in

some portions of

the 100-K Area. well 199-K-109A, and reached a peak of $\sim 18,000 \mathrm{pCi} / \mathrm{L}$ in 1997 . Concentrations declined following that peak value, and since 2002 , have remained variable within the range of several hundred up to $\sim 3,100 \mathrm{pCi} / \mathrm{L}$ (Figure 2.3-19). The elevated gross beta concentrations also observed in groundwater at this location appear to be caused primary by strontium- 90 . The elevated concentrations during the period 1996 through 2000 correlate with a period of sustained high water-table conditions (see hydrograph on Figure 2.3-19). This suggests that a raised water table remobilized strontium-90 that remained in the lower vadose zone beneath the KE drain field (116-KE-3). Periodic infiltration of water, perhaps as the result of precipitation events and loss from fire hydrant utility lines, may also have contributed to moving contamination from the vadose zone beneath the former drain field to groundwater (PNNL-12023).

Strontium-90 concentrations are lower at comparable locations near KW Reactor, and during 2006 continued to range from 24 to $34 \mathrm{pCi} / \mathrm{L}$, with essentially constant trends. Indications exist at well 199-K-107A of temporarily elevated levels during the high water-table conditions in 1996 and 1997, based on gross beta measurements, but the effect is not nearly as pronounced as at KE Reactor. Leakage from hydrant utility lines has not been reported near the northwest corner of the KW Basin and adjacent drain field. The strontium-90 observed at well 199-K-107A has not migrated any significant distance downgradient, and is not detected at well 199-K-132, which is midway between the KW Reactor and the Columbia River.

Strontium-90 Near the 100-K Trench. The effluent disposed to the former 100-K trench contained strontium-90, which is still present in groundwater affected by trench operations. The highest concentrations during FY 2006 are generally $<40 \mathrm{pCi} / \mathrm{L}$ and occur in the area between the central portion of the trench and the river (e.g., wells 199-K-20 and 199-K-21). Within this limited area, concentrations did increase during the high water-table period of 1996-1997, suggesting the continuing presence of strontium-90 in the lower vadose zone, and remobilization when the water table becomes elevated. Throughout most of the area containing the chromium plume targeted for interim remedial action, concentrations are near or below the drinking water standard of $8 \mathrm{pCi} / \mathrm{L}$. Also, most concentration trends indicate a gradual decline.

\subsubsection{Other Constituents}

Nitrate is widely distributed beneath the $100-\mathrm{K}$ Area. Potential sources include currently active septic systems and past-practices waste sites, but the distribution pattern does not clearly delineate specific source sites. Nitrate exceeds the drinking water standard $(45 \mathrm{mg} / \mathrm{L})$ at some wells in some areas. Concentration trends vary depending on monitoring location, and the cause for the variability is likely to be shifts in plume position because of groundwater flow. At some wells, nitrate concentrations rose in response to the unusually high water-table conditions during 1996 and 1997, suggesting proximity to a lower vadose zone source for nitrate.

Trichloroethene was detected during FY 2006 at wells 199-K-106A and 199-K-132, which are located within the downgradient flow path from the former KW condensate crib (116-KW-1). Concentrations were 2.9 and $1.7 \mu \mathrm{g} / \mathrm{L}$, respectively, at these wells (the drinking water standard is $5 \mu \mathrm{g} / \mathrm{L}$ ). Other volatile organic compounds that may found along with trichloroethene, such as tetrachloroethene and cis-1,2-dichloroethene, are not detected at these wells.

In the past, several metals have been measured in filtered samples at concentrations above the secondary drinking water standards (e.g., aluminum, iron, and manganese). These occurrences have not been positively connected to waste sites or waste streams. They are not considered contaminants of potential concern because of their (a) limited areal extent, (b) sporadic occurrence, and (c) possibility that their occurrence may be related to well 
construction and, therefore, not representative of groundwater conditions. However, their concentrations continue to be monitored as part of basic water quality analyses (e.g., collective analyses for major cations and anions).

\subsubsection{Interim Remedial Action for Chromium in Groundwater}

Interim remedial action under CERCLA at the 100-KR-4 Operable Unit initially targeted the chromium plume associated with the former $100-\mathrm{K}$ trench $(116-\mathrm{K}-2$ waste site). A pump-and-treat system was designed that removes hexavalent chromium from extracted groundwater and injects the treated effluent at an inland location upgradient of the former trench. A second area of contamination, near the KW Reactor complex, has been added to the interim remedial action, with a new pump-and-treat system expected to become operational in early 2007. The remedial action objectives and criteria for success remain the same as for the initial target plume.

As described in the remedial design/remedial action work plan for the initial interim action (DOE/RL-96-84), the performance criteria for these pump-and-treat systems includes achieving hexavalent chromium concentrations that do not exceed $22 \mu \mathrm{g} / \mathrm{L}$ in near-river wells. This target level is based on the U.S. Environmental Protection Agency's (EPA's) protection standard of $11 \mu \mathrm{g} / \mathrm{L}$ for freshwater aquatic organisms. Because some dilution of contaminants by river water occurs along the pathway between the aquifer and riverbed substrate where the protection standard applies, the interim action performance criteria considers a value of $22 \mu \mathrm{g} / \mathrm{L}$ in near-river compliance wells as being protective of aquatic life.

The pump-and-treat system at the $100-\mathrm{K}$ trench during FY 2006 involved ten extraction wells, five injection wells, and an ion-exchange resin treatment system (DOE/RL-2006-08). The system began operating in October 1997. Performance monitoring of the pump-andtreat system is described in an interim remedial action monitoring plan (DOE/RL-96-90). Three wells, located between the extraction wells and the Columbia River, are currently identified as compliance monitoring locations (wells 199-K-18, 199-K-20, and 199-K-117A; chromium trend charts for these wells are shown in Figures 2.3-5 and 2.3-6). Seven additional wells are monitored to help evaluate the performance of the system regarding aquifer conditions, along with aquifer tubes at eleven sites and several riverbank spring sites located along the rivershore. Lists of sampling frequencies and analyses performed are included in Appendix A.

The results of the interim remedial action for chromium are described in an annual summary report for each calendar year, which is prepared by the remedial action contractor. Highlights from the summary report for calendar year 2005 (DOE/RL2006-08) are presented in the following sections, and include updates for groundwater volumes treated and mass of chromium removed through September 2006.

The second five-year review of remedial actions being conducted under CERCLA was published in November 2006 (DOE/RL-2006-20). The review identified three issues pertaining to groundwater beneath the 100-K Area. Those issues and their associated follow-up actions are listed in Table 2.31 .

\section{Interim remedial action for groundwater near} the 100-K trench involves a pumpand-treat system that uses ionexchange resin to remove hexavalent chromium from extracted groundwater.
The remedial action objectives for the 100-KR-4 Operable Unit (ROD 1996a) are:

- Protect aquatic receptors in the river bottom from contaminants in groundwater entering the Columbia River.

- Protect human health by preventing exposure to contaminant in the groundwater.

- Provide information that will lead to the final remedy.

The contaminant of concern is hexavalent chromium. The record of decision specifies $22 \mu \mathrm{g} / \mathrm{L}$ as the concentration at compliance wells that is protective of aquatic organisms in the river environment. 


\section{Chromium concentrations are generally decreasing in the area of the 100-K trench pump-and- treat system.}

\subsubsection{Progress During FY 2006}

During the period October 1, 2005, through September 30, 2006, 501 million liters of groundwater were extracted and treated, and $\sim 20$ kilograms of hexavalent chromium were removed. Since the startup of operations in October 1997, the total volume of groundwater extracted is $\sim 3.61$ billion liters, and total mass of hexavalent chromium removed is $\sim 291$ kilograms. The 2006 average flow rate for each extraction well ranged between 52 and 166 liters/minute, with a combined average flow rate of 1,138 liters/minute (DOE/RL-2006-08). There were no major operational changes to the 100-KR-4 pump-andtreat network during FY 2006.

The four wells installed in late 2005 adjacent to well $199-\mathrm{K}-126$ to perform a treatability test using calcium polysulfide were sampled monthly throughout the year. Chromium concentrations remained at or slightly above detection limits in the wells used to monitor the effectiveness and longevity of the barrier. This test evaluated the practicality of treating chromium in the groundwater as an alternative to pump-and-treat systems, and a report describing the results is presented in DOE/RL-2006-17.

\subsubsection{Influence on Aquifer Conditions}

Chromium concentrations within the target plume area show generally decreasing trends (Figures 2.3-5, 2.3-6, and 2.3-7; see Section 2.3.1.1). During FY 2006, strongly decreasing trends continued at wells $199-\mathrm{K}-20$ and $199-\mathrm{K}-126$. More gradual decreasing trends are noted at wells 199-K-19, 199-K-120A, 199-K-22, and 199-K-129. Relatively constant concentrations during FY 2006 are observed at 199-K-117A, 199-K-125A, 199-K-37, and 199-K-130. Concentrations consistently at or below the protective level for interim action $(22 \mu \mathrm{g} / \mathrm{L})$ for near-river wells are observed only at well 199-K-117A.

Several wells are strongly influenced by infiltration of river water, where contaminant concentrations are reduced by dilution, i.e., by mixing of groundwater and river water. Periodic dilution is observed at well 199-K-114A, creating cyclic fluctuations of chromium concentrations (Figure 2.3-6). The relatively higher concentrations represent groundwater approaching the river, while the lower concentrations represent groundwater mixed with river water. A continuous presence of river water is observed at well 199-K-117A, as indicated by the low specific conductance of the samples. Exceptions to the generally decreasing trends occur at the southwest and northeast boundaries of the plume, at wells 199-K-18 (southwest) and possibly at 199-K-37 (northeast). The possible causes for these increases are discussed in Section 2.3.1.1.

Maximum chromium concentrations at some aquifer tube sites along the shore segment adjacent to the central portion of the plume appear to have decreased with time, especially for results more recent than 2003 (Figure 2.3-20). However, the number of results are limited, so conclusions regarding long-term trends are tentative. At the northern extent of the plume, maximum concentrations at tube sites show evidence for an increase with time (Figure 2.3-21), suggesting migration of the plume in that direction from the trench. The shallowest tubes at a particular site often show evidence for dilution by river water, as indicated by lower specific conductance of the samples. Even though some of the concentrations observed in tube samples are reduced by dilution, they are nevertheless representative of contaminants being transported to the hyporheic zone of the river by groundwater movement.

The injection of treated effluent at five wells has created a mound of uncertain magnitude on the water table. The injected treated effluent has migrated downgradient and arrived at wells 199-K-20, 199-K-116A, 199-K-119A, and 199-K-125A, as shown by increasing tritium concentrations at those wells (Figure 2.3-17). Tritium is a good tracer for showing the effects of injection, as effluent concentrations are higher than in groundwater near most of the extraction wells. During FY 2006, tritium concentrations in effluent were measured at 6,200 and 7,200 pCi/L (the first effluent in late 1997 had a level of $\sim 16,000 \mathrm{pCi} / \mathrm{L}$ ). The timing of the arrival of this plume front at the four wells does not correlate precisely with 
distance from the injection site, probably because of variability in flow paths and rates created by the pumping activities, and by heterogeneity in the aquifer.

Uncertainties regarding the pump-and-treat system's influence on aquifer conditions involve the (1) extent of plume inland of the trench, and whether or not chromium observed at well 699-78-62 is part of the plume; (2) source for chromium and tritium at wells 199-K-18 and 199-K-120A, where some concentration trends are increasing; (3) height and extent of the mound created at the injection site, and its influence on flow patterns; and (4) mass of potentially mobile chromium remaining in the lower vadose zone and in the aquifer upgradient of the trench. A new well (199-K-143) has been installed inland of well 199-K-126 to provide additional monitoring coverage for the areal extent of the chromium plume (see Table 2.3-1, Issue 3, Action 3-1).

\subsubsection{New Pump-and-Treat System Near KW Reactor}

Design and construction of a new pump-and-treat system to remediate the chromium plume in the unconfined aquifer near KW Reactor began during FY 2006 (see Section 2.3.1 for description of the plume). This remedial action responds to five-year review Issue 4, Action 4-1 (Table 2.3-1). The new system is described in a remedial design/remedial action work plan (DOE/RL-2006-52). As currently designed, the system will include four extraction wells, two injection wells, and ion-exchange treatment equipment similar to that previously used in the 100-KR-4 and 100-HR-3 Operable Units. Initial treatment capacity will be $379 \mathrm{~L} / \mathrm{min}$, with provision for increases to $757 \mathrm{~L} / \mathrm{min}$ if required. Operation of the new system is scheduled for winter 2006-2007.

\subsubsection{Facility Monitoring - K Basins}

The fuel storage basins located within the KE and KW Reactor buildings were used from the late 1970s to 2004 to store irradiated fuel from the 100-N Reactor, along with other miscellaneous fuel recovered during remedial actions at other reactor areas. Each basin holds 4.9 million liters of shielding water that is highly contaminated with long-lived radionuclides, some of which are mobile in the environment (e.g., tritium and strontium-90). The KE Basin has leaked in the past, and the leakage has affected groundwater. The vadose zone beneath the basin is also known to contain radionuclides that are absorbed onto soil. Information on the removal of spent fuel and contaminated sludge, and the demolition of these basins, can be found at DOE's Richland Operations Office web site (www.hanford. gov/rl; communications tab, programs, Spent Nuclear Fuel). Tri-Party Agreement (Ecology et al. 1989) Milestone M-34-00 covers the fuel removal and basin cleanup project, the latter now referred to as the K-Basins Closure Project.

Groundwater Monitoring. The K Basins sampling and analysis schedule complements other schedules associated with the 100-KR-4 Operable Unit. The monitoring plan for K Basins (PNNL-14033) describes the objectives for the monitoring:

- Characterize groundwater conditions between the K Basins and the Columbia River to provide a periodic status of current conditions and the attenuation of plumes.

- Distinguish between groundwater contamination associated with K Basins and contamination from other past-practices sources to help guide operational and remedial action decisions.

- Maintain a strategy for the potential expansion of monitoring capabilities to respond to future basin-related issues.

These objectives remain valid as long as shielding water remains in the basins. Once actual demolition and removal of the basins begins, the strategy and objectives for groundwater monitoring will be revisited. In the interim, two additional monitoring wells (199-K-141 and 199-K-142) have been installed in the area between KE Basin and the river. The
A new pump-and

treat system is

being installed

to remediate

chromium-

contaminated

groundwater near

the KW Reactor

building.

\section{All irradiated \\ fuel has been \\ removed from the}

$K$ Basins. Work to

remove radioactive

sludge continued

during FY 2006,

and planning for

demolition of the

basins is well

underway. 
installation of three new wells (199-K-138, 199-K-139, and 199-K-140) downgradient of the $\mathrm{KW}$ Basin, as part of a pump-and-treat system for chromium in that area, will also improve the monitoring capability near the KW Basin.

The primary indicator for detecting shielding water in groundwater is tritium, which is present at concentrations in the millions-of-picocuries per liter range in $\mathrm{KE}$ and $\mathrm{KW}$ Basin water. Other less mobile radionuclides (e.g., strontium-90, cesium-137) are also present at relatively high concentrations in shielding water. However, if small volumes or low rates of leakage were to occur, these contaminants might not show up in groundwater because they would be retained in the vadose zone beneath the basins. One additional tracer for shielding water is technetium-99, which is mobile, like tritium, but is at relatively low concentrations in the shielding water. Therefore, it might not be apparent in groundwater if only small volumes of basin water loss are involved.

Recent Groundwater Monitoring Trends. The results of monitoring under the K-Basins task are reported quarterly to K-Basins Closure Project staff and DOE. During FY 2006, tritium concentrations at wells 199-K-27 and 199-K-109A, which are located adjacent to the KE Basin on its northwest side in a position most likely to detect basin leakage, remained relatively constant, and at levels generally below the drinking water standard (see Figure 2.3-1 for locations, Figure 2.3-13 for concentration trends, and Section 2.3.1.2 for discussion of tritium contamination). Some unexplained variability at well 199-K-27 continues, but concentrations remain in the range of long-term monitoring. There is still no clear explanation as to the cause for the abrupt increase in concentrations that started in January 2003 at these wells. There has been no unexplained loss of water from the basin to account for the trend changes in groundwater. However, it is possible that very low rates of loss from the basin to the ground might not be detected by monitoring the basin volume and that a relatively small volume of shielding water could account for the trend changes seen in groundwater.

Near the KW Reactor, tritium concentrations at well 199-K-106A, located downgradient of the former $\mathrm{KW}$ condensate crib $(116-\mathrm{KW}-1$ waste site) have been rising gradually since 2001, with a sharp peaking in mid-2003 (Figure 2.3-14). The source for the tritium is likely to be the vadose zone beneath the former crib and not related to potential water loss from the KW Basin. 
Table 2.3-1. Issues and Actions for 100-K Area Groundwater in Second CERCLA Five-Year Review (adapted from DOE/RL-2006-20)

\begin{tabular}{|c|c|}
\hline Issues and Actions & Action Due Date \\
\hline \multicolumn{2}{|c|}{$\begin{array}{l}\text { Issue } 3 \text {. The southeastern extent of the chromium plume from the } 116-\mathrm{K}-2 \text { trench, northeast of the current } \\
\text { injection wells, has not been delineated. }\end{array}$} \\
\hline Action 3-1. Install three additional wells to further delineate the plume. & August 2008 \\
\hline \multicolumn{2}{|c|}{$\begin{array}{l}\text { Issue } 4 \text {. The small chromium plume at KW Reactor has reached the river. There is currently no active } \\
\text { remediation system in place for this plume. }\end{array}$} \\
\hline $\begin{array}{l}\text { Action } 4-1 \text {. Construct a new pump-and-treat facility to address the } \\
\text { chromium groundwater plume in the KW Reactor area. }\end{array}$ & August 2008 \\
\hline \multicolumn{2}{|c|}{$\begin{array}{l}\text { Issue } 5 \text {. Groundwater monitoring indicates that the expansion of the 100-K Area pump-and-treat extraction } \\
\text { system has not yet achieved the remedial action objective. }\end{array}$} \\
\hline $\begin{array}{l}\text { Action } 5-1 \text {. Expand the } 100-K \text { Area pump-and-treat system by } \\
378.5 \text { liters/minute to enhance remediation of the plume between the } \\
116-\mathrm{K}-2 \text { trench and the } \mathrm{N} \text { Reactor perimeter fence. }\end{array}$ & August 2008 \\
\hline $\begin{array}{l}\text { Action } 5-2 \text {. Add additional wells between the } 116-\mathrm{K}-2 \text { trench and the } \\
\mathrm{N} \text { Reactor perimeter fence for groundwater extraction, and connect the } \\
\text { additional wells to the pump-and-treat system. }\end{array}$ & March 2007 \\
\hline
\end{tabular}




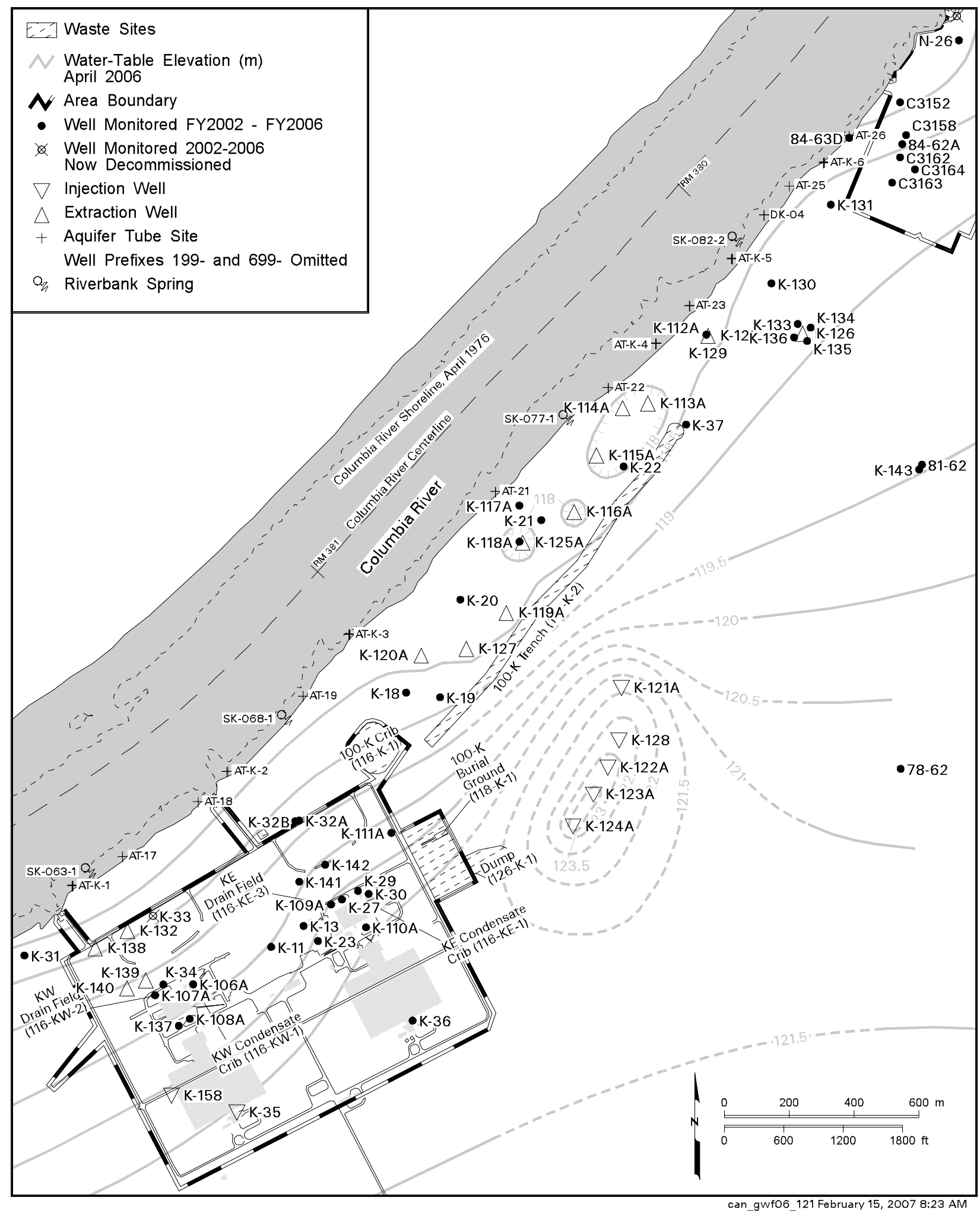

Figure 2.3-1. Location Map for 100-K Area Monitoring Wells, Shoreline Monitoring Sites, Waste Sites, and Facilities 


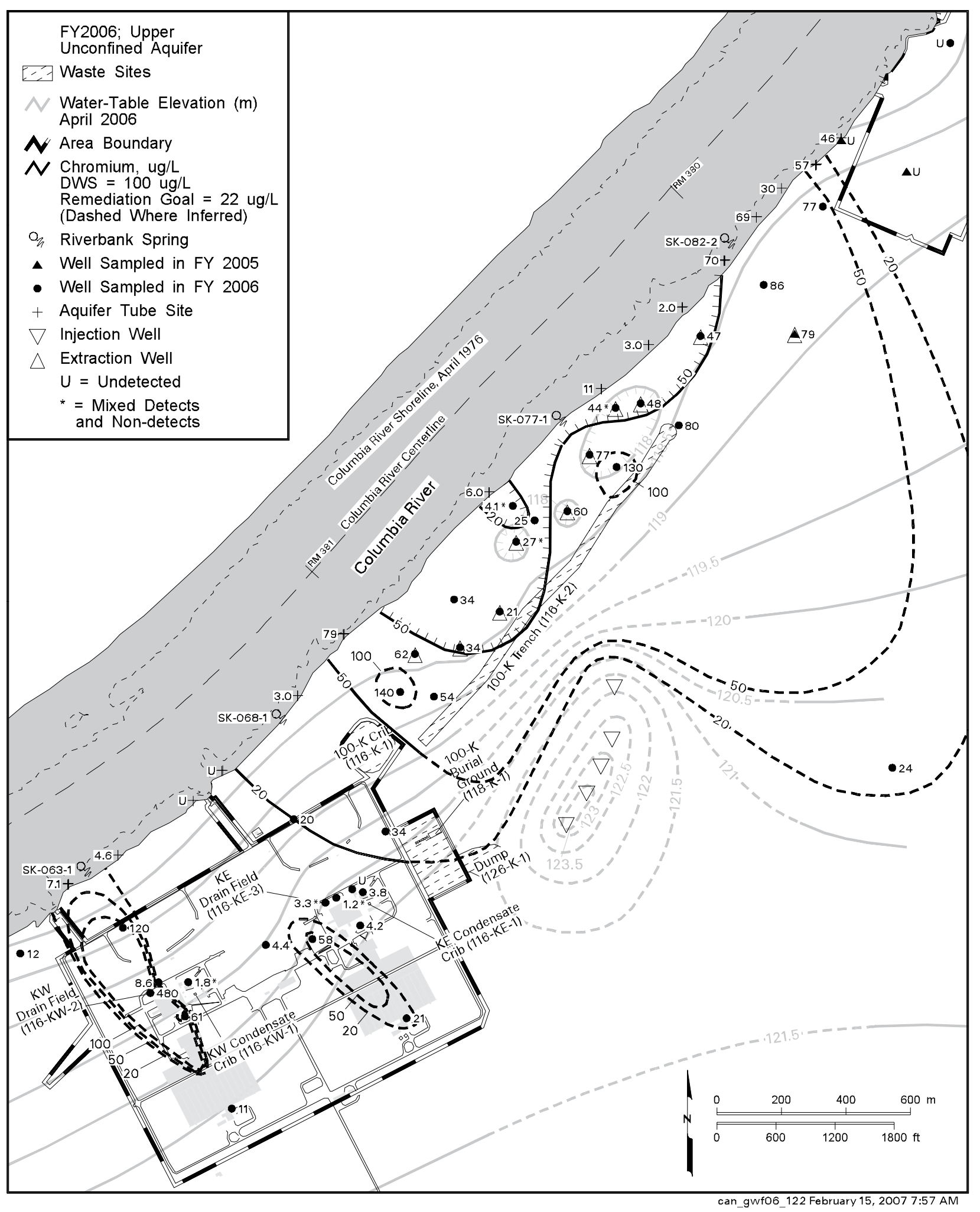

Figure 2.3-2. Chromium Concentrations in Upper Part of Unconfined Aquifer Beneath 100-K Area, Average Values for FY 2005 and 2006 


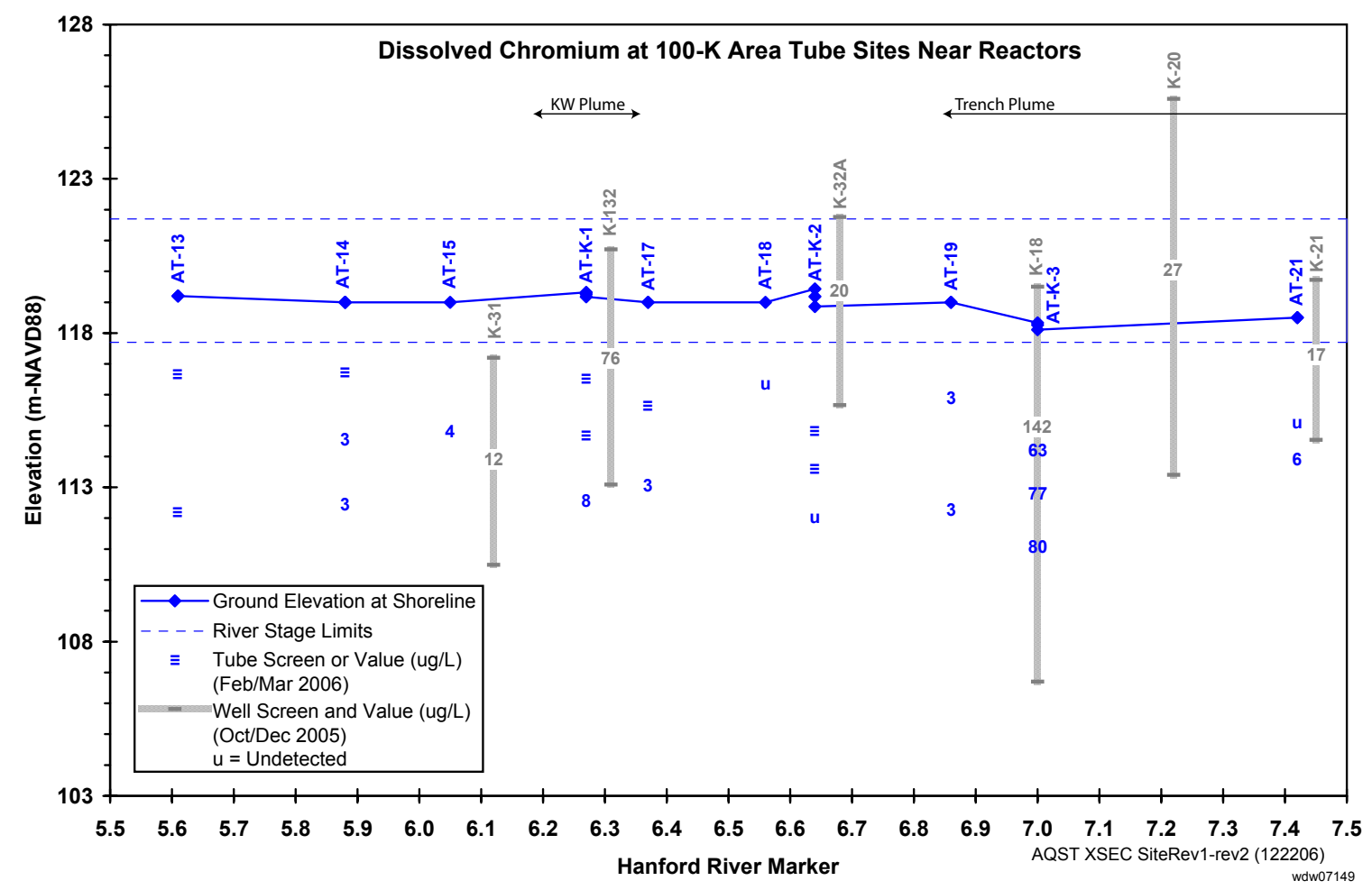

Figure 2.3-3. Chromium Concentrations at Aquifer Tube Sites Along the 100-K Shoreline Adjacent to the Reactors, February/March 2006

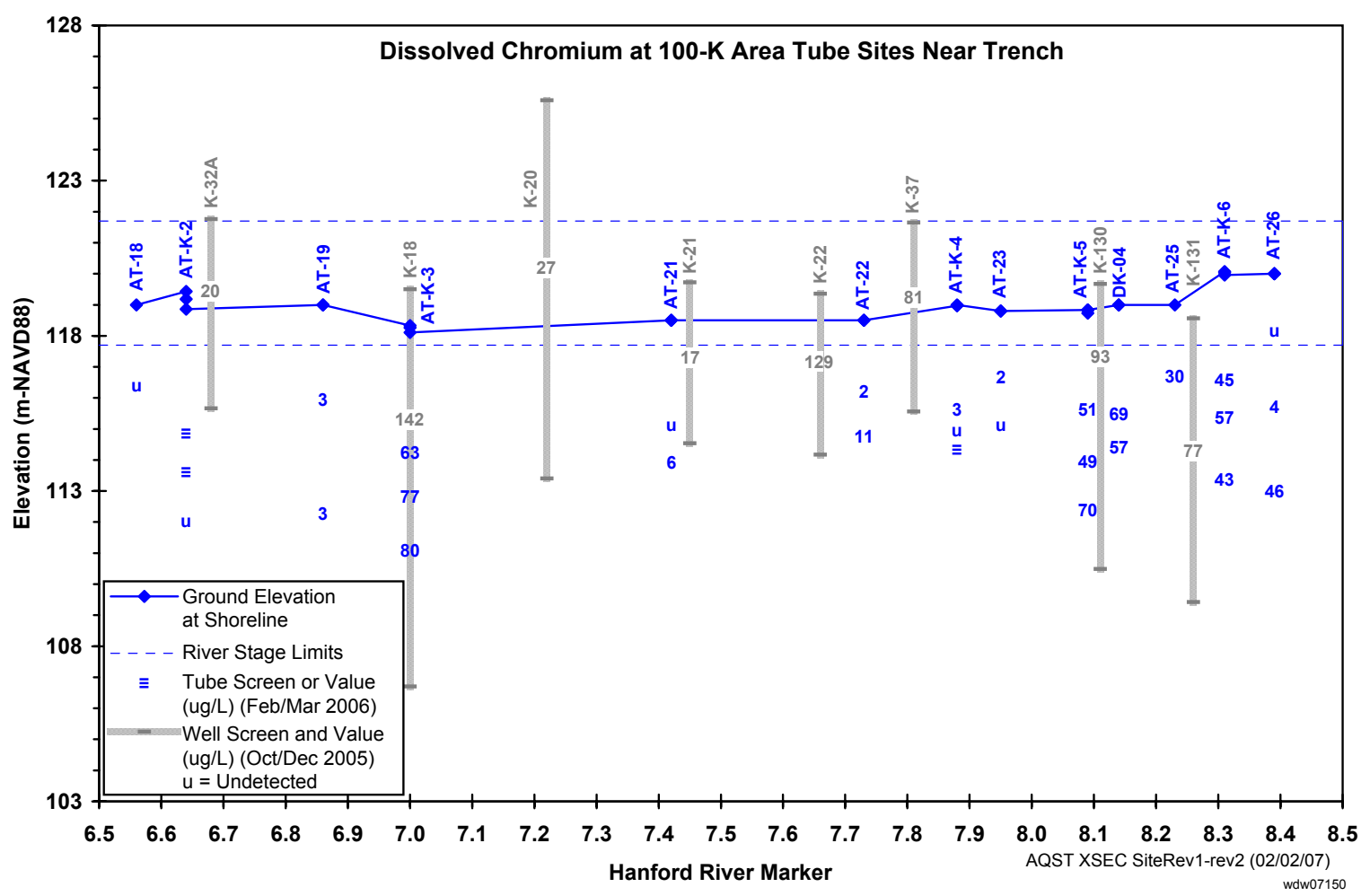

Figure 2.3-4. Chromium Concentrations at Aquifer Tube Sites Along the 100-K Shoreline Adjacent to the Former 100-K Trench, February/March 2006 

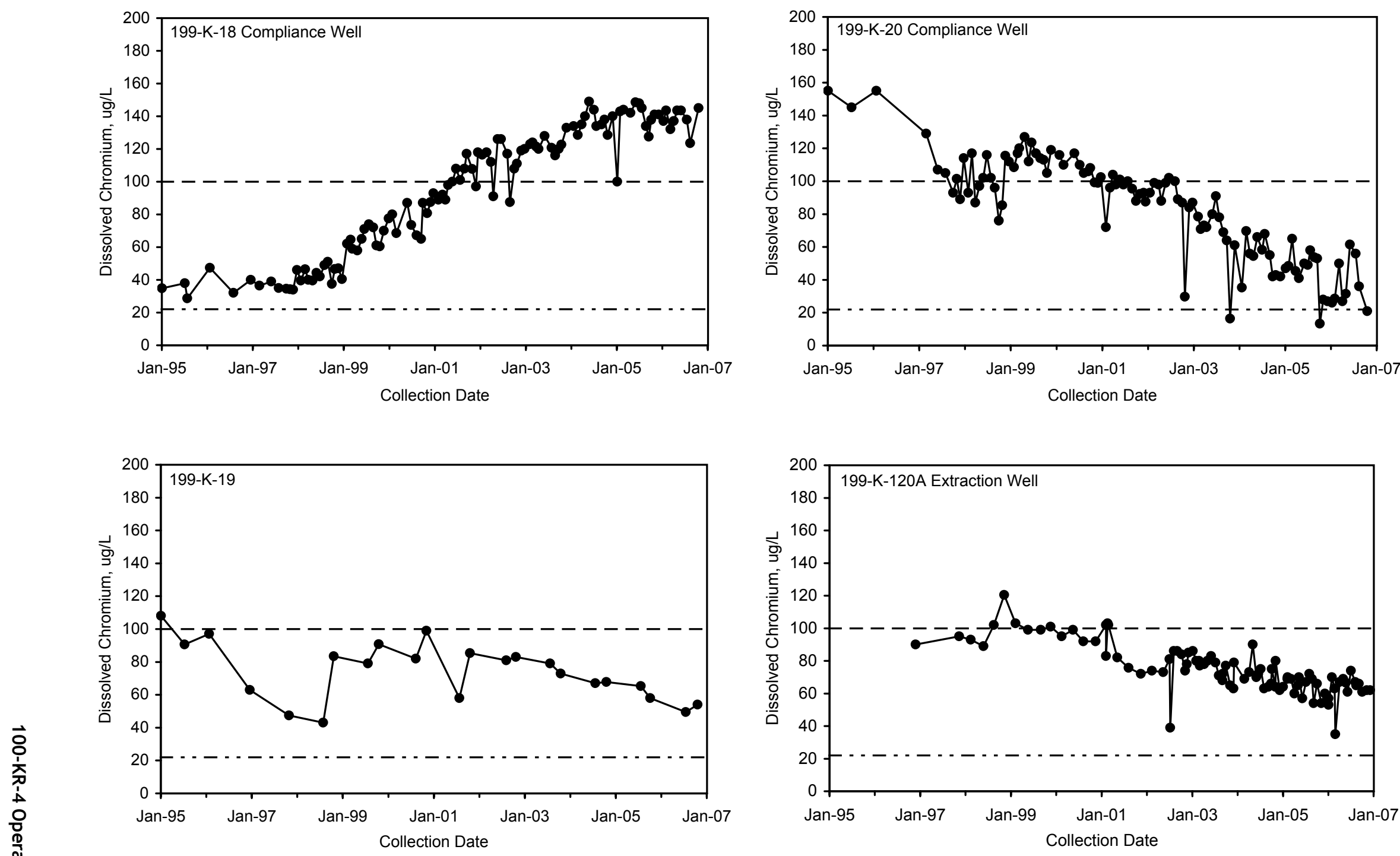

$$
\begin{aligned}
& --- \text { DWS } \\
& -\cdots-\text { Remedial Action Goal } \\
& \text { Replicate data averaged }
\end{aligned}
$$

Figure 2.3-5. Chromium Concentrations at Wells Located at the Southwest Edge of the 100-K Trench Plume 

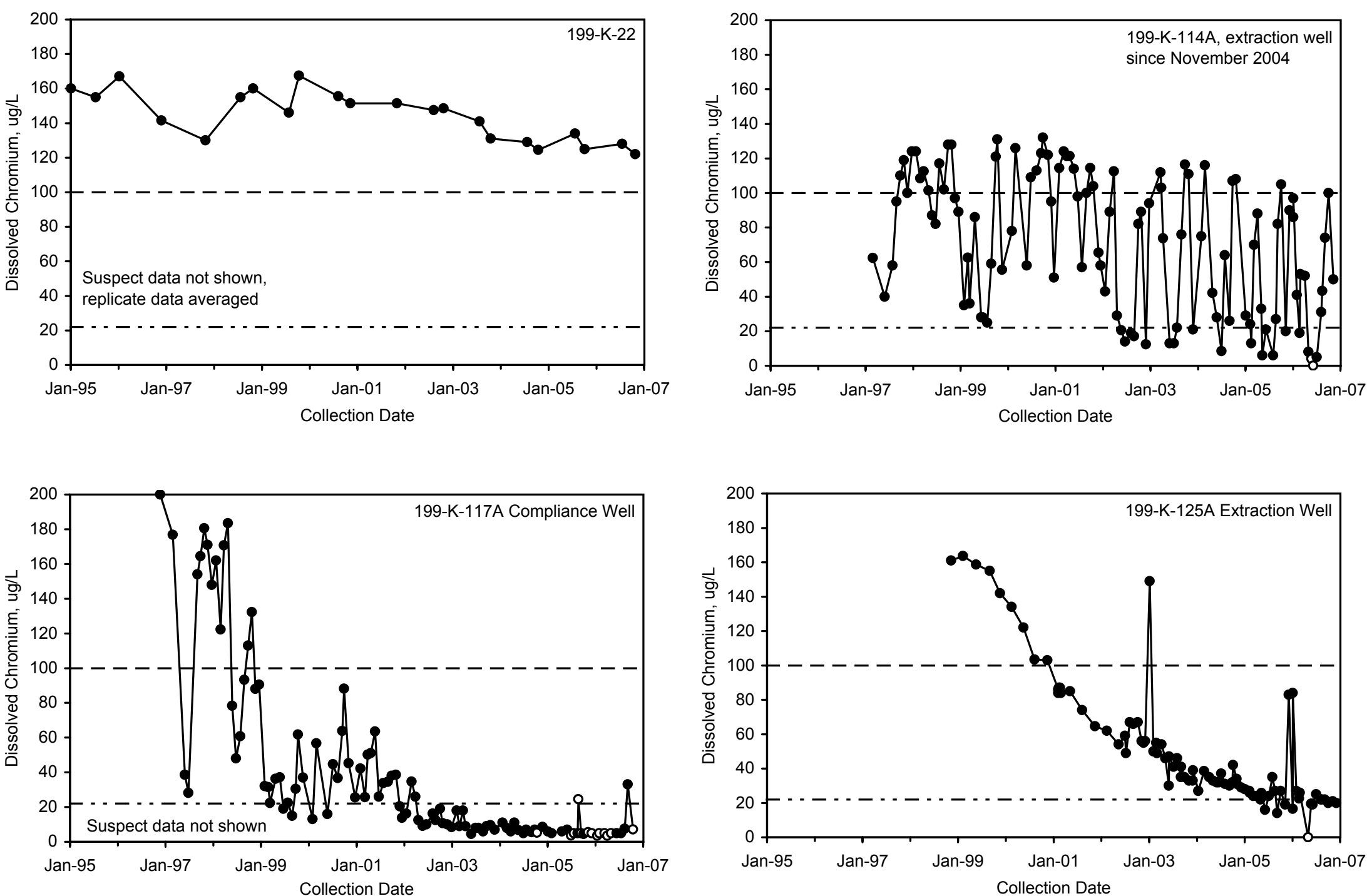

\section{- - - Remedial Action Goal}

Replicate data averaged,

open symbols used for non-detect values

Figure 2.3-6. Chromium Concentrations at Wells Located in the Central Portion of the 100-K Trench Plume 

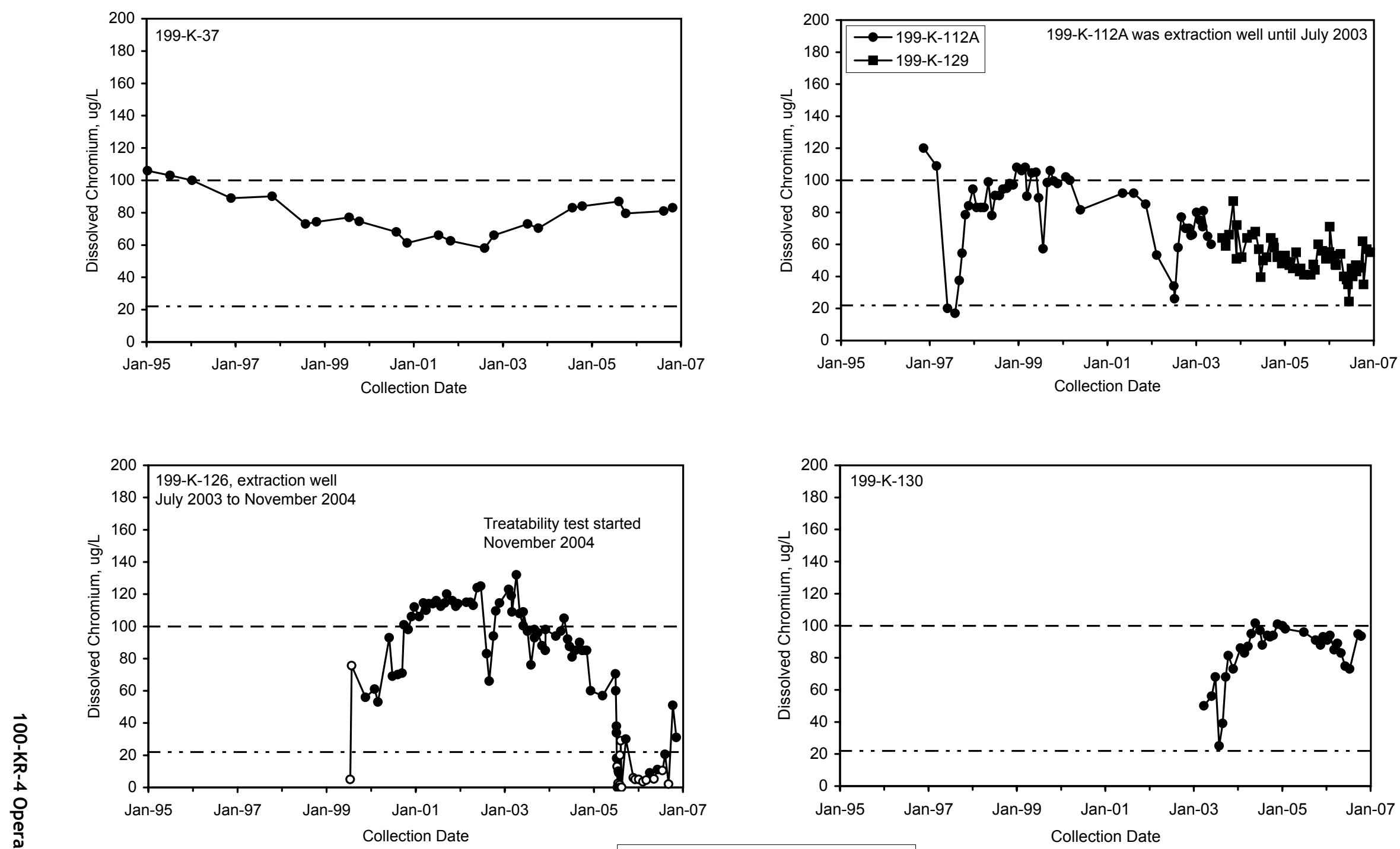

$$
\begin{aligned}
& \text { - - - R R } \\
& \text { Replicate data averaged, } \\
& \text { open symbols used for non-detect values }
\end{aligned}
$$

Figure 2.3-7. Chromium Concentrations at Wells Located at the Northeast Edge of the 100-K Trench Plume 


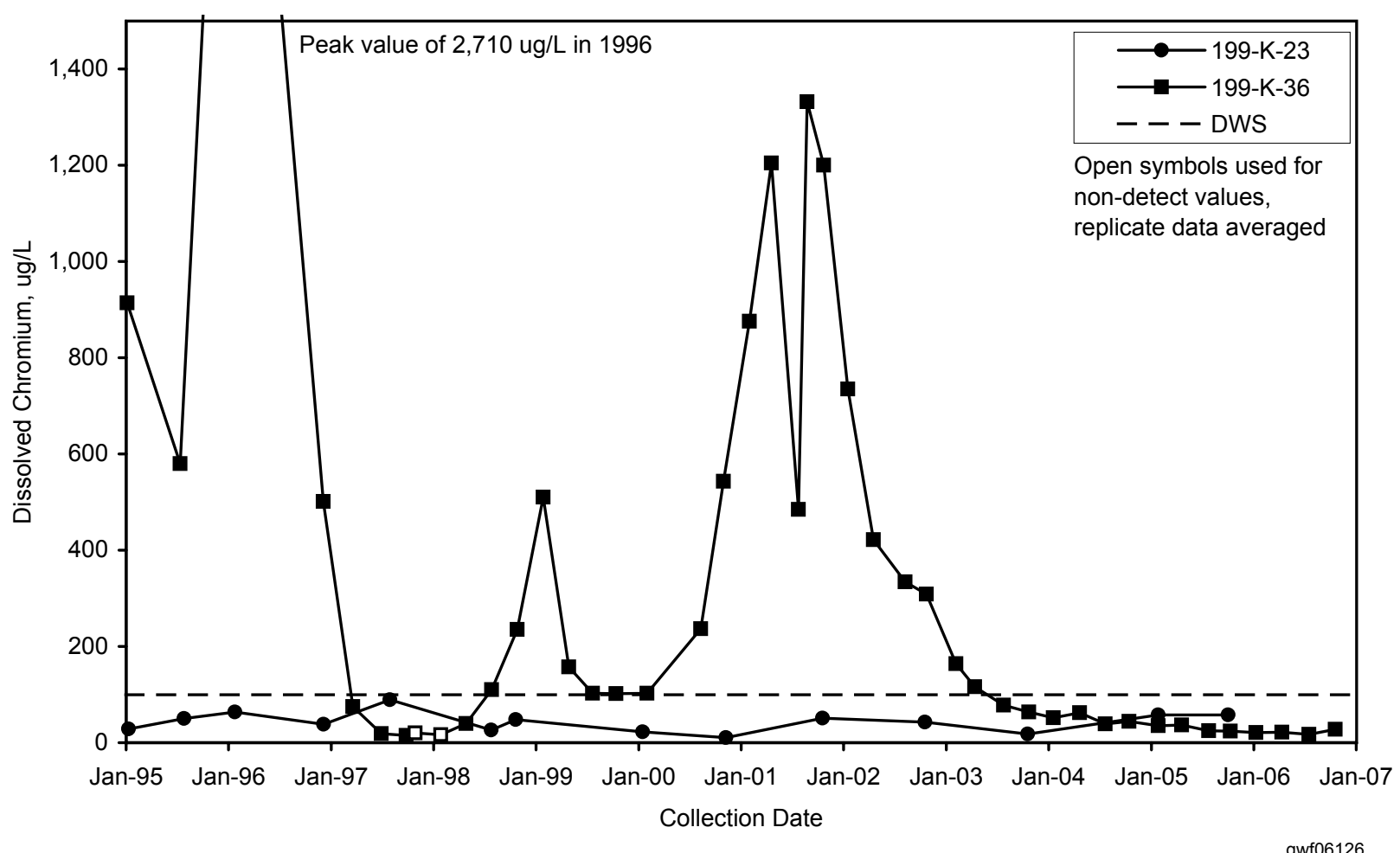

Figure 2.3-8. Chromium Concentrations in Groundwater Near KE Water Treatment Plant Basins

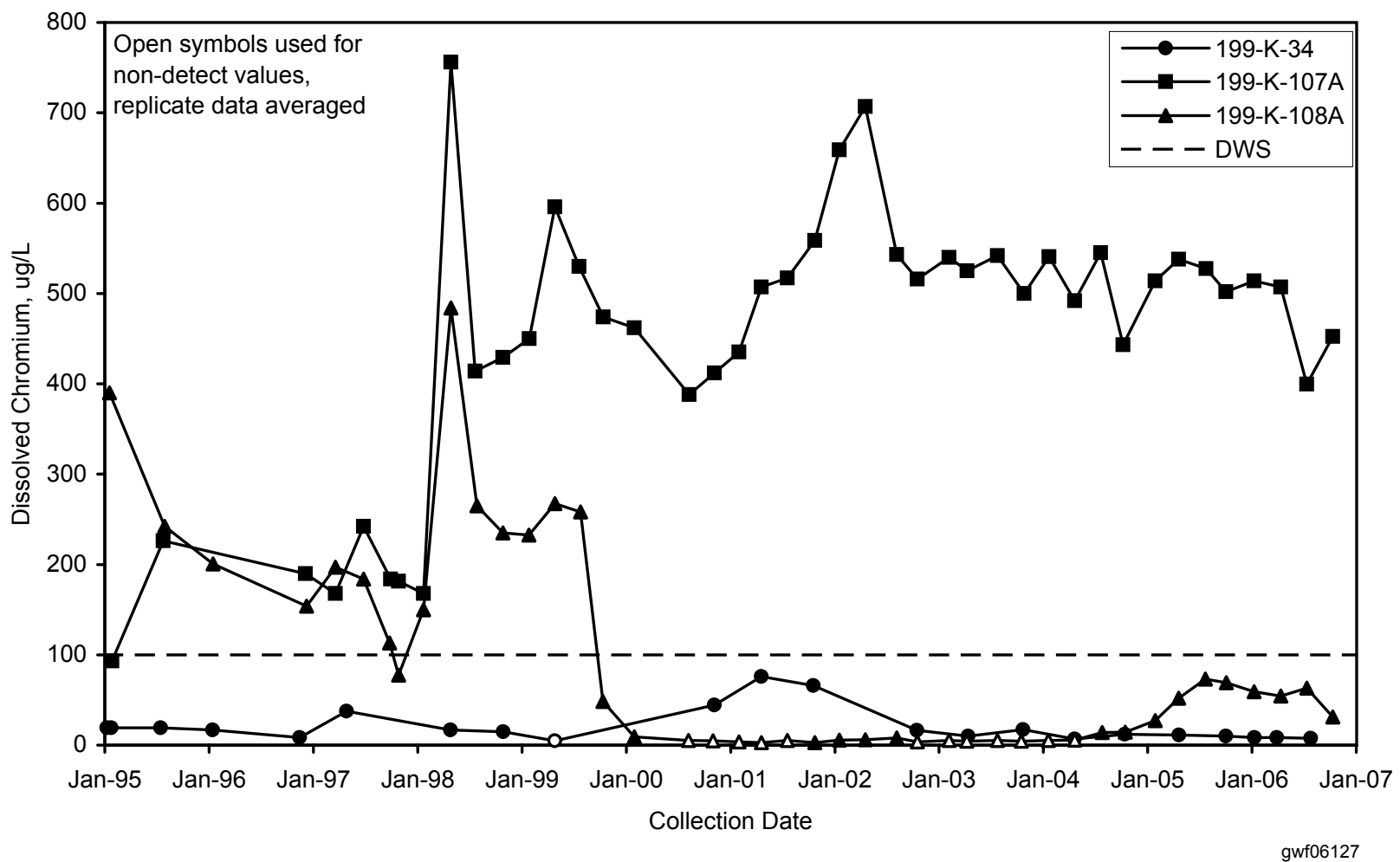

Figure 2.3-9. Chromium Concentrations in Groundwater Near KW Reactor Building 


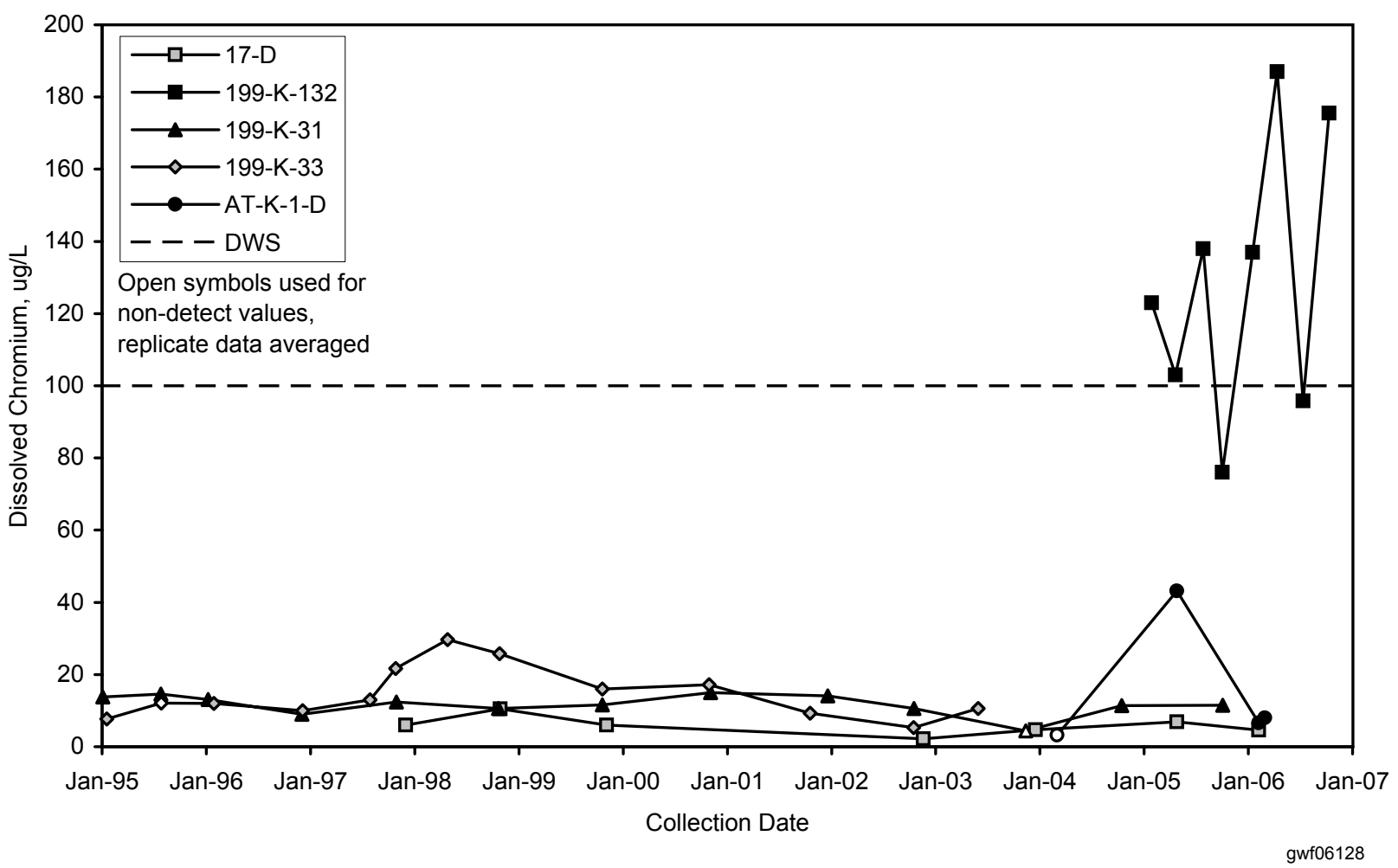

Figure 2.3-10. Chromium Concentrations in Groundwater Downgradient of the KW Reactor Building 


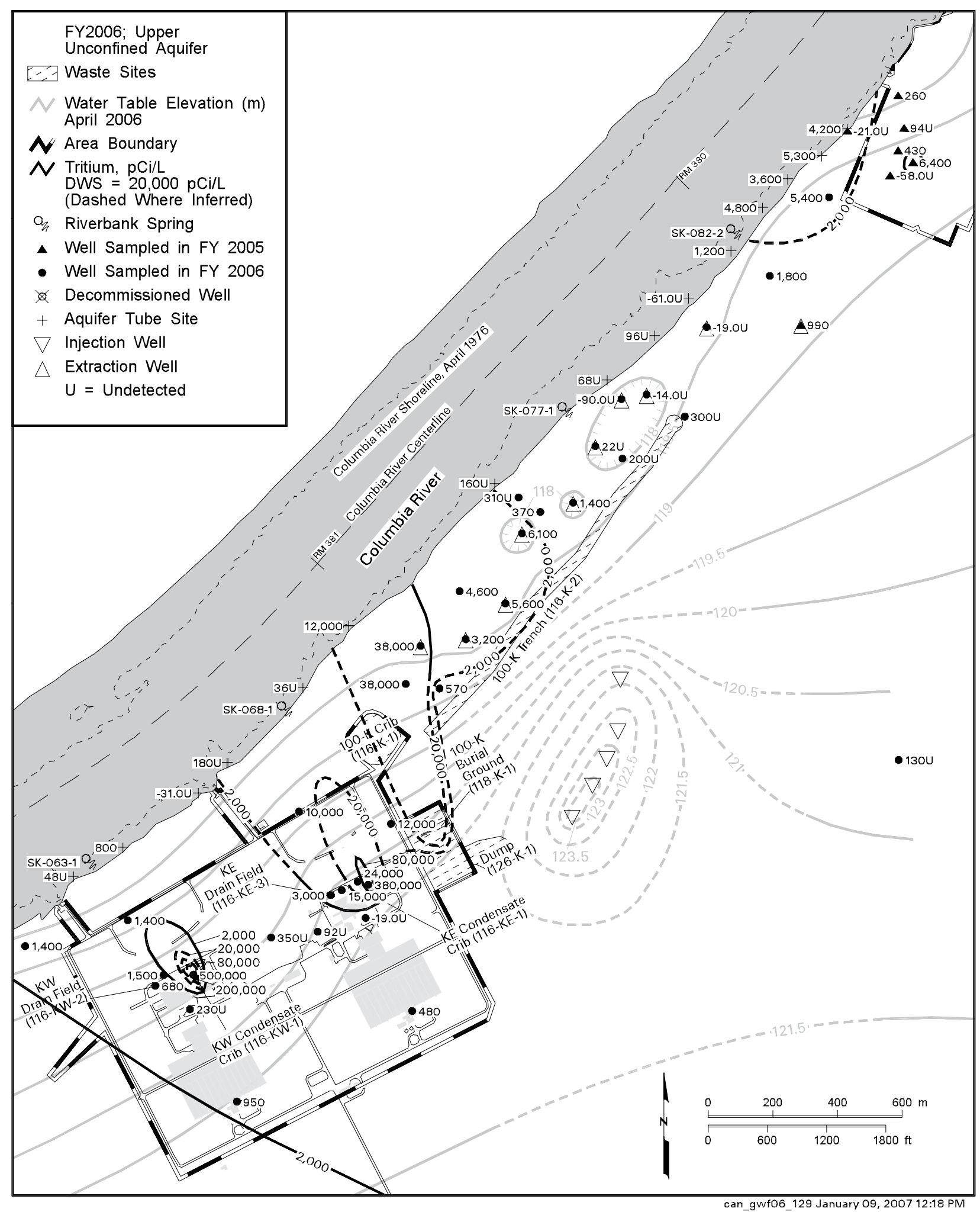

Figure 2.3-11. Tritium Concentrations in Upper Part of Unconfined Aquifer Beneath 100-K Area, Average Values for FY 2005 and 2006 


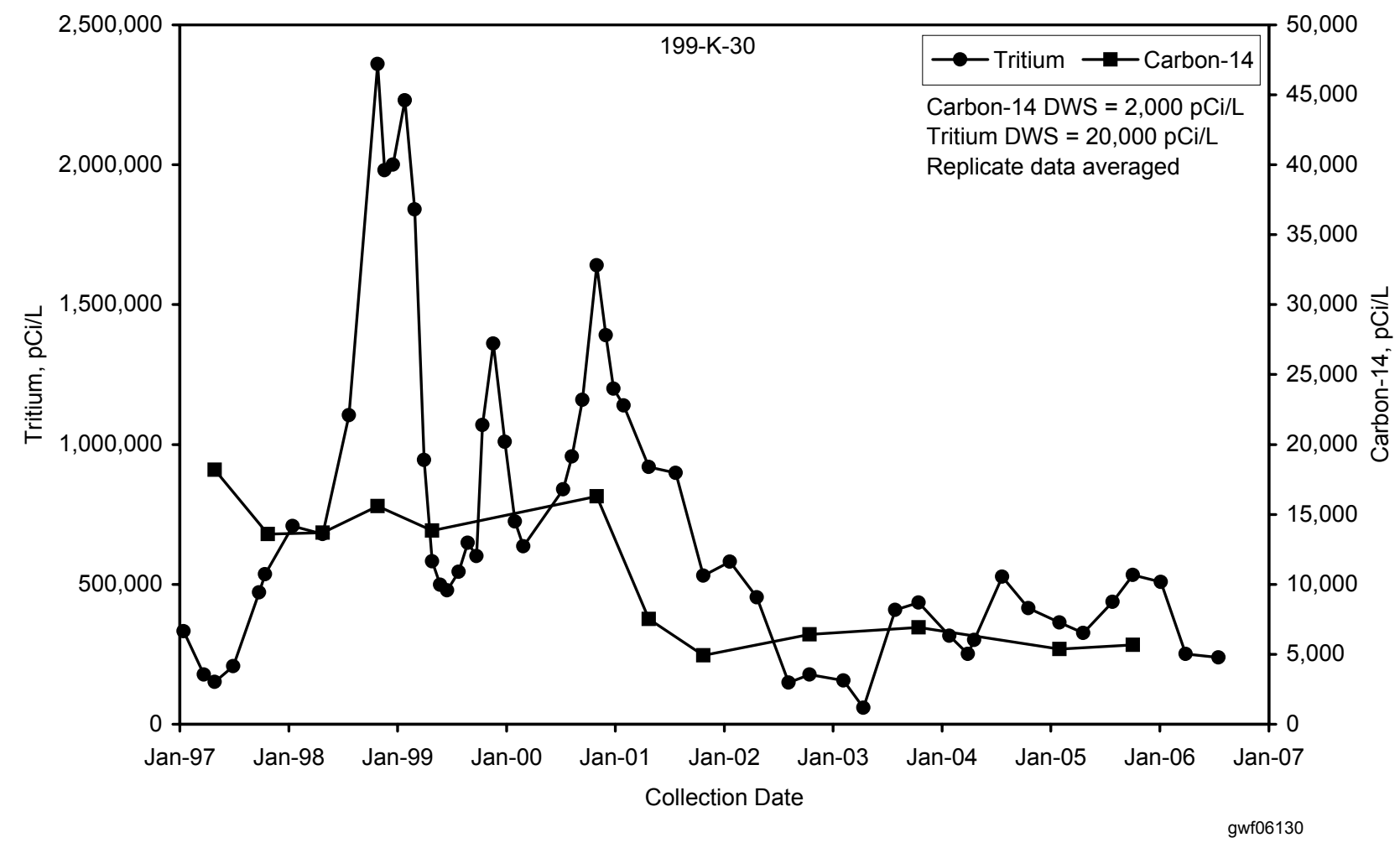

Figure 2.3-12. Tritium and Carbon-14 Concentrations in Groundwater Near Former KE Condensate Crib

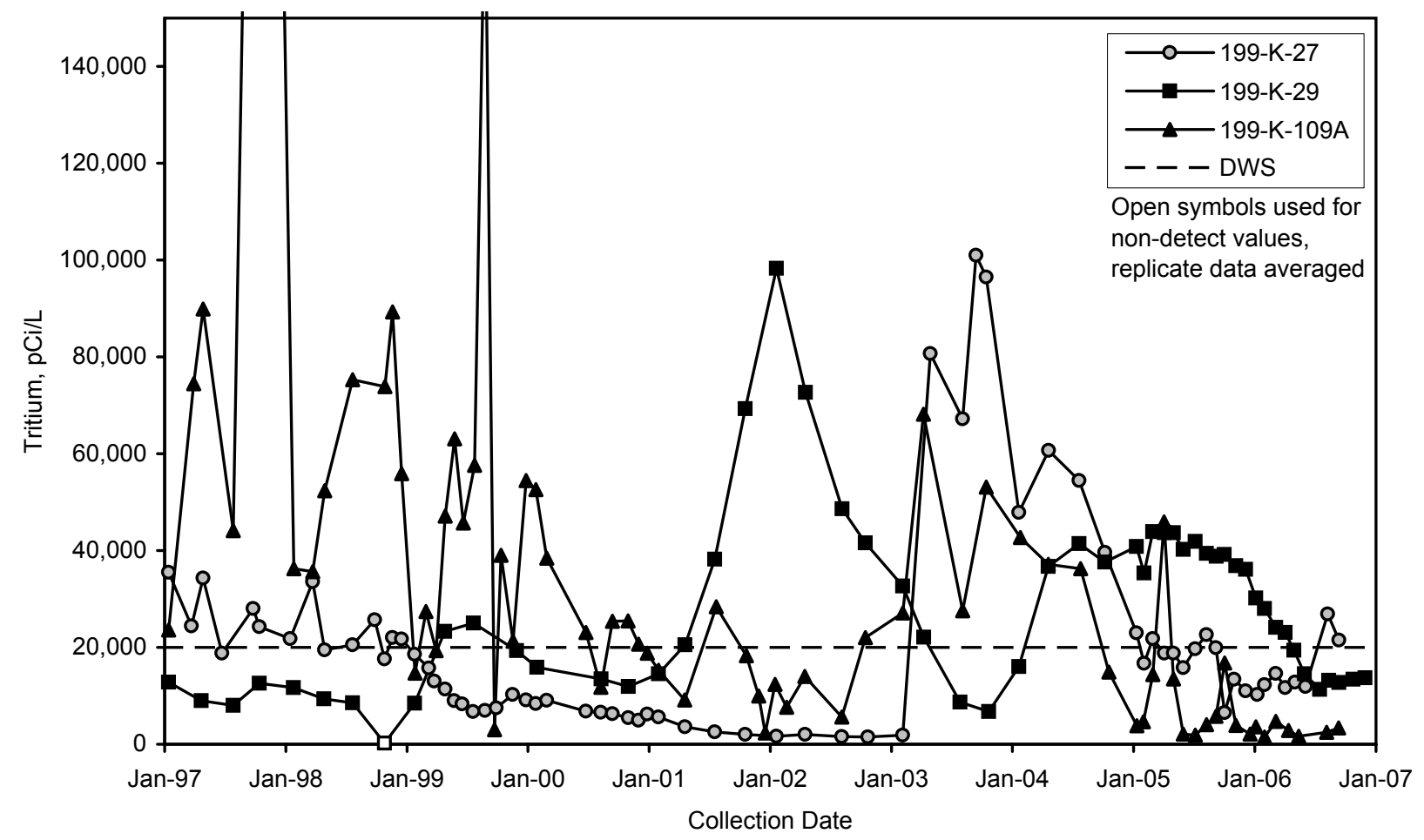

gwf06131

Figure 2.3-13. Tritium Concentrations in Groundwater Near KE Basin 


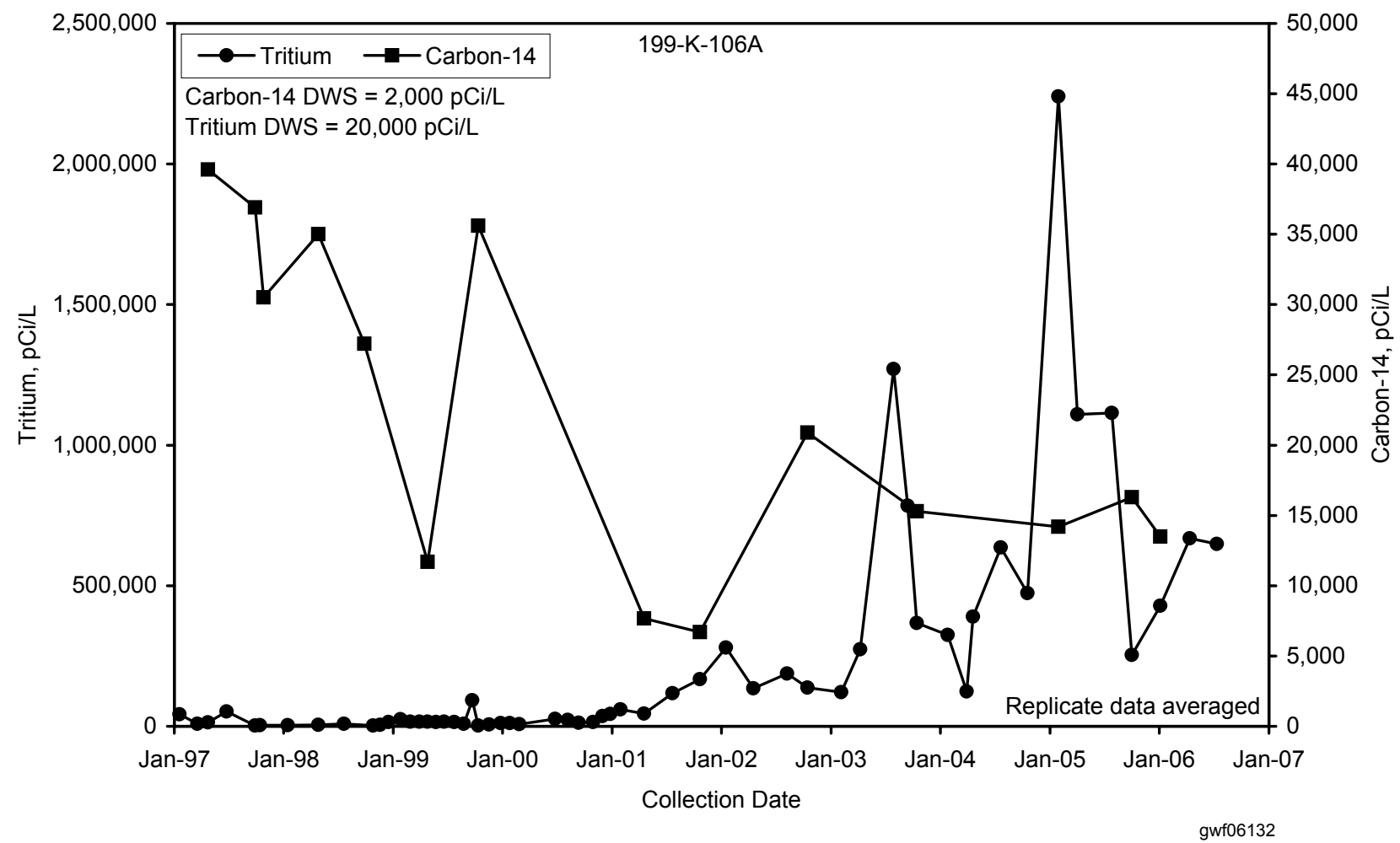

Figure 2.3-14. Tritium and Carbon-14 Concentrations in Groundwater Near Former KW Condensate Crib

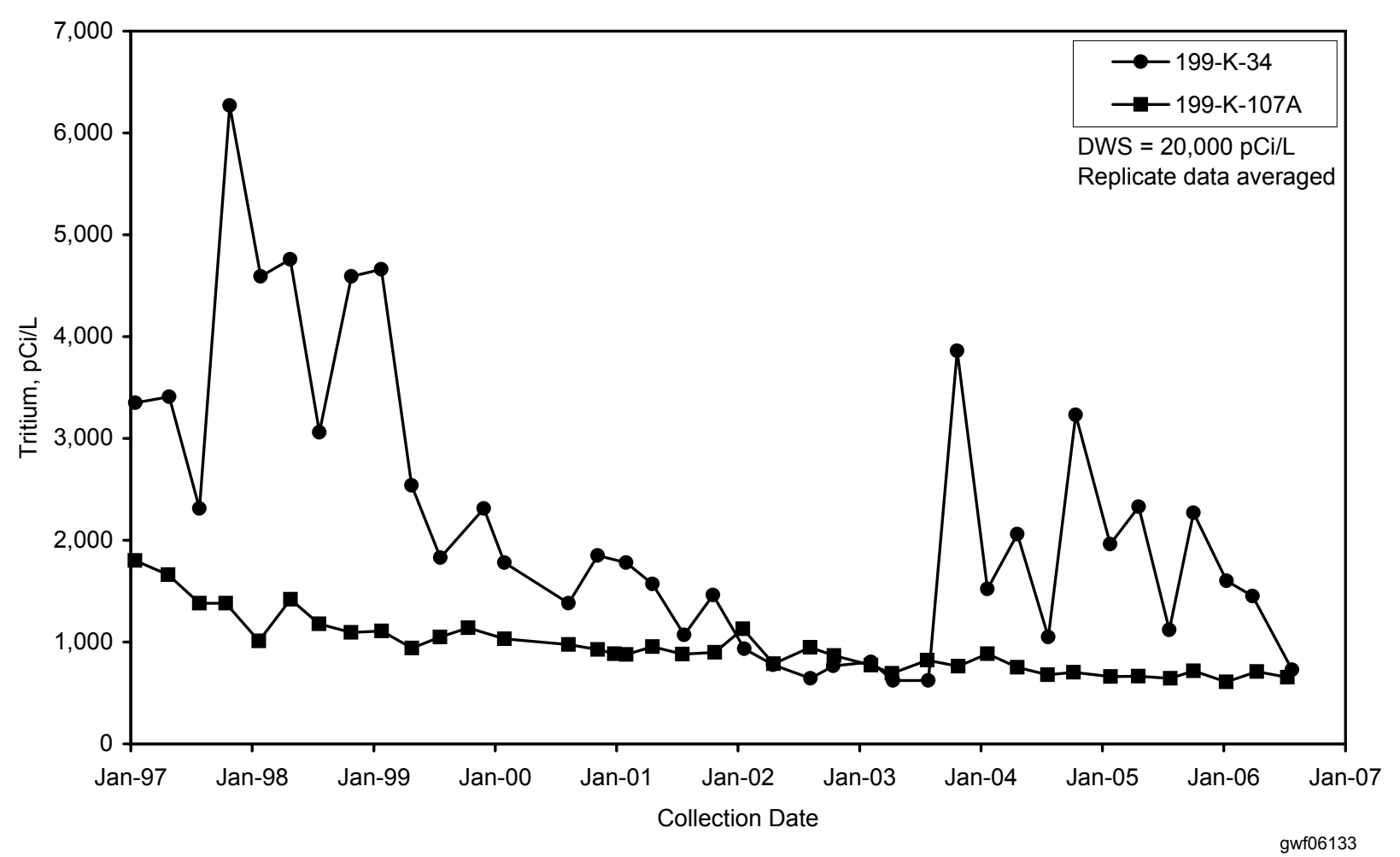

Figure 2.3-15. Tritium Concentrations in Groundwater Near KW Basin 


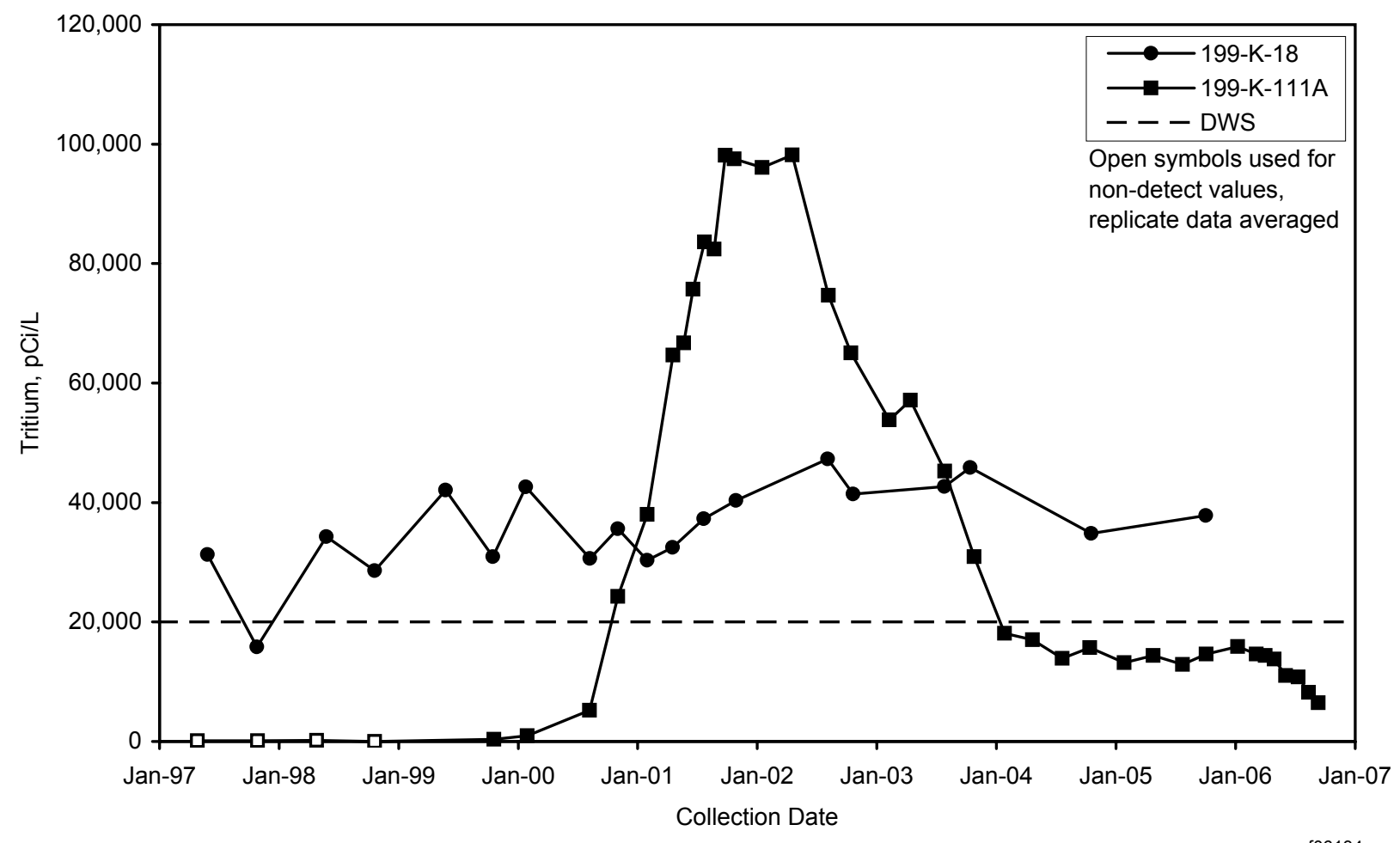

Figure 2.3-16. Tritium Concentrations in Groundwater Near 100-K Burial Ground

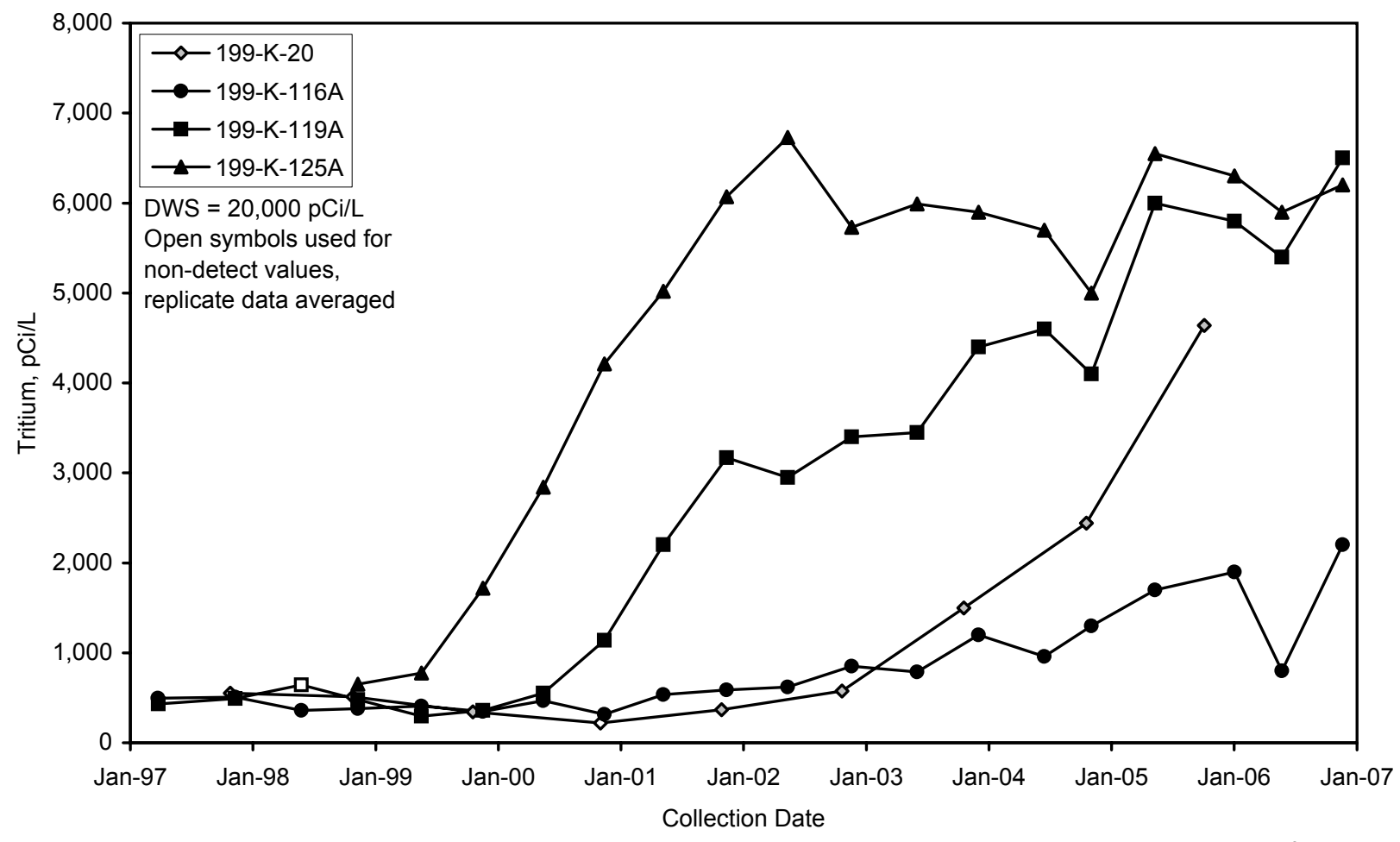

Figure 2.3-17. Tritium Concentrations at Wells Downgradient of the Injection Site for Treated Effluent from 100-K Trench Pump-and-Treat System 


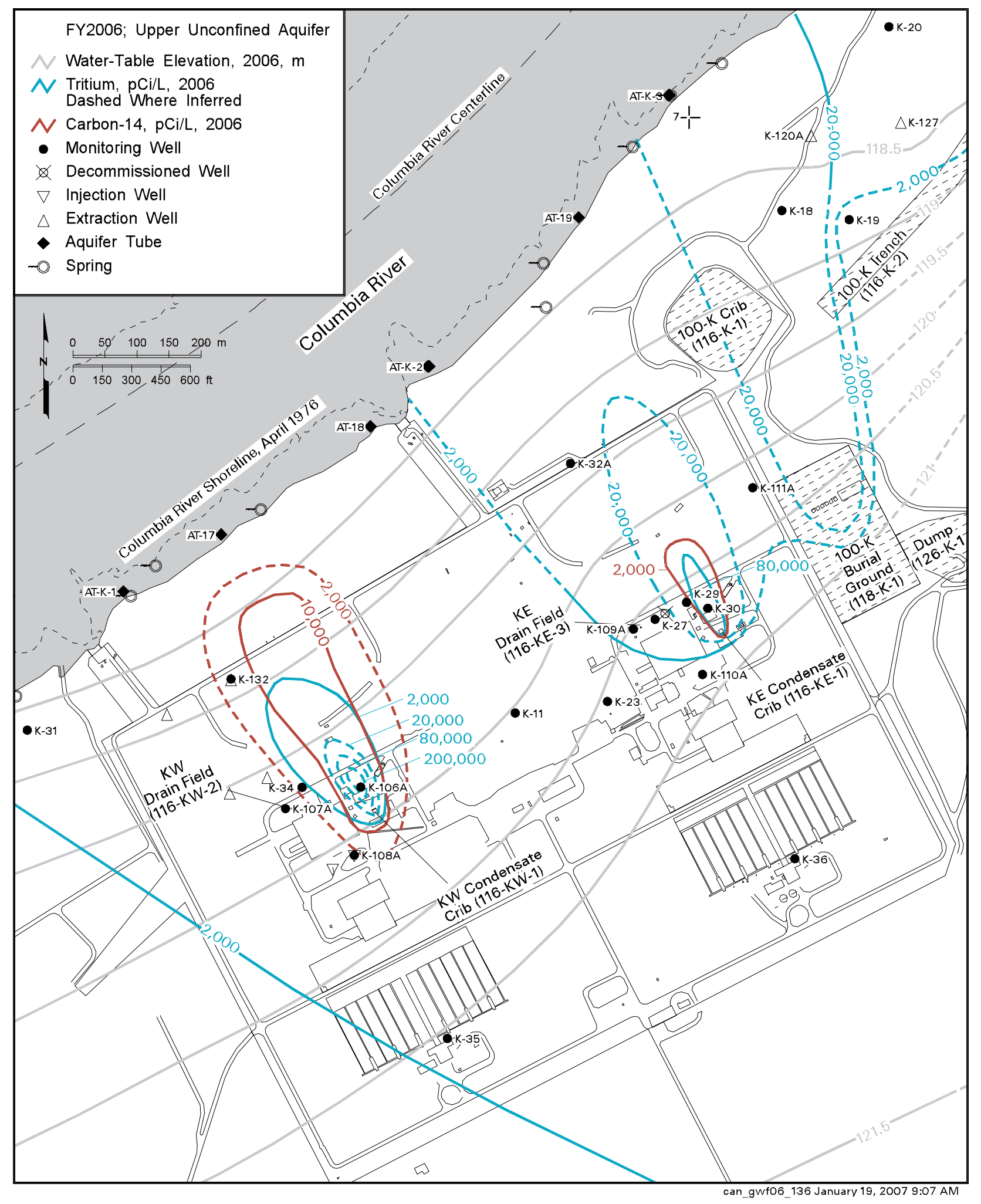

Figure 2.3-18. Carbon-14 and Tritium Plumes Between Former KW and KE Condensate Cribs and the Columbia River 


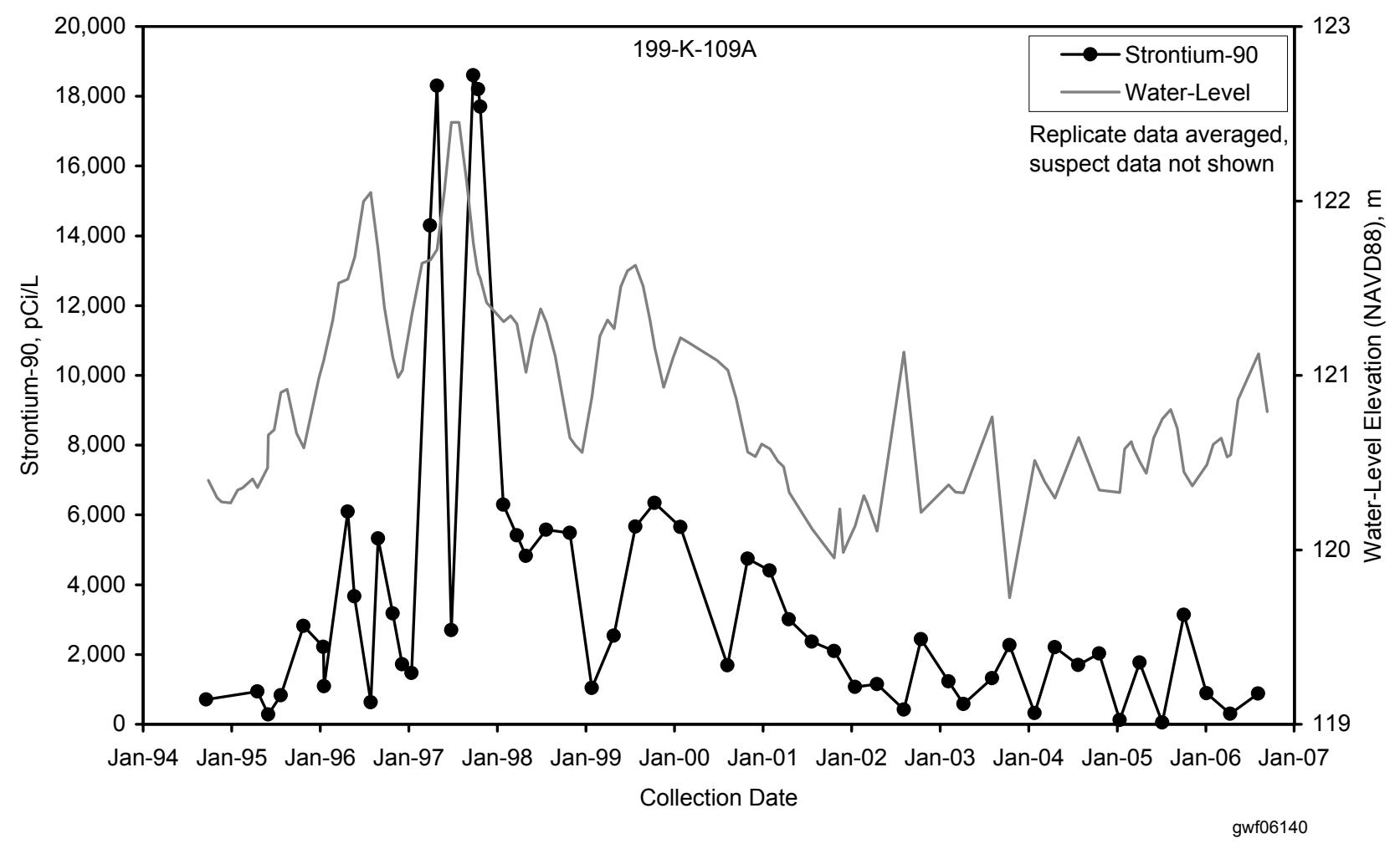

Figure 2.3-19. Strontium-90 Concentrations and Water-Table Elevation Near KE Basin

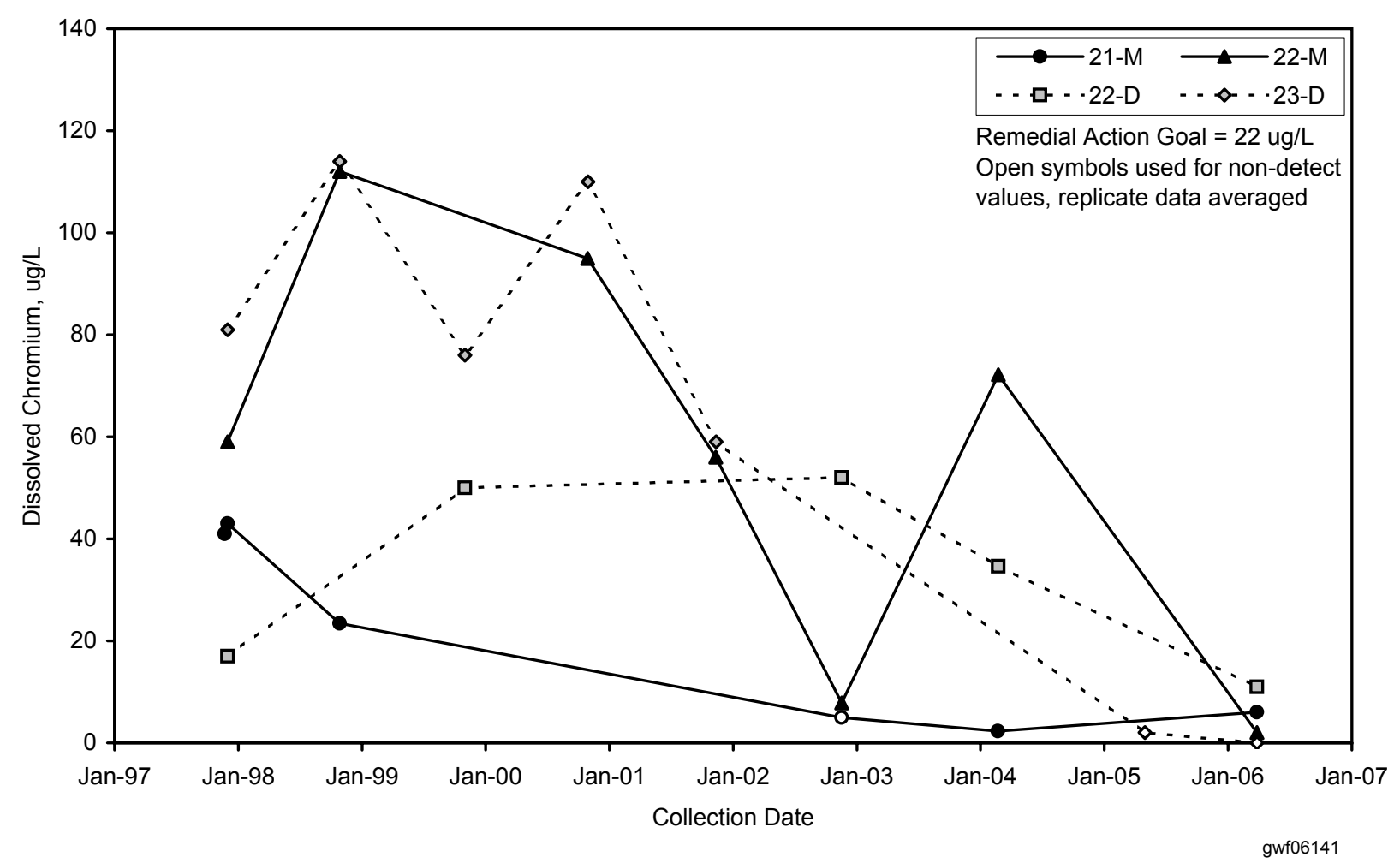

Figure 2.3-20. Chromium Concentration Trends at Aquifer Tube Sites Along Central Portion of $100-\mathrm{K}$ Trench Plume 


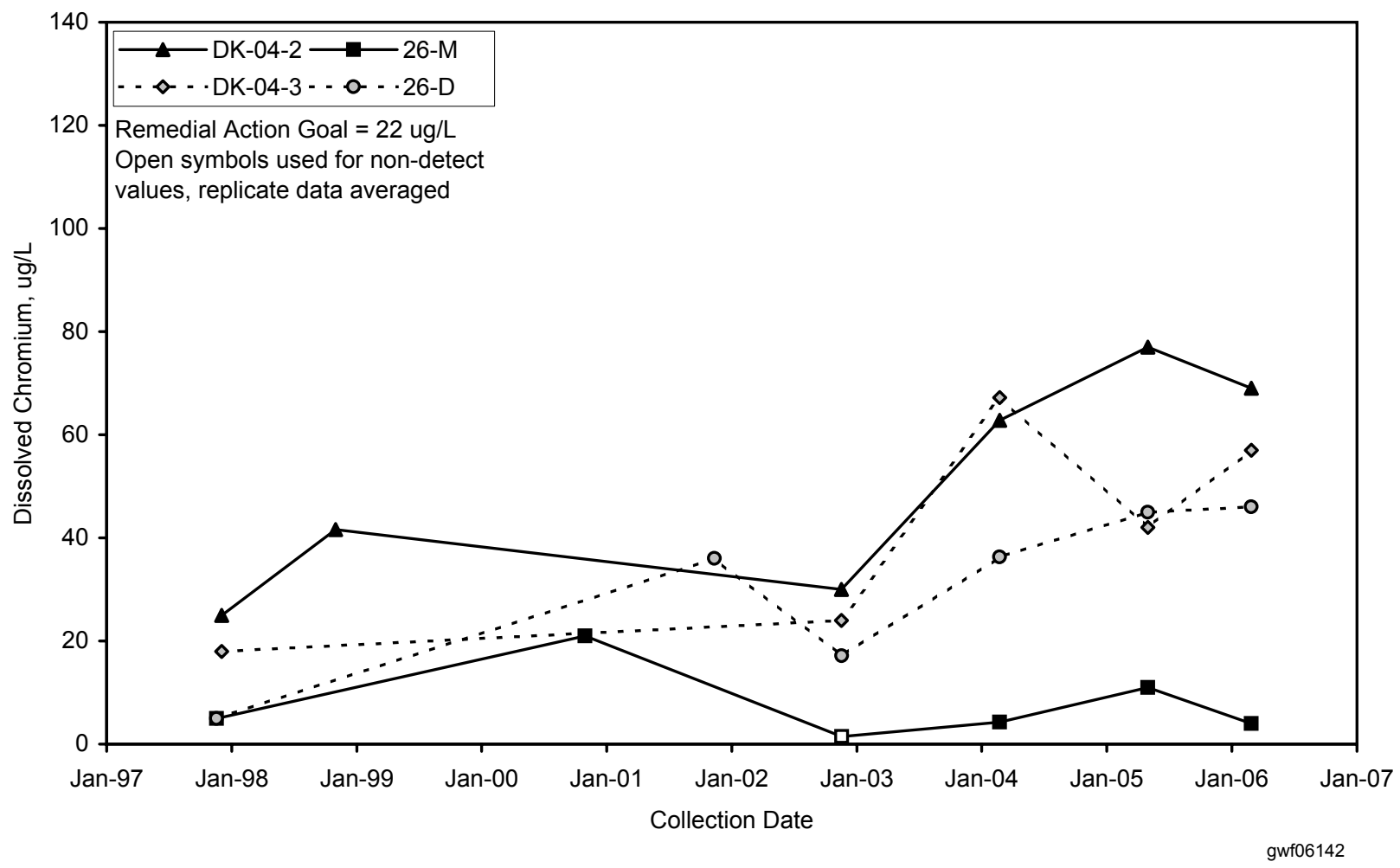

Figure 2.3-21. Chromium Concentration Trends at Aquifer Tube Sites Along North Portion of $100-\mathrm{K}$ Trench Plume 


\subsection{0-NR-2 Operable Unit}

\section{J. Hartman, R. J. Fabre, and R. F. Raidl}

The scope of this section is the 100-NR-2 groundwater interest area, which includes the 100-NR-2 Operable Unit (see Figure 1.0-1 in Section 1.0). The "groundwater interest areas" are informally defined to facilitate scheduling, data review, and interpretation. Figure 2.4-1 shows facilities and wells in this region and Figure 2.4-2 shows shoreline monitoring sites and wells in an area of particular interest for monitoring. Strontium-90 is the contaminant of greatest significance in groundwater at this operable unit. Groundwater is monitored to assess the performance of a Comprehensive Environmental Response, Compensation, and Liability Act (CERCLA) interim action pump-and-treat system for strontium-90, to monitor three Resource Conservation and Recovery Act (RCRA) sites, and to track other contaminant plumes for the Atomic Energy Act (AEA).

The 116-N-1 liquid waste disposal facility (116-N-1 facility) was excavated to remove contaminated sediment to a depth of 4.6 meters between September 2002 and October 2005, and was backfilled in fiscal year (FY) 2006. The 116-N-3 liquid waste disposal facility (116-N-3 facility) was excavated to a depth of $~ 4.6$ meters between June 2000 and August 2003, backfilled with clean soil in FY 2004 and 2005, and planted with native vegetation in December 2005. While excavations were underway, clean water was occasionally sprayed on the sites to control dust that could be an inhalation hazard for workers. The volume of dust-control water was minimized to reduce the likelihood that increased recharge would move contaminants from the vadose zone to groundwater.

Groundwater flows primarily to the north and northwest, toward the Columbia River (Figure 2.4-3). The water table is influenced by river stage, and until March 9, 2006, was influenced by groundwater extraction near the $116-\mathrm{N}-1$ facility and injection near the 116-N-3 facility. After the cessation of pumping on March 9, 2006, the water level in well 199-N-2, located near extraction well 199-N-103A, stayed level while the river stage declined, indicating a minor rebound effect (Figure 2.4-4). The water-level in well 199-N-2
Strontium-90 is the most significant groundwater contaminant beneath the 100-NR-2 Operable Unit. The general shape of the plume has not changed in many years.

Groundwater monitoring in the 100-NR-2 groundwater interest area includes the following monitoring activities:

\section{CERCLA and AEA Monitoring}

- Wells are sampled semiannually to annually for strontium-90 and co-contaminants. Sampling of three wells were delayed until FY 2007 (see Appendix A).

- Selected wells, aquifer tubes, and seep wells are sampled monthly to annually under a rebound/ shoreline groundwater monitoring plan.

Facility Monitoring

- Wells are sampled semiannually for the 116-N-1 liquid waste disposal facility for requirements of RCRA and AEA.

- Wells are sampled semiannually for the 120-N-1 percolation pond and 120-N-2 surface impoundment for requirements of RCRA and AEA.

- Wells were sampled semiannually for the 116-N-3 liquid waste disposal facility for requirements of RCRA.

- In FY 2006, sampling of three RCRA wells was delayed until FY 2007 because of scheduling constraints, and one well was sampled only once because of low water levels (see text and Appendix B).

- Monitoring is coordinated with other programs to avoid duplication. 


\section{Data from aquifer tubes along the shoreline helped define details of the strontium-90 \\ plume.}

began to rise in April, after river stage rose, and reached a peak in June, shortly after the river stage peaked. Thus, it is apparent that groundwater extraction had less impact on the water table than did river stage.

Well 199-N-34 is located near a former injection well. After injection ceased in March 2006, water levels in well 199-N-34 dropped (Figure 2.4-4).

During the period of high river stage in April through June 2006, there was a reversed gradient between the river and the aquifer, allowing river to flow inland. Water levels in well 199-N-146 are virtually the same as river stage, and were higher than in inland well 199-N-2 (Figure 2.4-4). Water levels declined during summer and early fall.

The remainder of this section describes contaminant plumes and concentration trends for the contaminants of concern under AEA, CERCLA, or RCRA monitoring.

\subsubsection{Groundwater Contaminants}

This section describes distributions and trends for the contaminants of concern for the 100-NR-2 Operable Unit (ROD 1999b). In addition to the strontium-90 plume, contaminants of concern include tritium, nitrate, sulfate, petroleum hydrocarbons, manganese, and chromium.

\subsubsection{Strontium-90}

The size and shape of the strontium-90 plume change very little from year to year, extending from beneath the 116-N-1 and 116-N-3 facilities to the Columbia River at levels above the drinking water standard (8 pCi/L) (Figure 2.4-5).

Aquifer tubes on the 100-N Area shoreline, installed in the past two years, have allowed a detailed depiction of the strontium-90 plume in the area of greatest interest. The aquifer tube network includes a horizontal array of tubes that monitor the aquifer at an elevation of 116.0 meters, where the highest gross beta concentrations were observed in previously installed tubes. Figure 2.4-6 shows strontium-90 concentrations in this portion of the 100-N Area in September 2006. Maximum concentrations (>1,000 pCi/L) consistently are detected in a few tubes at the previously identified center of the plume. The upstream extent of the plume at the $8-\mathrm{pCi} / \mathrm{L}$ drinking water standard is near aquifer tube Array-1A and well 199-N-96A.

Water samples collected from all the tubes in the horizontal array except Array-8A had strontium-90 concentrations above the drinking water standard. This was observed at various river stages (Figure 2.4-7). The tube with the maximum concentration (NVP2-116.0) showed lower concentrations during high river stage, perhaps because of changing groundwater flow directions. Samples did not appear to be diluted with river water, because the specific conductance of the samples varied very little. Other tubes did not show consistent relationships between strontium-90 concentration and river stage.

The northern part of the horizontal array (Array-8A through -14A) shows strontium-90 concentrations in the tens to hundreds of $\mathrm{pCi} / \mathrm{L}$ (Figure 2.4-5). The strontium-90 plume inland from the northern part of the array was affected by the pump-and-treat system, which drew down the water table into a less-contaminated portion of the aquifer. Rebound effects were not evident in these tubes in the six months following pump-and-treat shutdown (March to September 2006).

A series of vertical profile aquifer tubes and several multi-depth well clusters show that strontium-90 concentrations are highest near the top of the unconfined aquifer. Figure 2.4-8 is a geologic cross-section showing vertical strontium-90 distribution within the center of the plume. Concentrations $>100 \mathrm{pCi} / \mathrm{L}$ in groundwater are limited to the upper 3 meters of the aquifer, at an elevation between 115 and 118 meters in Ringold Formation unit E. The maximum concentrations are at $\sim 115.5$ to 116.0 meters. Strontium-90 concentrations remained above the 8 -pCi/L drinking 
water standard in the deepest tubes (elevation $\sim 115.1$ meters), so the bottom of the plume was not defined. Data from a pair of monitoring wells (199-N-67 and -69) adjacent to the 116-N-1 facility show that strontium 90 is undetected at an elevation of 113 meters.

Figure 2.4-9 shows the vertical distribution of strontium-90 at the $100-\mathrm{N}$ Area shoreline in the vertical profile aquifer tubes and monitoring wells 199-N-132 and -133 in June 2006. The maximum concentrations were measured at an elevation of 115.7 meters, in the Ringold Formation. Concentrations are much lower in the Hanford formation (i.e., well 199-N-133 and top two tubes in NVP1).

Strontium-90 trends show no obvious, long-term decline in concentrations, but significant variability related to water levels (Figure 2.4-10). When the water table rises beneath the former waste facilities, strontium-90 from the vadose zone is mobilized and concentrations in groundwater increase. Water levels and strontium-90 concentrations in wells near the 116-N-1 facility were high in the late 1980s, when liquid effluent was being discharged elsewhere in the 100-N Area, and declined after effluent discharges ceased. Concentrations rose again in the mid 1990s, which correlated with several years of relatively high river stage.

The water table in spring 2006 was the highest in ten years, and strontium-90 concentrations spiked sharply in three wells in June (Figure 2.4-10). The maximum concentration was $16,300 \mathrm{pCi} / \mathrm{L}$ in well 199-N-67. Levels in these wells declined in September 2006, but levels remained the highest since 2002.

Strontium-90 concentrations may be rebounding following cessation of groundwater extraction in the former extraction wells (Figure 2.4-11). As discussed in the previous paragraph, concentrations spiked in well 199-N-103A in June. Levels rose sharply in September in wells 199-N-75 and 199-N-105A. Continued monitoring is needed to determine if these changes were caused by rebound or simply reflect the high water table in spring 2006.

The 100-N Area aquifer tubes showed no clear relationship between strontium-90 concentrations and river stage. Based on observations in aquifer tubes elsewhere on the Hanford Site, it was anticipated that samples from the 100-N Area aquifer tubes would show signs of dilution during times of high river stage, with corresponding decreases in strontium-90 and specific conductance. This was not the case. As seen in Figure 2.4-12, some of the highest concentrations of gross beta were observed during periods of high river stage (e.g., tubes NVP2-115.7 and NVP2-115.4). Conversely, tube NVP2-116.0 did show a decline in gross beta as river stage increased in spring 2006 and a subsequent increase in beta as river stage declined. Specific conductance did not show a similar trend, so sample dilution with river water does not appear to be significant in the 100-N Area aquifer tubes.

\subsubsection{Tritium}

The tritium plume has diminished in the years since effluent discharge to the 116-N-1 and 116-N-3 facilities ceased in 1991. The remaining plume extends from the south part of the 116-N-3 facility to the river to the northwest at levels above the drinking water standard $(20,000 \mathrm{pCi} / \mathrm{L})$. Eleven wells had concentrations near the standard (17,000 to $26,000 \mathrm{pCi} / \mathrm{L})$ in FY 2006. Concentrations declined in the late 1980s and 1990s, but have stabilized since about 2000 (Figure 2.4-13).

Unlike strontium-90, tritium is present through the entire thickness of the unconfined aquifer. Concentrations have been near the drinking water standards in recent years in wells 199-N-69 and 199-N-70, completed at the base of the unconfined aquifer. Tritium declined below the drinking water standard in FY 2006 in well 199-N-80, which monitors a confined aquifer found in the Ringold Formation $(17,800 \mathrm{pCi} / \mathrm{L})$.

The shoreline aquifer tubes had very low or undetectable concentrations of tritium.

\section{Increases in}

strontium-90

concentration

in summer 2006

appear to be related

to high water

levels. Rebound

following cessation

of groundwater

extraction may

have affected

concentrations to a

lesser extent. 


\section{Nitrate concentrations continued to exceed the drinking water standard in FY 2006.}

\section{Petroleum hydrocarbons continued to be detected in 100-N Area groundwater, but concentrations declined.}

\subsubsection{Nitrate}

Nitrate concentrations exceed the drinking water standard $(45 \mathrm{mg} / \mathrm{L})$ beneath a portion of the 100-N Area (Figure 2.4-14). The highest nitrate concentrations in FY 2006 were again in well 199-N-67 near the 116-N-1 facility, with a maximum concentration of $410 \mathrm{mg} / \mathrm{L}$. Concentrations in other wells within the plume were much lower $(<80 \mathrm{mg} / \mathrm{L})$.

Figure 2.4-15 shows nitrate trend plots for two wells near the 116-N-1 facility for their entire period of record. The 116-N-1 facility was in use through 1985 . Figure 2.4-16 shows the nitrate trend in a well near the 116-N-3 facility, which was in use from 1983 to 1991. At both sites, nitrate concentrations were high in the mid-1980s and declined sharply by 1990. Recent concentrations are higher than levels observed in the mid-1980s. The reason for the variability is not known.

Near the $120-\mathrm{N}-1$ percolation pond in south $100-\mathrm{N}$ Area, nitrate concentrations also increased in the 1990s (Figure 2.4-17). During the pond's period of use (1977 to 1990), only low levels of nitrate $(\sim 1 \mathrm{mg} / \mathrm{L})$ were detected in effluent to the facility (see Appendix B of DOE/RL-96-39). Monitoring began in 1987 and nitrate concentrations in groundwater were also low (1 to $4 \mathrm{mg} / \mathrm{L}$ ). Nitrate levels exceeded the drinking water standard in well 199-N-59 from 1998 to 2006. Nearby well 199-N-72 showed a sharp increase in nitrate since FY 2004.

Anomalously low nitrate concentrations continued to be observed in well 199-N-18 (undetected). The low concentrations are believed to be caused by chemical reduction of the nitrate caused by biodegradation of hydrocarbons (Section 2.4.1.5). Other chemical constituents and parameters also support the interpretation of chemical reduction around well 199-N-18: low dissolved oxygen, low $\mathrm{pH}$, detectable nitrite, and high concentrations of metals (especially iron and manganese). Nitrate concentrations also were relatively low in well 199-N-16 (6.6 mg/L), which has shown contamination with petroleum hydrocarbons in the past.

\subsubsection{Sulfate}

The former $120-\mathrm{N}-1$ percolation pond introduced sulfate and sodium to $100-\mathrm{N}$ Area groundwater. Sulfate concentrations remain elevated in groundwater north and northwest of the $120-\mathrm{N}-1$ site. The plume did not change significantly in the past year (see Figure 2.4-13 in PNNL-15670 for a FY 2005 plume map). A second area of elevated sulfate concentrations underlies the $116-\mathrm{N}-3$ trench. This contamination is residual from previous flow conditions that carried sulfate from the $120-\mathrm{N}-1$ percolation pond inland and then toward the north.

The highest sulfate concentration in FY 2006 was 293 mg/L in well 199-N-59, adjacent to the $120-\mathrm{N}-1$ site. This was the only concentration that exceeded the secondary drinking water standard for sulfate $(250 \mathrm{mg} / \mathrm{L})$.

\subsubsection{Petroleum Hydrocarbons}

Petroleum hydrocarbons from a 1960s diesel fuel leak (DOE/RL-95-111) continued to be detected in 100-N Area groundwater. Of the affected wells, 199-N-18 is closest to the former leak site and had the highest levels of groundwater contamination. The maximum FY 2006 result for total petroleum hydrocarbons in the diesel range was $23 \mathrm{mg} / \mathrm{L}$, the lowest value since 2000 .

Evidence of low levels of hydrocarbon contamination have been observed in wells 199-N-3, 199-N-19, and 199-N-96A in the past (PNNL-14187, Section 2.4). These wells are located near well $199-\mathrm{N}-18$ and may be influenced by contamination from the same source. In FY 2006, total petroleum hydrocarbons were undetected.

Total organic carbons concentrations were slightly elevated in well 199-N-96A and in two nearby aquifer tubes (N116mArray-1A and -2A). Concentrations ranged from 1,300 to $2,600 \mu \mathrm{g} / \mathrm{L}$ in FY 2006. Total petroleum hydrocarbons were undetected. 
Near the N Reactor building, well 199-N-16 also has evidence of petroleum contamination, believed to be from a separate past source. Total petroleum hydrocarbons (diesel) were measured at up to $9.2 \mathrm{mg} / \mathrm{L}$ in FY 2006, about the same as the previous year.

\subsubsection{Manganese and Iron}

Manganese continued to exceed its secondary drinking water standard $(50 \mu \mathrm{g} / \mathrm{L})$ in two wells affected by petroleum contamination: 199-N-16 (809 $\mu \mathrm{g} / \mathrm{L})$ and 199-N-18 $(3,420 \mu \mathrm{g} / \mathrm{L})$. Iron also exceeded its secondary drinking water standard $(300 \mu \mathrm{g} / \mathrm{L})$ in well $199-\mathrm{N}-18(17,600 \mu \mathrm{g} / \mathrm{L})$. Biodegradation of the hydrocarbons creates reducing conditions, which increases the solubility of metals such as manganese and iron from the well casing or aquifer sediment.

\subsubsection{Chromium}

Only one well in the 100-N Area has chromium concentrations above the drinking water standard $(100 \mu \mathrm{g} / \mathrm{L})$. Well 199-N-80, which is completed in a thin, confined aquifer found in the Ringold Formation, had a maximum chromium concentration in FY 2006 of $\sim 163 \mu \mathrm{g} / \mathrm{L}$ in a field-filtered sample, a decline from previous years. The source for chromium in this deep horizon is unknown.

The highest dissolved chromium concentration in the unconfined aquifer in FY 2006 was $64 \mu \mathrm{g} / \mathrm{L}$ in well 199-N-64, in central 100-N Area. The well is not located near any of the three major liquid waste sites. Chromium concentrations were even higher in this well in the 1990s, exceeding the drinking water standard once (Figure 2.4-18). A downhole video survey of this well in September 2000 showed screen corrosion, which is the probable cause of the elevated chromium.

\subsubsection{Interim Groundwater Remediation for Strontium-90}

A pump-and-treat system began operating in the 100-N Area in 1995 as part of a CERCLA interim action for the 100-NR-2 Operable Unit (ROD 1999b). Because the pump-and-treat system did not meet the remedial action objectives, the Washington State Department of Ecology (Ecology), U.S. Environmental Protection Agency (EPA), and U.S. Department of Energy (DOE) approved a Tri-Party Agreement change control form ${ }^{(a)}$ in 2006 requiring the pump-and-treat system be put on cold standby and a permeable reactive barrier be constructed. The interim action ROD allowed the pump-and-treat system to be shut down with Ecology approval; therefore no explanation of significant difference to the $1999 \mathrm{ROD}$ was needed to shut down the system. The water was drained from the system, the treatment medium was removed, and the unit was placed in cold standby in early March 2006.

The second CERCLA five-year review was published in November 2006 (DOE/RL2006-20). The review identified two issues pertaining to the 100-N Area and two follow-up actions. The due date of both actions is September 2008:

- Issue 6: The pump-and-treat system is ineffective and inefficient in reducing the flux of strontium-90 to the Columbia River. The degree of protection provided by hydraulic control is unproven.

- Action 6-1. Implement the treatability test plan for permeable reactive barrier using apatite sequestration (DOE/RL-2005-96).

(a) Federal Facility Agreement and Consent Order Change Control Form M-16-06-01, "Establish Interim Milestone M-016-14, Complete Construction of a Permeable Reactive Barrier at 100-N." February 15, 2006. 
- Issue 7: Additional ecological data are needed to assess the interim actions and to develop a final cleanup standard. The shoreline impacts related to the diesel spill are not well known.

- Action 7-1: Perform additional data collection to support risk assessment, provide previously collected data, and collect additional pore water data from new and existing aquifer tubes.

The monitoring requirements for the 100-NR-2 interim action are specified by Tri-Party Agreement Change Control Form M-15-96-08 as modified by Fluor Hanford, Inc. ${ }^{\text {(b) }}$ Wells, constituents, and sampling frequencies for interim action monitoring are shown in Appendix A. During FY 2006, sampling was delayed in three wells.

DOE performed supplemental monitoring of the shoreline area affected by the pump-andtreat system from 2004 through the first half of FY 2006 to establish a baseline of monthly sampling results prior to initiating a treatability test of a permeable reactive barrier. The supplemental monitoring program, which is not described in a formal monitoring plan, is summarized in Appendix A. The monitoring program was revised after groundwater extraction ceased in March 2006 (PNNL-15798).

Additional groundwater monitoring is conducted in conjunction with field tests of apatite injection (see Section 2.4.2.2).

\subsubsection{Pump-and-Treat System}

Between October 2005 and March 2006, the 100-N pump-and-treat system extracted $\sim 49$ million liters of contaminated water and removed $\sim 0.1$ curie of strontium- 90 . The total amount removed since the system began operating in 1994 is $\sim 1.8$ curies.

The pump-and-treat system did not affect the distribution or concentration of strontium-90 in the aquifer to any observable extent. The extraction wells created a hydraulic sink between the 116-N-1 facility and the Columbia River and, thus, reduced or reversed the hydraulic gradient in the groundwater toward the Columbia River. The reduction or reversal of the hydraulic gradient resulted in less groundwater and strontium-90 discharging

The remedial action objectives in the 100-NR-2 Operable Unit (ROD 1999b) are:

- Protect the Columbia River from the adverse impact of groundwater contamination by limiting exposure pathways, reducing or removing sources, controlling groundwater movement, or reducing the concentration of contaminants.

- Protect the unconfined aquifer by implementing remedial actions that reduce the concentration of contaminants.

- Obtain information to evaluate technologies to remove strontium-90 and evaluate the impact to ecological receptors.

- Prevent destruction of sensitive wildlife habitat and minimize the disruption of cultural resources.

In 2006, Ecology added a requirement for the pump-and-treat system to be put on standby, and an alternative, in situ treatment technology to be tested. to the Columbia River through the N Springs area. However, the pump-and-treat system was not capable of completely controlling the water discharged because of the cyclical river stage and bank storage effects of the Columbia River.

The extraction wells have created an area of lower strontium-90 concentrations between the 116-N-1 trench and the Columbia River (Figure 2.4-5). However, this area does not represent significant cleanup of the aquifer. The low concentrations are believed to be caused by (a) draw down of the water table (strontium-90 concentrations are highest at the top of the aquifer and in the vadose zone); and (b) dilution with river water drawn in by pumping. Strontium-90 concentrations vary in response to a fluctuating water table and other changes in groundwater flow, but there are no clear upward or downward trends overall (Figure 2.4-11).

(b) Letter FH-0502977 from RG Gallagher (Fluor Hanford, Inc.) to Dr. LK Peters (Pacific Northwest National Laboratory), Tables Specifying Fluor Hanford Performance Sampling Requirements for Fiscal Year 2006, dated October 12, 2005. 
Additional details on the pump-and-treat system and operational data for calendar year 2005 are available in DOE/RL-2006-08. An upcoming report will present results for calendar year 2006.

\subsubsection{Permeable Reactive Barrier}

DOE has agreed to construct and evaluate the effectiveness of a permeable reactive barrier, using apatite sequestration technology, as part of the CERCLA remedial investigation/ feasibility study process and consistent with the 1999 interim remedial action record of decision for the 100-NR-1 and 199-NR-2 Operable Units (ROD 1999b).

DOE released a treatability test plan (DOE/RL-2005-96) to install a 90-meter apatite $\left[\mathrm{Ca}_{6}\left(\mathrm{PO}_{4}\right)_{10}(\mathrm{OH})_{2}\right]$ permeable reactive barrier near the Columbia River shoreline in FYs 2006 and 2007. Strontium-90 sequestration by this technology occurs through the injection of a calcium citrate phosphate solution. In situ biodegradation of the citrate results in apatite precipitation, adsorption of strontium-90 to the apatite, then apatite recrystallization with strontium substituting for calcium. Strontium-90 is held in place in the apatite mineral crystal structure where it decays naturally. Because of the potential for some strontium-90 to leach from the soil matrix, a low concentration injection was proposed. After the soils have been seeded with apatite and crystallization occurs, a high strength solution would be injected to create the final barrier with an approximate longevity of 300 years.

The initial pilot injection began in June 2006 to determine the effectiveness of the solution chemistry and the injection procedures that were developed from laboratory studies. Researchers injected 367,000 liters of solution over a 35-hour period in well 199-N-138. Groundwater was monitored in 11 adjacent wells during and after the injection. Field conditions, including highly dynamic river stage observed during the test period and surprisingly rapid microbial metabolism of the citrate resulted in the temporary mobilization of strontium-90 in the saturated test area higher than predicted in the laboratory column tests. Immediately following treatment at the first pilot test, strontium-90 concentrations in the monitoring wells increased an average of 10.5 times. Analytical results over the subsequent months indicated that the levels of strontium-90 declined after the initial mobilization of the strontium-90.

After discussions between DOE and Ecology, a second injection test was designed using a modified chemical reagent solution and a maximized injection rate that would overcome the phosphate sorption kinetics. The reagent was modified to account for the calcium desorption from the soil, and nitrate was removed to slow the microbial degradation rate. The targeted treatment area was the top 3 meters of the Ringold Unit E and the lower portion of the Hanford formation. The primary goal was the decreased strontium-90 mobilization within the area of influence of the test. A 227,000-liter injection test was performed in late September 2006 in well 199-N-137. Immediately following the second test, strontium-90 concentrations in adjacent wells increased an average of 3.3 times, well within the expected limits. Groundwater samples collected after the September injection showed that the levels of strontium-90 are decreasing, and in several monitoring wells have decreased below their levels before injection. A detailed report will be prepared after the completion of the 90 -meter barrier.

\subsubsection{Phytoremediation}

Phytoremediation has been identified as a potential technology for the removal of strontium-90 from the soil as a filter for groundwater along the Columbia River at the 100-N Area. Phytoremediation is a managed remediation technology in which plants are used to extract or sequester contaminants. Recent greenhouse and growth chamber studies of Coyote Willow have demonstrated the viability of phytoremediation to remove strontium-90 from the 100-N Area's soil and water. Coyote Willow is a perennial native shrub that grows along the Columbia River throughout the Hanford Site. Its root system readily invades the saturated zone and tolerates prolonged flooding. The apatite injection treatability test plan
DOE will test

two potential

technologies for

strontium-90

remediation at

100-N Area: a

permeable reactive

barrier and

phytoremediation. 


\section{Strontium-90 and tritium concentrations exceed drinking water standards at the 116-N-1 liquid waste disposal facility.}

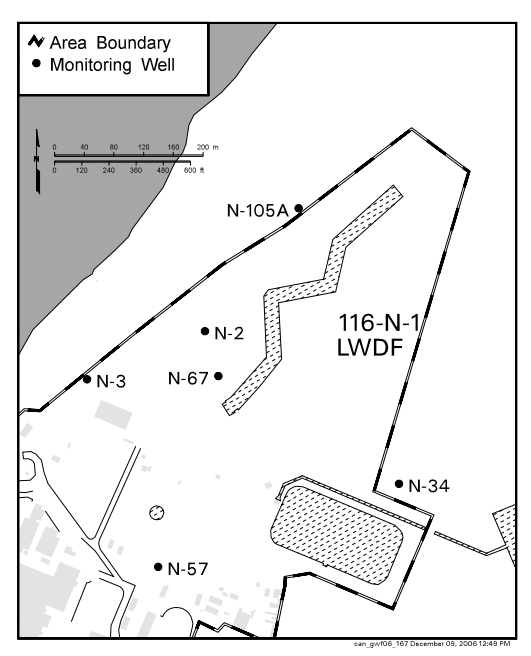

(DOE/RL-2005-96) describes phytoremediation as a technology to be evaluated during the March 2008 evaluation milestone as described in the Tri-Party Agreement change request (M-16-06-01 Change Control Form). If phytoremediation is favorably evaluated, it would be incorporated into the treatability test plan.

\subsubsection{Facility Monitoring}

This section describes results of monitoring individual facilities: the 116-N-1 and 116-N-3 facilities, 120-N-1 percolation pond, and 120-N-2 surface impoundment. Groundwater is monitored at these facilities to meet the requirements of RCRA for hazardous waste constituents and AEA for source, special nuclear, and by-product materials. Data from facility-specific monitoring are also integrated into the CERCLA groundwater investigations. Hazardous constituents and radionuclides are discussed jointly in this section to provide comprehensive interpretations for each facility. As discussed in Section 1.2, pursuant to RCRA units, DOE has sole and exclusive responsibility and authority to regulate source, special nuclear, and by-product materials. Groundwater data for these facilities are available in the Hanford Environmental Information System (HEIS 1994) and in the data files accompanying this report. Additional information including well and constituent lists, maps, flow rates, and statistical tables are included in Appendix B.

\subsubsection{116-N-1 (1301-N) Liquid Waste Disposal Facility}

This facility contaminated groundwater with radionuclides during its period of use in the 1960s through 1985. Strontium-90 and tritium concentrations in groundwater exceed drinking water standards. Results of monitoring were discussed in Section 2.4.1. The facility was excavated to remove shallow vadose zone sediment, where most of the radionuclide contamination resided, and was backfilled in FY 2006. Wells downgradient of the 116-N-1 facility are sampled quarterly to annually for strontium-90 and gamma activity. No gammaemitters were detected in FY 2006. Strontium-90 concentrations increased in several downgradient wells when the water table rose in June 2006 (see Section 2.4.1.1).

This facility is included in the Hanford Facility RCRA Permit (Ecology 1994a). The closure plan (see Appendix A of DOE/RL-96-39) states that RCRA monitoring during closure activities will follow the requirements of BHI-00725. That plan and a supplemental plan (PNNL-13914) are similar to an interim status indicator evaluation program (40 CFR 265.93(b), as referenced by WAC 173-303-400).

Groundwater flows to the northwest beneath the 116-N-1 facility, discharging to the Columbia River. The hydraulic gradient in March 2006 was 0.0019 , and flow rate was estimated to be between 0.04 to 0.69 meter/day (Appendix B).

Upgradient and downgradient wells are scheduled for sampling twice each year for contamination indicator parameters $(\mathrm{pH}$, specific conductance, total organic carbon, and total organic halides) and once for groundwater quality and site-specific parameters. The second sampling of two wells was delayed past the end of the fiscal year (see Section 1.2 and Appendix B). Other wells were sampled as scheduled.

Average specific conductance in downgradient well 199-N-3 dropped below the critical mean value in March 2006 but exceeded the value in October 2006 (delayed from September). This was a continuation of previous exceedances, and prior assessment results (WHC-SD-EN-EV-003) indicated the elevated specific conductance is related to constituents from the 120-N-1 percolation pond. Total organic carbon in well 199-N-3 exceeded the upgradient/downgradient comparison value in October 2006. The well is located near an area of contamination from an old diesel leak, and has had elevated total organic carbon in the past. Verification sampling was conducted in January 2007. Results were not available for inclusion in this report.

Upgradient/downgradient comparison values for indicator parameters have been revised based on recent data for use in FY 2007 comparisons (see Appendix B). 


\subsubsection{120-N-1 (1324-NA) Percolation Pond and 120-N-2 (1324-N) Surface Impoundment}

These facilities were used to treat and dispose of corrosive, non-radioactive waste from 1977 to 1990 . They have been remediated and backfilled.

These facilities are included in the Hanford Facility RCRA Permit (Ecology 1994a). The closure plan (see Appendix B of DOE/RL-96-39) states that RCRA monitoring during closure activities will follow the requirements of BHI-00725. That plan, and a supplemental plan (PNNL-13914), are similar to an interim status indicator evaluation program (40 CFR 265.93(b), as referenced by WAC 173-303-400).

Groundwater flows to the northwest beneath the $120-\mathrm{N}-1$ and $120-\mathrm{N}-2$ facilities, discharging to the Columbia River. The hydraulic gradient in March 2006 was 0.0032 , and flow rate was estimated to be between 0.07 to 1.2 meter/day (Appendix B).

During FY 2006, four of the five monitoring wells for this site were sampled twice for contamination indicator parameters and groundwater quality and site-specific parameters, as planned (see Appendix B). Downgradient well 199-N-59 contained too little water to sample in December 2005, but was successfully sampled in June 2006.

Average specific conductance values in wells downgradient of the facilities continued to exceed the critical mean values in FY 2006. A previous groundwater quality assessment indicated that the high specific conductance is caused by sulfate and

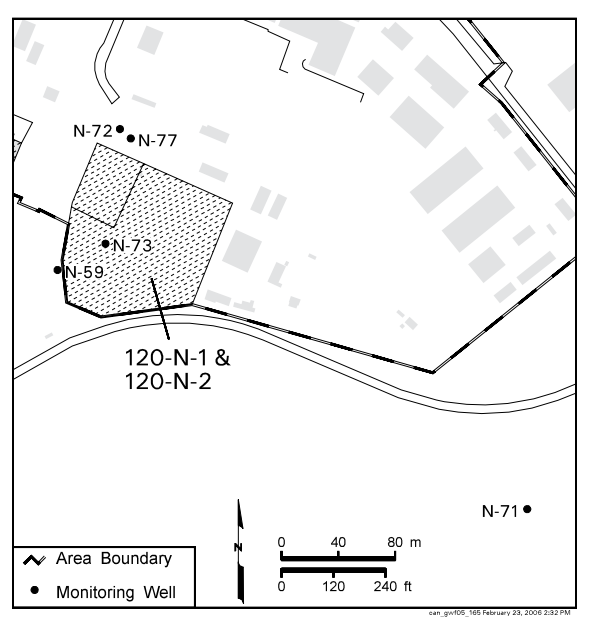
sodium (WHC-SD-EN-EV-003), which are not listed hazardous waste constituents. Because an assessment has already been completed and non-listed constituents caused the high conductance, detection monitoring has continued. Other indicators remained below critical mean values in FY 2006, and there are no plans to modify the network in FY 2007. Upgradient/downgradient comparison values for indicator parameters were revised based on recent data for use in FY 2007 comparisons (see Appendix B).

\subsubsection{116-N-3 (1325-N) Liquid Waste Disposal Facility}

This facility contaminated groundwater with radionuclides during its period of use from 1983 to 1991. Strontium-90 and tritium concentrations in groundwater downgradient of the facility exceed drinking water standards. Results of monitoring were discussed in Section 2.4.1. The facility was excavated to remove the shallow vadose zone material, which contains the highest concentrations of radionuclides. The site was backfilled with clean soil in FY 2005. Wells 199-N-27, 199-N-32, and 199-N-81 were monitored for strontium-90 and gamma emitters to look for potential impacts of source remediation and dust control on groundwater. Gamma emitters continued to be undetected in FY 2006, and strontium-90 concentrations continued in established ranges.

This facility is included in the Hanford Facility RCRA Permit (Ecology 1994a). The closure plan (Appendix A of DOE/RL-96-39) states that RCRA monitoring during closure activities will follow the requirements of BHI-00725. That plan, and a supplemental plan (PNNL-13914), are similar to an interim status indicator evaluation program (40 CFR 265.93(b), as referenced by WAC 173-303-400).

Groundwater flows to the north beneath the 116-N-3 facility, then turns to the northwest and discharges to the Columbia River. The hydraulic gradient in March 2006 was 0.0018 , and the groundwater flow rate was estimated to be between 0.02 to 0.45 meter/day (Appendix B).

All five wells were sampled twice for contamination indicator parameters $(\mathrm{pH}$, specific conductance, total organic carbon, and total organic halides) and once for groundwater quality and site-specific parameters, as planned. However, sampling of one well was delayed until November 2006 (see Section 1.2 and Appendix B).

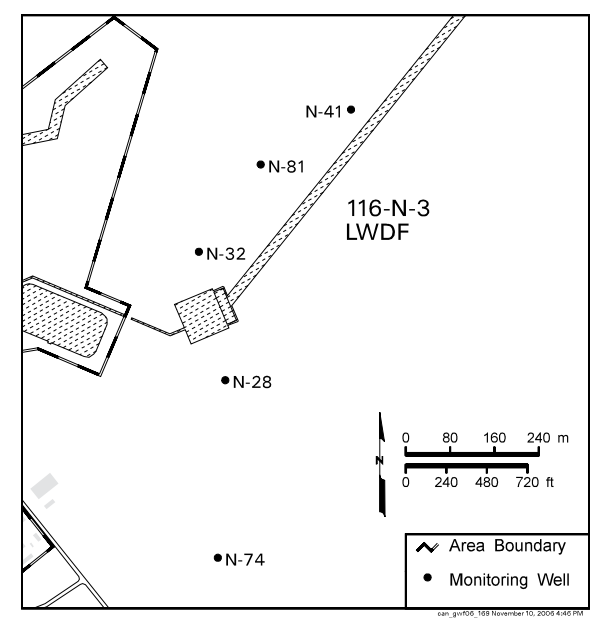


Average specific conductance values in downgradient wells 199-N-32 and 199-N-41 continued to exceed the critical mean value in FY 2006. This was a continuation of previous exceedances noted in 1999 through 2005. DOE notified Ecology of the original exceedance and submitted an assessment report that concluded the exceedance was caused by past discharges to the $120-\mathrm{N}-1$ percolation pond.

The $\mathrm{pH}$ of a sample from well 199-N-32 was below the lower limit of the critical range for that parameter in September 2006, and the $\mathrm{pH}$ of a sample from well 199-N-41 was above the upper limit in November 2006 (delayed from September). The low value in well $199-\mathrm{N}-32$ is consistent with the overall distribution of $\mathrm{pH}$ in $100-\mathrm{N}$ groundwater, and the exceedance may be an artifact of a narrow critical range. The high value in well 199-N-41 was anomalous. Verification sampling was conducted in both wells in January 2007, and all results were within the critical range.

Detection monitoring will continue in FY 2007. Upgradient/downgradient comparison values for indicator parameters were revised based on recent data for use in FY 2007 (see Appendix B).

\subsubsection{Geophysical Investigation}

DOE contracted the Confederated Tribes of the Umatilla Indian Reservation to conduct a geophysical investigation within the 100-NR-2 Operable Unit. The purpose of the investigation was to test the effectiveness of the Aquatrack ${ }^{\mathrm{TM}}$ method, a proprietary electromagnetic technology developed by Willowstick Technologies, LLC ${ }^{\mathrm{TM}}$ to identify subsurface saturation zones and preferential groundwater flow paths. The survey can detect the presence of electrically conductive groundwater flowing in preferential pathways from an induced current established through the zone of interest. Results of the investigation were published in FY 2006 (Repasky 2006).

The study focused on the area between the 116-N-1 facility and the Columbia River, and found that conductive highs and lows were readily visible from the collected data. The data were contoured and the magnetic contour lines were used to help visualize current flow through the subsurface. In the data collected, tight contours observed close to the 116-N-1 facility were attributed to a higher ion concentration in the groundwater. The study concludes that this discharged water mixes with the groundwater and flows in preferential flow paths, and that discharge of this water to the Columbia River appears to be concentrated in the southwest section of the survey. 


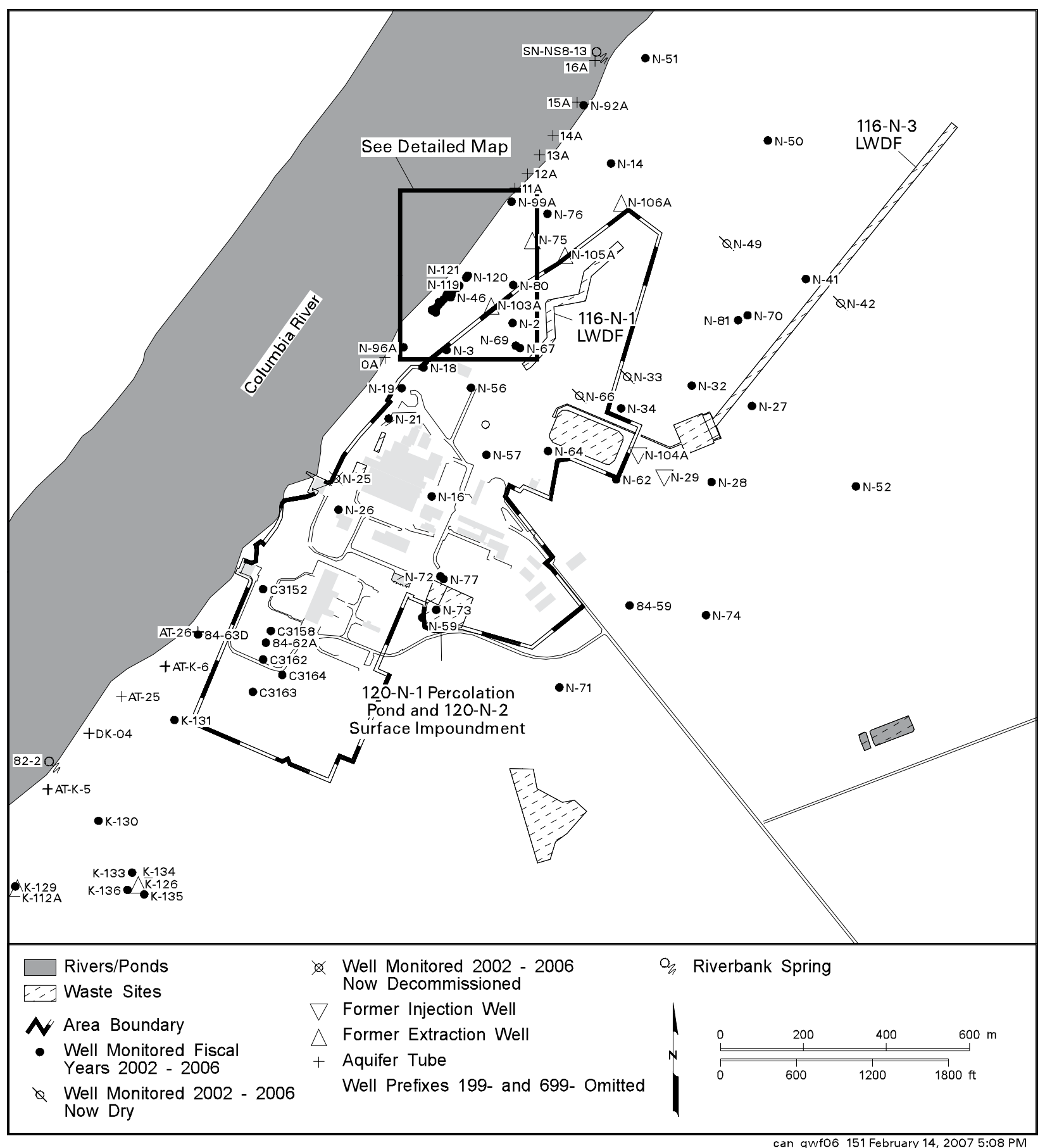

Figure 2.4-1. Groundwater Monitoring Wells in 100-N Area 


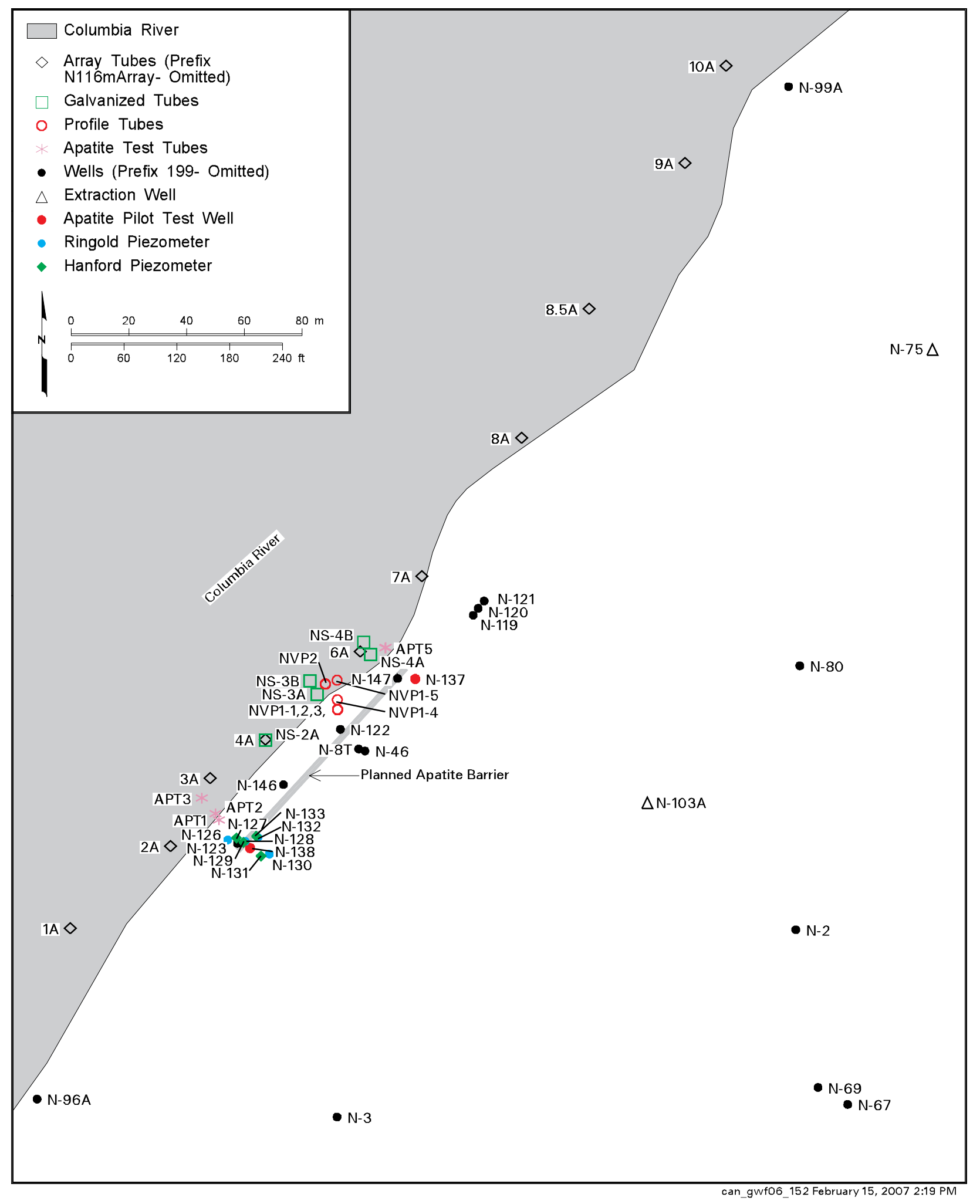

Figure 2.4-2. Aquifer Tubes, Seep Wells, and Monitoring Wells on 100-N Shoreline 


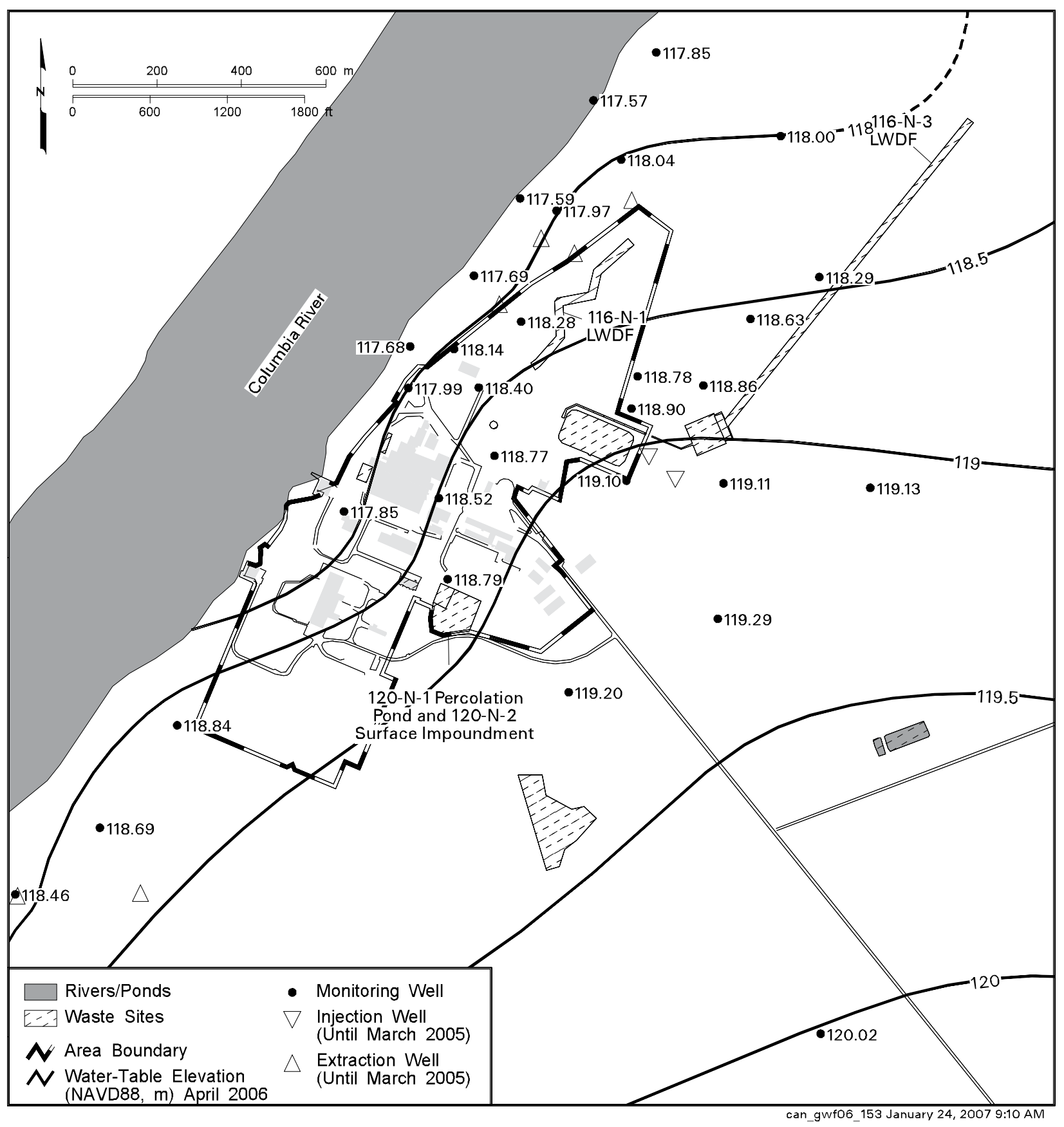

Figure 2.4-3. 100-N Area Water-Table Map, April 2006 


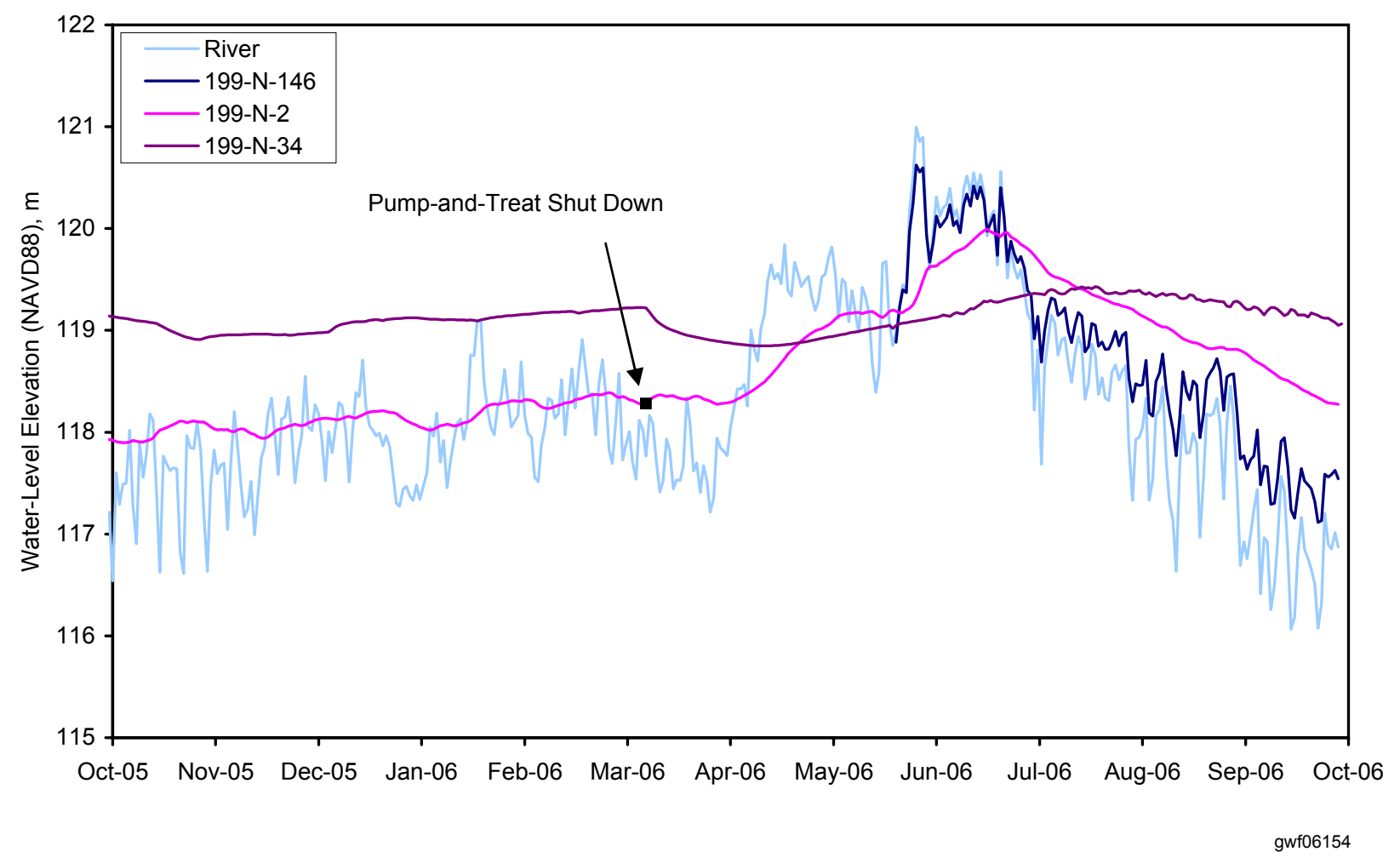

Figure 2.4-4. Water Levels in 100-N Area Monitoring Wells and the Columbia River (Daily average of hourly, automated measurements.) 


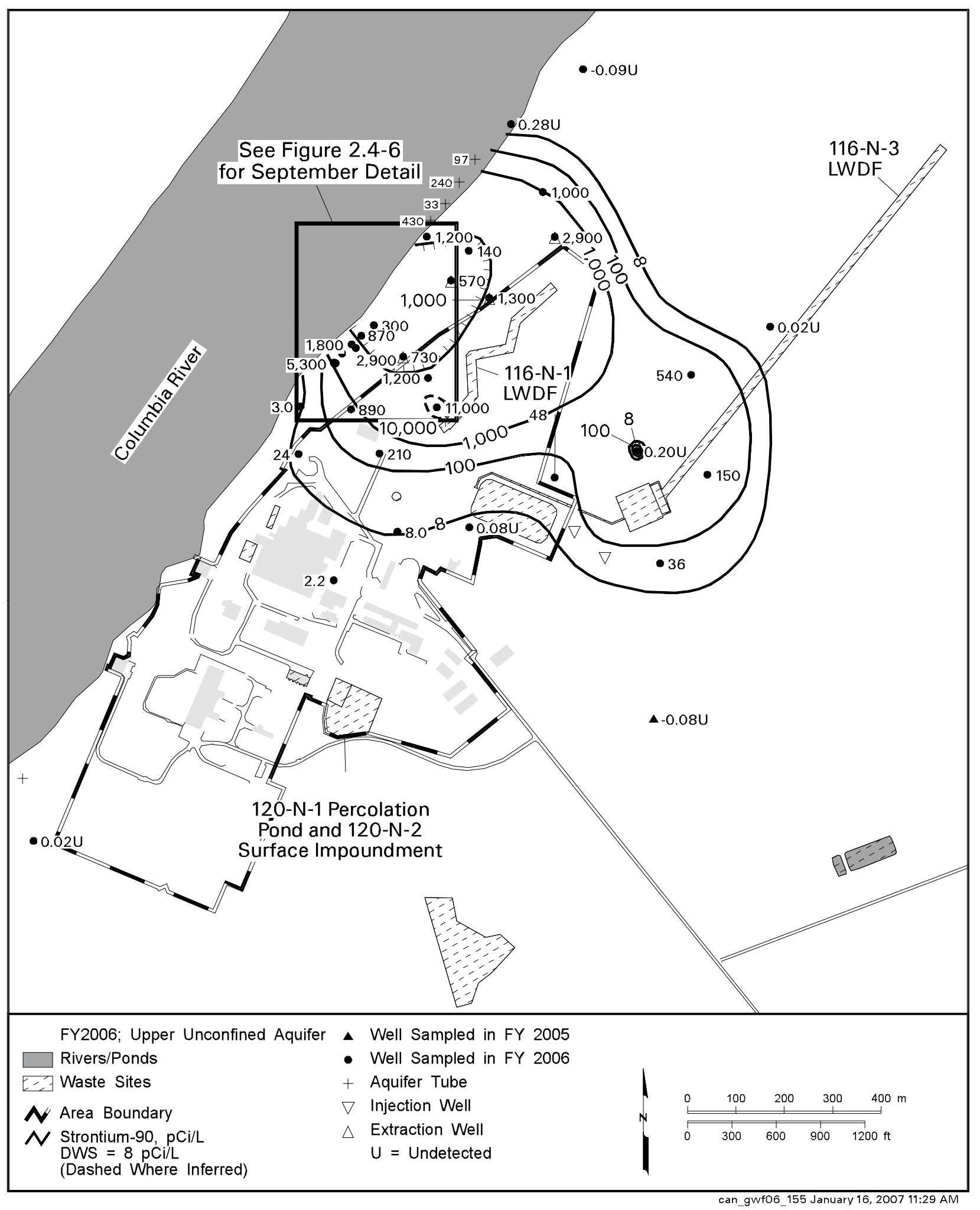

Figure 2.4-5. Average Strontium-90 Concentrations in 100-N Area, Upper Part of Unconfined Aquifer 


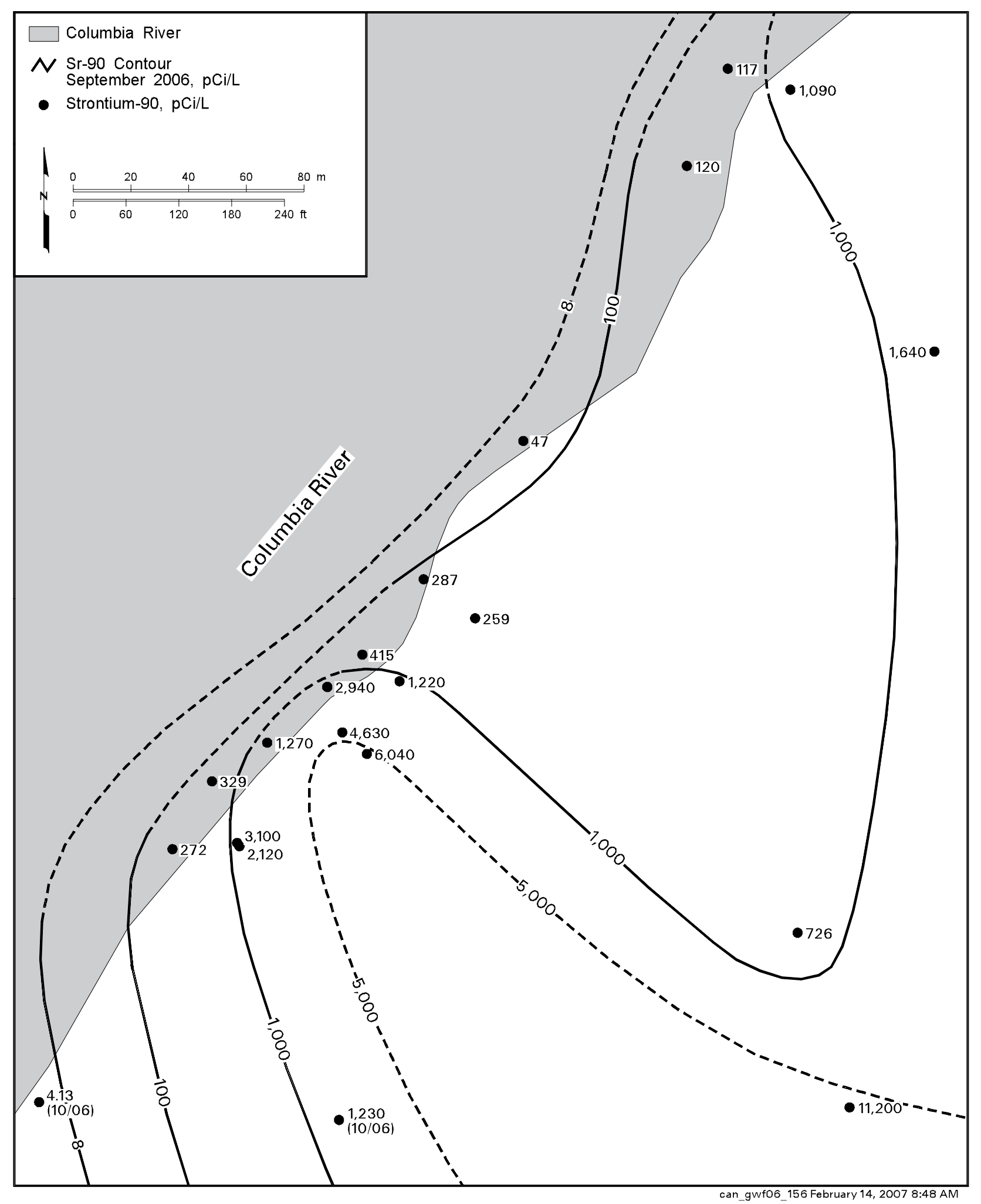

Figure 2.4-6. Strontium-90 Distribution in Shoreline Study Area, September 2006 


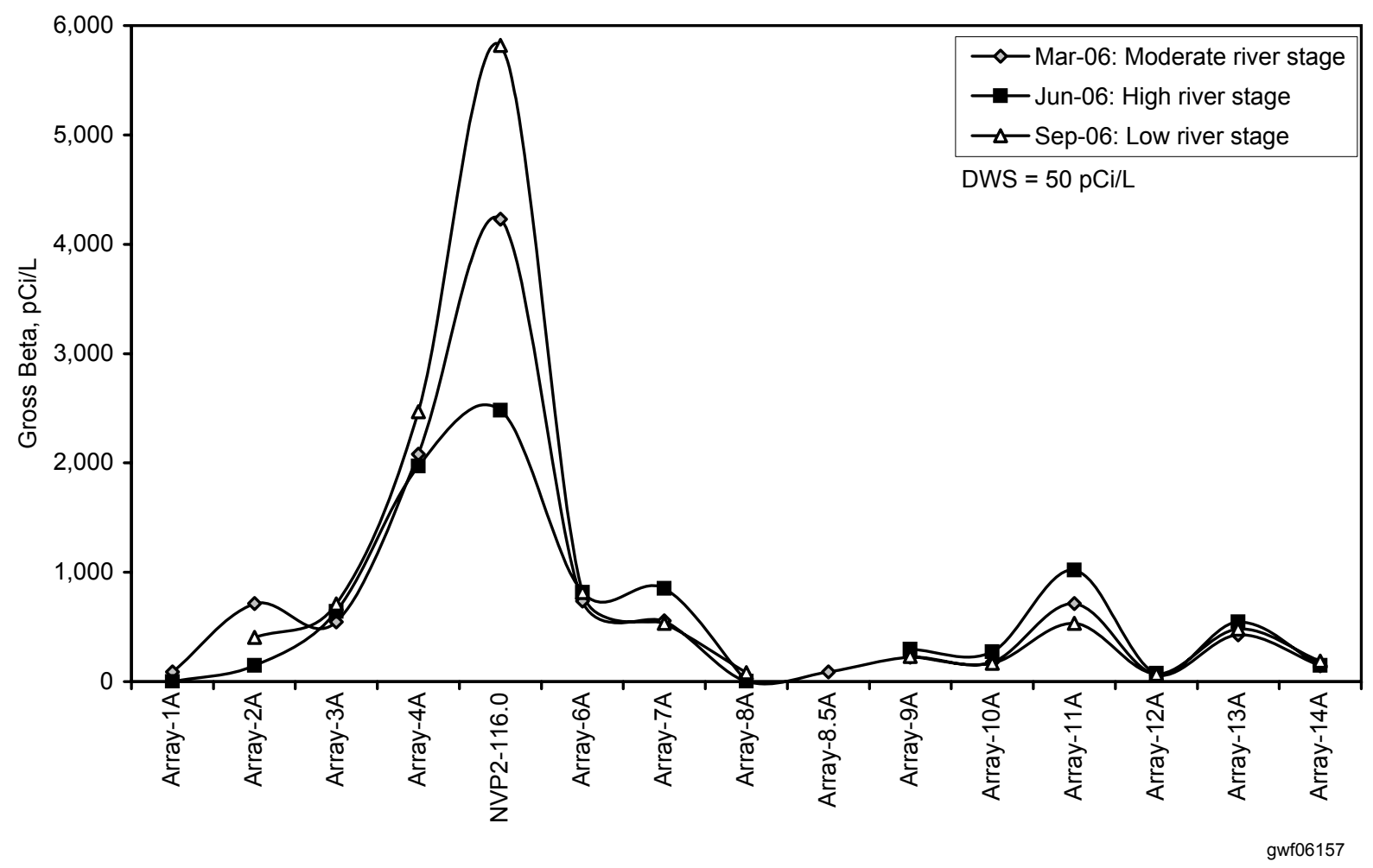

Figure 2.4-7. Gross Beta in Horizontal Array Aquifer Tubes (Strontium-90 concentrations are approximately half the value of the gross beta concentrations.) 


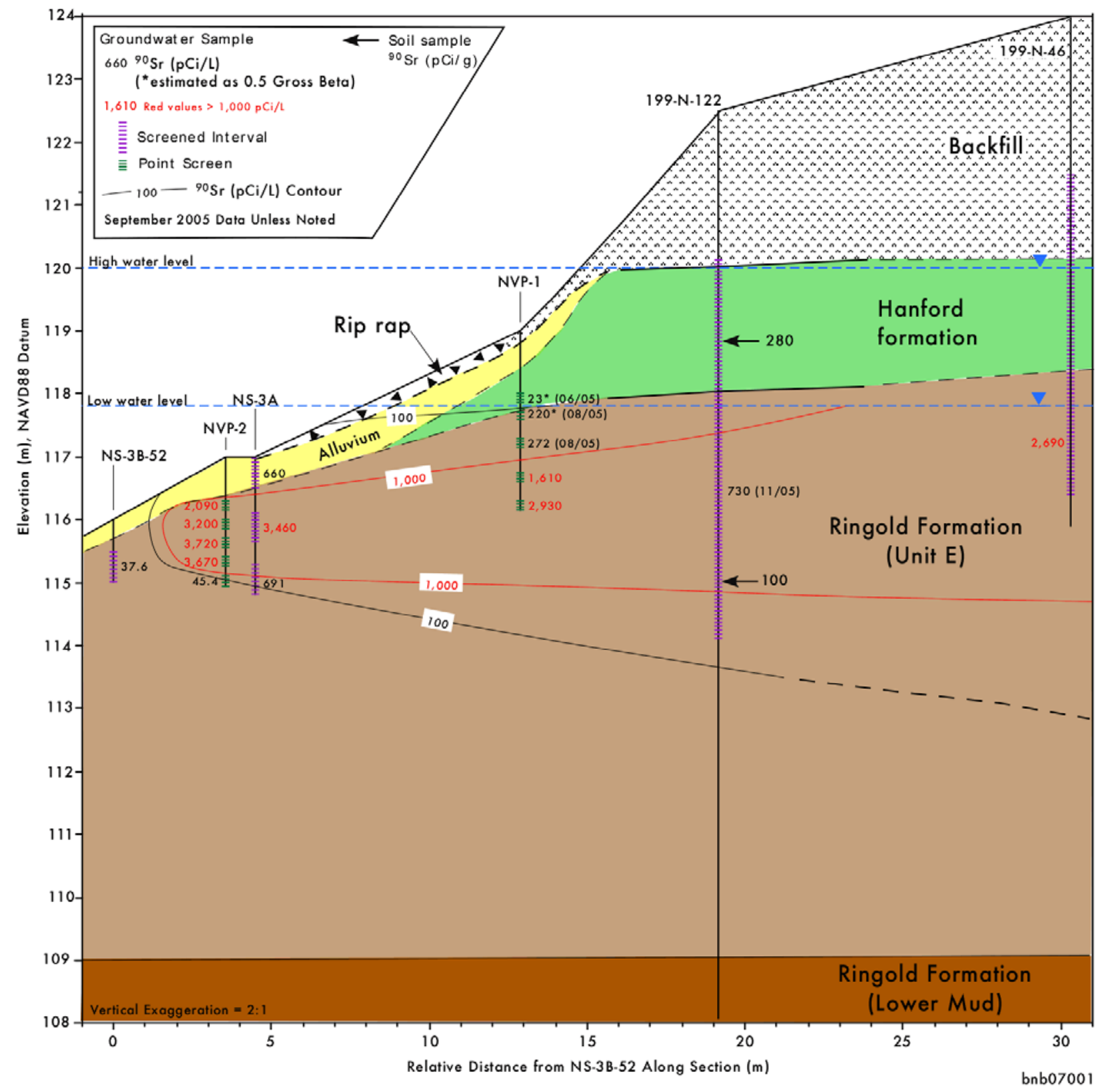

Figure 2.4-8. Stratigraphy and Vertical Strontium-90 Distribution at 100-N Area Shoreline in the Center of Strontium-90 Plume 


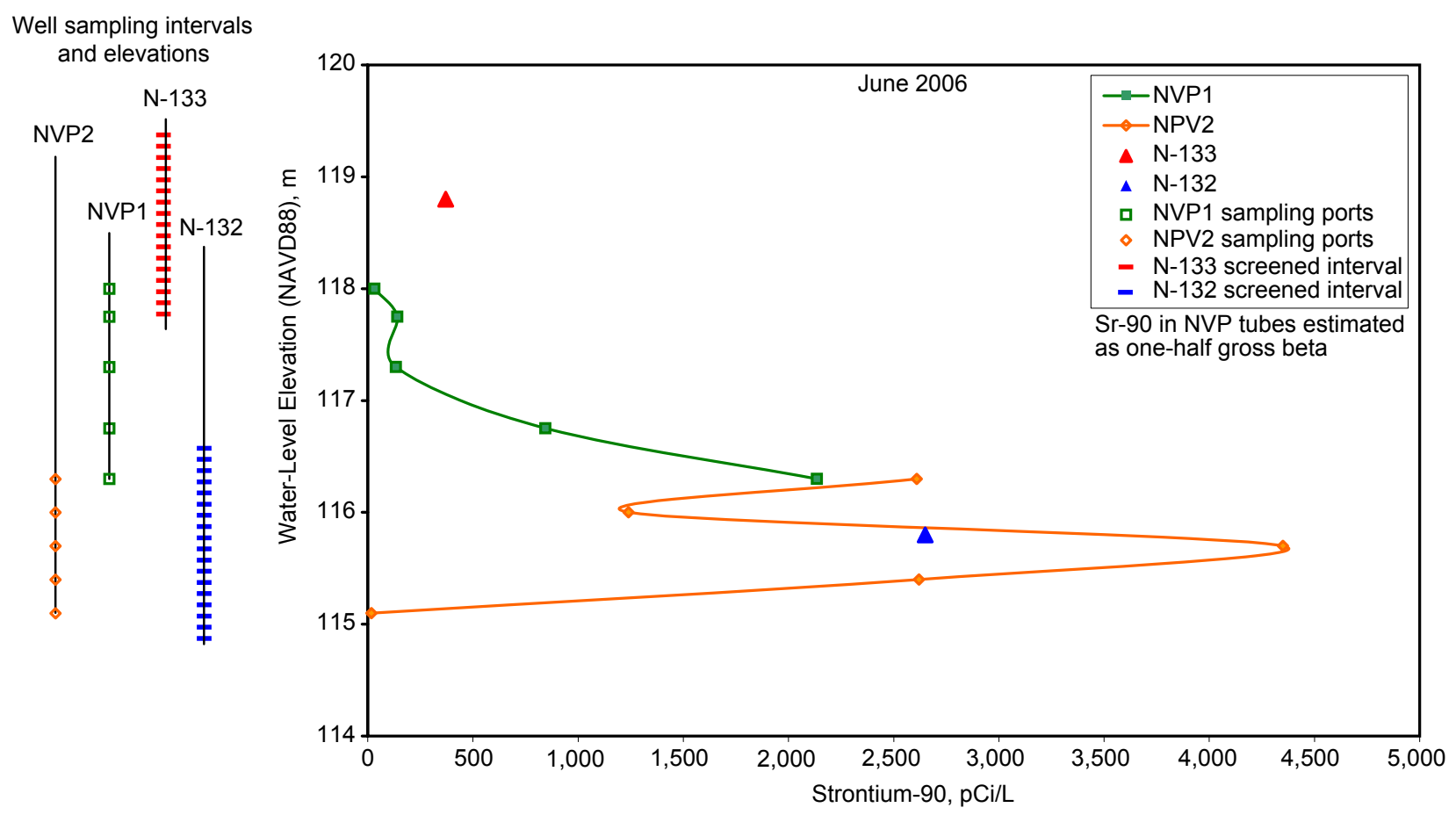

gwf06159

Figure 2.4-9. Strontium-90 Concentrations in Vertical Profile Aquifer Tubes at 100-N Area, June 2006 

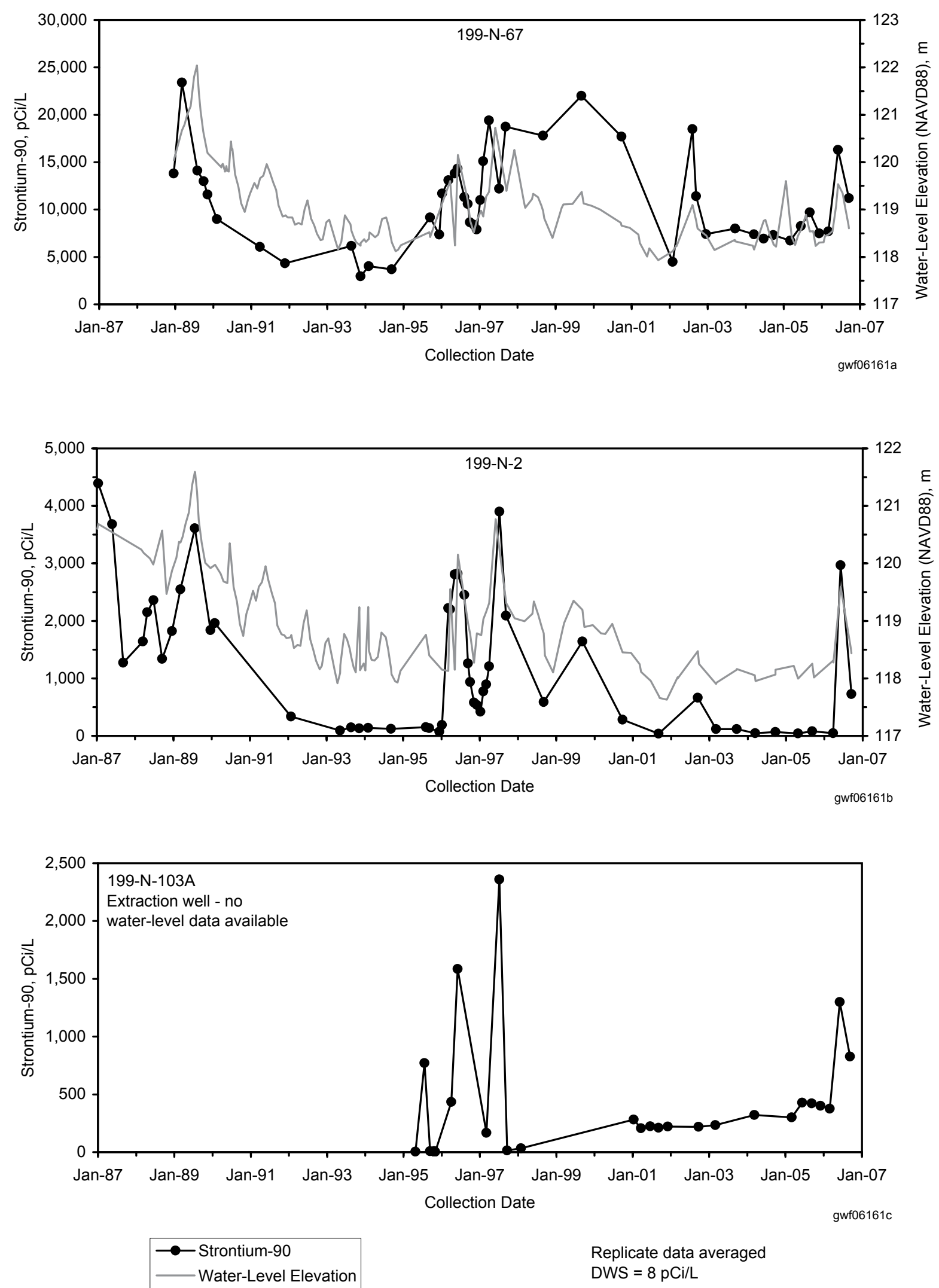

Replicate data averaged DWS $=8 \mathrm{pCi} / \mathrm{L}$

Figure 2.4-10. Strontium-90 Concentrations and Water Level Near 116-N-1 Facility 

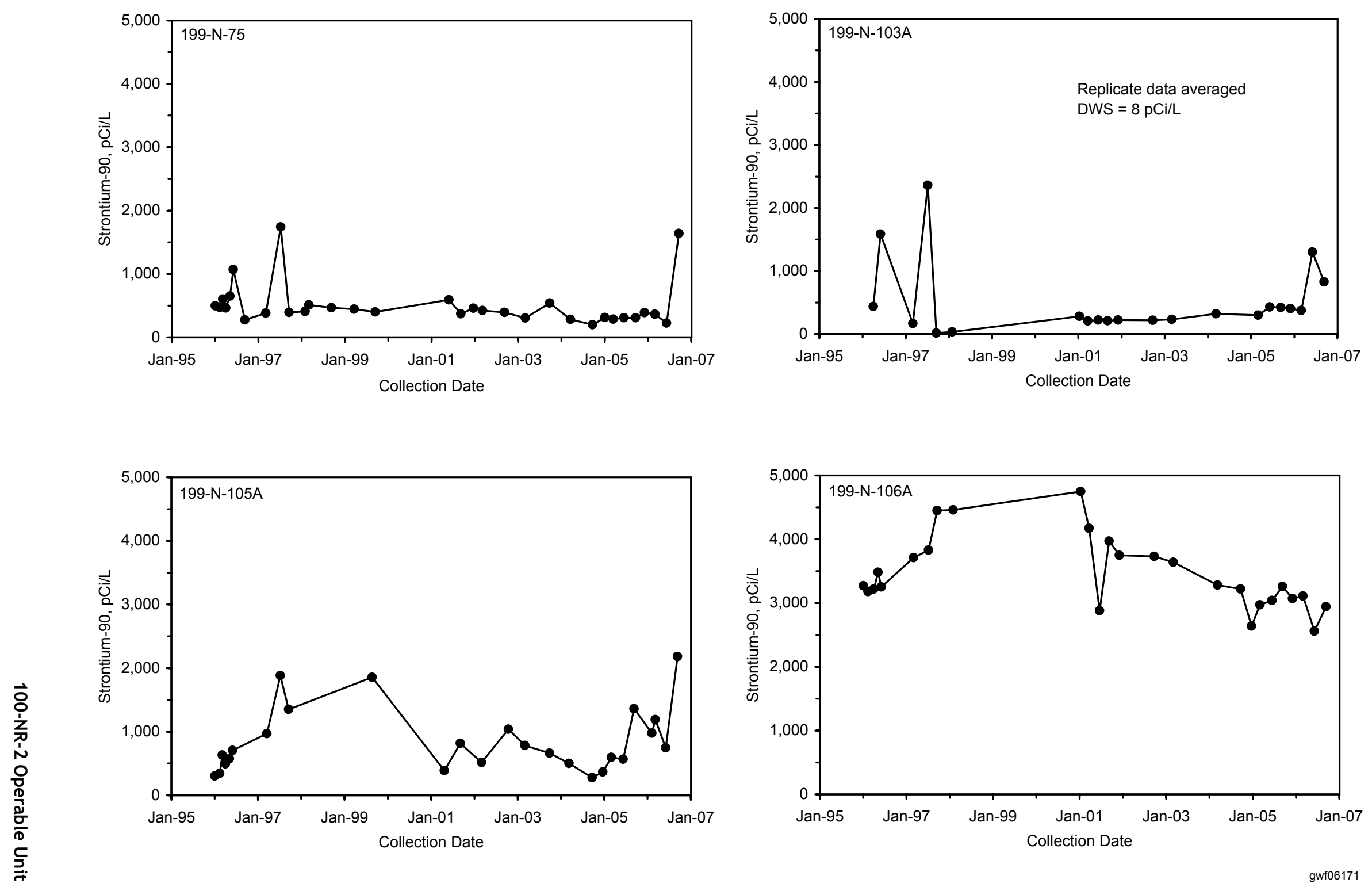

Figure 2.4-11. Strontium-90 Concentrations in Former Extraction Wells in 100-N Area 


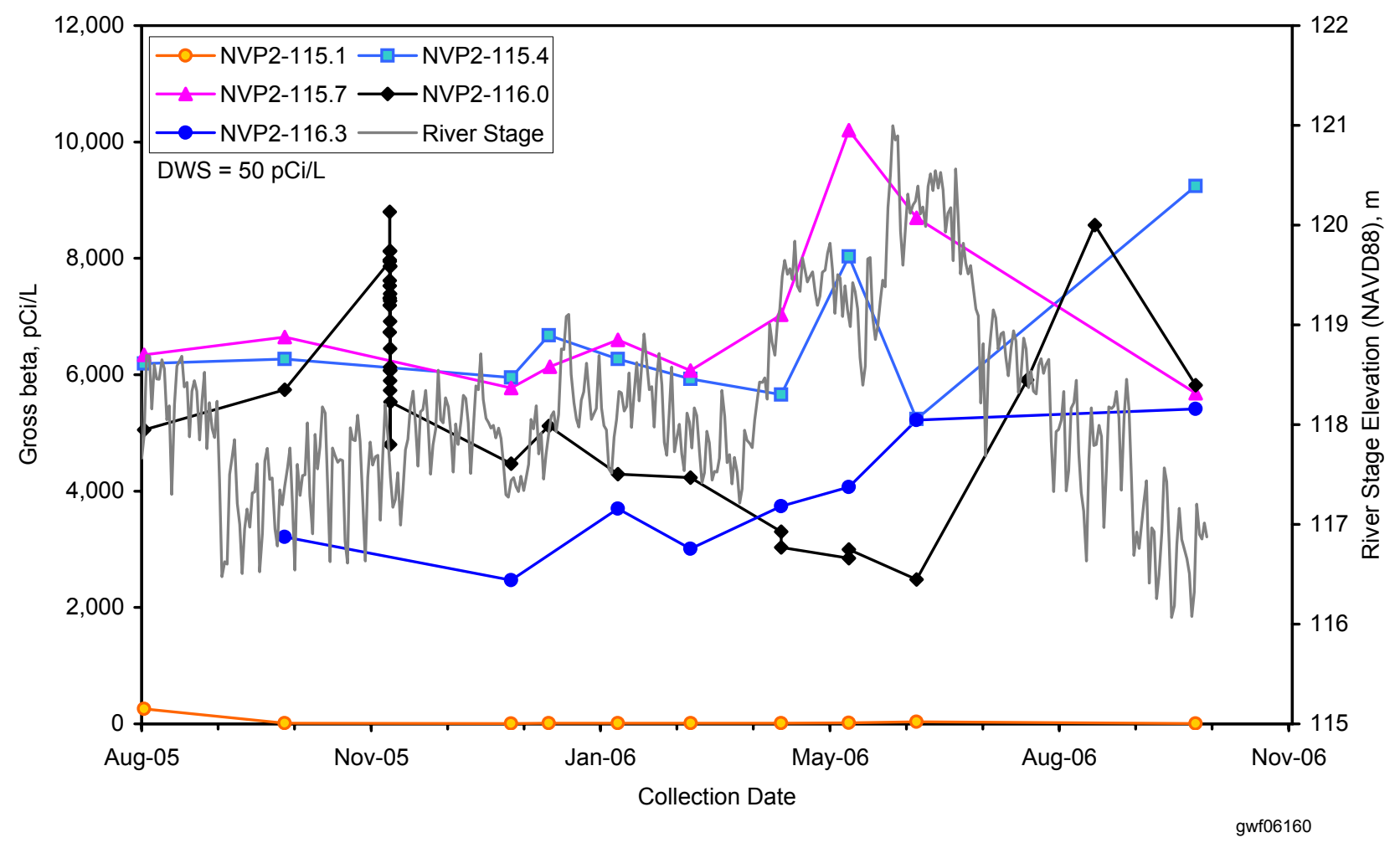

Figure 2.4-12. Gross Beta Concentrations in Vertical Profile Aquifer Tubes with Daily Average River Stage at 100-N Area 


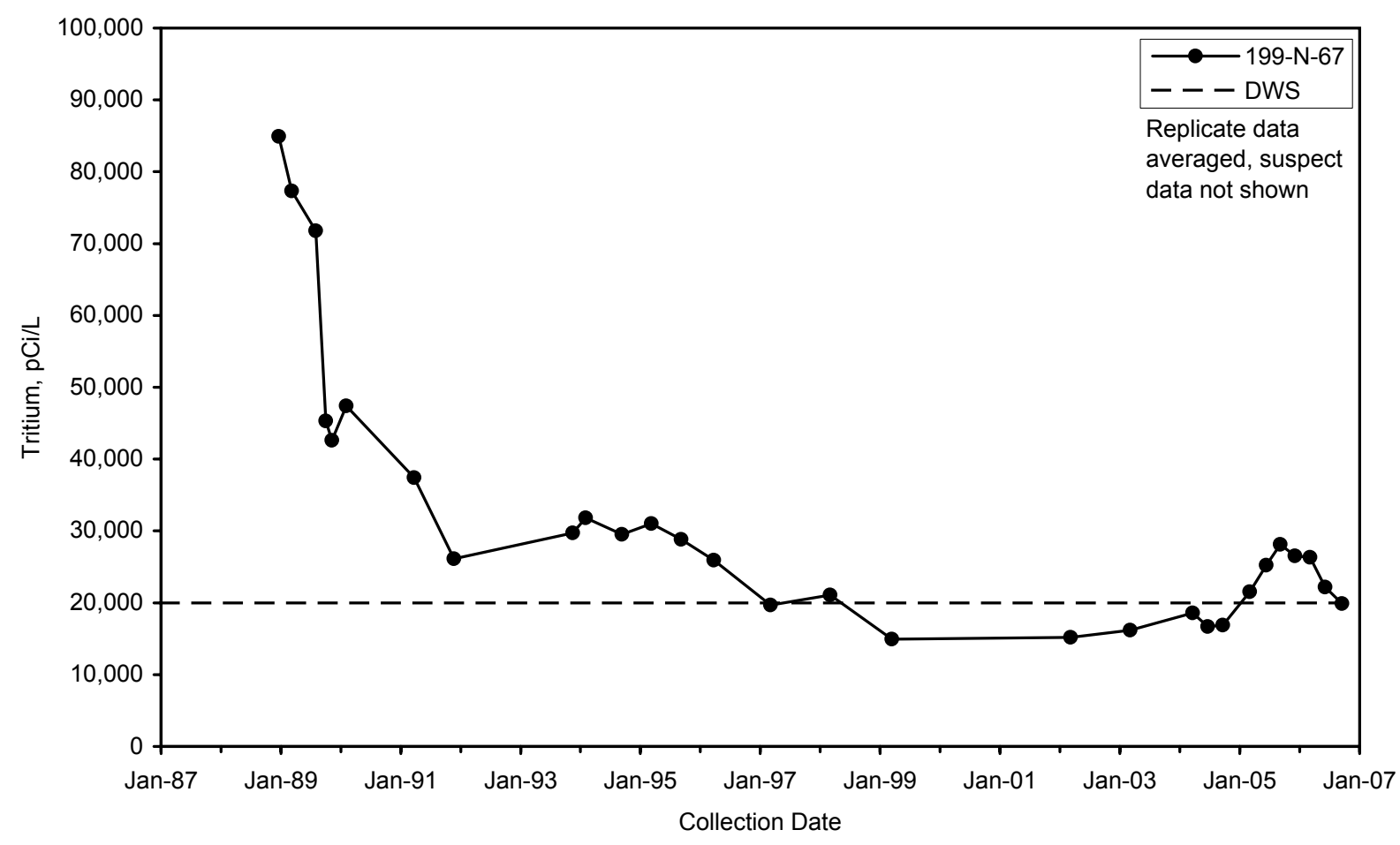

gwf06162a

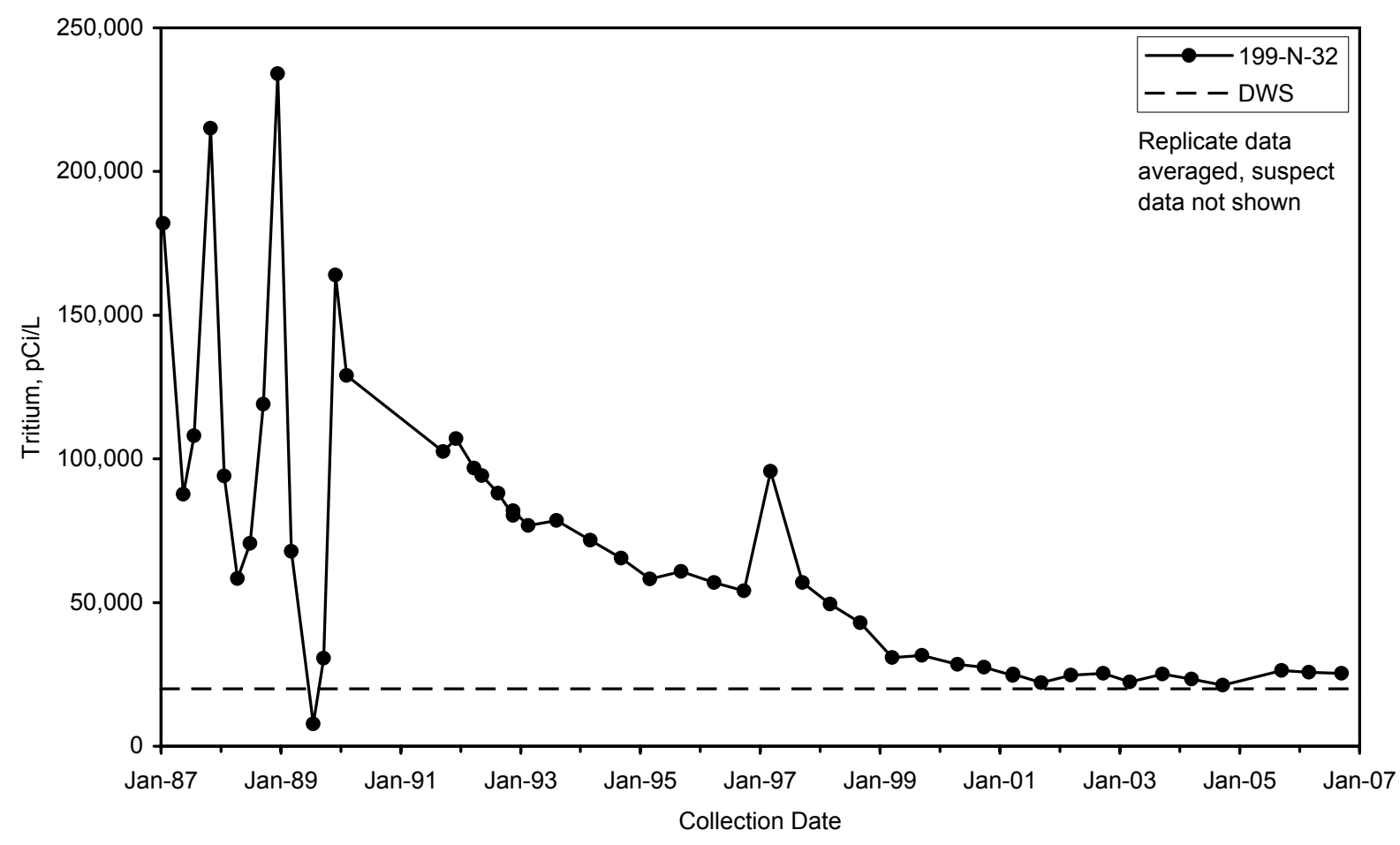

gwf06162b

gwf06162

Figure 2.4-13. Tritium Concentrations Near the 116-N-1 (top) and 116-N-3 (bottom) Facilities 


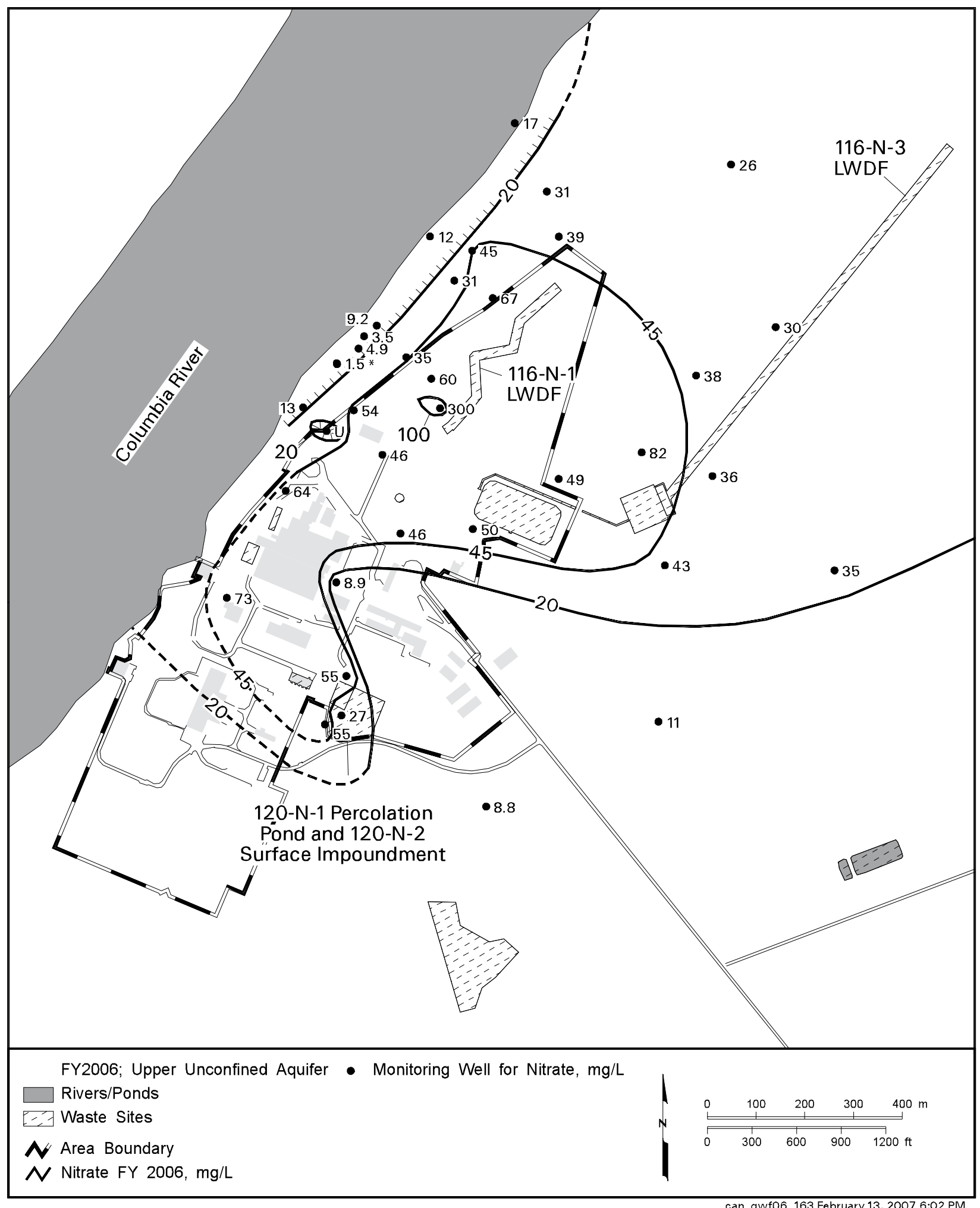

Figure 2.4-14. Average Nitrate Concentrations in 100-N Area, Upper Part of Unconfined Aquifer 


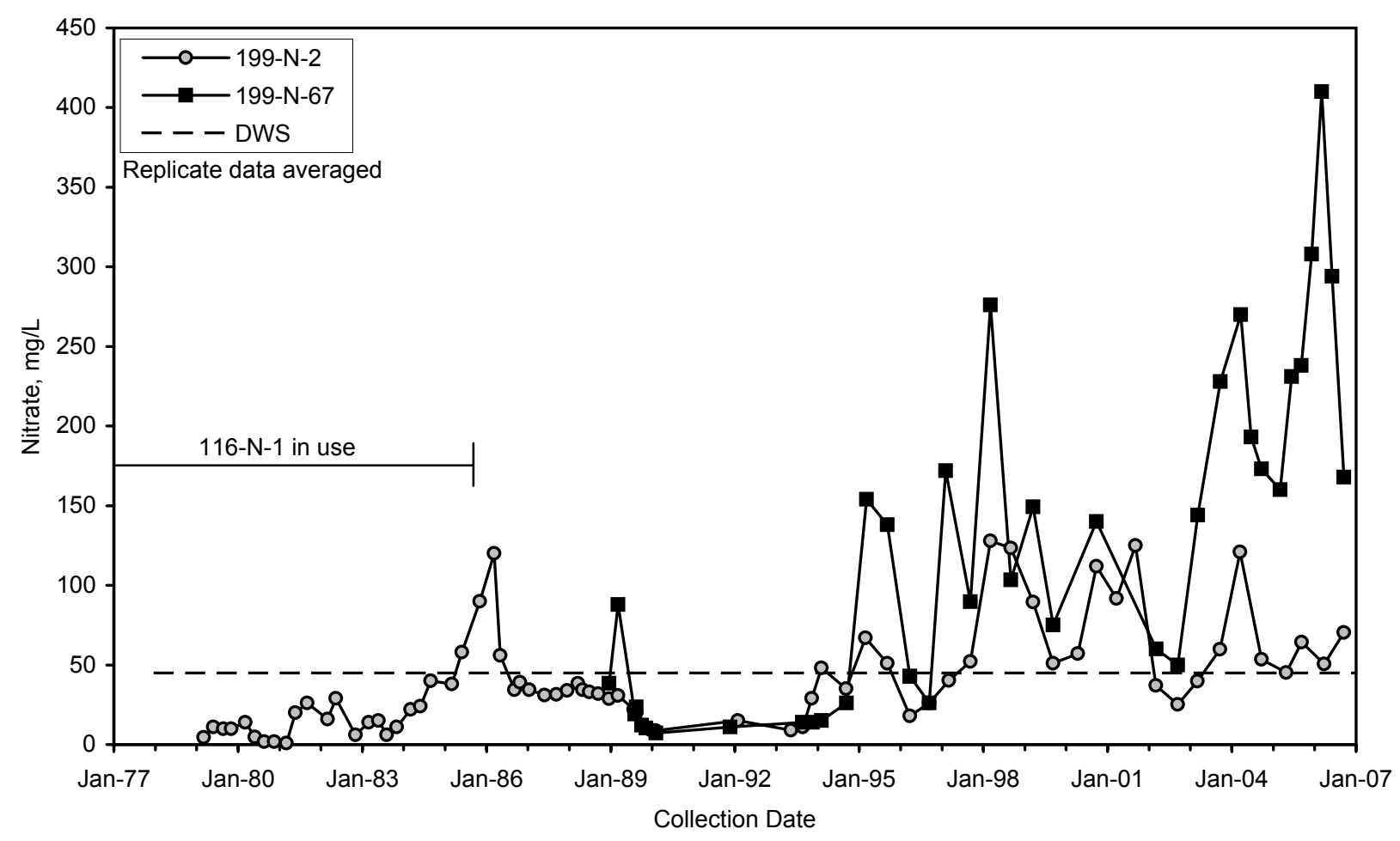

gwf06164

Figure 2.4-15. Nitrate Concentrations Near 116-N-1 Facility

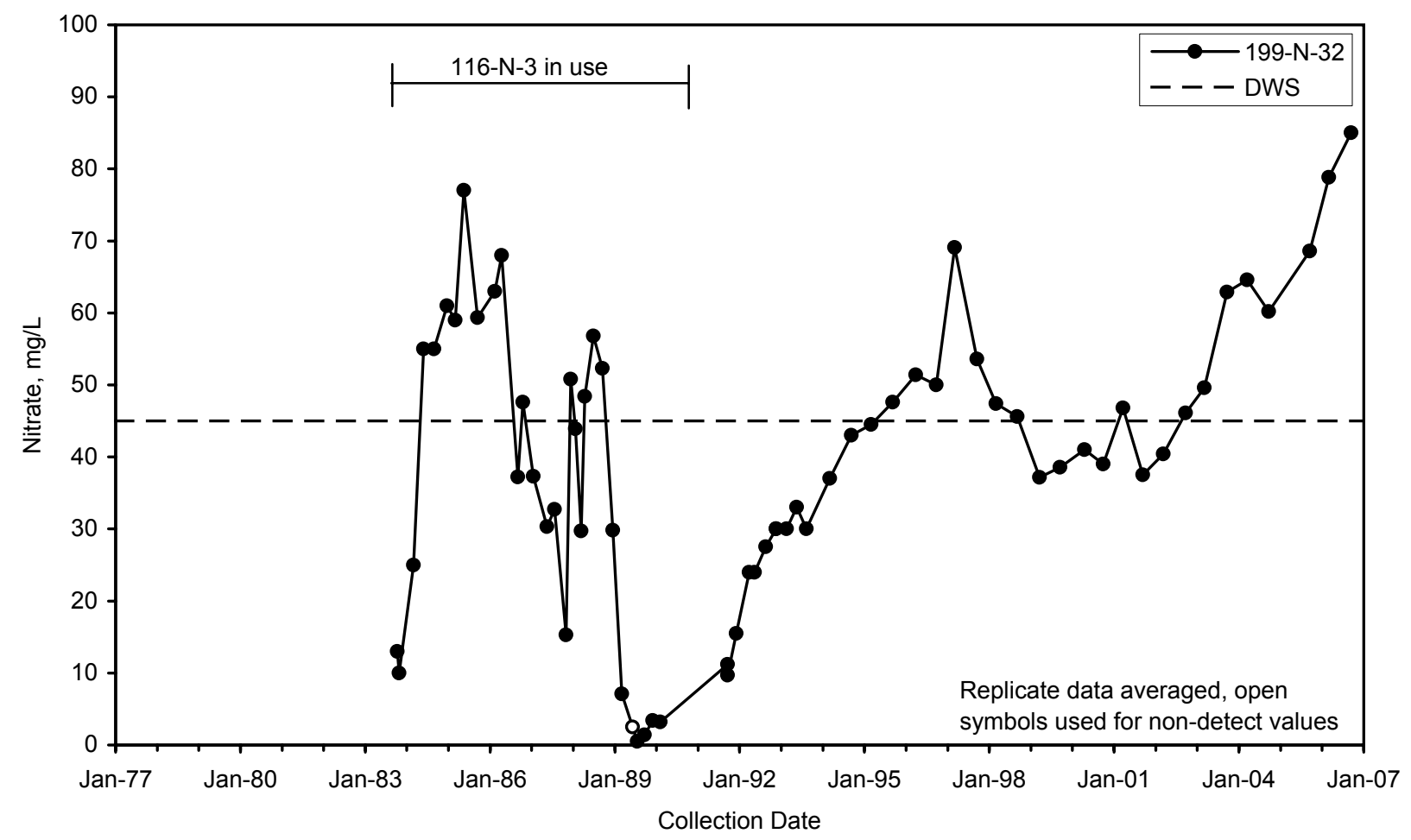

gwf06165

Figure 2.4-16. Nitrate Concentrations Near 116-N-3 Facility 


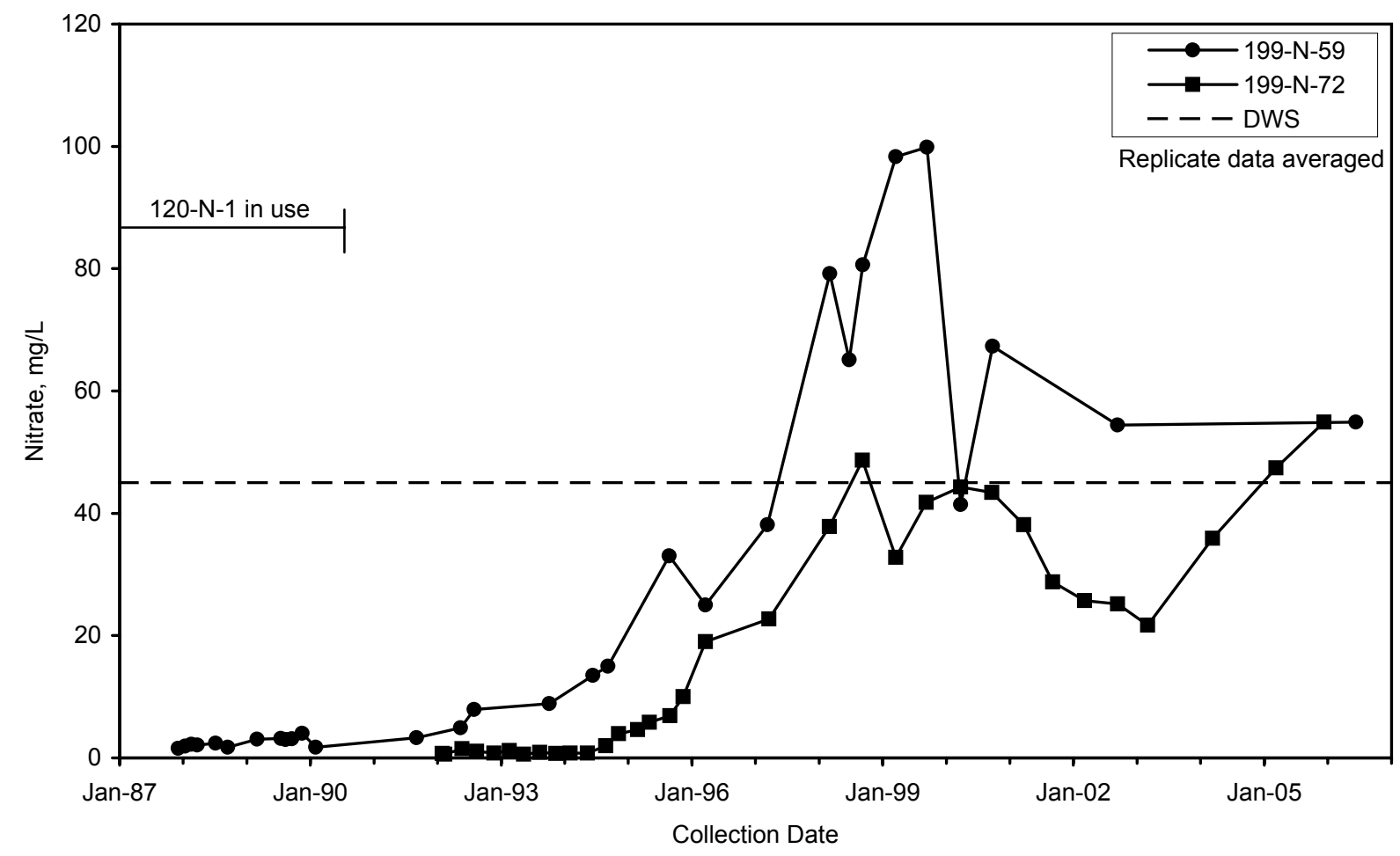

gwf06166

Figure 2.4-17. Nitrate Concentrations Near 120-N-1 Percolation Pond in South 100-N Area

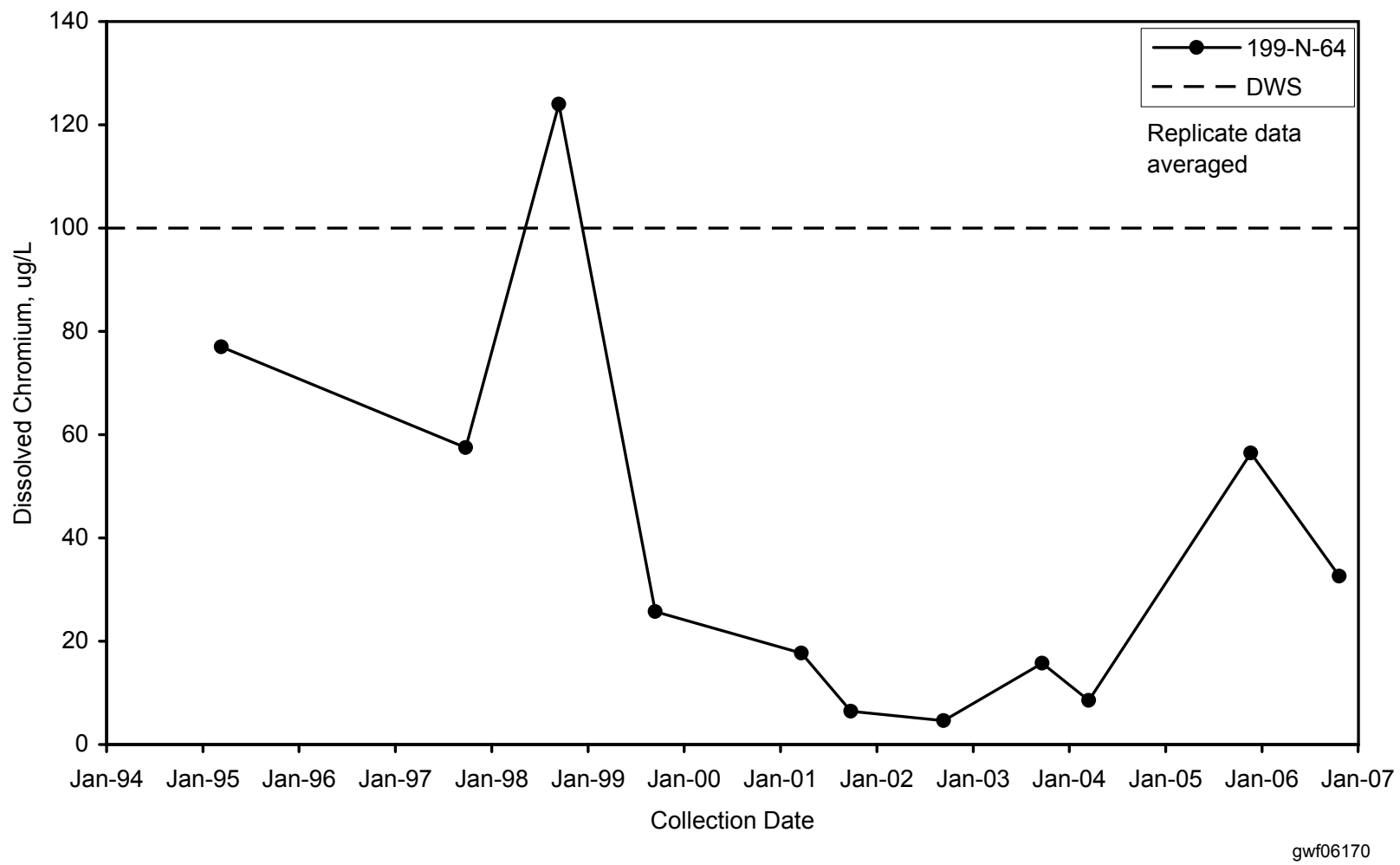

Figure 2.4-18. Dissolved Chromium in Well 199-N-64 


\subsection{0-HR-3-D Operable Unit}

\section{J. Hartman, R. O. Mahood, and R. F. Raidl}

The scope of this section is the 100-HR-3-D groundwater interest area, which occupies the west half of the 100-HR-3 Operable Unit (see Figure 1.0-1 in Section 1.0). The "groundwater interest areas" are informal designations to facilitate scheduling, data review, and interpretation. Figures 2.5-1 and 2.5-2 show facilities, wells, and shoreline monitoring sites in this region. Hexavalent chromium is the contaminant of greatest significance in groundwater. Groundwater is monitored to assess the performance of three Comprehensive Environmental Response, Compensation, and Liability Act (CERCLA) interim actions for chromium: two pump-and-treat systems and an in situ reduction-oxidation (redox) manipulation system. Groundwater also is monitored to track other contaminant plumes including strontium-90, tritium, nitrate, and sulfate.

Groundwater flows primarily to the north and northwest, toward the Columbia River (Figure 2.5-3). Near the Columbia River, including the redox site, the average flow direction is toward the northwest. Farther inland, average flow is northward. Leakage from the 182-D reservoir (see Section 2.5.2.2) and injection of treated groundwater into well 199-D5-42 form a broad groundwater mound in the central region of the 100-D Area.

The remainder of this section describes contaminant plumes and concentration trends for the constituents of interest under CERCLA and Atomic Energy Act (AEA) monitoring.

\subsubsection{Groundwater Contaminants}

This section describes the distribution and trends of chromium, strontium-90, tritium, nitrate, and sulfate in groundwater in the 100-D Area.

\subsubsection{Chromium}

Chromium contamination underlies most of the 100-D Area in two plumes. The north plume likely originated from cribs and trenches in the central 100-D Area and the south plume has unknown sources near the former 183-DR filter plant. An area devoid of chromium contamination between the two plumes is likely related to leakage of clean water from the 182-D reservoir (see Section 2.5.2.2).

Figure 2.5-4 shows chromium in the entire "horn" of the Hanford Site, which includes the 100-D and 100-H Areas and the 600 Area between. The few wells between the 100-D and 100-H Areas have concentrations ranging from undetected in well 699-86-42 to over $100 \mu \mathrm{g} / \mathrm{L}$ in well 699-97-43, near 100-H Area. The contamination is believed to have migrated eastward from the 100-D Area when there was a groundwater mound beneath the retention basins.

\section{Hexavalent \\ chromium is the \\ contaminant of}

greatest concern in

the 100-D Area.

Groundwater monitoring in the 100-HR-3-D groundwater interest area includes the following monitoring activities:

CERCLA and AEA Monitoring

- Wells and aquifer tubes near the pump-and-treat systems and the redox site are sampled monthly to annually for chromium and other contaminants.

- Wells throughout the 100-D Area and surrounding 600 Area are sampled monthly to biennially, and aquifer tubes are sampled annually.

- Except for two monthly samples, wells were sampled as scheduled in FY 2006 (see Appendix A). 


\section{At 100-D Area, three remediation systems help reduce the amount of chromium reaching the Columbia River: two pump- and-treat systems in the north and an in situ remediation system in the southwest.}

Figure 2.5-5 shows chromium distribution at the redox site in southwest 100-D Area in August 2006. The map was constructed using the average of values from August 2006, if available. If no August data were available, the sampling event closest to August was chosen.

Aquifer tubes provide additional monitoring points along the 100-D Area shoreline (Figure 2.5-6; see Figures 2.5-1 and 2.5-2 for aquifer tube locations). Historically, the highest concentrations were downgradient of the south chromium plume. The highest concentrations in fiscal year (FY) 2006 were $393 \mu \mathrm{g} / \mathrm{L}$ in the south plume (tube redox-3-3.3) and $333 \mu \mathrm{g} / \mathrm{L}$ in the north plume (tube 36-D). Figure 2.5-7 illustrates the depths of the aquifer tubes and screened intervals of wells near the shoreline. Chromium concentrations greater than $100 \mu \mathrm{g} / \mathrm{L}$ are detected in tubes from 1 to 8 meters below land surface near the shoreline. Concentrations in the shallowest tubes generally are lower than in deeper tubes because of dilution with river water, as indicated by specific conductance. However, some shallow tubes show little evidence of dilution, and chromium concentrations are high. For example, tube redox-3-3.3, which is only 1-meter deep, typically has specific conductance values over $600 \mu \mathrm{S} / \mathrm{cm}$ and chromium concentrations in the hundreds of $\mu \mathrm{g} / \mathrm{L}(393 \mu \mathrm{g} / \mathrm{L}$ in FY 2006).

North Plume. The north chromium plume extends from cribs, trenches, and pipelines near the former reactor building toward the north and west. Near the sources, chromium remained below the drinking water standard in well 199-D5-16 (Figure 2.5-8). However, concentrations have increased nearby in well 199-D5-15 over the past several years, reaching a maximum of 1,540 $\mathrm{gg} / \mathrm{L}$ in August 2006. The increase is caused by the elimination of nearby leaking water lines, which had diluted groundwater. Before 2002, specific conductance was often low $(<300 \mu \mathrm{S} / \mathrm{cm})$, indicating that groundwater was being diluted with fresh water. Since 2003, the specific conductance has stabilized at $\sim 600 \mu \mathrm{S} / \mathrm{cm}$, suggesting the dilution has ceased.

In the north 100-D Area near the pump-and-treat system, compliance wells continued to show variable chromium concentrations, with the lowest concentrations in the early summer when river stage was high (Figure 2.5-9). The concentrations remained above the $22 \mu \mathrm{g} / \mathrm{L}$ remedial action goal in the compliance wells except in spring and summer, when river stage was high and near-shore groundwater was diluted. The seasonal concentration peaks (fall and winter of each year) have declined since 2000. Section 2.5.2.1 contains more information about the pump-and-treat systems.

Chromium concentrations in wells on the southwest side of the north plume decreased from their peak values observed in 2004 (Figure 2.5-10). Wells 199-D5-20 and 199-D5-32 were converted to extraction wells in July 2004.

At the base of the upper aquifer, monitored by well 199-D8-54B in the north 100-D Area, chromium is near the detection limit while an adjacent shallow well has concentrations above the drinking water standard.

Chromium concentrations in aquifer tubes in the north 100-D Area are consistent with concentrations in the aquifer. The highest concentration was $333 \mu \mathrm{g} / \mathrm{L}$ at tube site AT-36, a decrease from the previous year.

South Plume. This chromium plume lies south and southwest of the 182-D

Plume areas (square kilometers) at the 100-HR-3-D Operable Unit:

Chromium, $100 \mu \mathrm{g} / \mathrm{L}-0.77$

Chromium, $20 \mu \mathrm{g} / \mathrm{L}-3.1$

Nitrate, $45 \mathrm{mg} / \mathrm{L}-0.77$

Tritium, 20,000 pCi/L -0.06 reservoir and west of the 183-DR filter plant, extending to the Columbia River (Figures 2.5-4 and 2.5-5). The source of this plume has not been located despite previous investigations (e.g., PNNL-13486). Potential sources of chromium contamination have recently been discovered in the 100-D Area. Pipelines used to transfer sodium dichromate solution (waste site 100-D-56) were found to contain highly concentrated sodium dichromate liquid (44,000 $\mu \mathrm{g} / \mathrm{L}$ hexavalent chromium). Field remediation began in June 2006 with removal of the sodium dichromate transfer lines. 
The core of the chromium plume, with concentrations $>500 \mu \mathrm{g} / \mathrm{L}$, is oriented eastwest. The redox barrier intersects the south chromium plume and terminates the highestconcentration portion of the plume.

Chromium concentrations in the central 100-D Area (e.g., wells 199-D5-33 and 199-D5-44) are very low, separating the south and north chromium plumes, probably because of infiltration of clean water from the 182-D reservoir. In FY 2006, chromium concentrations increased sharply in well 199-D5-34, located near the southeast corner of the reservoir (Figure 2.5-11). Formerly at levels below the detection limit, the chromium concentration reached $835 \mu \mathrm{g} / \mathrm{L}$ in August 2006. The increase in chromium concentration may reflect decreased dilution from the 182-D reservoir. Specific conductance of the August 2006 sample was $404 \mu \mathrm{S} / \mathrm{cm}$, and the level increased to $457 \mu \mathrm{S} / \mathrm{cm}$ in November 2006. Specific conductance of previous samples varied from 220 to $390 \mu \mathrm{S} / \mathrm{cm}$. The chromium increase in this well may reflect a merging of the north and south plumes.

Compliance monitoring wells downgradient of the redox barrier show inconsistent chromium trends (Figure 2.5-12). The northernmost well, 199-D4-83, shows variable chromium concentrations with decreasing peaks. Some concentrations were below the 20- $\mathrm{g} / \mathrm{L}$ remedial action goal in FY 2006. Well 199-D4-39, near the north end of the barrier, shows high variability since 2000, with decreasing concentrations since FY 2004. This well continued to have the highest concentrations in any of the redox compliance wells, with a value of $\sim 420 \mu \mathrm{g} / \mathrm{L}$ in August 2006. South of well 199-D4-39, chromium trends in wells 199-D4-23, 199-D4-84, 199-D4-85, and 199-D4-86 continued to decline overall, with some variability. Concentrations in well 199-D4-38 show an irregularly increasing trend in FY 2004 through 2006. Concentrations in wells 199-D4-23, 199-D4-85, and 199-D4-86, were below the remedial action goal $(20 \mu \mathrm{g} / \mathrm{L})$ for at least a portion of the fiscal year.

Chromium concentrations have decreased since monitoring began in aquifer tubes downgradient of the redox site. However, concentrations increased in some tubes in FY 2006 (Figure 2.5-13). The highest concentration in this region was $393 \mu \mathrm{g} / \mathrm{L}$ in redox-3-3.3.

\subsubsection{Strontium-90}

Two locations in the 100-D Area have a history of strontium-90 detections in groundwater: near the former retention basins in the north and near the D Reactor building in central 100-D Area.

Near the former retention basins, the strontium-90 concentration in well 199-D8-68 exceeded the 8-pCi/L drinking water standard in November and December 2005 (8.2 and $9.0 \mathrm{pCi} / \mathrm{L}$, respectively) and declined to $2.4 \mathrm{pCi} / \mathrm{L}$ in May 2006. Concentrations ranged from 2 to $14 \mathrm{pCi} / \mathrm{L}$ in the past 6 to 8 years. Strontium-90 was also detected in wells 199-D8-53, 199-D8-54A, 199-D8-69, and 199-D8-70, but at levels below the drinking water standard.

Near the former D Reactor, strontium-90 continued to be detected in well 199-D5-15 at levels below $4 \mathrm{pCi} / \mathrm{L}$. Nearby well 199-D5-16 continued to have no detectable strontium-90.

\subsubsection{Tritium}

Tritium concentrations remained below the $20,000-\mathrm{pCi} / \mathrm{L}$ drinking water standard in most wells in the 100-D Area, but continued to exceed the standard in wells near the south part of the redox barrier, as shown in Figure 2.5-14. The tritium contamination is believed to have originated as part of the 100-N Area tritium plume to the south. A peak of contamination moved past well 199-D3-2 in the late 1990s. Aquifer tube DD-44 had tritium concentrations exceeding the drinking water standard in the past, but none of the aquifer tubes was sampled for tritium in FY 2006.

The tritium concentration remained slightly above the drinking water standard $(20,200 \mathrm{pCi} / \mathrm{L})$ in FY 2006 in well 199-D5-17, located near waste sites associated with the

\author{
In FY 2006, \\ chromium \\ concentrations \\ increased sharply \\ in a well located \\ near the southeast \\ corner of the \\ 182-D reservoir.
}


former DR Reactor. Since 1996, concentrations have ranged from 12,000 to $26,400 \mathrm{pCi} / \mathrm{L}$ with no obvious increasing or decreasing trend. Concentrations in nearby wells remained below the standard.

\subsubsection{Nitrate}

Nitrate distribution is generally similar to chromium in the 100-D Area; both constituents form two plumes. The nitrate plume has changed little in the past two years (see Figure 2.5-16 in PNNL-15070 for FY 2004 map). Nitrate concentrations continued to exceed the drinking water standard ( $45 \mathrm{mg} / \mathrm{L}$ ) in both plumes, with a FY 2006 maximum concentration of $77 \mathrm{mg} / \mathrm{L}$ in well 199-D8-4 near the former 120-D-1 pond. The south plume is truncated by the redox system, which converts the nitrate to nitrite.

\subsubsection{Sulfate}

Sulfate concentrations remained $>100 \mathrm{mg} / \mathrm{L}$ beneath much of the 100-D Area. Excluding wells influenced by the redox system, concentrations all were below the secondary drinking water standard $(250 \mathrm{mg} / \mathrm{L})$ in FY 2006. Past injections of sodium dithionite solution at the redox site increased sulfate concentrations to levels above the standard in the barrier and in some downgradient wells and aquifer tubes.

\subsubsection{Gross Beta}

Samples from several of the wells in the redox barrier are analyzed for gross beta, and a few of these exceed the $50-\mathrm{pCi} / \mathrm{L}$ drinking water standard. The beta is caused by potassium-40 naturally present in the injected solution.

\subsubsection{Interim Groundwater Remediation for Chromium}

\section{During FY 2006,}

two pump-and-

treat systems

in the 100-D

Area extracted

291.6 million liters

of groundwater,

removing

85.2 kilograms

of hexavalent

chromium.
Three CERCLA remediation systems operate as interim actions to reduce the amount of chromium reaching the Columbia River in the 100-D Area: a pump-and-treat system in the north, a pump-and-treat system (known as DR-5) in the central 100-D Area, and an in situ redox manipulation barrier in the southwest. The DR-5 pump-and-treat system fills a gap between the north system and the redox barrier and also extracts contamination from high-concentration portions of the plume upgradient of the redox barrier.

The second CERCLA five-year review was published in November 2006 (DOE/RL2006-20). The review identified four issues pertaining to the 100-D Area. Those issues and associated follow-up actions are listed in Table 2.5-1.

\subsubsection{Pump-and-Treat Systems}

A pump-and-treat system in the north 100-D Area includes four extraction wells located near the former 116-D-7 and 116-DR-9 retention basins. The system began operating in July 1997 with two extraction wells (199-D8-53 and 199-D8-54A). In May 2002, wells 199-D8-68 and 199-D8-72 were converted to additional extraction wells.

Extracted groundwater is transferred via pipeline to the $100-\mathrm{H}$ Area where it is treated and injected into the aquifer. Monitoring requirements for this system are included in DOE/RL-96-90, as modified by DOE/RL-96-84. Long-term monitoring requirements in the 100-D Area were derived from Change Control Form 107 as modified by Fluor Hanford, Inc. ${ }^{\text {(a) }}$ Wells, constituents, and sampling frequencies for interim action monitoring are shown in Appendix A. Results of operational monitoring and additional details about the pump-and-treat system for calendar year 2005 can be found in DOE/RL-2006-08. Results for 2006 will be published in an upcoming annual report on the 100-HR-3, 100-KR-4, and 100-NR-2 pump-and-treat systems.

(a) Letter FH-0502977 from RG Gallagher (Fluor Hanford, Inc.) to Dr. LK Peters (Pacific Northwest National Laboratory), Tables Specifying Fluor Hanford Performance Sampling Requirements for Fiscal Year 2006, dated October 12, 2005. 
A second pump-and-treat system (DR-5 system) began operating at the end of July 2004 to treat increasing hexavalent chromium concentrations in the wells southwest of the original pump-and-treat system. The system was modified in FY 2005 to increase the rate of remediation and widen the capture zone. From August 2005 to present, the extraction wells have been 199-D5-20, 199-D5-32, 199-D5-39, and 199-D5-92. The extracted water is treated in the 100-D Area using a metal chelating medium and injected into well 199-D5-42.

Progress During FY 2006. The 100-D Area pump-and-treat systems are reducing overall contamination in the operable unit by removing contaminant mass. During FY 2006, the original 100-D Area pump-and-treat system extracted $\sim 214.7$ million liters of groundwater, removing 24.6 kilograms of hexavalent chromium. An additional 76.9 million liters of groundwater were processed and 60.6 kilograms of chromium removed by the DR-5 system.

A total of $~ 242.5$ kilograms of chromium has been removed from the 100-D chromium plume since the start up of the original system in July 1997. The DR-5 system has removed $\sim 105.4$ kilograms of chromium since July 2004, and an additional 30 kilograms were removed during a pilot-scale test conducted in the 100-D reactor area between August 1992 and August 1994 (DOE/RL-95-83). The total mass removed by all three systems is 377.9 kilograms through the end of FY 2006. The total hexavalent chromium in the north plume has been estimated at 590 kilograms (DOE/RL-94-95). That estimate did not include the chromium plume in the southwest 100-D Area nor in the vadose zone.

Influence on Aquifer Conditions. In FY 2006, chromium concentrations remained elevated in the 100-D Area, although the trend over the last four years is clearly down in compliance wells 199-D8-69 and 199-D8-70 (Figure 2.5-9). Chromium concentrations vary inversely with river stage, and have remained above the $22-\mu \mathrm{g} / \mathrm{L}$ remedial action goal except for occasional readings during summer months when river stage is high and dilution occurs.

DOE/RL-2006-08 presents results of operational monitoring and additional details about the pump-and-treat systems for calendar year 2005. Results for calendar year 2006 will be included in an upcoming report on the 100 Areas pump-and-treat systems.

\subsubsection{In Situ Redox Manipulation System}

This treatment system uses a change in redox potential to reduce dissolved hexavalent chromium in groundwater to trivalent chromium, a much less soluble and less toxic species. Objectives of the redox interim action are the same as for the 100-D Area pump-and-treat system except that the remedial action goal for chromium at the redox site is $20 \mu \mathrm{g} / \mathrm{L}$. Remedial action monitoring is described in DOE/RL-99-51.

Progress During Fiscal Year 2006. The in situ redox manipulation treatment zone is $\sim 680$ meters in length, aligned parallel to the Columbia River shoreline and $\sim 100$ to 200 meters inland. The treatment zone is designed to reduce the concentration of hexavalent chromium in groundwater to $\leq 20 \mu \mathrm{g} / \mathrm{L}$ at seven compliance wells situated between the

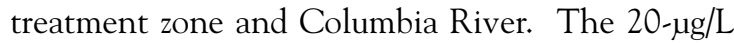
goal was met at two of the seven compliance wells: 199-D4-23 and 199-D4-86. (b) Chromium trends in the other compliance wells were generally decreasing although the decrease at well 199-D4-38 $8^{\text {(c) }}$ was insignificant (Figure 2.5-12).

\section{Chromium concentrations in wells on the southwest side of the north plume decreased from their peak values after they were converted to extraction wells.}

\section{Chromium}

concentrations

continued

decreasing in most

redox compliance

wells.

(b) FY 2005 average of filtered, total chromium and filtered, hexavalent chromium.

(c) Comparing FY 2005 and FY 2006 averages for filtered samples.

The remedial action objectives of the 100-HR-3 Operable Unit (ROD 1996a, 1999a) are:

- Protect aquatic receptors in the river bottom from contaminants in groundwater entering the Columbia River.

- Protect human health by preventing exposure to contaminant in the groundwater.

- Provide information that will lead to the final remedy.

The contaminant of concern is hexavalent chromium. The records of decision set the cleanup goal at compliance wells as $22 \mu \mathrm{g} / \mathrm{L}$ for the pump-and-treat system and $20 \mu \mathrm{g} / \mathrm{L}$ for the redox system. 
Results of water-level monitoring within the 182-D reservoir showed that $\sim 31$ million liters of water leaked to the ground between November 2005 and March 2006. Three distinct leakage events were identified: November 5 through December 15, 2005 ( 22 million liters); January 1 through February 3, 2006 ( 4.9 million liters); and from February 23 through March 13, 2006 ( 4.5 million liters). Leakage rates were 386, 100, and 163 liters/minute, respectively, for the three events. The water table below the reservoir rose temporarily in response to the first and third events. The water-table monitoring systems did not note an obvious response to the second leakage event. Leakage from the 182-D reservoir was identified as an issue in the CERCLA five-year review (see Table 2.5-1). The operating contractor lowered the water level in the reservoir, which reduced leakage. The level is maintained at 0.6 to 1.8 meters during pumping operations and 0.3 to 0.9 meter during "standby conditions." Water will only be pumped from the 182-D reservoir during emergency conditions, i.e., if unable to pump from the 182-B reservoir. At all other times, the 182-D reservoir will be maintained in a standby condition. As discussed in Section 2.5.1.1, chromium concentrations in nearby well 199-D5-34 increased in response to decreased leakage from the reservoir.

Influence on Aquifer Conditions. During FY 2006, as well as in recent years, chromium concentrations increased in redox barrier wells beyond what was expected based on the design. At the end of FY 2006, concentrations in barrier wells ranged from below detection limits to $380 \mu \mathrm{g} / \mathrm{L}$, with concentrations in $\sim 66 \%$ of the wells below the remedial action goal of $20 \mu \mathrm{g} / \mathrm{L}$. Most of the elevated concentrations are in the northeast half of the barrier.

Recent studies assessed possible causes of chromium breakthrough. Results of those studies include the following:

- Influence of nitrate on redox barrier longevity: Nitrate is reduced as groundwater flows through the redox barrier, but reduction of nitrate is slower than chromate. Thus, only a portion of the nitrate is reduced. The presence of nitrate is estimated to decrease the reductive capacity of the barrier from 160 pore volumes to 85 pore volumes, decreasing the estimated longevity from 20 to 10 years (PNNL-15262). However, the presence of nitrate does not account for specific locations of chromate breakthrough.

- Effect of geochemical and physical heterogeneity on chromate breakthrough: A laboratory investigation evaluated physical characterization data collected from four boreholes located near barrier wells showing chromium breakthrough. Results did not provide definitive support for any of the proposed hypotheses (high hydraulic conductivity zones, zones of low reducible iron, or high hydraulic conductivity zones with low reducible iron). One exception was at the water table, where there was some indication of low reductive capacity and a higher hydraulic conductivity. Laterally continuous, high-permeability zones that contain oxic sediment near the water table are the most likely explanation for chromium breakthrough at various locations along the barrier (PNNL-15499).

- Restoring the barrier: If the cause of laterally discontinuous breakthrough along the barrier is caused by oxic transport of chromate near the water table, additional dithionite treatment will not be effective. Treatment near the water table with a technology that emplaces considerable reductive capacity is needed, such as injectable zero valent iron (PNNL-15499). A treatability test is planned for FY 2007, as directed under the CERCLA five-year review (see Table 2.5-1). 
Table 2.5-1. Issues and Actions for 100-D Area Groundwater in Second CERCLA Five-Year Review (adapted from DOE/RL-2006-20)

\begin{tabular}{|c|c|}
\hline Issues and Actions & Action Due Date \\
\hline $\begin{array}{l}\text { Action } 8-1 \text {. Complete a field investigation to investigate } \\
\text { additional sources. }\end{array}$ & March 2009 \\
\hline $\begin{array}{l}\text { Action } 9-1 \text {. Perform additional characterization of the aquifer in } \\
\text { the horn and evaluate the need to perform remedial action. }\end{array}$ & September 2009 \\
\hline $\begin{array}{l}\text { Action 9-2. Incorporate the horn into the } 100-H R-3 \text { interim ROD } \\
\text { if Action } 9-1 \text { indicates the horn contains a plume that needs } \\
\text { immediate remediation. }\end{array}$ & September 2009 \\
\hline \multicolumn{2}{|l|}{ Issue 10. Data indicate leakage from the $182-\mathrm{D}$ reservoir. } \\
\hline $\begin{array}{l}\text { Action } 10-1 \text {. Direct the operating contractor to further minimize } \\
\text { leakage. }\end{array}$ & Completed \\
\hline $\begin{array}{l}\text { Action } 11-1 . \text { Initiate limited iron amendments to evaluate whether } \\
\text { this enhances barrier performance. }\end{array}$ & September 2007 \\
\hline
\end{tabular}




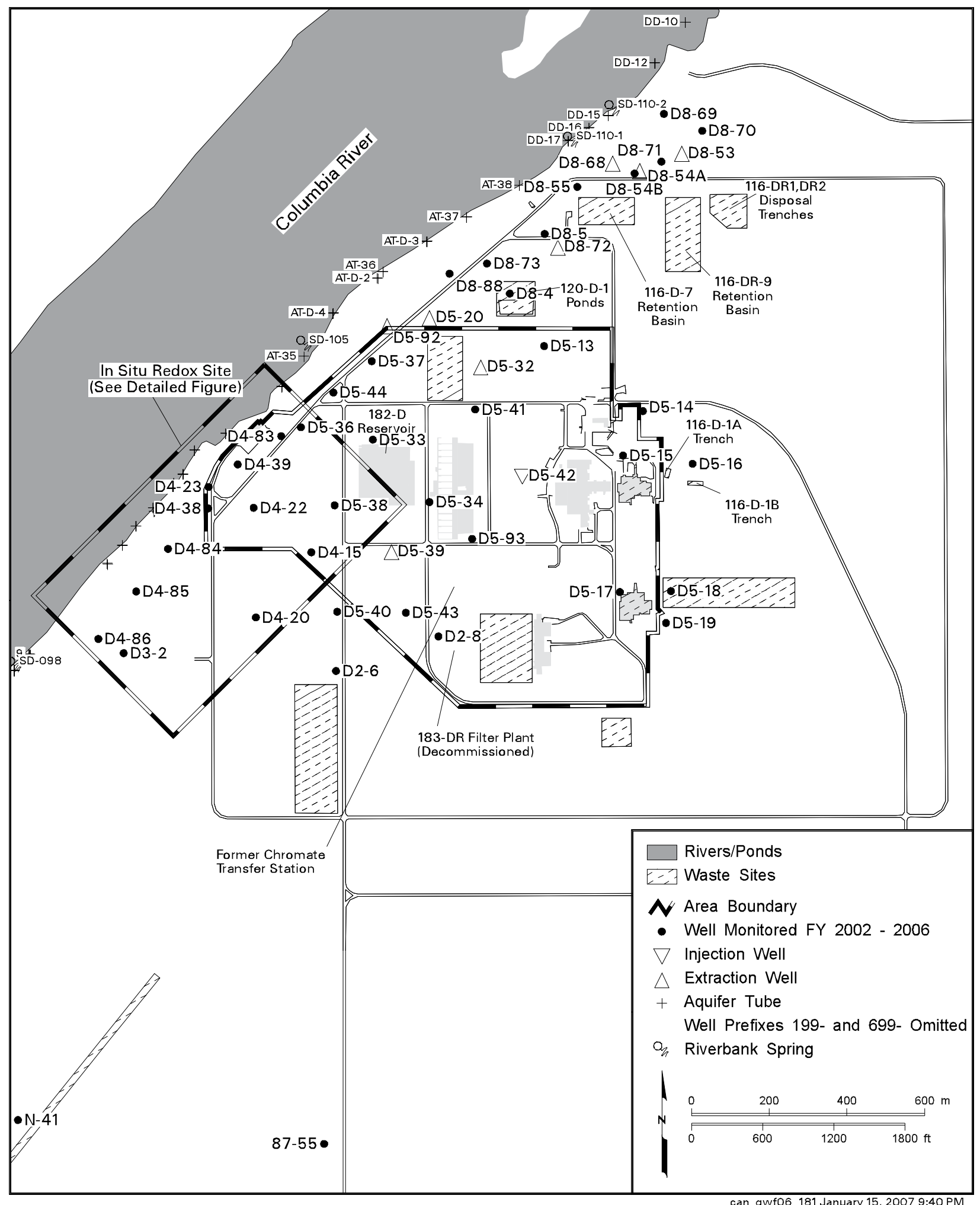

Figure 2.5-1. Groundwater Monitoring Wells in 100-D Area 


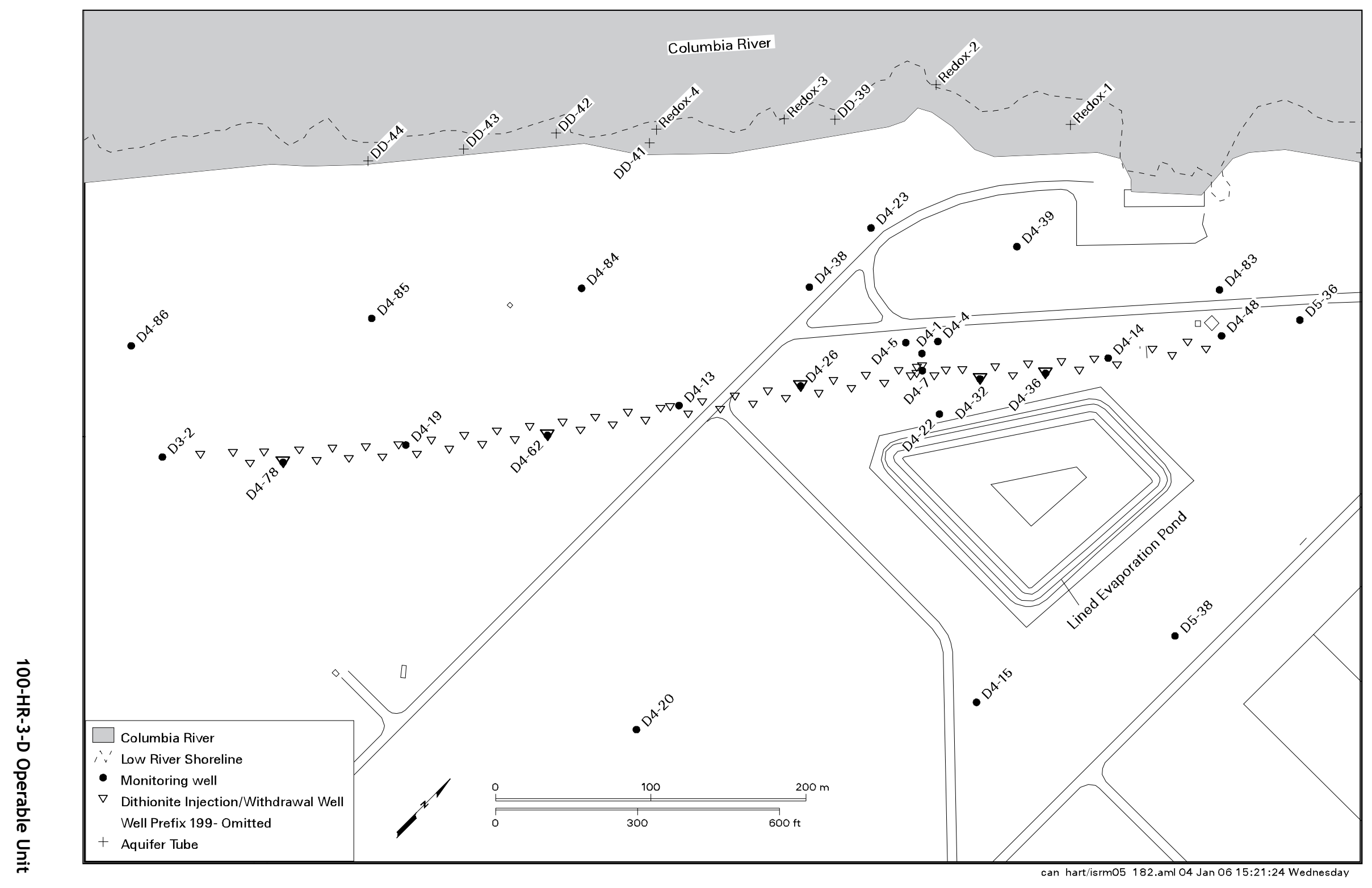

Figure 2.5-2. Groundwater Monitoring Wells Near Redox Site in 100-D Area 


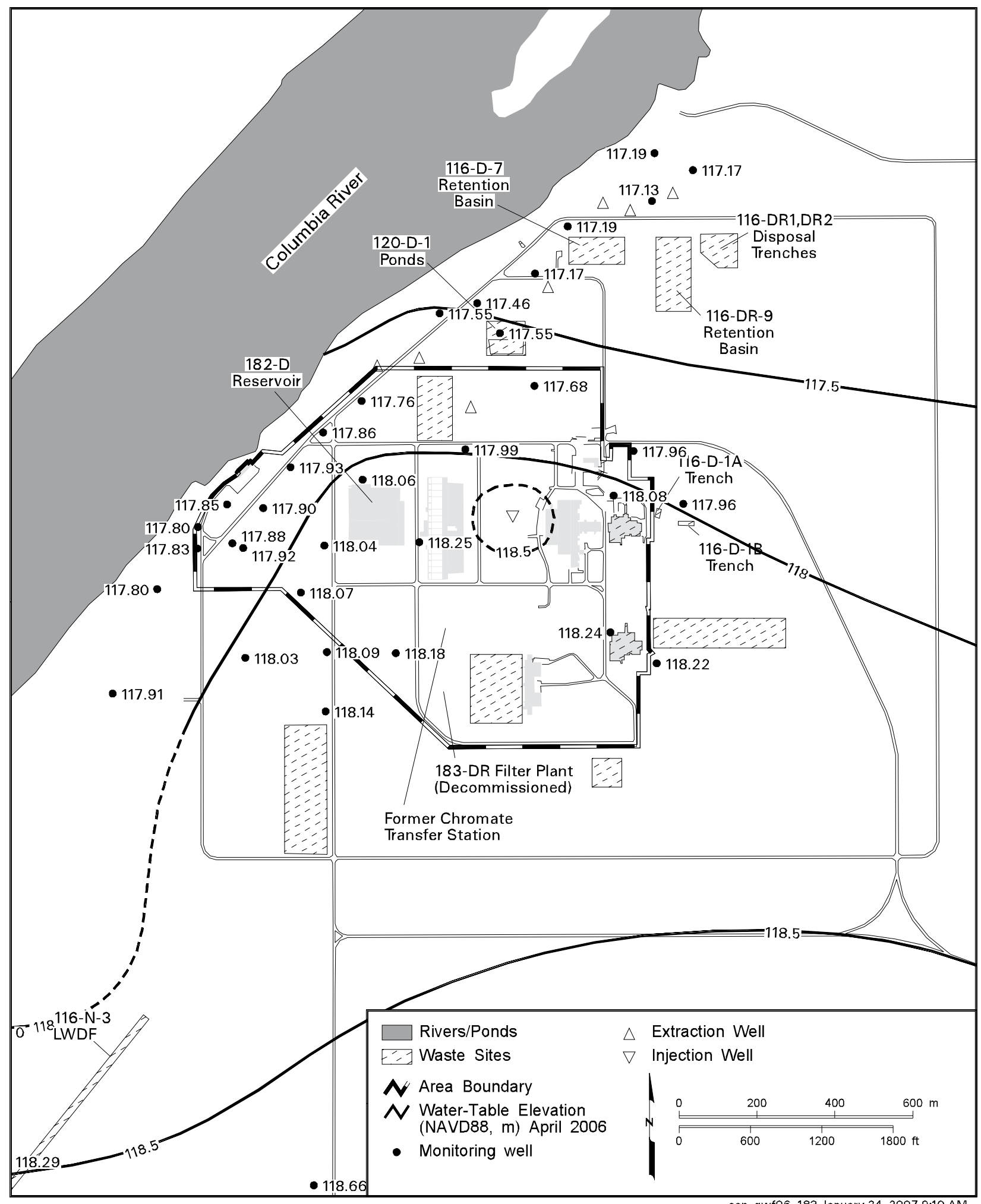

Figure 2.5-3. 100-D Area Water-Table Map, April 2006 


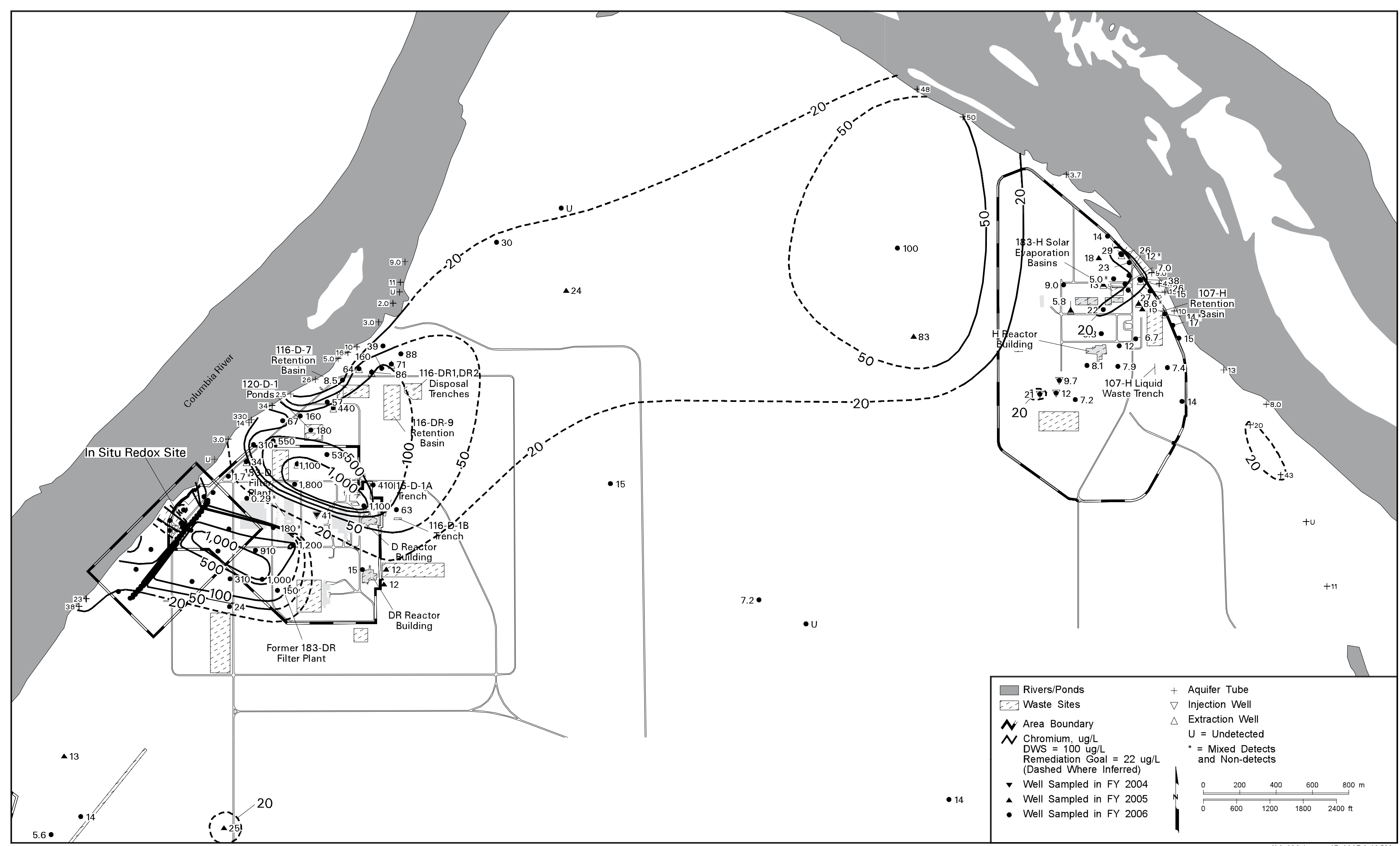

Figure 2.5-4. Dissolved Chromium Concentrations in 100-D and 100-H Areas, Upper Part of Unconfined Aquifer 


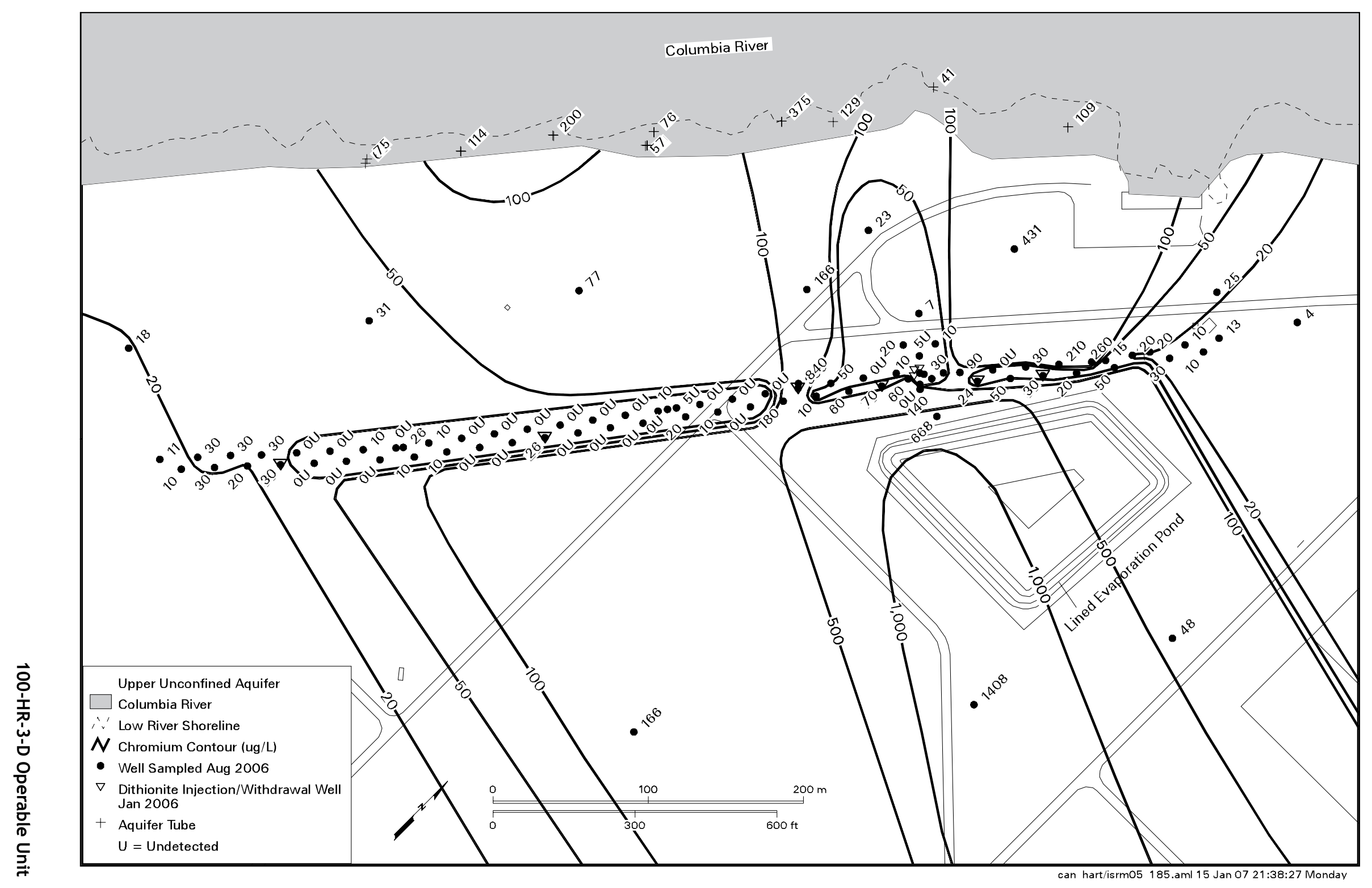

Figure 2.5-5. Dissolved Chromium Concentrations Near Redox Site, 100-D Area, August 2006 


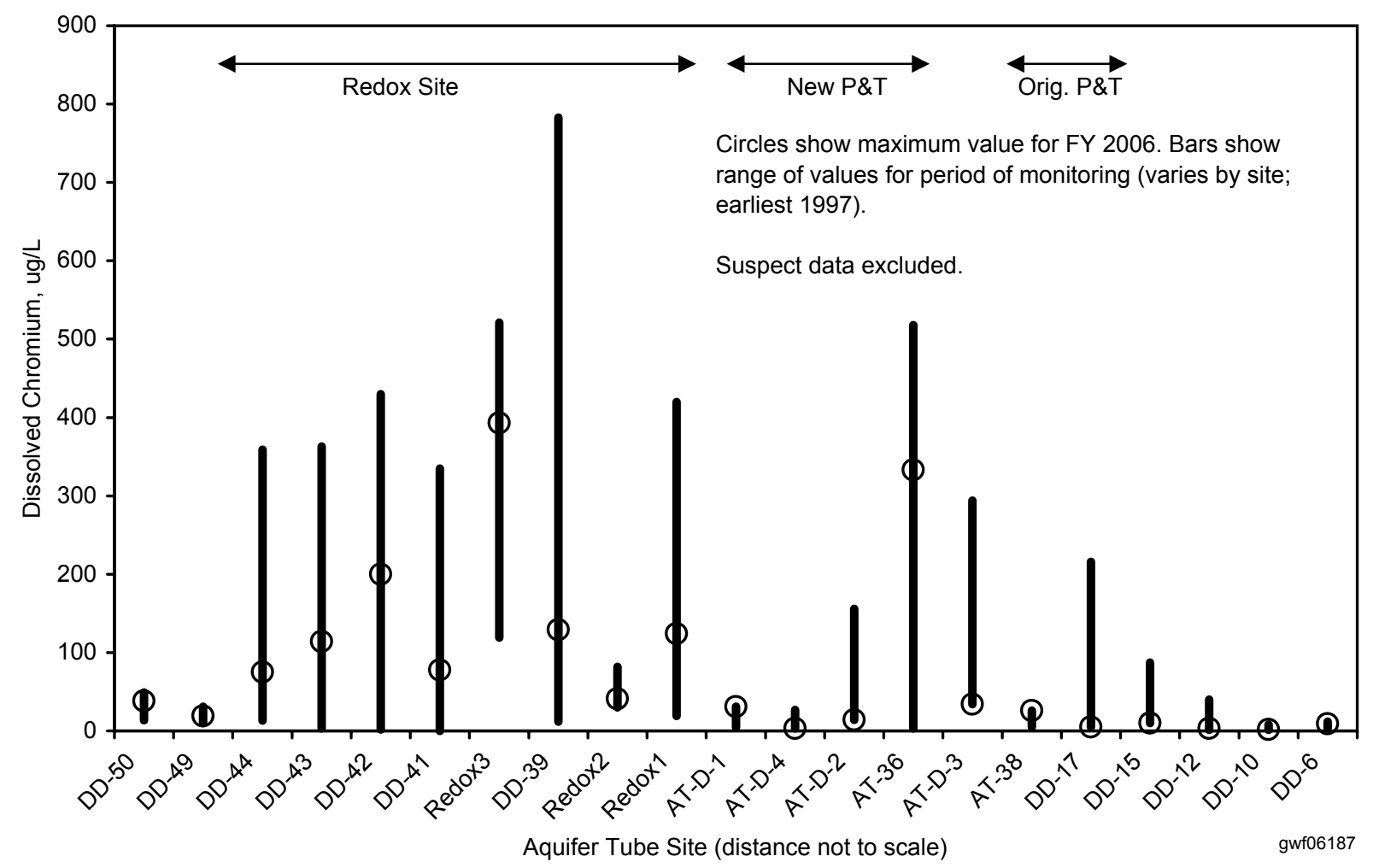

Figure 2.5-6. Dissolved Chromium Concentrations at Selected Aquifer Tube Sites at 100-D Area 

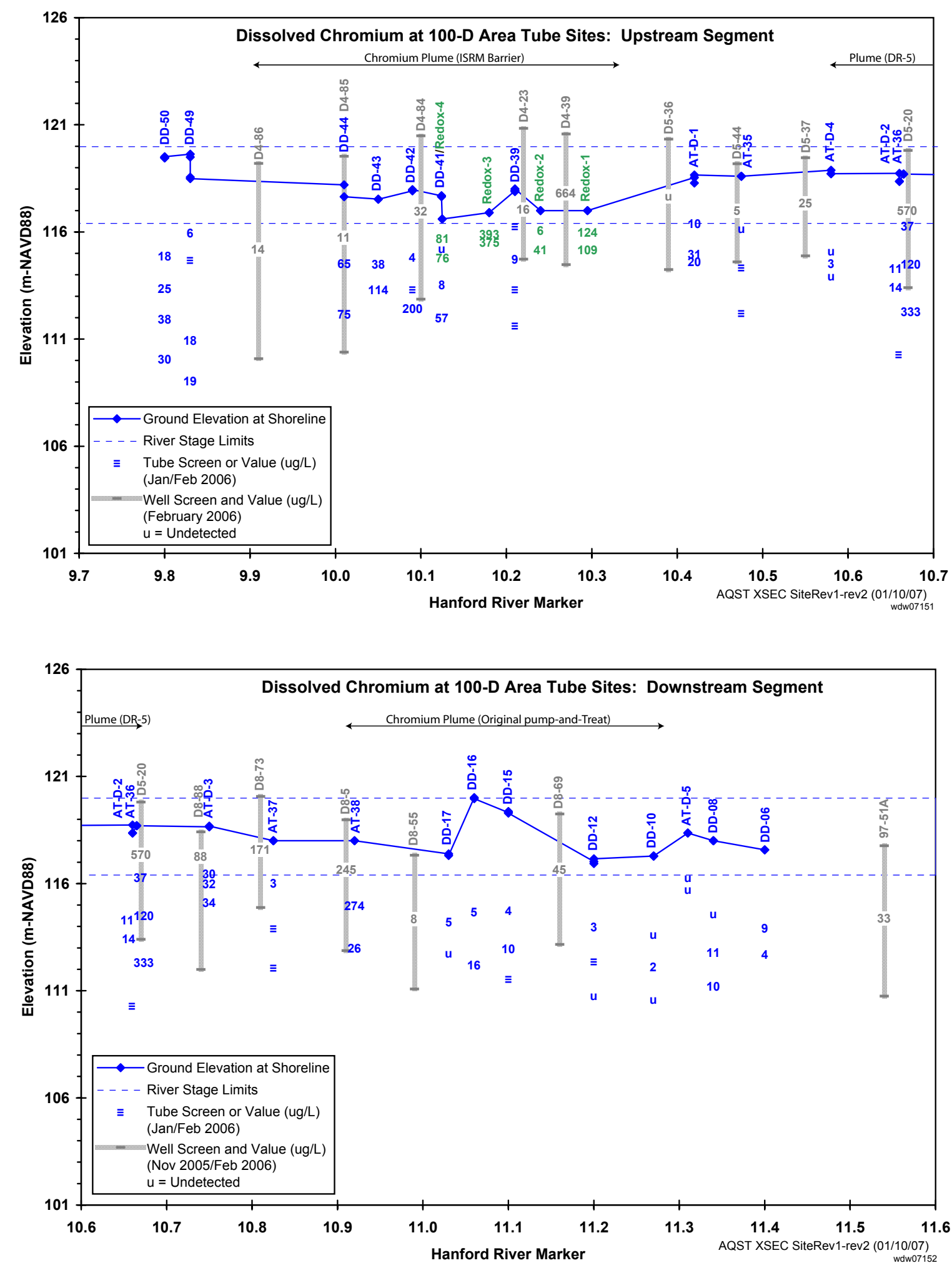

Figure 2.5-7. Cross-Section Parallel to Shoreline in 100-D Area Showing Aquifer Tube Depths, Projected Well Screen Intervals, and Dissolved Chromium Concentrations (Bottom of aquifer is at an elevation of about 92 meters.) 


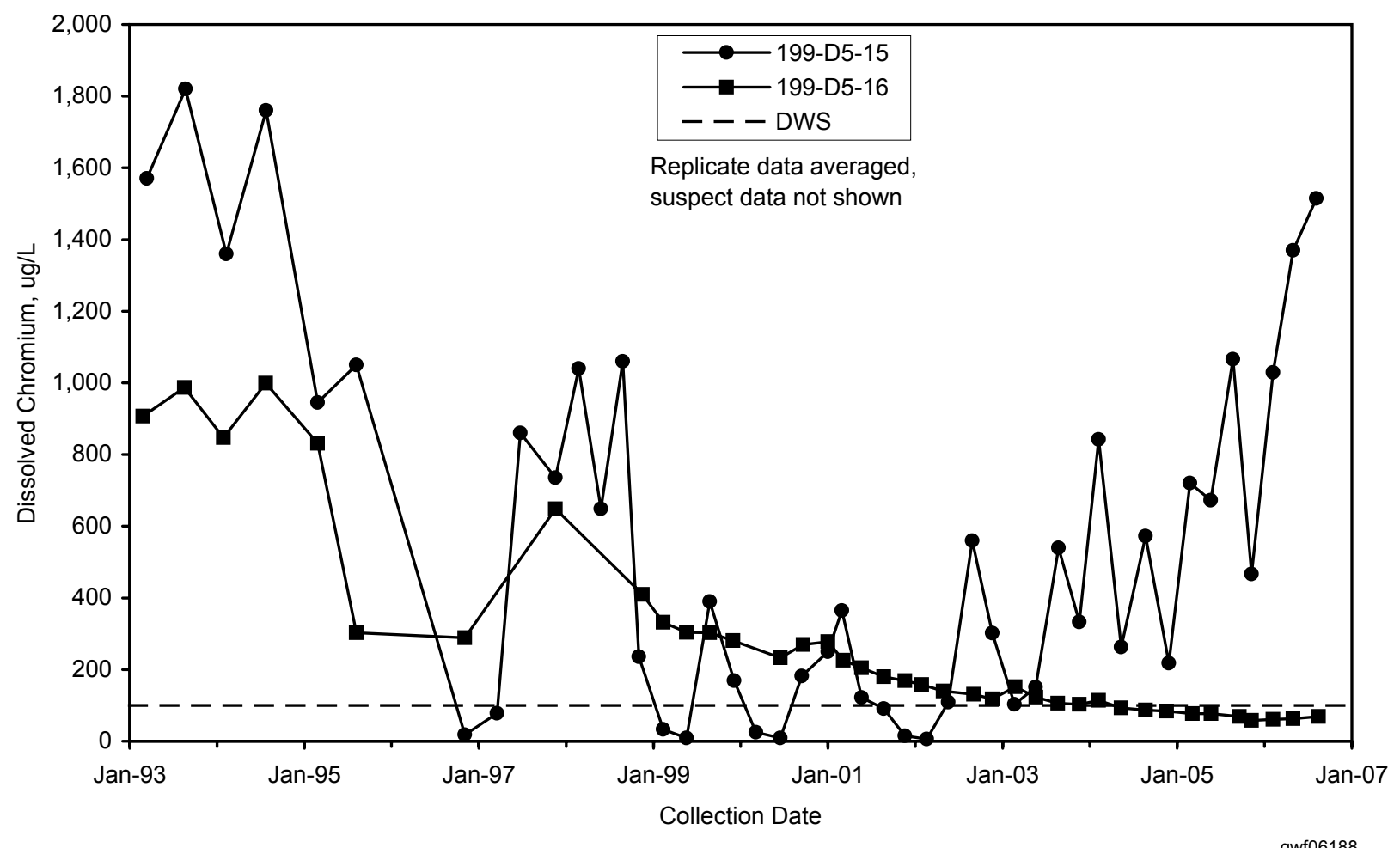

Figure 2.5-8. Chromium Concentrations in Wells Near Former D Reactor 

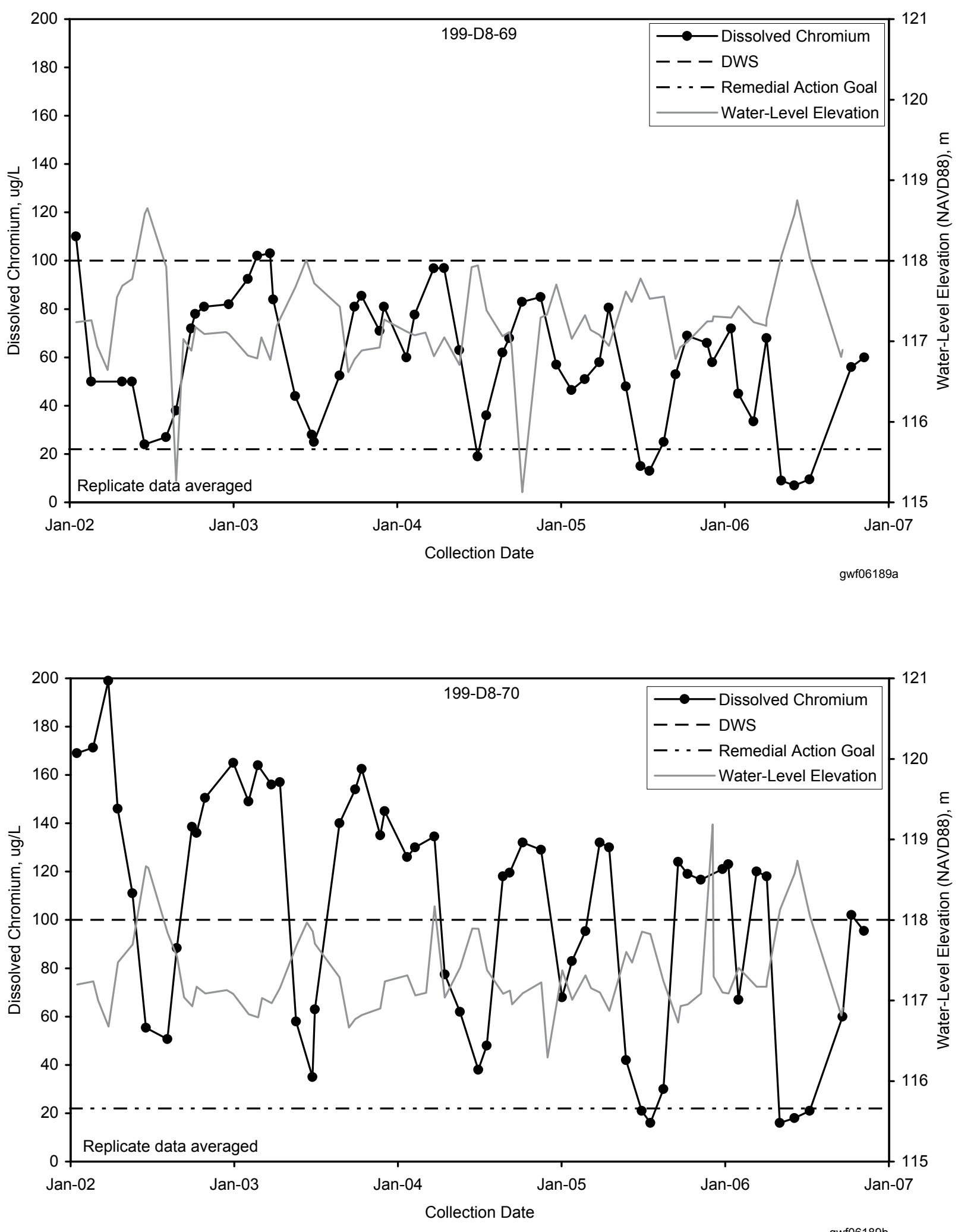

gwf06189

Figure 2.5-9. Dissolved Chromium Concentrations and Water Levels in Compliance Wells for 100-HR-3 Pump-and-Treat System at 100-D Area 


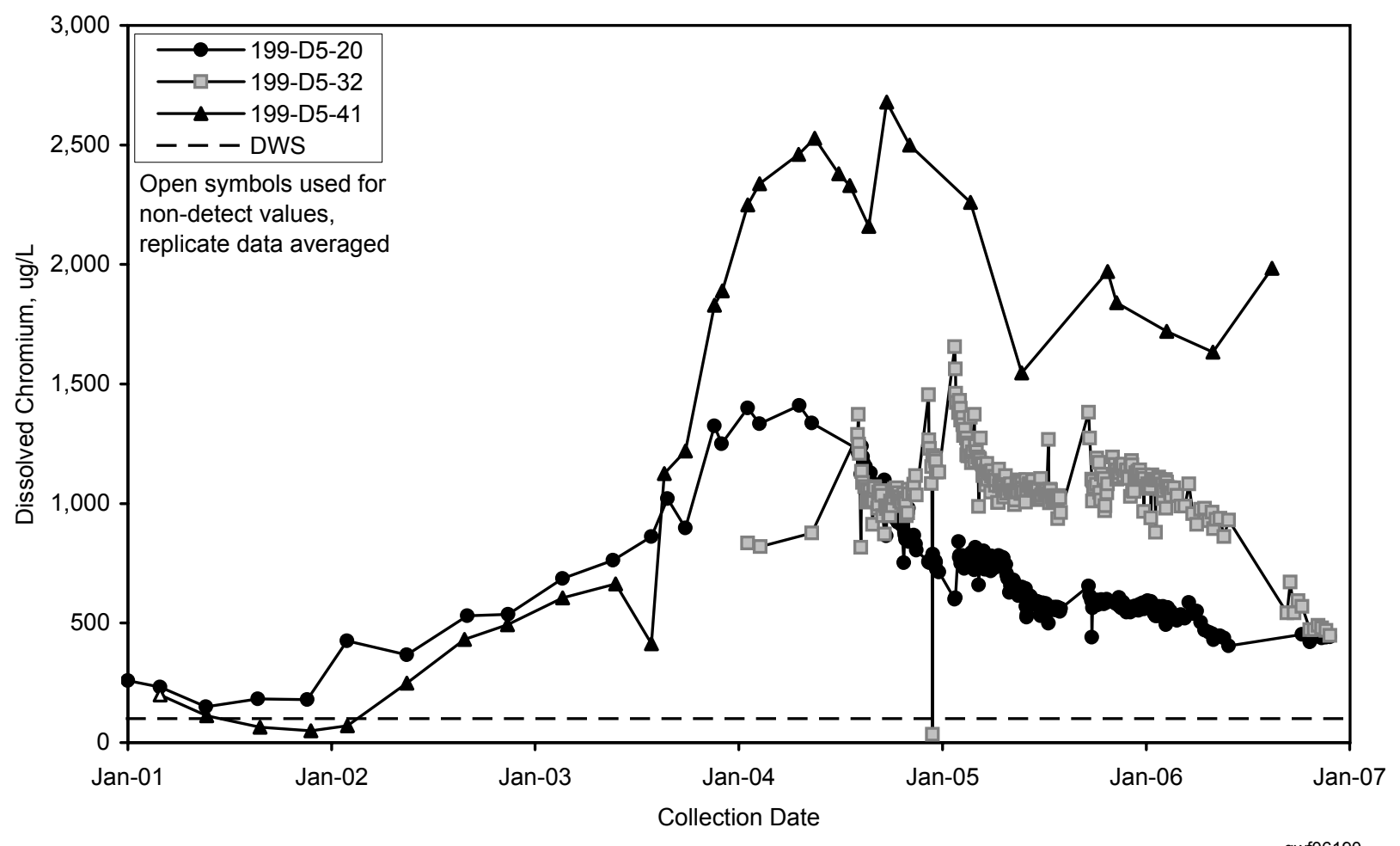

Figure 2.5-10. Dissolved Chromium Concentrations in Central 100-D Area

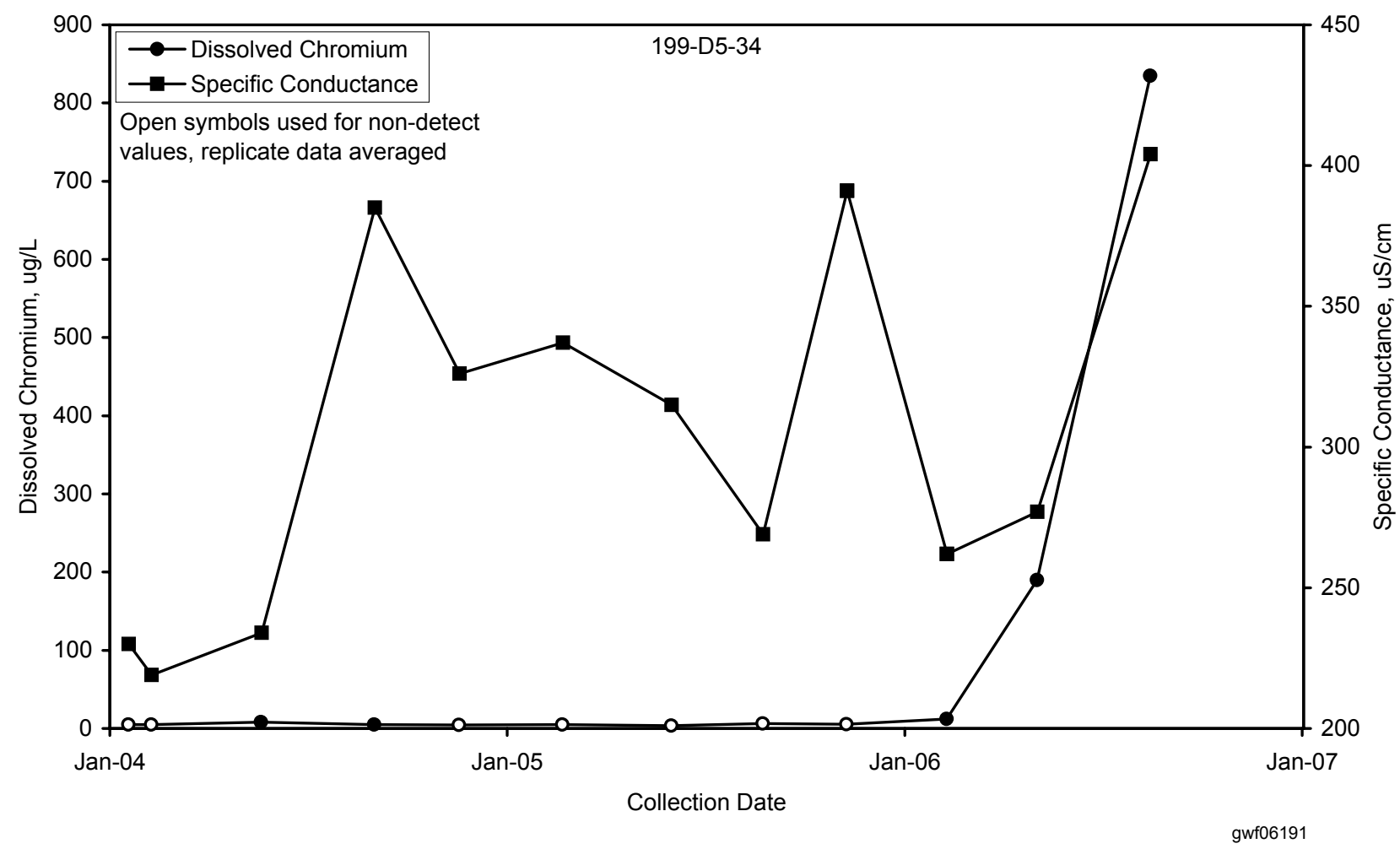

Figure 2.5-11. Dissolved Chromium Concentrations Southeast of 182-D Reservoir 

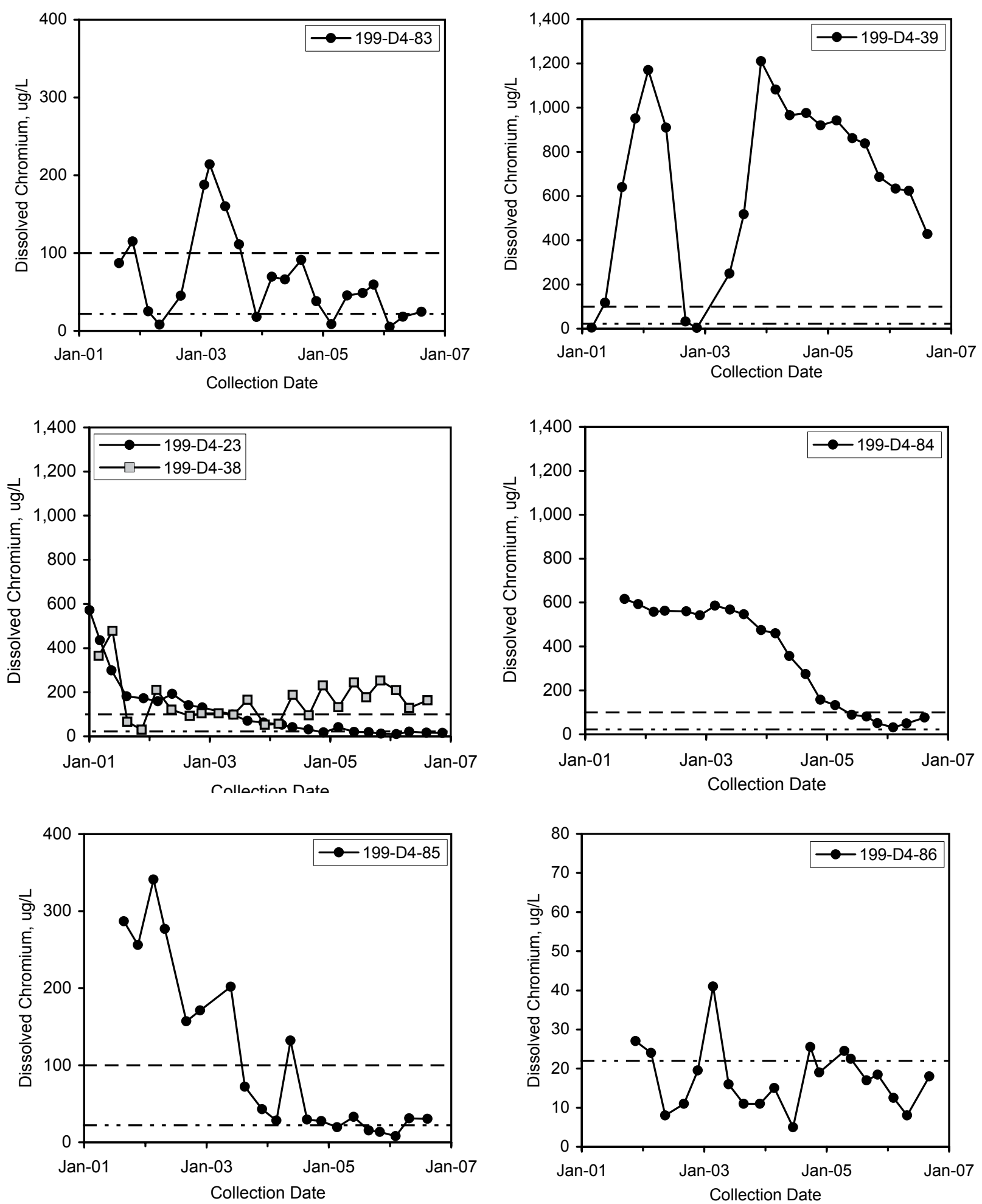

--- DWS
Suspect data not shown, replicate data averaged

gwf06192

Figure 2.5-12. Dissolved Chromium Concentrations in Compliance Wells Downgradient of Redox Barrier 

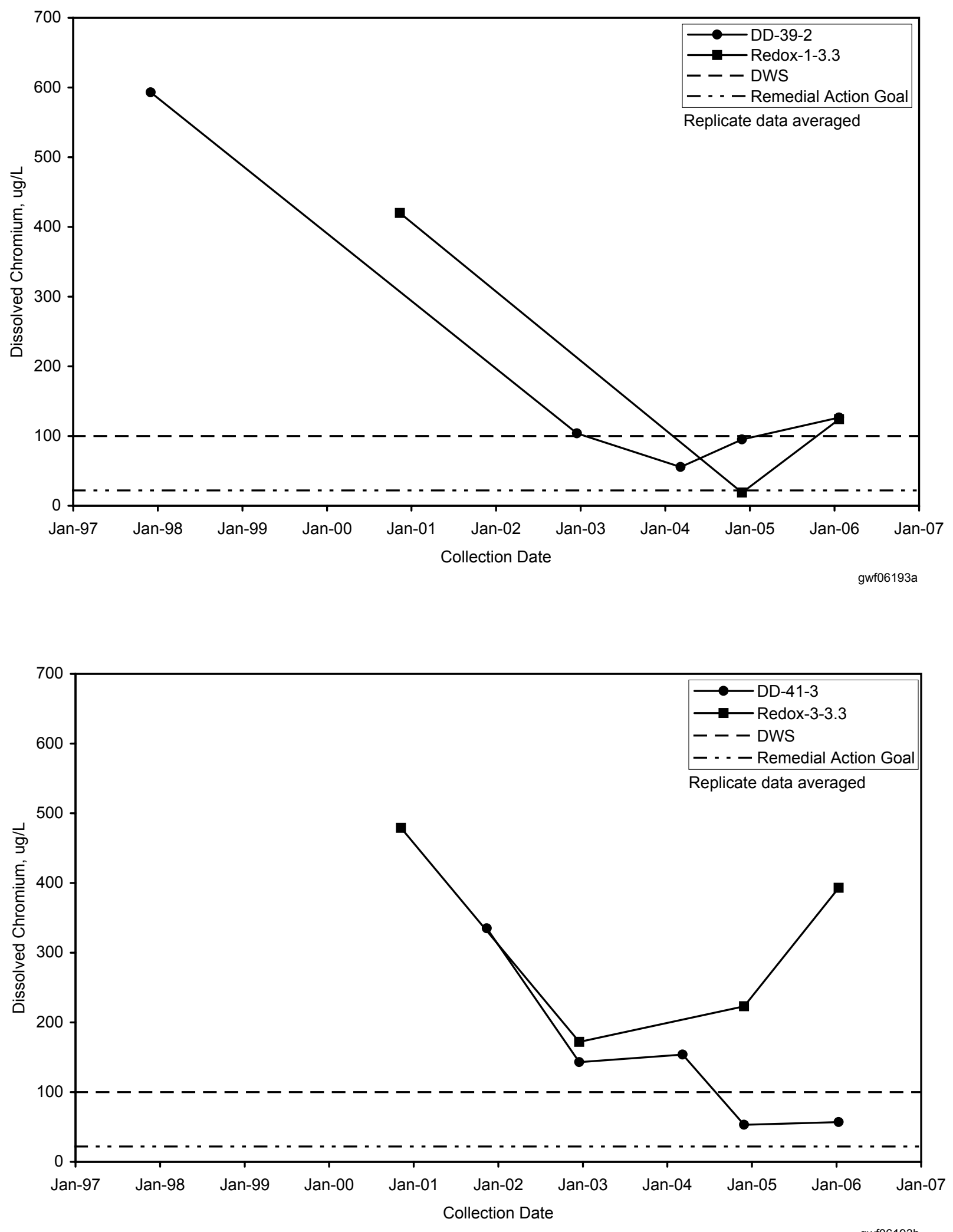

gwf06193b

gwf06193

Figure 2.5-13. Dissolved Chromium Concentrations in Aquifer Tubes Downgradient of Redox Barrier 


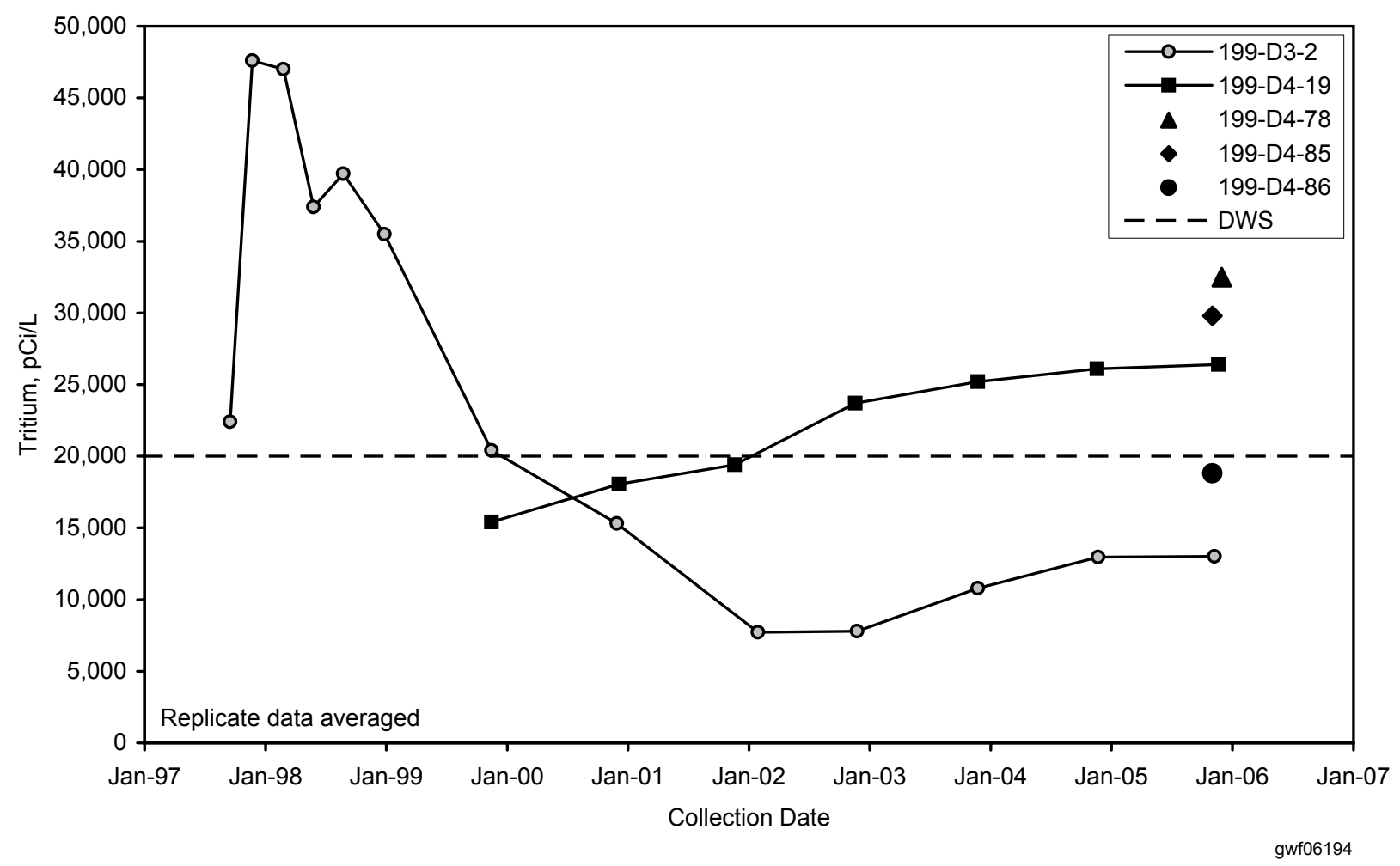

Figure 2.5-14. Tritium Concentrations in South 100-D Area 


\subsection{0-HR-3-H Operable Unit}

\section{J. Hartman and R. F. Raidl}

The scope of this section is the 100-HR-3-H groundwater interest area, which is the east portion of the 100-HR-3 Operable Unit (see Figure 1.0-1 in Section 1.0). The "groundwater interest areas" are informally defined to facilitate scheduling, data review, and interpretation. Figure 2.6-1 shows facilities, wells, and shoreline monitoring sites in this region. Chromium is the contaminant of greatest significance in groundwater. Groundwater is monitored to assess the performance of a Comprehensive Environmental Response, Compensation, and Liability Act (CERCLA) interim action pump-and-treat system for chromium, to track other contaminant plumes, and for the 116-H-6 evaporation basins, a Resource Conservation and Recovery Act (RCRA) unit.

Groundwater flows primarily from the southwest to northeast beneath the 100-H Area, discharging to the Columbia River (Figure 2.6-2). Local flow directions are influenced by groundwater extraction and injection. Groundwater flows generally toward the northeast across the entire horn of the Columbia River north of Gable Mountain, so groundwater approaching the 100-H Area may contain contaminants that originated in the 100-D and 100-N Areas.

The remainder of this section describes contaminant plumes and concentration trends for the contaminants of interest (Section 2.6.1), summarizes groundwater remediation (Section 2.6.2), and discusses groundwater monitoring of the 116-H-6 evaporation basins (Section 2.6.3).

\subsubsection{Groundwater Contaminants}

This section describes monitoring results for chromium, strontium-90, technetium-99, uranium, nitrate, and tritium.

\subsubsection{Chromium}

Hexavalent chromium is the contaminant of concern for the 100-HR-3 groundwater interim action (ROD 1996a), which includes the 100-H Area. The pump-and-treat system is discussed in Section 2.6.2. This section describes the distribution and trends of hexavalent chromium. Results for filtered samples analyzed for total chromium represent hexavalent chromium, which is more soluble than trivalent chromium (WHC-SD-EN-TI-302). Many groundwater samples also are analyzed specifically for hexavalent chromium.

Groundwater monitoring in the 100-HR-3-H groundwater interest area includes the following monitoring activities:

\section{CERCLA and AEA Monitoring}

- Wells are sampled monthly to semiannually to monitor the pump-and-treat system.

- Wells are sampled annually to biennially for contaminants of concern and constituents of interest.

- Riverbank springs and aquifer tubes are sampled annually along the 100-H Area river shore.

- During FY 2006, six wells were not sampled as scheduled (see Appendix A).

Facility Monitoring - 116-H-6 Evaporation Basins

- Four downgradient wells are sampled annually for requirements of RCRA and AEA.

- Sampling is coordinated with CERCLA to avoid duplication.

- In FY 2006, all wells were sampled as scheduled. 
Plume areas (square kilometers) at the 100-HR-3-H Operable Unit:

Chromium, $20 \mu \mathrm{g} / \mathrm{L}-3.9$

Nitrate, $45 \mathrm{mg} / \mathrm{L}-0.09$

Strontium-90, 8 pCi/L -0.17

Uranium, $30 \mu \mathrm{g} / \mathrm{L}-<0.01$

The 100-H Area chromium plume has shrunk significantly in recent years, and only small portions of the plume had FY 2006 average concentrations that exceeded the remedial action goal of $22 \mu \mathrm{g} / \mathrm{L}$ (see Figure 2.5-4 in Section 2.5). Concentrations in all shallow wells have been below the $100-\mu \mathrm{g} / \mathrm{L}$ drinking water standard since 2001. The plume had various sources, but the highest concentrations in fiscal year (FY) 2006 were in well 199-H4-3, located near the former 116-H-6 evaporation basins. FY 2006 chromium concentrations in this well ranged from $73 \mu \mathrm{g} / \mathrm{L}$ in July 2006 to $12 \mu \mathrm{g} / \mathrm{L}$ in September 2006 (Figure 2.6-3). Chromium concentrations in this area decreased more than an order of magnitude since the 1980s.

Chromium concentrations in the current six extraction wells are plotted in Figure 2.6-4. Concentrations declined during FY 2006, and were mostly below the $22-\mu \mathrm{g} / \mathrm{L}$ remedial action goal by late winter or spring, with the exception of well 199-H4-3. Concentrations in the latter well spiked in May and July 2006, to a maximum of $73 \mu \mathrm{g} / \mathrm{L}$. By September, concentrations were again below the remedial action goal. Coincident spikes of nitrate, technetium-99, and uranium were observed. The cause of the variability is unknown, but may relate to movement of contamination from the vadose zone into groundwater.

Chromium concentrations in wells $199-\mathrm{H} 4-12 \mathrm{C}$ and 199-H4-15CS, which monitor deeper in the Ringold Formation, continued to be elevated (maximum $95 \mu \mathrm{g} / \mathrm{L}$ in both wells). Concentrations are declining in well 199-H4-12C and stable in well 199-H4-15CS. Concentrations of other contaminants that would indicate the influence of the 116- $\mathrm{H}-6$

Chromium concentrations are all below the drinking water standard in the upper aquifer of 100-H Area, and most averaged less

than the 22- $\mu g / L$ remedial action goal in FY 2006. basins (nitrate, technetium-99, and uranium) are low in the deeper wells. The source of this deeper chromium is unknown.

Wells upgradient of the $100-\mathrm{H}$ Area continued to have chromium concentrations near the drinking water standard (maximum $106 \mu \mathrm{g} / \mathrm{L}$ in well 699-97-43), but concentrations show an overall decline since the early 1990s (Figure 2.6-5). The source of this contamination is probably old contamination that originated in the 100-D Area when a water-table mound was present there (WHC-SD-EN-TI-023). Figure 2.5-4 in Section 2.5 illustrates chromium distribution in the region between 100-D and 100-H Areas. Additional groundwater monitoring wells are planned for FY 2007 in this region to define the chromium plume.

Chromium concentrations in aquifer tubes are highest upstream and downstream of the main 100-H Area (Figure 2.6-6). Tubes AT-43 and AT-44, north of the 100-H Area, intercept part of the plume that has moved across the horn, and concentrations have been as high as $50 \mu \mathrm{g} / \mathrm{L}$ in recent years. South of the main $100-\mathrm{H}$ Area at tube sites 50 and 51 , the maximum concentration in FY 2006 was $43 \mu \mathrm{g} / \mathrm{L}$ (Figure 2.6-7). This contamination south of the main 100-H Area could have moved south along the shoreline from $100-\mathrm{H}$ Area sources. Chromium was lower in tubes monitoring the shoreline downgradient of the 100-H Area pump-and-treat system (undetected to $15 \mu \mathrm{g} / \mathrm{L}$ ).

\subsubsection{Strontium-90}

Strontium-90 concentrations continued to exceed the drinking water standard ( $8 \mathrm{pCi} / \mathrm{L})$ beneath a portion of the southeast 100-H Area near the former retention basin and disposal trenches. The plume distribution has not changed appreciably in over 10 years (see Figure 2.6-8 in PNNL-15670 for a FY 2005 map). The highest concentration in FY 2006 was $40 \mathrm{pCi} / \mathrm{L}$ in well $199-\mathrm{H} 4-63$. Strontium-90 was analyzed in two aquifer tubes in the 100-H Area in FY 2006. The concentrations were below the drinking water standard at 6.8 and $3.4 \mathrm{pCi} / \mathrm{L}$ in tubes $47-\mathrm{M}$ and AT-H-3-S, respectively.

\subsubsection{Technetium-99 and Uranium}

Technetium-99 is elevated in groundwater downgradient of the former 116- $\mathrm{H}-6$ evaporation basins, but levels did not exceed the drinking water standard $(900 \mathrm{pCi} / \mathrm{L})$ in FY 2006. The highest concentration was $870 \mathrm{pCi} / \mathrm{L}$ in well 199-H4-3, which historically had the highest technetium-99 concentrations in the 100-H Area (Figure 2.6-8). The high 
concentration was from a May 2006 sample, and was coincident with a chromium spike discussed in Section 2.6.1.1. Uranium showed a similar trend in FY 2006, with a maximum concentration of $85.5 \mu \mathrm{g} / \mathrm{L}$ in May 2006. Well 199-H4-12A was the only other well in the 100-H Area with concentrations above the 30- $\mu \mathrm{g} / \mathrm{L}$ drinking water standard in FY 2006.

Technetium-99 concentration declined sharply in well 199-H4-9, which had a concentration spike in FY 2005 (Figure 2.6-9). The trend in the well is highly variable. Uranium showed a similar trend. The cause of the variability in technetium-99 and uranium in well 199-H4-9 is unknown.

Technetium-99 and uranium were analyzed in samples from three aquifer tubes in FY 2006. The highest concentrations were in tube AT-H-3-S, where technetium-99 and uranium were reported at $35.4 \mathrm{pCi} / \mathrm{L}$ and $1.17 \mu \mathrm{g} / \mathrm{L}$, respectively.

\subsubsection{Tritium}

Tritium concentrations continued to decline in most wells. The highest concentration in the $100-\mathrm{H}$ Area was $4,380 \mathrm{pCi} / \mathrm{L}$ in well 199-H4-9. Well 699-97-43, located west (upgradient) of the $100-\mathrm{H}$ Area, continued to have a higher tritium concentration than wells within the 100-H Area $(6,030 \mathrm{pCi} / \mathrm{L})$.

\subsubsection{Nitrate}

Nitrate concentrations continued to exceed the drinking water standard ( $45 \mathrm{mg} / \mathrm{L})$ in numerous wells near the former 116-H-6 evaporation basins. The highest concentration was $253 \mathrm{mg} / \mathrm{L}$ in well 199-H4-3 in May 2006, coincident with spikes in co-contaminants discussed in previous sections.

A second nitrate plume in southeast 100-H Area is shrinking, and in FY 2006, the only results that exceeded the drinking water standard were in well 199-H4-46 (47.8 mg/L) and aquifer tube $50-\mathrm{M}(47.4 \mathrm{mg} / \mathrm{L})$. Nitrate concentrations have been stable at these sites in recent years.

\subsubsection{Interim Groundwater Remediation for Chromium}

A pump-and-treat system operates in the 100-H Area as part of a CERCLA interim action for the 100-HR-3-H Operable Unit (ROD 1996a). Interim remedial action monitoring is described in DOE/RL-96-90. Long-term monitoring requirements in the 100-H Area were derived from Change Control Form 107 as modified by Fluor Hanford, Inc. ${ }^{\text {(a) }}$ Figure 2.6-1 displays locations of extraction and injection wells and Appendix A lists sampling frequencies and constituents.

\subsubsection{Progress During FY 2006}

The 100-H pump-and-treat system is reducing overall contamination in the operable unit by removing contaminant mass. During FY 2006, the pump-and-treat system extracted $\sim 155.9$ million liters of groundwater from the $100-\mathrm{H}$ Area, removing $\sim 5.2$ kilograms of hexavalent chromium.

The pump-and-treat system has removed $\sim 47$ kilograms of hexavalent chromium from the 100-H Area groundwater since startup in July 1997. This represents more than the $\sim 42$ kilograms
Technetium-99, uranium, and nitrate declined from last year's sharp peaks in well 199-H4-9, northeast of the former 116-H-6 evaporation basins. The cause of the variability is unknown.

Nitrate
concentrations
exceed drinking
water standards
near the
former 116-H-6
evaporation basins.

The remedial action objectives for the 100-HR-3 Operable Unit (ROD 1996a) are:

- Protect aquatic receptors in the river bottom from contaminants in groundwater entering the Columbia River.

- Protect human health by preventing exposure to contaminant in the groundwater.

- Provide information that will lead to the final remedy.

The contaminant of concern is hexavalent chromium. The record of decision specifies the cleanup goal at compliance wells as $22 \mu \mathrm{g} / \mathrm{L}$.

(a) Letter FH-0502977 from RG Gallagher (Fluor Hanford, Inc.) to Dr. LK Peters (Pacific Northwest National Laboratory), Tables Specifying Fluor Hanford Performance Sampling Requirements for Fiscal Year 2006, dated October 12, 2005. 
During FY 2006, the pump-and-treat system extracted >155.9 million liters of groundwater from the 100-H Area, removing $\sim 5.2$ kilograms of hexavalent chromium. estimated in the plume in 1992 (WHC-SA-1674-VA). That estimate did not include chromium from upgradient sources (100-D Area) nor in the vadose zone.

The second CERCLA five-year review was published in November 2006 (DOE/RL2006-20). The review identified one issue ${ }^{(b)}$ pertaining to the $100-\mathrm{H}$ Area:

- Issue 12: Groundwater samples from one deep well extending below the aquitard exceed the drinking water standard. The extent of chromium in this zone is not well understood.

- Action 12-1: Perform additional characterization of the aquifer below the initial aquitard (due date September 2009).

\subsubsection{Influence on Aquifer Conditions}

Chromium concentrations in 100-H Area groundwater have declined, and the plume in the uppermost aquifer has shrunk. Those changes are likely due to a combination of the effects of the pump-and-treat system and dispersion (i.e., natural processes). In FY 2006, with Washington State Department of Ecology (Ecology) approval, U.S. Department of Energy (DOE) modified the injection well network, substituting well 199-H4-14 for 199-H3-2A. The major network changes since 1997 are summarized below:

\begin{tabular}{|c|c|c|c|}
\hline $1997-2004$ & January 2005 & August 2005 & February 2006 \\
\hline \multicolumn{4}{|c|}{ Extraction Wells } \\
\hline 199-H3-2A & 199-H4-4 & 199-H4-3 & 199-H4-3 \\
\hline 199-H4-7 & 199-H4-11 & 199-H4-4 & 199-H4-4 \\
\hline 199-H4-11 & 199-H4-12A & 199-H4-12A & 199-H4-12A \\
\hline 199-H4-12A & 199-H4-15A & 199-H4-15A & 199-H4-15A \\
\hline 199-H4-15A & 199-H4-64 & 199-H4-63 & 199-H4-63 \\
\hline 199-H4-65 & 199-H4-65 & 199-H4-64 & 199-H4-64 \\
\hline \multicolumn{4}{|c|}{ Injection Wells } \\
\hline 199-H3-3 & 199-H3-2A & $199-\mathrm{H} 3-2 \mathrm{~A}$ & 199-H4-14 \\
\hline 199-H3-4 & 199-H4-18 & 199-H4-7 & 199-H4-7 \\
\hline \multirow[t]{2}{*}{ 199-H3-5 } & 199-H3-5 & 199-H4-17 & 199-H4-17 \\
\hline & & 199-H4-18 & 199-H4-18 \\
\hline
\end{tabular}

Hexavalent chromium concentrations continued to decline in FY 2006 in compliance well 199-H4-5 and former compliance wells that have been converted to extraction wells. In September 2006, concentrations in former compliance wells 199-H4-4, 199-H4-63 and 199-H4-64 (now extraction wells) ranged from 12 to $18 \mu \mathrm{g} / \mathrm{L}$ (Figure 2.6-4). Similarly, concentrations continued a downward trend in compliance well $199-\mathrm{H} 4-5$ to $7 \mu \mathrm{g} / \mathrm{L}$ in September.

Results of performance monitoring are incorporated with the discussion of general contamination in Section 2.6.1. Results of operational monitoring and additional details about the pump-and-treat system for calendar year 2005 can be found in DOE/RL-2006-08. Results for 2006 will be published in an upcoming annual report on the 100-HR-3, 100-KR-4, and 100-NR-2 pump-and-treat systems.

(b) Another issue pertained to chromium in the "horn" between 100-D and 100-H Areas. It is discussed in Section 2.5. 


\subsubsection{Facility Monitoring - 116-H-6 (183-H) Evaporation Basins}

The 116-H-6 (183-H) evaporation basins are the only RCRA site in the 100-H Area. The unit was incorporated into the Hanford Facility RCRA Permit (Ecology 1994a). The site is monitored during the post-closure period under corrective action monitoring requirements of WAC 173-303-645(11)(g). The monitoring network comprises wells 199-H4-3, 199-H4-8, 199-H4-12A, and 199-H4-12C. Lists of wells and constituents monitored and a well location map are included in Appendix B.

One of the wells (199-H4-7) formerly in the RCRA network was converted to an injection well in August 2005. Thus, the well can no longer meet its objective to track chromium trends in groundwater. DOE and Ecology agreed that well 199-H4-8 would be substituted for well 199-H4-7(c) in the RCRA network.

The four wells in the RCRA network were sampled as scheduled in FY 2005 for the constituents of interest listed in the groundwater monitoring plan (PNNL-11573). Trends in the constituents of interest (except fluoride) were discussed in Section 2.6.1. Fluoride concentrations remained low $(<300 \mu \mathrm{g} / \mathrm{L})$ in groundwater downgradient of the 116-H-6 evaporation basins.

While the 100-HR-3 pump-and-treat system is operating, RCRA monitoring consists of annual sampling of four wells for chromium, fluoride, nitrate, technetium-99, and uranium. The latter two constituents are not regulated under RCRA but were included in the monitoring plan for completeness and were incorporated by reference in the Hanford Facility RCRA Permit (Ecology 1994a). The objective of monitoring during the operation of the pump-and-treat

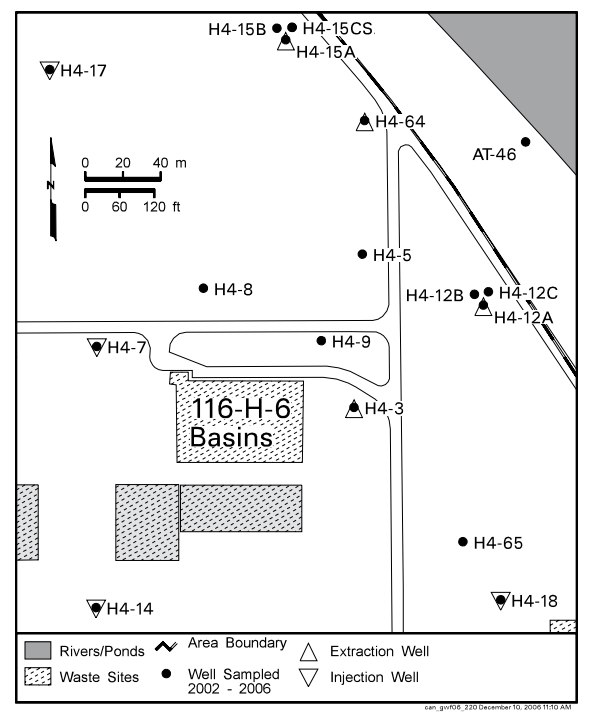
system is to determine whether concentrations of the contaminants of concern are

(c) Hanford Facility RCRA Permit Modification Notification Form, signed by GP Davis (Washington State Department of Ecology), January 10, 2006. 183-H Solar Evaporation Basins, Part VI, Chapter 2 and Attachment 37. 


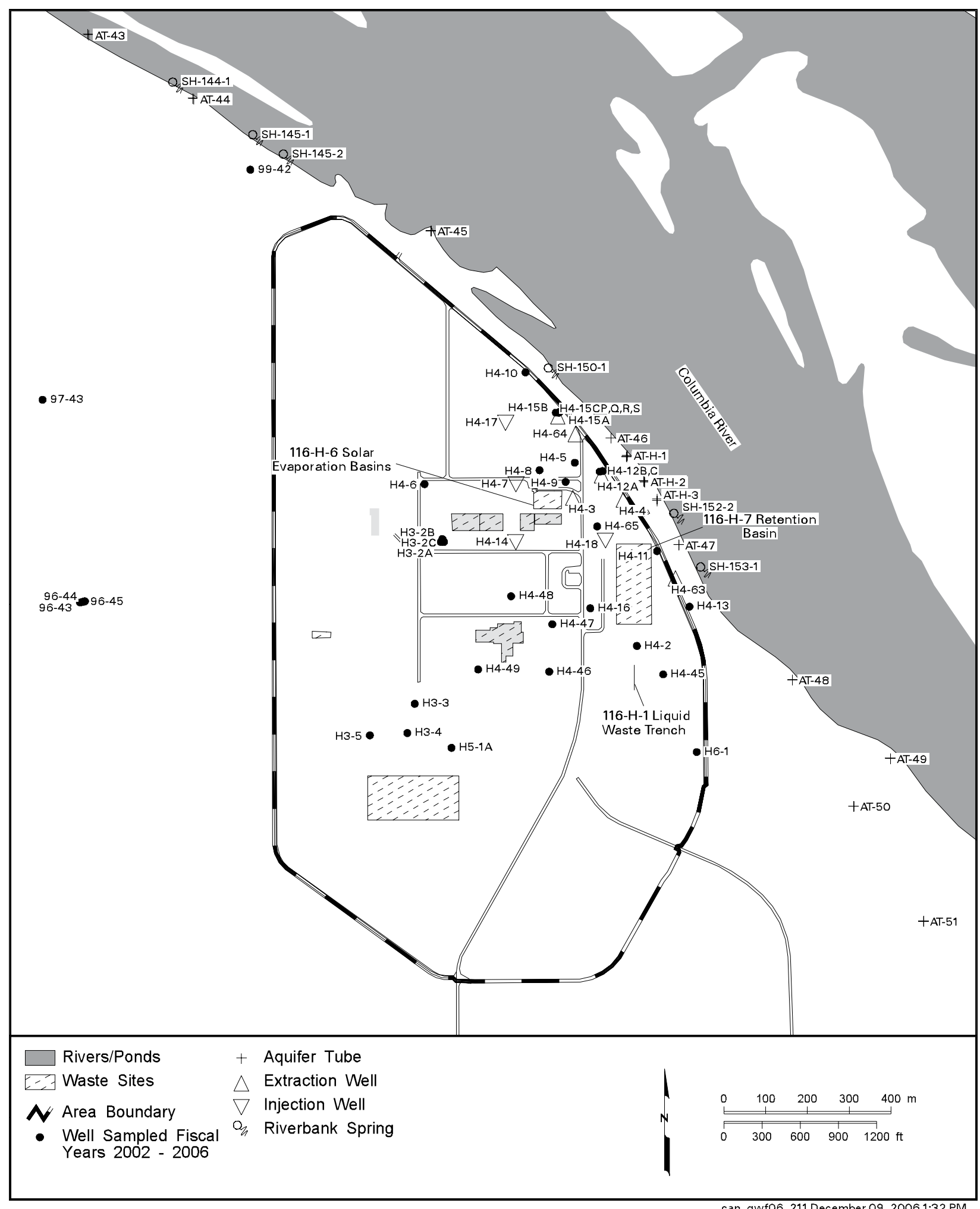

Figure 2.6-1. Groundwater Monitoring Wells in 100-H Area 


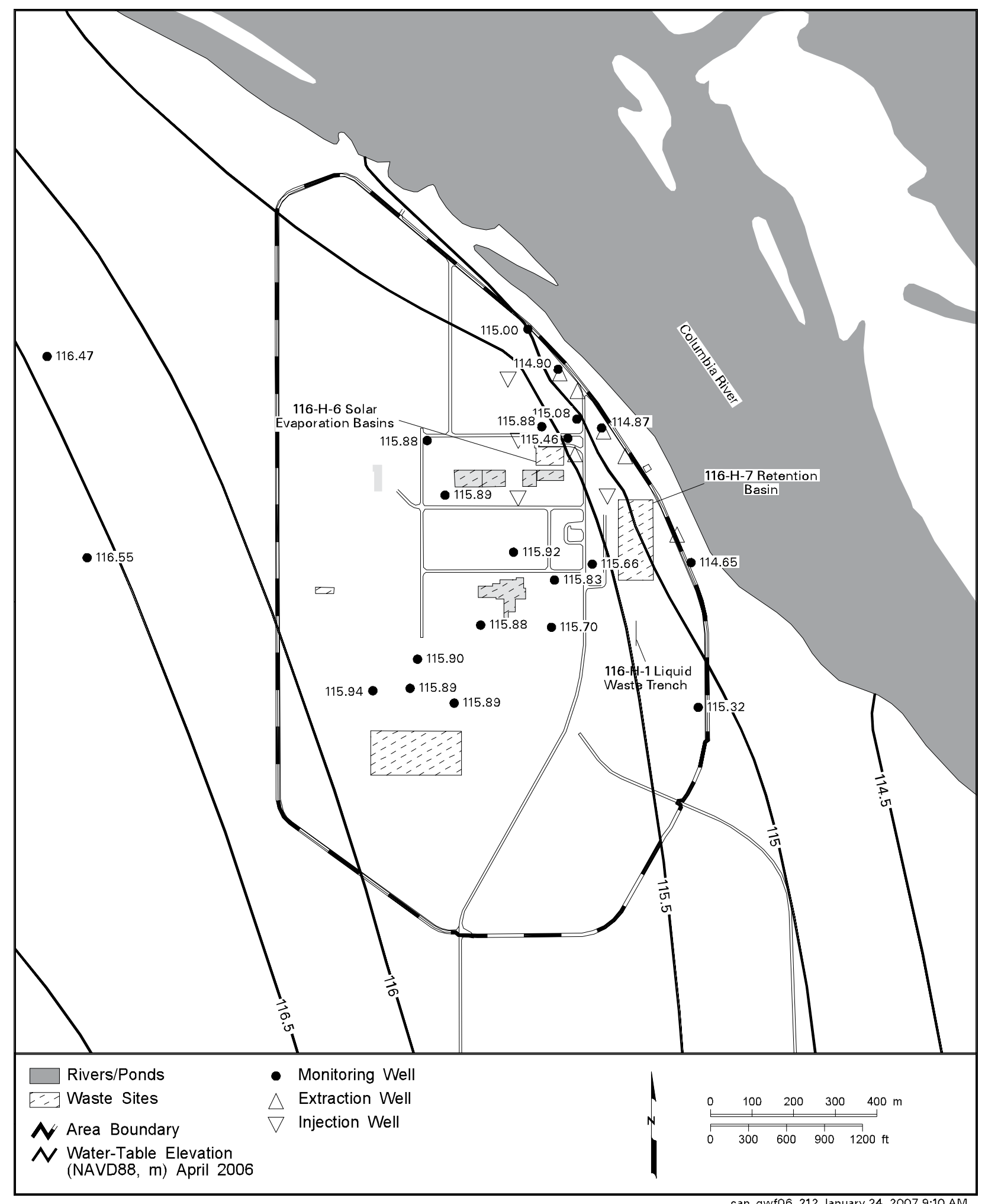

Figure 2.6-2. 100-H Area Water-Table Map, April 2006 


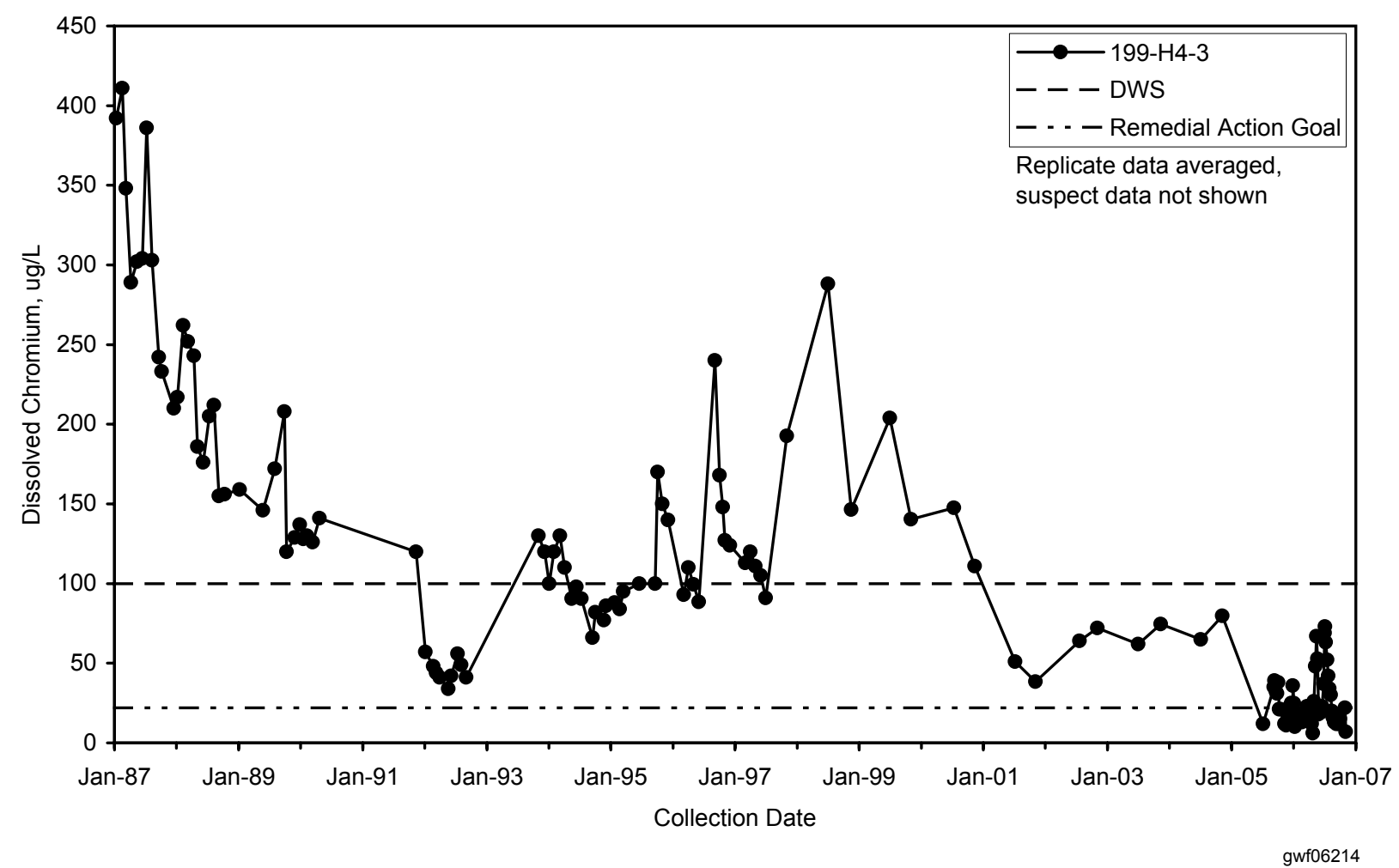

Figure 2.6-3. Chromium Concentrations East of 116-H-6 Evaporation Basins 


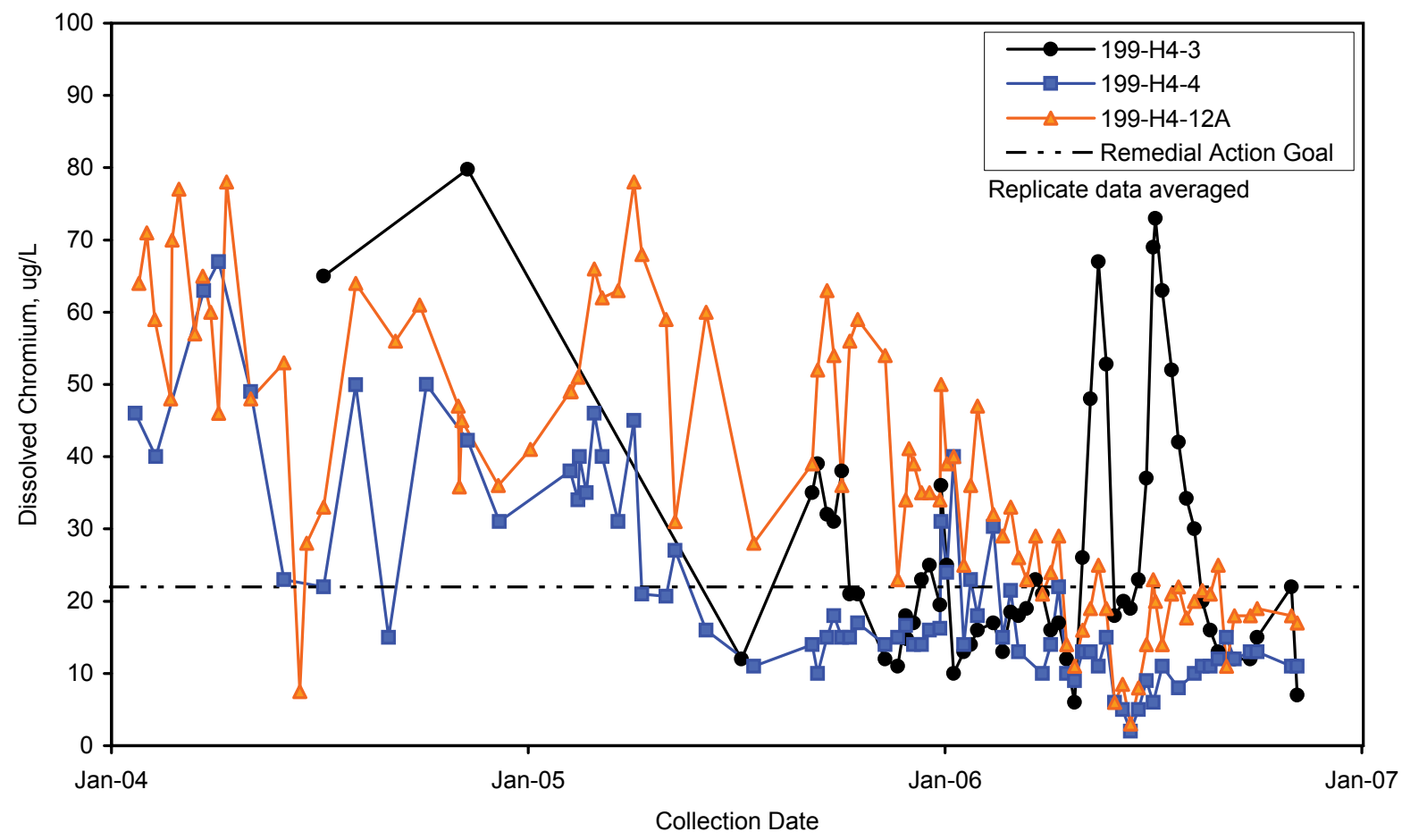

gwf06215a

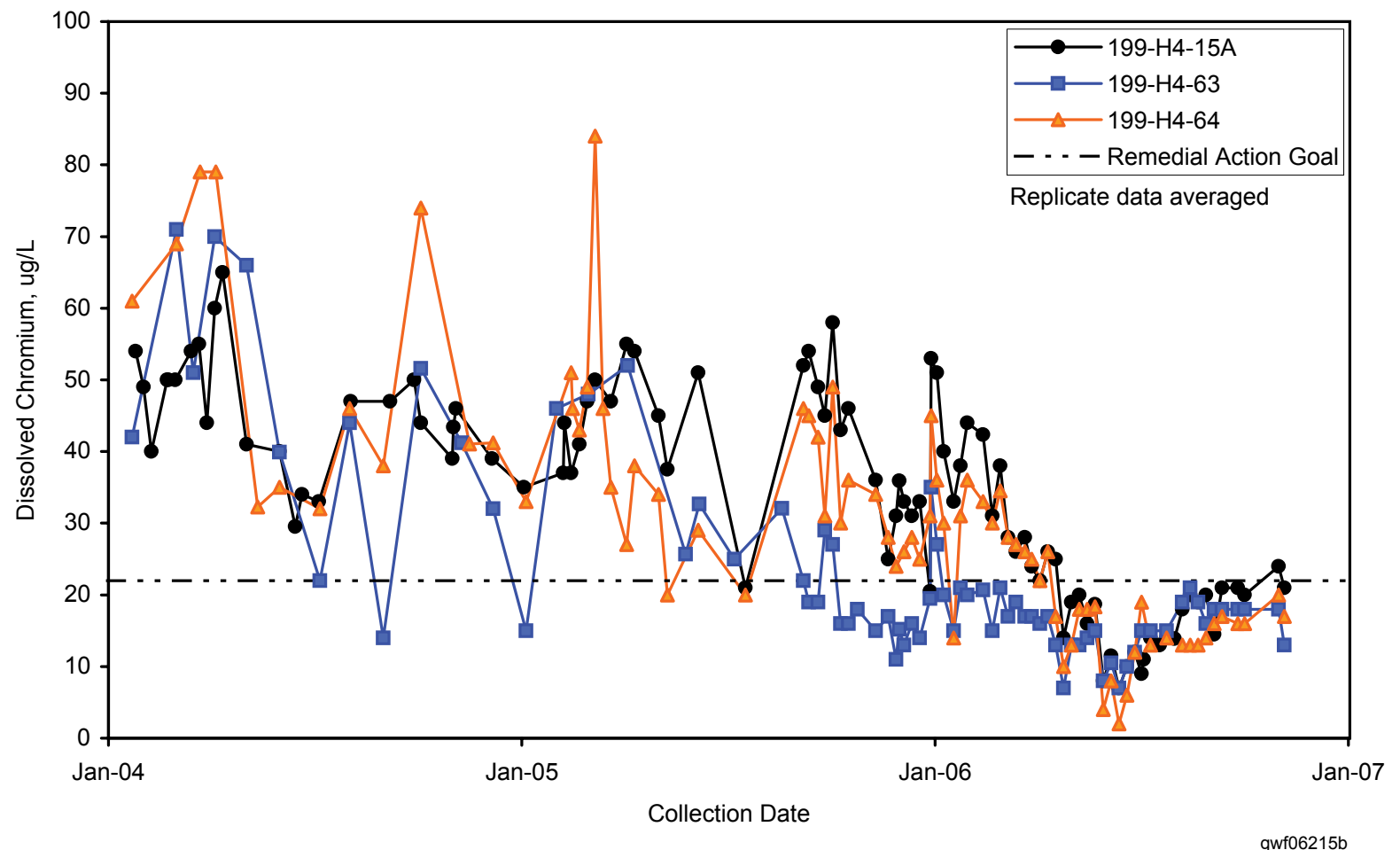

gwf06215

Figure 2.6-4. Chromium Concentrations in Extraction Wells for 100-HR-3 Pump-and-Treat System at $100-\mathrm{H}$ Area 


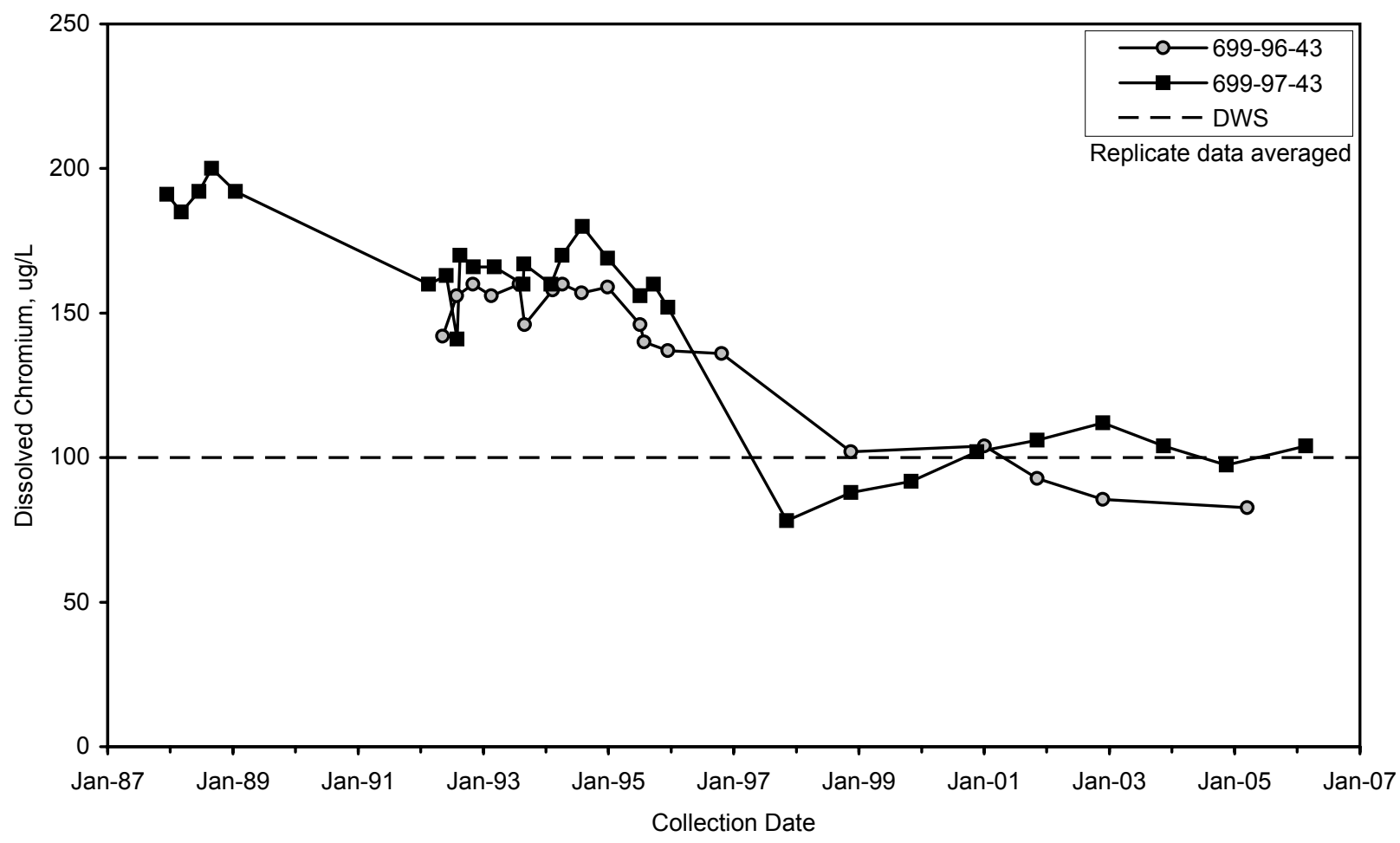

gwf06217

Figure 2.6-5. Chromium Concentrations Upgradient of 100-H Area

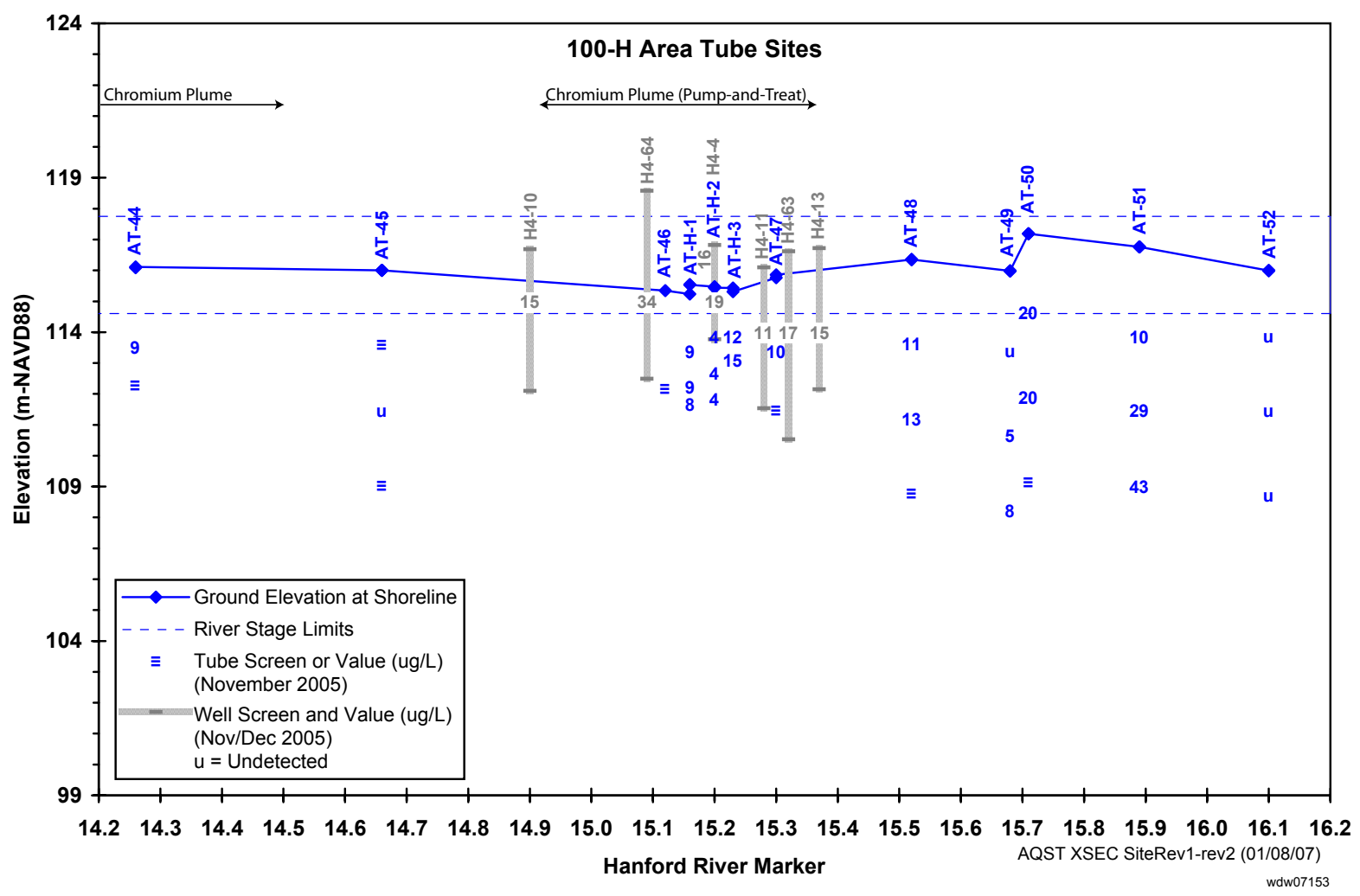

Figure 2.6-6. Sample Evaluations and Chromium Concentrations in Wells and Aquifer Tubes in 100-H Area 

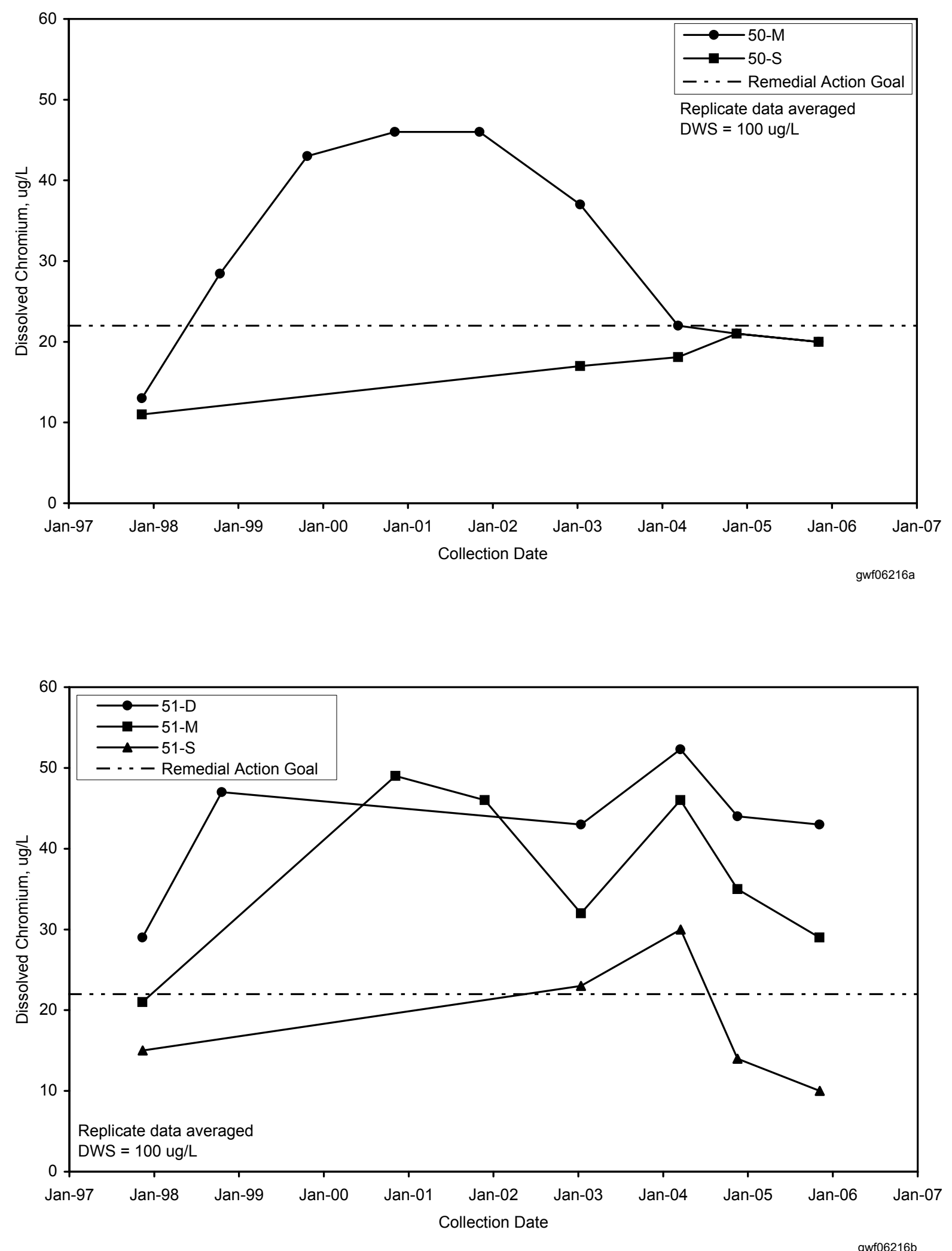

gwf06216

Figure 2.6-7. Chromium Concentrations in Aquifer Tubes South of 100-H Area 

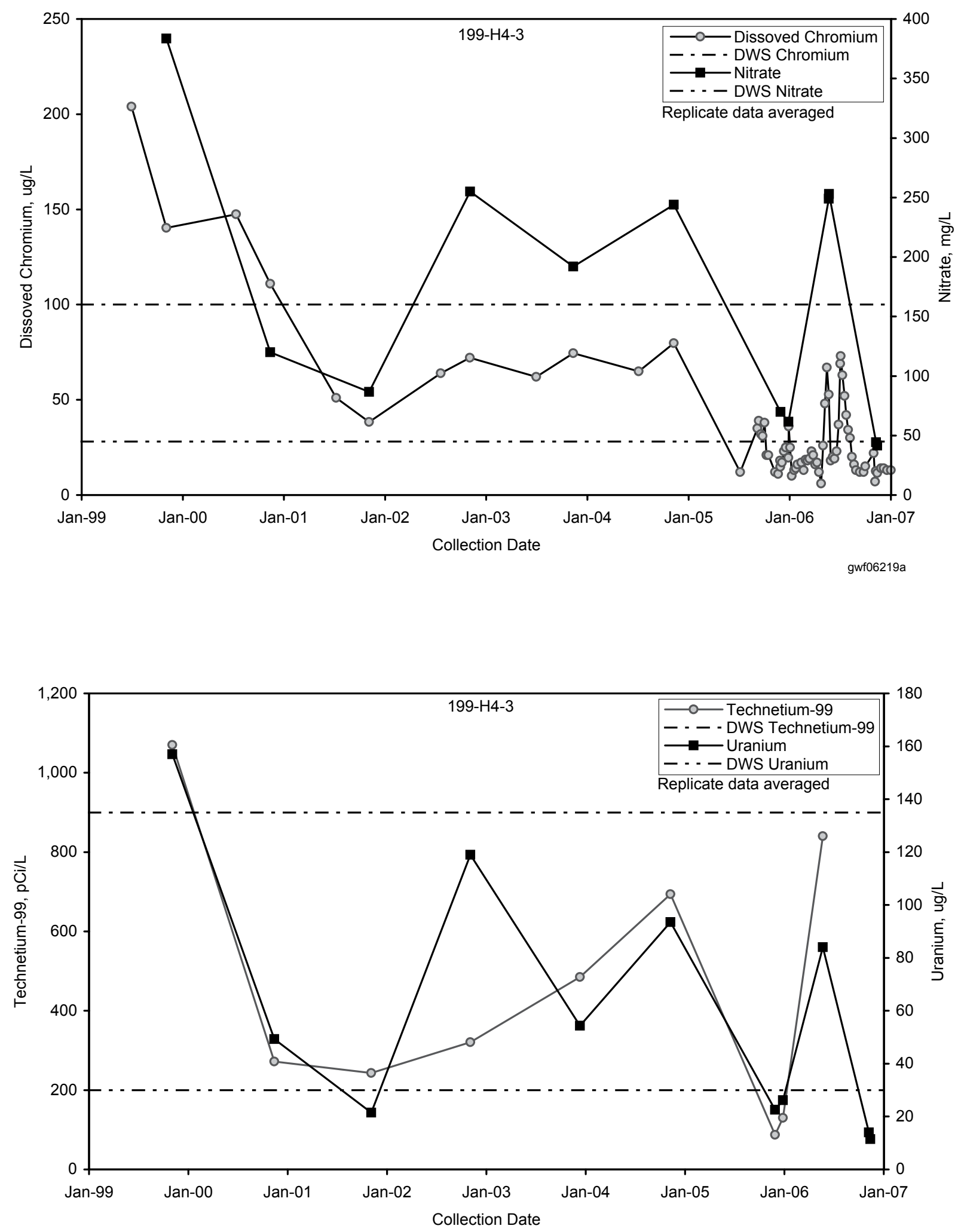

gwf06219b

gwf06219

Figure 2.6-8. Technetium-99, Uranium, Chromium, and Nitrate Concentrations East of 116-H-6 Evaporation Basins 


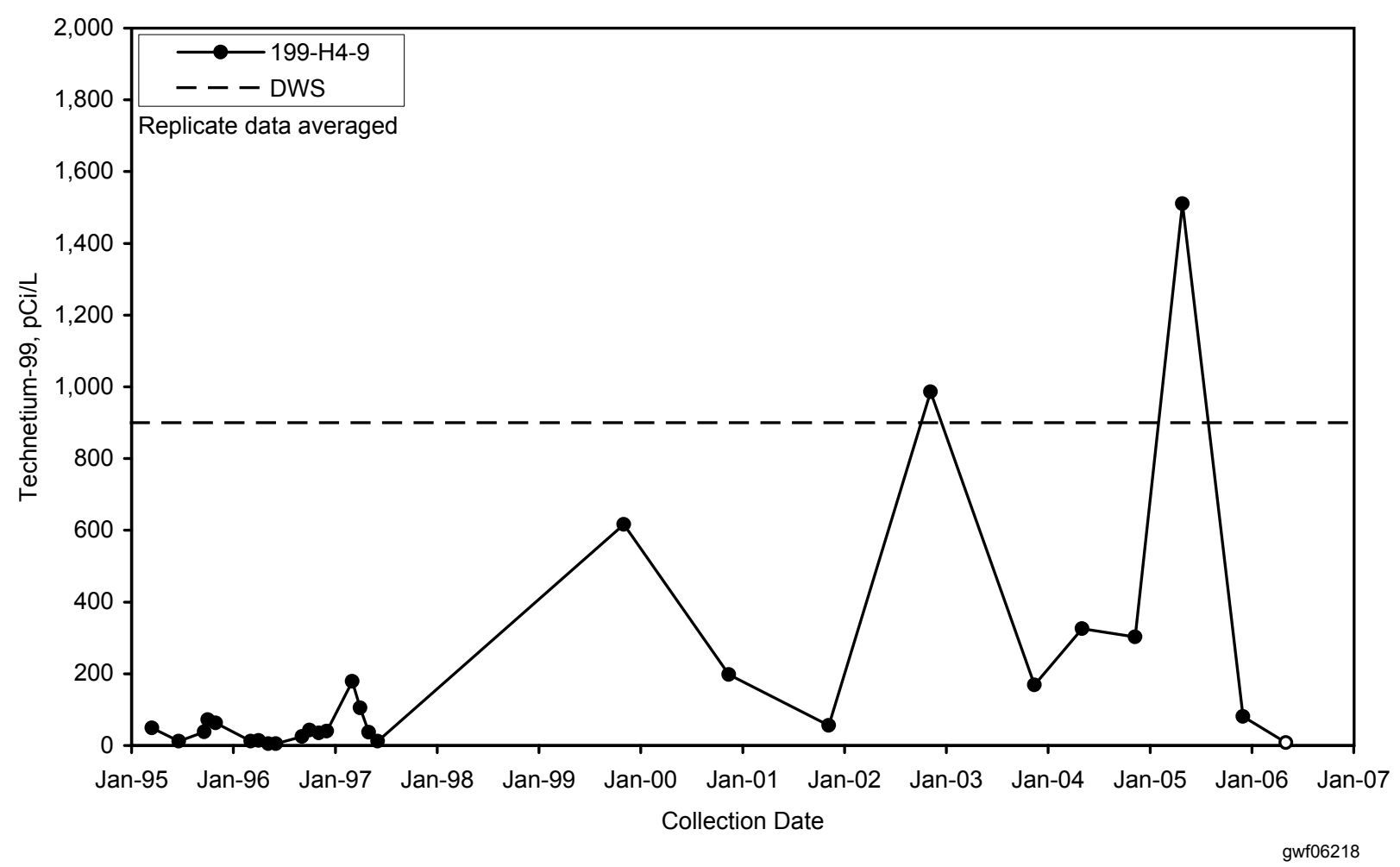

Figure 2.6-9. Technetium-99 Concentrations Northeast of 116-H-6 Evaporation Basins 


\subsection{0-FR-3 Operable Unit}

\section{J. Hartman}

The scope of this section is the 100-FR-3 groundwater interest area, which encompasses the 100-FR-3 Operable Unit and a large section of the 600 Area north of Gable Mountain (see Figure 1.0-1 in Section 1.0). The "groundwater interest areas" are informally defined to facilitate scheduling, data review, and interpretation. Figure 2.7-1 shows facilities, wells, and shoreline monitoring sites in the 100-F Area.

Groundwater flows primarily to the east and southeast beneath the 100-F Area (Figure 2.7-2). Movement of the nitrate plume indicates flow to the south-southeast.

The remainder of this section describes contaminant plumes and concentration trends for the contaminants of concern under the Comprehensive Environmental Response, Compensation, and Liability Act (CERCLA). Groundwater monitoring for the Atomic Energy Act (AEA) is integrated fully with CERCLA monitoring. Most of the former liquid waste sites in the 100-F Area have been excavated and backfilled. There are no active waste disposal facilities or Resource Conservation and Recovery Act (RCRA) sites in the 100-F Area.

\subsubsection{Groundwater Contaminants}

This section describes the distribution and trends of the contaminants of concern for the 100-FR-3 Operable Unit: nitrate, strontium-90, tritium, trichloroethene, uranium, and hexavalent chromium (DOE/RL-2003-49).

\subsubsection{Nitrate}

A large nitrate plume extends from the 100-F Area southward nearly 5 kilometers, although data are sparse in the 600 Area (see Figure 1.0-3 in Section 1.0). The plume did not change significantly between fiscal year (FY) 2005 and 2006.

Wells in the main 100-F Area continued to show levels of nitrate that exceeded the drinking water standard in FY 2006 (Figure 2.7-3). The highest FY 2006 nitrate concentration was $124 \mathrm{mg} / \mathrm{L}$ in well $199-\mathrm{F} 7-3$, a decline from the previous result. Concentrations had been increasing in this well from the late 1990s until 2002. Concentrations are lower and declining in well 199-F8-4.

South of the 100-F Area, nitrate concentrations are near $100 \mathrm{mg} / \mathrm{L}$ in wells 699-62-31 and 699-71-30. Concentrations increased in these wells since the early 1990s, but decreased in the most recent samples (October 2004 and January 2005, respectively).

Aquifer tubes south of the main 100-F Area also have elevated nitrate concentrations. Tubes at site AT- 75 typically exceed the drinking water standard ( $45 \mathrm{mg} / \mathrm{L})$, but this tube was not sampled in FY 2006 because it was a lower priority than other Hanford Site aquifer tubes.

Groundwater monitoring in the 100-FR-3 groundwater interest area includes integrated CERCLA and AEA monitoring:

- Wells are sampled annually or biennially.

- Aquifer tubes and seeps are scheduled for annual sampling.

- All of the scheduled wells were sampled in FY 2006.

- Six aquifer tubes and two seeps were not sampled as scheduled (see Appendix A). 


\subsubsection{Strontium-90}

Strontium-90 concentrations exceed the drinking water standard $(8 \mathrm{pCi} / \mathrm{L})$ beneath a portion of the 100-F Area around the 116-F-14 retention basin and nearby disposal trenches. The extent of the plume has not changed significantly in over 10 years (see Figure 2.7-5 in PNNL-15670 for FY 2005 map).

Well 199-F5-1 currently has the highest strontium-90 concentrations $(48.6 \mathrm{pCi} / \mathrm{L}$ in FY 2006; Figure 2.7-4). Strontium-90 also exceeded the drinking water standard in well $199-\mathrm{F} 5-46$ (13.4 pCi/L) and was near the standard in 199-F5-44 (7.55 pCi/L). The trends are neither increasing nor decreasing overall.

In December 2006, well 199-F5-6 was sampled with the "Spyder" sampling device to collect samples from discrete depths in the screened portion of the well. Samples were analyzed for strontium-90 and hexavalent chromium. Strontium-90 results from the Spyder sampling did not show any vertical stratification within the screened interval.

Plume areas (square kilometers) at the 100-FR-3 Operable Unit:

Chromium, $20 \mu \mathrm{g} / \mathrm{L}-3.0$

Nitrate, $45 \mathrm{mg} / \mathrm{L}-17.3$

Strontium-90, 8 pCi/L -0.16

Trichloroethene, $5 \mu \mathrm{g} / \mathrm{L}-2.4$
Strontium- 90 concentrations ranged from 5.08 to $6.73 \mathrm{pCi} / \mathrm{L}$, all in trend with recent results from routine sampling (Figure 2.7-5).

Strontium-90 does show vertical stratification in the only shallow/deep well pair in the 100-F Area, which monitors a broader range of depths than the screened interval of well 199-F5-6. Deep well 199-F5-43B consistently has no detectable strontium-90 while its shallow counterpart, well 199-F5-43A, typically detects 2 to $4 \mathrm{pCi} / \mathrm{L}$ of strontium-90 (Figure 2.7-6). Strontium-90 concentrations also tend to be higher in shallow aquifer tubes than in deeper aquifer tubes, but all results for FY 2006 were below the $8-\mathrm{pCi} / \mathrm{L}$ drinking water standard. The maximum concentration detected was $2.5 \mathrm{pCi} / \mathrm{L}$ in tube $64-\mathrm{M}$.

\subsubsection{Tritium}

Tritium concentrations are somewhat elevated beneath the south 100-F Area, but do not currently exceed the drinking water standard $(20,000 \mathrm{pCi} / \mathrm{L})$. The plume extends to the southeast into the 600 Area at concentrations above 2,000 pCi/L (see Figure 1.0-2 in Section 1.0).

The only well where tritium historically exceeded the drinking water standard is well $199-F 8-3$, near the $118-\mathrm{F}-1$ burial ground, where concentrations were nearly $180,000 \mathrm{pCi} / \mathrm{L}$ in the mid-1990s. Concentrations in this well declined in the late 1990s, and in FY 2006, the highest concentration was 19,800 pCi/L (Figure 2.7-7).

\subsubsection{Trichloroethene}

Trichloroethene concentrations in the southwest 100-F Area exceed the drinking water standard $(5 \mu \mathrm{g} / \mathrm{L})$. The plume appears to be centered west of the $100-\mathrm{F}$ Area but is not well defined because of a lack of wells. A soil-gas investigation (DOE/RL-95-99) helped define the area of contamination but did not identify the source of contamination. Wells 199-F7-1 and 699-77-36 had the highest concentrations of trichloroethene in FY 2006, 14 and $13 \mu \mathrm{g} / \mathrm{L}$, respectively (Figure 2.7-8).

As discussed in the FY 2005 report (PNNL-15670), trichloroethene has been detected in several wells 5 to 6 kilometers west of the 100-F Area at levels near and above the drinking water standard. The source of this contamination is not known, but it appears to be separate from the plume closer to the 100-F Area.

\subsubsection{Uranium and Gross Alpha}

For most of the period of operable unit groundwater monitoring, gross alpha has been monitored to screen for uranium. Uranium data were collected from FY 1996 to 2000 and FY 2005 to 2006.

Uranium concentrations have remained below the drinking water standard $(30 \mu \mathrm{g} / \mathrm{L})$ in all of the available data. The maximum concentration in recent years was $22.7 \mu \mathrm{g} / \mathrm{L}$ in 
well 199-F8-2 in the central 100-F Area, from an October 2004 sample (well is sampled biennially). Gross alpha concentrations in this well show no overall trend. Levels were above the drinking water standard $(15 \mathrm{pCi} / \mathrm{L})$ occasionally in the early 1990 s but are now below the standard (13 pCi/L in FY 2005). Gross alpha concentrations declined in well 199-F5-46 between FY 2004 and FY 2006, although uranium increased slightly (Figure 2.7-9).

\subsubsection{Hexavalent Chromium}

Chromium concentrations in groundwater beneath the 100-F Area are all below the drinking water standard $(100 \mu \mathrm{g} / \mathrm{L})$. The plume at levels above $20 \mu \mathrm{g} / \mathrm{L}$ covers an area between the reactor building and the Columbia River (see Figure 2.7-8 in PNNL-15670). The plume has changed little in the past 10 years. In addition to the main plume near the Columbia River, one well (199-F8-3) near the 118-F-6 burial ground showed a concentration of $36 \mu \mathrm{g} / \mathrm{L}$ in FY 2005 (the well is sampled biennially). This well has shown variable chromium concentrations throughout its history of monitoring.

No evidence of vertical stratification was evident in Spyder sampling results from well 199-F5-6, located in northeast 100-F Area. Hexavalent chromium ranged from 51 to $58 \mu \mathrm{g} / \mathrm{L}$ in FY 2006. Filtered, total chromium was at the top end of that range, $58 \mu \mathrm{g} / \mathrm{L}$. All of the values were within the range observed in recent years from routine sampling (analyzed as total chromium in filtered samples; Figure 2.7-10). The routine sample from this well, collected in October 2005, had the highest chromium in the 100-F Area in FY 2006, $83.3 \mu \mathrm{g} / \mathrm{L}$.

Figure 2.7-11 shows sampling depths of the Spyder samples, selected wells, and multi-depth aquifer tubes. Chromium concentrations in aquifer tubes at 100-F Area continued to be low in FY 2006. The highest concentration was $14 \mu \mathrm{g} / \mathrm{L}$ in tube AT-75-D, located south of the

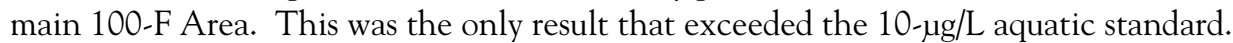

\subsubsection{Other Constituents}

Iron $(751 \mu \mathrm{g} / \mathrm{L})$, manganese $(89.6 \mu \mathrm{g} / \mathrm{L})$, and zinc $(5,020 \mu \mathrm{g} / \mathrm{L})$ were elevated in well 699-58-24, south of 100-F Area. These metals were even higher the last time the well was sampled in December 2003. The elevated metals are likely caused by casing corrosion.

Gross beta levels increased to $81.2 \mathrm{pCi} / \mathrm{L}$ in October 2005 in well 199-F8-3. That sample was not analyzed for strontium-90 (the only significant, known beta-emitter in the 100-F Area) or technetium-99. The well was re-sampled in February 2006 and analyzed for gross beta, strontium-90, technetium-99, tritium, and gamma emitters. Gross beta declined to $15.4 \mathrm{pCi} / \mathrm{L}$ in February, and tritium continued its previous trend (Figure 2.7-12). Strontium-90, technetium-99, and gamma-emitters were undetected. The cause of the gross beta spike, and similar spikes in the early 1990s, remain unexplained.

\subsubsection{Operable Unit Monitoring}

A record of decision has not yet been developed for the 100-FR-3 Operable Unit, and no active remediation of groundwater is underway. The U.S. Department of Energy (DOE) continues monitoring contaminant conditions while waste site remedial actions are conducted.

The groundwater sampling and analysis plan (DOE/RL-2003-49, Rev. 1) calls for annual sampling of 9 wells, 19 aquifer tube sites, and 3 shoreline seeps, and biennial sampling of 25 wells (see Appendix A). All of the 21 wells scheduled for sampling in FY 2006 were sampled successfully. Six of the aquifer tube sites, all located downgradient of the main 100-F Area, and one spring were not sampled. Tube and spring sampling depend on field conditions and is not always possible.

DOE and regulatory agencies are required to conduct reviews of the status of CERCLA response actions at least every five years. In November 2006, DOE released a five-year review report (DOE/RL-2006-20). The review identified no issues or actions for the 100-FR-3 Operable Unit.

\section{Chromium concentrations in 100-F Area groundwater remained below the drinking water standard in FY 2006.}

Transient spikes of gross beta in a well near a burial ground remain unexplained.

Until groundwater remediation decisions are made for the 100-FR-3

Operable Unit, groundwater will continue to be monitored for contaminant plumes and trends. 


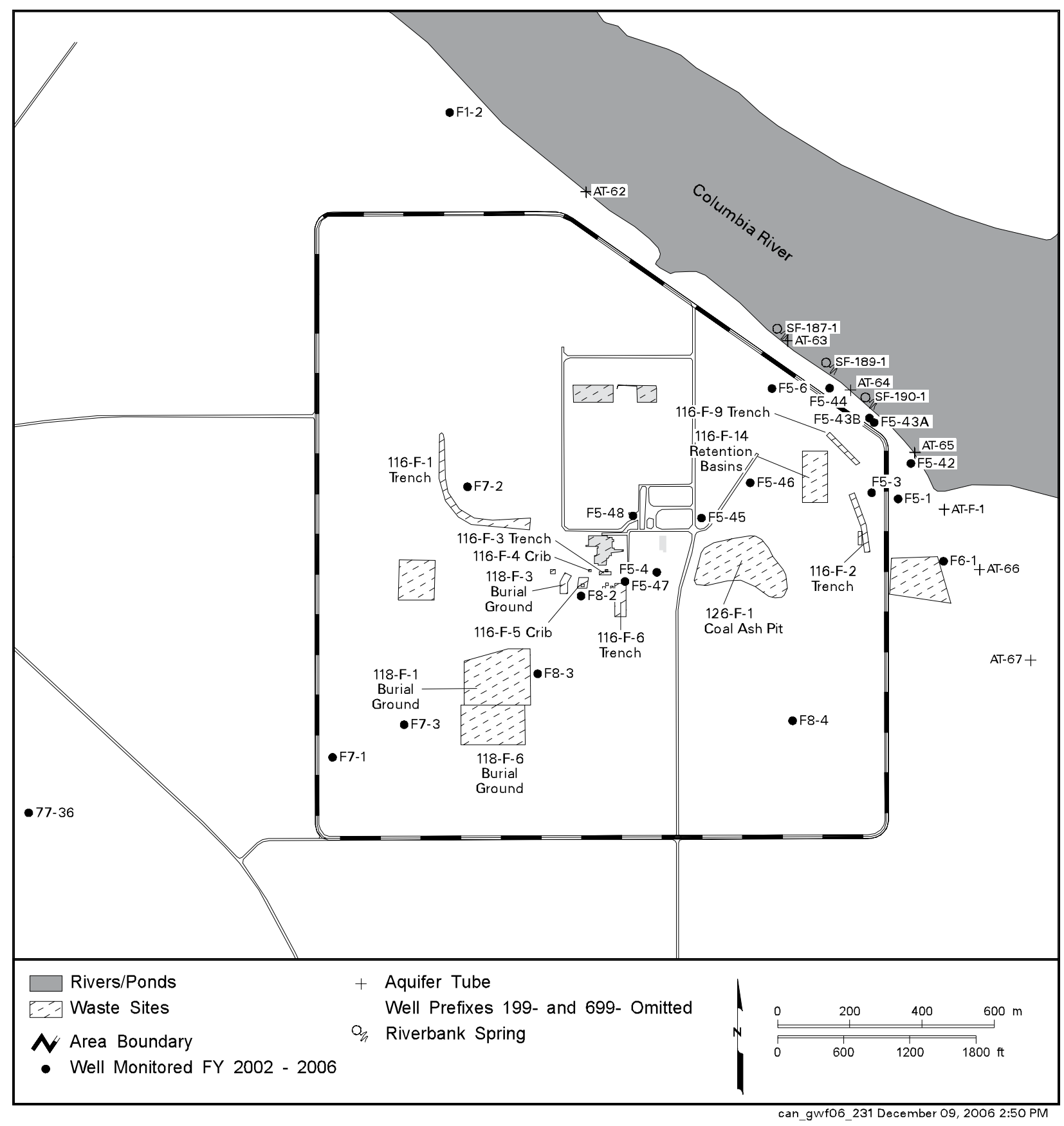

Figure 2.7-1. Groundwater Monitoring Wells in 100-F Area 


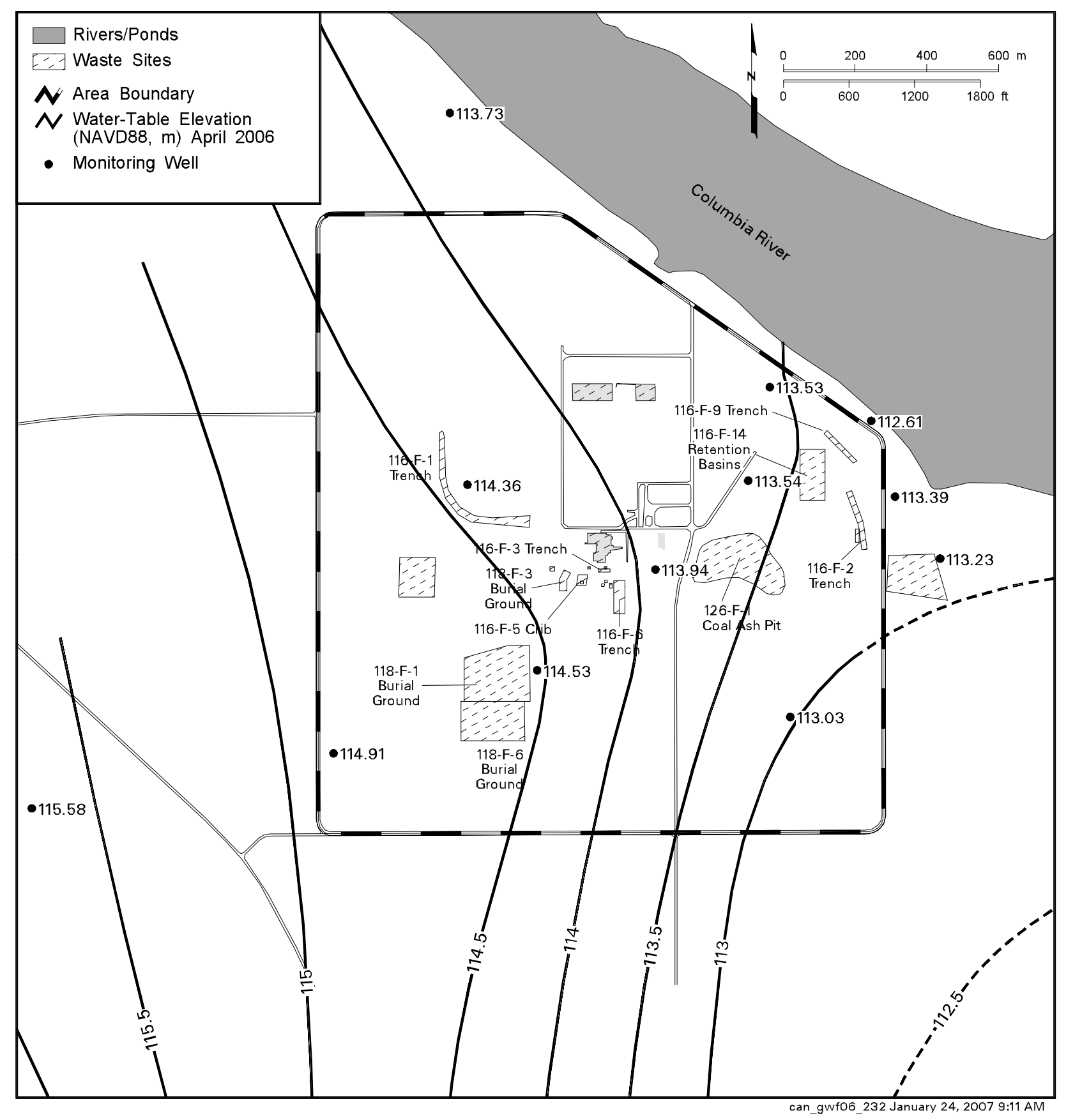

Figure 2.7-2. 100-F Area Water-Table Map, April 2006 


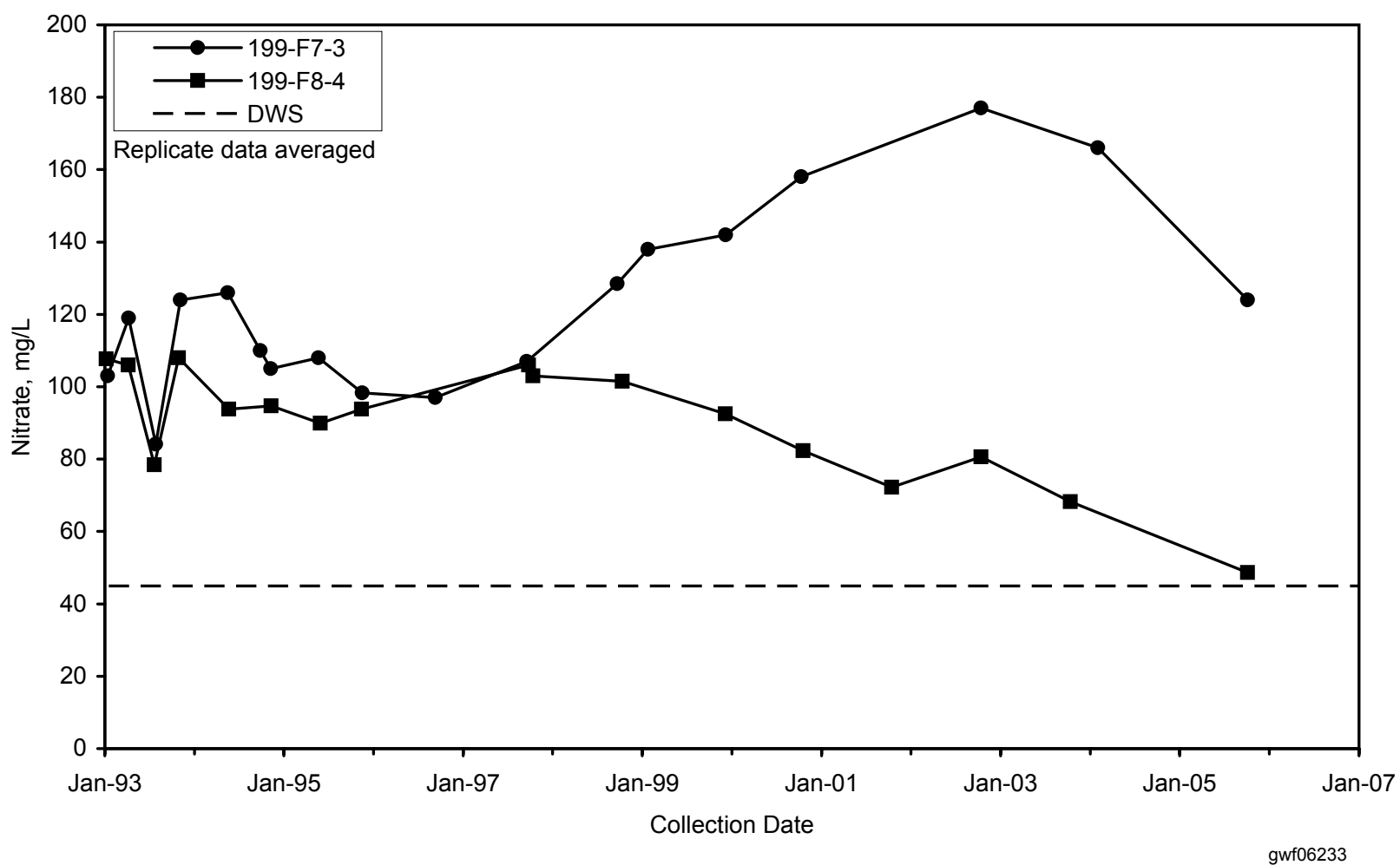

Figure 2.7-3. Nitrate Concentrations in Monitoring Wells in South 100-F Area

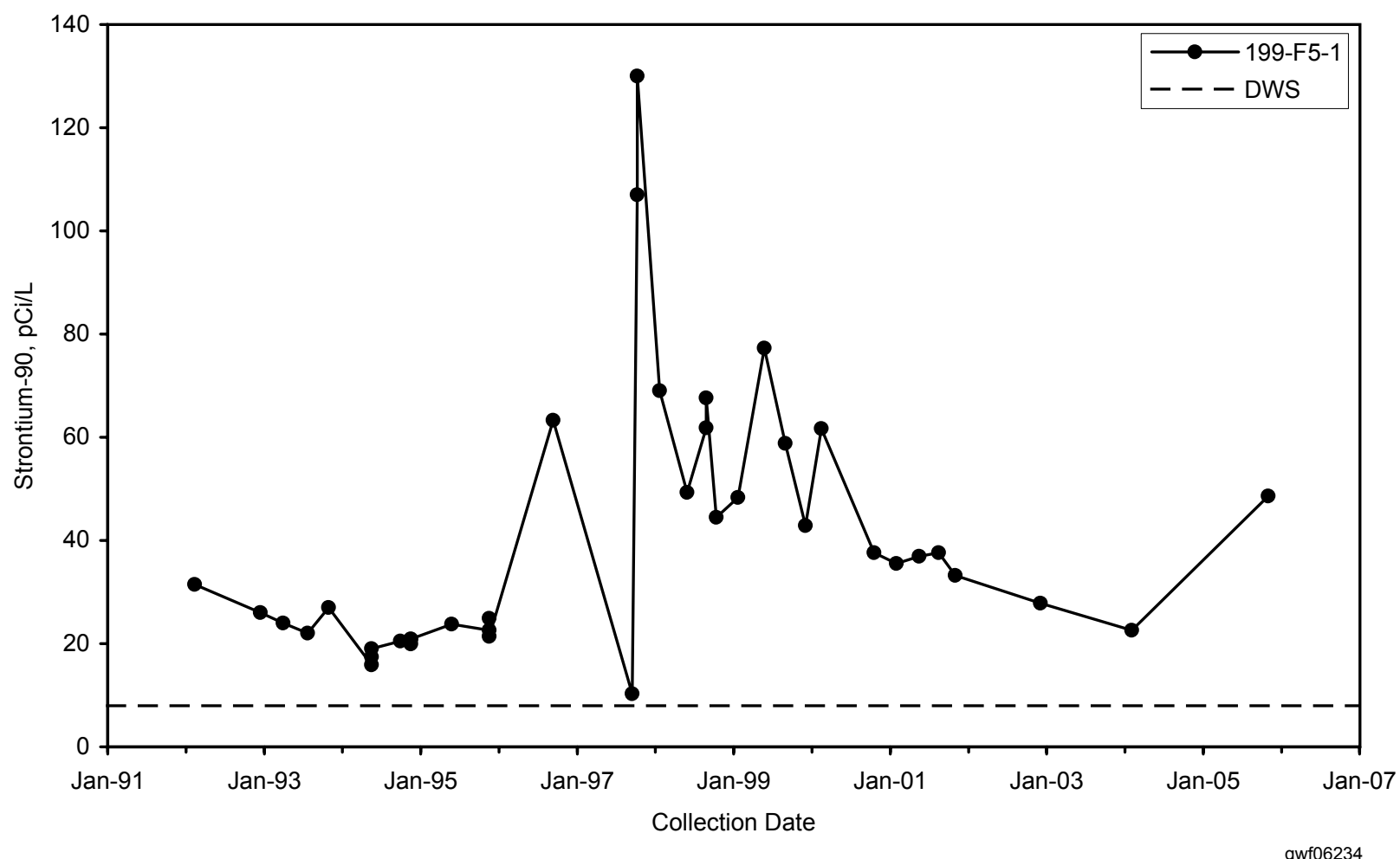

Figure 2.7-4. Strontium-90 Concentrations Near 116-F-2 Trench 


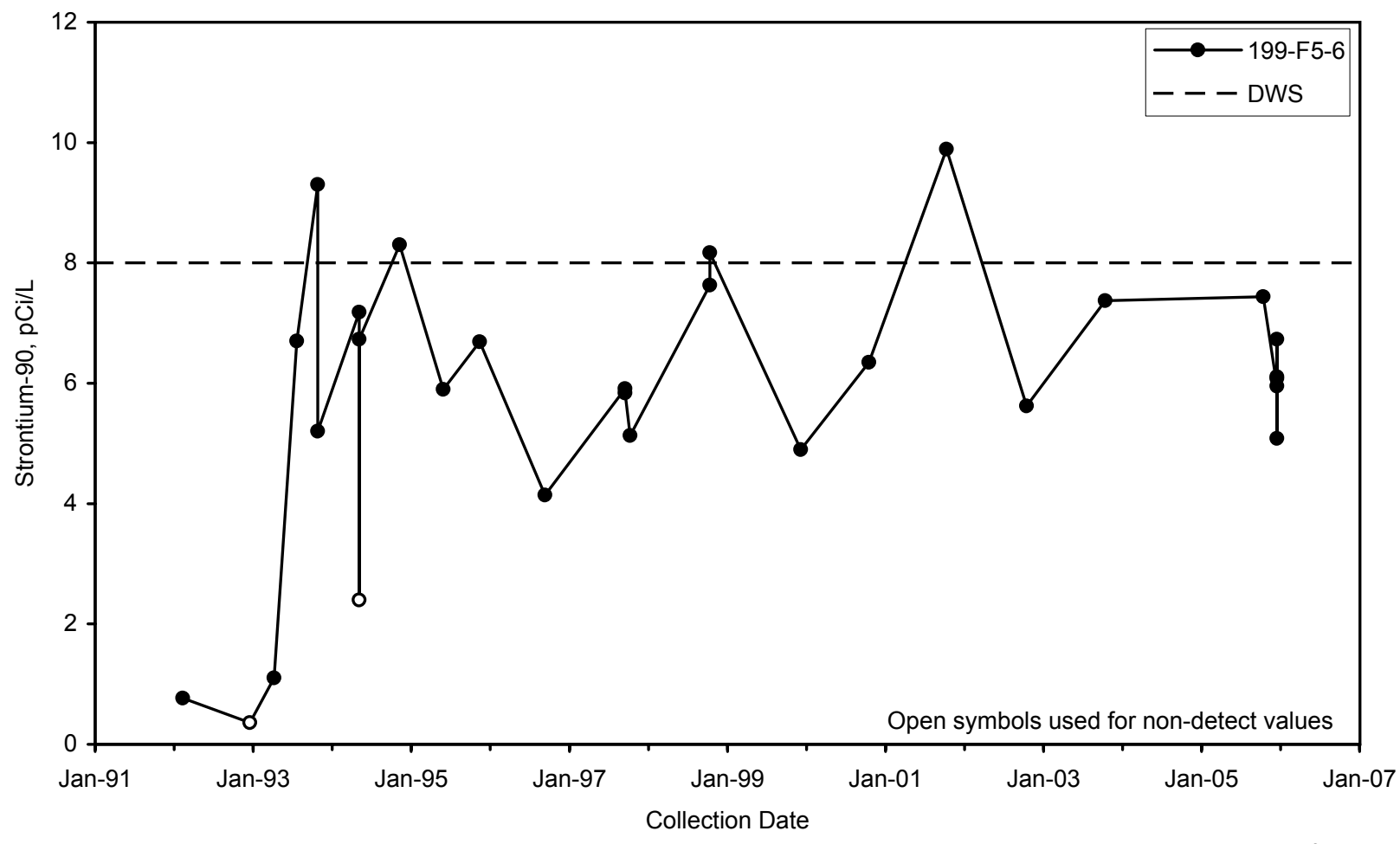

Figure 2.7-5. Strontium-90 Concentrations in Well 199-F5-6 in Northeast 100-F Area

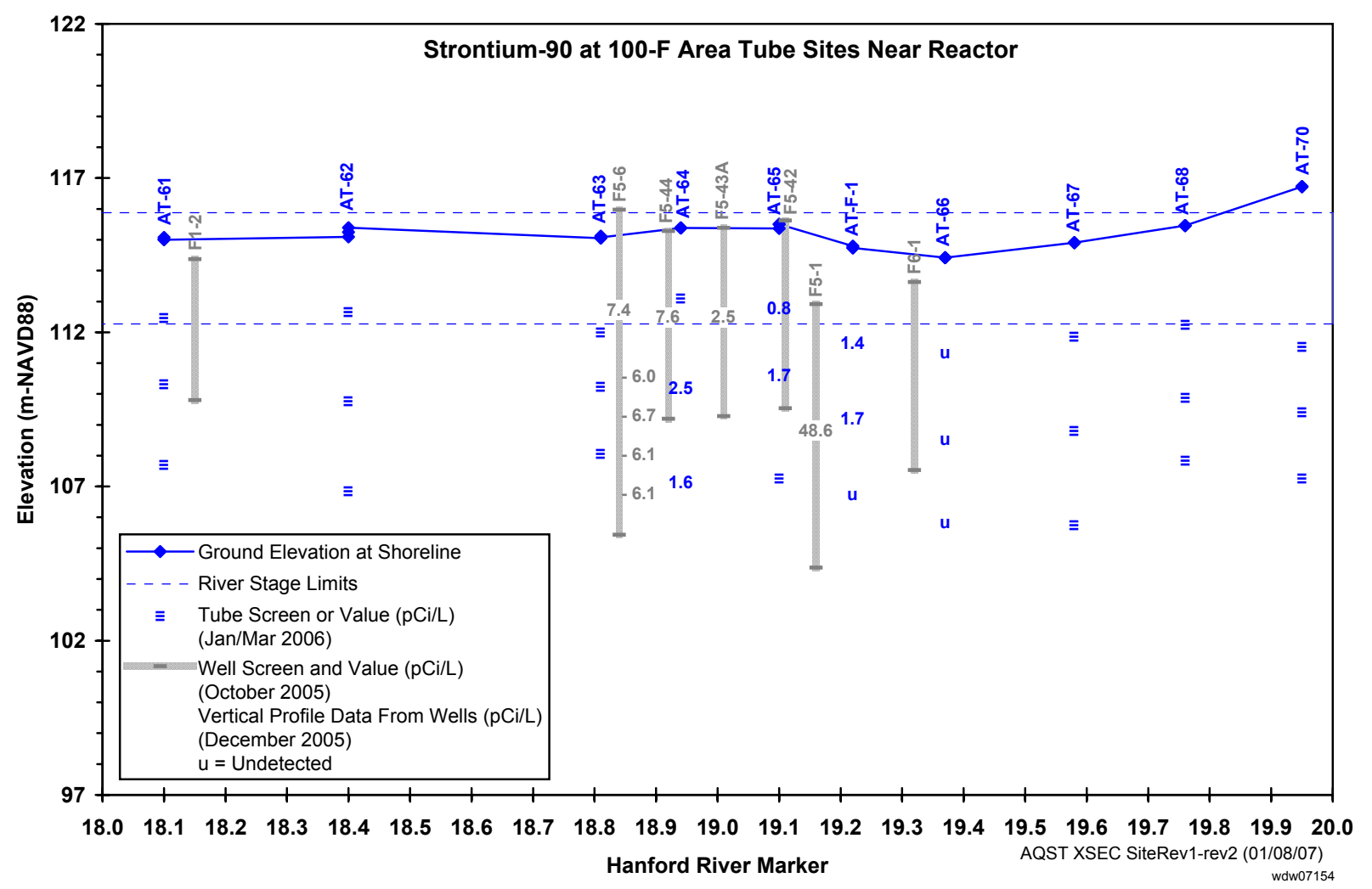

Figure 2.7-6. Sample Elevations and Strontium-90 Concentrations in Wells and Aquifer Tubes in 100-F Area 


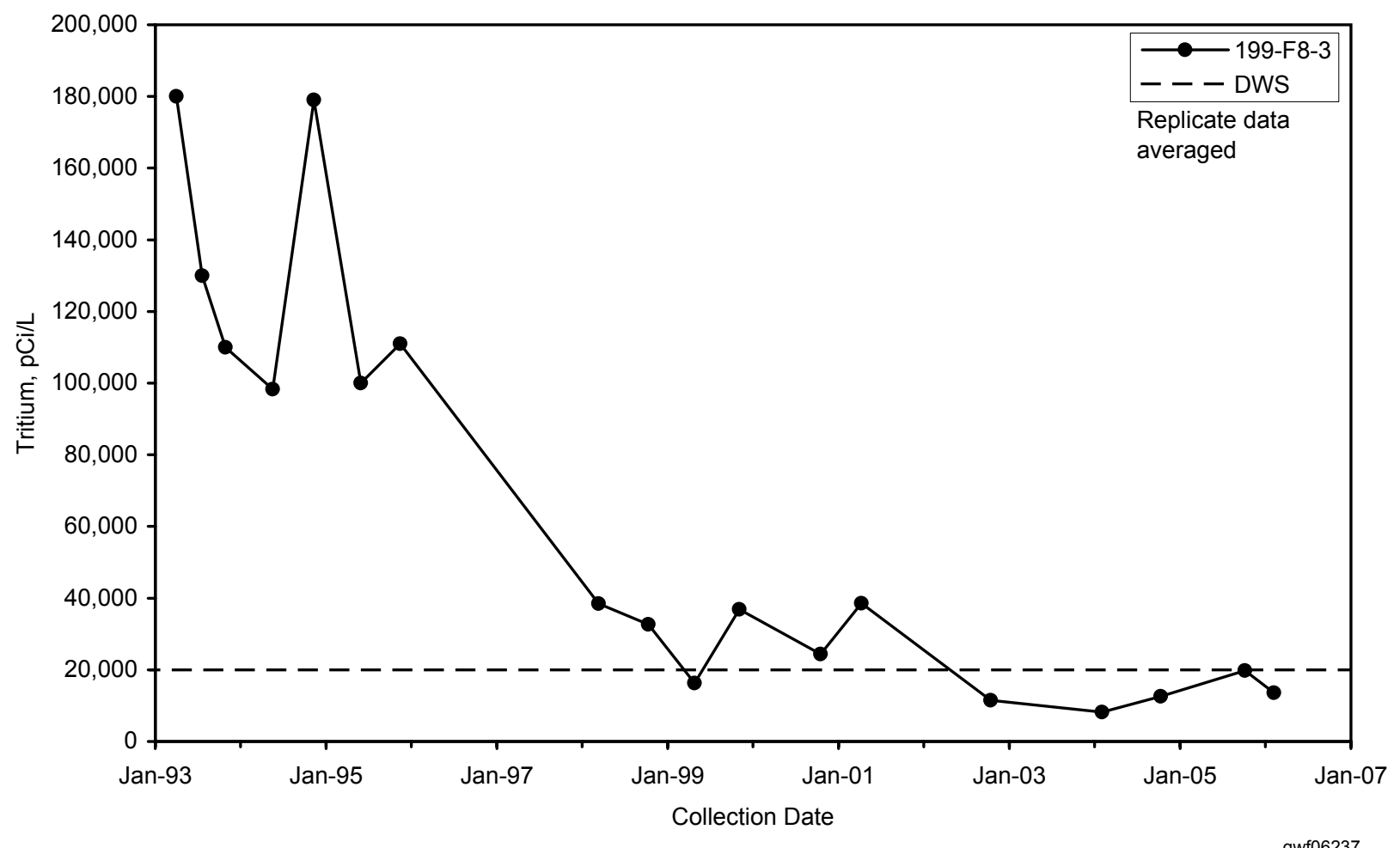

Figure 2.7-7. Tritium Concentrations Near 118-F-6 Burial Ground

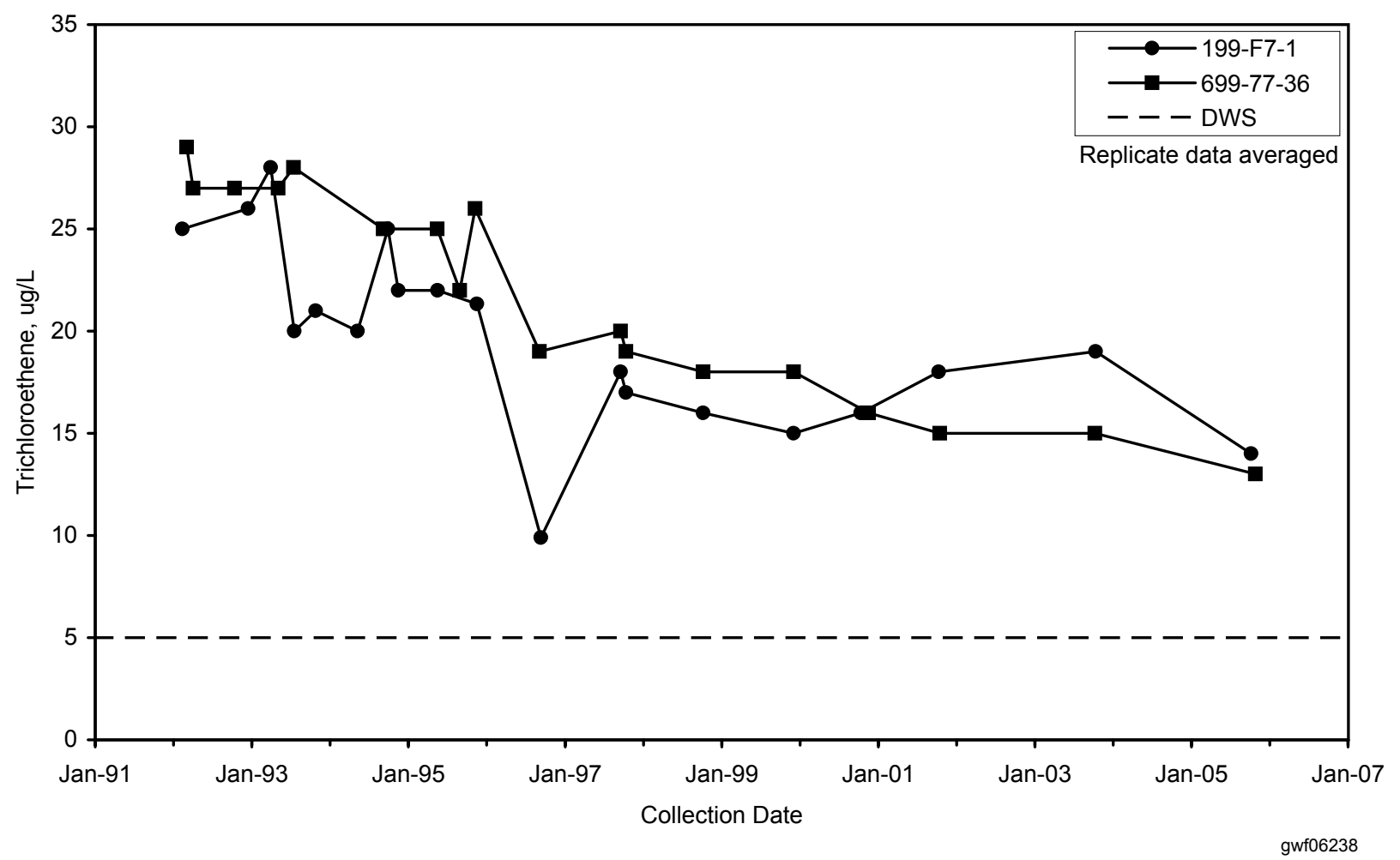

Figure 2.7-8. Trichloroethene Concentrations in Southwest 100-F Area 


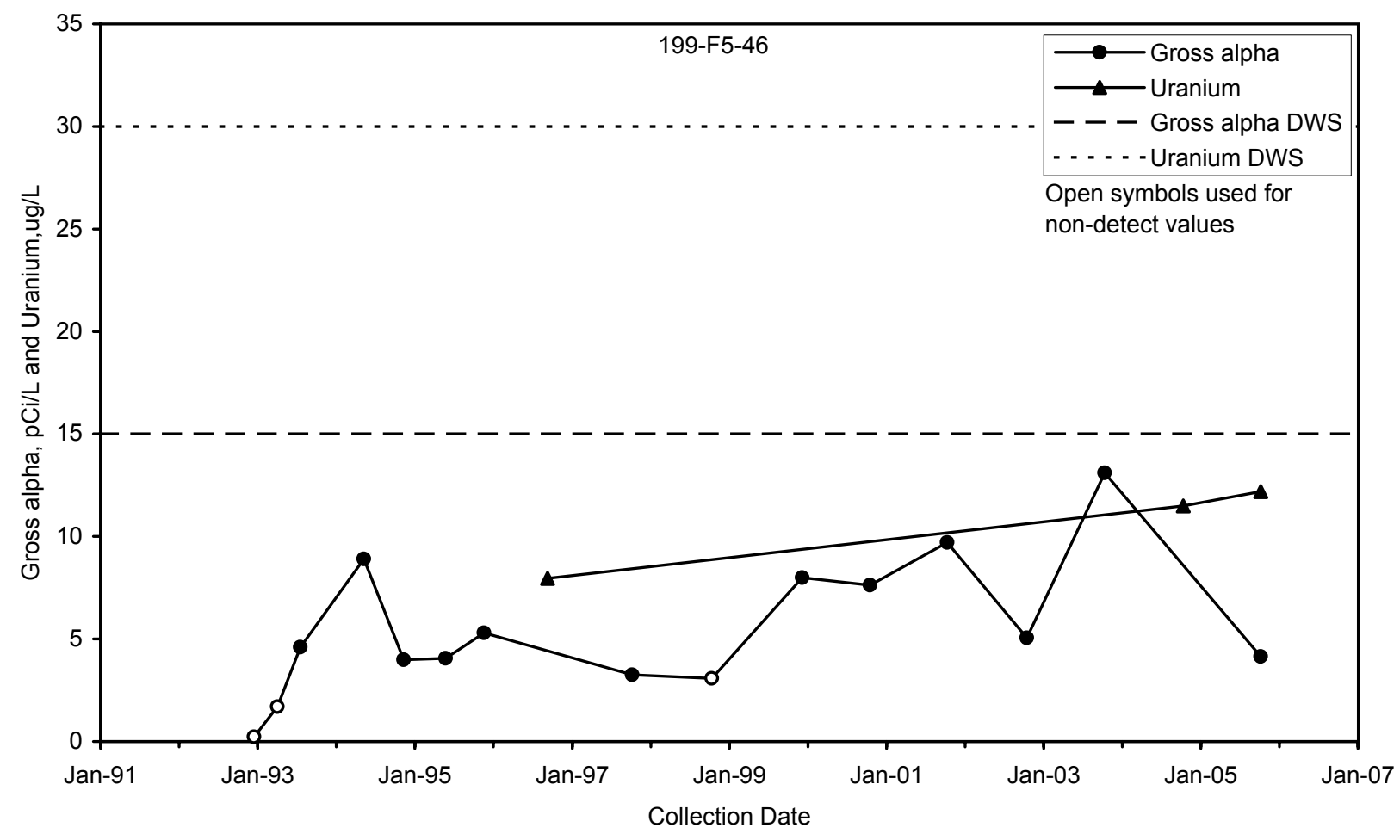

gwf06239

Figure 2.7-9. Uranium and Gross Alpha Concentrations in Well 199-F5-46, West of 116-F-14 Retention Basins

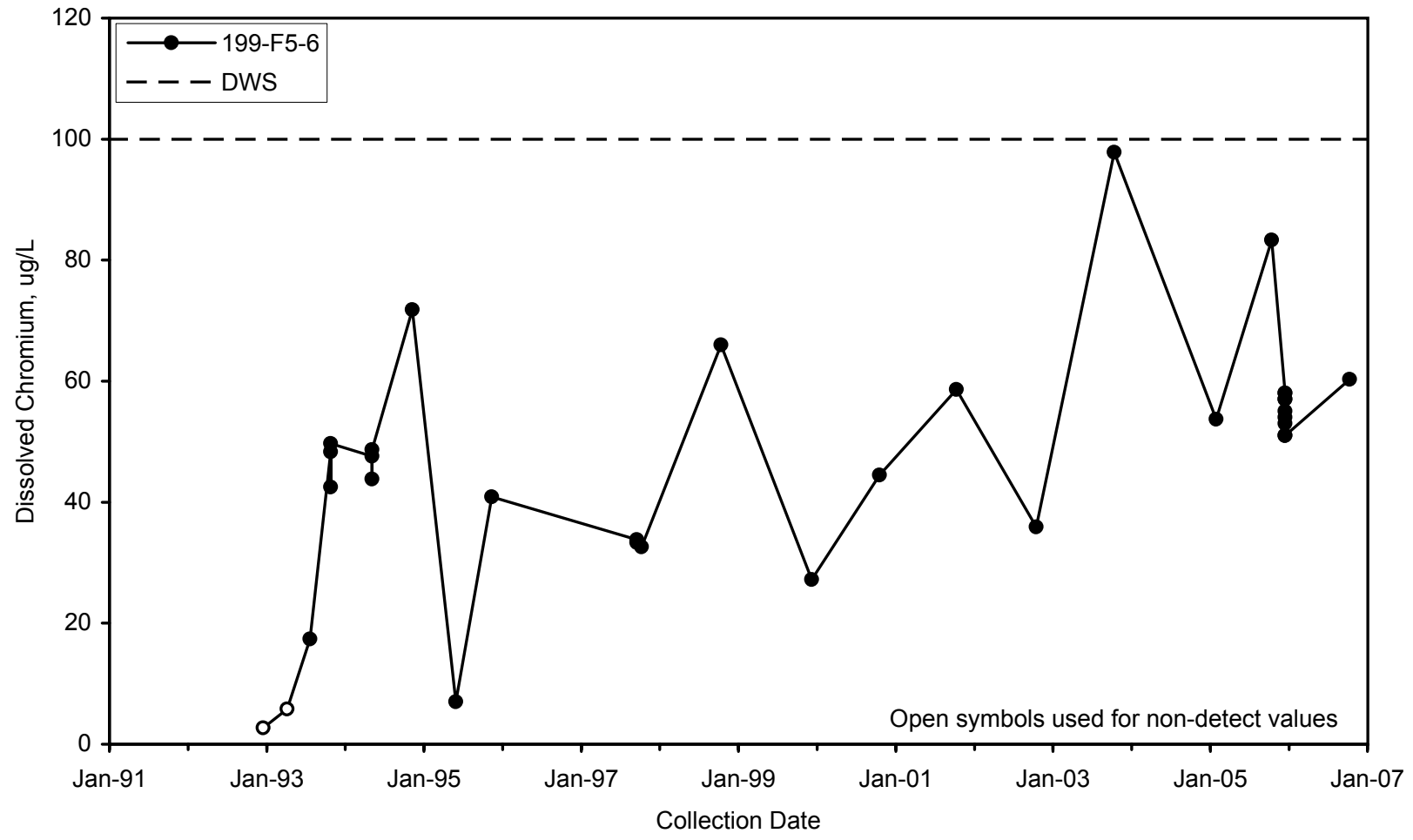

gwf06240

Figure 2.7-10. Dissolved Chromium Concentrations in Well 199-F5-6 in Northeast 100-F Area 

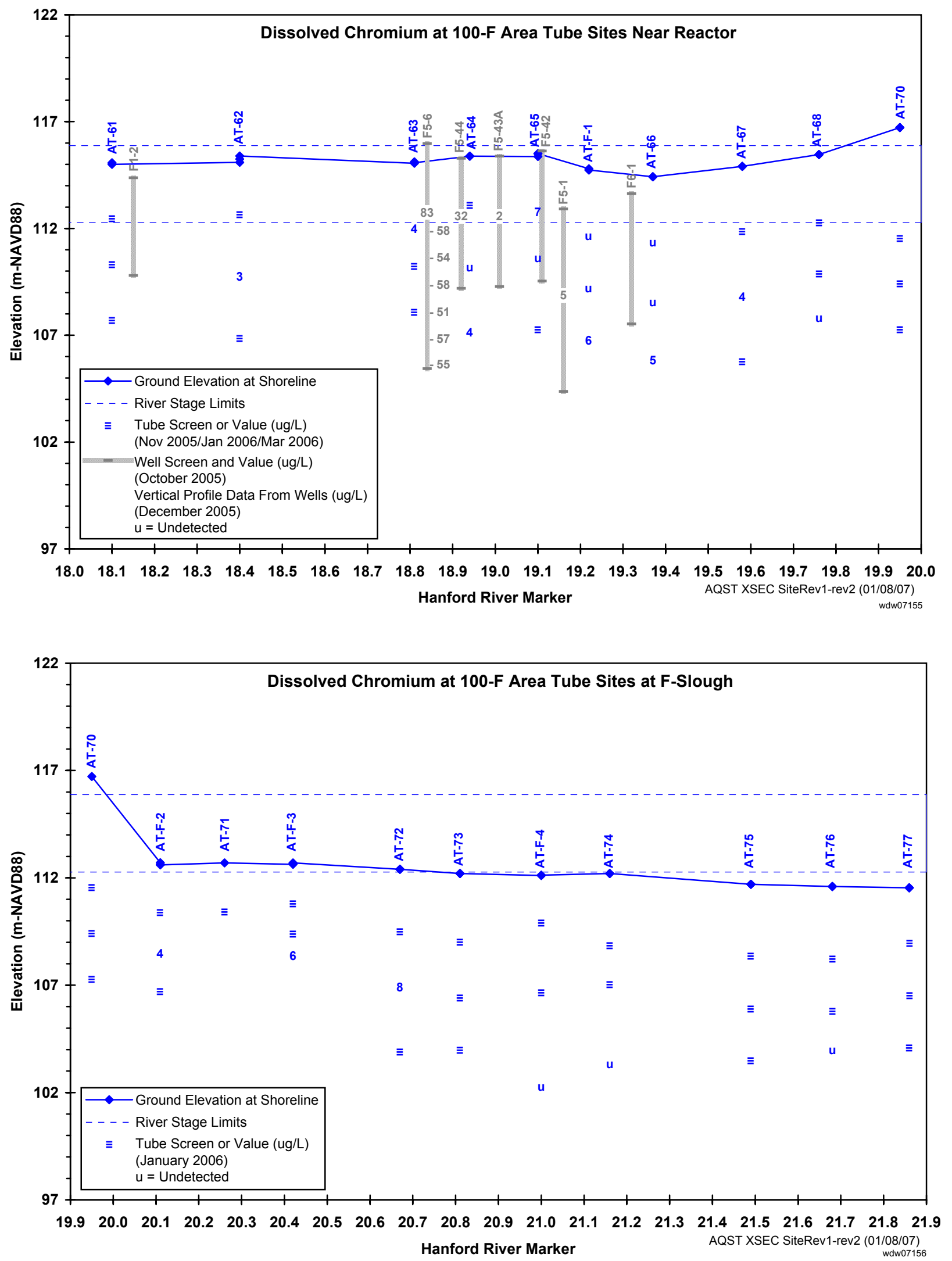

Figure 2.7-11. Sample Elevations and Chromium Concentrations in Wells and Aquifer Tubes in 100-F Area 


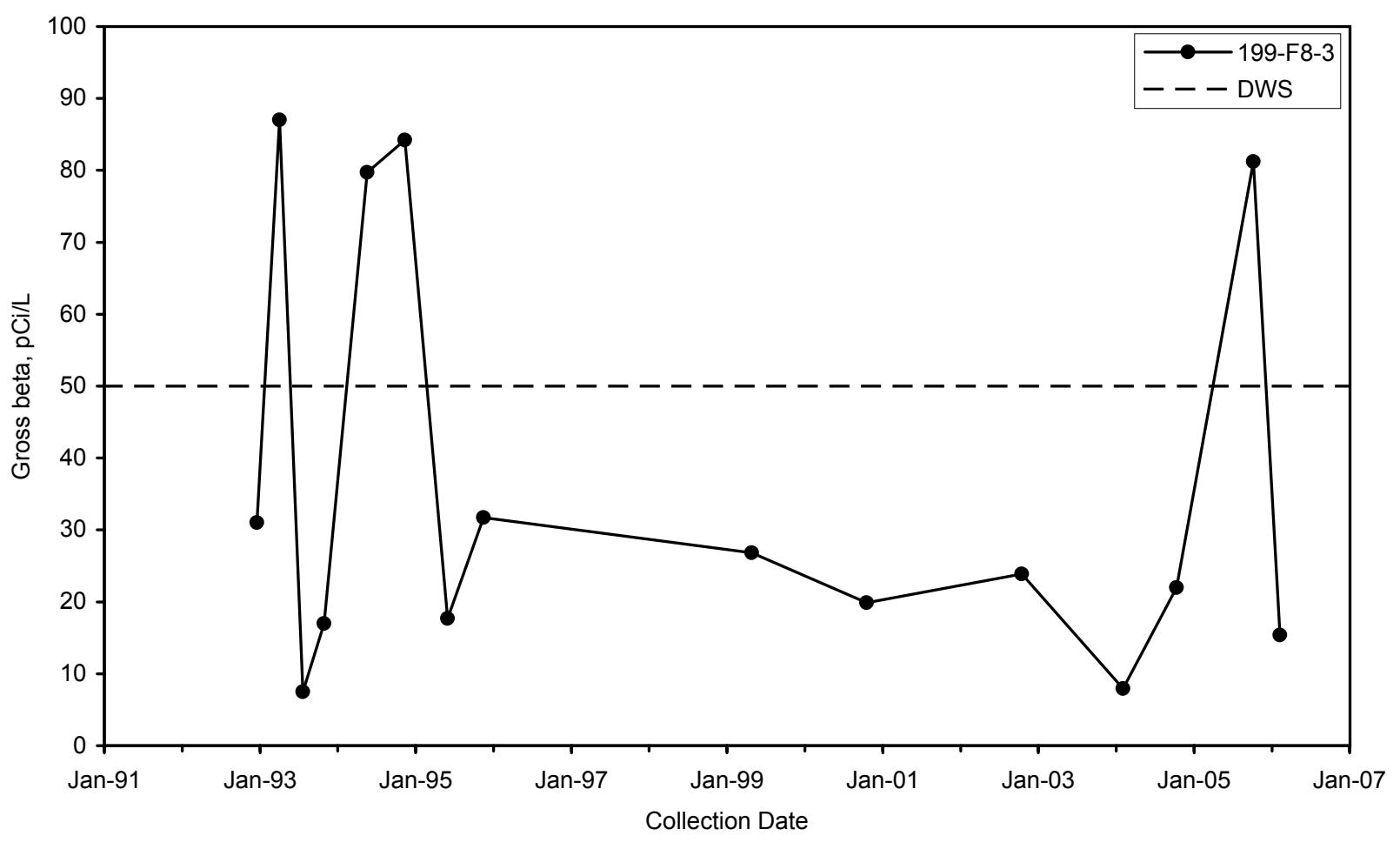

gwf06241a

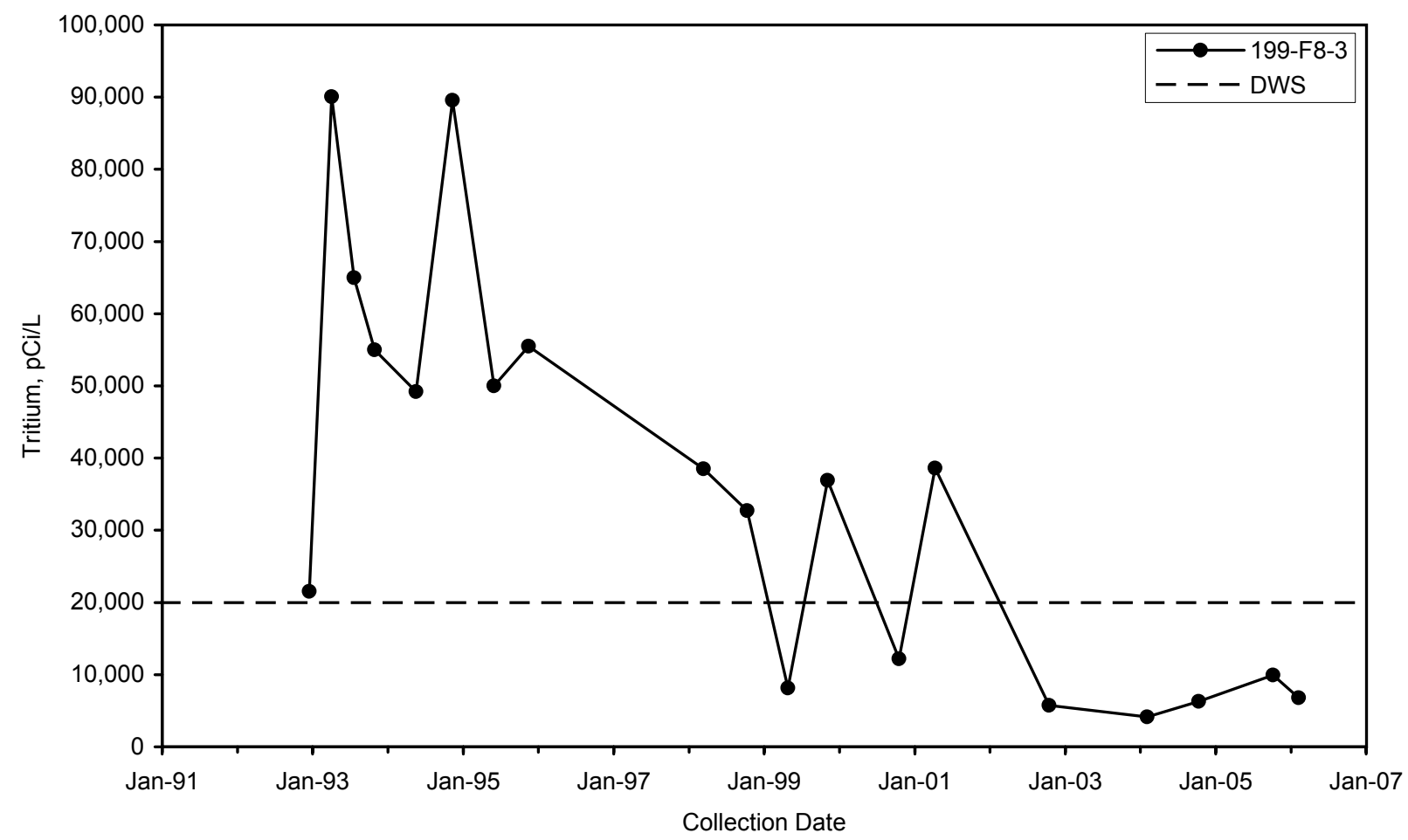

gwf06241b

gwf06241

Figure 2.7-12. Gross Beta and Tritium Concentrations Near 118-F-6 Burial Ground 


\subsection{0-ZP-1 Operable Unit}

\section{P. E. Dresel, D. G. Horton, D. B. Erb, and R. F. Raidl}

The scope of this section encompasses the 200-ZP-1 Operable Unit including the northern and central parts of the 200 West Area and the western 600 Area. This region is informally termed the 200-ZP-1 groundwater interest area (see Figure 1.0-1 in Section 1.0). The groundwater interest areas are informally defined to facilitate scheduling, data review, and interpretation. Figure 2.8-1 shows facilities and wells in this region. Groundwater is monitored to assess the performance of an interim action pump-and-treat system for carbon tetrachloride contamination, to track other contaminant plumes, and to support four Resource Conservation and Recovery Act (RCRA) units and the State-Approved Land Disposal Site. Data from facility-specific monitoring are also integrated into the Comprehensive Environmental Response, Compensation, and Liability Act (CERCLA) groundwater investigations. The contamination plumes mapped in this area include carbon tetrachloride, chloroform, trichloroethene, nitrate, chromium, fluoride, tritium, iodine-129, technetium-99, and uranium. Other contaminants were detected but at lower levels or in less extensive areas.

Groundwater in the north portion of the 200 West Area predominantly flows toward the east-northeast but is locally influenced by the 200-ZP-1 Operable Unit pump-and-treat system and effluent discharges to the State-Approved Land Disposal Site (Figure 2.8-2). The water table in the 200 West Area was raised by past discharge of wastewater and the aquifer is still re-equilibrating after the termination of discharges. Thus, the flow direction is changing with time. The flow direction in the north part of the operable unit has changed $\sim 35$ degrees over the past decade from a north-northeast direction to a more eastward direction.

Flow in the central part of the 200 West Area (the south part of the 200-ZP-1 Operable Unit) is heavily influenced by the operation of the 200-ZP-1 Operable Unit pump-and-treat remediation system. This system extracts water from the vicinity of the $216-Z$ cribs and trenches shown on Figure 2.8-2, treats it to remove carbon tetrachloride and other volatile organic compounds, then re-injects the water into the aquifer to the west of the area. A small groundwater mound is associated with the injection wells, and a region of drawdown is associated with the extraction wells, causing flow to converge on the extraction zone from all directions. The extension of the pump-and-treat extraction to the north of the baseline plume area in fiscal year (FY) 2005 is altering flow in that part of the 200 West Area. In particular, flow appears to have reversed beneath the Waste Management Area TX-TY

Groundwater monitoring in the 200-ZP-1 groundwater interest area includes the following monitoring activities:

\section{CERCLA Monitoring}

- Wells are sampled quarterly to biennially.

- In FY 2006, six wells were not sampled as scheduled and sampling was delayed at six wells (see Appendix A).

Facility Monitoring

- Wells are sampled semiannually for Low-Level Waste Management Area 3. One well went dry in FY 2006 and sampling of six wells was delayed until early FY 2007 (see Appendix B).

- Wells are sampled semiannually for Low-Level Waste Management Area 4.

- Wells are sampled quarterly to semiannually for Waste Management Area T.

- Wells are sampled quarterly to semiannually for Waste Management Area TX-TY.

- Wells are sampled quarterly to semiannually for the State-Approved Land Disposal Site. One well went dry in FY 2006 (see Appendix B). 


\section{Groundwater flows \\ toward the east- northeast except where affected by pumping, injection, or waste discharge.}

tank farms, affecting the assessment monitoring network and potentially drawing tank-farm associated contaminants into the new extraction wells of the pump-and-treat system. These flow conditions are expected to continue until the end of the pump-and-treat program, at which time the flow direction will resume a general west to east pattern.

The remainder of this section describes contaminant plumes and concentration trends for the contaminants of concern, summarizes the status of groundwater remediation efforts, and discusses the results of monitoring of specific facilities under CERCLA, RCRA, state permits, and the Atomic Energy Act (AEA).

\subsubsection{Groundwater Contaminants}

The groundwater contaminants of concern discussed in this section are defined in the 200-ZP-1 remedial investigation/feasibility study work plan (DOE/RL-2003-55). The contaminants of concern defined in the work plan, their preliminary target action levels, and summary of detection statistics are listed in Table 2.8-1. The remedial investigation identified contaminants for detailed risk assessment in the upcoming feasibility study. These contaminants are listed in Table 2.8-2, reproduced from the remedial investigation report (DOE/RL-2006-24). Other pertinent results of the remedial investigation will be summarized in the discussion of individual constituents.

During FY 2006, a number of wells were sampled for special characterization studies under the CERCLA investigations. The sampling included vertical profile sampling within existing wells and other non-routine methods. These samples are generally not included in the discussion here because they are not considered comparable to routine samples collected to represent general aquifer conditions and the studies are not yet complete.

\subsubsection{Carbon Tetrachloride}

Carbon tetrachloride contamination is found at levels greater than the drinking water standard $(5 \mu \mathrm{g} / \mathrm{L})$ in the groundwater under most of the 200 West Area (Figure 2.8-3). The main sources are believed to be the $216-Z$ cribs and trenches that received waste from the Plutonium Finishing Plant. The maximum carbon tetrachloride levels in groundwater are found near the Plutonium Finishing Plant and range up to 4,400 $\mathrm{\mu g} / \mathrm{L}$ in individual samples. This is considerably lower than the FY 2005 maximum of 5,300 $\mu \mathrm{g} / \mathrm{L}$ in individual samples. During FY 2006, extraction well 299-W15-34 had the highest average concentrations $(3,300 \mu \mathrm{g} / \mathrm{L})$. Thus, no wells showed a yearly average concentration $>4,000 \mu \mathrm{g} / \mathrm{L}$ in contrast to previous years.

Significant features of the carbon tetrachloride plume in the upper part of the aquifer include:

Plume areas (square kilometers) above the drinking water standard at the 200-ZP-1 Operable Unit:

*Carbon tetrachloride - 9.8

Chromium - 0.05

Iodine-129 - 0.94

Nitrate - 5.9

Technetium-99-0.08

Trichloroethene - 0.54

Tritium - 0.74

Uranium - 0.16

*Also includes portion of plume beneath 200-UP-1 Operable Unit.
- No wells showed average carbon tetrachloride concentrations $>4,000 \mu \mathrm{g} / \mathrm{L}$ in the 200 West Area in FY 2006. The area >2,000 $\mu \mathrm{g} / \mathrm{L}$ decreased between FY 2005 and FY 2006.

- An area of carbon tetrachloride at levels $>2,000 \mu \mathrm{g} / \mathrm{L}$ extends north to the vicinity of Waste Management Area TX-TY. The west side of this lobe is defined by well 299-W15-43, where the average concentration was $2,000 \mu \mathrm{g} / \mathrm{L}$, an increase from FY 2005. The carbon tetrachloride contamination reaches the north part of Waste Management Area TX-TY where concentrations in well 299-W15-765 averaged 2,800 $\mu \mathrm{g} / \mathrm{L}$ in FY 2006, a slight increase from FY 2005. In FY 2005, the pump-and-treat system was expanded to capture this northern extension on the plume. Monitoring wells 299-W15-40, 299-W15-42, 299-W15-43, and 299-W15-765, were turned into extraction wells (see Section 2.8.2.2). 
- Levels of carbon tetrachloride $>1,000 \mu \mathrm{g} / \mathrm{L}$ are seen in the northeast part of the 200-ZP-1 Operable Unit. Routine samples in FY 2006 from well 299-W11-10 near the east boundary of the 200 West Area contained $1,060 \mu \mathrm{g} / \mathrm{L}$ of carbon tetrachloride. The extent beyond the area boundary for this high concentration has not been determined since there are no wells for $\sim 2$ kilometers downgradient. Geostatistical analysis of data from 1996-2004 for carbon tetrachloride by Pacific Northwest National Laboratory (PNNL) indicated that concentrations in this part of the 200 West Area are consistent with low variability.

- In the past several years, increasing concentrations of carbon tetrachloride have been seen in the vicinity of the tank farms in Waste Management Area S-SX (in the 200-UP-1 Operable Unit). Concentrations appear to have declined in several wells in this area.

- Carbon tetrachloride levels continue to increase in well 699-48-71 indicating contamination is moving northeast from the 200 West Area. The carbon tetrachloride in this well reached $34 \mu \mathrm{g} / \mathrm{L}$ in January 2006 (Figure 2.8-4). There are no wells for a considerable distance downgradient from well 699-48-71 to track the leading edge of the carbon tetrachloride plume.

- The extent of carbon tetrachloride at the drinking water standard $(5 \mu \mathrm{g} / \mathrm{L})$ shown in Figure 2.8-3 did not change greatly from the previous year. Concentrations are declining on the western (upgradient) side of the plume.

Carbon tetrachloride remediation is the subject of the 200-ZP-1 interim action record of decision (ROD 1995a). The target for remediation is the area with concentrations $>2,000$ to 3,000 $\mu \mathrm{g} / \mathrm{L}$ in the vicinity of the $216-\mathrm{Z}$ cribs and trenches. The remediation activities and more details on the contaminant distribution are summarized in Section 2.8.2.

It is important to emphasize that the depiction of the extent of carbon tetrachloride in Figure 2.8-3 is the extent of contamination near the upper part of the aquifer but the three-dimensional extent is considerably more complex. Recent data indicate that the highest concentrations in some areas are found deeper in the aquifer. In particular, the FY 2004 installation of well 299-W13-1 in the east part of the 200 West Area showed that contamination extends deeper and farther east than previously demonstrated by monitoring shallow wells.

Depth-discrete data for 19 wells were evaluated in the 200-ZP-1 remedial investigation report (DOE/RL-2006-24). Depth-discrete groundwater samples were collected at $~ 9.1$-meter intervals as the wells were drilled. The depth-discrete data were supplemented by samples collected from existing wells. Data available in February 2006 were included in that report and are summarized here.

Most of the remedial investigation/feasibility study wells were drilled a minimum of 37 meters below the water table. Several of the wells were drilled deeper. Well 299-W15-49 was drilled to the top of the Ringold lower mud unit, $\sim 62$ meters below the water table. Well 299-W11-43 was drilled to $\sim 55$ meters below the water table. The lower mud unit was not present at this location. Well 299-W13-1 was drilled to the top of basalt at a depth of 160.8 meters. Well 299-W15-46 was drilled $\sim 92$ meters below the water table. This well was drilled near the 216-Z-9 trench, through the lower mud unit to the top of basalt at the base of the unconfined aquifer. All depth-discrete groundwater samples from the 19 remedial investigation/feasibility study wells were analyzed for volatile organic compounds and, in some cases, a variety of other analytes. In addition, depth-discrete samples were collected from 20 existing wells using a straddle-packer system between 2004 and 2006.

PNNL performed a geostatistical analysis of the three-dimensional carbon tetrachloride data in order to determine the geometry of the carbon tetrachloride plume. The geostatistical analysis was based primarily on deep carbon tetrachloride and chloroform data from depth-discrete sampling at 141 intervals in 26 boreholes and is described in more detail in

\section{Carbon}

tetrachloride

contamination

is found at levels

greater than the

drinking water

standard (5 $\mu \mathrm{g} / \mathrm{L})$

in groundwater

beneath most of the

200 West Area. 


\section{Carbon \\ tetrachloride \\ contamination \\ extends to the \\ bottom of the \\ unconfined aquifer.}

\section{Trichloroethene is \\ detected at levels \\ above the drinking \\ water standard \\ $(5 \mu g / L)$ in the \\ 200-ZP-1 Operable}

Unit.

\section{A well near the}

216-T-36 crib

has one of the

highest nitrate

concentrations

$(3,000 \mathrm{mg} / \mathrm{L})$ on the

Hanford Site.
DOE/RL-2006-24. The analysis showed significant carbon tetrachloride is present from the water table to the bottom of the unconfined aquifer. The aquifer thickness is $\sim 60$ meters and concentrations are particularly high to the east of the known source areas. High uncertainties were noted at greater depths in the aquifer and in the southeast where data are sparse.

The results of the carbon tetrachloride studies were integrated with geologic information to form a conceptual model of the plume geometry (DOE/RL-2006-24). The plume extends to the top of the Ringold lower mud unit where the mud is present and to the top of basalt where the mud is absent. Figures 2.8-5 and 2.8-6 illustrate the plume geometry. Note that the contamination occurs at increasing depth to the east of the known source areas and relatively low concentrations are seen at the water table in the east-central part of the 200 West Area. Along the downgradient plume extent, recharge from natural infiltration and less-contaminated former wastewater discharges contribute to reduced carbon tetrachloride concentrations in the upper portion of the unconfined aquifer.

The extent of carbon tetrachloride contamination deeper in the aquifer indicates that a significantly greater mass of carbon tetrachloride is present in the unconfined aquifer than previously calculated.

\subsubsection{Trichloroethene}

Trichloroethene is also detected at levels above the drinking water standard $(5 \mu \mathrm{g} / \mathrm{L})$ in the 200-ZP-1 Operable Unit (Figure 2.8-7). Trichloroethene contamination extends into the 200-UP-1 Operable Unit but, in wells completed across the water table, appears to form separate plumes at the $1 \mu \mathrm{g} / \mathrm{L}$ level (see Section 2.9.1.6). The main trichloroethene plume extends north and northeast from the vicinity of the $216-Z$ cribs and trenches, the 216-Z-9 trench in particular. Levels are lower and the extent is generally less than for carbon tetrachloride. The maximum trichloroethene concentration detected in FY 2006 routine monitoring was $27 \mu \mathrm{g} / \mathrm{L}$ in the November sample from new well 299-W15-50, north of the 216-Z-9 trench. Well 299-W15-50 is screened 7.6 to 18.3 meters below the water table and, thus, is not shown in Figure 2.8-7. The size of the plume is similar to FY 2005 in the northern part of the plume but has declined in the vicinity of the pump-and-treat system in the south.

\subsubsection{Chloroform}

Chloroform concentrations in the 200-ZP-1 wells remained below the $80-\mu \mathrm{g} / \mathrm{L}$ drinking water standard (the standard is defined for total trihalomethane) for routine samples collected during FY 2006. Several characterization samples collected from various depths during well drilling or by depth-discrete sampling contained chloroform at levels above the drinking water standard. Those values ranged up to $243 \mu \mathrm{g} / \mathrm{L}$ in well 299-W15-6, located near the 216-Z-9 trench. Possible chloroform sources include biodegradation of carbon tetrachloride and sanitary sewer discharges to the 2607-Z tile field.

The 200-ZP-1 remedial investigation/feasibility study work plan (DOE/RL-2003-55) designates a preliminary target action level of $7.17 \mu \mathrm{g} / \mathrm{L}$ based on cleanup levels and risk calculations under the Model Toxics Control Act (WAC 173-340) cleanup regulations. One of the recommendations of the 200-ZP-1 remedial investigation report (DOE/RL-2006-24) is that the feasibility study include an evaluation of laboratory contaminants and carbon tetrachloride degradation byproducts. These degradation products include chloroform, chloromethane, and methylene chloride (DOE/RL-2006-24).

\subsubsection{Nitrate}

Nitrate continued to be present in groundwater at concentrations above the drinking water standard (45 mg/L) beneath much of the 200-ZP-1 Operable Unit (Figure 2.8-8). The maximum concentration in this vicinity during FY 2006 was $3,230 \mathrm{mg} / \mathrm{L}$ in well 299-W10-4 near the 216-T-36 crib, south of Waste Management Area T. The average nitrate concentration in well 299-W10-4 was 3,000 mg/L for FY 2006, the same as in FY 2005. The nitrate contamination is more widespread than the tritium, iodine-129, or technetium-99 
contamination as discussed in Sections 2.8.1.7, 2.8.1.8, and 2.8.1.9, respectively. Multiple sources of nitrate probably exist in this area, including the cribs near Waste Management Area $T$ and the $216-Z$ crib and trench disposal facilities.

Elevated nitrate concentrations in well 299-W14-13 on the east side of Waste Management Area TX-TY generally correlate with elevated chromium, tritium, iodine-129, and technetium-99. Because of the lower levels of contaminants in surrounding wells, this contamination is interpreted as being from a nearby source and is discussed further in Section 2.8.3.4.

A new well, 299-W18-16, drilled east of the 216-Z-1A crib in FY 2005 contained nitrate at much higher concentrations than surrounding wells. The maximum nitrate reported in FY 2006 was 1,060 mg/L with a yearly average of $920 \mathrm{mg} / \mathrm{L}$.

Elevated nitrate levels are found in the west part of the Hanford Site (see Figure 1.0-3 in Section 1.0). This contamination is believed to be due to offsite agriculture because it is persistent, far upgradient of the site waste disposal areas, and is not associated with other Hanford contaminants. Constituents indicative of Hanford contamination, such as tritium, are low in this area. One well (699-36-93, see Figure 2.1-1 in Section 2.1 for location) in the west part of the Hanford Site had nitrate levels $(52 \mathrm{mg} / \mathrm{L})$ above the drinking water standard (45 mg/L) in FY 2006. Most wells in the west part of the site, upgradient of the production areas, are only sampled every three years.

\subsubsection{Chromium}

Chromium contamination is found at levels above the drinking water standard (100 $\mu \mathrm{g} / \mathrm{L})$ in filtered samples in the immediate vicinity of Waste Management Areas T and TX-TY (Figure 2.8-9). Chromium at lower levels extends downgradient toward or past the 200 West Area boundary.

Hexavalent chromium is included in this discussion because it is the most soluble and mobile form under Hanford aquifer conditions. Thus, all chromium in filtered groundwater samples is assumed to be soluble hexavalent chromium. The preliminary target action level for hexavalent chromium $(48 \mu \mathrm{g} / \mathrm{L})$ is lower than the preliminary target action level for total chromium $(100 \mu \mathrm{g} / \mathrm{L})$.

The chromium plume in the vicinity of Waste Management Area T has changed little in size over the past decade, although the extent of lower concentrations beyond the 200 West Area fence line is uncertain due to the lower density of monitoring wells. The highest levels are found south of Waste Management Area T. The highest dissolved chromium concentration was $650 \mu \mathrm{g} / \mathrm{L}$ and the average concentration was $550 \mu \mathrm{g} / \mathrm{L}$ in well 299-W10-4 during FY 2006. Chromium concentrations peaked in this well in October 2004 and have declined since that time. Chromium near Waste Management Area T is discussed in more detail in Section 2.8.3.3.

The first regular sample from well 299-W11-43, located northeast of Waste Management Area T, contained $150 \mu \mathrm{g} / \mathrm{L}$ of chromium. This well is completed $\sim 48$ meters below the water table. This concentration is higher than found in water-table wells in the general vicinity.

Chromium is also elevated east of Waste Management Area TX-TY in well 299-W14-13. The concentrations detected in filtered samples from this well in FY 2006 remained fairly constant with an average value of $740 \mu \mathrm{g} / \mathrm{L}$. The chromium contamination is associated with elevated nitrate, tritium, technetium-99, and iodine-129. The contamination is discussed further in Section 2.8.3.4.

\subsubsection{Fluoride}

Fluoride contamination at levels greater than the primary drinking water standard (4 mg/L) is seen in a local area around Waste Management Area T. In FY 2006, one well (299-W10-23) north of Waste Management Area T had a single fluoride concentration greater than the primary drinking water standard; however, the yearly average was below the

\section{The highest concentrations of chromium are found east of Waste Management Area TX-TY where the average concentration was $740 \mu g / L$.}




\section{The highest tritium}

concentrations were

in a well east of

Waste Management

Area TX-TY

where the average

concentration was

1.7 million $p C \mathrm{i} / \mathrm{L}$.

The highest

iodine-129

concentration

(72 $p C i / L)$ was in

a sample collected

during drilling

of new well

299-W14-11, east of

Waste Management

Area TX-TY in

FY 2006. standard (Figure 2.8-10). Several wells have concentrations above the secondary standard of $2 \mathrm{mg} / \mathrm{L}$. Release of lanthanum fluoride used in the bismuth phosphate process is a possible cause of this contamination.

\subsubsection{Tritium}

Tritium contamination at levels greater than the drinking water standard $(20,000 \mathrm{pCi} / \mathrm{L})$ in the 200-ZP-1 Operable Unit is mainly restricted to a plume extending northeast from waste disposal facilities in the vicinity of Waste Management Areas T and TX-TY. Multiple potential sources of tritium exist in this vicinity. In addition, tritium from permitted discharges at the State-Approved Land Disposal Site is found in the groundwater (Figure 2.8-11). Tritium at the State-Approved Land Disposal Site is discussed in Section 2.8.3.5.

The highest tritium concentrations in water-table wells remained at well 299-W14-13, located east of Waste Management Area TX-TY, where the concentration in FY 2006 ranged from 1.61 to 1.82 million $\mathrm{pCi} / \mathrm{L}$, with an average of 1.7 million $\mathrm{pCi} / \mathrm{L}$. The levels are similar to FY 2005. The maximum tritium concentration detected in this well was 2.94 million pCi/L in FY 2000. Well 299-W14-13 replaced well 299-W14-12, and the trend plot for these two wells indicates that the high contamination levels arrived at this location in 1999 (Figure 2.8-12). High levels of chromium, nitrate, technetium-99, and iodine-129 are associated with the tritium contamination. Data on the depth distribution of tritium near well 299-W14-13 are available from well 299-W14-11, which was drilled in FY 2005 and completed 12 to 15 meters below the water table. During FY 2006, the tritium concentration in this well varied between 62,800 and $346,000 \mathrm{pCi} / \mathrm{L}$ with an average of $230,000 \mathrm{pCi} / \mathrm{L}$. This contamination is discussed further in Section 2.8.3.4. Overall, tritium levels in the 200-ZP-1 Operable Unit are fairly low with only a few wells having average concentrations greater than the 20,000-pCi/L drinking water standard in FY 2006.

\subsubsection{8 lodine-129}

An iodine-129 plume is found in the 200-ZP-1 Operable Unit emanating from the vicinity of Waste Management Area TX-TY and extending to the northeast (Figure 2.8-13). The highest concentration detected during routine sampling in FY 2006 was in well 299-W14-13, where the concentration ranged from 19.0 to $42.7 \mathrm{pCi} / \mathrm{L}$ with an average of $33 \mathrm{pCi} / \mathrm{L}$, an increase from FY 2005 levels. During drilling of new well 299-W14-11 east of the waste management area, iodine- 129 was found at $72 \mathrm{pCi} / \mathrm{L}$ in a sample collected near the water table. Iodine-129 near Waste Management Area TX-TY is discussed further in Section 2.8.3.4. Determining the extent of iodine-129 contamination is difficult because the detection limit is at or sometimes above the drinking water standard.

\subsubsection{Technetium-99}

Technetium-99 within the 200-ZP-1 Operable Unit is found at levels significantly above the drinking water standard $(900 \mathrm{pCi} / \mathrm{L})$ on the east (downgradient) side of Waste Management Area T and the vicinity of Waste Management Area TX-TY (Figure 2.8-14). Evidence points to multiple sources of technetium-99 within those areas.

Well 299-W11-39, near the northeast corner of Waste Management Area T, had the highest concentration in samples collected near the water table in the area with values in FY 2006 ranging from 22,500 to 27,600 pCi/L. However, well 299-W11-46, which is screened between 6 and 12 meters below the water table, showed technetium-99 concentrations averaging $56,000 \mathrm{pCi} / \mathrm{L}$ in FY 2006 with a maximum concentration of 63,200 pCi/L. Thus, the highest technetium concentrations are found deeper in the aquifer. Technetium-99 concentrations south of Waste Management Area T, in well 299-W10-4, continued an overall upward trend with a FY 2006 average concentration of $890 \mu \mathrm{g} / \mathrm{L}$ compared to an average of $830 \mathrm{pCi} / \mathrm{L}$ in FY 2005. Individual samples from this well were above the drinking water standard. Technetium-99 contamination around Waste Management Area T is discussed in greater detail in Section 2.8.3.3.

Technetium-99 concentrations east of Waste Management Area TX-TY in well 299-W14-13 remained within the range of previous samples during FY 2006. The fiscal year 
average concentration in this well was $7,600 \mathrm{pCi} / \mathrm{L}$, a slight increase from the previous year's average of $7,100 \mathrm{pCi} / \mathrm{L}$. This contamination is associated with elevated levels of chromium, nitrate, tritium, and iodine-129. Somewhat lower technetium-99 concentrations averaging 2,500 pCi/L were found in adjacent well 299-W14-11, which is screened between 12 and 15 meters below the water table, indicating that the highest concentrations are found at the water table in contrast to Waste Management Area T. Technetium-99 concentrations increased sharply in wells on the west side of Waste Management Area TX-TY when the 200-ZP-1 Operable Unit pump-and-treat system was expanded to include wells west of the tank farms. Contamination exhibited in this area is discussed further in Section 2.8.3.4.

\subsubsection{Uranium}

Few analyses for uranium were performed on groundwater samples from the 200-ZP-1 Operable Unit during FY 2006 because most wells showed insignificant levels in previous monitoring. Some wells monitored near the single-shell tank farms and low-level burial grounds are sampled for gross alpha measurements, which would show an increase if uranium contamination appeared.

Uranium was detected above the drinking water standard (30 $\mu / \mathrm{L})$ in well 299-W11-37 in the northeast 200 West Area. The annual average uranium concentration detected in well 299-W11-37 was $100 \mu \mathrm{g} / \mathrm{L}$. The uranium concentration in this well has declined from over $450 \mu \mathrm{g} / \mathrm{L}$ in early 2000.

\subsubsection{Other Contaminants of Concern}

Most of the other contaminants of concern in the 200-ZP-1 remedial investigation/ feasibility study work plan (DOE/RL-2003-55) were not detected in FY 2006 sampling (Table 2.8-1). Other contaminants of concern that were detected at concentrations above the preliminary target action level are discussed in this section.

Antimony was reported as detected in three wells at levels above the $10-\mu \mathrm{g} / \mathrm{L}$ preliminary target action level in FY 2006. The detections were very close to the reported detection limit and, like sporadic detections in previous years, are believed to be false positives. In one of nine filtered samples from well 699-48-77A, antimony was reported as detected $(33.7 \mu \mathrm{g} / \mathrm{L})$. Antimony was not detected in the unfiltered sample from the same event. Antimony was detected in one of four filtered samples and in one of four unfiltered samples from well 699-48-77C with a maximum concentration of $44.3 \mu \mathrm{g} / \mathrm{L}$. One of four unfiltered samples from well 699-48-77D was reported as containing detectable antimony with a concentration of $58.1 \mu \mathrm{g} / \mathrm{L}$. Antimony was not detected in the other samples from these wells for the fiscal year.

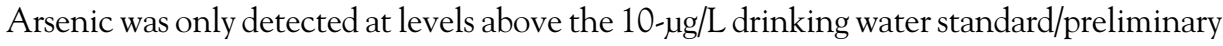
target action level in well 299-W10-4. The maximum concentration detected was $10.8 \mu \mathrm{g} / \mathrm{L}$. This value is slightly lower than the previous year's maximum. The subsequent sample was below the drinking water standard.

Iron was present at levels above the $300-\mu \mathrm{g} / \mathrm{L}$ preliminary target action level/secondary drinking water standard in one filtered sample from well 299-W11-45 near Waste Management Area T collected during drilling and in several unfiltered samples from other wells. Three other filtered samples from this well and well 299-W11-12 with high iron values were rejected as being suspect. Iron is a naturally occurring component of the aquifer sediment and is found in well materials; thus, elevated iron levels in unfiltered samples are not surprising. The high iron in the drilling water sample may be the result of lack of well screen or well development.

Manganese was detected at levels above the $50-\mu \mathrm{g} / \mathrm{L}$ preliminary target action level/ secondary drinking water standard in filtered samples from six 200-ZP-1 wells and unfiltered samples from one well in FY 2006. The highest concentration reported was $627 \mu \mathrm{g} / \mathrm{L}$ in a sample collected during drilling of well 299-W11-47. Elevated manganese values in the
Technetium-99

within the

200-ZP-1 Operable

Unit is found

above the drinking

water standard

downgradient of

Waste Management

Areas T and TX-TY.

Few analyses for

uranium were

performed on

groundwater

samples from the

200-ZP-1 Operable

Unit during

FY 2006 because

most wells showed

insignificant

levels in previous

monitoring. 
A pump-and-treat system and a vapor extraction system are installed in the 200-ZP-1 Operable

Unit to treat carbon tetrachloride contamination. first few years of sampling are not uncommon for new wells at the Hanford Site, probably due to reaction of groundwater with freshly crushed rock surfaces.

Methylene chloride was detected at levels above the drinking water standard $(5 \mu \mathrm{g} / \mathrm{L})$ in nine wells during FY 2006. Several of these samples were analyzed in a batch with high methylene chloride contamination in the associated blank so they are considered suspect. Of the samples not associated with contaminated blanks, the highest concentration was $10 \mu \mathrm{g} / \mathrm{L}$ in a sample from extraction well 299-W15-34. Methylene chloride (dichloromethane) could be a degradation product or impurity in carbon tetrachloride (tetrachloromethane) but is also a common laboratory contaminant.

Because of the uncertainty associated with the methylene chloride detection, one of the recommendations of the 200-ZP-1 remedial investigation report (DOE/RL-2006-24) is that the feasibility study include an evaluation of laboratory contaminants and degradation byproducts. These degradation products include chloroform, chloromethane, and methylene chloride. Further evaluation will allow a determination as to whether the methylene chloride is a degradation product or laboratory artifact and whether it will be included in the baseline risk assessment (DOE/RL-2006-24).

Tetrachloroethene is often detected at levels below the drinking water standard (5 ppb) in the 200-ZP-1 Operable Unit. In FY 2006, one well (299-W13-1) had a result with tetrachloroethene above the drinking water standard that was not flagged as suspect $(6.4 \mu \mathrm{g} / \mathrm{L})$. The previous result was also high, but three subsequent samples were below the drinking water standard/preliminary target action level.

\subsubsection{CERCLA Investigations and Interim Groundwater Remediation for Carbon Tetrachloride}

The U.S. Department of Energy (DOE) published the second CERCLA five-year review in November 2006 (DOE/RL-2006-20). This document provided a comprehensive evaluation of the status of groundwater and source operable unit investigations and cleanup actions. Findings for the 200 Area National Priority List site that are pertinent to the 200-ZP-1 Operable Unit include the following summary statement:

"Two pump-and-treatment systems and a vapor extraction system have been installed as interim actions to treat groundwater contamination in the 200 Areas. The 200-ZP-1 Groundwater Operable Unit has a pump-and-treatment system to remove carbon tetrachloride from the groundwater. This system was designed to address only the most concentrated portion of the shallow portion of the plume and will be expanded through the CERCLA remedial investigation/feasibility study process to address the deeper portion of the plume. A protectiveness determination for the pump-and-treat interim remedy is being deferred until a final remedy is selected through the CERCLA remedial investigation/feasibility study process."

Several issues and actions related to the 200-ZP-1 Operable Unit were identified:

- Issue 13. There is less than adequate deep groundwater monitoring data downgradient of T Tank Farm to define the nature and extent of technetium-99 contamination. Further characterize the technetium-99 groundwater plume near T Tank Farm.

- Action 13-1. Complete a data quality objective process and sampling plan to further characterize the technetium-99 groundwater plume near T Tank Farm (due date March 2007).

- Issue 14. The recent expansion of the 200-ZP-1 extraction well network near the TX-TY Tank Farm may result in technetium-99 contamination being pulled into the 200-ZP-1 treatment system. Treatment options for groundwater contaminated with technetium-99 need to be assessed. 
- Action 14-1. Assess treatment options to address technetium-99 near T Tank Farm (due date September 2007).

- Issue 16. Efficiency and effectiveness of the 200-ZP-1 pump-and-treat system could be increased by increasing the pumping rate to fully utilize the treatment capacity.

- Action 16-1. Increase the pump size in 200-ZP-1 extraction wells 299-W15-45 and 299-W15-47 (due date March 2007).

- Issue 17. Efficiency of the carbon tetrachloride remediation could be increased by increasing the use of the 200-ZP-2 vapor extraction system. The soil-vapor extraction system is in limited operation. Expanding the soil-vapor extraction operations should be evaluated.

- Action 17-1. Evaluate expanding the soil-vapor extraction operations. Also, specifically review converting former groundwater extraction well 299-W15-32 to a soil-vapor extraction well (due date March 2007).

Within the 200-ZP-1 Operable Unit, interim actions have been implemented for remediation of carbon tetrachloride, chloroform, and trichloroethene in the vicinity of the $216-Z$ liquid waste disposal units ( $216-Z$ cribs and trenches). Remediation of other groundwater contaminants will be determined through the remedial investigation/feasibility study process per Section 5.5 of the Hanford Federal Facility Agreement and Consent Order (Tri-Party Agreement) (Ecology et al. 1989). A Remedial Investigation/Feasibility Study Work Plan for the 200-ZP-1 Groundwater Operable Unit was prepared in FY 2004 (DOE/RL-2003-55) and implemented in FY 2005. The remediation investigation report (DOE/RL-2006-24) was published in October 2006.

Work on the feasibility study for the 200-ZP-1 Operable Unit is ongoing. The feasibility study will include the detailed risk assessment. In FY 2006, potential remediation methods for the 200-ZP-1 Operable Unit were screened (PNNL-15954). The screening considered the eight major contaminants and used a generalized conceptual model of the lateral extent and depth of contamination.

In FY 2006, a data quality objectives report (WMP-28324) was prepared for investigation of the extent of deep groundwater contamination in the eastern part of the 200 West Area. This report proposed the installation of five new deep groundwater monitoring wells.

A pump-and-treat system is operating in the 200-ZP-1 Operable Unit to contain and capture the high concentration portion of the carbon tetrachloride plume located north of the Plutonium Finishing Plant. The plume originated from discharges to the 216-Z-9, 216-Z-1A and 216-Z-18 cribs and has moved north and east of the waste sites. The pump-and-treat system was implemented as an interim remedial measure in three phases starting in 1996.

The remedial action objectives for the pump-and-treat system are to capture the high concentration area of the carbon tetrachloride plume at the water table, to reduce contaminant mass and to gather information to support future remedial investigation/feasibility study decisions (ROD 1995a). The high concentration plume is defined by the 2,000- to 3,000- $\mu \mathrm{g} / \mathrm{L}$-plume contour, which was initially centered beneath the Plutonium Finishing Plant and related waste sites. In 2005, concentrations of carbon tetrachloride exceeding the 2,000- $\mu \mathrm{g} / \mathrm{L}$ remedial action goal were reported at wells west of the TX and TY Tank Farms. Four
Treatment options are being assessed for technetium-99 contamination at Waste Management Areas $\mathrm{T}$ and TX-TY.
The remedial action objectives for the 200-ZP-1 Operable Unit (ROD 1995a) are:

- Reduce contamination in the area of highest concentration of carbon tetrachloride.

- Prevent further movement of these contaminants from the highest concentration area.

- Provide information that will lead to development of a final remedy that will protect human health and the environment.

EPA specified enhancements needed for the system in their 5-year review (EPA 2001). The record of decision for the interim remedial measure states the high concentration portion of the plume corresponds to the area within the 2,000- to 3,000- $\mu \mathrm{g} / \mathrm{L}$ contour of carbon tetrachloride. 


\section{Over 427 million \\ liters of carbon \\ tetrachloride \\ contaminated \\ groundwater were \\ treated in FY 2006.}

\section{One new extraction}

well was brought

on line for the

200-ZP-1 pump-

and-treat system

in FY 2006 at the

216-Z-9 trench. monitoring wells were converted to extraction wells and connected to the 200-ZP-1 pumpand-treat system. Pumping began there is late July 2005 and continued through FY 2006.

\subsubsection{Progress During FY 2006}

Carbon tetrachloride mass was reduced in the area of highest concentrations through pumping and treating of over 427 million liters from nine groundwater extraction wells. The average extraction rate, factoring in all down time, was 810 liters/minute, compared to an average pumping rate of 695 liters/minute in FY 2005 and the remedial action target pumping rate of 568 liters/minute. Most of the increase is attributed to the addition and steady operation of the four extraction wells in late FY 2005. Processing rates of up to 1,200 liters/minute were achieved for significant periods of time.

An existing well, 299-W15-6 at the 216-Z-9 trench, was converted for extraction and brought on line in late September 2006. This well is screened above the Ringold lower mud and will be operated for 3 to 6 months to determine if deep dense nonaqueous phase liquid is present beneath the waste site. This work is being conducted by Vista Engineering as part of their dense nonaqueous phase liquid characterization studies.

Carbon tetrachloride concentrations ranged from a low value of $460 \mu \mathrm{g} / \mathrm{L}$ at extraction well 299-W15-36 to a high value of 4,400 $\mu \mathrm{g} / \mathrm{L}$ at extraction well 299-W15-40. Concentrations at the pump-and-treat system's influent tank averaged 2,096 $\mu \mathrm{g} / \mathrm{L}$ in FY 2006, a slight decrease from 2,133 $\mu \mathrm{g} / \mathrm{L}$ in FY 2005. Treatment resulted in the removal of 889.7 kilograms of carbon tetrachloride from the 427.7 million liters of extracted groundwater. Since starting the pump-and-treat system in August 1994, over 10,197 kilograms of carbon tetrachloride have been removed from almost 3.19 billion liters of groundwater.

The most recent estimates of carbon tetrachloride inventories are given in DOE/RL2006-58. This document provides an estimate of a total of 570,000 to 920,000 kilograms of carbon tetrachloride discharged to the three primary waste sites, 216-Z-9, 216-Z-1A, and 216-Z-18. An estimate of carbon tetrachloride in the unconfined aquifer is also provided. The dissolved carbon tetrachloride is estimated to be 55,900 to 64,600 kilograms, with 44,500 to 51,400 kilograms sorbed to the aquifer sediments. An estimated 13,700 to 15,800 kilograms of carbon tetrachloride has degraded to chloroform below the water table.

Extraction wells have been sampled for technetium-99 to monitor plume movement and to ascertain if the pump-and-treat system is being affected by radiological contamination that could require changes to operations. Unlike past years where technetium-99 concentrations in injected water did not exceed 200 pCi/L, concentrations in FY 2006 have risen sharply for the injected water, to $540 \mathrm{pCi} / \mathrm{L}$ in September 2006. The potential to draw in other contaminant plumes observed on the east side of the TX and TY Tank Farms was recognized when the new wells were added to the extraction system, but the rate of increases in concentration was expected to be lower. Increases in the technetium-99 trends were detected in late 2005 and have continued to the present. Monthly analytical results from the treatment system's influent and effluent tanks indicate that technetium-99 is not being removed during the treatment process. If the effluent concentrations threaten to exceed the maximum contaminant level for technetium-99 (900 pCi/L), the system operation will be altered.

The elevated technetium-99 is coming from two extraction wells, 299-W15-765 and 299-W15-44 (at 3,090 and 1,090 pCi/L, respectively, in September 2006). The 216-T-19 crib is the suspected source for technetium-99 previously drawn into the treatment system through extraction wells 299-W15-35 and 299-W15-32/47, and currently at well 299-W15-44. Unusually high concentrations have been detected at monitoring well 299-W15-763 $(5,890 \mathrm{pCi} / \mathrm{L}, 8 / 06)$, located just west of the crib. For extraction well 299-W15-765, sources may include the $216-\mathrm{T}-21$ to $216-\mathrm{T}-25 \mathrm{cribs}$, the $216-\mathrm{T}-26$ to $216-\mathrm{T}-28 \mathrm{cribs}$, or the TX and TY Tank Farms. A treatability test of an ion exchange resin targeted to remove the technetium-99 is planned to start in March 2007 at the two extraction wells. 
The technetium-99 injected historically has served as an unintentional tracer and has been detected at wells downgradient from the injection wells. In well 299-W15-15 at Low-Level Waste Management Area 4, technetium-99 concentrations rose from 18.5 pCi/L in 1994 to $170 \mathrm{pCi} / \mathrm{L}$ in 2004 before declining to $134 \mathrm{pCi} / \mathrm{L}$ in July 2006. Simultaneously, carbon tetrachloride concentrations declined from $1,400 \mu \mathrm{g} / \mathrm{L}$ to non-detectable concentrations $(0.15 \mu \mathrm{g} / \mathrm{L})$ in the same time period.

\subsubsection{Influence on Aquifer Conditions}

During FY 2006, the $>2,000-\mu g / \mathrm{L}$ carbon tetrachloride contour region in the baseline plume area continued to shrink. At the same time, the newly emerged plume west of the TX and TY Tank Farms also decreased slightly in areal extent.

Concentrations at all baseline plume wells have continued to decline from previous years and three of the five wells in the baseline area were routinely below the 2,000- $\mathrm{\mu g} / \mathrm{L}$ remedial action goal. Concentrations in well 299-W15-36, the southernmost active extraction well, ranged between 450 and $650 \mu \mathrm{g} / \mathrm{L}$ in FY 2006. Only well 299-W15-34 consistently yielded carbon tetrachloride concentrations above $3,000 \mu \mathrm{g} / \mathrm{L}$, while well 299 -W15-35 was slightly above $2,000 \mu \mathrm{g} / \mathrm{L}$ in FY 2006.

Carbon tetrachloride concentrations at three of the four extraction wells that began operation in FY 2005 are consistently above the 2,000- $\mu \mathrm{g} / \mathrm{L}$ remedial action goal. Extraction wells 299-W15-40 and 299-W15-765 both exceeded 4,000 $\mu \mathrm{g} / \mathrm{L}$ $(4,400$ and $4,200 \mu \mathrm{g} / \mathrm{L}$, respectively) early in FY 2006, but did not maintain concentrations above 3,000 $\mu \mathrm{g} / \mathrm{L}$ for the remainder of the year. Well 299-W15-43, the most westerly of the converted extraction wells, averaged slightly below the $2,000-\mu \mathrm{g} / \mathrm{L}$ remedial action goal. The capture zones for these wells have not yet exceeded the contoured plume but reasonable control is expected within another 2 to 3 years.

Monitoring wells have shown declines in concentrations reflecting those observed

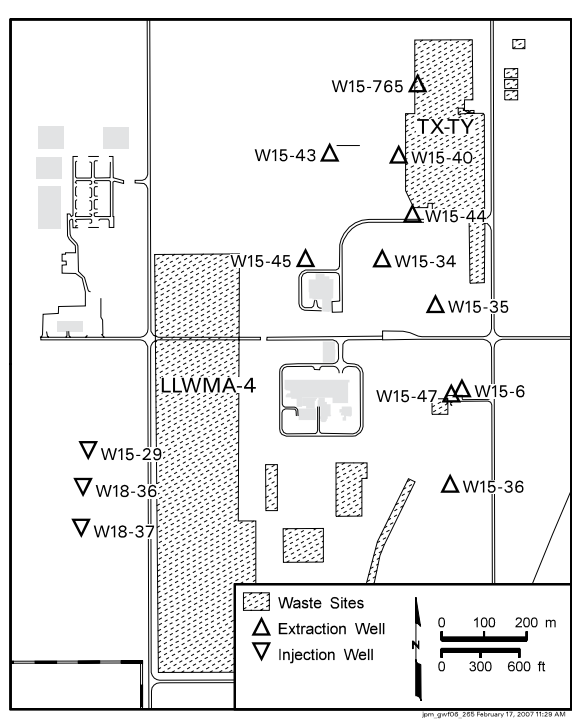
at baseline extraction wells. Well 299-W15-1, located upgradient of extraction well 299-W15-34, ended FY 2005 with a concentration of 5,300 $\mu \mathrm{g} / \mathrm{L}$, but declined sharply in FY 2006, reaching 1,900 $\mu \mathrm{g} / \mathrm{L}$ in August 2006. Another monitoring well (299-W15-7), located downgradient of and between 299-W15-34 and 299-W15-35, remained well below the 2,000- $\mathrm{\mu g} / \mathrm{L}$ remedial action goal. These data indicate that the area around the extraction wells is being remediated by the pump-and-treat system.

Carbon tetrachloride concentrations in upgradient monitoring wells 299-W15-30 and 299-W15-31A declined to between 600 and $800 \mu g / L$ by the end of FY 2006. Monitoring well 299-W15-49, located west of well 299-W15-45, yielded an annual average concentration of $295 \mu \mathrm{g} / \mathrm{L}$. Technetium-99 concentrations increased in these monitoring wells throughout the fiscal year. The declining carbon tetrachloride trends along with the increasing technetium-99 trends at these wells show the influence of the injection system in driving contaminated groundwater toward the extraction wells.

Deep aquifer monitoring at well 299-W13-1, located east of the remediation system, revealed an oscillating trend of carbon tetrachloride concentrations ranging between 1,400 and 2,200 $\mu \mathrm{g} / \mathrm{L}$ in FY 2006. The well is screened just above the Ringold lower mud unit which serves as a barrier to downward movement of contamination. A new well (299-W11-86) located east of the 221-T facility was drilled to the top of basalt in late FY 2006 and was sampled to determine the vertical distribution of carbon tetrachloride. Carbon tetrachloride was detected at 2,300 $\mu \mathrm{g} / \mathrm{L}$, above the remedial action goal, at a depth of 29 meters below the water table. The well was screened to monitor the aquifer directly above the Ringold lower mud but was damaged during construction and will be replaced.

Regional water levels indicate groundwater flow in the vicinity of the pump-and-treat system is to the east-northeast. In FY 2006, the water level declined 0.34 meter in well 
299-W15-49 to 0.45 meter at well 299-W15-39, and averaging at 0.41 meter for seven wells within the area of remediation. Well 299-W14-14 appears to be the least affected by extraction well capture zones and its 0.38 -meter decrease is taken as representative for the area around the pump-and-treat system. This is a sharp increase from the FY 2005 waterlevel decline of 0.25 meter, and may represent changes resulting from expansion of capture zones around extraction wells or from extraction in less permeable units.

\subsubsection{Facility Monitoring}

This section describes results of monitoring individual facilities such as treatment, storage, and disposal units, including tank farms. Some of these facilities are monitored under the requirements of RCRA for hazardous waste constituents and AEA for source, special nuclear, and by-product materials. Facility monitoring also supports CERCLA investigations of hazardous substances and radionuclides. Hazardous constituents and radionuclides are discussed jointly in this section to provide comprehensive interpretations of groundwater contamination for each facility. As discussed in Section 1.2 for RCRA sites, DOE has sole and exclusive responsibility and authority to regulate source, special nuclear, and by-product

Three new wells were added to the monitoring network at Low-Level Waste Management Area 3. materials. Groundwater data for these facilities are available in the Hanford Environmental Information System (HEIS 1994) and on the data files accompanying this report. Additional information including well and constituent lists, maps, flow rates, and statistical tables are included in Appendix B.

\subsubsection{Low-Level Waste Management Area 3}

Groundwater at Low-Level Waste Management Area 3 continued to be monitored under RCRA and AEA in FY 2006. Under 40 CFR 265.93(b) as referenced by WAC 173-303-400, the well network was sampled semiannually for RCRA indicator and site-specific parameters (PNNL-14859; see Appendix B). Five of six wells scheduled for the first semiannual sampling event were successfully sampled. Well 299-W7-12 had too little water to sample and was removed from the schedule. Three newly drilled wells (299-W10-29, 299-W10-30, and 299-W10-31) were added for the second semiannual sampling event. Sampling for the second event was delayed a month and completed in October 2006. General reasons for sampling delays are discussed in Section 1.2. One of the eight wells (299-W10-21) contained too little water to sample and was removed from the schedule. When wells go dry and no potential future use (e.g., well deepening) is identified, they are added to a list of wells to be decommissioned as described in Section 4.3. New downgradient well locations have been identified and prioritized under the Tri-Party Agreement (Ecology et al. 1989) Milestone M-24.

One of the remaining wastewater discharge facilities on site, the State-Approved Land Disposal Site, is located north of Low-Level Waste Management Area 3. Discharge to the facility began in December 1995. Although a local groundwater mound is seen near the discharge, it does not appear to have a major impact on flow in Low-Level Waste Management Area 3, as shown by the water-table map in Figure 2.8-2. The water table continues to decline in Low-Level Waste Management Area 3 monitoring wells in response to the greatly reduced discharge of wastewater to surface facilities around the 200 West Area. Monitoring at the State-Approved Land Disposal Site is discussed further in Section 2.8.3.5.

The groundwater flow in this portion of the 200 West Area is to the eastnortheast (69 degrees), based on trend surface fit to April 2006 water-level measurements, with a calculated gradient of 0.0018. An updated estimate of the hydraulic conductivity for Low-Level Waste Management Area 3 was developed this fiscal year using the model from PNNL-14753. This results in a range in hydraulic conductivity values of 2.5 to 10 meters/day. The estimated flow rate at Low-Level Waste Management Area 3 using these values is 0.015 to 0.18 meter/day 
(see Appendix B). This range is narrower than that calculated in previous years and has a slightly higher upper bound than the 0.12 meter/day calculated in FY 2005.

Under current flow directions, previously designated upgradient wells 299-W10-19, 299-W10-20, and 299-W10-21 remain upgradient of the east portion of the waste management area but are now downgradient of the southwest part of the waste management area. Nitrate and carbon tetrachloride routinely exceed drinking water standards in these wells. Flow and monitoring data collected since RCRA monitoring was instituted in the 1980s indicate that these constituents are from plumes originating from sources to the south. Changing flow directions mean that currently no monitoring wells exist on the upgradient (west) side of Low-Level Waste Management Area 3. For this reason, statistical upgradient/downgradient comparisons have been suspended until background statistics can be re-established. New upgradient wells have been proposed and are included in the Tri-Party Agreement priority list. No suitable upgradient wells have been identified for use in the interim.

Performance assessment monitoring of radionuclides at Low-Level Waste Management Area 3 is designed to complement RCRA detection monitoring and is aimed specifically at monitoring radionuclide materials that are not regulated under RCRA. The current goal of performance assessment monitoring at Low-Level Waste Management Area 3 is to gather data to assess changes in concentrations at downgradient wells and to provide sufficient supporting information from upgradient wells to interpret the changes. Under the current monitoring plan (DOE/RL-2000-72), technetium-99, iodine-129, and uranium are monitored specifically for performance assessment.

Contaminants detected in groundwater at Low-Level Waste Management Area 3 include the following:

- Technetium-99 concentrations are all $<20 \mathrm{pCi} / \mathrm{L}$ and generally show steady or declining trends. The highest concentration in FY 2006 was 18 pCi/L in well 299-W10-20, located on the south edge of Low-Level Waste Management Area 3. Although this well is currently downgradient of part of the burial ground, it was initially designated an upgradient well when flow was toward the north and has likely been affected by contaminant sources to the south. Well 299-W10-20 went dry prior to the second sampling event in FY 2006. The technetium-99 distribution in the 200-ZP-1 Operable Unit is discussed in Section 2.8.1.9.

- Uranium concentrations at Low-Level Waste Management Area 3 were $<2 \mu \mathrm{g} / \mathrm{L}$.

- Iodine-129 was not detected in any wells at Low-Level Waste Management Area 3. The minimum detectable activity is $\sim 0.3 \mathrm{pCi} / \mathrm{L}$.

- Tritium was not detected in any Low-Level Waste Management Area 3 wells in FY 2006.

- As discussed in Sections 2.8.1.1, 2.8.1.2, and 2.8.1.3, carbon tetrachloride and associated trichloroethene and chloroform concentrations in Low-Level Waste Management Area 3 wells are consistent with those seen in regional plumes. Only carbon tetrachloride was detected at levels above the drinking water standard. The highest concentration in a regular groundwater sample was $220 \mu \mathrm{g} / \mathrm{L}$ in well 299-W10-31 (the sample was collected in October 2006).

- The nitrate distribution at Low-Level Waste Management Area 3 is consistent with regional plumes, as discussed in Section 2.8.1.4. The maximum concentration (58.9 mg/L) was found in well 299-W10-20.

\subsubsection{Low-Level Waste Management Area 4}

Groundwater at Low-Level Waste Management Area 4 continued to be monitored under RCRA and AEA. Under 40 CFR 265.93(b) as referenced by WAC 173-303-400, the well network was sampled semiannually for RCRA indicator and site-specific parameters (PNNL-14859; see Appendix B for a table and map of well locations). Of the nine wells
Nitrate and carbon tetrachloride were detected above the drinking water standards at Low-Level Waste

Management Area 3 in FY 2006. 


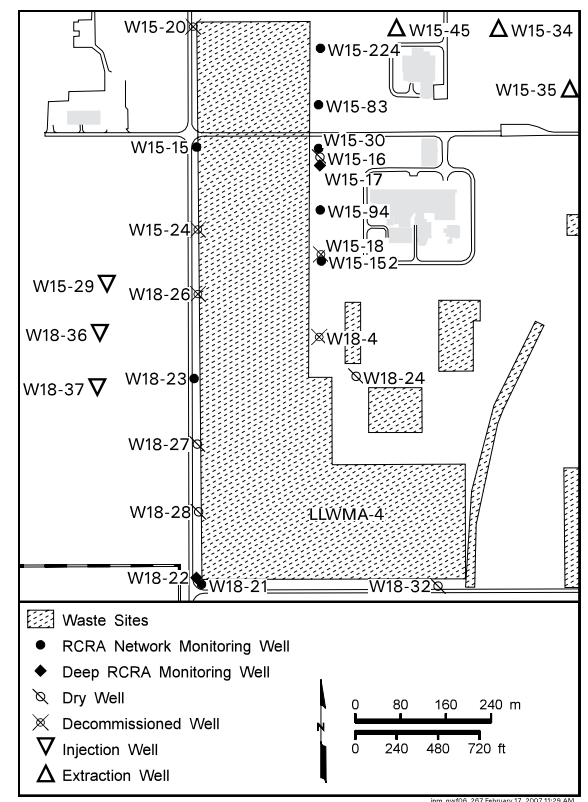

where sampling was attempted during the first semiannual sampling event, sampling was successful in all of the wells. The sampling included three wells (299-W15-83, 299-W15-94, and 299-W15-152) drilled the previous calendar year. An additional well (299-W15-224) was drilled in calendar year 2006 and added for the second sampling event. All ten wells were sampled successfully for the second event. New downgradient well locations have been identified and prioritized under the Tri-Party Agreement Milestone M-24.

The groundwater flow in this portion of the 200 West Area is interpreted to be generally to the east, based on water-table contours. The flow direction is affected to a large degree by the 200-ZP-1 pump-and-treat system, which has extraction wells to the east and injection wells to the west of this RCRA site. The gradient is steeper and has a component to the northeast in the north part of the area and is somewhat less steep with a component to the southeast in the south part of the area. The generalized flow direction using trend surface analysis of the July/August 2006 water level data was slightly north of east with a gradient of 0.004 . An updated estimate of the hydraulic conductivity for Low-Level Waste Management Area 4 was developed this fiscal year using the model from PNNL-14753. This results in a range in hydraulic conductivity values of 10 to 25 meters/day, somewhat higher than at Low-level Waste Management Area 3. The estimated flow rate at LowLevel Waste Management Area 4 using these values is $\sim 0.1$ to 1.0 meter/day (see Appendix B).

Downgradient wells 299-W15-30, 299-W15-83, 299-W15-94, and 299-W15-224 exceeded the statistical comparison value for total organic halides in all samples. Well 299-W15-30 is a replacement for well 299-W15-16, which has gone dry. DOE reported the exceedance of the statistical comparison value in well 299-W15-16 to the U.S. Environmental Protection Agency (EPA) and Washington State Department of Ecology (Ecology) in August 1999. The elevated total organic halide concentrations are consistent with observed levels of carbon tetrachloride from Plutonium Finishing Plant operations (see Section 2.8.1.1 and 2.8.2) although more data are needed from the new wells to establish trends. Carbon tetrachloride concentrations in well 299-W15-30 have declined from 7,100 $\mu \mathrm{g} / \mathrm{L}$ in 1997 to $660 \mu \mathrm{g} / \mathrm{L}$ by August 2006. Carbon tetrachloride and other volatile organic compounds were detected in vapor samples collected from the trenches and vadose zone within Low-Level Waste Management Area 4 during FY 2002. A soil-vapor extraction system was operated at the 218-W-4C burial ground from November 2003 through April 2004. The system was operated to remove the carbon tetrachloride from the burial ground trench and minimize the release of carbon tetrachloride to the environment. Approximately 11 kilograms of carbon tetrachloride were removed from trench T-04 in the 218-W-4C burial ground during FY 2004. The system was dismantled permanently to allow for removal of the soil overburden that covered the drums at the east end of trench T-04 (DOE/RL-2006-24).

The other indicator parameters, $\mathrm{pH}$, specific conductance and total organic carbon did not exceed the comparison values for FY 2006. Statistical comparison values for use in FY 2007 are listed in Appendix B.

Performance assessment monitoring of radionuclides at Low-Level Waste Management Area 4 is designed to complement the RCRA detection monitoring. The current goal of performance assessment monitoring at Low-Level Waste Management Area 4 is to gather data to assess changes in concentrations at downgradient wells and to provide sufficient supporting information from upgradient wells to interpret the changes. Under the current monitoring plan (DOE/RL-2000-72), technetium-99, iodine-129, and uranium are monitored specifically for performance assessment.

Contaminant characteristics at Low-Level Waste Management Area 4 include the following:

- Technetium-99 concentrations remained slightly elevated in wells on the west (upgradient) of Low-Level Waste Management Area 4 (wells 299-W15-15, 299-W18-21, 
and 299-W18-23). Technetium-99 concentrations were all $<200 \mathrm{pCi} / \mathrm{L}$. As discussed in Section 2.8.1.9, this occurrence may result at least in part from technetium-99 in water injected by the 200-ZP-1 pump-and-treat system. Technetium-99 concentrations have also increased since FY 2004 in well 299-W15-30 on the east (downgradient) side of Low-Level Waste Management 4. This indicates that the contamination has moved beneath the burial ground from upgradient. The highest technetium-99 concentration on the downgradient side of the burial ground was $155 \mathrm{pCi} / \mathrm{L}$ in the February sample from well 299-W15-152.

- Uranium concentrations are elevated in upgradient well 299-W18-21 in the southwest corner of the waste management area. Concentrations were just under the $30 \mu \mathrm{g} / \mathrm{L}$ drinking water standard in FY 2006. Uranium concentrations have been increasing in upgradient well 299-W18-23, but remained below $10 \mu \mathrm{g} / \mathrm{L}$ in FY 2006.

- Iodine-129 was not detected in Low-Level Waste Management Area 4 wells. The minimum detectable activity is $\sim 0.3 \mathrm{pCi} / \mathrm{L}$.

- Tritium levels were all $<2,000 \mathrm{pCi} / \mathrm{L}$ and, thus, less than one tenth of the drinking water standard.

- Nitrate continued to exceed the drinking water standard at many monitoring wells in Low-Level Waste Management Area 4. This contamination is not believed to be related to waste disposal at the burial grounds. Some of the nitrate contamination is related to injection of 200-ZP-1 treated water upgradient of the burial ground. The treatment system does not remove nitrate from the water.

- Carbon tetrachloride and associated trichloroethene and chloroform in the groundwater beneath Low-Level Waste Management Area 4 are consistent with regional plumes as shown in Sections 2.8.1.1, 2.8.1.2, and 2.8.1.3. Chloroform and trichloroethene concentrations remained below the drinking water standard. The highest carbon tetrachloride detected was $1,400 \mu \mathrm{g} / \mathrm{L}$ in the November sample from downgradient well 299-W15-30.

\subsubsection{Waste Management Area T}

Waste Management Area T is located in the north-central part of the 200 West Area and consists of the T Tank Farm and ancillary equipment (e.g., diversion boxes and pipelines). The tank farm contains twelve 2-million-liter tanks and four 208,000-liter tanks constructed between 1943 and 1944. Seven of the tanks in the waste management area are known or suspected to have leaked. This section describes groundwater monitoring at Waste Management Area T. A well location map and a table of wells and analytes for this waste management area are included in Appendix B.

The objective of RCRA groundwater monitoring at Waste Management Area T is to assess the extent and rate of movement of dangerous waste in groundwater that have a source from the waste management area (40 CFR 265.93(d) as referenced by WAC 173-303-400). The groundwater assessment plan for Waste Management Area T was updated in May 2006 (PNNL-15301) to incorporate information obtained from new wells drilled since the most recent Interim Change Notice to the previous plan (PNNL-12057-ICN-1). In addition to monitoring dangerous waste constituents for RCRA assessment, the site is monitored for CERCLA and AEA purposes. Waste Management Area $T$ was originally placed in RCRA assessment monitoring because of elevated specific conductance in downgradient well 299-W10-15 (WHC-SD-EN-AP-132). This area remains in assessment because of continued elevated contaminants observed in downgradient wells.

Dangerous waste constituents found beneath Waste Management Area T in FY 2006 are chromium and nitrate. These constituents probably originate from more than one source including the waste management area. Other constituents
Nitrate and carbon tetrachloride, from regional contaminant plumes, exceeded the drinking water standards at Low-Level Waste Management Area 4 in FY 2006.

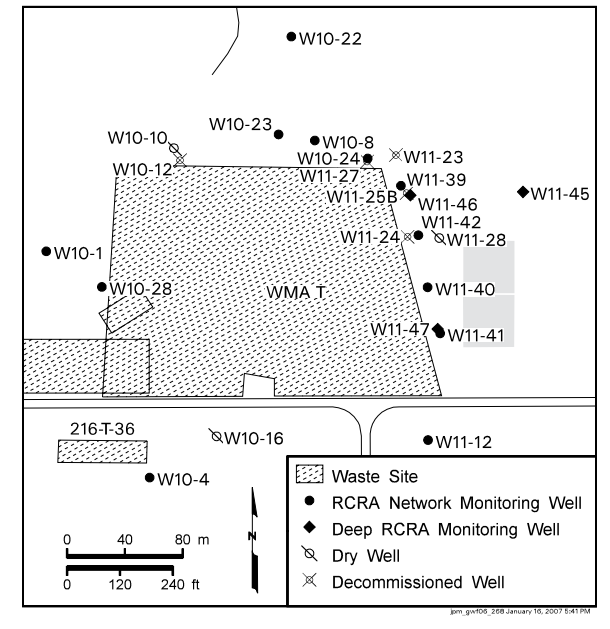




\section{Two new wells}

were installed at

Waste Management

Area T in FY 2006

to help delimit the

high technetium-99

plume east of the

waste management

area.

\section{A chromium plume extends from the west and southwest part of Waste Management Area $T$}

to the east and northeast of the waste management area. found beneath the waste management area in FY 2006 include carbon tetrachloride, trichloroethene, tritium, technetium-99, and cobalt-60. The carbon tetrachloride and trichloroethene do not appear to be from Waste Management Area T and are discussed in Sections 2.8.1.1 and 2.8.1.2. The tritium in most wells is believed to be part of a regional plume and is not attributed to the T Tank Farm. The technetium-99 plume, located east (downgradient) of the T Tank Farm, is attributed, at least in part, to the tank farm.

Calculated average linear groundwater flow velocities at Waste Management Area T range from 0.017 to 0.28 meter/day with most values $<0.1$ meter/day. Groundwater flow direction beneath the waste management area is between 85 and 98 degrees from north as determined by trend surface analyses (PNNL-13378; PNNL-14113) and the most current water-table map (Figure 2.8-2).

The monitoring network for Waste Management Area $\mathrm{T}$ includes fourteen wells that are sampled quarterly and two wells sampled semiannually. Two new RCRA assessment monitoring wells were installed in FY 2006. The first new well (299-W11-45) was constructed in April and first sampled routinely in May 2006. Well 299-W11-45 is located $\sim 80$ meters downgradient of wells 299-W11-25B and 299-W11-46 in which very high technetium-99 and chromium concentrations were discovered in 2005. The purpose of the well is to help ascertain the horizontal limit and, if present, the vertical distribution of the technetium-99 plume discovered in well 299-W11-25B.

The second new well (299-W11-47) was started in January 2006 and completed in April 2006. This well is located adjacent to existing well 299-W11-41 along the downgradient side of the waste management area for the purpose of learning the vertical extent of the technetium-99 and other contaminants in that area. Well 299-W11-47 was first routinely sampled during May 2006. Data collected during drilling of the well are discussed in the following paragraphs.

A data quality objectives process document, T Area Technetium-99 Data Quality Objectives Summary Report (WMP-28389, in publication) describes the location of new wells needed to further delineate the technetium-99 plume located east of Waste Management Area T. The first of these wells, 299-W11-48, was started during the winter of 2006.

A plume map depicting the FY 2006 average chromium concentration in wells in the uppermost part of the aquifer near the Waste Management Area T is shown in Figure 2.8-9. The map shows that the chromium plume extends from the west and southwest part of the waste management area to northeast of the waste management area. The highest average concentration in FY 2006 was in well 299-W10-4 (average $550 \mu \mathrm{g} / \mathrm{L}$ ) located at the southwest corner of the waste management area. The chromium concentration in upgradient well 299-W10-28 averaged $140 \mu \mathrm{g} / \mathrm{L}$ during FY 2006. The concentration in both wells decreased throughout the year. The chromium concentration in the upper part of the aquifer also exceeded the drinking water standard in three downgradient wells. The annual average chromium concentration exceeded the drinking water standard for the first time in well 299-W11-39 with an average concentration of $150 \mu \mathrm{g} / \mathrm{L}$. The chromium concentrations in downgradient wells 299-W11-41 and 299-W11-42 averaged 150 and $165 \mu \mathrm{g} / \mathrm{L}$, respectively, during the year.

The chromium concentration in wells 299-W11-45 and 299-W11-46, completed deeper in the aquifer, revealed higher concentrations of chromium than depicted by the upper part of the aquifer map (Figure 2.8-9). Chromium in well 299-W11-46, completed between 6 and 12 meters below the water table, averaged $290 \mu \mathrm{g} / \mathrm{L}$ during the year, greater than the $150 \mu \mathrm{g} / \mathrm{L}$ in adjacent shallow well 299-W11-39. Chromium in well 299-W11-45, located $\sim 80$ meters downgradient of well 299-W11-46 and completed between 8.5 and 13 meters below the water table, averaged $120 \mu \mathrm{g} / \mathrm{L}$. These concentrations show that the chromium plume at Waste Management Area T extends relatively deep in the aquifer and laterally to at least 80 meters downgradient of the waste management area. 
A fluoride plume, exceeding the secondary drinking water standard of 2,000 $\mu \mathrm{g} / \mathrm{L}$, extends from the southwest to the north and east of Waste Management Area T (Figure 2.8-10). The extent of the plume remained almost unchanged from the previous year. The highest fluoride concentration measured in FY 2006 at Waste Management Area T was 4,100 $\mu \mathrm{g} / \mathrm{L}$ during the third quarter of the fiscal year; this sample had the only concentration above the primary drinking water standard $(4,000 \mu \mathrm{g} / \mathrm{L})$.

A local nitrate plume sits within the regional nitrate plume and beneath Waste Management Area T (Figure 2.8-8). The extent of the plume did not change significantly from the previous year. The highest average concentrations were in upgradient well 299-W10-28 (2,000 mg/L) and well 299-W10-4 (3,000 mg/L). The highest downgradient concentration was in well 299-W11-42 (1,000 mg/L). The FY 2006 average nitrate concentration in other downgradient water-table wells was between 270 and $840 \mathrm{mg} / \mathrm{L}$. More than one source, including the Waste Management Area T, probably contributed to the nitrate plume beneath the waste management area, but the higher upgradient concentrations indicate greater contributions from other sources. A discussion of nitrate contamination in the north central part of 200 West Area is given in Section 2.8.1.4.

Tritium exceeded the interim drinking water standard $(20,000 \mathrm{pCi} / \mathrm{L})$ in two wells at Waste Management Area T. The average FY 2006 tritium concentration in well 299-W11-12, located at the southeast corner of the waste management area, was $44,000 \mathrm{pCi} / \mathrm{L}$, essentially unchanged from the previous year. The source of the tritium is thought to be farther south near the TX and TY Tank Farms (Figure 2.8-11). A more complete discussion of tritium in the groundwater beneath the north part of 200 West Area is in Section 2.8.1.7.

A technetium-99 plume is located along the east (downgradient) side of Waste Management Area T (Figure 2.8-14). Technetium-99 at levels near the drinking water standard (annual average of $890 \mathrm{pCi} / \mathrm{L}$ with a maximum of $1,010 \mathrm{pCi} / \mathrm{L}$ ) was also noted in well 299-W10-4, south of Waste Management Area T. The highest technetium-99 concentrations in the upper part of the aquifer are in downgradient well 299-W11-39 at the northeast corner of the waste management area, where the average technetium-99 concentration was $24,000 \mathrm{pCi} / \mathrm{L}$ in FY 2006. This was an increase from the previous year when the average concentration was $17,000 \mathrm{pCi} / \mathrm{L}$. The average technetium- 99 concentrations also increased in the three downgradient water-table wells south of well 299-W11-39. Figure 2.8-15 shows the trends in technetium-99 concentrations in water-table wells downgradient of Waste Management Area T.

Figure 2.8-16 shows the technetium-99 concentration versus time in three recently constructed downgradient wells that are screened below the water table at Waste Management Area T. Well 299-W11-46 is located adjacent to well 299-W11-39 and screened between 6 and 12 meters below the water table. The well is the replacement well for well 299-W11-25B, which had 181,000-pCi/L technetium-99 at 10 meters below the water table when it was drilled in 2005. Well 299-W11-46 averaged 56,000-pCi/L technetium-99 in FY 2006. This compares to the average of $24,000 \mathrm{pCi} / \mathrm{L}$ in the adjacent well 299-W11-39 and shows that the highest technetium-99 concentrations in the area are below the screened interval in well 299-W11-39.

Well 299-W11-45 is located about 80 meters downgradient of well 299-W11-46 and screened between 8.5 and 13 meters below the water table; technetium-99 averaged $18,000 \mathrm{pCi} / \mathrm{L}$ during FY 2006. The concentrations in this well show that the technetium-99 plume found east of the waste management area extends to at least 80 meters downgradient of the waste management area.

Well 299-W11-47 was drilled during the early part of calendar year 2006 adjacent to existing well 299-W11-41. Well 299-W11-47 is screened between 9 and 18 meters below the water table. The well was sampled every 1.5 meters by Kabis or bailer from the water table to 53 meters below the water table. The well was also sampled every 3 meters by purge and pump methods from 9 to 18 meters below the water table and every 6 meters from
The highest nitrate and chromium concentrations at Waste Management Area $T$ are in a well near the 216-T-36 crib.

The highest average technetium-99 concentration in the upper part of the aquifer was 24,000 $\mathrm{pCi} / \mathrm{L}$ at the northeast (downgradient) side of Waste Management Area T. 


\section{The highest average technetium-99} concentration in FY 2006 was $56,000 p C i / L$ in a downgradient well screened between 6 and 12 meters below the water table.

\section{Groundwater flow} direction at Waste Management Area TX-TY is greatly altered by the 200-ZP-1 pumpand-treat system.
18 to 49 meters below the water table. Comparing the bailed samples with the pumped samples suggests that the cable tool with hard tool drilling methods used to drill the well caused reduction of the technetium-99 because the pumped samples in the upper 15 meters of the aquifer contained significant technetium-99 whereas the bailed samples contained undetectable technetium-99. Figure 2.8-17 shows the technetium-99 concentration in pumped samples collected during drilling of well 299-W11-47. The highest technetium-99 concentration measured during drilling was $3,840 \mathrm{pCi} / \mathrm{L}$ at about 15 meters below the water table. However, no pumped samples were obtained shallower than 10 meters and the August 2006 sample from adjacent well 299-W11-41 shows that the highest concentration in the area is $7,110 \mathrm{pCi} / \mathrm{L}$ between the water table and 10 meters below the water table and is also plotted on Figure 2.8-17. Evidently, the highest concentrations in the technetium-99 plume downgradient of the southern part of the waste management area are near the water table whereas the highest concentrations downgradient of the northern part are at about 10 meters below the water table.

Figure 2.8-18 shows the nitrate concentration in samples collected during drilling of well 299-W11-47. The highest nitrate concentration was $863 \mathrm{mg} / \mathrm{L}$ at about 10 meters below the water table. This is very similar to the nitrate concentrations obtained from the August sampling of both well 299-W11-47 and adjacent well 299-W11-41.

Cobalt-60 exceeded the drinking water standard in well 299-W11-46 during FY 2006. Well 299-W11-46 replaced well 299-W11-25B when the latter well was damaged during construction. Cobalt-60 was reported in well 299-W11-25B when the borehole was first gamma-ray logged in March 2005 prior to well construction. A subsequent sample of groundwater collected after well development from well 299-W11-25B contained no detectable cobalt-60. However, cobalt- 60 was found between 19.5 and $23.6 \mathrm{pCi} / \mathrm{L}$ in adjacent well 299-W11-46 during FY 2006. These results are the first reports of cobalt-60 at Waste Management Area $\mathrm{T}$ in several years.

Arsenic was found above the drinking water standard $(10 \mu \mathrm{g} / \mathrm{L})$ in the February 2006 sample from well 299-W10-4 at 10.8 $\mu \mathrm{g} / \mathrm{L}$. Subsequent analyses for arsenic have been below the drinking water standard.

Figure 2.8-21b in the FY 2005 annual report (PNNL-15670) plotted the technetium-99/ nitrate ratio for boring 299-W11-25B and well 299-W11-45. The data for well 299-W11-45 were plotted incorrectly. Figure 2.8-19 shows the same figure with the corrected data. The data for boring 299-W11-25B have not changed and are similar to the technetium-99/nitrate ratios in pore water from two borings through the T-106 tank leak (see Figure 2.8-21a in PNNL-15670). The correct ratios for well 299-W11-45, shown in Figure 2.8-19), are less than those for the T-106 tank leak and less than those for 299-W11-25B. If the contamination found in well 299-W11-25B is the same as that found 80 meters downgradient in well 299-W11-45, then the contamination in the latter well is probably mixed with nitrate from the regional nitrate plume, thereby lowering the ratio. Alternatively, some technetium-99 may have sorbed to the aquifer sediment as the plume moved 80 meters from well 299-W11-25B to well 299-W11-45.

\subsubsection{Waste Management Area TX-TY}

Waste Management Area TX-TY is located in the north-central part of the 200 West Area and consists of the TX and TY Tank Farms and ancillary equipment (e.g., diversion boxes and pipelines). The tank farms contain twenty-four 2.9-million-liter tanks constructed between 1944 and 1952. Twelve of the tanks in the waste management area are known or suspected to have leaked. A well location map and a table of wells and analytes for this waste management area are shown in Appendix B.

Waste Management Area TX-TY was originally placed in RCRA assessment monitoring (40 CFR 265.93(d) as referenced by WAC 173-303-400) because of elevated specific conductance in downgradient wells 299-W10-27 and 299-W14-12 (WHC-SD-ENAP-132). The current groundwater assessment plan is PNNL-12072 as modified by 
PNNL-12072-ICN-1. The groundwater assessment plan is scheduled to be updated in FY 2007 to reflect new information from wells drilled since the existing plan was written. The objective of RCRA groundwater monitoring at Waste Management Area TX-TY is to assess the extent and rate of movement of dangerous waste in groundwater that have a source from the waste management area. In addition to monitoring dangerous waste constituents for RCRA assessments, the site is monitored for AEA and CERCLA.

The monitoring network for Waste Management Area TX-TY includes 16 wells that are sampled quarterly. All upgradient wells for the waste management area were converted to extraction wells for the 200-ZP-1 pump-and-treat system in July 2005. Groundwater flow direction varies beneath the waste management area due to influences from the pump-and-treat operation. In the north part of the waste management area, groundwater flow is changing from eastward to westward due to the recently converted extraction wells. South of Waste Management Area TX-TY, groundwater flow direction is toward extraction wells located south or southwest of the waste management area.

Dangerous waste constituents found beneath Waste Management Area TX-TY in FY 2006 are chromium and nitrate. Other constituents found beneath the waste management area in 2006 include carbon tetrachloride, trichloroethene, tritium, technetium-99, and iodine-129. The carbon tetrachloride and trichloroethene are attributed to Plutonium Finishing Plant operations and are discussed in Sections 2.8.1.1 and 2.8.1.2.

Nitrate concentrations exceeded the drinking water standard $(45 \mathrm{mg} / \mathrm{L})$ in all wells in the Waste Management Area TX-TY monitoring network in FY 2006. Figure 2.8-8 shows a plume map for nitrate in the area. The nitrate in groundwater beneath Waste Management Area TX-TY is within the regional nitrate plume that underlies much of the north 200 West Area.

The highest average nitrate concentration at the waste management area during FY 2006 was $468 \mathrm{mg} / \mathrm{L}$ in well 299-W14-13. This value was a slight increase from $430 \mathrm{mg} / \mathrm{L}$ during the previous fiscal year. The nitrate concentration increased substantially in three wells at the waste management area in 2006. Nitrate in well 299-W10-27, located east of the north part of the waste management area, increased from 153 to $433 \mathrm{mg} / \mathrm{L}$ during the year. Nitrate also increased from 135 to $268 \mathrm{mg} / \mathrm{L}$ in well 299-W15-763 and from 214 to $439 \mathrm{mg} / \mathrm{L}$ in well 299-W15-765. The latter two wells are influenced by the pump-and-treat system, and the nitrate is probably being drawn toward the wells from beneath the waste management area. Much of the nitrate contamination at Waste Management Area TX-TY is attributed to Plutonium Finishing Plant operations as well as past-practice disposal to cribs and trenches in the area. Some nitrate contamination also may be from Waste Management Area TX-TY, although distinguishing the different sources is extremely difficult. More discussion of nitrate in north-central 200 West Area is given in Section 2.8.1.4.

Chromium was detected above the drinking water standard $(100 \mu \mathrm{g} / \mathrm{L})$ in two wells at Waste Management Area TX-TY during FY 2006. The average chromium concentration in well 299-W14-13 was $740 \mu \mathrm{g} / \mathrm{L}$ during the year and the average chromium concentration in adjacent well 299-W14-11 was $94 \mu \mathrm{g} / \mathrm{L}$. Well 299-W14-13 is screened at the water table and well 299-W14-11 is screened between 11.6 and 14.6 meters below the water table. The chromium concentration in these two wells shows that the highest concentration in the plume occurs near the water table. Chromium concentrations in wells adjacent to the well pair 299-W14-11 and 299-W14-13 were less than the drinking water standard during the fiscal year, indicating that the chromium contamination is limited to the immediate area of the two wells. The most likely source for the chromium is assumed to be Waste Management Area TX-TY because no alternative sources have been identified.

A small tritium plume exists along the east-central part of Waste Management Area TX-TY (Figure 2.8-11). The tritium concentration exceeded the drinking water standard 


\section{The highest}

concentrations

of chromium,

technetium-

99, nitrate, and

iodine-129 at Waste

Management Area

TX-TY are very near

the water table.

The highest

iodine-129

concentration

measured during

routine sampling at

Waste Management

Area TX-TY in

FY 2006 was

$42.7 p C i / L$.
$(20,000 \mathrm{pCi} / \mathrm{L})$ in three wells in the area. The highest average tritium concentration was 1.7 million $\mathrm{pCi} / \mathrm{L}$ in well 299-W14-13 during the fiscal year, which was up slightly from 1.57 million $\mathrm{pCi} / \mathrm{L}$ during the previous year although concentrations have remained fairly stable since FY 2002. The average tritium concentration in the adjacent well, well 299-W14-11 (screened from 11.6 to 14.6 meters below the water table), was $230,000 \mathrm{pCi} / \mathrm{L}$. The tritium concentrations in these two wells indicate that the highest concentrations are near the water table in this area. The tritium concentration in well 299-W14-15, located south of well 299-W14-13, also exceeded the drinking water standard during the year with an average concentration of $54,000 \mathrm{pCi} / \mathrm{L}$, essentially unchanged from the previous year. The source for the high tritium in the area could be Waste Management Area TX-TY, the 242-T evaporator, the 216-T-19 crib and tile field (which received evaporator condensate from the 242-T evaporator), the 216-T-26 through 216-T-28 cribs, or a combination of these potential sources.

Technetium-99 exceeded the interim drinking water standard $(900 \mathrm{pCi} / \mathrm{L})$ in both wells in the well pair 299-W14-11 and 299-W14-13 at Waste Management Area TX-TY in FY 2006. The average technetium-99 concentration was 7,600 pCi/L in well 299-W14-13 and $2,500 \mathrm{pCi} / \mathrm{L}$ in deeper well 299-W14-11. These values indicate that the highest technetium-99 concentrations are near the water table, similar to chromium, nitrate, iodine-129, and tritium. The technetium-99 concentration also exceeded the drinking water standard in well 299-W14-15, located south of the wells 299-W14-13 and 299-W14-11. The average concentration was $940 \mathrm{pCi} / \mathrm{L}$ in well 299-W14-15 during the year. The source for the technetium-99 in these wells east of the waste management area could be the waste management area itself and/or one of the past-practice disposal facilities in the area or both.

Technetium-99 is also found at levels above the drinking water standard in wells south and west of the waste management area (Figure 2.8-14). Technetium-99 in these wells is thought to be drawn to the wells from beneath the TX and TY Tank Farms by extraction for the 200-ZP-1 pump-and-treat. Figure 2.8-20 shows the technetium-99 concentration versus time for four wells. Wells 299-W15-44 and 299-W15-765 were put into service as extraction wells in July 2005 and the technetium concentration began to increase in these wells shortly thereafter.

Iodine-129 was detected in two wells at Waste Management Area TX-TY during FY 2006. The highest iodine-129 concentration measured at the waste management area during the reporting period was $42.7 \mathrm{pCi} / \mathrm{L}$ in the August 2006 sample from well 299-W14-13; the average iodine-129 concentration in the well was $33 \mathrm{pCi} / \mathrm{L}$ during the year. Iodine-129 was not detected in adjacent and deeper screened well 299-W14-11 indicating that the iodine-129 contamination resides near the water table. This agrees with the iodine-129 analyses obtained during drilling of well 299-W14-11 (PNNL-15670). Iodine-129 also was detected in a single sample from well $299-\mathrm{W} 14-15$ with a concentration of $3.49 \mathrm{pCi} / \mathrm{L}$ in November 2005.

Manganese exceeded the secondary drinking water standard of $50 \mu \mathrm{g} / \mathrm{L}$ in well 299-W10-27 where the average FY 2006 concentration was $203 \mu \mathrm{g} / \mathrm{L}$. The manganese concentration has been high in this well since it was first sampled in 2001 although the concentration has decreased dramatically since that time. It is common for new wells on the Hanford Site to have elevated manganese values in the first few years of sampling, probably due to reaction of groundwater to freshly crushed rock surfaces.

\subsubsection{Groundwater Monitoring for the State-Approved Land Disposal Site}

The Hanford Site 200 Area Effluent Treatment Facility processes contaminated aqueous waste from Hanford Site facilities. The treated wastewater occasionally contains tritium, which is not removed by the Effluent Treatment Facility, and is discharged to the 200 Area State-Approved Land Disposal Site. During FY 2006, 15.7 million liters of water were 
discharged to the State-Approved Land Disposal Site as compared to 44.7 million liters in FY 2005. The decrease in volume in FY 2006 was primarily due to the elimination of discharges to the Effluent Treatment Facility from the 200-UP-1 pump-and-treat system.

A state waste discharge permit (WAC 173-216) requires groundwater monitoring at this site. The permit was granted in June 1995 and the site began operations in December 1995. Groundwater monitoring requirements are described in the site monitoring plan (PNNL-13121). Groundwater monitoring for tritium only was conducted in 11 wells around the facility (Appendix B). The permit stipulates requirements for groundwater monitoring and establishes enforcement limits for concentrations of 15 constituents in three additional wells immediately surrounding the facility (Appendix B).

Wells immediately surrounding the facility were sampled in September and November 2005 and January, April, and July 2006. Tritium tracking wells were sampled in September 2005 and January, March, July 2006. Water-level measurements in the three wells nearest the State-Approved Land Disposal Site indicated the continuation of a localized groundwater mound beneath the site as a result of discharges. This mound results in radial flow outward a short distance before the regional northeastward flow predominates. This condition also places several wells south of the State-Approved Land Disposal Site hydraulically downgradient

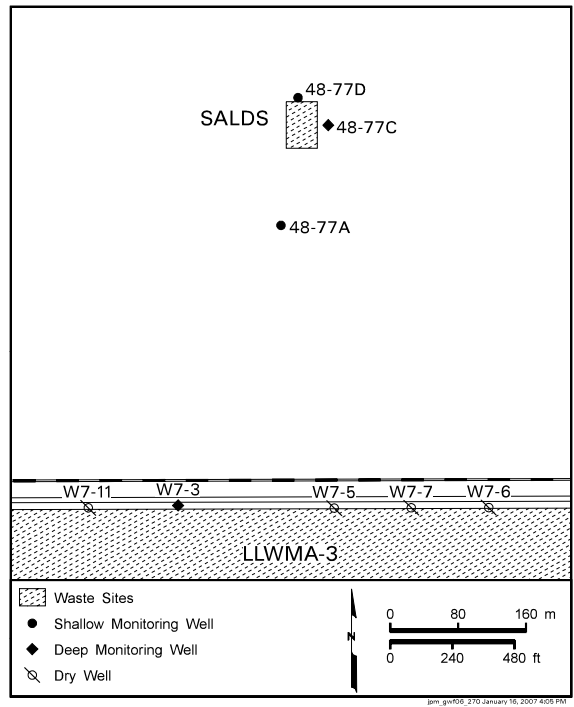
of the facility.

Many of the wells south of the State-Approved Land Disposal Site in the tritium-tracking network have gone dry in the past few years. Well 299-W7-12 went dry in FY 2006.

Average tritium concentrations decreased in two of three State-Approved Land Disposal Site proximal wells during FY 2006 compared with FY 2005 (Figure 2.8-21). During FY 2006, the maximum tritium concentrations for State-Approved Land Disposal Site proximal wells were $110,000 \mathrm{pCi} / \mathrm{L}$ at well $699-48-77 \mathrm{~A}, 119,000 \mathrm{pCi} / \mathrm{L}$ at well $699-48-77 \mathrm{C}$, and $82,000 \mathrm{pCi} / \mathrm{L}$ at well 699-48-77D. FY 2005 peak concentrations in the same wells were $280,000 \mathrm{pCi} / \mathrm{L}$, $150,000 \mathrm{pCi} / \mathrm{L}$, and $65,000 \mathrm{pCi} / \mathrm{L}$, respectively.

Concentrations of all chemical constituents with permit limits were within those limits during all of FY 2006. Acetone, benzene, and tetrahydrofuran were below method detection limits in all samples. Detectable concentrations of lead and copper $(0.1$ and $6.23 \mu \mathrm{g} / \mathrm{L}$, respectively) were reported at well 699-48-77A. Concentrations of major anions and cations continued below background levels observed prior to operation of the facility. This condition is due to dilution by the otherwise clean water discharged to the State-Approved Land Disposal Site.

For all wells, the hydraulic head in April 2006 had declined an average of 0.42 meter from March 2005 level, or an annual decrease of 0.38 meter/year. Water levels at the StateApproved Land Disposal Site proximal wells have declined at more rapid rates than outlying wells within the tritium-tracking system because discharge volumes decreased after cessation of the 200-UP-1 pump-and-treat system in January 2005.

Numerical flow-and-transport modeling of the State-Approved Land Disposal Site was last conducted in August 2004, as required by the permit (PNNL-14898). 
Table 2.8-1. Contaminants of Concern in all Wells in the 200-ZP-1 Groundwater Interest Area, FY 2006 (DOE/RL-2003-55)

\begin{tabular}{|c|c|c|c|c|c|c|c|c|c|}
\hline Constituent & 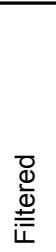 & 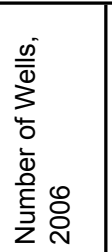 & 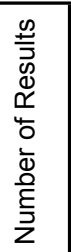 & 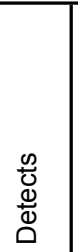 & $\begin{array}{l}\frac{\mathscr{N}}{\mathscr{U}} \\
\stackrel{\mathscr{\omega}}{\mathscr{Q}} \\
\end{array}$ & 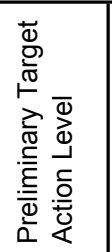 & 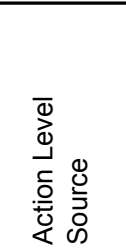 & 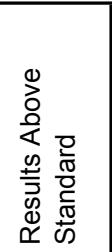 & 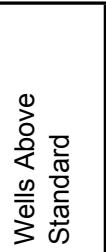 \\
\hline 1,1,1-Trichloroethane, $\mu \mathrm{g} / \mathrm{L}$ & $\mathrm{N}$ & 69 & 166 & & & 200 & $\mathrm{MCL}$ & & \\
\hline 1,1,1-Trichloroethane, $\mu \mathrm{g} / \mathrm{L}$ & $\mathrm{Y}$ & 4 & 8 & & & 200 & $\mathrm{MCL}$ & & \\
\hline 1,2-Dichloroethane, $\mu \mathrm{g} / \mathrm{L}$ & $\mathrm{N}$ & 69 & 166 & & & 5 & CRDL & & \\
\hline 1,2-Dichloroethane, $\mu \mathrm{g} / \mathrm{L}$ & $\mathrm{Y}$ & 4 & 8 & & & 5 & CRDL & & \\
\hline 2-Butanone, $\mu \mathrm{g} / \mathrm{L}$ & $\mathrm{N}$ & 69 & 205 & 1 & & 4,800 & CLARC & & \\
\hline 2-Butanone, $\mu \mathrm{g} / \mathrm{L}$ & $\mathrm{Y}$ & 4 & 8 & & & 4,800 & CLARC & & \\
\hline 2-Pentanone, 4-Methyl, $\mu \mathrm{g} / \mathrm{L}$ & $\mathrm{N}$ & 69 & 163 & & & 640 & CLARC & & \\
\hline 2-Pentanone, 4-Methyl, $\mu \mathrm{g} / \mathrm{L}$ & $\mathrm{Y}$ & 4 & 8 & & & 640 & CLARC & & \\
\hline Acetone, $\mu \mathrm{g} / \mathrm{L}$ & $\mathrm{N}$ & 69 & 205 & 28 & & 800 & CLARC & & \\
\hline Acetone, $\mu \mathrm{g} / \mathrm{L}$ & $\mathrm{Y}$ & 4 & 8 & & & 800 & CLARC & & \\
\hline Antimony, $\mu \mathrm{g} / \mathrm{L}$ & $\mathrm{N}$ & 17 & 27 & 2 & & 10 & CRDL & 2 & 2 \\
\hline Antimony, $\mu \mathrm{g} / \mathrm{L}$ & $\mathrm{Y}$ & 69 & 248 & 2 & & 10 & CRDL & 2 & 2 \\
\hline Arsenic, $\mu \mathrm{g} / \mathrm{L}$ & $\mathrm{N}$ & 3 & 13 & 13 & & 10 & CRDL & & \\
\hline Arsenic, $\mu g / L$ & $\mathrm{Y}$ & 12 & 26 & 20 & & 10 & CRDL & 1 & 1 \\
\hline Benzene, $\mu \mathrm{g} / \mathrm{L}$ & $\mathrm{N}$ & 69 & 205 & & & 5 & CRDL & & \\
\hline Benzene, $\mu \mathrm{g} / \mathrm{L}$ & $\mathrm{Y}$ & 4 & 8 & & & 5 & CRDL & & \\
\hline Cadmium, $\mu \mathrm{g} / \mathrm{L}$ & $\mathrm{N}$ & 18 & 28 & 1 & & 5 & $\mathrm{MCL}$ & & \\
\hline Cadmium, $\mu \mathrm{g} / \mathrm{L}$ & $\mathrm{Y}$ & 70 & 253 & 4 & & 5 & $\mathrm{MCL}$ & & \\
\hline Carbon disulfide, $\mu \mathrm{g} / \mathrm{L}$ & $\mathrm{N}$ & 69 & 166 & 30 & & 800 & CLARC & & \\
\hline Carbon disulfide, $\mu \mathrm{g} / \mathrm{L}$ & $\mathrm{Y}$ & 4 & 8 & & & 800 & CLARC & & \\
\hline Carbon tetrachloride, $\mu \mathrm{g} / \mathrm{L}$ & $\mathrm{N}$ & 74 & 331 & 299 & & 3 & CRDL & 283 & 55 \\
\hline Carbon tetrachloride, $\mu \mathrm{g} / \mathrm{L}$ & $\mathrm{Y}$ & 5 & 20 & 20 & & 3 & CRDL & 19 & 5 \\
\hline Carbon-14, pCi/L & $\mathrm{N}$ & 4 & 5 & 5 & & 2,000 & $\mathrm{MCL}$ & & \\
\hline Cesium-137, pCi/L & $\mathrm{N}$ & 22 & 33 & & & 60 & $\mathrm{MCL}$ & & \\
\hline Cesium-137, pCi/L & $\mathrm{Y}$ & 1 & 12 & & & 60 & MCL & & \\
\hline Chlorobenzene, $\mu \mathrm{g} / \mathrm{L}$ & $\mathrm{N}$ & 18 & 60 & & & 100 & $\mathrm{MCL}$ & & \\
\hline Chlorobenzene, $\mu \mathrm{g} / \mathrm{L}$ & $\mathrm{Y}$ & 2 & 6 & & & 100 & $\mathrm{MCL}$ & & \\
\hline Chloroform, $\mu \mathrm{g} / \mathrm{L}$ & $\mathrm{N}$ & 74 & 331 & 287 & & 7 & CLARC & 229 & 37 \\
\hline Chloroform, $\mu \mathrm{g} / \mathrm{L}$ & $\mathrm{Y}$ & 5 & 20 & 20 & & 7 & CLARC & 16 & 3 \\
\hline Chromium, $\mu \mathrm{g} / \mathrm{L}$ & $\mathrm{N}$ & 17 & 27 & 26 & & 100 & $\mathrm{MCL}$ & 8 & 8 \\
\hline Chromium, $\mu \mathrm{g} / \mathrm{L}$ & $\mathrm{Y}$ & 69 & 248 & 222 & & 100 & $\mathrm{MCL}$ & 37 & 11 \\
\hline cis-1,2-Dichloroethene, $\mu \mathrm{g} / \mathrm{L}$ & $\mathrm{N}$ & 68 & 152 & 3 & & 70 & $\mathrm{MCL}$ & & \\
\hline cis-1,2-Dichloroethene, $\mu \mathrm{g} / \mathrm{L}$ & $\mathrm{Y}$ & 3 & 3 & & & 70 & MCL & & \\
\hline Cresol (total): & & & & & & 80 & CLARC & & \\
\hline 2-Methylphenol (cresol, o-), $\mu \mathrm{g} / \mathrm{L}$ & $\mathrm{N}$ & 16 & 23 & & & & & & \\
\hline 3+4 Methylphenol (cresol, $\mathrm{m}+\mathrm{p}$ ), $\mu \mathrm{g} / \mathrm{L}$ & $\mathrm{N}$ & 16 & 23 & & & & & & \\
\hline Cyanide, $\mu g / L$ & $\mathrm{~N}$ & 5 & 9 & & & 200 & $\mathrm{MCL}$ & & \\
\hline Ethylbenzene, $\mu \mathrm{g} / \mathrm{L}$ & $\mathrm{N}$ & 69 & 160 & & & 700 & $\mathrm{MCL}$ & & \\
\hline
\end{tabular}


Table 2.8-1. (contd)

\begin{tabular}{|c|c|c|c|c|c|c|c|c|c|}
\hline Constituent & 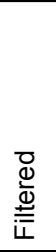 & 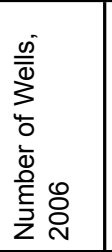 & 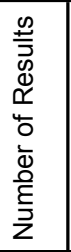 & 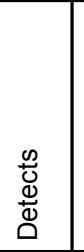 & $\begin{array}{l}\frac{\mathscr{D}}{0} \\
\frac{\mathscr{\omega}}{\mathscr{Q}} \\
\underline{\square}\end{array}$ & 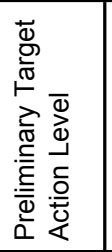 & 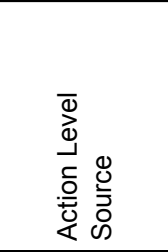 & 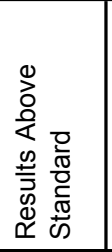 & 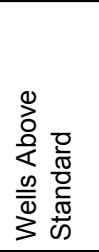 \\
\hline Ethylbenzene, $\mu \mathrm{g} / \mathrm{L}$ & $Y$ & 4 & 8 & & & 700 & MCL & & \\
\hline Fluoride, $\mu \mathrm{g} / \mathrm{L}$ & $\mathrm{N}$ & 91 & 265 & 265 & & 4,000 & MCL & 1 & 1 \\
\hline Fluoride, $\mu \mathrm{g} / \mathrm{L}$ & $\mathrm{Y}$ & 4 & 9 & 8 & & 4,000 & $\mathrm{MCL}$ & & \\
\hline Hexavalent chromium, $\mu \mathrm{g} / \mathrm{L}$ & $\mathrm{N}$ & 1 & 1 & & & 48 & CLARC & & \\
\hline Hexavalent chromium, $\mu \mathrm{g} / \mathrm{L}$ & $\mathrm{Y}$ & 5 & 10 & 3 & & 48 & CLARC & 1 & 1 \\
\hline lodine-129, pCi/L & $\mathrm{N}$ & 55 & 144 & 8 & & 1 & MCL & 8 & 3 \\
\hline Iodine-129, pCi/L & $\mathrm{Y}$ & 3 & 7 & & & 1 & MCL & & \\
\hline Iron, $\mu \mathrm{g} / \mathrm{L}$ & $\mathrm{N}$ & 17 & 27 & 23 & & 300 & 2nd MCL & 7 & 6 \\
\hline Iron, $\mu \mathrm{g} / \mathrm{L}$ & $\mathrm{Y}$ & 69 & 248 & 114 & 3 & 300 & 2nd MCL & 1 & 1 \\
\hline Lead, $\mu \mathrm{g} / \mathrm{L}$ & $\mathrm{N}$ & 4 & 14 & 4 & & 15 & MCL & & \\
\hline Lead, $\mu \mathrm{g} / \mathrm{L}$ & $\mathrm{Y}$ & 19 & 38 & 1 & & 15 & MCL & & \\
\hline Lithium, $\mu \mathrm{g} / \mathrm{L}$ & $\mathrm{Y}$ & 4 & 5 & & & & TBD & & \\
\hline Magnesium, $\mu \mathrm{g} / \mathrm{L}$ & $\mathrm{N}$ & 17 & 27 & 27 & & & TBD & & \\
\hline Magnesium, $\mu \mathrm{g} / \mathrm{L}$ & $\mathrm{Y}$ & 69 & 248 & 248 & & & TBD & & \\
\hline Manganese, $\mu \mathrm{g} / \mathrm{L}$ & $\mathrm{N}$ & 18 & 28 & 19 & & 50 & 2nd MCL & 1 & 1 \\
\hline Manganese, $\mu \mathrm{g} / \mathrm{L}$ & $\mathrm{Y}$ & 70 & 253 & 135 & & 50 & 2nd MCL & 39 & 6 \\
\hline Mercury, $\mu g / L$ & $\mathrm{~N}$ & 3 & 13 & 6 & & 2 & MCL & & \\
\hline Mercury, $\mu g / L$ & $Y$ & 18 & 33 & 5 & & 2 & MCL & & \\
\hline Methylene chloride, $\mu \mathrm{g} / \mathrm{L}$ & $\mathrm{N}$ & 69 & 205 & 29 & & 5 & MCL & 13 & 9 \\
\hline Methylene chloride, $\mu \mathrm{g} / \mathrm{L}$ & $\mathrm{Y}$ & 4 & 8 & 1 & & 5 & $\mathrm{MCL}$ & & \\
\hline n-Butylbenzene, $\mu \mathrm{g} / \mathrm{L}$ & $\mathrm{N}$ & 4 & 4 & & & 320 & CLARC & & \\
\hline n-Butylbenzene, $\mu \mathrm{g} / \mathrm{L}$ & $\mathrm{Y}$ & 1 & 1 & & & 320 & CLARC & & \\
\hline Neptunium-237, pCi/L & $\mathrm{N}$ & 4 & 5 & & & 15 & MCL & & \\
\hline Nickel, $\mu \mathrm{g} / \mathrm{L}$ & $\mathrm{N}$ & 17 & 27 & 21 & & 320 & CLARC & & \\
\hline Nickel, $\mu \mathrm{g} / \mathrm{L}$ & $Y$ & 69 & 248 & 59 & & 320 & CLARC & & \\
\hline Nitrate, $\mu \mathrm{g} / \mathrm{L}$ & $\mathrm{N}$ & 92 & 307 & 306 & 1 & 12,400 & Background & 278 & 83 \\
\hline Nitrate, $\mu \mathrm{g} / \mathrm{L}$ & $\mathrm{Y}$ & 4 & 16 & 16 & & 12,400 & Background & 16 & 4 \\
\hline Nitrite, $\mu \mathrm{g} / \mathrm{L}$ & $\mathrm{N}$ & 90 & 264 & 16 & 8 & 3,268 & $\mathrm{MCL}$ & & \\
\hline Nitrite, $\mu \mathrm{g} / \mathrm{L}$ & $\mathrm{Y}$ & 3 & 4 & & & 3,268 & MCL & & \\
\hline Phenol (total): & & & & & & & TBD & & \\
\hline 2,3,4,6-Tetrachlorophenol, $\mu \mathrm{g} / \mathrm{L}$ & $\mathrm{N}$ & 16 & 18 & & & & & & \\
\hline 2,4,5-Trichlorophenol, $\mu \mathrm{g} / \mathrm{L}$ & $\mathrm{N}$ & 16 & 18 & & & & & & \\
\hline 2,4,6-Trichlorophenol, $\mu \mathrm{g} / \mathrm{L}$ & $\mathrm{N}$ & 16 & 18 & & & & & & \\
\hline 2,4-Dichlorophenol, $\mu \mathrm{g} / \mathrm{L}$ & $\mathrm{N}$ & 16 & 23 & & & & & & \\
\hline 2,4-Dimethylphenol, $\mu \mathrm{g} / \mathrm{L}$ & $\mathrm{N}$ & 16 & 18 & & & & & & \\
\hline 2,4-Dinitrophenol, $\mu \mathrm{g} / \mathrm{L}$ & $\mathrm{N}$ & 16 & 18 & & & & & & \\
\hline 2,6-Dichlorophenol, $\mu \mathrm{g} / \mathrm{L}$ & $\mathrm{N}$ & 16 & 18 & & & & & & \\
\hline 2-Chlorophenol, $\mu \mathrm{g} / \mathrm{L}$ & $\mathrm{N}$ & 16 & 18 & & & & & & \\
\hline 2-Nitrophenol, $\mu \mathrm{g} / \mathrm{L}$ & $\mathrm{N}$ & 16 & 23 & & & & & & \\
\hline
\end{tabular}


Table 2.8-1. (contd)

\begin{tabular}{|c|c|c|c|c|c|c|c|c|c|}
\hline Constituent & $\begin{array}{l}\bar{d} \\
\overline{\bar{\omega}} \\
\dot{\bar{i}} \\
\end{array}$ & 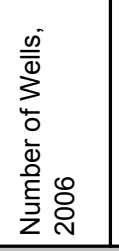 & 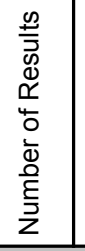 & 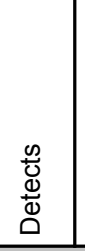 & 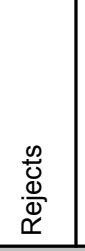 & 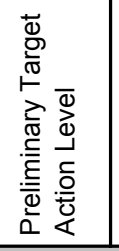 & 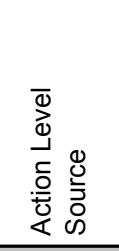 & 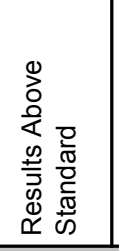 & 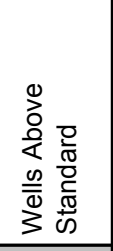 \\
\hline Dinoseb(2-secButyl-4,6-dinitrophenol), $\mu \mathrm{g} / \mathrm{L}$ & $\mathrm{N}$ & 16 & 18 & & & & & & \\
\hline 4,6-Dinitro-2-methylphenol, $\mu \mathrm{g} / \mathrm{L}$ & $\mathrm{N}$ & 16 & 18 & & & & & & \\
\hline 4-Chloro-3-methylphenol, $\mu \mathrm{g} / \mathrm{L}$ & $\mathrm{N}$ & 16 & 18 & & & & & & \\
\hline 4-Nitrophenol, $\mu \mathrm{g} / \mathrm{L}$ & $\mathrm{N}$ & 16 & 18 & & & & & & \\
\hline Pentachlorophenol, $\mu \mathrm{g} / \mathrm{L}$ & $\mathrm{N}$ & 16 & 23 & & & & & & \\
\hline Phenol, $\mu \mathrm{g} / \mathrm{L}$ & $\mathrm{N}$ & 16 & 28 & & & & & & \\
\hline Phosphate, $\mu \mathrm{g} / \mathrm{L}$ & $\mathrm{N}$ & 3 & 13 & & & & TBD & & \\
\hline Protactinium-231, pCi/L & $\mathrm{N}$ & 4 & 5 & & & 15 & MCL & & \\
\hline Selenium, $\mu g / L$ & $\mathrm{~N}$ & 3 & 13 & 7 & & 50 & MCL & & \\
\hline Selenium, $\mu g / L$ & Y & 3 & 13 & 7 & & 50 & MCL & & \\
\hline Selenium-79, pCi/L & $\mathrm{N}$ & 4 & 5 & 1 & & & MCL & & \\
\hline Silver, $\mu g / L$ & $\mathrm{~N}$ & 17 & 27 & 2 & & 80 & CLARC & & \\
\hline Silver, $\mu g / L$ & $\mathrm{Y}$ & 69 & 248 & 6 & & 80 & CLARC & & \\
\hline Strontium-90, pCi/L & $\mathrm{N}$ & 20 & 62 & 6 & & 8 & $\mathrm{MCL}$ & & \\
\hline Strontium-90, pCi/L & $\mathrm{Y}$ & 2 & 6 & & & 8 & MCL & & \\
\hline Technetium-99, pCi/L & $\mathrm{N}$ & 68 & 254 & 234 & 1 & 900 & MCL & 63 & 16 \\
\hline Technetium-99, pCi/L & Y & 6 & 73 & 68 & & 900 & MCL & 6 & 2 \\
\hline Tetrachloroethene, $\mu \mathrm{g} / \mathrm{L}$ & $\mathrm{N}$ & 74 & 231 & 88 & 4 & 5 & CRDL & 1 & 1 \\
\hline Tetrachloroethene, $\mu \mathrm{g} / \mathrm{L}$ & $\mathrm{Y}$ & 5 & 20 & 1 & & 5 & CRDL & & \\
\hline Toluene, $\mu \mathrm{g} / \mathrm{L}$ & $\mathrm{N}$ & 69 & 205 & 1 & & 1,000 & MCL & & \\
\hline Toluene, $\mu \mathrm{g} / \mathrm{L}$ & Y & 4 & 8 & & & 1,000 & $\mathrm{MCL}$ & & \\
\hline Total cresols, $\mu \mathrm{g} / \mathrm{L}$ & $\mathrm{N}$ & 4 & 5 & & & 80 & CLARC & & \\
\hline trans-1,2-Dichloroethene, $\mu \mathrm{g} / \mathrm{L}$ & $\mathrm{N}$ & 68 & 152 & & & 100 & MCL & & \\
\hline trans-1,2-Dichloroethene, $\mu \mathrm{g} / \mathrm{L}$ & Y & 3 & 3 & & & 100 & MCL & & \\
\hline Trichloroethene, $\mu \mathrm{g} / \mathrm{L}$ & $\mathrm{N}$ & 74 & 332 & 240 & & 5 & CRDL & 132 & 23 \\
\hline Trichloroethene, $\mu \mathrm{g} / \mathrm{L}$ & Y & 5 & 20 & 15 & & 5 & CRDL & 8 & 2 \\
\hline Tritium, $\mathrm{pCi} / \mathrm{L}$ & $\mathrm{N}$ & 84 & 259 & 215 & & 20,000 & MCL & 37 & 10 \\
\hline Tritium, $\mathrm{pCi} / \mathrm{L}$ & $\mathrm{Y}$ & 5 & 21 & 17 & & 20,000 & MCL & 4 & 2 \\
\hline Uranium, $\mu g / L$ & $\mathrm{~N}$ & 32 & 67 & 67 & & 30 & MCL & 4 & 1 \\
\hline Uranium, $\mu g / L$ & $\mathrm{Y}$ & 5 & 19 & 19 & & 30 & MCL & & \\
\hline Vanadium, $\mu \mathrm{g} / \mathrm{L}$ & $\mathrm{N}$ & 17 & 27 & 26 & & 112 & CLARC & & \\
\hline Vanadium, $\mu \mathrm{g} / \mathrm{L}$ & $\mathrm{Y}$ & 69 & 248 & 239 & & 112 & CLARC & & \\
\hline Xylenes (total), $\mu \mathrm{g} / \mathrm{L}$ & $\mathrm{N}$ & 69 & 166 & 2 & & 10,000 & MCL & & \\
\hline Xylenes (total), $\mu \mathrm{g} / \mathrm{L}$ & $\mathrm{Y}$ & 4 & 8 & & & 10,000 & $\mathrm{MCL}$ & & \\
\hline \multicolumn{10}{|c|}{$\begin{array}{l}\text { Shaded areas are groups of constituents with a single preliminary target action level. } \\
\text { CLARC = Cleanup Levels and Risk Calculations under the Model Toxics Control Act Cleanup Regulation (Ecology 2001). } \\
\text { CRDL = Contact-required detection limit. } \\
\text { MCL = Maximum contaminant level. } \\
\text { TBD = To be determined. }\end{array}$} \\
\hline
\end{tabular}


Table 2.8-2. Contaminants of Concern for Risk Evaluation in the Feasibility Study (after DOE/RL-2006-24)

\begin{tabular}{|c|c|c|c|}
\hline \multicolumn{3}{|c|}{ Human Health Contaminants of Concern } & \multirow{2}{*}{$\begin{array}{l}\begin{array}{c}\text { Ecological Contaminants of } \\
\text { Concern }\end{array} \\
\text { HQ }>1 \text {, Average } \\
\text { Concentration and } 0.5 \mathrm{DF}\end{array}$} \\
\hline $\begin{array}{l}\text { Group A (Potential Major } \\
\text { Risk Driver) Analytes }\end{array}$ & $\begin{array}{c}\text { Group B Analytes With } \\
<10 \% \text { of Results > PRG } \\
\text { and } 95 \% \text { UCL of Results > } \\
\text { PRG }\end{array}$ & $\begin{array}{c}\text { Group B Analytes With } \\
>10 \% \text { of Results > PRG } \\
\text { and } 95 \% \text { UCL of Results > } \\
\text { PRG }\end{array}$ & \\
\hline Carbon tetrachloride $^{(\mathrm{a})}$ & Antimony & Hexavalent chromium & Carbon tetrachloride \\
\hline Chromium (total) & 1,2-dichloroethane & Iron & Cyanide \\
\hline $\mathrm{I}-129$ & $\begin{array}{l}\text { Tetrachloroethene } \\
\text { (Tetrachloroethylene, } \\
\text { perchloroethene) }\end{array}$ & Chloroform & Hexavalent chromium \\
\hline Nitrate & & & Uranium (total) \\
\hline \multicolumn{4}{|l|}{ Tc-99 } \\
\hline \multicolumn{4}{|l|}{$\begin{array}{c}\text { Trichloroethene } \\
\text { (Trichloroethylene, TCE) }\end{array}$} \\
\hline \multicolumn{4}{|l|}{ Tritium } \\
\hline \multicolumn{4}{|l|}{$\begin{array}{l}\text { Uranium (total and } \\
\text { radioactive) }\end{array}$} \\
\hline \multicolumn{4}{|c|}{$\begin{array}{l}\text { (a) Retain methylene chloride for additional evaluation because it is a potential degradation product of carbon } \\
\text { tetrachloride. } \\
\text { DF = Dilution factor. } \\
\text { HQ = Hazard quotient. } \\
\text { PRG = Preliminary remediation goal. } \\
\text { UCL = Upper confidence limit. }\end{array}$} \\
\hline
\end{tabular}




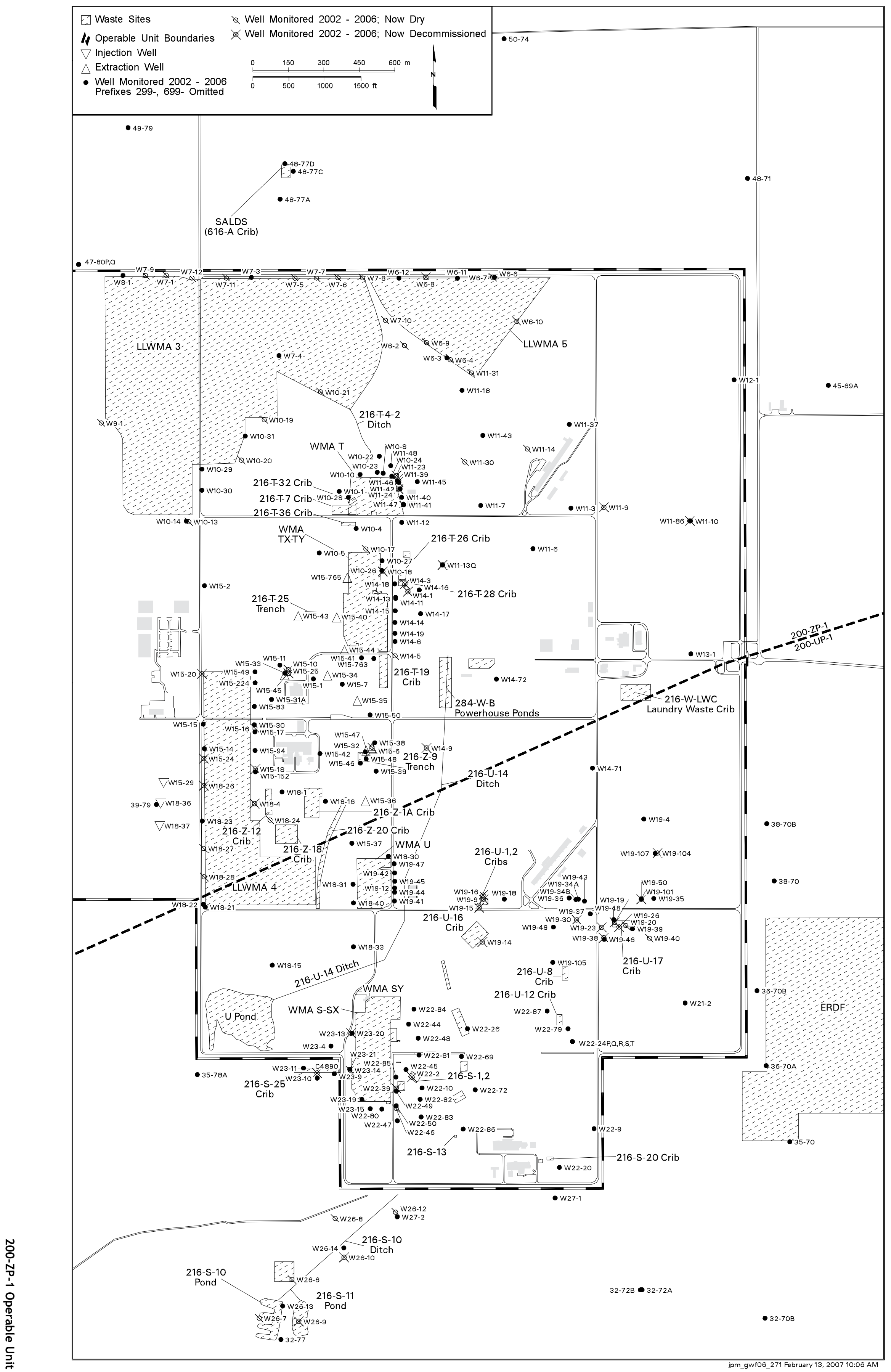

Figure 2.8-1. Groundwater Monitoring Wells in 200 West Area 


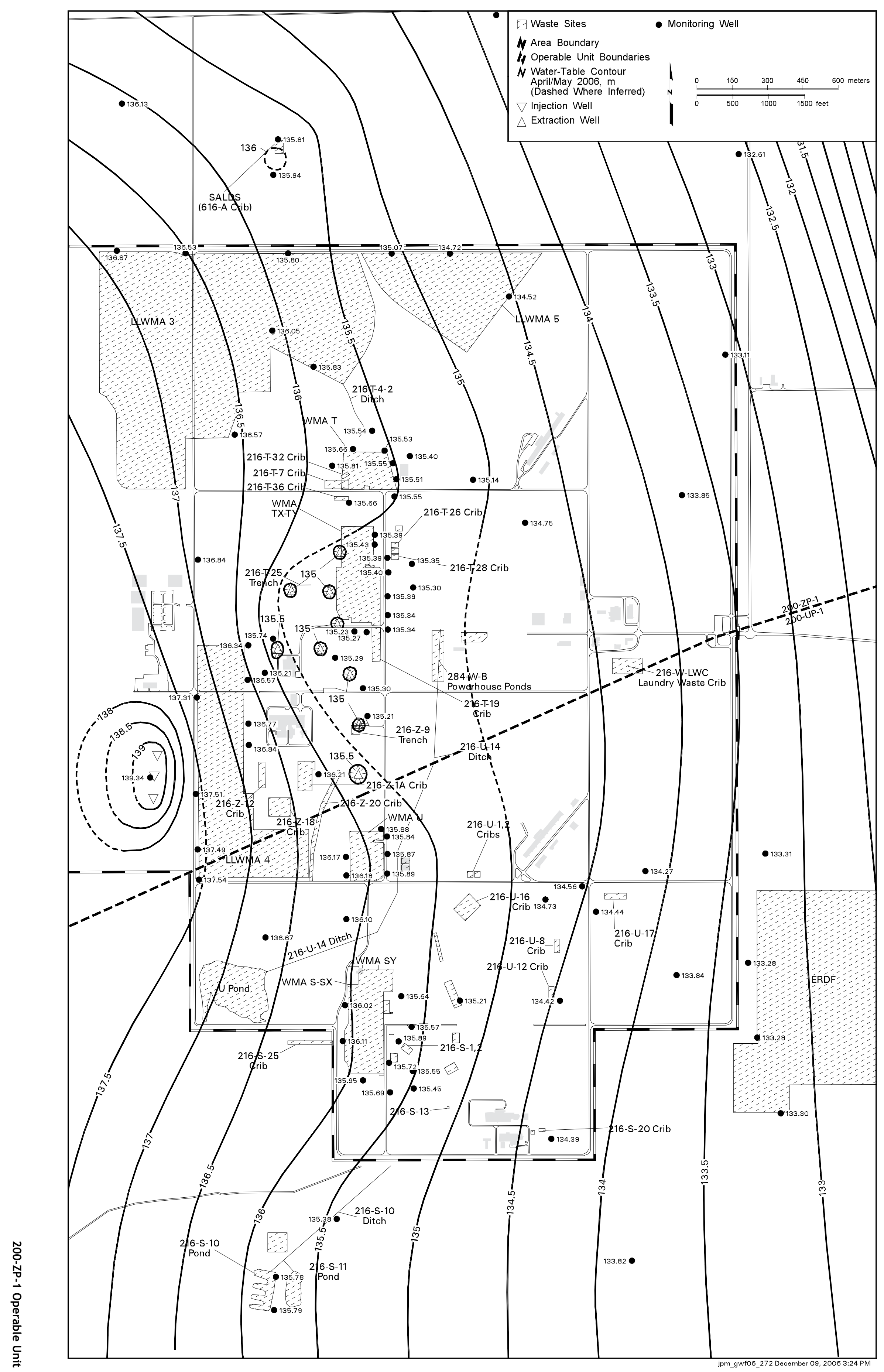

Figure 2.8-2. 200 West Area Water-Table Map, April/May 2006 


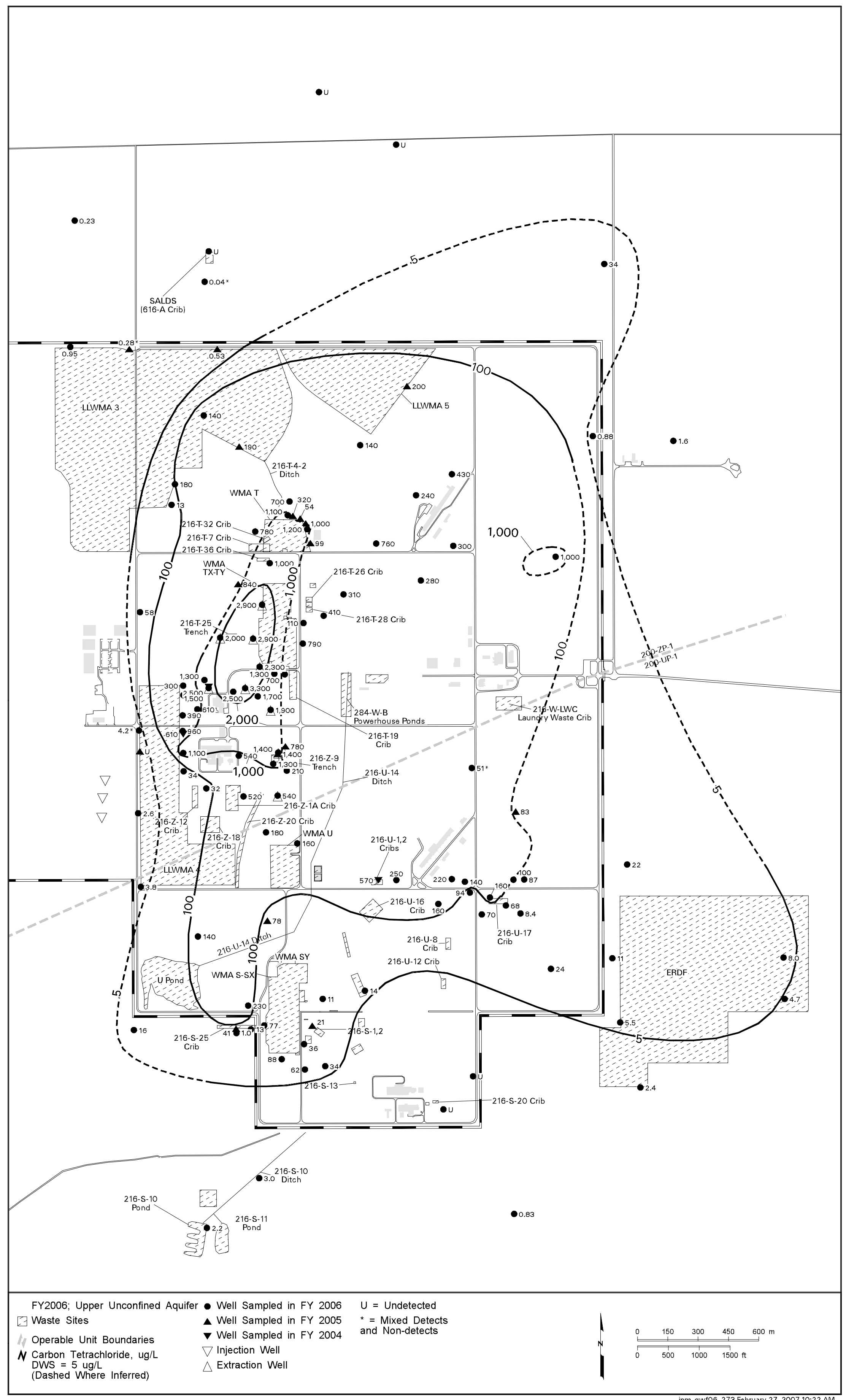

Figure 2.8-3. Average Carbon Tetrachloride Concentrations in 200 West Area, Upper Part of Unconfined Aquifer 


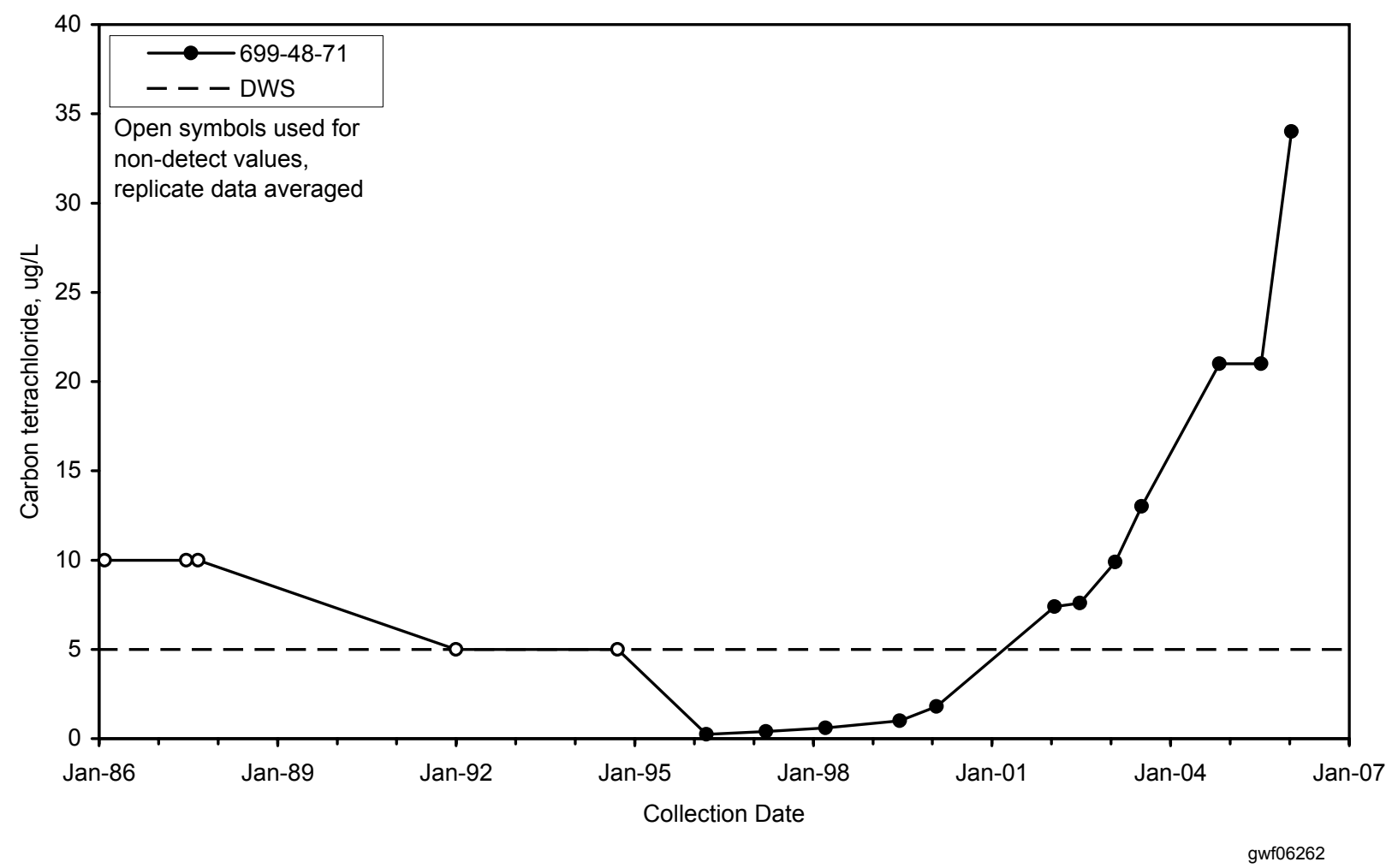

Figure 2.8-4. Carbon Tetrachloride Concentrations at Well 699-48-71, Northeast of the 200 West Area 


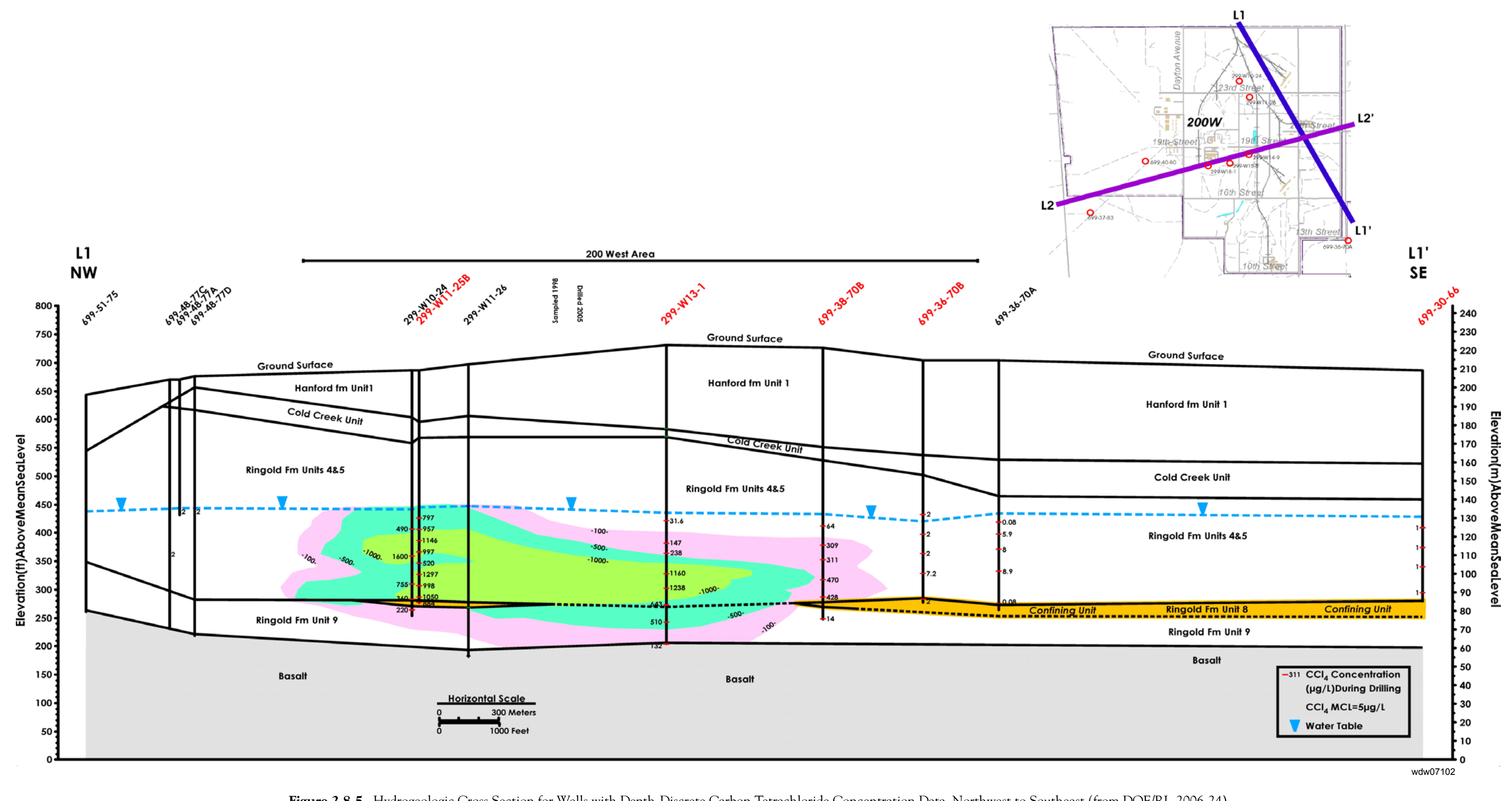




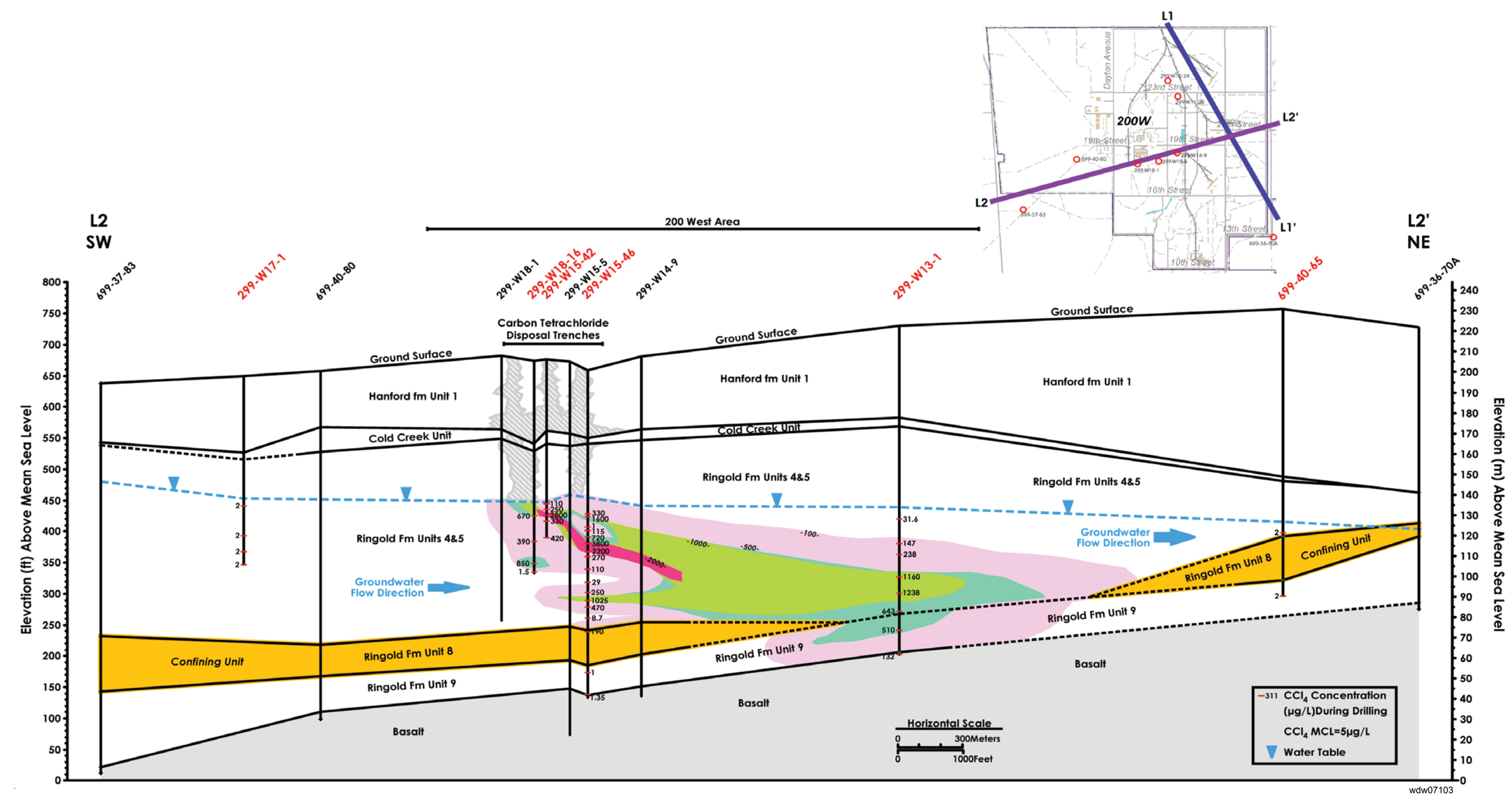

Figure 2.8-6. Hydrogeologic Cross Section for Wells with Depth-Discrete Carbon Tetrachloride Concentration Data, Southwest to Northeast (from DOE/RL-2006-24) 


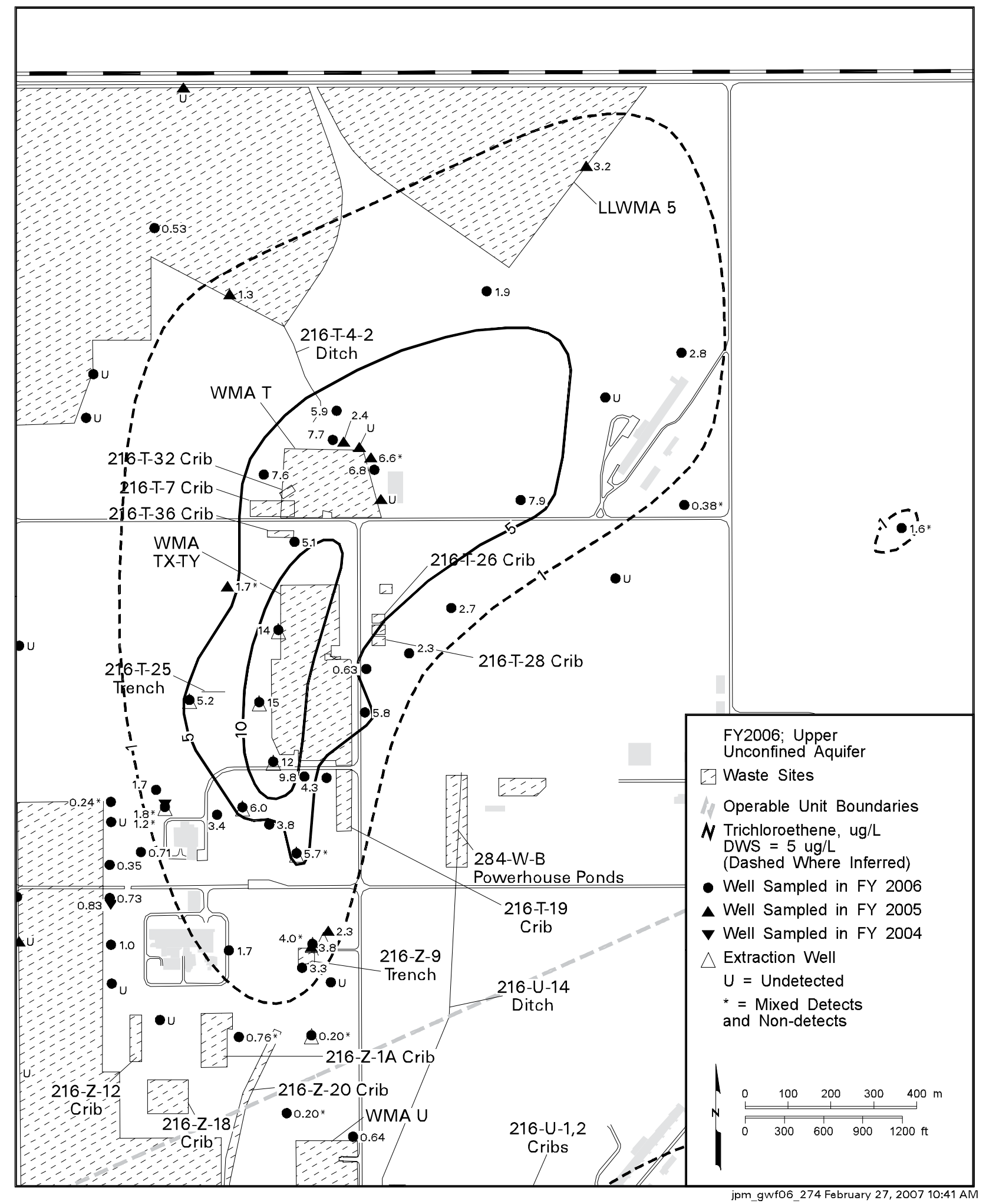

Figure 2.8-7. Average Trichloroethene Concentrations in Central and North 200 West Area, Upper Part of Unconfined Aquifer 


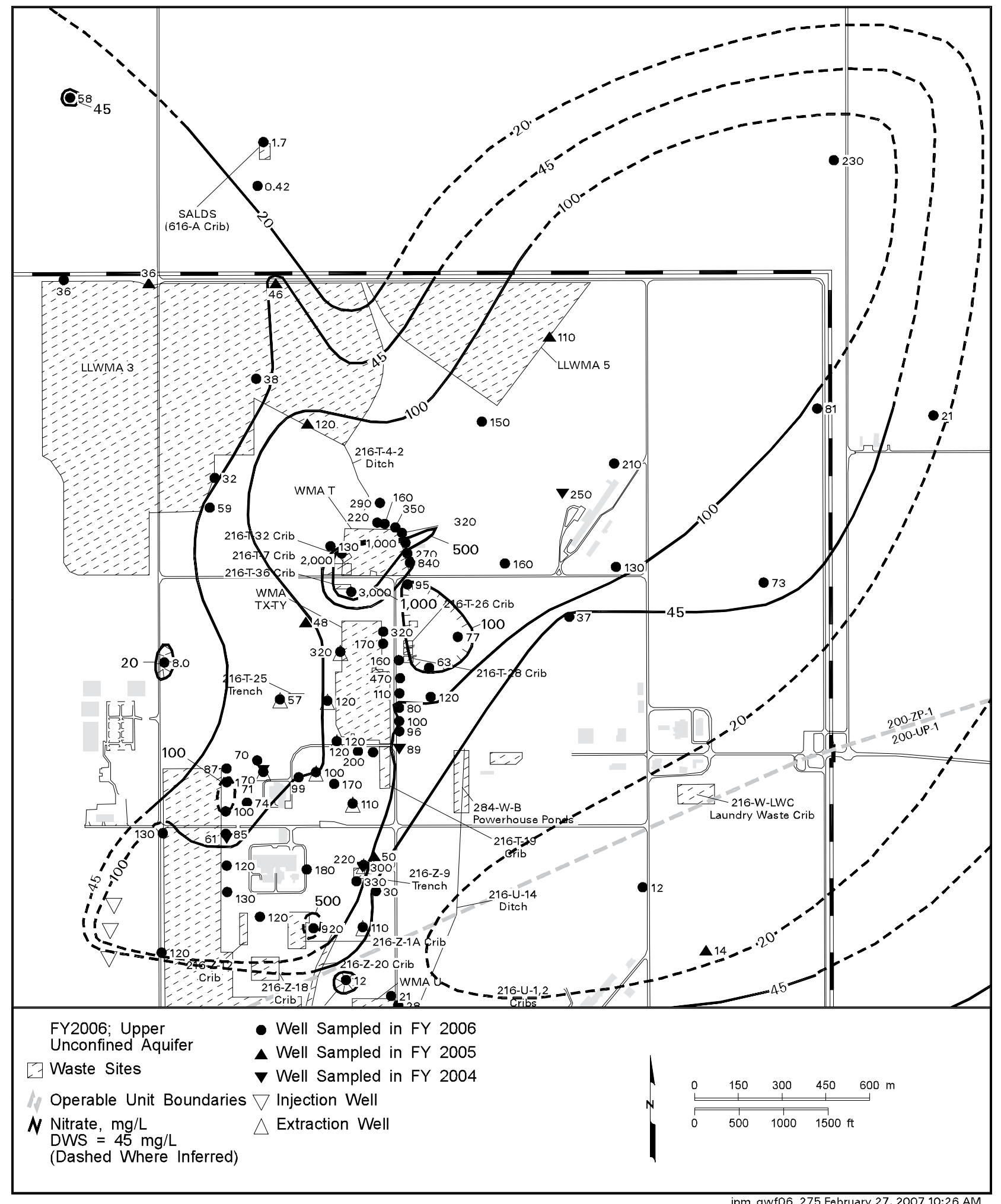

Figure 2.8-8. Average Nitrate Concentrations in Central and North 200 West Area, Upper Part of Unconfined Aquifer 


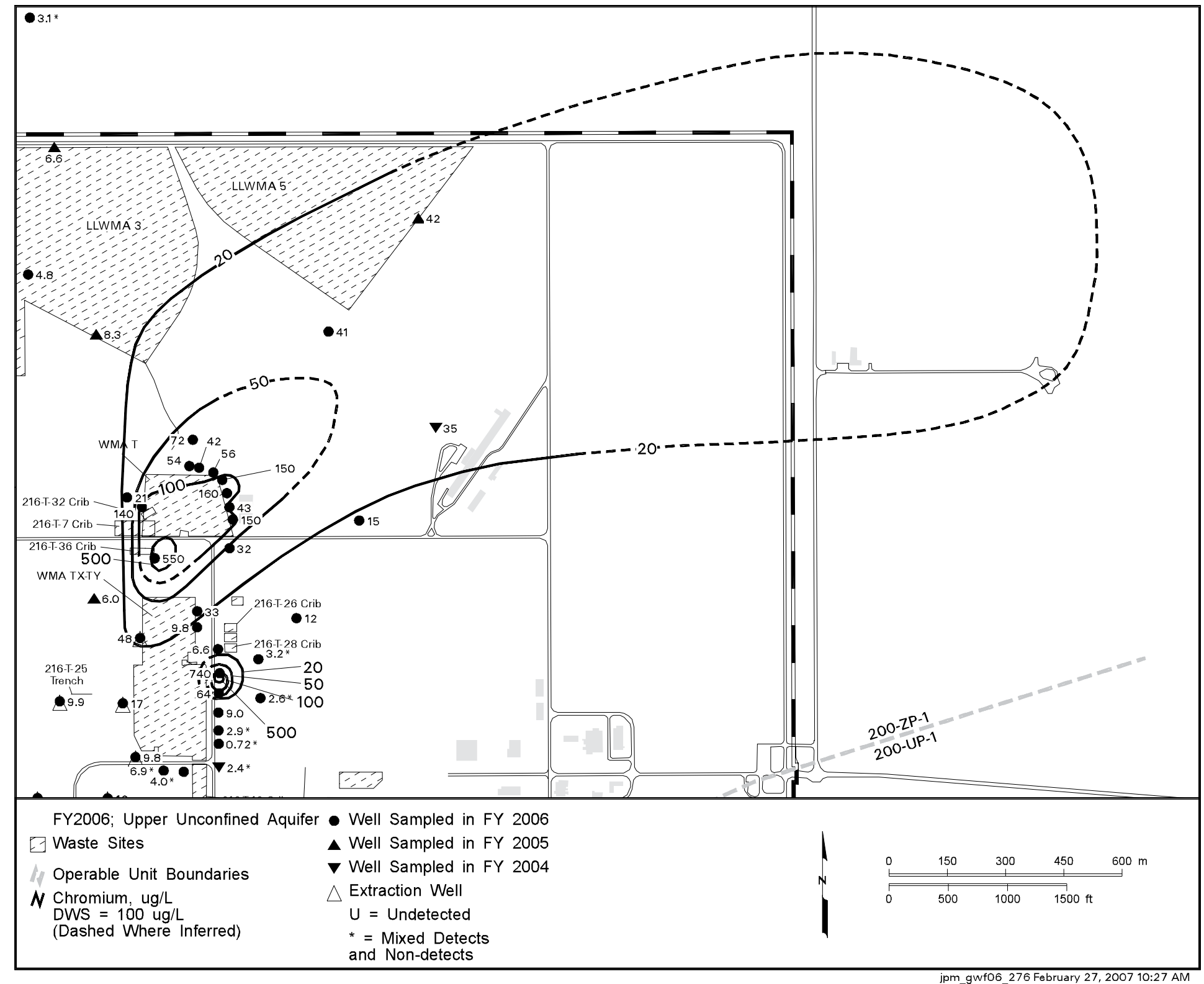

Figure 2.8-9. Average Dissolved Chromium Concentrations Near Waste Management Areas T and TX-TY, Upper Part of Unconfined Aquifer 


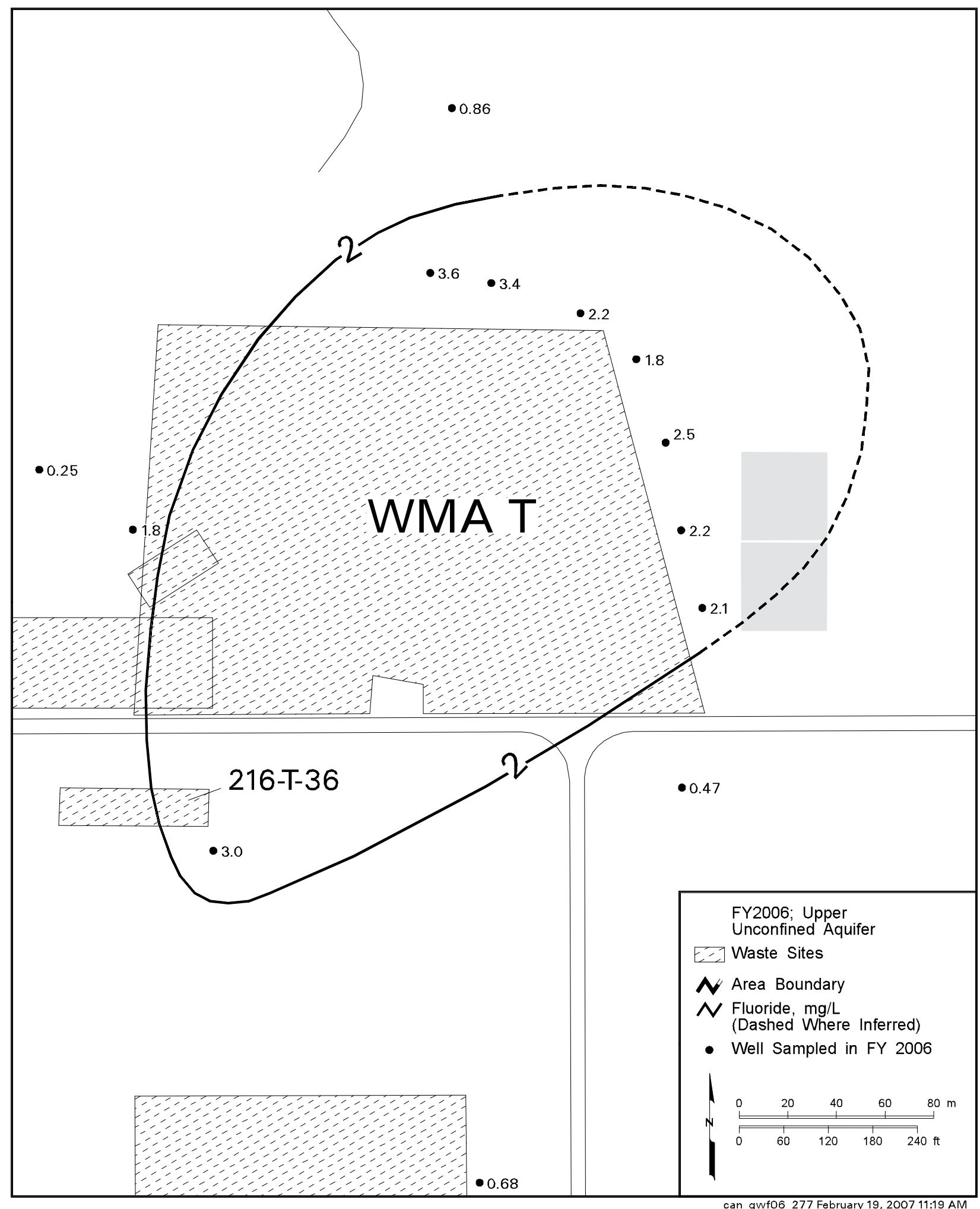

Figure 2.8-10. Average Fluoride Concentrations Near Waste Management Area T in North 200 West Area, Upper Part of the Unconfined Aquifer 


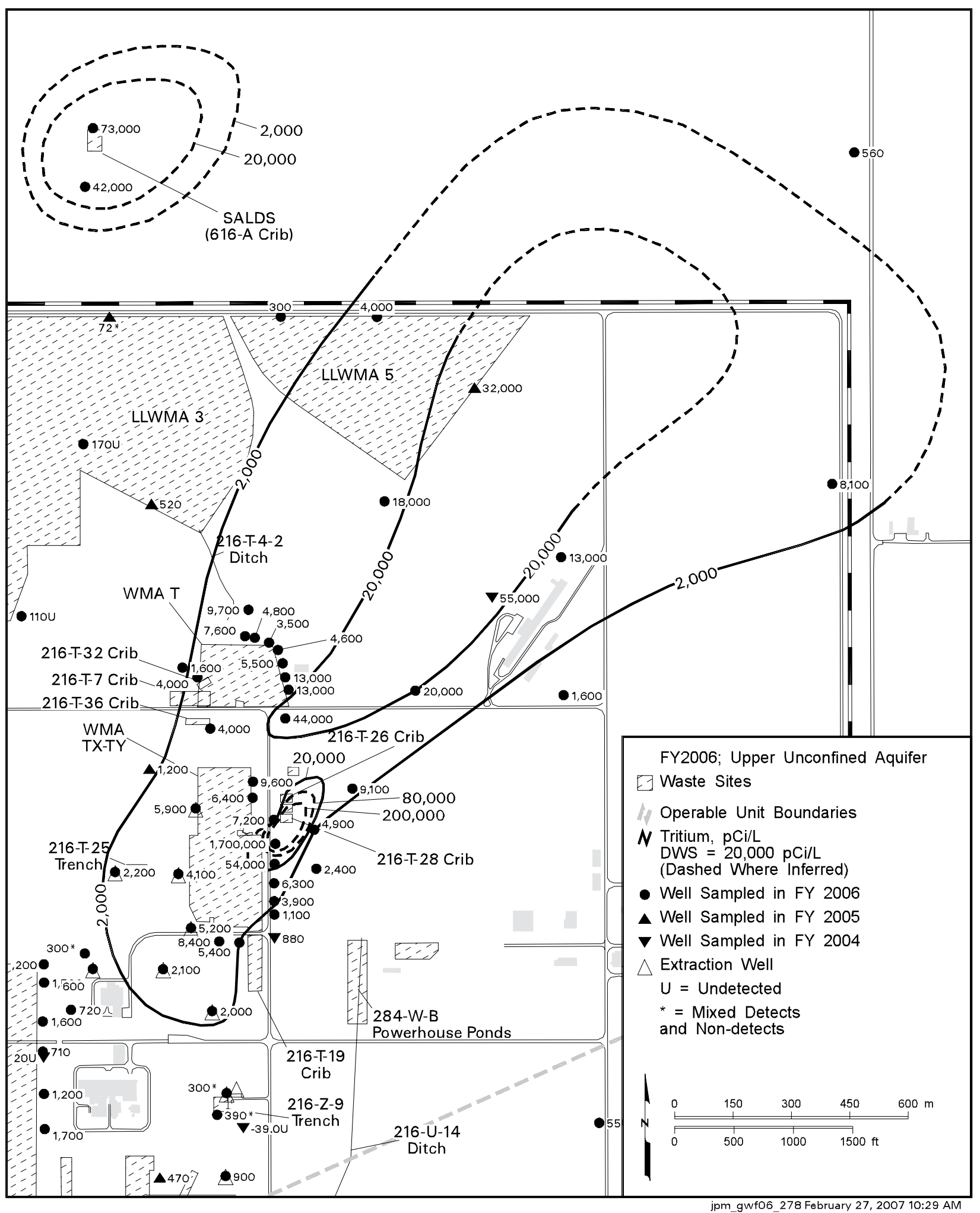

Figure 2.8-11. Average Tritium Concentrations in North 200 West Area, Upper Part of Unconfined Aquifer 


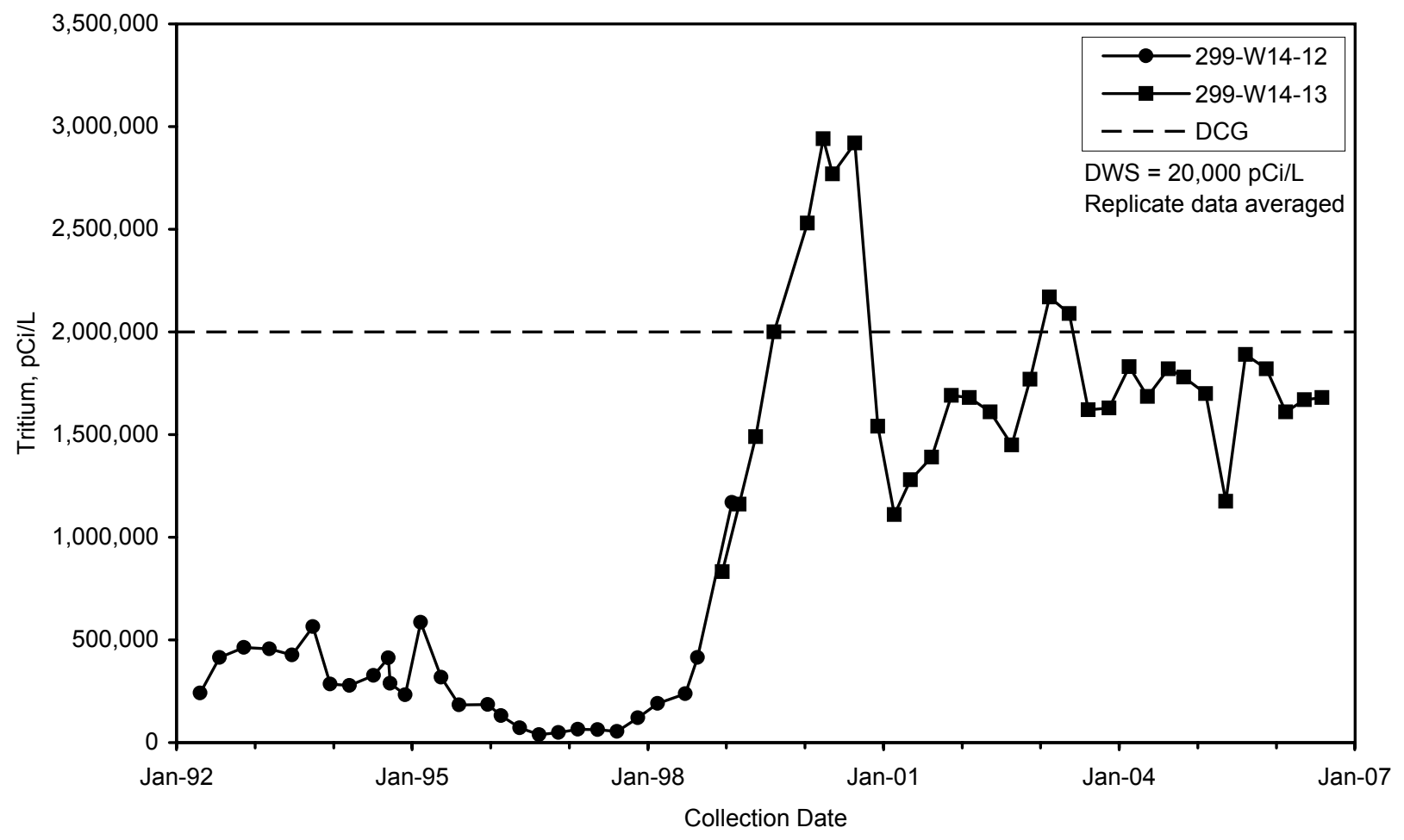

gwf06279

Figure 2.8-12. Tritium Concentrations versus Time in Wells 299-W14-12 and 299-W14-13, Waste Management Area TX-TY 


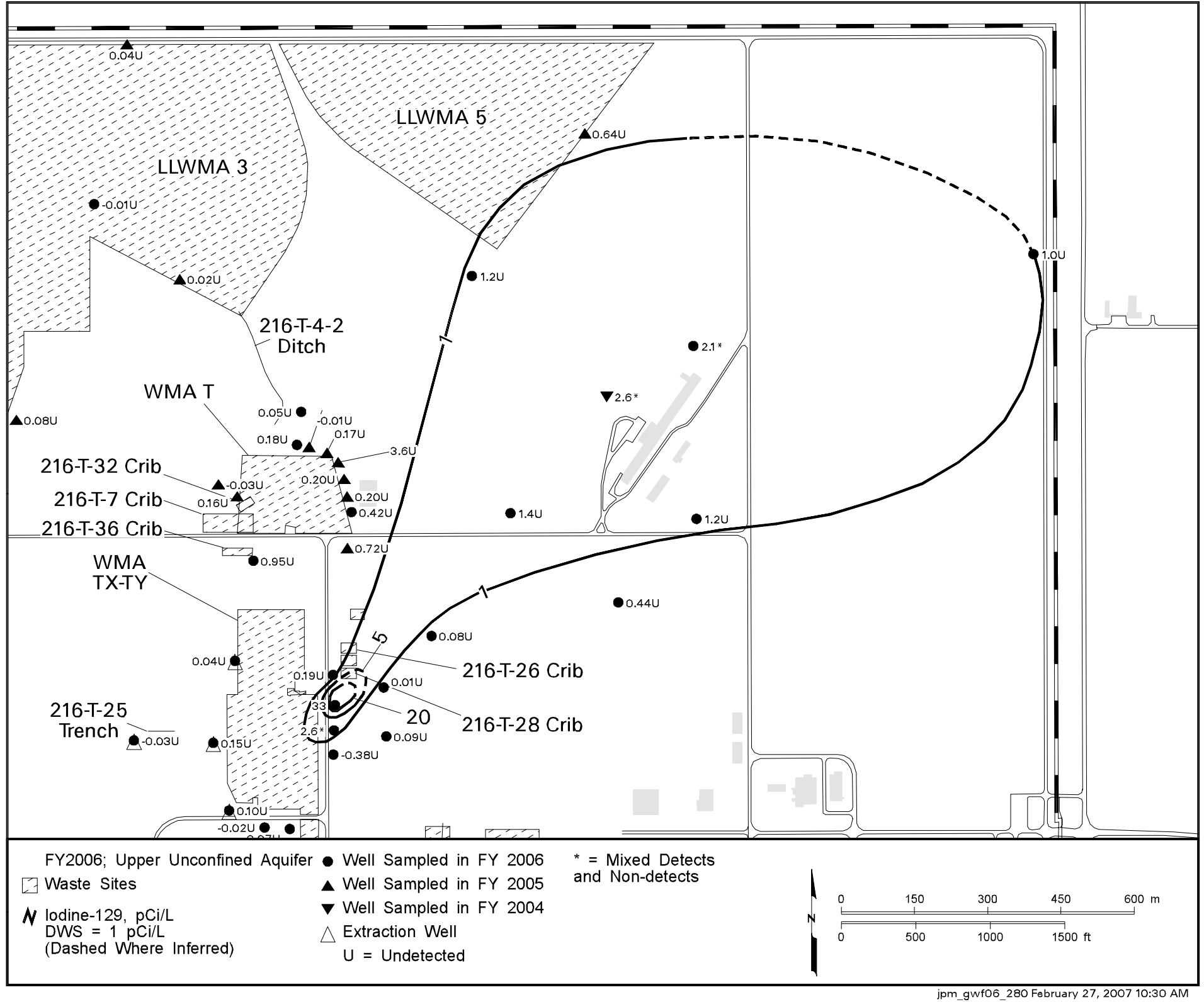

\begin{tabular}{l}
$N$ \\
$\infty$ \\
\multirow{1}{*}{}
\end{tabular}

Figure 2.8-13. Average Iodine-129 Concentrations in North 200 West Area, Upper Part of Unconfined Aquifer 


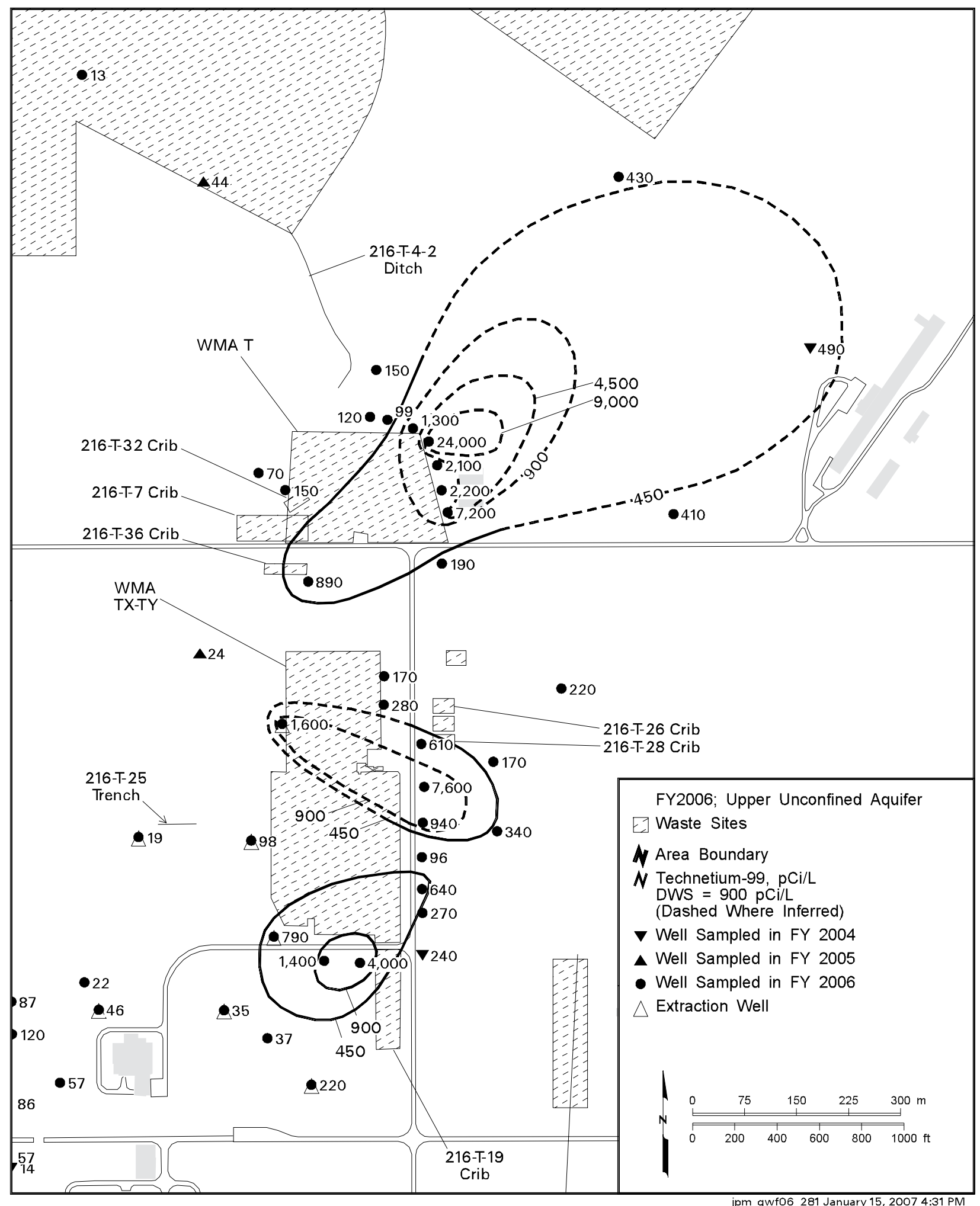

Figure 2.8-14. Average Technetium-99 Concentrations in North 200 West Area, Upper Part of Unconfined Aquifer 


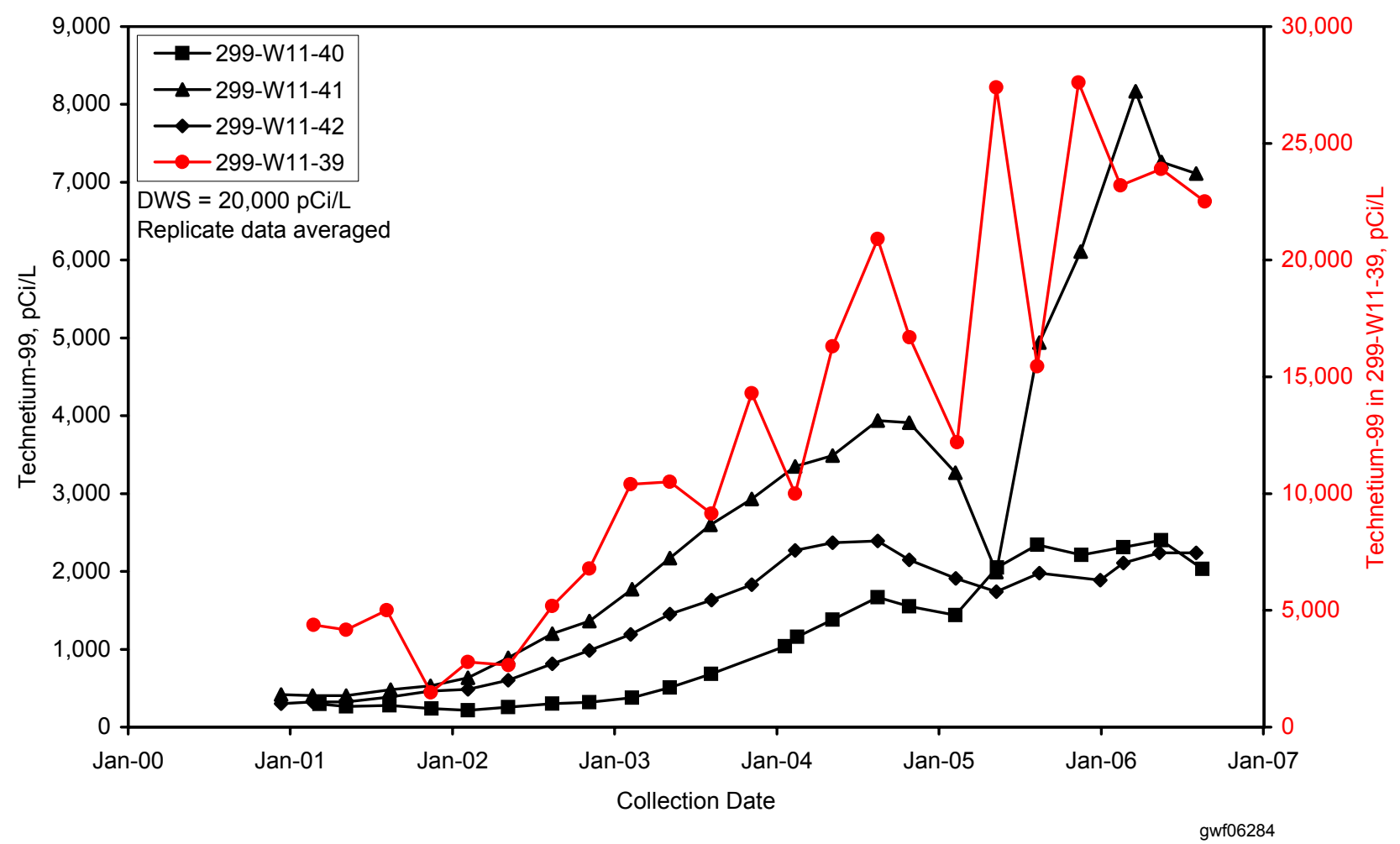

Figure 2.8-15. Technetium-99 Concentrations in Selected Downgradient Water-Table Wells at Waste Management Area T

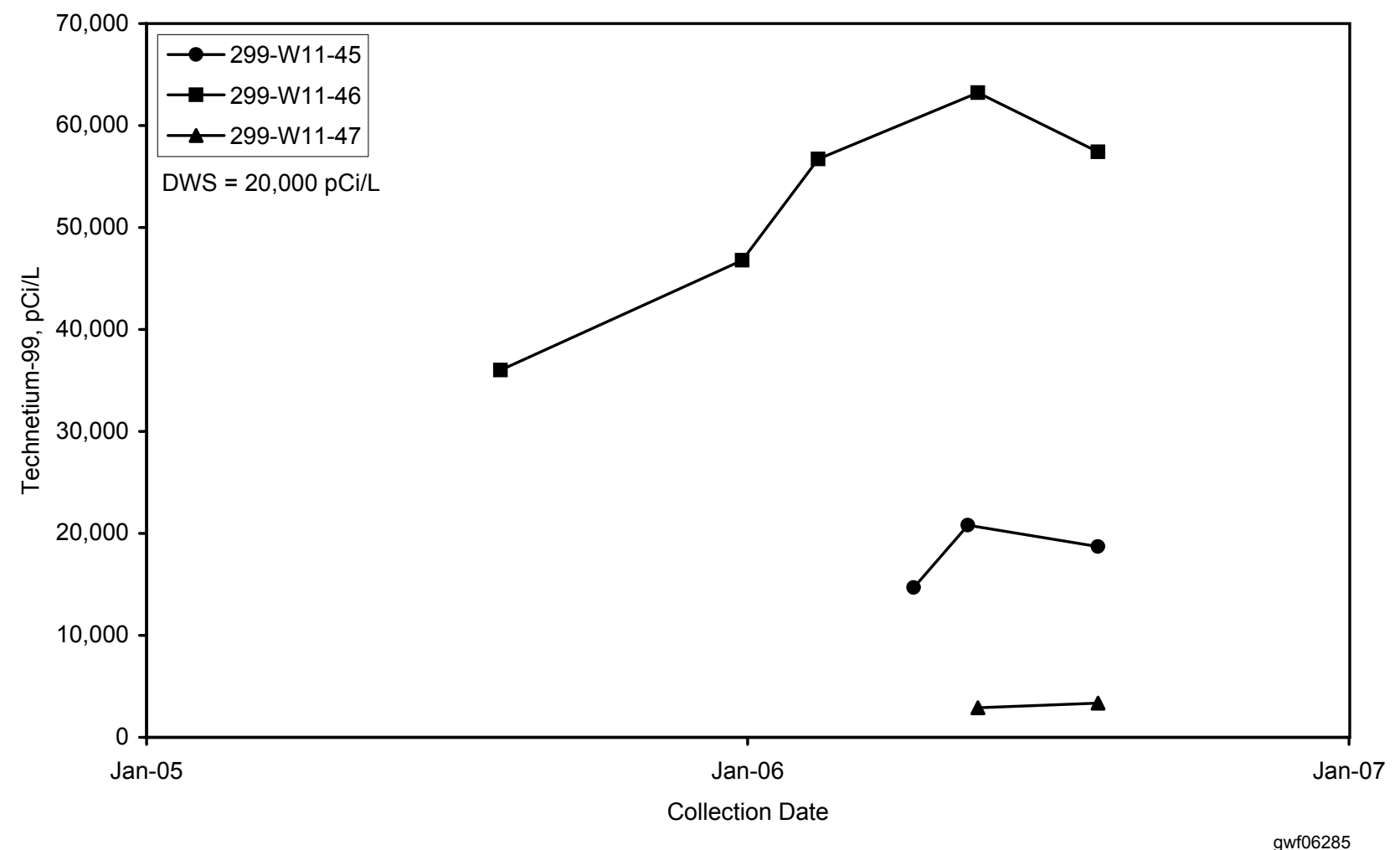

Figure 2.8-16. Technetium-99 Concentrations in Wells Screened Below Water Table at Waste Management Area T 


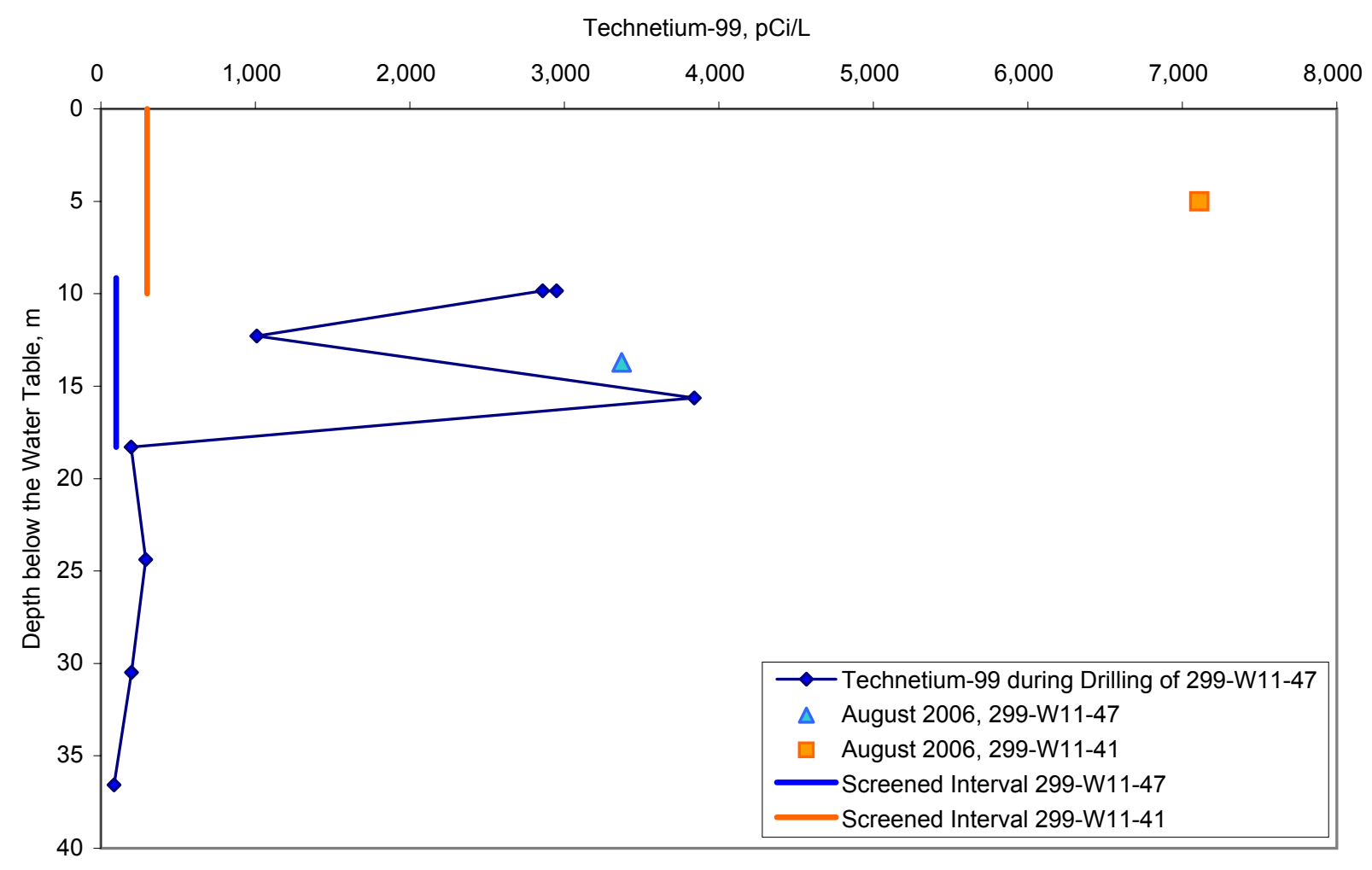

Figure 2.8-17. Depth Distribution of Technetium-99 at Well 299-W11-47

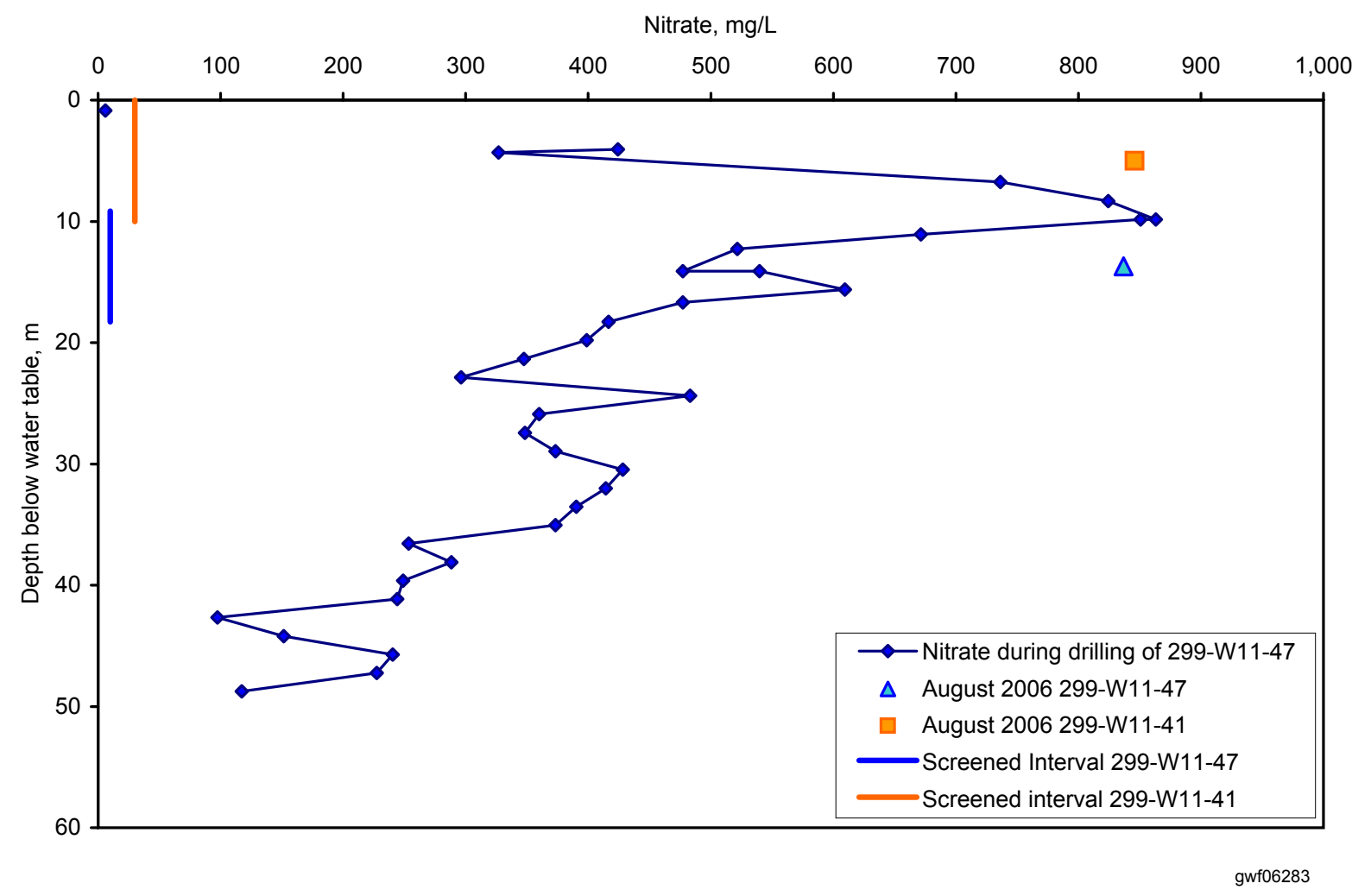

Figure 2.8-18. Nitrate Concentrations at Well 299-W11-47 


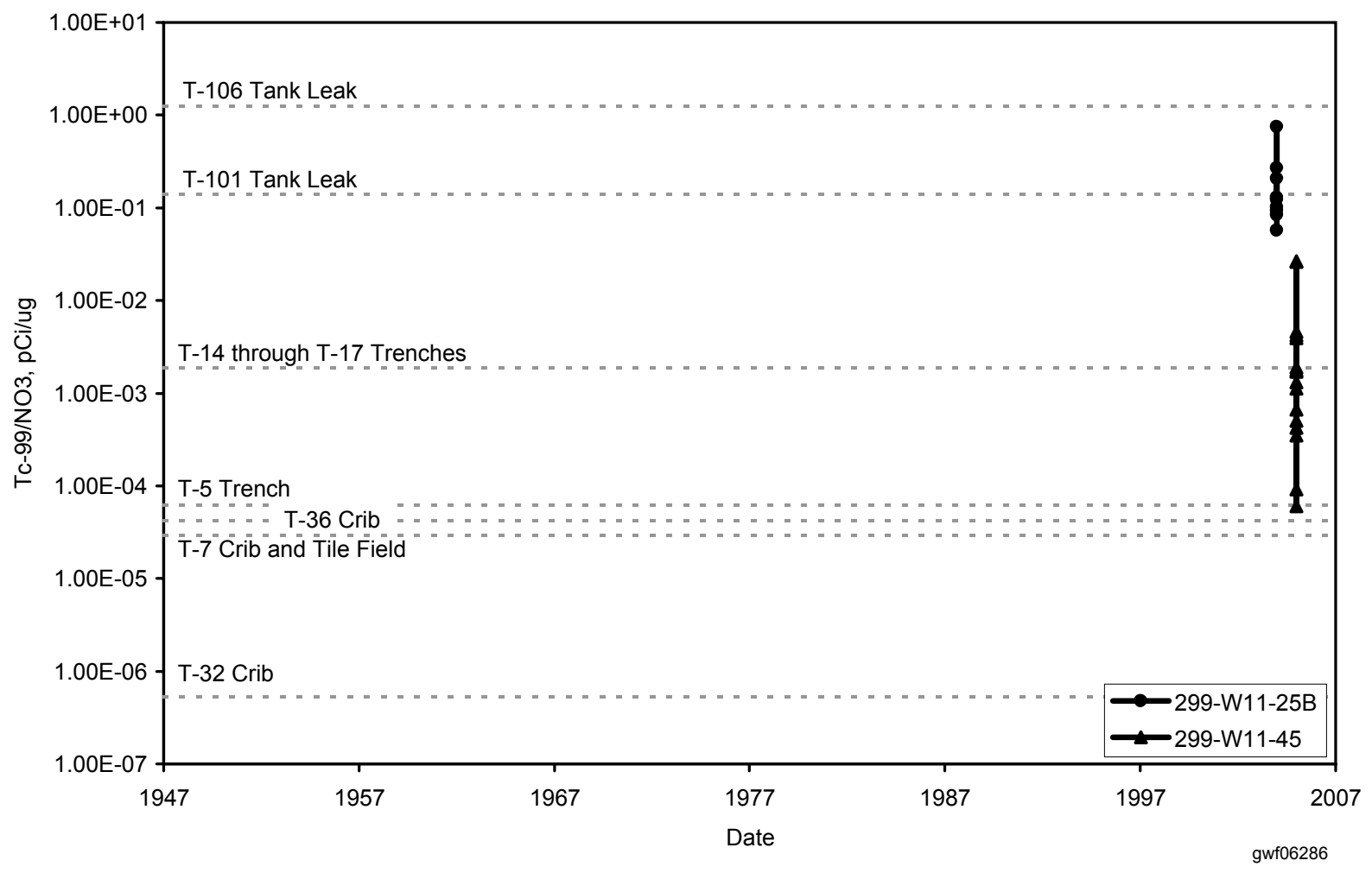

Figure 2.8-19. Technetium-99/Nitrate Concentration Ratio for Groundwater at Waste Management Area T

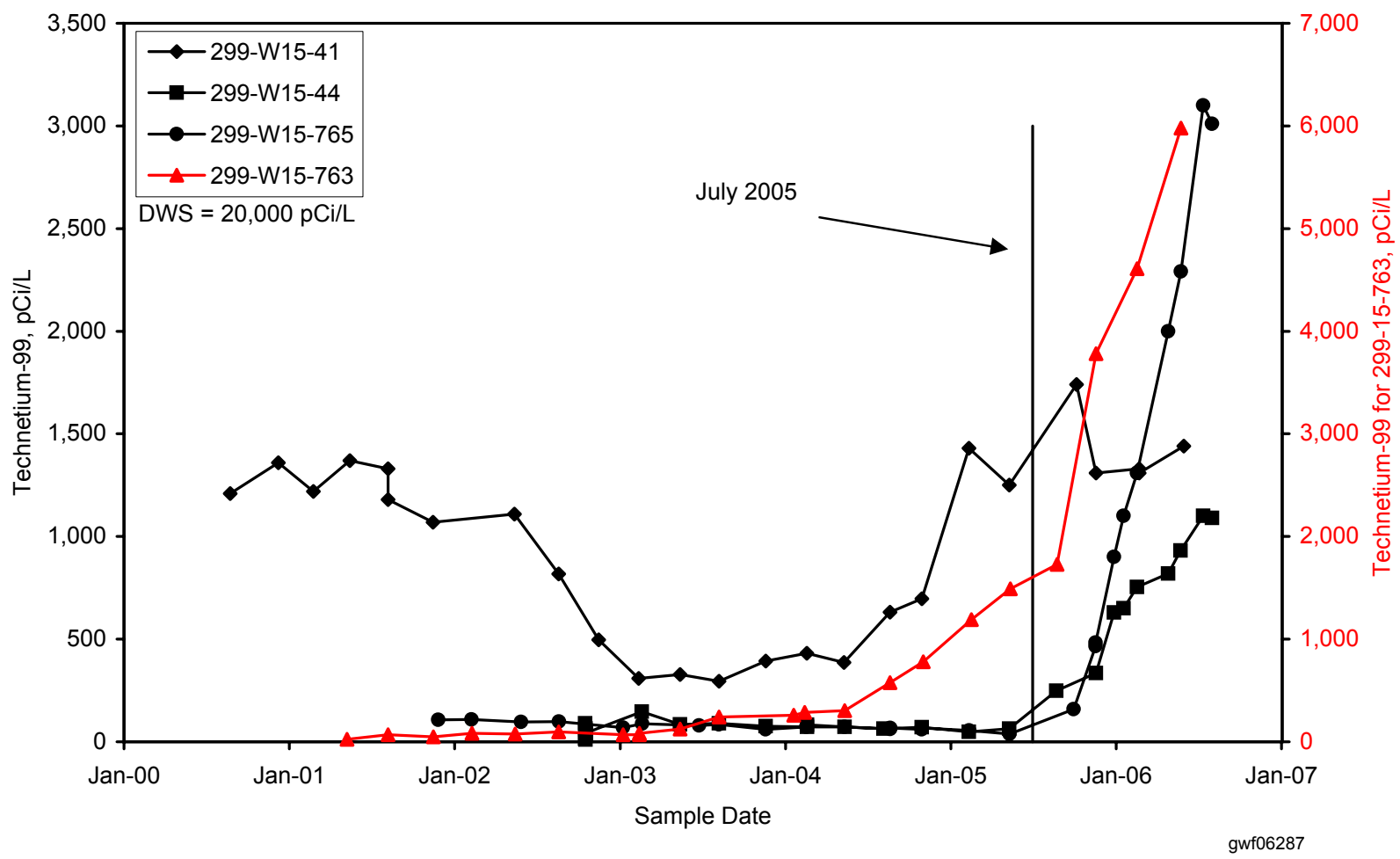

Figure 2.8-20. Technetium-99 Concentration Versus Time for Four Wells at Waste Management Area TX-TY Influenced by the 200-ZP-1 Pump-and-Treat System (Wells 299-W15-44 and 299-W15-763 are extraction wells.) 


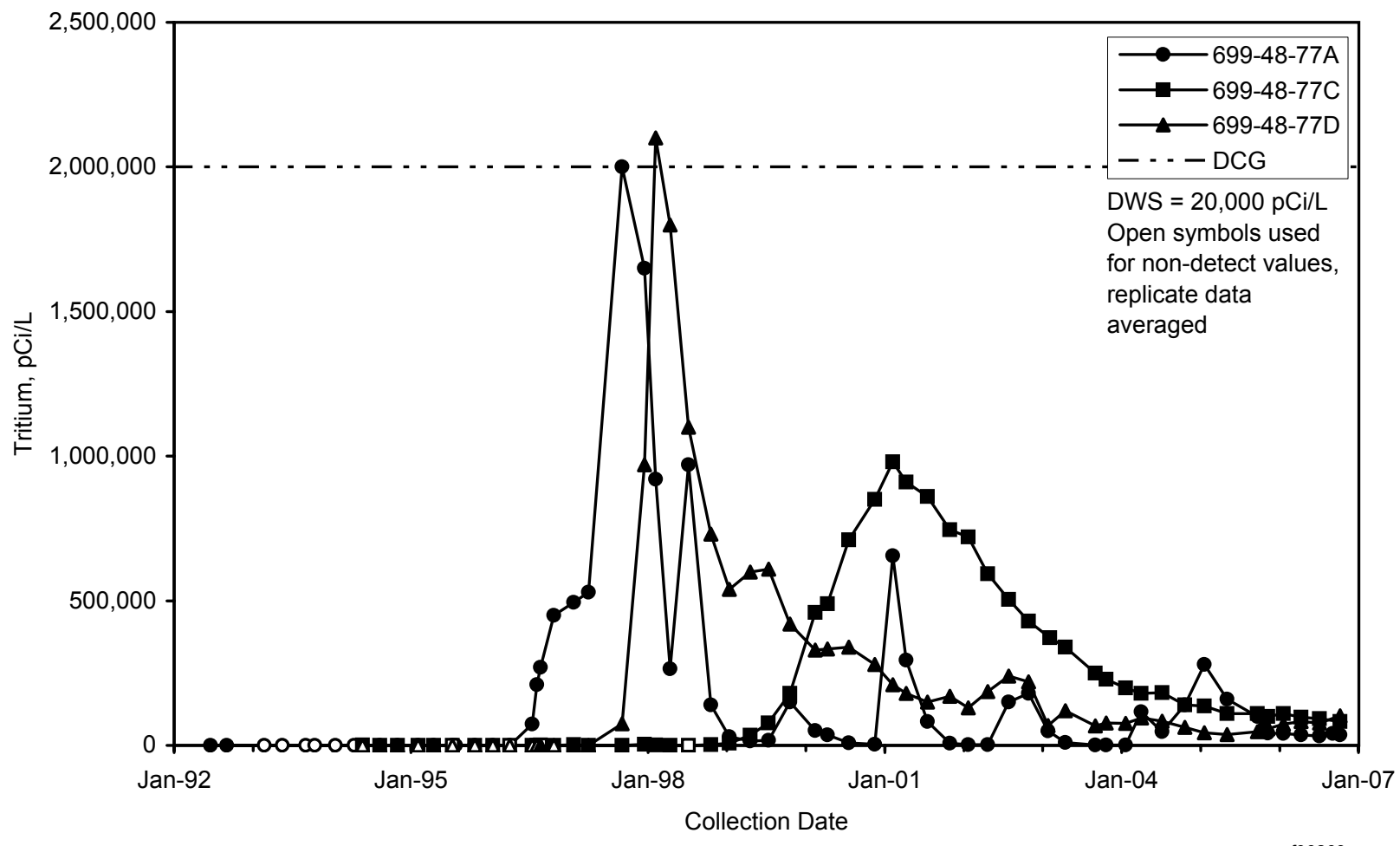

gwf06263

Figure 2.8-21. Tritium Concentrations in Wells Monitoring the State-Approved Land Disposal Site 


\subsection{0-UP-1 Operable Unit}

\section{J. P. McDonald, R. M. Smith, B. A. Williams, D. B. Erb, and R. L. Weiss}

The scope of this section is the 200-UP-1 groundwater interest area, which addresses groundwater contaminant plumes beneath the southern third of the 200 West Area and adjacent portions of the surrounding 600 Area (see Figure 1.0-1 in Section 1.0). This region includes the 200-UP-1 Operable Unit. The "groundwater interest areas" are informal designations to facilitate scheduling, data review, and interpretation. Figure 2.9-1 shows facilities and wells in the 200-UP-1 Area. Technetium-99, uranium, tritium, iodine-129, nitrate, and carbon tetrachloride are the contaminants of greatest significance in groundwater and form extensive plumes within the region. Groundwater is monitored to

- Evaluate the extent and migration of existing contaminant plumes within the interest area.

- Assess the technetium-99 and uranium concentration response to the termination of groundwater extraction at an interim action pump-and-treat remediation system (i.e., a rebound study).

- Assess the rate and extent of contaminant migration from Waste Management Areas U and S-SX, as well as the 216-U-12 crib, under the Resource Conservation and Recovery Act (RCRA).

- Detect impacts to groundwater quality from the 216-S-10 pond and ditch under RCRA.

- Detect impacts to groundwater quality from operation of the Environmental Restoration Disposal Facility under a Comprehensive Environmental Response, Compensation, and Liability Act (CERCLA) record of decision (ROD 1995b).

- Identify emerging groundwater contamination issues within the interest area.

In addition to technetium-99 and uranium, high-priority contaminants of concern include strontium-90, trichloroethene, chloroform, chromium, cadmium, and arsenic (DOE/RL-92-76).

Groundwater monitoring in the 200-UP-1 groundwater interest area includes the following monitoring activities:

CERCLA and AEA Monitoring

- Wells are sampled quarterly to biennially for contaminants of concern and constituents of interest.

- Four wells are sampled semiannually at the Environmental Restoration Disposal Facility. Radium and total organic halides were not analyzed in FY 2006 (see Appendix B).

- Most wells were sampled as scheduled, but some were delayed until FY 2007 (see Appendix A).

Facility Monitoring

- Wells are sampled quarterly at Waste Management Area U for RCRA and AEA.

- Wells are sampled quarterly at Waste Management Area S-SX for RCRA and AEA.

- Wells are sampled semiannually under RCRA for the 216-S-10 pond and ditch. Sampling frequency for several constituents is being revised.

- Wells are sampled quarterly for RCRA at the 216-U-12 crib.

- In FY 2006, fourth quarter samples from numerous RCRA wells were delayed until FY 2007 because of schedule conflicts and access restrictions relating to extreme fire danger (see text and Appendix B). 
The sampling and analysis plan for fiscal year (FY) 2006 sampling of the 200-UP-1 Operable Unit is incorporated into the Remedial Investigation/Feasibility Study Work Plan for the 200-UP-1 Groundwater Operable Unit (DOE/RL-92-76). This plan integrates CERCLA and Atomic Energy Act (AEA) monitoring, and is a revision of the original integrated plan issued during June 2002 (DOE/RL-2002-10). Appendix A presents the monitoring well network for the 200-UP-1 Operable Unit, including a well list, sampling frequencies, and analyte lists.

Plume areas (square kilometers) above the drinking water standard at the 200-UP-1 Operable Unit:

Chromium - 1.09

Iodine-129-4.76

Nitrate -6.60

Technetium-99-0.29

Tritium -6.97

Uranium - 0.52

* Carbon tetrachloride included in Section 2.8.

Groundwater flow in the uppermost unconfined aquifer is primarily to the east within the 200-UP-1 groundwater interest area (see Figure 2.8-2 in Section 2.8). Water levels have been falling in this area since the 1980s, and flow directions have generally changed from southeast to east during this time. When $U$ Pond and the 216-U-14 ditch were active, a groundwater mound resulted in radial flow in the northwest portion of the interest area (e.g., see PNNL-16069). Discharges to ground ceased in the mid-1990s, and the groundwater flow resumed its pre-Hanford flow direction toward the east. Based on water-level measurements in March 2005 and April 2006, the water-table elevation fell by an average of 0.23 meter in the south 200 West Area over the 13-month period.

In 2005, twelve new wells were proposed for the operable unit to support a remedial investigation/feasibility study (DOE/RL-92-76). Six of these wells were installed during calendar year 2006, and their locations are shown in Figure 2.9-1. The wells were installed just north of the 200-UP-1 pump-and-treat area (299-W19-107), near the 216-U-8 crib (299-W19-105), upgradient from the 216-U-12 crib (299-W22-87), and downgradient from Waste Management Area S-SX (299-W22-69, 299-W22-72, and 299-W22-86). Sampling results for these wells are included in the following sections, as appropriate.

The remainder of this section describes contaminant plumes and concentration trends for the contaminants of concern under CERCLA, RCRA, and AEA monitoring.

\subsubsection{Groundwater Contaminants}

Large-scale waste disposal at the 200-UP-1 groundwater interest area began during the early 1950s when plutonium separation operations began at the Reduction-Oxidation (REDOX) Plant and uranium recovery operations began at U Plant. In general, the highlevel radioactive waste was stored in underground storage tanks while other liquid waste streams were sent to ponds and cribs. Groundwater plumes of nitrate, tritium, and iodine-129 formed from the pond and crib waste. These plumes continued to grow in size while effluent disposal operations continued. Effluent disposal to the ponds and cribs ceased during the 1990s. At present, the groundwater plumes from these sources are dispersing naturally. However, constituents of lower mobility in the vadose zone beneath the ponds and cribs may potentially reach the water table in the future and affect groundwater quality.

Within the tank farms (Waste Management Areas U and S-SX), some of the underground storage tanks have leaked, resulting in contamination of the vadose zone beneath the tanks. Some of this contamination has migrated downward and reached the water table (e.g., PNNL-11810). Currently, plumes of nitrate, technetium-99, and chromium from the tank farms are found in groundwater and are generally growing in areal extent and exhibit increasing constituent concentrations. In addition, carbon tetrachloride is migrating into the 200-UP-1 groundwater interest area from the 200-ZP-1 interest area and represents a growing contamination issue.

The following sections provide an overview of the contaminant plumes and contaminants of concern for the 200-UP-1 groundwater interest area. These sections are a summary of the combined results of CERCLA, RCRA, and AEA monitoring performed in this area 
with the focus being the upper part of the unconfined aquifer. Information on the vertical distribution of contaminants in the aquifer is given where available.

\subsubsection{Technetium-99}

Technetium-99 concentrations occur above the drinking water standard $(900 \mathrm{pCi} / \mathrm{L})$ in three regions of the 200-UP-1 groundwater interest area: downgradient from the 216-U-1,2 cribs, at Waste Management Area S-SX, and at Waste Management Area U (Figure 2.9-2). A technetium-99 plume emanates from the $216-\mathrm{U}-1,2 \mathrm{cribs}$, which were active in the $1950 \mathrm{~s}$ and 1960s. The plume extends $\sim 1.5$ to 2 kilometers east into the 600 Area. When effluent was disposed at the nearby 216-U-16 crib in the mid-1980s, it migrated north along a caliche layer and mobilized the technetium-99 and uranium in the soil column beneath the 216-U-1,2 cribs, adding contaminant to the groundwater plume (DOE/RL-92-76). Historically, the highest measured technetium-99 concentration in the 216-U-1,2 cribs plume was 41,000 pCi/L in well 299-W19-24 (west of the 216-U-17 crib) during October 1989.

An interim remedial action pump-and-treat system operated in the central part of the 216-U-1,2 cribs plume from 1994 until early 2005. Operation of this system caused the plume to bifurcate into a high concentration portion captured by the pump-and-treat system and a lower concentration portion outside the capture zone that has continued to migrate into the 600 Area. The remediation effort was successful in reducing concentrations below the remedial action goal of 9,000 pCi/L. During January 2005, groundwater extraction was terminated and a rebound study was initiated. Monthly sampling was performed to assess plume response to the termination of pumping. The rebound study concluded in January 2006, and technetium-99 concentrations at all monitoring wells were below the remedial action goal throughout FY 2006. The maximum measured concentration in this plume during FY 2006 was 2,920 pCi/L in well 299-W19-43 during December 2005. The maximum concentration in the 600 Area is expected to be $<4,200 \mathrm{pCi} / \mathrm{L}$, which is the historical maximum concentration measured at well 699-38-70 as the plume migrated past this well. Section 2.9.2 gives a more thorough discussion of the rebound study.

At Waste Management Area S-SX, a technetium-99 plume originates from the southwest corner of the waste management area and another plume originates from the north part. During FY 2006, the technetium-99 concentration in well 299-W23-19 (located in the SX Tank Farm near the source of the south plume) decreased to below the U.S. Department of Energy (DOE) derived concentration guide of $100,000 \mathrm{pCi} / \mathrm{L}$ after peaking at $137,000 \mathrm{pCi} / \mathrm{L}$ during September 2005 (Figure 2.9-3). At the end of the fiscal year, the concentration was measured at 43,200 pCi/L. The trend at this well indicates that technetium-99 is entering the aquifer in an episodic manner.

The south plume from Waste Management Area S-SX represents a growing contamination issue. For most of the wells monitoring this plume, technetium-99 trends are either stable or increasing. A new well (299-W22-86) was installed 350 meters downgradient from the waste management area along the extended plume centerline. Technetium-99 was found near the water table at $1,950 \mathrm{pCi} / \mathrm{L}$, indicating the plume occurs farther downgradient than previously interpreted.

The north plume at Waste Management Area S-SX originates from the S Tank Farm. Historically, the highest measured technetium-99 concentration in this plume was $4,600 \mathrm{pCi} / \mathrm{L}$ in well 299-W22-48 during September 2002. The maximum concentration measured during FY 2006 was 1,420 pCi/L in well 299-W22-26 at the 216-S-9 crib, which is an increase from non-detectable levels in 2002 and is consistent with the eastward migration of this plume. At a new well (299-W22-69) installed 325 meters downgradient of the waste management area, technetium- 99 was found at $764 \mathrm{pCi} / \mathrm{L}$, just below the drinking water standard. These results mean the plume is migrating downgradient and extends farther to the east than previously interpreted. Concentrations remain relatively low compared to the south plume, and no significant increases have occurred (except those expected due to
A pump-and-treat system rebound study concluded in January 2006, and all technetium-99 concentrations downgradient of the 216-U-1,2 cribs were below the remedial action $\operatorname{goal}(9,000 \mathrm{pCi} / \mathrm{L})$ throughout the year.

Concentrations of technetium-99 in well 299-W23-19, at

Waste Management Area S-SX, decreased from $137,000 \mathrm{pCi} / \mathrm{L}$ in September 2005 to $43,200 \mathrm{pCi} / \mathrm{L}$ in September 2006. 


\section{Uranium responded more slowly than technetium-99 to the pump-and- treat system. All concentrations were below the remedial action goal $(480 \mu g / L)$ but above the drinking water standard (30 $\mu g / L)$ within the pump- and-treat area.}

the downgradient migration of the plume). This indicates that the plume is currently not a growing contamination issue. Section 2.9.3.2 has more information about technetium-99 at this waste management area.

Technetium-99 concentrations in the downgradient wells at Waste Management Area U are elevated compared to concentrations in the upgradient wells. Thus, the U Tank Farm is a source of technetium-99 contamination (PNNL-13282). However, concentrations are very low compared to Waste Management Area S-SX. The drinking water standard has only been exceeded recently in two wells (299-W19-45 at 1,200 pCi/L and 299-W19-47 at $\sim 1,300 \mathrm{pCi} / \mathrm{L})$. Concentrations are increasing in three wells, declining in one well, and stable in two wells. The downgradient extent of the plume is not known, due to a lack of well coverage beyond the current downgradient wells. Refer to Section 2.9.3.1 for more information about technetium-99 at this waste management area.

Depth-discrete groundwater sampling during well installation between FY 2003 and FY 2006 has provided information on the vertical distribution of contamination within the groundwater interest area. This sampling was called for by the Remedial Investigation/Feasibility Study Work Plan for the 200-UP-1 Groundwater Operable Unit (DOE/RL-92-76). The results of depth-discrete sampling for technetium-99 (and uranium) within the plume emanating from the 216-U-1,2 cribs are shown in Figure 2.9-4, and the depth-discrete sampling results for the southern part of the 200 West Area are shown in Figure 2.9-5. Three locations exist within the interest area where technetium-99 was found above the drinking water standard relatively deep below the water table: well 299-W19-46 (1,360 pCi/L at 19 meters below the water table), well 299-W19-49 (1,320 pCi/L at 28 meters below the water table), and well $699-38-70 \mathrm{C}(1,200 \mathrm{pCi} / \mathrm{L}$ down to the lower mud unit at 33 meters below the water table). At all other locations, technetium-99 concentrations above the drinking water standard are limited to the upper 20 meters of the aquifer or less (for well 299-W19-46, concentrations were $<300$ pCi/L above 19 meters depth). Wells 299-W22-47, 299-W22-86, and 299-W22-69 (Figure 2.9-5) demonstrate that the technetium-99 plumes from Waste Management Area S-SX are limited to the upper 20 meters of the aquifer.

\subsubsection{Uranium}

Within the 200-UP-1 groundwater interest area, uranium primarily occurs in an extensive plume downgradient from the 216-U-1,2 cribs (Figure 2.9-6) and is associated with the technetium-99 plume there. The plume extends a total of $\sim 1.5$ kilometers to the east at levels above the $30-\mu \mathrm{g} / \mathrm{L}$ drinking water standard. Uranium adsorbs to soil particles and is not as mobile in the aquifer as technetium-99. The uranium originated from the $216-\mathrm{U}-1,2$ cribs that were active in the 1950s and 1960s. As with technetium-99, additional mass was added to the plume when effluent disposed at the nearby $216-\mathrm{U}-16$ crib in the mid-1980s migrated north along a caliche layer in the vadose zone and mobilized the technetium-99 and uranium in the soil column beneath the 216-U-1,2 cribs (DOE/RL-92-76).

An interim remedial action pump-and-treat system operated on a high concentration part of this plume from 1994 until early 2005. The remediation effort was successful in reducing uranium concentrations below the remedial action goal of $480 \mu \mathrm{g} / \mathrm{L}$, but concentrations at most wells continued to exceed the drinking water standard of $30 \mu \mathrm{g} / \mathrm{L}$. The remedial action goal was ten times the Model Toxics Control Act standard at the time the record of decision was issued (ROD 1997), which was $48 \mu \mathrm{g} / \mathrm{L}$. This standard has since been revised to $30 \mu \mathrm{g} / \mathrm{L}$.

During January 2005, groundwater extraction was terminated and a rebound study was initiated. Monthly sampling was performed to assess plume response to the termination of pumping. The rebound study concluded in January 2006, and uranium concentrations at all monitoring wells were below the remedial action goal throughout FY 2006. The maximum measured concentration during FY 2006 was $442 \mu \mathrm{g} / \mathrm{L}$ in well 299-W19-36 during January. Most wells within this plume exhibit stable concentrations above the drinking water standard. Section 2.9.2 gives a more thorough discussion of the rebound study. 
Near the source of this plume, uranium continues to be elevated in well 299-W19-18, although the concentration has decreased since it was previously sampled in 2004 (Figure 2.9-7). During March 2006, uranium was measured at $460 \mu \mathrm{g} / \mathrm{L}$, down from $600 \mu \mathrm{g} / \mathrm{L}$ in May 2004. The small change in uranium concentration in this well over the past 10 years may be due to an ongoing source of uranium to the aquifer water, such as continued leaching from the vadose zone beneath the 216-U-1,2 cribs or desorption of uranium from the aquifer sediment, or it may be due to the slow migration of uranium compared to technetium-99.

Uranium was previously detected in the 1990s at well 299-W22-21 near the 216-S-13 crib. The crib was active from 1951 to 1966 , and it is reported to have received waste containing 91 kilograms of uranium (ARH-CD-745). In 1973, the uranium concentration in well 299-W22-21 peaked at 8,700 $\mathrm{g} / \mathrm{L}$. This well has gone dry, but when it was last sampled in 1997, uranium was found at $150 \mu \mathrm{g} / \mathrm{L}$. New well 299-W22-86 was installed $\sim 40$ meters north-northeast of the crib, and the uranium concentration was found to be $\sim 3 \mu \mathrm{g} / \mathrm{L}$. Since the new well is cross-gradient from the crib, rather than downgradient, the question of whether there is still a uranium plume emanating from the 216-S-13 crib remains unknown.

Depth-discrete sampling results for uranium during well installation between FY 2003 and FY 2006 are shown in Figure 2.9-4 for the plume emanating from the 216-U-1,2 cribs and in Figure 2.9-5 for the south part of the 200 West Area. Uranium was found above the drinking water standard only in the $216-\mathrm{U}-1,2$ cribs plume, and the data indicate that the plume is limited to the upper $\sim 20$ meters of the aquifer. There were no exceedances of the drinking water standard below 20 meters depth. Even in those wells (299-W19-46, 299-W19-49, and $699-38-70 \mathrm{~B}$ ) in which technetium-99 was found above the drinking water standard relatively deep in the aquifer, uranium was not elevated at the same depths. Uranium was not detected above the drinking water standard in the south part of the 200 West Area - all measured uranium concentrations were $<5 \mu \mathrm{g} / \mathrm{L}$.

\subsubsection{Tritium}

Disposal facilities associated with REDOX Plant are the primary sources of tritium in the 200-UP-1 groundwater interest area. The REDOX Plant operated from 1952 until 1967, although effluent releases continued to occur after this time. A large tritium plume emanates from the south part of the 200 West Area from REDOX Plant cribs to the east and northeast, extending $\sim 5$ kilometers at levels above the $20,000-\mathrm{pCi} / \mathrm{L}$ drinking water standard. Two high concentration areas occur within this plume - a large one extending to the east and northeast from the 200 West Area and a smaller one extending $~ 550$ meters to the east-southeast from the vicinity of the 216-S-25 crib (Figure 2.9-8).

Measured concentrations in the eastern high concentration area range from $\sim 200,000$ to 1 million $\mathrm{pCi} / \mathrm{L}$. Concentrations are generally declining at six wells and increasing at three, suggesting that the plume has localized areas of high concentrations probably due to the merging of plumes from several different sources. When these areas migrate past wells, increasing concentrations can occur. However, the plume overall exhibits declining concentrations and the areal extent as defined by the $2,000-\mathrm{pCi} / \mathrm{L}$ contour has changed little, indicating natural attenuation by dispersion and radiological decay.

Tritium occurs above the drinking water standard in nine wells downgradient of the 216-S-25 crib. Concentrations fluctuate in a single well (299-W23-9) on the downgradient side of the crib. Farther downgradient, trends are stable in four wells and increasing in four wells. Radioactive liquid effluent was disposed to this crib from 1973 through 1980, and in 1985, effluent from a pump-and-treat system at the 216-U-1,2 cribs was disposed to this crib. In the vadose zone beneath this crib, tritium in the residual soil moisture is likely to be slowly migrating to the water table, which would account for the fluctuating tritium concentration trend in well 299-W23-9. The plume has migrated under Waste Management Area S-SX, but the tank farms are not considered a direct source of tritium to the groundwater. Tritiated water in the tanks was removed by the 242-S evaporator and disposed of at the 216-S-25
The tritium plume emanating from the southeast 200 West Area is attenuating through dispersion and radiological decay. 


\section{A high \\ concentration \\ portion of the \\ iodine-129 plume \\ is migrating to \\ the east out of the \\ 200 West Area into}

the 600 Area. crib. The areal extent of the plume is growing as evidenced by increasing trends in the farfield downgradient wells 299-W22-82 and 299-W22-83 for Waste Management Area S-SX. New well 299-W22-86 was installed along the extended centerline of this plume during the year, and tritium was found in this well at $\sim 11,000 \mathrm{pCi} / \mathrm{L}$.

At new well 299-W22-72, installed northeast of the 216-S-7 crib, tritium was found above the drinking water standard at $20,500 \mathrm{pCi} / \mathrm{L}$. This well is to the north of the tritium plume emanating from the $216-\mathrm{S}-25 \mathrm{crib}$, so tritium at this location is interpreted to be associated with the high concentration area to the east (Figure 2.9-8). The source of this tritium is uncertain. It could originate from the vadose zone beneath the 216-S-7 crib, which was active from 1956 to 1965, or it could be from sources farther upgradient.

Information on the vertical distribution of tritium in the aquifer is sparse. Three of the eight wells (299-W19-48, 699-30-66, and 699-36-70B) installed within the operable unit during calendar year 2004 were sampled for tritium at different depths during drilling. The results indicate that tritium mainly occurs in the upper part of the aquifer near the water table. However, none of these wells were located in a high concentration portion of the plume.

\subsubsection{4 lodine-129}

Iodine-129 plumes in the 200-UP-1 groundwater interest area originate from both U Plant and REDOX Plant disposal facilities (Figure 2.9-9). One plume emanates from the vicinity of the 216-U-1,2 cribs, while another originates from the south part of the 200 West Area. At the current level of monitoring detail, these plumes merge downgradient and become indistinguishable. This combined plume (as defined by the $1-\mathrm{pCi} / \mathrm{L}$ contour level) extends to the east a total distance of $\sim 3.5$ kilometers. Measured concentrations near the REDOX Plant cribs are below the drinking water standard.

Groundwater sampling results near the 216-U-1,2 and 216-U-12 cribs are flagged as non-detectable (Figure 2.9-9) but are believed to represent valid approximations of the iodine-129 concentration in the aquifer because the laboratory is conservative by requiring confirmation through the presence of a secondary (less sensitive) energy peak prior to considering the iodine-129 detected. In the late 1980s, shortly after the large uranium release to the aquifer beneath the $216-\mathrm{U}-1,2 \mathrm{cribs}$, iodine- 129 was detected at $\sim 30 \mathrm{pCi} / \mathrm{L}$. Iodine-129 was detected at $\sim 9 \mathrm{pCi} / \mathrm{L}$ in 2000 in a single well just before it went dry (well 299-W19-3). Similarly at the 216-U-12 crib, iodine- 129 was detected at $\sim 12 \mathrm{pCi} / \mathrm{L}$ during the 1990s. Thus, these cribs were a source of iodine-129, and it is reasonable to conclude that the vadose zone beneath these cribs contains residual iodine-129 that may be currently leaching into the aquifer.

A high concentration part of the iodine-129 plume has migrated to the east out of the 200 West Area into the surrounding 600 Area. Measured concentrations in the central part of this plume typically range up to $\sim 30 \mathrm{pCi} / \mathrm{L}$. Concentrations are generally declining or stable throughout the plume, and dispersion is slowly reducing the plume size (i.e., the region of the plume above the drinking water standard). Radiological decay is not a factor in the declining areal extent, because iodine-129 has a long half-life (17 million years).

\subsubsection{Strontium-90}

During FY 2006, 12 analyses for strontium-90 were performed on samples collected from 7 wells within the groundwater interest area. Strontium-90 was detected in only a single well: 299-W22-10, located downgradient of the 216-S-1,2 cribs. The result was $27 \mathrm{pCi} / \mathrm{L}$ during December 2005, which is above the drinking water standard $(8 \mathrm{pCi} / \mathrm{L})$. Concentrations have been declining in this well after increasing to $76 \mathrm{pCi} / \mathrm{L}$ in December 2001. The 216-S-1,2 cribs received highly acidic waste from the REDOX Plant between 1952 and 1956. In 1955, the waste is believed to have corroded the casing of a nearby well (299-W22-3), which allowed the effluent to bypass the soil column and flow down the well directly into groundwater (Waste Information Data System [WIDS]). This is the postulated pathway by which strontium-90 may have reached groundwater. 


\subsubsection{Chlorinated Hydrocarbons}

Carbon tetrachloride occurs above the drinking water standard $(5 \mu \mathrm{g} / \mathrm{L})$ in numerous wells within the 200-UP-1 groundwater interest area. At the water table, the plume is widespread in the south 200 West Area, and extends $\sim 1$ kilometer east into the 600 Area (Figure 2.8-3 in Section 2.8). The plume originated from waste disposal sites associated with the Plutonium Finishing Plant in the 200-ZP-1 groundwater interest area. Concentration trends are increasing in ten wells, decreasing in six wells, and fluctuating but generally stable in numerous wells. No clear spatial pattern exists among wells having increasing or decreasing

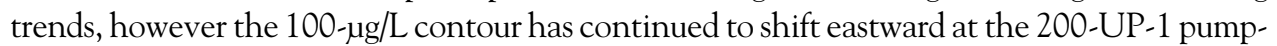
and-treat area indicating that the plume is expanding eastward. Depth-discrete sampling in the eastern part of the plume shows that concentrations generally increase with depth to the Ringold Formation lower mud unit, although decreasing concentrations with depth were found at new well 299-W19-105. The highest measured concentration during FY 2006 was $610 \mu \mathrm{g} / \mathrm{L}$ in well $699-38-70 \mathrm{~B}$, completed from 35 to 40 meters below the water table in the east part of the plume beyond the 200 West Area boundary. The pattern of increasing concentrations with depth is not consistent with what has been observed in the west part of the plume. Depth-discrete sampling during installation of well 299-W22-47 at Waste Management Area S-SX showed that concentrations peaked (at $96 \mu \mathrm{g} / \mathrm{L}$ ) 12 meters below the water table and then quickly declined to about the drinking water standard 37 meters below the water table. See Section 2.8 for more information regarding the vertical distribution of carbon tetrachloride in the aquifer.

Chloroform is a degradation product of carbon tetrachloride, and tends to occur in the same wells with carbon tetrachloride. Thus, some degradation of carbon tetrachloride may be occurring, although chloroform could have been introduced to the aquifer from the 2607-Z tile field (see Section 2.8). A total of 163 chloroform analyses were performed on samples from 54 wells within the 200-UP-1 groundwater interest area, and no exceedances of the drinking water standard $(80 \mu \mathrm{g} / \mathrm{L})$ were observed in FY 2006. The maximum concentration measured during FY 2006 was $16 \mu \mathrm{g} / \mathrm{L}$ in well 299-W15-37. Depth-discrete sampling during new well installation showed that concentrations tend to increase with depth, similar to carbon tetrachloride.

Trichloroethene is found within the 200-UP-1 groundwater interest area above the drinking water standard $(5 \mu \mathrm{g} / \mathrm{L})$ only in the vicinity of the pump-and-treat system. A total of 163 trichloroethene analyses were performed on samples from 54 wells within the interest area, and the drinking water standard was exceeded in only three wells in FY 2006: 299-W19-107, 699-38-70B, and 699-38-70C. The maximum concentration measured was $7 \mu \mathrm{g} / \mathrm{L}$ in a depth-discrete sample 39 meters below the water table collected during drilling of well 299-W19-107. Other depth-discrete sampling results also show that concentrations tend to increase with depth. The distribution of trichloroethene does not coincide with the distribution of carbon tetrachloride. Trichloroethene is thought to have originated from a local source near U Plant.

In previous years, trichloroethene concentrations had been above the drinking water standard near the 216-S-20 crib. Trichloroethene was measured at $50 \mu \mathrm{g} / \mathrm{L}$ in 299-W22-20 in 1991, but concentrations have been declining in this area and are now well below the drinking water standard. This observation suggests that the plume has either migrated away from the crib area and/or has degraded and dispersed naturally. However, this general process of attenuation cannot be confirmed due to the lack of well coverage in downgradient areas.

\subsubsection{Chromium}

Chromium is found in four regions of the 200-UP-1 groundwater interest area: at Waste Management Area S-SX, at the 216-S-10 pond and ditch, in the vicinity of the 216-S-20 crib, and in the 600 Area east and southeast of the 200 West Area. During FY 2006, samples from six wells exceeded the drinking water standard $(100 \mu \mathrm{g} / \mathrm{L})$. The highest concentration

\section{Carbon \\ tetrachloride is \\ widespread in \\ the 200-UP-1 \\ groundwater \\ interest area \\ but this plume \\ originated from \\ disposal facilities \\ in the 200-ZP-1 \\ groundwater \\ interest area.}

\section{Depth-discrete \\ sampling during \\ well installation}

shows that carbon

tetrachloride,

chloroform, and

trichloroethene

concentrations

generally increase

with depth in the

eastern part of the

operable unit. 


\section{In well 299-W23-19 at Waste Management Area S-SX, chromium concentrations decreased during FY 2006 from $1,710 \mu \mathrm{g} / \mathrm{L}$ in December to $707 \mu g / L$ in September.}

\section{Multiple sources of nitrate created a large plume, which is moving to the east.}

occurred at well 299-W23-19, where filtered total chromium was measured at 1,730 $\mu \mathrm{g} / \mathrm{L}$ in December 2005, but had declined to $707 \mu \mathrm{g} / \mathrm{L}$ at the end of the fiscal year (Figure 2.9-3). The chromium fluctuations in this well is interpreted to indicate that contaminant enters the aquifer from the vadose zone beneath the tank farm in an episodic manner. In general, chromium concentrations are increasing at Waste Management Area S-SX and the areal extent of the plume is growing. Chromium at Waste Management Area S-SX is further discussed in Section 2.9.3.2.

Filtered total chromium has been found above the drinking water standard in well 299-W26-7 at the 216-S-10 pond and ditch. The sample collected in June 2003 yielded a result of $209 \mu \mathrm{g} / \mathrm{L}$. The well has since gone dry, so no further sampling is possible. The source for this contamination is unconfirmed, but it could be the 216-S-10 pond and ditch, even though well 299-W26-7 is an upgradient well. The areal extent of the plume appears to be small and stable, because chromium concentrations in downgradient and side-gradient wells are at minimal to non-detectable levels.

Filtered total chromium is frequently detected in wells east and southeast of the 200 West Area. An interpretation of the chromium extent in this area is shown on the map of major hazardous chemical plumes in the summary section of this report. The filtered total chromium concentration in well 699-32-62 was $150 \mu \mathrm{g} / \mathrm{L}$ in October 2005 . Chromium concentrations have declined slowly since this constituent was first analyzed for at this well in 1992. Filtered total chromium is also above the drinking water standard at 699-30-66 $(102 \mu \mathrm{g} / \mathrm{L}$ in February 2006), which is completed deep in the aquifer just above the lower mud unit. This indicates that chromium may occur throughout the aquifer thickness in this region. The sources and extent of this contamination are uncertain. The location of this plume is consistent with disposal to the REDOX Plant ponds/ditches south and southwest of the 200 West Area. Chromium is detected in several other wells in this area, but its extent to the south is not well defined.

Filtered total chromium has also been found above the drinking water standard in well 299-W22-20, adjacent to the 216-S-20 crib. A concentration of $560 \mu \mathrm{g} / \mathrm{L}$ was measured in September 2004, and concentrations had been increasing since 2000. This well was sampled twice during FY 2006 with results of $216 \mu \mathrm{g} / \mathrm{L}$ in December falling to $10 \mu \mathrm{g} / \mathrm{L}$ in August. This well has a perforated, carbon steel casing and is filling with fine sand. The sand is known to quickly destroy sample pump seals, so the well must be sampled with a bailer and cannot be purged. In addition, the well is going dry and manganese is elevated suggesting that reducing conditions are becoming prevalent. Thus, the latest sample results may not be representative of the aquifer.

\subsubsection{Nitrate}

Nitrate plumes in the 200-UP-1 groundwater interest area are thought to have originated from both the U Plant and REDOX Plant disposal facilities and are widespread throughout the area. Potential sources of nitrate from U Plant include the 216-U-1,2; 216-U-8; and 216-U-12 cribs. The nitrate plumes from these and other sources merge downgradient into a single large plume, which extends to the east and northeast a total distance of $\sim 4$ kilometers (Figure 2.9-10). Nitrate sources from REDOX Plant disposal facilities may also have contributed to this plume. With a few exceptions, concentrations throughout the large plume outside the 200 West Area are stable or declining. On the eastern margin of the plume, concentrations are stable in wells 699-36-61A and 699-44-64, and rising in well 699-40-62.

Within the pump-and-treat area, nitrate concentrations had been increasing in well 299-W19-43, presumably in response to the termination of pumping for the rebound study. During FY 2006, nitrate concentrations stabilized at $\sim 1,600 \mathrm{mg} / \mathrm{L}$. Nitrate concentrations increased sharply in 299-W19-37 during FY 2006, from $62 \mathrm{mg} / \mathrm{L}$ in October to $536 \mathrm{mg} / \mathrm{L}$ in August. These values are higher than concentrations measured historically at the 216-U-1,2 cribs in the 1970s and 1980s, which were typically $\sim 100$ to $\sim 300 \mathrm{mg} / \mathrm{L}$. Thus, it appears that 
nitrate may have a local source in the vicinity of the pump-and-treat area. Section 2.9.2 gives a more thorough discussion of nitrate at the pump-and-treat area.

The occurrence of nitrate above the drinking water standard deep in the unconfined aquifer does not appear to be widespread. The nitrate distribution depicted in Figure 2.9-10 represents nitrate concentrations in the upper portion of the unconfined aquifer, since most of the wells are screened across the water table. Of the wells actively sampled within the interest area, six are screened deeper in the aquifer (wells 299-W19-34A, 299-W19-34B, 299-W27-2, 699-30-66, 699-38-70B, and 699-38-70C), and five of these are within the mapped nitrate plume (well 299-W27-2 is outside the plume area). In only one of these deeper wells, 699-38-70C, is nitrate found at levels above the 45-mg/L drinking water standard. This specific well yielded an average concentration of $190 \mathrm{mg} / \mathrm{L}$ during FY 2006. Depth-discrete sampling results for nitrate during installation of new well 299-W19-107 show elevated levels of nitrate in the upper part of the aquifer, although concentrations did not exceed the drinking water standard (Figure 2.9-11).

Waste Management Area $U$ is a source of nitrate to groundwater (see Section 2.9.3.1). Nitrate concentrations in two of the downgradient wells remained above the drinking water standard during FY 2006. The maximum measured nitrate concentration at the U Tank Farm during FY 2006 was $110 \mathrm{mg} / \mathrm{L}$ in well 299-W19-44.

Nitrate occurs in two small plumes associated with REDOX Plant disposal facilities: one near the 216-S-20 crib and another near the 216-S-25 crib. Well 299-W22-20 downgradient of the $216-\mathrm{S}-20 \mathrm{crib}$ had an average nitrate concentration of $140 \mathrm{mg} / \mathrm{L}$ for the fiscal year. From 1952 through 1972, this crib received waste from laboratory hoods and decontamination sinks in the 222-S Building, along with laboratory waste from the 300 Area. In well 299-W23-9, at the downgradient end of the 216-S-25 crib, concentrations have been elevated in recent years, suggesting that a pulse of nitrate has entered the aquifer from the soil column beneath the crib. A sample collected in August 2006 from this well showed a nitrate concentration of $320 \mathrm{mg} / \mathrm{L}$.

The nitrate plume originating from the 216-S-25 crib merges with a nitrate plume emanating from Waste Management Area S-SX (see Section 2.9.3.2). Nitrate from the tank farm is co-variate with technetium-99. In well 299-W23-19 at the southwest corner of Waste Management Area S-SX, nitrate decreased in concentration during FY 2006 (coincident with the technetium-99 and chromium decline) from $960 \mathrm{mg} / \mathrm{L}$ in December to $400 \mathrm{mg} / \mathrm{L}$ in September.

\subsubsection{Other Constituents}

Arsenic and cadmium are listed as contaminants of concern for the 200-UP-1 Operable Unit (DOE/RL-92-76). During FY 2006, 31 analyses were performed for arsenic in 16 wells and 152 analyses were done for cadmium in 54 wells. No detections above a drinking water standard $(10 \mu \mathrm{g} / \mathrm{L}$ for arsenic and $5 \mu \mathrm{g} / \mathrm{L}$ for cadmium) were observed.

The contaminants of concern for the 200-UP-1 Operable Unit have been classified into an initial list of high priority constituents (i.e., strontium-90, iodine-129, technetium-99, uranium, tritium, carbon tetrachloride, chloroform, trichloroethene, chromium, arsenic, cadmium, and nitrate) to support integrated CERCLA and AEA long-term monitoring, as well as additional constituents of concern specifically identified to support the remedial investigation/feasibility study (DOE/RL-92-76). These additional constituents of concern are documented in the remedial investigation/feasibility study work plan (DOE/RL-92-76) and include an extended list of volatile organic compounds, metals, anions, ammonium ion, ammonia, cyanide, sulfide, cresols, phenols, total petroleum hydrocarbons (kerosene range), beta emitters (carbon-14 and selenium-79), alpha emitters (neptunium-237 and protactinium-231), and gamma emitters (cesium-137 and cobalt-60).

One well, 699-38-70, was sampled for the additional constituents of concern during FY 2006. Other than those constituents that are naturally present in groundwater (i.e.,

\section{The occurrence of nitrate above the drinking water standard deep in the unconfined aquifer does not appear to be widespread.}




\section{1,4-Dioxane was detected at $120 \mu \mathrm{g} / \mathrm{L}$ in well 299-W22-20 adjacent to the 216-S-20 crib. This constituent had previously been detected in FY 2002 and FY 2003.}

magnesium, manganese, and vanadium), no unqualified detections of an additional contaminant of concern occurred in this sampling. Tetrachloroethene was detected at $0.2 \mu \mathrm{g} / \mathrm{L}$, but this was qualified as an estimated value below the quantitation limit of the analytical method and is less than the drinking water standard $(5 \mu \mathrm{g} / \mathrm{L})$. Sampling of the additional constituents was planned for September in five of the six new wells installed within the operable unit, but this sampling was delayed until early FY 2007 (see Section 1.2).

In FY 2002 and FY 2003, 1,4-dioxane was detected in 299-W22-20 near the 216-S-20 crib at levels of 110 to $160 \mu \mathrm{g} / \mathrm{L}$. This constituent was not detected in subsequent samples collected between FY 2004 to early FY 2006. However, 1,4-dioxane was again found at $120 \mu \mathrm{g} / \mathrm{L}$ in a sample collected during August, 2006 (Figure 2.9-12). 1,4-Dioxane is typically used as a solvent stabilizer and tends to occur in association with chlorinated solvent plumes. A federal drinking water standard has not been established for this constituent.

\subsubsection{Interim Groundwater Remediation for Technetium-99 and Uranium}

Prior to startup of a rebound study on January 26, 2005, the pump-and-treat system at the 200-UP-1 Operable Unit operated as an interim remedial action to contain the high concentration portions of the technetium-99 and uranium plumes suspected to be emanating

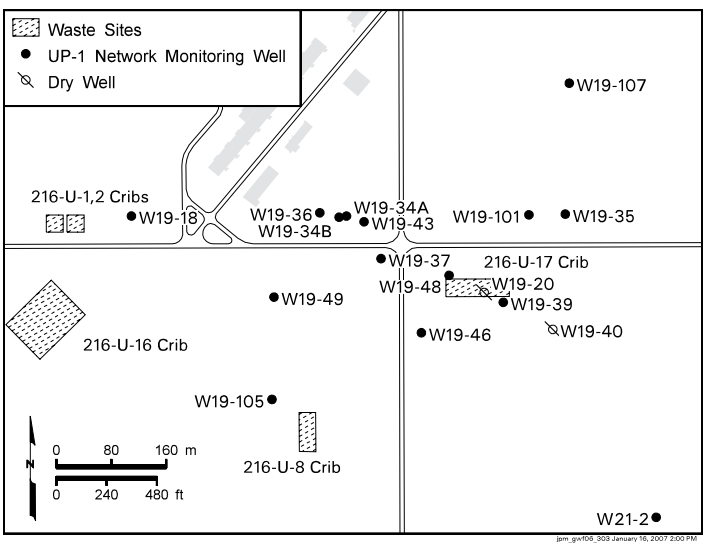
from the 216-U-1,2 cribs, and to reduce the concentrations in these plumes (ROD 1997). The rebound study commenced following 18 months of groundwater extraction with technetium-99 and uranium concentrations in groundwater below their remedial action goals. The extraction pumps were turned off and the rebound study was initiated with first weekly and then monthly groundwater sampling at 10 wells. Two new wells were drilled in late FY 2005 and were added to the monthly sampling in FY 2006. Another six wells were drilled around the greater 200-UP-1 Operable Unit in calendar year 2006, but only two were in the vicinity of the baseline plumes (wells 299-W19-105 and 299-W19-107). Since the start of the rebound study, the pump-and-treat system has remained on hot standby and can be restarted with minimal maintenance activities.

The rebound study concluded on January 25, 2006, following 1 year of monthly sampling, analysis, and trending of primary contaminants of concern uranium and technetium-99, as well as secondary contaminants of concern carbon tetrachloride and nitrate. Following the conclusion of the rebound study, a report was prepared summarizing the analytical data (WMP-30847). For the remainder of FY 2006, semi-annual groundwater monitoring around the baseline plume area continued at the same wells. For the past 3 years, contaminant levels have remained below the uranium and technetium-99 interim remedial action goals of $480 \mu \mathrm{g} / \mathrm{L}$ and 9,000 pCi/L, respectively. The remedial investigation and feasibility study process, proposed plan, and record of decision will determine if additional remedial actions are needed.

The second CERCLA five-year review was published in November 2006 (DOE/RL2006-20). One issue and associated action was identified for the 200-UP-1 Operable Unit:

- Issue 18: The remedial action objective for uranium was based on the Washington State Model Toxics Control Act cleanup standard of $48 \mu \mathrm{g} / \mathrm{L}$. Since this time, EPA has established a drinking water standard of $30 \mu \mathrm{g} / \mathrm{L}$. There are also some other issues to be addressed within the ROD, including the limited quarterly pumping requirement at well 299-W23-19, adjusting the pumping requirement for 200-UP-1 due to limited flow within the extraction well network, and technetium-99 groundwater contamination at other locations within the operable unit. 
- Action 18-1: Prepare an explanation of significant difference for 200-UP-1 interim ROD (due June 2008).

Ecology is currently preparing an explanation of significant difference that may revise the remedial action objective for uranium. After the explanation of significant difference is issued, a decision will be made on whether or not to restart the pump-and-treat system. Quarterly pumping at well 299-W23-19 is addressed in Section 2.9.3.2.

\subsubsection{Progress During FY 2006}

The rebound study was conducted to determine if the residual masses of contaminants remaining in the aquifer system were capable of recontaminating groundwater to levels above the remedial action goals $(9,000 \mathrm{pCi} / \mathrm{L}$ for technetium-99 and $480 \mu \mathrm{g} / \mathrm{L}$ for uranium) under unstressed regional groundwater flow. With sufficient residual mass, contaminants attached or sorbed to soil particles could go back into solution at higher concentrations than measured during pump-and-treat operations if a longer residence time from a reduced groundwater flow rate was available. The rate at which this would occur was qualitatively measured by regular sampling and trending of concentration changes. The data were reported in the rebound study letter report (WMP-30847) and demonstrated that the remedial

The remedial action objectives for the 200-UP-1 Operable Unit (ROD 1997) are:

- Reduce contamination in the areas with the highest concentration to below $480 \mu \mathrm{g} / \mathrm{L}$ for uranium and 9,000 pCi/L for technetium-99.

- Reduce potential adverse human health risks through reduction of contaminant mass.

- Prevent further movement of these contaminants from the highest contamination area.

- Provide information that will lead to the development and implementation of a final remedy that will protect human health and the environment. action goals for technetium-99 and uranium were not likely to be exceeded in the future.

Since the treatment system did not operate in FY 2006, additional groundwater was not extracted from the 200-UP-1 plume area and no contaminant mass was removed from the aquifer. Over 853 million liters have been treated since startup of remediation activities in FY 1994. A total of 118.8 grams of technetium-99, 211.8 kilograms of uranium, 34.6 kilograms of carbon tetrachloride, and 34,716 kilograms of nitrate have been removed from the aquifer.

Hydraulic head trends at several groundwater wells within the 200-UP-1 baseline plume area were used to determine the decline in groundwater elevations. The water table declined an average of 0.23 meter/year in FY 2006 within the baseline plume area. This rate is equal to that in FY 2005, but is significantly lower than that observed in FY 2004 and FY 2003 when the water level decline was 0.37 meter/year. The water level at well 299-W19-40 dropped below the bottom of the well screen after January 2006, so this well can no longer be sampled.

New wells 299-W19-49 and 299-W19-101 were drilled in August and September 2005 to help bound the northern and southwestern extent of the technetium-99 and uranium plumes. These wells were sampled in FY 2006 for both the rebound study and for quarterly monitoring following the conclusion of the rebound study. Of the six additional wells installed across the 200-UP-1 operable unit in support of the remedial investigation, two of them, 299-W19-105 and 299-W19-107, were drilled in the vicinity of the baseline plume area. Well 299-W19-105 is located near the northwest corner of the 216-U-8 crib, while well 299-W19-107 is located $\sim 150$ meters north of well 299-W19-35. The technetium-99 and uranium concentrations in both these wells are below their respective drinking water standards. For more detailed information about groundwater conditions during FY 2006, refer to the pump-and-treat annual report (DOE/RL-2006-73).

The rebound study

demonstrated

that sufficient

contaminant mass

was removed from

the aquifer such

that technetium-99

and uranium

concentrations

remained below

the remedial

action objectives

throughout the

fiscal year. 


\section{Based on current trends, technetium-99 and uranium concentrations are not expected to exceed their remedial action goals within the next fiscal year.}

\subsubsection{Influence on Aquifer Conditions}

Figures 2.9-13 and 2.9-14 show the technetium-99 and uranium plumes for the upper unconfined aquifer at the pump-and-treat area, based on average concentrations for the fiscal year. Maps depicting the baseline technetium-99 and uranium plumes in 1995 and the current plumes in FY 2006 are presented in the summary of this report.

The results of the rebound study and semi-annual groundwater sampling indicate that enough technetium-99 and uranium was removed from the aquifer such that concentrations of both constituents remained below their respective remedial action goals at all wells for FY 2006. Technetium-99 concentrations did not exceed 3,000 pCi/L at any of the wells in FY 2006 and were below the $900-\mathrm{pCi} / \mathrm{L}$ drinking water standard at 9 of the 12 wells around the baseline plume area. In general, all technetium-99 trends were stable or declining. A slowly rising trend at well 299-W19-43 peaked at 2,970 pCi/L in December 2005, but then declined for most of FY 2006 (Figure 2.9-15). In addition, contaminant concentrations tended to decrease with distance from the source area. The highest technetium-99 concentrations were reported at the two wells closest to the presumed source (216-U-1,2 cribs), 216-W19-36 and 299-W19-43, which averaged 2,090 and 2,550 pCi/L, respectively, during FY 2006. Well 299-W19-35 is an exception to this trend, with stable concentrations averaging $1,280 \mathrm{pCi} / \mathrm{L}$ for FY 2006, which is higher than many other wells closer to the source.

Uranium trends were generally stable, declining, or slightly increasing for all but one well. Concentrations ranged from $<1$ to $442 \mu \mathrm{g} / \mathrm{L}$, but only three of the twelve wells were consistently below the 48- $\mu \mathrm{g} / \mathrm{L}$ Model Toxics Control Act (WAC 173-340) standard on which the remedial action goal was based. Uranium concentrations remain above the $30-\mu \mathrm{g} / \mathrm{L}$ drinking water standard at all 10 wells in the network that are screened across the water table. Wells 299-W19-46, 299-W19-48, and 299-W19-101 exhibited minor increases in uranium concentrations. Only well 299-W19-37, located near former injection well 299-W19-36, showed a significant increase in uranium. Concentrations in this well reached $306 \mu \mathrm{g} / \mathrm{L}$ in August 2006, a 50\% increase over the February result of $206 \mu \mathrm{g} / \mathrm{L}$ (Figure 2.9-16). As with technetium-99 trends, uranium concentration levels at most wells decline with distance from the presumed source area. Based on current data, none of the wells are expected to exceed the remedial action goal concentration within the next fiscal year.

The secondary contaminants of concern, carbon tetrachloride and nitrate, presented a broader response to cessation of pump-and-treat operations. Carbon tetrachloride concentrations exceeded the $5-\mu \mathrm{g} / \mathrm{L}$ drinking water standard at all wells in the baseline plume area with most values between 50 and $200 \mu \mathrm{g} / \mathrm{L}$. This is still far below the 200-ZP-1 pump-and-treat remedial action goal of 2,000 to 3,000 $\mu \mathrm{g} / \mathrm{L}$. The source waste sites for this plume are around the Plutonium Finishing Plant. The correlation of concentration trends with proximity to the source area is not valid for carbon tetrachloride. The highest concentrations were observed at well $699-38-70 \mathrm{~B}$ farthest from the source, where values from 310 to $610 \mu \mathrm{g} / \mathrm{L}$ were encountered. This well is screened at a depth of $\sim 35$ to $\sim 40$ meters below the water table.

Nitrate concentrations were above the drinking water standard of $45 \mathrm{mg} / \mathrm{L}$ in 7 of 12 wells, two of which yielded nitrate concentrations consistently above $200 \mathrm{mg} / \mathrm{L}$. The nitrate concentration at well 299-W19-43, located just downgradient of former injection well 299-W19-36, has remained at well over $1,400 \mathrm{mg} / \mathrm{L}$ in FY 2006. This approaches the $1,930 \mathrm{mg} / \mathrm{L}$ concentration encountered when the well was first sampled for anions in January 2003, but which quickly declined when the well became an extraction well later in the same year (Figure 2.9-17). The other well, 299-W19-37, has shown a steady increase since the first rebound study sample taken in FY 2006, and has increased by almost an order of magnitude, to $536 \mathrm{mg} / \mathrm{L}$, since October 2005 (Figure 2.9-17). The presumed source for the nitrate is the $216-\mathrm{U}-1,2$ cribs, although there may be a local source in the vicinity of the pump-and-treat area. As for carbon tetrachloride, no apparent relationship of nitrate concentrations with proximity to the source area exists. 
Theoretically, the cessation of pumping could result in the migration of high concentration portions of the technetium-99 and uranium plumes (i.e., concentrations above the remedial action objectives) to regions beyond the capture zone of the extraction wells. This could result in loss of the ability to re-establish hydraulic control over these plumes by the resumption of extraction well pumping. However, contaminant trends at downgradient wells are not increasing, indicating no loss of control for the two contaminants at this time.

\subsubsection{Facility Monitoring}

This section describes results of monitoring individual facilities such as treatment, storage, and disposal units, including tank farms. Some of these facilities are monitored under the requirements of RCRA for hazardous waste constituents and the AEA for source, special nuclear and by-product materials. Data from facility-specific monitoring are also integrated into the CERCLA groundwater investigations. Hazardous constituents and radionuclides are discussed jointly in this section to provide comprehensive interpretations of groundwater contamination for each facility. As discussed in Section 1.2 pursuant to RCRA, the source, special nuclear, and by-product material component of radioactive mixed waste are not regulated under RCRA and are regulated by DOE acting pursuant to its AEA authority.

Detailed groundwater monitoring is conducted at five facilities within the 200-UP-1 Operable Unit. Four of these sites are monitored in accordance with RCRA regulations. Assessment monitoring is conducted at Waste Management Areas U and S-SX and the 216-U-12 crib, and detection monitoring is conducted at the 216-S-10 pond and ditch. Groundwater monitoring at the Environmental Restoration Disposal Facility is conducted in accordance with a CERCLA record of decision (ROD 1995b). Groundwater data for these facilities are available from the Hanford Environmental Information System (HEIS 1994) and the data files accompanying this report.

\subsubsection{Single-Shell Tank Waste Management Area U}

The objective of RCRA monitoring at this waste management area is to assess the nature and extent of groundwater contamination with hazardous constituents and determine their rate of movement in the aquifer (40 CFR 265.93(d) and WAC 173-303-400). Groundwater monitoring under the AEA tracks radionuclides in the waste management area and surrounding vicinity. Appendix B includes a well location map and lists of wells and constituents monitored for Waste Management Area U.

Waste Management Area U was placed into assessment status in 2000 when specific conductance in groundwater monitoring wells downgradient of the waste management area exceeded upgradient levels (PNNL-13185). An assessment of that finding determined that the waste management area had affected groundwater quality as evidenced by elevated concentrations of nitrate and possibly chromium in wells downgradient of the waste management area (PNNL-13282). Contaminant concentrations did not exceed their respective drinking water standards, and the area affected appeared to be limited to the southeast corner of the waste management area. Groundwater quality is assessed at Waste Management Area U according to PNNL-13612. The monitoring network includes nine wells sampled quarterly - two upgradient and seven downgradient of the waste management area. All wells were sampled successfully in FY 2006. The monitoring network is adequate to assess the impact of the waste management area on groundwater quality beneath the site.

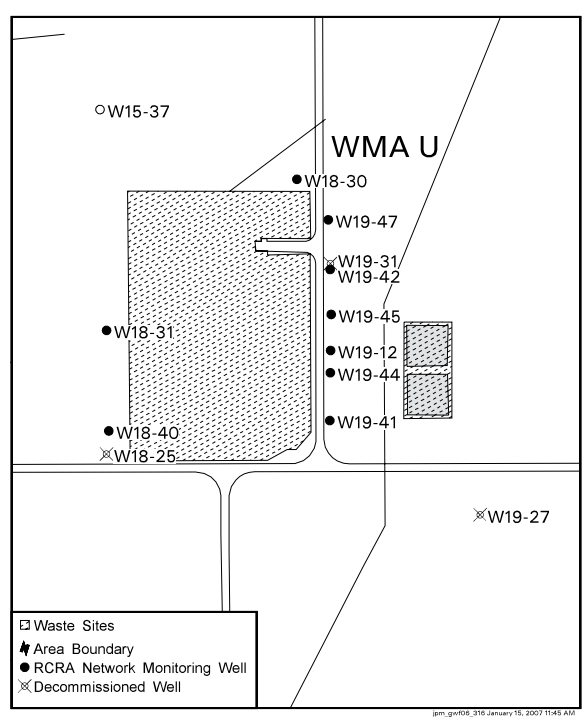

Groundwater Flow. Groundwater flow conditions at Waste Management Area U have varied greatly over the past several decades because of changing wastewater disposal in areas surrounding the waste management area, but groundwater flow has been generally to 
The contaminant plume at Waste

Management

Area $U$ includes two

major constituents:

nitrate and

technetium-99. the east since 1996. During FY 2006, the direction and velocity of groundwater flow have remained the same as in the previous year. The rate at which the water table is dropping has also remained constant at 0.3 meter/year in all of the monitoring wells during FY 2006. Therefore, the hydraulic gradient has not changed. The average linear velocity based on a hydraulic conductivity of 6.12 meters/day, a specific yield of 0.17 determined in well 299-W19-42 (PNNL-13378), and a gradient of 0.0021 is calculated to be $\sim 0.08$ meter/day or 28 meters/year (see Appendix B).

Groundwater Contamination. Groundwater chemistry beneath Waste Management Area U in FY 2006 remained similar to that presented in FY 2005 for wells downgradient of the waste management area. The waste management area has been identified as the source for a small contaminant plume that is limited to the downgradient (east) side of the site (PNNL-13282). Plume constituents of interest originally included chromium, nitrate, and technetium-99, but chromium concentrations decreased in the past to near the analytical detection limit where they remained in FY 2006.

Currently, the Waste Management Area U contaminant plume includes two major constituents: nitrate and technetium-99. During FY 2006, measured technetium-99 concentrations continued to exceed the drinking water standard $(900 \mathrm{pCi} / \mathrm{L})$ in wells 299-W19-45 ( 1,200 pCi/L) and 299-W19-47 ( 1,300 pCi/L). Nitrate and technetium-99 appear to have different sources because they have different distributions within the plume. These constituents are both mobile in groundwater and would be expected to travel together if they were from the same source. Nitrate concentrations are highest in the south half of the plume and technetium-99 concentrations are highest in the north half of the plume (Figure 2.9-18).

Nitrate concentrations continued to increase in all but one monitoring well at Waste Management Area U, including the two upgradient wells. Nitrate concentrations were above the drinking water standard (45 mg/L) in two downgradient wells, 299-W19-41 and 299-W19-44, at maximum concentrations of $\sim 70$ and $\sim 110 \mathrm{mg} / \mathrm{L}$, respectively. These are the only wells with nitrate concentrations above the drinking water standard at the waste management area.

Carbon tetrachloride is found in groundwater beneath Waste Management Area U at concentrations above its drinking water standard of $5 \mu \mathrm{g} / \mathrm{L}$. Well 299-W18-30 is the only well analyzed for carbon tetrachloride, and it contained levels of $165 \mu \mathrm{g} / \mathrm{L}$ in August 2006, a factor of two decrease from FY 2005. The regional carbon tetrachloride distribution (see Figure 2.8-3 in Section 2.8) indicates that the carbon tetrachloride found in the Waste Management Area U vicinity originates from liquid waste disposal sites at the Plutonium Finishing Plant located northwest of the waste management area.

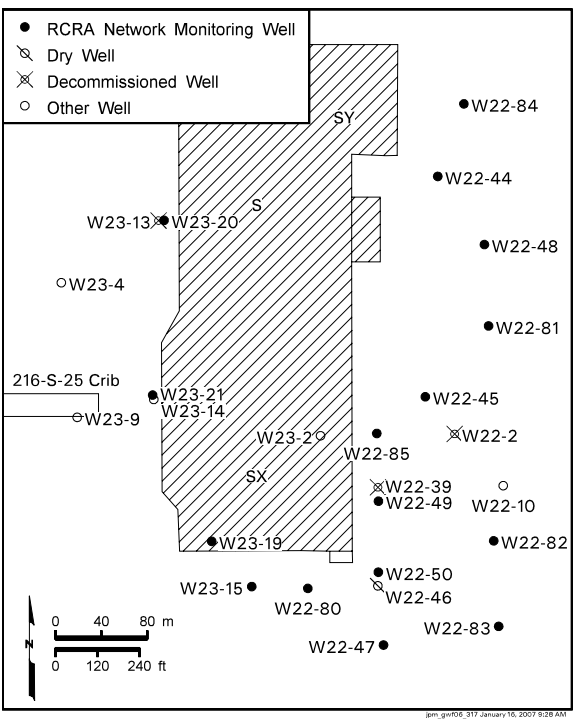

\subsubsection{Single-Shell Tank Waste Management Area S-SX}

The objective of RCRA monitoring at this waste management area is to assess the nature and extent of groundwater contamination with hazardous constituents and determine their rate of movement in the aquifer. Groundwater monitoring under the AEA tracks radionuclides in the waste management area and surrounding vicinity. Appendix B includes a well location map and lists of wells and constituents monitored for Waste Management Area S-SX.

Waste Management Area S-SX was placed into assessment status (40 CFR 265.93(d) and WAC 173-303-400) in 1996 at the direction of Ecology because of elevated specific conductance and technetium-99 (not regulated by RCRA) in downgradient monitoring wells. An assessment of the waste management area determined (first determination) that multiple sources within the waste management area had affected groundwater quality with elevated concentrations of nitrate, technetium-99, and chromium in wells downgradient of the waste management area (PNNL-11810). Groundwater is monitored according to PNNL-12114. This 
plan was revised in early FY 2007 to add three new monitoring wells drilled as part of the 200-UP-1 Operable Unit remedial investigation.

At the end of the fiscal year, the monitoring network consisted of 19 wells: 2 upgradient and 16 downgradient of the waste management area, and 1 well located within the area. During FY 2006, three new wells, 299-W22-69, 299-W22-72, and 299-W22-86, were informally added to the network (formalized in early FY 2007 with PNNL-12114-ICN-4). All the wells in the network are scheduled for quarterly sampling, and all (except the new wells) were sampled as scheduled for the first three quarters of FY 2006. Only one well was sampled as scheduled in the fourth quarter (September). Several samples scheduled for the fourth quarter were collected in October ( 15 wells), November (two wells), and two wells (299-W22-84 and 299-W23-21) were missed (see Section 1.2). Construction of the three new wells was finished in March, and these wells were sampled as completed wells for the first time in June 2006. Depth-discrete samples were collected from these wells during drilling, and the results indicated that groundwater plumes were present near the water table at two of the three locations (wells 299-W22-69 and 299-W22-86), as shown in Figure 2.95. Over the past several years, the leading fronts of contaminant plumes emanating from the waste management area (as indicated by concentrations above background levels) had migrated beyond the farthest downgradient monitoring wells in the network. With the addition of the three new distant downgradient wells, these plumes have been interpreted to extend farther eastward.

Groundwater Flow. During FY 2006, the direction and rate of groundwater flow remained the same as in the previous year, despite the falling water-table elevation. The rate at which the water table is declining remained the same as last year, at $\sim 0.3$ meter/ year based on water-level measurements in the monitoring wells. This decline was the same in all wells across the waste management area; therefore, the hydraulic gradient has remained stable. Estimates of groundwater flow velocity, using travel times for tritium and technetium-99 between monitoring wells in the vicinity of Waste Management Area S-SX, suggest groundwater flow rates of 0.07 to 0.14 meter/day, or 25 to 50 meters/year. Calculated average linear velocities (using Darcy's method) based on hydraulic conductivity and tracer test data, also suggest similar flow rates (0.009 to 0.36 meter/day or 3 to 130 meters/year; see Appendix B). The groundwater flow direction inferred from water-table elevation contours suggests an east-southeast flow direction over the larger area around the waste management area (see Figure 2.8-2 in Section 2.8). This direction of flow is consistent with the observed contaminant plume migration.

Groundwater Contamination. Groundwater beneath this waste management area is contaminated with nitrate, chromium, and technetium-99 attributed to two general source areas within the waste management area. One source area is in the S Tank Farm and the other is located to the south in the SX Tank Farm. Nitrate also has other sources in the vicinity, most notably the $216-S-25$ crib. The nitrate, chromium, and technetium-99 plumes are depicted in Figures 2.9-19, 2.9-20, and 2.9-21, which show average concentrations for the fiscal year. Carbon tetrachloride (see Figure 2.8-3 in Section 2.8) is also present in groundwater beneath the waste management area, but its source is upgradient of the waste management area (PNNL-13441). Tritium is also present beneath the waste management area as seen in Figure 2.9-8, but its source is the 216-S-25 crib located just west (upgradient) of the SX Tank Farm (PNNL-13441).

The northern plume has migrated eastward from the S Tank Farm. Maximum nitrate concentrations are just above the drinking water standard $(45 \mathrm{mg} / \mathrm{L})$, which was similar to that observed in FY 2005. Technetium 99 concentrations generally remained about the same or decreased during FY 2006, with the highest concentrations about twice the 900-pCi/L drinking water standard. The maximum chromium concentration in the plume decreased to $\sim 12 \mu \mathrm{g} / \mathrm{L}$.

\section{Sources within \\ Waste Management \\ Area S-SX have \\ contaminated \\ groundwater with \\ nitrate, chromium, \\ and technetium-99.}

Decreases of chromium and technetium-99 concentrations in well 299-W23-19 at Waste Management Area S-SX indicate that a pulse of contamination

that entered the

aquifer in FY 2005

has migrated downgradient. 


\section{In 2003, DOE and}

Ecology agreed

extended purging

during sampling at

well 299-W23-19

to remove

technetium-99 from

the groundwater.

This practice

continued during

FY 2006. to the practice of

The contaminant plume from the SX Tank Farm in the south portion of the waste management area includes nitrate, chromium, and technetium-99. The extent of the SX Tank Farm plume is now interpreted to be farther east based on sample results from new well 299. W22-86. This well is screened across the water table, and technetium-99 was found at 1,950 $\mathrm{pCi} / \mathrm{L}$ in the sample collected during June 2006. Nitrate and chromium were elevated in this well, but below their respective drinking water standards. In the source area as represented by well 299-W23-19, concentrations of all three plume constituents decreased greatly, by about a factor of three. In this well, filtered total chromium concentrations decreased from $1,750 \mu \mathrm{g} / \mathrm{L}$ in December 2005 to $\sim 600 \mu \mathrm{g} / \mathrm{L}$ in June 2006, and then increased slightly to $~ 700$ $\mu \mathrm{g} / \mathrm{L}$ in September, seven times the drinking water standard of $100 \mu \mathrm{g} / \mathrm{L}$ (Figure 2.9-3). In addition, technetium- 99 and nitrate concentrations decreased by a factor of $\sim 3$, returning to concentrations observed in FY 2004. These data suggest that the pulse of contamination that entered the aquifer in FY 2005 has migrated downgradient.

Constituent concentrations in the middle of the south plume, represented by well 299-W22-50, and further downgradient represented by well 299-W22-83, continued on the same trends as reported in FY 2005. In the middle of the plume, constituent concentrations reached a peak in FY 2003 and have continued to decrease or remain stable throughout FY 2006 (Figure 2.9-22).

Groundwater Treatment. To remove technetium-99 from the groundwater, the practice of extended purging while sampling at well 299-W23-19 was continued during FY 2006. This practice was agreed to by DOE and Ecology and was begun in 2003. After samples are collected from this well each quarter, purging of the well is continued at a higher flow rate until a minimum of 3,785 liters of water is removed from the aquifer. This water is transferred to the Effluent Treatment Facility for treatment and disposal. Table 2.9-1 presents the date, amount of water collected, and a calculation of the mass and activity of technetium-99 removed from the aquifer. A total of $\sim 0.00115$ curie ( $\sim 0.072 \mathrm{gram})$ of technetium- 99 was recovered during FY 2006. Since the start of this treatment in 2003, a total of $\sim 0.0046$ curie ( 0.27 gram) of technetium-99 has been recovered.

\subsubsection{216-S-10 Pond and Ditch}

The 216-S-10 pond and ditch was active from 1951 through 1991 and

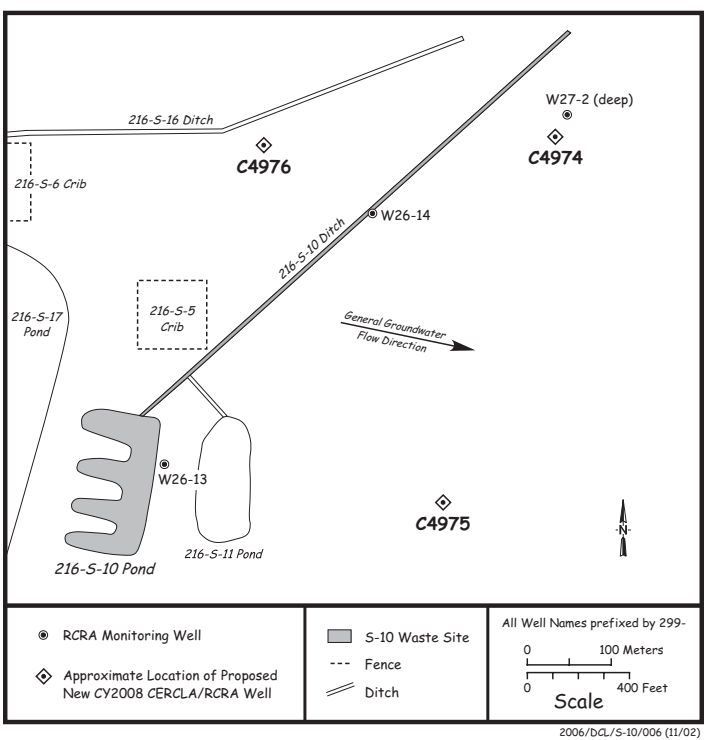
received effluent primarily from the REDOX Plant chemical sewer. The site is monitored semiannually under RCRA interim status indicator parameter monitoring (40 CFR 265.93(b) and WAC 173-303-400) to detect any effect on groundwater from past facility operations. Groundwater monitoring under the AEA tracks radionuclides in the waste management area and surrounding vicinity. Appendix B includes a well location map and lists of wells and constituents monitored for the 216-S-10 pond and ditch.

RCRA groundwater monitoring has been conducted under interim status requirements since 1991 . The $216-\mathrm{S}-10$ pond and ditch unit has not received liquid waste since October 1991. The treatment, storage, and disposal unit will be closed under RCRA and the Washington State Hazardous Waste Management Act (RCW 70.105). The RCRA closure plan for the 216-S-10 pond and ditch is being coordinated with the CERCLA 200-CS-1 source operable unit in accordance with Tri-Party Agreement Milestone M-15-39C. The proposed 216-S-10 pond and ditch groundwater closure approach will be post-closure monitoring under a final status detection monitoring program.

The current RCRA monitoring network consists of two downgradient wells (the others having gone dry): well 299-W26-13 located near the pond and well 299-W26-14 located just east of the central portion of the ditch. Upgradient well 299-W26-7 went dry in 2003. The network also includes one deep downgradient well, 
299-W27-2, which is screened at the bottom of the uppermost unconfined aquifer. RCRA requirements for interim status monitoring specify that a minimum of one upgradient and three downgradient monitoring wells are needed to monitor the site. All new RCRA wells installed at Hanford are negotiated annually by Ecology, DOE, and the U.S. Environmental Protection Agency (EPA) and approved under the Tri-Party Agreement (Ecology et al. 1989) Milestone M-24-00. One new upgradient well and two downgradient wells are currently planned under the Tri-Party Agreement Milestone M-24-57 to be installed in FY 2008. During FY 2006, all wells were sampled as scheduled.

Groundwater Flow. Groundwater flow conditions beneath the 216-S-10 pond and ditch have varied greatly over the past several decades because of changing wastewater disposal in areas surrounding the site, but groundwater flow has been generally to the east-southeast for the last several years. During FY 2006, the direction and velocity of groundwater flow have remained the same as in the previous year. The rate at which the water table is dropping has also remained constant at $\sim 0.3$ meter/year in all of the monitoring wells during FY 2006. Therefore, the hydraulic gradient has not changed. The average linear velocity has remained essentially the same as in FY 2005 and ranges from 0.08 to 2.25 meters/day or 29 to 820 meters/year (see Appendix B).

Groundwater Sampling. The comparison of RCRA indicator parameters (specific conductance, $\mathrm{pH}$, total organic carbon, and total organic halides) between upgradient and downgradient wells was conducted using the most recent collected background values of contaminant indicator parameters from well 299-W26-7 before it went dry in 2003 (see Appendix B). One new upgradient and two downgradient wells have been approved for installation surrounding the 216-S-10 pond and ditch in 2008 per Tri-Party Agreement Milestone M-24-57. When data from the new upgradient well become available, new background values will be calculated and used for the required upgradient/downgradient comparisons. Based on statistical evaluations of contamination indicator parameters conducted during FY 2006, there were no statistically significant differences (i.e., constituents in the downgradient wells were not elevated compared to the upgradient well). Therefore, this site remains in detection monitoring.

There are several constituents detected in wells near the 216-S-10 pond and ditch that are being tracked by the monitoring network. Chromium is being tracked because it was elevated above the drinking water standard for several years in well 299-W26-7, which is now dry. Also, elevated concentrations of nickel and carbon tetrachloride have been detected again this year in the deep monitoring well 299-W27-2. Because there have been no detections of nickel in the shallow monitoring wells, the 216-S-10 pond and ditch is not believed to be the source of this constituent. Carbon tetrachloride concentrations in well 299-W27-2 have averaged above the drinking water standard $(5 \mu \mathrm{g} / \mathrm{L})$ since 2001 . The source is believed to be liquid waste disposal sites at the Plutonium Finishing Plant.

Elevated chromium concentrations at well 299-W26-7 (now dry) had exceeded the drinking water standard $(100 \mu \mathrm{g} / \mathrm{L})$ during the past 10 -year life of the well. This may have been caused by short-term releases migrating through the vadose zone from past effluent releases to the pond or from upgradient sources. Historical records document a 1983 release to the 216-S-10 ditch of a high-salt waste (simulated tank waste) containing hexavalent chromium. Although well 299-W26-7 was designated as an upgradient well, it is located very close to one lobe of the pond system and may have been affected by drainage spreading laterally in the vadose zone or by a mound on the water table when the facility was in operation (see Appendix B). A REDOX Plant disposal pond, which is located immediately upgradient of the 216-S-10 pond and ditch, is also a potential source of the chromium contamination. Chromium is a hazardous waste constituent for the treatment, storage, and disposal unit, and the 216-S-10 pond and ditch cannot currently be ruled out as the source of the contamination.
All but three of the monitoring wells for the 216-S-10 pond and ditch have gone dry. New wells are planned for installation in FY 2008.

No exceedances

of an indicator parameter were found during FY 2006, so the 216-S-10 pond and ditch remains in detection monitoring. 
Nitrate concentrations were co-variate with chromium concentrations in wells 299-W26-7, 299-W26-9, 299-W26-10, and 299-W26-12, which are now dry. The upgradient well 299-W26-7 had the highest nitrate concentrations. These and other data presented in PNNL-14070 suggest that the 216-S-10 pond could be the source of this nitrate and chromium increase. Although chromium and nitrate were elevated in the dry upgradient well 299-W26-7, significant concentrations of these constituents have not been detected in the downgradient wells. But, well 299-W26-13 which is located downgradient of the pond and replaced well 299-W26-9, shows increasing levels of chromium (from 5 up to $15 \mu \mathrm{g} / \mathrm{L}$ ), but not yet near the drinking water standard. By comparison chromium in the other down gradient well 299-W26-14, located away from the pond and centered along the ditch portion of the facility, remains essentially undetected. This difference could suggest that a localized source is present near the pond.

\subsubsection{216-U-12 Crib}

The 216-U-12 crib is located $\sim 600$ meters south of U Plant in the southeast portion of the 200 West Area. The crib is an unlined, gravel-bottom, percolation crib 3 meters by

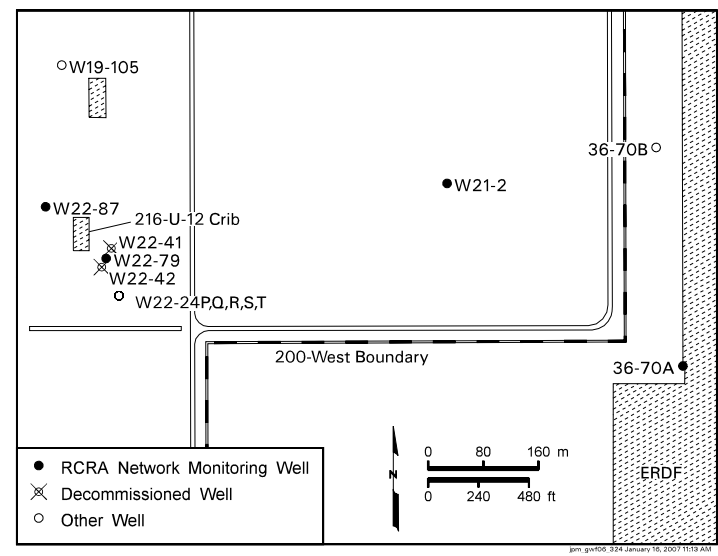

30 meters, and 4.6 meters deep. The crib received process effluent from U Plant, including corrosive liquid condensate from the 224-U Building, and operated from 1960 through 1972 and again from 1981 until it was permanently retired in February 1988. A yearly average of over 10.2 million liters/year of effluent was disposed to the crib from 1960 through 1972 (RHO-CD-673). Total volume disposed to the 216-U-12 crib exceeded 133 million liters from 1960 through 1972.

The current objective of RCRA monitoring at the 216-U-12 crib is to assess the nature and extent of groundwater contaminated with hazardous constituents and determine their rate of movement in the aquifer. The site is in assessment for elevated specific conductance, and nitrate and is sampled quarterly. Groundwater monitoring under the AEA tracks radionuclides at this crib and surrounding vicinity. Appendix B includes a well location map and lists the wells and constituents monitored for the 216-U-12 crib.

During FY 2006, the 216-U-12 crib was regulated under a RCRA interim status assessment program (40 CFR 265.93(d) and WAC 173-303-400). During FY 2006, the groundwater monitoring network was revised (PNNL-14301-Rev2-ICN-1) by replacing the non-RCRA compliant upgradient well (299-W22-26) with a new RCRA compliant upgradient well (299-W22-87) located much nearer to the 216-U-12 crib. The network includes one upgradient and three downgradient wells sampled quarterly (see Appendix B). The new upgradient well was first sampled during June 2006. During FY 2006, sampling of three wells was delayed until early FY 2007 (see Section 1.2).

The objective of interim status assessment monitoring is to assess the migration of hazardous waste constituents out of the vadose zone into groundwater and to support the delineation of the existing known plumes that, through RCRA/CERCLA integration, is being managed under the CERCLA and AEA 200-UP-1 Operable Unit monitoring program. The existing 216-U-12 crib plumes co-mingle with plumes from other U Plant and REDOX Plant source areas, making it difficult to distinguish the areal extent of specific plumes emanating from the crib.

Groundwater Flow. Based on the water-level elevations in the surrounding wells, the direction of groundwater flow beneath the 216-U-12 crib continued relatively unchanged toward the east-southeast to east (see Figure 2.8-2 in Section 2.8). The pre-Hanford flow direction in the vicinity of the $216-\mathrm{U}-12$ crib is believed to have been from west to east, and it is expected that groundwater flow will eventually return to a more eastward direction. The water-table elevation continued to decline around the 216-U-12 crib and vicinity. Annual 
water-level declines in the monitoring wells ranged between $\sim 0.18$ to 0.33 meter. Average linear groundwater flow velocities remained essentially the same as last year, ranging from $\sim 0.03$ to $\sim 0.05$ meter/day or 11 to 18 meters/year (see Appendix B). The hydraulic gradient was calculated between new well 299-W22-87 and existing well 299-W22-79.

Groundwater Contamination. During FY 2006, the key indicator parameter, specific conductance, continued to decline in the near field downgradient monitoring well 299-W22-79, and in the far field downgradient wells 299-W21-2 and 699-36-70A. Specific conductance is below the former critical mean $(457.8 \mu \mathrm{S} / \mathrm{cm})$ and declining in well 299-W22-79, and it declined below the former critical mean during June in well 699-36-70A. Specific conductance remains above the former critical mean in 299-W21-2. Specific conductance in the new upgradient well (299-W22-87) was reported at $218 \mu \mathrm{S} / \mathrm{cm}$ for the June sampling event. The data from these wells, including past results from the dry network wells, indicate that the bulk of the mobile residual vadose contamination (i.e., nitrate and technetium-99) beneath the 216-U-12 crib has moved into the groundwater and has migrated beyond the near field point-of-compliance well (299-W22-79).

The regional nitrate and technetium-99 plumes are a co-mingled series of smaller plumes with sources from several cribs (216-U-1,2; 216-U-8; and 216-U-12) in the U Plant area. During FY 2006, nitrate concentrations increased slightly in well 299-W22-79 (from 24 to $29 \mathrm{mg} / \mathrm{L}$ ); however, since 2002 , the overall trend has been downward at this well. Nitrate concentrations declined in far-field wells 699-36-70A and 299-W21-2, although concentrations remain above the drinking water standard. Nitrate in the upgradient well (299-W22-87) was $\sim 2 \mathrm{mg} / \mathrm{L}$. The co-contaminant, technetium-99 (which is not regulated under RCRA), continued to be detected in all downgradient network wells but at levels well below the drinking water standard of $900 \mathrm{pCi} / \mathrm{L}$. The highest value reported for FY 2006 was 162 pCi/L in well 299-W21-2. Technetium-99 was found at only $13 \mathrm{pCi} / \mathrm{L}$ in upgradient well 299-W22-87. All other constituents remained on trend or near background throughout the year.

\subsubsection{Environmental Restoration Disposal Facility}

The Environmental Restoration Disposal Facility is a low-level radioactive mixed waste facility where waste from surface remedial actions on the Hanford Site is disposed. The site was designed to meet RCRA standards, although it was not permitted as a RCRA facility. Groundwater monitoring is conducted in accordance with a CERCLA record of decision (ROD 1995b). The groundwater flow direction beneath the site is toward the east-northeast. One upgradient well (699-36-70A) and three downgradient wells (699-37-68, 699-36-67, and 699-35-66A) are sampled semiannually, typically in March and September. All four wells were sampled as planned during FY 2006. Appendix B contains additional information regarding the Environmental Restoration Disposal Facility. For a discussion of leachate monitoring at this facility, see Section 3.1 and see WCH-88 for calendar year 2005 groundwater and leachate monitoring results. Calendar year 2006 results will be described in an upcoming report. See BHI-00873 for the groundwater sampling and analysis plan.

Groundwater Sampling. Results of groundwater monitoring at the Environmental Restoration Disposal Facility continued to indicate that the facility has not adversely impacted groundwater quality. Several constituents (tritium, iodine-129, nitrate, and carbon tetrachloride) are present in the groundwater at or above drinking water standards, but these constituents are elevated in both the upgradient and downgradient wells. Figures 2.9-8, 2.9-9, and 2.9-10 in this section, and Figure 2.8-3 in Section 2.8 indicate that these plumes originated in the 200 West Area and have migrated into the vicinity of the Environmental Restoration Disposal Facility.
The 216-U-12 crib monitoring well network was revised during FY 2006 and includes one new upgradient well and three downgradient wells.

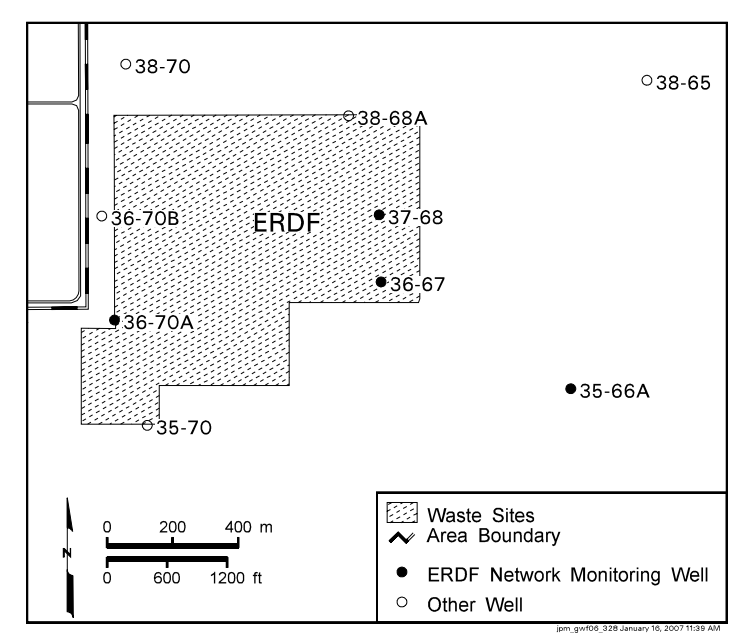


Results of groundwater monitoring at the

Environmental

Restoration

Disposal Facility continued to

indicate that the

facility has not

adversely impacted

groundwater

quality.
Both filtered and unfiltered samples are collected for metals (except for uranium samples, which are unfiltered). No sampling results were noted significantly out of trend during FY 2006. Overall, uranium appears to be continuing to trend downward but to a lesser degree than previous years. Both technetium-99 and gross beta appear to be continuing to trend upward in two downgradient wells (699-37-68 and 699-35-66A) and downward in the upgradient well (699-36-70A). The gross beta and technetium-99 increases appear less than in the previous years. Nitrate levels appear to be decreasing except for well 699-35-66A which is stable at a very low level. These trends will continue to be monitored. Overall, the FY 2006 results appear stable. High turbidity (suspended solids), a common source for variability in the analytical results, was not seen in the FY 2006 sampling. 
Table 2.9-1. Quantity of Treated Groundwater and Technetium-99 Mass Removed from the Aquifer during Extended Purging at Well 299-W23-19, FY 2006

\begin{tabular}{|l|c|c|c|c|}
\hline \multicolumn{1}{|c|}{ Sample Date } & $\begin{array}{c}\text { Volume of Water Treated } \\
\text { Liters }(\mathrm{gal})\end{array}$ & $\begin{array}{c}\text { Technetium-99 } \\
\text { Concentration } \\
(\mathrm{pCi} / \mathrm{L})\end{array}$ & $\begin{array}{c}\text { Activity of Technetium-99 } \\
\text { Removed }(\mathrm{Ci})\end{array}$ & $\begin{array}{c}\text { Mass of } \\
\text { Technetium-99 } \\
\text { Removed }(\mathrm{g})\end{array}$ \\
\hline December 21, 2005 & $5,223(1,380)$ & 89,900 & 0.00047 & 0.028 \\
\hline March 29, 2006 & $6,283(1,660)$ & 47,100 & 0.00030 & 0.018 \\
\hline June 21, 2006 & $4,739(1,252)$ & 42,900 & 0.00020 & 0.012 \\
\hline September 27, 2006 & $5,450(1,440)$ & 43,200 & 0.00023 & 0.014 \\
\hline Totals & $\mathbf{2 1 , 6 9 5 ( 5 , 7 3 2 )}$ & NA & $\mathbf{0 . 0 0 1 1 5}$ & $\mathbf{0 . 0 7 2}$ \\
\hline NA = Not applicable. & & & \\
\hline
\end{tabular}




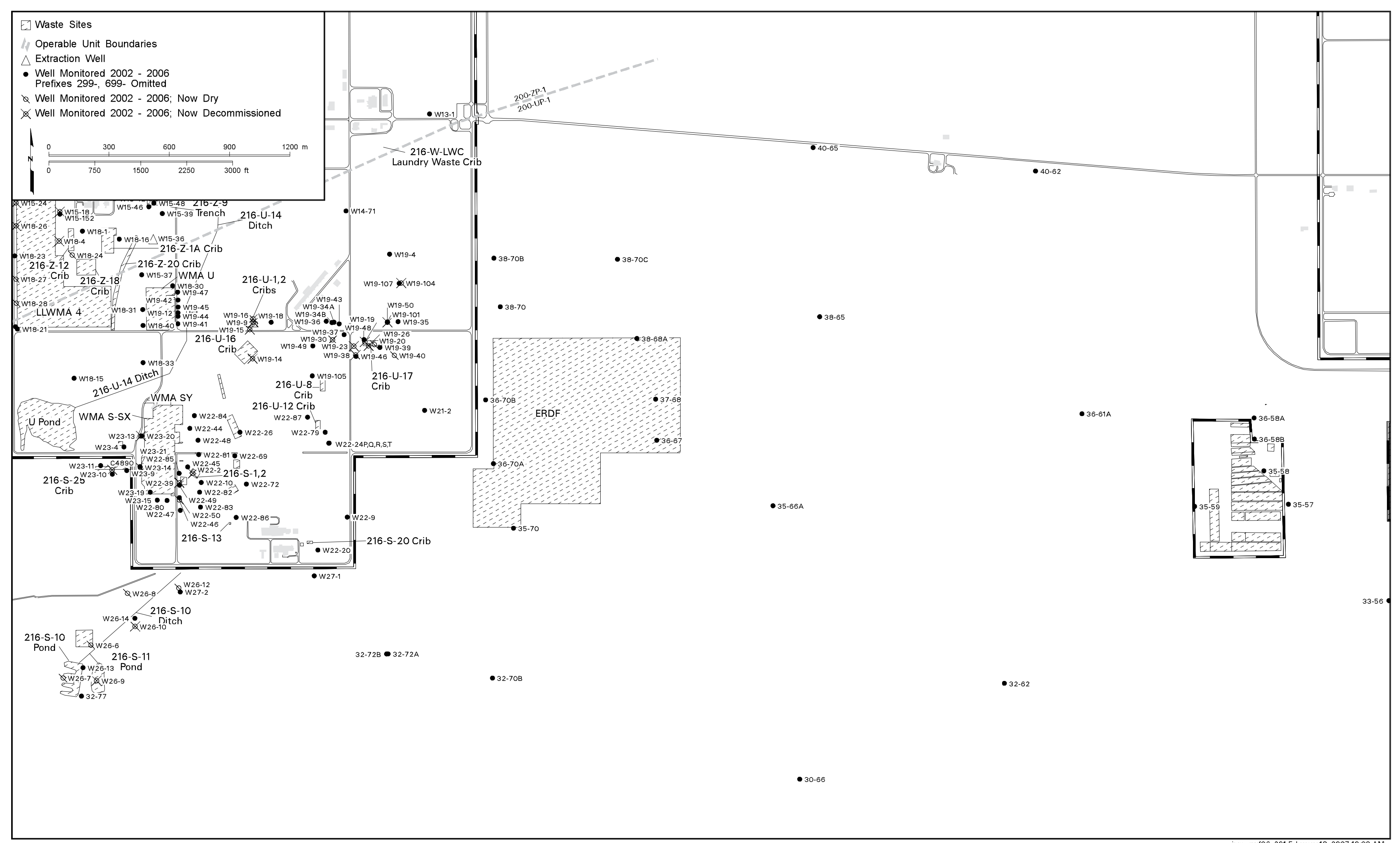

Figure 2.9-1. Facilities and Groundwater Monitoring Wells in 200-UP-1 Groundwater Interest Area 


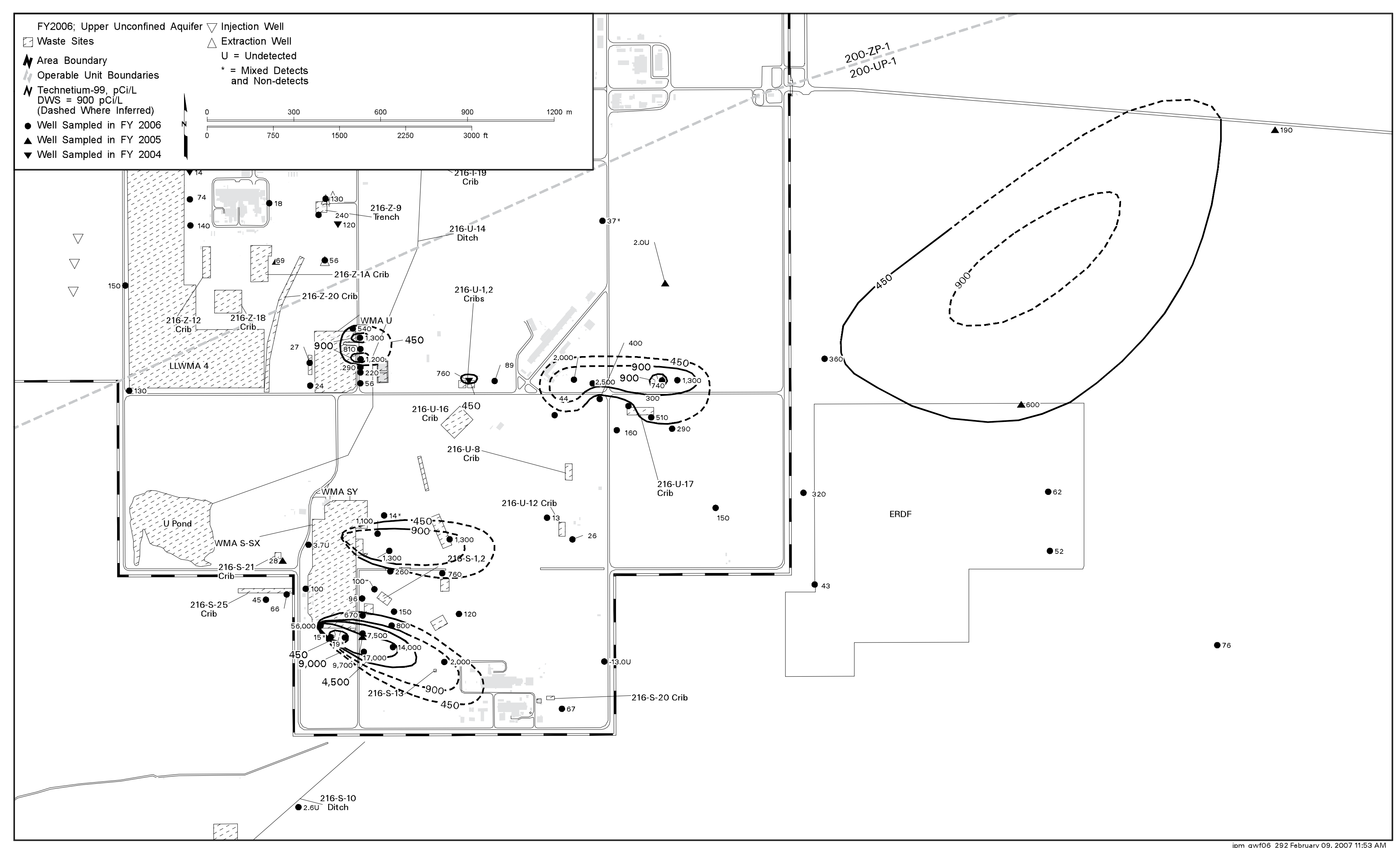

Figure 2.9-2. Average Technetium-99 Concentrations in 200-UP-1 Groundwater Interest Area, Upper Part of Unconfined Aquifer 


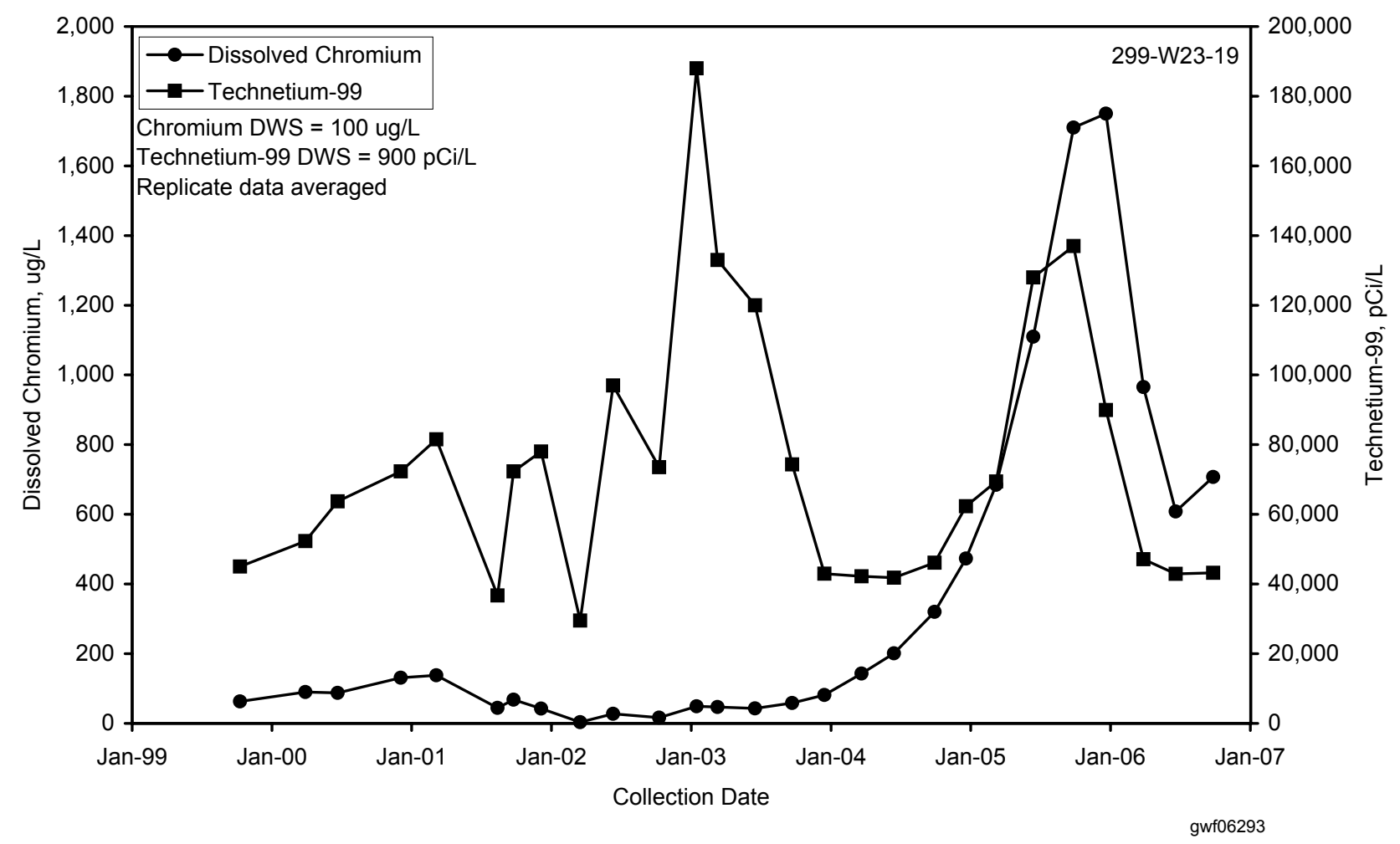

Figure 2.9-3. Chromium and Technetium-99 Concentrations in Well 299-W23-19 Near a Source Area Within the South Portion of Waste Management Area S-SX 


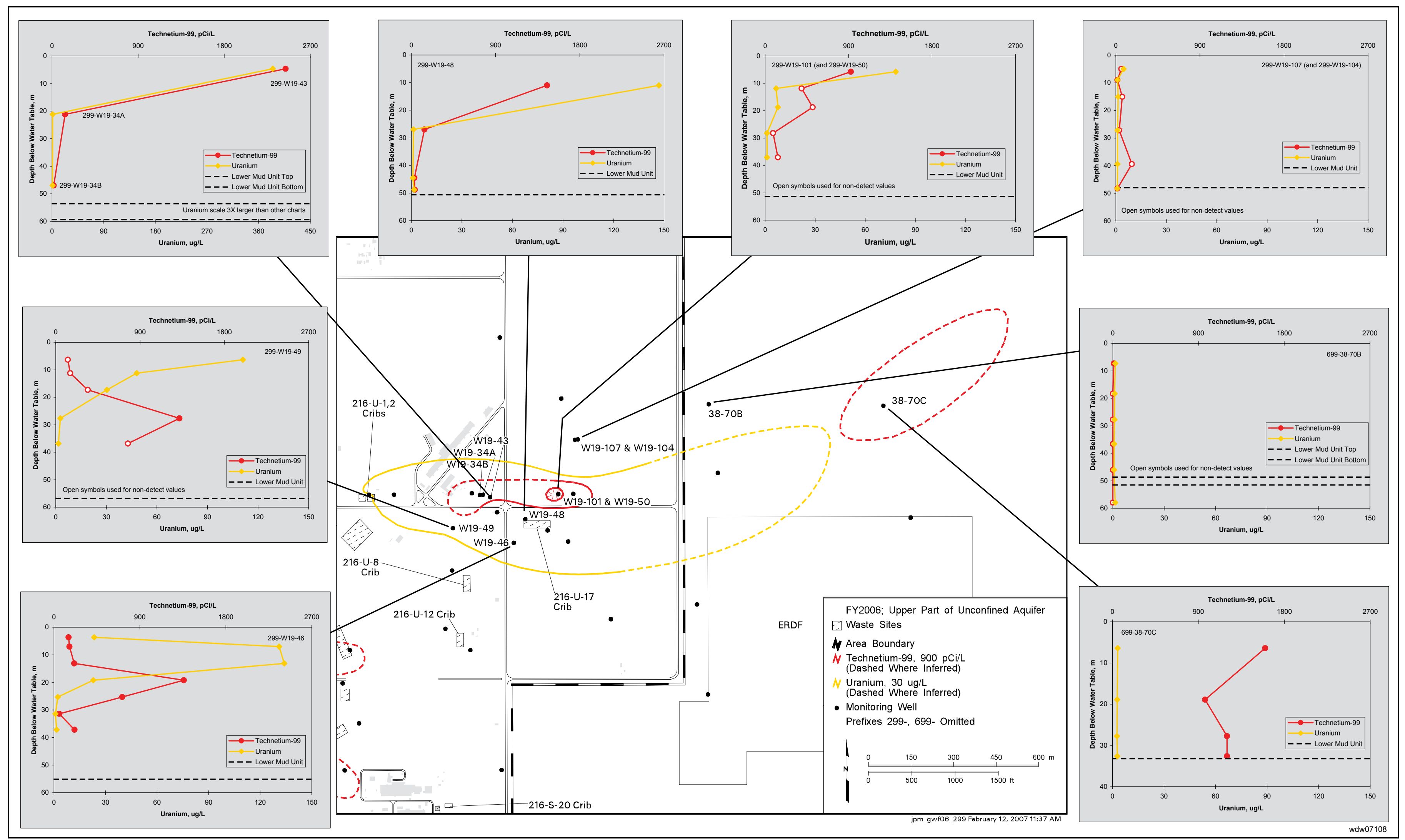

Figure 2.9-4. Depth-Discrete Sampling Results for Technetium-99 and Uranium in Northern Part of 200-UP-1 Groundwater Interest Area 


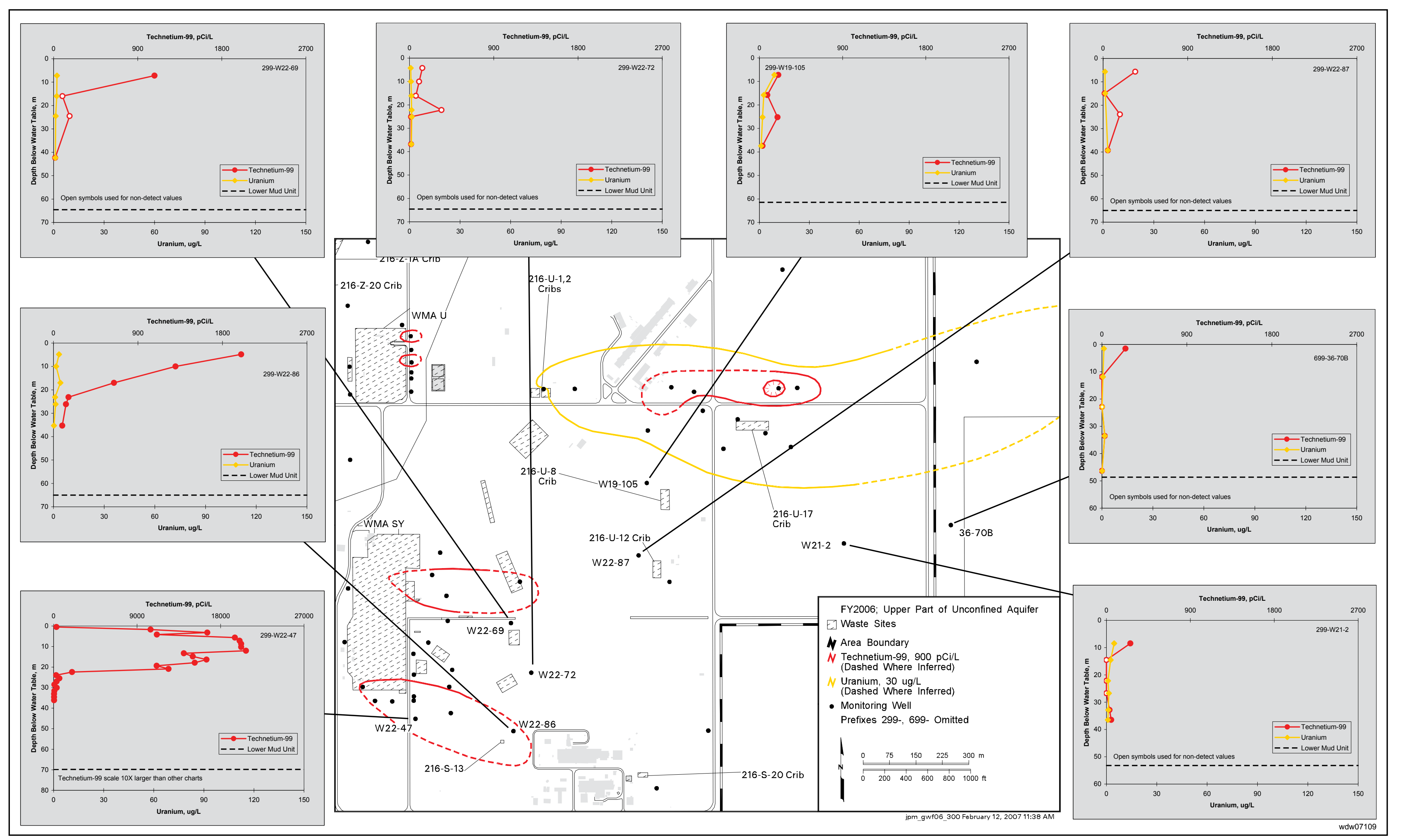

Figure 2.9-5. Depth-Discrete Sampling Results for Technetium-99 and Uranium in Southern Part of 200-UP-1 Groundwater Interest Area 


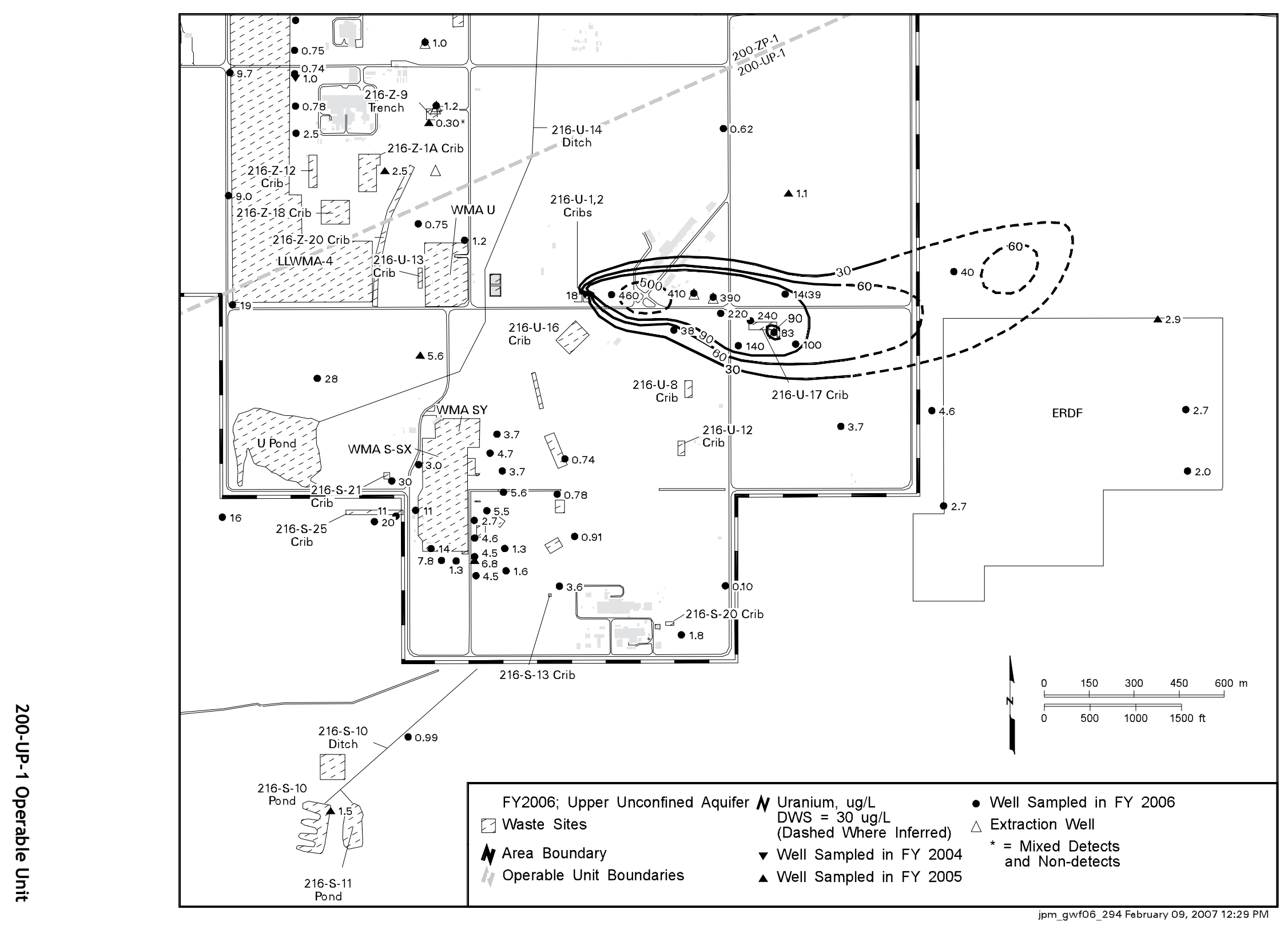

Figure 2.9-6. Average Uranium Concentrations in 200-UP-1 Groundwater Interest Area, Upper Part of Unconfined Aquifer 


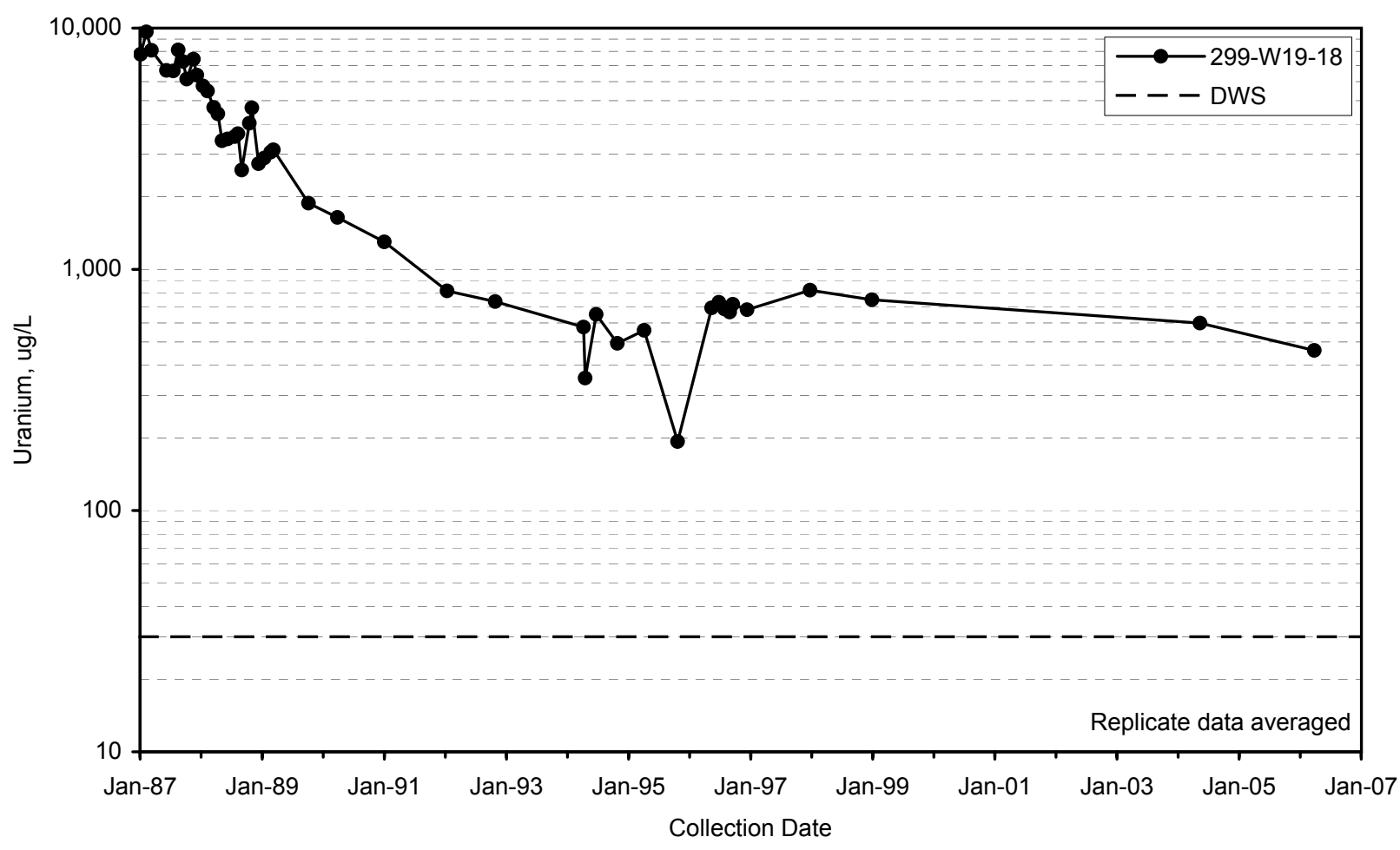

gwf06295

Figure 2.9-7. Uranium Concentrations in Well 299-W19-18 Near 216-U-1,2 Cribs 


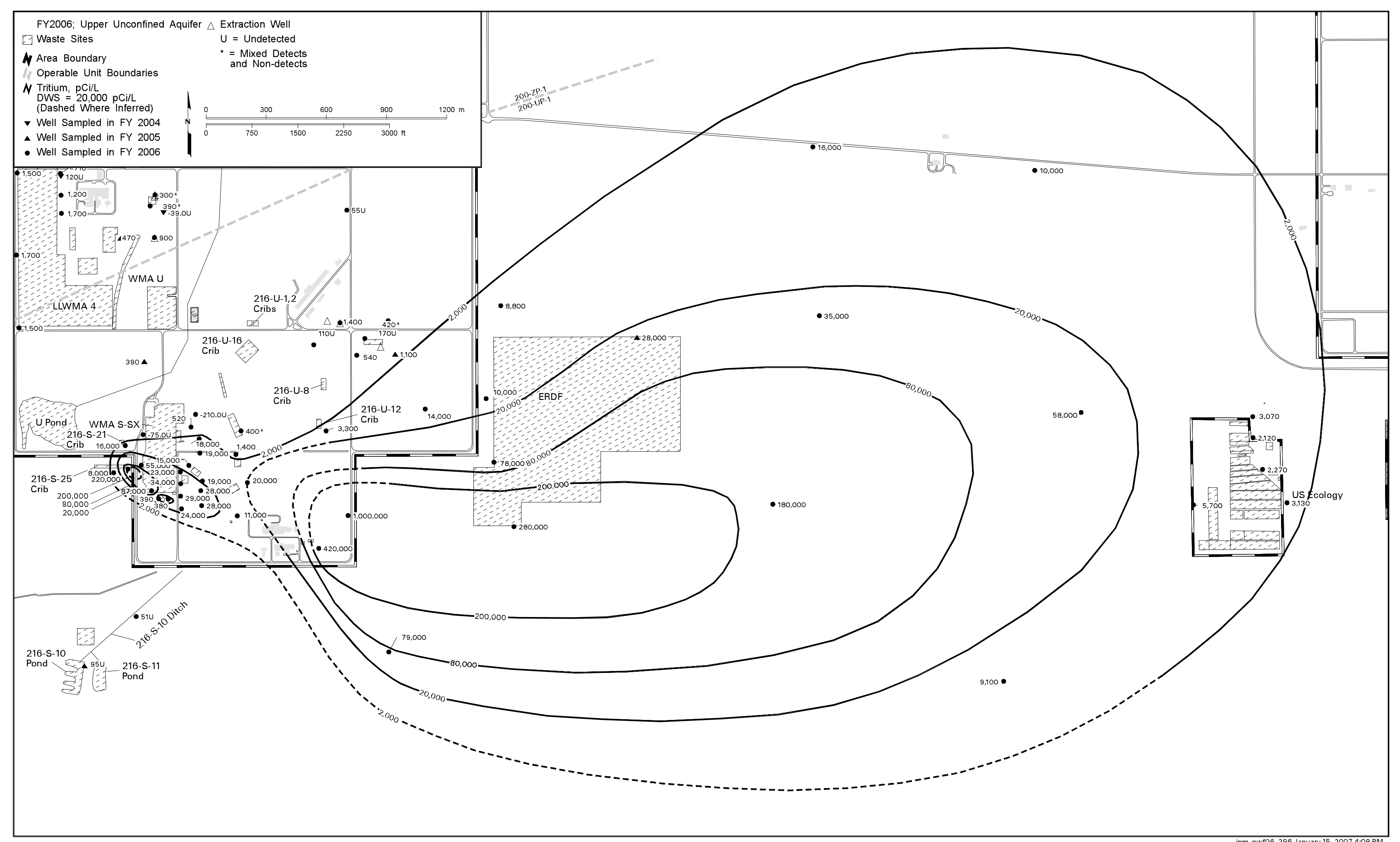

Figure 2.9-8. Average Tritium Concentrations in 200-UP-1 Groundwater Interest Area, Upper Part of Unconfined Aquifer

Jipm gwto6 296 Januarr 15, 2007 4:09 PM 


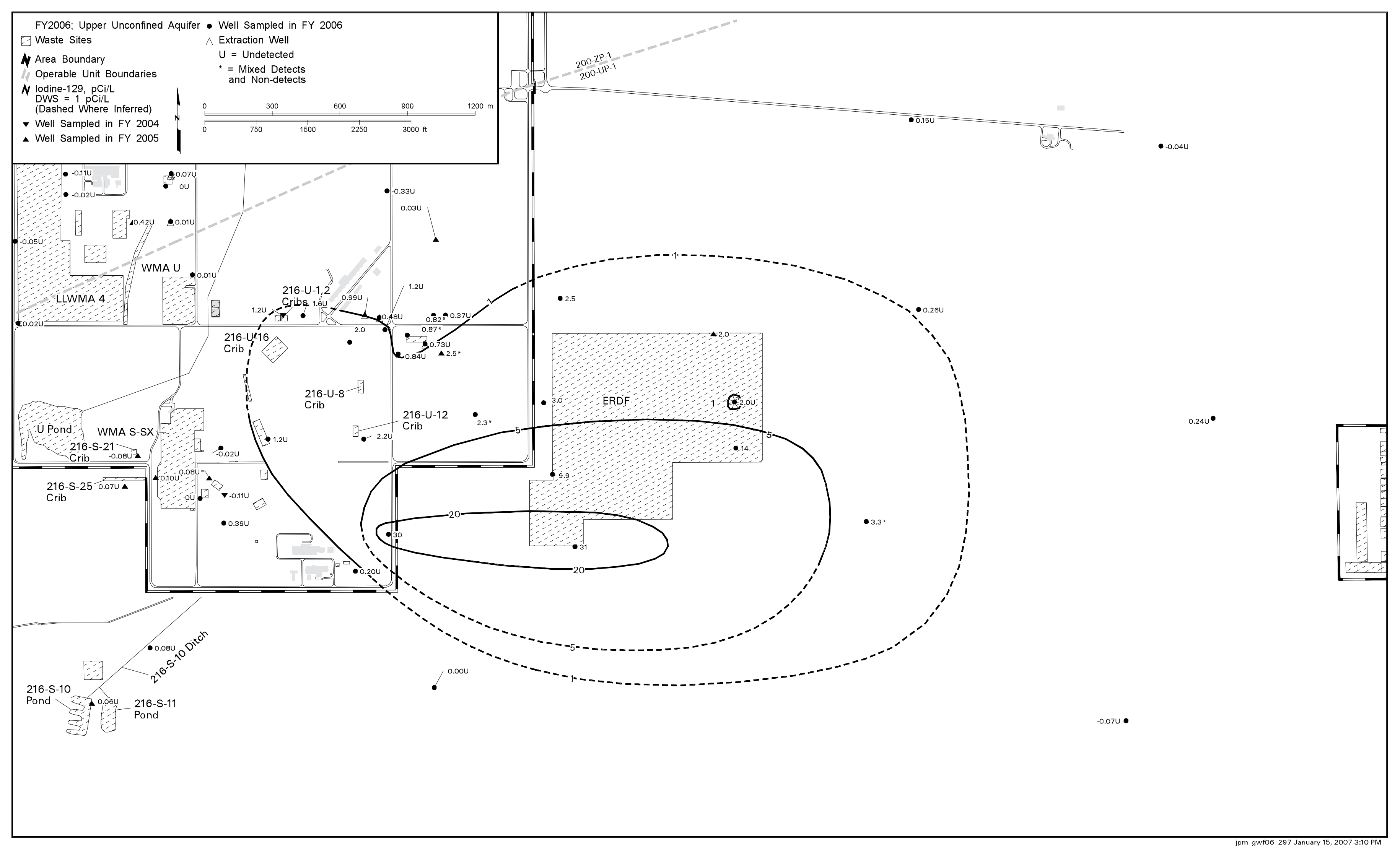

Figure 2.9-9. Average Iodine-129 Concentrations in 200-UP-1 Groundwater Interest Area, Upper Part of Unconfined Aquifer 


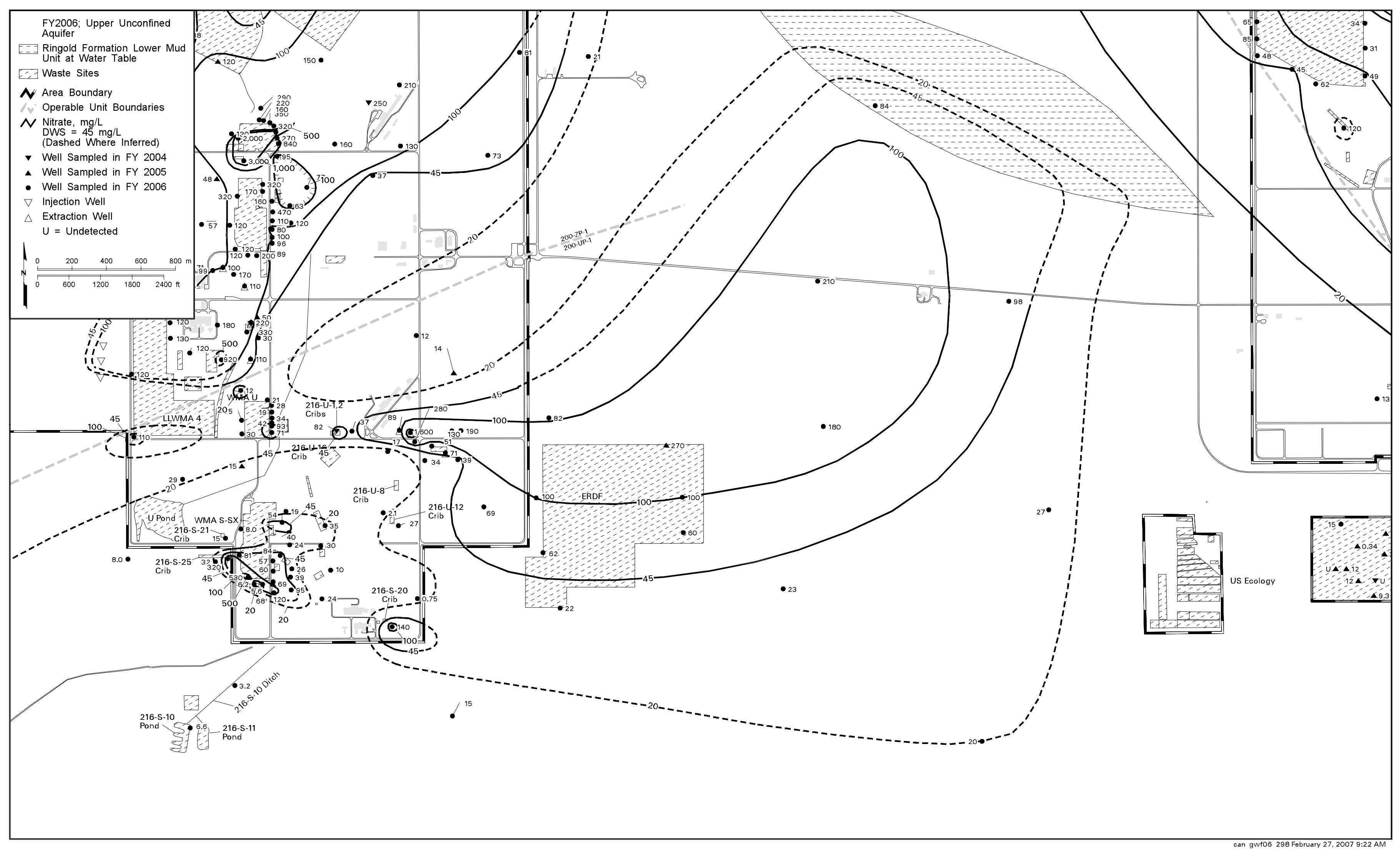

Figure 2.9-10. Average Nitrate Concentrations in 200-UP-1 Groundwater Interest Area, Upper Part of Unconfined Aquifer 


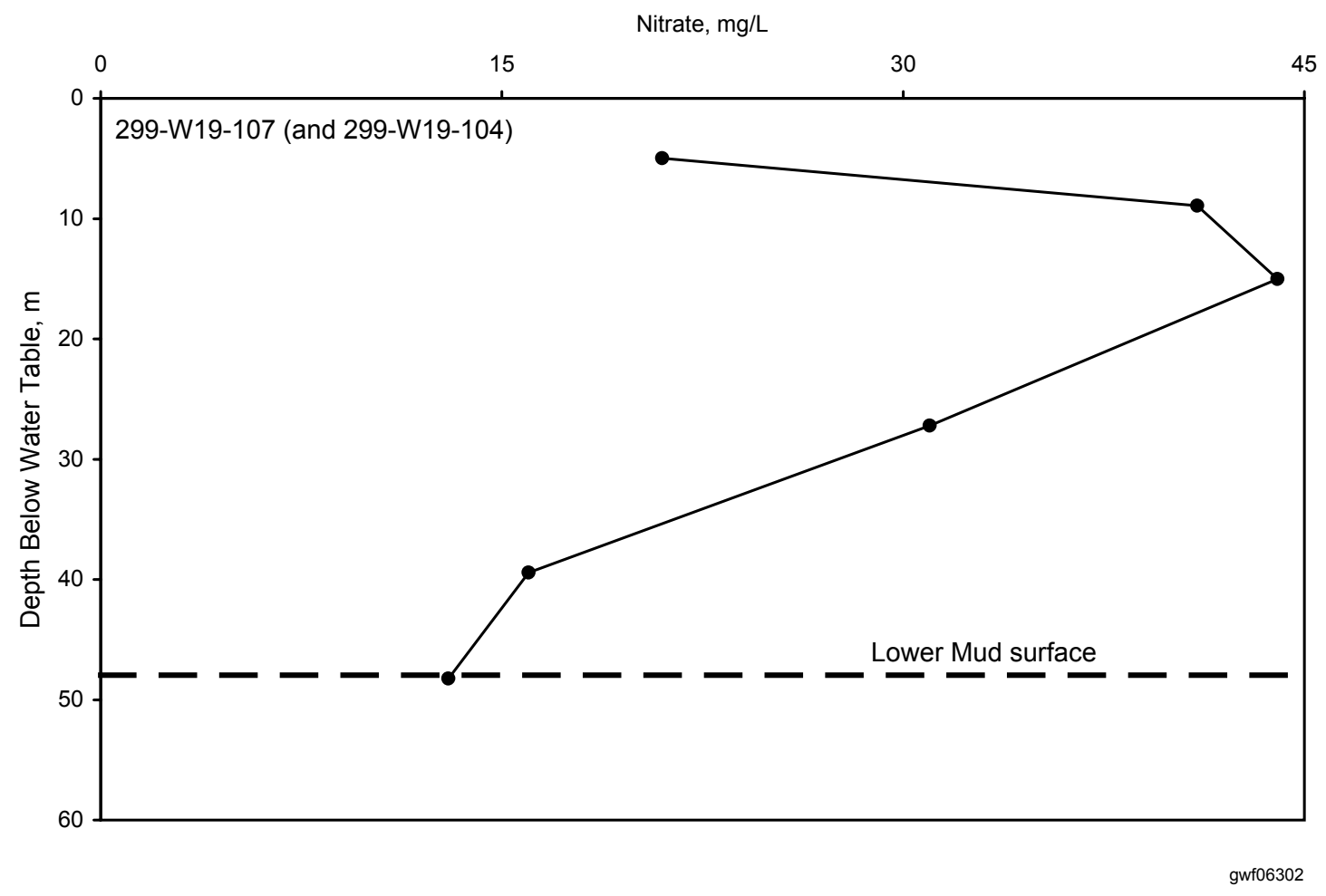

Figure 2.9-11. Depth-Discrete Sampling Results for Nitrate at New Well 299-W19-107 (and 299-W19-104) at the Pump-and-Treat Area (Samples were collected during drilling between March 28, 2006 and April 10, 2006.)

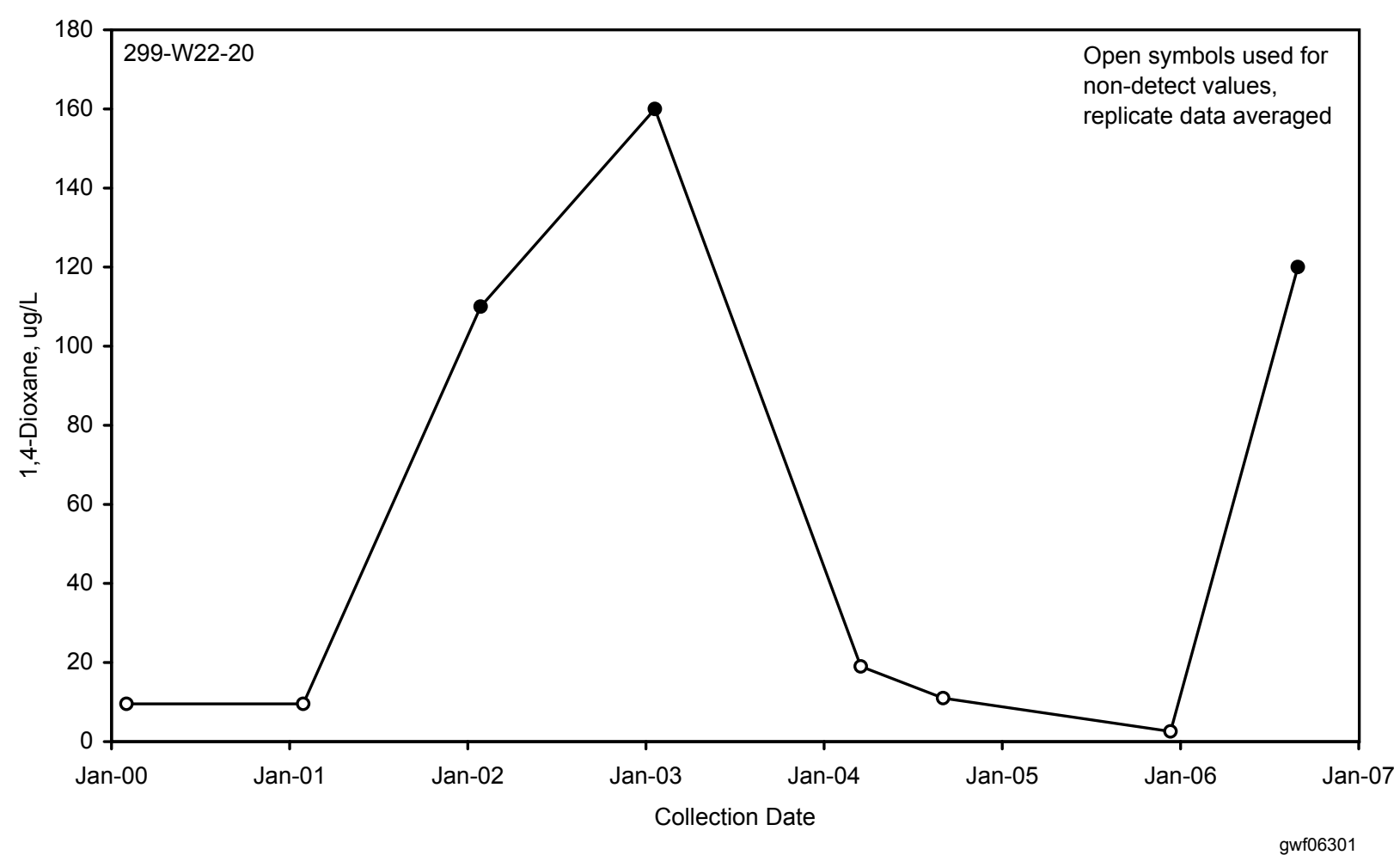

Figure 2.9-12. 1,4-Dioxane Concentrations in Well 299-W22-20 Near 216-S-20 Crib 


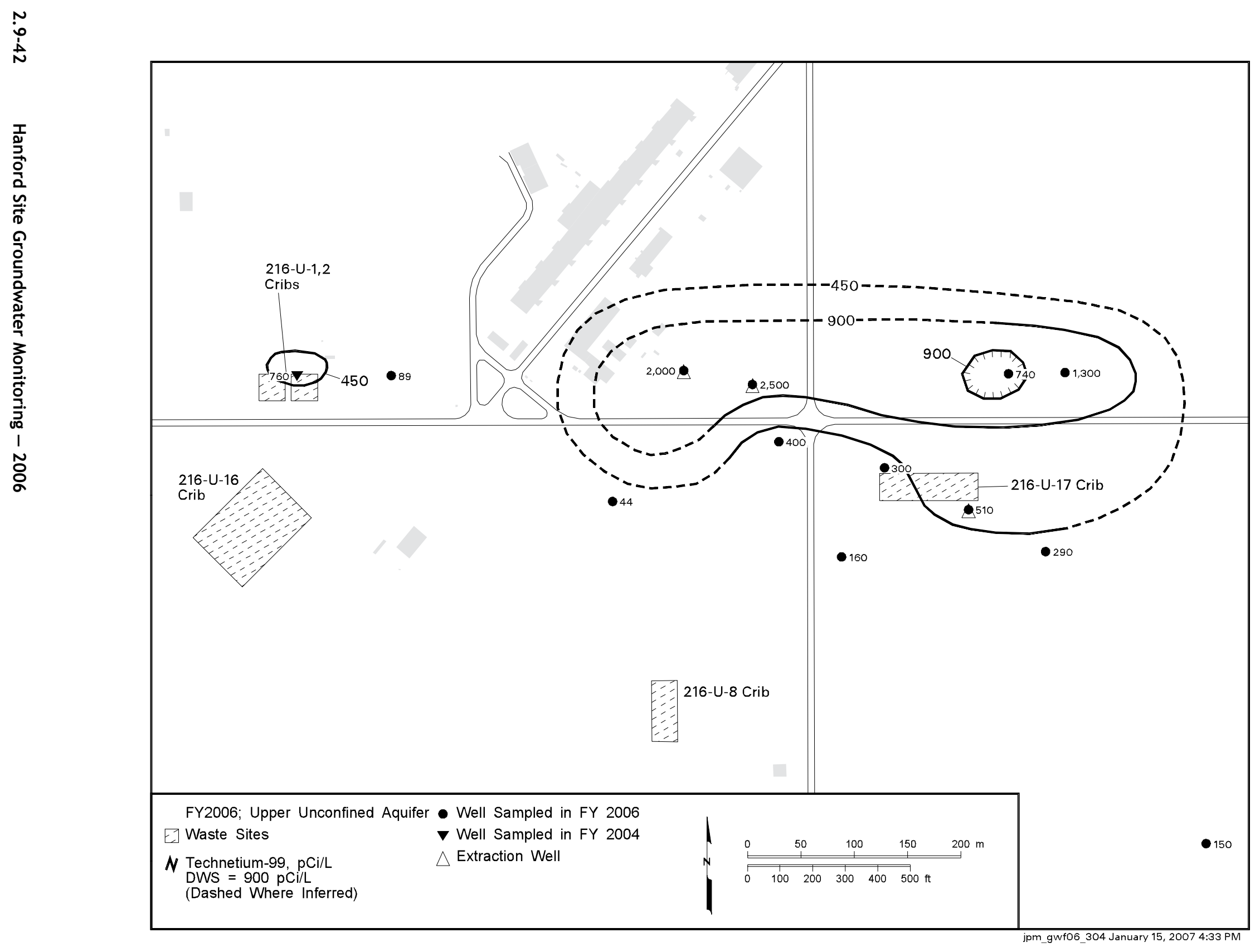

Figure 2.9-13. Average Technetium-99 Concentrations in 200-UP-1 Pump-and-Treat Area, Upper Part of Unconfined Aquifer 


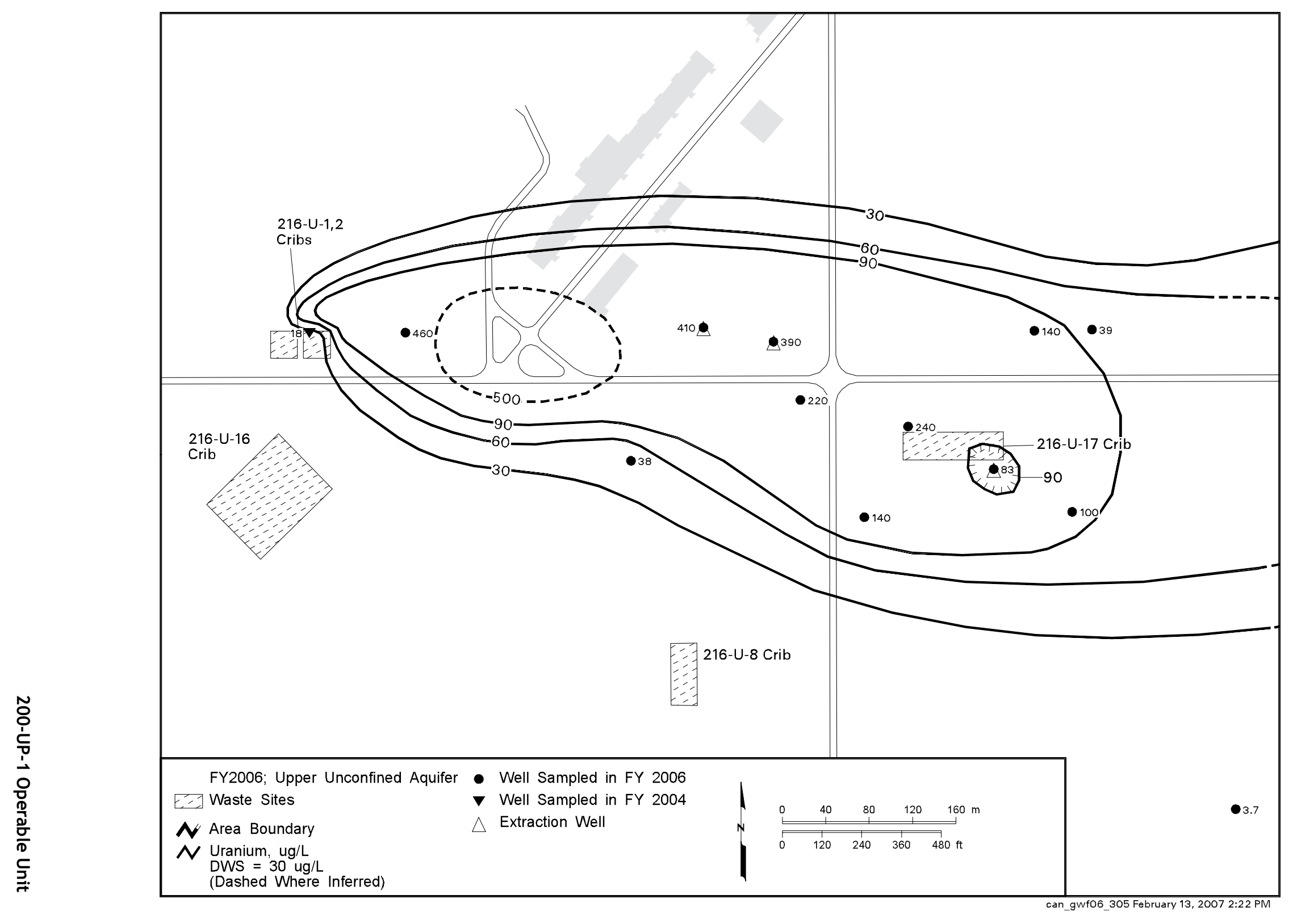

Figure 2.9-14. Average Uranium Concentrations in 200-UP-1 Pump-and-Treat Area, Upper Part of Unconfined Aquifer 


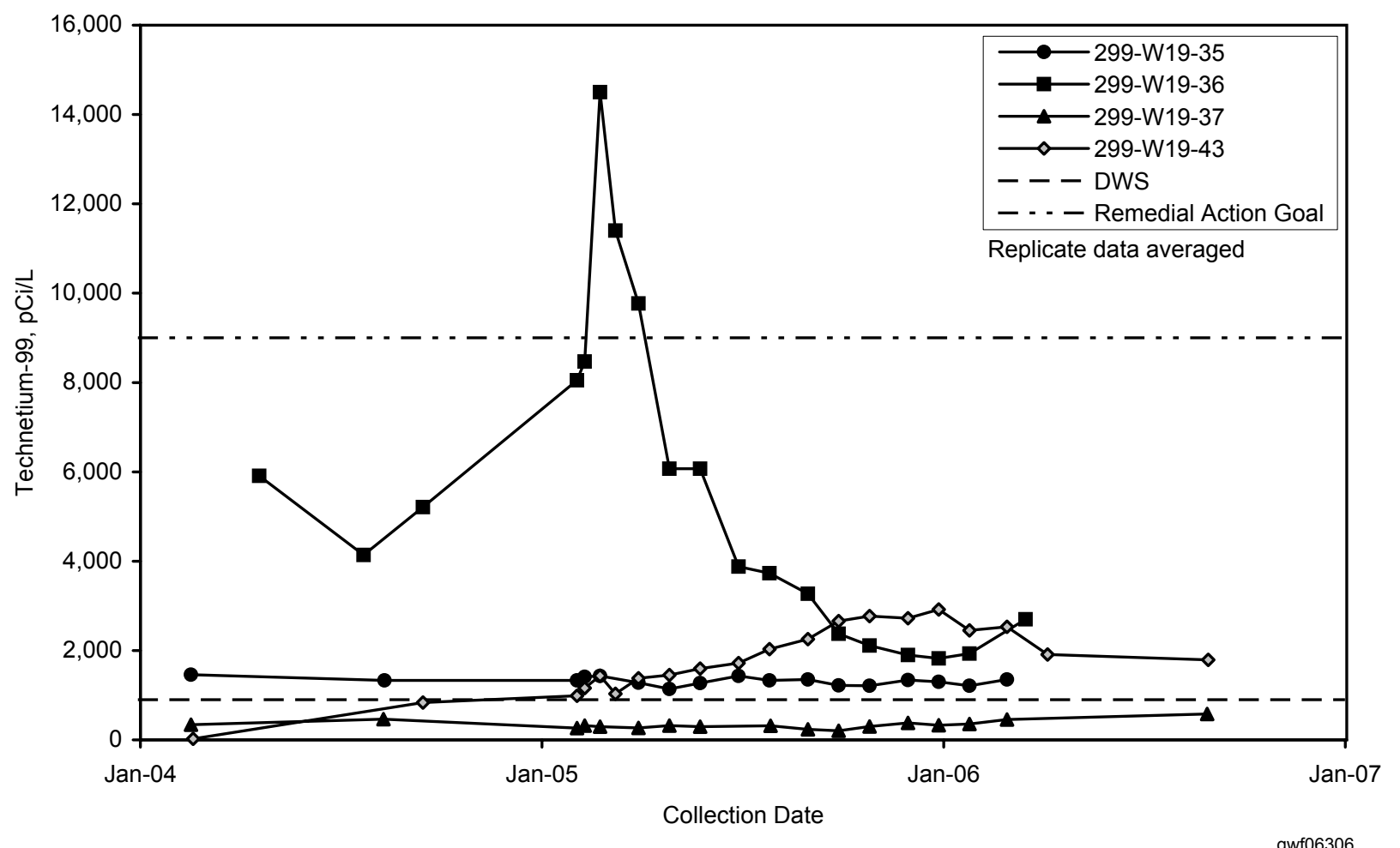

Figure 2.9-15. Technetium-99 Concentrations in Selected Wells at 200-UP-1 Pump-and-Treat Area

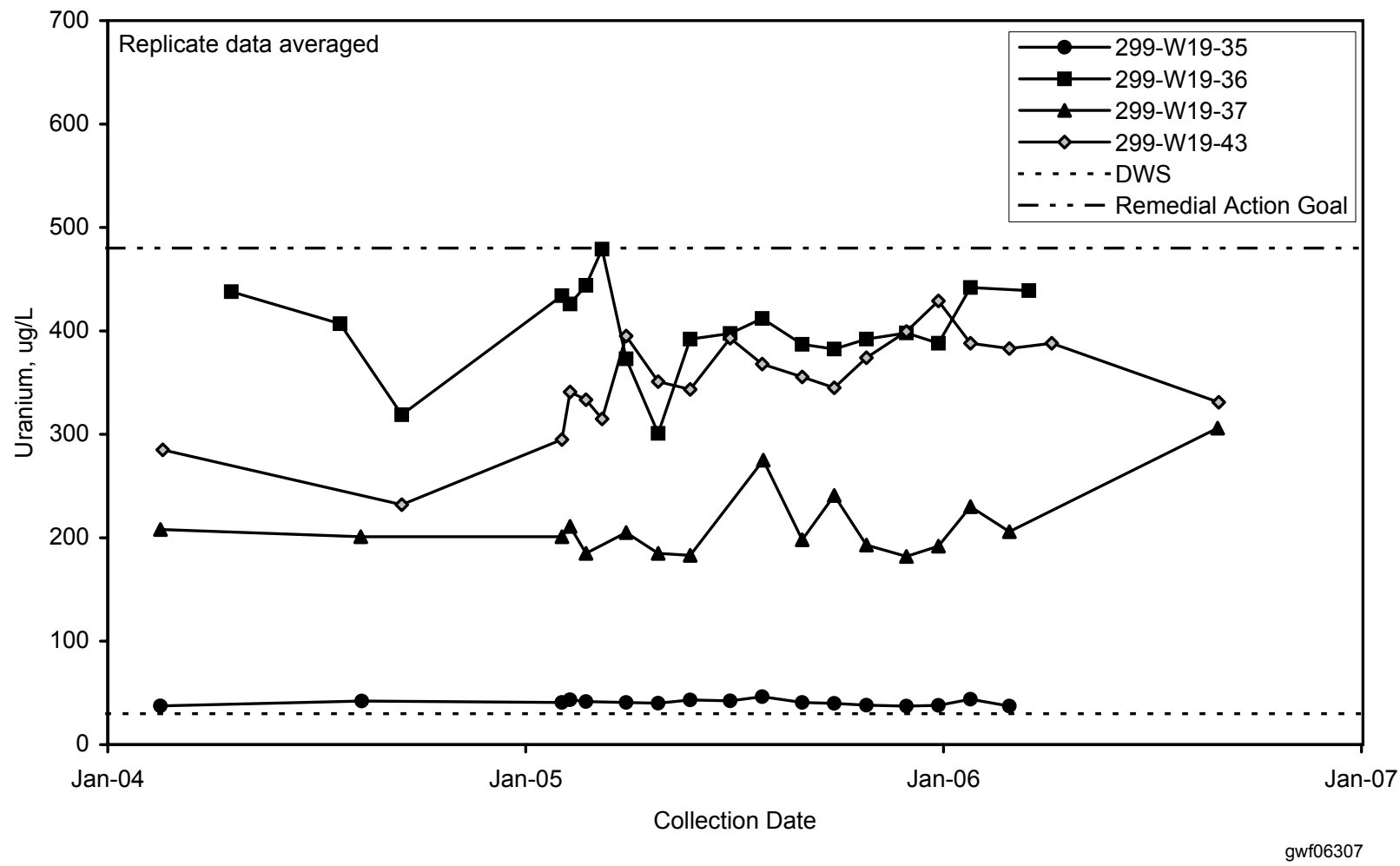

Figure 2.9-16. Uranium Concentrations in Selected Wells at 200-UP-1 Pump-and-Treat Area 


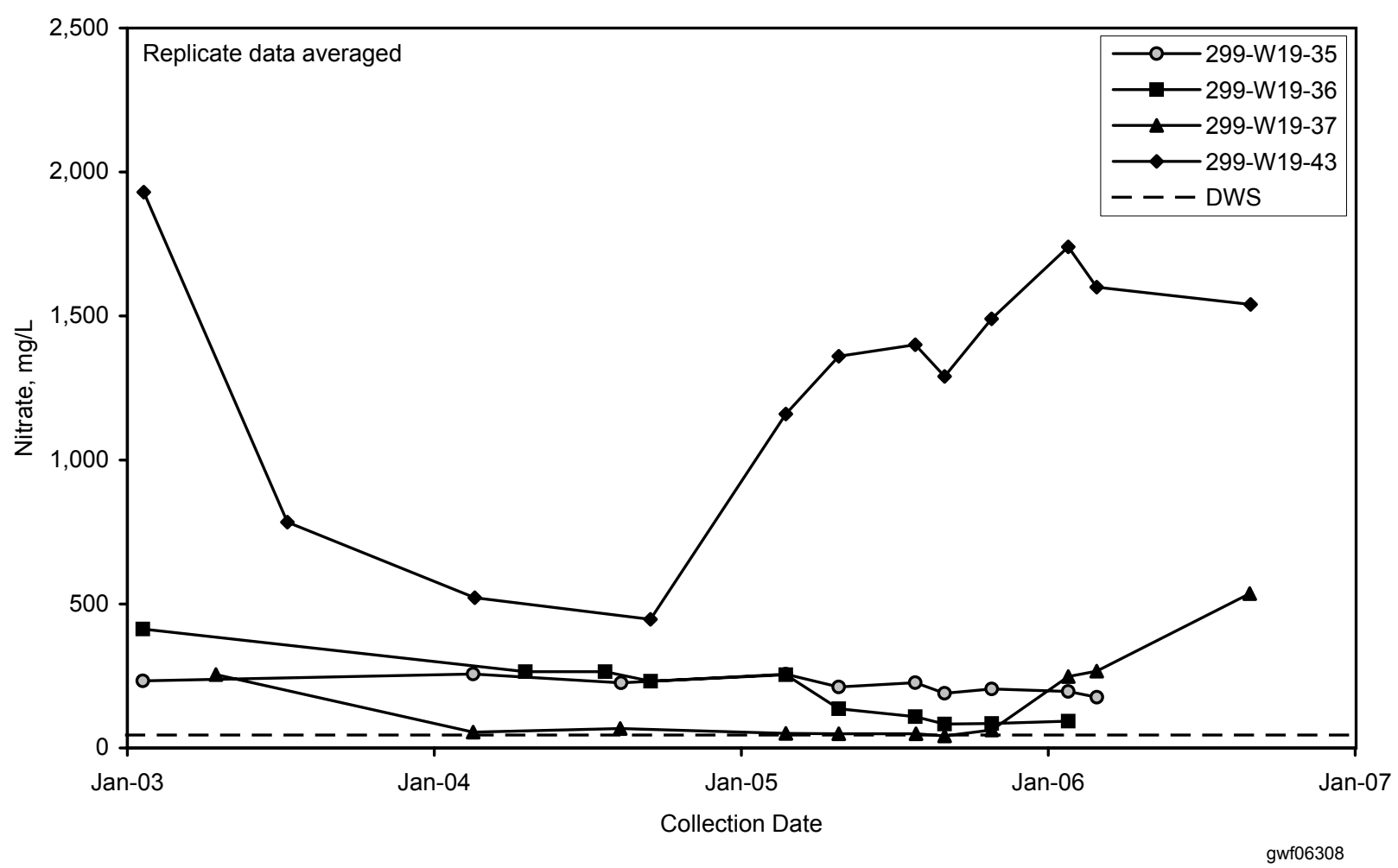

Figure 2.9-17. Nitrate Concentrations in Selected Wells at 200-UP-1 Pump-and-Treat Area 


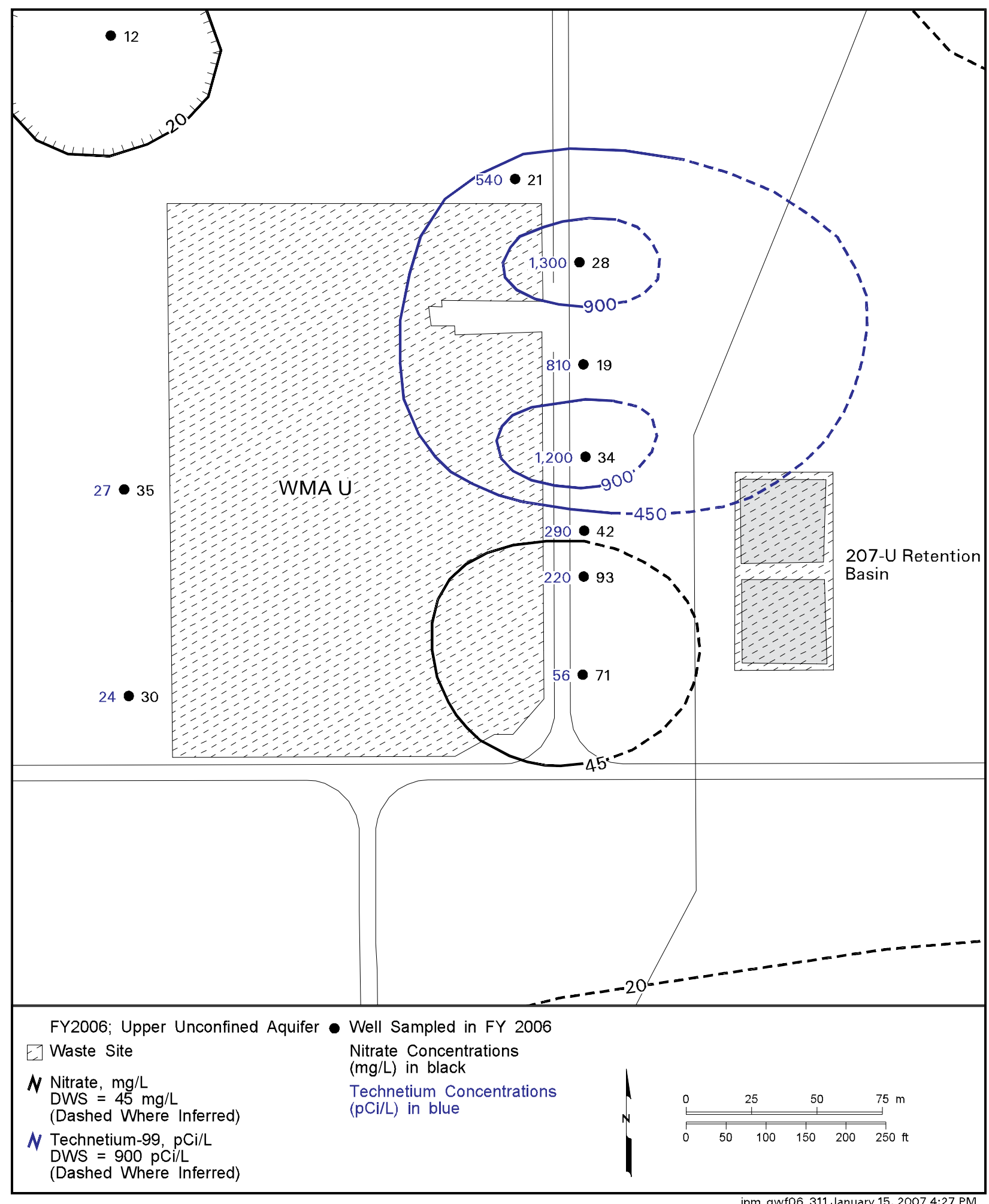

Figure 2.9-18. Average Nitrate and Technetium-99 Concentrations at Waste Management Area U, Upper Part of Unconfined Aquifer 


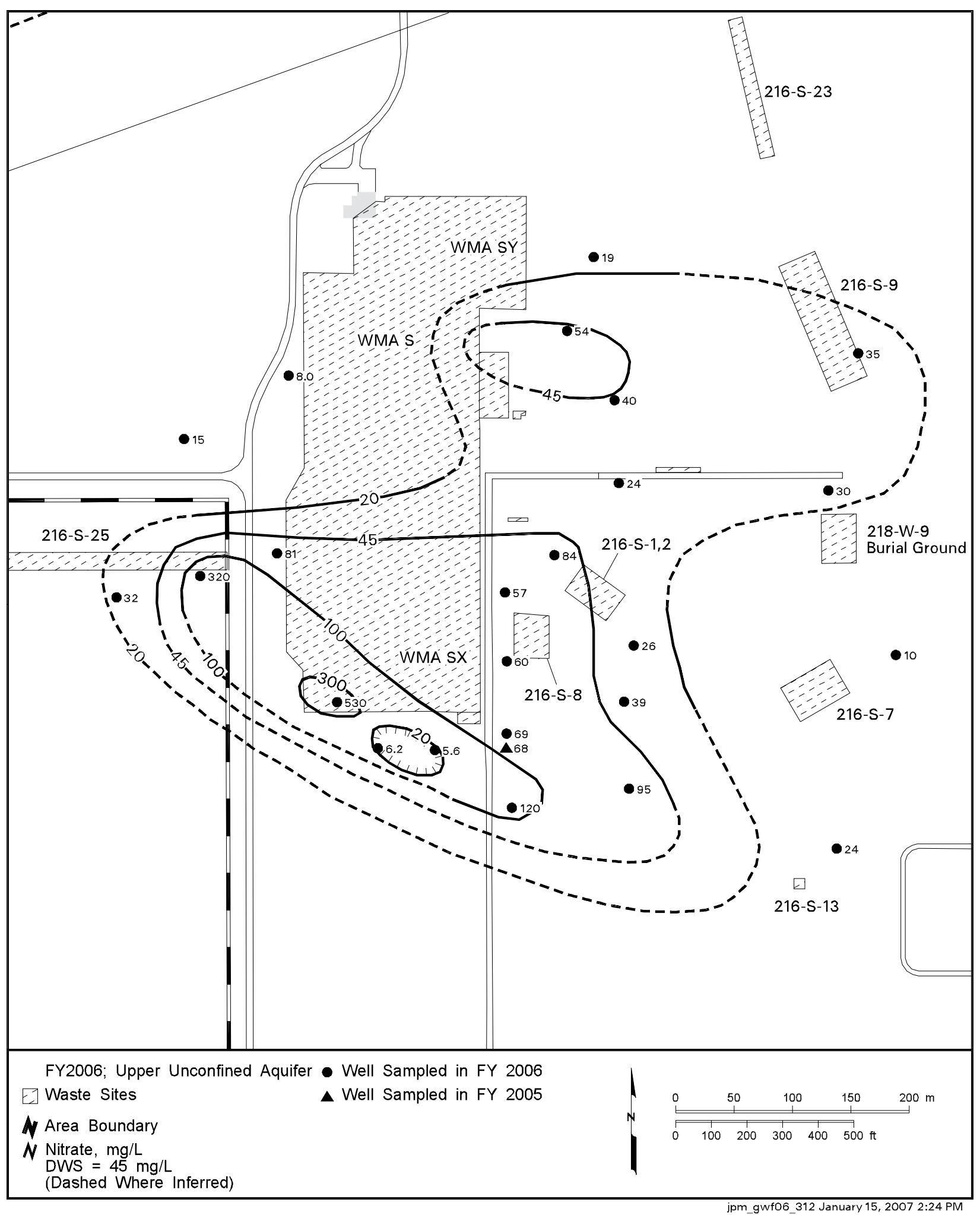

Figure 2.9-19. Average Nitrate Concentrations at Waste Management Area S-SX, Upper Part of Unconfined Aquifer 


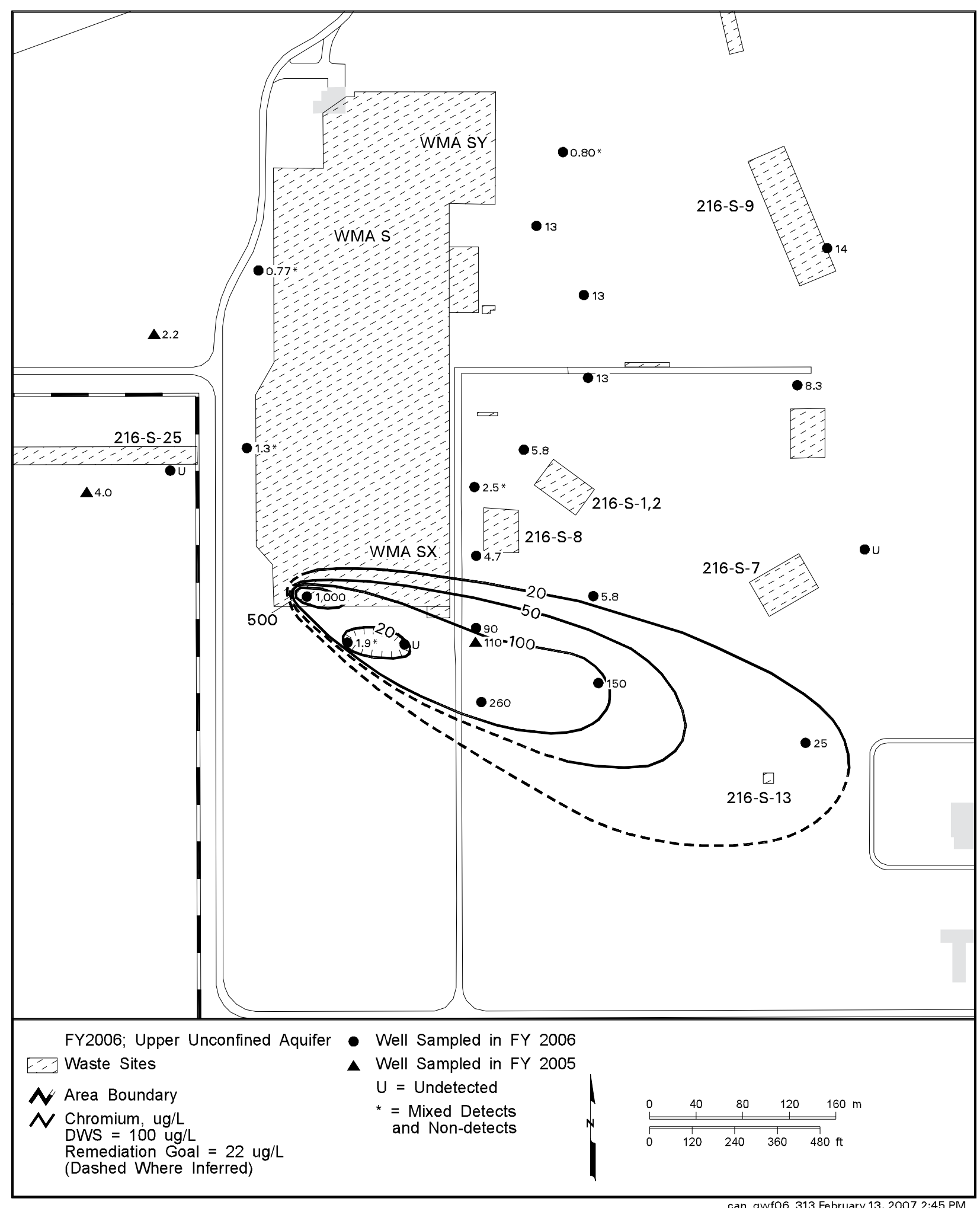

Figure 2.9-20. Average Chromium Concentrations at Waste Management Area S-SX, Upper Part of Unconfined Aquifer 


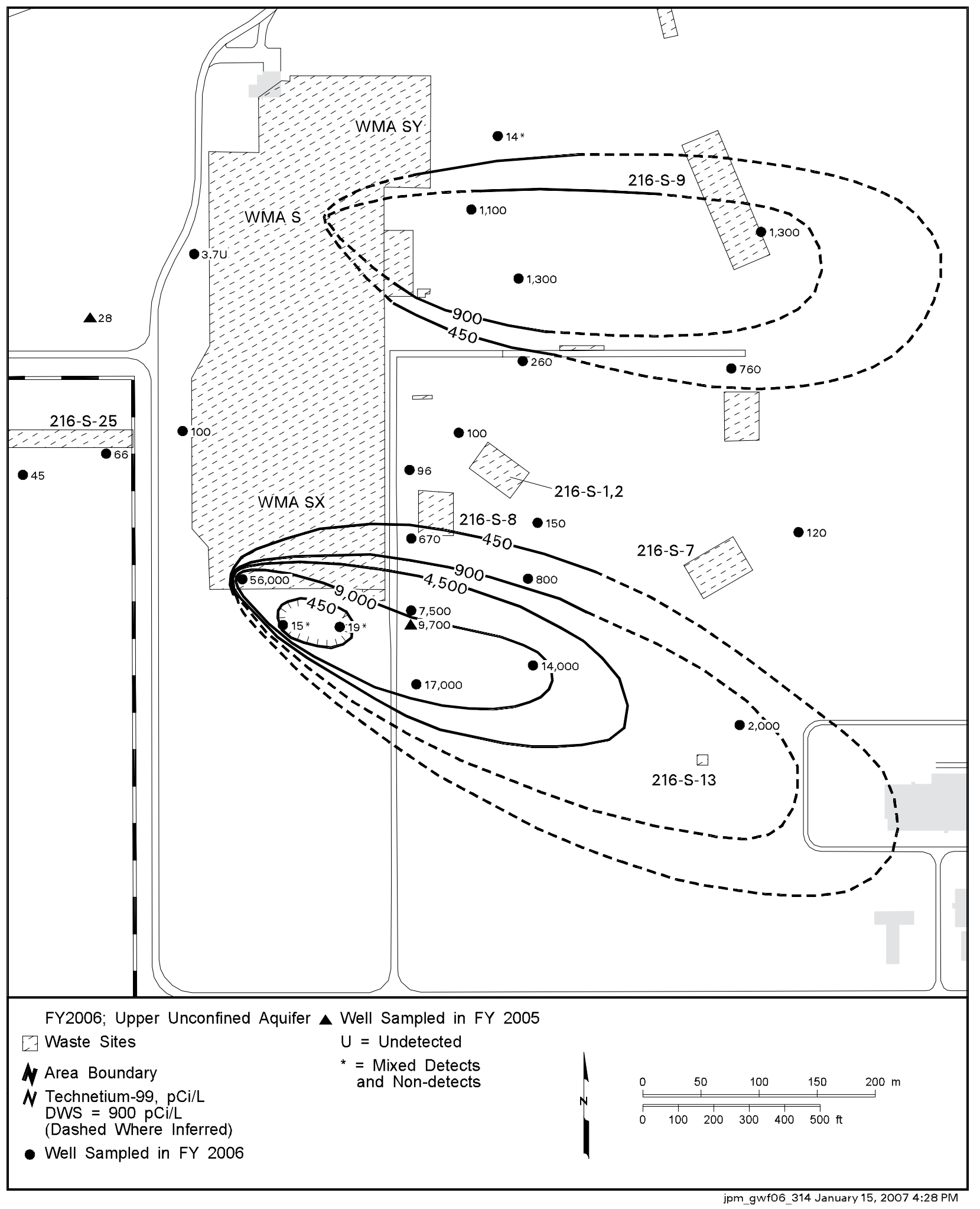

Figure 2.9-21. Average Technetium-99 Concentrations at Waste Management Area S-SX, Upper Part of Unconfined Aquifer 


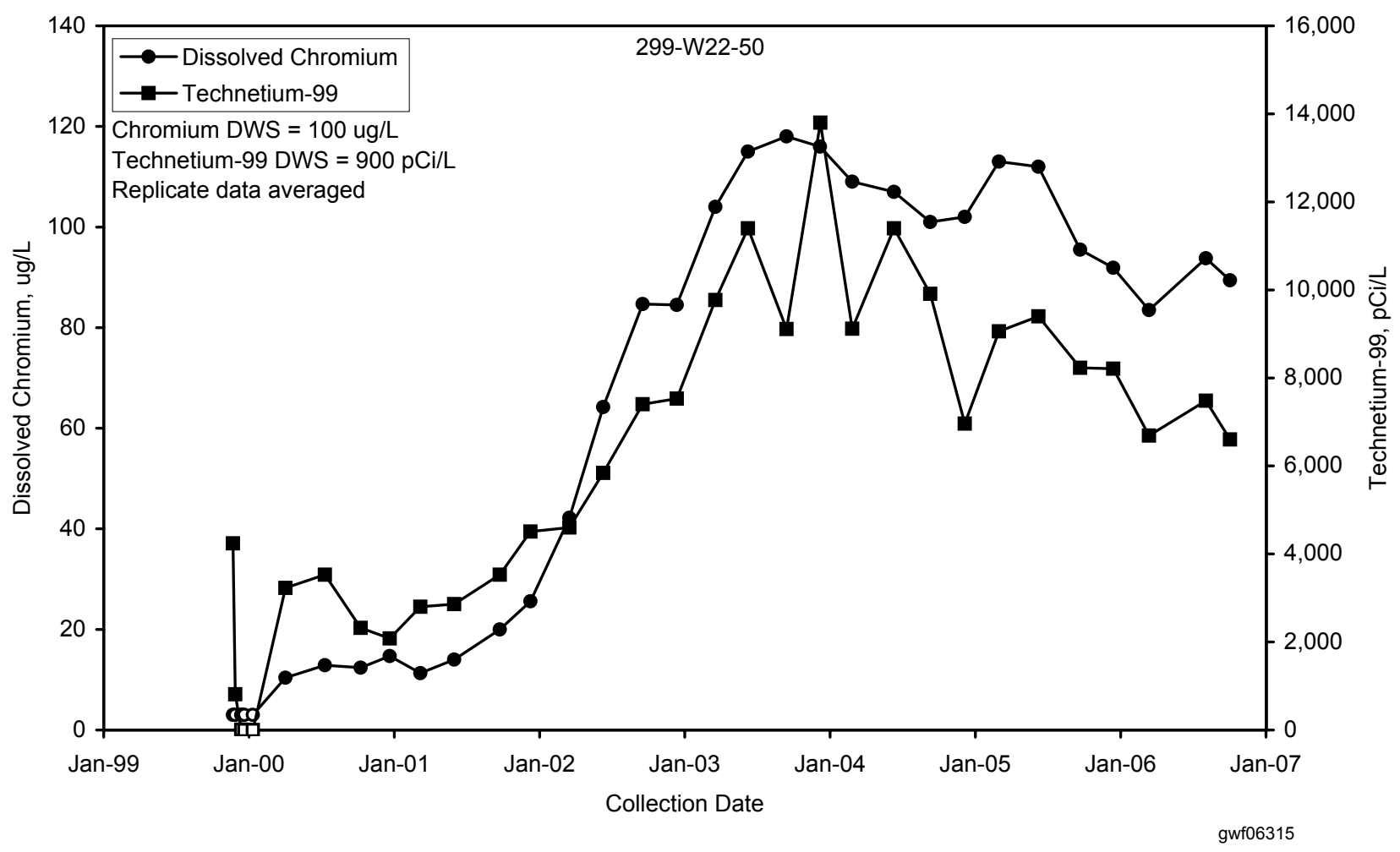

Figure 2.9-22. Chromium and Technetium-99 Concentrations in Well 299-W22-50 Near the Middle of a Plume Emanating from the South Portion of Waste Management Area S-SX 


\subsection{0-BP-5 Operable Unit}

\section{E. C. Thornton, G. S. Thomas, P. E. Dresel, S. M. Narbutovskih, and M. D. Sweeney}

The scope of this section is the 200-BP-5 groundwater interest area, which includes the 200-BP-5 Operable Unit (see Figure 1.0-1 in Section 1.0). The "groundwater interest areas" are informal designations to facilitate planning, scheduling, and interpreting groundwater data. This operable unit includes several Resource Conservation and Recovery Act (RCRA) units and Comprehensive Environmental Response, Compensation, and Liability Act (CERCLA) past-practice sites in the north part of the 200 East Area and extends north to Gable Gap. Figures 2.10-1 and 2.10-2 show facilities and wells in this operable unit. The south part of the 200 East Area lies within the 200-PO-1 Operable Unit and is discussed in Section 2.11. The boundary between the two operable units is shown in Figure 2.10-1.

Technetium-99 is the contaminant of greatest concern in the 200-BP-5 Operable Unit owing to its mobility and broad areal extent of contamination (DOE/RL-2001-49; PNNL-14049). Uranium, though more limited in terms of areal distribution, has also recently been recognized as an important contaminant of concern. Groundwater is monitored in this operable unit to define the regional extent of technetium-99, uranium, and other significant contaminants across the operable unit as well as the local extent of contamination associated with specific RCRA treatment, storage, and disposal units in the area.

The small differences in water-table elevation across the operable unit (i.e., a very small hydraulic gradient) make it impossible in some areas to determine the direction of groundwater flow from water-table maps (see Figure 2.1-2 in Section 2.1). Groundwater currently entering the 200 East Area from the west flows to the Columbia River along two general paths: one to the southeast and one to the northwest through Gable Gap. The location of the divide between these two paths is undefined. The water table has been generally declining following the decrease in liquid effluent discharges to the soil; therefore, the extent of the basalt units above the water table continues to increase.

Extremely low water-table gradient, overlapping contamination source signatures, complex vadose zone stratigraphy, and past hydrologic features (e.g., mounding from disposal) have all combined to produce a complex picture of contaminant occurrence and movement in the aquifer. At present, only pieces of information are available to determine with certainty the contaminant sources, vadose zone contamination, actual flow directions, and contaminant
Technetium-99 is

the contaminant

of greatest

concern in the

200-BP-5 Operable

Unit.

Groundwater monitoring in the 200-BP-5 Operable Unit includes the following monitoring activities:

CERCLA and AEA Monitoring

- Wells are sampled annually to triennially for contaminants of concern and supporting parameters in the uppermost aquifer.

- Additional wells are sampled triennially in the upper basalt-confined aquifer (see Section 2.14).

- Sampling of six wells was delayed until early FY 2007 because of scheduling constraints, and one well went dry (see Appendix A).

Facility Monitoring

- Wells are sampled quarterly to semiannually at Waste Management Area B-BX-BY.

- Wells are sampled quarterly to semiannually at the 216-B-63 trench.

- Wells are sampled semiannually at Low-Level Waste Management Areas 1 and 2.

- Wells are sampled semiannually at the Liquid Effluent Retention Facility.

- Wells are sampled quarterly at Waste Management Area C.

- Three RCRA wells were not sampled as scheduled and some others were delayed (see Appendix B). 


\section{Small differences in water elevations make it difficult to define the water- table surface in 200-BP-5 Operable Unit.}

migration pathways in specific portions of the 200-BP-5 Operable Unit and adjacent areas of the 200 East Area. Hypotheses are presented throughout this section in terms of what is known about each waste management area and its surroundings. Work is ongoing to resolve discrepancies in the conceptual models that are represented in this section.

The fact that plumes of tritium, nitrate, and technetium-99 have migrated through Gable Gap proves that groundwater flowed from the northern 200 East Area toward the northwest in the past. Distribution of the uranium plume in the northwest 200 East Area suggests that some degree of northwest flow may remain. These plumes are discussed in greater detail in Section 2.10.1.

Water-level measurements are generally made in March and are used to construct Hanford Site water-table maps. Small differences in water elevations make it difficult to define the water-table surface in 200-BP-5 Operable Unit. The range in water-level elevation is only $\sim 4$ centimeters across the 200 East Area, which may be on the order of the total uncertainty associated with determining water-level elevations.

Water-elevation measurements were collected in July 2006, when the variation in barometric pressure and its effects on measurements were considered to be minimal. The results of this effort are presented in the water-table map shown in Figure 2.10-3. A comparison of water-table contours to the northeast and southwest of the 200 East Area, with the elevation data points in 200 East, suggest that there is a general low in water elevation in a trend to the northwest-southeast direction across the 200 East Area, which is consistent with the geometry of contaminant distributions in the region and also with the trend of high-permeability aquifer sediment.

The upper basalt-confined aquifer is also monitored in the 200-BP-5 Operable Unit because of the potential for migration of contaminants from the overlying unconfined aquifer (Section 2.14). The basalt north of the 200 East Area was significantly eroded by late Pleistocene flooding, which may facilitate aquifer intercommunication. Discharge to overlying or underlying aquifers in the vicinity of the Gable Butte/Gable Mountain structural area, for example, may occur through erosional windows in the basalt where removal of the Elephant Mountain basalt has left a region of intercommunication between the Rattlesnake Ridge interbed aquifer and the unconfined aquifer. Wells 699-55-60A and 699-53-55A may have gone directly from the Hanford formation into the Rattlesnake Ridge interbed during drilling (DOE/RL-2005-76).

Section 2.10.1 provides general information regarding geometry of contaminant plumes and concentration trends for contaminants of concern. Section 2.10.2 discusses aspects of groundwater monitoring specific to the 200-BP-5 Operable Unit. Specific information regarding contaminant distribution for RCRA units within the 200-BP-5 Operable Unit is presented in Section 2.10.3.

\subsubsection{Groundwater Contaminants}

Plume areas (square kilometers) above the drinking water standard at the 200-BP-5 Operable Unit:

Cyanide - 0.17

Iodine-129-3.73

Nitrate -5.88

Strontium-90 -0.72

Technetium-99-3.48

Tritium -0.28

Uranium - 0.33
This section summarizes the distribution of groundwater contamination in the 200-BP-5 Operable Unit. Specific information is provided for several CERCLA units (the 216-B-5 reverse well, BY cribs, and Gable Mountain Pond) as well as general information regarding regional contaminant distribution, particularly in the Gable Gap area. Contaminants discussed include tritium, uranium, iodine-129, technetium-99, cobalt-60, cyanide, strontium-90, cesium-137, plutonium-239/240, and nitrate (PNNL-14049). See Figure 2.10-1 for locations of wells monitored in the 200 East Area and Figure 2.10-2 for locations of wells monitored in the 600 Area for the 200-BP-5 Operable Unit.

Plume maps presented in this section are based on annual average values from wells completed at the top of the unconfined aquifer. 


\subsubsection{Tritium}

Tritium contamination is widespread throughout the northwest part of the 200 East Area and within the 200-BP-5 Operable Unit (Figure 2.10-4). The contamination extends north through the gap between Gable Mountain and Gable Butte and to the Columbia River and southeast through the 200-PO-1 Operable Unit (see Figure 1.0-2 in Section 1.0).

Tritium concentrations above the drinking water standard can be found between Gable Mountain and Gable Butte (see Figure 1.0-2 in Section 1.0), which indicates past migration of this contaminant through Gable Gap. Well 699-61-62 in Gable Gap produced a tritium concentration of $21,300 \mathrm{pCi} / \mathrm{L}$ in fiscal year (FY) 2006 (Figure 2.10-5). Tritium concentrations in wells 699-60-60 (25,850 pCi/L) and 699-64-62 (18,600 pCi/L) also increased slightly in FY 2006 but have been trending downward over the past decade. Well 699-72-73, located between the $100-\mathrm{B} / \mathrm{C}$ and $100-\mathrm{K}$ Areas, exceeded the drinking water standard in FY 2001. Tritium concentrations subsequently declined, but a slightly higher value of $17,700 \mathrm{pCi} / \mathrm{L}$ was reported in FY 2006.

Tritium values increased for several years at the south end of Waste Management Area B-BX-BY, but may be starting to decline. The maximum tritium value in this region in FY 2004 was 19,900 pCi/L in well 299-E33-21, but a value of $13,700 \mathrm{pCi} / \mathrm{L}$ was reported in the second half of FY 2006 (Section 2.10.3.1).

\subsubsection{Nitrate}

A nitrate plume originating in the 200 East Area extends beyond the boundary fence line northwest toward the Columbia River (see Figure 1.0-3 in Section 1.0) which, like tritium, indicates groundwater flow and contaminant migration in the past has been through Gable Gap. The nitrate contamination within the northeast part of the 200 East Area consists of a west plume beneath the west portion of Low-Level Waste Management Area 1, and an east plume extending from the northern portion of the BY cribs toward the northwest (Figure 2.10-6) and to the southeast extending to the 216-B-8 crib. The northwest portion of the nitrate plume extends through the gap between Gable Butte and Gable Mountain to the Columbia River at levels less than the drinking water standard (45 mg/L).

The west part of the nitrate plume, extending through the west portion of Low-Level Waste Management Area 1, appears to be part of a larger plume extending primarily from the Plutonium-Uranium Extraction (PUREX) facility in the 200-PO-1 Operable Unit. Other historical sources for this plume may include facilities in the northern part of the 200 East Area (e.g., BY cribs). This plume apparently moved to the northwest under past flow conditions during the period of high discharge to 200 East Area facilities and the B Pond area.

Nitrate is also found in localized plumes east of Low-Level Waste Management Area 2 and beneath the C Tank Farm. The highest nitrate concentrations in the 200 East Area are in the vicinity of the BY and 216-B-8 cribs. High concentrations of nitrate are associated with the cobalt-60, cyanide, and technetium-99 plume originating from the BY cribs (PNNL-13080). The highest nitrate concentrations measured in FY 2006 were found in well 299-E33-4 (3,200 mg/L), near the BY cribs. The highest value for nitrate associated with the 216-B-8 crib during FY 2006 was a concentration of $881 \mathrm{mg} / \mathrm{L}$ reported for well 299-E33-16.

Nitrate continued to be detected in wells monitoring Gable Mountain Pond at levels above the drinking water standard (see Figure 1.0-3 in Section 1.0). In FY 2006, a nitrate value of $88 \mathrm{mg} / \mathrm{L}$ was measured in well $699-53-47 \mathrm{~A}$ and a value of $177 \mathrm{mg} / \mathrm{L}$ in well 699-53-48A (Figure 2.10-7).

\subsubsection{3 lodine-129}

Iodine-129 contamination is present throughout the 200-BP-5 Operable Unit. The iodine-129 plume extends to the northwest toward the Gable Mountain/Gable Butte gap and southeast through the 200-PO-1 Operable Unit (see Figure 1.0-4 in Section 1.0). Levels greater than the iodine-129 drinking water standard $(1 \mathrm{pCi} / \mathrm{L})$ have not passed beyond the gap between Gable Mountain and Gable Butte. A region of elevated iodine-129 concentrations
The tritium plume

extends northward

through Gable Gap.
The highest nitrate concentrations

are in the vicinity of the BY and 216-B-8 cribs. 


\section{A plume of technetium-99 extends from the area of the BY cribs to beyond the north boundary of 200 East Area. The plume has moved through Gable Gap at levels below the drinking water standards.}

$(\sim 5 \mathrm{pCi} / \mathrm{L})$ had been present in Waste Management Area B-BX-BY but wells in this area reported $<5$ pCi/L during FY 2006 (Figure 2.10-8). The laboratory's detection limit for iodine-129 is in some cases greater than the $1-\mathrm{pCi} / \mathrm{L}$ drinking water standard. The laboratory requires that both primary and secondary energy peaks are present before they consider iodine-129 detected. Requiring the secondary (less sensitive) energy peak adds conservatism to the laboratory's report (i.e., they do not report a detection unless they are very sure of it). However, many of the values flagged as non-detected are believed to be real detections, and they are contoured as such. The contour lines in plume maps (Figure 2.10-8) are dashed to show that the distribution of iodine-129 at levels near the drinking water standard is less certain than other contaminants

\subsubsection{Technetium-99}

A plume of technetium-99 extends from the area of the BY cribs and Waste Management Area B-BX-BY to the northwest (Figure 2.10-9). A significant portion of the plume is north of the 200 East boundary and may represent early releases of technetium- 99 from the BY cribs (PNNL-13080), but near-field technetium-99 concentration levels are the result of more recent contributions from tanks and local cribs. Detection of technetium-99 north of the gap between Gable Mountain and Gable Butte indicates that technetium-99 has historically moved north into and through the gap.

Eight wells were successfully sampled in the Gable Gap area north of the 200 East Area boundary in FY 2006 (Figure 2.10-9). Concentrations of technetium-99 in well 699-49-57A increased from the mid-1990s to 2003 but have not changed significantly since then (Figure 2.10-10). A new well, 699-50-59, sampled quarterly for technetium-99 in FY 2006 (DOE/RL-2005-76) has improved the understanding of the distribution of this contaminant in the vicinity of Gable Gap as reflected in Figure 2.10-9. The maximum concentration of technetium-99 thus far in well 699-50-59 is $1,680 \mathrm{pCi} / \mathrm{L}$.

In the late 1990s, rising technetium-99 concentrations were seen in the BY crib area in wells 299-E33-7 and 299-E33-38 (Figure 2.10-10). In early 1999, the trends for both wells began to track together and reached an apparent maximum in late 2000. These trends reflect relatively recent breakthrough into the saturated zone of contamination from the vadose zone at the BY cribs. In particular, high concentrations of technetium-99 in well 299-E33-38 (average of 17,200 pCi/L in FY 2006) and well 299-E33-4 (42,900 pCi/L in FY 2006) indicate a continuing source of contamination from the vadose zone to groundwater. A general correlation of concentration trends for technetium-99, nitrate, cobalt-60, iron, and cyanide in wells 299-E33-7 and 299-E33-38 and local distribution of these constituents indicates that the primary source of technetium-99 contamination was related to past discharges of ferrocyanide-containing waste to the BY cribs (PNNL-13080; PNNL-14049).

\subsubsection{Cobalt-60 and Cyanide}

Cobalt-60 and cyanide continued to be detected in a number of wells in the 200-BP-5 Operable Unit. Cobalt- 60 has a relatively short half-life ( 5.3 years) and is generally found at levels less than the drinking water standard $(100 \mathrm{pCi} / \mathrm{L})$. Cyanide is found at levels above the drinking water standard $(200 \mu \mathrm{g} / \mathrm{L})$ only near the BY cribs. These constituents are useful for distinguishing contaminant groups and contaminant sources and were generally associated with ferrocyanide waste streams generated by uranium scavenging operations conducted during the mid-1950s. Thus, cyanide and cobalt- 60 are generally found together in this area.

A plume of cyanide extends from the vicinity of the BY cribs toward the northwest (Figure 2.10-11). It is important to recognize that the cyanide plume identified north of the 200 East Area fence line has existed since monitoring began for this constituent in 1988. Since then, the plume has shifted westward as groundwater elevations have declined exposing basalt above the water table and causing wells to the east 
to dry. The maximum cyanide concentration in the operable unit in FY 2006 was $1,470 \mu \mathrm{g} / \mathrm{L}$ from well 299-E33-4 located in the north part of the BY cribs. Well 299-E33-38, located in the south part of the cribs, had a maximum cyanide value of $523 \mu \mathrm{g} / \mathrm{L}$ in FY 2006. Cyanide contamination trends in wells located at the BY cribs are similar to those of technetium-99, cobalt-60, and nitrate and may be related to past discharges of ferrocyanide waste to the BY cribs (PNNL-13080; PNNL-14049) and possibly BY Tank Farm (WIDS).

The highest cobalt-60 values in FY 2006 also were detected in wells monitoring the BY cribs, and the cribs are believed to be the source of this contamination. The highest cobalt-60 concentration in FY 2006 was in well 299-E33-4 (290 pCi/L) located in the north part of the BY cribs. Well 299-E33-38, located in the south part of the cribs, had a maximum cobalt-60 value of 59.3 pCi/L in FY 2006.

\subsubsection{Uranium}

Uranium contamination in the 200-BP-5 Operable Unit is limited to three isolated areas:

- Wells monitoring Waste Management Area B-BX-BY and BY cribs.

- Wells near the 216-B-5 injection well.

- Wells 299-E28-21 and 299-E28-18 at the 216-B-62 crib.

Wells in all three of these areas exceeded the drinking water standard for uranium (30 $\mu \mathrm{g} / \mathrm{L})$ during FY 2006.

Waste Management Area B-BX-BY. The body of evidence indicates that multiple sources contribute to the uranium groundwater contamination in Waste Management Area B-BX-BY. The primary source is currently considered to be the tank BX-102 overfill event. This is based on both the geophysical logging data collected by Stoller, Inc. (see Section 3.2.2.3) showing a cluster of high uranium concentrations in boreholes adjacent to the BX Tank Farm and isotopic analyses showing strong similarities between uranium in the groundwater plume and the overfill event (PNNL-14187; Christensen et al. 2004; Sobczyk 2004). The uranium from the overfill event likely migrated laterally through the vadose zone to the water table. The highest uranium concentrations in the 200-BP-5 Operable Unit during the last several years occur within and to the east of the BY Tank Farm (Figure 2.10-12). The contamination is present in a narrow northwest-southeast band. The BY cribs have been characterized as having a significant uranium inventory, $\sim 775 \mathrm{~kg}$ (RPP-26744), and should not be ruled out as a potential source of groundwater contamination. Uranium concentrations have been increasing in well 699-49-57A in the last several years $(15.4 \mu \mathrm{g} / \mathrm{L}$ reported in FY 2006). This may suggest that the plume is migrating to the northwest toward the Gable Gap area (Figure 2.10-13). Uranium concentrations of this magnitude also have been detected in proximal wells during the 1990s. In FY 2006, the highest uranium concentrations were detected in wells 299-E33-9 (804 $\mu \mathrm{g} / \mathrm{L}), 299-\mathrm{E} 33-18$ $(732 \mu \mathrm{g} / \mathrm{L})$, and 299-E33-38 (357 $\mu \mathrm{g} / \mathrm{L})$. Section 2.10.3.1 includes additional discussion of uranium at Waste Management Area B-BX-BY.

216-B-5 Injection Well. Uranium contamination is associated with the cesium-137, plutonium, and strontium-90 contamination found at the former 216-B-5 injection well. The highest uranium concentration detected in FY 2006 at this site was $96 \mu \mathrm{g} / \mathrm{L}$ in well 299-E28-23, located only $\sim 1$ meter from the injection well (Figures 2.10-1 and 2.10-12). Uranium concentrations are roughly stable in well 299-E28-23. Uranium values were significantly lower than this in wells 299-E28-24 (20.2 $\mu \mathrm{g} / \mathrm{L})$ and 299-E28-25 (17.1 $\mu \mathrm{g} / \mathrm{L})$ located farther from the injection well. During FY 2006, a uranium value of $37.0 \mu \mathrm{g} / \mathrm{L}$ was reported for well 299-E28-6, located south of the injection well. Uranium concentrations have been generally declining to stable in well 299-E28-6. It is not known if the source of uranium contamination in this well is the 216-B-5 injection well.

216-B-62 Crib. Uranium was detected consistently at levels slightly above the drinking water standard $(30 \mu \mathrm{g} / \mathrm{L})$ in wells monitoring the 216-B-62 crib, located northwest of B Plant

\section{Uranium}

contamination

in the 200-BP-5

Operable Unit is

limited to three

isolated areas:

Waste Management

Area B-BX-BY and

surrounding cribs,

216-B-5 injection

well, and 216-B-62

crib. 


\section{Wells near the 216-B-5 injection well have elevated concentrations of low-mobility contaminants including cesium-137, plutonium, and strontium-90.}

(Figure 2.10-12). Uranium concentrations were over $200 \mu \mathrm{g} / \mathrm{L}$ in the mid-1980s, but declined to current levels by the early 1990s. The maximum FY 2006 uranium concentration at the 216-B-62 crib was 37.4 $\mu \mathrm{g} / \mathrm{L}$ reported for well 299-E28-18. Uranium concentration levels between 15 and $18 \mu \mathrm{g} / \mathrm{L}$ also have been found along the west side of Low-Level Waste Management Area 1, but no wells in this area exceeded the drinking water standard in FY 2006 (Figure 2.10-12). The uranium detected on the west side of Low-Level Waste Management Area 1 may have originated at the 216-B-62 crib or its predecessor, the $216-\mathrm{B}-12 \mathrm{crib}$.

\subsubsection{Cesium-137 and Strontium-90}

Cesium-137 has relatively low mobility and is generally found near the source. Well 299-E28-23 near the 216-B-5 injection well has consistently had concentrations of cesium-137 greater than the drinking water standard $(200 \mathrm{pCi} / \mathrm{L})$ but less that the U.S. Department of Energy (DOE) derived concentration guide $(3,000 \mathrm{pCi} / \mathrm{L})$. In FY 2006, values of 880 and $902 \mathrm{pCi} / \mathrm{L}$ were reported for this well. All other wells sampled at this site had cesium-137 concentrations below the drinking water standard in FY 2006.

Several wells near the 216-B-5 injection well have had elevated concentrations of strontium-90. Four wells (299-E28-2, 299-E28-23, 299-E28-24, and 299-E28-25) had concentrations of strontium-90 above the drinking water standard $(8.0 \mathrm{pCi} / \mathrm{L})$ in FY 2006. Two of these wells continued to have strontium-90 concentrations greater than the DOE derived concentration guide $(1,000 \mathrm{pCi} / \mathrm{L})$ in past years and in FY 2006 (Figure 2.10-14). The highest strontium-90 concentration was reported for well 299-E28-23, with reported values of 3,290 and 3,390 pCi/L in FY 2006. Concentrations have been declining in this well since 2000. Strontium-90 also exceeded the DOE derived concentration guide in well 299-E28-25, with a value of 2,040 pCi/L reported in FY 2006.

In several wells near Gable Mountain Pond, strontium-90 concentrations rose in the 1990s and have declined since 2000 but remain above the drinking water standard. The plume did not change significantly during FY 2006. Strontium-90 was detected in groundwater at levels above the DOE derived concentration guide in well 699-53-47A in FY 2000, but was below the guide in FY 2003, 2004, 2005, and 2006. The concentration in this well was $679 \mathrm{pCi} / \mathrm{L}$ in FY 2006 (Figure 2.10-15). Well 699-53-48A sampling indicated an apparent decrease in strontium-90 in FY 2006 with a reported value of $397 \mathrm{pCi} / \mathrm{L}$ versus a value of $741 \mathrm{pCi} / \mathrm{L}$ in FY 2005. Strontium-90 concentrations in both wells have decreased from their peaks in the late 1990s.

\subsubsection{Plutonium}

Plutonium-239 and plutonium-240 were detected in past years in samples taken from several wells near the 216-B-5 injection well. Plutonium contamination is relatively immobile and, therefore, is found only near the injection well. The highest reported plutonium concentration in FY 2006 was for well 299-E28-23 that had reported filtered values of 7.32 and $8.42 \mathrm{pCi} / \mathrm{L}$ and unfiltered values of 17.4 and $19.7 \mathrm{pCi} / \mathrm{L}$, which are both below the DOE derived concentration guide for plutonium $(30 \mathrm{pCi} / \mathrm{L})$. The lower concentration in the filtered versus unfiltered samples suggests that a portion of the plutonium is associated with particulates. The concentration of plutonium in well 299-E28-23 has not exhibited a clear change in trend in recent years. Other wells sampled near the 216-B-5 injection well site have also had plutonium levels below the DOE derived concentration guide in recent years.

\subsubsection{Chloride and Sulfate}

Chloride and sulfate concentrations have been increasing over much of the 200-BP-5 Operable Unit since the mid to late 1990s and have recently exceeded the secondary drinking water standards in a few instances. Trend plots for selected wells at BY cribs, the 216-B-8 crib, and Waste Management Area $C$ for chloride and sulfate are provided in Figures 2.10-16 and $2.10-17$, respectively, to illustrate the increasing trend for these constituents. In particular, the chloride level in well 299-E33-4 increased rapidly in FY 2006 and exceeded the secondary drinking water standard of $250 \mathrm{mg} / \mathrm{L}$. However, this well is nearly dry and may 
not be representative of general aquifer conditions. The secondary drinking water standard of sulfate $(250 \mathrm{mg} / \mathrm{L})$ has also recently been exceeded in wells 299-E33-4 and 299-E33-16.

\subsubsection{Mercury}

Low levels of mercury (drinking water standard $=2 \mu \mathrm{g} / \mathrm{L}$ ) have appeared sporadically in the northwest portion of the 200 East Area in some wells monitoring the BY cribs and low-level burial grounds. In most wells in this area, samples have been analyzed for mercury routinely as far back as the late 1980s to the present. All but a few results during this period have historically been below detection limits (minimum detection limits ranging from 0.05 to $0.2 \mu \mathrm{g} / \mathrm{L}$ ). Recently, however, mercury results in a few wells have been above detection limits with the most conspicuous of these occurring in well 299-E33-7 in November 2006 at a concentration of $4.3 \mu \mathrm{g} / \mathrm{L}$. This well is situated at the northwest corner of the $216-\mathrm{B}-50 \mathrm{crib}$ in the BY cribs facility. Well 299-E33-34, which is located near the northeast corner of Low-Level Waste Management Area 1, has also shown consistent detections of mercury in the last five consecutive samples since 2003, with a maximum concentration of $0.19 \mu \mathrm{g} / \mathrm{L}$ in December 2005. Section 2.10.3.3 provides additional discussion of mercury in this area.

\subsubsection{Operable Unit Monitoring}

CERCLA monitoring requirements in the 200-BP-5 Operable Unit have been defined in the sampling and analysis plan (DOE/RL-2001-49). The sampling and analysis plan was revised in late FY 2004 to integrate Atomic Energy Act (AEA) monitoring and make slight modifications in the 200-BP-5 monitoring network. The revised monitoring plan was implemented in FY 2005. CERCLA monitoring includes sampling of the regional plumes, 216-B-5 injection well site, BY cribs, and Gable Mountain Pond. Results of monitoring are discussed in Section 2.10.1. An interim or final record of decision has not been established yet for the 200-BP-5 Operable Unit. This report is the only formal report presently being prepared on a regular basis for the unit.

The 200-BP-5 monitoring network and analytes are listed in Appendix A. In FY 2006, sampling was planned for 66 wells. Of these, 58 wells were successfully sampled during FY 2006. Seven wells could not be sampled until early FY 2007 because of scheduling constraints (see Appendix A). Well 299-E34-7 could not be sampled because it is now dry.

\subsubsection{Facility Monitoring}

This section describes results of monitoring at individual units such as treatment, storage, and disposal units or tank farms. Some of these facilities are monitored under the requirements of RCRA for hazardous waste constituents and AEA for source, special nuclear, and by-product materials. Data from facility-specific monitoring are also integrated into the CERCLA groundwater investigations. Hazardous constituents and radionuclides are discussed jointly in this section to provide comprehensive interpretations of groundwater contamination for each facility. As discussed in Section 1.2, pursuant to RCRA, the source, special nuclear, and by-product material components of radioactive mixed waste are not regulated under RCRA and are regulated by DOE acting pursuant to its AEA authority. Therefore, while this report may be used to satisfy RCRA reporting requirements, the inclusion of information on radionuclides in such a context is for information only and may not be used to create conditions or other restrictions set forth in any RCRA permit.

The 200-BP-5 Operable Unit contains six RCRA sites with groundwater monitoring requirements: Waste Management Area B-BX-BY, 216-B-63 trench, Low-Level Waste Management Areas 1 and 2, Liquid Effluent Retention Facility, and Waste Management Area C. This section summarizes results of statistical comparisons, assessment studies, and other developments for FY 2006. Groundwater data are available in the Hanford
CERCLA

monitoring in

the 200-BP-5

Operable Unit

includes sampling

of the regional

plumes, 216-B-5

injection well

site, BY cribs, and

Gable Mountain

Pond. 
Environmental Information System (HEIS 1994) and on the data files accompanying this report. Additional information including well and constituent lists, maps, flow rates, and statistical tables are included in Appendix B.

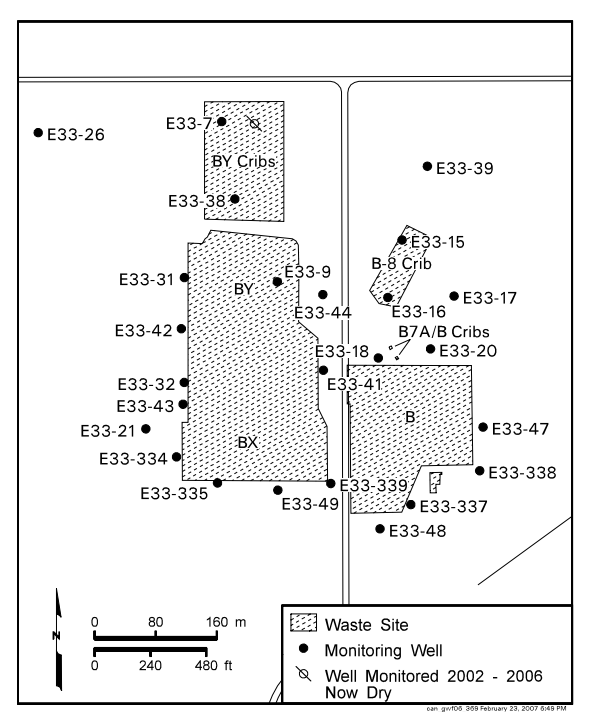

\subsubsection{Waste Management Area B-BX-BY}

Located in the northwest part of the 200 East Area, this waste management area consists of the B, BX, and BY Tank Farms along with ancillary waste transfer lines and diversion boxes. Monitored under the requirements of RCRA and AEA, it is currently in a RCRA groundwater quality assessment program because, in 1996, elevated specific conductance was found in a downgradient well above the critical mean. In 1998, a first determination assessment showed recent fresh water flooding from leaking water lines, most likely, drove residual tank-related waste in the vadose zone to the groundwater close to well 299-E33-41 (PNNL-11826). Based on 40 CFR 265.93(d) paragraph (7), the site must continue in quarterly monitoring to determine contaminant levels and the rate and extent of migration until final facility closure (PNNL-11826). Sampling is also conducted to monitor for new occurrences of groundwater contamination that may be related to farm operations. (Due to the complex hydrologic system and uncertainties in determining flow rate and direction, the rate of contaminant migration is not provided for the waste management area.)

Sampling was conducted quarterly in most wells surrounding the facility and in nearby past-practice liquid disposal facilities to differentiate groundwater contamination that is tank-related from that associated with the surrounding waste facilities. One exception to the quarterly sampling is well 299-E33-9, located in the BY Tank Farm, which is the center of uranium contamination $(804 \mu \mathrm{g} / \mathrm{L})$ in this area. This well was scheduled for quarterly sampling, but because of limited tank farm access, it was sampled only twice during FY 2006. The fourth quarterly sampling was missed in three wells and delayed until early FY 2007 in one well (Appendix B). Some far-field wells were sampled semiannually to provide information under surrounding past-practice liquid effluent disposal facilities such as the BY cribs, the 216-B-8 crib, and the 216-B-7A and 216-B-7B cribs. The far-field wells are not included in the assessment plan, but data from these wells help distinguish non-tank farm sources that may have impacted groundwater quality from tank-related sources. Radionuclides are tracked under AEA monitoring at the site. Appendix B includes a well location map, an estimate of local migration rates, a list of wells and the constituents monitored for Waste Management Area B-BX-BY.

In summary, assessment studies have identified several distinct suites of contaminants with possibly different sources based on chemical associations, spatial and temporal relationships, historic plume movement, knowledge of process chemistry, pattern matching, plume tracking and characteristic chemical ratios of constituent concentrations (PNNL-13116; PNNL-14187; PNNL-14548; PNNL-SA-39825; PNNL-SA-50098). A brief description of these contaminant suites is provided below. For a more complete discussion, see PNNL-15070; PNNL-13116; PNNL-14187; PNNL-14548; PNNL-SA-39825; PNNL-13788.

- Nitrate, technetium-99, sulfate, uranium and nitrite. These contaminants are located under and southeast of the BY Tank Farm. With the recent migration of nitrite and uranium to the vicinity of the 216-B-8 crib, this local area now may include the area east of the BY Tank Farm. Currently, technetium-99, nitrate, and uranium are found in concentrations above the drinking water standards of $900 \mathrm{pCi} / \mathrm{L}, 45 \mathrm{mg} / \mathrm{L}$, and $30 \mu \mathrm{g} / \mathrm{L}$, respectively. The uranium concentration in well 299-E33-9 of $804 \mu \mathrm{g} / \mathrm{L}$ is the highest in the 200 East Area. Further assessment of the source is ongoing. Recent results are presented later in this section.

- Tritium and nitrate. This contaminant suite is found on the southwest corner and along the south border of the waste management area. The tritium concentration rose sharply from the local background value of $\sim 1,800 \mathrm{pCi} / \mathrm{L}$ to over $16,000 \mathrm{pCi} / \mathrm{L}$ in 
seven wells at nearly the same time beginning in early 1999. The sharply rising trend indicated the wells are close to point of contaminant entry into the groundwater (see Figure 2.10-12 in PNNL-15070). Movement through the vadose zone from a perched water table with elevated tritium and low levels of nitrate located $\sim 4.5$ meters above the water table under the BX Tank Farm is, most likely, the source of this contamination. The contamination in this perched water table is probably associated with the in-tank solidification process because this is the only local source for large quantities of tritium condensate. These wastes were generated in the 1960s and 1970s. In the last few years, nitrate concentrations decreased. However, during FY 2006, nitrate levels again started to increase while tritium concentrations decreased. These small increases in nitrate may be associated with increasing technetium-99 and uranium concentrations, apparently migrating from the more highly contaminated suite found to the north. Alternatively, or in addition, this contamination may be the result of spreading of the source in the vadose zone or dispersion in groundwater.

- Technetium-99, nitrate, uranium, sulfate, tritium, cobalt-60, and cyanide. This contaminant suite, found under and around the BY cribs, comprises the highest levels of contamination in the groundwater at the B complex of facilities, except for the maximum uranium concentration under the BY Tank Farm. This suite is associated with waste released in the past to the BY cribs

In FY 2006, concentrations of technetium-99, nitrate, and tritium under the BY cribs exceeded historic concentrations. FY 2006 maximum concentrations under the cribs were technetium -99 at $42,900 \mathrm{pCi} / \mathrm{L}$, nitrate at $3,150 \mathrm{mg} / \mathrm{L}$, uranium at $338 \mu \mathrm{g} / \mathrm{L}$, sulfate at $282 \mathrm{mg} / \mathrm{L}$, cyanide at $1,470 \mu \mathrm{g} / \mathrm{L}$, cobalt- 60 at $290 \mathrm{pCi} / \mathrm{L}$, and tritium at $95,500 \mathrm{pCi} / \mathrm{L}$. Uranium data from the late 1950 s until the late 1980 s are not available for comparison to current groundwater concentrations.

- Nitrate, nitrite, technetium-99, and uranium. Located under the 216-B-8 crib is another unique grouping of contaminants. Nitrate levels in FY 2006 ranged from $11 \mathrm{mg} / \mathrm{L}$ south of the BX Tank Farm to 3,200 mg/L beneath the BY cribs. Until recently, this area lacked the high levels of nitrite and uranium associated with the contamination under the BY Tank Farm. Since 2003, nitrite has been detected consistently in the groundwater with a maximum value of $624 \mu \mathrm{g} / \mathrm{L}$ observed in 2005. Normally, uranium in this vicinity is present in the groundwater ranging from 25 to $35 \mu \mathrm{g} / \mathrm{L}$ from 2003 to 2006, significantly lower levels than found under the BY cribs. The most recent value from August 2006 sampling is $344 \mu \mathrm{g} / \mathrm{L}$. This sample was re-analyzed to confirm the sharp increase in uranium at the 216-B-8 crib. Until recently, it appeared that residual waste left in the vadose zone under and around the 216-B-8 crib was, most likely, the source for groundwater contamination in this location. The elevated nitrite and uranium suggest influences from the tank farms may be affecting groundwater conditions at the 216-B-8 crib. Further evidence of changing groundwater conditions is seen in the sharp increases in nitrate from 664 to $881 \mathrm{mg} / \mathrm{L}$ and in technetium-99 from 3,360 to 11,800 pCi/L during FY 2006.

Although the first two contaminant groups are attributed to waste sources associated with the tank farms, contamination from the BY cribs may be affecting the groundwater in the northern part of the waste management area. Uranium contamination extends to the northwest from beneath Waste Management Area B-BX-BY and surrounding cribs. Also, based on the changing conditions at the 216-B-8 crib and farther south, groundwater contamination associated with the tank farms may be affecting the levels and suite of contaminants east and south of the farms. Consequently, the following discussion, which covers the FY 2006 assessment activities, will include reference to each of the four suites of contaminants as necessary, to distinguish between the sources and migration routes.

Due to the large uncertainties associated with groundwater flow direction and rate beneath Waste Management Area B-BX-BY, the rate of contaminant migration is not provided here.

\section{Assessment studies at Waste Management Area B-BX-BY have identified several distinct groups of contaminants.}




\section{Sources within}

Waste Management

Area B-BX-BY

have contributed

to groundwater

contamination

with uranium,

technetium-99, and

nitrate.
The discussion that follows provides more than one conceptual model for groundwater flow based on different lines of evidence. The remedial investigation/feasibility study process for 200-BP-5 Operable Unit will collect additional information that is expected to reduce the uncertainties associated with groundwater flow and ultimately lead to a single conceptual model.

The migration of the uranium plume in the past 10 years indicates flow to the northwest (Figure 2.10-12). The plume likely had its source in Waste Management Area B-BX-BY. If the increasing uranium in wells northwest of the waste management area came from the same source, it would be concluded that the plume is migrating to the northwest. However, there are no direct hydraulic gradient data to confirm this. Uranium levels in the south part of the tank farms are much lower. Increasing trends for nitrate, technetium-99, and uranium in wells on the south boundary of the site (Figures 2.10-18, 2.10-19, and 2.10-20) may reflect some component of southward flow, but may also be explained by contaminants spreading in the vadose zone and/or dispersing in groundwater.

Because the hydraulic gradient is nearly flat across the 200 East Area, small inaccuracies in water elevations are important when estimating flow direction and rate. Changing atmospheric pressure also influences water levels, although these effects are reduced by taking water-level measurements at a site over a short time interval during periods when atmospheric pressure is relatively stable. Some information indicates the possibility of generally southward groundwater flow beneath Waste Management Area B-BX-BY.

An analysis of gradients inferred from water-level elevations presented in RPP-23748 suggests a southwest regional flow direction (Figure 2.10-21). This study used water-table elevations from wells 299-E33-14, 699-49-57A and 699-50-53A from 1999 to 2001, providing a regional view of flow. A similar analysis, using water elevations from wells around the B-BX-BY waste management area from 1991 to 2005 is presented in Figure 2.10-22. The seven wells used in this analysis form the only subset of wells with a common elevation survey, thereby eliminating one of the major sources of error in water elevations. Hydrographs, showing the relative differences the water table over time were presented in Hartman 2004 . $^{\text {(a) }}$ Corrections for borehole deviations were made in data from two wells that showed consistently low elevations compared to nearby wells. This analysis indicates local flow at the waste management area may be to the south. The remaining potential source of error, introduced by wells in which deviation has not been determined, may need to be addressed to confirm this conclusion.

As might be expected, the edge of the aquifer near the basalt subcrop in the north and northeast corner of 200 East Area is slowly receding back to pre-Hanford conditions as water levels go down. If water levels eventually fall to estimated pre-Hanford water levels, most of the area under Waste Management Area B-BX-BY and the Low-Level Waste Management Area 2 will be devoid of aquifer. The aquifer has already receded from several local areas leaving basalt above the water table north of the BY cribs and in the northern part of Low-Level Waste Management Area 2. Recent drilling of well 699-48-50B, north of low-level burial ground 1, confirm the basalt above groundwater extends farther to the west than previously known, potentially blocking flow to the north in this area. The top of basalt, which forms the base of the thin unconfined aquifer, dips south to southwest on an erosional surface with up to 3.5 meters of local relief. Consequently, the influence of the basalt surface on flow in the unconfined aquifer in this general area can be expected to vary by specific location.

Contaminant levels continued to increase to new maxima across Waste Management Area B-BX-BY and the BY cribs. Contaminant trends are shown for wells that either

(a) Hartman, MJ. 2004. Quarterly Resource Conservation and Recovery Act Groundwater Monitoring Data for the Period July through September, 2004. Letter Report from Pacific Northwest National Laboratory to U.S. Department of Energy, Richland, Washington. 
display a recent maximum value or show sharp annual increases in concentrations for nitrate, technetium-99, cyanide and uranium in Figures 2.10-23, 2.10-24, 2.10-25, and 2.10-26. With the exception of uranium under the BY Tank Farm, the highest contaminant concentrations are found under the BY cribs with levels decreasing to the south through the waste management area. For example, nitrate concentrations in FY 2006 range from $\sim 3,200$ to $916 \mathrm{mg} / \mathrm{L}$ under the BY cribs (Figure 2.10-23). Around the tank farms, maximum nitrate values in FY 2006 range from $881 \mathrm{mg} / \mathrm{L}$ at the $216-\mathrm{B}-8$ crib to $365 \mathrm{mg} / \mathrm{L}$ in well 299-E33-44 on the east side of the BY Tank Farm (Figure 2.10-24). The August sampling event was missed in well 299-E33-44. Increases were observed to the east and south at wells 299-E33-16 (881 mg/L) and 299-E33-18 (536 mg/L), as shown in Figure 2.10-24. Nitrate concentrations on the south border of the tanks farms are increasing, but are below the drinking water standard of $45 \mathrm{mg} / \mathrm{L}$.

Cyanide concentrations continue to increase under the BY cribs, ranging from 1,470 to $219 \mu \mathrm{g} / \mathrm{L}$ (Figure 2.10-23). In general cyanide is limited to the groundwater under the BY cribs, the primary location within the B complex of facilities that scavenged waste was disposed to the ground. Hence, it is expected that cyanide be found in the groundwater under the cribs. In the past, low levels of cyanide were also found under the BY Tank Farm in well 299-E33-9, the location of the maximum uranium values. However, during FY 2006, low levels of cyanide are found east of the BY Tank Farm in well 299-E33-44 with a maximum value of $21.4 \mu \mathrm{g} / \mathrm{L}$ and at the $216-\mathrm{B}-8 \mathrm{crib}$ at $11.4 \mu \mathrm{g} / \mathrm{L}$. The $216-\mathrm{B}-8 \mathrm{crib}$ did not receive scavenged waste.

Large increases in technetium-99 contamination were also observed across the site (Figure 2.10-25), especially under the BY cribs with a concentration of $42,900 \mathrm{pCi} / \mathrm{L}$ in well 299-E33-4 and 22,000 pCi/L at well 299-E33-38. Increasing concentrations were also observed around the tank farms to the south. For example, in well 299-E33-18, the concentration increased from $6,000 \mathrm{pCi} / \mathrm{L}$ in April to $14,000 \mathrm{pCi} / \mathrm{L}$ in September 2006. Likewise in well 299-E33-16, the concentration increased from 5,510 to $11,800 \mathrm{pCi} / \mathrm{L}$ over the same time period. Levels are also increasing on the west side of the Waste Management Area B-BX-BY with levels ranging from 3,120 pCi/L to below the drinking water standard at $408 \mathrm{pCi} / \mathrm{L}$. Technetium-99 is also increasing along the southern edge of the BX and B Tank Farms with maximum values at about half the drinking water standard. (A sample collected in November 2006 exceeded the drinking water standard, indicating an increasing trend at this location.)

Uranium trends for selected wells are shown in Figure 2.10-26. The highest value in the groundwater is $804 \mu \mathrm{g} / \mathrm{L}$, which is located under the BY Tank Farm in well 299-E33-9, and was last sampled in June 2006. Large increases in uranium concentration were observed in August at both the 216-B-8 crib with a value of $344 \mu \mathrm{g} / \mathrm{L}$ in well 299-E33-16 and the 216-B-7A and $216-\mathrm{B}-7 \mathrm{~B}$ cribs at $732 \mu \mathrm{g} / \mathrm{L}$ in well 299-E33-18. The sample in well 299-E33-16 was re-analyzed and confirmed these results. In well 299-E33-38, one of the only locations under the BY cribs to have elevated uranium, concentrations have not changed significantly since May 2004 when uranium was at $337 \mu \mathrm{g} / \mathrm{L}$. The August 2006 value was $338 \mu \mathrm{g} / \mathrm{L}$.

Stiff diagrams using major ion chemistry from groundwater data from B-BX-BY wells highlight major sources of groundwater contamination (Figure 2.10-27). Data were compared, both temporally and spatially, for locations under and around the waste management area. The cations used are sodium, potassium, calcium and magnesium while the anions are chloride, bicarbonate, sulfate and nitrate. Groundwater data from beneath most surrounding facilities in the early 1990s produce similar stiff diagram signatures. This was during a period when groundwater contamination was low, indicating little impact from waste facilities on groundwater quality during this time.

A comparison of Stiff diagrams, based on more recent data, provide at least three observations (right side of Figure 2.10-27). First as levels of contamination increased, patterns with unique signatures developed under the BY cribs in wells 299-E33-7 and 299-E33-38.

\section{The historical discharge of effluent to the ground in and around Waste Management Area B-BX-BY resulted in complex patterns of groundwater contamination.}




\section{Comparison of Stiff diagrams for wells 299-E33-9 and 299-E33-18 may suggest separate contaminant sources.}

Second, south of the BY cribs in well 299-E33-44 as nitrate and technetium-99 concentrations increased with decreasing uranium in the last few years, the major ion chemistry pattern begins to resemble that under the BY cribs.

Finally, the most singular pattern, seen in only one location, is under the BY Tank Farm at well 299-E33-9. This local area of the groundwater is the center of the uranium plume. Although it has been suggested the high levels of uranium under the BY Tank Farm are associated with the same uranium source as found in the groundwater at well 299-E33-18, a comparison of recent Stiff diagrams of these two wells may suggest other conclusions. The major ion chemistry patterns are different. These results might suggest a separate contaminant source causing contamination under the BY Tank Farm that is different from either that under the BY cribs or the source associated with contamination found at the 216-B-7A and 216-B-7B cribs.

Further evidence that contamination found in the groundwater near the $216-\mathrm{B}-7 \mathrm{~B}$ and 216-B-7A cribs may be from a local source comes from analyses of spectral gamma logging for two wells and one characterization borehole. Well 299-E33-41 is located between well 299-E33-18, near the 216-B-7A and 216-B-7B cribs and borehole 299-E33-45, located inside the BX Tank Farm. It has been suggested that uranium in the groundwater at well 299-E33-18 is directly associated with a pocket of highly contaminated soil found in borehole 299-E33-45. This contaminated soil, which has high levels of technetium-99, nitrate and uranium, has been linked to an early metal waste leak from the 241-BX-102 tank. Spectral gamma logs were recently run in both groundwater wells. Based on analyses by scientists at Stoller, Inc., the data provide the following observations (see Section 3.2.2.3).

First, the level of uranium concentration at a depth of $\sim 73$ meters below the top of casing at well 299-E33-18 increased significantly from 439 to $1,237 \mathrm{pCi} / \mathrm{g}$ over the last 9 years while levels in well 299-E33-41 remained steady at about 1,000 pCi/g. When uranium values for the isotopes, uranium-235 and uranium-238 are compared on log-log cross plots for well 299-E33-18 and borehole 299-E33-45 it is seen that the two distinct trends exist (Figure 2.10-28). In the BX-102 tank leak characterization borehole (299-E33-45), uranium concentrations fall on a trend defined by the ratio uranium-235/uranium-238 equal to 0.04 while at the 216-B-7A and 216-B-7B cribs data from well 299-E33-18 follow a uranium-235/ uranium 238 ratio of 0.08 . This difference suggests that the uranium observed at the $216-\mathrm{B}-7 \mathrm{~A}$ and $216-\mathrm{B}-7 \mathrm{~B}$ cribs has twice the enrichment ratio as contaminated soils near the BX-102 tank and, thus, the contaminant sources are different for the two areas. In between the two source facilities, results from well 299-E33-41 appear to correlate to 216-B-7A and 216-B-7B facilities above 59 meters in the well. Below this depth, the data follow the trend associated with the BX-102 tank leak. Apparently, the two different contaminant sources affected the soils at well 299-E33-41.

Results of assessment investigations (PNNL-14187) indicate that most contamination in the groundwater plumes may be associated with residual waste left in the soil from past waste discharges. This historical discharge of effluent to the ground in and around Waste Management Area B-BX-BY resulted in complex patterns of groundwater contamination. Evidence was discussed in PNNL-14187, with further data shown above, that may indicate multiple vadose zone source areas are contributing to groundwater contamination in multiple areas. However, another explanation is that contamination that was originally pushed to the north is now moving back into the waste management area along the structure on the basalt surface. Alternatively, dense pockets of waste may exist on the basalt surface left from the original discharges to the crib and tank-farm-associated leaks in the past. Further investigations are planned by the 200-BP-5 remedial investigation/feasibility studies to assist in developing and evaluating alternate conceptual models to explain the observed contaminant trends. Quarterly monitoring of the groundwater at Waste Management Area B-BX-BY will continue. 


\subsubsection{216-B-63 Trench}

Interim detection monitoring at the 216-B-63 trench requires that the 12 network wells be sampled semiannually for total organic carbon, total organic halides, specific conductance, $\mathrm{pH}$, temperature, and turbidity (Appendix $\mathrm{B}$ ). Groundwater quality parameters including alkalinity, metals, and anions are also monitored, but on an annual schedule with phenols. No specific evidence for hazardous waste impacting groundwater has been detected at the 216-B-63 trench.

In June 2006, three wells exceeded the critical range for $\mathrm{pH}$ (downgradient wells 299-E33-36 and 299-E34-8, and upgradient well 299-E27-11), and one downgradient well (299-E33-37) exceeded the critical mean for total organic halides. The $\mathrm{pH}$ exceedance exhibited the same pattern as an earlier episode involving the narrow critical range at 216-B-63 trench. No resampling was scheduled for the $\mathrm{pH}$ exceedance. Verification sampling was conducted for well 299-E33-37 in November 2006. Results of total organic halogen analyses from split samples sent to two laboratories were non-detects, indicating that the results from the April 2006 samples that exceeded the critical mean were not valid.

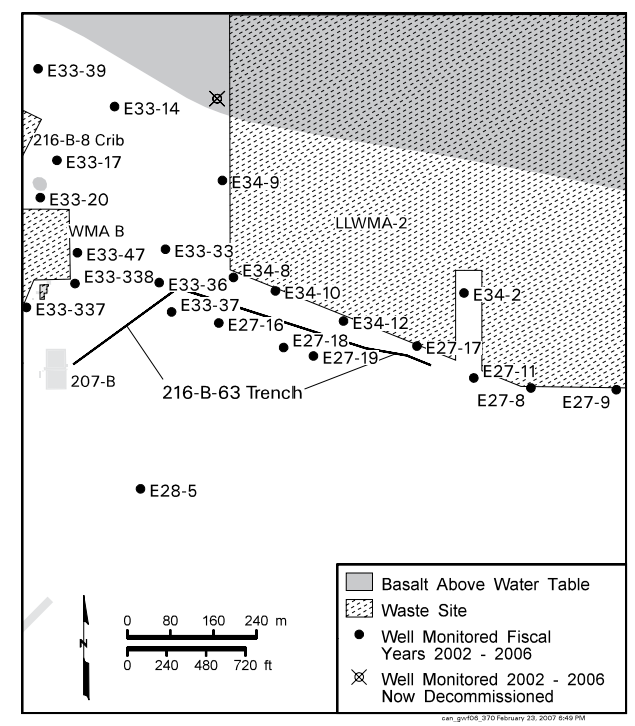

Groundwater flow direction or rate beneath the 216-B-63 trench have not changed during FY 2006. The hydraulic gradient is too low to define a dominant flow direction or rate with certainty. The flat gradient is due in part to the highly transmissive Hanford formation sands and gravels that dominate the suprabasalt stratigraphy.

\subsubsection{Low-Level Waste Management Area 1}

Groundwater at Low-Level Waste Management Area 1 continued to be monitored under RCRA and AEA. Under 40 CFR 265.93(b) as referenced by WAC 173-303-400, the well network was sampled semiannually for RCRA indicator and site-specific parameters (PNNL-14859; DOE/RL-2000-72). All 17 wells were successfully sampled during both scheduled samplings. Appendix B includes a well location map, a list of wells, and the constituents monitored.

The groundwater gradient in this part of the 200 East Area is almost flat, making the determination of groundwater flow direction difficult (Figure 2.10-3). Based on movement of the uranium plume, flow direction to the northwest is indicated (Figure 2.10-12). Past analysis of water-level data also indicate flow toward the northwest. Trend surface analysis performed on FY 2003 through FY 2005 water-level data indicated highly variable flow direction (PNNL-15670). No meaningful flow rate could be calculated, given the variability and low gradient. The FY 2006 data were used to define a flow direction to the north, as discussed in the following paragraphs. However, considerable uncertainty remains in the determination of a dominant flow direction. In addition, the temporal and spatial variability in flow are not understood. For these reasons, no attempt will be made to update the interim status designation of upgradient and downgradient wells until a stable flow direction is re-established.

In 2005, a network of 10 groundwater wells was established in the vicinity of Low-Level Waste Management Area 1 to conduct a detailed water-level study. The wells are all screened across the water table with relatively short saturated screened intervals, have been surveyed in the North American Vertical Datum of 1988 (NAVD88), and had gyroscopic surveys to correct the water-level data for deviations of the boreholes from vertical.

A trend surface analysis was performed on the manual measurements collected during FY 2006. For each date that measurements were collected, the least squares fit of a plane to the observed hydraulic heads was determined using the spreadsheet method of Devlin (2003), modified to provide the gradient direction as degrees from true north (azimuth). However, three wells exerted a significant influence

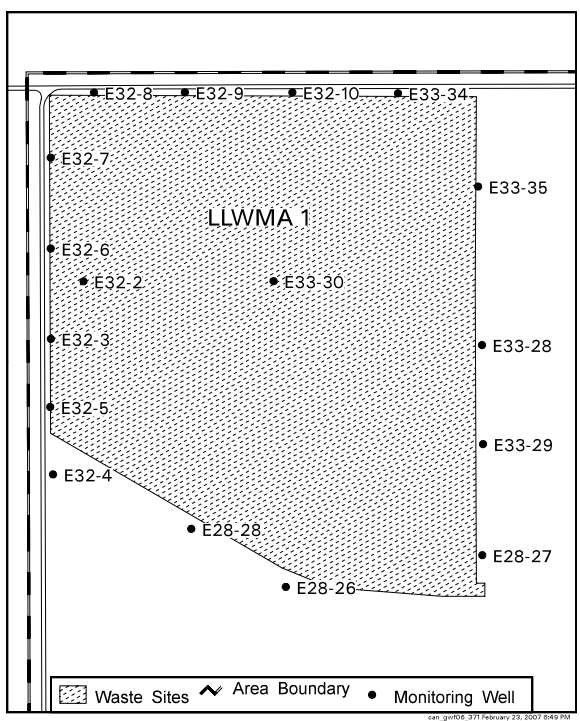




\section{Contaminant}

levels beneath

Low-Level Waste

Management Area 1

are consistent with

regional plumes. on the results, suggesting that significant errors remain in the observed hydraulic head data. A possible source of this error is inaccuracies in the well elevation surveys. Thus the trend surface analysis of the remaining seven wells is considered to be the best estimate of flow direction and gradient for fiscal year 2006. The seven well network indicated an average gradient of $2.2 \times 10^{-5}$ meter per meter with a direction of 358 degrees (i.e., north).

An additional source of uncertainty in water-level measurement and comparison is due to fluctuations in barometric pressure. Discussions concerning the effect of barometric pressure on well water-level measurements and its relationship to surrounding aquifer total head are presented in detail in Rasmussen and Crawford (1997), PNNL-13078, and Spane (2002). In FY 2006, PNNL demonstrated the general process for removing barometric pressure fluctuations from Low-Level Waste Management Area 1 well 299-E32-6, using automated water-level logging data for October 2005. Barometric pressures used in this study were obtained from measurements provided by the Hanford Meteorological Station network for Station \#6, which is located in the northeast quadrant of the 200 East Area.

Figure 2.10-29 shows that the total head response in well 299-E32-6 closely mimics the barometric pressure signal, due to the rapid transmission of the barometric pressure to the water table. Also shown on the figure is the barometric-pressure corrected total head response, based on the multiple-regression deconvolution method described in Rasmussen and Crawford (1997) and PNNL-13078. As shown in the corrected plots in the figure, the effects of temporal barometric pressure fluctuations have been effectively removed. The corrected response represents what well water-level and total head response would be without barometric pressure fluctuation effects (i.e., under uniform or linear trending barometric pressure conditions). This technique may prove useful for future determinations of flow rates and directions in areas of low gradient.

Specific conductance continued to exceed the statistical upgradient/downgradient comparison value (critical mean) in downgradient well 299-E33-34, with values ranging from 1,401 to $1,462 \mu \mathrm{S} / \mathrm{cm}$. This continues a generally increasing trend since 1998 (Figure 2.10-30). Well 299-E32-10, west of well 299-E33-34, also exceeded the statistical comparison value in the second half of FY 2005 but not in FY 2006 due to increasing background concentrations. The specific conductance exceedance is related to a regional nitrate plume (Figure 2.10-6). DOE notified Ecology of the exceedance in 1999. Anomalous specific conductance measurements and major ion concentrations in well 299-E32-5 are discussed in the following paragraphs.

The December 2005 sample from well 299-E32-5 had elevated cation and anion concentrations. The reported nitrate was above the primary drinking water standard and the reported sulfate was above the secondary standard, although the specific conductance was on trend. However, it was found that the post-sampling specific conductance measurement was elevated at $946 \mu \mathrm{S} / \mathrm{cm}$ (the quadruplicate measurements for the sample event are taken immediately before filling the sampling bottles). During verification sampling in February 2006, the specific conductance increased sharply, then stabilized at $\sim 650 \mu \mathrm{S} / \mathrm{cm}$. Calcium, magnesium, sodium, chloride, nitrate and sulfate were elevated in the February sample but were lower than the December result. Chromium was somewhat elevated with a maximum concentration of $35.4 \mu \mathrm{g} / \mathrm{L}$ in the December sample. No corresponding increase was noted in the radionuclides. Only nitrate was above the drinking water standard. Although nitrate was used extensively at Hanford it is also found in the undisturbed sediments. Increases in sulfate were noted at the State-Approved Land Disposal Site when it first started operation and are attributed to leaching of sulfate from the sediments. Subsequent sampling results were variable but indicate the increased major ion concentrations continue.

Several wells showed elevated total organic carbon results for the June 2006 sampling. None of the wells had average concentrations for the replicate samples that were above the statistical comparison value. The elevated results appear to be related to laboratory error. 
Widespread analytical issues with total organic halides were reported in PNNL-15670, Appendix C for FY 2005. Results for Low-Level Waste Management Area 1 quadruplicate samples remained variable in FY 2006, but all averages were below the statistical comparison value. The $\mathrm{pH}$ results for all wells were below the statistical comparison value in FY 2006. Statistical comparison values to be used for indicator parameters in FY 2007 are listed in Appendix B.

Very low levels of mercury are consistently seen in recent samples from well 299-E33-34, located in the northeast corner of Low-Level Waste Management Area 1 (Figure 2.10-31). The drinking water standard is $2 \mu \mathrm{g} / \mathrm{L}$. Mercury is not commonly detected in Hanford groundwater samples and is not considered highly mobile in typical conditions. Wells 299-E33-7 and 299-E33-38 near the BY cribs were also sampled for mercury because those areas are believed to be the source of other contaminants found in well 299-E33-34. The results indicate the presence of mercury beneath these facilities (Figure 2.10-31). The highest value, $4.30 \mu \mathrm{g} / \mathrm{L}$, was detected in well 299-E33-7 in the northwest corner of the BY cribs. Well 299-E33-34 has been impacted by technetium-99, nitrate, cyanide, and other constituents attributed to sources in or near the BY cribs and the B-BX-BY tank farms. During the May 2006 sampling, one well (299-E33-7), located at the BY cribs, had a reported mercury concentration of $3.1 \mu \mathrm{g} / \mathrm{L}$. That sample was analyzed out of hold time due to blank contamination in the initial analysis.

Performance assessment monitoring of radionuclides at Low-Level Waste Management Area 1, under AEA authority, is designed to complement the RCRA detection monitoring and is aimed specifically at monitoring radionuclide materials that are not regulated under RCRA. Performance assessment monitoring at Low-Level Waste Management Area 1 is performed per DOE/RL-2000-72 to gather data to assess changes in concentrations at downgradient wells and to provide sufficient supporting information from upgradient wells to interpret the changes. Iodine-129, technetium-99, tritium, and uranium are monitored semiannually specifically for performance assessment.

Contaminant characteristics at Low-Level Waste Management Area 1 include the following:

- Technetium 99 concentrations continued to be elevated in several wells (299-E33-34, 299-E32-10, 299-E33-35) near the northeast corner of Low-Level Waste Management Area 1. The highest concentrations in FY 2006 remained in well 299-E33-34 and showed an increase from the fairly stable values of previous years (Figure 2.10-32). The maximum technetium- 99 concentration was $11,000 \mathrm{pCi} / \mathrm{L}$ in the June 2006 sample. The contamination levels are consistent with regional plumes that appear to have originated in the vicinity of the BY cribs (Figure 2.10-9). Two wells (299-E32-2 and 299-E32-6) near the west boundary of Low Level Waste Management Area 1 have also shown generally increasing technetium-99 concentrations in recent years that continued in FY 2006. However, levels remained $<60 \mathrm{pCi} / \mathrm{L}$ and were only slightly higher than surrounding and upgradient wells.

- Uranium values remained relatively steady in well 299-E33-34 in the northeast corner of the waste management area after an increase in 2002. The average uranium concentration in well 299-E33-34 was $96.9 \mu \mathrm{g} / \mathrm{L}$ with a maximum of $103 \mu \mathrm{g} / \mathrm{L}$ in the June 2006 sample. This is associated with a relatively recent plume with possible origins in the vicinity of Waste Management Area B-BX-BY (Figure 2.10-12). The uranium plume has impacted other wells surrounding this part of the waste management area (e.g., wells 299-E32-10 and 299-E33-35), but concentrations are significantly less (22.4 and $5.18 \mu \mathrm{g} / \mathrm{L}$, respectively).

- Uranium levels stayed fairly stable in most wells on the west side of Low-Level Waste Management Area 1 in FY 2006. Levels remained below the drinking water standard. The history of uranium contamination prior to regular monitoring of the burial ground wells is difficult to establish, but the source may have been cribs west of B Plant and south of the waste management area.

\section{Levels of specific conductance, total organic carbon, and total organic halides in an upgradient well at Low-Level Waste Management Area 2 were elevated. The source is unknown.}


- Tritium contamination is also believed to be from regional plumes, not related to the burial grounds (Figure 2.10-4). Tritium concentrations were less than the drinking water standard in FY 2006. Concentrations that had been increasing along the north and east side of the waste management area appear to have declined slightly in late FY 2006 except in well 299-E33-34.

- Iodine-129 contamination in this area is consistent with regional plumes and believed to be from liquid waste facilities (Figure 2.10-8).

- Nitrate contamination at Low-Level Waste Management Area 1 is mapped as two separate plumes at the drinking water standard, both extending from areas outside of the burial ground. The contours shown in Figure 2.10-6 are similar to those from previous years. The highest concentrations are in the northeast plume, approximately coincident with the technetium-99 plume. Thus, the northeast nitrate plume has a likely source in the BY cribs, the 216-B-8 crib, and other nearby waste sites. Nitrate in the June 2006 sample from well 299-E33-34 increased to $713 \mathrm{mg} / \mathrm{L}$, the highest seen in the area. Further sampling results will be used to determine if this is a trend or if the increase is due to possible laboratory error. Anomalously high nitrate in well 299-E32-5 is discussed in the preceding paragraphs.

- Low levels of chromium contamination continue to be detected in filtered samples from well 299-E33-34, in the northeast corner of Low-Level Waste Management Area 1. The FY 2006 average chromium concentration was $21.5 \mu \mathrm{g} / \mathrm{L}$. The drinking water standard for chromium is $100 \mu \mathrm{g} / \mathrm{L}$. Elevated chromium in well 299-E32-5 is discussed above but remains unexplained.

\subsubsection{Low-Level Waste Management Area 2}

Groundwater at Low-Level Waste Management Area 2 continued to be monitored under RCRA and AEA. Under 40 CFR 265.93(b) as referenced by WAC 173-303-400, the well network was sampled semiannually for RCRA indicator and site-specific parameters (PNNL-14859; DOE/RL-2000-72). The well network was sampled twice for indicator and site-specific parameters. Sampling was successful at nine wells for both sampling rounds. As reported in last year's annual report (PNNL-15670), two wells (299-E34-5 and 299-E34-7) went dry in early FY 2006. Appendix B includes a well location map, an estimate of local migration rates, a list of wells, and the constituents monitored.

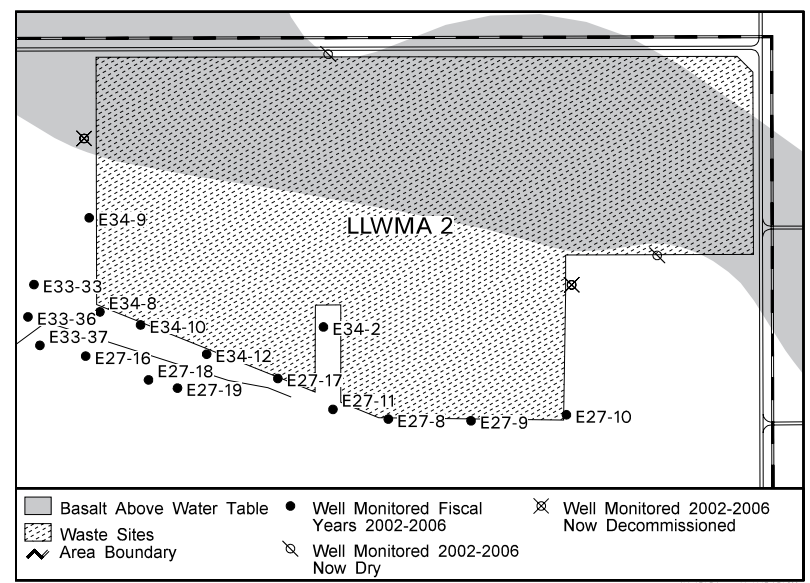
to the southwest is indicated by the movement of the nitrate plume from well 299-E34-7 to well 299-E27-10 (discussed further in the following paragraphs). Well 299-E34-5 went dry in early FY 2006. In past years the gradient has been calculated using wells along the 
southern boundary of the waste management area, assuming flow to the west. If the gradient is calculated between wells 299-E27-10 and 299-E27-17 using the October 2005 data, the value is 0.00005 .

No attempt will be made to update upgradient well designations used in the statistical tests until a stable flow direction is evident. The basalt surface above the water table in the north part of Low-Level Waste Management Area 2 constrains possible flow directions for the unconfined aquifer. However, it is possible that the flow is influenced by continued drainage of the unsaturated sediment and recharge moving laterally on the basalt surface to the saturated aquifer sediment. Given the broad uncertainties in flow direction and low gradient in this area, flow rates are not estimated.

Statistical comparison values for the four indicator parameters, specific conductance, $\mathrm{pH}$, total organic carbon, and total organic halide, were not exceeded in the FY 2006 samples from Low-Level Waste Management Area 2. Specific conductance along the south side of the area has exhibited a generally increasing trend in the eastern wells (299-E27-10, 299-E27-9, and 299-E27-8) for the past several years. These wells appear to be impacted by groundwater with elevated sulfate, chloride, nitrate, calcium, total organic carbon, and total organic halides found at well 299-E34-7 and reported in PNNL-15670. The wells farther east lead the increase, as shown for nitrate in Figure 2.10-33. These trends may support a component of flow to the west.

Upgradient well 299-E34-7 is no longer used to calculate critical mean values because of the anomalous chemistry in this well. Appendix B lists the initial statistical comparison values to be used in FY 2007 based on data for the other upgradient wells. Well 299-E34-7 went dry in early FY 2007 and has been removed from the sample schedule.

Performance assessment monitoring of radionuclides at Low-Level Waste Management Area 2, under AEA authority, is designed to complement the RCRA detection monitoring and is aimed specifically at monitoring radionuclide materials that are not regulated under RCRA. The current goal of performance assessment monitoring at Low-Level Waste Management Area 2 is to gather data to assess changes in concentrations at downgradient wells using statistical tests and to provide sufficient supporting information from upgradient wells to interpret the changes. Under the current monitoring plan (DOE/RL-2000-72), technetium-99, iodine-129, and uranium are monitored specifically for performance assessment.

Contaminant characteristics at Low-Level Waste Management Area 2 include the following:

- Technetium-99 concentration continued to increase in upgradient well 299-E27-10 southeast of Waste Management Area 2, where the concentration reached an average of $85 \mathrm{pCi} / \mathrm{L}$ for FY 2006. This contamination is believed to be from past disposal of liquid waste in the 200 East Area and unrelated to Low-Level Waste Management Area 2 because this is an upgradient well. Other wells in the monitoring network have lower technetium-99 concentrations.

- Tritium contamination was found at levels less than the drinking water standard. The tritium concentrations were consistent with regional plumes (Figure 2.10-4 and Section 2.10.1.1).

- Iodine-129 concentrations were $<5 \mathrm{pCi} / \mathrm{L}$ in Low-Level Waste Management Area 2 wells. The levels were consistent with the regional iodine-129 plume (Figure 2.10-8 and Section 2.10.1.3) and do not appear to be related to a burial ground source.

- Uranium concentrations in Low-Level Waste Management Area 2 samples were $<5 \mu \mathrm{g} / \mathrm{L}$ and do not indicate a burial ground source.

- Nitrate contamination at levels above the drinking water standard was restricted to upgradient well 299-E27-10 on the east side of Low-Level Waste Management 
Area 2, with a FY 2006 average of $59.4 \mathrm{mg} / \mathrm{L}$. Upgradient well 299-E34-7 had higher concentrations in previous years but has gone dry.

\subsubsection{Liquid Effluent Retention Facility}

The Liquid Effluent Retention Facility operates under final status permit

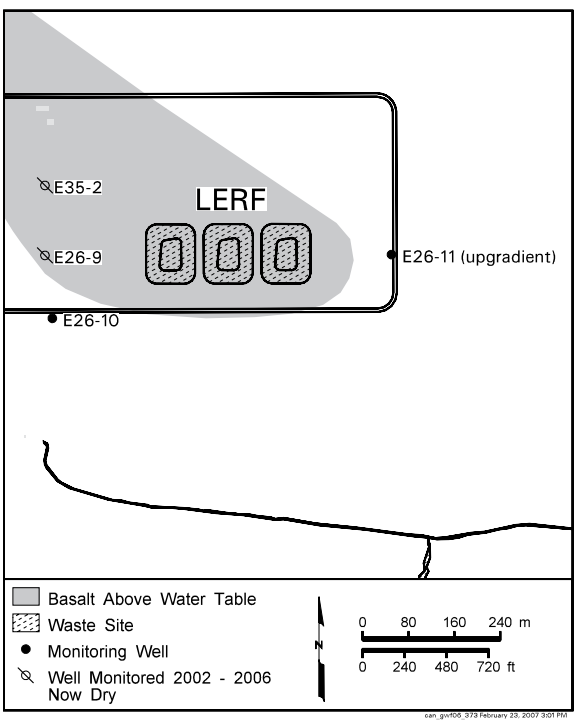
conditions stipulated as agreed to by Ecology and DOE. The current groundwatermonitoring network is hydrogeologically inadequate to monitor the unit. Two of the three groundwater wells installed to monitor the compliance side of the unit are dry and the water table has dropped below the top of basalt. Therefore, statistical evaluation of the indicator parameters (specific conductance, $\mathrm{pH}$, total organic carbon, and total organic halide) is not conducted. To remedy this problem, DOE and Ecology are negotiating a process to modify the RCRA permit that will lead to a more refined understanding of Liquid Effluent Retention Facility hydrostratigraphy, and will create a regulatory framework that will allow the unit to operate with proper statistical assessment tools. Until a final decision is made, it has been agreed that interim status detection monitoring requirements would be retained.

In FY 2006, specific conductance and sulfate continued to rise in well 299-E26-10, the remaining downgradient well in the Liquid Effluent Retention Facility monitoring network. Nitrate has also been rising in this well, and in wells south and east of the Liquid Effluent Retention Facility. The regional rise of anions and cations is evident in wells located in the central and eastern portions of 200 East Area. Downgradient wells installed for the Liquid Effluent Retention Facility before it began receiving waste recorded the early indications of the regional rise in specific conductance.

The uppermost aquifer beneath the Liquid Effluent Retention Facility is under evaluation as part of a groundwater evaluation plan. This plan will be part of a revision of the Liquid Effluent Retention Facility operating permit that will form the basis for future groundwater monitoring at the unit. The current plan assumes that groundwater continues to move in a southwest direction, one of the flow directions outlined in previous reports (PNNL-14804). The flow rate is $\sim 0.24$ meter/day.

\subsubsection{Waste Management Area C}

Groundwater at this waste management area is monitored under a RCRA interim status indicator program to detect if dangerous waste constituents associated with the facility have

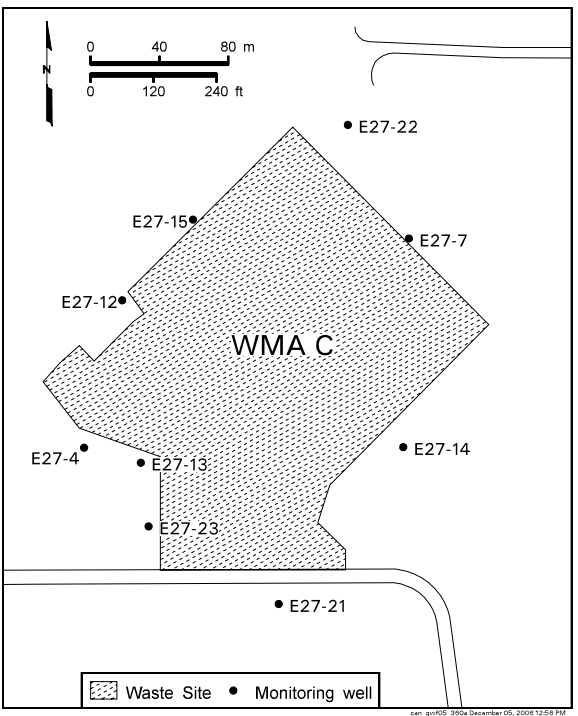
compromised groundwater quality as required under 40 CFR 265.93(b) as referenced by WAC 173-303-400 and AEA. Although semiannual sampling is required by RCRA, wells are sampled quarterly in accordance with tank waste retrieval monitoring requirements (e.g., RPP-21895). The required RCRA semiannual sampling confirms that indicator parameter critical means were not exceeded. Radionuclides are tracked under AEA at the site. The following discussion covers monitoring conducted during FY 2006 and the local hydrogeology at the C Tank Farm.

Located in the northeast part of the 200 East Area, Waste Management Area C consists of the C Tank Farm, the 244-CR vault, ancillary waste transfer lines, and seven diversion boxes. Three wells, scheduled for sampling in September 2006, were sampled late in October 2006. A well location map, a list of network wells, the critical mean values used for upgradient/downgradient comparisons in FY 2007 and the site specific constituents are available in Appendix B.

No discernible changes in flow direction were seen during FY 2006. Flow direction cannot be determined from water-table maps alone. As seen in Figure 2.10-3, the variation in water levels is only a few centimeters. Ranging from southwest to south-southwest, the flow direction was determined by in situ flow measurements with the colloidal borescope, plume tracking and water elevations 
(PNNL-13788). A similar flow direction was reported this year in RPP-23748. Gradients from a series of three-point problems using water-elevation data over time from wells near the farm were mapped on a rose-diagram. These results, shown in Figure 2.10-34, support a southwest flow direction. However, the gradient in this area is considered too low to calculate a reliable flow rate.

The rate of water-table decline beneath Waste Management Area C decreased from 10 centimeters/year in FY 2005 to 7 centimeters/year in FY 2006. If this rate of decline continues, replacement of the older wells in the network may be required in 6 or 7 years.

Upgradient, specific conductance ranges from 689 to $650 \mu \mathrm{S} / \mathrm{cm}$ with a maximum value of $883 \mu \mathrm{S} / \mathrm{cm}$ found downgradient on the southeast side. Sulfate dominates the specific conductance signature across the site. The rising sulfate concentrations are primarily from an upgradient source near the basalt subcrop where the value has been as high as $671 \mathrm{mg} / \mathrm{L}$. Well 299-E27-14, southeast of Waste Management Area C, has produced a recent result of $245 \mathrm{mg} / \mathrm{L}$ sulfate.

A better understanding of contamination that may be related to the tank farm is gained from comparing nitrate and technetium-99 trends. Figure 2.10-35 shows a comparison between nitrate concentrations for June 2005 and June 2006. Over most of the site, nitrate is elevated above the background value of $12.4 \mathrm{mg} / \mathrm{L}$ (WHC-EP-0595). At $56.7 \mathrm{mg} / \mathrm{L}$, values on the southeast side are above the drinking water standard of $45 \mathrm{mg} / \mathrm{L}$. Concentrations are, however, increasing only slowly except in downgradient well 299-E27-14. Consequently, there is little effect on the specific conductance from nitrate.

Technetium-99 concentrations range from $32.2 \mathrm{pCi} / \mathrm{L}$ in upgradient well 299-E27-22 to 4,390 in downgradient well 299-E27-4 (Figure 2.10-36). Although technetium-99 $(2,760 \mathrm{pCi} / \mathrm{L}$ FY 2002) in upgradient well 299-E27-7 declined to the current value of $114 \mathrm{pCi} / \mathrm{L}$, concentrations have increased downgradient except in well 299-E27-4. The concentration in this downgradient well $(8,370 \mathrm{pCi} / \mathrm{L}$ in 2004$)$ has decreased to $4,390 \mathrm{pCi} / \mathrm{L}$. As seen in Figure 2.10-37, a value of 3,430 pCi/L was detected in June 2006 in well 299-E27-23 on the southwest side of the farm. Well 299-E27-14 has produced technetium-99 results above the drinking water standard since 2001. Migration of this technetium-99 plume from northeast to southwest is seen by comparing contaminant trends (Figure 2.10-36) and plume maps from multiple years as shown in Figure 2.10-37.

Although the technetium-99 contamination appears to be moving from the farm, the source of contamination in downgradient well 299-E27-4 may be a local pocket of contaminated soils. This well is close to several unplanned releases. This elevated technetium-99 is found with low levels of nitrate (Figure 2.10-35) providing a low nitrate to technetium-99 ratio of 5.1. Generally a nitrate to technetium-99 ratio less than 10 indicates the source of contamination may be tank-related as discussed for nearby well 299-E27-13 in PNNL-14187 and PNNL-14548.

Although seen sporadically at several locations in the groundwater at Waste Management Area C during FY 2006, cyanide levels have remained steady in upgradient well 299-E27-7 since 2004. In FY 2006, concentrations ranged from 36.8 to $24.8 \mu \mathrm{g} / \mathrm{L}$ (drinking water standard $200 \mu \mathrm{g} / \mathrm{L}$ ). The C Tank Farm is the only known local source for cyanide (HNF-SD-WM-TI-740). Consequently, like the low nitrate to technetium-99 ratio, the presence of cyanide in the groundwater suggests the source is tank-related waste left in the vadose zone. Additionally, the sharp rise and fall of the technetium-99 peak at well 299-E27-7 (Figure 2.10-36) indicates a short travel distance from the point of entry into the groundwater to the well (PNNL-14548). The farm is the only contaminant source close to this well. Further insight into the source or sources of the groundwater contamination at this waste management area may be possible as the current trends develop over time.

\section{Concentrations of technetium-99 generally increased in downgradient wells in Waste Management Area C.}




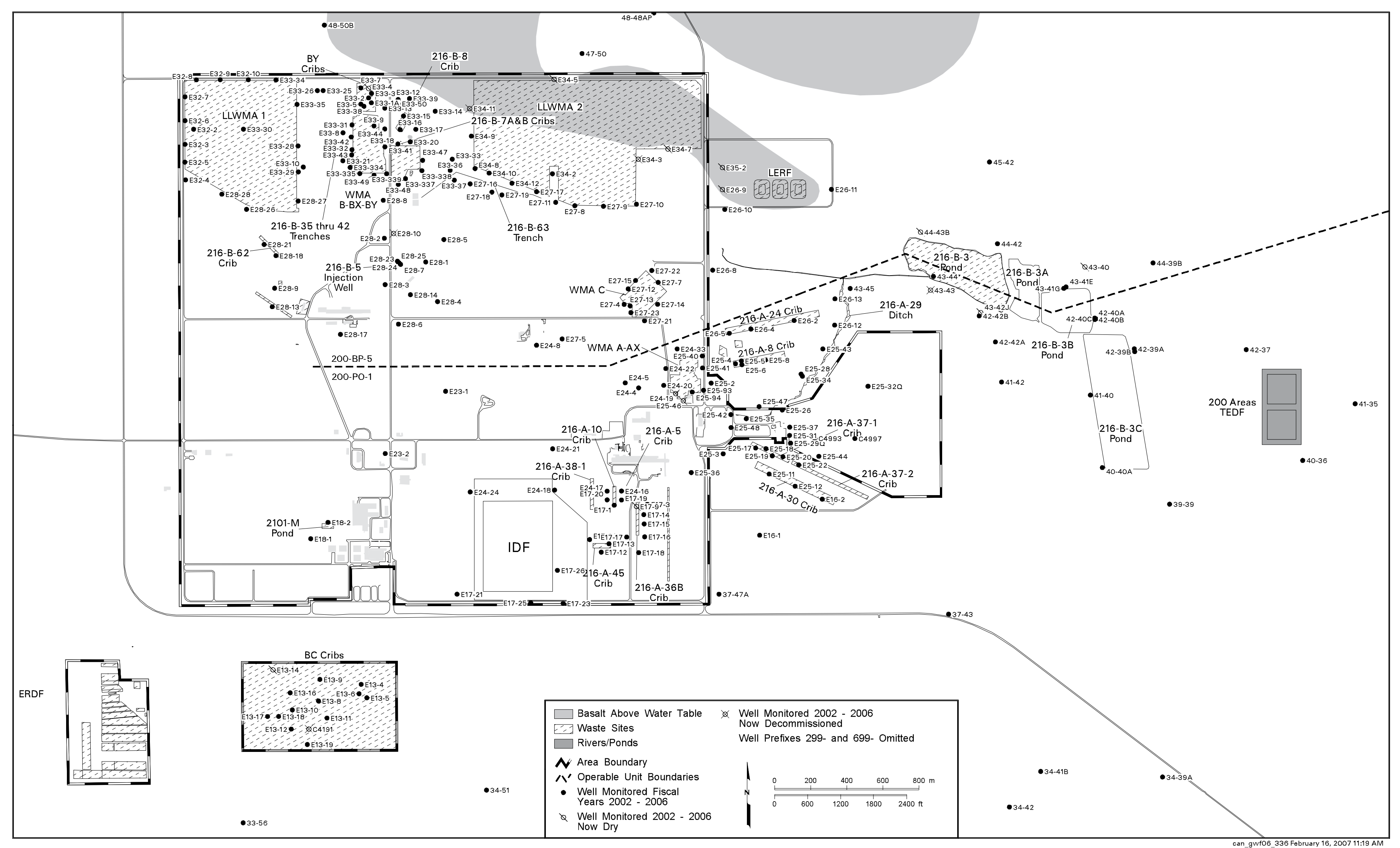

Figure 2.10-1. Groundwater Monitoring Wells in 200 East Area 


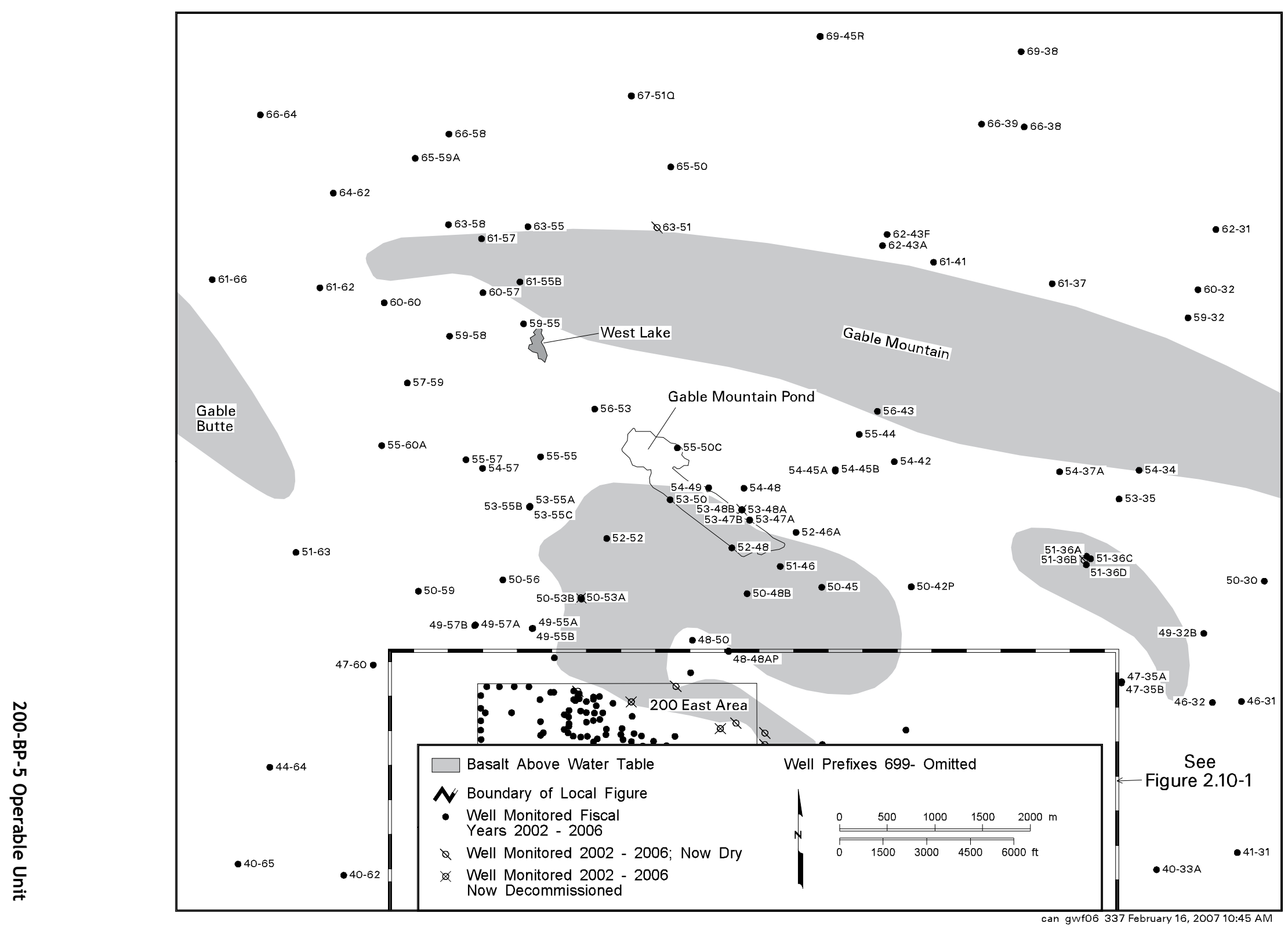

Figure 2.10-2. Groundwater Monitoring Wells Located in 600 Area Associated with 200-BP-5 Operable Unit 


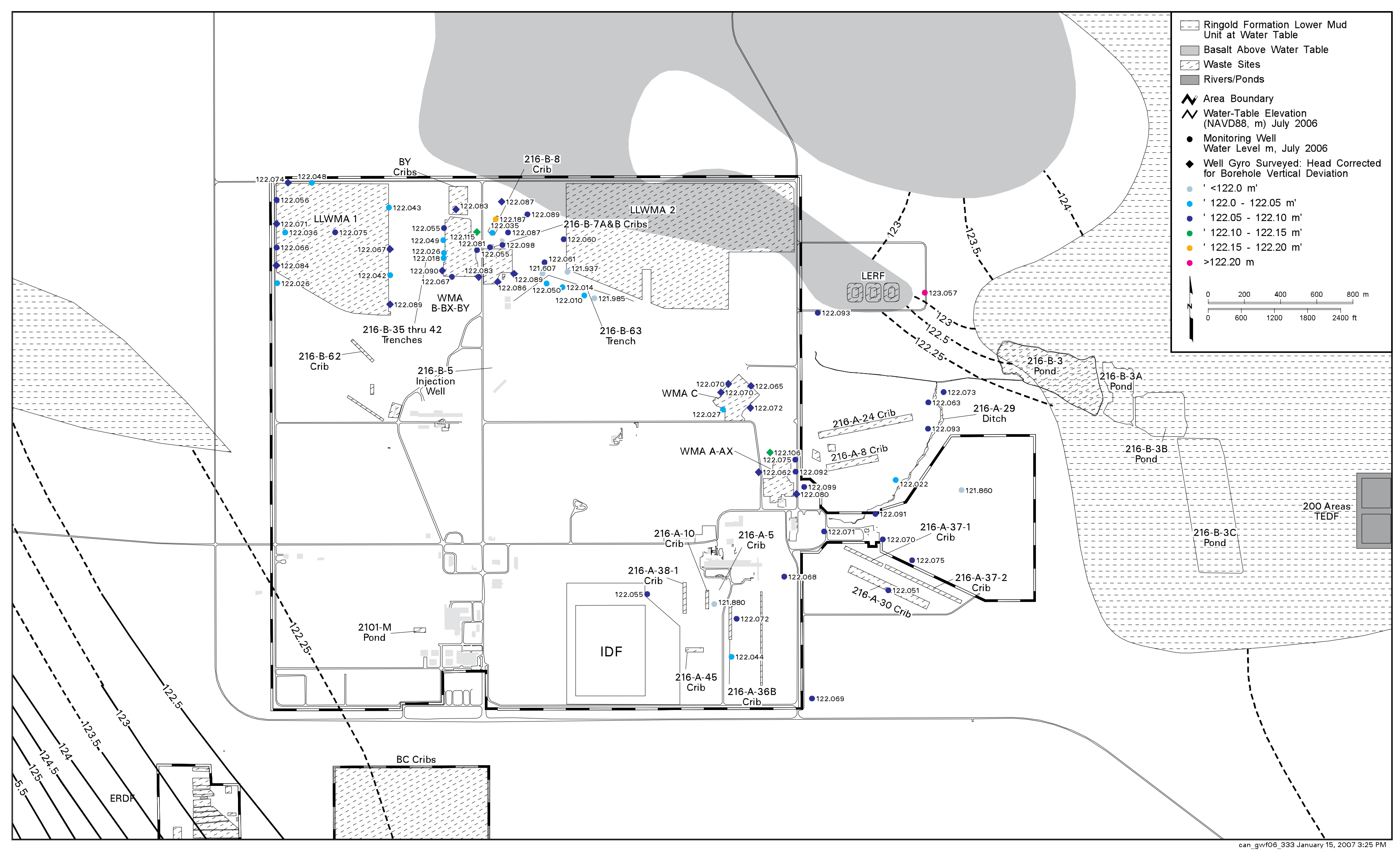

Figure 2.10-3. 200 East Area Water-Table Map, July 2006 


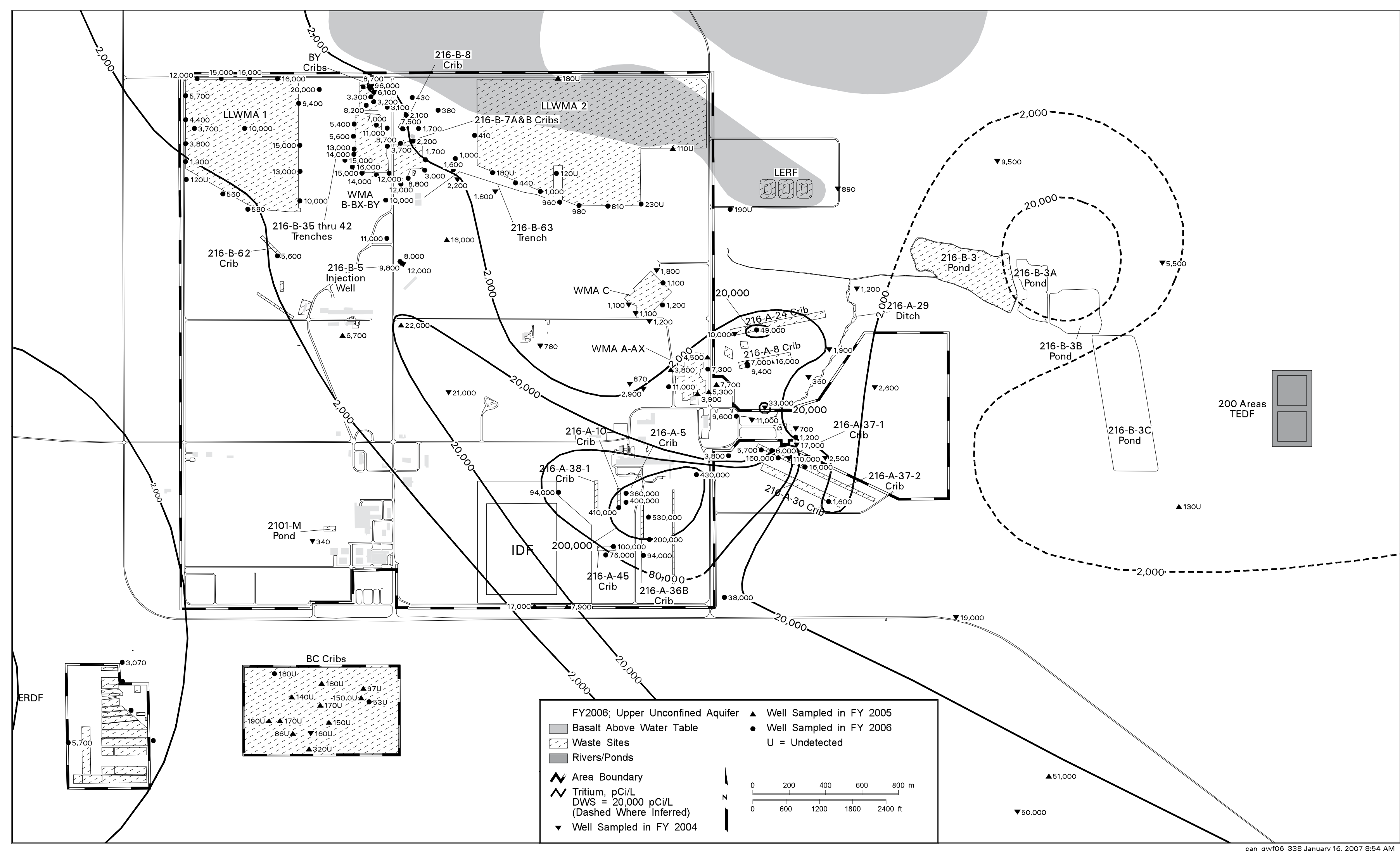

Figure 2.10-4. Average Tritium Concentrations in 200 East Area, Upper Part of Unconfined Aquifer 


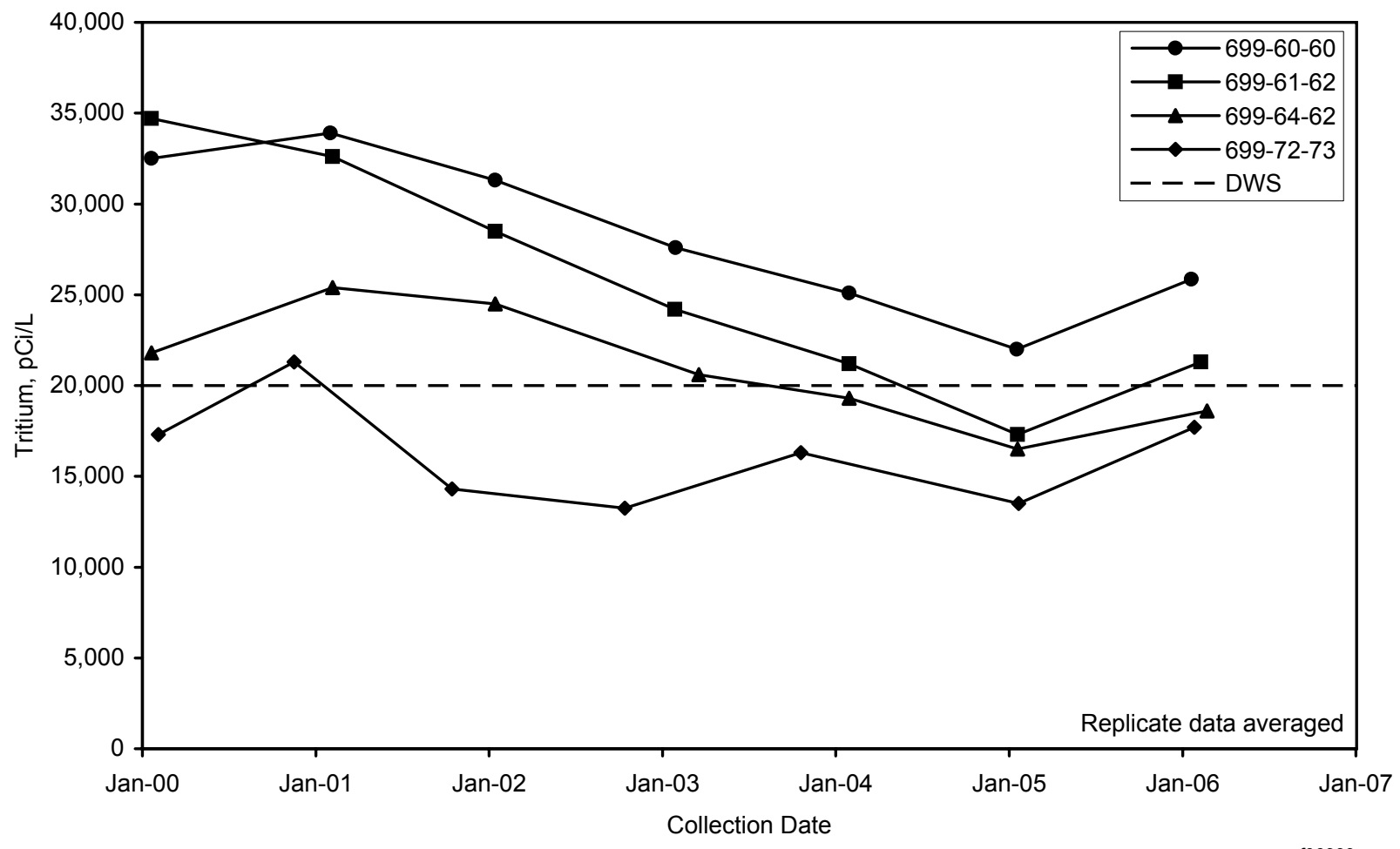

gwf06339

Figure 2.10-5. Tritium Concentrations in Wells Located in Gable Gap Area 


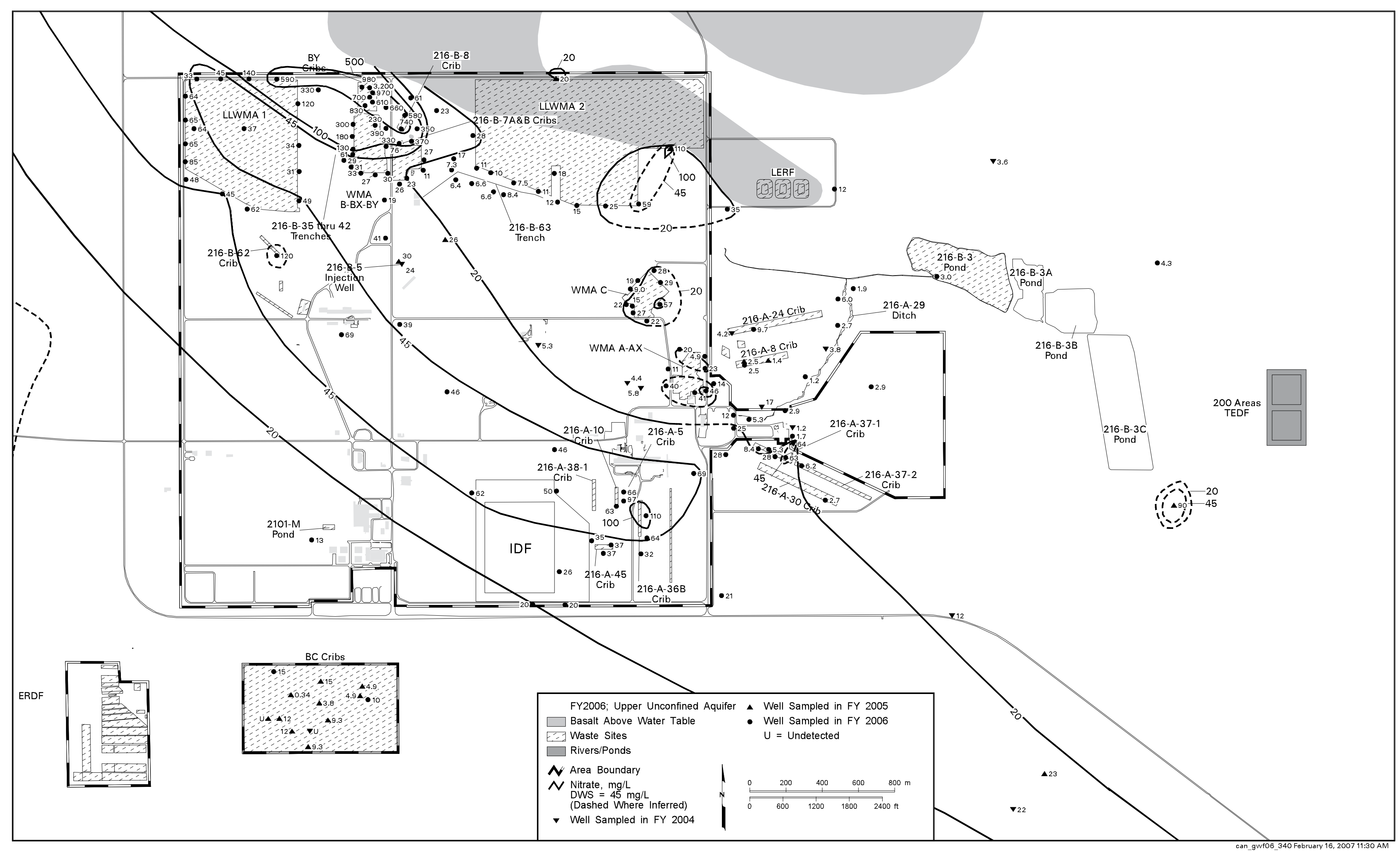

Figure 2.10-6. Average Nitrate Concentrations in 200 East Area, Upper Part of Unconfined Aquifer 


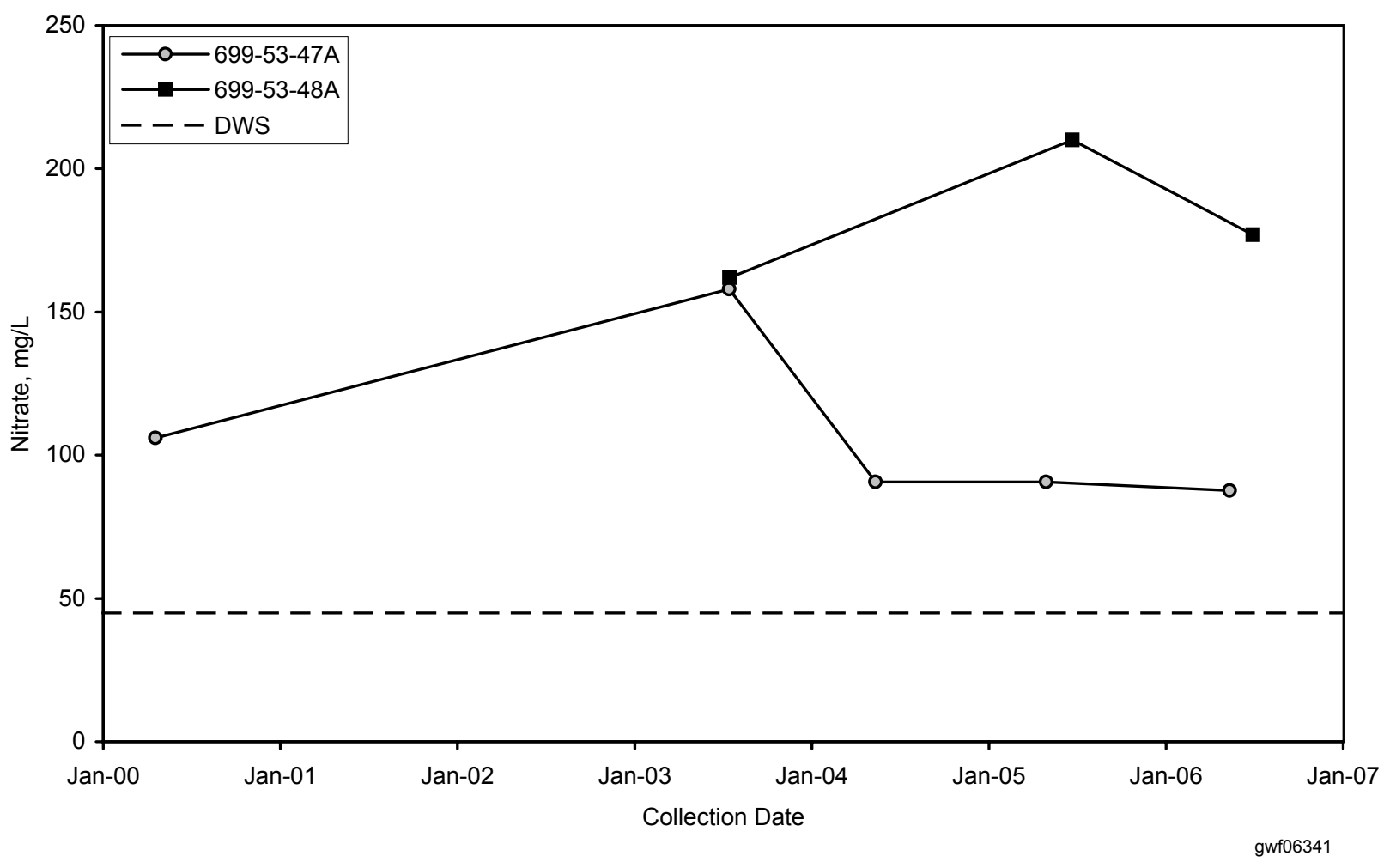

Figure 2.10-7. Nitrate Concentrations in Wells 699-53-47A and 699-53-48A at Gable Mountain Pond 


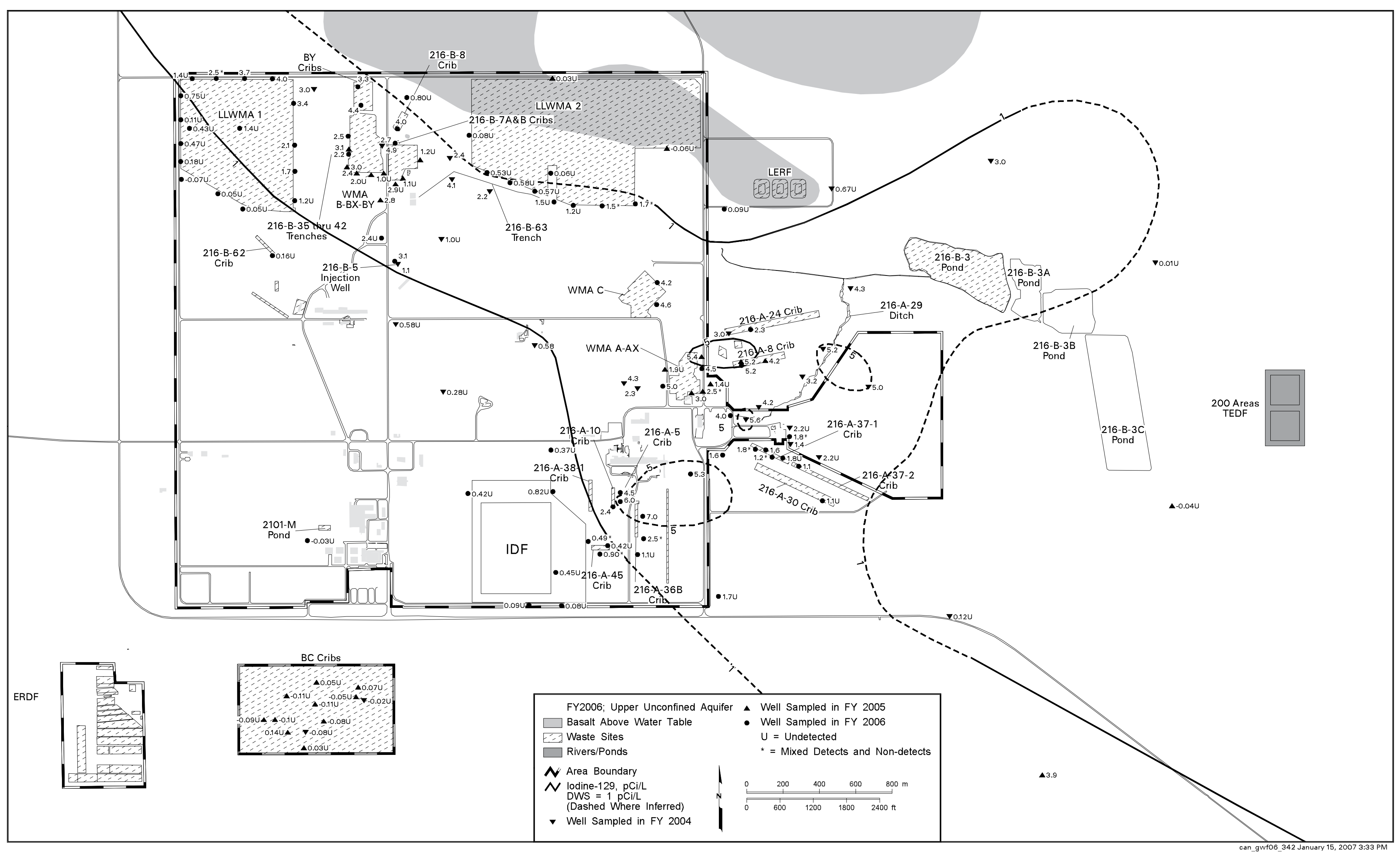

Figure 2.10-8. Average Iodine-129 Concentrations in 200 East Area, Upper Part of Unconfined Aquifer 


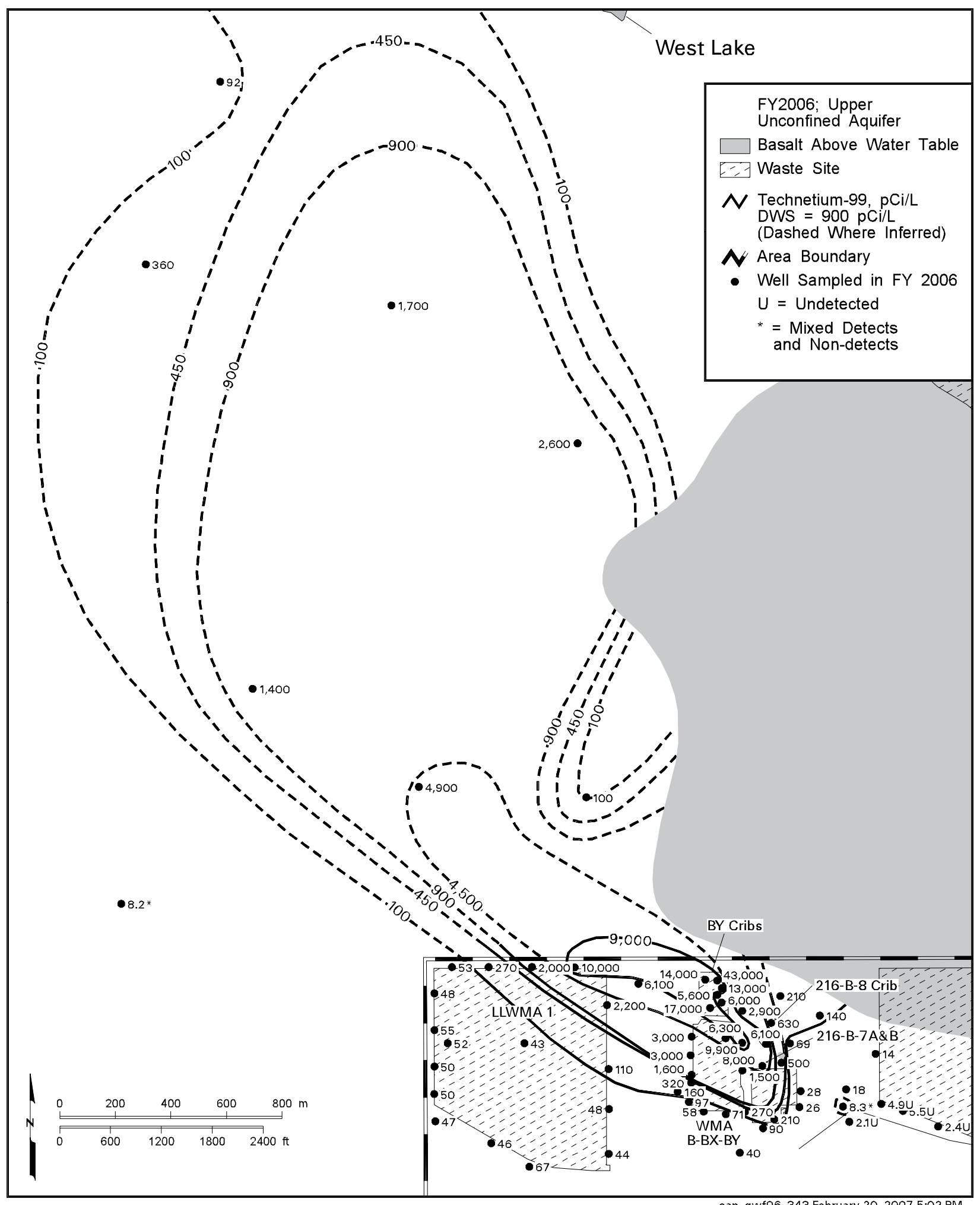

Figure 2.10-9. Average Technetium-99 Concentrations in North 200 East Area, Upper Part of Unconfined Aquifer 


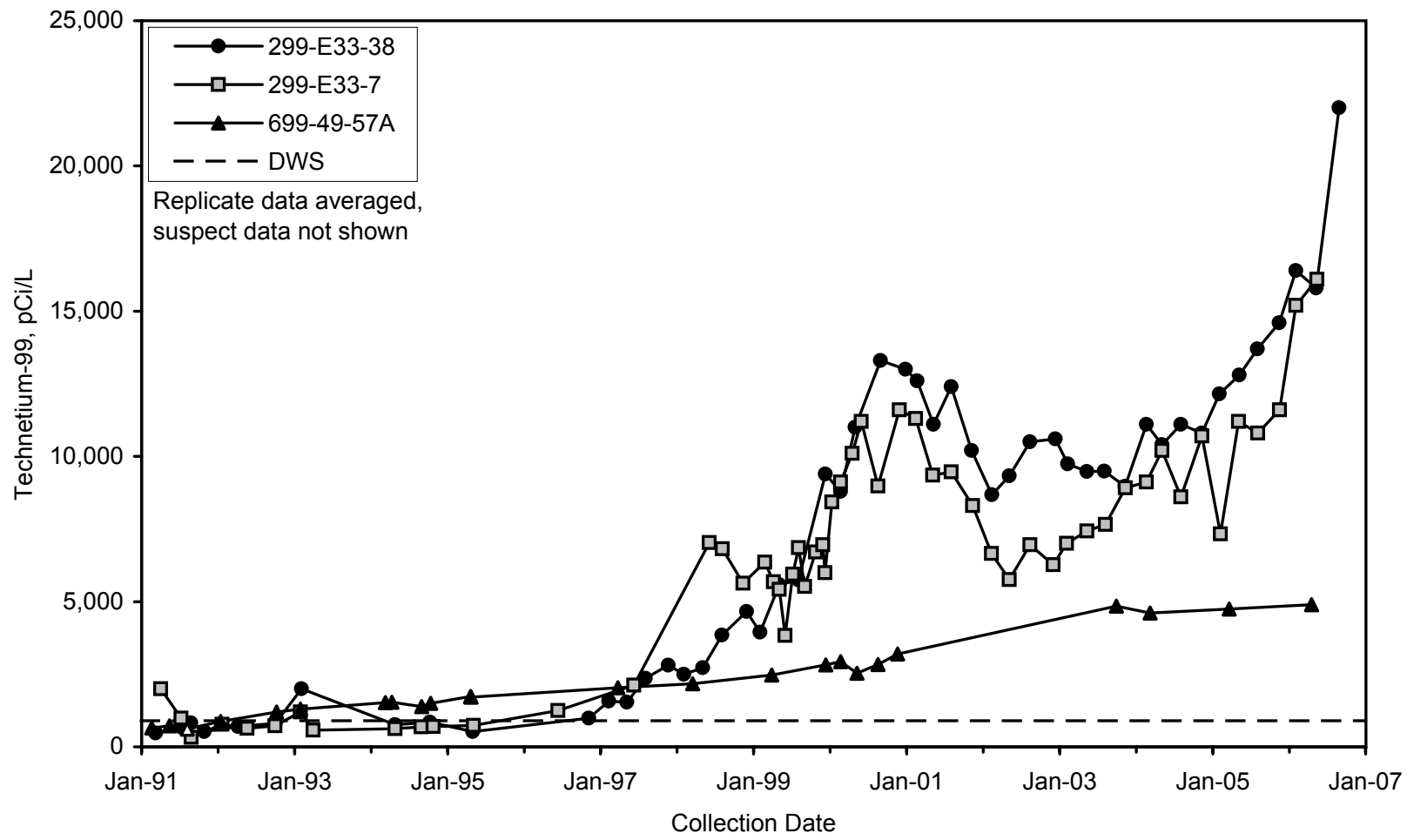

gwf06344

Figure 2.10-10. Technetium-99 Concentrations in Wells 299-E33-7 and 299-E33-38 at the BY Cribs and Well 699-49-57A North of 200 East Area 


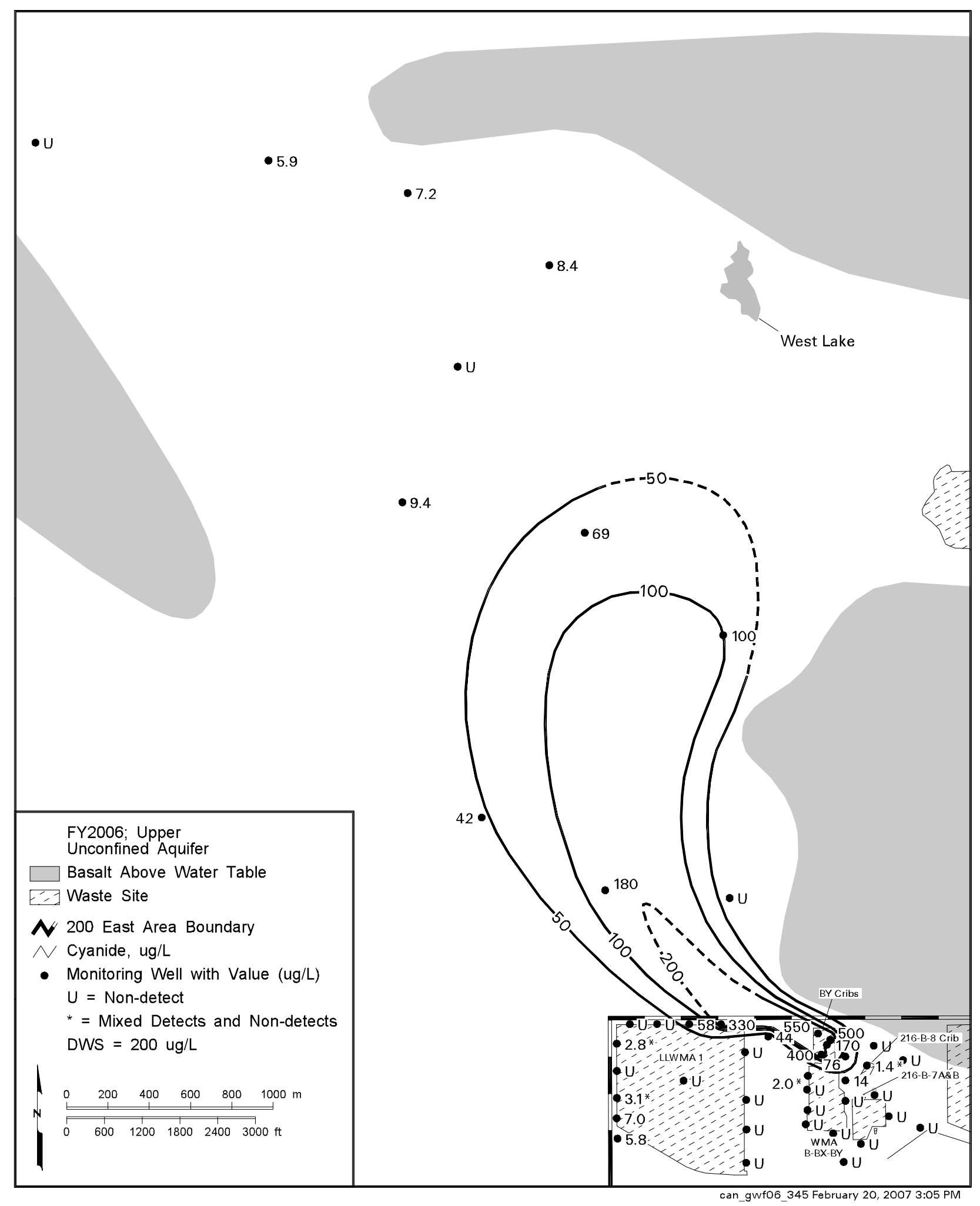

Figure 2.10-11. Cyanide Concentrations in North 200 East Area, Upper Part of Unconfined Aquifer 


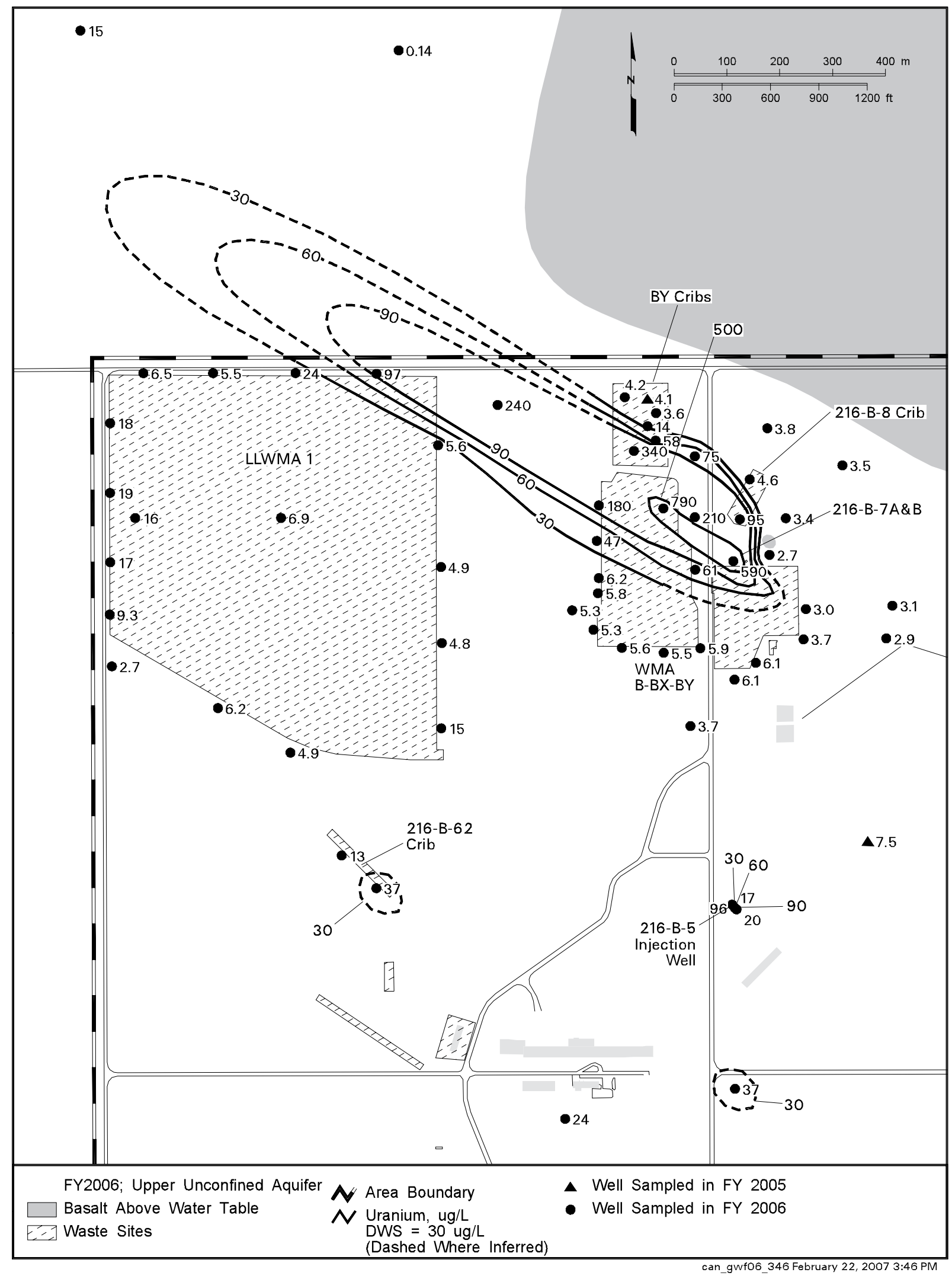

Figure 2.10-12. Average Uranium Concentrations in Northwest 200 East Area, Upper Part of Unconfined Aquifer 


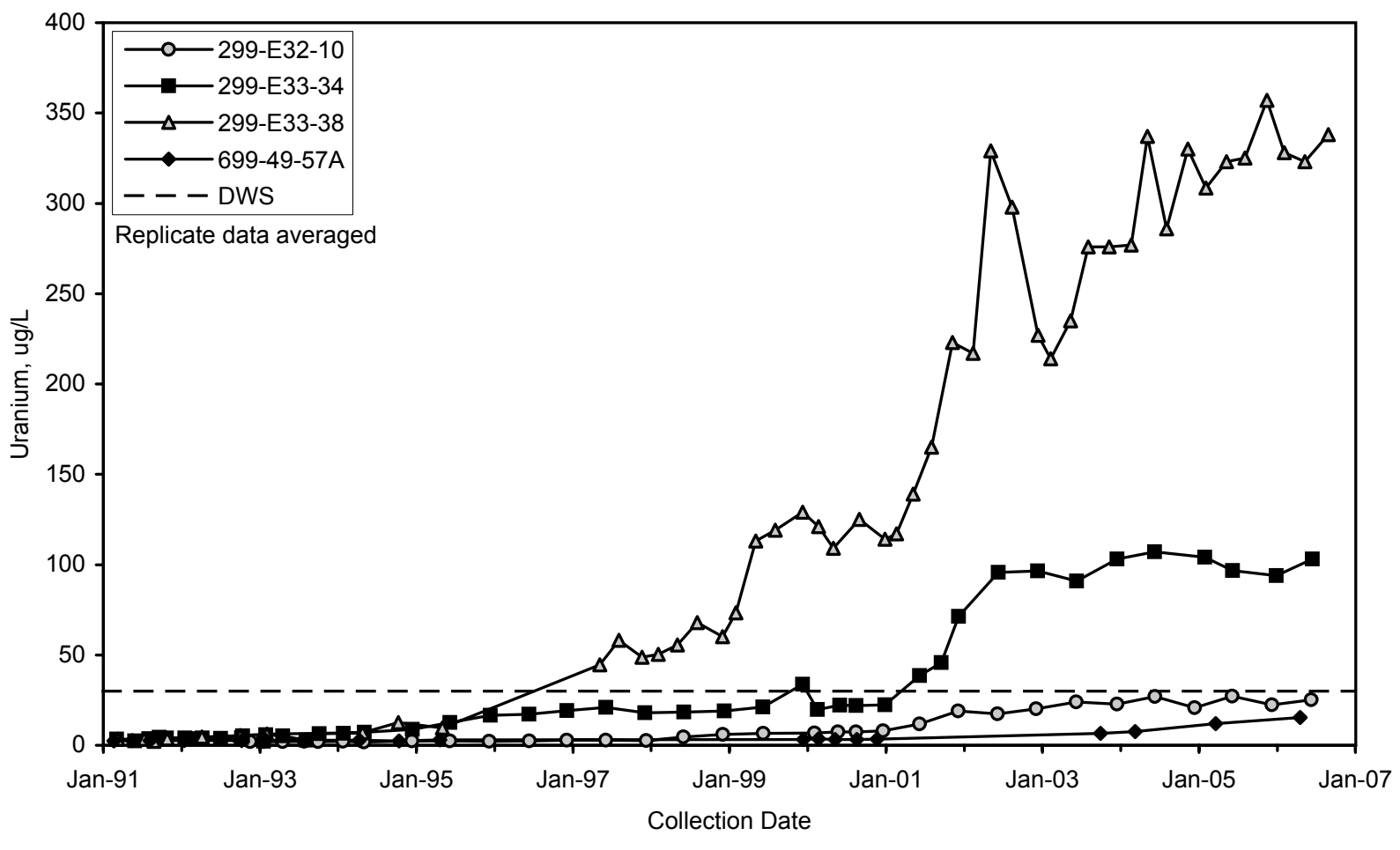

gwf06347a

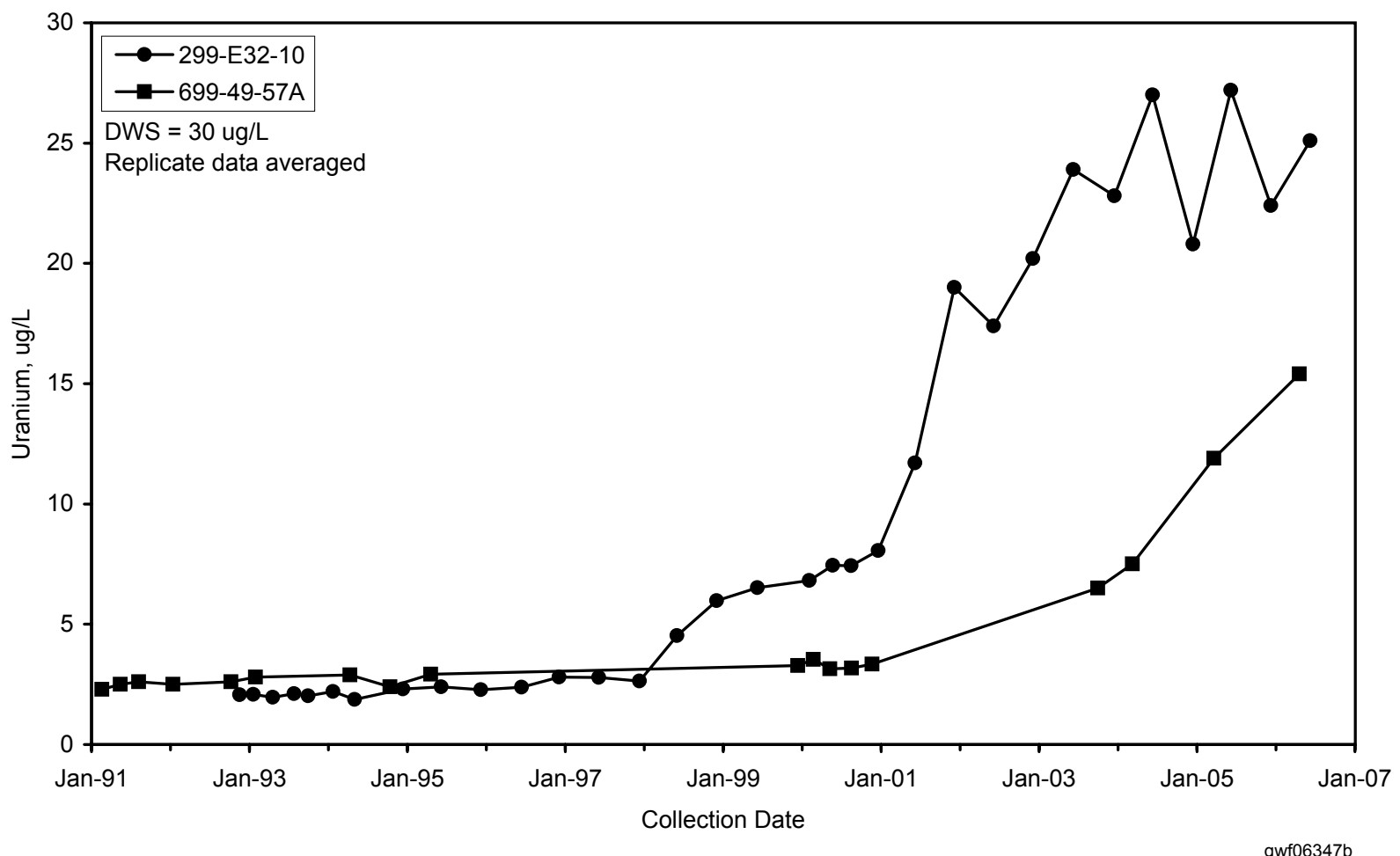

gwf06347

Figure 2.10-13. Uranium Concentrations in Wells in Northwest 200 East Area 


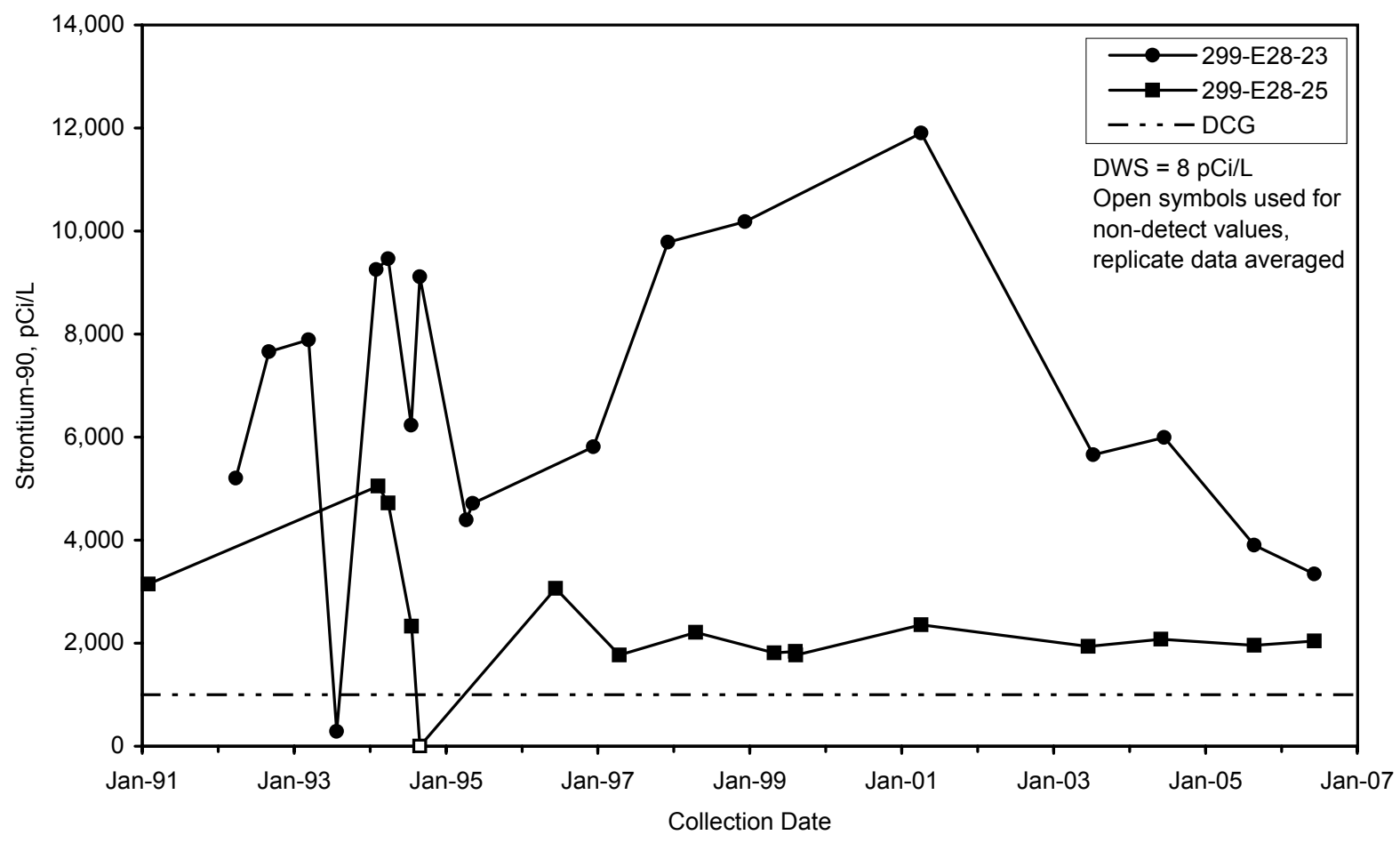

gwf06348

Figure 2.10-14. Strontium-90 Concentrations in Wells 299-E28-23 and 299-E28-25 at the 216-B-5 Injection Well Site

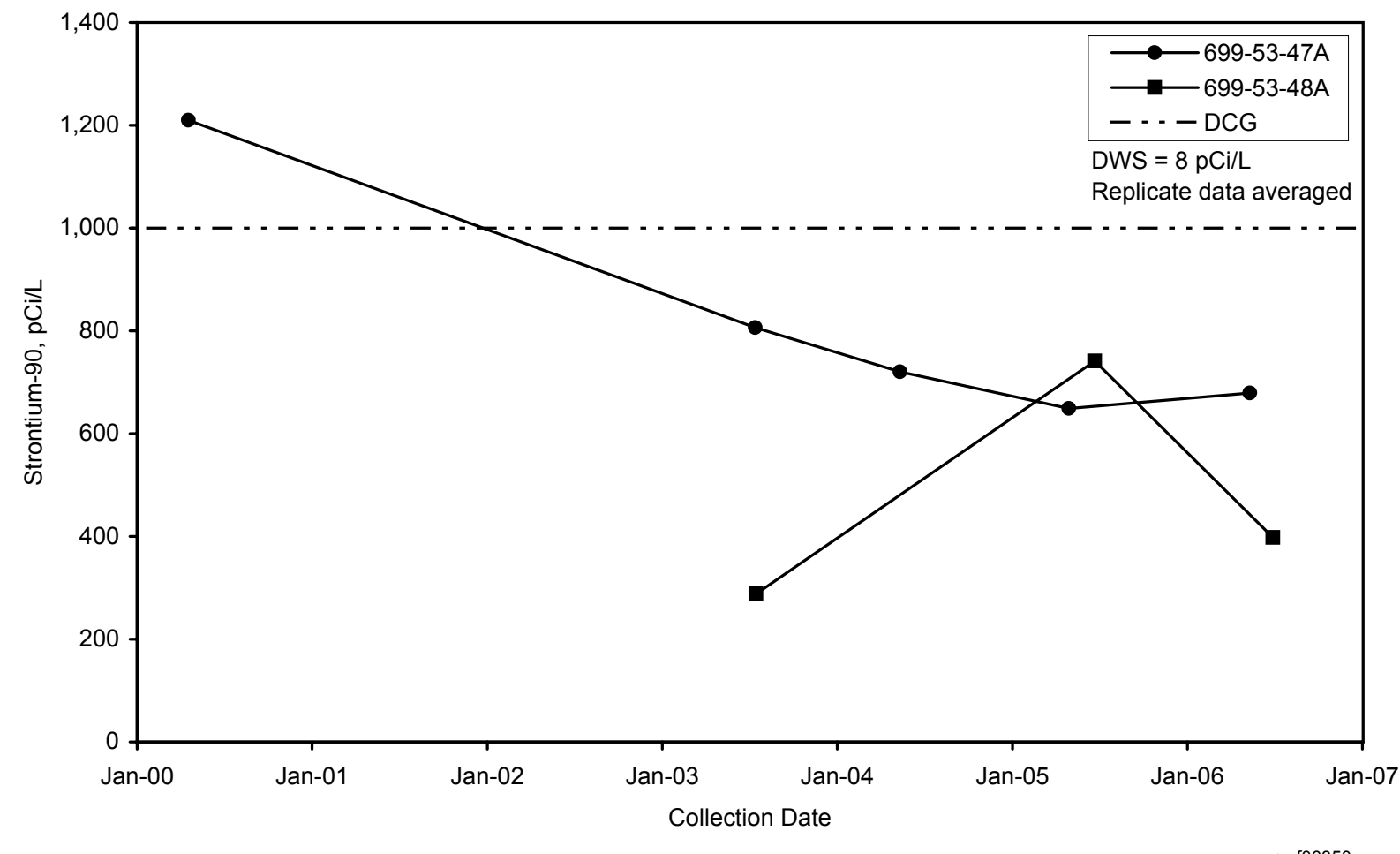

Figure 2.10-15. Strontium-90 Concentrations in Wells 699-53-47A and 699-53-48A at Gable Mountain Pond 


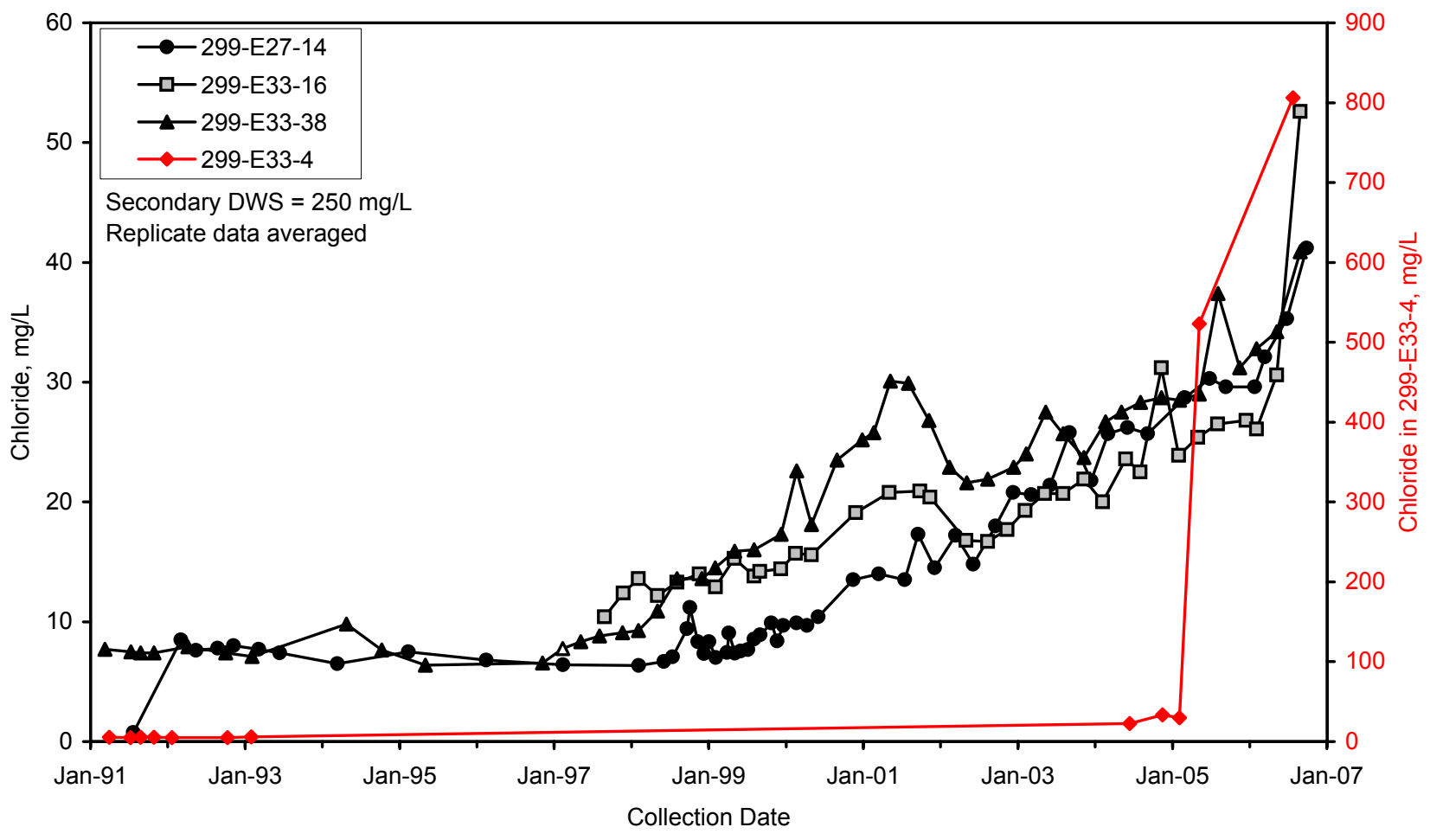

Figure 2.10-16. Chloride Concentrations in Selected Wells in 200-BP-5 Operable Unit

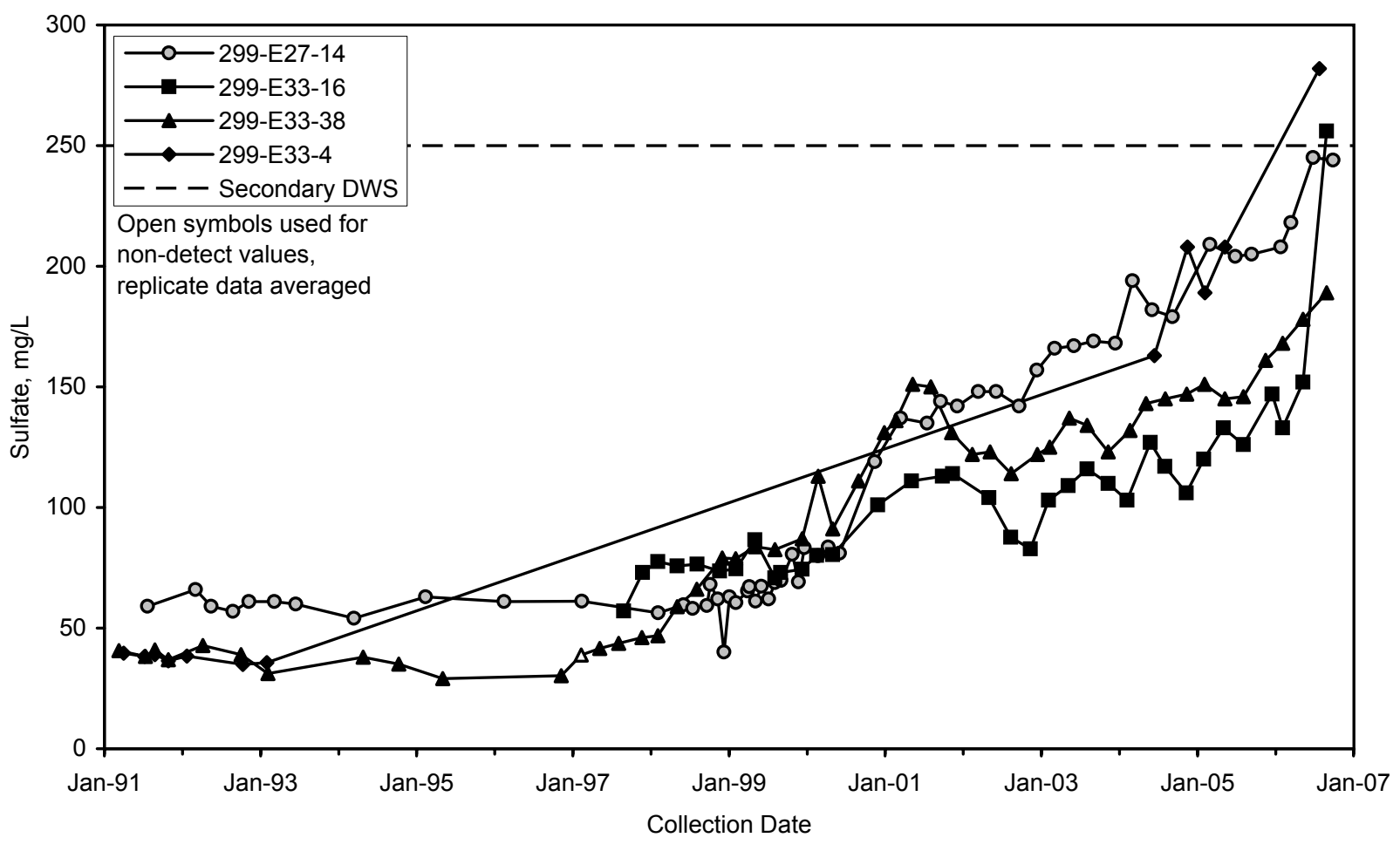

Figure 2.10-17. Sulfate Concentrations in Selected Wells in 200-BP-5 Operable Unit 

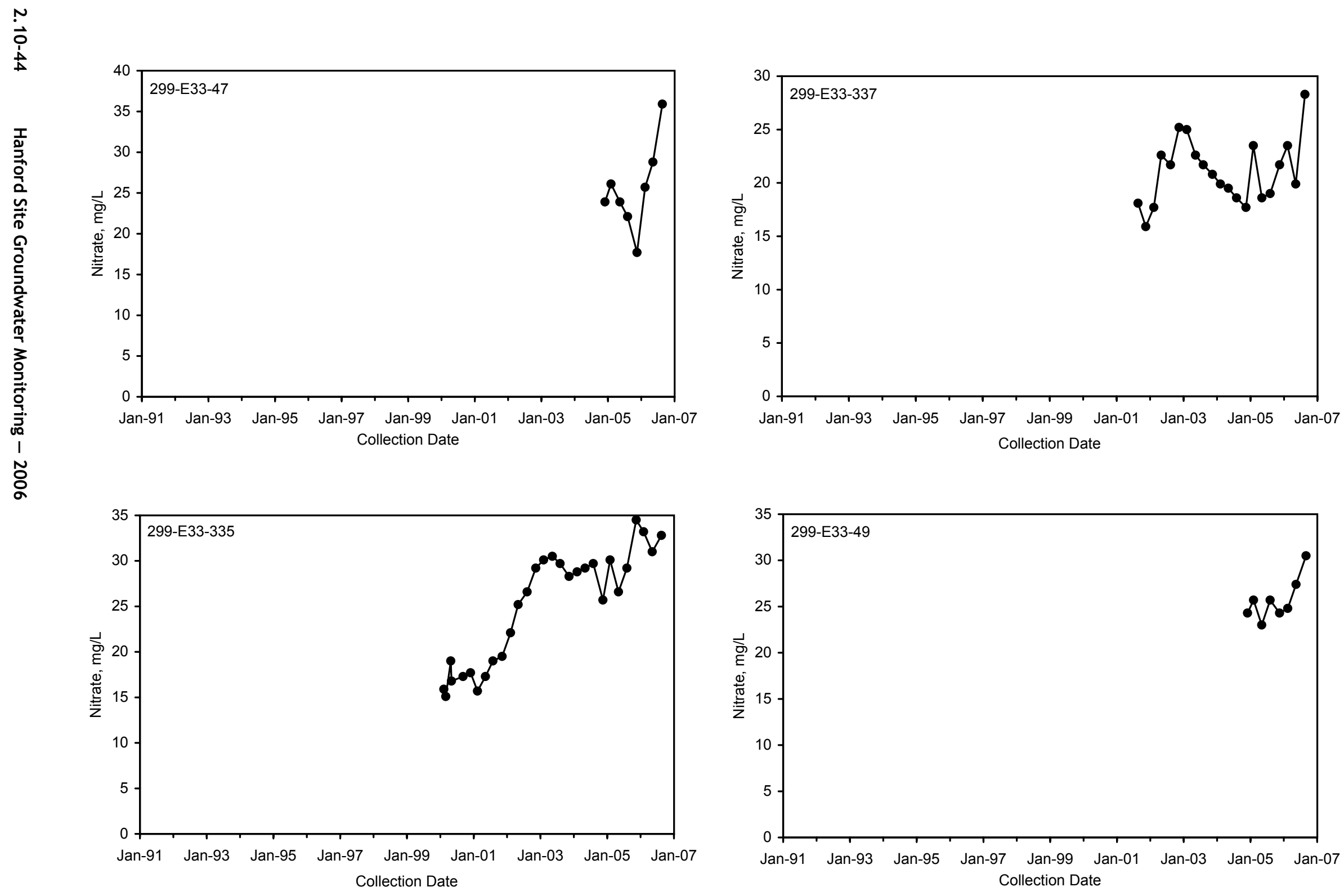

$$
\begin{aligned}
& \text { DWS }=45 \mathrm{mg} / \mathrm{L} \\
& \text { Replicate data averaged }
\end{aligned}
$$

Figure 2.10-18. Nitrate Concentrations on South Side of Waste Management Area B-BX-BY 

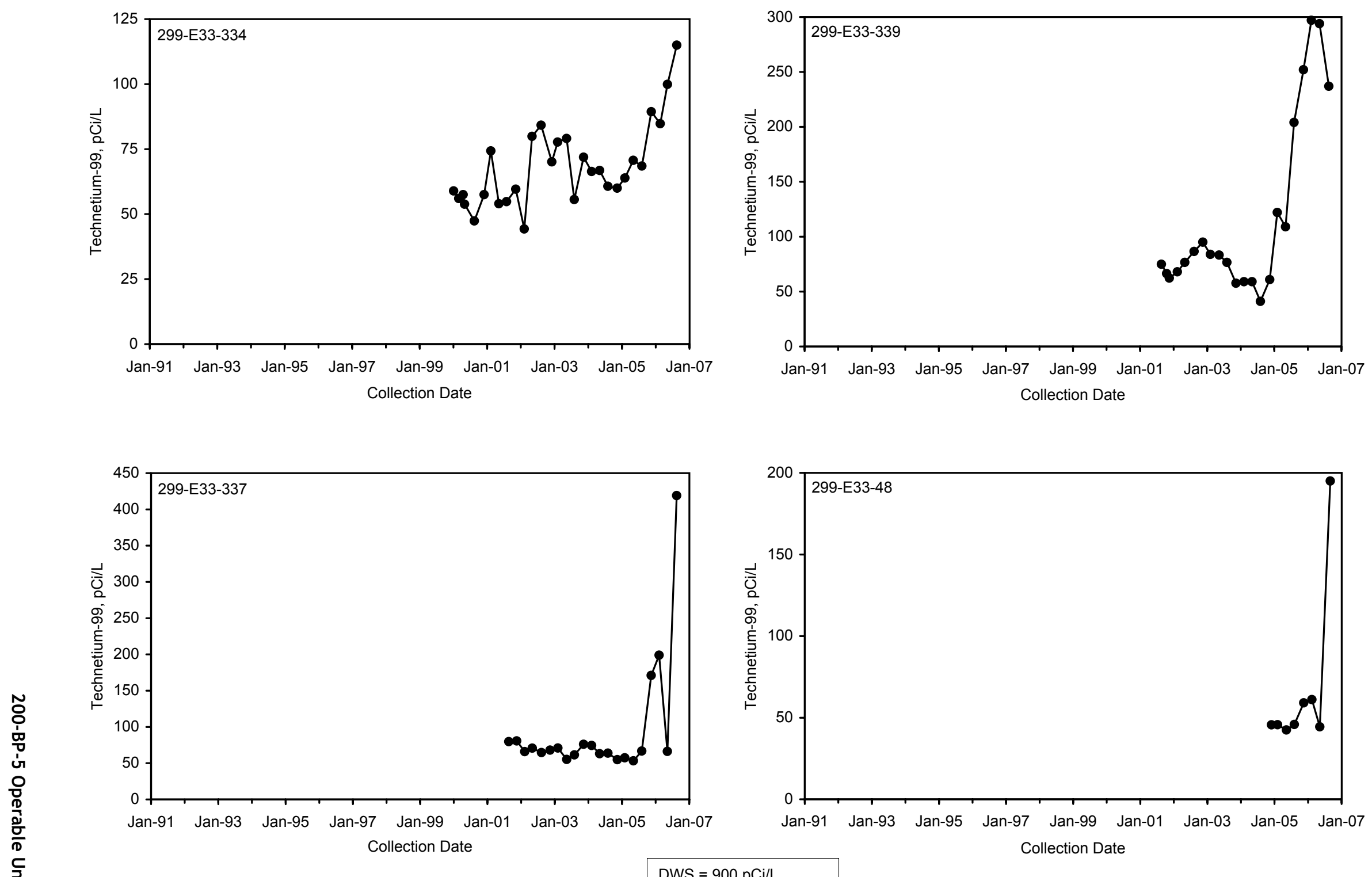

$$
\begin{aligned}
& \text { DWS }=900 \mathrm{pCi} / \mathrm{L} \\
& \text { Replicate data averaged }
\end{aligned}
$$

Figure 2.10-19. Technetium-99 Concentrations on South Side of Waste Management Area B-BX-BY 

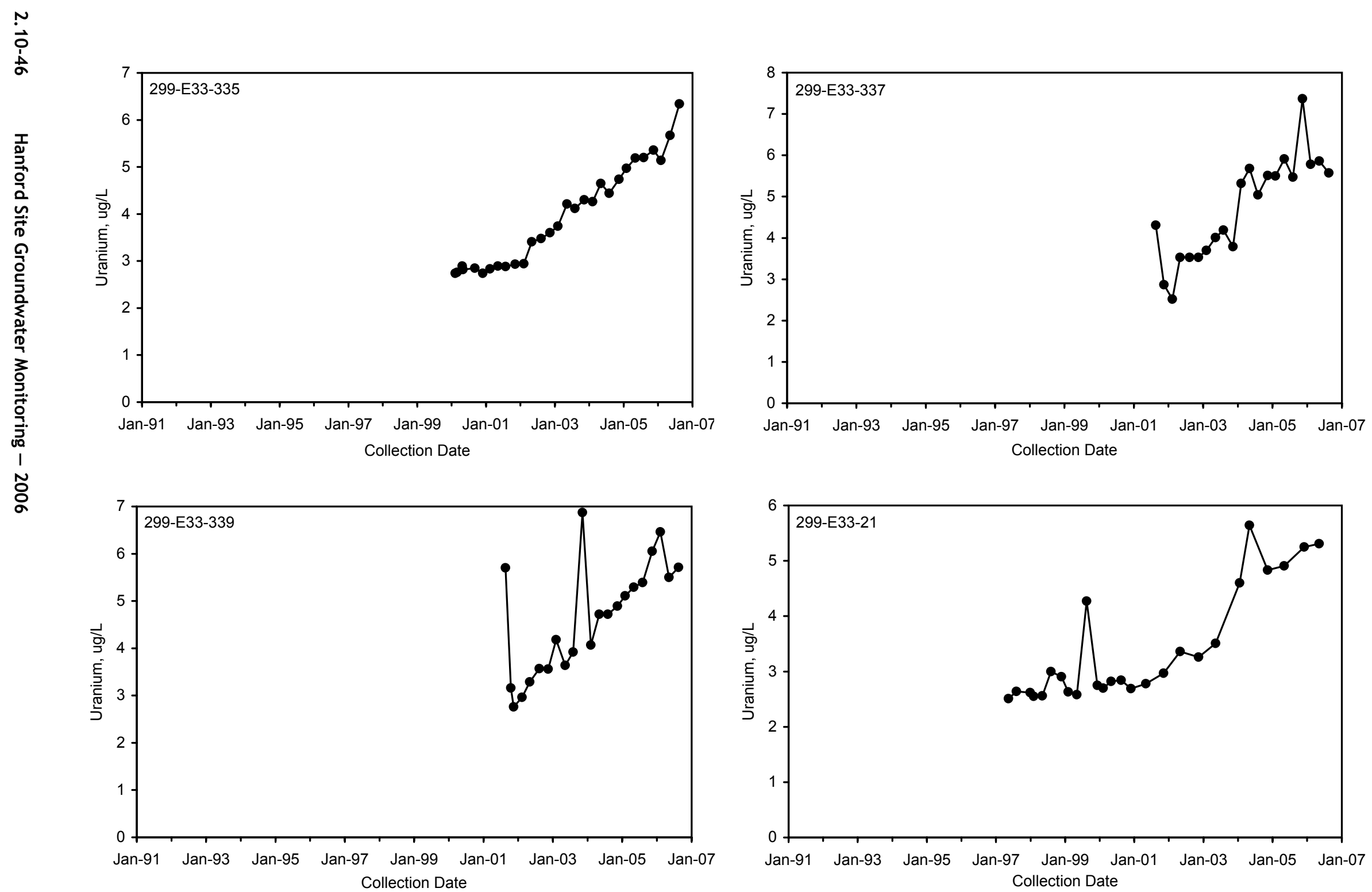

DWS $=30 \mathrm{ug} / \mathrm{L}$

Replicate data averaged

Figure 2.10-20. Uranium Concentrations on South Side of Waste Management Area B-BX-BY 


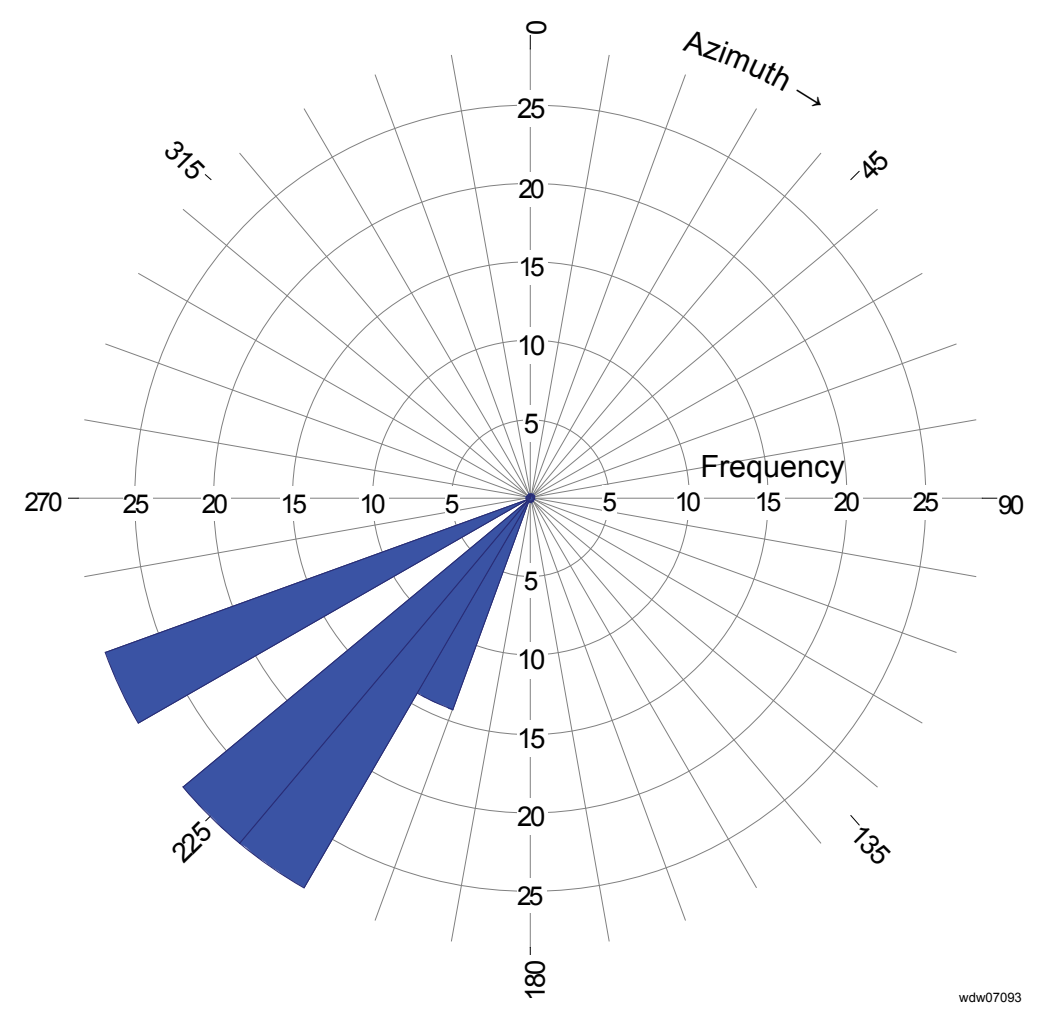

Figure 2.10-21. Groundwater Flow Directions Near Waste Management Area B-BX-BY from 1999 to 2001 (RPP-23748)

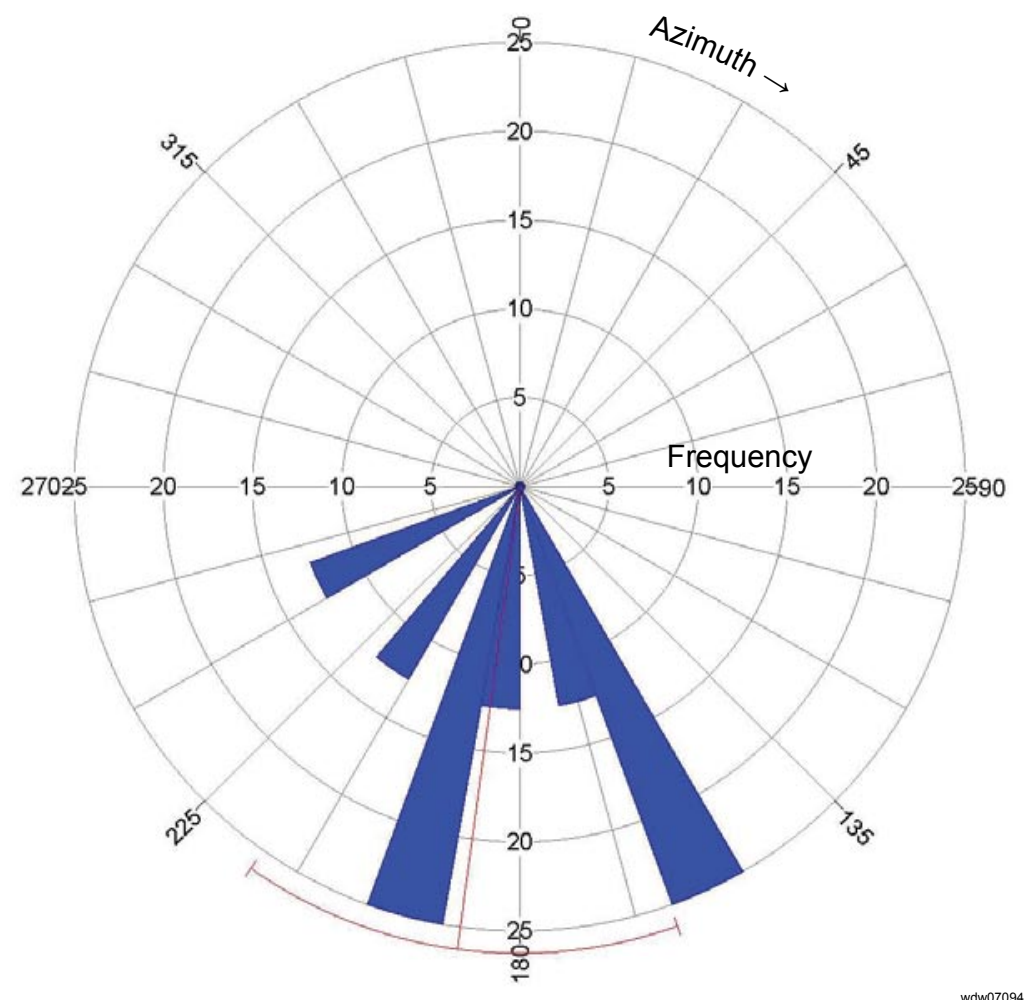

Figure 2.10-22. Groundwater Flow Directions Near Waste Management Area B-BX-BY from 1991 to 2005 

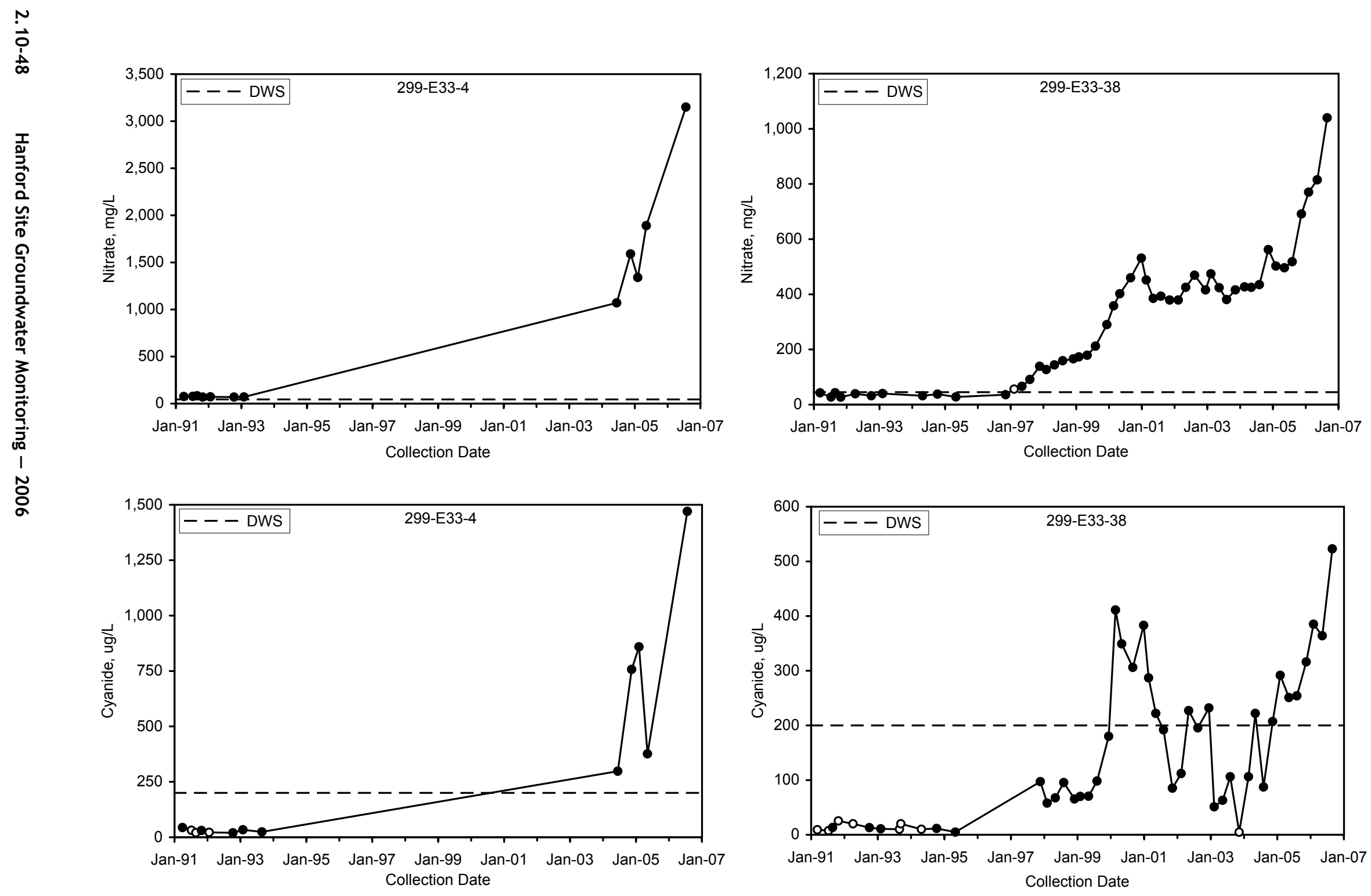

Open symbols used for non-detect values, replicate data averaged

Figure 2.10-23. Nitrate and Cyanide Concentrations Beneath BY Cribs 

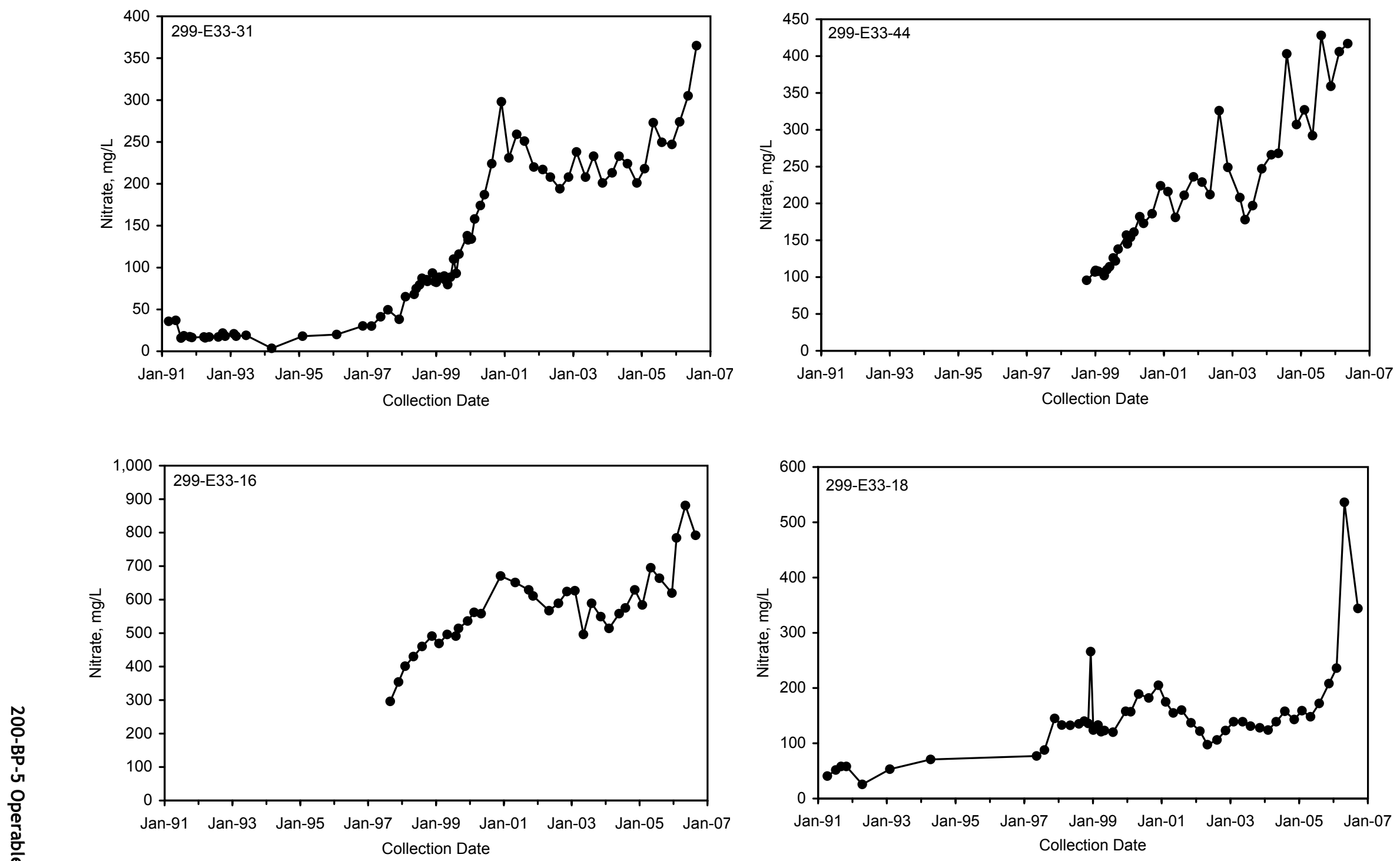

DWS $=45 \mathrm{mg} / \mathrm{L}$

Replicate data averaged

Figure 2.10-24. Nitrate Concentrations in Central Waste Management Area B-BX-BY 
$\stackrel{N}{0}$
ํ.
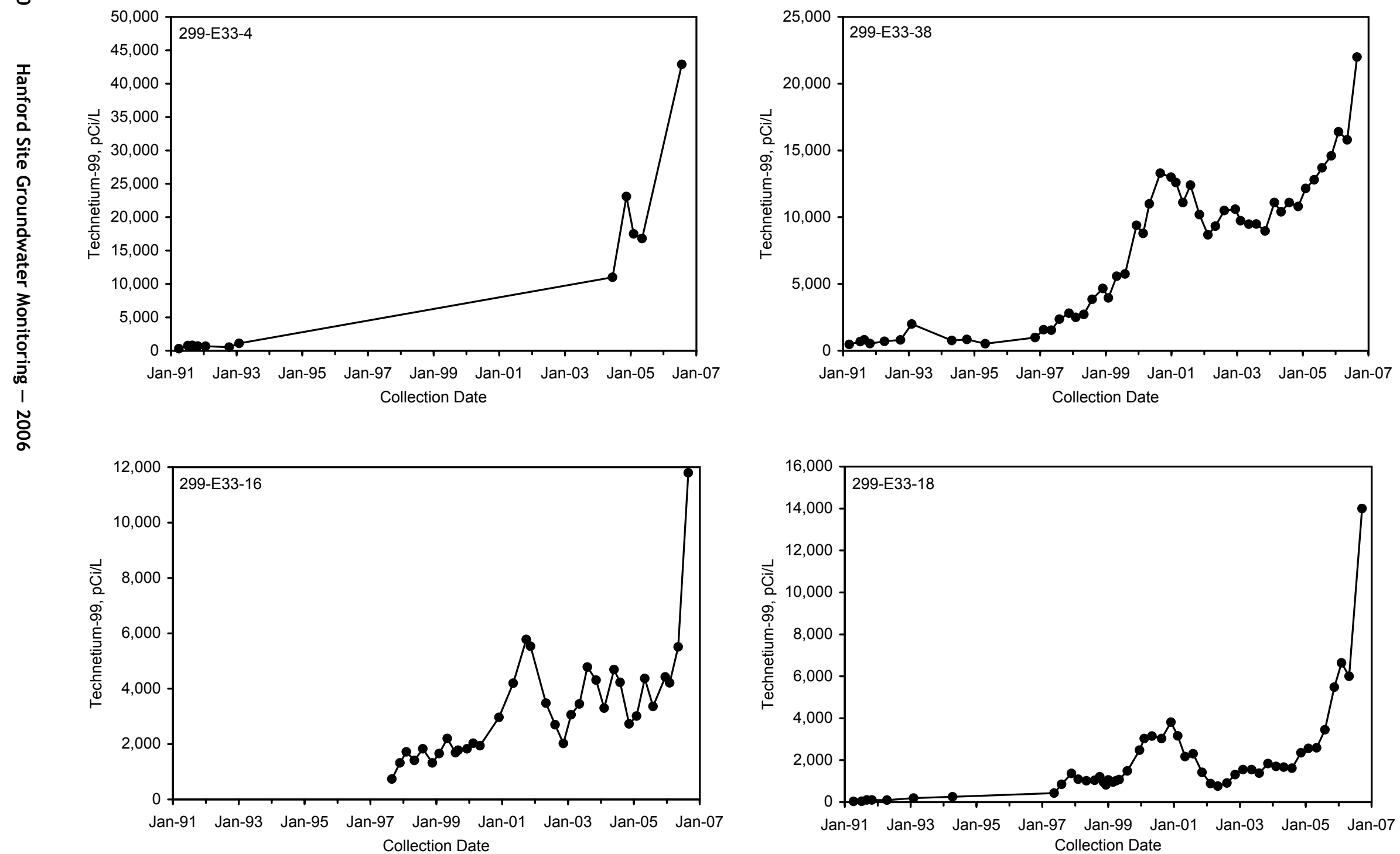

DWS $=900 \mathrm{pCi} / \mathrm{L}$

Replicate data averaged

Figure 2.10-25. Technetium-99 Concentrations Beneath and South of BY Cribs 

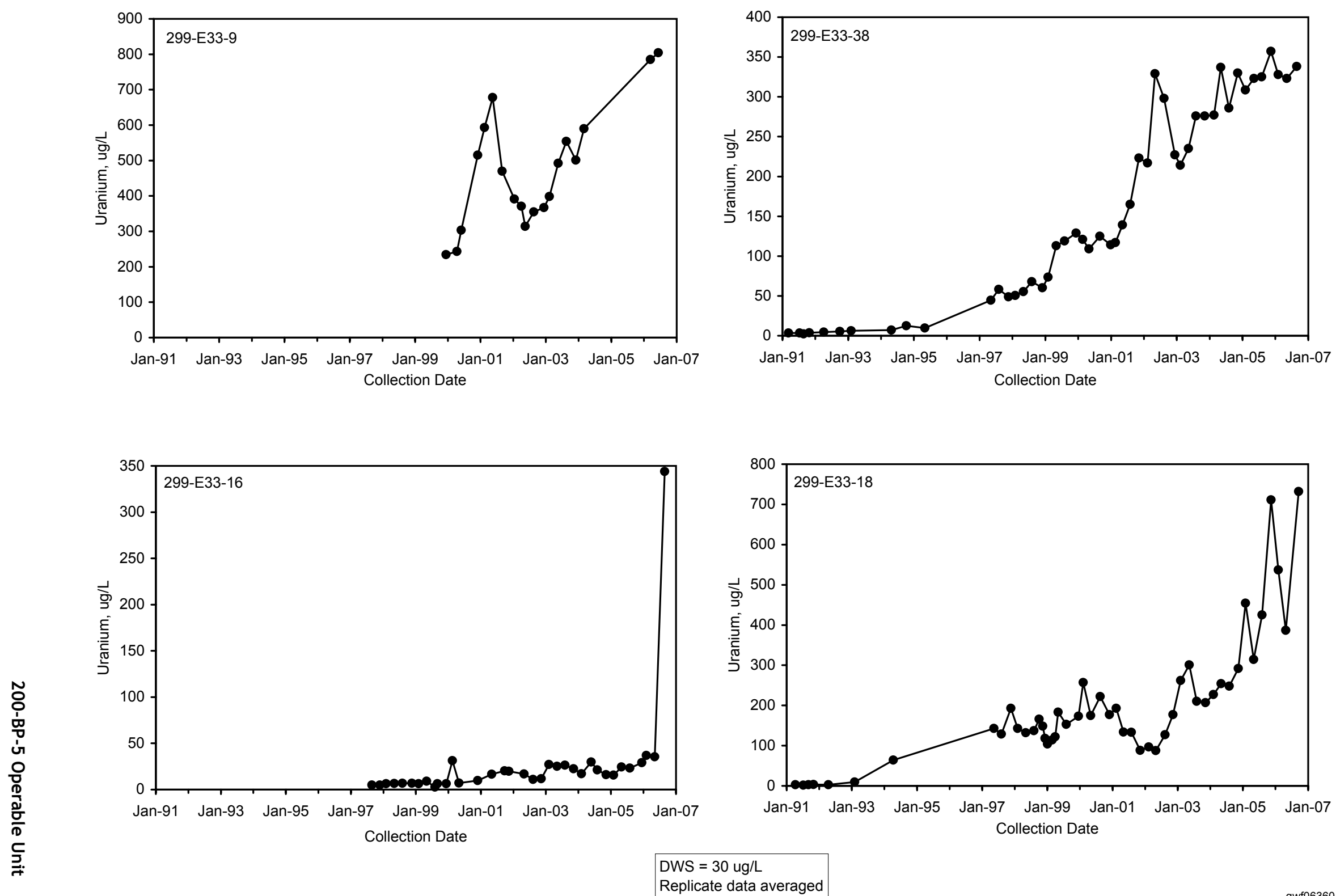

$\stackrel{N}{\overrightarrow{0}}$
U্

Figure 2.10-26. Uranium Concentrations at Waste Management Area B-BX-BY 


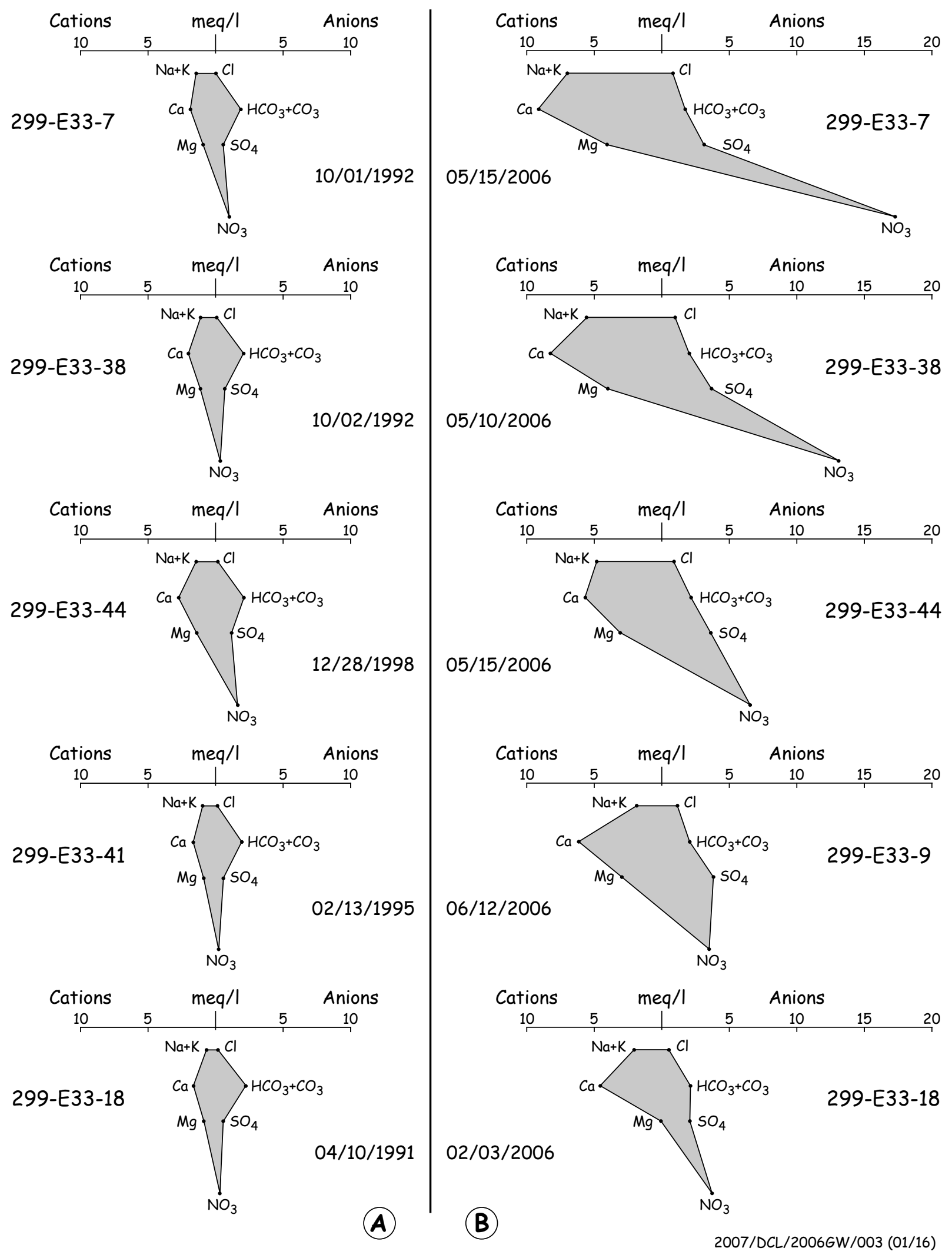

Figure 2.10-27. Stiff Diagrams for Wells at Waste Management Area B-BX-BY 

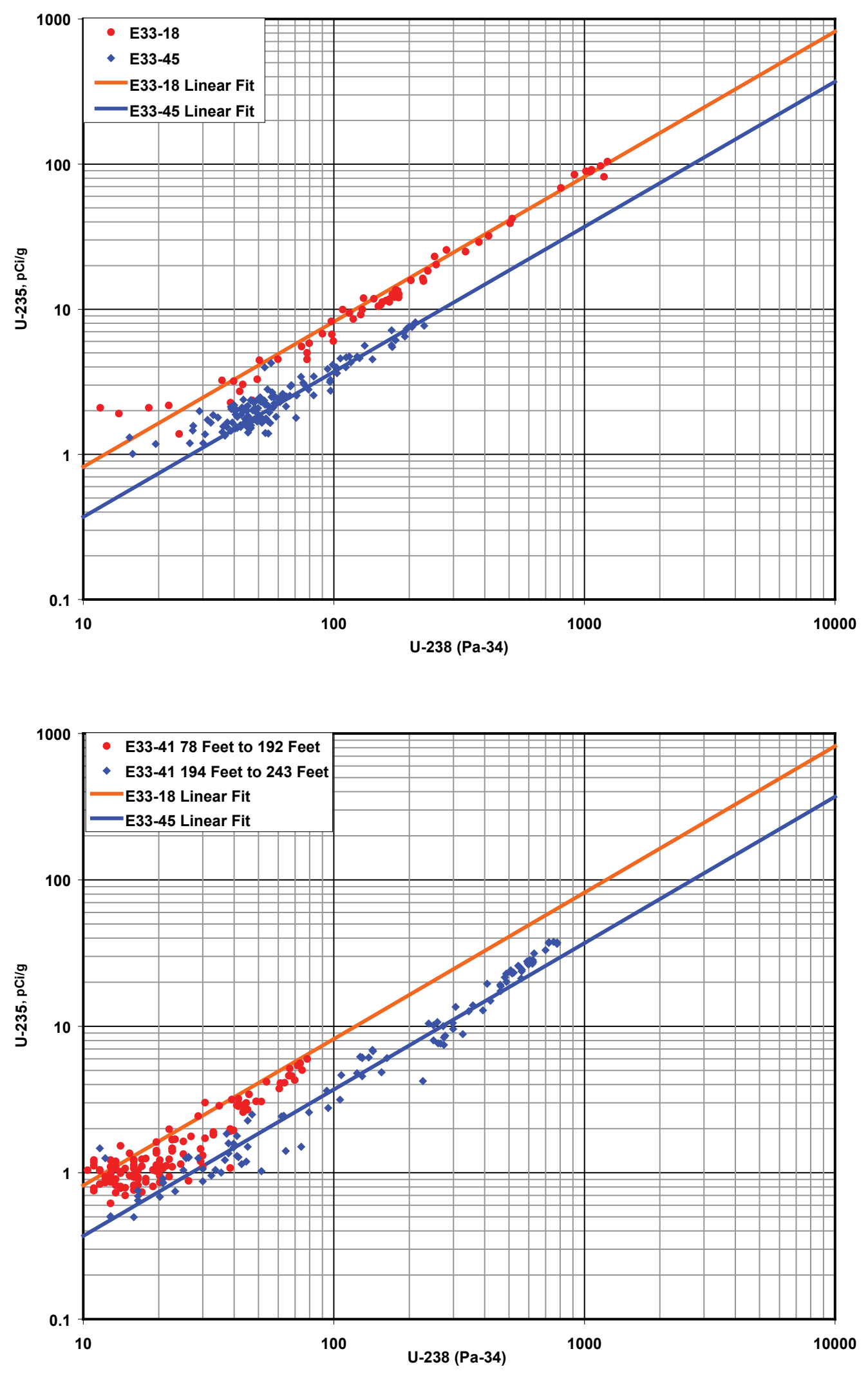

Figure 2.10-28. Cross Plots of Uranium Isotopes from Spectral Gamma Log Data 


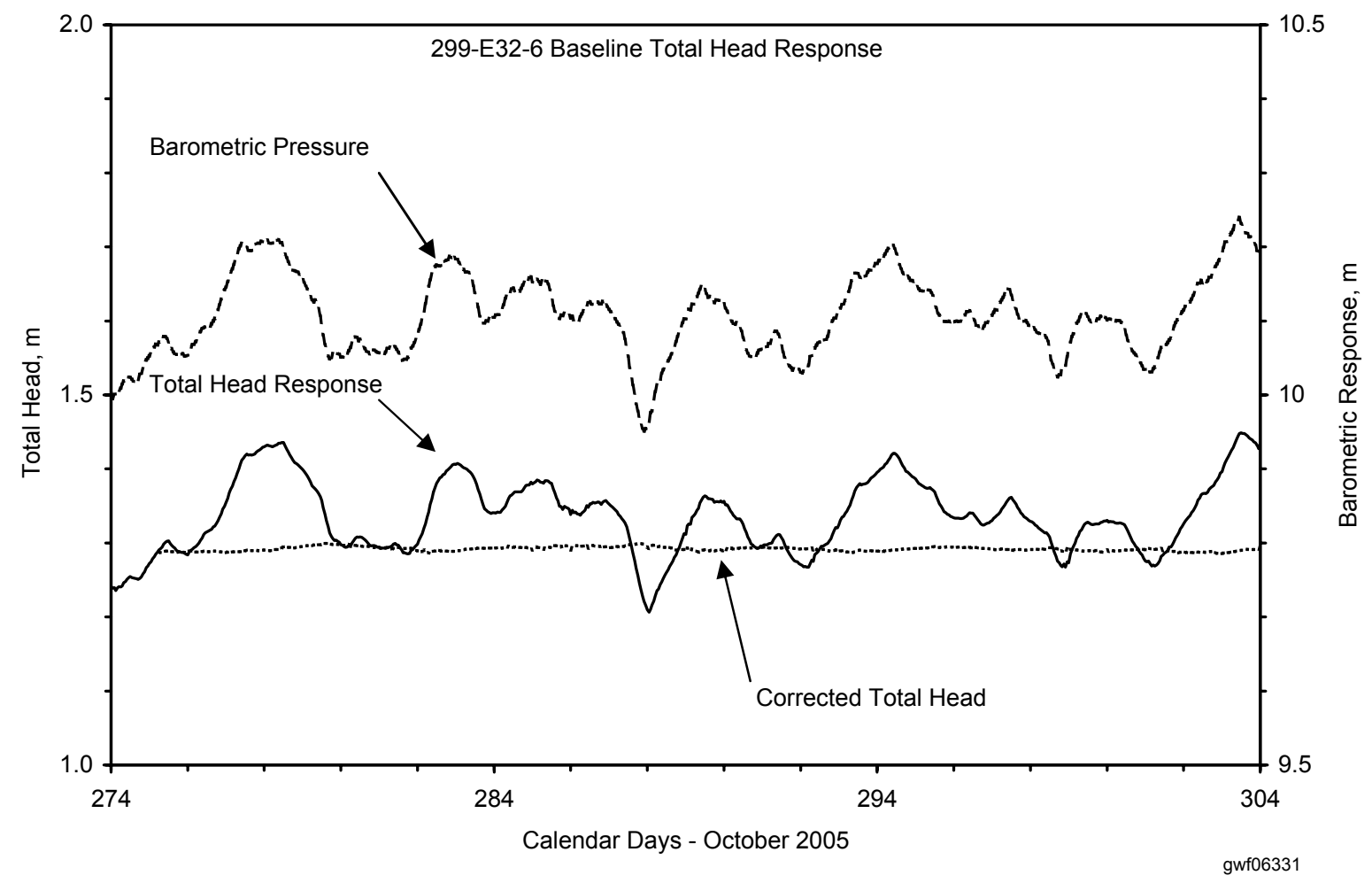

Figure 2.10-29. October 2005 Barometric Pressure, Total Head, and Total Head Corrected for Barometric Effects in Low-Level Waste Management Area 1 Well 299-E32-6

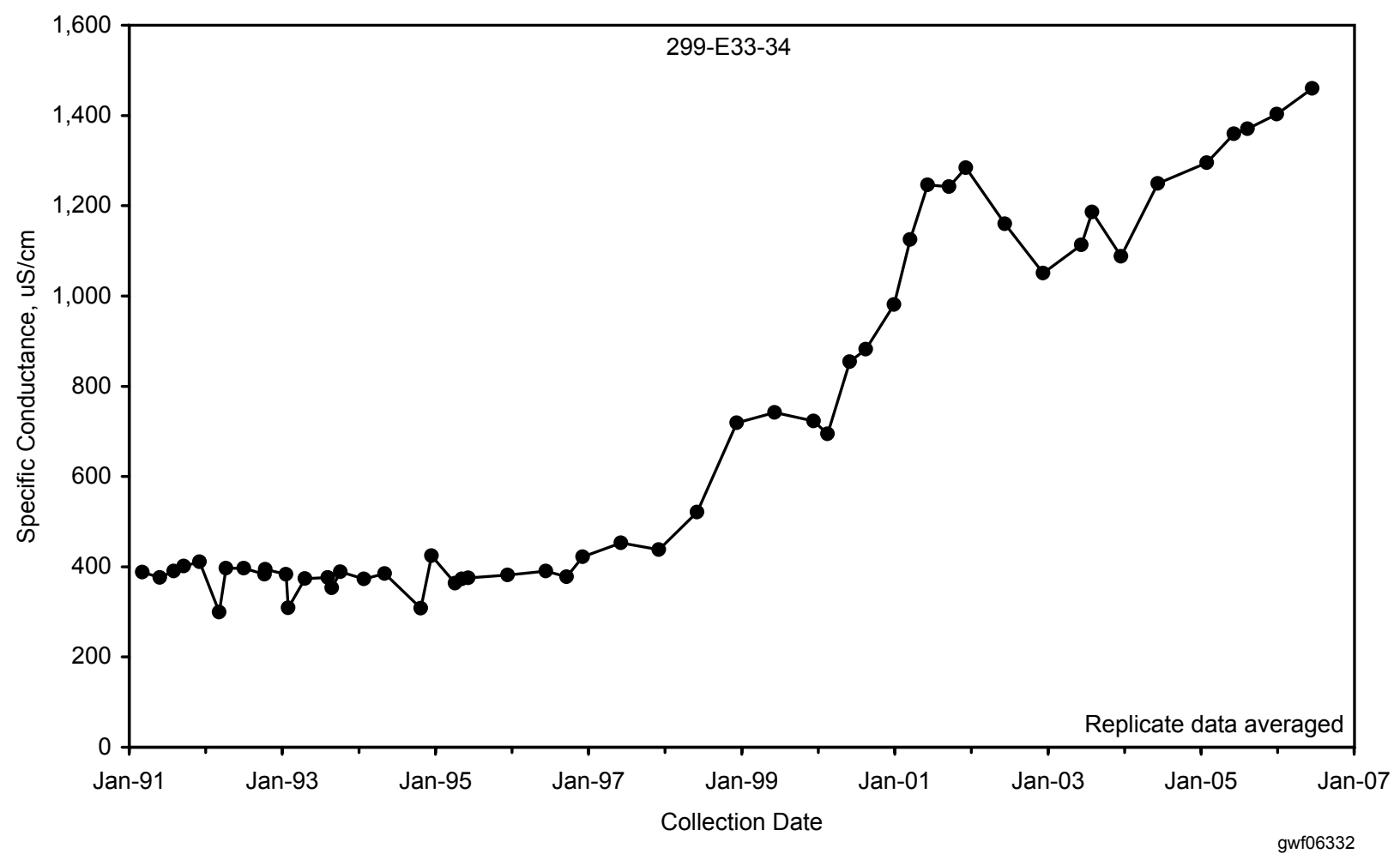

Figure 2.10-30. Specific Conductance in Well 299-E33-34 Near Northeast Corner of Low-Level Waste Management Area 1 


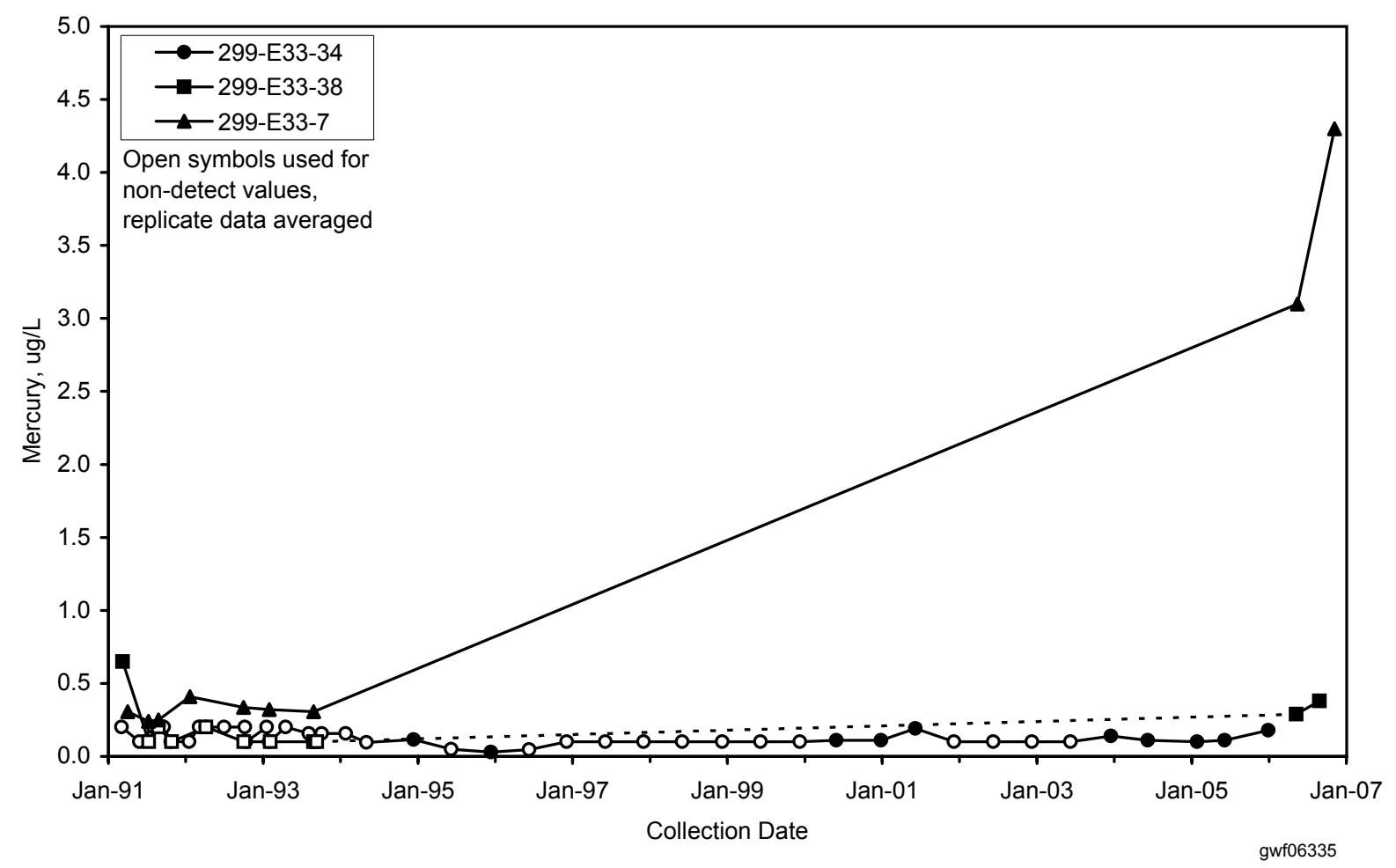

Figure 2.10-31. Mercury Concentrations in Well 299-E33-34 Near Northeast Corner of Low-Level Waste Management Area 1

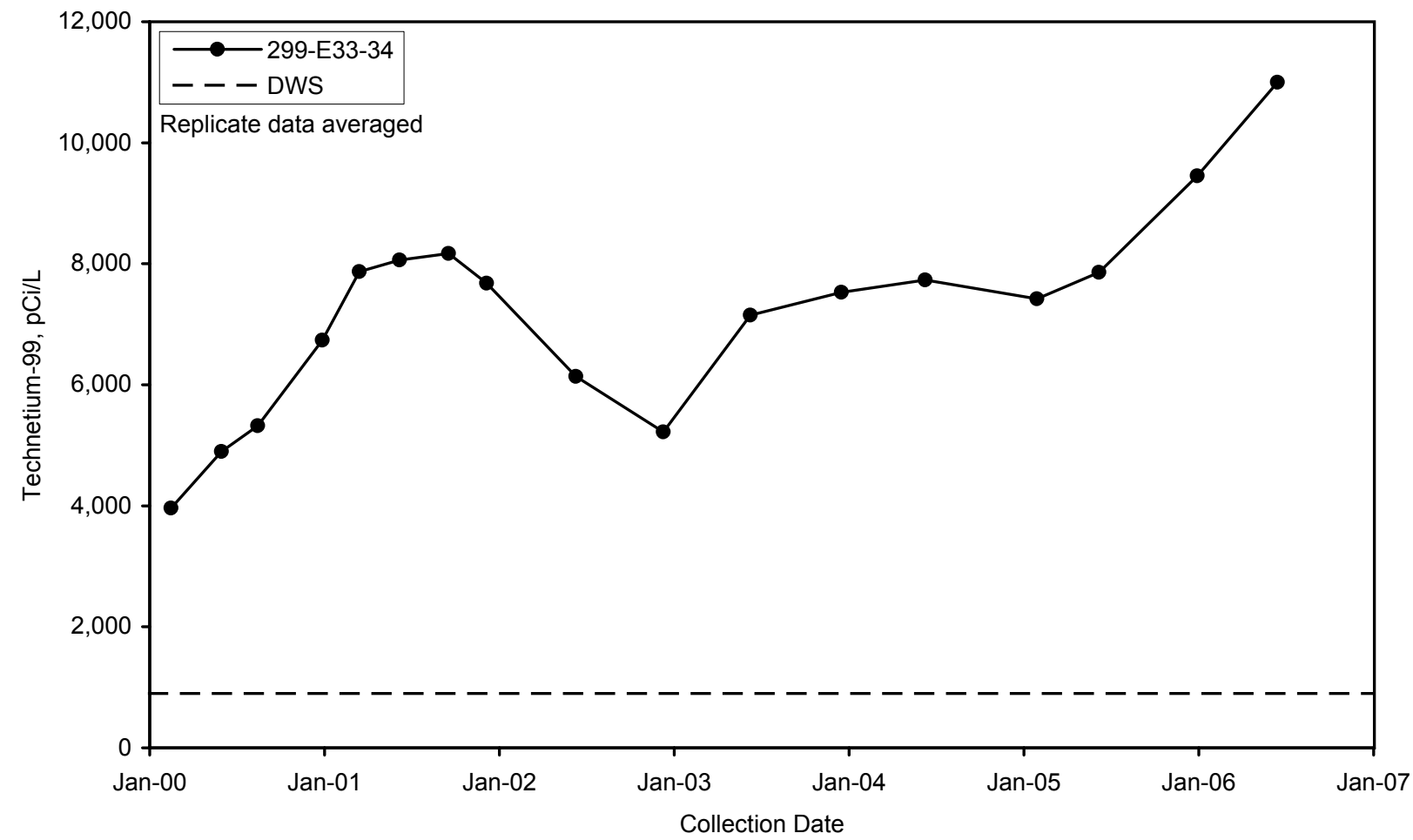

gwf06334

Figure 2.10-32. Technetium-99 Concentrations in Well 299-E33-34 Near Northeast Corner of Low-Level Waste Management Area 1 


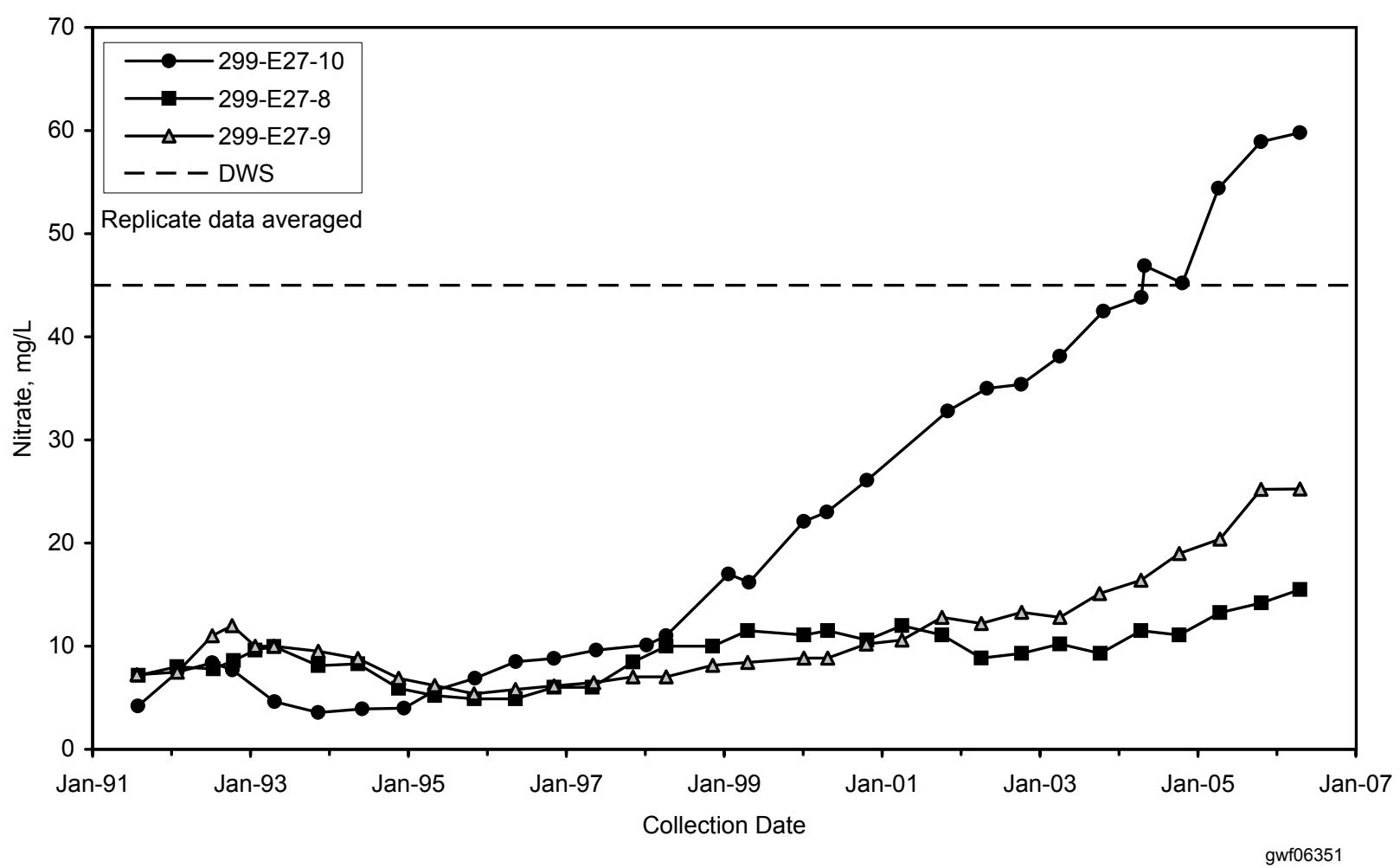

Figure 2.10-33. Nitrate Concentrations in Low-Level Waste Management Area 2 Wells

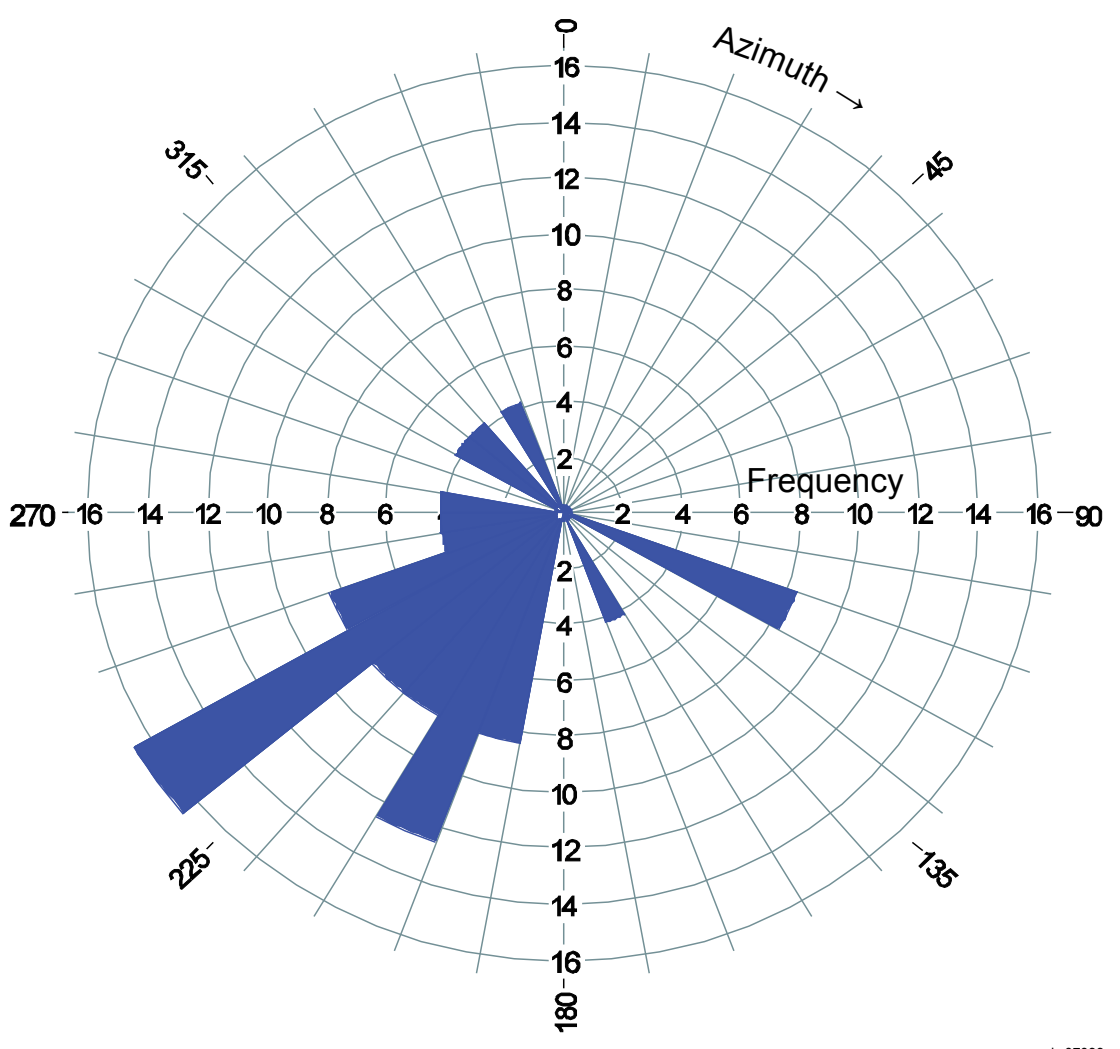

Figure 2.10-34. Groundwater Flow Directions from 1990 to 2003 at C Tank Farm (from RPP-23748) 

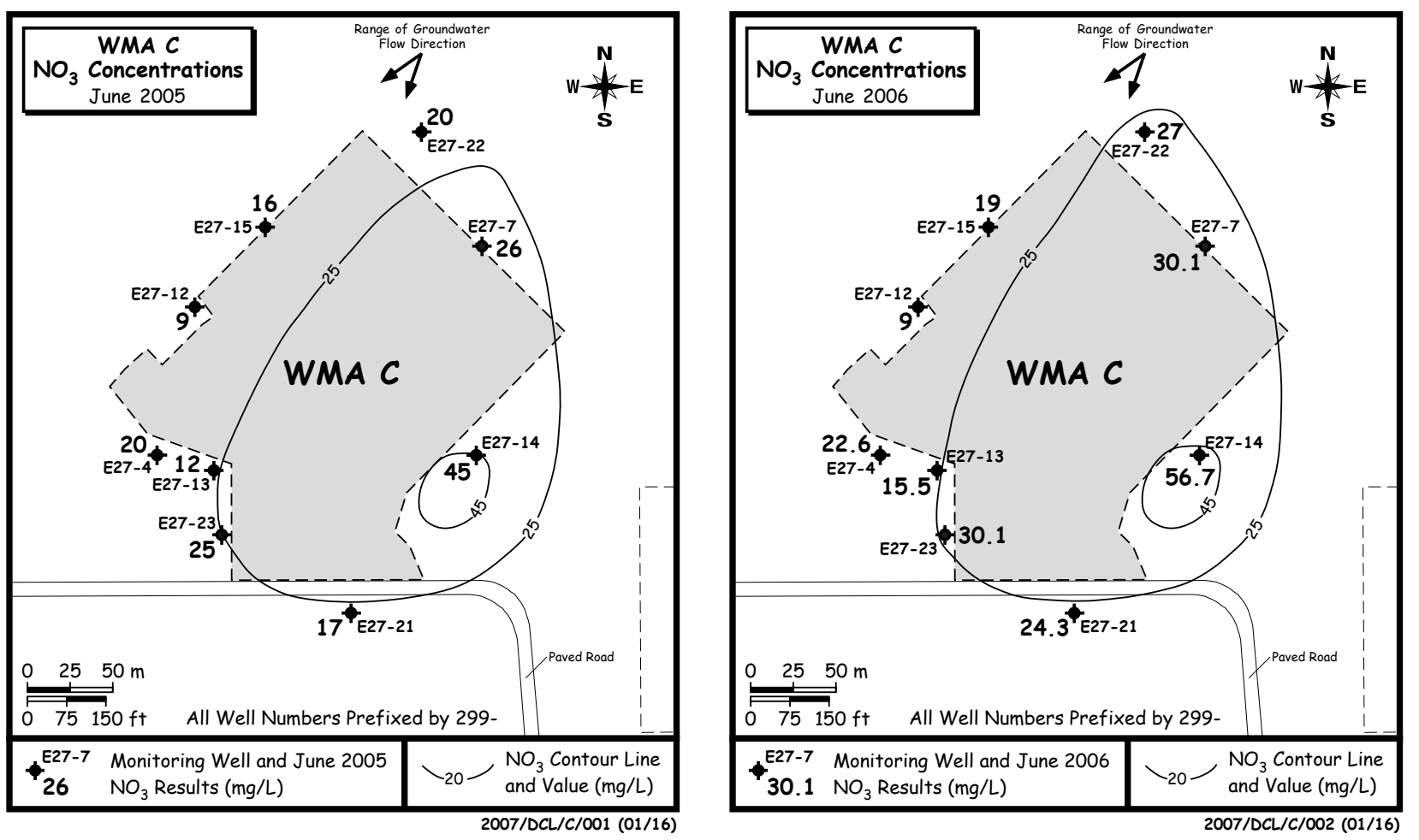

Figure 2.10-35. Nitrate Concentrations at Waste Management C, June 2005 and June 2006

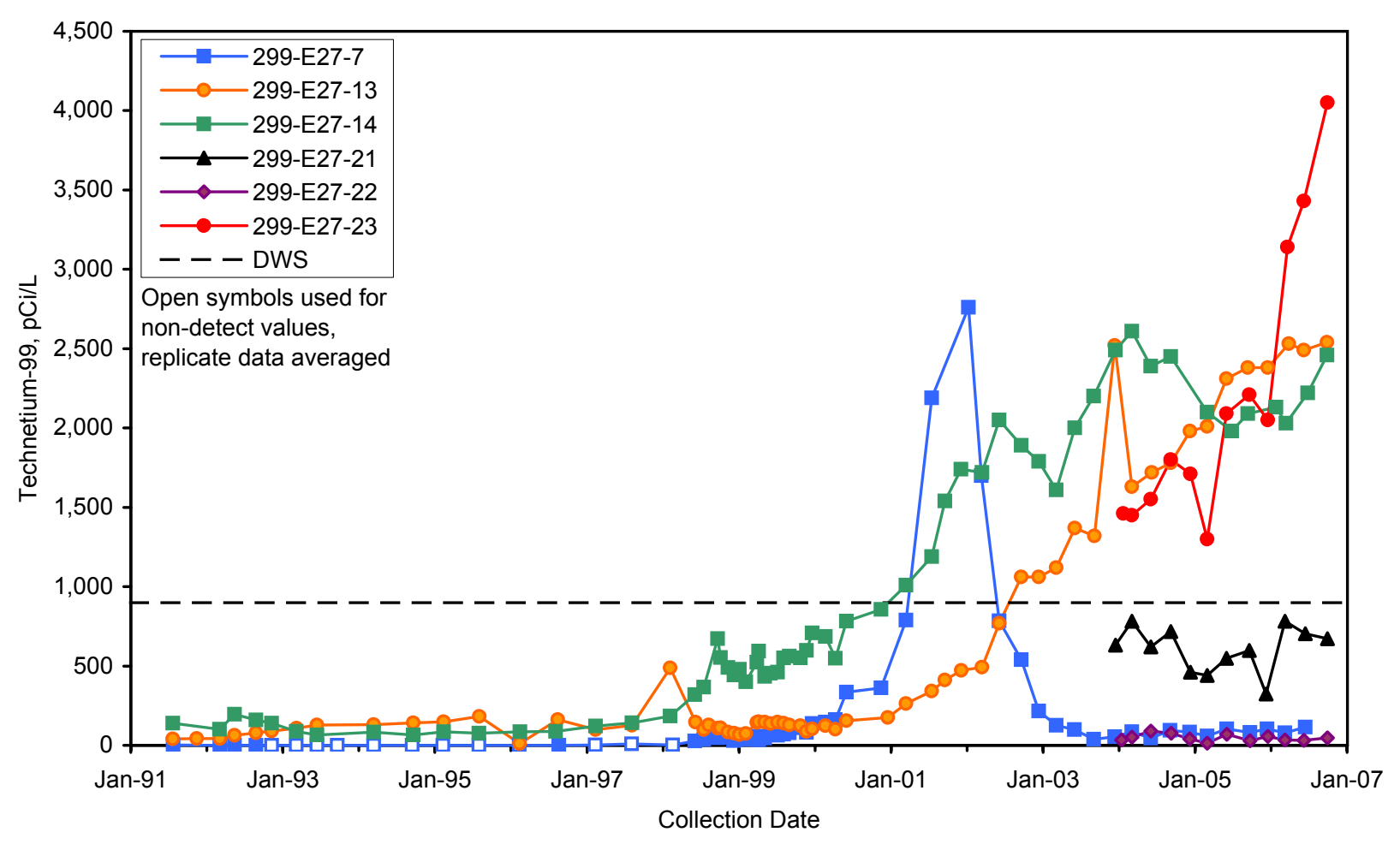

gwf06365

Figure 2.10-36. Technetium-99 Concentrations at Waste Management $\mathrm{C}$ 

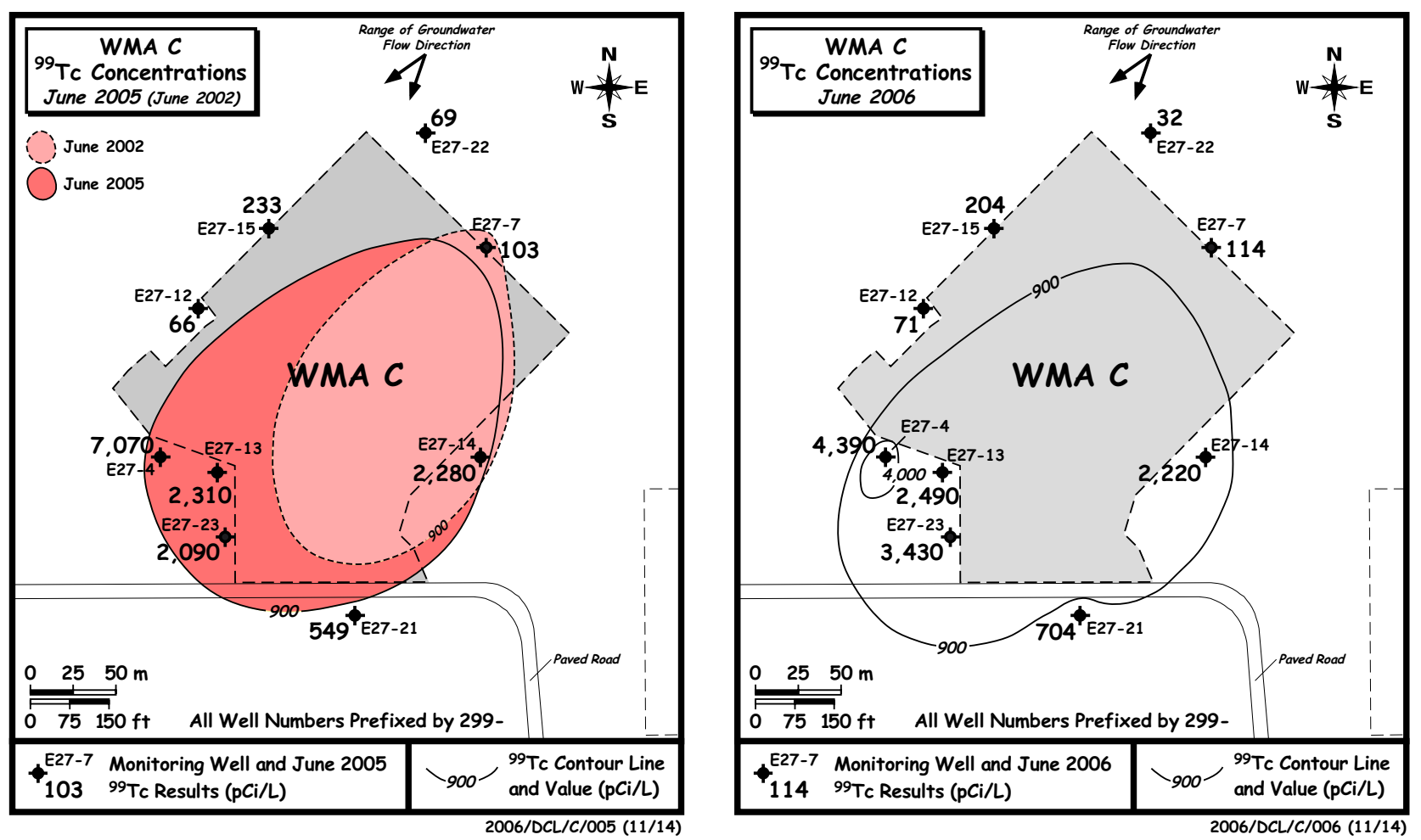

Figure 2.10-37. Technetium-99 Concentrations at Waste Management Area C, June 2002, June 2005, and June 2006 


\subsection{0-PO-1 Operable Unit}

\section{J. W. Lindberg, S. M. Narbutovskih, M. D. Sweeney, D. B. Barnett, D. G. Horton, and E. C. Thornton}

The scope of this section is the 200-PO-1 groundwater interest area, which includes the 200-PO-1 Operable Unit (see Figure 1.0-1 in Section 1.0). The "groundwater interest areas" are informal designations to facilitate scheduling, data review, and interpretation. This area encompasses the south portion of the 200 East Area and a large triangle-shaped portion of the Hanford Site extending to the Hanford town site to the east and the 300-FF-5 groundwater interest area to the southeast. The 216-B-3 pond (B Pond) straddles two operable units but is considered part of the 200-PO-1 interest area. The BC cribs are completely outside of the 200-PO-1 Operable Unit, but potential groundwater contamination there is discussed in this section because waste water from processes in the 200-PO-1 Operable Unit may have been disposed there. The locations of local facilities and wells used in near-field monitoring of the southern 200 East Area are shown in Figure 2.11-1. The locations of wells used in the remainder of the 200-PO-1 Operable Unit far-field area and shoreline monitoring sites within the 600 Area are provided in Figures 2.1-1 and 2.11-2.

Tritium, nitrate, and iodine-129 are the contaminants with the largest plumes in groundwater. Other contaminants of concern in more localized areas include strontium-90 and technetium-99. Contaminants of potential concern include arsenic, chromium, manganese, vanadium, cobalt-60, cyanide, and uranium.
Tritium, nitrate, and iodine-129 are the contaminants of greatest significance in this operable unit.

Groundwater monitoring in the 200-PO-1 groundwater interest area includes the following monitoring activities:

\section{CERCLA Monitoring}

-Wells and aquifer sampling tube sites (along the Columbia River) are sampled annually to triennially for tritium, nitrate, and iodine-129 plus other constituents depending on location.

- In FY 2006, sampling at one well was delayed until FY 2007, and sampling at three aquifer tubes did not occur because they are no longer in service (see Appendix A for details).

Facility Monitoring

- Wells are sampled semiannually at the Integrated Disposal Facility for RCRA and operational monitoring.

- Near-field wells are sampled quarterly to semiannually at the RCRA PUREX cribs facility for RCRA monitoring. Far-field wells are co-sampled with the 200-PO-1 Operable Unit.

- Wells at the single-shell tank Waste Management Area A-AX are monitored quarterly for RCRA and AEA monitoring.

- Wells are sampled semiannually at the 216-A-29 ditch for RCRA monitoring.

- Four wells are sampled semiannually at the 216-B-3 pond (B Pond) for RCRA monitoring.

- Wells are sampled quarterly at the 200 Area Treated Effluent Disposal Facility under a Washington State waste discharge permit (WAC 173-216).

- Wells are sampled semiannually at the Nonradioactive Dangerous Waste Landfill for RCRA monitoring.

- Wells are sampled quarterly at the Solid Waste Landfill under a Washington State solid waste landfill permit (WAC 173-304).

- Water supply wells at the 400 Area are sampled quarterly to annually for AEA.

- Wells not sampled as planned included two wells that were missed, eleven wells that were delayed due mainly to fire danger, and one well in which constituents analyzed in collected samples were not as planned (see Appendix B for details). 


\section{Groundwater in the 200-PO-1 Operable Unit generally flows to the southeast and east.}

\section{Concentrations of tritium continue \\ to decline as \\ the plume is \\ attenuating \\ naturally.}

The primary monitoring objective is to meet the groundwater monitoring requirements for the Comprehensive Environmental Response, Compensation, and Liability Act (CERCLA), Resource Conservation and Recovery Act (RCRA), Washington Administrative Code (WAC), and the Atomic Energy Act (AEA) as directed in U.S. Department of Energy (DOE) Orders. The goal for the 200-PO-1 Operable Unit is to monitor the contaminants of concern (and potential concern) until final clean-up decisions are made. Included within the operable unit are six RCRA units including the Plutonium-Uranium Extraction (PUREX) cribs (called the RCRA PUREX cribs), Waste Management Area A-AX (single-shell tanks), 216-A-29 ditch, Integrated Disposal Facility, B Pond, and the Nonradioactive Dangerous Waste Landfill. Two other facilities that are not regulated under RCRA but are subject to WAC requirements are the 200 Area Treated Effluent Disposal Facility and Solid Waste Landfill. Water supply wells in the 400 Area are monitored primarily for tritium under AEA.

Groundwater in the unconfined aquifer generally flows southeastward in the west portion of the operable unit and northeastward, eastward, and southeastward in the east portions of the operable unit as groundwater approaches the Columbia River (see Figure 2.1-2 in Section 2.1). A detailed discussion of 200 East Area hydrogeology can be found in PNNL-12261. Further discussion of more local groundwater flow characteristics are found in Section 2.11.3.

The remainder of this section describes contaminant plumes and concentration trends for the contaminants of concern under CERCLA, RCRA, AEA, and WAC monitoring.

\subsubsection{Groundwater Contaminants}

This section describes the major contaminants of concern within the 200-PO-1 Operable Unit including tritium, iodine-129, nitrate, strontium-90, technetium-99, and other contaminants of potential concern. Greater details at various RCRA or WAC facilities are discussed in Section 2.11.3.

\subsubsection{Tritium}

The source for the large tritium plume that extends from the southeast portion of the 200 East Area to the Columbia River (Figure 1.0-2 in Section 1.0) is in the vicinity of the PUREX cribs. ${ }^{\text {(a) }}$ The highest concentrations of tritium (drinking water standard $20,000 \mathrm{pCi} / \mathrm{L}$ ) in this plume remain near these cribs (Figure 2.10-4 in Section 2.10). The highest reported level of tritium during fiscal year (FY) 2006 was $571,000 \mathrm{pCi} / \mathrm{L}$ for a sample collected March 2006 at well 299-E17-14 near the 216-A-36B crib. (Note: The 200-PO-1 Operable Unit well with the highest tritium concentration in recent years was well 299-E17-9 near the 216-A-36B crib. This well went dry in FY 2003. The last tritium analysis from this well in October 2002 was 5.6 million pCi/L.)

Concentrations of tritium continued to decline as the plume attenuates naturally due to radioactive decay and dispersion combined with the general decreasing source that resulted from the termination of PUREX Plant operations. Wells in the east portion of the 200-PO-1 Operable Unit have tritium concentrations above 80,000 pCi/L (Figure 1.0-2 in Section 1.0) from an early period of discharge to the PUREX cribs (PNNL-11141). The area of the tritium plume with concentrations above $80,000 \mathrm{pCi} / \mathrm{L}$ in the eastern portion of the Hanford Site is $\sim 23$ square kilometers. In 1996, this portion of the plume was $~ 66$ square kilometers. The wells within this portion of the plume are expected to continue to experience decreasing concentrations as portions of the plume with higher concentrations (representing the two periods of PUREX Plant operations) move beyond the wells into the river or decay and disperse. Model results suggest that groundwater containing tritium concentrations exceeding

(a) The term "PUREX cribs" refers to all the cribs in the southeast part of the 200 East Area and east of the 200 East Area where PUREX wastewater was discharged. Three of these cribs are monitored under RCRA and are termed RCRA PUREX cribs (see Section 2.11.3.2). 
$20,000 \mathrm{pCi} / \mathrm{L}$ will continue to discharge at this location for 40 to 50 years (PNNL-11801). These wells more distant from the source are sampled once every 3 years, and most were sampled during FY 2004. They will be sampled again in FY 2007. Wells in the south of the 200-PO-1 Operable Unit, immediately north of the 300 Area, also have decreasing tritium concentrations indicating that the southward migration of the plume has slowed or stopped because of the effects of dispersion and radioactive decay (see more about tritium near the 300 Area in Section 2.12.1.5).

Wells near the PUREX cribs generally show a steady to decreasing trend as demonstrated in the trend plot for well 299-E17-14 (Figure 2.11-3) located near the 216-A-36B crib. However, a few of the wells near the PUREX cribs show increasing trends more recently as demonstrated in the trend plots for well 299-E24-16 (Figure 2.11-4) located near the 216-A-10 crib and well 299-E25-36 located about 1,500 meters northeast of the 216-A-36B crib (Figure 2.11-4). The increasing trend at well 299-E25-36 may indicate a shift in the local groundwater flow pattern from southeast to more eastward.

The zone of lower tritium concentration near Energy Northwest (Figure 1.0-2 in Section 1.0) is suspected to be due to the effect of a zone of lower hydraulic conductivity in the unconfined aquifer where the water table is within the upper portion of the Ringold Formation that locally may have a greater degree of cementation. Tritium at the 618-11 burial grounds located just west of Energy Northwest is discussed in Section 2.12.1.5.

200-PO-1 Operable Unit wells screened below the upper parts of the unconfined aquifer (in the middle portions or lower portions of the unconfined aquifer) or deeper in confined aquifers generally show very little groundwater contaminated with tritium. Tritium was not detected at the 200 Area Treated Effluent Disposal Facility during FY 2006. The wells there are screened at the first occurrence of groundwater below the Ringold Formation lower mud unit where the aquifer is locally confined (i.e., potentiometric surface is within the lower mud unit). Well 499-S1-8J (a water-supply well in the 400 Area) is screened in the lower portion of the Ringold Formation (but not confined) and had tritium levels during FY 2006 that ranged from 2,840 to $3,240 \mathrm{pCi} / \mathrm{L}$. These levels are lower than other wells in the 400 Area that are screened at the water table. Typically, wells screened at the water table in this area are affected by the large tritium plume from the 200 East Area and have tritium levels ranging from 14,000 to $28,000 \mathrm{pCi} / \mathrm{L}$ (see Figure 1.0-2 in Section 1.0). Tritium was not detected in the Laser Interferometer Gravitational Wave Observatory (LIGO) well (699-S2-34B), which is screened in a basalt-confined aquifer, in a sample taken during January 2006. Similarly, five other deep 200-PO-1 wells screened in basalt aquifers (and sampled triennially including FY 2006) showed no detectable tritium during FY 2006.

\subsubsection{2 lodine-129}

The iodine-129 plume (Figure 1.0-4 in Section 1.0) extends southeast into the 600 Area from the 200 East Area and appears to coincide with the tritium and nitrate plumes (see Figures 1.0-2 and 1.0-3 in Section 1.0). The iodine-129 plume is dispersing at a very slow rate. During FY 2006, the highest concentrations of the iodine-129 plume were near the sources of the plume, i.e., the PUREX cribs, where concentrations ranged from below the analysis method detection level to $9.1 \mathrm{pCi} / \mathrm{L}$ in well 299-E17-14 (near the 216-A-36B crib) (see Figure 2.10-8 in Section 2.10). The gradually decreasing trend for iodine-129 at this well (Figure 2.11-5) is typical of the gradually decreasing trend for iodine-129 in the vicinity of the PUREX cribs. Iodine-129 was not detected during FY 2006 in the few wells that sample deeper in the unconfined aquifer and confined aquifers.

\subsubsection{Nitrate}

The extent of the nitrate plume that originated in the 200 East Area (Figure 1.0-3 in Section 1.0) is nearly identical to the tritium plume. However, the area with nitrate concentration above the drinking water standard $(45 \mathrm{mg} / \mathrm{L})$ is more restricted than the area with tritium above its drinking water standard $(20,000 \mathrm{pCi} / \mathrm{L})$. Nitrate at levels above the

\section{The iodine-129 plume is dispersing, but at a very slow rate.}


The nitrate plume

\section{appears to have}

receded except for

portions of the

200 East Area and

near the 300 Area

to the south. drinking water standard north of the 400 Area and at Energy Northwest, within the area impacted by the PUREX cribs, can be attributed to wastewater disposal activities in those areas. The highest reported concentration of nitrate during FY 2006 within the 200-PO-1 interest area was at well 299-E17-14 (see Figure 2.10-6 in Section 2.10) with a reported value of $127 \mathrm{mg} / \mathrm{L}$ in July 2006. The overall nitrate plume (see Figure 1.0-3 in Section 1.0) appears to have receded slightly over previous years throughout most of its extent except for the southern-most portions of the plume near the 300 Area (see Section 2.12.1.4) and in the immediate vicinity of the PUREX cribs (PNNL-15070; PNNL-15670) and Waste Management Area A-AX (see Figure 2.11-1 for locations of PUREX cribs and Waste Management Area A-AX and wells in the vicinity).

Wells near the PUREX cribs in the southeast portion of the 200 East Area continued to show stable or increasing nitrate trends during FY 2006. The trend at well 299-E24-16 near the 216-A-10 crib is typical of the increasing trend (Figure 2.11-6). The increase in nitrate concentration was also observed at the upgradient well 299-E24-18, to the east at well 299-E25-17 near the 216-A-37-1 crib, and at wells near Waste Management Area A-AX (see Section 2.11.3.3). This increase in nitrate at many of the wells in the southeast portion of the 200 East Area most likely is due to changing groundwater flow conditions related to the cessation of wastewater discharges at B Pond. These increasing concentrations would be consistent with a reversal of nitrate-contaminated groundwater that moved northwestward in the PUREX cribs area during the active life of B Pond.

Nitrate was detected in a few wells that are deeper into the unconfined aquifer or lower confined aquifer. However, none of the deeper wells had reported nitrate concentrations exceeding the nitrate drinking water standard $(45 \mathrm{mg} / \mathrm{L}$ ). At the Nonradioactive Dangerous Waste Landfill, nitrate concentrations were as high as $20.4 \mathrm{mg} / \mathrm{L}$ in well 699-26-35C, which is a well screened at the top of the low permeability unit (bottom of the unconfined aquifer there) in the upper Ringold Formation. Beneath the Ringold Formation lower mud unit at B Pond and the 200 Area Treated Effluent Disposal Facility (the uppermost aquifer there), nitrate concentrations continue to be low (below $6.8 \mathrm{mg} / \mathrm{L}$ ). In the lower portions of the unconfined aquifer beneath the 216-A-29 ditch (well 299-E25-28), the nitrate concentration was below $1.6 \mathrm{mg} / \mathrm{L}$. In the water supply well 499-S1-8J in the 400 Area, which is screened in the lower portion of the Ringold Formation, nitrate is not detected (below $0.044 \mathrm{mg} / \mathrm{L}$ ). Nitrate also remains undetected in the Laser Interferometer Gravitational Wave Observatory well (699-S2-34B), and three other wells screened in lower basalt aquifers beneath the 200-PO-1 interest area. One deep-basalt well (699-24-1P, north of Energy Northwest in the 600 Area) had a single nitrate result that was detectable $(0.248 \mathrm{mg} / \mathrm{L})$. However, this result is not consistent with the historical trend at this well, and is undergoing further review.

\subsubsection{Strontium-90}

A localized area of strontium-90 (a beta-emitter) contamination exists near the 216-A-36B crib (a PUREX crib). Well 299-E17-14 was the only well with strontium-90 concentrations above the drinking water standard ( $8 \mathrm{pCi} / \mathrm{L}$ ) during FY 2006, with a maximum of $21 \mathrm{pCi} / \mathrm{L}$. The trend for strontium-90 in well 299-E17-14 shows an increasing trend from 1997 to 2001 , and then a slightly fluctuating trend that overall is neither increasing nor decreasing (Figure 2.11-7). The impact is localized because of the low mobility of strontium-90 compared to tritium, iodine-129, and nitrate.

\subsubsection{Technetium-99}

Technetium-99 (a beta-emitter) continues to be detected at Waste Management Area A-AX at activity levels far above the drinking water standard $(900 \mathrm{pCi} / \mathrm{L})$ and was detected indirectly (from gross beta measurements) at the PUREX cribs. Although most wells at Waste Management Area A-AX had technetium-99 levels below the drinking water standard, groundwater samples collected from well 299-E25-93 had technetium-99 
concentrations ranging from 6,700 to $7,740 \mathrm{pCi} / \mathrm{L}$, and well 299-E24-33 had technetium-99 concentrations ranging from 729 to $1,010 \mathrm{pCi} / \mathrm{L}$ during FY 2006. Concentrations in well 299-E25-93 were lower than previous years (Figure 2.11-8). Levels in well 299-E24-33 increased throughout FY 2006 and exceeded the $900-\mathrm{pCi} / \mathrm{L}$ drinking water standard for the first time. For more information about technetium-99 at Waste Management Area A-AX, refer to Section 2.11.3.3).

\subsubsection{Other Constituents}

Other constituents such as arsenic, chromium, manganese, and vanadium are also contaminants of concern at various facilities within the 200-PO-1 Operable Unit (DOE/RL2003-04, Rev. 0). Chromium, cobalt-60, cyanide, and uranium are potential contaminants of concern at the BC cribs. Filtered arsenic was detected at wells near the PUREX cribs, Waste Management Area A-AX, and 216-A-8, -30, and -24 cribs (see Figure 2.11-1 for crib locations) in concentrations ranging from 1 to $11 \mu \mathrm{g} / \mathrm{L}$ during FY 2006. However, these concentrations are not significantly different from Hanford groundwater background values (DOE/RL-96-61).

During FY 2006, the highest dissolved chromium concentration in 200-PO-1 Operable Unit groundwater was $41.1 \mu \mathrm{g} / \mathrm{L}$ at well 299-E13-14 at the BC cribs (Figure 2.11-1). (The drinking water standard for chromium is $100 \mu \mathrm{g} / \mathrm{L}$.) Chromium concentrations in wells at the BC cribs area and southwest 200 East Area may be influenced by a plume of chromium entering the area from the west or southwest (see Section 2.9.1.7 and the report summary in this report that includes a figure on the distribution of hazardous chemicals in groundwater at the Hanford Site). No other 200-PO-1 Operable Unit wells were reported to have dissolved chromium results exceeding the drinking water standard during FY 2006.

None of the wells in the 200-PO-1 Operable Unit had manganese concentrations that exceeded the $50-\mu \mathrm{g} / \mathrm{L}$ secondary drinking water standard during FY 2006. The highest concentrations reported ranged from 34 to $42 \mu \mathrm{g} / \mathrm{L}$ at well 299-E25-19 (216-A-37-1 crib) for filtered samples. In the last 10 years, filtered manganese has ranged from 18 to 64 at this well, and the last time the concentration exceeded the drinking water standard was in 2001 with a value of $52 \mu \mathrm{g} / \mathrm{L}$. Well 299-E25-19 is an older Hanford well that is constructed of carbon steel casing and is not compliant with WAC 173-160. Older wells like this are known to occasionally have anomalously high concentrations of manganese or iron suggesting that the results are not representative of the aquifer.

Vanadium concentrations ranged in the 200-PO-1 Operable Unit from $5.7 \mu \mathrm{g} / \mathrm{L}$ at well 299-E18-1 (upgradient well for the Integrated Disposal Facility) to the single result of $40.7 \mu \mathrm{g} / \mathrm{L}$ at well 299-E25-22 (216-A-37-2 crib). The area with the highest levels of vanadium is near the 216-A-37-1 and -2 cribs, 216-A-29 ditch, and B pond. In wells having enough values to establish trends, the trends appear to be stable to slightly declining. There is no drinking water standard for vanadium.

Groundwater monitoring results at the BC cribs for FY 2006 showed that the contaminants of concern (chromium, cobalt-60, cyanide, and uranium, as well as the other 200-PO-1 Operable Unit contaminants of concern) were either not detected or were similar to background concentrations. The only exception was chromium at well 299-E13-14 with a result of $41.1 \mu \mathrm{g} / \mathrm{L}$. Elevated chromium concentrations in the BC cribs area may be due to the chromium plume (discussed above) flowing into the area from the west or southwest. (See previous chromium discussion in this section.)

Although fluoride is not a contaminant of concern in the 200-PO-1 Operable Unit, it was reported at a concentration of $7.3 \mathrm{mg} / \mathrm{L}$ in well 699-S2-34B (the LIGO well - at the Laser Interferometer Gravitational-Wave Observatory, located in the south-central Hanford Site). This deep well is screened in a basalt-confined aquifer that is known to have elevated concentrations of fluoride. Since the well was first sampled in 2001, fluoride results ranged from 5.8 to $8.5 \mathrm{mg} / \mathrm{L}$.
One well at Waste

Management

Area A-AX had

technetium-99

levels ranging from

6,700 to $7,740 \mathrm{pCi} / \mathrm{L}$

during FY 2006,

which is a decrease

from FY 2005.

\author{
A plume of \\ chromium entering \\ the 200 East Area \\ from the southwest \\ may be causing \\ increased dissolved \\ chromium levels in \\ the southwestern \\ portion of the \\ 200 East Area and \\ $B C$ cribs.
}




\subsubsection{Operable Unit Monitoring}

The 200-PO-1 Operable Unit contains a large portion of the Hanford Site (see Figure 1.0-1 in Section 1.0 and Figure 2.11-2). Its boundaries are generally defined by the largest contaminant plume of the operable unit - tritium. The north boundary is the line separating the 200-BP-5 Operable Unit with the 200-PO-1 Operable Unit in the 200 East Area and the 2,000-pCi/L tritium contour line that extends eastward to the Columbia River. The southwest boundary in the $2,000-\mathrm{pCi} / \mathrm{L}$ tritium contour line. The south boundary coincides with the north boundary of the 300-FF-5 Operation Unit, and the east boundary is the Columbia River. The BC cribs, located south of the 200 East Area (Figures 2.11-1 and 2.11-2), are outside the 200-PO-1 Operable Unit boundary, but wells there are included in the 200-PO-1 Operable Unit monitoring network, although the majority of waste disposed there came from U Plant in the 200 West Area.

During FY 2006, work began on a data quality objectives study for groundwater remediation in the 200-PO-1 Operable

Unit.

Tritium, iodine-129, and dissolved iron were the only groundwater constituents that exceeded drinking water standards during FY 2006 in the Southeast

Transect.
Groundwater monitoring at the 200-PO-1 Operable Unit makes certain that requirements for CERCLA and AEA are met. The goal is to monitor the groundwater contamination of concern until final cleanup decisions are made. A record of decision has not been written for this operable unit. The results of 200-PO-1 Operable Unit groundwater monitoring for FY 2006 included in this report constitute the official report for FY 2006. No separate report exists as there would be for an operable unit with a record of decision and an operation and maintenance plan or ongoing remediation. During FY 2006 work began on a data quality objectives report for groundwater remediation in the 200-PO-1 Operable Unit. The document is expected to be completed during FY 2007 and will provide the basis for Rev. 2 of the 200-PO-1 Operable Unit sampling and analysis plan.

In FY 2006, groundwater sampling and analysis in the 200-PO-1 Operable Unit was conducted under the revised sampling and analysis plan (DOE/RL-2003-04, Rev. 1), and the data and analyzed results are discussed in this report. Appendix A includes a list of wells and constituents. All of the wells were sampled as scheduled except one that was delayed until early FY 2007.

The 200-PO-1 Operable Unit sampling analysis plan (DOE/RL-2003-04, Rev. 1) specifies sampling two lines of "guard wells" annually to screen for a comprehensive list of analyses. One of the lines of guard wells (the Southeast Transect) is located southeast of the 200 East Area (Figure 2.11-2) and ensures that unexpected contaminants do not migrate out of the 200 East Area undetected. The other line (the River Transect) is located along the Columbia River (Figure 2.11-2). Its purpose is to assess the concentration of any groundwater contamination that may reach the river. The comprehensive list of analytes for both transects includes iodine-129, tritium, anions (including nitrate), gross alpha and beta, gamma scan, metals, strontium-90, and volatile organic compounds.

At the Southeast Transect, chloride, chromium, gross alpha, gross beta, iodine-129, iron, manganese, nitrate, sulfate, tritium, and a few volatile organic compounds were detected during FY 2006. However, the only constituents exceeding drinking water standards were iodine-129 in two wells, iron in one well, and tritium in two wells. The iodine-129 and tritium exceedances were consistent with their location within the major iodine-129 and tritium plumes coming from the 200 East Area (see Sections 2.11.1.1 and 2.11.1.2). The exceedance of iron (344 $\mu \mathrm{g} / \mathrm{L}$ at well 699-24-46) was in an older-style non-WAC-compliant (WAC 173-160) well constructed of carbon steel casing. Exceedances of the iron secondary drinking water standard $(300 \mu \mathrm{g} / \mathrm{L})$ are common in these older wells and not necessarily representative of local groundwater conditions. 1,1,1-trichloroethene, carbon tetrachloride, chloroform, tetrachloroethene, and trichloroethene were also detected at levels below $1 \mu \mathrm{g} / \mathrm{L}$ in a few Southeast Transect wells. However, all of these were estimated values because they were at levels very close to the volatile organic analysis method detection limit. Furthermore, most of the detected volatile organic compounds at Southeast Transect were in a single well (699-26-33) located at the Non-Radioactive Dangerous Waste Landfill. Low levels of organic compounds are known to occur in groundwater in this area (see Section 2.11.3.7). 
At the River Transect, chloride, chromium, gross alpha and beta, iron, manganese, nitrate, sulfate, tritium, carbon tetrachloride, and chloroform were detected during FY 2006. The only constituent exceeding its drinking water standard was tritium in two wells (699-41-1A and 699-46-4) located near the Hanford town site. These results are consistent with known concentrations of the site-wide tritium plume at this location (see Section 2.11.1.1). The detection of carbon tetrachloroethene and chloroform were at well 699-20-E12O at levels below $1 \mu \mathrm{g} / \mathrm{L}$. Well 699-20-E12O is located northeast of Energy Northwest and along the Columbia River (Figure 2.11-2). Like the detected volatile organic compound detections at the Southeast Transect, the low levels of volatile organics reported at the River Transect (well 699-20-E12O) were estimated values because they were at levels very close to the volatile organic analysis method detection limit. This same well has higher than normal $\mathrm{pH}$ levels (8.9 for FY 2006) compared to surrounding wells and decreasing specific conductance, alkalinity, and nitrate over previous levels in this well. The well is also an older, complex well with multiple piezometers. It will continue to be observed closely to determine the reason for these anomalies.

Three of the six aquifer tube locations $(84,85$, and 86) near the Hanford town site were sampled as scheduled during FY 2006. The tube sampled at each location was deepest (i.e., 84-D, 85-D, and 86-D). Aquifer tubes at the other three locations (81, 82, and 83) were either lost or destroyed. Most constituents analyzed in the aquifer tube samples were not detected, most likely due to the high degree of mixing with river water. Specific conductance is a good indicator of groundwater/river water mixing, and reported specific conductance values were low (139 to $235 \mu \mathrm{S} / \mathrm{cm}$ ), indicating more river water than groundwater in the samples. (Typically, groundwater in the unconfined aquifer near the Hanford town site has specific conductance values about $400 \mu \mathrm{S} / \mathrm{cm}$, whereas river water typically has a specific conductance value about $130 \mu \mathrm{S} / \mathrm{cm}$.) The only constituents detected in the aquifer tube samples were nitrate (in all three tube locations), and gross beta and tritium at one location (86-D). The nitrate results were $753 \mu \mathrm{g} / \mathrm{L}$ at 84-D, $930 \mu \mathrm{g} / \mathrm{L}$ at 85-D, and 5,750 at 86-D. Gross beta and tritium results at $86-\mathrm{D}$ were 3.27 and $3,790 \mathrm{pCi} / \mathrm{L}$, respectively.

The second CERCLA five-year review was published in November 2006 (DOE/RL2006-20). The review identified one issue and an associated action pertaining to the 200-PO-1 Operable Unit.

- Issue 15: Soil resistivity measurements have detected large regions of anomalously high soil conductivity in the area south of PUREX around the 216-A-4 crib and near the $\mathrm{BC}$ cribs and trenches.

- Action 15-1: Complete data quality objective process and sampling plan to further characterize the high soil conductivity measurements detected at the BC cribs and trenches. The action due date is December 2007.

\subsubsection{Facility Monitoring}

This section describes results of monitoring individual facilities such as treatment, storage, or disposal units including tank farms. Groundwater at some of these facilities is monitored under the requirements of RCRA for hazardous waste constituents and AEA for radionuclides including source, special nuclear, and by-product materials. Data for facilityspecific monitoring are also integrated into the CERCLA groundwater investigations. Hazardous constituents and radionuclides are discussed jointly in this section to provide comprehensive interpretations for each facility. As discussed in Section 1.2, pursuant to RCRA, the source, special nuclear, and by-product material components of radioactive mixed waste are not regulated under RCRA and are regulated by DOE acting pursuant to its AEA authority. Groundwater data for these facilities are available in the Hanford Environmental Information System (HEIS 1994) and on the data files accompanying this report. Additional information including well and constituent lists, maps, flow rates, and statistical tables are included in Appendix B.
Nitrate, gross

beta, and tritium

were the only

groundwater

constituents

detected in aquifer

tube samples.

Levels were below

drinking water

standards. 


\section{The 200-PO-1}

Operable Unit

contains six

RCRA sites, two

sites regulated

by WAC, and one

site regulated

exclusively under

AEA groundwater

requirements.
The 200-PO-1 Operable Unit contains six RCRA sites, two sites regulated by the WAC, and one site regulated exclusively under AEA groundwater requirements. This section summarizes results of statistical comparisons, assessment studies, and other developments for FY 2006.

\subsubsection{Integrated Disposal Facility}

Construction of the Integrated Disposal Facility began in September 2004 and was completed in April 2006. DOE submitted a Part B RCRA permit application to the Washington State Department of Ecology (Ecology), and it was incorporated into the Hanford Facility RCRA Permit on April 9, 2006. The Integrated Disposal Facility operation is schedule to begin in 2010 .

The objective of RCRA and operational monitoring at the Integrated Disposal Facility is to determine whether the facility has impacted groundwater quality. The facility is not yet operational, and the current monitoring is directed at obtaining background values for monitoring constituents. The current groundwater monitoring network consists of three upgradient wells and four downgradient wells (Appendix B). One future well remains to be installed at a future date when required by facility expansion.

The Integrated Disposal Facility consists of an expandable, double-lined landfill with $\sim 7$ hectares of liner constructed. The facility is located in the south-central part of 200 East Area (see Figure 2.11-1 for location of the site and Appendix B for a list of network wells, their locations, and groundwater constituents monitored). The landfill is divided lengthwise (north/south) into two distinct cells, one for the disposal of low-level radioactive waste (east cell) and the other for the disposal of mixed waste (west cell).

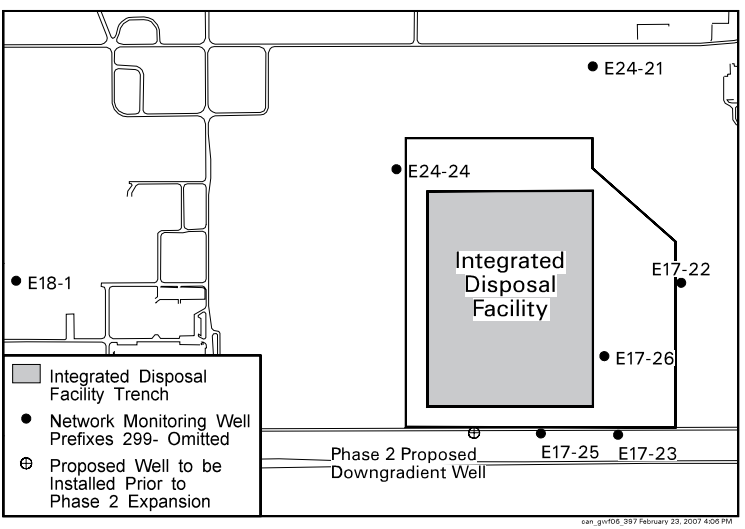

The facility is a RCRA-compliant landfill (i.e., a double high-density polyethylene lined trench with leachate collection and leak detection system). The constructed liner is $\sim 442$ meters wide by 160 meters in length and up to 15 meters deep. The landfill will contain four layers of waste containers separated vertically by 0.9 meter of soil. The current waste disposal capacity is $\sim 163,000$ cubic meters. The waste will be segregated into a RCRA-permitted side and a non-RCRA-permitted side.

The delineation of groundwater flow directions and water-table gradients are difficult to estimate from water-level data due to a flat water table. Based on the geometry of existing contaminant plumes and on regional water-level measurements, the groundwater flow direction is estimated to be toward the east to southeast at rates between 0.002 to 0.0075 meter/day.

All groundwater monitoring wells in the Integrated Disposal Facility monitoring network were sampled twice quarterly for one year (June 2005 through May 2006) to determine baseline conditions. The data are being reviewed to determine if these data can be used as the background groundwater data required by the Integrated Disposal Facility portion [Operating Unit 11] of the Hanford RCRA permit [Permit condition III. 11. E.1.a]. Collection of semiannual samples (four independent sampling events each 6-month period) is continuing while background data are under review.

The Integrated Disposal Facility operational monitoring plan was published in 2005 (RPP-PLAN-26534). That plan called for analyses of gross alpha, gross beta, technetium-99, and iodine-129 in groundwater. Therefore, these constituents have been added to the list of RCRA indicator parameters and supplemental groundwater quality parameters (alkalinity, anions, metals, temperature, and turbidity) for analysis. The complete sampling schedule including all constituents and sampling frequency is in Appendix B.

The Integrated Disposal Facility monitoring wells were sampled as scheduled in FY 2006 with the following exceptions. The December 2005 sampling (third quarter background 
sampling) of well 299-E17-26 occurred in January 2006 because of a broken pump; the August 2006 sampling of well 299-E18-1 occurred in September 2006 because of extreme fire danger; well 299-E17-25 was not sampled in July 2006 because it needed well maintenance and the well maintenance organization was under a "stop work" order; and the complete Appendix IX list was not obtained in July 2005 but was analyzed in January 2007. The following paragraphs address the impacts of these exceptions to the overall Integrated Disposal Facility sampling program as well as statistical ramifications.

Permit condition III.11.E.1.a. requires "Prior to initial waste placement in the IDF landfill, the Permittees shall sample all groundwater monitoring wells in the IDF network twice quarterly for one first year to determine baseline conditions." This requirement was met by collecting the required eight background samples from all the Integrated Disposal Facility wells during the first year, June 2005 through May 2006. The missed sampling event at well 299-E17-25 occurred after the initial background period (June 2005 through May 2006), which should have minimal impact on statistical evaluations because currently the background data are under review.

Also, Permit condition III.11.E.1.a. requires "For the first sampling event (and only the first), samples for each well will include all constituents in 40 CFR 264 Appendix IX." Sampling all Integrated Disposal Facility wells once for the Appendix IX constituents was delayed until January 2007. The delay of analyzing for Appendix IX constituents has no impact on statistical evaluations of Integrated Disposal Facility groundwater monitoring data because statistical evaluations are limited to chromium, specific conductance, total organic carbon, total organic halides, and $\mathrm{pH}$. It also should not impact the overall sampling program because no waste has been placed in the Integrated Disposal Facility yet.

One analytical result for iron and one result for chromium exceeded their drinking water standards during the year. The results are not considered representative of dissolved metals in the aquifer because they are from unfiltered samples that may contain particulates, which may be artifacts of well construction. The iron and chromium concentrations from the filtered samples were less than the drinking water standard and on trend. Nitrate concentrations were routinely near or above the drinking water standard $(45 \mathrm{mg} / \mathrm{L})$ in samples from well 299-E24-21 and 299-E24-24 during FY 2006. The highest nitrate concentration was $65.5 \mathrm{mg} / \mathrm{L}$ in well 299-E24-24. Both well 299-E24-24 and well 299-E24-21 are located in the regional nitrate plume that is presumed to originate from the PUREX cribs east of the Integrated Disposal Facility (see Section 2.11.3.2).

\subsubsection{RCRA PUREX Cribs}

The RCRA PUREX cribs are located in the southeast part of the 200 East Area and include three cribs (216-A-10, 216-A-36B, and 216-A-37-1; Figure 2.11-1) monitored under RCRA interim status to assess groundwater quality. Other nearby cribs also received PUREX waste (e.g. 216-A-45 crib) but are not regulated as RCRA treatment, storage, or disposal units. They are monitored collectively under the 200-PO-1 Operable Unit.

The objective of RCRA monitoring at these cribs is to assess the nature and extent of groundwater contamination with hazardous constituents and determine their rate of movement in the aquifer per (40 CFR 265-93(d) as referenced by WAC 173-303-400). Groundwater monitoring under AEA tracks radionuclides at the cribs and surrounding vicinity. Appendix B includes a well location map and list of wells and constituents monitored for the RCRA PUREX cribs.

Groundwater flow direction in the vicinity of the two west cribs (216-A-10 and 216-A-36B) is most likely toward the southeast; in the vicinity of the 216-A-37-1 crib, it is estimated to be to the south or southwest. (See Appendix B for more information on flow direction

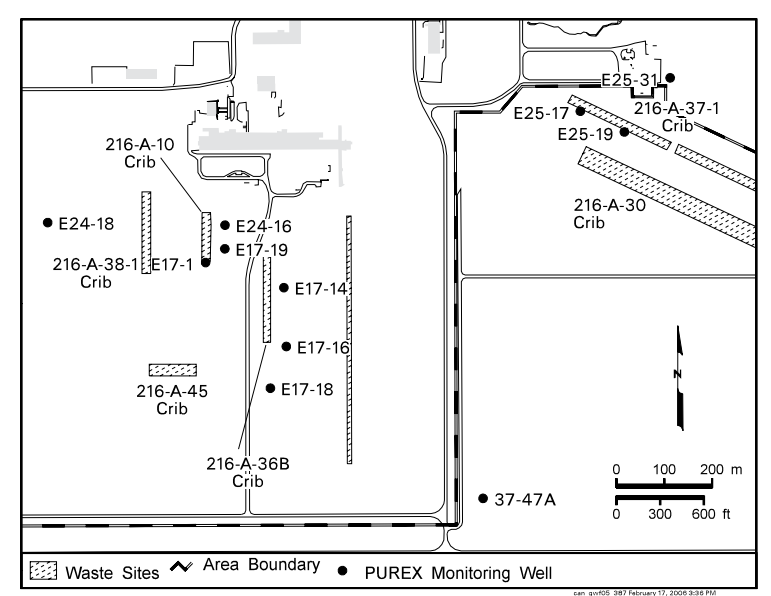




\section{Several of the wells near the RCRA PUREX cribs had increases in nitrate concentrations during FY 2006.}

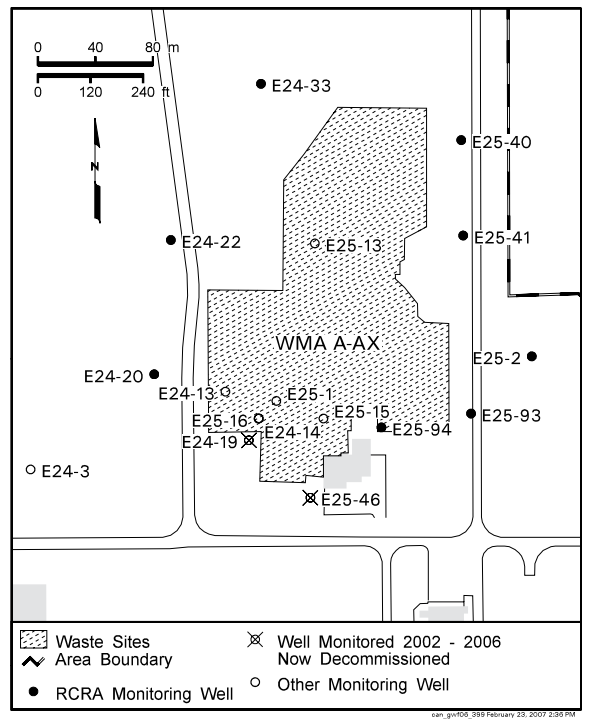

and rate.) The RCRA PUREX cribs are located in a region where several groundwater contamination plumes contain constituents that exceed drinking water standards. The similarities in effluent constituents disposed to these cribs, as well as to the 216-A-45 crib, make determining the contribution of the RCRA PUREX cribs difficult.

The RCRA PUREX cribs groundwater monitoring plan (PNNL-11523) was revised during FY 2005 to bring the plan up to date with sampling, analysis, quality assurance, and data management and reporting protocols in practice for the groundwater project. In FY 2006, the revised plan was implemented, and all samples were collected as scheduled.

Nitrate concentrations continued to exceed the drinking water standard beneath and downgradient of the RCRA PUREX cribs. It is the only dangerous waste constituent exceeding drinking water standards in the vicinity of the RCRA PUREX cribs. The nitrate plume continues to generally attenuate in much of its downgradient extent in the 600 Area between the 200 East Area and the Columbia River. However, several of the wells near the RCRA PUREX cribs are showing increases in nitrate concentration (see Section 2.11.1.3). The reason for the increased concentrations is not known, but it may be related to residual nitrate contamination in the vadose zone that continues to enter the saturated zone. The increases could also be related to changes in groundwater flow paths due to the decreasing amount of groundwater flow from B Pond and a greater contribution of groundwater flow from the northwest.

\subsubsection{Single-Shell Tank Waste Management Area A-AX}

Since FY 2005, this site has been monitored according to a RCRA assessment program (PNNL-15315) to determine whether dangerous waste or dangerous waste constituents from the regulated unit have compromised groundwater quality. Radionuclides are tracked under AEA monitoring. Results are presented for the first year of RCRA assessment investigations.

Located along the east border of the 200 East Area, Waste Management Area A-AX consists of the A Tank Farm, AX Tank Farm, 244-AR vault, ancillary waste transfer lines and seven diversion boxes. A well location map with a list of network wells and the site specific constituents used for the assessment monitoring are available in Appendix B.

During FY 2006, no discernible changes in groundwater flow direction or rate were apparent. The flow direction, determined from local water levels, in situ flow measurements with the colloidal borescope, and plume tracking is estimated to range from east southeast to southeast (PNNL-14187). A similar range of directions from a separate analysis was reported this year in RPP-23748. Gradients from a series of three-point analyses using water-level data over time from wells near the waste management area were mapped on a rose-diagram (Figure 2.11-9).

The saturated screen interval ranges from 1.6 to 10 meters in RCRA network wells while the aquifer thickness is $\sim 27$ meters. The average rate of water-table decline for FY 2006 was 5 centimeters, almost half the rate of decline for FY 2005, suggesting the rate of water-table decline may be slowing. Thus, even the older RCRA-compliant wells may not need replacing for some time. The estimated flow rate at Waste Management Area A-AX was calculated to range from 0.77 to 1.0 meter/day (see Appendix B).

The monitoring network includes four recently installed wells and four older wells. Two additional downgradient wells are scheduled for installation in FY 2009, one to complete the monitoring network as designed in PNNL-13023 and another to replace a well with a corroding screen. A recent borehole survey has shown that the casing and screen are corroding in well 299-E25-40. This well shows low levels of chromium in the groundwater. Further discussion of this problem at Waste Management Area A-AX can be found in PNNL-13788, PNNL-14187, PNNL-14548, and PNNL-15070. Three wells, scheduled for sampling in 
September 2006, were not sampled until early FY 2007 (see Appendix B). Consequently, fourth quarter data from these wells are not available for this assessment update.

At present, it appears that two distinct contaminant plumes are developing, one in the north under the AX Tank Farm and one in the south, under the A Tank Farm (Figure 2.11-10). These distinct plumes can be recognized based on differences in both trend plots of nitrate and technetium-99 and in concentration maps of these constituents. For example, in Figure 2.11-11, the highest nitrate at the site is found in both upgradient and downgradient wells monitoring the A Tank Farm (south plume). Here nitrate ranged from $42.5 \mathrm{mg} / \mathrm{L}$ upgradient to $47.8 \mathrm{mg} / \mathrm{L}$ downgradient for the June 2006 sampling event. Nitrate concentrations are lower in the north plume ranging from 22.6 to $26.6 \mathrm{mg} / \mathrm{L}$. Two wells, 299-E24-22 and 299-E25-2, located between the plumes of rising contamination had lower values from 12.4 to $13.7 \mathrm{mg} / \mathrm{L}$, showing no significant increase over the last year.

Trends of technetium-99 also suggest two distinct plumes. The trend plot in Figure 2.11-12 illustrates the distinctly high technetium-99 concentrations found in well 299-E25-93 in the south plume. The initial technetium-99 concentration in this well in December 2005 was $13,100 \mathrm{pCi} / \mathrm{L}$, suggesting a locally high contaminant source just upgradient of the well. The June 2006 concentration remains uniquely high at 7,740 pCi/L. The next highest technetium-99 value is upgradient of the AX Tank Farm in well 299-E24-33, increasing from $451 \mathrm{pCi} / \mathrm{L}$ in 2005 to $1,010 \mathrm{pCi} / \mathrm{L}$ in June 2006. On the downgradient side of the AX Tank Farm, technetium-99 has increased from 179 to $445 \mathrm{pCi} / \mathrm{L}$ during the last year.

As with nitrate, a mapped view of technetium-99 plumes (Figure 2.11-13) shows the wells (299-E25-2 and 299-E24-22) between the two plumes at distinctly lower values, ranging from 27.4 to $180 \mathrm{pCi} / \mathrm{L}$. There were little to no changes in technetium-99 concentration at these two wells since last year. While both technetium-99 and nitrate results suggest a contaminant source local to well 299-E25-93, possibly associated with the A Tank Farm, the well (299-E24-33) upgradient to the AX Tank Farm has unique subsurface conditions. The presence of a perched water zone found at a depth of 78 meters below the surface during drilling shows that liquids have migrated from the surface to near the water table, at a depth of 85 meters. The presence of coliform bacteria in the groundwater at this well provides further evidence that liquids have migrated from the surface to the vicinity of this well.

The sulfate concentrations continue to rise downgradient of the waste management area and in the northern upgradient well (299-E24-33) as shown in Figure 2.11-14. With regional trends displaying increasing sulfate and calcium across the northern part of the 200 East Area, separating local effects from these upgradient influences is difficult. The same upgradient influence from farther north in wells monitoring Low-Level Waste Management Area 2 is seen at Waste Management Area C. At Waste Management Area A-AX, the largest increases are seen in the north, increasing from 46 to $108 \mathrm{mg} / \mathrm{L}$ in well 299-E24-33 and from 82 to $110 \mathrm{mg} / \mathrm{L}$ in downgradient well 299-E25-41 during the last year. Although the mapped view shows the regional influence, the local effect of two distinct centers of contamination can still be seen in Figure 2.11-15.

The northern plume appears to have an upgradient source close to well 299-E24-33, although the source or sources of this plume are unknown. The well is located near the infrastructure of several waste transfer operations, past and present. For example in 1998, a liquid level drop was observed in an active catch tank (241-AX-152) within the farm (HNF-EP-0182, Rev. 142). By 2001, the tank was declared an assumed leaker and was removed from service, with the contents pumped to nearby double-shell tank, AY-102 (HNF-EP-0182, Rev. 197). Both farms have experienced appreciable transfers of liquid waste with 2.7 million liters from tank 241-A-101 and 2.1 million liters from 241-AX-101 (HNF-EP-0182, Rev. 131). However, relating a specific event at the surface with contamination observed in the groundwater may not be possible without further subsurface investigation in the vadose zone. At present, the locations of contaminated soil that may be the source of the groundwater contamination appear to be local to upgradient well (299-E24-33) for the AX Tank Farm plume and to downgradient well (299-E25-93)

\section{It appears that two distinct contaminant plumes are developing in the north and south portions of Waste Management Area A-AX.}

\author{
Technetium-99 \\ concentrations \\ remained high in \\ well 299-E25-93 \\ with a June 2006 \\ result of \\ 7,740 pCi/L.
}




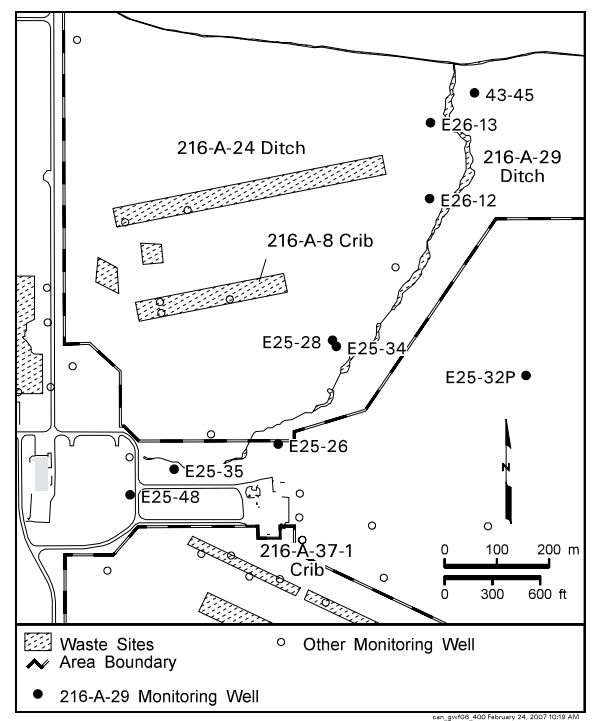

for the A Tank Farm plume. Rising contamination in the groundwater at Waste Management Area A-AX may be related to more than one pocket of contaminated soil resulting in two distinct plumes.

\subsubsection{216-A-29 Ditch}

The groundwater beneath the 216-A-29 ditch is monitored for evidence of hazardous waste migration as required by interim status RCRA regulations (40 CFR 265.93(b) as referenced by WAC 173-303-400). The nine wells of the groundwater monitoring network are sampled semiannually for constituents that include contamination indicator parameters and annually for groundwater quality parameters and site-specific constituents (PNNL-13047; see Appendix B for list of wells, their locations, and groundwater constituents monitored). The well network is adequate for the current groundwater flow directions.

Groundwater samples were collected and analyzed as scheduled at all nine wells monitoring the 216-A-29 ditch in FY 2006. Specific conductance continues to remain above the critical mean in wells 299-E25-35 and 299-E25-48. Sulfate, magnesium, sodium and nitrate are also rising in well 299-E25-48. Both of these wells are downgradient of the head end of the unit that was in nearly constant saturated conditions throughout its service life. The cause of this contamination may be sulfuric acid discharges to the 216-A-29 ditch (WHC-SD-EN-EV-032). Specific conductance also exceeded the critical mean value in well 299-E26-13, located on the upgradient west side of the ditch. Exceedances of the specific conductance critical mean have been reported in previous years at this site, but do not cause the site to be placed in RCRA assessment monitoring.

The direction of groundwater flow near the 216-A-29 ditch is generally to the southsouthwest, and the gradient is largely flat (see Appendix B). The lower mud unit of the Ringold Formation inhibits flow to the east near the 216-A-29 ditch and groundwater is forced to the south around it. The estimated groundwater flow rate is $\sim 0.1$ meter/day.

\subsubsection{216-B-3 Pond Facility (B Pond)}

The original B Pond system included the main pond and three expansion ponds (Figure 2.11-1). The main pond and an adjacent portion of 216-B-3-3 ditch are regulated now under RCRA and require groundwater monitoring under 40 CFR 265.93(b) as referenced by WAC 173-303-400. These features are the regulated remnants of a more expansive system of ponds and ditches, most of which have been clean closed. The B Pond system continued in an interim status, indicator parameter evaluation program during FY 2006. The monitoring plan, including the well network, constituents of concern, sampling and analysis procedure, and a conceptual model is described by PNNL-15479.

The current network wells and hydraulic gradient configuration allows upgradient/

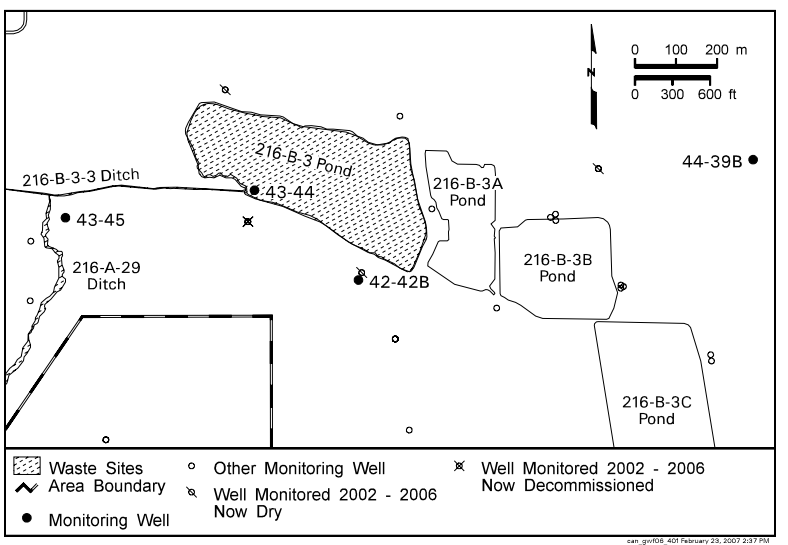
downgradient comparisons as prescribed by RCRA and WAC procedures for interim status facilities. The groundwater monitoring well network for the B Pond system consists of a total of four wells (see Appendix B). Well 699-44-39B is located in an area currently upgradient of the B Pond with three wells (699-42-42B, 699-43-44, and 699-43-45) located at the downgradient edges of the main pond and 216-B-3-3 ditch (Figure 2.11-1). The wells are sampled semiannually for B Pond. In FY 2006, the second semiannual sampling event scheduled for July was postponed at B Pond due to extreme wildfire danger on the Hanford Site, which limited access to off-road wells. These wells were rescheduled and sampled in November 2006, but no analytical results for that period were available in time for this report. Hence, analytical results discussed below are based on one (January 2006) sampling event. 
For the January 2006 samples, no averaged replicate (or individual replicate) results exceeded the limits of quantitation for indicator parameters total organic halides and total organic carbon. Both $\mathrm{pH}$ and specific conductance in well 699-43-45 have displayed a slight upward trend over the past several years, and probably represent a gradual return to pre-operational conditions in the aquifer following dilution by wastewater disposal made up of water derived from the Columbia River. These trends now appear to be leveling off. Specific conductance remains below site-wide background (DOE/RL-96-61) in all B Pond network wells.

Nitrate continued to show upward trends in wells 699-42-42B and 699-43-45 during 2006. The highest nitrate result was in well 699-43-44 in January 2006 with the reported value of $3.05 \mathrm{mg} / \mathrm{L}$. Sulfate has also trended upward in wells $699-42-42 \mathrm{~B}$ and $699-43-45$ in recent years. However, levels of both nitrate (maximum $\sim 6.6 \mathrm{mg} / \mathrm{L}$ in well 699-42-42B) and sulfate (maximum $21.7 \mathrm{mg} / \mathrm{L}$ in well 699-42-42B) remain far below estimates of site-wide groundwater background concentrations ( 42 and $55 \mathrm{mg} / \mathrm{L}$, respectively).

Based on 2006 water-level measurements in the B Pond area, groundwater flow direction, based on hydraulic gradients between wells 699-44-39B, 699-43-44, and 699-43-45, was estimated as west-southwest to south-southeast. Based on a September 2006 gradient of 0.002 between wells 699-44-39B (upgradient well) and 699-42-42B, an average hydraulic conductivity of 1.0 meter/day, and an estimated effective porosity of 0.25 , the average linear flow velocity of groundwater is estimated at 0.01 meter/day (Appendix B). Head measurements in vertically separated wells 699-43-41E (shallow) and 699-43-41G (deep) indicated that a downward flow potential still exists near the main pond, although it continues to diminish. The head difference between these two wells, as determined by September 20, 2006 water-level measurements, was $\sim 0.4$ meter. The September 2005 difference was $\sim 0.5$ meter.

\subsubsection{200 Area Treated Effluent Disposal Facility}

The 200 Area Treated Effluent Disposal Facility is located southeast of the B-Pond RCRA facility and has received effluent since June 1995. Groundwater beneath the facility is monitored under a Washington State waste discharge permit (WAC 173-216, PNNL-13032). Three wells, 699-40-36, 699-41-35 and 699-42-37, monitor groundwater beneath the facility.

Because no unconfined aquifer exists beneath the 200 Areas Treated Effluent Disposal Facility, the groundwater monitoring wells used are installed in the locally confined aquifer below the Ringold Formation lower mud unit (see also Section 2.14). Thus, these three wells are isolated from the effects of the effluent from the disposal facility by the relatively impermeable silts and clays of the Ringold Formation lower mud unit (PNNL-14098). The quarterly analytical results from these wells are used to demonstrate continuation of the isolation.

Based on hydraulic head measurements in FY 2006, and estimates of effective porosity and hydraulic conductivity, groundwater flow potential in the confined aquifer beneath the 200 Area Treated Effluent Disposal Facility is directed southwest at 0.0004 meter/day. Historically, major ionic composition and extremely low tritium concentration have suggested that groundwater in the Ringold Formation confined aquifer beneath this facility is isolated from groundwater in the adjacent unconfined aquifer, and its water quality is largely unaffected by Hanford Site operations. Results of annual low-level tritium analyses confirm this interpretation. However, hydraulic head continues to decline in all three wells at the 200 Area Treated Effluent Disposal Facility as a result of the dissipating pressure effect of historical discharges at the nearby B Pond facility.

Groundwater samples are collected quarterly from wells for a list of constituents required by the state waste-discharge permit ST-4502 (Ecology 2000). Three of the constituents (cadmium, lead and $\mathrm{pH}$ ) are compared with specific enforcement limits set by the permit (see Appendix B). All scheduled samples were collected during FY 2006, and no enforcement
During FY 2006, groundwater indicator

parameters remained below

their critical mean values in B Pond monitoring wells.

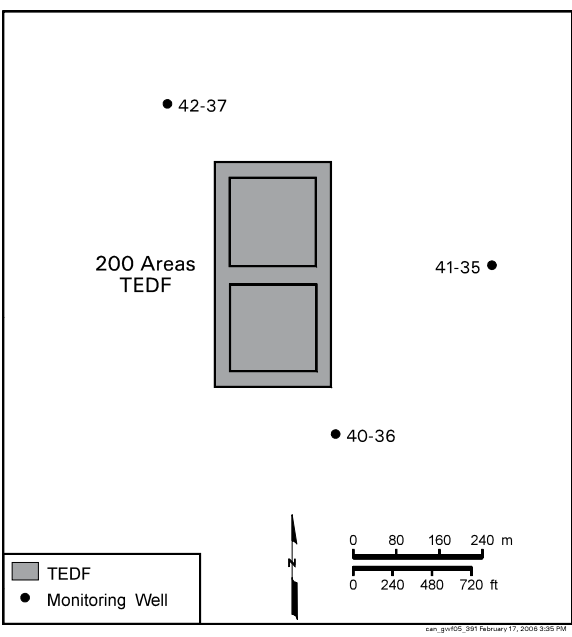
At the 200 Area Treated Effluent Disposal Facility, all scheduled samples were collected during FY 2006, and no enforcement limits were exceeded. 
limits were exceeded. Most results for anions, metals and radionuclide indicators have been below Hanford Site groundwater background levels (e.g., WHC-EP-0595 and DOE/RL-96-61) since monitoring began at the site.

\subsubsection{Nonradioactive Dangerous Waste Landfill}

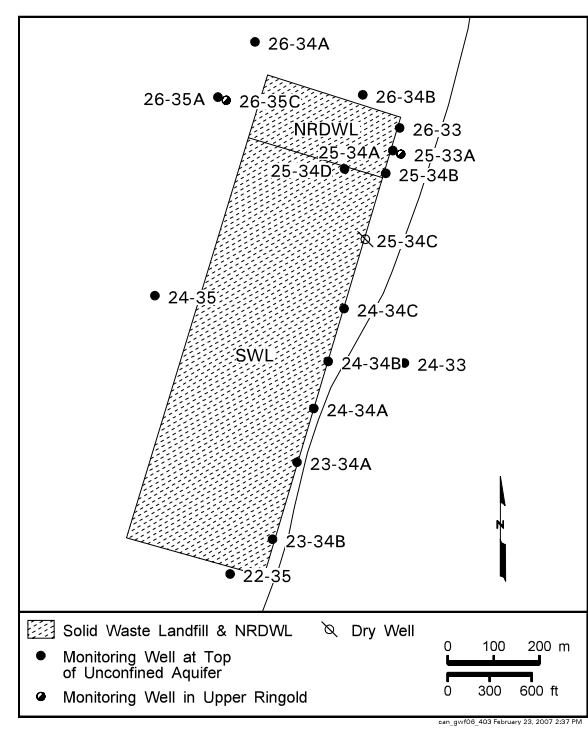

The critical mean

value for specific

conductance

continues to be

exceeded at the

Nonradioactive

Dangerous Waste

Landfill and is

most likely due to

the influence of the

nearby Solid Waste

Landfill.

The Nonradioactive Dangerous Waste Landfill is located southeast of the 200 East Area next to the Solid Waste Landfill (Figure 2.11-2). The two landfills are collectively known as the Central Landfill. The objective of RCRA monitoring at the Nonradioactive Dangerous Waste Landfill is to determine if hazardous waste constituents from the landfill have contaminated groundwater (40 CFR 265.93(b) as referenced by WAC 173-303-400). Appendix B includes a well location map and lists of wells and constituents monitored for the landfill. Groundwater flow direction is southeast as determined from the general direction of movement of major 200 East Area plumes (see beginning of Section 2.11).

Monitoring of the Nonradioactive Dangerous Waste Landfill focuses on the RCRA interim status indicator parameters: $\mathrm{pH}$, specific conductance, total organic carbon, and total organic halides (PNNL-11523; Appendix B). Volatile organic compounds are monitored because they may represent groundwater contamination originating from this landfill. Nitrate is present in groundwater and has a source in the 200 East Area (see Section 2.11.1.3). The groundwater quality parameters (chloride, iron, manganese, phenols, sodium, and sulfate) are required analytes, but during FY 2006 were either not detected or were reported in concentrations below their respective drinking water standards.

Wells at the Nonradioactive Dangerous Waste Landfill (Appendix B) are sampled semiannually, usually in February and August. During FY 2006, all of the Nonradioactive Dangerous Waste Landfill network wells were sampled as scheduled except for the August 2006 sampling event at wells 699-26-35A and 699-26-34B. The sampling was delayed until early FY 2007 because of extreme wildfire danger on the Hanford Site in August 2006.

Three of the four indicator parameters $(\mathrm{pH}$, total organic carbon, and total organic halides) did not exceed their critical means in downgradient wells where valid upgradient/ downgradient comparisons could be made. However, the critical mean for specific conductance $(599 \mu \mathrm{S} / \mathrm{cm})$ was exceeded at four downgradient wells during FY 2006, 699-25-34A, 699-25-34B, 699-25-34D, and 699-26-33. Specific conductance at these four wells ranged from $505 \mu \mathrm{S} / \mathrm{cm}$ at well $699-25-34 \mathrm{D}$ to $629 \mu \mathrm{S} / \mathrm{cm}$ at well $699-25-34 \mathrm{~B}$. Exceedances of the specific conductance critical mean has occurred in prior years and were interpreted to be due to increases in the concentrations of non-hazardous constituents (bicarbonate, sulfate, and magnesium) at the Solid Waste Landfill to the south. When the specific conductance exceedance was first discovered in FY 2001, the DOE notified Ecology of the exceedance by letter on June 7, 2001. (a) An accompanying report served as both the assessment plan and assessment report. The assessment plan proposed a continuing detection monitoring program at the site. Drinking water standards of the groundwater quality parameters and volatile organic compounds were not exceeded at Nonradioactive Dangerous Waste Landfill network wells during FY 2006.

\subsubsection{Solid Waste Landfill}

The Solid Waste Landfill is located with the Nonradioactive Dangerous Waste Landfill at the Central Landfill (Figure 2.11-2). It is regulated by Ecology under WAC 173-304. WAC 173-304 constituents and site-specific constituents (including volatile organic

(a) Letter from JG Morse (U.S. Department of Energy, Richland, Washington) to J Hedges (Washington State Department of Ecology), Results of Assessment at the Non-Radioactive Dangerous Waste Landfill, dated June 7, 2001. 
compounds and filtered arsenic) are analyzed on groundwater samples collected quarterly (PNNL-13014; Appendix B). Compliance is determined by comparing results from monitoring downgradient wells with statistically derived background threshold values from upgradient wells. Groundwater flow direction in this area is southeast as inferred from the general direction of movement of major 200 East Area plumes (see beginning of Section 2.11). The well network for the Solid Waste Landfill includes two upgradient and seven downgradient wells and is shown in Appendix B.

Disposed waste at the Solid Waste Landfill has impacted groundwater with minor chlorinated hydrocarbon contamination (Table 2.11-1). The only chlorinated hydrocarbon consistently exceeding its WAC 173-200-40 limit $(0.8 \mu \mathrm{g} / \mathrm{L})$ was tetrachloroethene. The highest reported tetrachloroethene result during FY 2006 was $1.7 \mu \mathrm{g} / \mathrm{L}$ at the downgradient well 699-24-33. In recent years, the trend for tetrachloroethene has been stable to slightly decreasing in concentration at Solid Waste Landfill wells.

Some downgradient wells continue to show higher chemical oxygen demand, chloride, coliform bacteria, specific conductance, sulfate, and lower $\mathrm{pH}$. The lower $\mathrm{pH}$ apparently is a result of high concentrations of carbon dioxide in the vadose zone resulting from the degradation of sewage material disposed to the Solid Waste Landfill (see Section 5.3 of DOE/RL-93-88; PNL-7147; WHC-SD-EN-TI-199). The elevated chemical oxygen demand, coliform bacteria, and possibly the specific conductance, may also be related to the disposed sewage material.

WAC 173-304 Parameters. Each WAC 173-304 parameter is discussed separately in the following paragraphs. See Appendix B for a complete list of all results for required constituents at the Solid Waste Landfill during FY 2006. Table 2.11-1 shows concentration ranges of the chlorinated hydrocarbons during the same period. The increased amount of detail in the discussions of individual groundwater constituents (compared to other sections of this report) is provided to meet the annual reporting requirements of the groundwater monitoring plan (PNNL-13014).

- Ammonium - Results for ammonium ion in all Solid Waste Landfill wells during FY 2006 were below the method detection limit ( of $6.69 \mu \mathrm{g} / \mathrm{L}$ ) except for the results of $69.2 \mu \mathrm{g} / \mathrm{L}$ at well 699-22-35 and 61.0 $\mathrm{gg} / \mathrm{L}$ at well 699-24-34B for samples collected in May 2006. The two results above the method detection limit are not typical of historical values at these wells and are undergoing further review. Background threshold value for ammonium was $90 \mu \mathrm{g} / \mathrm{L}$. See Appendix B for a total list of FY 2006 background threshold values for WAC 173-304 required parameters.

- Chemical Oxygen Demand - Chemical oxygen demand at Solid Waste Landfill wells during FY 2006 ranged from less than $9.2 \mathrm{mg} / \mathrm{L}$ (the method detection limit) to $135 \mathrm{mg} / \mathrm{L}$. The background threshold value $(10 \mathrm{mg} / \mathrm{L})$ was exceeded at most of the Solid Waste Landfill wells during FY 2006, including the two upgradient wells. Elevated chemical oxygen demand values could be an indication of groundwater contaminated by sewage, which was known to be discharged to Solid Waste Landfill trenches.

- Chloride - All but one of the Solid Waste Landfill downgradient wells had at least one of the four quarterly results that exceeded the $7.8 \mathrm{mg} / \mathrm{L}$ background threshold value. The highest result was $35 \mathrm{mg} / \mathrm{L}$ at well 699-24-34A for a sample collected in November 2005. However, this result is more than four times higher than the typical historical result for this well so it is undergoing further review. Chloride concentrations have been increasing at several of the Solid Waste Landfill downgradient wells since 2002.

- Coliform Bacteria - Five downgradient wells and both upgradient wells had at least one of the four quarterly results with a value that exceeded the background threshold value for coliform bacteria ( 1 colony/100 milliliters). The highest reported value was 13.2 colony/100 milliliters at the upgradient well $699-24-35$ for a sample collected February 2006. Elevated results for coliform bacteria at Solid Waste Landfill well have
Disposed waste

at the Solid

Waste Landfill

has impacted

groundwater

including minor

volatile organic

compound

contamination.

The background

threshold value for

chemical oxygen

demand (10 mg/L)

was exceeded at

most Solid Waste

Landfill wells

during FY 2006. 
The background threshold value for specific conductance (583 $\mu \mathrm{S} / \mathrm{cm})$ was exceeded in most Solid Waste Landfill wells during FY 2006. historically been random and sporadic. However, like chemical oxygen demand, elevated levels of coliform bacteria are expected in groundwater when sewage was known to be disposed at the Solid Waste Landfill.

- Filtered Iron - None of the filtered iron results for FY 2006 exceeded the $160 \mu \mathrm{g} / \mathrm{L}$ background threshold value. The reported values ranged from $<25 \mu \mathrm{g} / \mathrm{L}$ (the method detection limit) at five of the wells to $158 \mu \mathrm{g} / \mathrm{L}$ at well 699-22-35. Filtered iron results as elevated as $158 \mu \mathrm{g} / \mathrm{L}$ are reported occasionally at Solid Waste Landfill wells, but are not typical of the overall historical results.

- Filtered Manganese - Although filtered manganese results as high as $3.6 \mu \mathrm{g} / \mathrm{L}$ (at well 699-23-34B) were reported at Solid Waste Landfill wells during FY 2006, most of the results were less than the $2.5 \mu \mathrm{g} / \mathrm{L}$ method detection limit.

- Nitrate - Nitrate results at Solid Waste Landfill wells during FY 2006 ranged from 12 to $18.1 \mathrm{mg} / \mathrm{L}$ except for the single result of $46.9 \mathrm{mg} / \mathrm{L}$ at well $699-24-34 \mathrm{~A}$ for a sample collected in November 2005 . However, the $46.9 \mathrm{mg} / \mathrm{L}$ result is well above the historical trend for well 699-24-34A, is probably an error, and is undergoing further review. The background threshold value is $29 \mathrm{mg} / \mathrm{L}$. The Solid Waste Landfill is located on the western edge of the major nitrate plume emanating from the 200 East Area (Figure 1.0-3 in Section 1.0), and the nitrate reported in Solid Waste Landfill wells may be mostly from the 200 East Area sources.

- Nitrite - Nitrite is historically not detected in Solid Waste Landfill wells. However, May 2006 results at all of the Solid Waste Landfill wells were elevated. Results at the upgradient wells were 56 and $79 \mu \mathrm{g} / \mathrm{L}$, and results at the downgradient wells ranged from 112 to $305 \mu \mathrm{g} / \mathrm{L}$. Background threshold value is $89 \mu \mathrm{g} / \mathrm{L}$. These elevated results are most likely sampling or laboratory errors and are under further review.

- Field pH - Measured values in downgradient network wells ranged from 6.6 to 7.13. The background threshold range is 6.68 to 7.84 . Three of the downgradient wells (699-23-34A, 699-23-34B, and 699-24-34A) had results that were lower than 6.68. The lowest reported value was 6.6 at well 699-23-34A. Trends of $\mathrm{pH}$ are relatively steady at Solid Waste Landfill wells.

- Specific Conductance - Specific conductance values for FY 2006 at all but one of the network wells (background well 699-26-35A) exceeded the 583- $\mu \mathrm{S} / \mathrm{cm}$ background threshold value during FY 2006. Six of the downgradient wells also exceeded the maximum contaminant level $(700 \mu \mathrm{S} / \mathrm{cm})$ of WAC 246-290-310. The highest reported value was $826 \mu \mathrm{S} / \mathrm{cm}$ at well 699-22-35 for a sample collected February 2006. Specific conductance values at Solid Waste Landfill wells have remained relatively stable since 2001. Elevated specific conductance may be due to increased concentrations of sulfate and other anions in groundwater at the Solid Waste Landfill.

- Sulfate - Reported results in downgradient wells ranged from 41.1 to $66.9 \mathrm{mg} / \mathrm{L}$. The background threshold value was $47.2 \mathrm{mg} / \mathrm{L}$ and was exceeded at three downgradient wells (699-23-34A, 699-24-43A, and 699-24-34B). Overall trend at these three wells is slightly increasing.

- Temperature-One reported result at well 699-24-34A exceeded the $20.7^{\circ} \mathrm{C}$ background threshold value. It was $21^{\circ} \mathrm{C}$ at well 699-24-34A in May 2006. However, this single elevated result is not consistent with the trend at this well or any of the Solid Waste Landfill wells, and is probably a measurement error. The other temperature measurements all ranged between $17^{\circ} \mathrm{C}$ and $20.1^{\circ} \mathrm{C}$.

- Total Organic Carbon - All reported total organic carbon results for Solid Waste Landfill

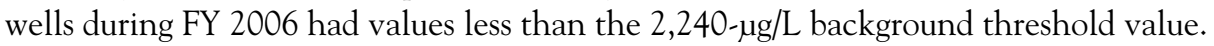
The range of values for FY 2006 was $<470$ to 2,200 $\mu \mathrm{g} / \mathrm{L}$. In previous years, spurious values for total organic carbon have been reported in Solid Waste Landfill wells. Elevated 
total organic carbon is consistent with what might be expected when groundwater is contaminated with sewage as it has at the Solid Waste Landfill.

- Filtered Zinc - Reported values for filtered zinc during FY 2006 ranged from less than the analytical method detection limit $(9.6 \mu \mathrm{g} / \mathrm{L})$ to $35.1 \mu \mathrm{g} / \mathrm{L}$ in downgradient wells. The background threshold value was $42.3 \mu \mathrm{g} / \mathrm{L}$, and none of the results exceeded it during FY 2006.

Site-Specific Parameters. Site-specific parameters at the Solid Waste Landfill include chlorinated hydrocarbons and two other constituents (1,4-dioxane and filtered arsenic) detected by the leachate collection system beneath the trenches at the landfill. Slightly elevated concentrations of chlorinated hydrocarbons continued to be detected at the Solid Waste Landfill during FY 2006. Carbon tetrachloride, tetrachloroethene, and filtered arsenic exceeded the groundwater criteria set forth in WAC 173-200. The range of reported concentrations of chlorinated hydrocarbons is given in Table 2.11-1.

Chlorinated hydrocarbons were detected in all Solid Waste Landfill network wells, including the upgradient wells. The chlorinated hydrocarbons detected included 1,1,1-trichloroethane, carbon tetrachloride, chloroform, tetrachloroethene, and trichloroethene. The general trends for these detected chlorinated hydrocarbons in Solid Waste Landfill wells are decreasing. Of the chlorinated hydrocarbons detected, only carbon tetrachloride and tetrachloroethene exceeded their WAC 173-200 limits during FY 2006. Carbon tetrachloride concentrations exceeded the 0.3- $\mu \mathrm{g} / \mathrm{L}$ WAC 173-200 limit in two wells (699-22-35 and 699-24-33 - both downgradient wells). The maximum detected value during FY 2006 was $0.76 \mu \mathrm{g} / \mathrm{L}$ in well 699-24-33. Tetrachloroethene concentrations exceeded the 0.8- $\mu \mathrm{g} / \mathrm{L}$ WAC 173-200 limit in six downgradient wells and one upgradient well. The highest value reported was $1.7 \mu \mathrm{g} / \mathrm{L}$ also at well 699-24-33. None of the chlorinated hydrocarbon results for FY 2006 exceeded federal drinking water standards.

A potential cause of the widespread, low-level chlorinated hydrocarbon contamination at the Solid Waste Landfill, including the upgradient wells and the adjacent Nonradioactive Dangerous Waste Landfill wells, is the dissolution of vadose zone vapors into groundwater. However, the source of the vapors is uncertain. Other possible sources include chlorinated hydrocarbons dissolved in the liquid sewage of the catch tank liquid from the 1100 Area heavy equipment garage and bus shop that were disposed to the Solid Waste Landfill (PNNL-13014).

Filtered arsenic (federal drinking water standard $10 \mu \mathrm{g} / \mathrm{L}$; WAC 173-200 limit $0.05 \mu \mathrm{g} / \mathrm{L}$ ) was detected at all Solid Waste Landfill wells. The highest concentration detected was 3.5 $\mu \mathrm{g} / \mathrm{L}$ in well 699-24-35. Although filtered arsenic was discovered in the leachate

collection system at the trenches, the occurrence of arsenic in groundwater at the Solid Waste Landfill is probably due to natural processes (i.e., occurs naturally in Hanford Site groundwater - Hanford Site background is up to $10 \mu \mathrm{g} / \mathrm{L}$; DOE/RL92-23), or there is an upgradient source (e.g., 200 East Area).

During FY 2006, all scheduled samples were collected at the Solid Waste Landfill except for August 2006 sampling events at wells 699-23-34A, 699-24-35, and 699-26-35A. The August 2006 samples at these three wells were not collected due to access restrictions for off-road wells during a period of extreme wildfire hazards. Because the window of opportunity for quarterly sampling expired when the missed wells were not sampled before the end of the fiscal year, no further effort to collect the missed samples is planned. The next quarterly sampling event occurred in November 2006.

\subsubsection{400 Area Water Supply Wells}

Primary groundwater monitoring activities in the 400 Area involve monitoring of the 400 Area water supply wells. Monitoring is also conducted to provide information needed to describe the nature and extent of site-wide contamination
Of the chlorinated

hydrocarbons

detected, carbon

tetrachloride and

tetrachloroethene

exceeded their

respective

WAC 173-200 limits

during FY 2006.

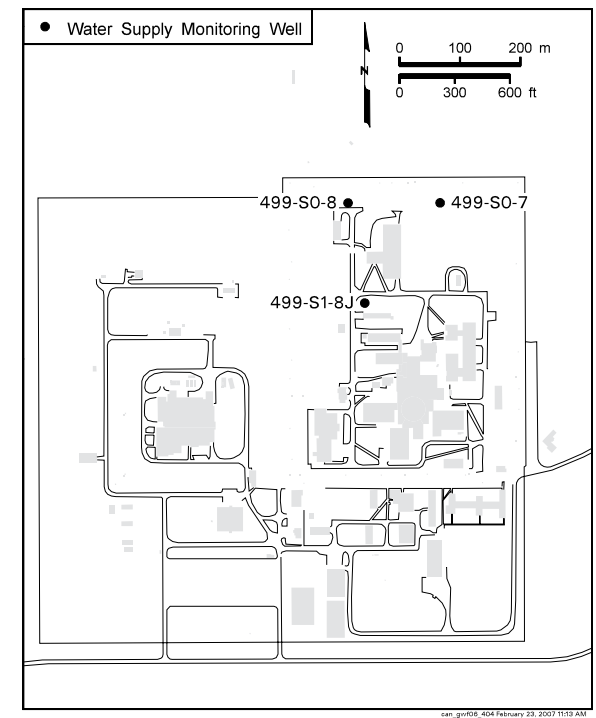




\section{Tritium was} measured at levels below the drinking water standard $(20,000 \mathrm{pCi} / \mathrm{L})$ in all three of the 400 Area water supply wells. (primarily nitrate, tritium, and iodine-129). This section discusses the monitoring of the 400 Area water supply wells, specifically tritium, and general aspects of groundwater chemistry in the 400 Area. The water supply wells were sampled quarterly as scheduled in FY 2006.

The Hanford Site water-table map (Figure 2.1-2 in Section 2.1) indicates that flow is generally to the east-southeast across the 400 Area. The water table is located near the contact of the Ringold Formation and Hanford formation, which is $\sim 49$ meters below ground surface (WHC-EP-0587). Hanford formation sediment dominates groundwater flow in the 400 Area because of its relatively high permeability compared to that of sediment in the Ringold Formation.

Elevated levels of tritium associated with the groundwater plume originating from the vicinity of the PUREX Plant in the 200 East Area were identified in 400 Area wells as in previous years (see Figure 1.0-2 in Section 2.1). Groundwater tritium levels are relevant to the water supply wells, which provide drinking water and emergency supply water for the 400 Area. Well 499-S1-8J serves as the main water supply well, while wells 499-S0-7 and 499-S0-8 are backup supply wells. Well 499-S1-8J has lower tritium concentrations because it is screened at a greater depth than the other two water supply wells. The tritium concentrations in wells 499-SO-7, 499-S0-8, and 499-S1-8J are compared in Figure 2.11-16 to that of the 400 Area drinking water supply. Tritium was measured at levels below the drinking water standard $(20,000 \mathrm{pCi} / \mathrm{L})$ in all three of the water supply wells in FY 2006. Tritium levels in well 499-S1-8J (the main water supply well) during FY 2006 ranged from 2,840 to $3,240 \mathrm{pCi} / \mathrm{L}$.

Tritium remained below the drinking water standard $(20,000 \mathrm{pCi} / \mathrm{L})$ and the 4-millirem/ year dose equivalent in the drinking water supply, sampled at a tap, for all sampling events in FY 2006 (Figure 2.11-16). Nitrate remained below the drinking water standard in FY 2006 for the water supply wells. Data from FY 2006 and earlier from these wells indicate no other constituents are present at levels above their drinking water standards. 
Table 2.11-1. Ranges of Reported Chlorinated Hydrocarbon Concentrations in Solid Waste Landfill Wells, FY 2006

\begin{tabular}{|c|c|c|c|c|c|c|c|c|c|c|}
\hline Constituent & Limit $(\mu \mathrm{g} / \mathrm{L})$ & $699-22-35$ & $699-23-34 \mathrm{~A}$ & $699-23-34 B$ & $699-24-33$ & $699-24-34 A$ & 699-24-34B & $699-24-34 C$ & $699-24-35$ & $699-26-35 A$ \\
\hline 1,1,1-Trichloroethane & WAC 200 & $0.96-1.3$ & $0.88-1.2$ & $0.9-1.5$ & $0.68-1.3$ & $0.57-0.85$ & $0.69-0.94$ & $0.59-0.8$ & $0.8-1.0$ & $<0.08-0.62$ \\
\hline 1,1,2-Trichloroethane & MCL 5.0 & $<0.23$ & $<0.23$ & $<0.23$ & $<0.23$ & $<0.23$ & $<0.23$ & $<0.23$ & $<0.23$ & $<0.23$ \\
\hline 1,2-Dichloroethane & WAC 0.5 & $<0.21$ & $<0.21$ & $<0.21$ & $<0.21$ & $<0.21$ & $<0.21$ & $<0.21$ & $<0.21$ & $<0.21$ \\
\hline 1,4-Dichlorobenzene & WAC 4.0 & $<0.2$ & $<0.2$ & $<0.2$ & $<0.2$ & $<0.2$ & $<0.2$ & $<0.2$ & $<0.2$ & $<0.2$ \\
\hline 1,4-Dioxane & WAC 7.0 & $<12.0$ & $<12.0$ & $<12.0$ & $<12.0$ & $<12.0$ & $<12.0$ & $<12.0$ & $<12.0$ & $<12.0$ \\
\hline Carbon tetrachloride & WAC 0.3 & $<0.15-0.36$ & $<0.15$ & $<0.15-0.16$ & $<0.15-0.76$ & $<0.15-0.29$ & $<0.15$ & $<0.15$ & $<0.15$ & $<0.15$ \\
\hline Chloroform & WAC 7.0 & $0.33-0.4$ & $0.2-0.28$ & $0.32-0.53$ & $<0.19$ & $<0.19$ & $<0.19$ & $<0.19$ & $<0.19$ & $<0.19$ \\
\hline cis-1,2-Dichloroethene & MCL 70 & $<0.27$ & $<0.27$ & $<0.27$ & $<0.27$ & $<0.27$ & $<0.27$ & $<0.27$ & $<0.27$ & $<0.27$ \\
\hline Tetrachloroethene & WAC 0.8 & $<0.1-0.79$ & $0.67-1.4$ & $<0.1-0.87$ & $0.29-1.7$ & $0.56-1.1$ & $0.92-1.5$ & $0.82-1.6$ & $0.39-1.2$ & $0.1-0.66$ \\
\hline Trans-1,2-dichloroethene & MCL 100 & $<0.16$ & $<0.16$ & $<0.16$ & $<0.16$ & $<0.16$ & $<0.16$ & $<0.16$ & $<0.16$ & $<0.16$ \\
\hline Trichloroethene & WAC 3.0 & $0.42-0.45$ & $0.43-0.48$ & $0.31-0.39$ & $0.57-0.81$ & $<0.2-0.55$ & $<0.2-0.6$ & $<0.2-0.7$ & $<0.2-0.48$ & $<0.2-0.37$ \\
\hline $\begin{array}{l}\text { Values in bold exceed limi } \\
M C L=\text { Maximum contamin } \\
\text { WAC = Washington Admin }\end{array}$ & $\begin{array}{l}\text { f WAC 17 } \\
\text { level (Fe } \\
\text { ative Cod }\end{array}$ & $\begin{array}{l}-40 . \\
\text { Arinking } \\
\text { C 173-2 }\end{array}$ & tandard). & & & & & & & \\
\hline
\end{tabular}




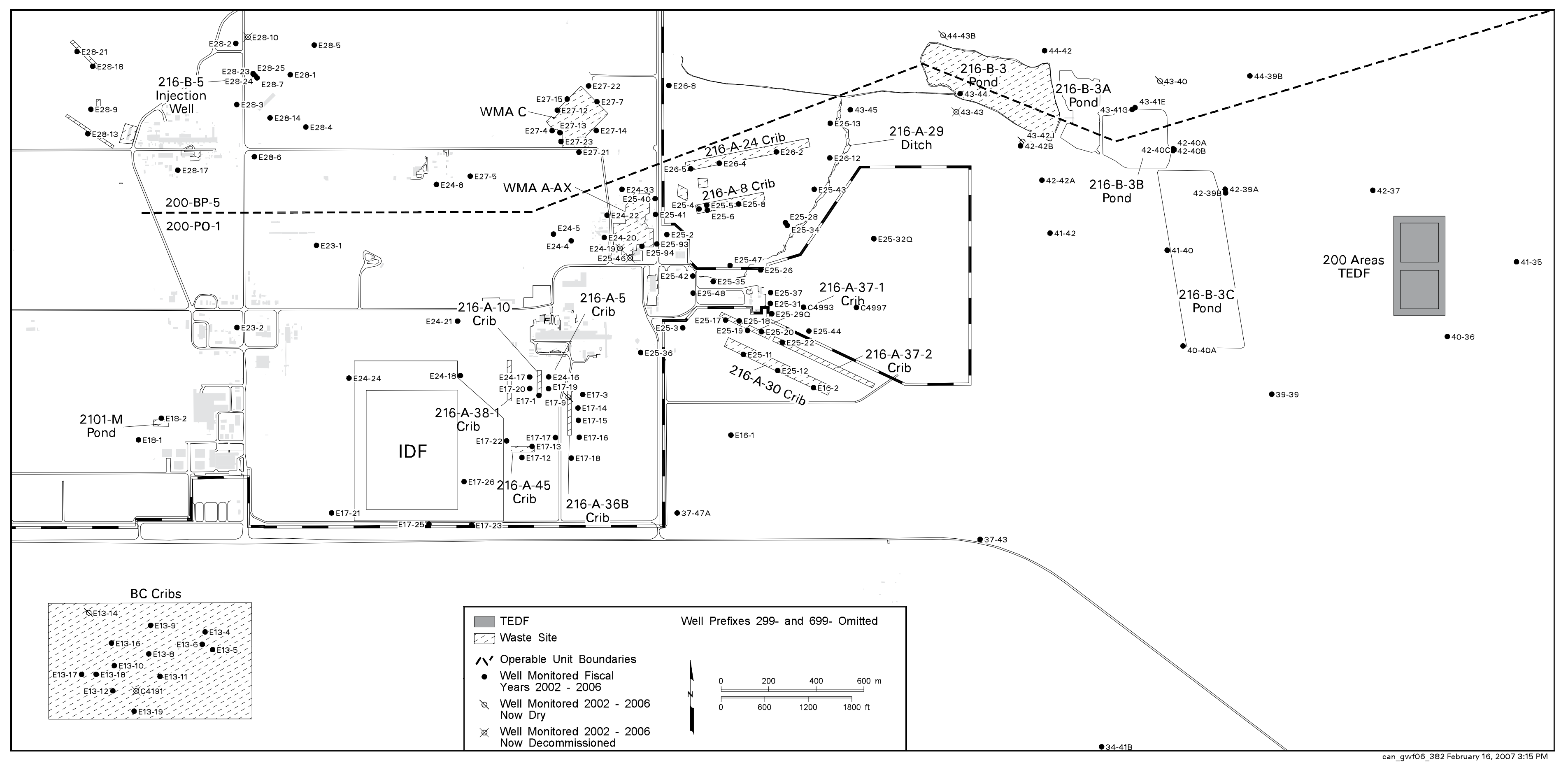

Figure 2.11-1. Facilities and Groundwater Monitoring Wells in North Portion of 200-PO-1 Operable Unit 


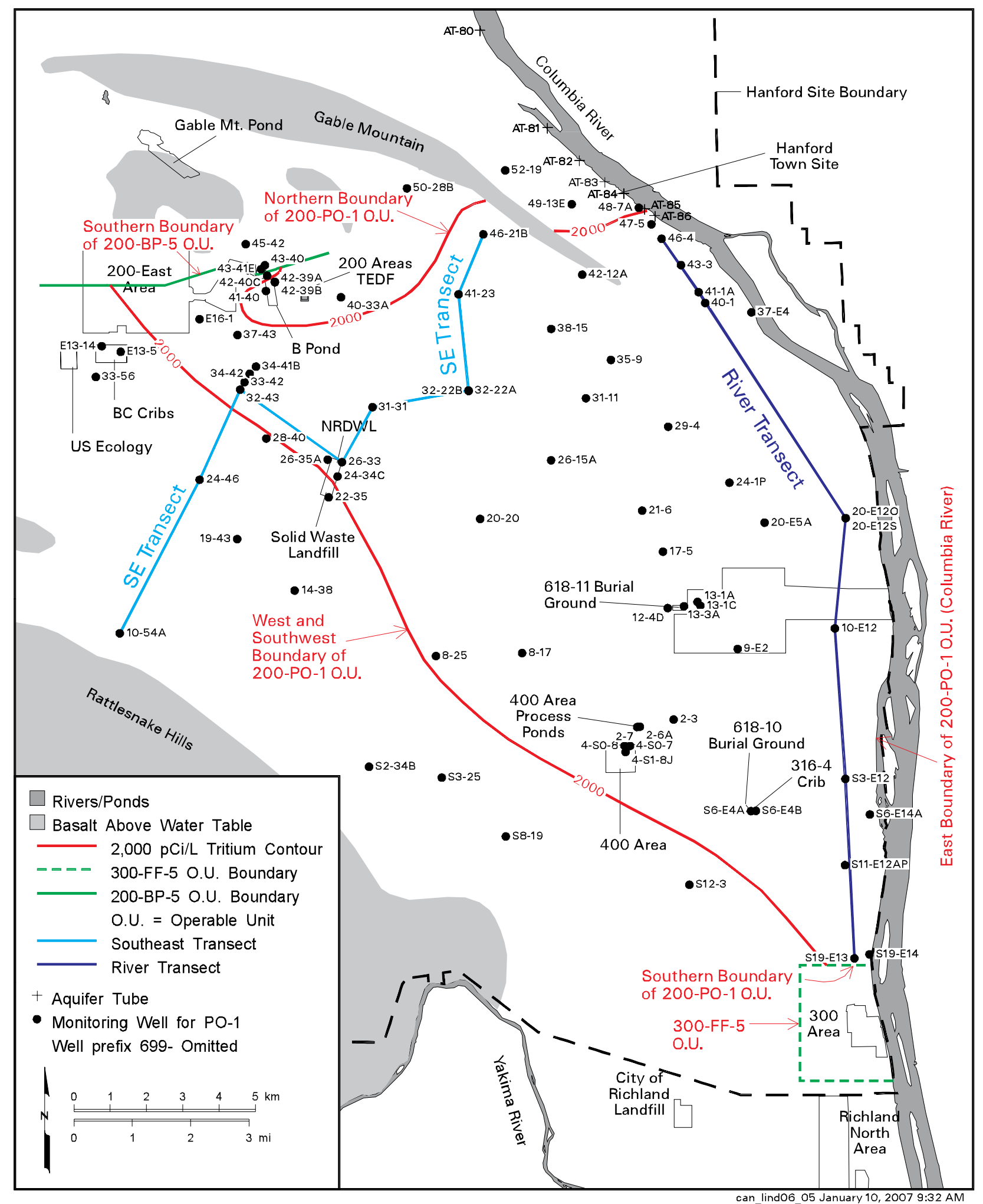

Figure 2.11-2. 200-PO-1 Operable Unit Boundaries, Far-Field Monitoring Wells, and Transects 


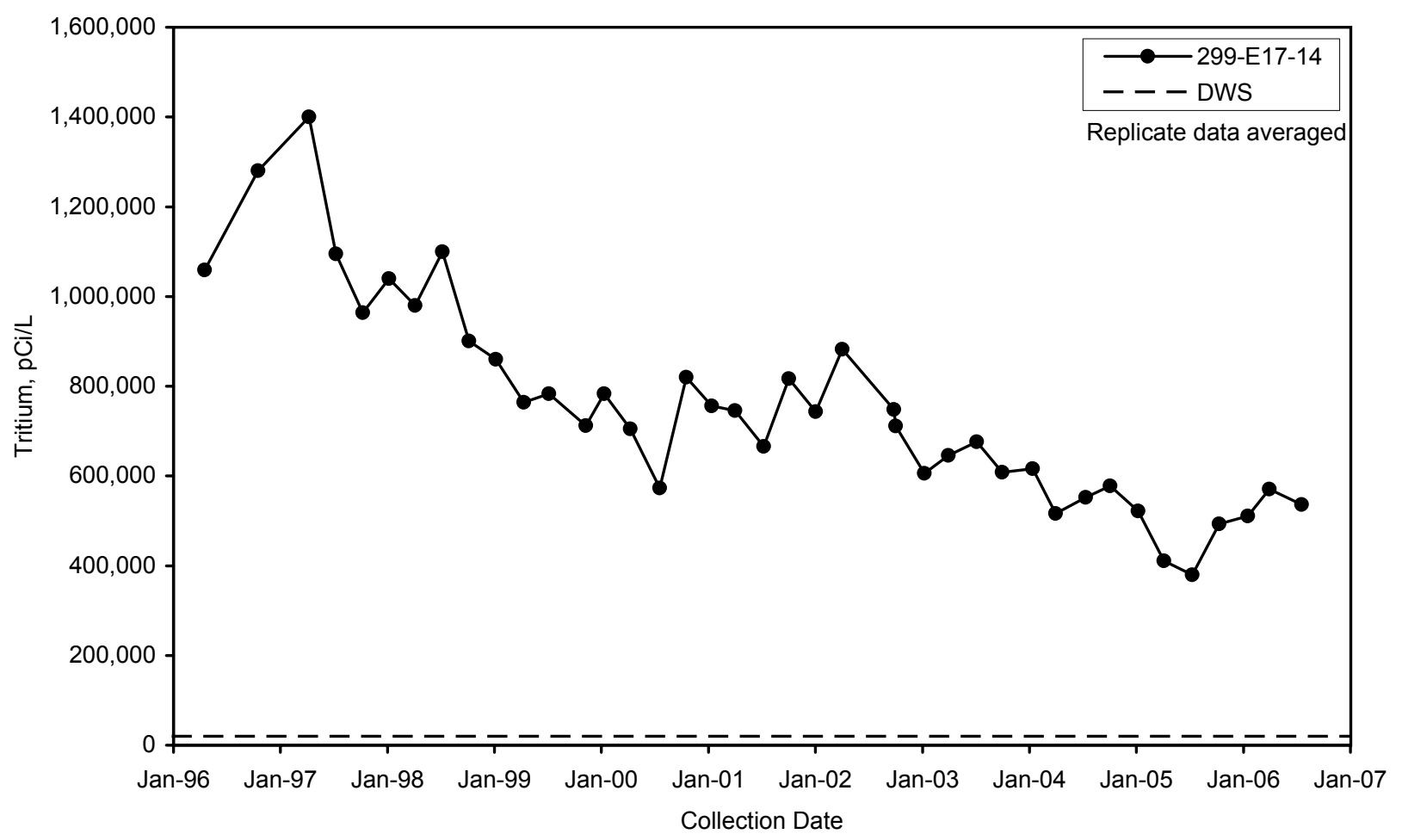

gwf06384

Figure 2.11-3. Tritium Concentrations in Well 299-E17-14 at 216-A-36B Crib

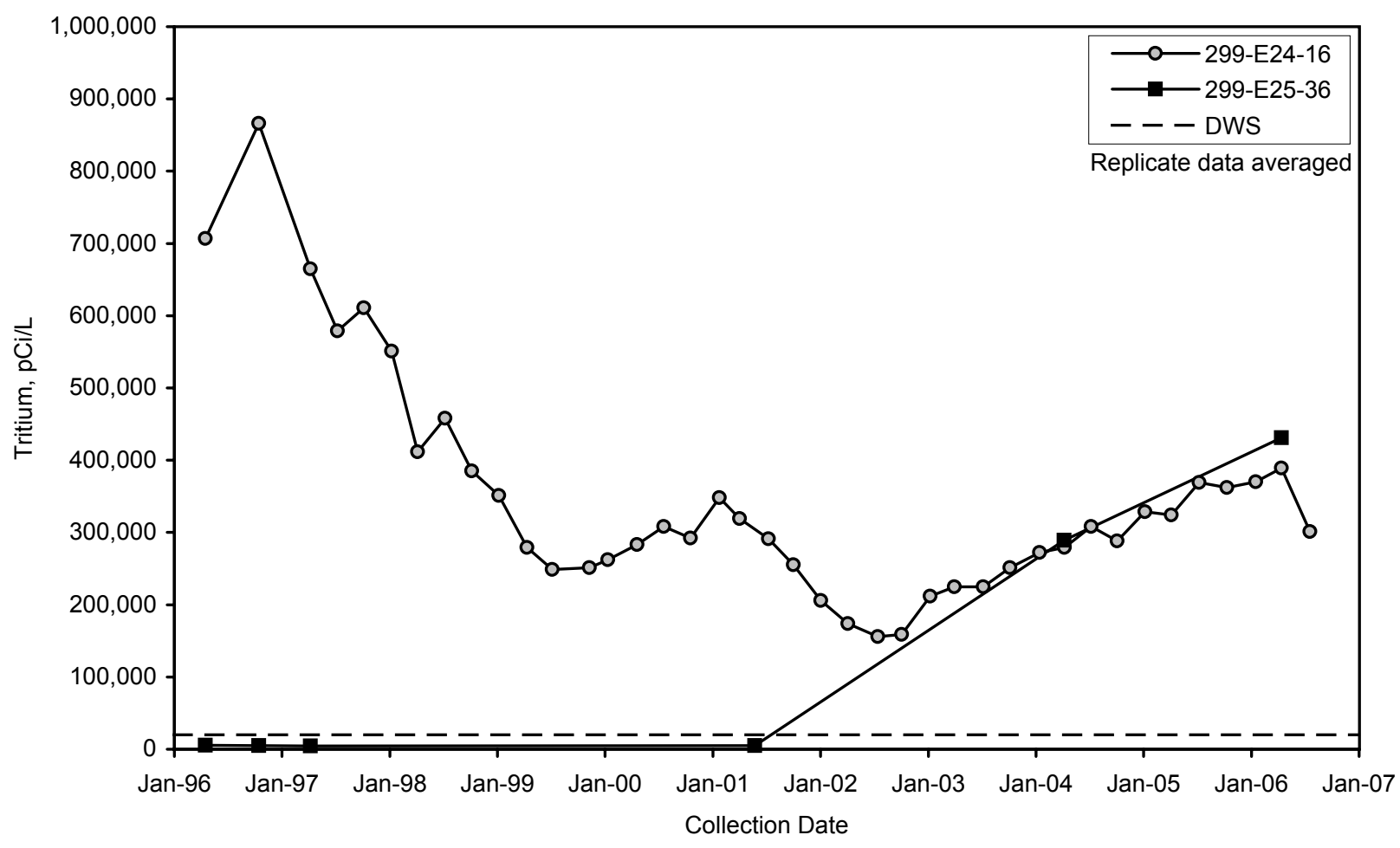

Figure 2.11-4. Tritium Concentrations at Wells 299-E24-16 (216-A-10 Crib) and 299-E25-36 (between 216-A-36B and 216-A-37-1 cribs) 


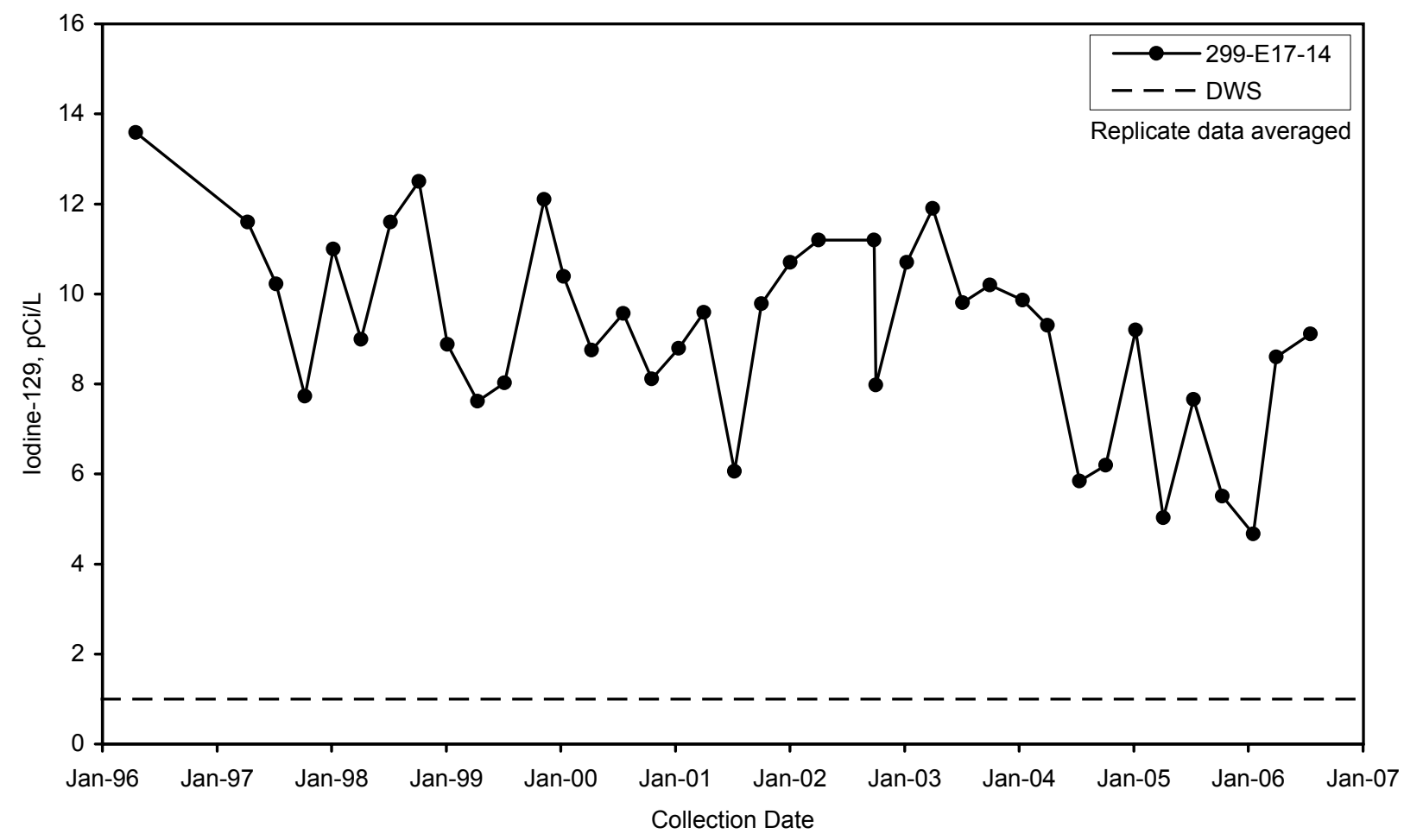

gwf06386

Figure 2.11-5. Iodine-129 Concentrations in Well 299-E17-14 at 216-A-36B Crib

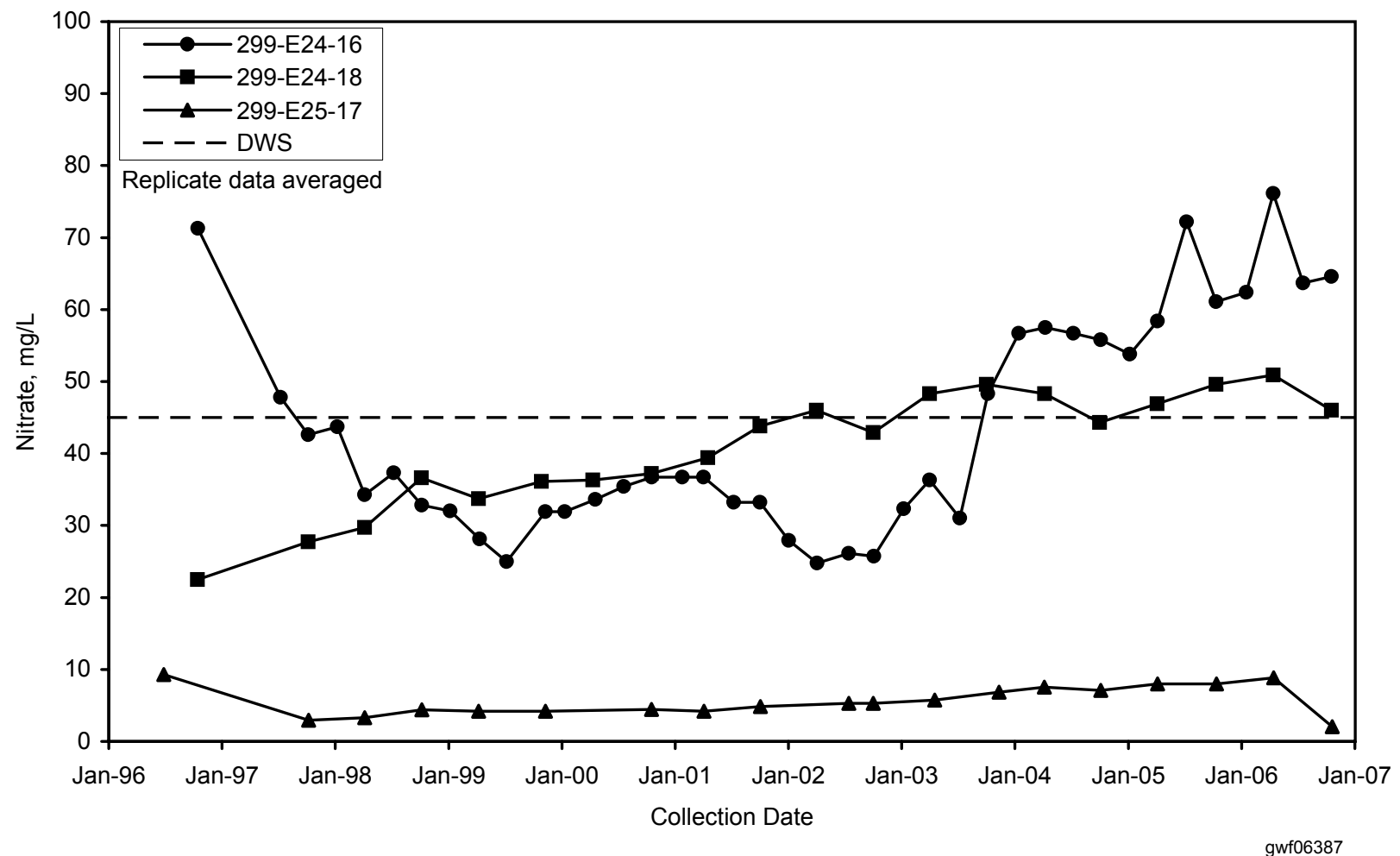

Figure 2.11-6. Nitrate Concentrations in Wells 299-E24-16 at the 216-A-10 Crib, 299-E24-18 Upgradient of the 216-A-10 Crib, and 299-E15-17 at the 216-A-37-1 Crib 


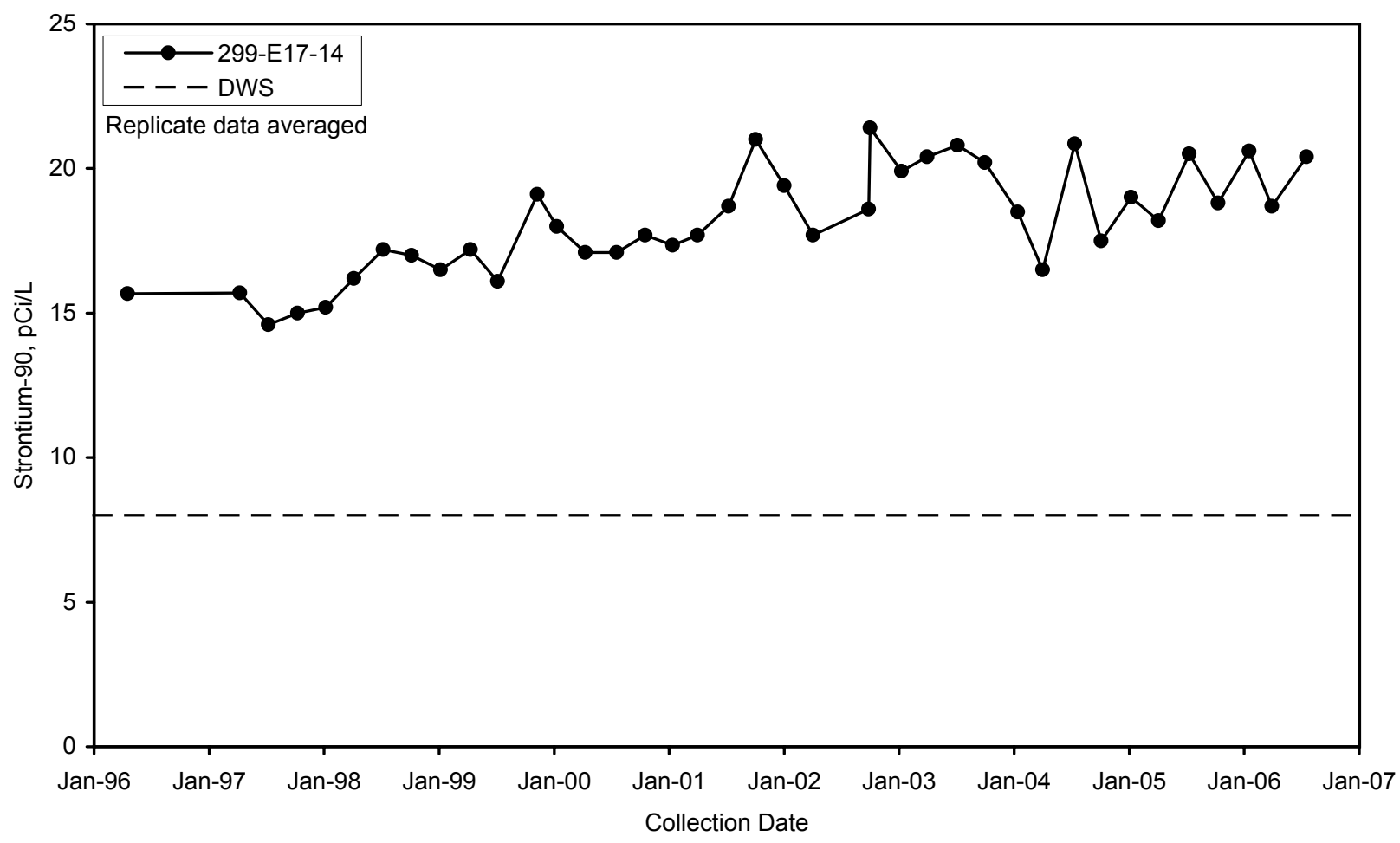

Figure 2.11-7. Strontium-90 Concentrations in Well 299-E17-14 at 216-A-36B Crib

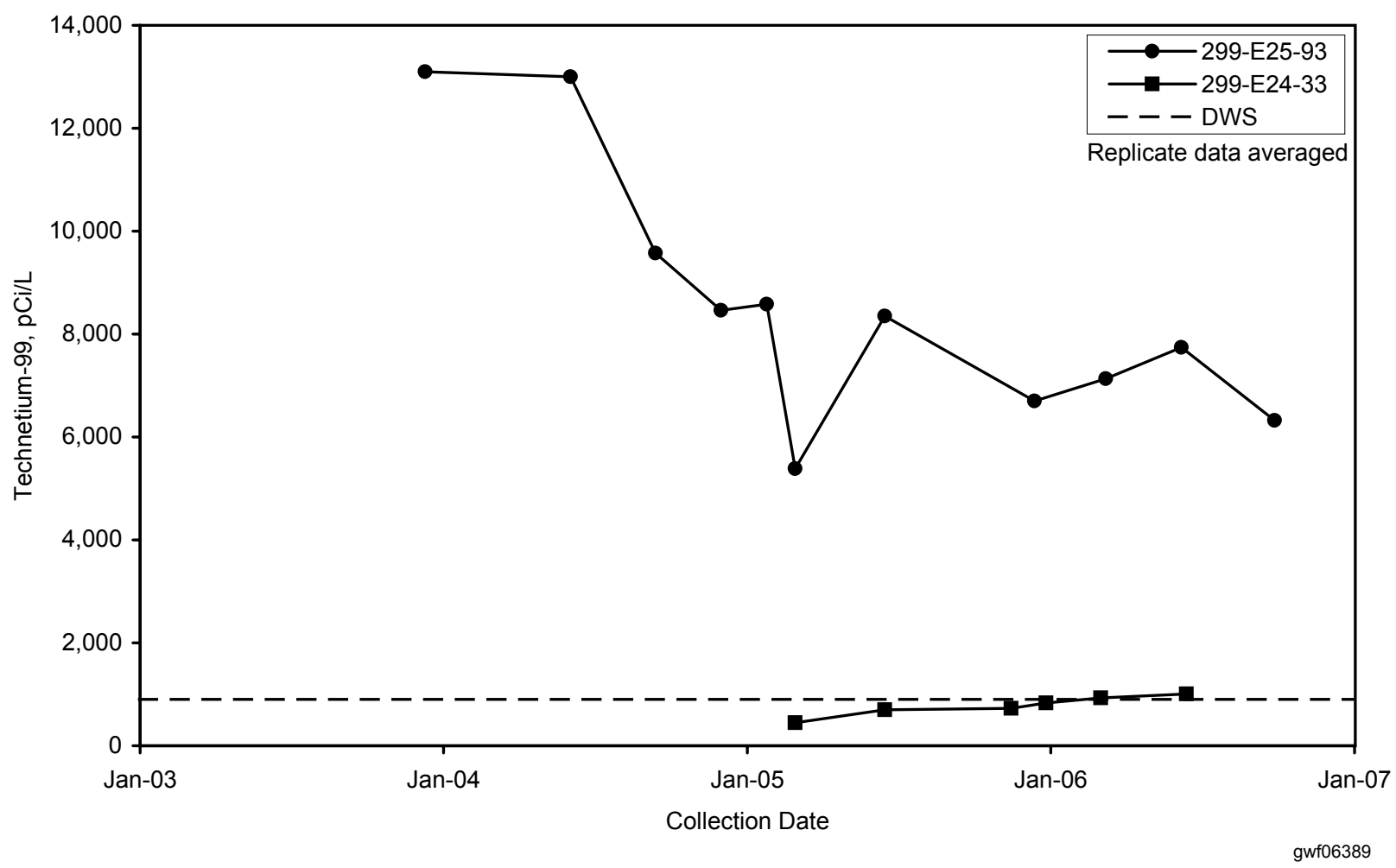

Figure 2.11-8. Technetium-99 Concentrations in Wells 299-E25-93 and 299-E24-33 at Waste Management Area A-AX 


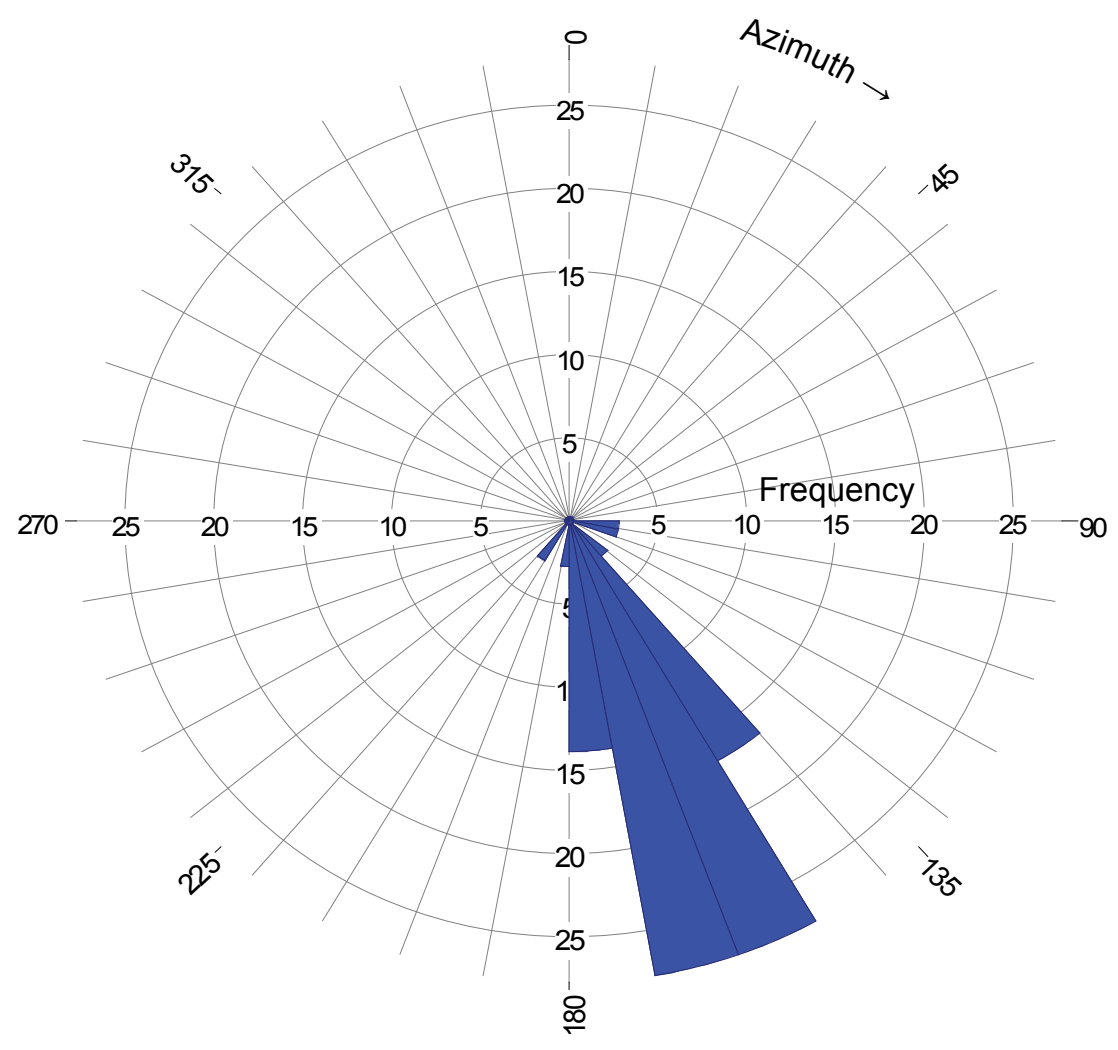

Figure 2.11-9. Groundwater Flow Directions at the A and AX Tank Farms from 1990 to 2003 (after RPP-23748)

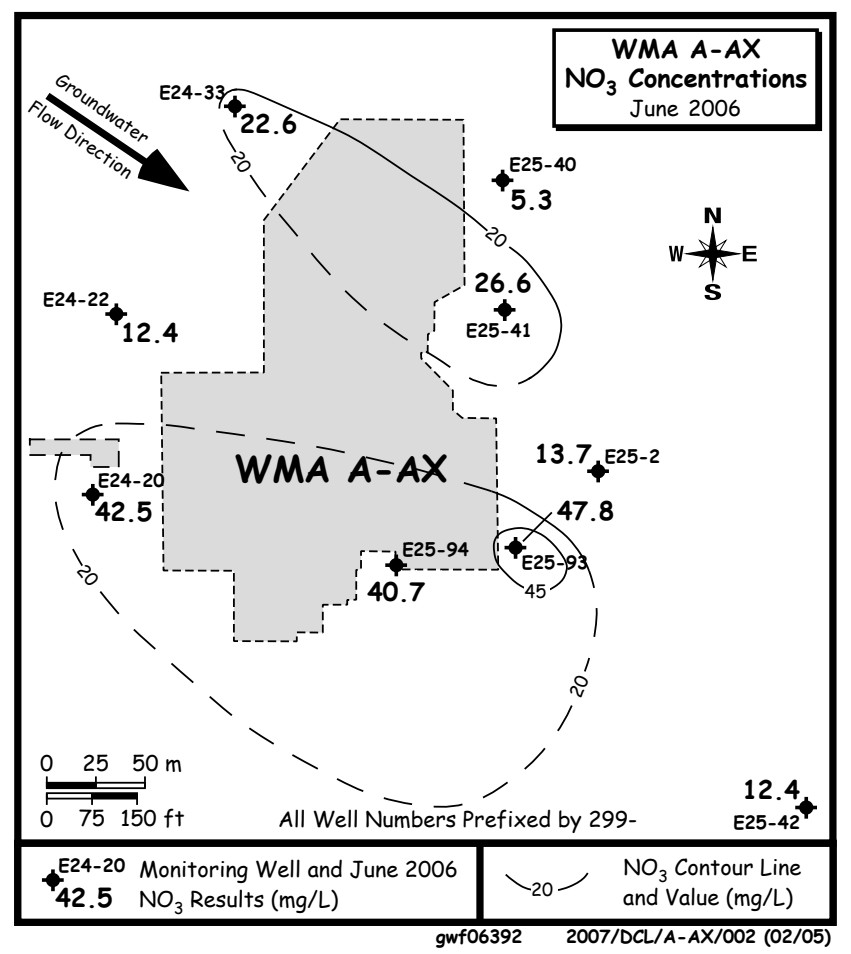

Figure 2.11-10. Nitrate Concentrations in Groundwater at Waste Management Area A-AX, June 2006 


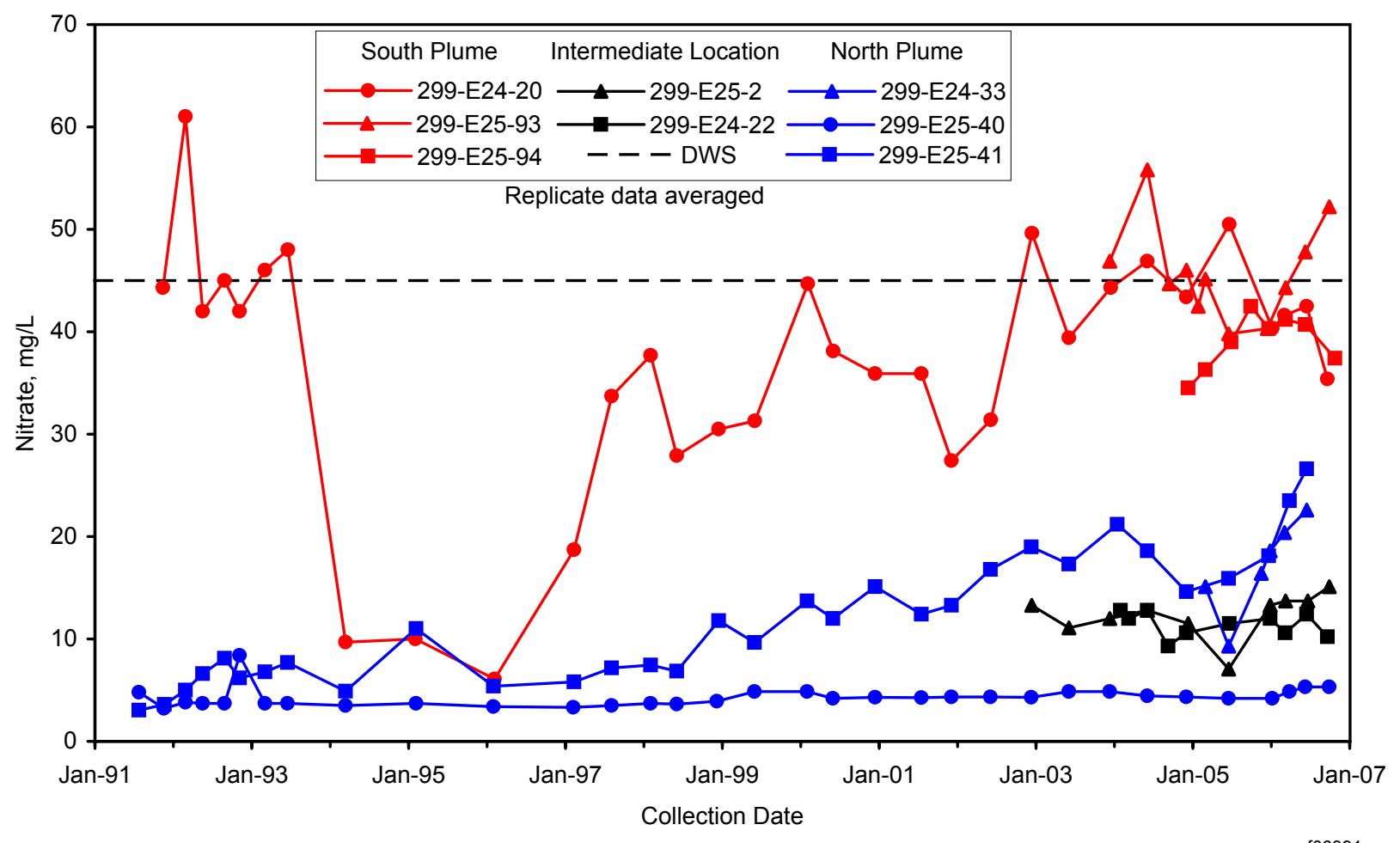

Figure 2.11-11. Nitrate Concentrations in Groundwater at Waste Management Area A-AX

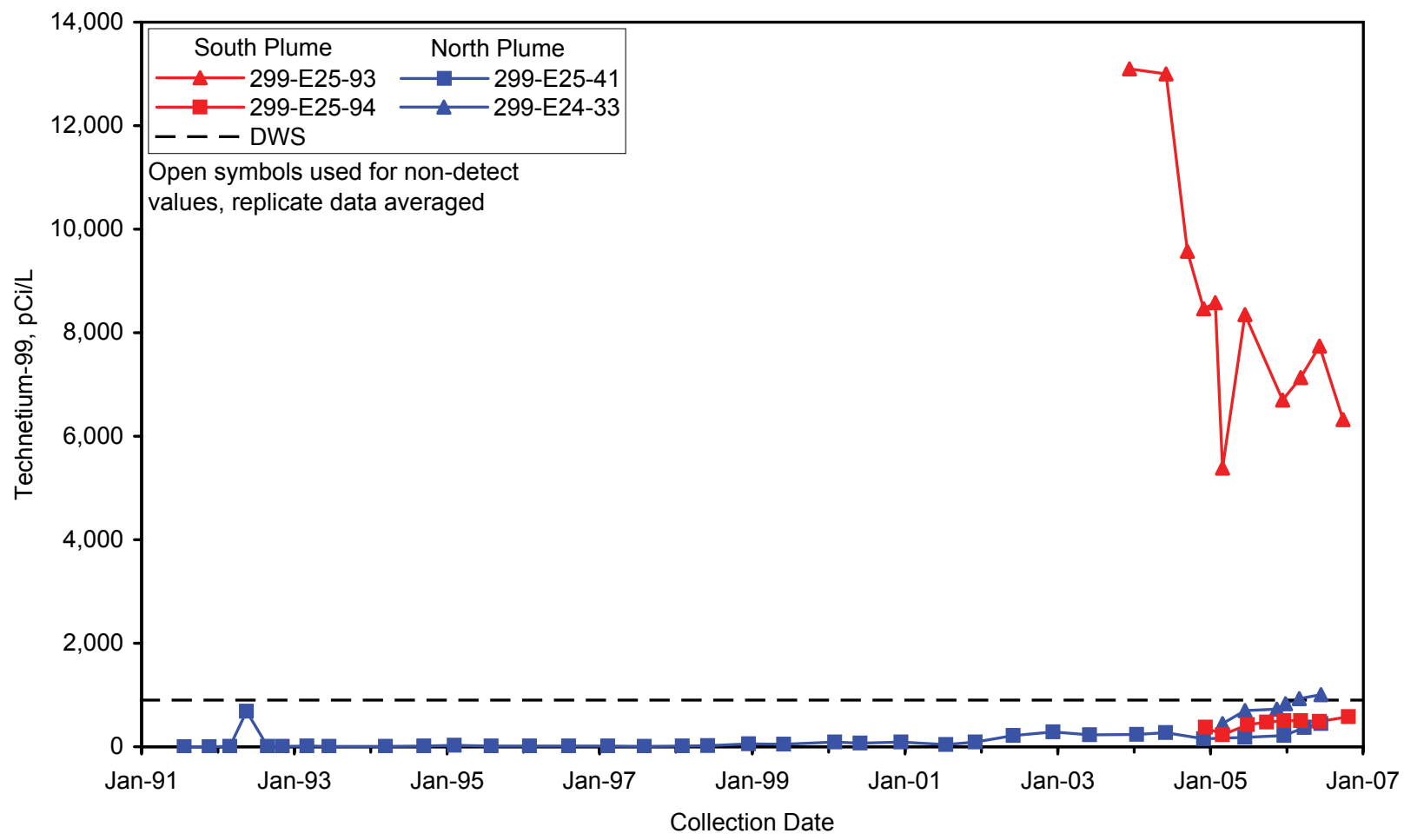

gwf06393

Figure 2.11-12. Technetium-99 Concentrations in Groundwater at Waste Management Area A-AX 


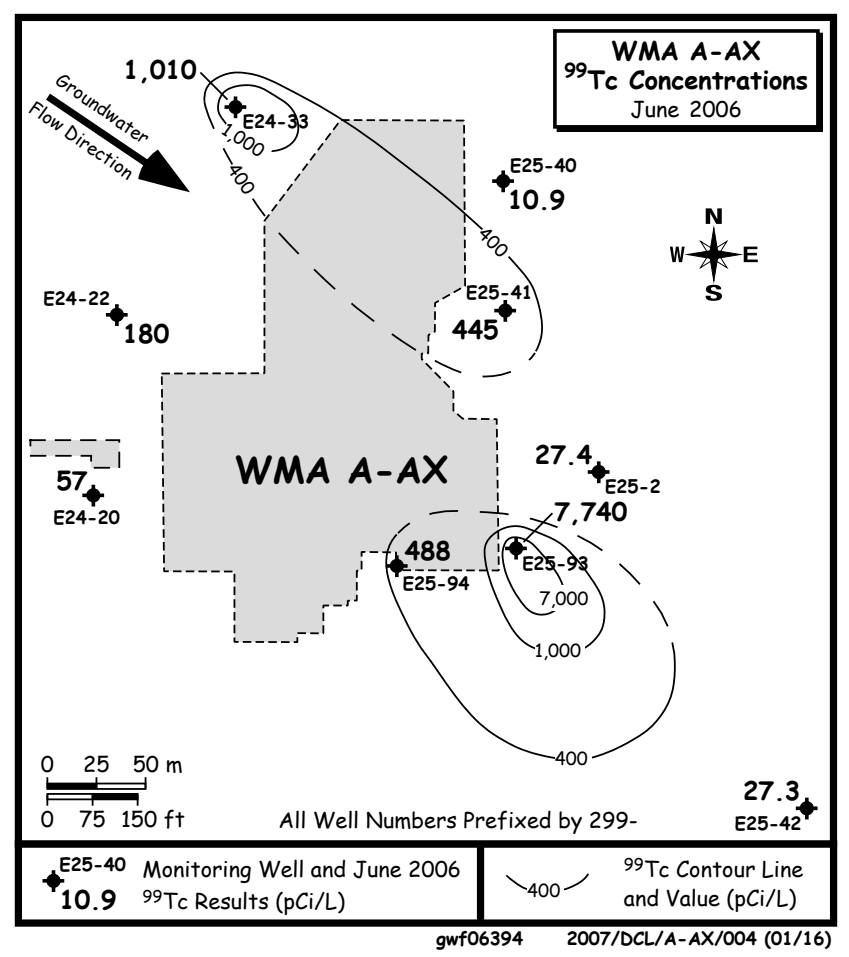

Figure 2.11-13. Technetium-99 Concentrations in Groundwater at Waste Management Area A-AX, June 2006

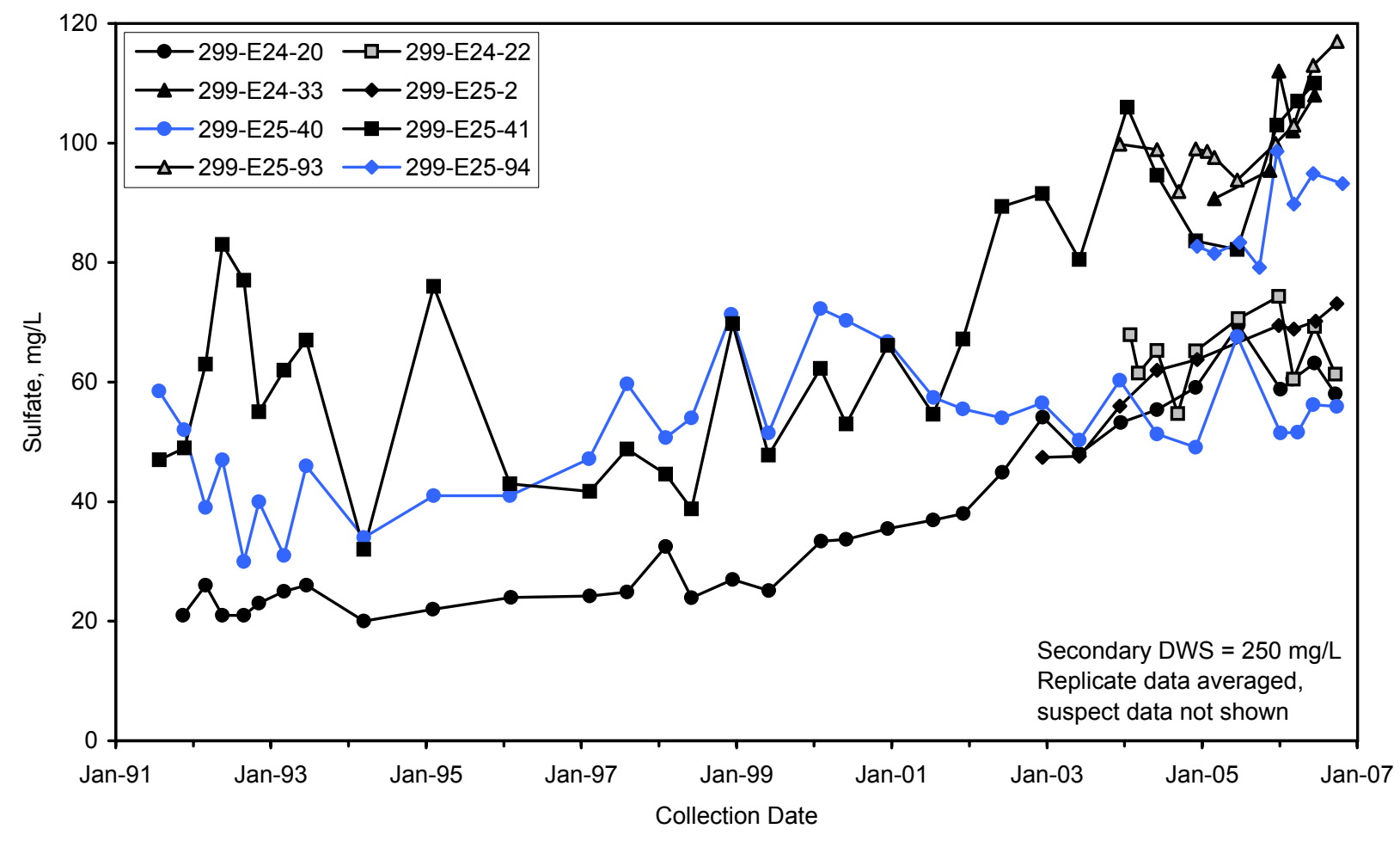

gwf06395

Figure 2.11-14. Sulfate Concentrations in Groundwater at Waste Management Area A-AX 


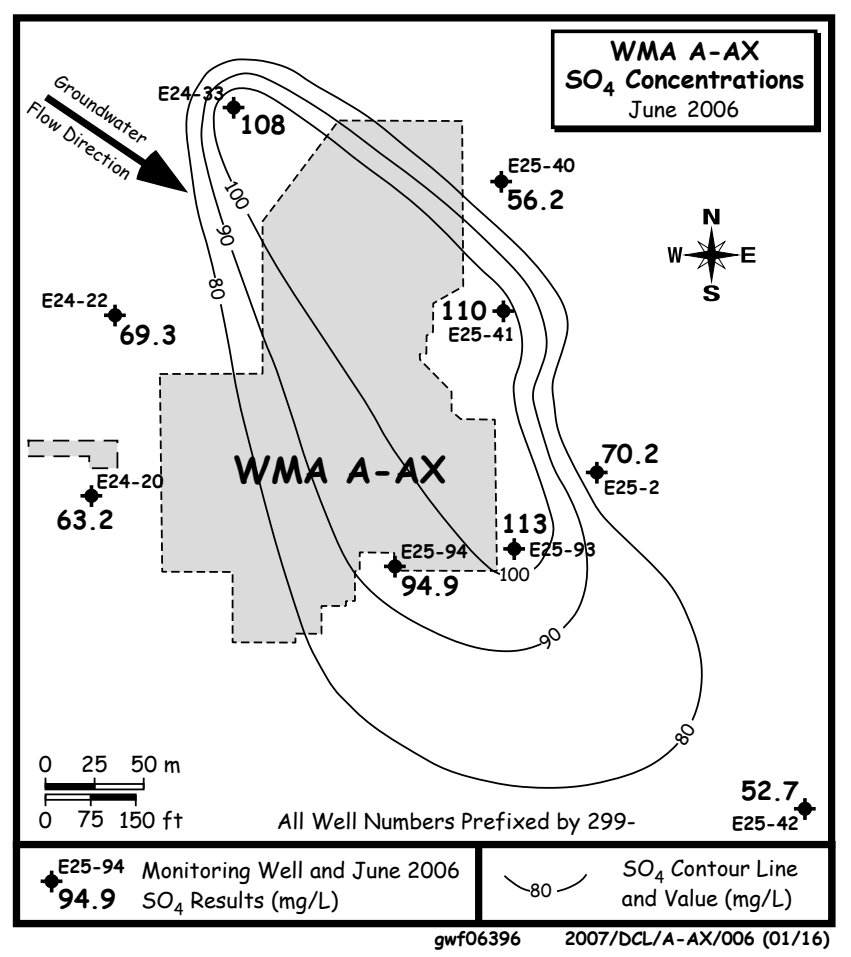

Figure 2.11-15. Sulfate Concentrations in Groundwater at Waste Management Area A-AX, June 2006 

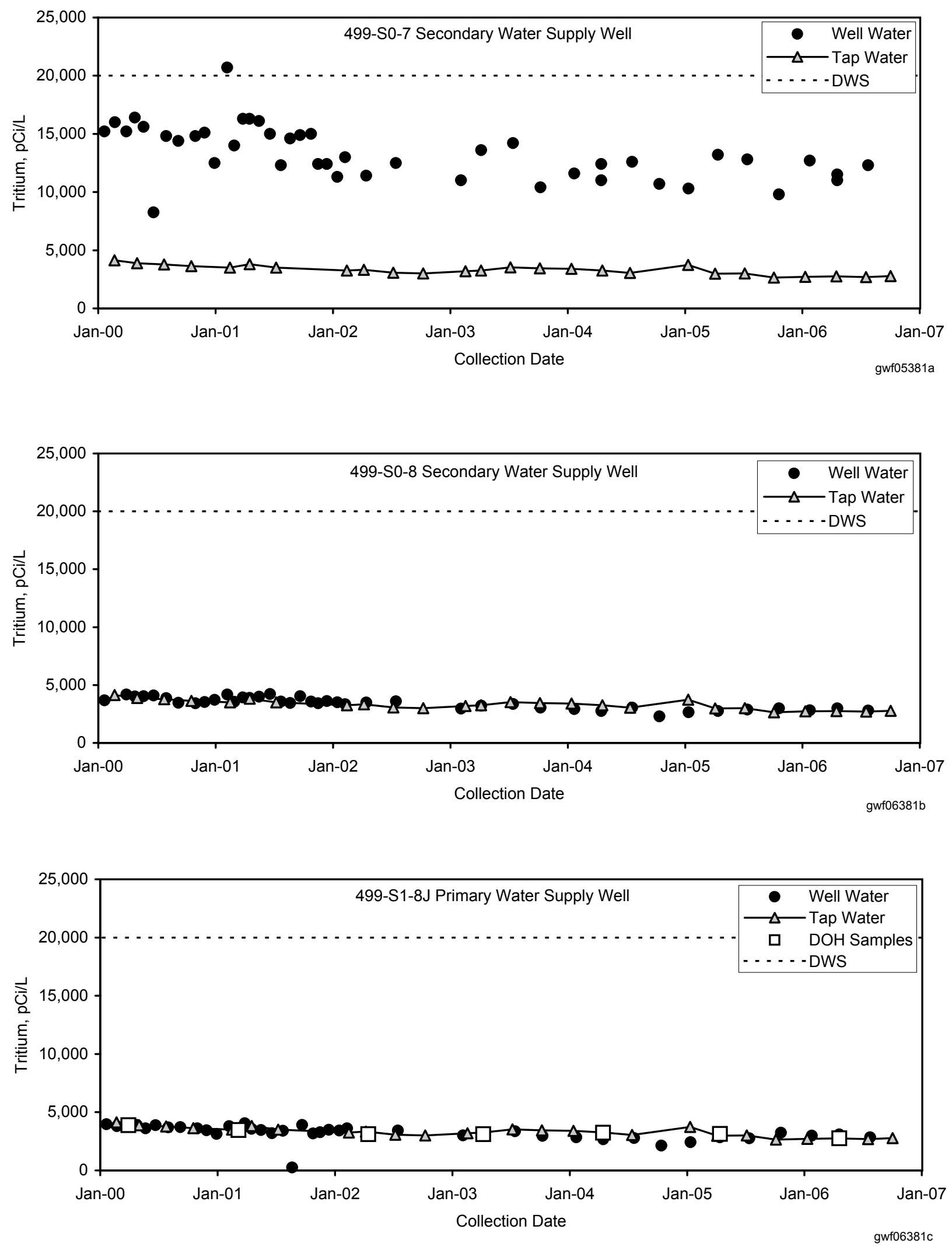

Figure 2.11-16. Tritium Concentrations in 400 Area Water Supply Wells 


\subsection{0-FF-5 Operable Unit}

\section{R. E. Peterson, J. W. Lindberg, and B. A. Williams}

The 300-FF-5 Operable Unit includes groundwater affected by releases from waste sites and facilities associated with the 300-FF-1 and 300-FF-2 Operable Units, as defined under Comprehensive Environmental Response, Compensation, and Liability Act (CERCLA). Primary sources for contaminants that have impacted groundwater are the former liquid waste disposal facilities in the 300 Area, and burial grounds and a crib at two outlying subregions, i.e., the 618-11 burial ground and the 618-10 burial ground/former 316-4 cribs. The operable unit lies within a larger groundwater interest area (see Figure 1.0-1 in Section 1.0), which has been defined informally for scheduling, data evaluation, and interpretation purposes. Investigations are underway in the groundwater interest area to (a) track changes in the extent of groundwater contaminants, (b) monitor trends in contaminant levels with time, and (c) comply with Resource Conservation and Recovery Act (RCRA) requirements associated with the former 300 Area process trenches.

The 300-FF-5 Operable Unit subregions and their relationship to the 300-FF- 1 and 300-FF-2 Operable Units are shown in Figure 2.12-1. The 300 Area contains former nuclear fuel fabrication facilities, fuel research laboratories, liquid effluent disposal sites, and several solid waste burial grounds. An index map to 300 Area monitoring wells, waste sites, buildings, and shoreline monitoring sites is shown in Figure 2.12-2. The two outlying subregions of the operable unit (i.e., the 618-11 burial ground near Energy Northwest and the 618-10 burial ground) received primarily solid radioactive waste from the 300 Area during the period 1954 to 1967 . The former 316-4 cribs, which are located adjacent to the 618-10 burial ground, received uranium-bearing organic liquid waste during the period 1948 to 1956. Index maps to the 300-FF- 5 North subregions are provided as Figure 2.12-3.

Groundwater flow in the unconfined aquifer beneath the 300-FF-5 groundwater interest area is generally to the east and southeast (Figure 2.12-4). Flow converges into the 300 Area from regions to the northwest, west, and southwest, and ultimately discharges to the Columbia River along the 300 Area shoreline as riverbank springs and through the adjacent riverbed. In the northern and central portions of the 300 Area, flow direction is predominantly toward the southeast, while in the southern portion, flow is more eastward, as inferred from water-table elevations recorded during most of any particular year. This flow pattern reflects medium-to-low river stage conditions. As river discharge rises during late May or June, the direction of groundwater flow temporarily shifts to more southward in the northern portion
Groundwater flows toward the east and southeast across the 300-FF-5 interest area and discharges

to the Columbia

River.

Groundwater monitoring in the 300-FF-5 groundwater interest area includes the following monitoring activities:

Long-Term Monitoring under CERCLA and AEA

- Wells are sampled semiannually to monitor uranium, volatile organic compounds, and other contaminants.

- Aquifer tubes are sampled semiannually to annually.

- Riverbank springs, sediment, and associated biota are sampled annually (coordinated with Public Safety and Resource Protection Program monitoring).

Facility Corrective Action Monitoring at Former 300 Area Process Trenches

- Wells were sampled eight times during FY 2006 to monitor uranium and volatile organic carbons under RCRA.

- Monitoring was coordinated with other programs to avoid duplication. 
Plume areas (square kilometers) above the drinking water standard at the 300-FF-5 Operable Unit:

*Tritium -0.21

Uranium - 0.53

* Excludes tritium from 200-PO-1 Operable Unit. of the 300 Area. Seasonal changes in river stage are reflected in water levels measured at wells located as far as inland as 360 meters from the river (PNL-8580).

Because of highly transmissive aquifer materials, groundwater flow velocities can be quite high, with documented plume migration rates up to 10 meters per day (PNL-5408, pp. 45-49). However, in spite of high velocities, rapidly changing hydraulic gradients and their orientation, which are the consequence of daily, weekly, and seasonal cycles in river stage, apparently result in relatively low discharge rates to the Columbia River. Efforts to more accurately quantify these rates were underway during fiscal year (FY) 2006 as part of the 300-FF-5 Phase III Feasibility Study (DOE/RL-2005-41) and will continue during FY 2007.

Variability in the configuration of the water table also influences contaminant concentrations. During the spring runoff period of high river discharge conditions, river water infiltrates the banks and mixes with groundwater, thus diluting the concentrations of contaminants carried by groundwater. The rate at which groundwater discharges to the river is lowest during the period of high river stage because of bank storage effects (e.g., reduced gradients and actual reversal of flow direction at the shoreline). Farther inland, higher water-table elevations may result in groundwater coming in contact with contaminants held in the lower vadose zone, thus remobilizing those contaminants. Consequently, higher concentrations may be observed during the early summer months, particularly in areas beneath former liquid waste disposal sites.

The remainder of this section describes contaminant plumes and concentration trends for contaminants of concern or potential concern listed in sampling and analysis plans that support CERCLA and RCRA requirements. Following those descriptions, the status of the interim remedial action conducted under CERCLA and the facility monitoring under RCRA are discussed.

\subsubsection{Groundwater Contaminants}

Contaminants of concern, or potential concern, for the 300-FF-5 Operable Unit have been identified in several regulatory decision documents. Under CERCLA, the initial record of decision (ROD 1996b) and subsequent explanation of significant difference (EPA 2000) identify contaminants of concern for each of the three subregions of the operable unit. Under RCRA, constituents of concern for corrective action monitoring of groundwater beneath the former 300 Area process trenches are identified in a groundwater monitoring plan (WHC-SD-EN-AP-185, as amended).

The contaminant of greatest significance in groundwater beneath the 300 Area is uranium, which has persisted as a plume for a long time. Additional contaminants of potential concern from 300 Area sources are the volatile organic compounds cis-1,2-dichloroethene, tetrachloroethene, and trichloroethene. While not specifically listed in the record of decision, strontium-90, gross alpha, and gross beta are also monitored because those radiological indicators have exceeded standards. Contaminants from sources outside of the 300 Area that migrate into the subregion include tritium, nitrate, and trichloroethene.

For the 300-FF-5 North subregions, the contaminant of greatest significance is tritium at the 618-11 burial ground, where a plume of limited areal extent, but containing concentrations that greatly exceed the drinking water standard, is present. This plume lies upgradient of and beneath the Energy Northwest complex. At the 618-10 burial ground and former 316-4 cribs subregion, the contaminants of potential concern are uranium and tributyl phosphate. These two contaminants are known to have been disposed to the former 316-4 cribs. Some evidence suggests that uranium may also have been released from waste in the 618-10 burial ground. No evidence to date suggests a release of tritium from the 618-10 burial ground, as has occurred at the 618-11 burial ground. Technetium-99, tritium, and nitrate have migrated into the 300-FF-5 North subregions from upgradient sources in the 200 East Area. 
Most contaminants of potential concern, as identified in regulatory decision documents, show either a decrease or relatively constant concentration trend during the years since the initial remedial investigation for the operable unit was conducted in the early 1990s (PNNL-15127).

\subsubsection{Uranium}

Uranium is a contaminant in groundwater beneath the 300 Area and beneath the 618-10 burial ground/316-4 cribs subregion. In the 300 Area, it was introduced to groundwater by disposal of fuel fabrication effluent to large infiltration ponds and trenches. Disposal of uranium-bearing effluent to waste facilities ended in 1986 (PNNL-13645), and excavation of contaminated soil and backfilling at all of the major liquid waste disposal sites has been completed as of early 2004. At the former 316-4 cribs, it was disposed to open-bottomed infiltration cribs along with liquid effluent containing organic compounds. These cribs were excavated in 2004, and the excavation backfilled; some uranium and tributyl phosphate remain in the soil beneath the excavation.

Uranium is moderately mobile in the vadose zone and aquifer, with some sorption onto sediment particles. The mobility of uranium within waste sites, the underlying vadose zone, and in the aquifer is highly variable and depends on (a) the chemical makeup of the waste effluent and (b) the subsurface geochemical environment, especially the carbonate content, $\mathrm{pH}$, and surface properties of minerals (PNNL-14022; PNNL-15121). Uranium in groundwater is typically monitored using chemical analyses for total uranium in an unfiltered sample. In the river environment, uranium in shoreline media and river water is monitored using analyses for specific isotopes. Results for each type of analysis can be converted to the other to provide comparable data sets.

The U.S. Environmental Protection Agency (EPA) National Primary Drinking Water Standard for uranium is $30 \mu \mathrm{g} / \mathrm{L}$. The standard is based primarily on uranium's chemical toxicity to humans, which is associated with damage to internal organs. Protection standards for freshwater aquatic organisms have not been established by EPA. A recent literature review regarding the chemical toxicity of uranium to non-human biota describes the relationship between toxicity and water hardness (i.e., the amount of calcium and other cations) for aquatic organisms (Sheppard et al. 2005). The range of predicted no-effect concentrations is from $5 \mu \mathrm{g} / \mathrm{L}$ for freshwater plants and invertebrates (without considering hardness) to $2,800 \mu \mathrm{g} / \mathrm{L}$ for fish (assuming water hardness similar to the Columbia River). Until further regulatory guidance becomes available for the toxicity of uranium to freshwater organisms, the drinking water standard is being used as the level for protection along the 300 Area shoreline where contaminated groundwater discharges to the river.

300 Area Uranium Plume. The persistent uranium plume in the 300 Area subregion is shown in Figures 2.12-5 and 2.12-6, which portray conditions during December 2005 and June 2006, respectively, for the upper portion of the unconfined aquifer. These two time periods represent (a) typical long-term average conditions (December), and (b) short-term conditions during the period of the seasonal high water table (June). The plume is defined by concentrations exceeding $10 \mu \mathrm{g} / \mathrm{L}$ (natural background concentrations for uranium in this sub-region are in the 5 to $8 \mu \mathrm{g} / \mathrm{L}$ range). Concentration trends since 2000 within the plume are shown in Figure 2.12-7 for three wells located in the vicinity of the former 300 Area process trenches, which was the most recently active liquid waste disposal site. Concentrations in shallow wells in FY 2006 were all below 200 gg/L.

The area where uranium-contaminated groundwater exceeds the drinking water standard $(30 \mu \mathrm{g} / \mathrm{L})$ is $\sim 0.4$ square kilometers. New estimates for the mass of dissolved uranium in this area of the plume are being prepared as part of the continuing Phase III Feasibility Study, which is underway during FY 2007. Rough estimates suggest a mass on the order of tens of kilograms (PNNL-15127, pp. 2.2 to 2.4); however, these estimates are likely to be revised upward, based on new data available to describe the hydrogeologic framework of the plume (see Section 2.12.3).

\section{Uranium is the contaminant of greatest significance in groundwater at this operable unit.}

The persistent uranium plume in the 300 Area extends over an area of $\sim 1$ square kilometer with concentrations exceeding $10 \mu g / L$. 


\section{Seasonal river stage conditions cause variability in uranium concentrations in groundwater.}

\section{Uranium contamination is primarily limited to the uppermost part of the unconfined aquifer at the 300 Area.}

Although the areal extent of the plume is quite consistent from year to year, concentrations at wells within the plume vary significantly with the seasons. These changes are related to cyclic changes in river stage, which near the river result in river water infiltrating the near-river aquifer. Uranium concentrations in the approaching groundwater are reduced by dilution and possibly also by increasing the amount that is sorbed onto aquifer solids, which is enhanced in the presence of lower-bicarbonate river water (PNNL-15121, pp. 3.3 to 3.5). Throughout most of the year (i.e., August through April), the river maintains lowto-moderate stage elevation, while during late May and June, the stage is typically high. It is during the seasonal high river stage that dilution of contaminants in groundwater near the river is greatest. This dilution effect is illustrated by uranium concentration trends at two wells located near the river and within the uranium plume, where uranium concentrations decrease when the water-table elevation is increased (Figure 2.12-8). At these wells, infiltrating river water has mixed with groundwater, thus diluting the contamination concentrations.

The elevation of the water table beneath the 300 Area responds quickly to changes in river stage. Seasonal variability in uranium concentrations in 300 Area groundwater is also caused by fluctuations in water-table elevation, which are driven by river-stage fluctuations. Higher concentrations are frequently observed in some portions of the plume when the water table is elevated above long-term levels, e.g., during the spring river freshet each May and June (see map in Figure 2.12-6). These higher concentrations may be the consequence of remobilizing uranium that is sequestered in the lower portion of the vadose zone (PNNL-15127, p. 3.29 to 3.30). This is most pronounced beneath liquid waste disposal sites, such as the former 300 Area process trenches (316-5 waste site) and 307 process trench (316-3 waste site). The increases in uranium concentrations when the water table is elevated are illustrated in Figure 2.12-9 for well 399-1-11, which is located within the footprint of the former 300 Area process trenches.

The uranium plume maps shown in Figures 2.12-5 and 2.12-6 represent conditions in the upper portion of the unconfined aquifer. Several wells in the 300 Area have open intervals for sampling that are in the lower portion of the unconfined aquifer (e.g., wells with a "B" suffix and well 399-1-8). Uranium concentrations in samples from these wells are typically near background levels, suggesting little to no downward migration of contaminant uranium. The highest value observed during FY 2006 was $13.5 \mu \mathrm{g} / \mathrm{L}$ at well 399-1-16B, which is located downgradient from the former 300 Area process trenches where uranium-bearing effluent was most recently released. The range in that well during the year was 5.1 to $13.5 \mu \mathrm{g} / \mathrm{L}$, which is very close to the range assumed for natural uranium in saturated Hanford gravels. Many results for samples from other "B" wells are non-detects, suggesting that those wells may be completed in lithologic units with a lower background level of uranium. At depths below the unconfined aquifer, uranium has not been detected at the few wells that monitor the uppermost confined aquifer.

Groundwater is also monitored at eight sites located along the 300 Area shoreline. Aquifer tubes were installed at multiple depths at each of these sites in 2004 and have now been sampled five times, with two sampling events conducted during FY 2006: January 2006 and September 2006. The results of this sampling are shown on Figure 2.12-10, along the results from previous events. The values shown on the map are the highest observed at a tube site for a particular sampling event. The highest value recorded for a tube sample is $394 \mu \mathrm{g} / \mathrm{L}$, although this result is under review and believed to be nonrepresentative of aquifer conditions. A more reasonable maximum value for recent uranium concentrations in groundwater near the river is $\sim 200 \mu \mathrm{g} / \mathrm{L}$, based on other results from aquifer tubes and from near-river monitoring wells.

The results from tube sites are consistent with uranium concentrations observed in December 2005 at near-river wells, even though the concentrations observed in samples from tubes are not directly comparable to concentrations observed from wells, because of the difference in screen length (i.e., 0.15 meters for tubes versus 3 to 7 meters for typical wells). 
The highest values from tubes are generally from sites adjacent to the central core area of the groundwater plume, i.e., near sites AT-3-3 and AT-3-4. However, concentrations in nearriver wells may be somewhat lower at times because of dilution by infiltrating river water, and possibly for additional reasons related to construction differences between wells and tubes. However, the relative distribution of tube results along the shoreline does help in defining the boundaries of the plume and also reveals information about the vertical distribution of contamination. Most of the tubes in the 300 Area appear to be installed below the zone of infiltration of river water, although some variability in contaminant concentrations observed in the shallowest tubes may be the result of dilution by river water.

Results from all tubes sampled in January and September 2006 are shown in Figure 2.12-11, which is a cross section oriented along the 300 Area shoreline. The results illustrate the variability in uranium concentrations, much of which is likely to be the result of heterogeneity in plume characteristics in the aquifer. A second cross section is presented that shows the position of the aquifer tubes relative to the hydrostratigraphic units (Figure 2.12-12). The position of near-river monitoring wells have also been projected onto this cross section, to provide perspective on the representativeness of samples collected from the various sites. This figure, when viewed with the analytical results in Figure 2.12-11, supports the presumption that most uranium contamination is contained within the saturated Hanford gravels. The maximum depth of the adjacent river channel is also projected onto this cross section, and it can be seen that samples collected from tubes are representative of the groundwater that is discharging through the riverbed.

Uranium Near 618-10 Burial Ground and 316-4 Cribs. Uranium concentrations are elevated above natural background levels (i.e., 5 to $8 \mu \mathrm{g} / \mathrm{L}$ ) at several wells near the southeast side of the 618-10 burial ground and the former 316-4 cribs. Concentrations at well 699-S6-E4A, which is located within the excavation footprint for the former cribs, rose during the initial excavation period in 2004 to a high value of $42 \mu \mathrm{g} / \mathrm{L}$, along with tributyl phosphate, a co-contaminant. During FY 2006, following a period of relatively lower concentrations while backfilling operations were underway, uranium concentrations once again rose to a high value of $42 \mu \mathrm{g} / \mathrm{L}$ (Figure 2.12-13). The cause for the variability in uranium concentrations at this well is likely related to excavation and backfilling activities. Well 699-S6-E4L, which is located adjacent to the southeast side of the burial ground, also shows elevated uranium concentrations during excavation activities, although concentrations decreased gradually from 31 to 29 g/L during FY 2006.

Results from research activities involving uranium isotopes in groundwater from wells 699-S6-E4A and 699-S6-E4L have previously indicated that there are two distinct sources for the uranium in groundwater at this location. A known source is the former $316-4$ cribs; a second potential source in this subregion is the 618-10 burial ground, where small volume containers of liquid waste containing uranium were placed in trenches (WHC-MR-0415). While no new information from these investigations has evolved during FY 2006, the research is continuing.

\subsubsection{Volatile Organic Compounds}

Contaminants of concern or potential concern in groundwater beneath the 300 Area include cis-1,2-dichloroethene, trichloroethene, and tetrachloroethene. The origins of these volatile organic compounds in groundwater include past disposal to 300 Area facilities, and movement into the 300 Area from off-site sources to the southwest. Beneath the 618-10 burial ground and former 316-4 cribs, organic compounds previously identified as of potential concern include tributyl phosphate and petroleum hydrocarbons.

300 Area Organic Compounds. During FY 2006, cis-1,2-dichloroethene, trichloroethene, and tetrachloroethene continued to be detected in 300 Area groundwater samples during routine monitoring. Only cis-1,2-dichloroethene was observed at concentrations exceeding the drinking water standard ( $70 \mu \mathrm{g} / \mathrm{L})$, and only at one well. This well (399-1-16B) is located
Aquifer tube results continue to show

that the sites with

the highest reported uranium values are adjacent to the central core area of the groundwater plume.

During FY 2006, volatile organic compounds were discovered at elevated levels in deep groundwater from characterization boreholes. 


\section{Groundwater \\ in the 300 Area \\ and 300-FF-5 \\ North region is contaminated with \\ nitrate from sources \\ outside of the \\ operable unit.}

downgradient from the former 300 Area process trenches (316-5) and has a screened opening near the base of the unconfined aquifer. The concentration trend at this well has remained remarkably constant for many years (Figure 2.12-14). During FY 2006, cis-1,2-dichloroethene ranged from 120 to $160 \mu \mathrm{g} / \mathrm{L}$ at this well.

Trichloroethene was detected during FY 2006 at numerous wells in the 300 Area and also at other wells southwest of the 300 Area, where there are additional potential sources for trichloroethene (Figure 2.12-15). All of these measurements showed concentrations

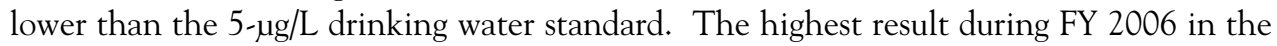
300 Area was 4.7 at well 399-4-12, which is the water supply well for the aquariums in the Life Sciences Building (331). Of the 30 wells in the 300 Area where trichloroethene was detected in FY 2006, all but three have open sampling intervals that include the uppermost portion of the unconfined aquifer (i.e., near the water table). The three exceptions, wells $399-1-8,399-1-16 B$, and 399-1-17B, have open intervals in the lower portion of the unconfined aquifer. These three wells are located downgradient of the former 300 Area process trenches, a likely disposal site for volatile organic compounds.

Tetrachloroethene was also detected at very low concentrations at six wells in the 300 Area during FY 2006. Most of these detections were in wells screened at the water table and located in the southern portion of the 300 Area; there is no definitive evidence pointing to a specific source. The range of concentrations measured was 0.2 to $0.44 \mu \mathrm{g} / \mathrm{L}$ (drinking water standard is $5 \mu \mathrm{g} / \mathrm{L})$. In the northern portion of the 300 Area, tetrachloroethene concentrations in the past at wells downgradient of the former 300 Area process trenches have been as high as $38 \mu \mathrm{g} / \mathrm{L}$ (July 1998 in well 399-1-17A); however, during FY 2006, results were reported as non-detects.

During the limited field investigation in the 300 Area (Section 2.12.3.2), volatile organic compounds were found in water samples collected in May 2006 during the drilling of four characterization boreholes (see Figure 2.12-2 for locations). Concentrations found in shallow samples collected during drilling were comparable to those monitored by the routine network. However, at depths below typical screened intervals, some unexpectedly high concentrations were encountered. At well 399-3-18, located at the southeast corner of the former South Process Pond (316-1), trichloroethene was measured at 63 and $51 \mu \mathrm{g} / \mathrm{L}$ at sample depths just below the bottom of the final screened interval chosen for the well. At well 399-3-20, located adjacent to the south side of the 307 process trench (316-3), trichloroethene was measured at $630 \mu \mathrm{g} / \mathrm{L}$ in a deep drilling sample (i.e., 8 meters below the bottom of the final screened interval for the well). All of these samples were re-analyzed to confirm the unexpectedly high concentrations. Also, the trichloroethene degradation product cis-1,2-dichloroethene was present in these samples, as was tetrachloroethene. In September 2006, samples were collected from aquifer tube sites along the shoreline adjacent to well 399-3-18, and one of the samples revealed trichloroethene at $96 \mu \mathrm{g} / \mathrm{L}$. All of the drilling samples, and possibly the aquifer tube samples, came from a relatively fine-grained unit within the upper portion of the Ringold Formation (Figure 2.12-16). One possibility being investigated as to the origin for these volatile organic compounds is that the samples reveal older contamination than that observed in the overlying, more transmissive sediment.

The travel times for volatile organic compounds to move from the characterization boreholes through the fine-grained sediment to the river would be long compared to travel times for contaminants in the overlying portion of the aquifer, because of the difference in permeability of these two hydrologic units. Once at the aquifer/river interface, discharge would therefore occur at a relatively low rate, and volatilization in the river flow would occur rapidly, thus reducing the concentrations in river water to negligible levels in a very short distance. Because of unknowns regarding (a) the horizontal and vertical extent of this newly discovered zone of contamination, and (b) the source or origin for the waste effluent, the U.S. Department of Energy (DOE) is moving ahead with further investigations that may involve drilling additional boreholes. 
Organic Compounds in the 300-FF-5 North Subregions. Tributyl phosphate has been detected in the past in groundwater beneath the former 316-4 cribs (see Figure 2.12-3 for location map). The cribs received liquid waste associated with research conducted at the 321 Separations Laboratory in the 300 Area during the period 1948 to 1954 (DOE/RL97-1047, p. 1.24). The waste contained tributyl phosphate and uranium. Tributyl phosphate concentrations were elevated somewhat in early 2004, along with uranium, during the period when crib removal actions were underway. Since then, concentrations have remained very low, and no tributyl phosphate was detected in FY 2006 samples from nearby wells 699-S6-E4K and 699-S6-E4L. The semivolatile compound tends to bind to soil in the vadose zone, where it slowly degrades with time. It is not very soluble in water and, therefore, not widely dispersed via water transport mechanisms. A drinking water standard for tributyl phosphate has not be established.

Petroleum hydrocarbons (both diesel and gasoline) were detected in groundwater during the refurbishment of well 699-S6-E4A in 1995. The source may have been past leaks or spills from a fuel tank associated with operation of the former 316-4 cribs. Monitoring conducted since 1995 has shown non-detections at wells in the general vicinity, and analyses for petroleum hydrocarbons were discontinued during FY 2006.

\subsubsection{Tritium}

Tritium-contaminated groundwater in the 300-FF-5 Operable Unit is associated with two primary sources. One is the site-wide tritium plume that originates in the 200 East Area (see Figure 1.0-2 in Section 1.0 and Section 2.11.1.1) and extends over all subregions of the 300-FF-5 Operable Unit. The second source is the 618-11 burial ground, which is located just to the west of the Energy Northwest complex. Concentrations attributed to the site-wide plume as it reaches the 300-FF-5 subregions are shown in Figure 2.12-17 and are generally $<20,000 \mathrm{pCi} / \mathrm{L}$, depending on location. In the region just to the north of the 300 Area, concentrations are decreasing with time, as the site-wide plume attenuates by radioactive decay and dispersion (see discussion of 200 East Area tritium plume in Section 2.11.1.1).

Tritium at 618-11 Burial Ground. High concentrations of tritium were detected in early 1999 at well 699-13-3A, which is located immediately to the east of the 618-11 burial ground. Subsequent investigations (PNNL-13675) identified a contaminant plume that extends downgradient as a narrow plume of concentrations much higher than the surrounding site-wide plume from 200 East Area (Figure 2.12-18). Concentrations near the presumed burial ground source have declined since peak values in 1999 and 2000, with concentrations at well 699-13-3A continuing to decline during FY 2006 (Figure 2.12-19). The trend near the burial ground at well 699-13-3A suggests the possibility that an episodic event of unknown nature caused a release of tritium from buried materials and/or mobilization of tritium in the vadose zone. The removal of tritium sources in the 618-11 burial ground is expected to be no later than 2018, per Tri-Party Agreement (Ecology et al. 1989) Milestone M-016-00B. Changes in concentrations at wells farther away from the burial ground reflect migration of the plume, i.e., they include constant or gradually increasing concentrations trends.

\subsubsection{Other Constituents}

In addition to the contaminants of concern or potential concern that are formally recognized in decision documents, other constituents of interest that are being monitoring at various locations in the 300-FF-5 Operable Unit because they either exceed the drinking water standard or are helpful in characterizing contamination in the aquifer. These include radiological constituents gross alpha, gross beta, plutonium, strontium-90, and tritium, and the chemical constituent nitrate.

300 Area. Radiological contamination in the 300 Area, other than uranium, is generally at low levels. Gross alpha, which is associated with uranium, exceeds the drinking water standard of $15 \mathrm{pCi} / \mathrm{L}$ at numerous 300 Area wells, as expected because of the uranium plume. Gross beta, a second radiological criteria for drinking water, does not exceed the 50-pCi/L

\section{The very high concentration of tritium adjacent to the 618-11 burial ground has continued to decline in recent years, although the plume continues to migrate downgradient toward the east.}




\section{Along the 300 Area shoreline, sampling and analysis at various sites and of various media are being conducted under several programs, with primarily semiannual sampling.}

standard in the 300 Area, although it is measurable at numerous wells. One potential source for this activity is the radiological decay chain associated with uranium; other possibilities are low levels of technetium- 99 and strontium-90 at isolated locations and background levels from natural sources (e.g., potassium-40). Common causes for elevated gross beta activity because of Hanford Site contaminants are strontium-90 and technetium-99, neither of which are found at significantly elevated levels in 300 Area groundwater.

Strontium-90 has been detected at relatively low levels and as an isolated occurrence at well 399-3-11 in previous years (PNNL-13788). Results from well 399-3-11 during FY 2006 were 3.3 and $2.7 \mathrm{pCi} / \mathrm{L}$ for samples collected during January and July 2006, respectively (the drinking water standard is $8 \mathrm{pCi} / \mathrm{L}$ ). The source for the strontium- 90 is not clearly evident, but one candidate is an historical long-term leak from transfer lines associated with the 307 Retention Basins. The leak was discovered in 1969 and resulted in an estimated loss of 10 curies of strontium-90 (WIDS Unplanned Release UPR-300-1).

During the excavation of the 618-2 burial ground in 2006, unexpected occurrences of plutonium and other radiological contamination in the soil were encountered. Some contamination was measured in a test pit excavated to the water table, leading to concerns about previously undetected impacts to groundwater. Increased monitoring was conducted at the nearest monitoring well (399-1-2) and plutonium was not detected in groundwater samples. Previous measurements at other wells in the vicinity have not revealed detectable plutonium.

Nitrate in groundwater beneath the 300 Area is generally present at concentrations less than the drinking water standard of $45 \mathrm{mg} / \mathrm{L}$, except for the southern portions of the 300 Area (Figure 2.12-20). Concentration trends for 300 Area wells during the period 1992 through 2004 are presented in PNNL-15127, Table 2.10. The origin for nitrate in 300 Area groundwater is past disposal of liquid effluent during the operating years, and possibly septic systems. Groundwater concentrations were somewhat higher during the 1970s and 1980s, although they never greatly exceeded the drinking water standard. In the region immediately south of the 300 Area (southern extent of the 300-FF-5 Operable Unit), nitrate concentrations are relatively higher and do exceed the drinking water standard, with concentrations as high as $100 \mathrm{mg} / \mathrm{L}$ (e.g., $104 \mathrm{mg} / \mathrm{L}$ at well 699-S28-E13A) during FY 2006. This nitrate originates at sources to the southwest of the 300 Area, and possibly includes agricultural and industrial activities (see Section 2.13). Concentrations are gradually increasing in wells and at shoreline sites in the southern part of the 300 Area, as nitrate-laden groundwater from the southwest migrates into the area.

618-11 and 618-10 Burial Ground Subregions (300-FF-5 North). The outlying waste sites in the north portion of the 300-FF-5 Operable Unit lie within the large contaminant plume that originates in the 200 East Area. This plume contains radiological contamination by tritium, technetium-99, and iodine-129 (see Section 2.11 for description of this plume). While detectable, concentrations for those radionuclides observed at the two northern subregions are below drinking water standards, with the exception of the tritium plume associated with the 618-11 burial ground release. Gross alpha measurements exceed the drinking water standard at two wells near the 618-10 burial ground, presumably as the result of uranium contamination, and gross beta exceeds the drinking water standard at one well near the 618-11 burial ground, with technetium-99 being the likely cause.

Background levels of nitrate upgradient of the 618-11 burial ground are in the range of 20 to $40 \mathrm{mg} / \mathrm{L}$, while in the vicinity of the $618-11$ burial ground concentrations are somewhat higher and exceed the $45-\mathrm{mg} / \mathrm{L}$ drinking water standard (Figure 2.12-19). For example, values during FY 2006 at well 699-13-3A were in the range 65 to $71 \mathrm{mg} / \mathrm{L}$ and at well $699-12-2 \mathrm{C}$ in the range 70 to $77 \mathrm{mg} / \mathrm{L}$. The cause for these higher values near the burial ground is not confirmed; they may reflect the influence of an active septic system operated by Energy Northwest, or possibly some hydrogeologic characteristic that has caused retention of more contaminated groundwater from earlier years. Trends for the last several years indicated 
relatively constant nitrate levels, but with some variability. At the 618-10 burial ground, nitrate concentrations are generally consistent with values expected for the leading edge of the site-wide plume and are below the drinking water standard.

\subsubsection{Operable Unit Interim Remedial Action}

A decision for interim action involving groundwater beneath waste sites in the 300 Area portion of the 300-FF-5 Operable Unit was made in 1996 (ROD 1996b). The geographic extent of groundwater under this record of decision was subsequently expanded in 2000 to include groundwater potentially impacted by waste sites in two outlying areas north of the 300 Area, i.e., beneath the 618-11 burial ground and 618-10 burial ground/316-4 cribs waste sites (EPA 2000). The interim remedy as stated in the record of decision is:

- Continued monitoring of groundwater that is contaminated above health-based levels to ensure that concentrations continue to decrease.

- Institutional controls to ensure that groundwater use is restricted to prevent unacceptable exposures to groundwater contamination.

In 2004, activities were renewed on the operable unit's remedial investigation and feasibility studies. A new Tri-Party Agreement milestone (M-016-68) was developed in early 2005 for a Phase III Feasibility

The remedial action objectives for groundwater in the 300-FF-5 Operable Unit (ROD 1996b) are:

- Protect human and ecological receptors from exposure to contaminants in the soil and debris.

- Protect receptors from exposure to contaminants in the groundwater and control the sources of contamination to minimize future impacts to groundwater.

- Protect the Columbia River such that contaminants in the groundwater or soil after remediation do not result in an impact to the river that would exceed the Washington State surface water quality standards.

The record of decision sets the objective concentrations as the drinking water standards for cis-1,2-dichloroethene, trichloroethene, and uranium. In 2000, EPA expanded the record of decision to include groundwater beneath the 300-FF-5 North region (EPA 2000).

Study report on remedial action alternatives and a

draft proposed plan. A work plan was prepared (DOE/RL-2005-41) that describes these additional efforts, which include updated computer simulations of groundwater flow and uranium transport; a limited field investigation involving multiple characterization boreholes; an update to the human health and ecological risk assessment; and an assessment of potential remedial action technologies for the 300 Area uranium plume. Work in all these areas continued during FY 2006 and is summarized in Section 2.12.3.

\subsubsection{Five-Year Reviews of Record of Decision}

Because contamination remains in the 300-FF-5 Operable Unit, the CERCLA process requires a review of the effectiveness of the record of decision every 5 years. The results of the first five-year review (EPA 2001) indicated that the remedial actions at 300 Area source waste sites were proceeding in an effective manner to protect human health and the environment. EPA re-affirmed that the cleanup goals and remedy selection for groundwater were still appropriate. However, the review also found that additional work was needed to better characterize the performance of natural processes in reducing the levels of contaminants of concern. This led to a revised operations and maintenance plan in 2002 (DOE/RL-95-74) that contained increased requirements for monitoring, especially along the 300 Area shoreline, and for analysis of natural processes that lead to attenuation of contamination. An outgrowth of the first review also led to an expanded groundwater report for FY 2004 that contained detailed information on historical trends and current conditions for contaminants of potential concern for the operable unit. Publication of an expanded groundwater report for FY 2004 (PNNL-15127) and a work plan for a Phase III Feasibility Study (DOE/RL-2005-41) was also a requirement of Tri-Party Agreement Milestone M-016-68, and this milestone was met on March 31, 2005.

Key elements of
the interim remedy
include continued
monitoring of
groundwater to
verify previously
modeled predictions
of contaminant
attenuation.




More frequent
measurements of
uranium and other
water quality
parameters are
being made at sites
along the 300 Area
shoreline to better
characterize the
variability in
contaminant
concentrations
brought on by the
Columbia River
stage influence.

The second five-year review of the 300-FF-5 record of decision was conducted during the period summer 2005 through spring 2006. That review was published in November 2006 (DOE/RL-2006-20). One issue and associated action item are listed for the 300-FF-5 Operable Unit:

- Issue 19: Predicted attenuation of uranium contaminant concentrations in the groundwater under the 300 Area has not occurred. DOE is currently performing additional characterization and treatability testing in the evaluation of more aggressive remedial alternatives.

- Action 19-1: Complete focused feasibility study for 300-FF-5 Operable Unit to provide better characterization of the uranium contamination, develop a conceptual model, validate ecological consequences, and evaluate treatment alternatives. Concurrently test injection of polyphosphate into the aquifer to immobilize the uranium and reduce the concentration of dissolved uranium. (Due date September 2008).

\subsubsection{Interim Remedial Action Monitoring}

Implementation of the interim remedy specified in the record of decision (ROD 1996b; EPA 2000) is described in the operable unit operations and maintenance plan, as revised in 2002 (DOE/RL-95-73) and a sampling and analysis plan (DOE/RL-2002-11), which was revised in June 2006. The Executive Summary for the operations and maintenance plan describes specific monitoring objectives for the period of interim action:

- Verify that natural attenuation reduces groundwater contamination concentrations to drinking water maximum contaminant levels over a reasonable time period.

- Confirm that contaminant concentrations in the river seeps do not exceed ambient water-quality criteria or established remediation goals (drinking water standards).

- Validate contaminant fate and transport conceptual models.

Progress toward meeting these interim action monitoring objectives has been described in detail previously in an expanded groundwater report for FY 2004 (PNNL-15127). Continued monitoring during FY 2005 and FY 2006 has produced information that is generally consistent with historical trends, expectations, and existing conceptual models as described in the report for FY 2004.

For the 300 Area subregion, 44 monitoring wells were in service during FY 2006 as part of the groundwater monitoring effort. In addition, samples were collected from eight aquifer tube sites and two riverbank springs along the shoreline. Groundwater monitoring included semiannual sampling at many of the monitoring wells during December 2005 and June 2006, with the intent of characterizing average seasonal conditions (December) and the spring period of high water-table elevations (June) that are caused by the spring runoff to the Columbia River. The semiannual sampling applies to wells that monitor the upper part of the unconfined aquifer, including the water table. Other wells that monitor deeper horizons are sampled annually. Some new wells were sampled quarterly to establish baseline conditions at their locations. Exceptions to the planned scheduled for FY 2006 are listed in Appendix A.

At the 618-11 burial ground subregion, six wells are sampled quarterly. All of these wells monitor the upper part of the unconfined aquifer. At the 618-10 burial ground/316-4 cribs subregion, six wells are sampled quarterly, semiannually, or annually, depending on proximity to the waste sites. All of the wells used at these two subregions monitor the upper part of the unconfined aquifer. 


\subsubsection{Phase III Feasibility Study}

The work plan for the Phase III Feasibility Study for the 300-FF-5 Operable Unit (DOE/RL-2005-41) is focused on uranium contamination in the 300 Area subregion of the operable unit. This contaminant of concern has persisted at elevated levels far longer than predicted by the initial remedial investigation (DOE/RL-94-85). Therefore, additional evaluation of potential remedial action technologies, i.e., evaluation beyond the information presented in the initial feasibility study report (DOE/RL-93-22), is underway. The objective for the Phase III Feasibility Study is to re-evaluate the remedy for the uranium plume. The ultimate goal for remedial action is to "...select remedial actions that have the potential to (1) restore, to the extent possible, the 300-FF-5 aquifer to its highest and best beneficial use, and (2) reduce risk to human health and the environment" (DOE/RL-2005-41, p. 7).

The Phase III Feasibility Study includes several major components: Evaluation of potential engineered solutions to reduce the level of uranium contamination in 300 Area groundwater; a limited field investigation in the 300 Area to better define the distribution and geochemical characteristics of uranium; computer simulation of groundwater flow and transport in the 300 Area; and an updated assessment of ecological and human health risks posed by contaminants in the 300-FF-5 Operable Unit groundwater.

\subsubsection{Evaluation of Remedial Action Alternatives for 300 Area Uranium}

During FY 2006, an inventory of potential remedial action technologies to reduce the level of uranium contamination in groundwater was assembled. The primary subset of technologies that offers promise are those that use in situ methods to reduce the mobility of uranium in the environment and/or cause permanent sequestration of uranium. Preliminary screening of these technologies was completed for two of three criterion-applicability and effectiveness. Screening for the third criteria, relative cost, will continue during 2007 as relevant information is developed from the limited field investigation and modeling efforts.

\subsubsection{Limited Field Investigation Drilling Project, 300 Area}

A limited field investigation was initiated during FY 2006 in the 300 Area to obtain detailed information on (a) the distribution of uranium in the vadose zone and aquifer and (b) the mobility characteristics of uranium encountered. The primary purpose for the limited field investigation, which continues during FY 2007, is to provide information for the selection of potential remedial action technologies to reduce uranium contamination in the aquifer (DOE/RL-2005-47).

During FY 2006, four characterization boreholes were drilled in the 300 Area (Figure 2.12-2). The locations chosen for these boreholes are representative of various combinations of proximity to waste sites and the Columbia River. Continuous core was obtained whenever possible throughout the vadose zone and aquifer at each of these boreholes, two of which extended down through the entire unconfined aquifer (399-1-23 and 399-3-18). Water samples were collected at depth-specific intervals in the saturated zone; hydraulic tests were conducted at multiple depth intervals; and geophysical logging, including spectral gamma and neutron moisture logging, was conducted in each borehole to aid in defining stratigraphic contacts. Spectral gamma logging was also run in an attempt to identify contaminant uranium. However, the level of uranium contamination encountered was less than the detection limit for gamma logging. The four boreholes were completed as monitoring wells, with screened intervals placed across the water table. The completed wells were added to the 300-FF-5 monitoring network and first sampled during the summer of 2006.

Initial laboratory analyses of sediment samples included moisture content and total uranium from select core intervals, and solution chemistry for all groundwater samples. Subsequent laboratory analyses, which continue during FY 2007, include particle-size
Key aspects of

the Phase III

feasibility study

that continued

during FY 2006

included a limited

field investigation,

three-dimensional

computer modeling

of groundwater

flow and uranium

transport,

laboratory studies

associated with

potential remedial

action technologies,

and an updated risk

assessment. 


\section{A limited field investigation involving four boreholes has resulted in a better description of the hydrogeologic framework for the 300 Area uranium plume.}

distribution and solution chemistry of water extracts from sediment core samples. The results from this lab work will support the geochemical investigation of uranium sequestration in vadose zone sediment. Hydraulic test results were evaluated to determine aquifer flow parameters. Geophysical logs were correlated, calibrated, and evaluated to ground truth the spectral gamma logging results with laboratory-derived uranium results.

The drilling and analytical results, along with interpretations to date, have been assembled in a report that became available in draft form in January 2006. Preliminary highlights of some of those findings include:

Updated Hydrogeologic Framework for the 300 Area. The detailed descriptions of the vadose zone and aquifer stratigraphy at each characterization borehole have provided new insight on the hydrogeology beneath the 300 Area. These locations have become the new "type" locations for detailed stratigraphic information. The results from the characterization boreholes were also used to guide a review of historical geologic and geophysical logs from existing wells, which resulted in a significant revision of the database used to represent the hydrogeologic framework for the 300 Area. This revised framework is now the basis for input parameters used in computer simulation models for groundwater flow (Section 2.12.3.3 below).

The uppermost hydrologic unit beneath the 300 Area is composed of highly permeable sediment (gravel and sandy gravel) assigned to the informally defined Hanford formation. This uppermost interval in the unconfined aquifer provides a direct, transmissive pathway to the Columbia River, with variations in interval thickness causing distinct preferential flow channels. The hydrologic unit overlies more indurated, finer-grained, and substantially less permeable Ringold Formation sediment. Initial interpretations of limited field investigation data corroborate earlier suggestions that uranium contamination is primarily restricted to the Hanford formation.

More Accurate Information on the Vertical Distribution of Uranium. Prior to the limited field investigation drilling activity, it was assumed that easily measurable quantities of contaminant uranium would be encountered in the vadose zone at locations near former liquid waste disposal sites. This assumption was based on a knowledge of historical operations and sampling done as part of source remedial actions. It was also suspected that relatively elevated uranium concentrations are present in the lower vadose zone near the water table throughout the area of the plume. These expectations were part of the conceptual site model for uranium, as described in the expanded groundwater report for FY 2004 (PNNL-15127, pp. 3.2 to 3.4 ).

The initial results at each of the four characterization "type" locations do not reveal evidence for relatively high levels of contaminant uranium in the vadose zone, nor for an elevated zone of contaminants near the water table. Where contamination may be present, the level is lower than can be detected by the spectral gamma logging methods used during the limited field investigation. Although evaluation of spectral gamma logging capability for detecting anthropogenic uranium continues, its detection limit is currently estimated at $\sim 5 \mathrm{pCi} / \mathrm{g}$. Analysis of sediment samples in the laboratory continues during FY 2007; however, initial laboratory results for sediment samples, using water extracts, indicate concentrations of $<5 \mathrm{pCi} / \mathrm{g}$ for samples from the characterization boreholes. There is evidence from continuing laboratory work, which involves the extraction of uranium from sediment samples, for a mobile fraction that may be significant in helping to maintain the currently mapped plume in groundwater. This laboratory work is continuing during FY 2007 and the results will be described in the final report for the limited field investigation (expected spring 2007).

Water samples were also collected from the saturated zone at various depths in the four boreholes. Uranium concentrations in these samples confirm that contamination is generally confined to the uppermost hydrologic unit, and concentrations are consistent with those observed during routine groundwater monitoring. A relatively fine-grained sandy unit in the Ringold Formation apparently acts as a barrier to downward migration of uranium contamination. 


\subsubsection{Simulation of Groundwater Flow and Transport}

Development of a groundwater flow model for the greater 300 Area continued during FY 2006. Significant improvements to the hydrogeologic framework used by the model were made as a result of information derived from the four limited field investigation characterization boreholes. The new information is a product of detailed descriptions of cores, analysis of sediment samples, and geophysical logging. New insight on stratigraphy also facilitated reinterpreting historical geological and geophysical logs for existing wells.

EarthVision ${ }^{\mathrm{TM}}$ software is used to store and manage the three-dimensional subsurface spatial data for the 300 Area, and this database was updated. Special emphasis was placed on describing the contact between Hanford gravels and the underlying Ringold Formation, as flow in the aquifer above this contact plays a dominant role in movement of the uranium plume. A new structure contour map for the contact was prepared and used to condition graphical simulations of the subsurface. EarthVision ${ }^{\mathrm{TM}}$ was used to prepare new cross sections, block diagrams, and structure contour maps.

All groundwater flow and transport models currently associated with the 300 Area rely on the same subsurface spatial data maintained in EarthVision ${ }^{\mathrm{TM}}$ for their hydrostratigraphic framework. These models use the computer code Subsurface Transport Over Multiple Phases (STOMP) for simulating flow and transport in the vadose zone and aquifer (PNNL-15782). Computer simulation of groundwater flow in the 300 Area is complicated by heterogeneous aquifer properties, and by frequent and rapid changes in the water-table configuration that are caused by fluctuations in Columbia River flows. Therefore, frequent measurement of water levels (e.g., hourly) are required to provide data for simulating water levels and groundwater flow.

The model relies on a comprehensive database of hourly water-level measurements that were obtained during the early 1990s as part of the initial remedial investigation for the operable unit (PNL-9437). This model is being used to estimate the hydraulic properties of the aquifer, as well as to provide estimates for groundwater flux to the Columbia River. Groundwater flow and transport simulations are also being constructed for a smaller subregion of the 300 Area as part of a treatability test for uranium that involves injection of polyphosphate (PNNL-16008). The domain of this submodel extends from the southern end of the former 300 Area process trenches (316-5 waste site) to the northern part of the former South Process Ponds (316-1 waste site), and includes the area that extends to the river. This submodel uses data collected from a high-frequency water-level monitoring network established in 2004 by the Remedial Action and Closure Science Project (see Section 2.12.3.4).

\subsubsection{Research Activities Involving the 300 Area Uranium Plume}

The Remediation and Closure Science Project is supporting the 300-FF-5 Phase III Feasibility Study and associated treatability tests with a comprehensive program of laboratory, field, and simulation research tasks. The overall objective is to develop improved conceptual and numerical models of flow and reactive transport that govern uranium transport within the vadose zone-aquifer-river hydrologic system in the 300 Area. In particular, the research provides a scientific foundation for field-scale descriptions of multi-component uranium surface complexation sensitive to differences between river water and aquifer water chemistry $(\mathrm{pH}$, alkalinity, major ion chemistry, aqueous complexation controlling uranium mobility, and kinetic mineral reactions), kinetically controlled uranium mass transfer between mobile and less mobile phases, and spatially and temporally variable transport processes. These descriptions target long-term predictions of uranium migration and fate, which are required for scientifically defensible evaluations of remedial action strategies, including monitored natural attenuation.

\author{
Computer \\ simulation of \\ groundwater \\ flow beneath \\ the 300 Area is \\ providing better \\ estimates for \\ contaminant \\ distribution \\ patterns and flux to \\ the Columbia River.
}




\section{An update to the human health and ecological risk assessment for the 300-FF-5 Operable Unit was completed in FY 2006.}

Laboratory investigations include mineralogical analyses of sediment recently sampled in the limited field investigation, characterization of uranium geochemistry in sediment above and below the water table as well as from the Ringold and Hanford lithologic units, and the refinement of a surface complexation adsorption-desorption model that accounts for the effects of pore water $\mathrm{pH}$, bicarbonate concentration, and sediment texture. Field geophysical investigations are using electrical resistivity and self-potential measurements to estimate spatially distributed hydrologic and geochemical properties of the sediment. In time-lapse mode, the geophysics will be used, in part, to identify the contributions of recharge and mixing of river and groundwater.

Conceptual models for the geochemistry of uranium in the subsurface environment have evolved as the result of laboratory studies and field investigations. The new laboratory results and field observations are being incorporated in computer simulations of uranium transport in the vadose zone and aquifer. These simulations include provisions for the dynamic hydrologic environment created by Columbia River stage fluctuations. In addition, biological fate and transport studies are focused on a risk-based criterion for aquatic organisms based on uranium exposure and uptake experiments. The results for all of these efforts will be summarized in the conceptual site model report for the 300 Area uranium plume, which is planned for publication in September 2007.

\subsubsection{Update to Human Health and Ecological Risk Assessment}

A human health and ecological risk assessment for the 300-FF-5 Operable Unit was performed in FY 2006, as part of updating the information needed to support the Phase III Feasibility Study. The three operable unit subregions, i.e., 300 Area, 618-11 subregion, and 618-10/316-4 subregion were considered in the assessment, as was the city of Richland. Impacts were assessed for five current human use scenarios, plus hypothetical direct access to drinking water from the aquifer and Columbia River. The scenarios are residential farmer, child recreation, casual recreation, avid recreation, and industrial. Food product concentrations for human scenarios with food consumption (i.e., residential farmer, and casual and avid recreation) were calculated in the ecological risk assessment. The results for the assessment will be published during FY 2007.

The updated ecological assessment models 81 aquatic and riparian species. The 300 Area is assumed to lie within the riparian zone. The upland zone in this assessment is the 618-11 burial ground and the 618-10 burial ground/316-4 cribs waste sites. In these upland subregions, the groundwater is at sufficient depth to prevent access by ecological organisms under current conditions. Therefore, no ecological assessment was done for these outlying subregions. However, an additional 53 upland species could be included in a future assessment if site conditions and/or exposure scenarios change significantly. The city of Richland location is assessed as a riparian location.

\subsubsection{Uranium Treatablility Test, 300 Area}

A treatability test to immobilize uranium in the aquifer beneath the 300 Area began during FY 2006 (PNNL-16008). The test involves first determining the groundwater flow characteristics in the vicinity of the test site, followed by injection of polyphosphate into the aquifer. The site chosen to conduct the test is near the south end of the former 300 Area process trenches, where the last waste effluents containing uranium were disposed, and is near well 399-1-23 (Figure 2.12-2). During FY 2006, bench-scale tests were conducted, drilling associated with characterizing the site was completed, and a tracer was injected into the aquifer. Once the characterization of groundwater movement in the area is completed, final design for polyphosphate injection, and the actual injection activities, will be conducted during FY 2007. A final report on performance of the method is currently scheduled for May 2008. 


\subsubsection{Facility Monitoring: RCRA Compliance at 300 Area Process Trenches}

The former 300 Area process trenches (316-5 waste site) received effluent discharges of mixed waste from fuel fabrication and nuclear research laboratories in the 300 Area from 1975 through 1994. The trenches were remediated in 1991 under a CERCLA expedited response action by scraping contaminated soil to the north end of the facility (DOE/RL92-32). Additional remedial actions were undertaken in 1997 and 1998 by excavating more contaminated soil and ancillary structures (BHI-01164), and final backfilling with clean soil was completed in early 2004.

In addition to the groundwater monitoring conducted as part of 300-FF-5 Operable Unit activities under CERCLA, this former liquid waste disposal facility has been monitored under the requirements of RCRA for hazardous waste constituents, and under the Atomic Energy Act for uranium. Hazardous constituents and uranium are discussed jointly with respect to RCRA so that a comprehensive description of potential impacts to groundwater associated with this disposal unit is presented. With respect to treatment, storage, or disposal units regulated under RCRA, the DOE has the responsibility and authority to regulate radiological source, special nuclear, and by-product materials at DOE-owned nuclear facilities (see discussion in Section 1.2). Groundwater monitoring required by RCRA is conducted in accordance with WAC 173-303-645(11), "Corrective Action Program," and the Hanford Facility RCRA Permit, Part VI, Chapter 1 (Ecology 1994a). The modified closure plan (DOE/RL-93-73), which is incorporated into the Hanford Facility RCRA Permit, states that groundwater remediation is deferred to the CERCLA 300-FF-5 Operable Unit.

During FY 2006, RCRA groundwater monitoring for this disposal unit was conducted under a plan that has been in effect since 1997 (WHC-SD-EN-AP-185, as amended). Constituents monitored are uranium (total), cis-1,2-dichloroethene, trichloroethene, and tetrachloroethene. (Note: Uranium was included in the monitoring plan for completeness and incorporated by reference into the Hanford Facility RCRA Permit [Ecology 1994b].) The sampling schedule for the RCRA network of eight wells was designed to accommodate two semiannual sampling events, with four time-independent samples collected during each period. This has resulted in a sampling frequency of monthly for 8 months of the year (December, January, February, March, June, July, August, and September). During FY 2006, this sampling was essentially accomplished as planned (see Appendix B), and reports on the effectiveness of the corrective action monitoring program were prepared semiannually per WAC 173-303-645(11)(g).

Only two of the four constituents of interest for RCRA monitoring at the former disposal facility continued to exceed their respective drinking water standards during FY 2006, i.e., cis-1,2-dichloroethene and uranium. Cis-1,2-dichloroethene remained at concentrations approximately twice the 70- $\mathrm{gg} / \mathrm{L}$ drinking water standard at downgradient well 399-1-16B, which monitors conditions in the lower portion of the unconfined aquifer (see Figure 2.12-14). Other volatile organic compounds, such as trichloroethene and tetrachloroethene, continue to be detected in wells near the disposal unit, but at levels below their respective drinking

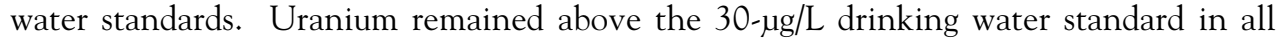
three of the downgradient wells screened in the upper portion of the unconfined aquifer (Figure 2.12-7).
Cis-1,2dichloroethene, a volatile organic compound, and uranium remain above drinking water standards downgradient of the former 300 Area process trenches, which are regulated under RCRA. 


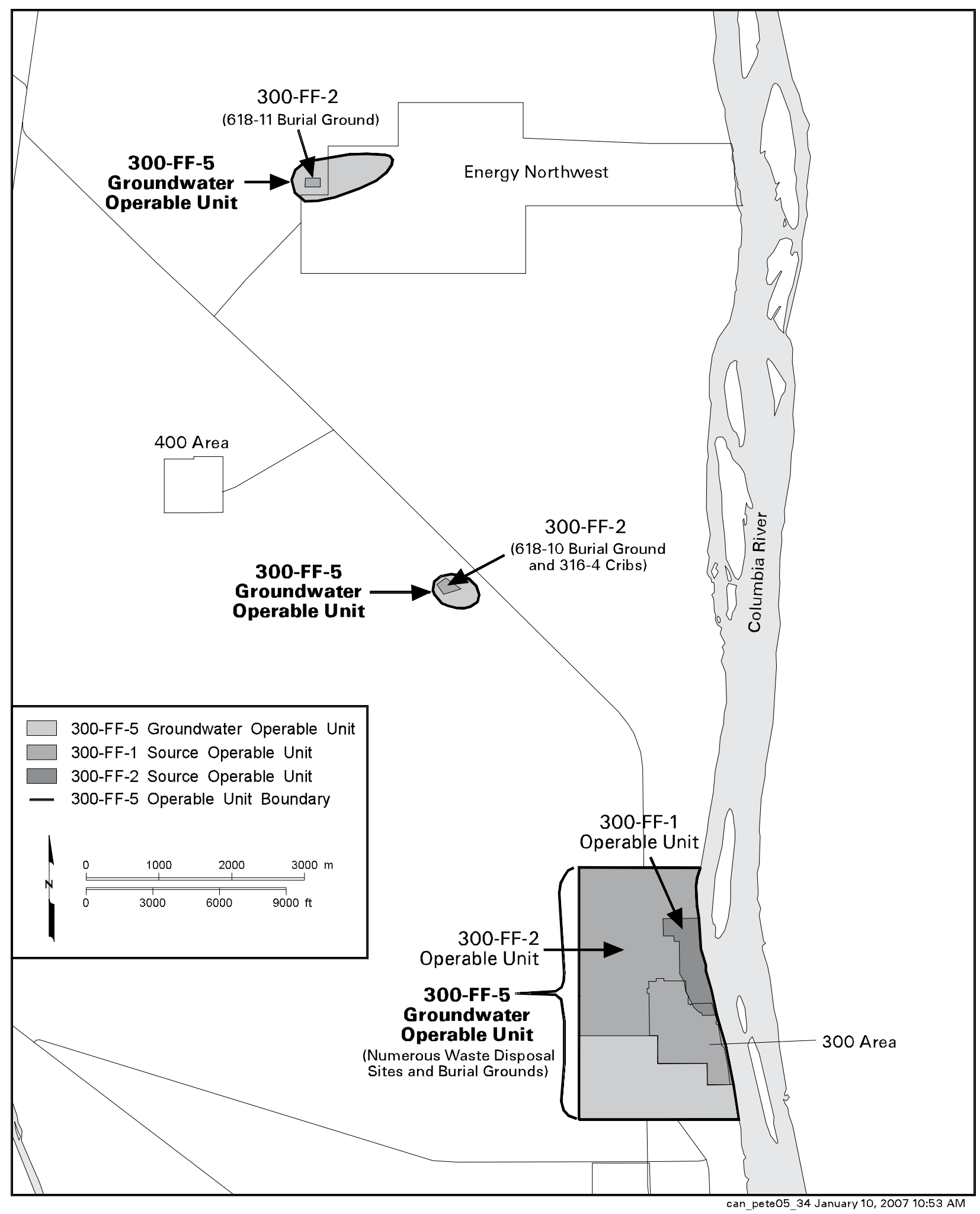

Figure 2.12-1. Operable Units Defined for the 300 National Priorities List Site 


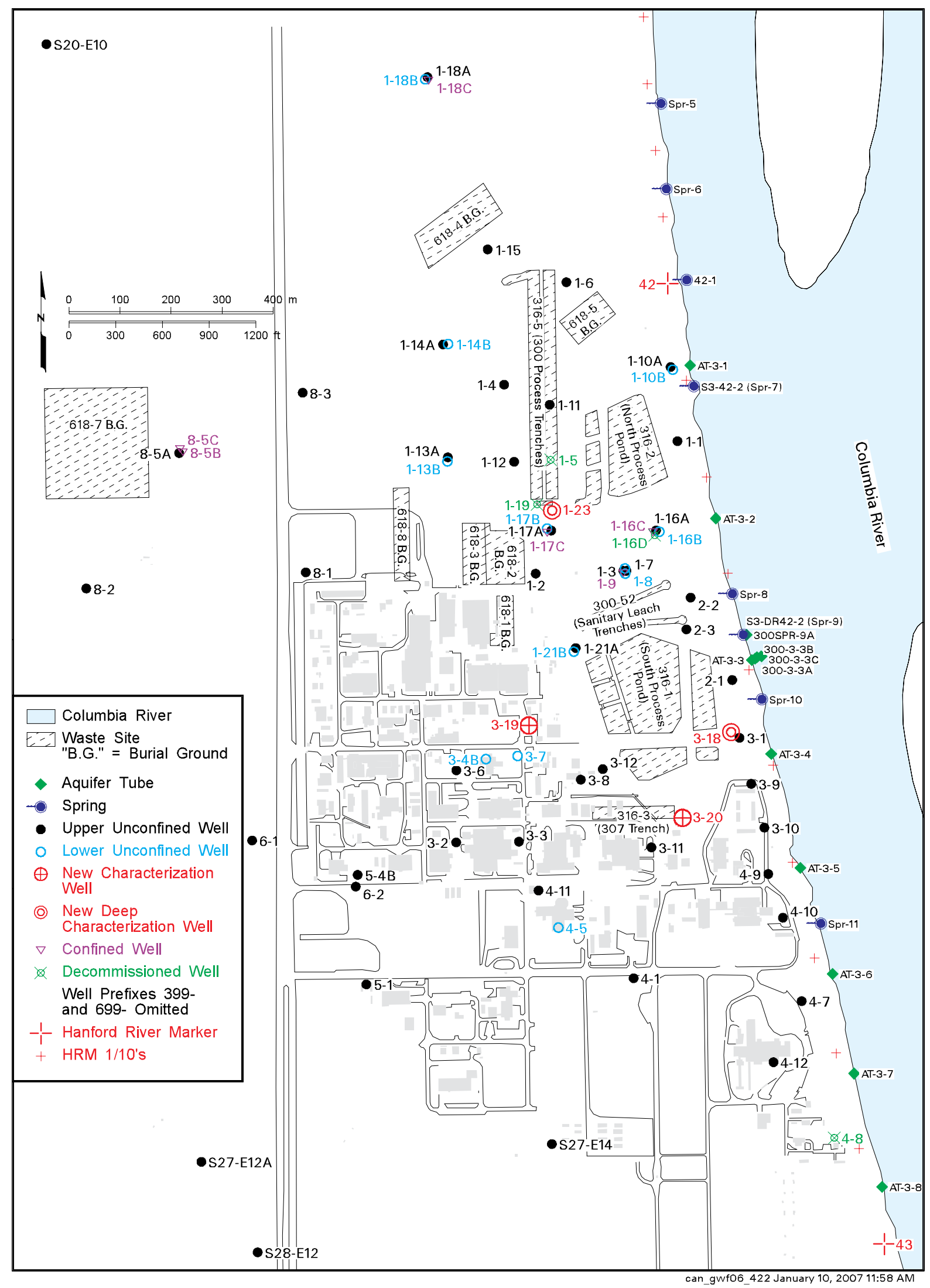

Figure 2.12-2. Groundwater Monitoring Wells in 300 Area 

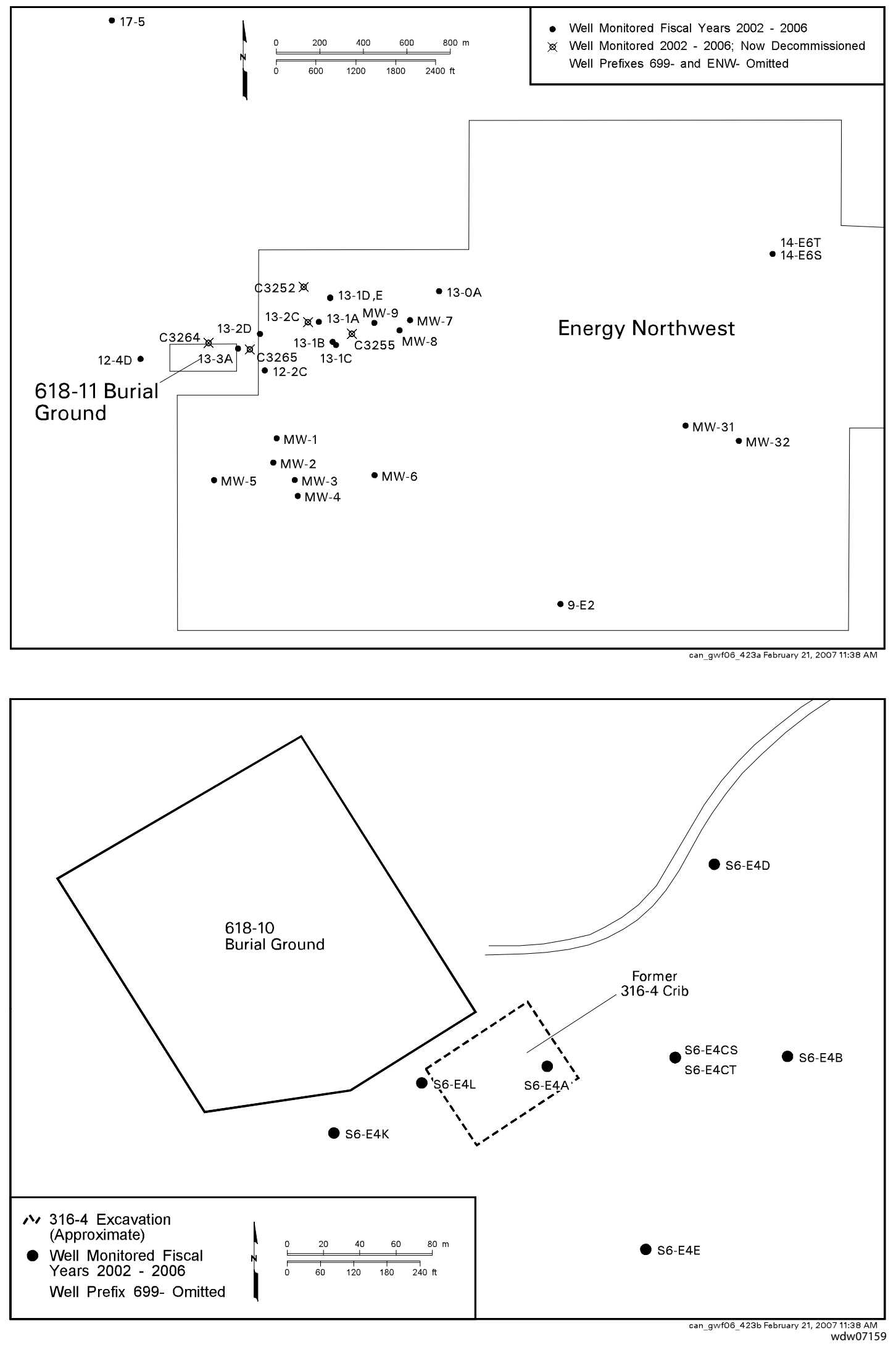

Figure 2.12-3. Groundwater Monitoring Wells in 300-FF-5 North Subregion 


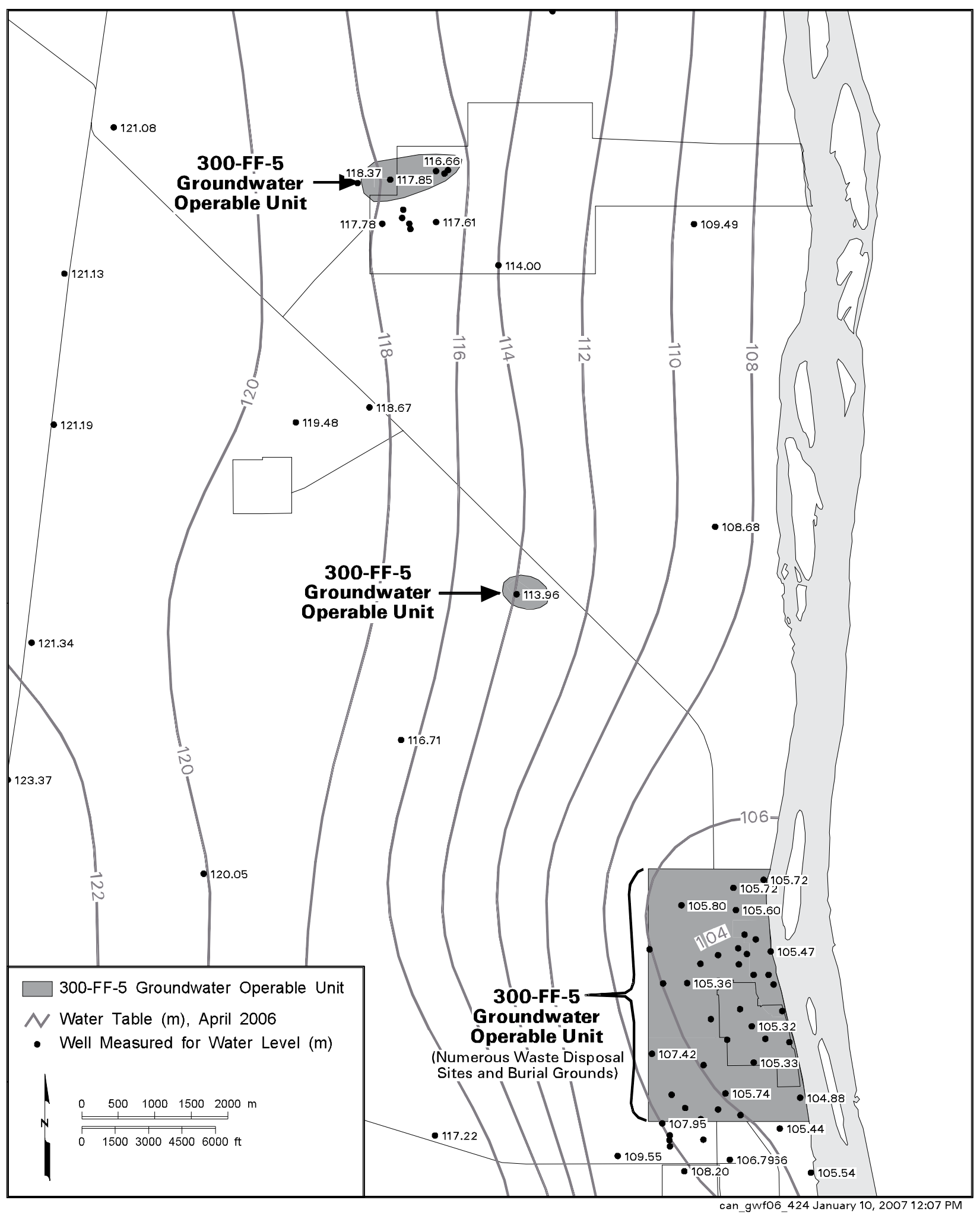

Figure 2.12-4. Water-Table Map for 300-FF-5 Operable Unit, April 2006 


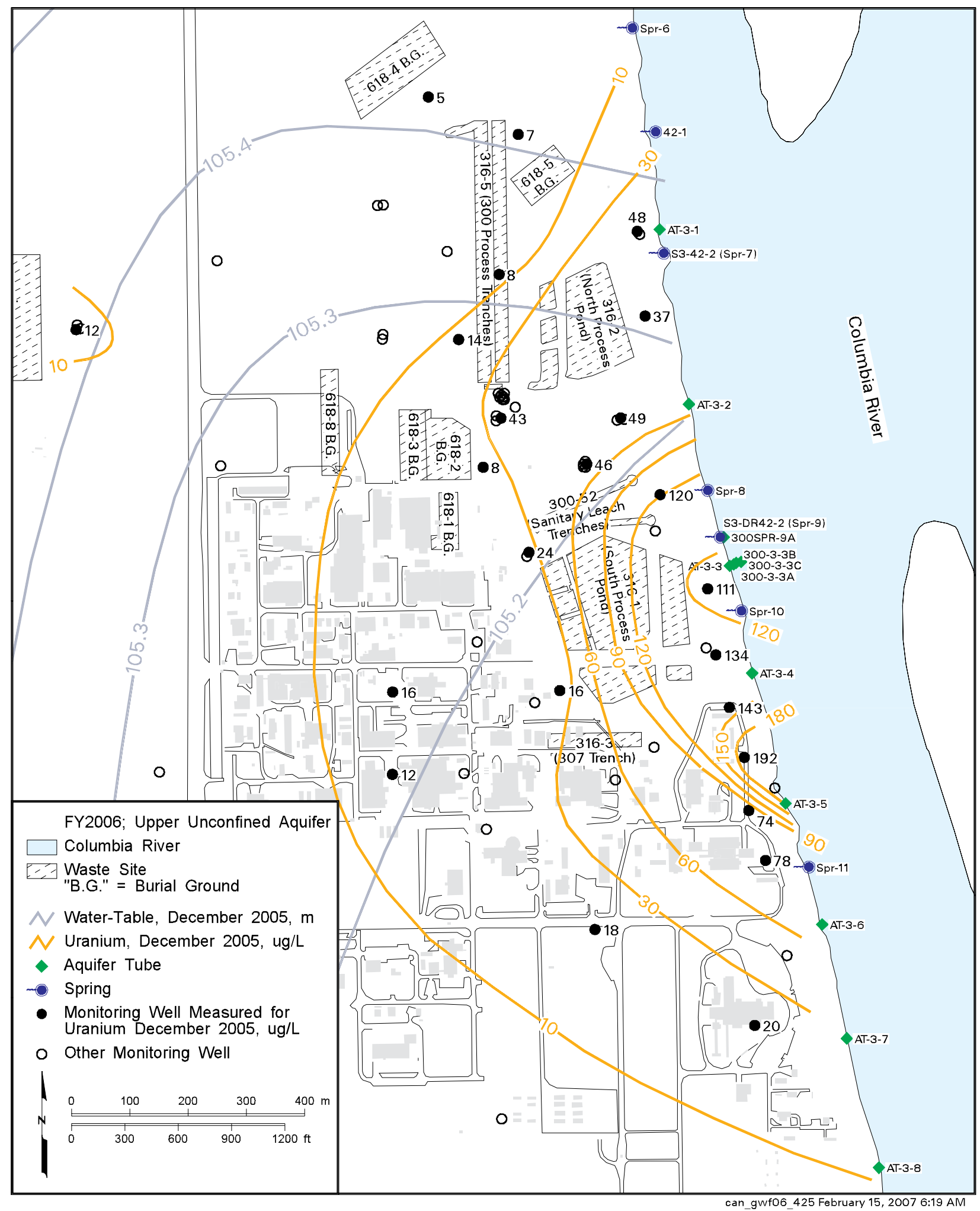

Figure 2.12-5. Uranium Concentrations in Upper Part of Unconfined Aquifer Beneath 300 Area, December 2005 


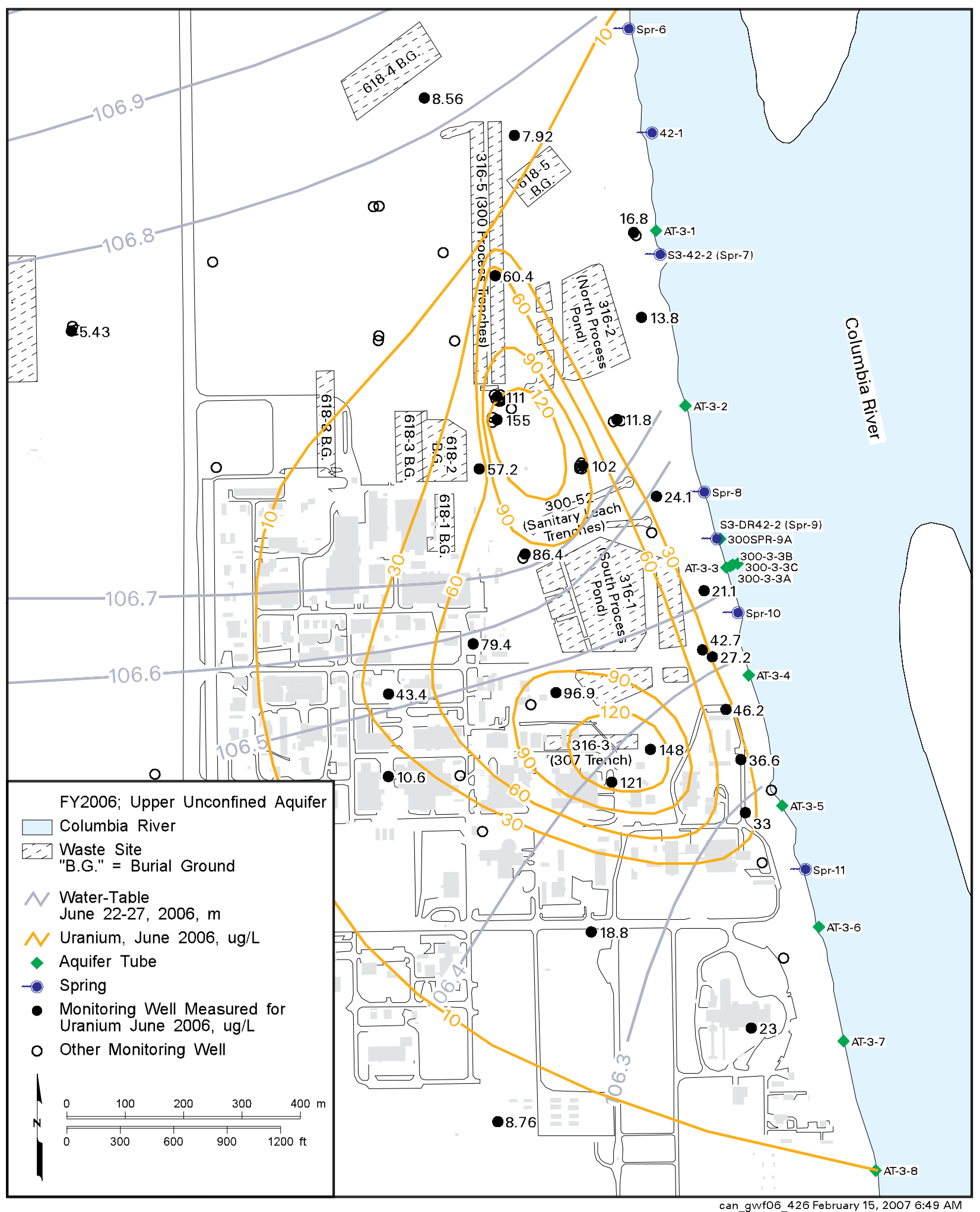

Figure 2.12-6. Uranium Concentrations in Upper Part of Unconfined Aquifer Beneath 300 Area, June 2006 


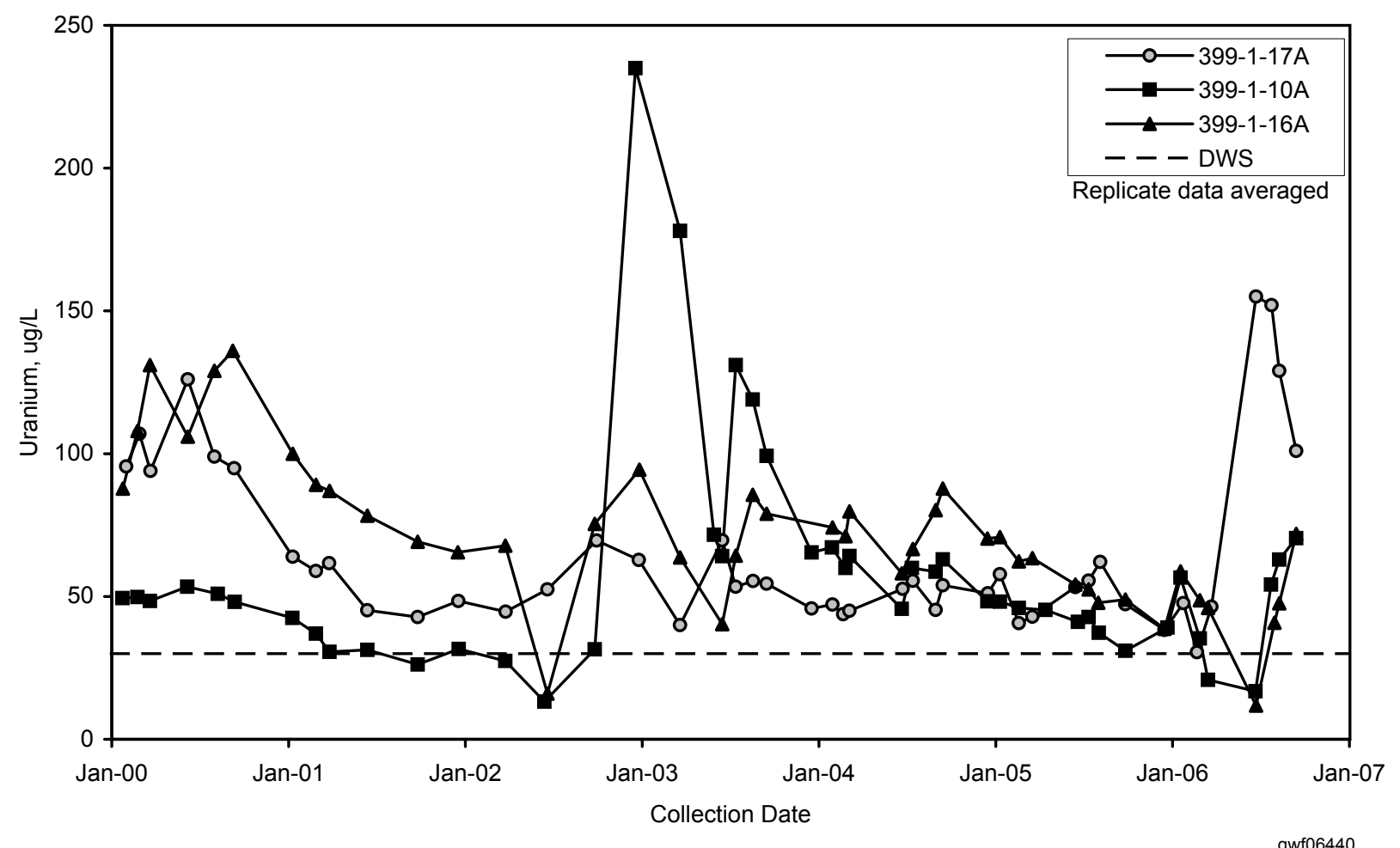

Figure 2.12-7. Uranium Trends in RCRA Monitoring Wells Downgradient from Former 300 Area Process Trenches

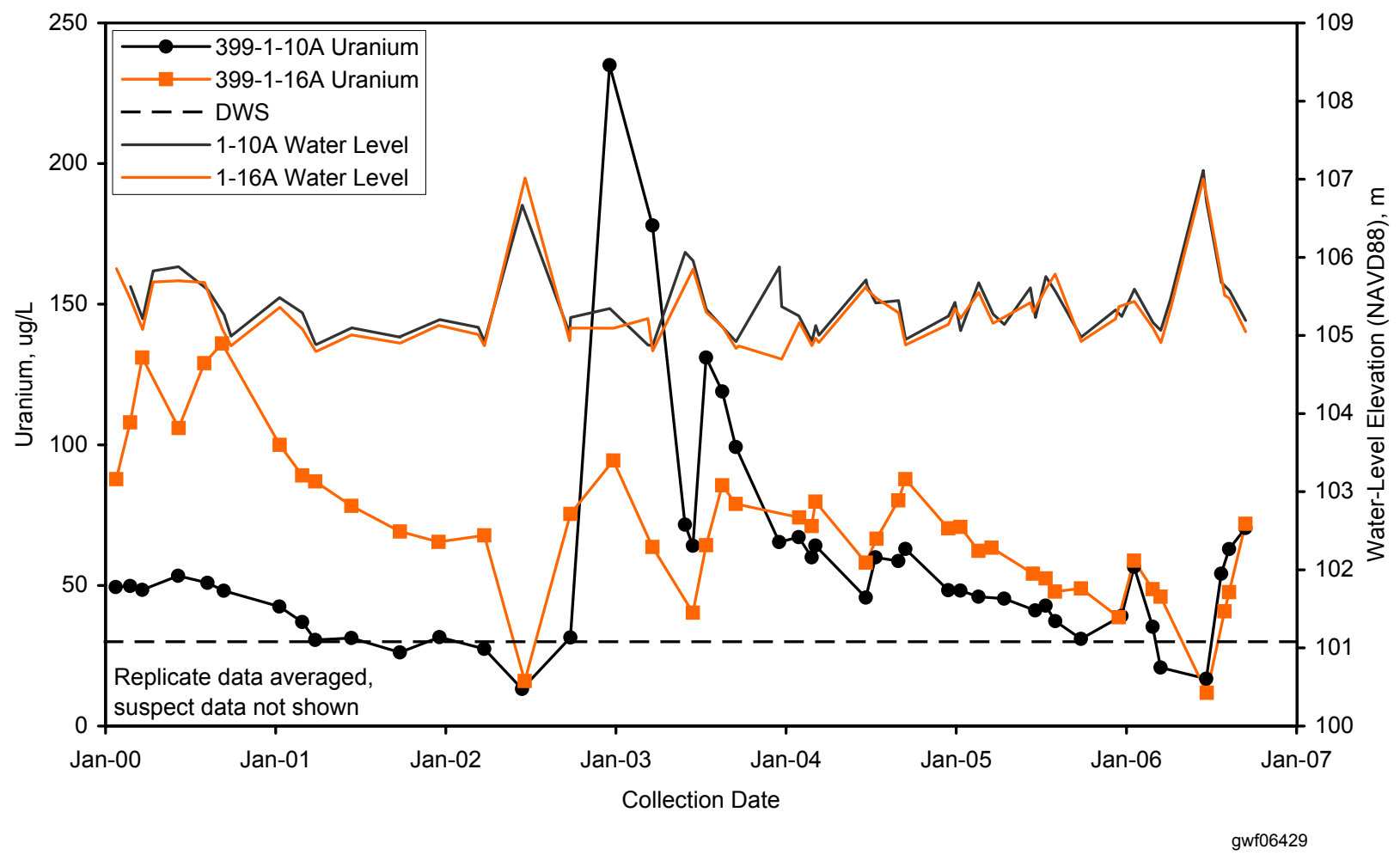

Figure 2.12-8. Correlation Between Uranium Concentrations and Water-Table Elevation at Well Close to Columbia River 


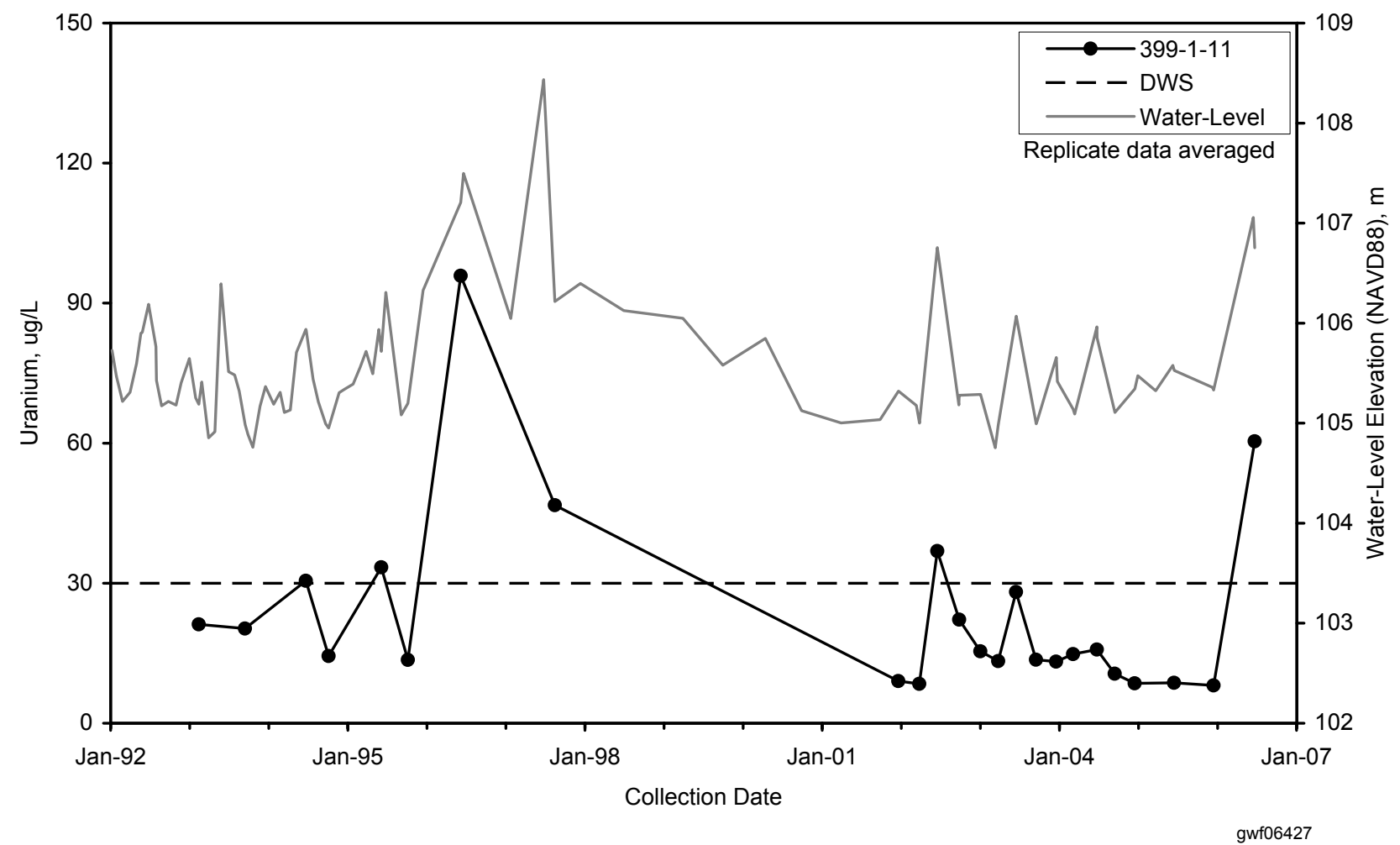

Figure 2.12-9. Correlation Between Uranium Concentrations and Water-Table Elevation at Well Near Waste Site 


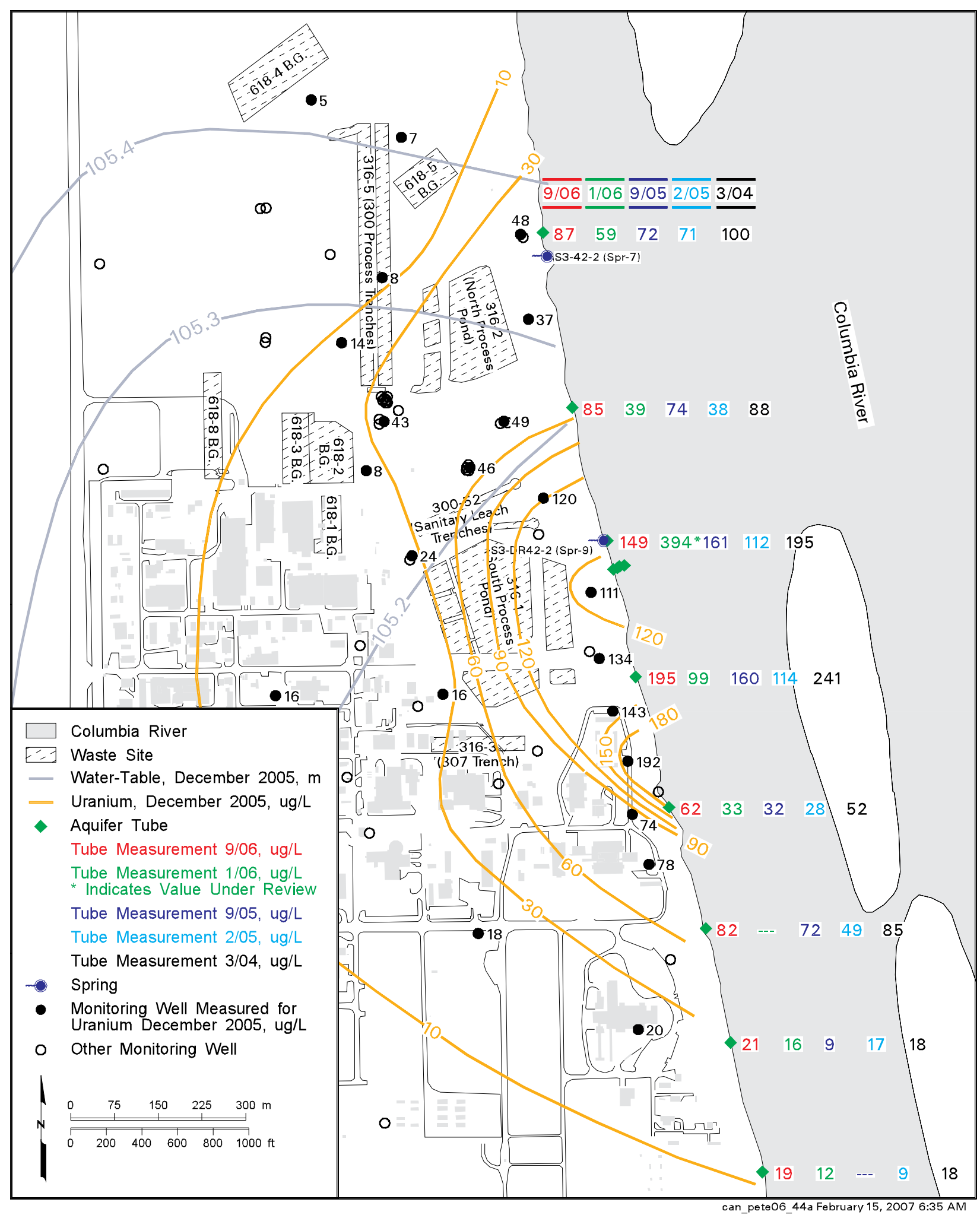

Figure 2.12-10. Uranium Concentrations at Aquifer Tube Sites Along 300 Area Shoreline 


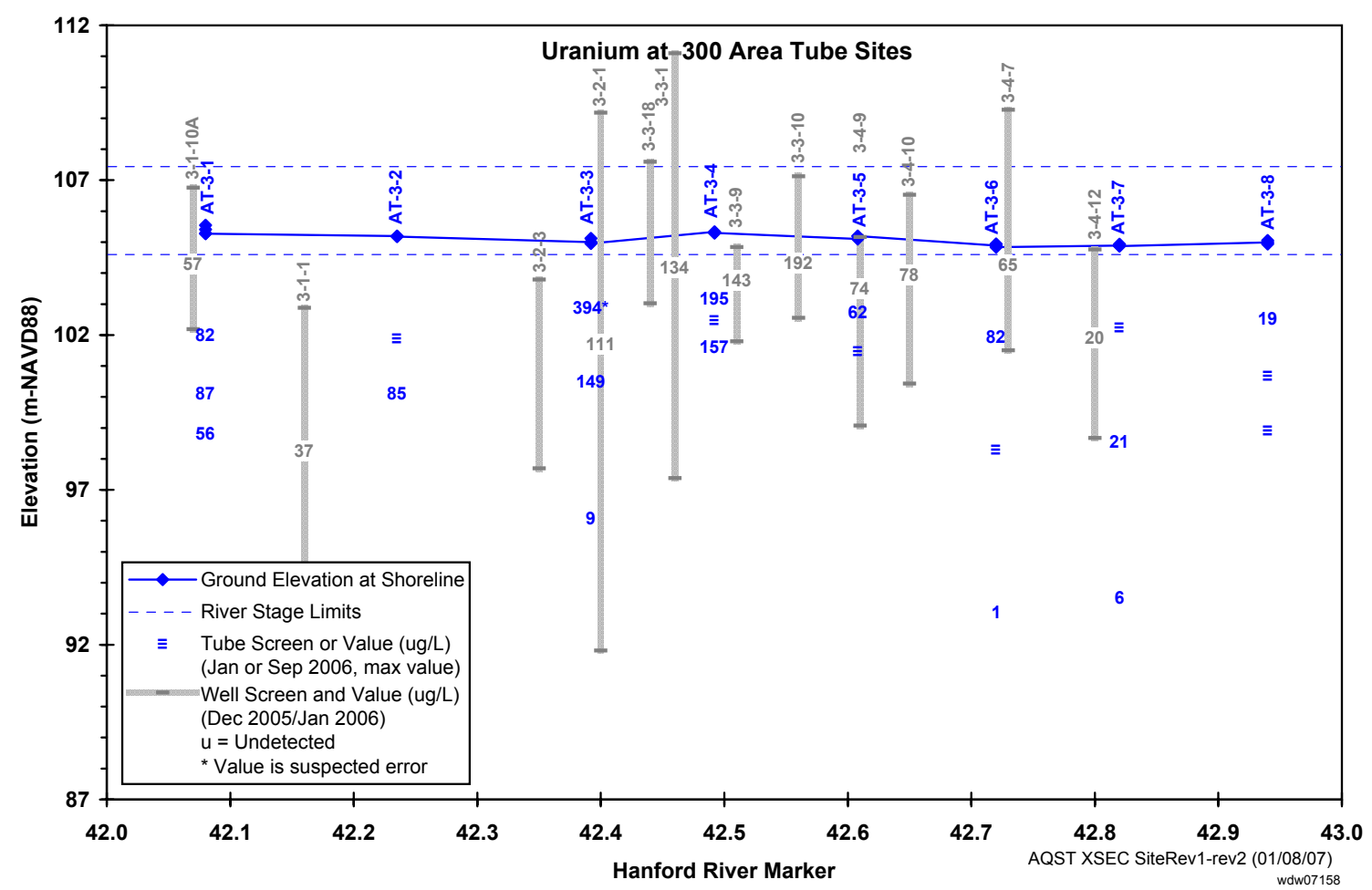

Figure 2.12-11. Cross Section Showing Uranium Concentrations at Multiple Depths in Aquifer Tubes Along 300 Area Shoreline

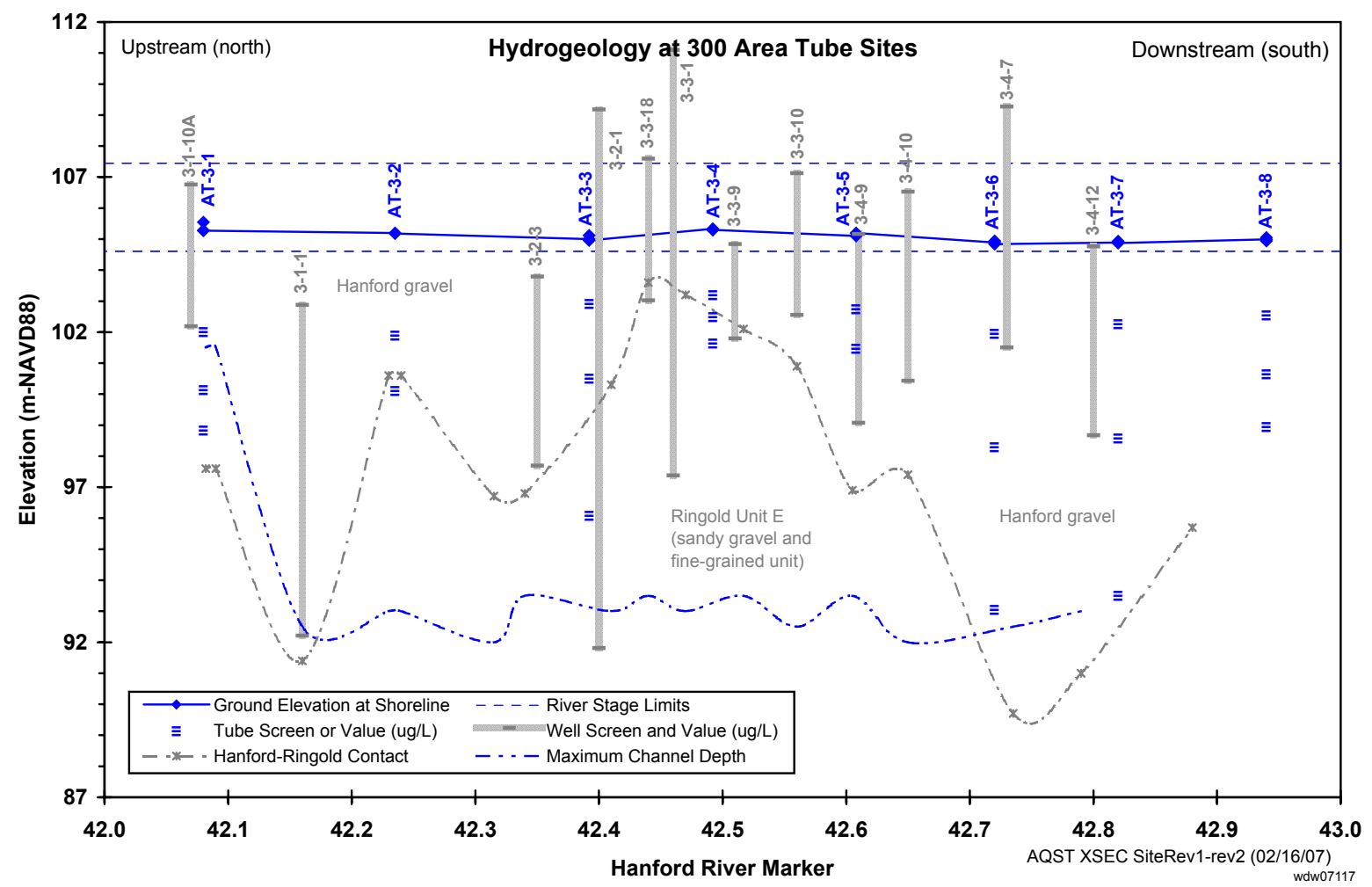

Figure 2.12-12. Cross Section Showing Relationship Between Aquifer Tube, Near-River Wells, and Hydrostratigraphy at 300 Area Shoreline 


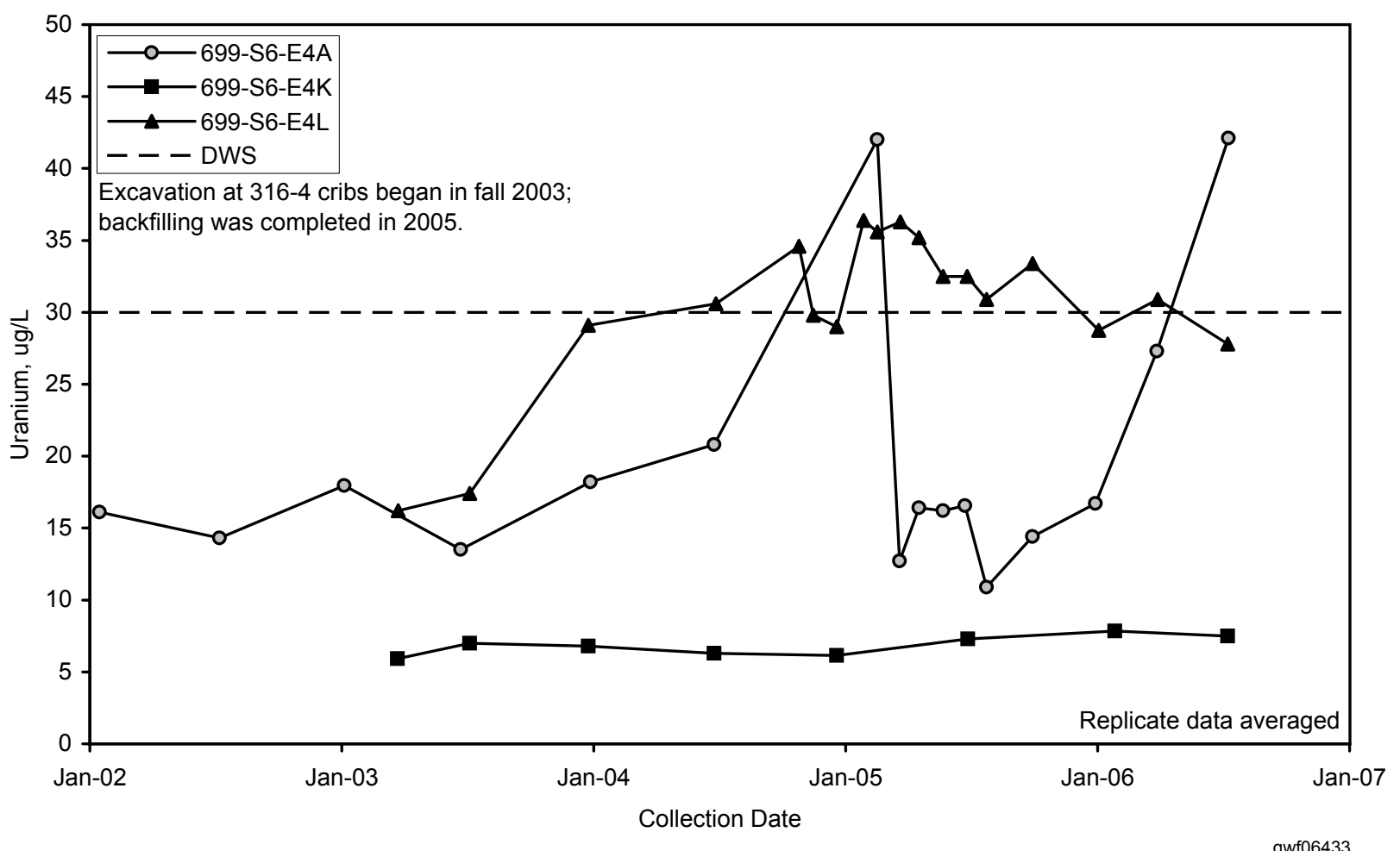

Figure 2.12-13. Uranium Concentrations at Wells Near 316-4 Cribs Remedial Action Site

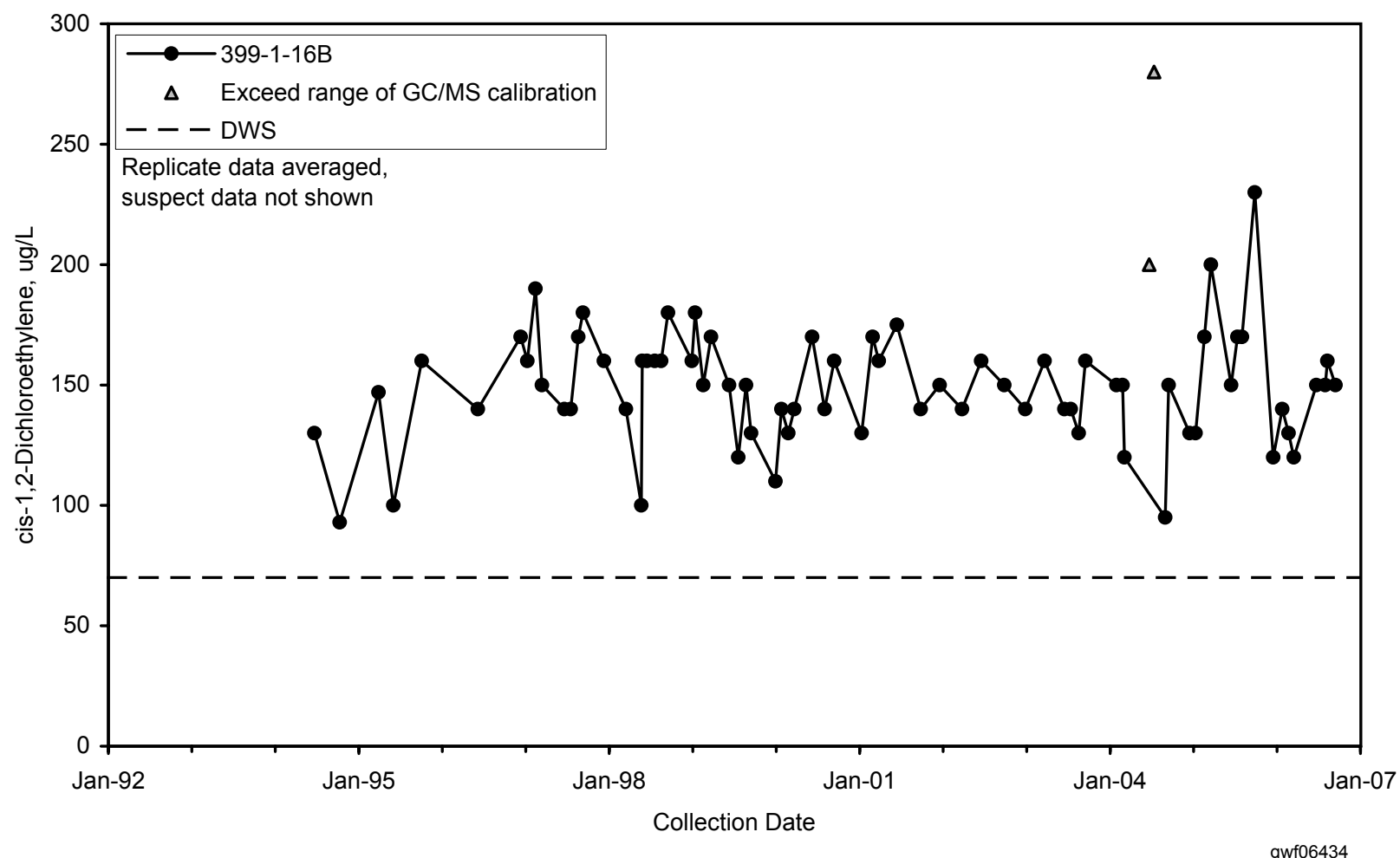

Figure 2.12-14. Concentrations of cis-1,2-Dichloroethene at Well 399-1-16B Near Former 300 Area Process Trenches 


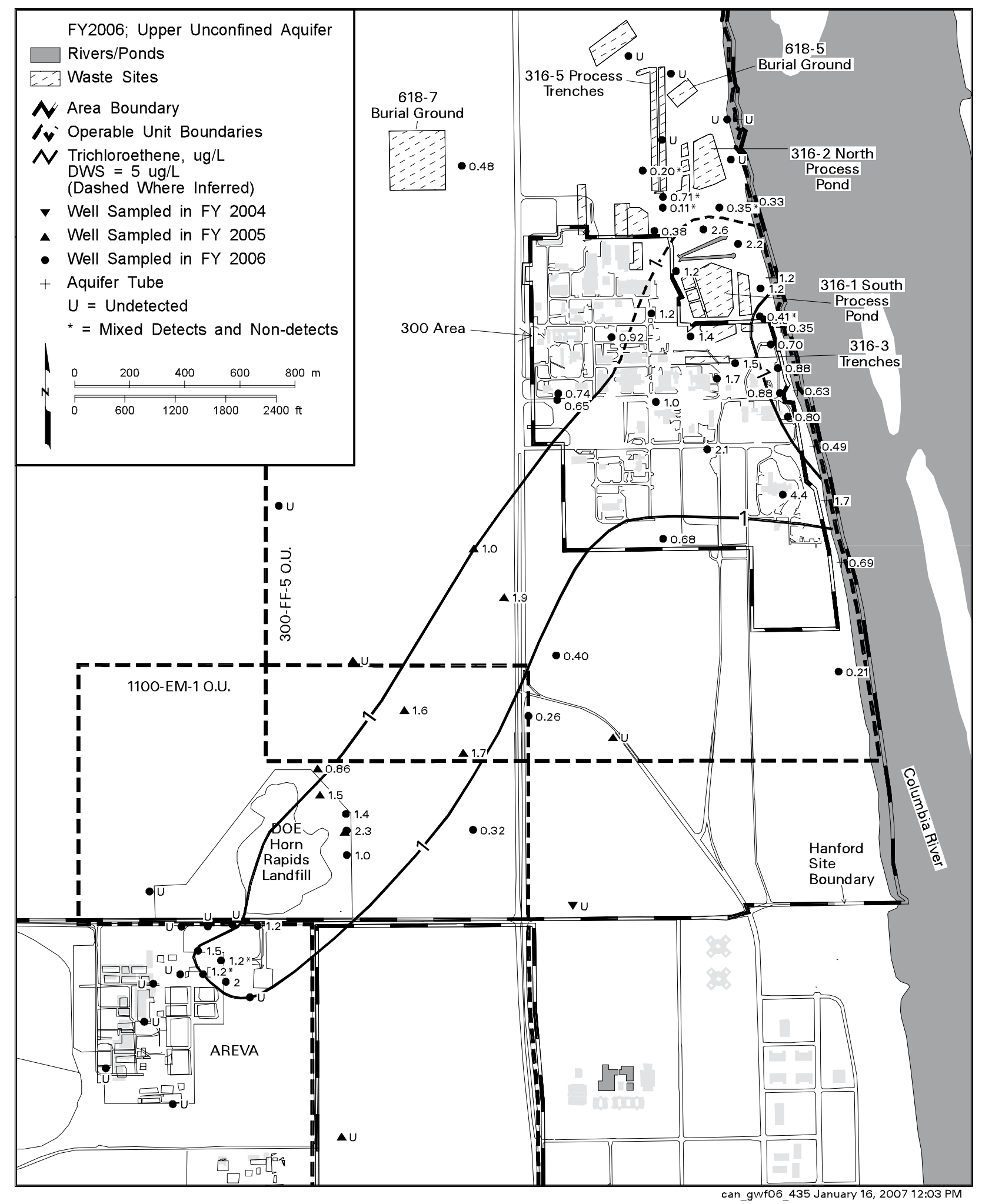

Figure 2.12-15. Average Trichloroethene Concentrations in the Vicinity of 300 Area, Upper Part of Unconfined Aquifer 


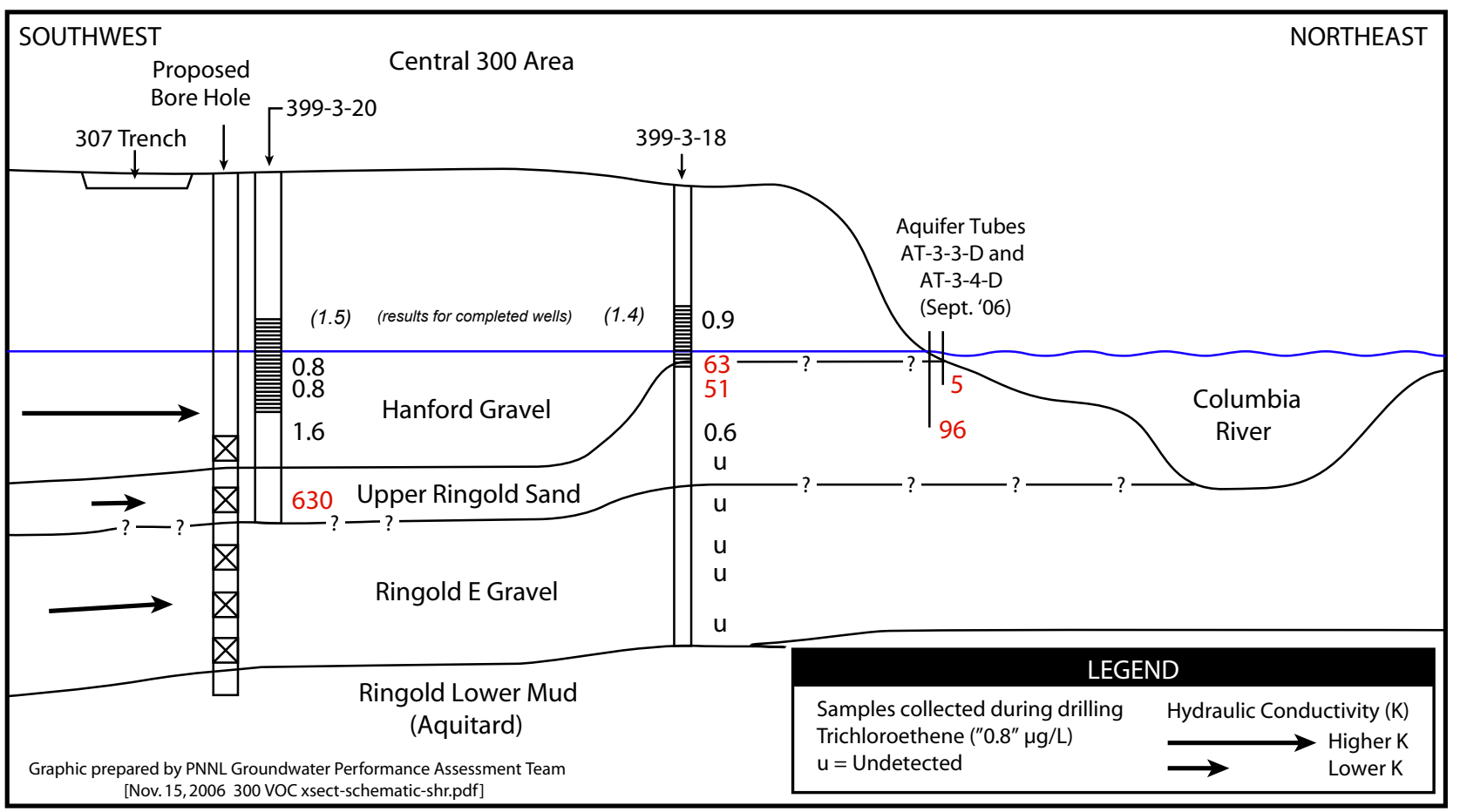

Figure 2.12-16. Trichloroethene in Samples Collected during Limited Field Investigation Drilling, May 2006 


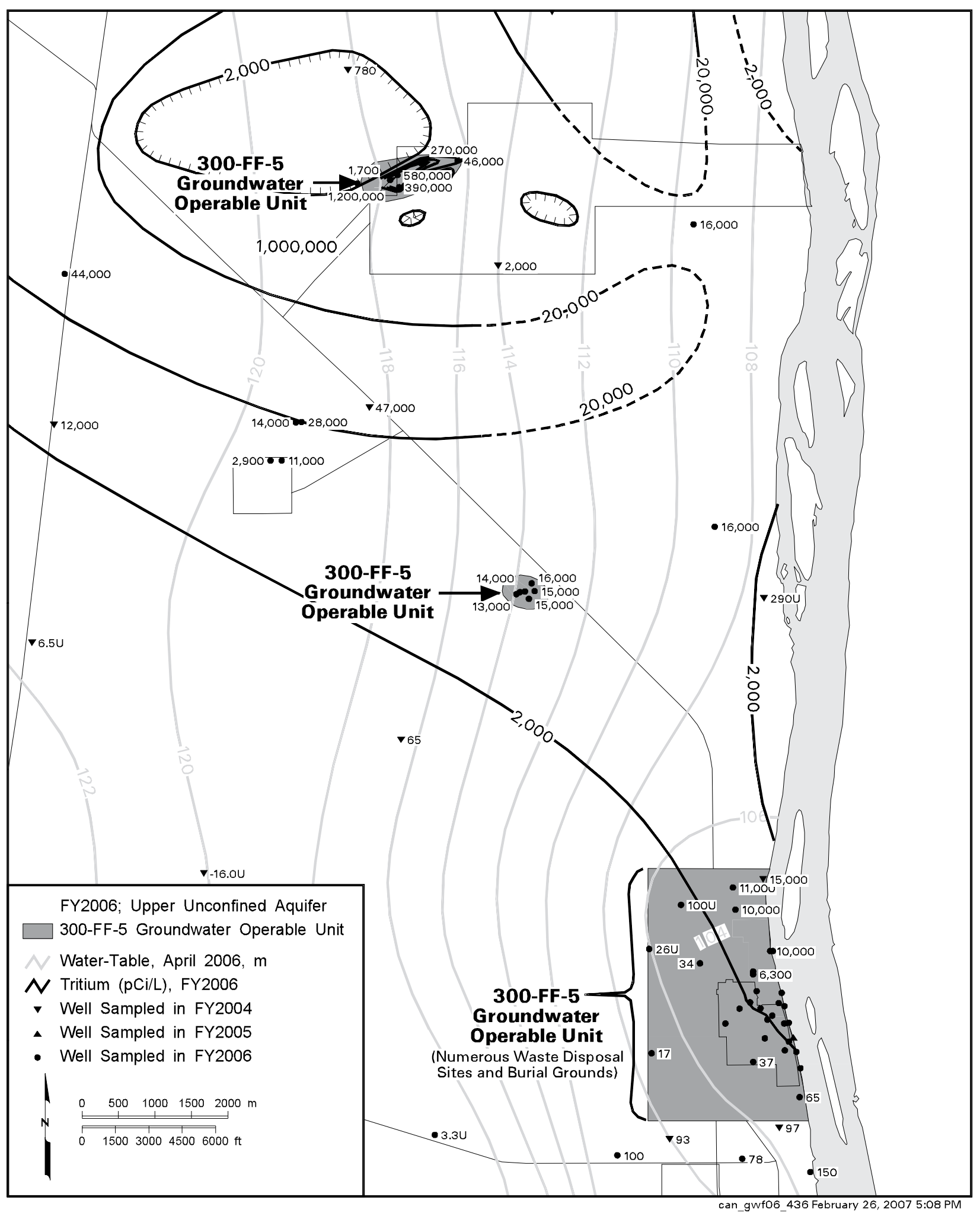

Figure 2.12-17. Average Tritium Concentrations in 300-FF-5 Operable Unit, Upper Part of Unconfined Aquifer 


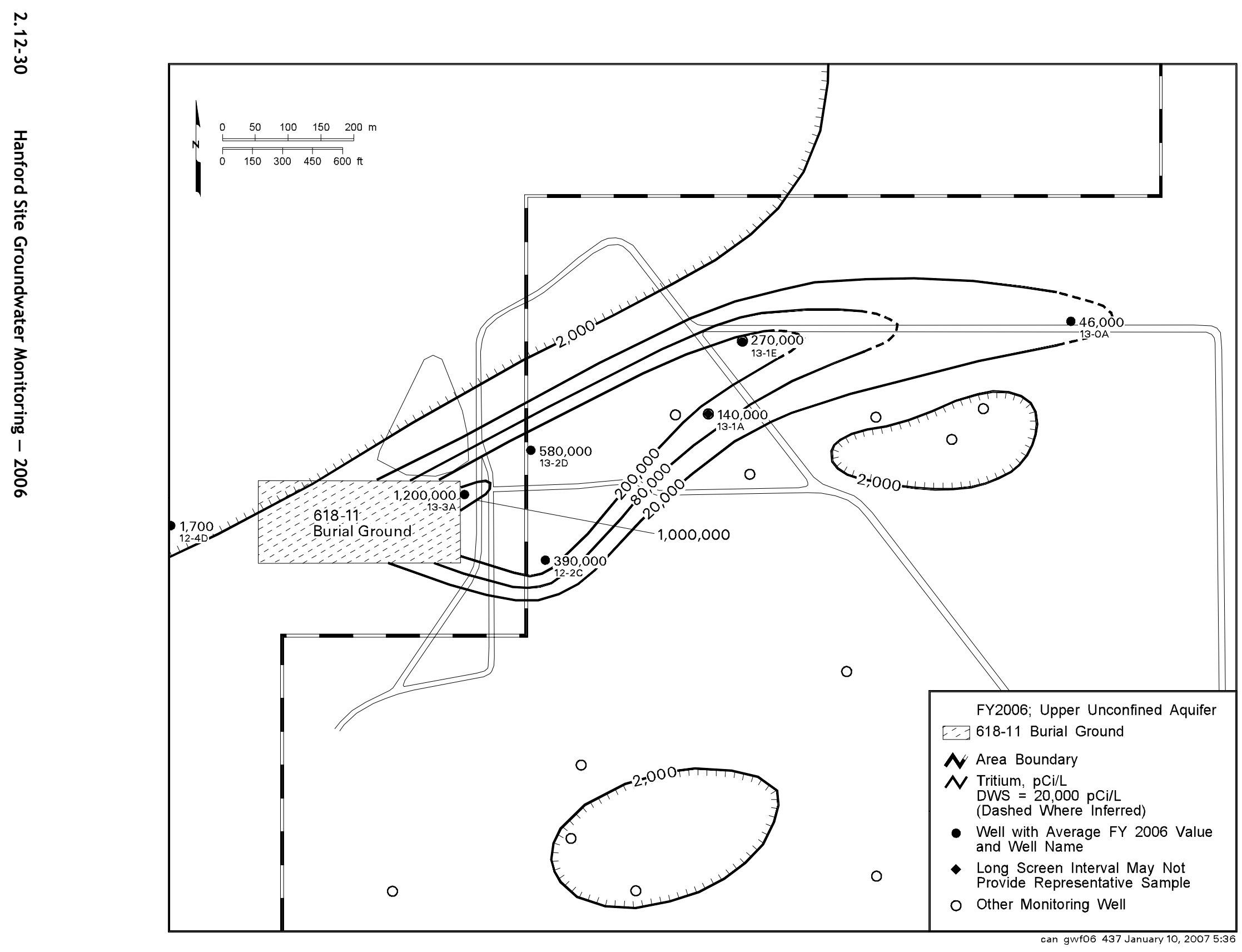

Figure 2.12-18. Average Tritium Concentrations at 618-11 Burial Ground, Upper Part of Unconfined Aquifer 


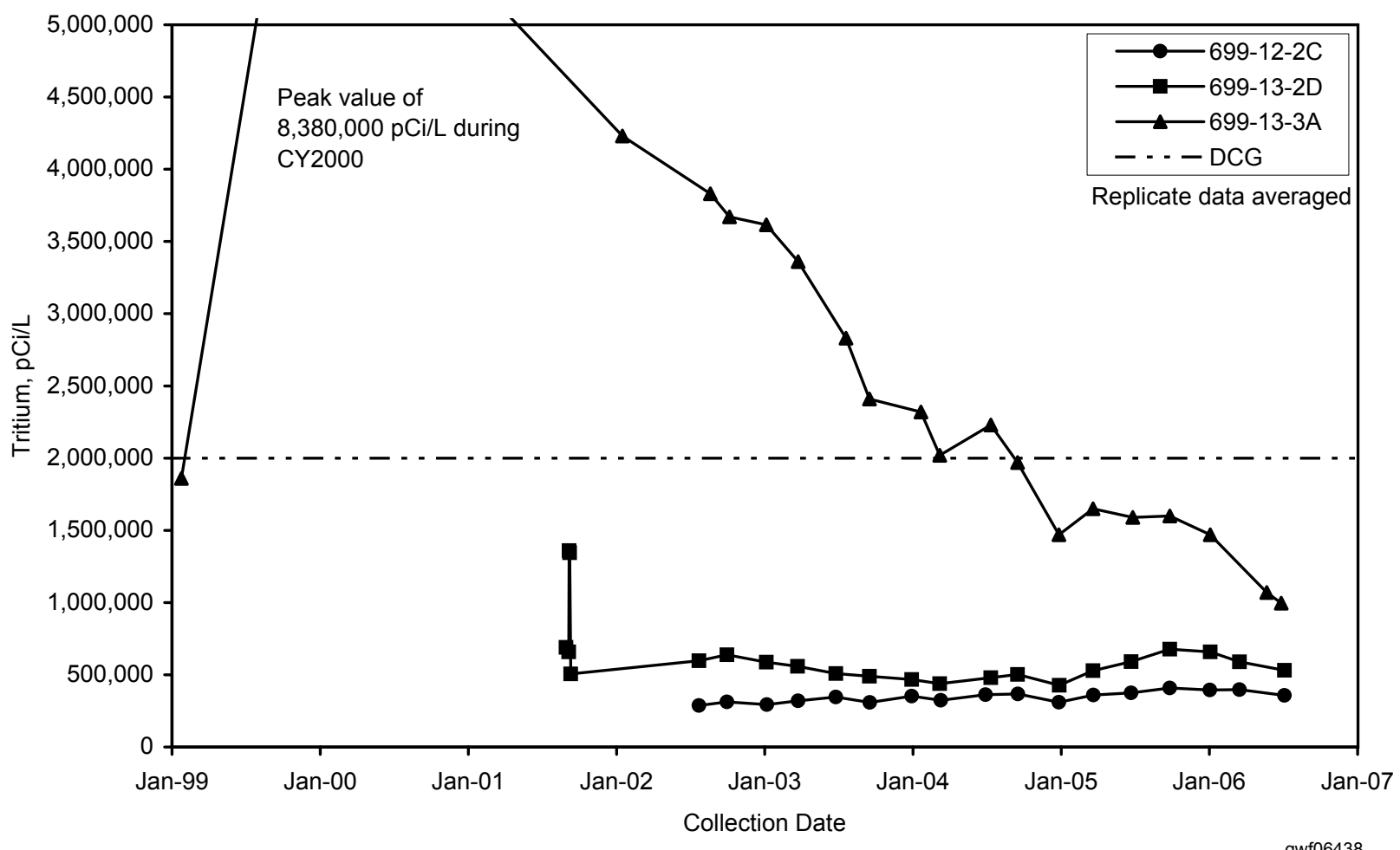

Figure 2.12-19. Tritium Concentration in Wells Near 618-11 Burial Ground 


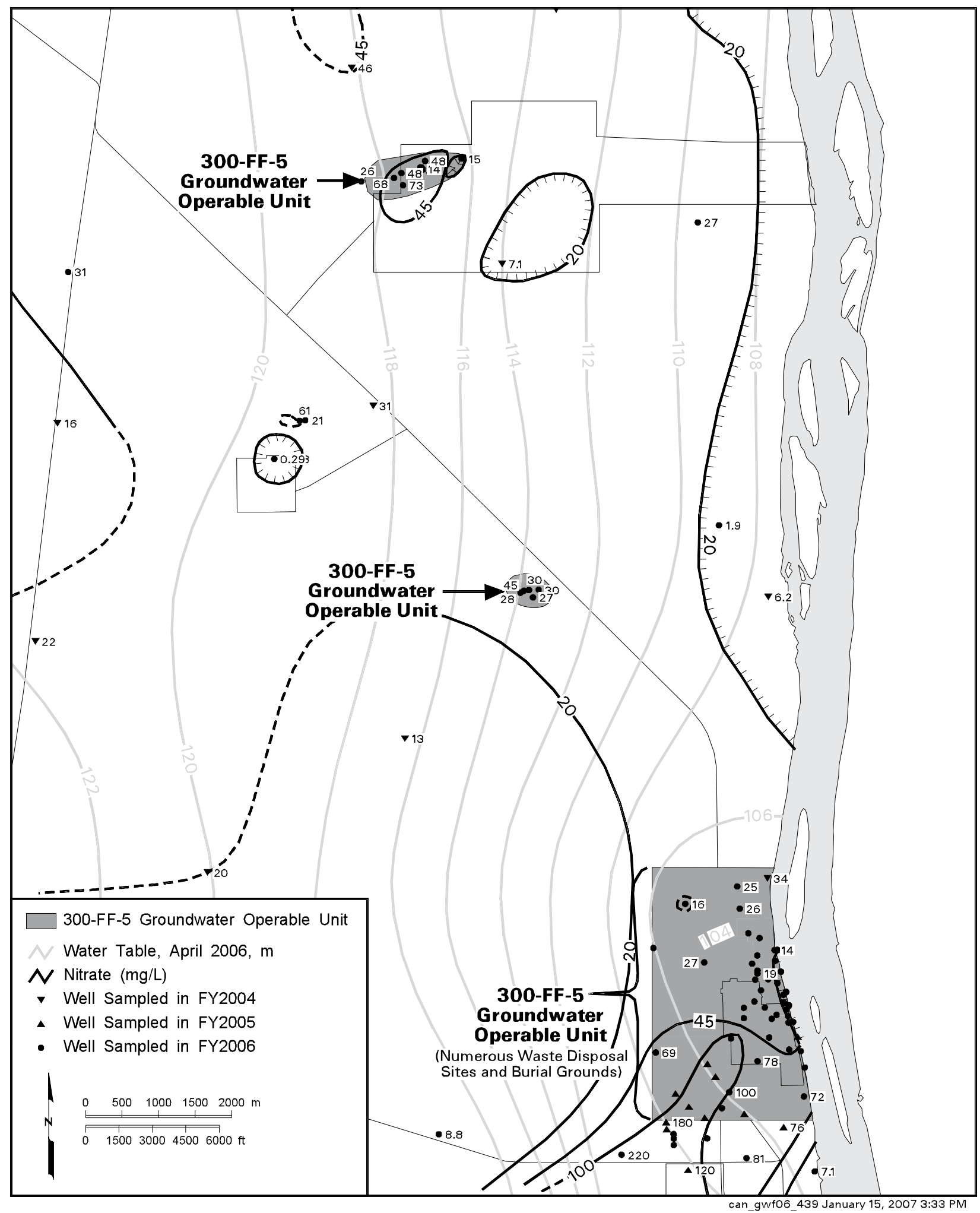

Figure 2.12-20. Average Nitrate Concentrations in 300-FF-5 Operable Unit, Upper Part of Unconfined Aquifer 


\subsection{0-EM-1 Operable Unit}

\section{R. Newcomer}

The scope of this section is the 1100-EM-1 groundwater interest area, which includes the 1100-EM-1 Operable Unit, a large south portion of the Hanford Site, and the offsite area to the south of the Hanford Site, including the areas formerly designated as the 1100 and 3000 Areas of the Hanford Site (see Figure 1.0-1 in Section 1.0). The groundwater interest areas are informal designations to aid planning, scheduling, and data interpretation. Figure 2.13-1 shows facilities, wells, and shoreline monitoring sites in this region. The focus of this section is the central and east portions of the 1100-EM-1 groundwater interest area near the south boundary of the Hanford Site. Trichloroethene and nitrate are the contaminants of greatest significance in groundwater. Groundwater is monitored for the 1100-EM-1 Operable Unit to assess the performance of natural attenuation of volatile organic compounds. In addition to the trichloroethene plume, contaminants of concern include breakdown products of trichloroethene (vinyl chloride and 1,1-dichloroethene) and nitrate.

Figure 2.13-2 shows the April 2006 water-table elevations and corresponding groundwater flow directions for the east portion of the 1100-EM-1 groundwater interest area. Watertable elevation contours in the west portion of Figure 2.13-2, which are consistent with the site-wide water-table map in Figure 2.1-2, are controlled by water-level measurements in wells and by Yakima River stage west of the map area. Groundwater in the 1100-EM-1 groundwater interest area generally flows eastward from the Yakima River (see Figure 2.1-2 in Section 2.1) and discharges to the Columbia River. In the northeast part of the 1100-EM-1 groundwater interest area, groundwater flows northeast and converges with groundwater beneath the 300 Area before discharging to the Columbia River. In the east-central part of the 1100-EM-1 groundwater interest area, groundwater flow from the west is diverted to the northeast and southeast around a recharge mound created by the city of Richland's North Richland Well Field and recharge ponds before discharging to the Columbia River. Agricultural irrigation supplied primarily by the Columbia River recharges the unconfined aquifer between the Yakima and Columbia Rivers.

\subsubsection{Groundwater Contaminants}

This section describes the distribution of groundwater contaminants in the 1100-EM-1 groundwater interest area. Groundwater contaminants discussed are chlorinated hydrocarbons (primarily trichloroethene), tritium, nitrate, uranium, ammonia, and fluoride.

Groundwater monitoring in the 1100-EM-1 groundwater interest area includes the following monitoring activities:

CERCLA Monitoring

- Compliance wells are monitored for trichloroethene, breakdown products, and nitrate.

- One well is sampled annually for filtered chromium.

- In FY 2006, only six of the fourteen 1100-EM-1 compliance monitoring wells were sampled as scheduled (see Appendix A).

\section{AEA Monitoring}

- Wells are sampled annually and semiannually for tritium, volatile organic compounds, nitrate, and general chemistry.

- A few isolated wells are sampled annually for uranium, gross alpha, gross beta, technetium-99, and ammonia. 


\section{Trichloroethene concentrations continue to decrease in all plume areas near DOE's Horn}

Rapids Landfill.

Plume areas (square kilometers) above the drinking water standard at the 1100-EM-1 Operable Unit:

*Nitrate -4.49

* Primarily from offsite sources.

\subsubsection{Chlorinated Hydrocarbons}

Trichloroethene contamination occurs in the 1100-EM-1 groundwater interest area beneath the U.S. Department of Energy's (DOE's) inactive Horn Rapids Landfill and offsite in AREVA wells (Figure 2.13-3). The distribution of trichloroethene in the upper part of the unconfined aquifer shows that the plume has an elongated configuration. This configuration reflects the northeast flow direction toward the 300 Area. The thickness of the unconfined aquifer in this area is $\sim 6$ to 9 meters. Most of the wells used for monitoring trichloroethene have screen intervals that penetrate the upper $\sim 4.5$ to 8.5 meters of the unconfined aquifer. One well monitors the lower $\sim 3$ meters of the unconfined aquifer. Two wells, one upgradient and one downgradient of the landfill, monitor the confined aquifer below the clayey silt aquitard but above the basalt surface.

Quarterly trichloroethene sample concentrations continued to be $<5 \mu \mathrm{g} / \mathrm{L}$ in all AREVA wells during the first two quarters of fiscal year 2006 (E06-01-20054Q; E06-01-2006-1Q). AREVA data for the third and fourth quarters of FY 2006 were not published by the time this report was published. The maximum trichloroethene concentration during these first two quarters was $2.1 \mu \mathrm{g} / \mathrm{L}$ immediately downgradient of the process lagoons. The past use of solvent to install and maintain process lagoon liners at AREVA is the only potential source of trichloroethene identified in the eastern portion of the 1100-EM-1 groundwater interest area (DOE/RL-92-67).

Trichloroethene concentrations have decreased in all the plume areas near DOE's Horn Rapids Landfill. Trichloroethene concentrations decreased by an order of magnitude in this area since monitoring began in 1990 (Figure 2.13-4). In FY 2006, trichloroethene concentrations were all $<5 \mu \mathrm{g} / \mathrm{L}$, ranging from less than detection to $2.3 \mu \mathrm{g} / \mathrm{L}$ downgradient of the landfill. The decreased concentrations in the majority of wells downgradient of DOE's Horn Rapids Landfill suggest that some elements of natural attenuation (e.g., volatilization, passive pumping) may have reduced the plume mass. For a discussion of trichloroethene in the 300 Area, see Section 2.12.1.2.

Potential breakdown products of trichloroethene, including vinyl chloride and 1,1-dichloroethene, continued to show levels less than their respective minimum detection limits during FY 2006.

The city of Richland monitors groundwater in the upper part of the unconfined aquifer quarterly for chemical constituents at their Horn Rapids Sanitary Landfill (formerly Richland Landfill). The landfill is located in the central portion of the 1100-EM-1 groundwater interest area adjacent to the southern boundary of the Hanford Site (refer to Figure 2.13-1 for location). Chlorinated hydrocarbons were detected in city landfill monitoring wells between $\sim 1$ and 1.5 kilometers south of the Hanford Site boundary at levels above their respective drinking water standards during the first quarter of FY 2006 (City of Richland 2006). City of Richland data for the second, third, and fourth quarters of FY 2006 were not published by the time this report was published. The highest concentrations during first

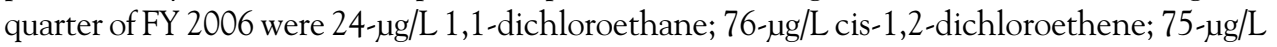
tetrachloroethene; and 27- $\mathrm{gg} / \mathrm{L}$ trichloroethene. During FY 2006, these constituents were below their respective minimum detection limits at onsite well 699-S31-1 just northeast of the city's sanitary landfill.

A confined aquifer found in the Ringold Formation is monitored for trichloroethene downgradient of the inactive DOE Horn Rapids Landfill. This confined aquifer lies below a clayey silt aquitard, but above the basalt surface, at a depth of $\sim 18$ to 21 meters below the water table. Trichloroethene has not been detected in this confined aquifer since monitoring began in 1991, which suggests that the trichloroethene plume in the unconfined aquifer did not migrate downward into the underlying confined aquifer. 


\subsubsection{Tritium}

The 200 Area tritium plume extends southward toward the 1100-EM-1 groundwater interest area at levels below $2,000 \mathrm{pCi} / \mathrm{L}$. Tritium continues to be closely monitored because of its proximity to the city of Richland's North Well Field (Figure 2.13-5). Tritium levels were slightly elevated above background in wells west and north of the city of Richland's North Well Field during FY 2006. The background geometric mean tritium concentration in the upper part of the unconfined aquifer was determined to be $63.9 \mathrm{pCi} / \mathrm{L}$ (DOE/RL-96-61). However, these levels are far below the drinking water standard $(20,000 \mathrm{pCi} / \mathrm{L})$. Trends in tritium concentrations in wells west and south of the city of Richland's North Well Field have consistently shown fluctuating levels in the last few years, as shown in Figure 2.13-6.

Tritium is not migrating in groundwater from the Hanford Site 200 Areas tritium plume to the city of Richland well field. Factors limit the migration of the tritium plume into the east portion of the 1100-EM-1 groundwater interest area:

- Groundwater generally flows from west to east between the Yakima River, a recharge source, and the Columbia River.

- Artificial recharge from agricultural irrigation in the west and central portions of the 1100-EM-1 groundwater interest area south of the Hanford Site contributes to the eastward and northeastward flow.

- Groundwater flow is directed outward from the elevated groundwater levels at the city of Richland's North Well Field because of ponds used to recharge the well field.

These factors produce converging groundwater flow lines in the 300 Area and discharge to the Columbia River (Figure 2.13-2). Figure 2.13-5 shows a region of low tritium concentrations between the 200 Areas tritium plume and the slightly elevated tritium concentrations near the North Richland Well Field and recharge ponds. Thus, no indication exists that the tritium plume is migrating southward to and affecting the city of Richland well field. Tritium in groundwater in the 300 Area is discussed in Section 2.12.

\subsubsection{Nitrate}

The nitrate distribution in the east portion of the 1100-EM-1 groundwater interest area is shown in Figure 2.13-7. Nitrate contamination in this area is likely the result of industrial and agricultural uses off the Hanford Site. Agricultural uses include application of fertilizers onto irrigation circles in the central portion of the 1100-EM-1 groundwater interest area (Figure 2.13-1).

Nitrate concentrations above the drinking water standard ( $45 \mathrm{mg} / \mathrm{L}$ ) are found over much of the east portion of the 1100-EM-1 groundwater interest area and continued to increase in a number of wells in FY 2006 (Figure 2.13-8). Some of the highest nitrate levels occur near an offsite facility (AREVA) and DOE's inactive Horn Rapids Landfill. Elevated nitrate near these areas is likely the result of agricultural activities to the west and southwest. The highest nitrate concentration in this area was $413 \mathrm{mg} / \mathrm{L}$ immediately downgradient of the AREVA facility. Nitrate data for the offsite AREVA wells are reported in E06-01-2006-1Q. Another potential source of nitrate is the ConAgra (Lamb Weston) facility located southwest of the 1100-EM-1 groundwater interest area.

Nitrate concentrations continued to be elevated in wells downgradient of DOE's inactive Horn Rapids Landfill in FY 2006. The highest nitrate concentration was $253 \mathrm{mg} / \mathrm{L}$. An example of elevated nitrate concentrations showing an increasing trend occurs immediately downgradient of the landfill at well 699-S31-E10D (Figure 2.13-8). The shape of
Monitoring data show that the

Richland North

Well Field is not

contaminated

by the Hanford

Site tritium

plume through

the groundwater

flow system.
The remedial action objectives for the 1100-EM-1 Operable Unit (ROD 1993) are:

- Attain concentration of $<5 \mu \mathrm{g} / \mathrm{L}$ trichloroethene at designated point of compliance.

- Protect environmental receptors in surface waters by reducing groundwater contaminant concentrations in the plume. 


\section{Uranium contamination is present near DOE's inactive Horn Rapids Landfill, but the source is located offsite.}

the nitrate plume (as defined by the 100-mg/L contour) near the AREVA facility and DOE's inactive Horn Rapids Landfill indicates that nitrate in these areas continues to migrate in a northeast direction toward the 300 Area. Groundwater and aquifer tube sample data, shown in Figure 2.13-7, indicates that groundwater with nitrate levels above the drinking water standard discharges to the Columbia River immediately south of the 300 Area.

\subsubsection{Gross Alpha and Uranium}

Elevated levels of gross alpha and uranium occur downgradient of an offsite industrial facility (AREVA) near DOE's inactive Horn Rapids Landfill. The highest gross alpha level was $67 \mathrm{pCi} / \mathrm{L}$ immediately downgradient of the AREVA facility during FY 2006 (E06-01-2006-1Q). Several wells downgradient of the AREVA facility showed gross alpha levels that were above the drinking water standard $(15 \mathrm{pCi} / \mathrm{L})$, which excludes uranium. It is probable that the gross alpha levels are largely attributed to uranium because of industrial uses offsite. If gross alpha is attributed to uranium with natural isotopic abundances, then $67-\mathrm{pCi} / \mathrm{L}$ gross alpha is equivalent to $97-\mu \mathrm{g} / \mathrm{L}$ uranium, which is above the drinking water standard $(30 \mu \mathrm{g} / \mathrm{L})$ for uranium.

The distribution of uranium near DOE's inactive Horn Rapids Landfill is shown in Figure 2.13-9. The map shows a small plume of uranium with levels less than the drinking water standard $(30 \mu \mathrm{g} / \mathrm{L})$ near the landfill. Uranium concentrations in wells downgradient of the landfill have been increasing since 1996. Uranium concentrations ranged up to $21.6 \mu \mathrm{g} / \mathrm{L}$, with the highest concentration immediately downgradient of DOE's Horn Rapids Landfill (Figure 2.13-10).

\subsubsection{Other Constituents}

Ammonia and gross beta are found at low levels in wells near an offsite industrial facility (AREVA).

Ammonia - Concentrations of ammonia in the AREVA facility wells generally remained steady in FY 2006 (E06-01-2006-1Q). The highest average concentration detected was $14.3 \mathrm{mg} / \mathrm{L}\left(\right.$ as $\mathrm{NH}_{3}$ ) in well SPC-GM-8. Ammonia is typically absorbed by plants and soil microorganisms or is taken up as an exchangeable ion on soil particles (Hausenbuiller 1972). However, ammonia is usually less stable than nitrate in a biological system like the soil medium and is rapidly converted to nitrate. Ammonia was detected in several wells downgradient of the AREVA facility in FY 2006. The fact that ammonia is found in the groundwater suggests that relatively high concentrations reached the soil column.

Gross Beta-Gross beta continued to be detected in wells downgradient of AREVA during FY 2006 (E06-01-2006-1Q). The highest average gross beta measurement in FY 2006 was $57 \mathrm{pCi} / \mathrm{L}$ in well SPC-GM-8. Low levels of technetium-99, detected near DOE's inactive Horn Rapids Landfill, may be related to the gross beta measurements.

\subsubsection{Operable Unit Monitoring}

The 1100-EM-1 Operable Unit, which contains DOE's inactive Horn Rapids Landfill, was placed on the National Priorities List in 1989 and de-listed from the National Priorities List in 1996. Results of the Comprehensive Environmental Response, Compensation, and Liability Act (CERCLA) investigation for this operable unit are presented in the final remedial investigation study (DOE/RL-92-67) and the record of decision (ROD 1993). The selected remedy for groundwater is monitored natural attenuation of volatile organic compounds, with institutional controls on drilling of new water supply wells. Monitoring includes analysis of trichloroethene, its breakdown products (e.g., vinyl chloride and 1,1-dichloroethene), and nitrate in wells downgradient of DOE's inactive Horn Rapids Landfill, as recommended in the sampling plan (PNNL-12220). A list of wells and constituents are provided in Appendix A. 
The second CERCLA five-year review was published in November 2006 (DOE/RL2006-20). The review identified one issue and action associated with the 1100-EM-1 Operable Unit:

- Issue 20: Groundwater monitoring for the 1100-EM-1 Operable Unit is no longer necessary but continues following an extended period of monitoring that shows contaminant levels are below the maximum contaminant level and continue to show a downward trend.

- Action 20-1: Submit a change request to modify groundwater monitoring for the 1100-EM-1 Operable Unit (due date June 2007). 


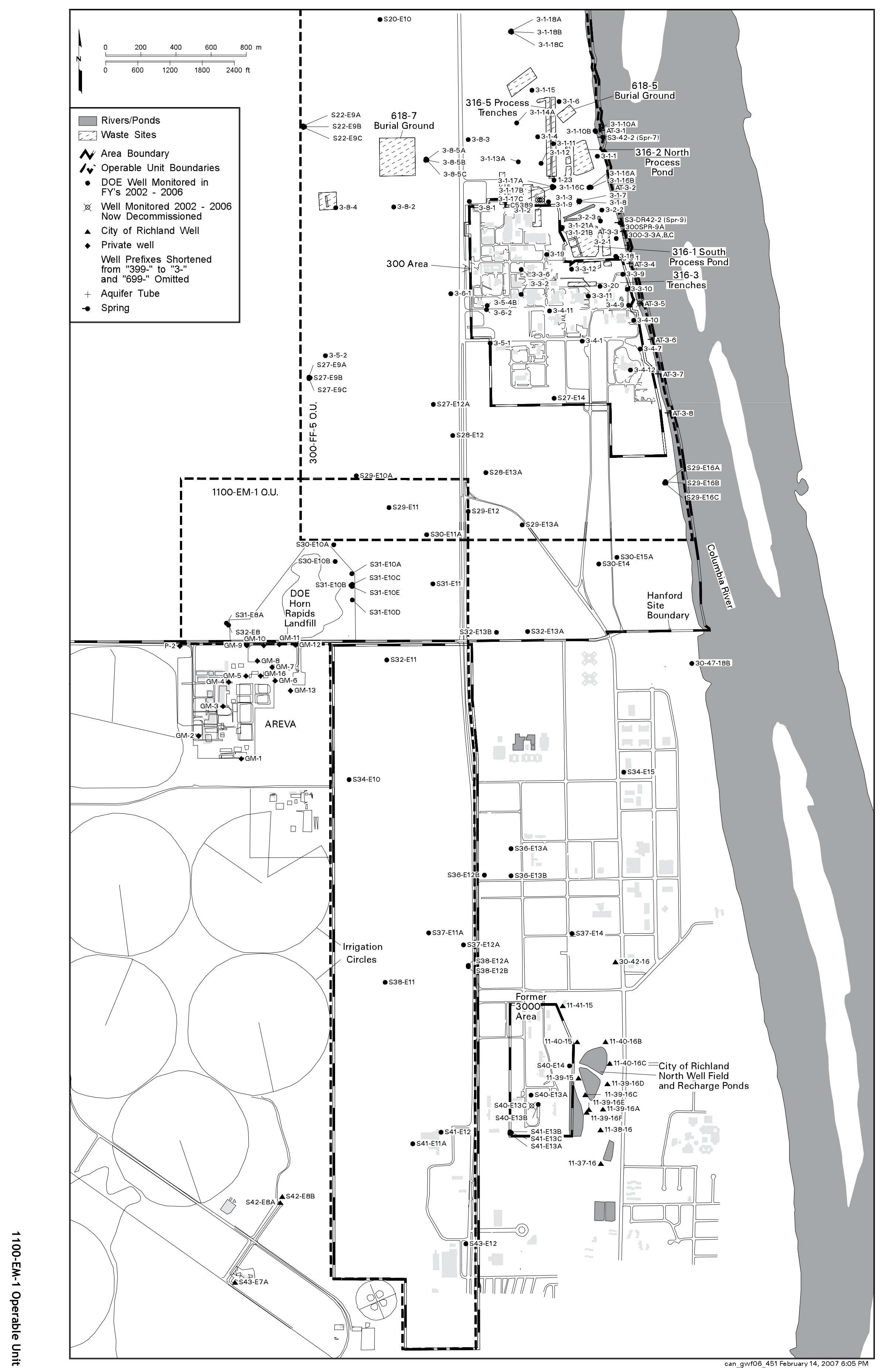

Figure 2.13-1. Groundwater Monitoring Wells and Facilities in 1100-EM-1 and 300 Areas 


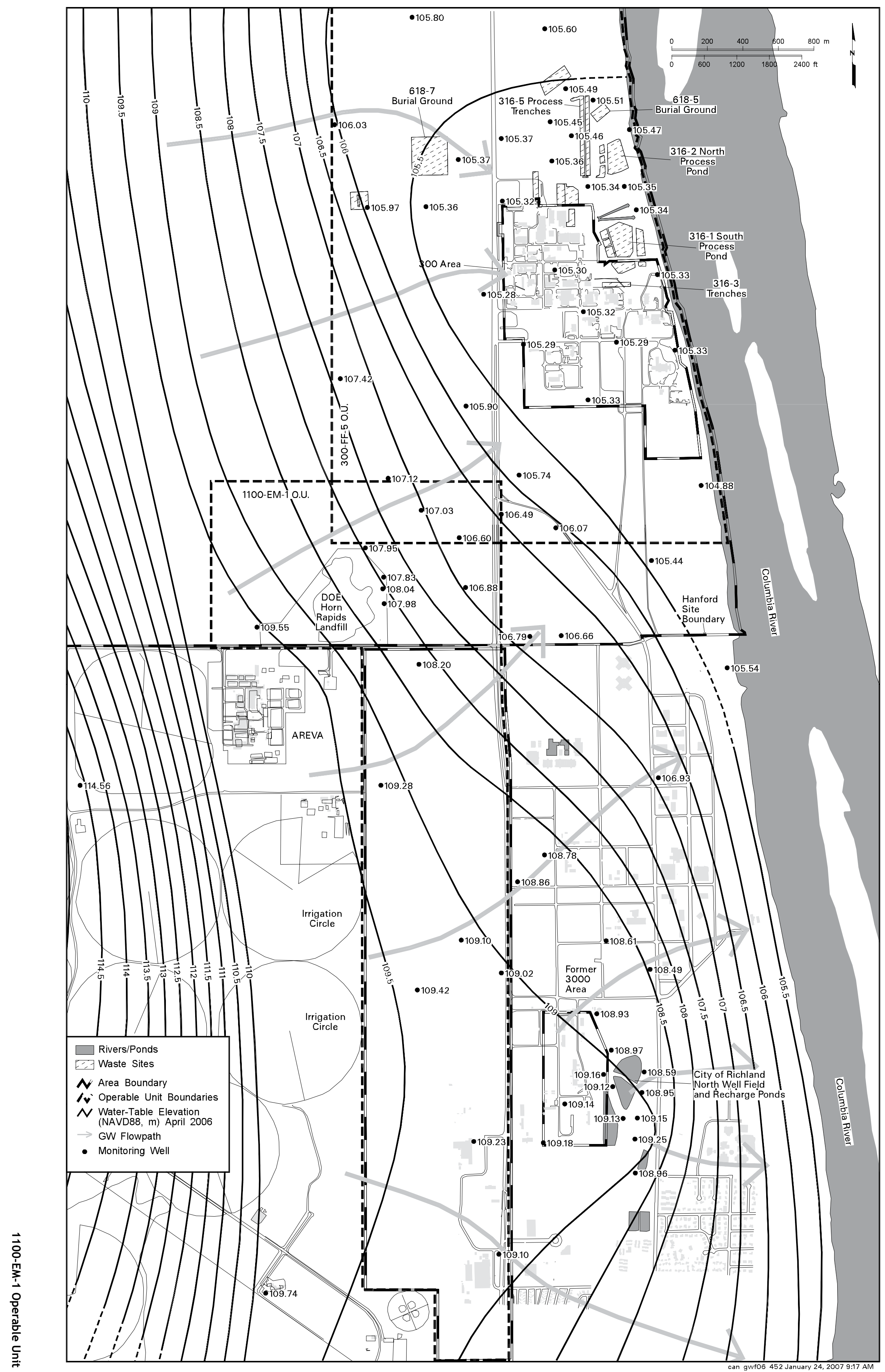

Figure 2.13-2. Water-Table Map for 1100-EM-1 and 300 Areas, April 2006 


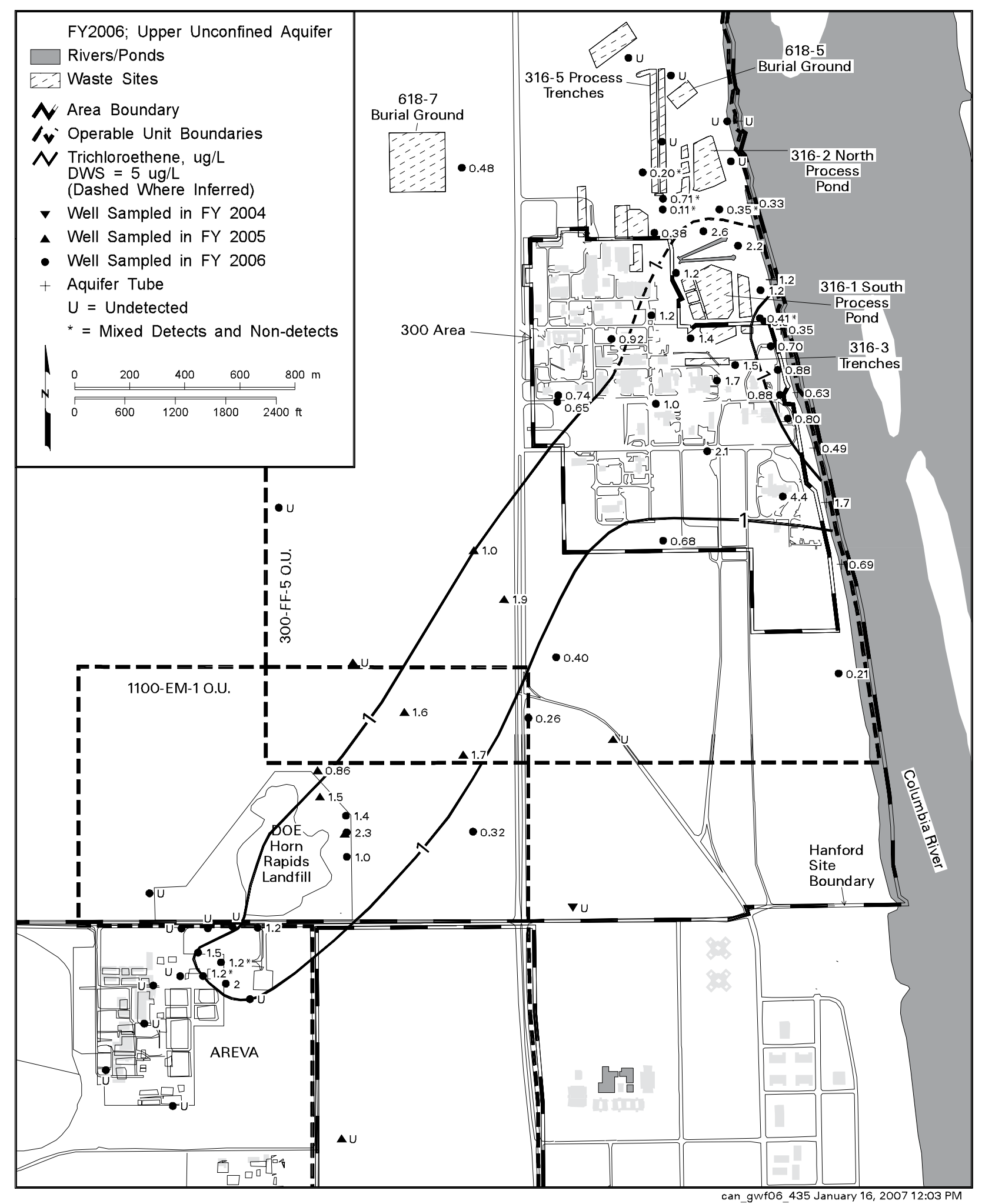

Figure 2.13-3. Average Trichloroethene Concentrations in 1100-EM-1 Area Groundwater, Upper Part of Unconfined Aquifer 


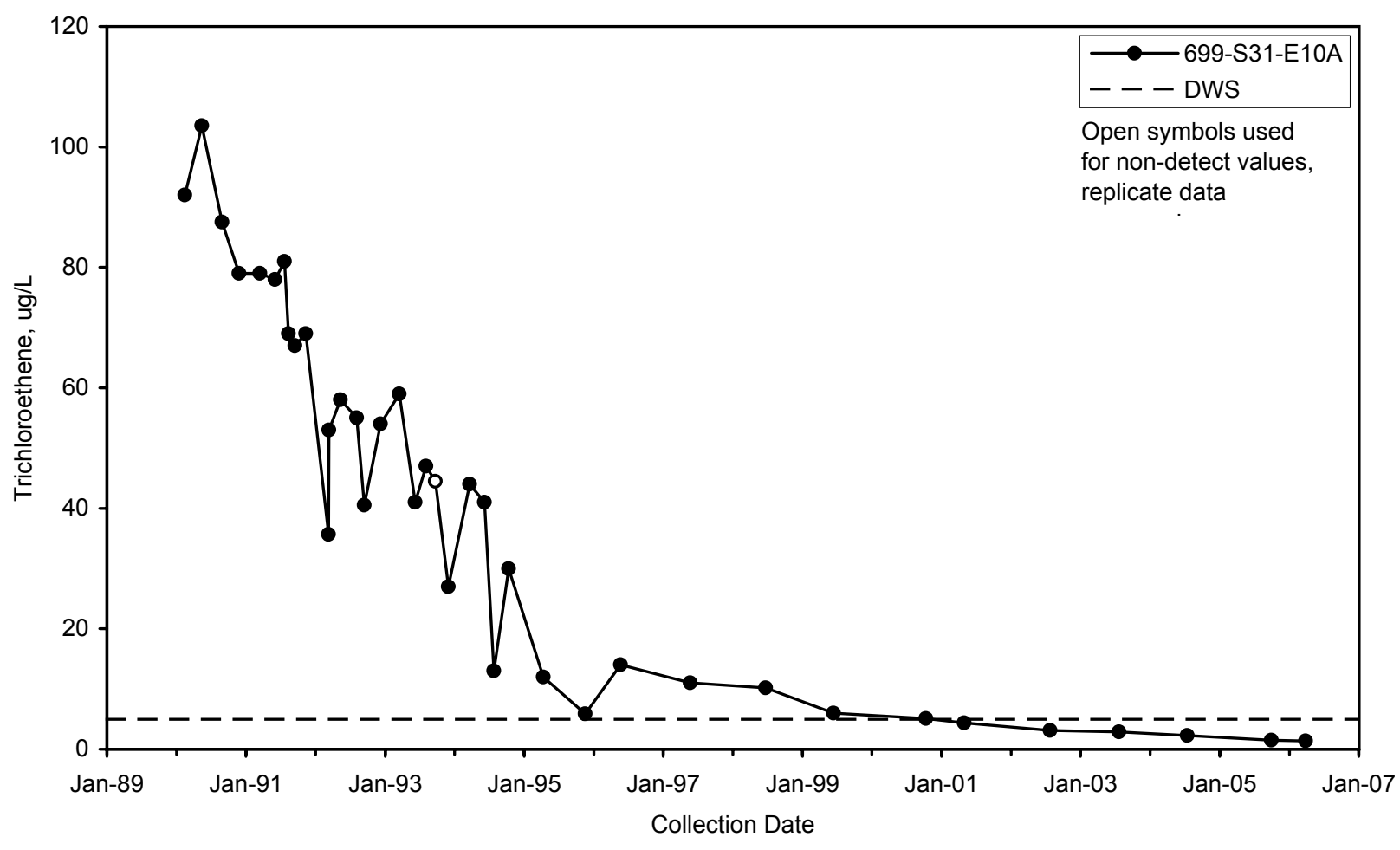

gwf06454

Figure 2.13-4. Trichloroethene Concentrations Near the U.S. Department of Energy's Inactive Horn Rapids Landfill 


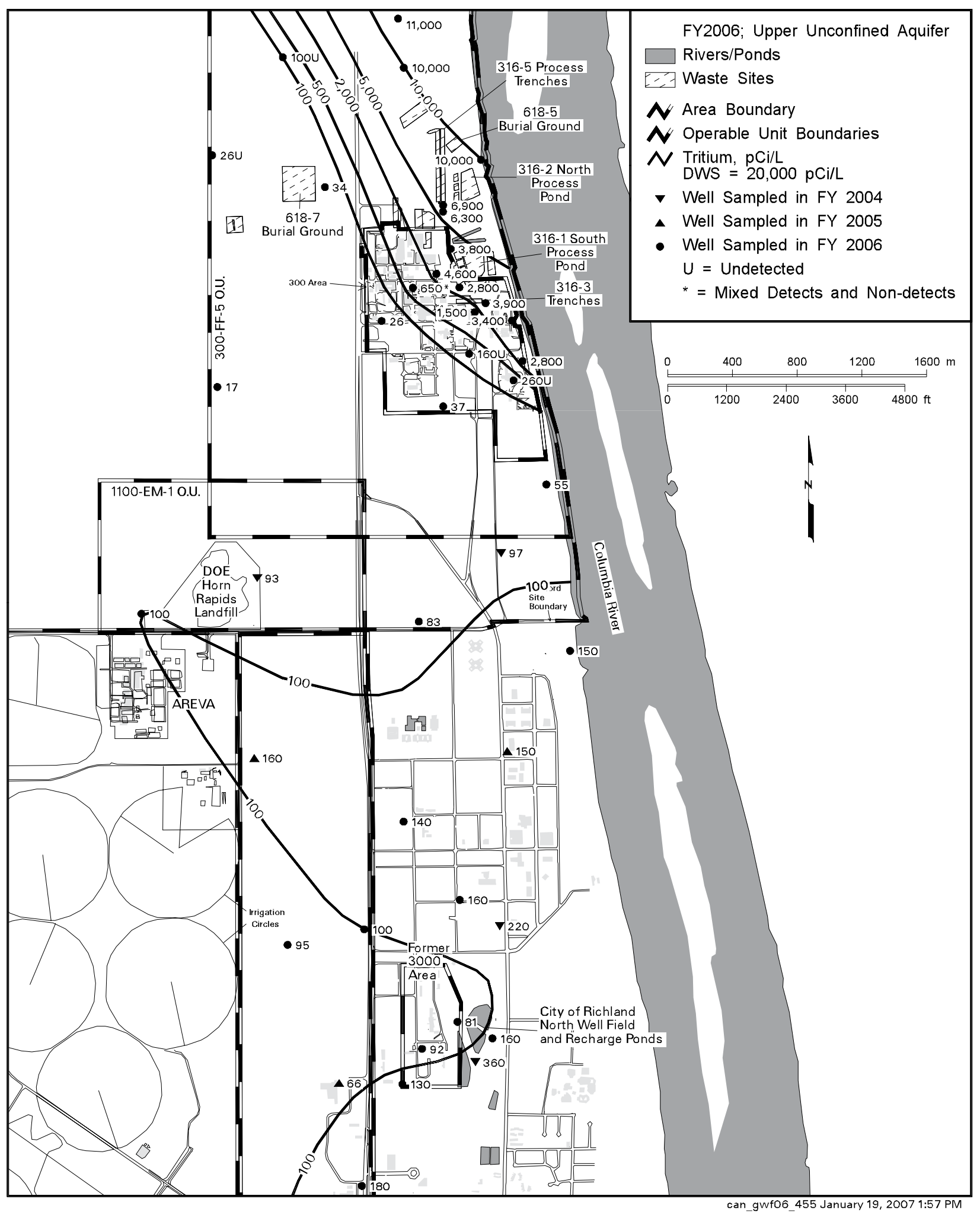

Figure 2.13-5. Average Tritium Concentrations in 300 and 1100-EM-1 Areas, Upper Part of Unconfined Aquifer 


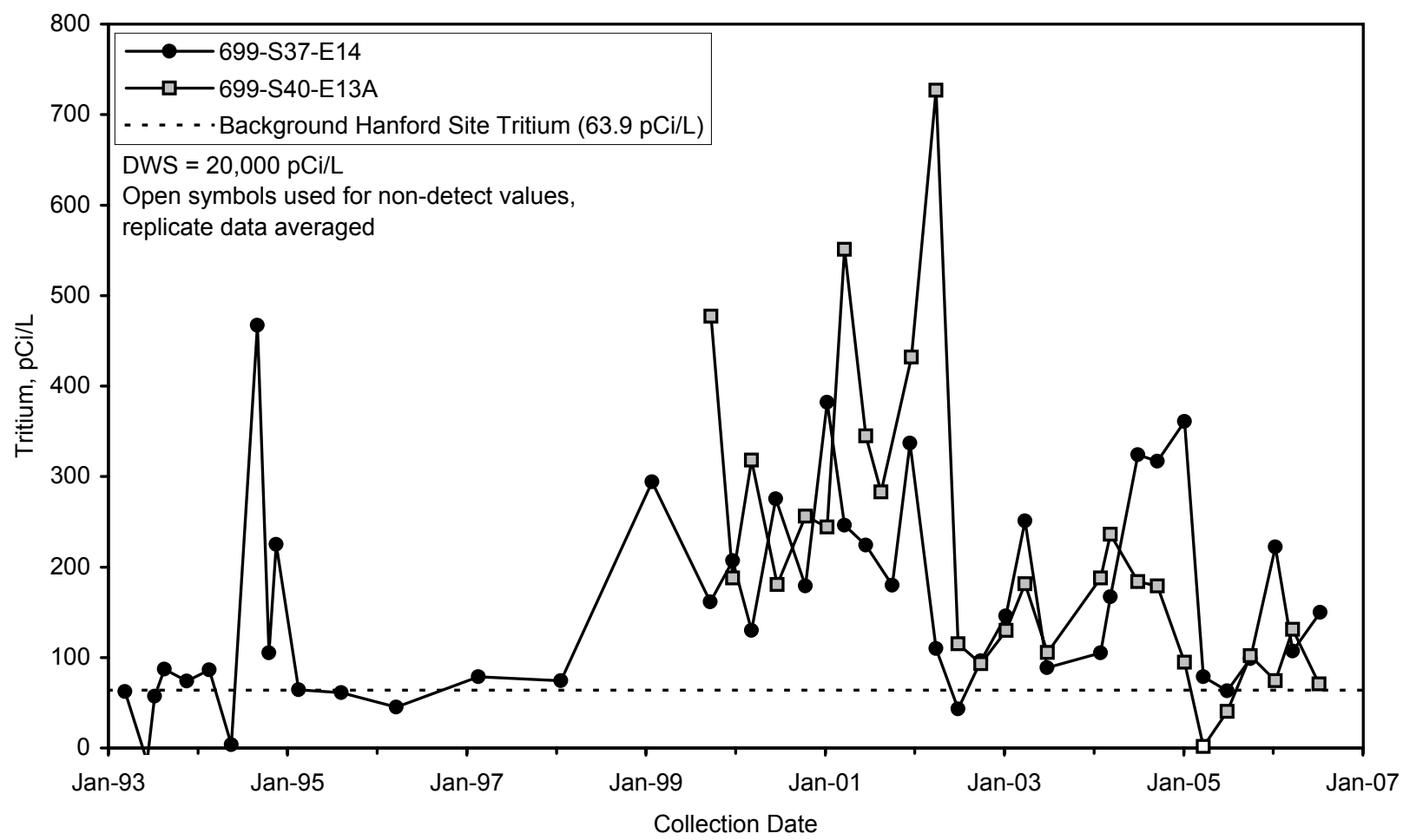

gwf06456

Figure 2.13-6. Tritium Concentrations in Selected Wells in 1100-EM-1 Groundwater Interest Area 


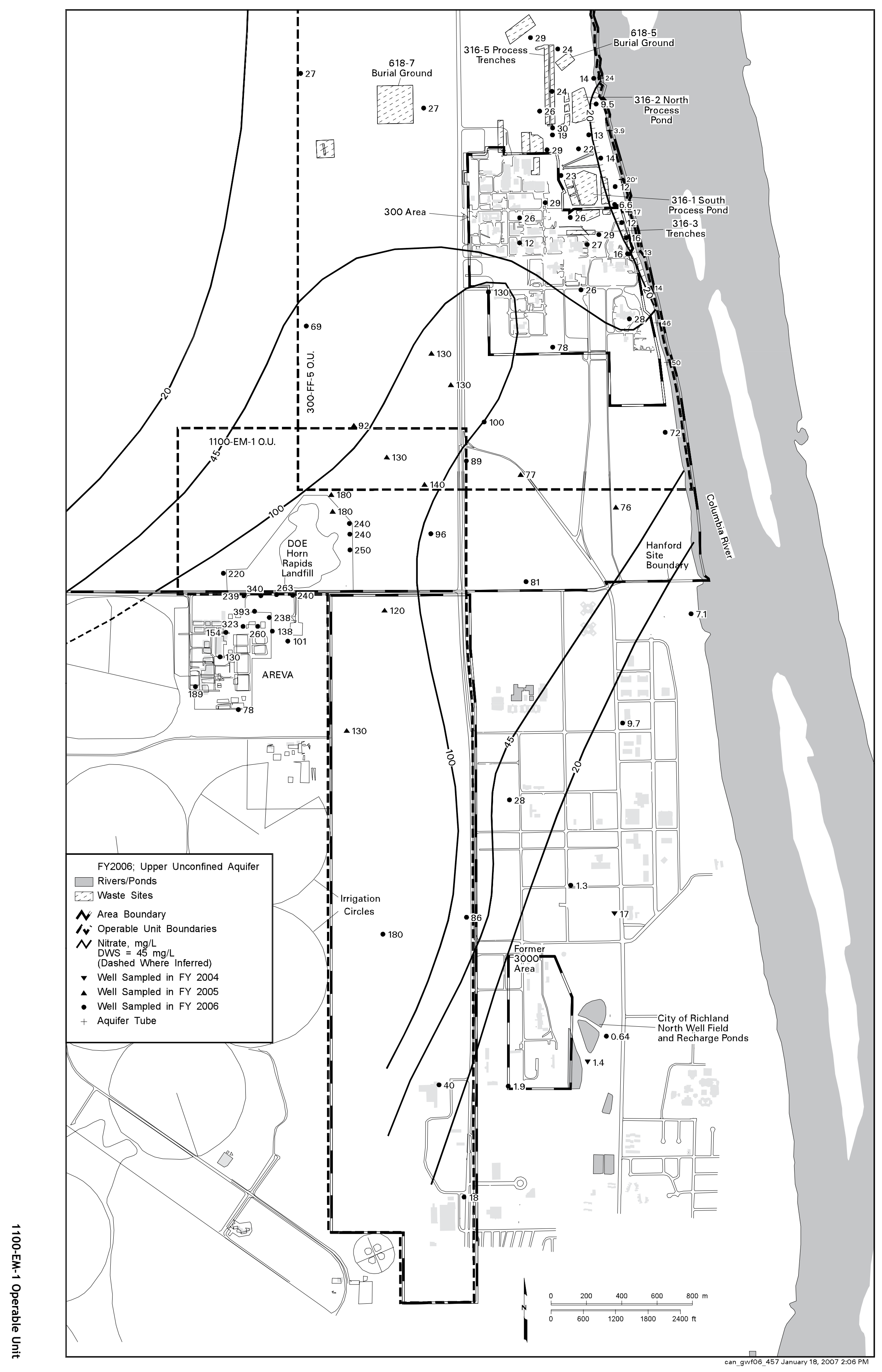

Figure 2.13-7. Average Nitrate Concentrations in 1100-EM-1 Area, Upper Part of Unconfined Aquifer 


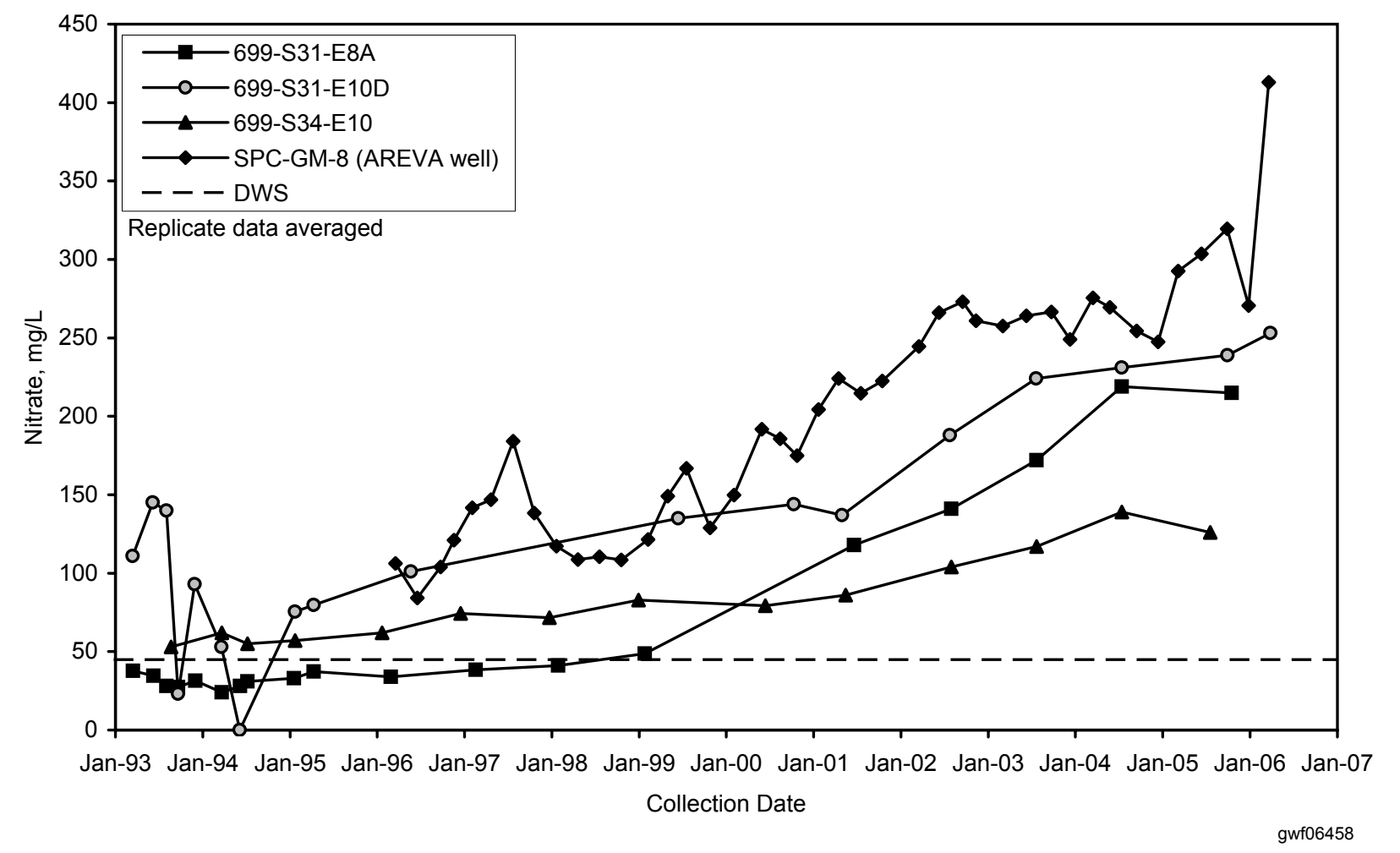

Figure 2.13-8. Nitrate Concentrations in Selected Wells in 1100-EM-1 Groundwater Interest Area (data for well SPC-GM-8 taken from E06-01-20044Q) 


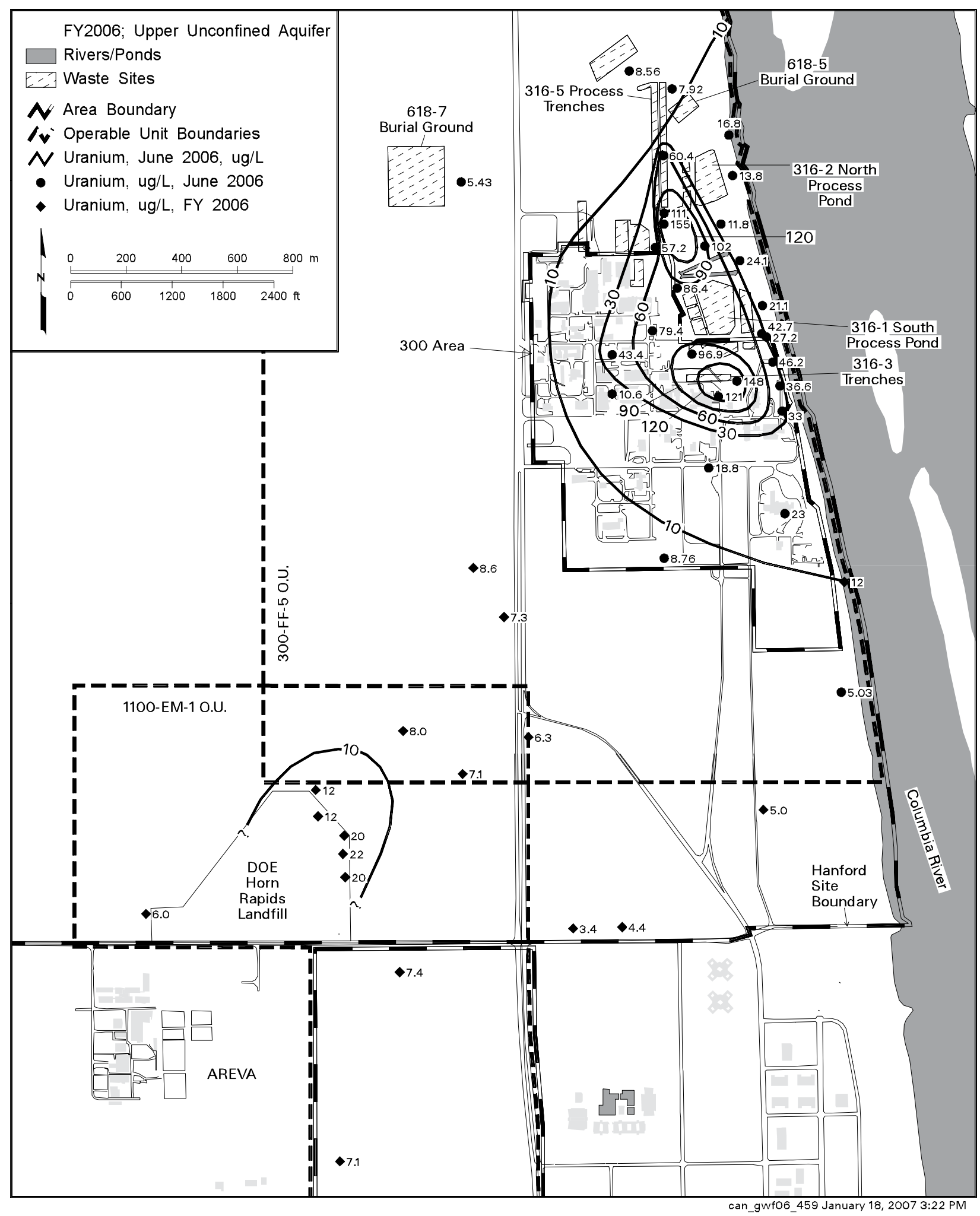

Figure 2.13-9. Uranium Concentrations in 1100-EM-1 and 300 Areas, Upper Part of Unconfined Aquifer, 2006 


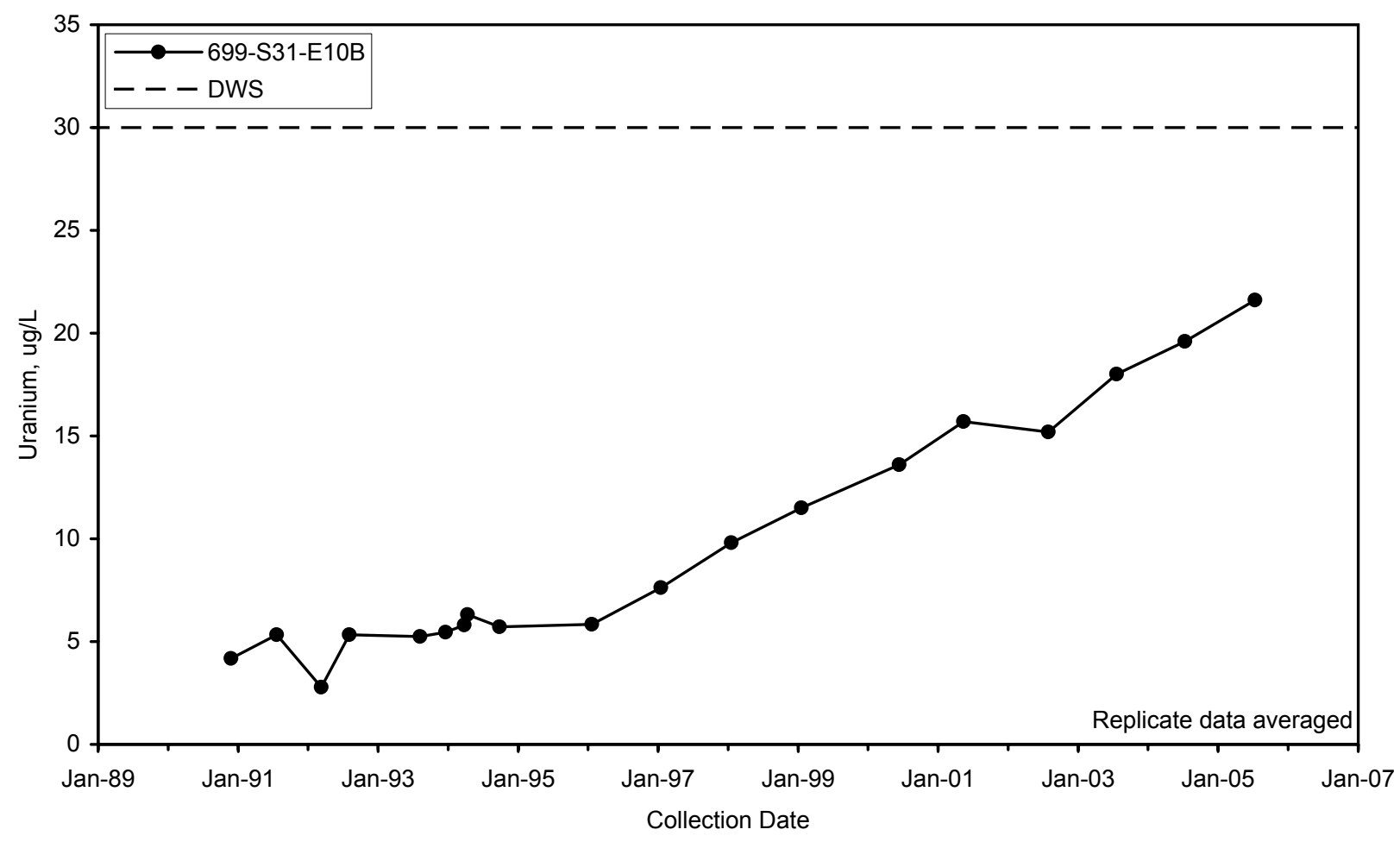

gwf06460

Figure 2.13-10. Uranium Concentrations Near the U.S. Department of Energy's Inactive Horn Rapids Landfill 


\subsection{Confined Aquifers}

\section{R. Newcomer and J. P. McDonald}

This section describes groundwater flow and quality within the Ringold Formation and upper basalt-confined aquifers. The Ringold Formation confined aquifer is described only for the 200 Areas Central Plateau and the area near the inactive B Pond system because few wells monitor this aquifer. The upper basalt-confined aquifer is described for much of the Hanford Site, primarily the area south of Gable Butte and Gable Mountain.

\subsubsection{Ringold Formation Confined Aquifer}

Groundwater quality in the Ringold Formation confined aquifer is monitored because of the past and potential future for downward migration of contaminants from the overlying unconfined aquifer.

The Ringold Formation confined aquifer occurs within fluvial sand and gravel comprising the lowest sedimentary unit of the Ringold Formation (unit 9). It is confined below by basalt and above by the lower mud unit (unit 8).

\subsubsection{Groundwater Flow in the Ringold Formation Confined Aquifer}

Figure 2.14-1 presents the interpreted potentiometric surface for a portion of the Ringold Formation confined aquifer. This map is subject to uncertainty because only a few wells monitor this aquifer. However, generalized flow patterns can be inferred from the available data when the hydrogeologic framework (i.e., extent of the confining unit, presence of basalt subcrops, influence of the May Junction Fault) is taken into account.

Groundwater flow in the Ringold Formation confined aquifer is generally west to east near the 200 West Area and west to east along the south boundary of the aquifer near the Rattlesnake Hills. This flow pattern indicates that recharge occurs west of the 200 West Area in upgradient areas within the Cold Creek Valley, as well as in the Dry Creek Valley and possibly the Rattlesnake Hills. In the central portion of the aquifer in the vicinity of the 200 East Area, flow converges from the west, south, and east before discharging to the unconfined aquifer where the confining mud unit (unit 8) is absent (PNNL-12261). This water is thought to flow southeastward over the top of the confining unit (PNNL-15479), although the exact location of the division between northwest and southeast flow within the 200 East Area unconfined aquifer is not known. Water-level elevation data from well pair 299-E25-28 and 299-E25-34, which monitor different depths of the unconfined aquifer (Figure 2.14-2), as well as from piezometers 299-E25-32P and 299-E25-32Q also monitoring different depths, suggest a slight upward gradient along the confining unit boundary. This upward gradient is consistent with the discharge of groundwater from the confined aquifer to the overlying unconfined aquifer.

Elevated water levels are present in the Ringold Formation confined aquifer northeast of $B$ Pond as a remnant of past wastewater discharges to this facility. This causes southwest flow beneath B Pond to the 200 East Area. Eastward flow away from the region of elevated water levels does not occur, because the May Junction Fault, located east of B Pond, is thought to be a hydrologic barrier preventing flow to the east (PNNL-12261). South of the B Pond area, the flow of water divides with some moving northwest toward the 200 East Area and some moving toward the east or southeast. The location of this flow divide is not accurately known, due partly to a lack of water-level data in this area and because the southward extent of the May Junction Fault is not well defined.

The potentiometric contours for the Ringold Formation confined aquifer, shown in Figure 2.14-1, are similar to the potentiometric surface contours for the upper basalt-confined
Groundwater in the Ringold Formation confined aquifer flows generally west to east in the vicinity of the 200 West Area and west to east along the south boundary of the aquifer. 


\section{Groundwater}

quality in the

upper basalt-

confined aquifer is

monitored because

of the potential

for downward

migration of

contaminants

from the overlying

unconfined aquifer. aquifer (see Section 2.14.2.1), indicating that flow patterns in the central portion of the Hanford Site are similar in both aquifers. Basalt bedrock from Gable Gap into the 200 East Area vicinity was significantly eroded by late Pleistocene catastrophic flooding (RHO-BWILD-5), which facilitates intercommunication between the unconfined and confined aquifers. The 200 East Area vicinity is a discharge area for both of the confined aquifers, which explains the similar flow patterns.

Water levels declined in the Ringold Formation confined aquifer during the period from March 2005 to April/May 2006. The declines in individual wells ranged from 0.05 to 0.22 meter within the aquifer, and up to 0.44 meter in the 200 West Area along the boundary between the confined and unconfined aquifers. The potentiometric surface is responding to the curtailment of liquid effluent discharges to ground since the discharge volume peaked in the mid 1980s. As in previous years, the declines were largest in the 200 West Area (up to 0.44 meter) and the B Pond vicinity (up to 0.22 meter).

\subsubsection{Groundwater Quality in the Ringold Formation Confined Aquifer}

The 200 Areas Central Plateau and the area near the inactive B Pond system are the two known areas where contamination can migrate from the unconfined aquifer into the Ringold Formation confined aquifer. Groundwater chemistry data for the Ringold Formation confined aquifer are limited to wells near the 200 Area Treated Effluent Disposal Facility and B Pond facilities. During fiscal year (FY) 2006, three wells were sampled that are completed in the Ringold Formation confined aquifer (Figure 2.14-3). Data for potential contaminants of interest are listed in Table 2.14-1. Iodine-129 in a single well was the only contaminant present at a level above the drinking water standard. The well is located north of B Pond and has elevated tritium (Table 2.14-1).

\subsubsection{Upper Basalt-Confined Aquifer}

Groundwater quality in the upper basalt-confined aquifer is monitored because of the potential for downward migration of contaminants from the overlying unconfined aquifer. Contaminants that reach the upper basalt-confined aquifer have the potential to migrate through the aquifer and deeper confined aquifers to areas off the Hanford Site. The upper basalt-confined aquifer is also monitored to assess the potential migration of contaminants onto the Hanford Site from offsite sources. Additional information regarding the potential for contaminants to migrate off the Hanford Site can be found in PNL-10817 and PNNL-14107.

Within the upper basalt-confined aquifer system, groundwater occurs within basalt fractures and joints, interflow contacts, and sedimentary interbeds within the upper Saddle Mountains Basalt. The thickest and most widespread sedimentary unit in this system is the Rattlesnake Ridge Interbed, which is present beneath much of the Hanford Site. Groundwater also occurs within the Levey Interbed, which is present only in the south portion of the site. An interflow zone occurs within the Elephant Mountain Member of the upper Saddle Mountains Basalt and also may be significant to the lateral transmission of water. This system is confined by the dense, low-permeability, interior portions of basalt flows and in some places by Ringold Formation silt and clay units overlying the basalt.

Figure 2.14-3 shows the location of the upper basalt-confined aquifer monitoring wells on the Hanford Site. Most of the wells are completed in the Rattlesnake Ridge Interbed near the 200 East Area in the central part of the Hanford Site. A few wells are completed in the Elephant Mountain interflow zone, the Levey Interbed, or a composite of one or more interbeds and/or interflow zones within the upper Saddle Mountains Basalt. 


\subsubsection{Groundwater Flow in the Upper Basalt-Confined Aquifer}

Figure 2.14-4 presents an approximation of the April/May 2006 potentiometric surface for the upper basalt-confined aquifer system south of Gable Butte and Gable Mountain. The region to the north of Gable Butte and Gable Mountain was not contoured because of insufficient well control. (See PNL-8869 for a generalized potentiometric surface map of this area.) The upper basalt-confined aquifer is interpreted to not exist in Cold Creek Valley and along the west portion of the Gable Mountain/Gable Butte structural area due to the absence of the Rattlesnake Ridge interbed.

Recharge to the upper basalt-confined aquifer system is believed to occur from upland areas along the margins of the Pasco Basin and results from the infiltration of precipitation and surface water where the basalt and interbeds are exposed at or near ground surface. Recharge may also occur through the overlying aquifers (i.e., the unconfined aquifer or confined aquifer in the Ringold Formation) in areas where the hydraulic gradient is downward, and from deeper basalt aquifers where an upward gradient is present. The Yakima River may also be a source of recharge to this aquifer system. The Columbia River represents a discharge area for this aquifer system in the south portion of the Hanford Site, but not for the north portion (PNL-8869). Discharge also occurs to the overlying aquifers in areas where the hydraulic gradient is upward. Discharge to overlying or underlying aquifers in the vicinity of the Gable Butte/Gable Mountain structural area may occur through erosional windows in the basalt.

South of Gable Butte and Gable Mountain, groundwater in the upper basalt-confined aquifer system generally flows from west to east across the Hanford Site toward the Columbia River. The May Junction Fault, located east of B Pond and in a north-south trend, acts as a barrier to groundwater flow in the unconfined aquifer and the confined aquifer within the Ringold Formation (PNNL-12261). It may also impede the movement of water in the upper basalt-confined aquifer system by juxtaposing permeable units opposite impermeable units. As with the Ringold Formation confined aquifer, a flow divide is interpreted to exist southeast of the 200 East Area and B Pond in the upper basalt-confined aquifer system, but the exact location of this divide is uncertain due to a lack of well control in the area.

Groundwater flow rates within the Rattlesnake Ridge Interbed have been estimated to be between 0.7 and 2.9 meters/year (PNL-10817). This flow rate is considerably slower than most estimates for the overlying unconfined aquifer system. The sediment comprising the interbed consists mostly of tuffaceous sandstone along with silts and clays, and is less permeable than the sediments in the unconfined aquifer. Also, the magnitude of the hydraulic gradient is generally lower than in the unconfined aquifer.

The vertical hydraulic gradient between the upper basalt-confined aquifer system and the overlying aquifer varies spatially (Figure 2.14-5). A downward gradient exists in the west portion of the Hanford Site, near the B Pond recharge mound, as well as in the regions north and east of the Columbia River. In the B Pond vicinity, the vertical head gradient between the unconfined aquifer system and the upper basalt-confined aquifer system has diminished in recent years but remains downward. In other areas of the Hanford Site, the hydraulic gradient is upward from the upper basalt-confined aquifer to the overlying aquifer system.

In the 200 East Area vicinity, the potentiometric surface in Figure 2.14-4 is similar to the potentiometric surface for the Ringold Formation confined aquifer (compare with Figure 2.14-1). The basalt in this area was significantly eroded by late Pleistocene catastrophic flooding, which facilitates aquifer intercommunication (RHO-BWI-LD-5). In the 200 East Area and to the immediate north, the vertical hydraulic gradient between the upper basaltconfined aquifer system and the overlying aquifer is upward. Therefore, it is likely the upper basalt-confined aquifer system currently discharges to the overlying aquifer in this region.

Water levels in the upper basalt-confined aquifer declined over most of the Hanford Site from March 2005 to April/May 2006. In the 200 East Area and to the immediate
Groundwater in

the upper basaltconfined aquifer system generally flows from west to east across

the Hanford Site toward the Columbia River. 
The small amount

of contamination

detected in the

upper basalt-

confined aquifer is

attributed to areas

where confining

units of basalt are

absent or where

wells provided

a pathway for

migration.

\section{Cyanide, nitrate,}

and technetium-99

were elevated

in one well in

the 200 East/

Gable Mountain

region, an area of

intercommunication

between the

upper basalt-

confined aquifer

and the overlying

unconfined aquifer. north and east (near B Pond), water-level declines in wells ranged from 0.07 to 0.28 meter, with an increase of 0.02 meter observed in one well. Water-level declines in wells near the 200 West Area ranged from 0.03 to 0.13 meter. The declines are in response to curtailed effluent disposal activities in the 200 Areas and are consistent with water-level declines in the overlying unconfined aquifer and confined aquifer in the Ringold Formation.

Water levels in the upper basalt-confined aquifer along the Columbia River in the east part of the site (i.e., wells 699-13-1C and 699-24-1P) demonstrate long-term increasing trends, although measurements from year to year fluctuate. The long-term increase is interpreted to be the result of offsite irrigation east of the Columbia River (PNL-8869). After two years of declines, the water level began to increase again (0.03 meter in well 699-13-1C) for March 2005 to April/May 2006.

\subsubsection{Groundwater Quality in the Upper Basalt-Confined Aquifer}

The upper basalt-confined aquifer is affected by contamination much less than the overlying unconfined aquifer system. Contamination found in the upper basalt-confined aquifer is most likely attributed to areas where confining units of basalt have been eroded away or were never deposited and where past disposal of large amounts of wastewater resulted in downward hydraulic gradients. In some areas, wells penetrating the upper basalt-confined aquifer system provided a downward pathway for contaminant migration. Because of these factors, intercommunication between the aquifers permitted groundwater flow from the unconfined aquifer to the underlying confined aquifer, thereby increasing the potential to spread contamination.

An area of intercommunication between the unconfined and upper basalt-confined aquifer systems was first identified in the north part of the 200 East Area (RHO-BWI-ST-5; RHO-RE-ST-12 P). Several confined aquifer wells north and east of the 200 East Area have shown evidence of intercommunication with the overlying unconfined aquifer (PNL-10817). Intercommunication between the unconfined and confined aquifers in this region has been attributed to erosion of the upper Saddle Mountains Basalt and a downward hydraulic gradient that resulted from groundwater mounding associated with past wastewater disposal to the ground. However, this groundwater mounding has diminished in recent years (see Section 2.14.1).

Wells completed in the upper basalt-confined aquifer system are routinely sampled on the Hanford Site. Most of these wells are sampled every 3 years, and a few are sampled annually. During FY 2004 through 2006, 33 samples were collected from 19 wells and analyzed for chemical and radiological constituents. Many of the samples were analyzed for tritium, iodine-129, and nitrate because these constituents (1) are the most widespread in the overlying unconfined aquifer, (2) are some of the most mobile constituents in groundwater, and (3) provide an early warning for potential contamination in the upper basalt-confined aquifer system. Groundwater samples from the upper basalt-confined aquifer were also analyzed for anions (besides nitrate), cations, cyanide, gross alpha, gross beta, gamma-emitters, strontium-90, technetium-99, and uranium isotopes. Data for the potential contaminants of interest are listed in Table 2.14-2. A full data set is included in the data files that accompany this report.

Distribution of sample results for selected constituents and wells across the Hanford Site for FY 2004 through 2006 is shown in Figure 2.14-6. Tritium at the Hanford Site ranged from less than the detection limits near the discharge area in the east-southeast portion of the Hanford Site to $5,080 \mathrm{pCi} / \mathrm{L}$ east of the 200 East Area. Concentrations have been decreasing at this location since 1996 (Figure 2.14-7). This elevated tritium is located in the 200 East Area/Gable Mountain region, an area of intercommunication with the overlying contaminated unconfined aquifer. Nearby wells completed in the Ringold Formation show elevated but declining trends. Near the 618-11 burial ground, where a source of tritium has 
contaminated the unconfined aquifer at high levels, tritium was detected at a concentration of $31.6 \mathrm{pCi} / \mathrm{L}$ in the upper basalt-confined aquifer in FY 2004. An upward hydraulic gradient exists at this location.

In the north part of the 200 East Area, technetium-99 continued to be elevated in the upper basalt-confined aquifer in one well (Figure 2.14-6). The technetium-99 concentration was $1,060 \mathrm{pCi} / \mathrm{L}$ in this well (299-E33-12) in 2006. However this level, which exceeds the drinking water standard $(900 \mathrm{pCi} / \mathrm{L})$, is slightly lower than concentrations since a seal was placed in the well in the early 1990s (Figure 2.14-8). Contamination in this well is attributed to migration of high-salt waste down the borehole during construction when it was open to both the unconfined and confined aquifers (RHO-RE-ST-12 P). A seal was placed in this well to prevent intercommunication between the unconfined and confined aquifers. This well is located in the vicinity of a technetium-99 plume in the overlying unconfined aquifer (Section 2.10.1). An area of complete erosion of the Saddle Mountains Basalt occurs in the northeast corner of the 200 East Area, east of this well (RHO-RE-ST-12 P).

Cyanide and nitrate are also elevated in the same well (299-E33-12) that technetium-99 is elevated in (Figure 2.14-9). However, these co-contaminants are at levels that do not exceed their respective drinking water standards. Concentrations of cyanide and nitrate have declined slightly at this well since the early 1990s. Like technetium-99, this contamination is associated with migration of high-salt waste down the borehole during well construction when it was open to both the unconfined and confined aquifers (RHO-RE-ST-12 P). Cyanide and nitrate are co-contaminants with much higher concentrations in the unconfined aquifer in the north part of the 200 East Area.

Nitrate levels in the upper basalt-confined aquifer typically range from less than detectable to $\sim 37 \mathrm{mg} / \mathrm{L}$ across the Hanford Site. Higher levels indicate intercommunication with the overlying contaminated unconfined aquifer (RHO-BWI-ST-5; RHO-RE-ST-12 P; PNL-10817). The majority of wells with higher nitrate in the upper basalt-confined aquifer occur near Gable Mountain and the 200 East Area (Table 2.14-2).

Some samples collected from upper basalt-confined aquifer wells were analyzed for iodine-129. These wells are located beneath or near the iodine-129 plume contained within the overlying unconfined aquifer. Iodine-129 was not detected in the upper basalt-confined aquifer during FY 2004 through 2006 (Table 2.14-2).

A few samples collected from upper basalt-confined aquifer wells were analyzed for gamma-emitting and uranium isotopes. Gamma-emitting isotopes were not detected in the upper basalt-confined aquifer on the Hanford Site, including the Gable Mountain/200 East Area. Uranium isotopes were not detected in this aquifer in the eastern part of the Hanford Site during FY 2004 through 2006.

In summary, cyanide, nitrate, and technetium-99 were elevated in an upper basaltconfined aquifer well in the north part of the 200 East Area. Migration of high-salt waste via the well bore during its construction is responsible for this contamination. Tritium was predominantly detected at low levels or was not detected. One elevated tritium concentration near the 200 East Area is associated with intercommunication between the upper basaltconfined aquifer and the overlying unconfined aquifer but was less than the drinking water standard. Iodine-129, strontium-90, gamma-emitting isotopes, and uranium isotopes were not detected above the minimum detection limits in the upper basalt-confined aquifer.

\section{Gamma-emitting isotopes were not detected in the upper basalt- confined aquifer on the Hanford Site}


Table 2.14-1. Potential Contaminants of Interest in Ringold Formation Confined Aquifer, FY 2004 through FY 2006

\begin{tabular}{|c|c|c|c|c|c|c|c|c|}
\hline Well & Sample Date & $\begin{array}{c}\text { Gross Alpha } \\
(\mathrm{pCi} / \mathrm{L})\end{array}$ & $\begin{array}{c}\text { Gross Beta } \\
(\mathrm{pCi} / \mathrm{L})\end{array}$ & $\begin{array}{l}\text { lodine-129 } \\
(\mathrm{pCi} / \mathrm{L})\end{array}$ & $\begin{array}{l}\text { Nitrate } \\
(\mathrm{mg} / \mathrm{L})\end{array}$ & $\begin{array}{c}\text { Specific } \\
\text { Conductance } \\
(\mu S / \mathrm{cm})\end{array}$ & $\begin{array}{l}\text { Tritium } \\
(\mathrm{pCi} / \mathrm{L})\end{array}$ & $\begin{array}{c}\text { Uranium } \\
(\mu \mathrm{g} / \mathrm{L})\end{array}$ \\
\hline $699-40-36$ & $10 / 22 / 03$ & $1.54 \mathrm{U}$ & 9.53 & NA & 0.102 & 295 & NA & NA \\
\hline $699-40-36$ & $01 / 21 / 04$ & 3.03 & 8.82 & NA & 0.0974 & 308 & NA & NA \\
\hline $699-40-36$ & $04 / 01 / 04$ & 2.65 & 10.9 & NA & $0.0487 \mathrm{U}$ & 315 & NA & NA \\
\hline 699-40-36 & 07/07/04 & 2.91 & 9.23 & NA & $0.0753 \mathrm{~B}$ & 316 & NA & NA \\
\hline $699-40-36$ & $10 / 20 / 04$ & $0.95 \mathrm{U}$ & 6.5 & NA & $0.204 \mathrm{~B}$ & 309 & $8.53 \mathrm{U}$ & 3.57 \\
\hline 699-40-36 & 01/19/05 & 5 & 4.1 & NA & 6.02 & 314 & NA & 7.56 \\
\hline $699-40-36$ & 05/03/05 & 4.7 & 5.4 & NA & $0.0974 \mathrm{U}$ & 313 & NA & 3.48 \\
\hline 699-40-36 & 09/21/05 & 2.2 & 6.4 & NA & $0.0797 \mathrm{U}$ & 306 & NA & 3.44 \\
\hline $699-40-36$ & $11 / 08 / 05$ & 3.8 & 5.7 & NA & $0.0797 \mathrm{U}$ & NA & $-11.1 \mathrm{U}$ & 3.82 \\
\hline $699-40-36$ & 01/19/06 & 2.8 & 7.6 & NA & $0.0797 \mathrm{U}$ & NA & NA & 3.46 \\
\hline $699-40-36$ & $04 / 11 / 06$ & 4.4 & 8.8 & NA & $0.102 \mathrm{~B}$ & NA & NA & 3.64 \\
\hline 699-40-36 & 07/05/06 & $1.5 \mathrm{U}$ & 6.6 & NA & 0.0974 B & NA & NA & 3.21 \\
\hline $699-41-35$ & $10 / 22 / 03$ & 4.51 & 9.58 & NA & 0.908 & 322 & 23.2 & NA \\
\hline 699-41-35 & $01 / 21 / 04$ & 2.45 & 7.44 & NA & 1.02 & 323 & NA & NA \\
\hline 699-41-35 & 04/01/04 & 5.3 & 11.4 & NA & 0.974 & 328 & NA & NA \\
\hline $699-41-35$ & 07/07/04 & 2.95 & 10.9 & NA & 0.797 & 329 & NA & NA \\
\hline 699-41-35 & $10 / 20 / 04$ & 2.75 & 5.85 & NA & 0.872 & 324 & 13.92 & 5.61 \\
\hline 699-41-35 & $01 / 19 / 05$ & 4.3 & 6.8 & NA & 0.930 & 326 & NA & 11.83 \\
\hline $699-41-35$ & 05/03/05 & 5.4 & 6.3 & NA & 0.792 & 328 & NA & 5.41 \\
\hline 699-41-35 & 09/21/05 & 3.8 & 6.5 & NA & 0.850 & 321 & NA & 5.32 \\
\hline $699-41-35$ & $11 / 08 / 05$ & 3.6 & 6.8 & NA & 0.801 & 320 & $5.44 \mathrm{U}$ & 5.82 \\
\hline $699-41-35$ & 01/19/06 & 2.8 & 8.9 & NA & 0.810 & 324 & NA & 5.32 \\
\hline 699-41-35 & $04 / 11 / 06$ & 5.4 & 8.6 & NA & 0.788 & NA & NA & 5.47 \\
\hline $699-41-35$ & $07 / 05 / 06$ & 3 & 9.2 & NA & 0.832 & NA & NA & 5.18 \\
\hline $699-42-37$ & $10 / 22 / 03$ & 7.18 & 7.37 & NA & $6.200 \mathrm{D}$ & 358 & 13.5 & NA \\
\hline $699-42-37$ & $01 / 21 / 04$ & 5.45 & 4.85 & NA & 6.640 & 359 & NA & NA \\
\hline $699-42-37$ & $04 / 01 / 04$ & 4.76 & 10.5 & NA & $6.640 \mathrm{D}$ & 369 & NA & NA \\
\hline $699-42-37$ & 07/07/04 & 6.61 & 6.89 & NA & $5.310 \mathrm{D}$ & 373 & NA & NA \\
\hline $699-42-37$ & $10 / 20 / 04$ & 2.9 & 5.6 & NA & 6.68 & 339 & $1.82 \mathrm{U}$ & 7.09 \\
\hline $699-42-37$ & 01/19/05 & 3.7 & 6.6 & NA & $0.0974 \mathrm{U}$ & 368 & NA & 3.86 \\
\hline $699-42-37$ & 05/03/05 & 3.8 & 6.5 & NA & 6.33 & 368 & NA & 6.85 \\
\hline $699-42-37$ & 09/21/05 & 4.2 & 3.9 & NA & 6.51 & 355 & NA & 6.70 \\
\hline $699-42-37$ & $11 / 08 / 05$ & 5.6 & 5.4 & NA & 6.73 & 352 & $16.0 \mathrm{U}$ & 7.18 \\
\hline $699-42-37$ & 01/19/06 & 3.4 & 5.6 & NA & 6.51 & 368 & NA & 6.8 \\
\hline $699-42-37$ & $04 / 11 / 06$ & 6.2 & 6.1 & NA & 6.73 & NA & NA & 7.13 \\
\hline $699-42-37$ & 07/05/06 & $1.7 \mathrm{U}$ & 7.7 & NA & 6.73 & NA & NA & 6.38 \\
\hline $699-45-42$ & $07 / 28 / 04$ & NA & NA & 2.98 & 3.59 & 279 & 9,530 & NA \\
\hline \multicolumn{9}{|c|}{$\begin{array}{l}B=\text { Analyte detected at a value less than the contract required detection limit. } \\
D=\text { Analyzed at a secondary dilution factor. } \\
N A=\text { Not analyzed. } \\
U=\text { Below detection limit. }\end{array}$} \\
\hline
\end{tabular}


Table 2.14-2. Potential Contaminants of Interest in Upper Basalt-Confined Aquifer, FY 2004 through 2006

\begin{tabular}{|c|c|c|c|c|c|c|c|c|c|c|c|c|}
\hline Well & Sample Date & $\begin{array}{c}\text { Cesium-137 } \\
\text { (pCi/L) }\end{array}$ & $\begin{array}{c}\text { Cobalt-60 } \\
(\mathrm{pCCi} L)\end{array}$ & $\begin{array}{c}\text { Cyanide } \\
(\mu \mathrm{g} / \mathrm{L})\end{array}$ & $\begin{array}{c}\text { Gross Alpha } \\
(\mathrm{pCi} / \mathrm{L})\end{array}$ & $\begin{array}{c}\text { Gross Beta } \\
(\mathrm{pCCi} / \mathrm{L})\end{array}$ & $\begin{array}{l}\text { Iodine-129 } \\
(\mathrm{pCi} / \mathrm{L})\end{array}$ & Nitrate $(\mathrm{mg} / \mathrm{L})$ & $\begin{array}{c}\text { Specific } \\
\text { Conductance } \\
(\mu \mathrm{S} / \mathrm{cm})\end{array}$ & $\begin{array}{l}\text { Strontium-90 } \\
(\mathrm{pCi} / \mathrm{L})\end{array}$ & $\begin{array}{c}\text { Technetium-99 } \\
(\mathrm{pCCi} / \mathrm{L})\end{array}$ & $\begin{array}{l}\text { Tritium } \\
(\mathrm{pCi} / \mathrm{L})\end{array}$ \\
\hline 199-H4-2 & $07 / 17 / 06$ & NA & NA & NA & $1.07 \mathrm{U}$ & 10.5 & $\mathrm{NA}$ & 0.416 & 241 & NA & NA & 7.33 \\
\hline 299-E16-1 & 10/06/03 & NA & NA & NA & $0.289 \mathrm{U}$ & 12.2 & NA & $0.0487 \mathrm{U}$ & 307 & NA & NA & 9.11 \\
\hline 299-E16-1 & $06 / 14 / 06$ & NA & NA & NA & $0.284 \mathrm{U}$ & 9.4 & $-0.027 \mathrm{U}$ & $0.0177 \mathrm{U}$ & 312 & NA & NA & $-32.8 \mathrm{U}$ \\
\hline 299-E26-8 & $10 / 02 / 03$ & NA & NA & NA & 4.32 & 12.1 & NA & 3.67 & 307 & NA & NA & 16.3 \\
\hline 299-E26-8 & $06 / 14 / 06$ & NA & NA & NA & 1.84 & 14.1 & $-0.132 U$ & 2.35 & 288 & NA & NA & 7.81 \\
\hline 299-E33-12 & $06 / 21 / 04$ & $-0.322 \mathrm{U}$ & $6.03 \mathrm{U}$ & 22.9 & 3.0 & 254 & $0.544 \mathrm{U}$ & $36.7 \mathrm{D}$ & 342 & NA & 1,090 & 153 \\
\hline 299-E33-12 & $03 / 18 / 06$ & NA & NA & NA & NA & NA & NA & NA & 340 & NA & 1,060 & NA \\
\hline $399-5-2$ & $06 / 23 / 04$ & NA & NA & NA & 8.5 & 8.66 & NA & $0.0394 \mathrm{~B}$ & 361 & NA & NA & $5.22 \mathrm{U}$ \\
\hline $699-13-1 C$ & $10 / 27 / 03$ & NA & NA & NA & $1.03 \mathrm{U}$ & 3.67 & NA & $0.0974 \mathrm{C}$ & 251 & NA & NA & 31.6 \\
\hline 699-24-1P & 10/28/05 & NA & NA & NA & $0.569 \mathrm{U}$ & 5.99 & NA & $0.044 \mathrm{U}$ & 374 & NA & NA & $11.2 \mathrm{U}$ \\
\hline 699-24-1P & 07/06/06 & NA & NA & NA & $1.33 \mathrm{U}$ & 8.91 & NA & 0.248 & 357 & NA & NA & $113 U$ \\
\hline 699-32-22B & 10/08/03 & NA & NA & NA & $1.78 \mathrm{U}$ & 11.5 & $-0.0353 \mathrm{U}$ & $0.0487 \mathrm{U}$ & 395 & NA & NA & $6.08 \mathrm{U}$ \\
\hline 699-32-22B & 10/08/03 & NA & NA & NA & $1.1 \mathrm{U}$ & 12 & $0.00454 \mathrm{U}$ & $0.0487 \mathrm{U}$ & 395 & NA & NA & 12.5 \\
\hline 699-32-22B & $06 / 28 / 06$ & NA & NA & NA & $1.27 \mathrm{U}$ & 12.5 & $0.0329 \mathrm{U}$ & $0.0177 \mathrm{U}$ & 377 & NA & NA & NA \\
\hline 699-42-E9B & 09/10/03 & $-0.446 \mathrm{U}$ & $-0.696 \mathrm{U}$ & NA & $0.862 \mathrm{U}$ & 6.52 & $0.0105 \mathrm{U}$ & 0.328 & 425 & NA & NA & NA \\
\hline 699-42-E9B & 07/19/04 & $2.88 \mathrm{U}$ & $-1.4 \mathrm{U}$ & NA & $0.62 \mathrm{U}$ & 11.4 & $0.0578 \mathrm{U}$ & $0.0177 \mathrm{U}$ & 431 & NA & NA & $0.168 \mathrm{U}$ \\
\hline 699-42-E9B & 10/12/05 & $1.12 \mathrm{U}$ & $0.785 \mathrm{U}$ & NA & $0.276 \mathrm{U}$ & 10.6 & $0.0962 \mathrm{U}$ & $0.0443 \mathrm{U}$ & 428 & NA & NA & 7.15 \\
\hline 699-42-E9B & $07 / 25 / 06$ & $-0.669 \mathrm{U}$ & $0.425 \mathrm{U}$ & NA & $0.985 \mathrm{U}$ & 13 & $-0.0034 \mathrm{U}$ & 0.124 & 425 & NA & NA & $4.38 \mathrm{U}$ \\
\hline 699-42-E9B & $07 / 25 / 06$ & $0.253 \mathrm{U}$ & $-1.4 \mathrm{U}$ & NA & $0.0592 \mathrm{U}$ & 11.2 & $0.0222 \mathrm{U}$ & $0.0177 \mathrm{U}$ & 425 & NA & NA & 8.04 \\
\hline $699-42-40 \mathrm{C}$ & 10/09/03 & NA & NA & NA & 1.8 & 12.6 & $0.253 \mathrm{U}$ & $4.87 \mathrm{D}$ & 324 & NA & NA & 5080 \\
\hline 699-49-57B & 03/09/04 & $0.605 \mathrm{U}$ & $-0.488 \mathrm{U}$ & $4.7 \mathrm{U}$ & $1.61 \mathrm{U}$ & 5.72 & $-0.843 \mathrm{U}$ & 1.15 & 302 & NA & $-2.39 \mathrm{U}$ & $-28.5 \mathrm{U}$ \\
\hline 699-49-57B & $03 / 21 / 05$ & $0.423 \mathrm{U}$ & $-1.2 \mathrm{U}$ & $2 \mathrm{U}, \mathrm{N}$ & NA & NA & $-0.0396 \mathrm{U}$ & $1.06 \mathrm{~N}$ & 304 & NA & $1.35 \mathrm{U}$ & $14.3 \mathrm{U}$ \\
\hline 699-49-57B & $03 / 13 / 06$ & $0.651 \mathrm{U}$ & $-1.56 \mathrm{U}$ & $2.4 \mathrm{U}$ & NA & NA & $0.067 \mathrm{U}$ & 1.11 & 300 & NA & $0.295 \mathrm{U}$ & $-63.8 \mathrm{U}$ \\
\hline 699-50-53B & 10/08/03 & NA & NA & NA & NA & NA & $0.0922 \mathrm{U}$ & $10.6 \mathrm{D}$ & 360 & NA & $1.38 \mathrm{U}$ & $-92.8 \mathrm{U}$ \\
\hline 699-50-53B & 06/28/06 & NA & NA & NA & NA & NA & $0.0167 \mathrm{U}$ & $12 \mathrm{D}$ & 360 & NA & $-0.42 \mathrm{U}$ & $4.16 \mathrm{U}$ \\
\hline $699-52-46 A$ & 06/30/04 & NA & NA & NA & 4.74 & 8.83 & NA & 1.86 & 338 & $0.16 \mathrm{U}$ & NA & 10.7 \\
\hline 699-54-34 & 07/01/04 & NA & NA & NA & $1.51 \mathrm{U}$ & 6.68 & NA & $12.4 \mathrm{D}$ & 291 & NA & NA & $5.17 \mathrm{U}$ \\
\hline $699-56-43$ & $10 / 09 / 03$ & NA & NA & NA & 2.47 & 6.33 & NA & $4.43 \mathrm{D}$ & 320 & NA & NA & 15.9 \\
\hline $699-56-43$ & $07 / 07 / 06$ & NA & NA & NA & 1.6 & 5.14 & NA & $4.87 \mathrm{D}$ & 319 & NA & NA & $0.815 \mathrm{U}$ \\
\hline $699-56-53$ & 10/08/03 & NA & NA & NA & 2.41 & 8.41 & NA & 0.930 & 368 & NA & NA & $16.9 \mathrm{U}$ \\
\hline 699-S11-E12AP & $02 / 03 / 04$ & NA & NA & NA & NA & NA & NA & $0.0487 \mathrm{U}$ & 335 & NA & NA & $-22.9 \mathrm{U}$ \\
\hline 699-S11-E12AP & $02 / 01 / 05$ & NA & NA & NA & NA & NA & NA & NA & 362 & NA & NA & $-0.298 \mathrm{U}$ \\
\hline 699-S11-E12AP & 06/29/06 & NA & NA & NA & $-0.216 \mathrm{U}$ & 8.54 & NA & $0.0177 \mathrm{U}$ & 360 & NA & NA & $128 \mathrm{U}$ \\
\hline 699-S2-34B & 01/21/04 & NA & NA & NA & NA & NA & NA & $0.0487 \mathrm{U}$ & 591 & NA & NA & $-75 U$ \\
\hline 699-S24-19P & 07/13/04 & NA & NA & NA & NA & NA & NA & 0.708 & 285 & NA & NA & 13.5 \\
\hline \multicolumn{13}{|c|}{$\begin{array}{l}\text { B = Analyte detected at a value less than the contract required detection limit, but greater than or equal to the minimum detection limit. } \\
C=\text { Analyte detected in both the sample and the associated quality control blank. } \\
D=\text { Analyzed at a secondary dilution factor. } \\
N=\text { Spike sample recovery is outside control limits. } \\
N A=\text { Not analyzed. } \\
U=\text { Below detection limit. }\end{array}$} \\
\hline
\end{tabular}




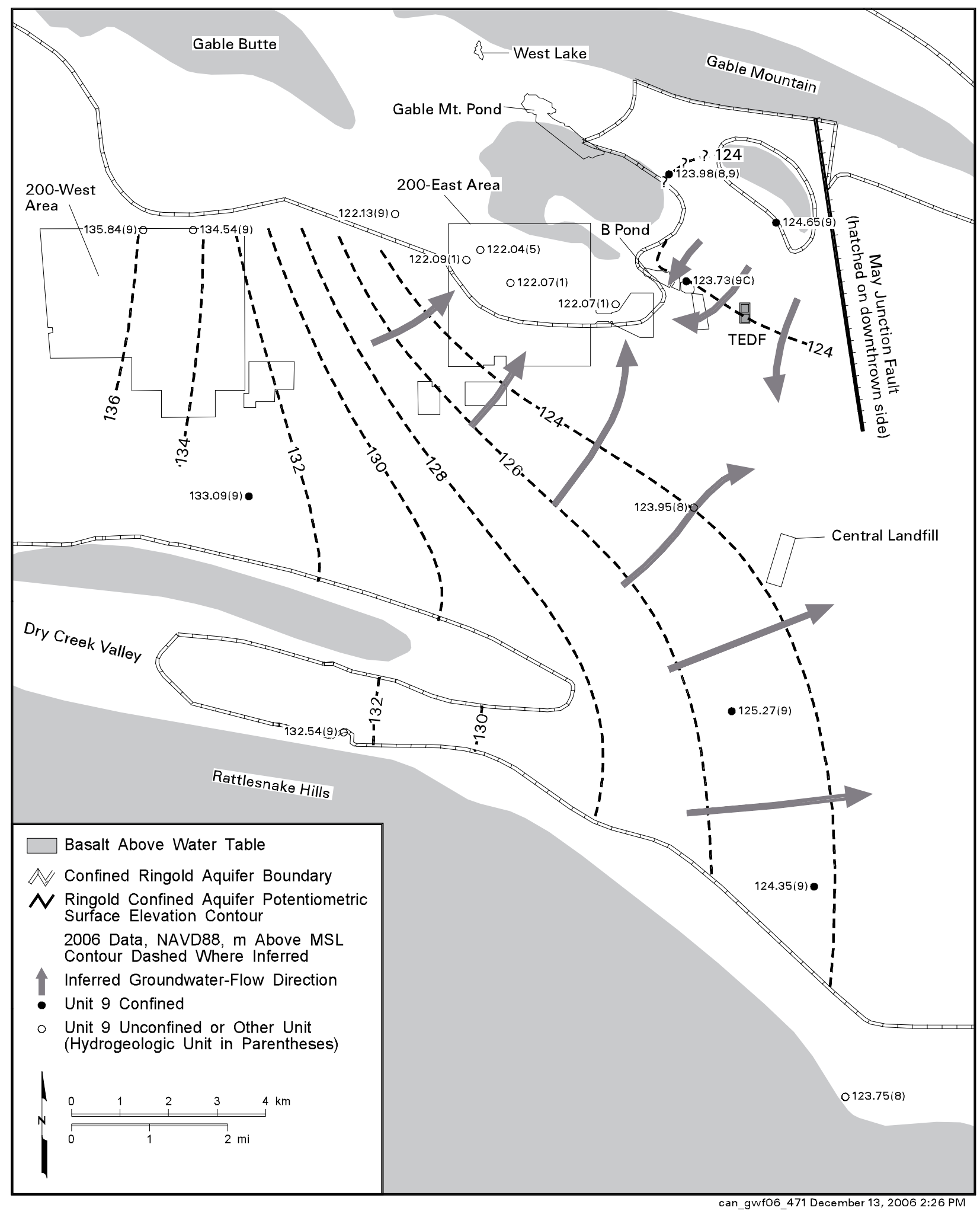

Figure 2.14-1. Potentiometric Surface Map of Ringold Formation Confined Aquifer (Unit 9), Central Hanford Site, April/May 2006 (compare with Figure 2.14-4) 


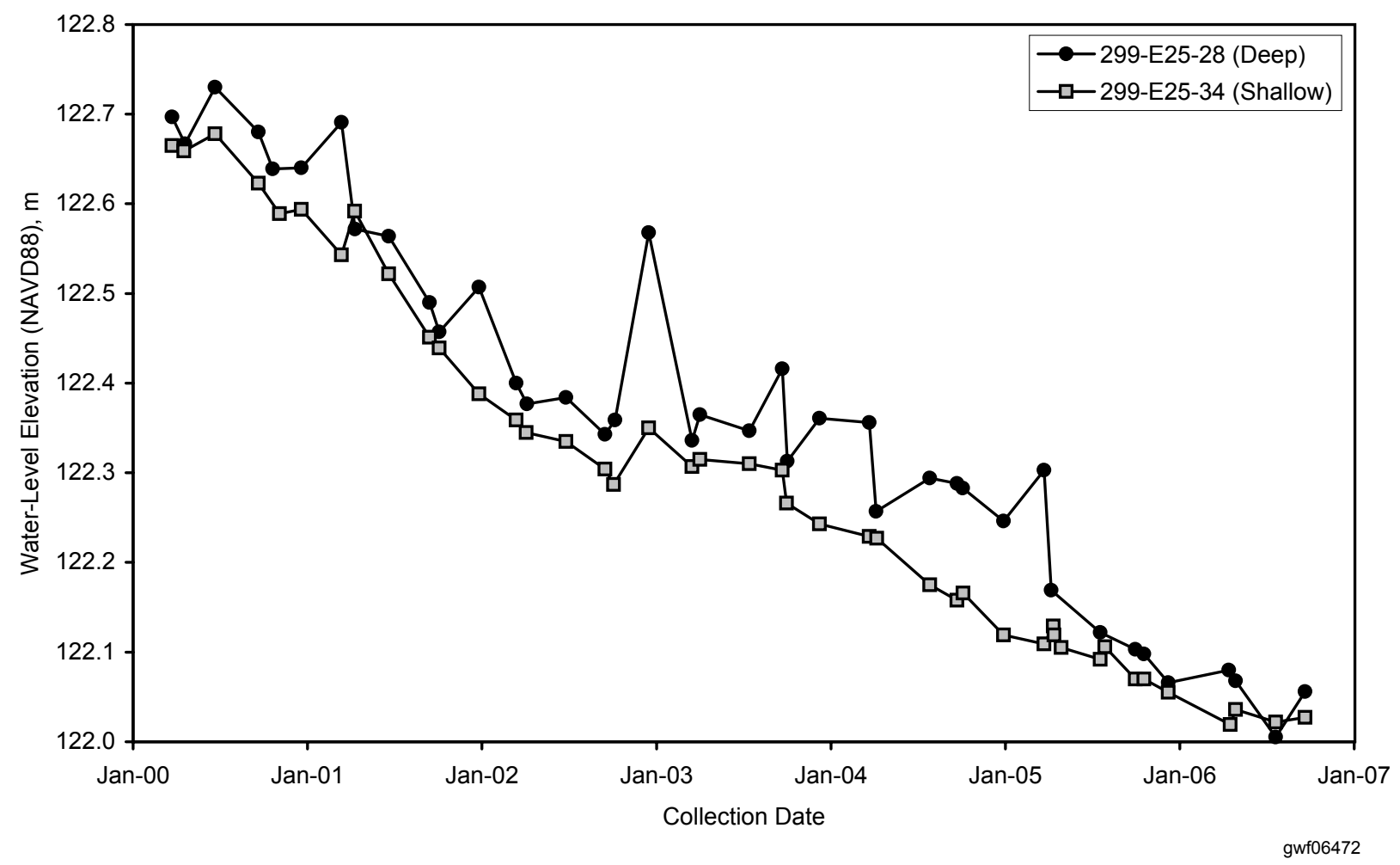

Figure 2.14-2. Water-Level Elevation in Wells Monitoring Different Depths of the Unconfined Aquifer Near 200 East Area 


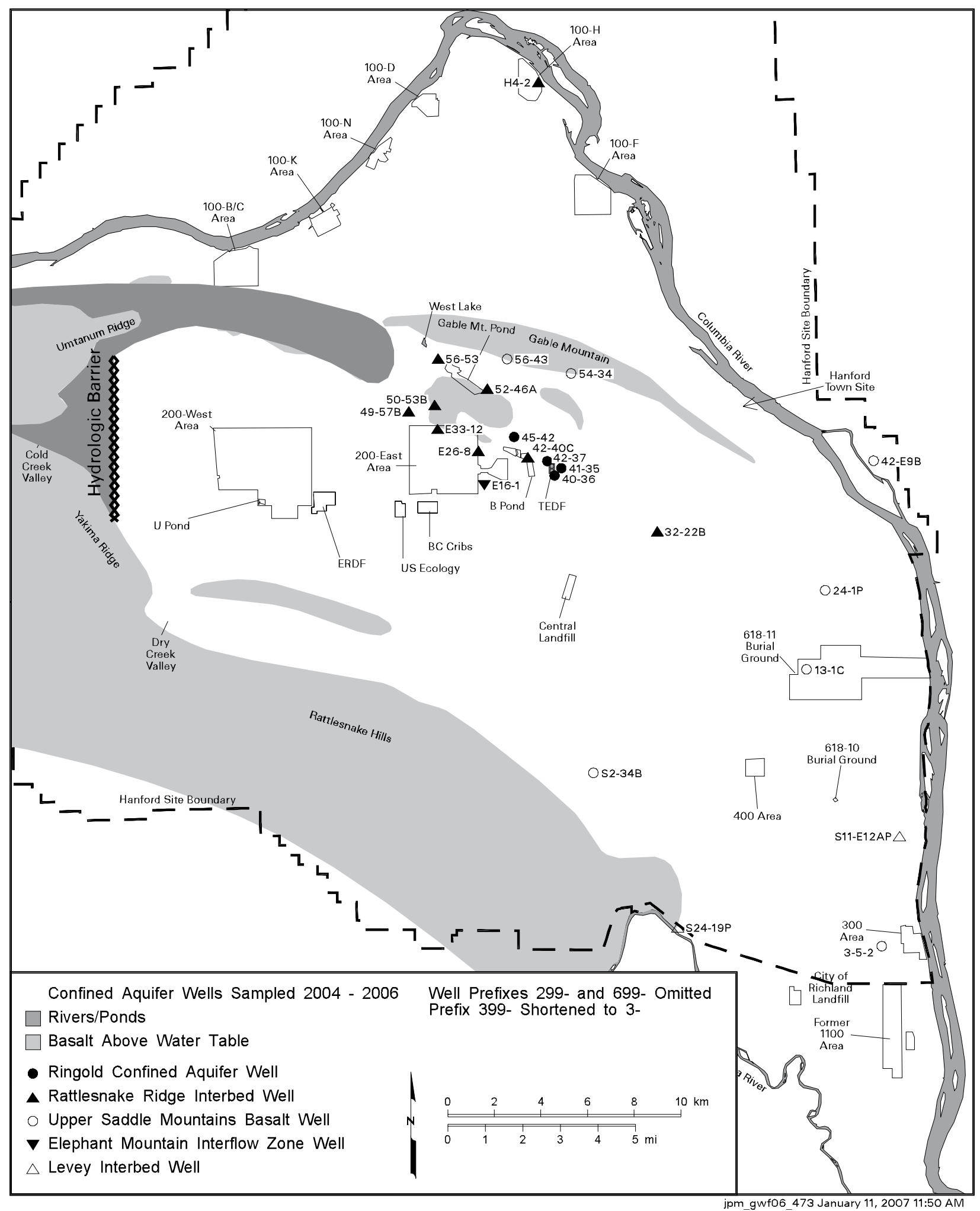

Figure 2.14-3. Groundwater Monitoring Wells Sampled in Ringold Formation Confined and Upper Basalt-Confined Aquifers, FY 2004 through 2006 


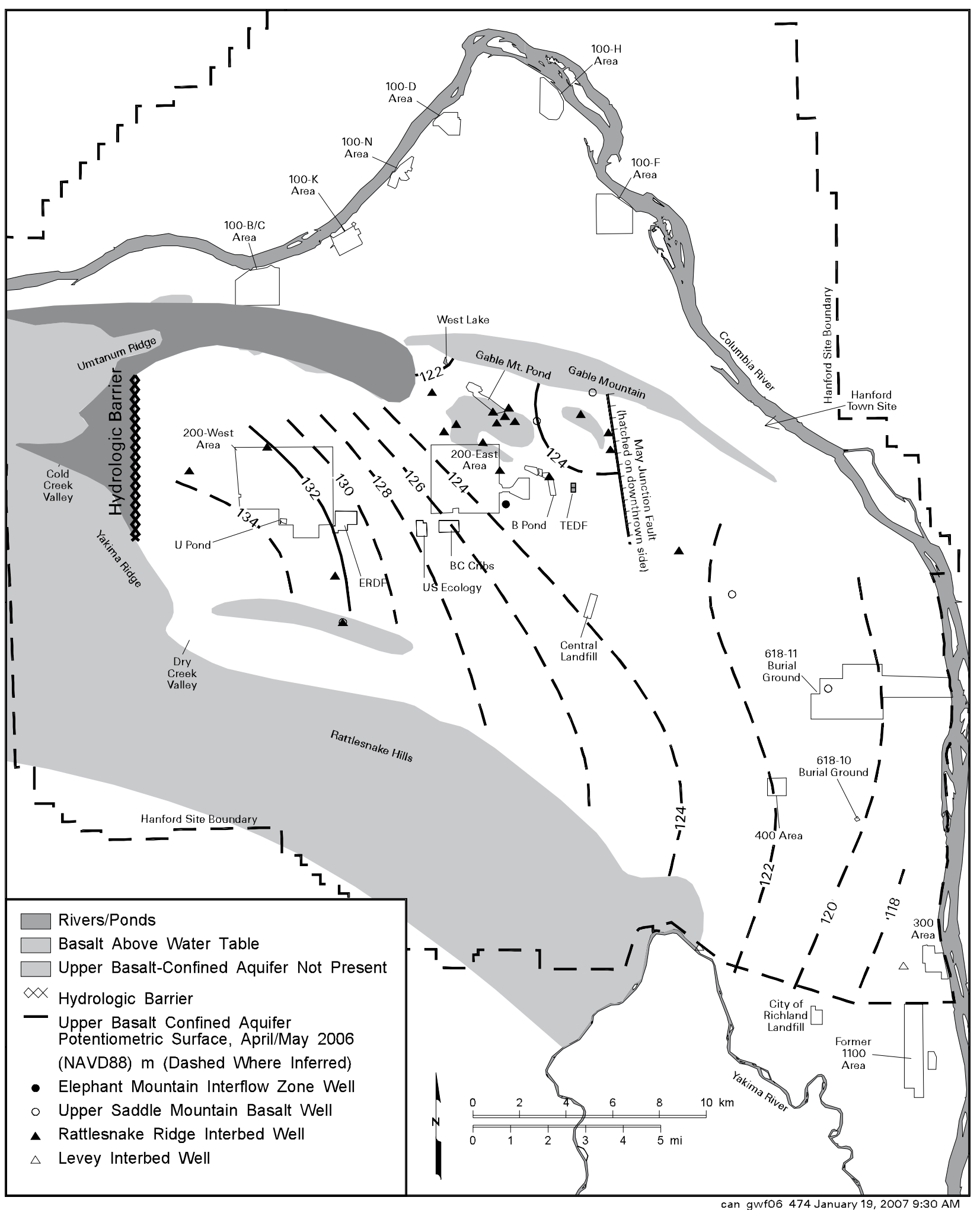

Figure 2.14-4. Potentiometric Surface Map of Upper Basalt-Confined Aquifer System, April/May 2006 (compare with Figure 2.14-1) 


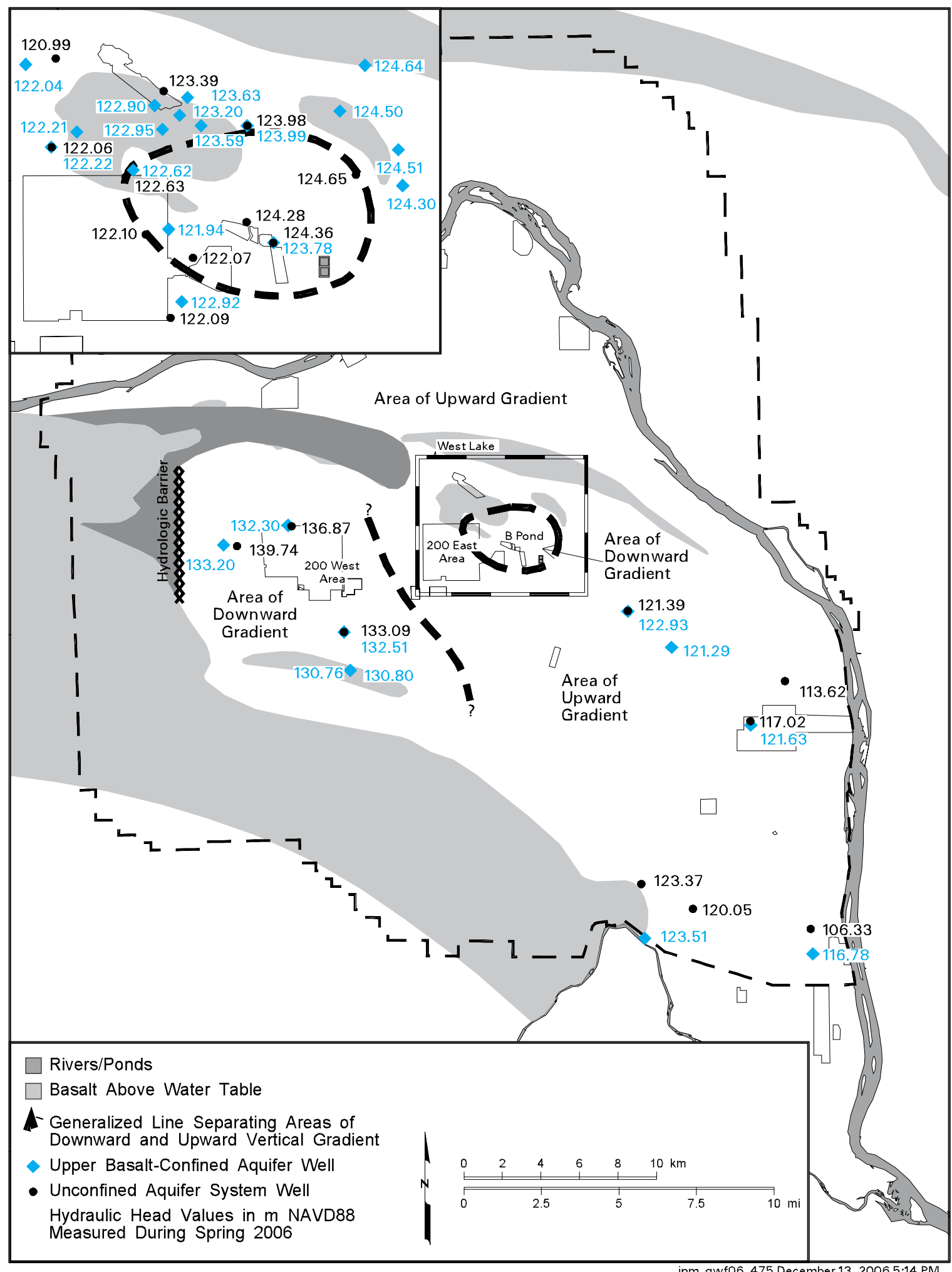

Figure 2.14-5. Comparison of Observed Heads for Upper Basalt-Confined Aquifer and Overlying Unconfined Aquifer 


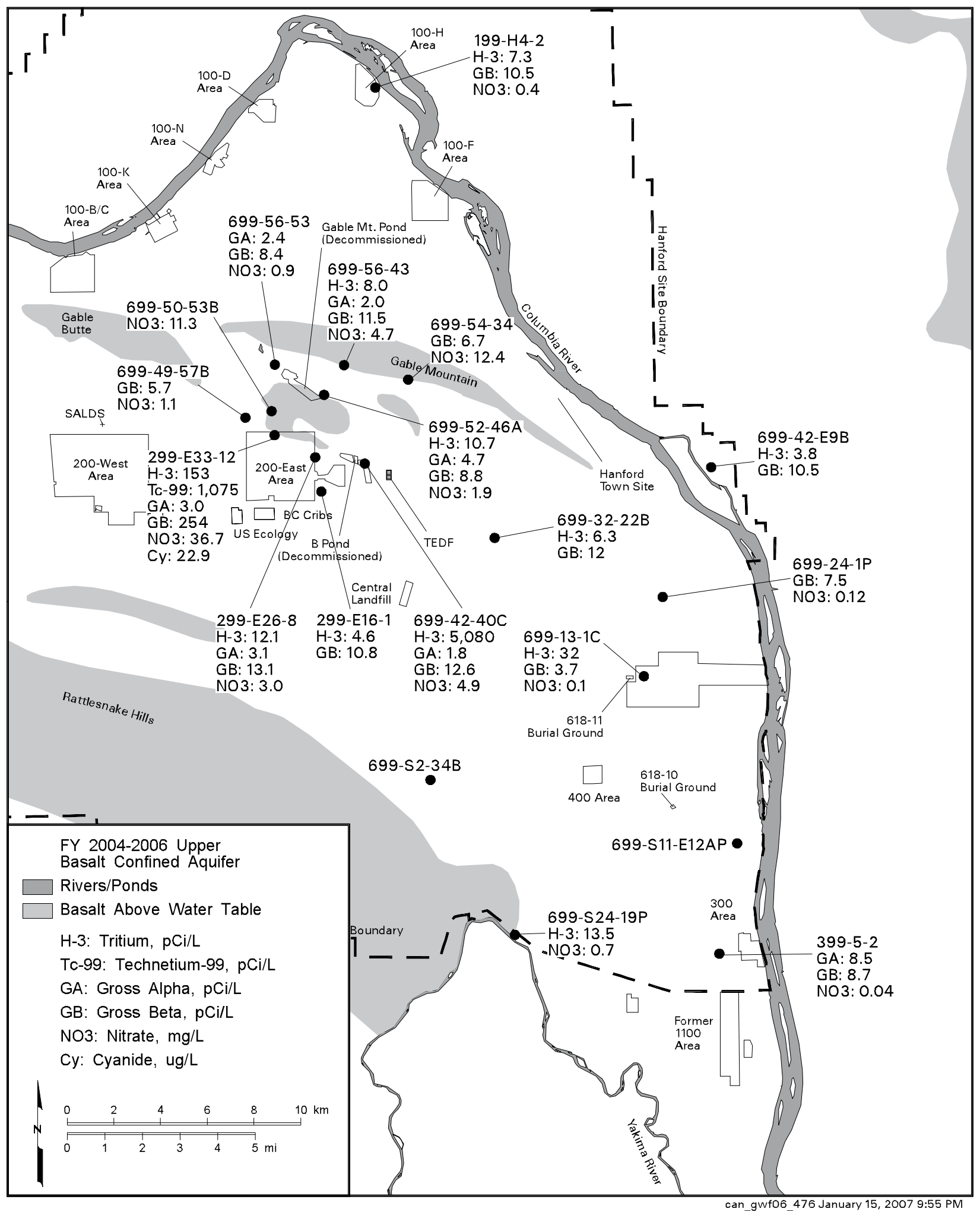

Figure 2.14-6. Distribution of Chemical and Radiological Constituents in Upper Basalt-Confined Aquifer, FY 2004 through 2006 


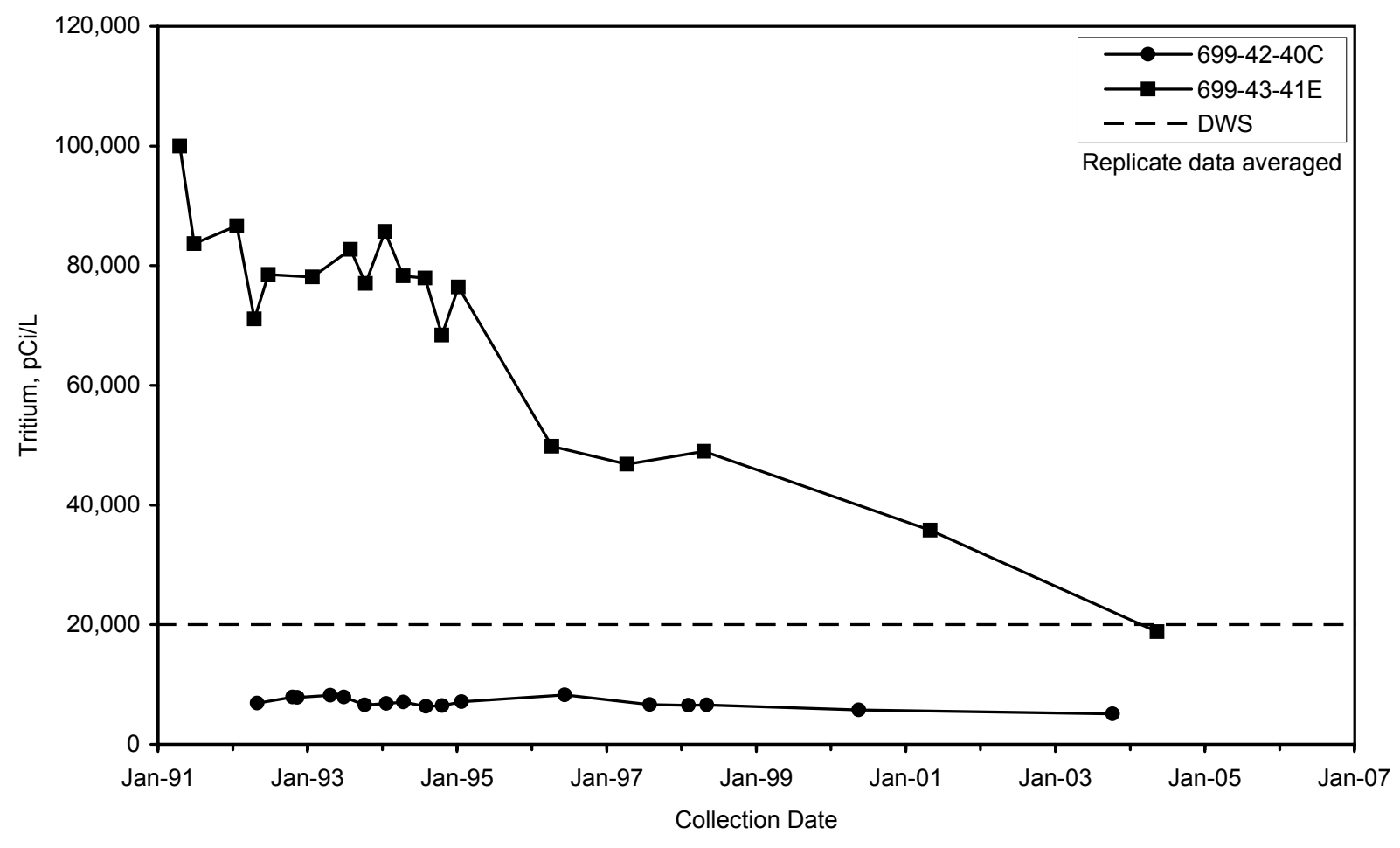

gw06477

Figure 2.14-7. Tritium Concentrations in Wells 699-42-40C (Upper Basalt-Confined Aquifer) and 699-43-41E (Unconfined Aquifer)

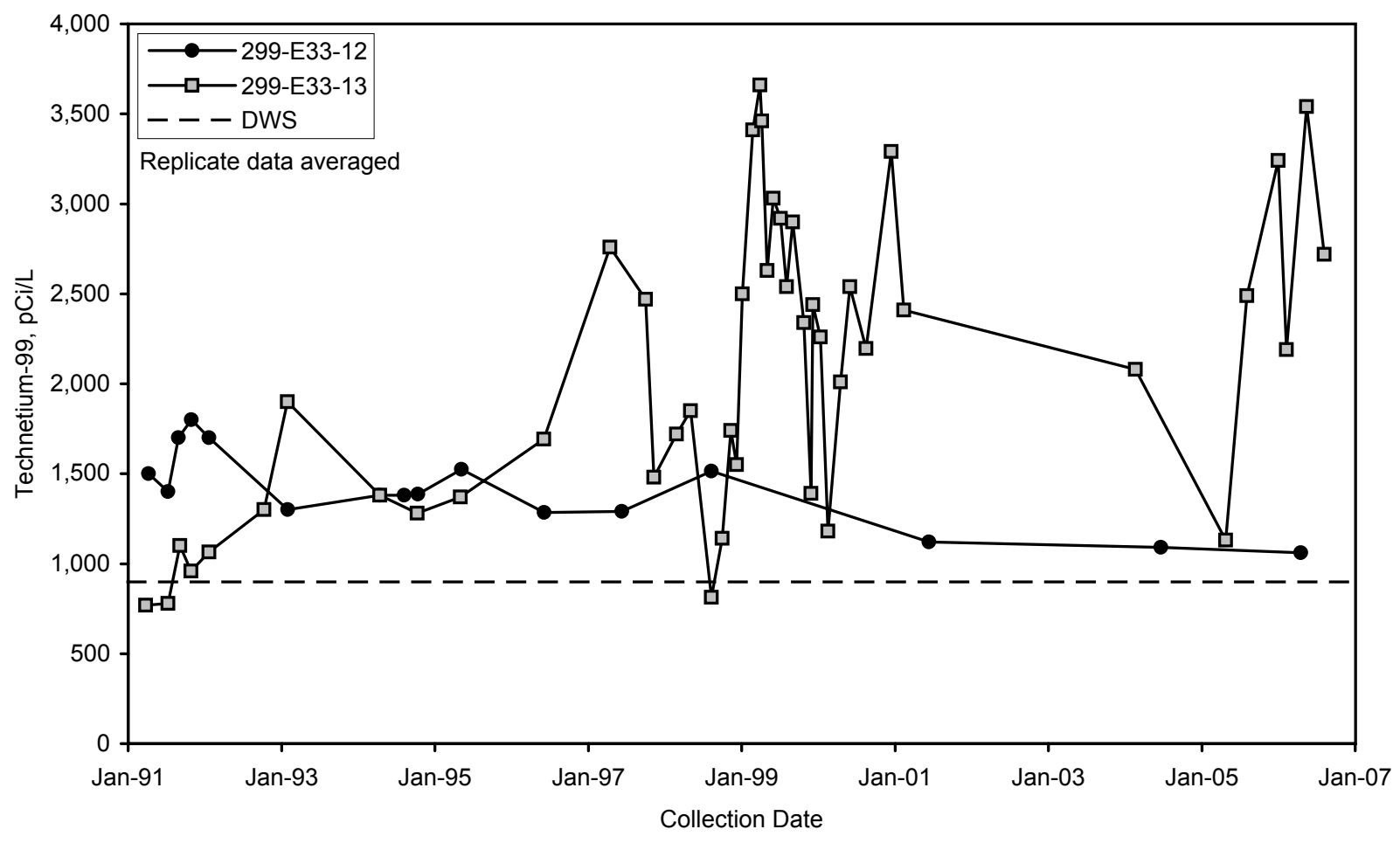

Figure 2.14-8. Technetium-99 Concentrations in Wells 299-E33-12 (Upper Basalt-Confined Aquifer) and 299-E33-13 (Unconfined Aquifer) 


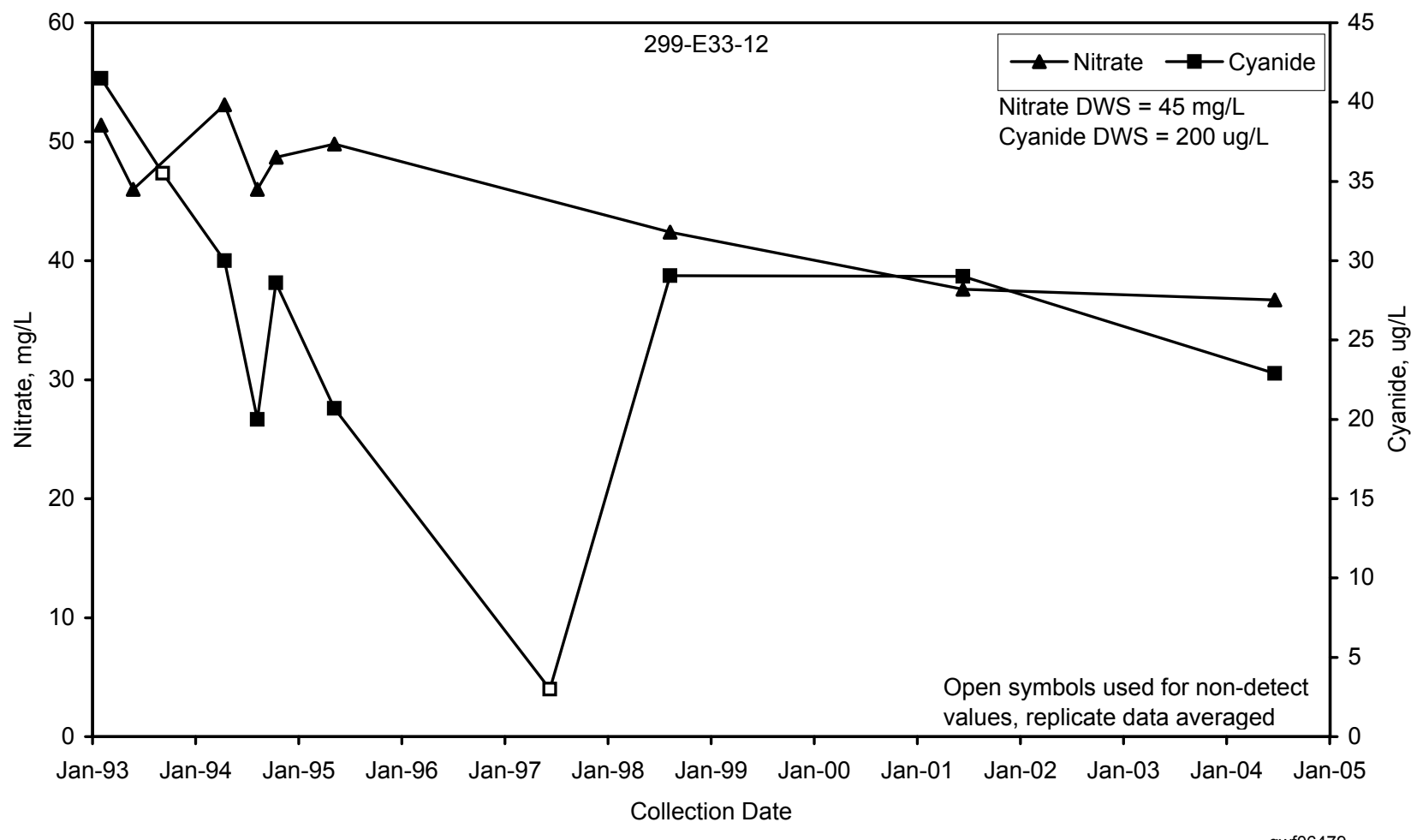

Figure 2.14-9. Cyanide and Nitrate Concentrations in Well 299-E33-12 


\subsection{Vadose Zone Monitoring, Characterization, and Special Studies}

\section{G. Horton}

Radioactive and hazardous waste in the soil column from past intentional liquid waste disposal, unplanned leaks, solid waste burial grounds, and underground tanks are potential sources of continuing and future vadose zone and groundwater contamination at the Hanford Site. Characterization of the subsurface and vadose zone monitoring were conducted during fiscal year (FY) 2006 to better understand the distribution of subsurface contaminants and to track the movement of vadose zone contamination. Also, several technical studies were completed that could lead to new understandings of moisture and contaminant movement in the vadose zone, contaminant interactions with the soil column, and new and improved methods to characterize and monitor the vadose zone.

This chapter summarizes major findings from those efforts, focused primarily on vadose zone soil contamination associated with past single-shell tank leaks and liquid disposal to ground as a result of spent fuel processing.

An overview of major soil sources of groundwater contamination is provided in PNNL-13080. This chapter discusses vadose zone contamination that could affect groundwater in the future. An overall evaluation depends, to a large degree, on integration of vadose zone and groundwater monitoring and characterization data to present a comprehensive picture of contaminant fate and transport. Significant FY 2006 vadose zone results are summarized here. However, the bulk of the data interpretation on the effect to groundwater is presented and discussed in Chapter 2 of this document. 


\subsection{Vadose Zone Monitoring}

\section{G. Horton}

Vadose zone monitoring, using leachate and soil-gas sampling, occurred at three areas on the Hanford Site in fiscal year (FY) 2006. Leachate and soil-gas monitoring continued at the Environmental Restoration Disposal Facility and the Solid Waste Landfill. Also, soilgas monitoring at the carbon tetrachloride expedited-response-action site continued during FY 2006. These monitoring efforts are summarized in the following sections.

\subsubsection{Leachate Monitoring at the Environmental Restoration Disposal Facility}

\section{A. St. John and R. L. Weiss}

Washington Closure Hanford, LLC operates the Environmental Restoration Disposal Facility to dispose of radioactive and mixed waste generated during waste management and remediation activities at the Hanford Site. In FY 2006, Washington Closure Hanford, LLC published the results of groundwater and leachate monitoring and sampling at the Environmental Restoration Disposal Facility during the calendar year 2005 (WCH-88, Rev. 0). The groundwater results are discussed in Section 2.9; this section summarizes the vadose zone results.

The Environmental Restoration Disposal Facility began operation in July 1996. Located between the 200 East and 200 West Areas (see Figure 2.9-1 in Section 2.9), the facility is currently operating four disposal cells. Throughout calendar year 2005, 921,540 metric tons of remediation waste were disposed at the facility. A total of $\sim 5.69$ million metric tons of remediation waste have been placed in the Environmental Restoration Disposal Facility from initial operations start-up through calendar year 2005.

Each cell was constructed with a double liner system to collect leachate resulting from water added as a dust suppressant and natural precipitation. The liners deliver the leachate to sumps beneath the cells where it is sampled. A composite sample of leachate was collected in duplicate in June and December 2005 from the sumps associated with the upper liners of cells 1 through 4 . The samples were analyzed for selected metals, anions, selected organic compounds, total dissolved solids, gross alpha, gross beta, and selected radionuclides. The purposes of the analyses are to provide data for leachate delisting analyses and to assess whether additional analytes should be added to the routine groundwater monitoring program at the Environmental Restoration Disposal Facility.

The composite leachate samples contained detectable concentration of common metals, anions, and mobile radionuclides. Constituents that were generally increasing in concentration include chromium, specific conductance, bromide, nitrate, gross alpha, and possibly total uranium. The following is a summary of those analytes with increasing trends:

- Chromium concentrations have been slowly increasing at a stable rate over the past 3 years. The chromium concentration averaged $\sim 36.9 \mu \mathrm{g} / \mathrm{L}$ in December 2005, up slightly from $33.7 \mu \mathrm{g} / \mathrm{L}$ in December 2003.

- Specific conductance remained fairly stable from June 2002 to December 2004, at which time a fairly significant increase was observed. That trend reversed itself in 2005 and the average December 2005 specific conductance value was $2,772 \mu \mathrm{S} / \mathrm{cm}$ compared to the average December 2004 value of 3,500 $\mu \mathrm{S} / \mathrm{cm}$. 


\section{Leachate is collected beneath part of the Solid Waste Landfill. Samples tested during July 2005 through June 2006 did not identify any areas of concern.}

- Bromide was not detected in leachate samples until June 2004 (735 $\mu \mathrm{g} / \mathrm{L})$ and increased in December $2004(990 \mu \mathrm{g} / \mathrm{L})$. The results from the 2005 analyses (average December value of 793) indicate that the bromide concentration may be stabilizing or may be decreasing.

- Nitrate concentrations continued to increase at a fairly steady rate through 2004 but appear to have dropped to lower concentration during 2005. The average December 2005 nitrate concentration was $320 \mathrm{mg} / \mathrm{L}$, down from $492.5 \mathrm{mg} / \mathrm{L}$ in December 2004.

- Uranium concentration appeared to be generally increasing through June 2005 to 1,060 $\mu \mathrm{g} / \mathrm{L}$ but decreased to $\sim 848 \mu \mathrm{g} / \mathrm{L}$ in December 2005.

Groundwater monitoring data for chromium, bromide, nitrate, gross alpha, and uranium were examined to determine whether the Environmental Restoration Disposal Facility has affected groundwater. In all cases, groundwater concentrations for these constituents remained stable. Based on this comparison, it appears that the Environmental Restoration Disposal Facility leachate has not affected groundwater.

The target constituents for the groundwater monitoring program are consistent with the leachate monitoring program. Based on that evaluation, no additional constitutes are recommended for addition to the groundwater monitoring program at the Environmental Restoration Disposal Facility landfill.

\subsubsection{Leachate and Soil-Gas Monitoring at the Solid Waste Landfill}

\section{B. B. Nelson-Maki and B. J. Dixon}

The Solid Waste Landfill is a disposal facility in the center of the Hanford Site (part of the Central Landfill illustrated on Figure 2.1-2 in Section 2.1). The Solid Waste Landfill covers an area of $\sim 26.7$ hectares and began operating in 1973 to receive non-hazardous, nonradioactive sanitary waste generated from Hanford Site operations. The Solid Waste Landfill stopped receiving waste in 1996 and an "interim cover" consisting of 0.6 to 1.2 meters of soil was placed over all trenches. Current monitoring at the Solid Waste Landfill consists of quarterly sampling of groundwater, soil gas, and leachate. Recent groundwater monitoring results are discussed in Section 2.11. This section summarizes leachate and soil-gas monitoring results. The results are forwarded annually to Washington State Department of Ecology (Ecology).

In all, the Solid Waste Landfill consists of single trenches and double trenches. Based on trench geometry and the thickness of the waste layer, the capacity of a trench per linear meter is 27.6 cubic meters for the single trenches and $\sim 100$ cubic meters for the double trenches. Based on this estimate, total design capacity of the Solid Waste Landfill is $\sim 596,000$ cubic meters.

One of the double trenches overlies a lined basin lysimeter designed to collect leachate generated by infiltration through the overlying refuse. (All other trenches are unlined). This lysimeter covers an area of $\sim 88$ square meters. A discharge pipe continuously drains leachate by gravity flow from the basin to a nearby collection pump. However, leachate collected from this lysimeter may not be representative of leachate drainage throughout the entire landfill area because the lysimeter only collects leachate from one of the double trenches and is installed under one of the newer trenches built after implementation of regulations that restrict land disposal practices. Still, the lysimeter provides some indication of the rate of infiltration and some of the contaminants that may be released to the vadose zone beneath the site.

Leachate is collected from the basin lysimeter every 10 to 14 days. Figure 3.1-1 shows the rate of leachate generated over the past 9 years. Prior to calendar year 2003, the generation 
rate was consistently between 4 to 8 liters/day. However, during the July 2003 through June 2004, and July 2004 through June 2005 reporting periods, the generation rates increased significantly (i.e., $\sim 19$ liters/day and 16.3 liters/day, respectively). This increase mainly was attributed to above average rainfall recorded at the Hanford Site

For the reporting period between July 2005 through June 2006, the leachate generation rate decreased to $\sim 6.4$ liters/day (Figure 3.1-1). This was about a $60 \%$ decrease in leachate generation from the previous year, when the daily average was $\sim 16.3$ liters/day. This decrease is attributed mainly to lower than normal precipitation recorded at the Hanford Site during July through December 2005. However, during January through June 2006, precipitation at the Hanford Site was higher than normal. The Hanford Meteorological Station recorded 9.1 centimeters of rain during the December 2005 through February 2006 period, which is $135 \%$ of normal (i.e., 6.8 centimeters).

Leachate is sampled and tested quarterly for indicator parameters listed in WAC 173-304-490 and annually for site-specific constituents, which cover a complete range of metals and organics. Concentrations measured during July 2005 through June 2006 are similar to previous concentrations and did not identify any areas of concern. Some of the indicator parameters and some organic constituents and metals continued to be above WAC 173-200 groundwater quality criteria and/or drinking water standards established in WAC 246-290-310. However, no constituent was above the drinking water standard at the point of compliance, which is the groundwater at the Solid Waste Landfill boundary (see Section 2.11.3.8). Table 3.1-1 shows analytical results for key constituents in the Solid Waste Landfill leachate.

Monitoring the soil gas at the Solid Waste Landfill is performed to demonstrate that the air quality performance standards are met. Soil-gas monitoring at the Solid Waste Landfill uses eight shallow monitoring stations located around the perimeter of the landfill. Each station consists of two soil-gas probes at depths of $\sim 2.75$ and 4.6 meters. Soil gas is monitored quarterly to determine concentrations of carbon dioxide, methane, and several key volatile organic compounds. During the reporting period, between July 2005 and June 2006, results were consistent with results for monitoring during previous years. Contaminants of concern were either not detected or were at or near detection limits.

\subsubsection{Carbon Tetrachloride Monitoring and Remediation}

\section{J. Rohay}

Soil-vapor extraction is being used to remove carbon tetrachloride from the vadose zone in the 200 West Area. The U.S. Environmental Protection Agency (EPA) and Ecology authorized DOE to initiate this remediation in 1992 as a Comprehensive Environmental Response, Compensation, and Liability Act (CERCLA) expedited response action. The following discussion summarizes FY 2006 activities associated with the carbon tetrachloride removal. A report containing detailed results of FY 2006 activities will be published in FY 2007. For descriptions of past work, see BHI-00720, WMP-21327, WMP-26178, WMP-30426, and Section 3.1.3 in PNNL-15670. WMP-30426 describes the soil-vapor extraction system and the well fields. See Figure 3.1-2 for locations of vapor extraction wells.

The 14.2-cubic-meter/minute soil-vapor extraction system was operated at the 216-Z-1A well field from April 3 through July 25, 2006. The soil-vapor extraction system was operated at the 216-Z-9 well field from July 31 through September 29, 2006. The system was maintained in standby mode from October 19, 2005 through April 2, 2006. The 28.3- and 42.5-cubicmeter/minute soil-vapor extraction systems did not operate and were not maintained during FY 2006. Temporarily suspending soil-vapor extraction operations at each well field allows the carbon tetrachloride concentrations to recharge and be more economically extracted when operations resume.

\author{
Soil-vapor \\ extraction is \\ being used to \\ remove carbon \\ tetrachloride from \\ the vadose zone in \\ the 200 West Area.
}




\section{Approximately \\ 78,900 kilograms \\ of carbon \\ tetrachloride have \\ been removed from}

the vadose zone

since extraction

operations started

in 1991.
To track the effectiveness of the remediation effort, soil-vapor concentrations of carbon tetrachloride were monitored at the inlet to the soil-vapor extraction system and at individual online extraction wells during the 6-month operating period. To assess the impact of the soilvapor extraction system on subsurface concentrations, soil-vapor concentrations of carbon tetrachloride were monitored at off-line wells and probes during the entire fiscal year.

Remediation efforts during FY 2006 also included passive soil-vapor extraction.

\subsubsection{Soil-Vapor Extraction}

Soil-vapor extraction to remove carbon tetrachloride from the vadose zone resumed April 3, 2006, at the 216-Z-1A well field. Online wells were selected within the perimeter of the 216-Z-1A tile field. Extraction wells open near the less-permeable Cold Creek unit, where the highest carbon tetrachloride concentrations have consistently been detected in the past, were selected to optimize mass removal of contaminant. Initial carbon tetrachloride concentrations measured at the soil-vapor extraction inlet were $\sim 13 \mathrm{ppmv}$ (Figure 3.1-3). This concentration was slightly lower than the maximum concentration ( $25 \mathrm{ppmv})$ measured when the soil-vapor extraction system last operated at this site in 2005.

Soil-vapor extraction resumed July 31, 2006, at the 216-Z-9 well field. Initial extraction was from wells close to the 216-Z-9 trench. As extraction continued, additional wells close to the trench and farther away from the trench were brought online. Extraction wells open near the less-permeable Cold Creek unit, where the highest carbon tetrachloride concentrations have consistently been detected in the past, were selected to optimize mass removal of contaminant. Extraction wells open near the groundwater also were selected. The new slant well, 299-W15-48, drilled under the 216-Z-9 trench in 2006 as part of the remedial investigation for the 200-PW-1 Operable Unit, was brought online in August 2006. (See Section 3.2.3 for description of characterization efforts at the 200-PW-1 Operable Unit.) During the 9 weeks of extraction in FY 2006, the maximum carbon tetrachloride concentration measured at the soil-vapor extraction system inlet was $\sim 41 \mathrm{ppmv}$ (Figure 3.1-3). This concentration was lower than the maximum concentration ( $>87 \mathrm{ppmv})$ measured when the soil-vapor extraction system last operated at this site in 2005.

As of September 2006, 78,900 kilograms of carbon tetrachloride had been removed from the vadose zone since extraction operations started in 1991 (Table 3.1-2). The mass of carbon tetrachloride removed in FY 2006 was 173 kilograms. WMP-30426 provides the amounts of carbon tetrachloride removed per year between 1991 and 2005. Since initiation, the extraction systems are estimated to have removed $7 \%$ of the residual mass at $216-Z-1 \mathrm{~A} / 216-Z-12 / 216-Z-18$ well field and $23 \%$ of the mass at $216-Z-9$ well field. This estimate assumes that all of the mass that has not been lost to the atmosphere ( $21 \%$ of the original inventory), dissolved in groundwater ( $2 \%$ of the original inventory), or biodegraded ( $1 \%$ of the original inventory) was still available in the vadose zone as residual mass in 1991 when extraction operation began (WMP-30426; WHC-SD-EN-TI-101).

\subsubsection{Monitoring at Off-Line Wells and Probes}

During FY 2006, soil-vapor concentrations of carbon tetrachloride were monitored near the ground surface, near the Cold Creek unit $(\sim 40$ meters below ground surface $[\mathrm{bgs}])$, and near groundwater ( $\sim 66$ meters bgs). Soil-vapor concentrations were monitored near the ground surface and groundwater to evaluate whether non-operation of the soilvapor extraction system negatively affects the atmosphere or groundwater. The maximum concentration detected near the ground surface (between 2 and 10 meters bgs) was 6 ppmv. Near the groundwater (between 53 and 66 meters bgs), the maximum concentration was 14 ppmv. Soil-vapor concentrations also were monitored above and within the Cold Creek unit to provide an indication of concentrations that could be expected during restart of the soil-vapor extraction system. The maximum concentration detected near the Cold Creek unit (between 25 and 44 meters bgs) was 394 ppmv in well 299-18-165 (35 meters bgs) within the 216-Z-1A tile field. During monitoring in FY 1997 through 2005, the highest 
carbon tetrachloride concentrations in the 216-Z-1A/216-Z-12/216-Z-18 well field were detected in wells at the 216-Z-1A tile field.

At the 216-Z-9 well field, the maximum carbon tetrachloride concentration detected near the Cold Creek unit was $24 \mathrm{ppmv}$ at soil-vapor probe CPT-24 (36 meters bgs). South of the 216-Z-9 trench $~ 90$ meters, the maximum carbon tetrachloride concentration detected was $241 \mathrm{ppmv}$ at soil-vapor probe CPT-28 (27 meters bgs). North of the 216-Z-9 trench $\sim 200$ meters, the maximum carbon tetrachloride concentration detected was $53 \mathrm{ppmv}$ at soil-vapor probe CPT-9A ( 15 meters bgs). The maximum carbon tetrachloride concentration detected in the vadose zone overlying the Cold Creek unit (between 11 and 23 meters bgs) was 160 ppmv at soil-vapor probe CPT-21A (20 meters bgs) near the 216-Z-9 trench.

The temporary suspension of soil-vapor extraction in FY 2006 appears to have caused minimal detectable vertical transport of carbon tetrachloride through the soil surface to the atmosphere. This interpretation is supported by data that show carbon tetrachloride concentrations did not increase significantly at the near-surface monitoring probes. In addition, suspending operations of the soil-vapor extraction system appears to have had no negative impact on groundwater quality, because carbon tetrachloride concentrations did not increase significantly near the water table during that time.

\subsubsection{Passive Soil-Vapor Extraction}

Passive soil-vapor extraction is a remediation technology that uses naturally induced pressure gradients between the subsurface and the ground surface to drive soil vapor to the surface. In general, falling atmospheric pressure causes subsurface vapor to move to the atmosphere through wells, whereas rising atmospheric pressure causes atmospheric air to move into the subsurface. Passive soil-vapor extraction systems are designed to use this phenomenon to remove carbon tetrachloride from the vadose zone.

Passive soil-vapor extraction systems were installed at the end of FY 1999 at eight boreholes that are open near the vadose-groundwater interface at the 216-Z-1A/216-Z-12/216-Z-18 well field. The passive systems are outfitted with check valves that only allow soil-vapor flow out of the borehole (i.e., one-way movement), and canisters holding granular activated carbon that adsorbs carbon tetrachloride upstream of the check valves before the soil vapor is vented to the atmosphere. The check valve prohibits flow of atmospheric air into the borehole during a reverse barometric pressure gradient, which tends to dilute and spread carbon tetrachloride vapors in the subsurface.

The wells are sampled periodically upstream of the granular activated carbon canisters when atmospheric pressure is falling and the wells are venting. The maximum carbon tetrachloride concentrations measured at the three wells (299-W18-6, 299-W18-7, and 299-W18-246) in the vicinity of the 216-Z-1A tile field ranged from 13 to 34 ppmv. The maximum carbon tetrachloride concentrations measured at the four wells (299-W18-10, 299-W18-11, 299-W18-12, and 299-W18-247) in the vicinity of the 216-Z-18 crib ranged from 9 to 14 ppmv.
Passive soil-vapor extraction uses naturally induced pressure gradients to drive soil vapor to the surface. 
Table 3.1-1. Solid Waste Landfill Leachate Monitoring Results - Key Constituents

\begin{tabular}{|c|c|c|c|c|c|c|}
\hline \multirow[b]{2}{*}{ Parameter ${ }^{(a)}$} & \multicolumn{4}{|c|}{ Results by Quarter } & \multirow[b]{2}{*}{ GWQC $^{(b)}$} & \multirow[b]{2}{*}{$\mathrm{MCL}^{(\mathrm{c})}$} \\
\hline & 3rd 2005 & 4th 2005 & 1st 2006 & 2nd 2006 & & \\
\hline \multicolumn{7}{|c|}{ Indicator Parameters } \\
\hline Ammonia as $\mathrm{N}(\mathrm{mg} / \mathrm{L})$ & 0.321 & 0.450 & NT & 0.272 & NA & NA \\
\hline $\begin{array}{l}\text { Chemical oxygen demand } \\
\text { (mg/L) }\end{array}$ & 217 & 222 & 239 & 222 & NA & NA \\
\hline Dissolved iron $(\mu \mathrm{g} / \mathrm{L})$ & 1,180 & 16,600 & 9,350 & 9,930 & $300 \mu \mathrm{g} / \mathrm{L}$ & $300 \mu \mathrm{g} / \mathrm{L}$ \\
\hline Dissolved manganese $(\mu \mathrm{g} / \mathrm{L})$ & 1,510 & 1,500 & 1,350 & 1,520 & $50 \mu \mathrm{g} / \mathrm{L}$ & $50 \mu \mathrm{g} / \mathrm{L}$ \\
\hline Dissolved zinc $(\mu \mathrm{g} / \mathrm{L})$ & 21.6 & 115 & $<3.0$ & 1,180 & $5,000 \mu \mathrm{g} / \mathrm{L}$ & $5,000 \mu \mathrm{g} / \mathrm{L}$ \\
\hline $\mathrm{pH}$ & 7.05 & 6.82 & NT & 7.36 & $6.5-8.5$ & NA \\
\hline $\begin{array}{l}\text { Specific conductance } \\
(\mu \mathrm{S} / \mathrm{cm})\end{array}$ & 1,970 & 1,770 & 1,920 & 1,930 & NA & $700 \mu \mathrm{S} / \mathrm{cm}$ \\
\hline Total organic carbon (mg/L) & 81.7 & 80.3 & 79.5 & 77.6 & NA & NA \\
\hline \multicolumn{7}{|c|}{ Site-Specific Parameters } \\
\hline 1,1,1-Trichloroethane $(\mu \mathrm{g} / \mathrm{L})$ & NT & NT & NT & $<1.0$ & $200 \mu \mathrm{g} / \mathrm{L}$ & $200 \mu \mathrm{g} / \mathrm{L}$ \\
\hline 1,1-Dichloroethane $(\mu \mathrm{g} / \mathrm{L})$ & NT & NT & NT & $<1.0$ & $1.0 \mu \mathrm{g} / \mathrm{L}$ & NA \\
\hline 1,4-Dichlorobenzene $(\mu \mathrm{g} / \mathrm{L})$ & NT & NT & NT & $5.4^{(e)}$ & $4 \mu \mathrm{g} / \mathrm{L}$ & NA \\
\hline 1,4-Dioxane $(\mu \mathrm{g} / \mathrm{L})$ & NT & NT & NT & $<12.0$ & $7 \mu \mathrm{g} / \mathrm{L}$ & NA \\
\hline Arsenic $(\mu \mathrm{g} / \mathrm{L})$ & NT & NT & NT & 30.4 & $0.05 \mu \mathrm{g} / \mathrm{L}$ & $10 \mu \mathrm{g} / \mathrm{L}$ \\
\hline Barium $(\mu \mathrm{g} / \mathrm{L})$ & NT & NT & NT & 518 & $1,000 \mu \mathrm{g} / \mathrm{L}$ & $2,000 \mu \mathrm{g} / \mathrm{L}$ \\
\hline Cadmium $(\mu \mathrm{g} / \mathrm{L})$ & NT & NT & NT & $<0.04$ & $0.01 \mathrm{mg} / \mathrm{L}$ & $0.005 \mathrm{mg} / \mathrm{L}$ \\
\hline Carbon tetrachloride $(\mu \mathrm{g} / \mathrm{L})$ & NT & NT & NT & $<1.0$ & $0.3 \mu \mathrm{g} / \mathrm{L}$ & $5 \mu \mathrm{g} / \mathrm{L}$ \\
\hline Chloride (mg/L) & 236 & 221 & NT & 215 & $250,000 \mu \mathrm{g} / \mathrm{L}$ & $25,000 \mu \mathrm{g} / \mathrm{L}$ \\
\hline Chloroform $(\mu \mathrm{g} / \mathrm{L})$ & NT & NT & NT & $<1.0$ & $7.0 \mu \mathrm{g} / \mathrm{L}$ & NA \\
\hline Copper ( $\mu \mathrm{g} / \mathrm{L})$ & NT & NT & NT & 0.971 & $1,000 \mu \mathrm{g} / \mathrm{L}$ & NA \\
\hline Fluoride $(\mathrm{mg} / \mathrm{L})$ & 0.374 & $<0.200$ & NT & $<0.200$ & $4 \mathrm{mg} / \mathrm{L}$ & $4 \mathrm{mg} / \mathrm{L}$ \\
\hline Methylene chloride $(\mu \mathrm{g} / \mathrm{L})$ & NT & NT & NT & $4.0^{(f)}$ & $5 \mu \mathrm{g} / \mathrm{L}$ & NA \\
\hline Nickel $(\mu \mathrm{g} / \mathrm{L})$ & NT & NT & NT & 126 & NA & $0.1 \mathrm{mg} / \mathrm{L}$ \\
\hline Selenium $\mu \mathrm{g} / \mathrm{L})$ & NT & NT & NT & 2.24 & $10 \mu \mathrm{g} / \mathrm{L}$ & $50 \mu \mathrm{g} / \mathrm{L}$ \\
\hline Sulfate (mg/L) & 1.63 & 1.82 & NT & 2.76 & $250 \mathrm{mg} / \mathrm{L}$ & $25 \mathrm{mg} / \mathrm{L}$ \\
\hline Tetrachloroethene $(\mu \mathrm{g} / \mathrm{L})$ & NT & NT & NT & $<1.0$ & NA & NA \\
\hline Total dissolved solids (mg/L) & NT & NT & NT & 1,490 & $500 \mathrm{mg} / \mathrm{L}$ & $500 \mathrm{mg} / \mathrm{L}^{(\mathrm{d})}$ \\
\hline Total organic halides $(\mu \mathrm{g} / \mathrm{L})$ & NT & NT & NT & 877 & NA & NA \\
\hline Trichloroethene $(\mu \mathrm{g} / \mathrm{L})$ & NT & NT & NT & $<1.0$ & NA & NA \\
\hline \multicolumn{7}{|c|}{$\begin{array}{l}\text { (a) Units as provided in analytical results report. } \\
\text { (b) Groundwater quality criteria from WAC } 173-200 \text {. } \\
\text { (c) Maximum contaminant levels from WAC } 246-290 \text {. } \\
\text { (d) Required only when specific conductance exceeds } 700 \mu \mathrm{S} / \mathrm{cm} \text {. } \\
\text { (e) Averaged result from two samples: one sample result was }<1.0 \mu \mathrm{g} / \mathrm{L} \text {, and one sample result was } 9.80 \text {. } \\
\text { (f) Averaged result from two samples: one sample result was }<1.0 \mu \mathrm{g} / \mathrm{L} \text {, and one sample result was } 7.0 \text {. } \\
\text { NT = Not tested. } \\
\text { NA = Not applicable. }\end{array}$} \\
\hline
\end{tabular}


Table 3.1-2. Carbon Tetrachloride Inventory Removed by Vapor Extraction from Primary Disposal Sites

\begin{tabular}{|c|c|c|c|}
\hline Well Field & $\begin{array}{l}\text { Estimated Mass Discharged, } \\
1955 \text { to } 1973^{(a)}(\mathrm{kg})\end{array}$ & $\begin{array}{l}\text { Estimated Mass Lost to } \\
\text { Atmosphere, } 1955 \text { to } 1990^{(b)}(\mathrm{kg})\end{array}$ & $\begin{array}{l}\text { Mass Removed Using Soil-Vapor } \\
\text { Extraction, } 1991 \text { to September } 2006(\mathrm{~kg})\end{array}$ \\
\hline $216-Z-1 A$ & 270,000 & 56,700 & $24,604^{(\mathrm{c})}$ \\
\hline $216-Z-9$ & 130,000 to 480,000 & 27,300 to 100,800 & 54,280 \\
\hline $216-Z-18$ & 170,000 & 35,700 & - \\
\hline Total & 570,000 to 920,000 & 119,700 to 196,800 & 78,884 \\
\hline
\end{tabular}




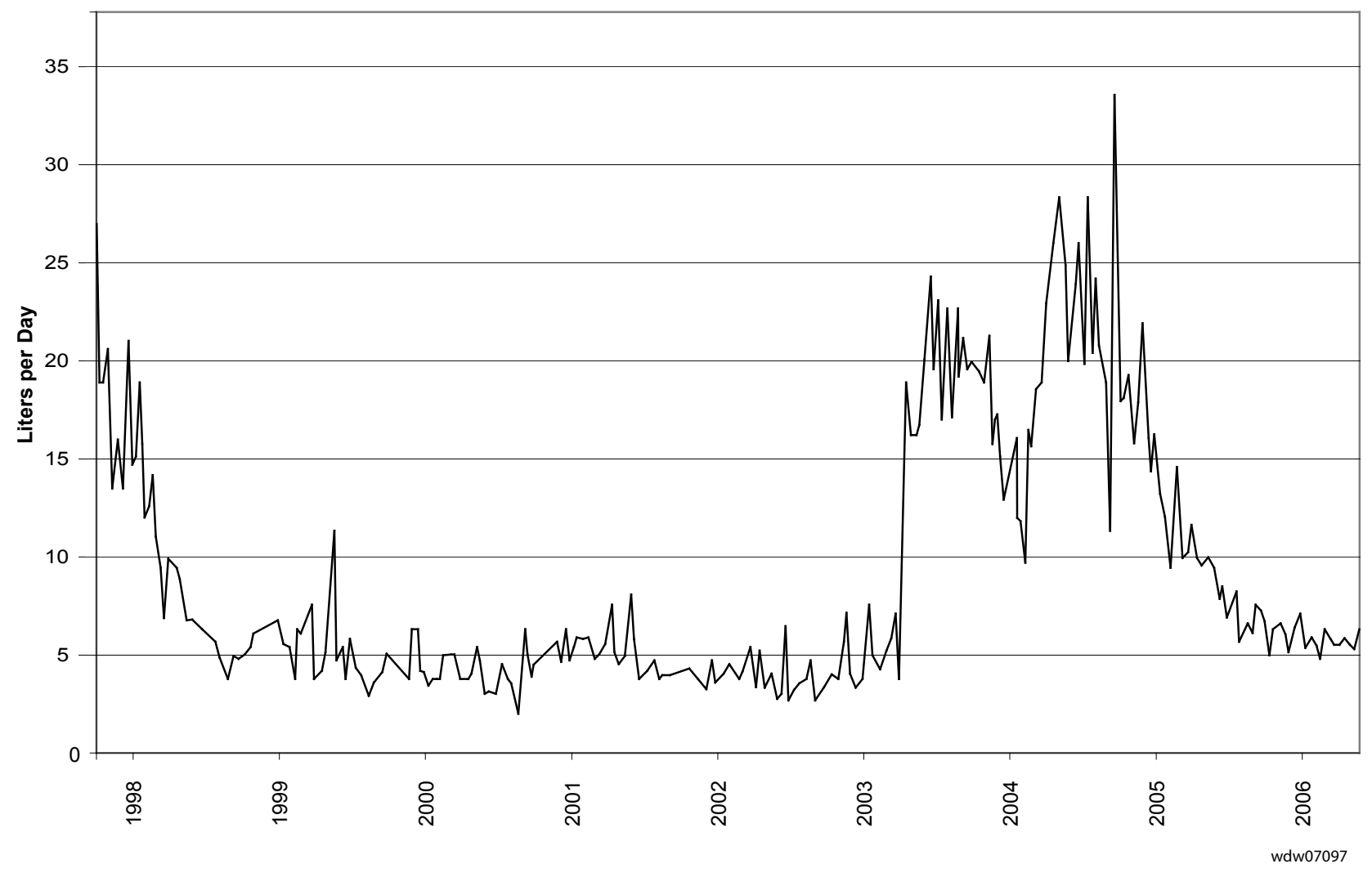

Figure 3.1-1. Leachate Collection Volumes at the Solid Waste Landfill 


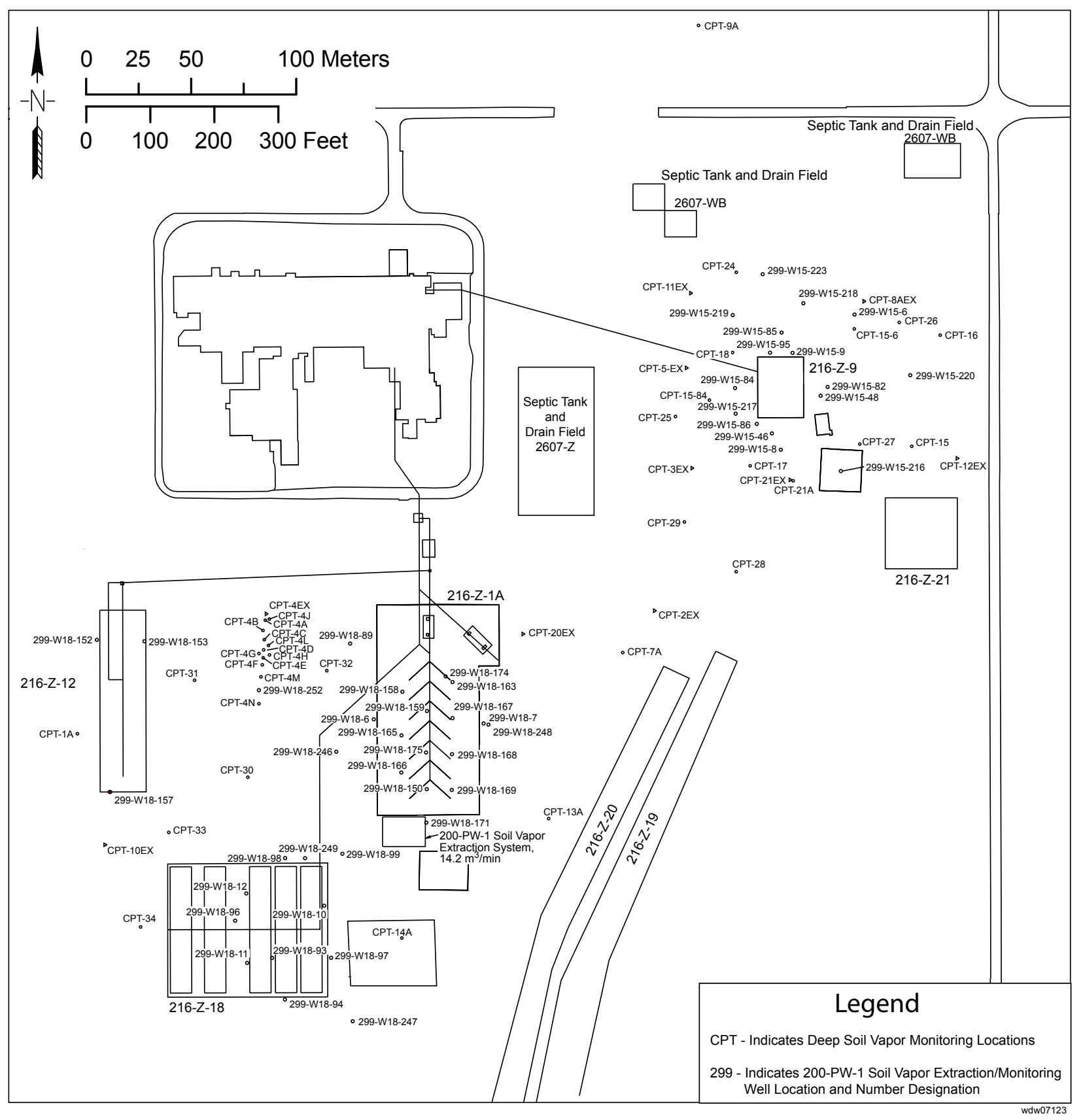

Figure 3.1-2. Locations of Carbon Tetrachloride Vapor-Extraction Wells at 216-Z-1A/216-Z-12/216-Z-18 and 216-Z-9 Well Fields 


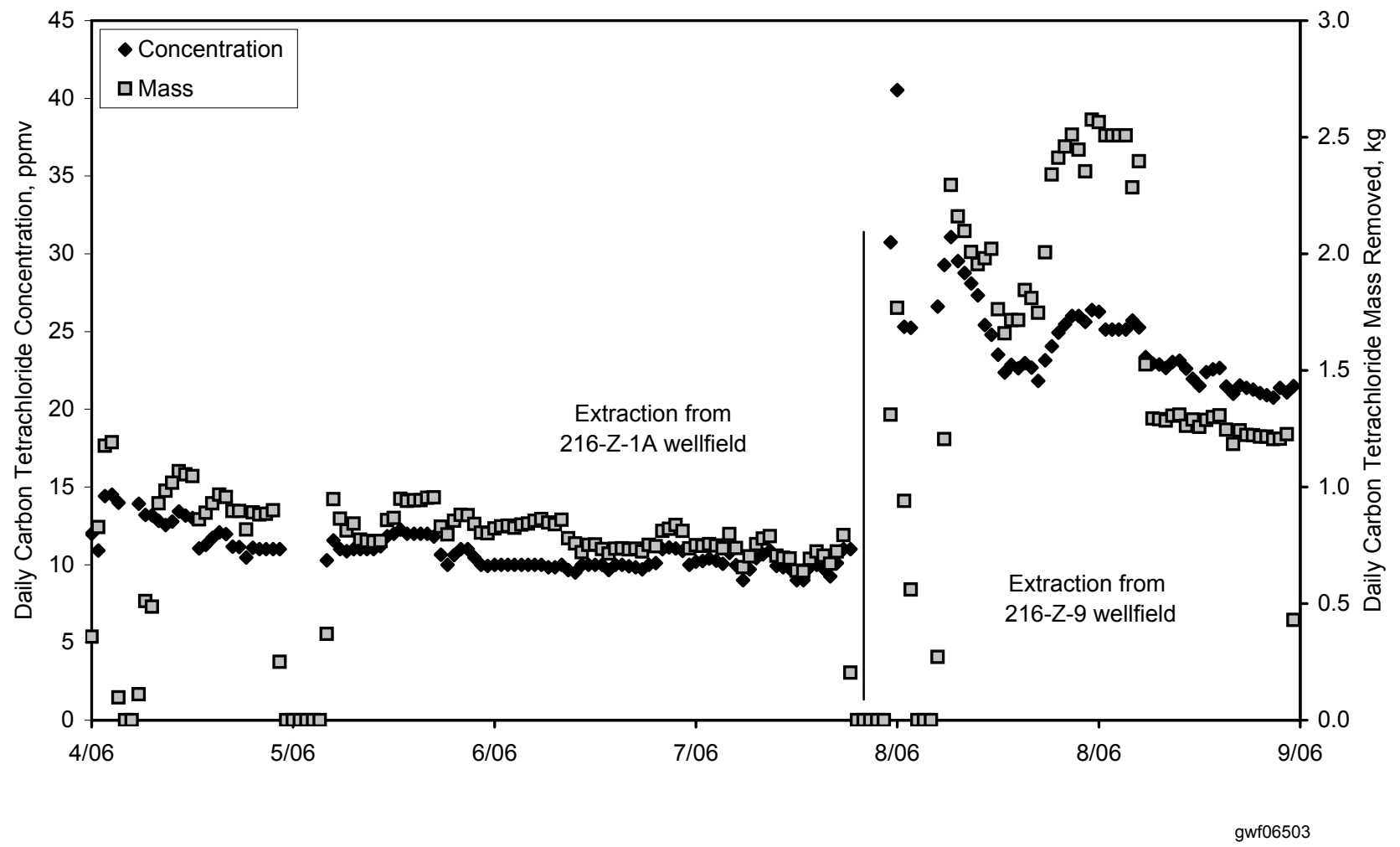

Figure 3.1-3. Time Series Concentrations and Mass of Carbon Tetrachloride in Soil Vapor Extracted from 216-Z-1A/216-Z-12/216-Z-18 and 216-Z-9 Well Fields 


\subsection{Selected Vadose Zone Characterization Studies}

This section describes characterization activities that occurred in fiscal year (FY) 2006. Characterization activities improve the understanding of physical and chemical properties of the vadose zone and vadose zone contamination and help delimit existing vadose zone contamination. The characterization activities summarized in this section include:

- Direct push technology for sampling the subsurface in tank farms.

- Geophysical logging at the Hanford Site with emphasis on uranium at 200-BP-5 Operable Unit.

- Characterization of plutonium and carbon tetrachloride for the 200-PW-1, 200-PW-3, and 200-PW-6 Operable Units.

\subsubsection{Application of Direct Push Technology in Tank Farms}

\section{A. Myers}

The Tank Farm Vadose Zone Project conducted a series of vadose zone sampling efforts inside tank farm waste management areas during FY 2006. To accomplish the work, a recently developed version of direct push technology was used. This direct push approach, the Hydraulic Hammer Unit, Figure 3.2-1, was demonstrated in several areas both inside and outside of the tank farms. In demonstration mode, the unit was able to vertically drive to depths of 39 meters below ground surface (bgs) and collect soil samples from depths as great as 24 meters. The unit was also successfully demonstrated in a non-vertical configuration, driving holes at 30, 45, and 60 degrees from the vertical. The Hydraulic Hammer Unit has been used in the BX, TY, C, and T Tank Farms, as well as locations such as the Mock Tank Site, Plutonium Finishing Plant and 100-N Area. Table 3.2-1 provides a summary of the work performed using this unit through FY 2006.

The Hydraulic Hammer Unit consists of a rotary, high-speed, hydraulic hammer mounted on a highly maneuverable and light weight backhoe. This configuration provides optimal mobility for operating in the tank farm environment where infrastructure precludes access by many larger pieces of drilling equipment. Rates of advancement are as high as a few meters per minute. Probe holes are generally placed in pairs; one to provide access for geophysical logging to select sample locations, and one to advance the single depth sampler.

The analysis of samples is ongoing and the results will be summarized in the FY 2007 annual report.

\subsubsection{Hanford Geophysical Logging}

\section{R. McCain}

Radiation measurements have been performed in boreholes since the early days of the Hanford Site to detect manmade radionuclides in the subsurface. Since 1995, the U.S. Department of Energy (DOE) Grand Junction (Colorado) Office has had responsibility for most geophysical logging activities at the Hanford Site. The Grand Junction Office developed specialized geophysical logging capabilities in support of the National Uranium Resource Evaluation. As the prime contractor for the DOE Grand Junction Office, the SM Stoller Corporation is responsible for geophysical logging activities at Hanford. However, the focus of the Grand Junction Office has shifted to long-term management of sites where 
remediation has been substantially completed, so future logging at the Hanford Site will be performed by SM Stoller Corporation under subcontract to the Hanford Site contractors.

Originally, the objective of the Hanford Geophysical Logging Project was to determine the nature and extent of subsurface contamination in the vicinity of the single-shell tank farms and to provide a baseline against which subsequent measurements could be compared. That effort was completed in 2000. High-resolution spectral gamma logs were prepared for 769 drywells in the single-shell tank farms. A tank summary data report was prepared for each of the 133 large single-shell tanks, and a tank farm report was prepared for each of the 12 single-shell tank farms. With completion of the tank farms baseline, geophysical logging activities are now performed in boreholes associated with liquid waste disposal sites. When requested, Stoller personnel also provide technical support to drywell monitoring activities performed by the tank farms contractor.

The vadose zone characterization project was established to log existing boreholes in or near waste sites in the Hanford 200 Areas and prepare reports summarizing log result, along with available geological data and operational history. This was intended to provide a baseline data set similar for that completed for the single-shell tank farms. Several reports were issued addressing areas in the B-BX-BY Waste Management Area. However, Stoller also provides geophysical logging services in support of well decommissioning, remedial investigation efforts by other contractors, and the groundwater monitoring program. It quickly became obvious that the demand for geophysical logs to support other activities was requiring a much greater share of available resources. Moreover, the emphasis on well decommissioning activities meant that many existing boreholes had to be logged before the opportunity was lost. As a result of these pressures, Stoller concentrated on providing logging services to other contractor activities, and the waste site summary reports are no longer prepared. Priority is given to logging boreholes scheduled for decommissioning, followed by remedial investigations and groundwater wells; as a result, few boreholes are logged as part of the original baseline characterization program.

During 2006, Stoller logged 128 boreholes. This includes existing boreholes, as well as new boreholes, drilled during 2006. Logged boreholes include:

- 8 boreholes for baseline logging.

- 69 to support well decommissioning.

- 29 boreholes to support remedial investigation efforts.

- 22 groundwater wells.

Borehole logs are provided directly to DOE and the Hanford Site contractors. They are also available via the internet at http:/www.hanford.gov/cp/gpp/data/gpl.cfm. The logs are incorporated into data sets and reports for individual projects and will not be discussed in this section. This section will focus on logging systems currently in use, detection of manmade uranium, and uranium in the 200-BP-5 Groundwater Operable Unit.

\subsubsection{Logging Systems in Use at Hanford}

In 2006, the Hanford Geophysical Logging Project operated three logging trucks, with various logging sondes. Each combination of a logging truck and sonde is considered a logging system, and each logging system is individually calibrated. Specific system combinations are indicated by the first two letters of the spectrum file name. For example, AE would indicate data collected using truck Gamma 1 (A) and detector "E" (a 70\% high-purity germanium [HPGe] detector). Table 3.2-2 illustrates detector systems currently in use.

In addition to the logging systems discussed above, Stoller has developed and deployed the radionuclide assessment system and the radionuclide monitoring system for use by tank farms personnel. The radionuclide assessment system uses a series of three sodium iodide detectors with limited spectral capability to conduct routine drywell monitoring in the single-shell tank farms. Results are compared against previous logs and baseline data to detect any changes 
that might indicate a tank leak or contaminant migration. The radionuclide monitoring system uses a neutron moisture log and hybrid gamma detector system (sodium iodide detector and two pairs of Geiger-Mueller detectors) to simultaneously measure moisture content and gross gamma activity in drywells near tanks undergoing waste retrieval operations.

\subsubsection{Detection of Manmade Uranium}

Uranium is ubiquitous in the environment as a naturally occurring trace element. Manmade uranium is the primary component of nuclear reactor fuel and a significant contaminant at the Hanford Site. Uranium-238 itself is primarily an alpha-emitter, with only a few low energy and low intensity gamma rays. It is essentially impossible to directly detect uranium-238 from analysis of gamma energy spectra collected from inside a steel-cased borehole. Uranium contains small amounts of uranium-235 ( $0.72 \mathrm{wt} . \%$ in natural uranium), which does emit detectable gamma rays, but the intensity of these emissions are well below detectable levels when uranium exists at or near background levels. Unless the uranium is highly concentrated or enriched, gamma emissions from uranium-235 are not likely to be helpful. Enrichment ratios in Hanford reactor fuel were generally relatively low.

Detection of uranium by spectral gamma logging depends on gamma emissions which originate from daughter isotopes in the uranium decay series. Figure 3.2-2 illustrates the uranium decay series, whereby uranium-238 decays through a series of alpha and beta emitters to stable lead-206. Each radionuclide is plotted by atomic weight on the $\mathrm{X}$-axis and atomic number on the Y-axis. For simplicity, only the dominant decay branches are shown. For each radionuclide, the half life is shown as a subscript to the element symbol. The colored circles indicate radionuclides with detectable gamma emissions. The half life of uranium-238 is much longer than any of the daughters. Eventually the daughter radionuclides in a sample of initially pure uranium-238 will reach secular equilibrium, where the activity of each daughter is equivalent to the activity of the parent. The time required for each radionuclide in the series to reach secular equilibrium depends on the half life of that radionuclide, as well as the half life of preceding radionuclides in the decay series. "Natural" uranium is presumed to have been undisturbed for millions of years, so that the activity of any daughter radionuclide is numerically equal to that of the parent. Conventional spectral gamma logs take advantage of this by using a gamma emission from bismuth-214 to quantify uranium.

When uranium is extracted from ore or is chemically processed, the daughter products in the decay series (protactinium, thorium, radium, polonium, bismuth, lead) are stripped away and decay equilibrium is disturbed. But radioactive decay continues and so the various members of the decay series will "build in" over time. Figure 3.2-3 shows how the activities of the various gamma-emitting members of the uranium decay series increase over time. For this graph, the initial activity of uranium-238 is set at 1.0, and the activity of each daughter is expressed relative to this. Note that both the $\mathrm{X}$ and $\mathrm{Y}$ axes are logarithmic, and that the time range goes from 0.001 years (about 8 hours) to 1 million years. Because uranium-238 has a half-life of about 4.47 billions years, the parent activity does not change perceptibly over this time frame. Note that the colors of the relative activity curves in Figure 3.2-3 correspond to the colors used to indicate gamma-emitting radionuclides in the uranium decay series plotted in Figure 3.2-2.

Protactinium $-234 \mathrm{~m}$ is the second member in the uranium decay series, and the first which emits gamma rays useful for quantification in cased boreholes. In an initially pure sample of uranium-238, the activity of protactinium- $234 \mathrm{~m}$ will increase relatively quickly, reaching secular equilibrium with the parent uranium-238 in less than a year. From this point on, the measured activity of protactinium $-234 \mathrm{~m}$ can be assumed to be equivalent to the activity of the parent uranium. However, the intensities of these gamma rays are very low; only about eight gammas are emitted for each 1,000 decays. At Hanford, typical background concentrations for natural uranium are in the range of about 0.5 to $2 \mathrm{pCi} / \mathrm{g}$, and gamma activity originating from protactinium $-234 \mathrm{~m}$ is not likely to be detectable at these levels. Experience with high resolution spectral gamma logging at Hanford indicates that with 
Carbon

tetrachloride has

migrated beyond

the 200-PW-1

Operable Unit

waste site

boundaries

resulting in a

dispersed carbon

tetrachloride plume

in the vadose zone. typical logging parameters, protactinium-234m can be detected at levels of 15 to $20 \mathrm{pCi} / \mathrm{g}$. With extended count times under ideal conditions, levels of detection below $5 \mathrm{pCi} / \mathrm{g}$ can be achieved. Therefore, detection of gamma activity associated with protactinium- $234 \mathrm{~m}$ can be taken as an indication of manmade uranium.

Activity levels for other gamma emitters in the uranium decay series (radium-226, lead-214, and bismuth-214) increase much more slowly, because of the relatively long half lives of intervening daughters, such as uranium-234 (245,500 years) and thorium-230 (75,380 years). Figure 3.2-3 shows that these radionuclides will not attain secular equilibrium with the parent uranium-238 until nearly a million years has elapsed. Since all uranium processing at Hanford has occurred within the last sixty years, the presence of gamma rays from these long lived radionuclides indicates that the uranium has lain undisturbed for at least several hundred thousand years and is, thus, from natural sources.

\subsubsection{Detection of Uranium in the Vadose Zone at 200-BP-5 Groundwater Operable Unit}

Wells 299-E33-18, 299-E33-41, and 299-E33-45, located in the source operable units above the 200-BP-5 Groundwater Operable Unit, were originally logged as part of the baseline characterization effort in 2001 to 2002 (see Figure 2.10-1 for location of wells at Waste Management Area B-BX-BY). Uranium-238 logs from these wells are shown in Figure 3.2-4. Evaluation of log results identified a plume of manmade uranium, which appeared to be extending downward and to the east-northeast from the general vicinity of tank BX-102, intersecting groundwater in the vicinity of well 299-E33-18. (Sobczyk et al. 2003). Evaluation of historical log data indicated that the uranium plume had arrived at well 299-E33-18 sometime between 1992 and 1997, which is roughly coincident with its first reported occurrence in groundwater samples in early 1993. For well 299-E33-18, the 1997 $\log$ indicated a maximum uranium -238 concentration of $439 \mathrm{pCi} / \mathrm{g}$ at 72.5 meters bgs. By 2001, the maximum concentration had increased to $623 \mathrm{pCi} / \mathrm{g}$, and the log data collected in 2006 indicated a maximum concentration of 1,237 pCi/g. In addition to uranium-238, uranium-235 was also detected, although at much lower concentrations. Also shown on Figure 3.2-4 are crossplots of uranium-235 (Y axis) versus uranium-238 (X axis) for each of the three wells. Note that the data show two distinct trends. Uranium concentrations in well 299-E33-45 follow a trend roughly equivalent to uranium-235 =0.04* uranium-238, whereas uranium concentrations in well 299-E33-18 follow a trend roughly equivalent to uranium $-235=0.08 *$ uranium -238 . This suggests that the uranium detected in well 299-E33-18 may come from a different source than the uranium encountered in well 299-E33-45. The uranium data in well 299-E33-41 tend to follow both trends. Below 59-meter depth, the data follow the trend in well 299-E33-45, whereas the data above 58.5 meters appears to more closely follow the trend in well 299-E33-18. Note that uranium concentrations in this interval are relatively low; this leads to higher relative error and more scatter in the data.

\subsubsection{Plutonium/Organic-Rich Group Operable Unit Characterization}

\section{W. Bratton, K. Moser, V. J. Rohay, and A. F. Shattuck}

Characterization of the vadose zone in 200 West Area at liquid waste disposal sites and the carbon tetrachloride plume was conducted during FY 2002 to 2006 as part of the Comprehensive Environmental Response, Compensation, and Liability Act (CERCLA) remedial investigation for the plutonium/organic-rich group operable unit, which includes the 200-PW-1, 200-PW-3, and 200-PW-6 Operable Units. Figures 3.2-5 through 3.2-8 show the locations of the past-practice disposal facilities in the operable units. 
- 200-PW-1 Operable Unit waste sites primarily received plutonium-rich and organic-rich waste (mostly carbon tetrachloride, tributyl phosphate, and lard oil) from processes within the Z Plant complex (now referred to as the Plutonium Finishing Plant or complex).

- 200-PW-3 Operable Unit waste sites received organic-rich wastes (primarily refined kerosene [normal petroleum hydrocarbon, tributyl phosphate, and butanol]) from other separations facilities such as S Plant (Reduction-Oxidation or REDOX process), A Plant (Plutonium-Uranium Extraction or PUREX process), U Plant (uranium recovery process), and the 201-C Building (Hot Semiworks process).

- 200-PW-6 Operable Unit waste sites received plutonium-rich wastes from the Plutonium Finishing Plant complex, but did not receive organic-rich waste from that complex.

The remedial investigation field work was conducted in accordance with the work plan (DOE/RL-2001-01). Data were collected to characterize the nature and extent of chemical and radiological contamination and the physical conditions in the vadose zone underlying the historical boundaries of the 216-Z-9 trench (200-PW-1 Operable Unit) and the 216-A-8 crib (200-PW-3 Operable Unit). Surface radiological surveys, borehole drilling, soil and soilvapor sampling, dense, nonaqueous-phase liquid (DNAPL) characterization, and borehole geophysical surveys were conducted as part of the field activities. These activities are summarized in various borehole reports (WMP-26264, WMP-30566, and WMP-27020).

In addition to characterization of these waste sites, the remedial investigation included characterization of the dispersed carbon tetrachloride vadose zone plume. As previously noted, the primary organic contaminants discharged to the 200-PW-1 Operable Unit waste sites were carbon tetrachloride, tributyl phosphate, and commercial lard oil. The carbon tetrachloride has migrated beyond the 200-PW-1 Operable Unit waste site boundaries, resulting in a dispersed carbon tetrachloride vadose zone plume. The purpose of the remedial investigation of the dispersed plume was to determine the nature and extent of the carbon tetrachloride contamination in the vadose zone and whether additional carbon tetrachloride sources exist in the vadose zone that are current or may be future sources of groundwater contamination. The dispersed plume remedial investigation activities, which were conducted in two phased steps, included the following:

- Passive and active soil-vapor surveys in the shallow vadose zone at engineered facilities that could be potential sources of carbon tetrachloride.

- Sampling in the deep vadose zone and top of the unconfined aquifer to evaluate whether vadose zone sources currently are impacting groundwater.

- Delineating the subsurface topography of fine-grained layers that could have influenced the contaminant migration pathways, such as the top of the Cold Creek unit, in the area surrounding the three primary carbon tetrachloride waste sites.

These activities are summarized in various reports (CP-13514; DOE/RL-2006-58). The comprehensive strategy for investigation of DNAPL in the 200 West Area was developed in FY 2003 (DOE/RL-2001-01). The DNAPL strategy included borehole drilling at the 216-Z-9 trench, investigation of any continuing sources indicated by the dispersed carbon tetrachloride plume investigation, and activities implemented by the Alternatives for Carbon Tetrachloride Source Term Location Project. This project included (1) the development of a viable conceptual model for the distribution of DNAPL in the vadose zone and unconfined aquifer, (2) the evaluation/proposal of characterization technologies to validate the model, and (3) the performance of the selected characterization activities to confirm the conceptual model that will describe the nature, extent, and mass of DNAPL. The Alternatives for Carbon Tetrachloride Source Term Location Project characterization activities are summarized in DOE/RL-2006-58.

\section{One well was \\ drilled at an angle beneath the 216-Z-9 trench to collect contaminated samples.}




\section{The highest concentrations of contaminants detected in the vadose zone at the 216-Z-9 trench are associated with fine-grained geologic layers.}

The data from these remedial investigation activities, as well as existing data, were included in Draft A of the Remedial Investigation Report (DOE/RL-2006-51). The report was prepared to fulfill requirements of Tri-Party Agreement (Ecology et al. 1989) Milestone M-015-45A (Submit Plutonium/Organic-Rich Operable Unit Remedial Investigation Report Including the Past Practice Waste Sites in the 200-PW-1 Operable Unit Plutonium/OrganicRich Process Condensate/Process Waste Group Operable Unit, 200-PW-3 Organic-Rich Process Condensate/Process Waste Group Operable Unit, and 200-PW-6 Plutonium-Rich Process Condensate/Process Waste Group Operable Unit). The data will support the evaluation of remedial alternatives in the feasibility study to be prepared in FY 2007.

\section{Remedial Investigation Activities}

216-Z-9 Trench (200-PW-1 Operable Unit). The 216-Z-9 trench is located in the 200 West Area, east of the Plutonium Finishing Plant complex. The 216-Z-9 trench consists of a 6-meter-deep excavation with a 37 - by 27 -meter concrete cover. The walls of the trench slope inward and downward to the 18- by 9-meter floor space, which had a slight slope to the south. The cover of the trench is supported by six concrete columns.

From July 1955 through June 1962, the 216-Z-9 trench received all solvent and aqueous waste from the RECUPLEX process that operated in the 234-5Z Building. The RECUPLEX process used nitric and hydrofluoric acids to produce soluble plutonium as plutonium nitrate and a carbon tetrachloride/tributyl phosphate solvent to recover the plutonium from the plutonium nitrate solutions. A criticality accident forced the closure of the RECUPLEX process in April 1962.

Two wells were drilled at the 216-Z-9 trench as part of the CERCLA remedial investigation. Well 299-W15-46 was drilled 4.6 meters south of the trench through the vadose zone and unconfined aquifer to the basalt bedrock, 160 meters bgs. Drilling was initiated in 2003 and completed in 2005. In 2006, well 299-W15-48 was drilled from east to west at a 32-degree angle underneath the trench to enable samples to be collected below the trench floor. The well was drilled through the Cold Creek unit to a total depth of 44 meters, measured along the length of the boring (37.5 vertical meters bgs). Well 299-W15-46 was completed as a groundwater monitoring well, and well 299-W15-48 was completed as a vapor extraction well.

Soil and soil-vapor samples were collected through the vadose zone during drilling of both wells to investigate the nature and extent of contamination underlying the waste site. The maximum carbon tetrachloride soil concentration was $380 \mathrm{mg} / \mathrm{kg}$ associated with a silt layer $\sim 19.8$-meters deep in well 299-W15-46. This same soil sample (from 19.4- to 20.1-meters bgs) contained carbon tetrachloride DNAPL based on both field screening and soil-equilibrium evaluations. The maximum carbon tetrachloride soil vapor concentration was 9,700 ppmv from a depth of 33.4 to 34.1 meters associated with the Cold Creek silt. The maximum concentration of plutonium-239/240 was 254,000 pCi/g detected in a sample from a vertical depth of 17.9 to 18.6 meters bgs in well 299-W15-48. The maximum concentration of plutonium-239/240 in well 299-W15-46 was from a similar depth (19.4 to 20.1 meters). The maximum concentration of americium-241 was 309,000 pCi/g, detected in a sample from the Cold Creek silt at a depth of 33.4 to 34.1 meters in well 299-W15-46. The maximum concentration of americium-241 in well 299-W15-48 was from a similar depth (30.6 to 31.1 vertical meters).

Manmade radionuclides detected in these two boreholes using spectral gamma geophysical logging were plutonium-239, americium-241, and protactinium-233; plutonium-241 was also detected in borehole 299-W15-48, and plutonium-240 was inferred to co-exist with the plutonium-241. The maximum concentration of plutonium-239 was $\sim 657,000 \mathrm{pCi} / \mathrm{g}$ at a vertical depth of 18.6 meters in well 299-W15-48. The maximum concentration of americium-241 was $\sim 400,000 \mathrm{pCi} / \mathrm{g}$ at a vertical depth of 35.4 meters in well 299-W15-46. 
These new data were supplemented with historical soil and soil-vapor sampling results, geophysical logging results, numerical-simulation results, and other data-collection and -analysis results. The data and analysis were integrated to develop and refine a contaminant distribution model for the 216-Z-9 waste site.

The following provides a summary of important remedial investigation findings related to the 216-Z-9 trench.

- Approximately 58 kilograms of plutonium were removed from the 216-Z-9 trench as part of trench floor mining activities completed from 1976 to 1978. An estimated 48 kilograms of plutonium remains in the trench.

- Radioactive contamination was identified in several boreholes using geophysical logging methods. The contamination was detected to a maximum depth of 59.4 meters bgs.

- Radioactive contamination in soil samples was detected to a maximum depth of 37.2 meters bgs.

- Soil-vapor samples collected from boreholes drilled in the vicinity of the trench prior to initiation of soil vapor extraction revealed carbon tetrachloride and other organic vapors at concentrations up to $20,910 \mathrm{ppmv}$.

- Soil samples from boreholes near the 216-Z-9 trench revealed carbon tetrachloride in soil up to $380 \mathrm{mg} / \mathrm{kg}$. This same soil sample (from 19.4 to 20.1 meters) contained carbon tetrachloride DNAPL based on both field screening and soil-equilibrium evaluations.

- A soil-vapor extraction system has been operated near the 216-Z-9 trench as an interim remedial action. Between March 1993 and September 2006, 54,280 kilograms of carbon tetrachloride were removed by the soil-vapor extraction system.

- In general, the highest concentrations of contaminants detected in the vadose zone soil have been in fine-grained layers (i.e., silts and the Cold Creek unit).

Dispersed Carbon Tetrachloride Vadose Zone Plume (200-PW-1 Operable Unit). Before remedial investigation of the dispersed plume, carbon tetrachloride had been found throughout the vadose zone within a 0.2 -square-kilometer area that included the known carbon tetrachloride waste sites near the Plutonium Finishing Plant (BHI-00720). Within this area, carbon tetrachloride had been found both within and beyond the boundaries of the known waste sites. Because one of the main purposes of the remedial investigation of the dispersed plume was to determine its extent, the size and scale of the dispersed carbon tetrachloride vadose zone plume can best be described by the remedial investigation area. Laterally, the investigation area was defined as the area outside of the known waste sites to the boundaries of the carbon tetrachloride groundwater plume that underlies an 11-squarekilometer area within the 200 West Area. Vertically, the investigation area included the entire vadose zone from the ground surface to the water table, which varies in depth from about 40.2 meters to greater than 75 meters in the 200 West Area.

The main contributor of carbon tetrachloride in the 200 West Area was releases of waste from the Plutonium Finishing Plant complex. To focus the remedial investigation of the dispersed plume, seven potential modes of carbon tetrachloride release were identified that may be associated with the carbon tetrachloride in the environment. The release modes identified included the following:

1. Leaks from drums of carbon tetrachloride in the drum storage area.

2. Releases of heating, ventilation, and air conditioning system condensate to engineered waste sites.

3. Plant process releases to the ground.

4. Leaks from plant process piping and drains to the ground under the Plutonium Finishing Plant.

\section{The carbon \\ tetrachloride \\ concentrations in \\ the vadose zone \\ are being reduced \\ by soil-vapor \\ extraction.}




\section{The highest radiological contamination at}

the 216-A-8 crib is within 18 meters of the ground surface.
5. Leaks from effluent-discharge pipelines,

6. Deliberate discharges through engineered liquid waste sites such as the 216-Z-1A tile field and the 216-Z-9 trench.

7. Releases from burial grounds.

In addition to investigating the seven potential release modes, the remedial investigation of the dispersed plume included investigation of the deep vadose zone and the top of the aquifer in eight areas of potentially persistent carbon tetrachloride concentrations in the groundwater plume.

The investigation of the dispersed carbon tetrachloride vadose zone plume was conducted in two steps. Step 1 focused on characterizing the shallow portion of the vadose zone overlying the highest concentration portion of the carbon tetrachloride groundwater plume. The Step 2 study extended deeper into the vadose zone and included the area overlying the entire carbon tetrachloride groundwater plume. Table 3.2-3 summarizes the number of samples collected as part of the remedial investigation of the dispersed plume.

The following provides a summary of important remedial investigation findings related to the dispersed carbon tetrachloride vadose zone plume:

- The highest carbon tetrachloride concentrations in the shallow, intermediate, and deep vadose zone generally are located within about 75 to 150 meters of the release sites. (The shallow, intermediate, and deep vadose zone generally correspond to the Hanford formation, the Cold Creek unit, and the Ringold Formation, respectively.)

- The carbon tetrachloride concentrations in the vadose zone around the release sites are being reduced by the soil-vapor extraction system and are significantly less than the initial concentrations measured in 1992 and 1993.

- Outside of the area around the release sites, carbon tetrachloride vapor concentrations up to about 10 to 12 ppmv were found at various locations in the vadose zone, but these concentrations are not considered to have the potential for significant current or future groundwater impacts.

- The soil-vapor and shallow-groundwater sampling at wells within the eight carbon tetrachloride groundwater "hot spot" areas indicated that the deep vadose zone soilvapor concentrations are not significant sources of groundwater contamination in these areas.

- An area of relatively high passive soil-vapor concentration was found northwest of the 216-Z-9 trench. The active soil-vapor investigations in this area and along the pipelines near this area did not identify any potential release areas in the shallow vadose zone. The highest active soil-vapor carbon tetrachloride concentration was 119 ppmv at 31.1 meters, above the top of the Cold Creek unit. This area may be associated with contamination from the 216-Z-9 trench that moved away from the trench area on the top of the Cold Creek unit and that is outside the capture zone of the soil-vapor extraction system.

- Carbon tetrachloride DNAPL was found at one sample depth in well 299-W15-46 in the shallow vadose zone, adjacent to the south side of the 216-Z-9 trench.

216-A-8 Crib (200-PW-3 Operable Unit). The 216-A-8 crib is located east of the A Tank Farm. The bottom dimensions of the crib are 259 by 6 meters. The long axis of the crib trends to the east-northeast. A 61-centimeter-diameter, schedule 20, perforated distribution line extends the length of the crib and rests on a 2-meter-thick layer of rock capped by a 30-centimeter-thick layer of gravel. The gravel fill is mounded over the distribution line. Two layers of Sisalkraft paper ${ }^{(a)}$ cover the gravel and prevent overlying

(a) Sisalkraft (paper) is a trademark of Fortifiber Corporation, Los Angeles, California. 
native sand backfill from filling the void space. The crib floor was excavated to a uniform elevation of 195 meters above mean sea level. The depth of the excavation varied from 4.9 to 5.8 meters below the 1955 ground surface. The site was surface stabilized in September 1990 by the addition of 0.6 meter of clean fill (DOE/RL-92-04). Water entered the crib through the 216-A-508 diversion box, located due west of the crib. The crib was permanently isolated in April 1995 by filling the 216-A-508 control structure with concrete.

The 216-A-8 crib received vapor condensate from the operation of several ventilation systems associated with the A, AX, AY, and AZ Tank Farms. The A Tank Farms complex first received self-boiling waste from PUREX in early 1956. The self-boiling waste generated a vapor phase that contained radioactive, organic, and inorganic contaminants. Between 1955 and 1958, the vapor phase was mixed directly with cooling water in two contact condensers, resulting in a large volume of liquid waste. During this time, the crib received over $99 \%$ of its reported uranium load, $98 \%$ of its plutonium load, and $83 \%$ of its beta fissionproduct load. Approximately $87 \%$ of the liquid waste, by volume, that the crib received over its 30-year-long operational life came from the contact condenser system during these 30 months (DOE/RL-92-04).

Sampling activities were conducted in 2004 to determine the best location for drilling a characterization borehole. These activities included pushing five GeoProbe boreholes along the length of the crib to depths of 3.7 to 4.6 meters bgs, collecting and analyzing soil-vapor samples from these boreholes, collecting and analyzing soil-vapor samples from five existing wells, and geophysically logging six existing wells (WMP-27020).

The results of the soil-vapor sampling investigations in the shallow and deep vadose zone did not conclusively indicate the presence of organics at any of the locations sampled. However, the geophysical logging investigation clearly identified the location with the highest radionuclide concentrations. Existing well 299-E25-5 exhibited the highest radionuclide concentrations, with a maximum cesium- 137 value of $30,800 \mathrm{pCi} / \mathrm{g}$ found at 7.6 meters below the top of the casing. The second highest levels were found in existing well 299-E25-6, with a cesium- 137 concentration of $50 \mathrm{pCi} / \mathrm{g}$ in the interval from 7.6 to 9.1 meters below the top of the casing. Therefore, based on the work plan (DOE/RL-2001-01) guidance and on the results of the soil-vapor sampling and borehole geophysical logging at the 216-A-8 crib, borehole C4545 was located on the south side of well 299-E25-5. This location is close to the center of the 216-A-8 crib and closer to well 299-E25-6, where contamination appeared to be slightly deeper.

Characterization borehole $\mathrm{C} 4545$ was drilled through the vadose zone to a total depth of 80.6 meters in 2005. The primary focus of the soil sampling in borehole C4545 beneath the 216-A-8 crib, was to characterize the vadose zone for the nature and distribution of organic and radiological contaminants. Evaluation of the nature and extent of contamination at this location is based on the evaluation of the new data supplemented with historical geophysical logging results. The data and analysis were integrated to develop and refine a contaminant distribution model for the representative waste site.

The following provides a summary of important RI findings related to the 216-A-8 crib.

- The highest radiological contamination associated with the crib was detected within 18 meters of the ground surface.

- The maximum extent of radiological contamination detected near the crib by geophysical logging techniques was 76.5 meters bgs. However, the source of the contamination at this depth is not known. 
Table 3.2-1. Direct Push Summary Table (June 2005 through September 2006)

\begin{tabular}{|c|c|c|c|c|c|c|}
\hline Locations & $\begin{array}{l}\text { Number of } \\
\text { Probe Holes }\end{array}$ & $\begin{array}{c}\text { Total } \\
\text { Footage }(\mathrm{m})\end{array}$ & $\begin{array}{l}\text { Number of } \\
\text { Samples }\end{array}$ & $\begin{array}{l}\text { Gross Gamma } \\
\text { Log Footage }(\mathrm{m})\end{array}$ & $\begin{array}{l}\text { Electrodes } \\
\text { Placed }\end{array}$ & $\begin{array}{c}\text { Moisture Log } \\
\text { Footage }(\mathrm{m})\end{array}$ \\
\hline $\begin{array}{l}\text { WMA C } \\
\text { (vertical) }\end{array}$ & 39 & 110 & 19 & 76 & - & 76 \\
\hline TY Tank Farm & 30 & 152 & 5 & 131 & - & - \\
\hline Mock Tank & 5 & 51 & - & - & - & - \\
\hline $100-N$ & 8 & 18 & - & - & - & - \\
\hline 200 West Area & 1 & 10 & - & - & - & - \\
\hline WMA C (angle) & 6 & 43 & 15 & 43 & 1 & 29 \\
\hline BX Tank Farm & 14 & 100 & 3 & 83 & 4 & - \\
\hline WMA T & 8 & 43 & 2 & 34 & 1 & - \\
\hline $\begin{array}{l}\text { Install Moisture } \\
\text { Arrays at } \\
\text { WMA T }\end{array}$ & 8 & 19 & - & - & - & - \\
\hline Total & 119 & 546 & 44 & 367 & 6 & 105 \\
\hline
\end{tabular}

Table 3.2-2. Hanford Geophysical Logging Project Logging Systems

\begin{tabular}{|c|c|c|c|c|}
\hline $\begin{array}{l}\text { Sonde } \\
\text { Serial Number }\end{array}$ & $\begin{array}{l}\text { Gamma } 1(A) \\
\text { HO 68B-3574 }\end{array}$ & $\begin{array}{l}\text { Gamma } 2(B) \\
\text { HO 68B-3572 }\end{array}$ & $\begin{array}{c}\text { Gamma } 3(\mathrm{C}) \\
\text { Removed from Service }\end{array}$ & $\begin{array}{l}\text { Gamma } 4 \text { (D) } \\
\text { HO 68B-3573 }\end{array}$ \\
\hline $\begin{array}{c}\text { A }\left(\mathrm{SGLS}^{1} 35 \% \mathrm{HPGe}^{2} \text { ) }\right. \\
\text { 34TP20893A (out of service) }\end{array}$ & & & & $\begin{array}{c}\text { DA }(05 / 11 / 05) \\
\text { DOE-EM/GJ891-2005 }\end{array}$ \\
\hline \multicolumn{5}{|l|}{$\begin{array}{c}\text { B (SGLS 35\% HPGe) } \\
\text { 36TP21095A }\end{array}$} \\
\hline C $\left(H R L S^{3}\right) 39 A 314$ & \multicolumn{2}{|c|}{ AC $^{4}(10 / 06 / 05)^{5}$ DOE-EM/GJ1019-2005 } & & \\
\hline \multicolumn{5}{|l|}{$\begin{array}{c}\text { D (SGLS 35\% HPGe) } \\
\text { 34TP11019B (out of service) }\end{array}$} \\
\hline $\begin{array}{c}\text { E (SGLS 70\% HPGe) } \\
\text { 34TP40587A }\end{array}$ & $\begin{array}{c}\text { AE (05/02/06) } \\
\text { DOE-EM/GJ1200-2006 }\end{array}$ & & & $\begin{array}{c}\text { DE (05/08/06) } \\
\text { DOE-EM/GJ1199-2006 }\end{array}$ \\
\hline $\begin{array}{c}\text { F }\left(\mathrm{NMLS}^{7}\right) \\
\mathrm{H} 380932510\end{array}$ & & $\begin{array}{c}\text { BF }(10 / 07 / 04) \\
\text { DOE-EM/GJ754-2004 }\end{array}$ & & $\begin{array}{c}\text { DF (04/28/06) } \\
\text { DOE-EM/GJ1191-2006 }\end{array}$ \\
\hline $\begin{array}{c}\text { G (SGLS 35\% HPGe) } \\
34 \text { TP10951A }\end{array}$ & $\begin{array}{c}\text { AG (11/29/05) } \\
\text { DOE-EM/GJ1052-2005 }\end{array}$ & & & $\begin{array}{c}\text { DG }(03 / 16 / 06) \\
\text { DOE-EM/GJ1162-2006 }\end{array}$ \\
\hline $\begin{array}{l}\text { H (NMLS) } \\
\text { H310700352 }\end{array}$ & & & & $\begin{array}{c}\text { DH }(03 / 06 / 06) \\
\text { DOE-EM/GJ1154-2006 }\end{array}$ \\
\hline $\begin{array}{l}\text { I }\left(\text { PNLS }^{8}\right) \\
\text { U1754 }\end{array}$ & & $\begin{array}{c}\text { BI } \\
\text { Calibration not required }\end{array}$ & & $\begin{array}{l}\text { DI } \\
\text { Calibration not required }\end{array}$ \\
\hline $\begin{array}{c}\mathbf{J}\left(\mathrm{NCLS}^{9}\right) \\
34 \text { TN1104A }\end{array}$ & & & & $\begin{array}{c}\text { DJ }(08 / 18 / 06) \\
\text { DOE-EM/GJ1315-2006 }\end{array}$ \\
\hline $\mathbf{K}\left(\mathrm{AZLS}^{10}\right)$ & \multicolumn{4}{|c|}{ Not currently deployed } \\
\hline \multicolumn{5}{|l|}{$\mathbf{L}$} \\
\hline $\begin{array}{l}\text { M (NMLS) } \\
\text { H340207279 }\end{array}$ & & $\begin{array}{c}\text { BM }(08 / 02 / 06) \\
\text { DOE-EM/GJ1283-2006 }\end{array}$ & & $\begin{array}{c}\text { DM }(03 / 06 / 06) \\
\text { DOE-EM/GJ1155-2006 }\end{array}$ \\
\hline $\begin{array}{c}\mathbf{N}(\text { SGLS 60\% HPGe) } \\
\text { 45-TP22010A }\end{array}$ & $\begin{array}{c}\text { AN (04/05/06) } \\
\text { DOE-EM/GJ1183-2006 }\end{array}$ & & & $\begin{array}{c}\text { DN (04/06/06) } \\
\text { DOE-EM/GJ1177-2006 }\end{array}$ \\
\hline \multicolumn{5}{|c|}{$\begin{array}{l}1 \text { Spectral gamma logging system. } \\
2 \text { High purity germanium. } \\
3 \text { High rate logging system. } \\
4 \text { First two letters of filename. } \\
5 \text { Date of most recent calibration. } \\
6 \text { Document number of most recent calibration certificate. } \\
7 \text { Neutron moisture logging system. } \\
8 \text { Passive neutron logging systems. } \\
9 \text { Neutron capture logging system. } \\
10 \text { Azimuthal logging system. }\end{array}$} \\
\hline
\end{tabular}


Table 3.2-3. Number of Samples Collected as Part of the 200-PW-1 Operable Unit Remedial Investigation

\begin{tabular}{|l|c|c|c|}
\hline \multicolumn{4}{|c|}{ Dispersed Plume Results by Sample Media } \\
\hline \multicolumn{1}{|c|}{ Vadose Zone Interval } & Passive Soil Vapor & Active Soil Vapor $^{(\mathbf{a})}$ & Soil Samples $^{(\mathrm{b})}$ \\
\hline Shallow & 749 & 1,800 & 330 \\
\hline Intermediate & 0 & 27 & 68 \\
\hline Deep & 0 & 273 & 182 \\
\hline Total sample results & $\mathbf{7 4 9}$ & $\mathbf{2 , 1 0 0}$ & $\mathbf{5 8 0}$ \\
\hline $\begin{array}{l}\text { (a) At 1,249 separate locations. } \\
\text { (b) At 78 separate locations. }\end{array}$
\end{tabular}




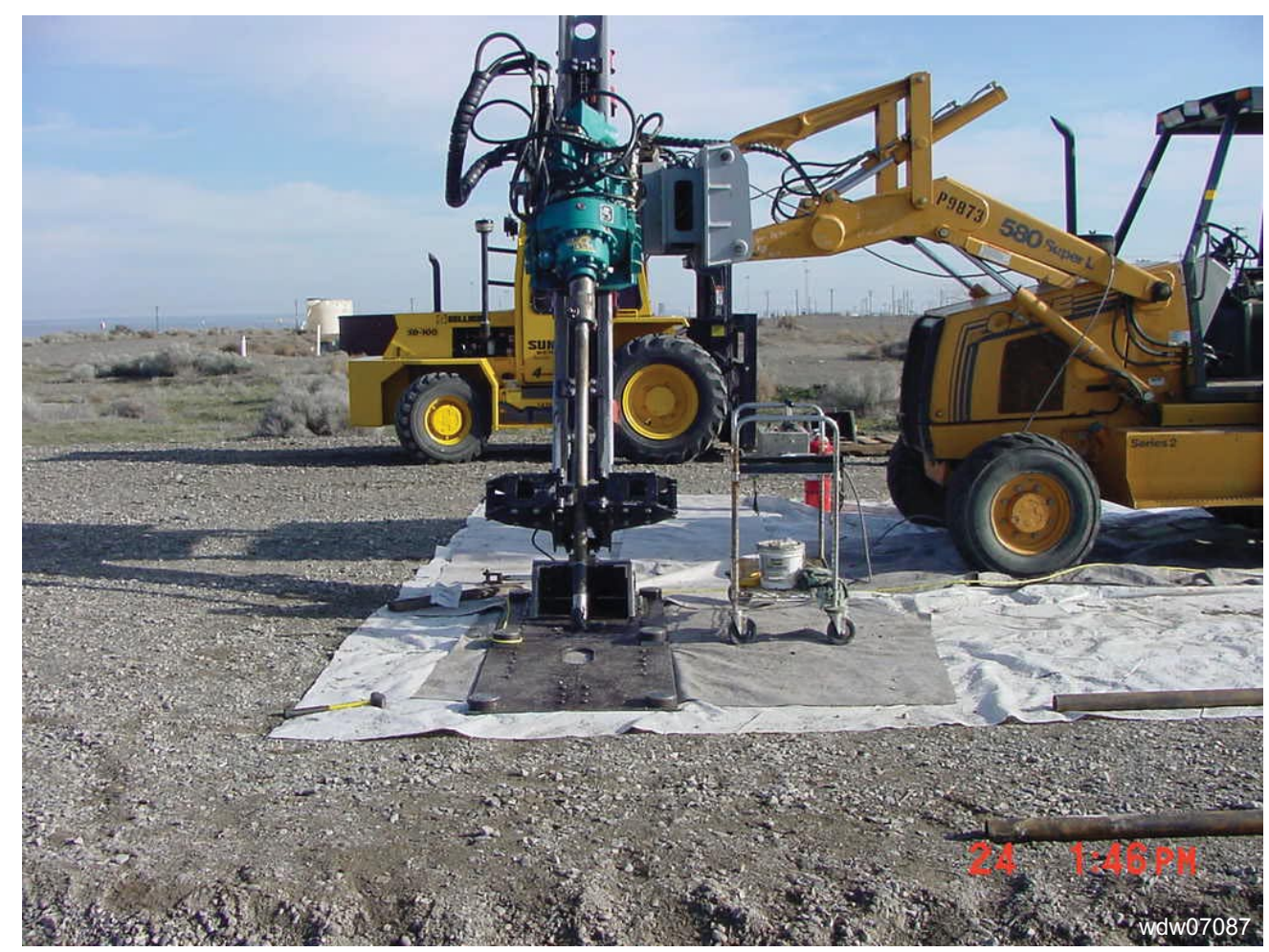

Figure 3.2-1. Demonstration of Hydraulic Hammer Unit in Non-Vertical Mode

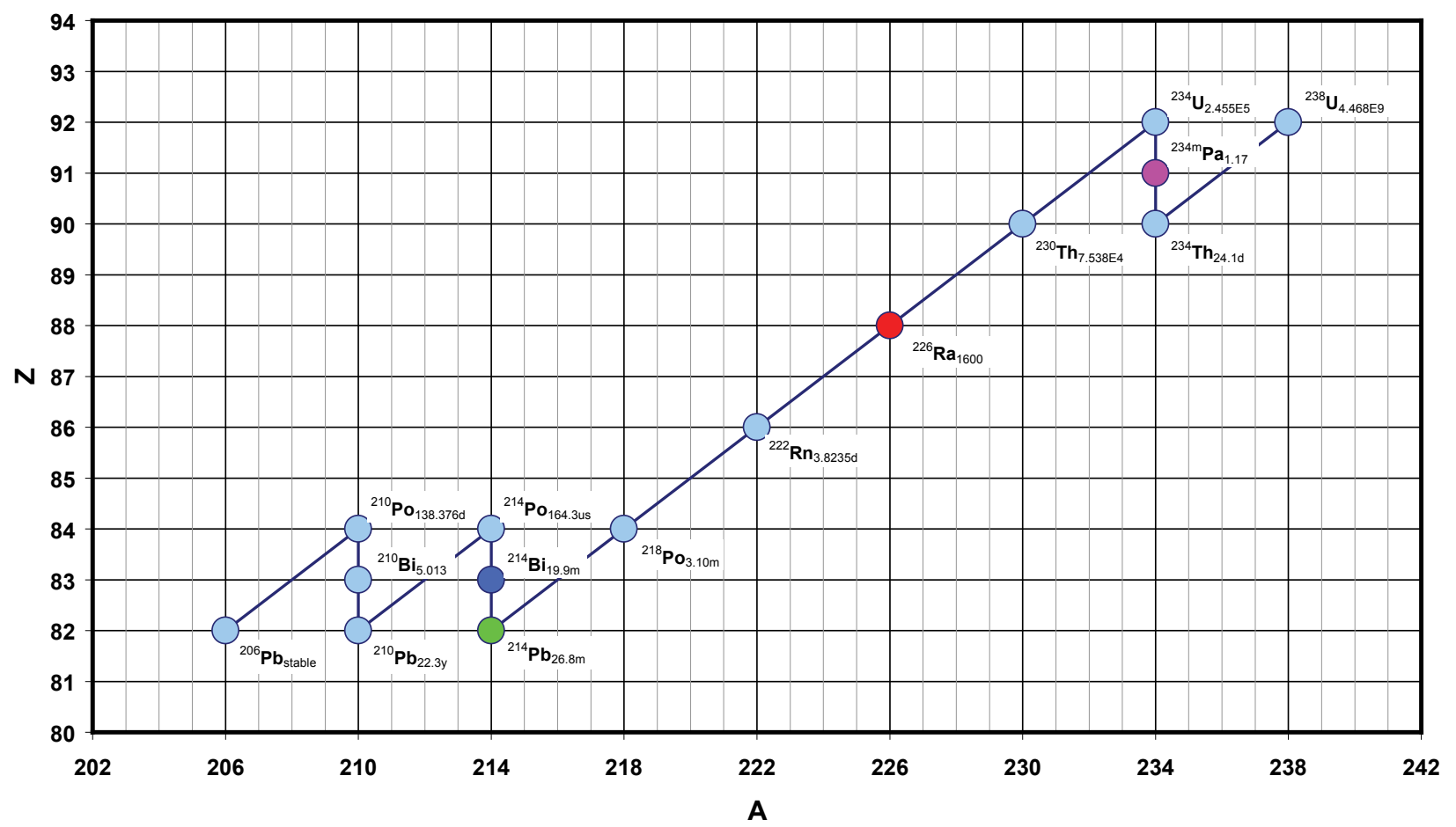

Figure 3.2-2. Uranium-238 Decay Series 


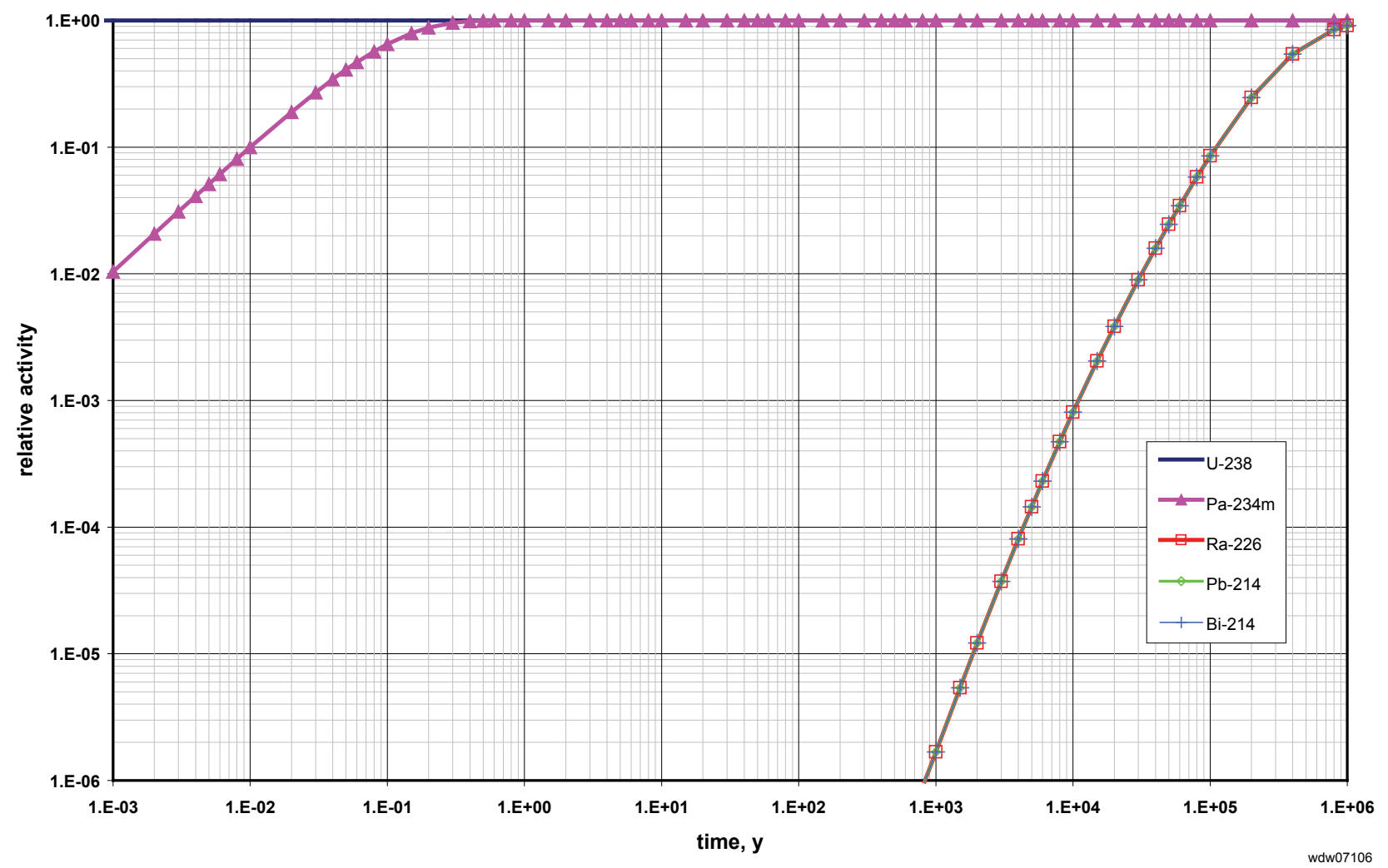

Figure 3.2-3. Build In of Gamma-Emitting Daughters in the Uranium-238 Decay Series 

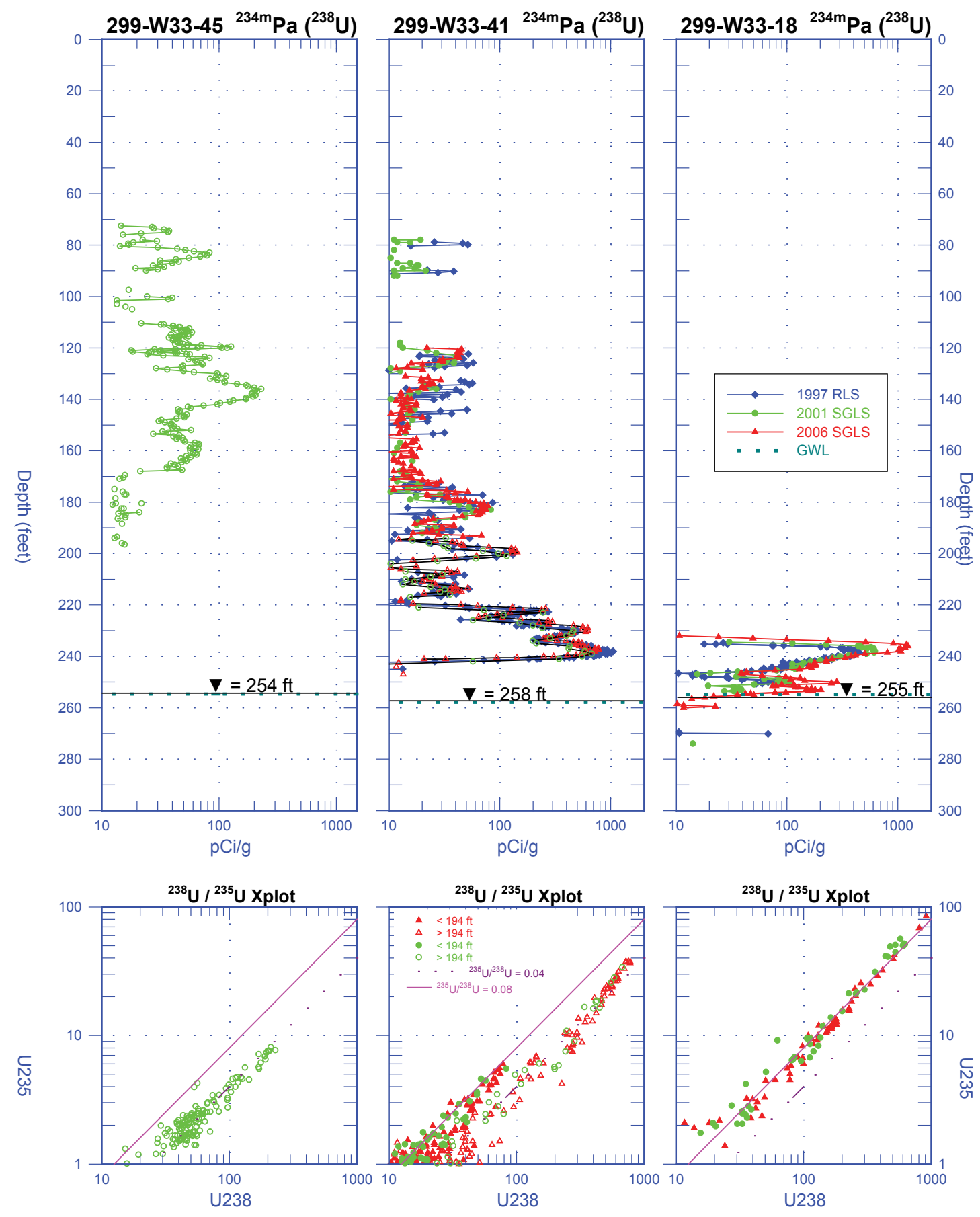

wdw07107

Figure 3.2-4. Vadose Zone Uranium at 200-BP-5 Groundwater Operable Unit 


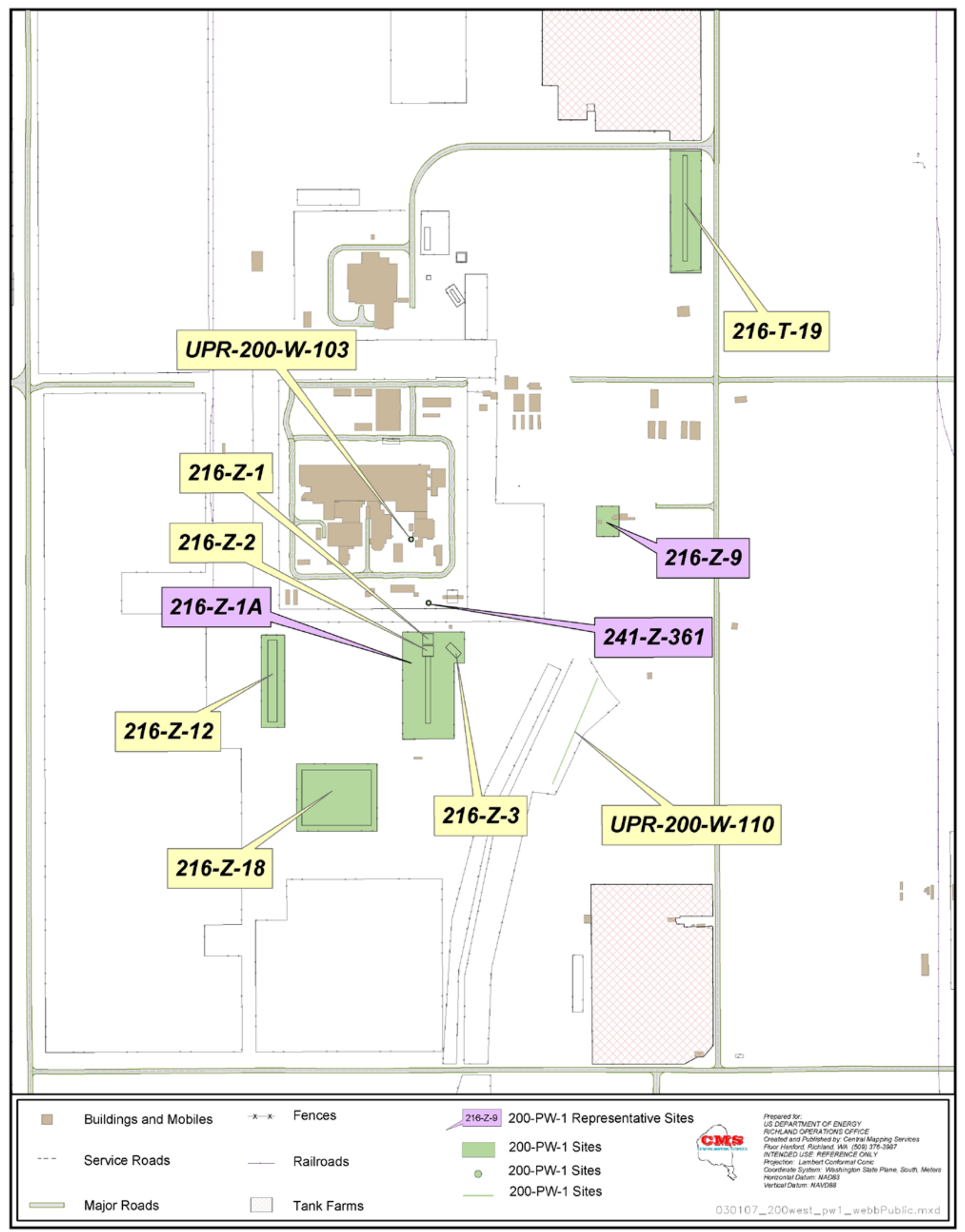

Figure 3.2.5. Locations of Past-Practice Disposal Facilities in 200-PW-1 Operable Unit, 200 West Area 


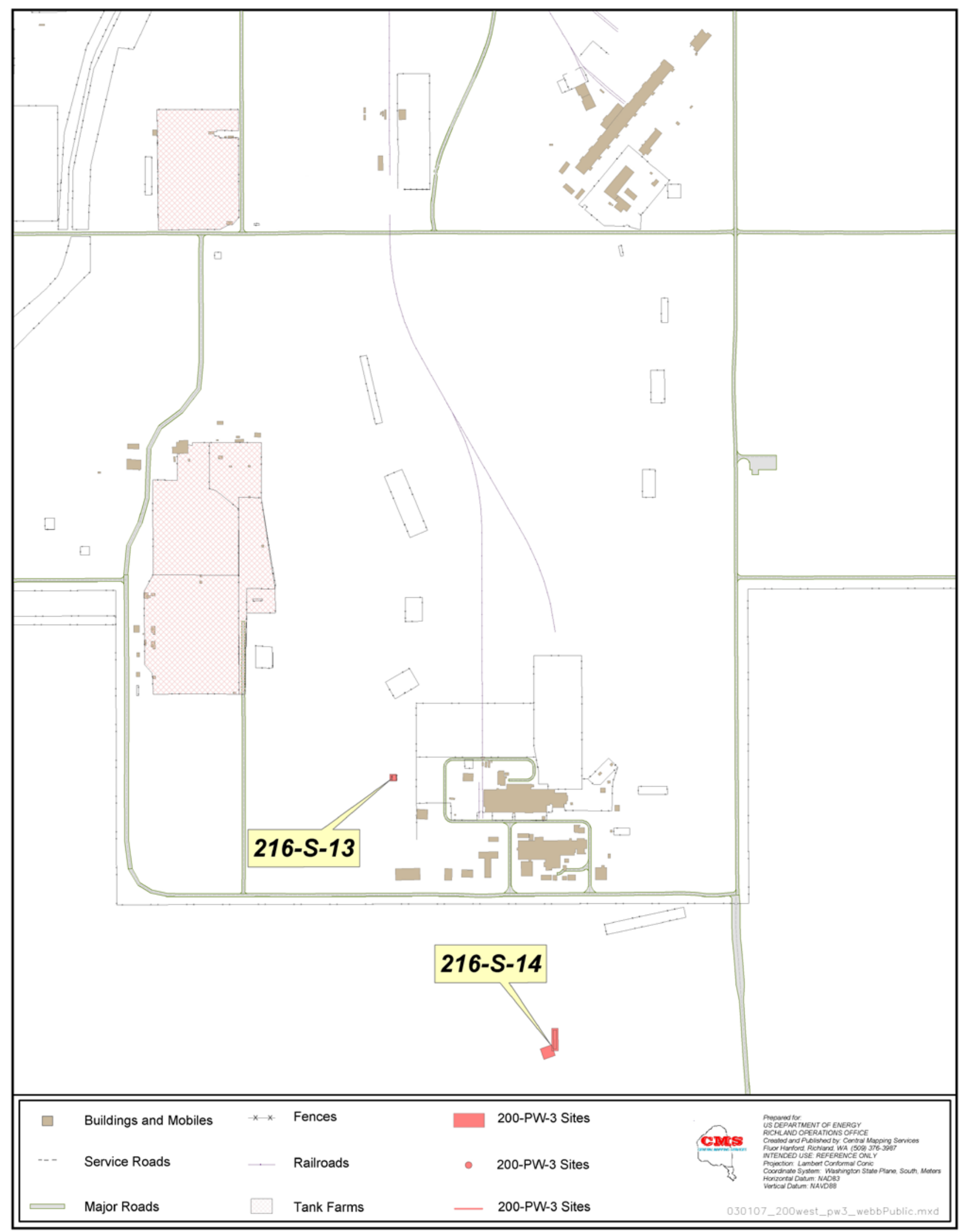

Figure 3.2-6. Locations of Past-Practice Disposal Facilities in 200-PW-3 Operable Unit, 200 West Area 


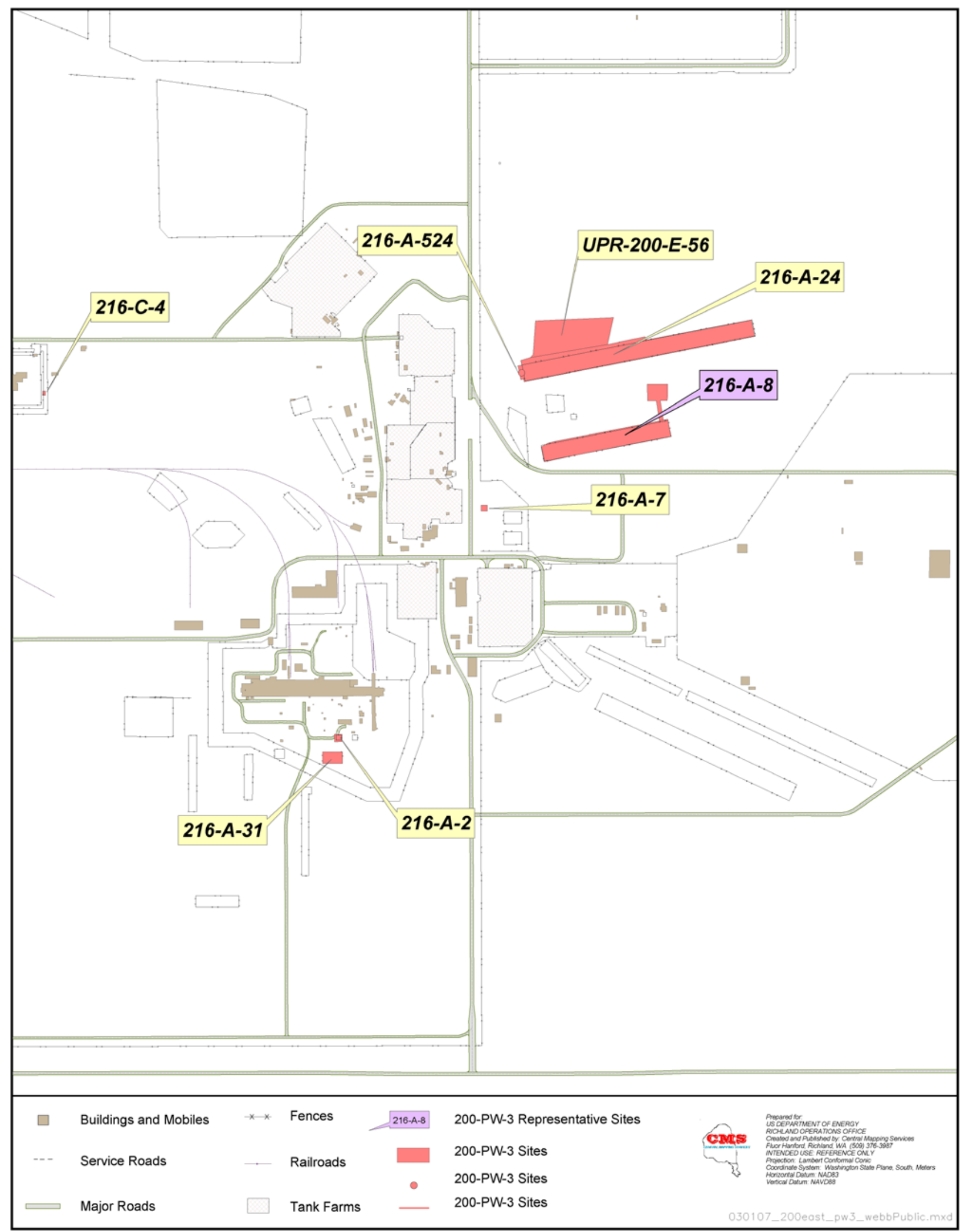

Figure 3.2-7. Locations of Past-Practice Disposal Facilities in 200-PW-3 Operable Unit, 200 East Area 


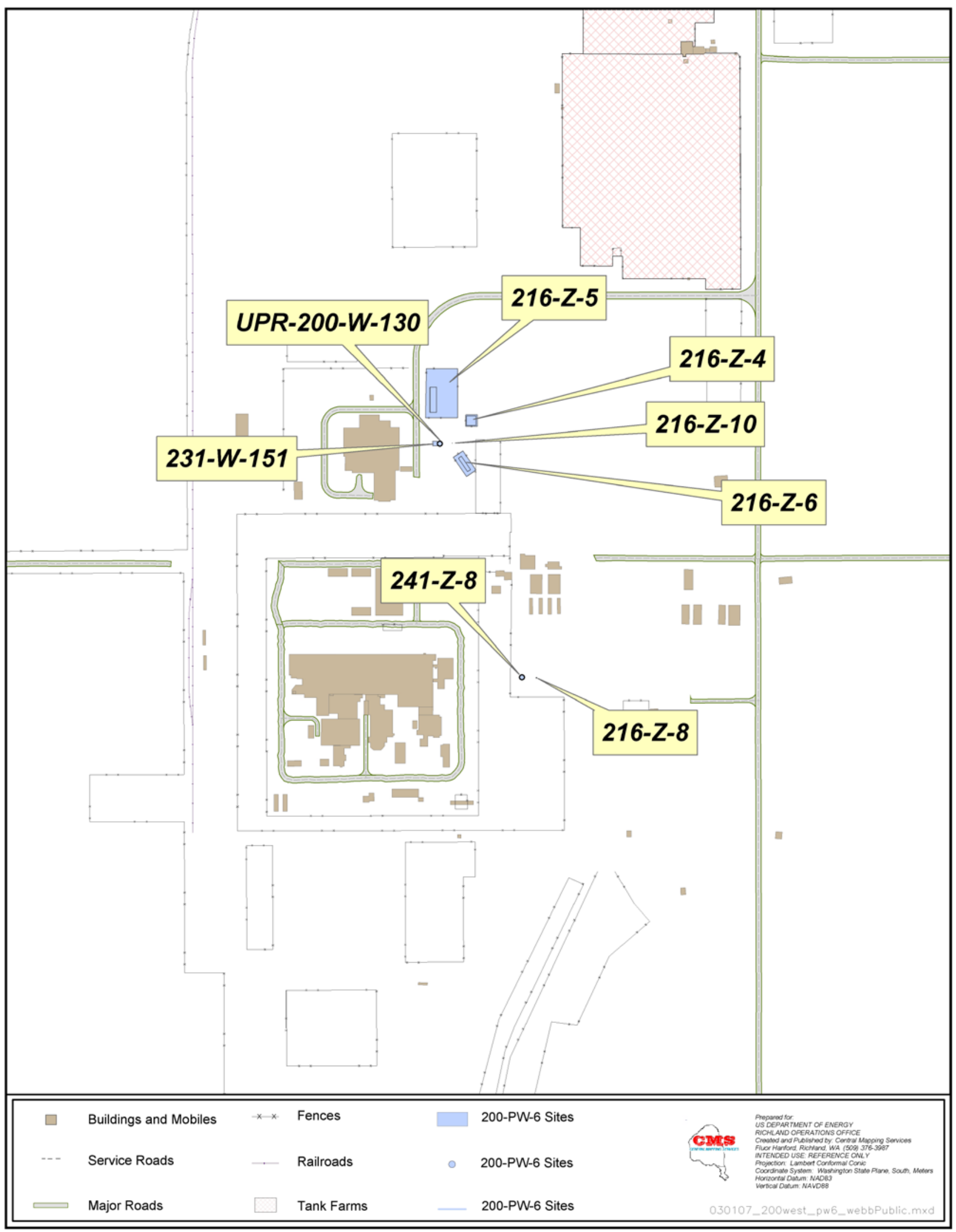

Figure 3.2-8. Locations of Past-Practice Disposal Facilities in 200-PW-6 Operable Unit, 200 West Area 


\subsection{Vadose Zone Studies}

Three activities were done in fiscal year (FY) 2006 concerning recharge rates at the Hanford Site. The first was a laboratory investigation to evaluate the effects of estimating gravel content when calculating recharge using the chloride mass balance method. The second was a field installation of instruments to monitor moisture beneath a future interim cover over the area of the T-106 single-shell tank leak. The third was an estimation of recharge using the chloride mass balance method at characterization well 699-S20-E10 at the 300-FF-5 Operable Unit. Finally, a tensorial conductivity-tortuosity model study was done to extend the model to unsaturated porous media with two or more immiscible fluids. This section summarizes these studies.

\subsubsection{Assessment of the Chloride Mass Balance Technique: Accounting for Gravel Content}

\section{J. M. Keller, M. J. Fayer, R. J. Serne, and M. M. Valenta}

The chloride mass balance method is frequently used to estimate recharge rates in arid and semiarid regions. To simplify the chloride analysis, the analysis is often limited to samples comprised of particles $<2$ millimeters in diameter, with the justification being that soil water within gravel voids and in the form of water film around gravels does not significantly contribute to the pore-water chloride of the bulk sample. To relate the chloride concentration derived from the $<2$-millimeter fraction to the bulk sample ( $>2$ and $<2$ millimeters), the chloride concentration is multiplied by the fraction of the bulk sample that is $<2$ millimeters. This study explored the validity of restricting chloride analysis to the $<2$-millimeter-size fraction and the accuracy of chloride concentration in the soil pore water $\left(\mathrm{Cl}_{s}\right)$ calculated from applying the fraction $<2$-millimeter multiplier.

Split-spoon soil samples were collected $\sim 1$ kilometer from the Hanford Meteorological Station in a location dominated by big sagebrush (Artemisia tridentate) and a variety of annual and perennial grasses. The samples were collected to a depth of 15 meters below ground surface. Each sample was homogenized and a sample for moisture content was collected. The remaining material was split into two subsamples. One subsample was air dried then divided into $>2$ - and $<2$-millimeter-size fractions. The $>2$ - and $<2$-millimeter fractions were analyzed for chloride content and soil moisture content. The second subsample, containing both the $>2$ - and $<2$-millimeter constituents, was air dried and analyzed for chloride and moisture contents. After the chloride and moisture content analyses were completed, the core material was reconstituted and particle size analysis performed on the bulk sample. The size distribution of the $>2$-millimeter fraction was obtained by dry sieving and the size distribution of the $<2$-millimeter fraction was measured using both the wet sieve and hydrometer analyses.

The particle size distribution of the core samples is presented in Table 3.3-1. The soil profile consists largely of gravel-dominated sediments with $58 \%$ to $85 \%$ gravel, which provides ample gravel fraction to evaluate the pore-water chloride concentration gravel correction approach.

The field gravimetric moisture content profile is shown in Figure 3.3-1. The profile is very dry, with moisture content ranging from 0.008 near the surface to 0.048 deeper in the soil profile. The low moisture content nearer the soil surface is characteristic of summer conditions at the Hanford Site resulting from minimal summer precipitation and active soil water extraction from shrubs and grasses.

Figure 3.3-2 shows pore-water chloride concentration for the three subsamples $(<2$ millimeters, $>2$ millimeters, and bulk) acquired from each core. The chloride

\author{
Vadose zone \\ studies are designed \\ to result in new, \\ innovative methods \\ for cleanup and \\ monitoring.
}




\section{Chloride mass \\ balance is being used at the Hanford \\ Site to estimate recharge rates.}

concentration profile for all three subsample sets trend each other. The $<2$-millimeter subsamples have the largest chloride concentration followed by the bulk samples and then the $>2$-millimeter samples.

The largest chloride concentration in the $>2$-millimeter subsamples contain is $62.8 \mathrm{mg} / \mathrm{L}$. The bulk subsample concentration at the same depth is $220.5 \mathrm{mg} / \mathrm{L}$, or nearly 3.5 times larger than the gravel fraction. Nonetheless, a significant amount of chloride is associated with the $>2$-millimeter sample. A general note of caution is that even though sieving removed most of the $<2$-millimeter fraction from the $>2$-millimeter particles, small amounts of silts and smaller particle were observed to adhere to the gravel material resulting in small amounts of $<2$-millimeter material in the $>2$-millimeter subsamples. This would tend to produce an inaccurately high chloride concentration for the $>2$-millimeter subsample.

Figure 3.3-3 shows pore-water chloride concentration for the bulk sample as well as for the gravel corrected $<2$-millimeter subsample. At a few depths, the gravel-corrected concentrations are similar to the bulk sample concentrations; however, at other depths the concentrations diverge significantly. For instance, at the 8.76-meter depth, the bulk chloride concentration is nearly twice as large as the gravel corrected value.

Because the pore-water chloride concentration is used to estimate recharge, it is useful to compare recharge values calculated from the bulk chloride content with the gravel corrected chloride content. An average chloride deposition rate of $40 \mathrm{mg} / \mathrm{m}^{2} /$ year has been estimated for the Hanford Site by Murphy et al. (1996), and this value was used for the comparison. The chloride concentration used for the comparison was obtained by plotting the cumulative chloride content with depth against the cumulative water content at the same depth (Figure 3.3-4). The slopes of the lines on Figure 3.3-4 equal the inverse of the chloride content for that depth interval. The straight line segments represent times of constant recharge conditions and slope changes signify changes in recharge conditions. Current recharge conditions are represented by the straight line segment nearest to the surface. Included in Figure 3.3-4 are the pore-water chloride concentrations $\left(\mathrm{Cl}_{\mathrm{s}}\right)$ and calculated recharge rate $(R)$ for the youngest time segment. The bulk sample has a chloride concentration of $16.3 \mathrm{mg} / \mathrm{L}$ resulting in a recharge estimate of $2.5 \mathrm{~mm} / \mathrm{year}$. The gravel corrected sample has a chloride content of $20.7 \mathrm{mg} / \mathrm{L}$ and an estimated recharge rate of $1.9 \mathrm{~mm} /$ year. For this data set, a $-24 \%$ error in recharge is introduced for this data set when the bulk sample chloride concentration is not used.

The magnitude of error in recharge rate that would occur from errors in the particlesize analysis was examined to further investigate error introduced by the gravel correction method. To do this, the fraction of sample that is $<2$ millimeters was reduced and increased from the measured values by $1 \%$ intervals up to $5 \%$. This resulted in recharge estimates that differed by as much as $21 \%(1.9 \mathrm{~mm} /$ year versus $2.3 \mathrm{~mm} /$ year $)$, suggesting the importance of accurately measuring the fraction of the bulk sample that is $<2$ millimeters when correcting chloride concentrations to reflect the bulk sample.

For this data set, it appears that significant errors are introduced while estimating recharge using a gravel-corrected pore-water chloride concentration. This may be avoided by, when possible, performing chloride analysis on the bulk sample as opposed to only the $<2$-millimeter-particle-size fraction.

\subsubsection{T Tank Farm Interim Cover Test}

\section{Z. F. Zhang and J. M. Keller}

The Hanford Site has 149 underground single-shell tanks that store hazardous radioactive waste. Many of these tanks and their associated infrastructure (e.g., pipelines, diversion boxes) have leaked. Some of the leaked waste has entered the groundwater. The largest known leak occurred from the T-106 tank in 1973. Many of the contaminants from that 
leak still reside within the vadose zone beneath the T Tank Farm. CH2M HILL Hanford Group, Inc. seeks to minimize movement of this residual contaminant plume by placing an interim cover on the surface. Such a cover is expected to prevent infiltrating water from reaching the plume and moving it further. Pacific Northwest National Laboratory is in the process of completing a monitoring plan to measure changes in moisture conditions beneath the interim cover. In FY 2006, two instrument nests were installed. Each instrument nest contains a neutron probe access tube, five capacitance sensors (to measure water content), four heat-dissipation units (to measure water potential), and a drain gauge (to measure soil water flux). Additionally, a meteorological station was installed outside of the tank farm. In FY 2007, additional instrument nests are being planned.

\subsubsection{Estimation of Recharge from Well 699-S20-E10 Using Chloride Mass Balance}

\section{J. M. Keller}

This section summarizes the work done to estimate recharge at the location of characterization well 699-S20-E10 at the 300-FF-5 Operable Unit. The well is located northwest of the 300 Area (see Figure 2.13-1 for well location). A more complete description of this work, along with other characterization activities at the well, is provided in PNNL-15417.

Recharge, defined as infiltrating water that reaches the water table, is the primary mechanism driving the transport of waste residing in the unsaturated zone to groundwater. In support of efforts to reduce uncertainties in recharge estimates at the 300-FF-5 Operable Unit, sediment core and grab samples from well 699-S20-E10 were analyzed for matric potential, water content, and pore water anions for purposes of estimating recharge conditions at the well location using the chloride mass balance method. The estimated present day recharge rate, based on the data presented below is $1.89 \mathrm{~mm} /$ year.

Anion concentrations were measured from solutions extracted from 1:1 soil to water mixtures by weight. The chloride concentration in the soil pore water was then calculated by dividing the concentration of the 1:1 extract by the soil moisture content and then multiplying by the dilution ratio of the 1:1 soil:water mixture. With certain assumptions, such as piston flow chloride transport, knowing the pore water chloride concentration allows for a recharge rate, $R\left(\mathrm{~mm} \mathrm{yr}^{-1}\right)$, to be calculated using a mass balance approach described by:

$$
\mathrm{P} \times \mathrm{Cl}_{\mathrm{p}}=\mathrm{R} \times \mathrm{Cl}_{\mathrm{s}}
$$

where $\quad P=$ average annual precipitation (millimeters year ${ }^{-1}$ )

$\mathrm{Cl}_{\mathrm{p}}=$ average chloride deposition rate, including both wet and dry fallout

$\mathrm{Cl}_{\mathrm{s}}=$ pore-water chloride content .

Murphy et al. (1996) estimated the chloride deposition rate for the Hanford Site to range from 0.220 to $0.230 \mathrm{mg} / \mathrm{L}$. This study used the median chloride deposition rate of $0.225 \mathrm{~mm} / \mathrm{L}$. An annual precipitation of $190 \mathrm{~mm} /$ year was used following the work of Gee et al. (2005) who estimated that value for a nearby lysimeter site.

Figure 3.3-5 shows the pore-water chloride distribution with depth in well 699-S20-E10. The chloride concentration shows a slight increase near the soil surface. This is often the case in arid regions in which chloride is concentrated near the surface due to plant transpiration or evaporative drying. A somewhat more constant concentration exists from $\sim 0.5$ to 6 meters depth below which is a large increase in chloride concentration that continues to $\sim 12$ meters depth reaching a maximum of $291 \mathrm{mg} / \mathrm{L}$ at $\sim 7.5$ meters depth. The bulge in chloride concentration probably represents past recharge conditions. The chloride bulge does not appear to be the result of a fluctuating water table because the chloride concentration of a groundwater sample collected soon after the well was completed
A recharge rate of 1.89 millimeters of moisture per year was estimated for one area in the 300-FF-5 Operable Unit. 
was $16.2 \mathrm{mg} / \mathrm{L}$ or nearly 18 times less than the maximum measured pore water chloride. Also, water-table-elevation data collected from nearby wells during the past 50 years do not suggest that the water table fluctuated enough for groundwater to intrude into the depth of the high chloride concentrations. A change in recharge conditions is a plausible cause for the chloride increase because the well is in an active dune in which surface conditions controlling recharge, such as soil texture and vegetation, are continually changing. In addition, the occurrence of range fires that alter the vegetative community may play a role in changing recharge conditions.

To determine the value of pore-water chloride concentration to apply in the calculation of recharge, the cumulative chloride content with depth was plotted against the cumulative water content at the same depth (Figure 3.3-6). The slopes from this plot equal the inverse of the pore water chloride content $\left(\mathrm{Cl}_{s}^{-1}\right)$ for that depth interval. The straight line segments represent times of constant recharge conditions and slope changes signify changes in recharge conditions. Included in Figure 3.3-6 are the pore-water chloride concentrations and the calculated recharge rates as well as the residence times represented by the chloride concentration before the change in slope. Current recharge conditions are represented by the straight line segment nearest to the surface, providing an estimated recharge rate of $1.89 \mathrm{~mm} /$ year. This is less than the recharge of $4.01 \mathrm{~mm} /$ year estimated from the chloride mass balance method by Murphy et al. (1996) for a primarily grass covered stabilized dune and slightly larger than the recharge of $1.11 \mathrm{~mm} /$ year estimated by PNNL-14744 for a dune vegetated with deep rooted shrubs. The vegetation around well 699-S20-E10 is predominately annual and perennial grasses with the surface soil classified as a Rupert Sand (BNWL-243). As a note of interest, the recharge rate calculated from the straight-line segment located at the depth of the chloride concentration bulge, potentially representing past recharge conditions, is $0.18 \mathrm{~mm} /$ year.

To further support drainage conditions at the site, the matric potential profile is shown in Figure 3.3-7. Whereas the matric potential data show some scatter, the overall trend is higher (less negative) matric potential with depth, with a trend toward unit gradient conditions, indicating gravity drainage. The sharp decrease in matric potential above $\sim 4$ meters implies potential upward water flow at the time of sampling, indicative of the dry summer conditions. This agrees with the increasing pore-water chloride concentration near the surface.

The estimated recharge rate(s) at this site can be used as an upper boundary condition for undisturbed areas in the subsurface flow and reactive transport models that are being developed for the 300 Area in support of the record of decision regarding the 300-FF-5 Operable Unit (ROD 1996b).

\subsubsection{Extension of the Tensorial Connectivity- Tortuosity Concept to Multifluid Systems in Porous Media}

\section{Z. F. Zhang, M. Oostrom, and A. L. Ward}

The hydraulic conductivity of unsaturated anisotropic soils has recently been described with a tensorial connectivity-tortuosity concept. This concept was extended to unsaturated porous media with two or three immiscible fluids. Mathematical expressions to describe the conductivity of each fluid in anisotropic porous media under unsaturated condition are derived in the form of symmetric second order tensors. The theory is applicable to the combination of any type of saturation-pressure formulation and a generalized hydraulic conductivity model. The extended model shows that the anisotropic coefficient of a fluid is independent of the saturation of other fluids. Synthetic Miller-similar soils having hypothetical anisotropy were defined by allowing the saturated hydraulic conductivity to have different correlation ranges for different directions of flow. 
The extended tensorial connectivity-tortuosity concept was tested using synthetic soils with four levels of heterogeneity and four levels of anisotropy. Numerical experiments of infiltration of two liquid phases, i.e., water and the nonaqueous phase liquid (NAPL) carbon tetrachloride, were carried out to test the extended model. The results show that, similar to water in a two-fluid (air-water) system, NAPL retention curves in a three-fluid (air-NAPLwater) system were independent of flow direction but dependent on soil heterogeneity, while the connectivity-tortuosity coefficients are functions of both soil heterogeneity and anisotropy (Figure 3.3-8). The extended tensorial connectivity-tortuosity model accurately describes unsaturated hydraulic functions of anisotropic soils and can be combined into commonly used relative permeability functions for use in multifluid flow and transport numerical simulations. 
Table 3.3-1. Percent Gravel, Sand, Silt, and Clay of Core Samples

\begin{tabular}{|c|c|c|c|c|}
\hline & Gravel & Sand & Silt & Clay \\
\hline Sample Midpoint Depth & $(>2 \mathrm{~mm})$ & $(2 \mathrm{~mm}-0.05 \mathrm{~mm})$ & $(0.05 \mathrm{~mm}-0.002 \mathrm{~mm})$ & $(<0.002 \mathrm{~mm})$ \\
\hline $\mathrm{m}$ & \multicolumn{4}{|c|}{$\%$} \\
\hline 0.2 & 63 & 28 & 7 & 2 \\
\hline 0.8 & 72 & 21 & 5 & 2 \\
\hline 1.4 & 71 & 21 & 7 & 1 \\
\hline 3.3 & 67 & 27 & 5 & 1 \\
\hline 3.9 & 63 & 28 & 7 & 2 \\
\hline 4.5 & 62 & 33 & 4 & 1 \\
\hline 5.1 & 72 & 22 & 4 & 2 \\
\hline 6.3 & 69 & 27 & 3 & 1 \\
\hline 8.8 & 85 & 11 & 3 & 1 \\
\hline 11.2 & 76 & 15 & 8 & 1 \\
\hline 11.8 & 58 & 30 & 11 & 1 \\
\hline 12.5 & 74 & 18 & 6 & 2 \\
\hline 13.5 & 71 & 21 & 6 & 2 \\
\hline 13.7 & 67 & 23 & 8 & 2 \\
\hline 14.2 & 80 & 17 & 3 & 0 \\
\hline 14.9 & 61 & 28 & 10 & 1 \\
\hline
\end{tabular}




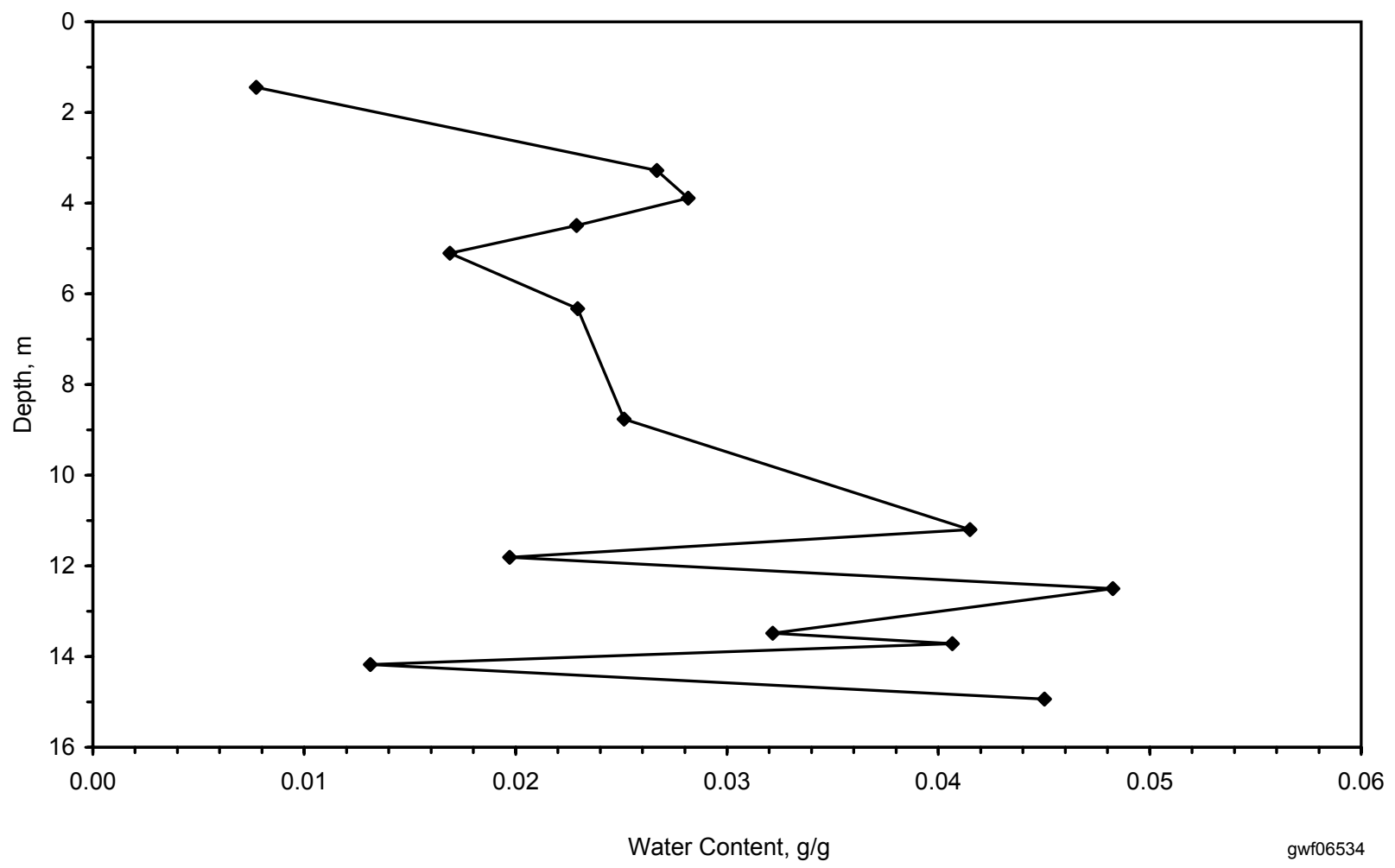

Figure 3.3-1. Field Gravimetric Moisture Content Profile Measured from Subsamples Taken from Homogenized Core Material

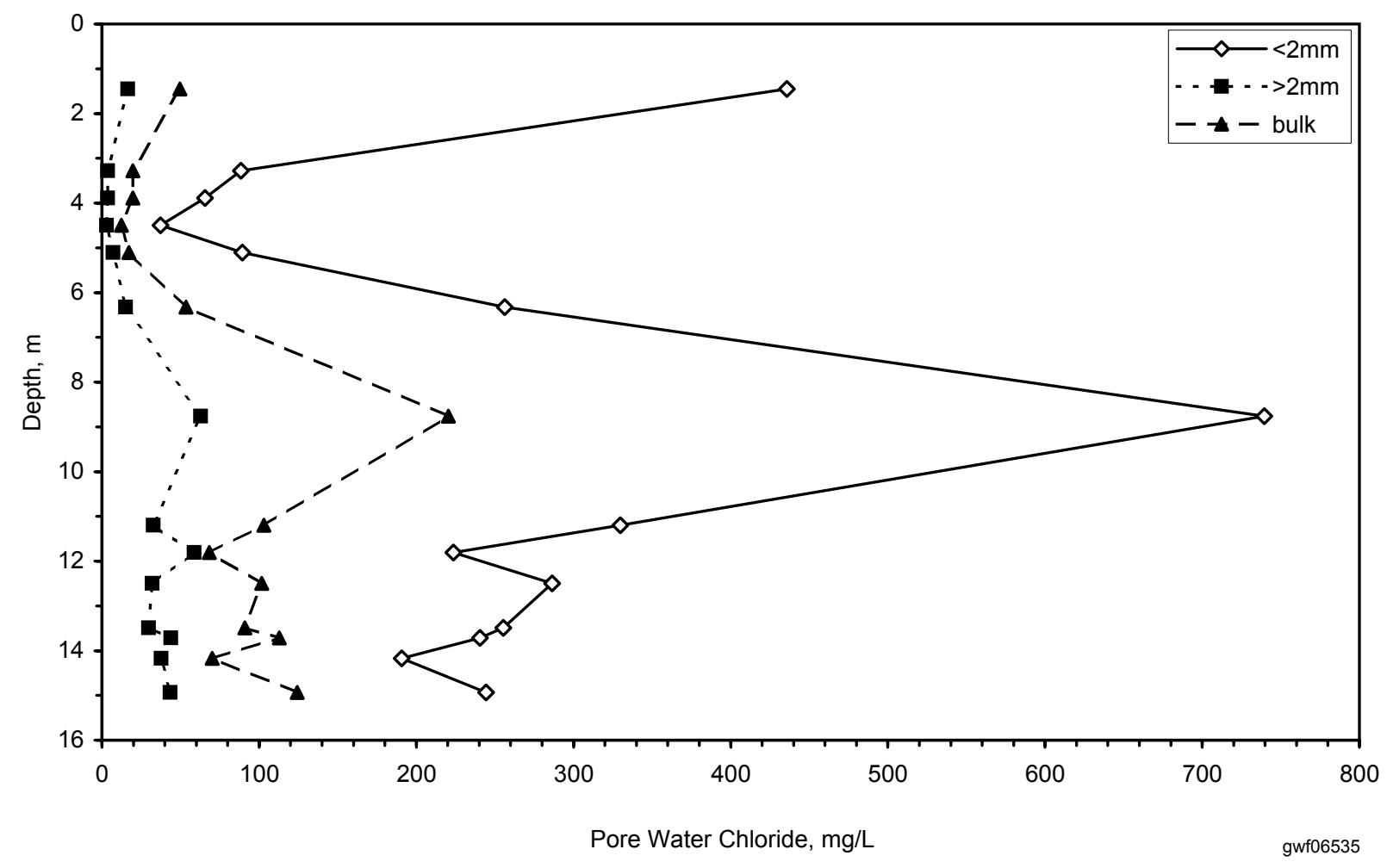

Figure 3.3-2. Soil Pore-Water Chloride Concentration $\left(\mathrm{Cl}_{\mathrm{s}}\right)$ Profile for the $<2 \mathrm{~mm},>2 \mathrm{~mm}$, and Bulk Core Subsamples 


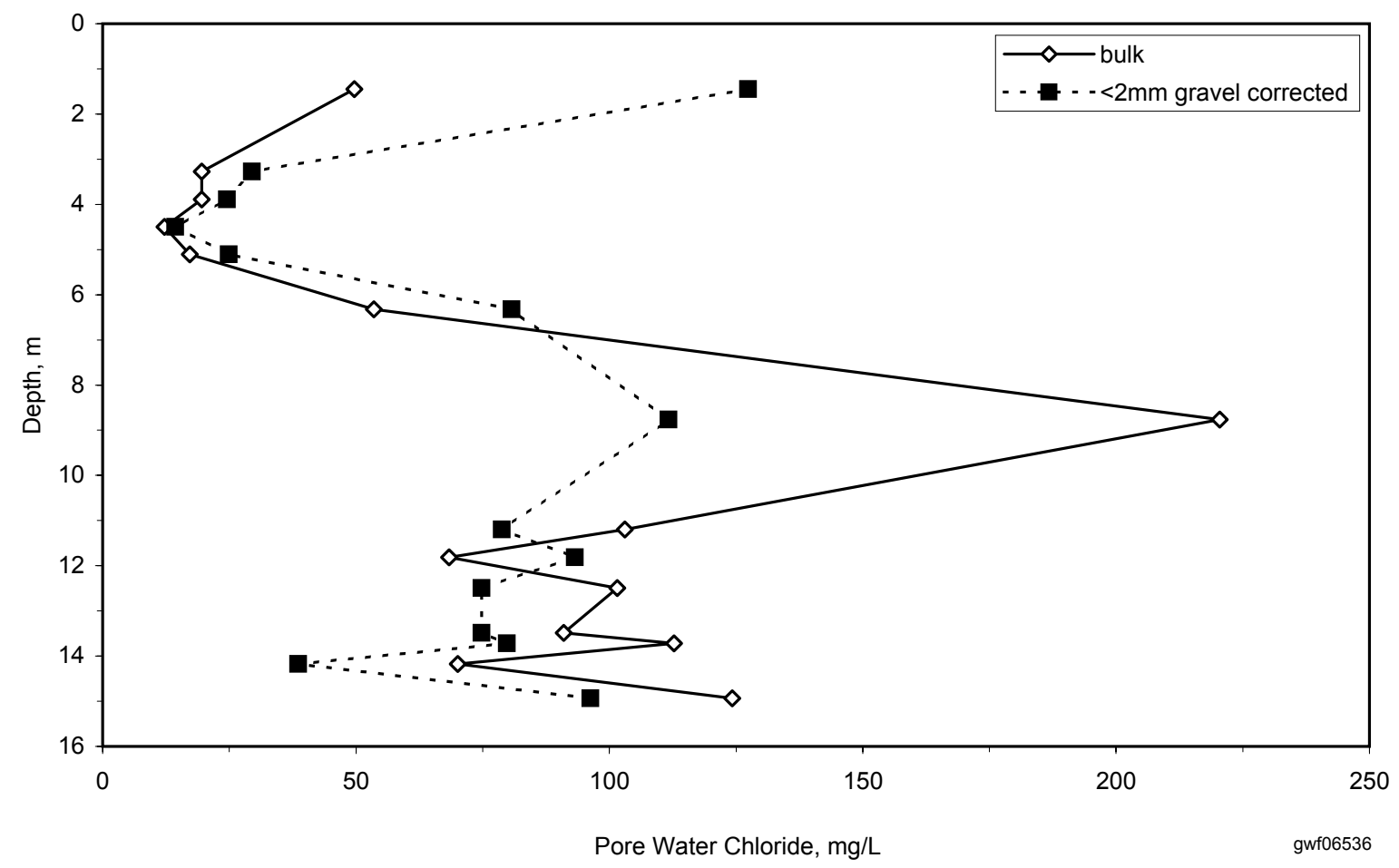

Figure 3.3-3. Soil Pore-Water Chloride Concentration $\left(\mathrm{Cl}_{s}\right)$ Profile from the Bulk Subsample and the Gravel Corrected $<2 \mathrm{~mm}$ Subsample

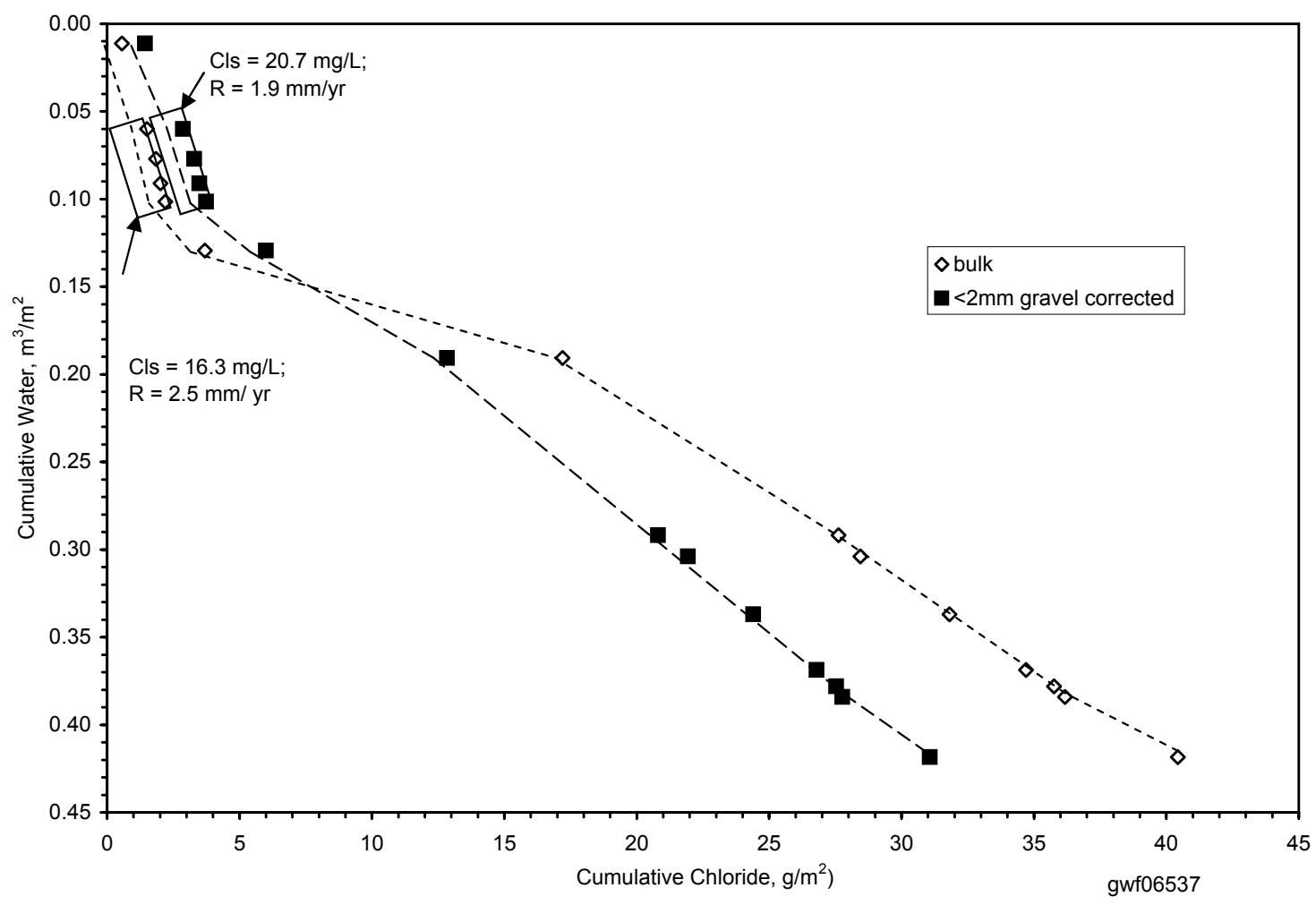

Figure 3.3-4. Cumulative Water Content and Cumulative Chloride Concentration with Increasing Depth. The straight lines indicate periods of constant recharge (R) conditions with the slopes of each line representing inverse pore-water chloride concentration $\left(\mathrm{Cl}_{s}^{-1}\right)$ for that time period. 


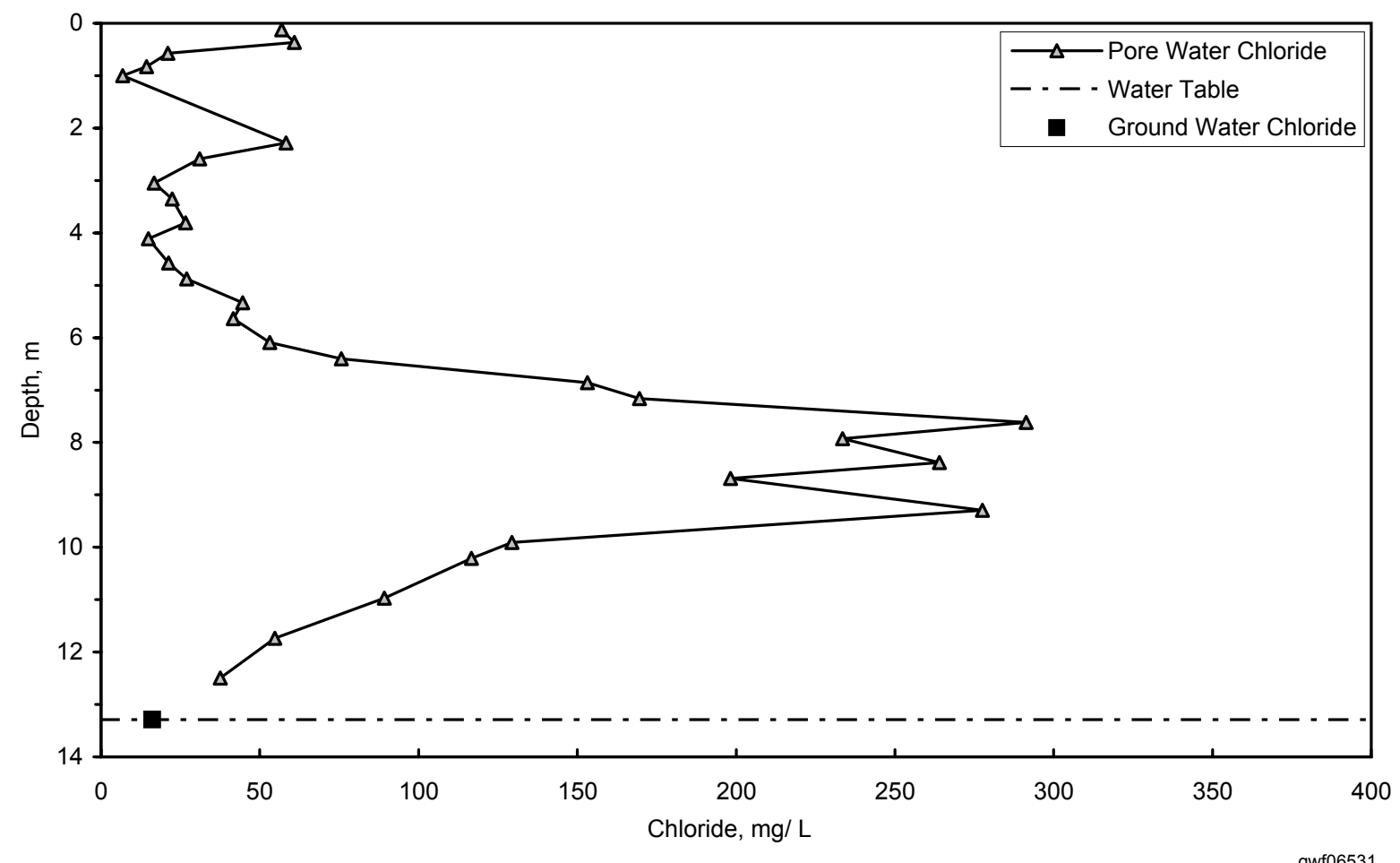

Figure 3.3-5. Pore-Water Chloride Profile and Groundwater Chloride Concentration for Well 699-S20-E10

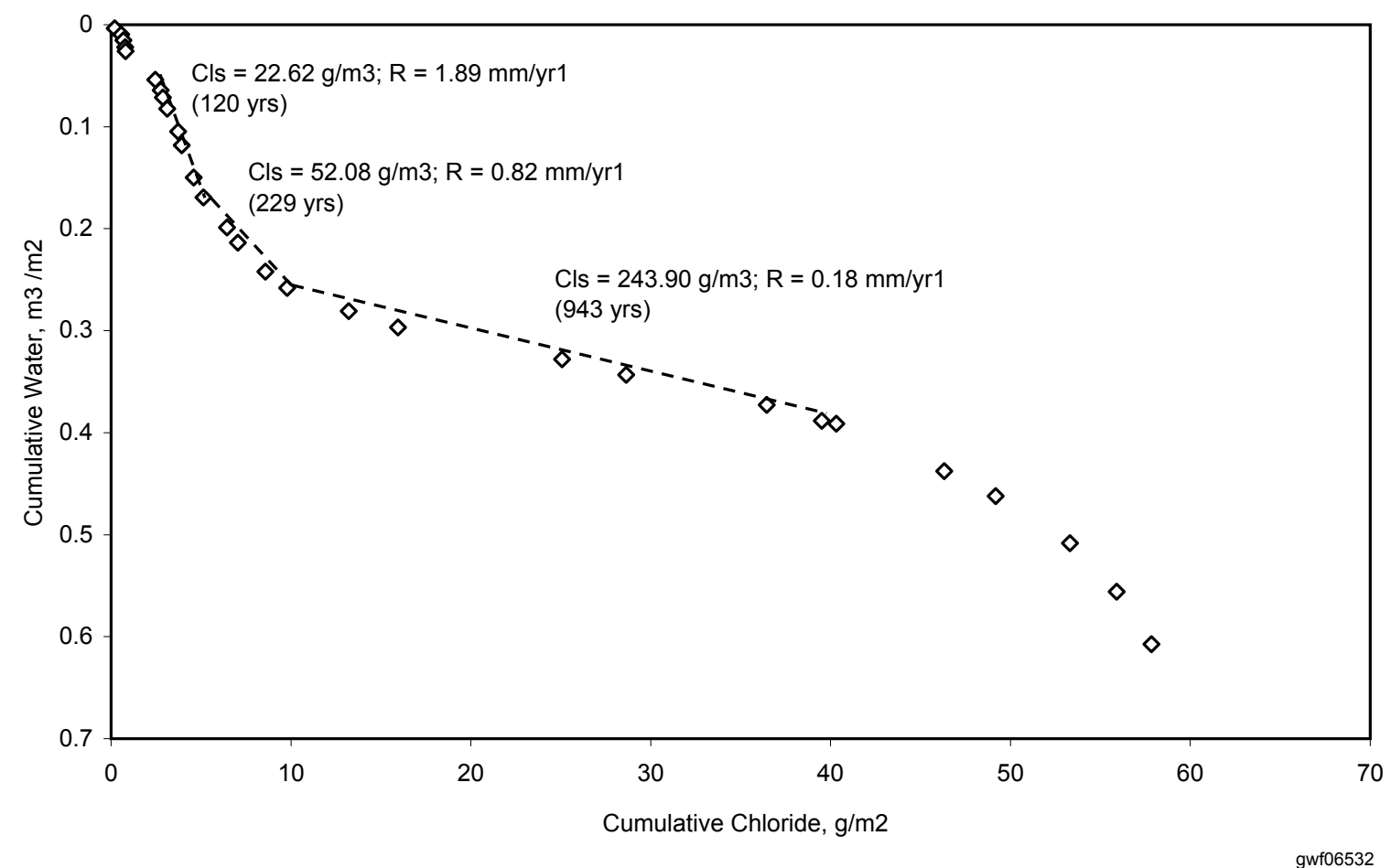

Figure 3.3-6. Cumulative Water Content and Cumulative Chloride with Increasing Depth (The straight lines indicate periods of constant recharge conditions with the slopes of each line representing $\mathrm{Cl}_{s}^{-1}$ for that time period. The number in parentheses is the chloride residence time at each line segment break.) 


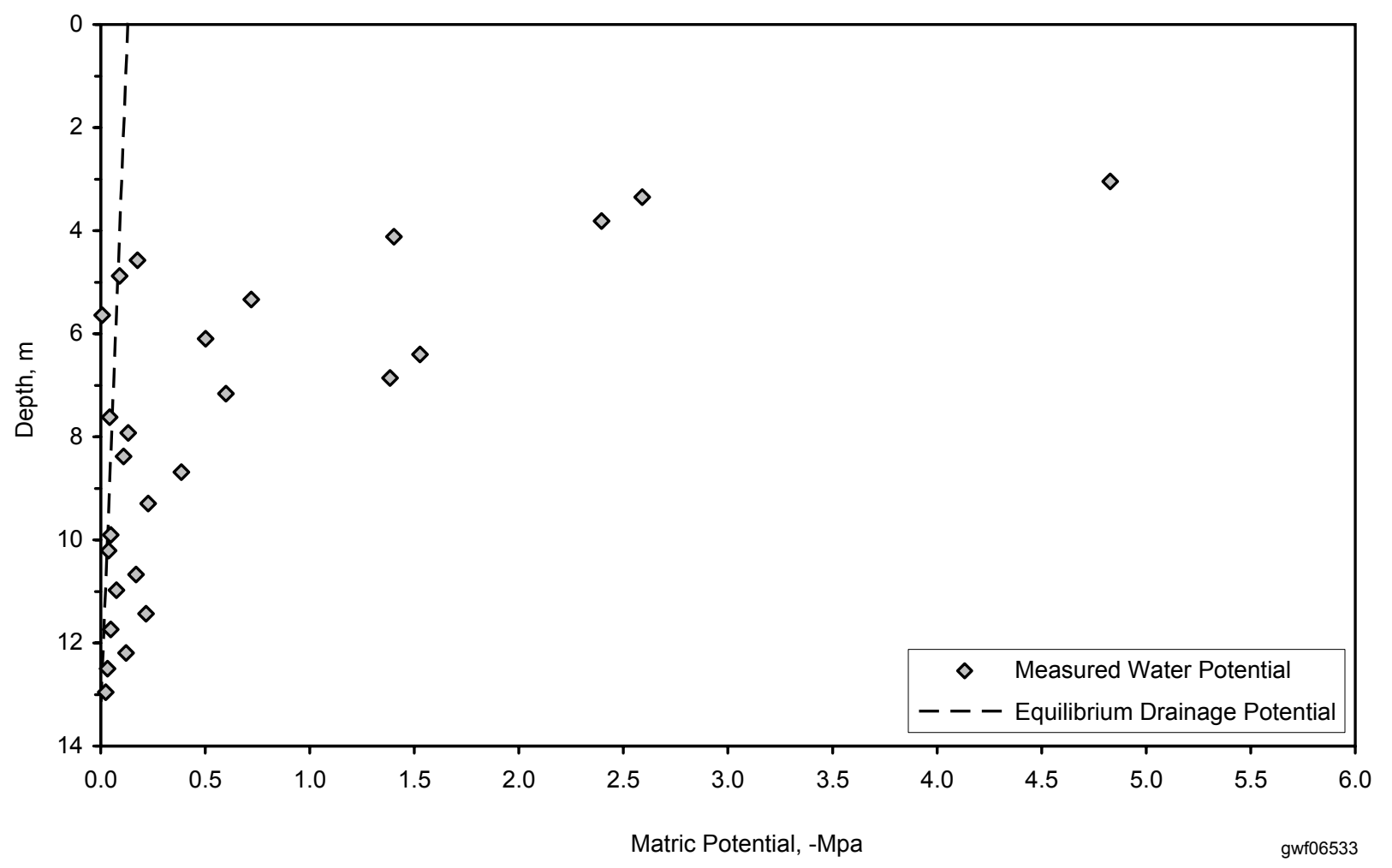

Figure 3.3-7. Matric Potential Profile for Well 699-S20-E10 

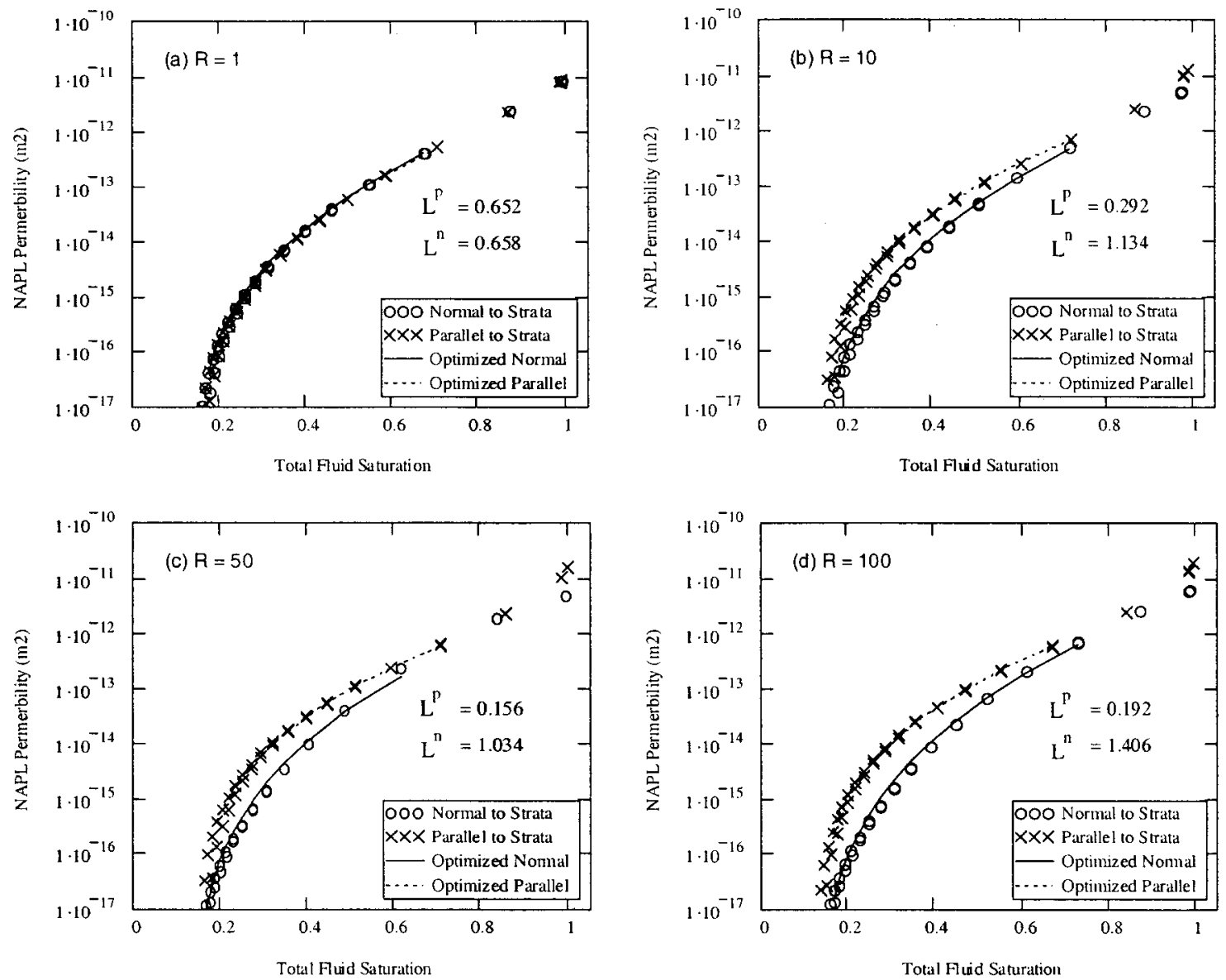

wdw07104

Figure 3.3-8. NAPL Permeability of Anisotropic Heterogeneous Soils with $\sigma_{Y}{ }^{2}=2.0$ and Different Anisotropy for $h_{w}=-0.2 \mathrm{~m}$. Variables: $\mathrm{L}^{\mathrm{p}}$ is the connectivity-tortuosity coefficient at the direction parallel, and $\mathrm{L}^{\mathrm{n}}$ at the direction normal to strata, respectively; $\mathrm{R}$ is the ratio of correlation lengths of the direction parallel and normal to strata; $\mathrm{Y}=\ln \left(\mathrm{K}_{\mathrm{s}}\right)$ with $\mathrm{K}_{\mathrm{s}}$ being the saturated hydraulic conductivity; and $\sigma_{\mathrm{Y}}{ }^{2}$ is the variance of $Y$. 


\subsection{Related Vadose Zone Studies Published in Fiscal Year 2006}

In addition to the studies described in Section 3.3, the results of several other studies were published during fiscal year (FY) 2006.

- Subsurface Geophysical Exploration of T Tank Farm.

- Subsurface Geophysical Exploration of S Tank Farm.

- Characterization of Vadose Zone Sediment below the C Tank Farm.

- Vadose Zone Transport Field Study.

- Development of Analytical Methods for Anionic Fission Products and Application to Sediment and Groundwater Samples from Tank Farm Waste Management Areas.

- Vadose Zone Hydrology Data Package for Hanford Assessments.

- Continued Development of a Prototype Borehole Geologic Database.

- Low-Flux Measurements in Desert Settings Using Water Fluxmeters.

These studies are summarized in this section by way of reproducing the abstract or summary directly from the report. The complete citation of each report is given and the interested reader is encouraged to consult the original reports, or the authors of the reports, to learn more about the individual activities.

\subsubsection{Subsurface Geophysical Exploration of T Tank Farm at the Hanford Site}

Rucker D, M Levitt, C Henderson, and K Williams. 2006. Surface Geophysical Exploration of T Tank Farm at the Hanford Site. RPP-RPT-28955, Revision 0, CH2M HILL Hanford Group, Inc., Richland, Washington.

The following information is excerpted directly from RPP-RPT-28955, Revision 0:

Executive Summary. This report presents the results of an investigation of the T tank farm at the U.S. Department of Energy's Hanford Site in Washington State and surrounding areas for subsurface contamination using electrical resistivity methods. The primary objective of this investigation was to demonstrate the ability to map subsurface contamination in and around the tank farms using electrical resistivity methods. The results show that the demonstration was successful and that technical challenges associated with deploying these methods in a tank farm environment can be managed by a combined analysis of data acquired from both surface electrodes and steel-cased wells. Additionally, the method provides a basis for defining regions that are free from contamination.

Subsurface characterization in the single-shell tank farms has historically been performed using characterization wells to collect soil samples or perform well logging. These techniques provide localized data ( 18 inches) around the wells. The interest in evaluating resistivity methods is that they can be used to extend the current level of understanding associated with subsurface contamination by providing spatial distributions that can be correlated with other characterization data. Resistivity data are sensitive to salts such as sodium nitrate, one of the major constituents in tank waste. Improved definition of subsurface contamination reduces uncertainties and increases confidence in making decisions under the Resource Conservation and Recovery Act of 1976 Corrective Action process and in support of single-shell tank waste retrieval and closure activities. Improved definition of subsurface contamination around the tank farms provides for improved integration with other projects that are responsible for managing cleanup of the cribs and 


\section{Electrical resistivity data in the T Tank Farm indicate that the T-106 leak has migrated directly beneath the tank.}

trenches surrounding the tank farms under the Comprehensive Environmental Response, Compensation, and Liability Act of 1980.

Electrical resistivity methods are well established for environmental settings that are relatively free of above ground and buried infrastructure. It is known that infrastructure such as pipelines, tanks, and electrical conduit can interfere with the resistivity data and make it difficult to differentiate between contamination and infrastructure. Several geophysical methods were used in this investigation to identify the presence and location of buried infrastructure as a prerequisite to collecting the resistivity data. Infrastructure was mapped using a variety of methods including magnetic gradiometry, electromagnetic induction, and ground-penetrating radar. The infrastructure map was used during the analysis and interpretation of the resistivity data to help differentiate between the effects of buried infrastructure from the effects of subsurface contamination.

Electrical resistivity data were collected using 27 surface electrode arrays or lines ranging from 280 to 680 meters (920 to 2,230 feet) in length and using 93 drywells and 17 groundwater wells. Data from the surface lines were collected to provide spatial coverage of the tank farm and surrounding cribs and trenches. The collection of geophysical data in support of subsurface characterization used at the T tank farm is referred to as "surface geophysical exploration" because it integrates the different geophysical methods in order to map subsurface contamination.

Electrical geophysical methods apply an electrical current to the ground and measure the voltage potential at another location. By using multiple electrodes at different locations, regions of lower resistivity can be mapped and subsequently interpreted as possible waste plumes. While resistivity methods are routinely used for characterizing subsurface conditions in a range of environmental settings, the application in a tank farm environment has been limited. Because of concerns over possible interference from tanks, piping, and other infrastructure, three different combinations of resistivity data were collected that included surface lines, wells (including drywells), and a combination of well-to-surface lines.

Three-dimensional modeling of the well-to-well resistivity data provided the best capability for mapping contamination within the tank farms. The well-towell resistivity data analyzed in a three-dimensional model serves to identify and delineate contaminant plume features within and around the tank farm. This resistivity technique provides an aerial distribution of contamination but cannot provide accurate depth information. Figure 3.4-1 shows the well resistivity data from drywells that have been segregated into different resistivity values (in units of ohm-meters). Lower resistivity values corresponding to higher contaminant concentrations are highlighted in red while lower concentrations are highlighted in blue. The results indicate that the T-106 leak has migrated directly beneath the tank. Within the tank farm, this mapping generally correlates with the current site conceptual model for subsurface contamination at the $T$ tank farm with the greatest extent of contamination associated with the T-106 leak. Two areas of interest where the results indicate areas of subsurface contamination that may extend beyond the current conceptual model are the north end of the farm between T-102 and T-103 and at the south end of the farm. These areas may warrant further investigation as these results identify contamination near tanks that are not classified as assumed leakers.

High-resolution resistivity techniques applied to data collected using the surface lines were able to identify and map plume features outside of the $T$ tank farm. Threedimensional inversion techniques provide additional information on the location, shape, and size of the plume. Figure 3.4-2 shows the plumes beneath the T-7 crib and T-14 through T-17 trenches interpreted from the three-dimensional inversion. 
Lower resistivity values corresponding to higher contaminant concentrations are highlighted in dark pink while lower concentrations are highlighted in light pink. The analysis shows that the plume features beneath the T-14 through T-17 trenches are well contained within the vadose zone while the plume features beneath the T-7 crib extend into the groundwater.

Analysis of the well-to-well resistivity data using only the groundwater wells was successful in identifying contaminant plume features at depth. Since these wells are in direct contact with the groundwater, low resistivity values are interpreted to indicate the presence of inorganic waste in the groundwater. Figure 3.4-3 shows the well resistivity data from groundwater wells that have been segregated into different resistivity values. Lower resistivity values corresponding to higher contaminant concentrations are highlighted in yellow while lower concentrations are highlighted in blue.

Having met the primary objective of demonstrating the ability of resistivity methods to map subsurface contamination in and around the tank farms, more detailed discussion on the types of detail that can be provided using resistivity methods is provided in response to the following questions:

- How well can surface geophysical exploration detect subsurface contamination in an electrically complex environment?

Resistivity data were collected from both surface electrodes and wells. Surface data provided valuable information over areas that were relatively free of infrastructure (i.e., the northeast trenches T-14 through T-17 and the western cribs T-5, T-7, and T-32). A three-dimensional representation of low resistivity values, indicative of increased moisture and/or an inorganic waste plume, showed that a plume in the northeast is confined to the vadose zone, and a plume to the west has reached the water table.

Surface data collected in areas that contained a high density of infrastructure had diminished resolution compared to areas with limited infrastructure. These areas included the tanks and an area southeast of the tank farm. In these areas, data from drywells and groundwater wells supplemented surface resistivity data. Three-dimensional inversion of the well-to-well data is able to detect subsurface contamination with sufficient resolution to locate contaminated regions and differentiate varying levels of contamination. The results of the resistivity data from drywells showed low resistivity values around tanks T-101, T-103, and T-106. Other tanks also show low resistivity areas of a smaller size, including tanks T-110 and $\mathrm{T}-112$. Last, the resistivity data showed a low resistivity zone around tank T-203.

From the groundwater well data, several low resistivity areas were identified. The largest was directly beneath the western cribs, known to have received liquid waste discharges of approximately 37 million gallons. These discharges appear to have reached the water table. Other areas of low resistivity include the northeast area directly outside of the farm boundary, the far north, and southeast of the tanks.

- How well can surface geophysical exploration differentiate between different contamination sources in close proximity?

The ability to differentiate between contamination sources varies. Several suspected plumes were imaged using resistivity methods. These include plumes directly beneath the northeast trenches and western crib systems. Although the plumes are large, analysis and evaluation of the data clearly indicate a contaminated region centered on the crib and trenches as shown 


\section{Surface resistivity}

data can be

used to track

contamination into

the groundwater at

Waste Management

Area T. in Figure 3.4-2. The plumes from these sources do not appear to be from other areas. Discrete vadose zone plumes were also seen around tanks T-101, T-103, T-106, T-110, T-112, and T-203. Tanks T-110, T-112, and T-203 are not classified as assumed leakers and these areas may warrant further investigation. It is unclear whether these tanks are actual sources, or if the plume around these tanks migrated from other locations.

- How deep in the environment can contaminants be tracked?

Surface resistivity data can be used to track contamination into the groundwater. Surface resistivity data can be used to differentiate a plume in the vadose zone from a plume in the saturated zone. The first of two examples includes the northeast trenches, where the plume is confined to the vadose zone; however, there is some loss in vertical resolution at greater depths. The second example is the western crib system, where the plume was imaged into the groundwater. The surface lines deployed allowed subsurface properties to be mapped in excess of 80 meters ( 260 feet) below ground surface, approximately 10 meters ( $30 \mathrm{feet}$ ) below the top of the water table.

The resistivity data collected using the wells lacks vertical resolution. A plume interpreted from well resistivity data could occur at any depth along the length of the wells. However, segregating the wells by depth, such as drywells which stop in the vadose zone versus groundwater wells which extend approximately 15 feet below the water table surface, allows for interpretation of separate depth zones. For the $\mathrm{T}$ tank farm, this segregation allowed the discovery of possible groundwater plumes beneath the western crib system, to the northeast of the tank farm boundary, to the far north, and southeast of the tanks.

- What limitations are associated with tank farm deployment?

The three-dimensional modeling of the well-to-well resistivity data provided the best capability for mapping contamination within the tank farms but it does not provide accurate depth information.

Analysis of the surface resistivity data collected within the tank farm provided limited value because the results could not adequately separate the effects of infrastructure on the data to differentiate one from the other. The algorithm used to process the surface data has not been refined to sufficiently model surface resistivity in an infrastructure-rich environment. Recommendations have been presented that may overcome this limitation.

Limitations in interpretation include the understanding of the resistivity data in terms of a waste plume or other hydrological properties. Resistivity values cannot be associated with individual contaminants without correlation to sample analysis.

- Can surface geophysical exploration extend the limited data available from drywell and physical soil samples?

Subsurface contamination maps developed using resistivity methods can be used to extend data collected from drywells and the analysis of soil samples. The resistivity results provide spatial distribution information for inorganic waste constituents that can be correlated to sample results to provide a basis for developing volumes and inventories for other contaminants of interest. 
A number of recommendations are discussed in the report to provide for improved efficiencies in data collection and analysis. Primary recommendations that streamline data collection or have the potential to make significant improvements in the results include:

- Reducing or eliminating the collection of electromagnetic and magnetic data outside the tank farm. These data provide little value to the analysis and interpretation of the results.

- Deploying a limited number of point electrodes at depth in or around the tank farm that can be used during collection of the well-to-well data. Use of a point electrode at a known depth will provide some resolution of depth for mapping contamination in the tank farms.

- Verification of the resistivity results through integration with future characterization activities.

- Developing relationships between electrical resistivity, hydrological, and geochemical data for the site.

\subsubsection{Surface Geophysical Exploration of S Tank Farm at the Hanford Site}

Rucker DF, M Levitt, C Henderson, and K Williams. 2006. Surface Geophysical Exploration of S Tank Farm at the Hanford Site. RPP-RPT-30976, CH2M HILL Hanford Group, Inc., Richland, Washington.

The following is excerpted from RPP-RPT-30976 with minor changes:

Executive Summary. During fiscal year 2006, a geophysical investigation was performed at the S Tank Farm on the U.S. Department of Energy's Hanford Site in Washington State. The objective of the investigation was to demonstrate the use of electrical resistivity methods to locate and map liquid injected into the tank farm vadose zone as a part of a simulated tank leak and to identify and map regions impacted by past leaks and spills. The geophysical methodology used on the $S$ tank farm was the same as presented in Surface Geophysical Exploration of T Tank Farm at the Hanford Site (RPP-RPT-28955).

The leak injection test performed at the $S$ tank farm is documented in Tank 241-S-102 High-Resolution Resistivity Leak Detection and Monitoring Testing Report (RPP-30121). The main purpose of the injection was to test the capabilities of the hydroGEOPHYSICS, Inc. high resolution resistivity - leak detection and monitoring (HRR-LDM) method for leak detection and leak quantification within a single-shell tank farm. The leak injection test consisted of a series of 10 injections, where a conductive fluid was discharged in well 40-02-10 near tank S-102. The LDM system was used to monitor the changes of electrical properties in the subsurface.

The electrical resistivity data acquisition phase for SGE included resistivity measurements on 8 surface electrode arrays oriented orthogonally and a set of 42 steel wells. The data collection concentrated primarily on the northern half of the $S$ tank farm. Resistivity data were collected before, during, and after the leak injection test. Additionally, resistivity data collected using the HRR-LDM system after each of the 10 leak injections were analyzed using the SGE methodology to more fully understand the migration of the injected fluid.

Results of the test show that the resistivity data collected through surface arrays and via well-to-well (WTW) arrays can be used to locate and map the injection liquid. Additionally, the investigation identified other areas across the $S$ tank farm that may be interpreted as contaminated regions. 
The S Tank Farm SGE results are superior to those obtained for the T tank farm and documented in RPP-RPT-28955. While the analysis of surface data in the $\mathrm{T}$ tank farm investigation experienced significant interference problems with metallic infrastructure, this investigation had little interference. Thus, the threedimensional representations can be evaluated using both surface data and WTW data. Analysis of both S and T farm results also demonstrated that WTW resistivity data has the capability to identify and delineate contaminant plume features within and around tank farms that have excessive metallic infrastructure such as pipes, tanks, diversion boxes, utilities, and cathodic protection.

Figure 3.4-4 shows the results of surface resistivity inversion modeling before (pre-leak) and after (post-leak) all leak injection testing. The figure shows a low resistivity plume beneath tank S-104, and how the low resistivity plume grows in size after the leak injection.

Figure 3.4-5 shows the results of the WTW inversion and the direct comparison with surface resistivity inversion results for both pre- and post-LEAK data sets. These results show that a majority of the low resistivity regions from the WTW and surface inversion overlap, giving a good indication of consistency among the two different electrode geometries. Those areas that do not overlap may be due to low resolution in data acquisition from either method or different coverage areas.

Several recommendations are suggested to improve the data acquisition, data quality, and data coverage of future SGE efforts at the Hanford Site tank farms.

- The success of SGE at both S and T Tank Farms lends credibility to the method for identifying historical leaks. It is recommended that all other farms be imaged with SGE, including a full-scale characterization of $S$ tank farm.

- Install permanent surface electrodes within the farm to reduce time and costs for SGE deployment. This idea was first initiated for S tank farm and the strategy should continue to other farms.

- Computational power was limited for both $S$ and $T$ tank farms. It is recommended that the EarthImager3D code be fully parallelized to run on a multi-processor personal computer with extended random access memory.

- Resistivity data collected with the HRR-LDM system were evaluated with a processing methodology developed primarily for SGE data. It is recommended that a larger LDM hardware system be developed that can monitor/characterize an entire farm, where SGE-type processing can be performed at pre-determined intervals to ensure that no leaks are occurring during retrieval.

- Vertical resolution is relatively low (compared to lateral resolution) for the surface resistivity data collection and non-existent for WTW resistivity. It is recommended that as many subsurface point electrodes be installed as possible, including electrical resistivity tomography (ERT) arrays that have many point electrodes along a single borehole. The ERT arrays would increase vertical resolution. 


\subsubsection{Characterization of Vadose Zone Sediments Below the C Tank Farm}

Brown CF, RJ Serne, BN Bjornstad, DG Horton, DC Lanigan, RE Clayton, TS Vickerman, IV Kutnyakov, KN Geiszler, SR Baum, KE Parker, and MJ Lindberg. 2006. Characterization of Vadose Zone Sediments Below the C Tank Farm: Borehole C4297 and RCRA Borehole 299-E27-22. PNNL-15503, Pacific Northwest National Laboratory, Richland, Washington.

The following information is excerpted directly from PNNL-15503:

Executive Summary. The overall goal of the Tank Farm Vadose Zone Project, led by CH2M HILL Hanford Group, Inc., is to define risks from past and future single-shell tank farm activities at the Hanford Site. To meet this goal, CH2M HILL Hanford Group, Inc. tasked scientists from Pacific Northwest National Laboratory (PNNL) to perform detailed analyses on vadose zone sediments from within Waste Management Area (WMA) C. This report is the first of two reports written to present the results of these analyses. Specifically, this report contains all the geologic, geochemical, and selected physiochemical characterization data collected on vadose zone sediment recovered from borehole C4297, installed adjacent to tank C-105, and from borehole 299-E27-22, installed directly north of the C Tank Farm. This report also presents the interpretation of data in the context of sediment types, the vertical extent of contamination, the migration potential of the contaminants, and the likely source of the contamination in the vadose zone below the $\mathrm{C}$ Tank Farm. The information presented in this report supports the WMA A-AX, C, and U field investigation report in preparation by CH2M HILL Hanford Group, Inc.

Sediments from borehole 299-E27-22 were characterized for their potential to be used as background (i.e., uncontaminated) sediments against which to compare contaminated sediments during the C Tank Farm characterization effort. Upon analysis of sediment samples from borehole 299-E27-22, elevated concentrations of chloride, nitrate, sulfate, phosphate, magnesium, calcium, strontium, and sodium were encountered at various depths within the borehole. Although no known spills have been recorded at the location where borehole 299-E27-22 was emplaced, the data strongly suggest the sediment has been contacted by a non-radiological waste stream. While the data from borehole 299-E27-22 are presented within this report, it is not recommended that the data be used holistically as background or baseline values for uncontaminated sediment. Instead, data from a companion report (Lindenmeier et al. 2002), which was an investigation of samples from borehole 299-E33-338, should be used for baseline comparisons.

A core log was generated for both boreholes and a geologic evaluation of all core samples was performed at the time of opening. Aliquots of sediment from the borehole core samples were analyzed and characterized in the laboratory for the following parameters: moisture content, gamma-emitting radionuclides, oneto-one sediment:water extracts (which provide soil $\mathrm{pH}$, electrical conductivity, cation, trace metal, and anion data), total carbon and inorganic carbon content, and $8 \mathrm{M}$ nitric acid extracts (which provide a measure of the total leachable contaminant content from the sediment). Two key radioactive contaminants, technetium-99 and uranium-238, along with other trace metals were determined in acid and water extracts using inductively coupled plasma-mass spectrometry (ICP-MS). The laboratory tests provided the following conclusions regarding contamination at the C Tank Farm:

1. Heterogeneities, including fine-grained thin lenses in the Hanford formation $\mathrm{H} 1$ and $\mathrm{H} 2$ units, likely cause anisotropy in water flow. Increased moisture was 
found to correlate with each of the fine-grained thin lenses intercepted by the coring. Average moisture contents for the Hanford formation $\mathrm{H} 1$ and $\mathrm{H} 2$ units in borehole 299-E27-22 were approximately the same as the moisture contents from the same units in borehole 299-E33-338, as well as in the contaminated borehole (C4297). This is likely an indication that any leak that has occurred in the vicinity of borehole C4297 was either small in total volume and/or occurred sufficiently long ago that residual vadose zone moisture has returned to background or "natural" conditions.

2. The $\mathrm{pH}$ profile for sediments from borehole $\mathrm{C} 4297$ showed elevated soil $\mathrm{pH}$ values (up to 9.53 vs. less than 8.0 for the remainder of the borehole) from 40.8 to $51.3 \mathrm{ft}$ below ground surface (bgs), which were indicative of alkaline tank fluid interactions. The first sample with a measurably elevated soil $\mathrm{pH}$, via 1:1 sediment:water extraction, was collected at a depth that coincided with the bottom of tank C 105. However, based on observations at other tank farms (SX and BX) where it is certain that caustic wastes are in the vadose zone, yet water extract $\mathrm{pH}$ values never exceed 10 , this study concluded that $\mathrm{pH}$ is not a very sensitive parameter to use for evaluating the extent of plume migration in the vadose zone. However, the elevated $\mathrm{pH}$ zone is considered to be a good indicator of the initial tank waste contact zone.

3. The average porewater corrected electrical conductivity (EC) from borehole 299-E27-22, at $8.68 \mathrm{mS} / \mathrm{cm}$, was more than a factor of three times greater than the average EC from borehole 299-E33-338 $(2.63 \mathrm{mS} / \mathrm{cm})$; further highlighting the fact that sediments from this borehole have been compromised by a waste spill or leak. The EC depth profile for borehole C4297 showed elevated EC in the Hanford formation $\mathrm{H} 1$ unit over the same depth range that exhibited elevated soil $\mathrm{pH}$ (40.8 to $51.3 \mathrm{ft}$ bgs). The peak pore-water-corrected EC value measured in sediments from borehole C4297 occurred at $45 \mathrm{ft}$ bgs with a concentration of $20.5 \mathrm{mS} / \mathrm{cm}$. Although measurably elevated, this value was approximately four times more dilute as that measured in sediments collected near tank BX-102, and was more than eighty times as dilute as the peak value in contaminated sediment collected near tank SX-108 (slant borehole).

4. Elevated sodium was measured in C4297 borehole sediments beginning at approximately $7 \mathrm{ft}$ bgs and extending to a depth of $71 \mathrm{ft}$ bgs. Speculation is that these trends indicate some chemical reaction between alkaline tank fluids and native sediments that formed a cation exchange front, whereby sodium replaced calcium and magnesium in the sediments as the dominant exchangeable cation.

5. In the core and grab samples from borehole C4297, there was a bimodal uranium concentration profile as a function of depth. A relatively small extractable uranium peak was measured in the 1:1 sediment:water extracts from 7 to $22 \mathrm{ft}$ bgs. The uranium present at this depth was likely associated with the cesium-137 activity measured shallow in the borehole $(2.5$ to $12 \mathrm{ft}$ bgs). The second peak of water-extractable uranium was observed at a depth corresponding to the bottom of tank C-105 (40 ft bgs) and extended to a total depth of $60 \mathrm{ft}$ bgs. However, due to the high dissolved (bi)carbonate concentration in this zone, some of the water-extractable uranium was likely naturally present labile uranium released as a function of uranyl-carbonate complexation. The maximum water extractable uranium concentration over this depth occurred at $57.2 \mathrm{ft}$ bgs with a peak value $2.17 \mathrm{E}-2 \mu \mathrm{g} / \mathrm{g}$. These samples were scanned using inductively coupled plasma mass spectrometry for the presence of uranium-236, which was not observed; therefore, it is unlikely that the majority of the uranium present over this zone resulted from Hanford processing activities. 
6. The nitrate water extract values for borehole C4297 were elevated beginning at a depth that corresponded to the bottom of tank C-105 (40 ft bgs) to as deep as $160 \mathrm{ft}$ bgs. Additionally, there were several anomalously high nitrate samples collected throughout the soil profile that could be lithology related. Nitrate migration in the subsurface is considered to be entirely conservative; in other words, it will move freely with the infiltrating water. Thus, nitrate concentration can be used to estimate the total vertical extent of a contaminant plume. Based on data from borehole C4297, it appears that a multi-modal, at least bimodal, waste signature is present. Based on the dilute nitrate profile, it appears that the maximum penetration of the "first" or "primary" plume is currently at a depth of approximately $160 \mathrm{ft}$ bgs. The peak maximum of the "second" plume occurred as deep as $114 \mathrm{ft}$ bgs and appeared to be less concentrated than the "primary" plume.

7. The first observance of technetium-99 in sediment samples from borehole C4297 occurred at $40.8 \mathrm{ft}$ bgs, a depth that corresponded closely to the bottom of tank C-105. Technetium-99, like nitrate, is considered to be completely conservative in mobility. Therefore, it is not surprising that technetium-99 exhibited a similar concentration profile to nitrate. Some differences were observed between the technetium-99 and nitrate profiles. As with nitrate, a bimodal concentration profile of technetium-99 contamination was present in C4297 borehole samples, with the primary technetium 99 peak occurring between 105 and $160 \mathrm{ft}$ bgs, and a smaller secondary peak present between 40 and $66 \mathrm{ft}$ bgs. Similar to the nitrate, the peak technetium-99 concentration present in these sediment samples was measured in the sample collected from approximately $137 \mathrm{ft}$ bgs.

8. Molybdenum, which is a fission product generated during the operation of nuclear reactors, can sometimes be used to delineate the profile of waste plumes in the subsurface. In the case of samples from borehole C4297, fission-produced molybdenum was clearly present between 26 and $64 \mathrm{ft}$ bgs. The primary zone of fission-produced molybdenum occurred between 55 and $64 \mathrm{ft}$ bgs; however, unlike the technetium-99 and nitrate contamination, it appears that all the fission-produced molybdenum in this borehole form a contiguous plume that is the result of a single contamination event. Therefore, the bimodal technetium-99 contamination profiles versus a single contaminant plume for molybdenum supports a two source contamination model.

Based on evaluating all these measurements, this study concluded that the C4297 borehole data establishes the vertical extent of tank contamination at this location. Tank waste-related contaminants were observed from just below ground surface $(2.5 \mathrm{ft}$ bgs $)$ to a total depth of approximately $160 \mathrm{ft}$ bgs. Six of the eight parameters measured ( $\mathrm{pH}, \mathrm{EC}$, sodium, nitrate, technetium-99, and molybdenum) exhibited distinct contaminant profiles as a function of depth. Additionally, two of the contaminants (nitrate and technetium-99) could be further characterized as having bi- or multimodal profiles, indicated at least two distinct waste sources have contributed to the contamination present in this borehole.

Selected concentration ratios of mobile contaminants in (a) the vadose zone sediments sampled from borehole C4297, (b) the WMA C groundwater contaminant plumes, and (c) specific single-shell tanks at the time of suspected leaks were used to assess whether there were indications that the groundwater contamination present at WMA C is related to current vadose zone contamination. Comparisons of contaminant ratios from all available data sets, as well as those measured in samples from borehole C4297, were performed. Initial attempts to relate the groundwater and pore water compositions used the ratios of the concentrations of various contaminants (technetium-99, fluoride, sulfate, sodium, 
Field studies show that fine-scale geologic features have a strong effect on largescale behavior of contaminant plumes. and nitrate) to one another. The agreement between the vadose zone pore water and contaminated groundwater data sets was not good. The technetium-99/nitrate ratios for samples from the contaminated zones in borehole C4297 were generally greater than about $0.2 \mathrm{pCi} / \mu \mathrm{g}$. Such values are greater than the technetium-99/ nitrate ratios in all of the groundwater wells except well 299-E27-4. However, the agreement for the other ratios between groundwater from well 299-E27-4 and pore water from borehole C4297 was not good, although there is certain to be some fractionation between technetium- 99 and the other constituents, especially sodium.

In summary, there is no current similarity between the present or past groundwater contamination and current pore water compositions from the contaminated borehole sediments. Therefore, the contaminants in the groundwater cannot be linked, currently or during the era of contaminant introduction in the vadose zone, to the pore water currently in the borehole sediments, which are believed to be derived from the liquids that leaked or spilled from tank C-105.

\subsubsection{Vadose Zone Transport Field Study}

Ward AL, ME Conrad, WD Daily, JB Fink, VL Freedman, GW Gee, GM Hoversten, JM Keller, EL Majer, CJ Murray, MD White, SB Yabusaki, and ZF Zhang. 2006. Vadose Zone Transport Field Study: Summary Report. PNNL-15443, Pacific Northwest National Laboratory, Richland, Washington.

The following information is excerpted directly from PNNL-15443:

Abstract. From FY 2000 through FY 2003, a series of vadose zone transport field experiments were conducted as part of the U.S. Department of Energy's Groundwater/Vadose Zone Integration Project Science and Technology Project, now known as the Remediation and Closure Science Project, and managed by the Pacific Northwest National Laboratory (PNNL). The series of experiments included two major field campaigns, one at a 299-E24-11 injection test site near PUREX and a second at a clastic dike site off Army Loop Road. The goals of these experiments were to improve our understanding of vadose zone transport processes; to develop data sets to validate and calibrate vadose zone flow and transport models; and to identify advanced monitoring techniques useful for evaluating flow-and-transport mechanisms and delineating contaminant plumes in the vadose zone at the Hanford Site. This report summarizes the key findings from the field studies and demonstrates how data collected from these studies are being used to improve conceptual models and develop numerical models of flow and transport in Hanford's vadose zone. Results of these tests have led to a better understanding of the vadose zone. Fine-scale geologic heterogeneities, including grain fabric and lamination, were observed to have a strong effect on the large-scale behavior of contaminant plumes, primarily through increased lateral spreading resulting from anisotropy. Conceptual models have been updated to include lateral spreading and numerical models of unsaturated flow and transport have revised accordingly. A new robust model based on the concept of a connectivity tensor was developed to describe saturation-dependent anisotropy in strongly heterogeneous soils and has been incorporated into PNNL's Subsurface Transport Over Multiple Phases (STOMP) simulator. Application to field-scale transport problems have led to a better understanding of plume behavior at a number of sites where lateral spreading may have dominated waste migration (e.g. BC Cribs and Trenches). The improved models have been also coupled with inverse models and newly-developed parameter scaling techniques to allow estimation of field-scale and effective transport parameters for the vadose zone. The development and utility of pedotransfer functions for describing fine-scale hydrogeochemical heterogeneity 
and for incorporating this heterogeneity into reactive transport models was explored. An approach based on grain-size statistics appears feasible and has been used to describe heterogeneity in hydraulic properties and sorption properties, such as the cation exchange capacity and the specific surface area of Hanford sediments. This work has also led to the development of inverse modeling capabilities for time-dependent, subsurface, reactive transport with transient flow fields using an automated optimization algorithm. In addition, a number of geophysical techniques investigated for their potential to provide detailed information on the subtle changes in lithology and bedding surfaces; plume delineation, leak detection. High-resolution resistivity is now being used for detecting saline plumes at several waste sites at Hanford, including tank farms. Results from the field studies and associated analysis have appeared in more than 46 publications generated over the past 4 years. These publications include test plans and status reports, in addition to numerous technical notes and peer reviewed papers.

\subsubsection{Development of Analytical Methods for Anionic Fission Products and Application to Sediment and Groundwater Samples from Tank Farm Waste Management Areas}

\section{F. Brown, P. E. Dresel, K. N. Geiszler, and R. J. Serne}

Technetium-99 is a contaminant of interest at numerous nuclear facilities because it is quite mobile in subsurface environments and is a key contributor to long-term risk. However, as a mono-isotopic fission product, technetium-99 is limited in its use as a signature to differentiate between different waste disposal pathways that could have contributed to subsurface contamination at these facilities. Ruthenium fission-product isotopes are attractive analogues for the characterization of technetium-99 sources because of their direct similarity to technetium with regard to subsurface mobility, their large fission yields, and low natural background concentrations. We developed an inductively coupled plasma mass spectrometry (ICP-MS) method capable of measuring ruthenium isotopes in groundwater samples and water extracts of vadose zone sediments. Samples were analyzed directly on a Perkin Elmer ELAN DRC II ICP-MS after a single pass through a 1-ml bed volume of Dowex AG 50W-X8 100-200 mesh hydronium-based cation exchange resin. Precise ruthenium isotopic ratio measurements were achieved using a low-flow Meinhard-type nebulizer and long sample acquisition times $(150,000 \mathrm{~ms})$. Relative standard deviations were maintained at less than $0.5 \%$ when the total ruthenium solution concentration was $0.1 \mathrm{ng} / \mathrm{ml}$ or higher. Application of this method using groundwater samples and vadose zone sediment water extracts from the Hanford Site showed that vadose zone sediments from borehole C4104 (emplaced adjacent to tank T-106) were contaminated by a single leak event. Further evaluation of groundwater samples collected from Waste Management Area T indicated that multiple sources (at least two) of contamination were present in the aquifer to the east of the T Tank Farm. The shallow groundwater samples had ruthenium isotopic ratios consistent with those measured in vadose zone samples from borehole C4104. Analysis of ruthenium isotopic ratios in depthdiscrete groundwater samples collected from wells adjacent to (299-W11-25B) and east of (299-W11-45) the T Tank Farm, respectively, resulted in two distinct sets of isotopic ratio data. These results have led to the inference that a yet unidentified source, distinct from the T-106 tank leak in 1973, is responsible for the high 99Tc concentrations observed with depth in the aquifer underlying Waste Management Area T.

\author{
Analysis of \\ ruthenium isotopes \\ from a borehole \\ next to tank T-106 \\ suggest that vadose \\ zone contamination \\ in that area is from \\ a single leak event.
}




\subsubsection{Vadose Zone Hydrogeology Data Package for Hanford Assessments}

Last, GV, EJ Freeman, KJ Cantrell, MJ Fayer, GW Gee, WE Nichols, BN Bjornstad, and DG Horton. 2006. Vadose Zone Hydrogeology Data Package for Hanford Assessments. PNNL-14702, Rev. 1, Pacific Northwest National Laboratory, Richland, Washington.

The following information was excerpted directly from PNNL-14702, Rev. 1:

Executive Summary. This data package documents the technical basis for selecting physical and geochemical parameters and input values that will be used in vadose zone modeling for Hanford assessments. This work was originally conducted as part of the Characterization of Systems Task of the Groundwater Remediation Project managed by Fluor Hanford, Inc., Richland, Washington, and revised as part of the Characterization of Systems Project managed by the Pacific Northwest National Laboratory (PNNL) for the U.S. Department of Energy, Richland Operations Office (DOE-RL).

This data package describes the geologic framework, the physical, hydrologic, and contaminant transport properties of the geologic materials, and deep drainage (i.e., recharge) estimates, and builds on the general framework developed for the initial assessment conducted using the System Assessment Capability (SAC) (Bryce et al. 2002). The general approach for this work was to update and provide incremental improvements over the previous SAC data package completed in 2001. As with the previous SAC data package, much of the data and interpreted information were extracted from existing documents and databases. Every attempt was made to provide traceability to the original source(s) of the data or interpretations.

Kincaid et al. (2004) identified 1,052 waste sites from the Waste Information Data System (WIDS) sites and several existing and future storage sites for inclusion in Hanford assessments, with analyses to be conducted on a site-by-site basis whenever inventory and release data permit. ${ }^{(a)}$ The complexity of these assessments, together with the lack of detailed characterization data for some of the fine-scale fate and transport processes necessitates simplification of site features, release events, and contaminant fate and transport processes to those factors considered most dominant. The dominant factors affecting modeling of transport of contaminants through the vadose zone include: (1) waste inventory and release estimates, (2) estimates of deep drainage (recharge), (3) the hydrogeologic profiles and properties of the vadose zone affecting aqueous phase advection and dispersion, and (4) estimates of geochemical reactions (e.g., sorption and precipitation) affecting the retardation of contaminants. The last three of these data types are addressed by this data package. The first one, waste inventory and release estimates, is addressed in the inventory and release model data packages.

Many large scale Hanford assessments will generally use a one-dimensional vadose zone model for computational efficiency (although the SAC framework is not inherently limited to a one-dimensional representation), configured to account for lateral spreading, and in selected cases, conditioned against multi-dimensional model results (Kincaid et al. 2004). In this report, and that of Kincaid et al. (2004), waste sites are grouped into a number of geographic areas assumed to have similar

(a) Originally 974 of 2,730 Waste Information Data System (WIDS) sites were identified for inclusion in a large-scale Hanford assessment. Further work identified 48 more waste sites bringing the total to 1,022 . Subsequent reviews identified an additional 30 sites that have been included, many of which account for offsite transfers of waste and nuclear material. This brings the total to 1,052. 
hydrogeologic structure and properties. Hydrogeologic units were identified and their thickness specified for each of these hydrogeologic provinces. To account for uncertainty in the model parameters, a stochastic distribution was developed for each process model parameter for each hydrogeologic unit.

The vadose zone hydrostratigraphic profiles and hydrogeochemical property distributions for Hanford assessments are represented by 30 generalized onedimensional vertical columns representing 17 general geographic areas and 13 site-specific locations. Each hydrostratigraphic profile (template) is configured with the hydraulic and geochemical parameters necessary to simulate the flow and transport through the vadose zone using the Subsurface Transport Over Multiple Phases (STOMP) code (White and Oostrom 2000). As many as five variations of a single hydrostratigraphic template are incorporated for some geographic areas in order to more accurately represent the depth of waste release, the thickness of the vadose zone beneath the point of release, and variations in contaminant distribution coefficients $\left(K_{d}\right.$ values) associated with different waste chemistry designations. Each template represents the vadose zone using a few major hydrostratigraphic units that are treated as horizontal layers with constant thicknesses, and that are homogeneous and isotropic. Hydraulic and geochemical parameters for each hydrostratigraphic unit are represented by stochastic distributions to facilitate sensitivity and uncertainty analyses.

This data package is a compilation of the data available to support Hanford assessments. As site characterization is completed at waste sites, and as investigations into contaminant behavior are completed, the uncertainty in this information will be reduced and, as a result, the uncertainty in future assessments will be reduced.

\subsubsection{Continued Development of a Prototype Borehole Geologic Database}

\section{G. V. Last, R. D. Mackley, and D. C. Lanigan}

Last GV, RD Mackley, and DC Lanigan. 2006. Borehole Geologic Data for the 216-Z-Crib Facilities. A Status of Data Assembled through the Hanford Borehole Geologic Information System (HBGIS). PNNL-16103, Rev. 0, Pacific Northwest National Laboratory, Richland, Washington.

The following information was excepted directly from PNNL-16103, Rev. 0:

Abstract. The Pacific Northwest National Laboratory (PNNL) is assembling existing borehole geologic information to aid in determining the distribution and potential movement of contaminants released t the environment and to aid selection of remedial alternatives. This information is being assembled via the Hanford Borehole Geologic Information System (HBGIS), which is being developed as part of the characterization of Systems Project, managed by PNNL, and the Remediation Decision Support Task of the Groundwater Remediation Project, managed by Fluor Hanford, Inc.

The purpose of this particular study was to assemble the existing borehole geologic data pertaining to sediments underlying the 216-Z Crib Facilities and the Plutonium finishing Plant Closure Zone. The primary objective for fiscal year 2006 was to assemble the data, complete log plots, and interpret the location of major geologic contacts for each major borehole in and around the primary disposal facilities that received carbon tetrachloride. To date, 154 boreholes located within or immediately adjacent to 19 of the $216-Z$ crib facilities have been incorporated into HBGIS. Borehole geologic information for the remaining three Z-crib facilities 
is either lacking (dg. 216-Z-13, -14, and -15), or has been identified as a lesser priority to be incorporated at a later date.

\subsubsection{Low-Flux Measurements in Desert Settings Using Water Fluxmeters}

Gee GW, JM Keller, ZF Zhang, AL Ward, and BJ Andraski. 2006. Low-Flux Measurements in Desert Settings Using Water Fluxmeters. PNNL-SA-49677, Pacific Northwest National Laboratory, Richland, Washington.

The following abstract was published in 2006 (PNNL-SA-49677) and presented at the 18th World Congress of Soil Science in Philadelphia, Pennsylvania:

Water fluxes must be known to assess contaminant fluxes in the vadose zone. In desert settings, water fluxes are generally very low and often sporadic, responding to extreme events such as rapid snowmelt or heavy but infrequent rainstorms during winter periods, when evaporation is low. A series of water fluxmeters with divergent controls were placed in simulated barren waste-burial grounds located at the U.S. Department of Energy's Hanford Site near Richland, Washington and at a U.S. Geological Survey test site south of Beatty, Nevada, to measure drainage and estimate recharge. The fluxmeters were monitored for over 3 years at each site. Results indicated that at the cold desert Hanford site, as much as $60 \mathrm{~mm}$ ( $1 / 3$ of the annual precipitation) occurs as drainage through coarse sediments that are kept vegetation free. The water fluxmeter data are consistent with observed water potential profiles and also with measured flux rates obtained from on-site deep-drainage lysimeters. For Beatty, a warm desert site, there is annually less precipitation and significantly less drainage than at the Hanford Site. During the first three years of operation there was less than $1 \mathrm{~mm}$ of drainage, as measured with the water fluxmeters. While one of the two fluxmeters subsequently failed to operate, the other unit began draining after nearly 4 years of operation. This occurred in response to excess winter rains and also to additional water added to the lysimeter surface. The finer soil at the Beatty site in most winters is likely responsible for wicking winter rain to the surface where it evaporates. However, with bare surfaces, the water potential in the simulated waste site at Beatty remains high and the potential for drainage remains correspondingly high. Additional years of flux measurements will be required to fully document recharge at Beatty. This study was supported by the Hanford Site Remediation and Closure Project sponsored by the U.S. Department of Energy under contract DE-AC06-76RL01830 and at the Amargosa Desert Research Site by the U.S. Geological Survey's Toxic Program. 


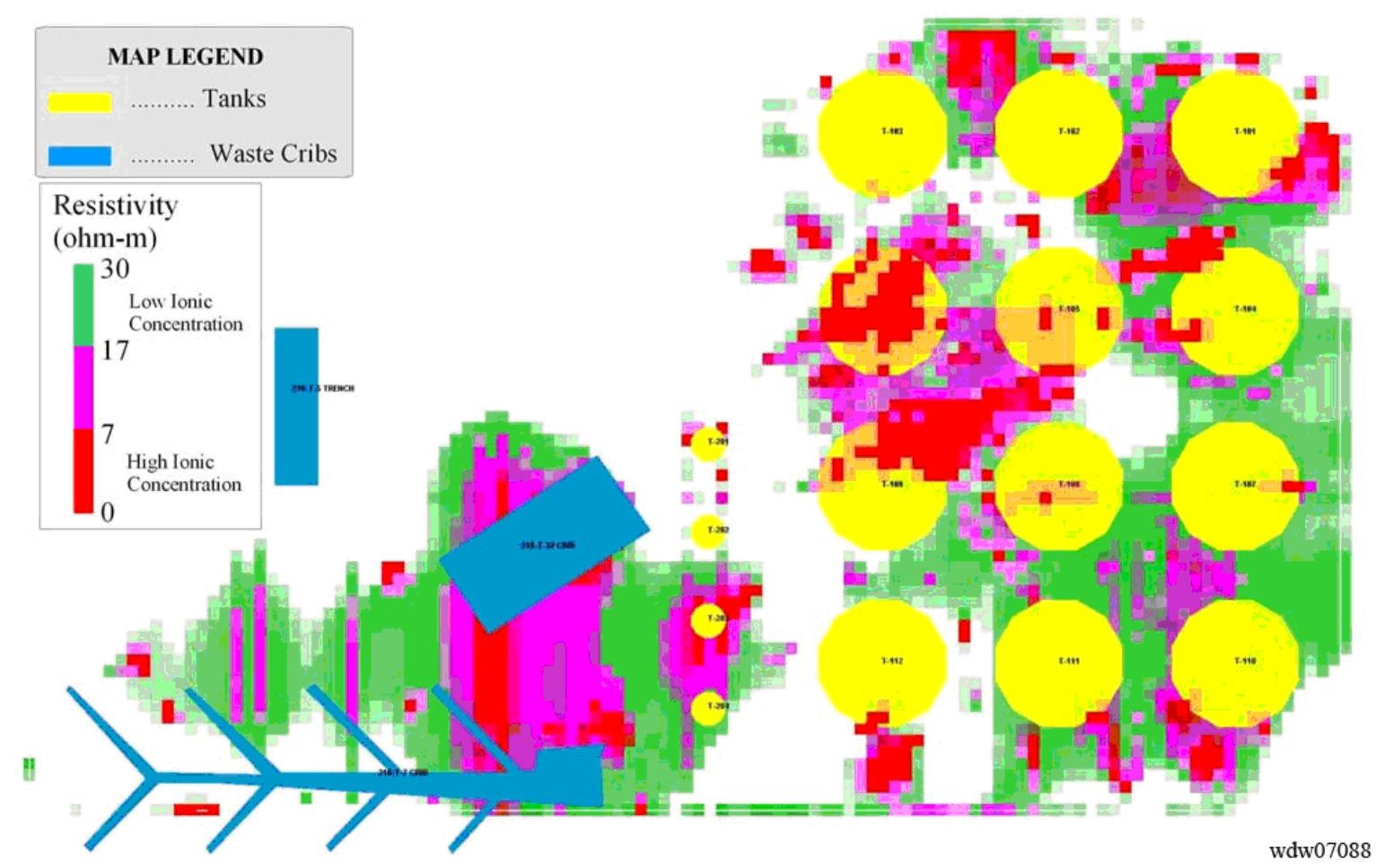

Figure 3.4-1. Well-to-Well Inversion of Drywells in and Around the T Tank Farm (RPP-RPT-28955)

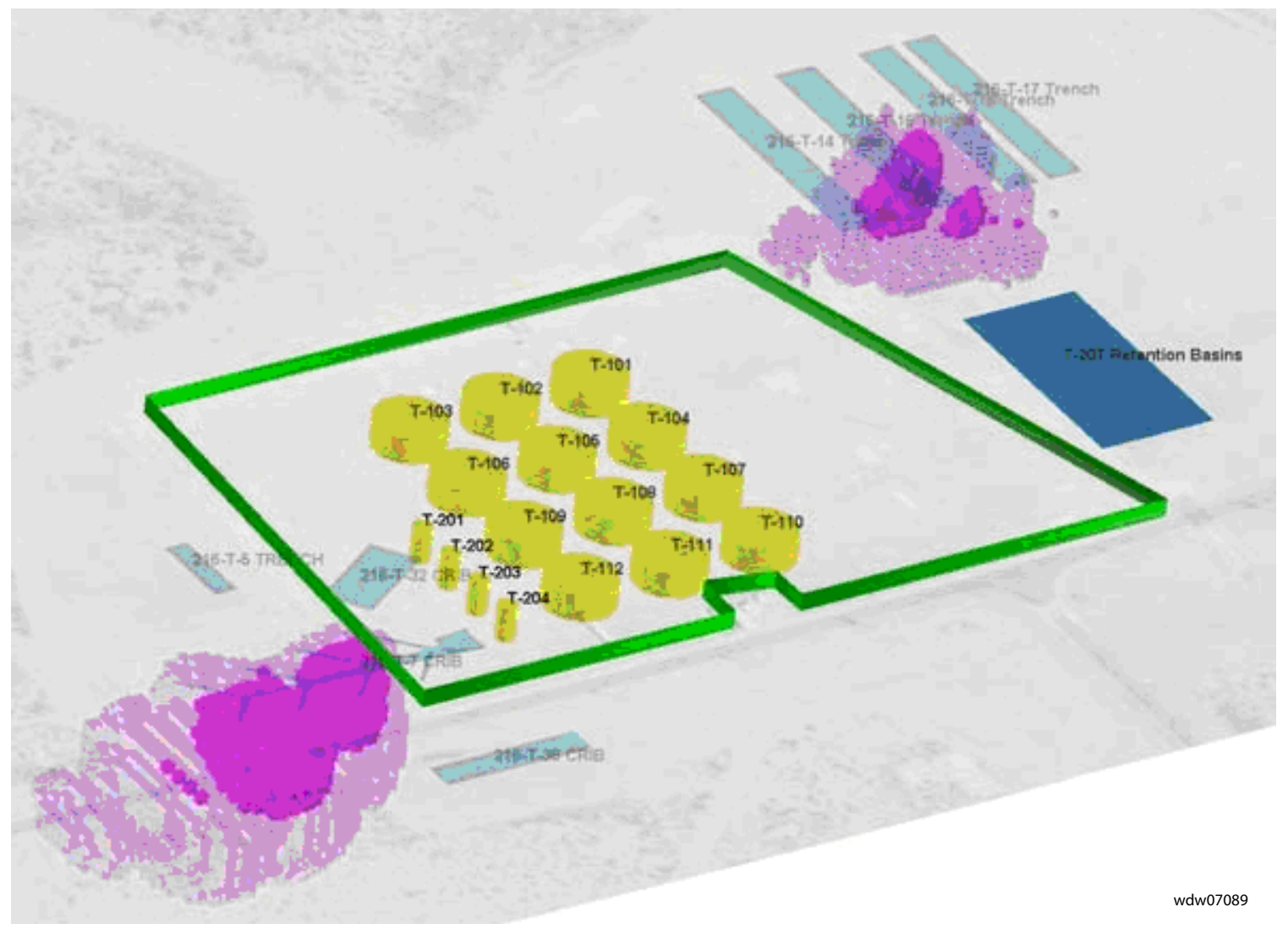

Figure 3.4-2. Resistivity Data Beneath the Northeast Trenches and Western Cribs (RPP-RPT-28955) 


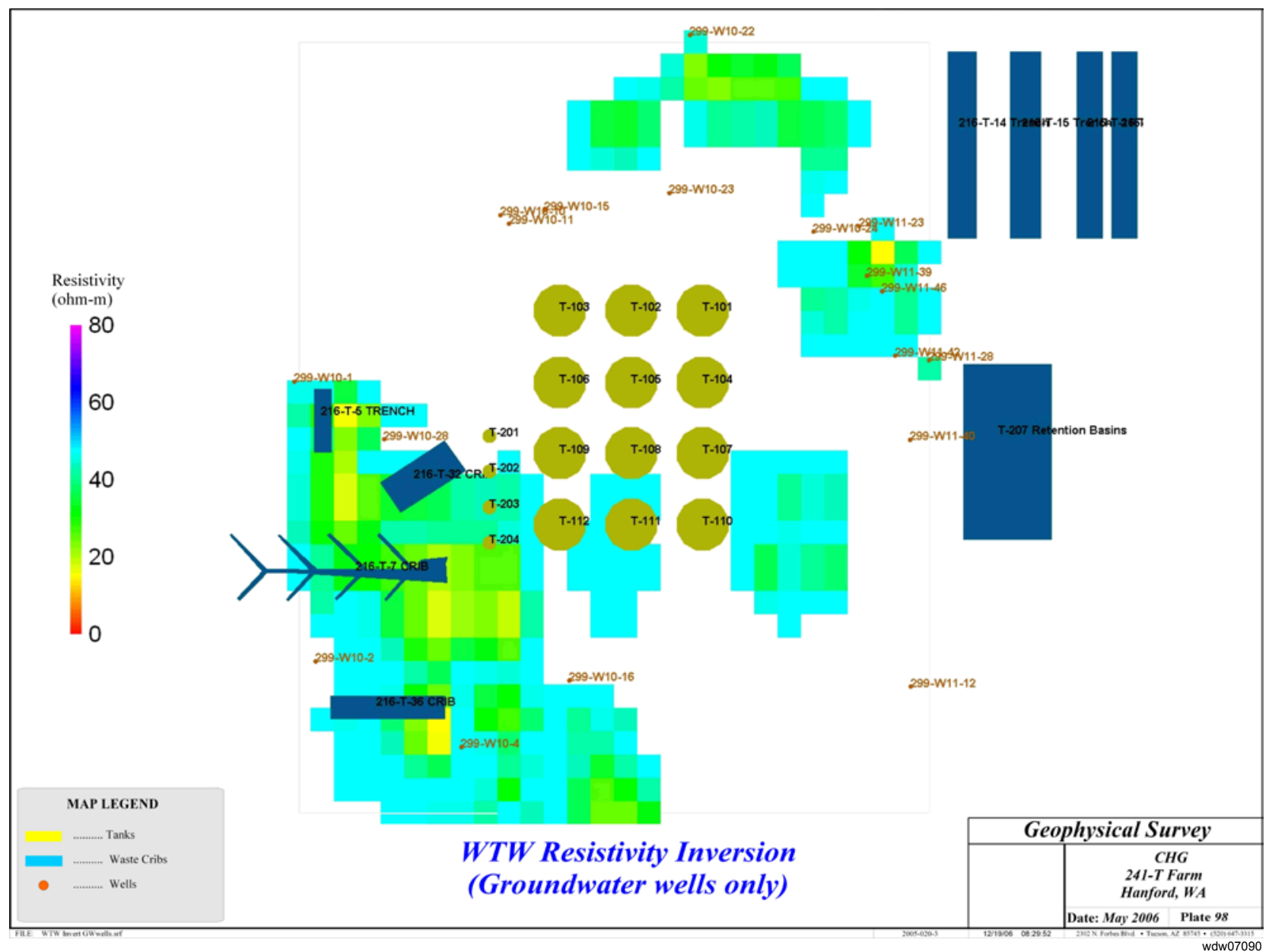

Figure 3.4-3. Well-to-Well Inversion of Groundwater Wells in and Around T Tank Farm (Note: No groundwater wells located around tanks.) (RPP-RPT-28955) 

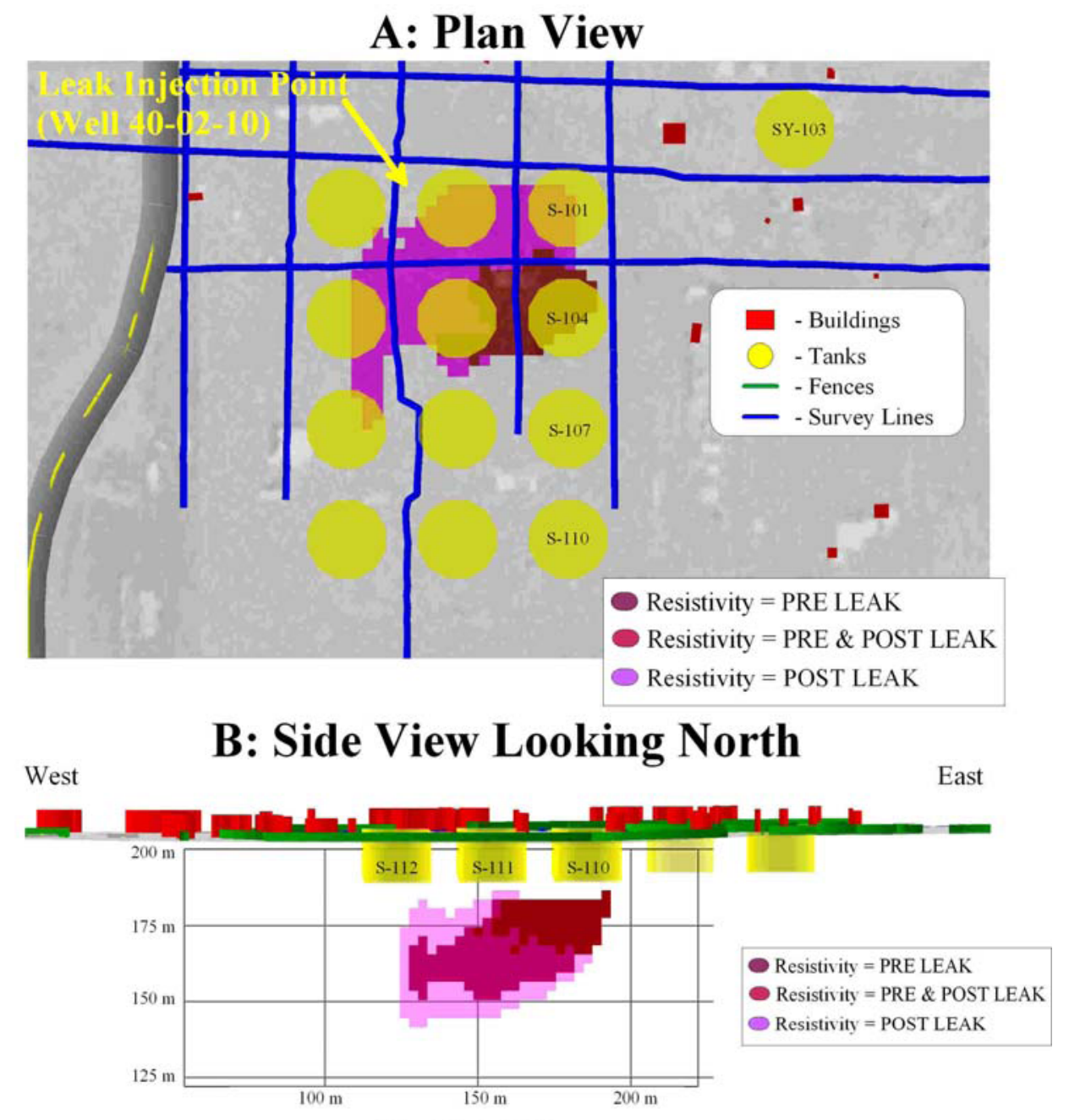

\section{C: 3D View}

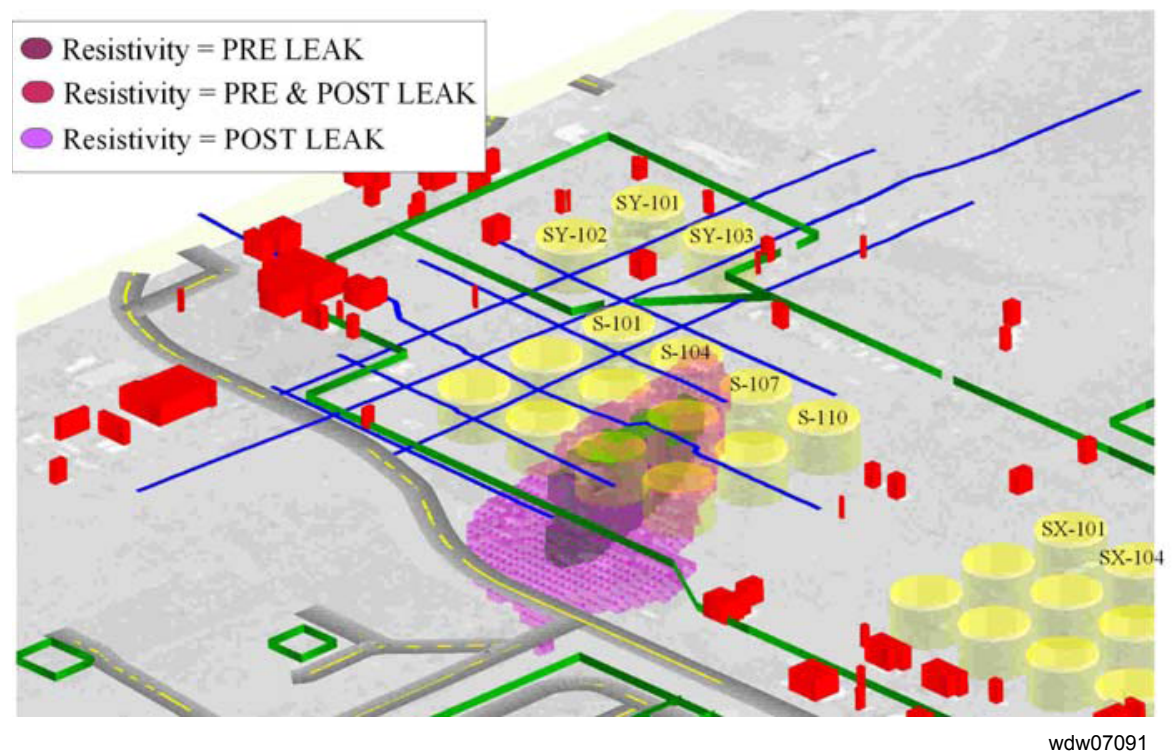

Figure 3.4-4. Views of Pre- and Post-LEAK Surface Inversion Results for the 1-2 ohm-m Level (a) Plan View, (b) Side View, and (c) Three-Dimensional View (RPP-RPT-30976) 

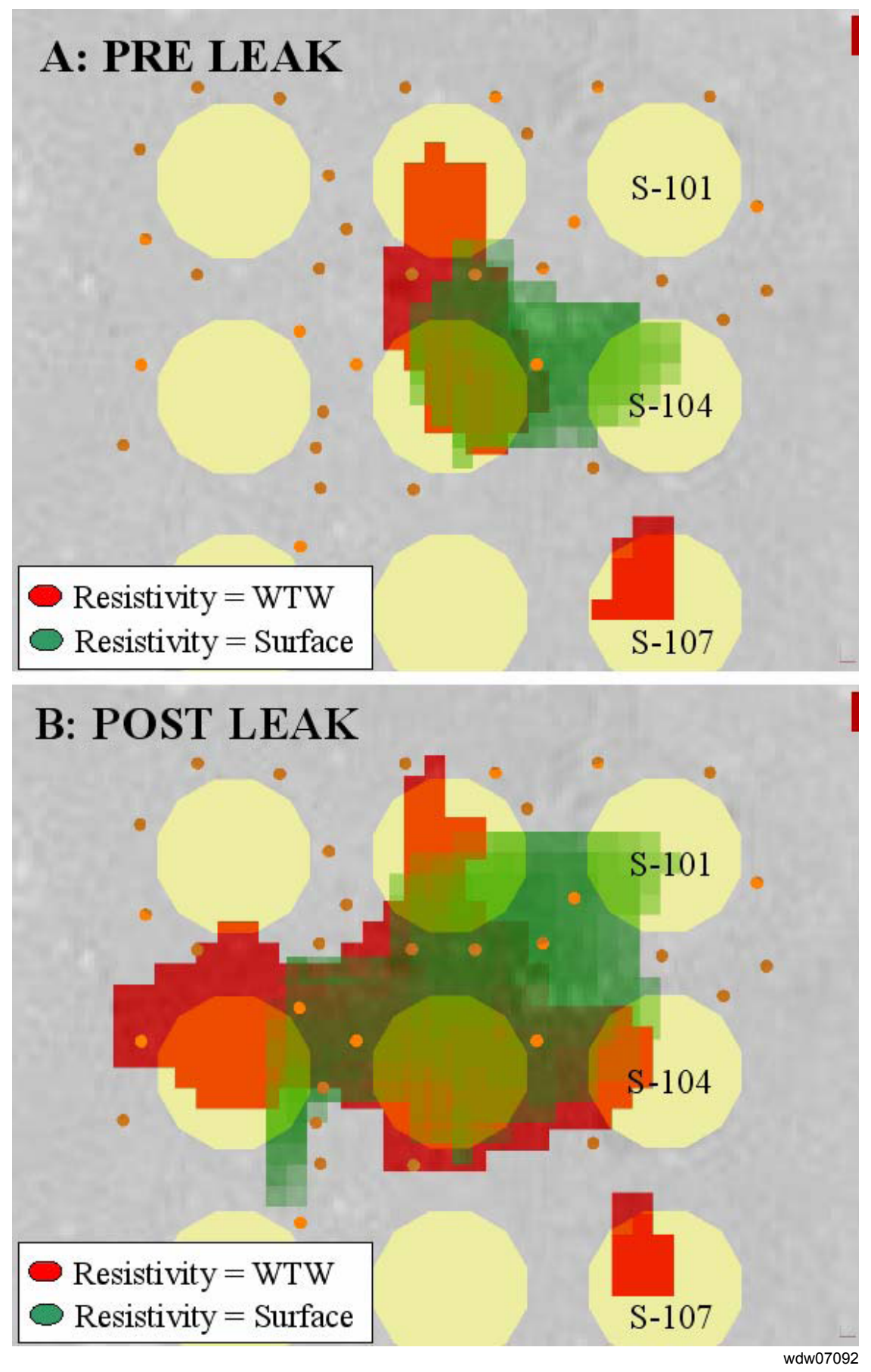

Figure 3.4-5. Direct Comparison of WTW Inversion with Surface Inversion, with WTW Opacity (red) of 1-14 ohm-meters and Surface Opacity (green) of 1-1.5 ohm-meters (RPP-RPT-30976) 


\subsection{Well Installation, Maintenance, and Decommissioning}

\section{B. A. Williams and G. G. Kelty}

This section describes new well installation, maintenance, and decommissioning activities conducted on the Hanford Site during fiscal year (FY) 2006. In addition, FY 2006 characterization borehole installation activities are summarized.

Approximately 7,544 unique well identification numbers have been identified at the Hanford Site. All wells, characterization boreholes, aquifer tubes, soil-gas probes, piezometers, or other subsurface excavations are required to receive a unique Hanford well identification number (Figures 4.0-1 and 4.0-2). To date, 3,094 of these, or $\sim 41 \%$ of the total, identified with unique well identification numbers, have been decommissioned.

During FY 2006, a total of 2,934 unique well identification numbers were documented as 'in use' (this number includes 2,169 wells, 127 piezometers within host wells, 356 aquifer tubes, 244 soil gas, and 38 push technology boreholes). A total of 53 new monitoring wells were installed during FY 2006. A total of 82 wells were physically decommissioned during FY 2006 and a total of 357 temporary boreholes and subsurface installations were administratively decommissioned by records management.

During review of candidate wells for decommissioning, a records review is conducted to clearly identify the wells location and its attributes by performing (a) a thorough review of the entries for these candidate wells in the Hanford Environmental Information System (HEIS), and (b) a review of records from other contractors. These data are used to define and locate the wells to be decommissioned in the field. The candidate wells that are not found in the field after a reasonable search using field inspections, global satellite positioning technology, and subsurface magnetometry are considered decommissioned without previous record and are subsequently administratively decommissioned to remove them from the in-use status.

\subsection{Well Installation}

The Groundwater Performance Assessment Project (groundwater project) along with the Groundwater Remediation Project defines the need for new wells at the Hanford Site.

Based on groundwater monitoring requirements, DOE, EPA, and Ecology agree on new wells needed and prioritize the requirements of RCRA, CERCLA, and AEA. During FY 2006, 53 new wells were installed on the Hanford Site:

- Sixteen for CERCLA/RCRA/AEA monitoring (fulfilling Tri-Party Agreement Milestone M-24-57 commitments).

- Thirty-seven to support groundwater contaminant barrier studies, treatability testing, and ongoing or new groundwater investigations.

Well maintenance is performed to support groundwater sampling. Non-routine maintenance varies and depends on specific problems identified in the field. During FY 2006, 209 wells received non-routine maintenance.

Wells are decommissioned when they are no longer used; they are in poor condition; they pose an environmental, safety, or health hazard; or they are in the path of remediation activities. During FY 2006, 82 vadose zone monitoring wells were decommissioned. Another 357 wells were administratively decommissioned during FY 2006. 


\section{The revised}

Tri-Party

Agreement

milestone includes

a prioritized list

and schedule for

installation of

60 wells over

4 years.
Each year, the groundwater project identifies new wells to meet the requirements of the Resource Conservation and Recovery Act (RCRA) detection and assessment groundwater monitoring requirements; characterization and monitoring for the Comprehensive Environmental Response, Compensation, and Liability Act (CERCLA); and long-term monitoring of regional groundwater plumes under U.S. Department of Energy (DOE) Orders based on the Atomic Energy Act (AEA). These efforts include ongoing RCRA assessment of groundwater contamination, replacement of monitoring wells that go dry because of the declining regional water table, replacement of wells that need to be decommissioned, improvement of spatial coverage of the detection monitoring networks or for plume monitoring, and characterization of subsurface contamination.

The Groundwater Remediation Project, managed by Fluor Hanford, Inc., annually determines the need for new wells associated with remediation (i.e., pump-and-treat and treatability testing), performance assessment monitoring, and plume characterization to fulfill obligations of CERCLA. Other projects may also request new wells based on specific needs (i.e., vadose investigations, seismic investigations, and other research (e.g., in situ reductionoxidation [redox] manipulation, treatability testing to reduce uranium concentrations in groundwater, and treatability testing for the bio-reduction of chromate and nitrate groundwater plumes).

New RCRA, CERCLA, and AEA well proposals are reviewed, prioritized, and approved annually as defined under the Tri-Party Agreement (Ecology et al. 1989) Milestone M-24. All new wells are constructed and decommissioned in accordance with the provisions of WAC 173-160. Well needs are integrated and documented via the data quality objectives process (e.g., CP-15329). This process integrates the borehole and well data needs of the various Hanford Site regulatory driven projects (i.e., CERCLA, RCRA, and AEA). Based on the data quality objectives documentation process, the Washington State Department of Ecology (Ecology), U.S. Environmental Protection Agency (EPA), and DOE (the Tri-Parties) annually negotiate an integrated well drilling list that coordinates and prioritizes the requirements of RCRA, CERCLA, and AEA under Tri-Party Agreement Milestone M-24-57. In 2004, the Tri-Parties renegotiated the milestone and prioritized and scheduled the installation of 60 wells over 4 years between calendar year 2003 to 2006 at a minimum rate of installation of 15 wells per year.

During FY 2006, a total of 53 new wells were installed at the Hanford Site (Table 4.0-1). Approximate locations of the new wells are shown on Figure 4.0-3. Tri-Party Agreement Milestone M-24-57 approved the installation of 16 of these wells, which include 6 RCRA wells and 10 CERCLA wells.

All six RCRA wells were drilled in the 200 West Area: two at single-shell tank Waste Management Area $\mathrm{T}$ and the remaining four at the Low-Level Burial Grounds Waste Management Area 3 (three wells) and 4 (one well). The single-shell Waste Management Area $T$ wells were for continued assessment of groundwater contaminants downgradient of the tank farm (i.e., technetium-99). The other wells were installed downgradient of low-level waste management areas as detection monitoring wells.

The ten CERCLA wells installed included six new wells in the 200 West Area within the 200-UP-1 Operable Unit and four new wells in the 300-FF-5 Operable Unit.

Six new wells in the 200-UP-1 Operable Unit were installed as part of an ongoing characterization program to collect contaminant distribution data for the widespread and deep-seated plume of carbon tetrachloride. The four new wells in the 300-FF-5 Operable Unit, drilled to support a CERCLA limited field investigation (DOE/RL-2005-47), provide new data to characterize the vadose zone and the upper unconfined aquifer for uranium contamination. For details about the specific activities conducted at these operable units during 2006, refer to specific sections of this report.

Thirty-seven non-Tri-Party Agreement wells were also installed in FY 2006:

- 29 wells installed at 100-N Area to support performance monitoring at the apatite barrier in the 100-NR-2 Operable Unit. 
- 2 wells installed for the Natural and Accelerated Bioremediation Research (NABIR) Project.

- 4 wells installed in the 100-K Area in support of the 100-KR-4 Operable Unit chromium pump-and-treat system.

- 2 vadose characterization boreholes installed to investigate dense nonaqueous phase liquid (DNAPL) contamination beneath the 216-Z-9 trench and the 216-Z-1A tile field.

Water well reports for all newly constructed wells, as required in WAC 173-160, are submitted to Ecology. Data packages for new wells installed during FY 2006 will provide detailed information about the wells including the detailed geologic and geophysical descriptions and a listing of characterization activities (i.e., sediment and groundwater sampling, aquifer testing, geophysical logging, etc.). Detailed drilling and construction records for the new wells are also electronically stored in the drilling contractor database.

Six new aquifer sampling tubes were installed along the Columbia River shore during FY 2006. All six of the new aquifer tubes were installed in the 100-N Area shoreline (N-Springs) to support either science and technology work or the apatite-barrier treatability test. No new aquifer sampling tubes were installed during FY 2006 for the routine CERCLA aquifer tube network along the Columbia River. The new monitoring points are similar to aquifer tubes monitored elsewhere on the Hanford Site shoreline and range in depth from 0.8 to 2.4 meters.

During FY 2006, a number of temporary vadose characterization boreholes were installed around the Hanford Site to support various projects. These boreholes, while temporary, are more cost-effective and can be used to supplement data collected during installation of permanent monitoring wells and in areas that are more difficult for the larger drill rigs to access. The temporary boreholes are installed for subsurface characterization of radiological constituents, volatile organics (e.g., carbon tetrachloride), hydrogeologic property determination (e.g., moisture, grain size distribution), and etc. During FY 2006, 85 temporary boreholes (i.e., cone penetrometer, direct push technology boreholes, auger, and/or drilled boreholes) were installed. Table 4.0-2 provides a summary of the number, program, and general location of these temporary boreholes. All of the temporary boreholes were decommissioned after data acquisition was completed. Chapter 3 of this report provides more details about vadose characterization studies conducted during FY 2006.

\subsection{Well Maintenance}

Maintenance of groundwater wells is performed to meet regulatory requirements (e.g., Ecology 1994a, Condition II.F.2) in response to non-routine problems identified in the field. During FY 2006, non-routine maintenance was completed in 209 wells (258 total maintenance events). A summary of non-routine maintenance activities by regulatory program is presented in Table 4.0-3.

Non-routine maintenance tasks, which include both surface and surface aspects, are varied and depend on the specific problem encountered at a well. Surface tasks include conducting field inspections, well labeling, maintenance and replacement of locking well caps, casing repairs, diagnosis and repair of surface electrical wiring, and pump-discharge fitting. Subsurface tasks typically include repairing and replacing sampling pumps, performing camera surveys, pump and equipment retrieval, and tubing replacement. It should be noted that in the past, the distinction between routine and non-routine maintenance activities was based upon a set grouping of activities and a 5-year cleaning cycle. Currently, any well requiring maintenance to maintain sampling efficiency is repaired under the non-routine maintenance program. This means that if a project scientist determines that a well is losing sampling efficiency, those tasks typically conducted under routine maintenance (identified
Well maintenance activities include casing repairs, repairing and replacing sampling pumps, pump and equipment retrieval, and tubing replacement. 
above) can be requested to be conducted under the non-routine tasks. Therefore, while not following a 5-year maintenance schedule, wells are still being maintained as needed to meet specific project and schedule requirements.

\subsection{Well Decommissioning}

A well becomes a candidate for decommissioning if (1) its use has been permanently discontinued (i.e., it has gone dry); (2) its condition is so poor that its continued use is impractical; (3) it is in the path of intended remediation, excavation, and construction activities; or (4) it poses an environmental, safety, or public health hazard (e.g., casing corrosion). At this time, decommissioning is generally driven by the long-range environmental restoration schedule (DOE/RL-96-105), available funding, and provisions of WAC 173-160. In addition, the list of candidate decommissioning wells is expanded to include wells identified in the Hanford well database that have been removed from the groundwater project's well maintenance list (i.e., an indication of no further well use). However, all candidate wells must be reviewed and approved for decommissioning by the contractors and other potential well users prior to actual decommissioning.

During FY 2006, a total of 82 vadose zone monitoring well installations were physically decommissioned (Table 4.0-4 and Figure 4.0-4). The 82 selected wells for physical decommissioning have been identified as (1) discontinued use; (2) inadequate construction (no surface seals, old detracting materials, i.e., rusted casings); (3) located inside or within 15.2 meters of a waste site; and (4) poses an environmental, safety, or public health hazard due to their location inside the waste sites and ability to further transport chemical and radiological hazards deeper into the vadose zone and possibly to the groundwater. Due to budget limitations and limited amount of groundwater wells available as candidates for decommissioning inside closure zones, no groundwater wells were attempted for decommissioning in FY 2006. In addition, a total of 357 temporary boreholes and subsurface installations were administratively decommissioned by records management. These wells have previously been taken out of service and decommissioned and no physical well remains to be located. For example, in some instances, Hanford unique well identification numbers were obtained to drill wells, but drilling was subsequently cancelled. In other instances, the wells were drilled but the casings (if present) were pulled as the holes were backfilled. Table 4.0-2 lists these characteristic boreholes installed and subsequently decommissioned in FY 2006. Other wells were completed and in use for a period of time and then decommissioned, but the administrative record of their decommissioning was not filed at the time of their decommissioning. To date, a total of 3,094 unique well identification numbers ( $41 \%$ of the total Hanford Site well installations, both permanent and temporary) have been either administratively removed from the well inventory or physically decommissioned.

Decommissioning activities result in the permanent removal of a well, borehole, or piezometer from service and from the Hanford Site active well inventory. Decommissioning is performed in accordance with Ecology standards (WAC 173-160), applicable variances, and conditions defined in the Hanford Facility RCRA Permit (Ecology 1994a, Condition II.F.2). Decommissioning involves backfilling a well with impermeable material to prevent vertical movement of water and/or contaminants. For resource protection wells, decommissioning typically is performed by placing sand across the screen interval and filling the casing with an impermeable material (e.g., bentonite or cement grout). For older, non-compliant wells, the casing(s) is perforated and pressure grouted. The sealing of the annular space between the casing(s) and formation is intended to minimize the creation of preferential pathways. Where possible, the casing is removed and a brass survey marker identifying the well is set in grout at the surface and over the well location. If the casing cannot be removed, the casing is generally cut $\sim 1$ meter below ground surface and the identifying brass survey marker is set in the grout below land surface; the hole is then backfilled to grade. 
Table 4.0-1. Well Installations for FY 2006

\begin{tabular}{|c|c|c|c|c|}
\hline WELL_ID & WELL_NAME & Program & TPA Well & Facility \\
\hline C5112 & $199-K-137$ & Chromium Pump-and-Treat & No & 100-KR-4 OU \\
\hline C5113 & $199-K-138$ & Chromium Pump-and-Treat & No & 100-KR-4 OU \\
\hline C5114 & $199-K-139$ & Chromium Pump-and-Treat & No & 100-KR-4 OU \\
\hline C5115 & $199-K-140$ & Chromium Pump-and-Treat & No & $100-K R-4$ OU \\
\hline C5032 & $199-\mathrm{N}-126$ & N-Barrier & No & 100-NR-2 OU \\
\hline C5033 & $199-\mathrm{N}-127$ & N-Barrier & No & 100-NR-2 OU \\
\hline C5034 & $199-\mathrm{N}-128$ & N-Barrier & No & 100-NR-2 OU \\
\hline C5035 & $199-\mathrm{N}-129$ & N-Barrier & No & 100-NR-2 OU \\
\hline C5036 & $199-\mathrm{N}-130$ & N-Barrier & No & 100-NR-2 OU \\
\hline C5037 & $199-\mathrm{N}-131$ & N-Barrier & No & 100-NR-2 OU \\
\hline C5038 & $199-\mathrm{N}-132$ & N-Barrier & No & 100-NR-2 OU \\
\hline C5039 & $199-\mathrm{N}-133$ & N-Barrier & No & 100-NR-2 OU \\
\hline C5042 & $199-\mathrm{N}-136$ & N-Barrier & No & 100-NR-2 OU \\
\hline C5043 & $199-\mathrm{N}-137$ & N-Barrier & No & 100-NR-2 OU \\
\hline C5044 & $199-\mathrm{N}-138$ & N-Barrier & No & 100-NR-2 OU \\
\hline C5045 & $199-\mathrm{N}-139$ & N-Barrier & No & 100-NR-2 OU \\
\hline C5046 & $199-\mathrm{N}-140$ & N-Barrier & No & 100-NR-2 OU \\
\hline C5047 & $199-\mathrm{N}-141$ & N-Barrier & No & 100-NR-2 OU \\
\hline C5048 & $199-\mathrm{N}-142$ & N-Barrier & No & 100-NR-2 OU \\
\hline C5049 & $199-\mathrm{N}-143$ & N-Barrier & No & 100-NR-2 OU \\
\hline C5050 & $199-\mathrm{N}-144$ & N-Barrier & No & 100-NR-2 OU \\
\hline C5051 & $199-\mathrm{N}-145$ & N-Barrier & No & 100-NR-2 OU \\
\hline C5052 & $199-\mathrm{N}-146$ & N-Barrier & No & 100-NR-2 OU \\
\hline C5116 & $199-\mathrm{N}-147$ & N Barrier & No & 100-NR-2 OU \\
\hline C5316 & $199-N-148$ & N-Barrier & No & 100-NR-2 OU \\
\hline C5317 & $199-\mathrm{N}-149$ & N-Barrier & No & 100-NR-2 OU \\
\hline C5318 & $199-\mathrm{N}-150$ & N-Barrier & No & 100-NR-2 OU \\
\hline C5319 & $199-\mathrm{N}-151$ & N-Barrier & No & 100-NR-2 OU \\
\hline C5320 & $199-\mathrm{N}-152$ & N-Barrier & No & 100-NR-2 OU \\
\hline C5321 & $199-\mathrm{N}-153$ & N-Barrier & No & 100-NR-2 OU \\
\hline C5322 & $199-\mathrm{N}-154$ & N-Barrier & No & 100-NR-2 OU \\
\hline C5323 & $199-\mathrm{N}-155$ & N-Barrier & No & 100-NR-2 OU \\
\hline C5324 & $199-\mathrm{N}-156$ & N-Barrier & No & 100-NR-2 OU \\
\hline C4988 & 299-W10-29 & RCRA & TPA & LLWMA-3 \\
\hline C4989 & 299-W10-30 & RCRA & TPA & LLWMA-3 \\
\hline C5194 & 299-W10-31 & RCRA & TPA & LLWMA-3 \\
\hline C4948 & 299-W11-45 & RCRA & TPA & SST WMA T \\
\hline C4990 & 299-W11-47 & RCRA & TPA & SST WMA T \\
\hline C4986 & 299-W15-224 & RCRA & TPA & LLWMA-4 \\
\hline C3427 & 299-W15-48 & Vadose Investigation & No & 216-Z-9 Trench \\
\hline C4965 & 299-W18-253 & Vadose Investigation & No & 216-Z-1A Tile Field \\
\hline C4968 & 299-W19-105 & CERCLA & TPA & 200-UP-1 OU \\
\hline C5193 & 299-W19-107 & CERCLA & TPA & 200-UP-1 OU \\
\hline C4969 & 299-W22-69 & CERCLA & TPA & 200-UP-1 OU \\
\hline
\end{tabular}


Table 4.0-1. (contd)

\begin{tabular}{|c|c|c|c|c|}
\hline WELL_ID & WELL_NAME & Program & TPA Well & Facility \\
\hline C4970 & 299-W22-72 & CERCLA & TPA & 200-UP-1 OU \\
\hline C4971 & 299-W22-86 & CERCLA & TPA & 200-UP-1 OU \\
\hline C4977 & 299-W22-87 & CERCLA & TPA & 200-UP-1 OU \\
\hline C5000 & $399-1-23$ & CERCLA & TPA & $300-F F-5$ OU \\
\hline C4999 & $399-3-18$ & CERCLA & TPA & $300-F F-5$ OU \\
\hline C5001 & $399-3-19$ & CERCLA & TPA & $300-F F-5$ OU \\
\hline C5002 & $399-3-20$ & CERCLA & TPA & $300-F F-5$ OU \\
\hline C5191 & 699-96-41 & NABIR & No & \\
\hline C5192 & 699-96-42 & NABIR & No & \\
\hline \multicolumn{5}{|c|}{$\begin{array}{l}\text { CERCLA = Comprehensive Environmental Response, Compensation, and Liability Ac } \\
\text { LLWMA = Low-level waste management area. } \\
\text { NABIR = Natural and Accelerated Bioremediation Research Project. } \\
\text { OU = Operable unit. } \\
\text { RCRA = Resource Conservation and Recovery Act } . \\
\text { SST = Single-shell tank. } \\
\text { TPA = Tri-Party Agreement Milestone M-24-57 (Ecology et al. 1989) approved well. } \\
\text { WMA = Waste management area. }\end{array}$} \\
\hline
\end{tabular}


Table 4.0-2. Characterization Boreholes, Soil-Gas Probes, and Push Technology Installation for FY 2006

\begin{tabular}{|c|c|c|c|}
\hline WELL_ID & Program & Facility & Location \\
\hline C5117 & DOE-ORP Tank Farm Vadose & SST WMA BX-BY & 200 East Area \\
\hline C5119 & DOE-ORP Tank Farm Vadose & SST WMA BX-BY & 200 East Area \\
\hline C5121 & DOE-ORP Tank Farm Vadose & SST WMA BX-BY & 200 East Area \\
\hline C5123 & DOE-ORP Tank Farm Vadose & SST WMA BX-BY & 200 East Area \\
\hline C5124 & DOE-ORP Tank Farm Vadose & SST WMA BX-BY & 200 East Area \\
\hline C5125 & DOE-ORP Tank Farm Vadose & SST WMA BX-BY & 200 East Area \\
\hline C5127 & DOE-ORP Tank Farm Vadose & SST WMA BX-BY & 200 East Area \\
\hline C5129 & DOE-ORP Tank Farm Vadose & SST WMA BX-BY & 200 East Area \\
\hline C5131 & DOE-ORP Tank Farm Vadose & SST WMA BX-BY & 200 East Area \\
\hline C5132 & DOE-ORP Tank Farm Vadose & SST WMA BX-BY & 200 East Area \\
\hline C5133 & DOE-ORP Tank Farm Vadose & SST WMA BX-BY & 200 East Area \\
\hline C5134 & DOE-ORP Tank Farm Vadose & SST WMA BX-BY & 200 East Area \\
\hline C5135 & DOE-ORP Tank Farm Vadose & SST WMA BX-BY & 200 East Area \\
\hline C5137 & DOE-ORP Tank Farm Vadose & SST WMA BX-BY & 200 East Area \\
\hline C5104 & DOE-ORP Tank Farm Vadose & SST WMA C & 200 East Area \\
\hline C5105 & DOE-ORP Tank Farm Vadose & SST WMA C & 200 East Area \\
\hline C5106 & DOE-ORP Tank Farm Vadose & SST WMA C & 200 East Area \\
\hline C5107 & DOE-ORP Tank Farm Vadose & SST WMA C & 200 East Area \\
\hline C5108 & DOE-ORP Tank Farm Vadose & SST WMA C & 200 East Area \\
\hline C5109 & DOE-ORP Tank Farm Vadose & SST WMA C & 200 East Area \\
\hline C4591 & DOE-ORP Tank Farm Vadose & SST WMA T & 200 West Area \\
\hline C4593 & DOE-ORP Tank Farm Vadose & SST WMA T & 200 West Area \\
\hline C4595 & DOE-ORP Tank Farm Vadose & SST WMA T & 200 West Area \\
\hline C4596 & DOE-ORP Tank Farm Vadose & SST WMA T & 200 West Area \\
\hline C4597 & DOE-ORP Tank Farm Vadose & SST WMA T & 200 West Area \\
\hline C4598 & DOE-ORP Tank Farm Vadose & SST WMA T & 200 West Area \\
\hline C4599 & DOE-ORP Tank Farm Vadose & SST WMA T & 200 West Area \\
\hline C4601 & DOE-ORP Tank Farm Vadose & SST WMA T & 200 West Area \\
\hline C5306 & DOE-ORP Tank Farm Vadose & SST WMA T & 200 West Area \\
\hline C5307 & DOE-ORP Tank Farm Vadose & SST WMA T & 200 West Area \\
\hline C5309 & DOE-ORP Tank Farm Vadose & SST WMA T & 200 West Area \\
\hline C5310 & DOE-ORP Tank Farm Vadose & SST WMA T & 200 West Area \\
\hline C5311 & DOE-ORP Tank Farm Vadose & SST WMA T & 200 West Area \\
\hline C5312 & DOE-ORP Tank Farm Vadose & SST WMA T & 200 West Area \\
\hline C5314 & DOE-ORP Tank Farm Vadose & SST WMA T & 200 West Area \\
\hline C5315 & DOE-ORP Tank Farm Vadose & SST WMA T & 200 West Area \\
\hline $\mathrm{C} 4610$ & DOE-ORP Tank Farm Vadose & SST WMA TX-TY & 200 West Area \\
\hline C4617 & DOE-ORP Tank Farm Vadose & SST WMA TX-TY & 200 West Area \\
\hline C4618 & DOE-ORP Tank Farm Vadose & SST WMA TX-TY & 200 West Area \\
\hline C4622 & DOE-ORP Tank Farm Vadose & SST WMA TX-TY & 200 West Area \\
\hline C4623 & DOE-ORP Tank Farm Vadose & SST WMA TX-TY & 200 West Area \\
\hline $\mathrm{C} 4625$ & DOE-ORP Tank Farm Vadose & SST WMA TX-TY & 200 West Area \\
\hline $\mathrm{C} 4627$ & DOE-ORP Tank Farm Vadose & SST WMA TX-TY & 200 West Area \\
\hline C4633 & DOE-ORP Tank Farm Vadose & SST WMA TX-TY & 200 West Area \\
\hline C4637 & DOE-ORP Tank Farm Vadose & SST WMA TX-TY & 200 West Area \\
\hline
\end{tabular}


Table 4.0-2. (contd)

\begin{tabular}{|c|c|c|c|}
\hline WELL_ID & Program & Facility & Location \\
\hline C5008 & DOE-ORP Tank Farm Vadose & SST WMA TX-TY & 200 West Area \\
\hline C5010 & DOE-ORP Tank Farm Vadose & SST WMA TX-TY & 200 West Area \\
\hline C5012 & DOE-ORP Tank Farm Vadose & SST WMA TX-TY & 200 West Area \\
\hline C5016 & DOE-ORP Tank Farm Vadose & SST WMA TX-TY & 200 West Area \\
\hline C5018 & DOE-ORP Tank Farm Vadose & SST WMA TX-TY & 200 West Area \\
\hline C5020 & DOE-ORP Tank Farm Vadose & SST WMA TX-TY & 200 West Area \\
\hline C5003 & EuroDrill percussion drilling near Z-9 Trench & 216-Z-9 Trench & 200 West Area \\
\hline C5004 & EuroDrill percussion drilling near Z-9 Trench & 216-Z-9 Trench & 200 West Area \\
\hline C5096 & Geotechnical Borings at Mock Test Site 200 East & Mock Tank Site & 200 East Area \\
\hline C5097 & Geotechnical Borings at Mock Test Site 200 East & Mock Tank Site & 200 East Area \\
\hline C5098 & Geotechnical Borings at Mock Test Site 200 East & Mock Tank Site & 200 East Area \\
\hline C5099 & Geotechnical Borings at Mock Test Site 200 East & Mock Tank Site & 200 East Area \\
\hline C5100 & Geotechnical Borings at Mock Test Site 200 East & Mock Tank Site & 200 East Area \\
\hline C5229 & Vista DPT Work around $216-Z-9$ and $216-Z-1 A$ cribs & & 200 West Area \\
\hline C5230 & Vista DPT Work around $216-Z-9$ and $216-Z-1 A$ cribs & & 200 West Area \\
\hline C5231 & Vista DPT Work around $216-Z-9$ and $216-Z-1 A$ cribs & & 200 West Area \\
\hline C5232 & Vista DPT Work around $216-Z-9$ and $216-Z-1 A$ cribs & & 200 West Area \\
\hline C5233 & Vista DPT Work around $216-Z-9$ and $216-Z-1 A$ cribs & & 200 West Area \\
\hline C5234 & Vista DPT Work around $216-Z-9$ and $216-Z-1 A$ cribs & & 200 West Area \\
\hline C5235 & Vista DPT Work around $216-Z-9$ and $216-Z-1 A$ cribs & & 200 West Area \\
\hline C5236 & Vista DPT Work around $216-Z-9$ and $216-Z-1 A$ cribs & & 200 West Area \\
\hline C5237 & Vista DPT Work around $216-Z-9$ and $216-Z-1 A$ cribs & & 200 West Area \\
\hline C5238 & Vista DPT Work around $216-Z-9$ and $216-Z-1 A$ cribs & & 200 West Area \\
\hline C5239 & Vista DPT Work around $216-Z-9$ and $216-Z-1 A$ cribs & & 200 West Area \\
\hline C5240 & Vista DPT Work around $216-Z-9$ and $216-Z-1$ A cribs & & 200 West Area \\
\hline C5241 & Vista DPT Work around $216-Z-9$ and $216-Z-1 A$ cribs & & 200 West Area \\
\hline C5242 & Vista DPT Work around $216-Z-9$ and $216-Z-1 A$ cribs & & 200 West Area \\
\hline C5328 & Vista DPT Work around $216-Z-9$ and $216-Z-1 A$ cribs & 216-Z-9 Trench & 200 West Area \\
\hline C5329 & Vista DPT Work around $216-Z-9$ and $216-Z-1 A$ cribs & 216-Z-9 Trench & 200 West Area \\
\hline C5330 & Vista DPT Work around $216-Z-9$ and $216-Z-1$ A cribs & 216-Z-9 Trench & 200 West Area \\
\hline C5331 & Vista DPT Work around $216-Z-9$ and $216-Z-1$ A cribs & 216-Z-9 Trench & 200 West Area \\
\hline C5332 & Vista DPT Work around $216-Z-9$ and $216-Z-1 A$ cribs & 216-Z-9 Trench & 200 West Area \\
\hline C5333 & Vista DPT Work around $216-Z-9$ and $216-Z-1 A$ cribs & 216-Z-9 Trench & 200 West Area \\
\hline C5334 & Vista DPT Work around $216-Z-9$ and $216-Z-1 A$ cribs & 216-Z-9 Trench & 200 West Area \\
\hline C5198 & Vista DPT work at Cold Test site in 200E, Z-9 Trench, Z1A Tile Field, Z-18 Crib & & 200 West Area \\
\hline C5199 & Vista DPT work at Cold Test site in 200E, Z-9 Trench, Z1A Tile Field, Z-18 Crib & & 200 West Area \\
\hline C5200 & Vista DPT work at Cold Test site in 200E, Z-9 Trench, Z1A Tile Field, Z-18 Crib & & 200 West Area \\
\hline C5201 & Vista DPT work at Cold Test site in 200E, Z-9 Trench, Z1A Tile Field, Z-18 Crib & & 200 West Area \\
\hline C5202 & Vista DPT work at Cold Test site in 200E, Z-9 Trench, Z1A Tile Field, Z-18 Crib & & 200 West Area \\
\hline C5203 & Vista DPT work at Cold Test site in 200E, Z-9 Trench, Z1A Tile Field, Z-18 Crib & & 200 West Area \\
\hline \multicolumn{4}{|c|}{$\begin{array}{l}\text { All listed boreholes decommissioned following data acquisition. } \\
\text { DOE = U.S. Department of Energy. } \\
\text { DPT = Direct push technology. } \\
\text { ORP = Office of River Protection. } \\
\text { SST = Single-shell tank. } \\
\text { WMA = Waste management area. }\end{array}$} \\
\hline
\end{tabular}


Table 4.0-3. Well Maintenance Summary for FY 2006

\begin{tabular}{|l|c|}
\hline \multicolumn{1}{|c|}{ Program } & Non-Routine \\
\hline CERCLA & 145 \\
\hline RCRA & 24 \\
\hline Total & $\mathbf{2 0 9}$ \\
\hline $\begin{array}{l}\text { CERCLA = Comprehensive Environmental } \\
\text { Response, Compensation, and Liability Act. } \\
\text { RCRA = Resource Conservation and } \\
\text { Recovery Act. }\end{array}$ \\
\hline
\end{tabular}


Table 4.0-4. Vadose Zone Wells Decommissioned during FY 2006

\begin{tabular}{|c|c|c|}
\hline HEIS Well ID & Well Name & Comment \\
\hline A5910 & 299-E24-53 & FY 2006 Physically Decommissioned \\
\hline A5912 & 299-E24-55 & FY 2006 Physically Decommissioned \\
\hline A5913 & 299-E24-56 & FY 2006 Physically Decommissioned \\
\hline A5914 & 299-E24-57 & FY 2006 Physically Decommissioned \\
\hline A5918 & 299-E24-63 & FY 2006 Physically Decommissioned \\
\hline A6644 & 299-E26-51 & FY 2006 Physically Decommissioned \\
\hline A6645 & 299-E26-52 & FY 2006 Physically Decommissioned \\
\hline A6646 & 299-E26-53 & FY 2006 Physically Decommissioned \\
\hline A6647 & 299-E26-54 & FY 2006 Physically Decommissioned \\
\hline A6648 & 299-E26-55 & FY 2006 Physically Decommissioned \\
\hline A6649 & 299-E26-56 & FY 2006 Physically Decommissioned \\
\hline A6650 & 299-E26-57 & FY 2006 Physically Decommissioned \\
\hline A6651 & 299-E26-58 & FY 2006 Physically Decommissioned \\
\hline A6652 & 299-E26-59 & FY 2006 Physically Decommissioned \\
\hline A6653 & 299-E26-60 & FY 2006 Physically Decommissioned \\
\hline A6654 & 299-E26-61 & FY 2006 Physically Decommissioned \\
\hline A6655 & 299-E26-62 & FY 2006 Physically Decommissioned \\
\hline A6656 & 299-E26-63 & FY 2006 Physically Decommissioned \\
\hline A6657 & 299-E26-64 & FY 2006 Physically Decommissioned \\
\hline A6659 & 299-E26-66 & FY 2006 Physically Decommissioned \\
\hline A6661 & 299-E26-68 & FY 2006 Physically Decommissioned \\
\hline A6662 & 299-E26-69 & FY 2006 Physically Decommissioned \\
\hline A6664 & 299-E26-71 & FY 2006 Physically Decommissioned \\
\hline A6665 & 299-E26-72 & FY 2006 Physically Decommissioned \\
\hline A6666 & 299-E26-73 & FY 2006 Physically Decommissioned \\
\hline A6667 & 299-E26-74 & FY 2006 Physically Decommissioned \\
\hline A6668 & 299-E26-75 & FY 2006 Physically Decommissioned \\
\hline A6669 & 299-E26-76 & FY 2006 Physically Decommissioned \\
\hline A6804 & 299-E28-53 & FY 2006 Physically Decommissioned \\
\hline A6805 & 299-E28-54 & FY 2006 Physically Decommissioned \\
\hline A6806 & 299-E28-55 & FY 2006 Physically Decommissioned \\
\hline A6807 & 299-E28-56 & FY 2006 Physically Decommissioned \\
\hline A6808 & 299-E28-57 & FY 2006 Physically Decommissioned \\
\hline A6809 & 299-E28-58 & FY 2006 Physically Decommissioned \\
\hline A6810 & 299-E28-59 & FY 2006 Physically Decommissioned \\
\hline A6811 & 299-E28-60 & FY 2006 Physically Decommissioned \\
\hline A6812 & 299-E28-61 & FY 2006 Physically Decommissioned \\
\hline A6813 & 299-E28-62 & FY 2006 Physically Decommissioned \\
\hline A6816 & 299-E28-65 & FY 2006 Physically Decommissioned \\
\hline A6817 & 299-E28-66 & FY 2006 Physically Decommissioned \\
\hline A6818 & 299-E28-67 & FY 2006 Physically Decommissioned \\
\hline A6819 & 299-E28-68 & FY 2006 Physically Decommissioned \\
\hline A6825 & 299-E28-74 & FY 2006 Physically Decommissioned \\
\hline
\end{tabular}


Table 4.0-4. (contd)

\begin{tabular}{|c|c|c|}
\hline HEIS Well ID & Well Name & Comment \\
\hline A6826 & 299-E28-75 & FY 2006 Physically Decommissioned \\
\hline A6835 & 299-E28-84 & FY 2006 Physically Decommissioned \\
\hline A6836 & 299-E28-85 & FY 2006 Physically Decommissioned \\
\hline A6837 & 299-E28-86 & FY 2006 Physically Decommissioned \\
\hline A6838 & 299-E28-87 & FY 2006 Physically Decommissioned \\
\hline A6839 & 299-E28-88 & FY 2006 Physically Decommissioned \\
\hline A6840 & 299-E28-89 & FY 2006 Physically Decommissioned \\
\hline A7296 & 299-W11-54 & FY 2006 Physically Decommissioned \\
\hline A7297 & 299-W11-55 & FY 2006 Physically Decommissioned \\
\hline A7298 & 299-W11-56 & FY 2006 Physically Decommissioned \\
\hline A7299 & 299-W11-57 & FY 2006 Physically Decommissioned \\
\hline A7300 & 299-W11-58 & FY 2006 Physically Decommissioned \\
\hline A7301 & 299-W11-59 & FY 2006 Physically Decommissioned \\
\hline A7302 & 299-W11-60 & FY 2006 Physically Decommissioned \\
\hline A7303 & 299-W11-61 & FY 2006 Physically Decommissioned \\
\hline A7304 & $299-W 11-62$ & FY 2006 Physically Decommissioned \\
\hline A7305 & 299-W11-63 & FY 2006 Physically Decommissioned \\
\hline A7306 & 299-W11-64 & FY 2006 Physically Decommissioned \\
\hline A7307 & 299-W11-65 & FY 2006 Physically Decommissioned \\
\hline A7308 & 299-W11-66 & FY 2006 Physically Decommissioned \\
\hline A7309 & 299-W11-67 & FY 2006 Physically Decommissioned \\
\hline A7310 & 299-W11-68 & FY 2006 Physically Decommissioned \\
\hline A7311 & 299-W11-69 & FY 2006 Physically Decommissioned \\
\hline A7322 & 299-W11-80 & FY 2006 Physically Decommissioned \\
\hline A7323 & 299-W11-81 & FY 2006 Physically Decommissioned \\
\hline A7496 & 299-W15-198 & FY 2006 Physically Decommissioned \\
\hline A7497 & 299-W15-199 & FY 2006 Physically Decommissioned \\
\hline A7498 & 299-W15-200 & FY 2006 Physically Decommissioned \\
\hline A7499 & 299-W15-201 & FY 2006 Physically Decommissioned \\
\hline A7501 & 299-W15-203 & FY 2006 Physically Decommissioned \\
\hline A7504 & 299-W15-206 & FY 2006 Physically Decommissioned \\
\hline A7507 & 299-W15-209 & FY 2006 Physically Decommissioned \\
\hline A7508 & 299-W15-210 & FY 2006 Physically Decommissioned \\
\hline A7509 & 299-W15-211 & FY 2006 Physically Decommissioned \\
\hline A7510 & 299-W15-212 & FY 2006 Physically Decommissioned \\
\hline A7512 & 299-W15-214 & FY 2006 Physically Decommissioned \\
\hline A7513 & 299-W15-215 & FY 2006 Physically Decommissioned \\
\hline A7378 & 299-W15-77 & FY 2006 Physically Decommissioned \\
\hline A7877 & 299-W22-73 & FY 2006 Physically Decommissioned \\
\hline \multicolumn{3}{|c|}{$\begin{array}{l}\text { FY = Fiscal year. } \\
\text { ID = Identification. } \\
\text { HEIS = Hanford Environmental Information System. }\end{array}$} \\
\hline
\end{tabular}




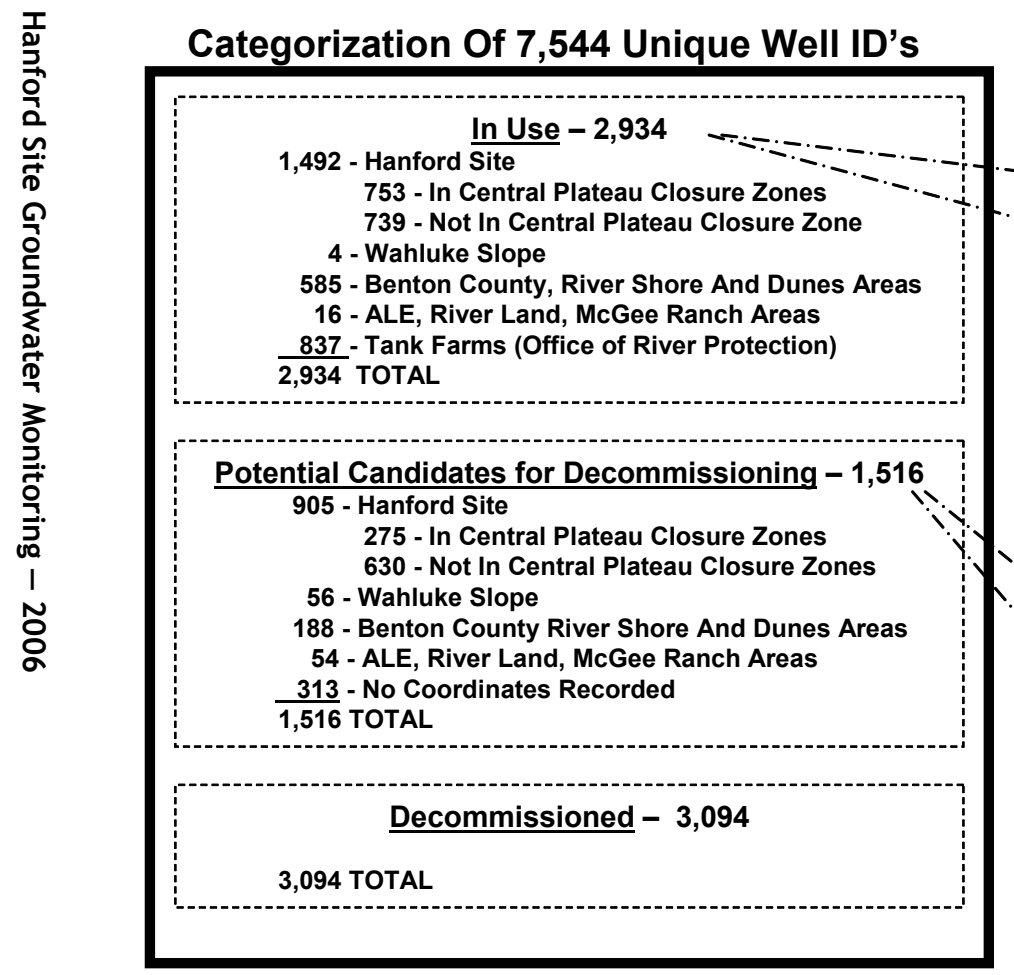

DATA CURRENT TO 11/27/06 AND SUBJECT TO CHANGE SEE FIGURE 4.0-2 FOR GEOGRAPHIC BOUNDARIES

$\underline{\text { Well }}=$ Water wells, resource protection wells, instrumentation wells, dewatering wells and geotechnical soil borings

as defined in WAC-173-160-111 (48).

Awaiting drilling = A location that was assigned an HWIS ID number and currently is awaiting drilling or being drilled, but not yet completed as a well.

Drilling cancelled $=$ A location that was assigned an HWIS ID number for planning purposes, but subsequently was never drilled.
In Use - 765

127 - Piezometers Within Host Wells

356 - Aquifer Tubes

244 - Soil Gas

38 - Geoprobes

$\rightarrow 765$ TOTAL

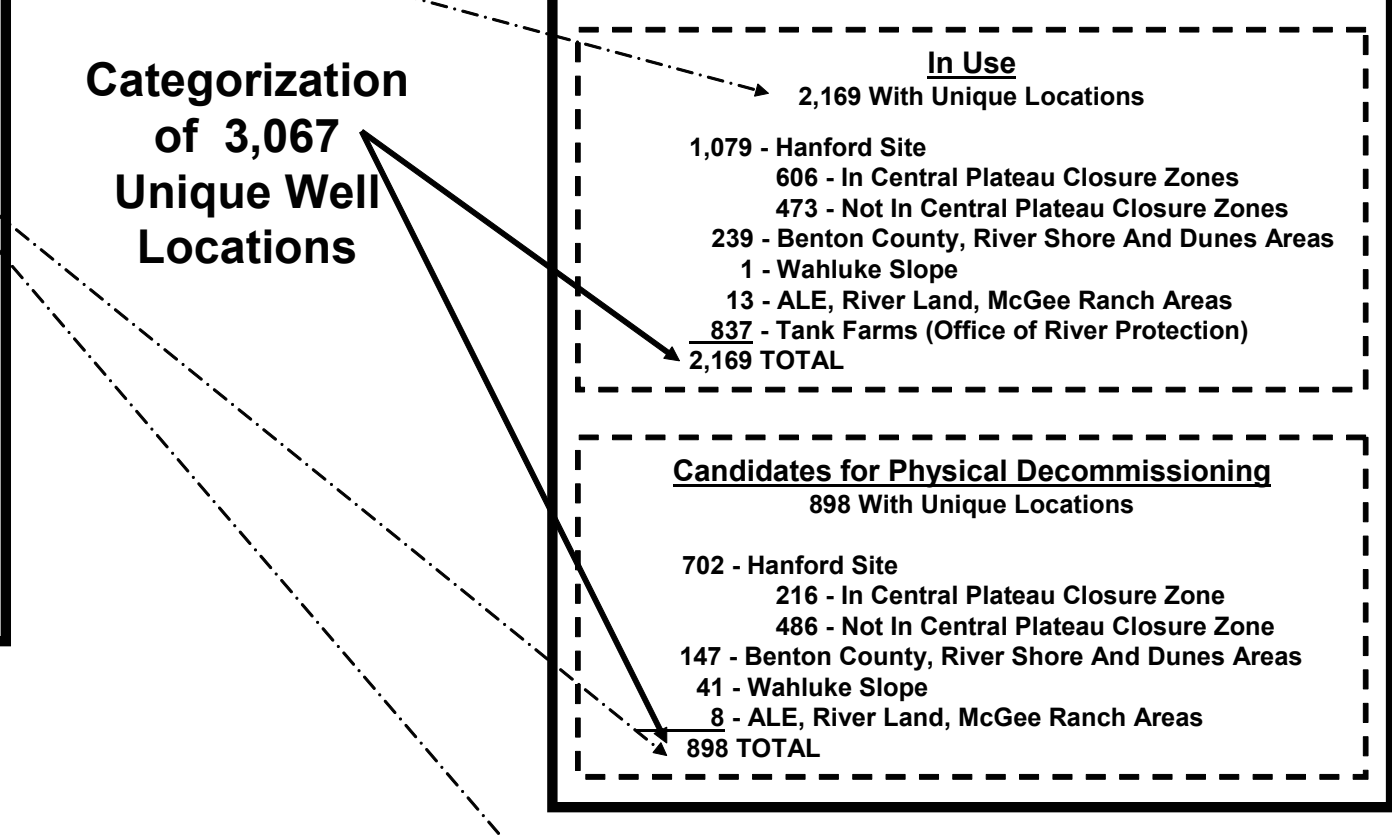

Potential Candidates for Decommissioning - 618 535 - Candidates for Administrative Decommissioning 83 - Piezometers Within Host Wells

618 TOTAL

Figure 4.0-1. Categorization of Unique Well Identification Numbers 


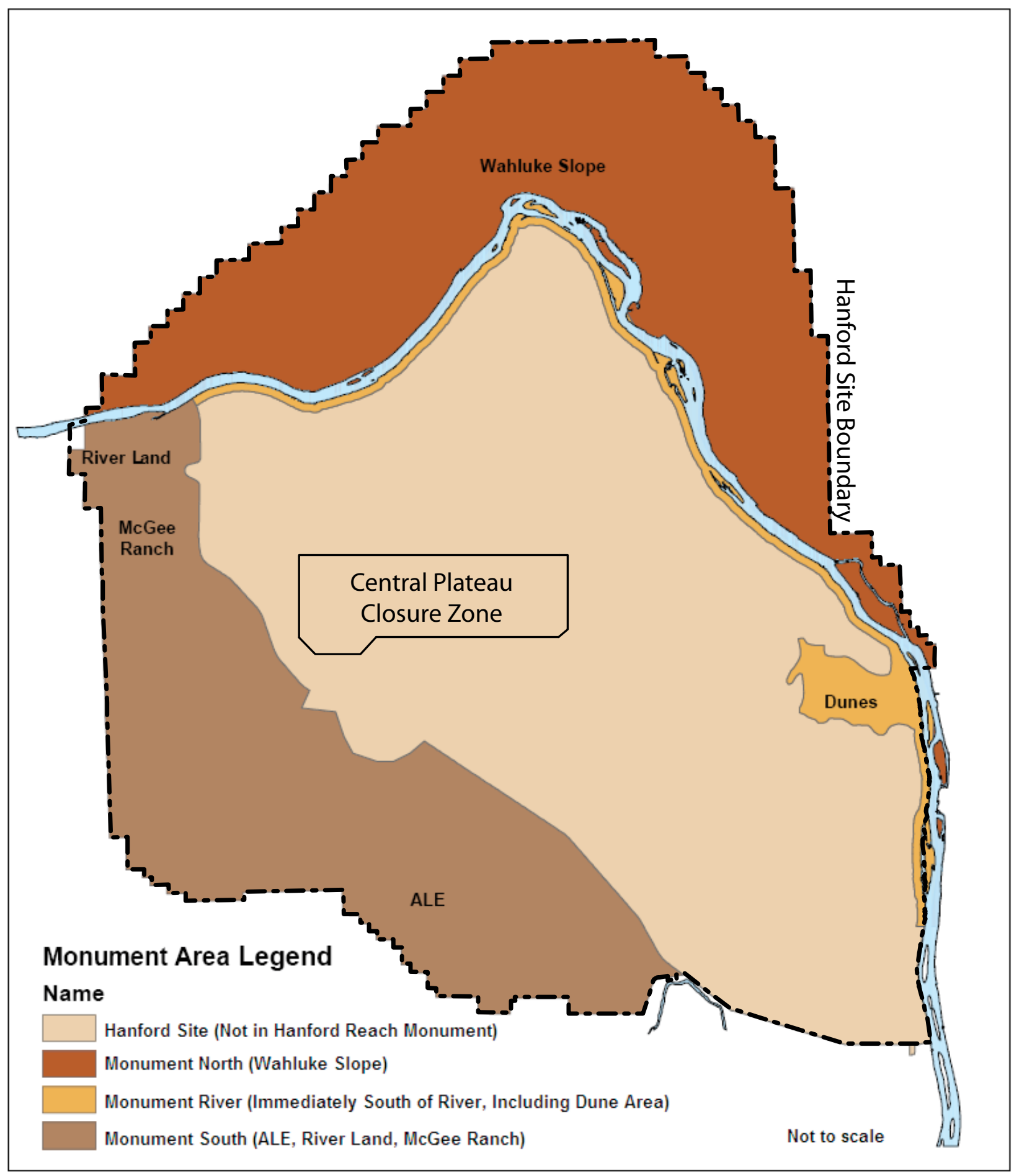

wdw07121

Figure 4.0-2. Hanford Site and Surrounding Area Depicting Various Geographic Regions, Richland, Washington 


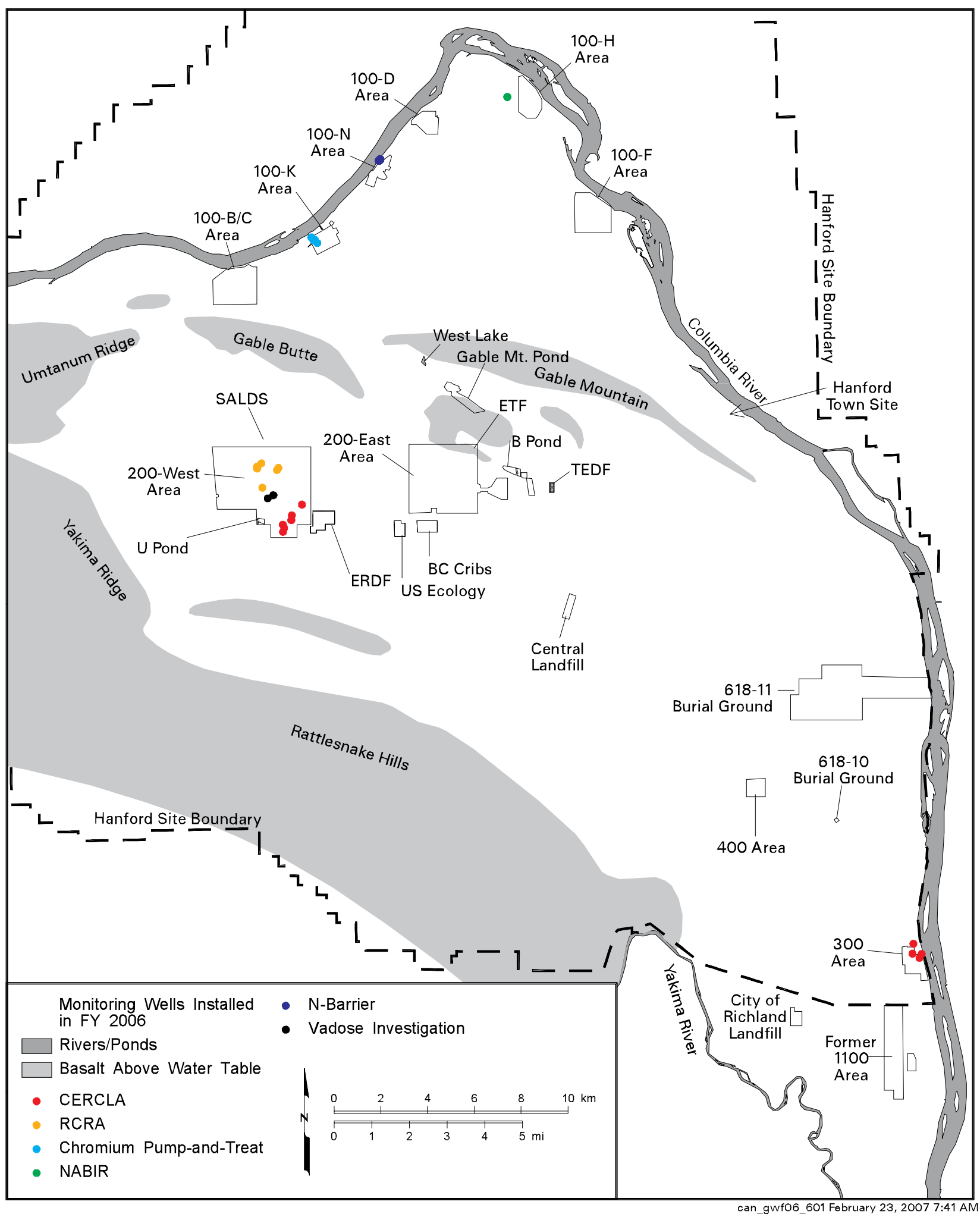

Figure 4.0-3. Groundwater Monitoring Wells and Aquifer Tubes Installed in FY 2006 


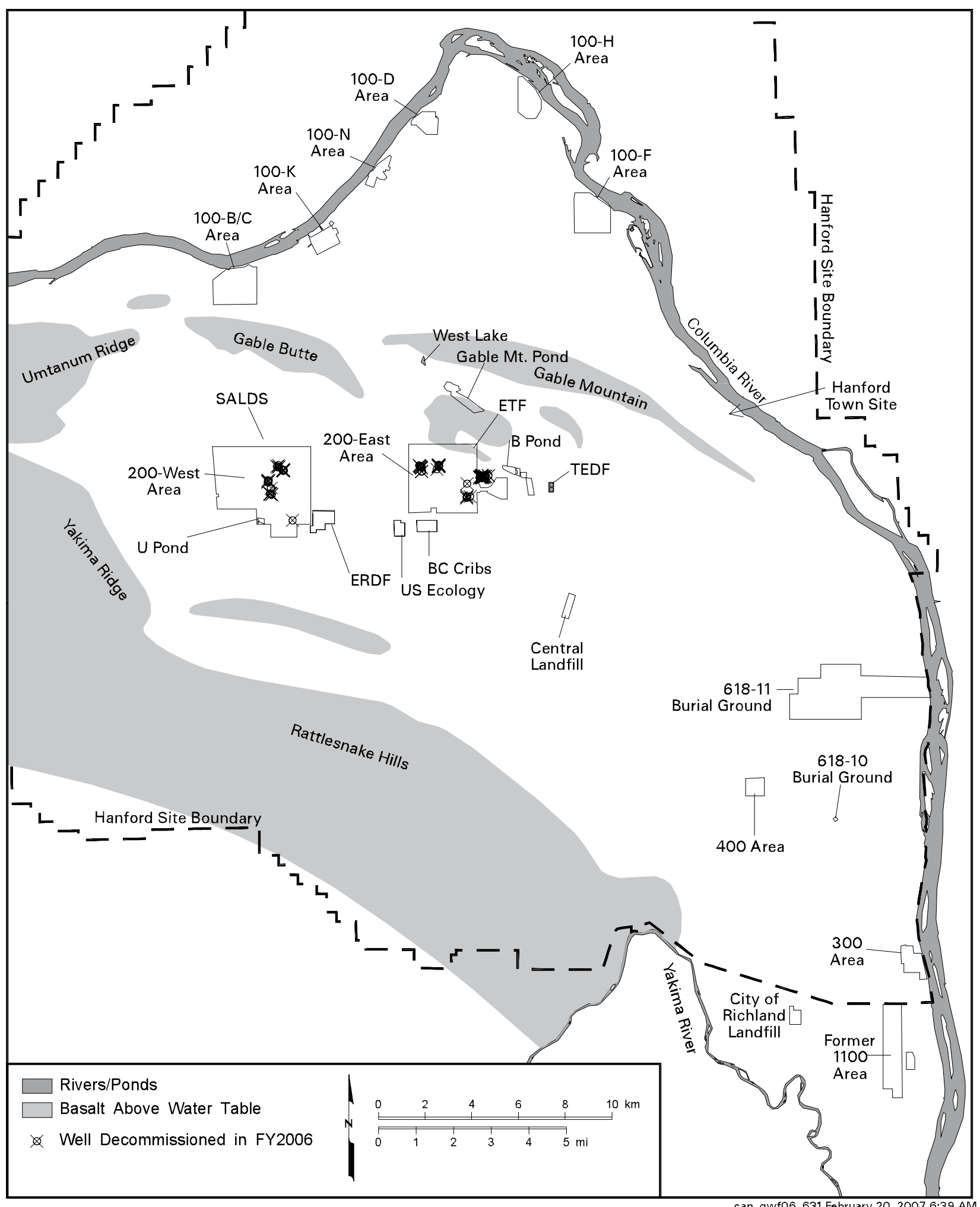

Figure 4.0-4. Vadose Zone Monitoring Wells Decommissioned during FY 2006 


\subsection{References}

\section{Public Laws}

Atomic Energy Act of 1954. As amended, Ch. 1073, 68 Stat. 919, 42 USC 2011 et seq.

Comprehensive Environmental Response, Compensation, and Liability Act. 1980. Public Law 96-510, as amended, 94 Stat. 2767, 42 USC 9601 et seq.

Resource Conservation and Recovery Act. 1976. Public Law 94-580, as amended, 90 Stat. 2795, 42 USC 6901 et seq.

\section{Code of Federal Regulations}

40 CFR 141. "National Primary Drinking Water Regulations; Radionuclides; Proposed Rule." U.S. Environmental Protection Agency, Code of Federal Regulations.

40 CFR 143. "National Secondary Drinking Water Regulations.” U.S. Environmental Protection Agency, Code of Federal Regulations.

40 CFR 264, Appendix IX. “Ground-Water Monitoring List.” U.S. Environmental Protection Agency, Code of Federal Regulations.

40 CFR 265. "Interim Status Standards for Owners and Operators of Hazardous Waste Treatment, Storage, and Disposal Facilities." U.S. Environmental Protection Agency, Code of Federal Regulations.

40 CFR 265.93(b) and (d). "Interim Status Standards for Owners and Operators of Hazardous Waste Treatment, Storage, and Disposal Facilities; Preparation, Evaluation, and Response." U.S. Environmental Protection Agency, Code of Federal Regulations.

\section{Revised Code of Washington}

RCW 70.105. "Washington State Hazardous Waste Management Act." Revised Code of Washington, Olympia, Washington.

\section{Washington Administrative Code}

WAC 173-160. "Minimum Standards for Construction and Maintenance of Wells." Washington Administrative Code, Olympia, Washington.

WAC 173-200. "Water Quality Standards for Ground Waters of the State of Washington." Washington Administrative Code, Olympia, Washington.

WAC 173-200-40. "Water Quality Standards for Ground Waters of the State of Washington; Criteria." Washington Administrative Code, Olympia, Washington.

WAC 173-201A. "Water Quality Standards for Surface Waters of the State of Washington.” Washington Administrative Code, Olympia, Washington.

WAC 173-216. "Waste Discharge Permit Program." Washington Administrative Code, Olympia, Washington.

WAC 173-303-400. "Dangerous Waste Regulations; Interim Status Facility Standards." Washington Administrative Code, Olympia, Washington.

WAC 173-303-645. "Dangerous Waste Regulations; Releases from Regulated Units." Washington Administrative Code, Olympia, Washington.

WAC 173-303-645(9) and (11)(g). "Dangerous Waste Regulations; Releases from Regulated Units." Washington Administrative Code, Olympia, Washington. 
WAC 173-304. "Minimum Functional Standards for Solid Waste Handling." Washington Administrative Code, Olympia, Washington.

WAC 173-304-490. "Minimum Functional Standards for Solid Waste Handling; Ground Water Monitoring Requirements." Washington Administrative Code, Olympia, Washington.

WAC 173-340. "Model Toxics Control Act-Cleanup." Washington Administrative Code, Olympia, Washington.

WAC 246-290. “Group A Public Water Supplies.” Washington Administrative Code, Olympia, Washington.

WAC 246-290-310. "Maximum Contaminant Levels (MCLs) and Maximum Residual Disinfectant Levels (MRDLs)." Washington Administrative Code, Olympia, Washington.

\section{Other References}

ARH-CD-745. 1976. Input and Decayed Values of Radioactive Liquid Wastes Discharged to the Ground in the 200 Areas Through 1975. Prepared by JD Anderson (Atlantic Richfield Hanford Company) for the U.S. Department of Energy Research and Development Administration, Richland, Washington.

BHI-00720, Rev. 6. 2002. Performance Evaluation Report for Soil Vapor Extraction Operations at the Carbon Tetrachloride Site, February 1992 - September 2001/June 2002. VJ Rohay, Bechtel Hanford, Inc., Richland, Washington.

BHI-00725. 1996. 100-N Pilot Project: Proposed Consolidated Groundwater Monitoring Program. JV Borghese, MJ Hartman, SP Luttrell, CJ Perkins, JP Zoric, and SC Tindall, Bechtel Hanford, Inc., Richland, Washington.

BHI-00873. 1996. Description of Work for Routine Groundwater Sampling at the Environmental Restoration Disposal Facility. BH Ford, Bechtel Hanford, Inc., Richland, Washington.

BHI-01164. 1998. 300 Area Process Trenches Verification Package. Bechtel Hanford, Inc., Richland, Washington.

BNWL-B-360. 1974. Selected Water Table Contour Maps and Well Hydrographs for the Hanford Reservation, 1944-1973. KL Kipp and RD Mudd, Pacific Northwest Laboratories, Richland, Washington.

BNWL-243. 1966. Soil Survey Hanford Project in Benton County, Washington. BF Hajek, Pacific Northwest Laboratory, Richland, Washington.

Christensen JN, PE Dresel, ME Conrad, K Maher, and DJ Depaolo. 2004. "Identifying the Sources of Subsurface Contamination at the Hanford Site in Washington using High-Precision Uranium Isotopic Measurements." Environmental Science and Technology 38(12):3330-3337.

City of Richland. 2006. Horn Rapids Landfil Environmental Monitoring Report Calendar Year 2005. Public Works Department, Richland, Washington.

CP-13514. 2003. 200-PW-1 Operable Unit Report on step 1 Sampling and Analysis of the Dispersed Carbon Tetrachloride Vadose Zone Plume. VJ Rohay and DC Weekes, Fluor Hanford, Inc., Richland Washington.

CP-15329, Rev. 0. 2003. Data Quality Objective Summary Report for Establishing a RCRA/CERCLA/AEA Integrated 200 West and 200 East Area Groundwater Monitoring Network. Prepared by ME Byrnes (Fluor Hanford, Inc.) and BA Williams (Pacific Northwest National Laboratory) for the U.S. Department of Energy, Richland, Washington.

Devlin JF. 2003. "A Spreadsheet Method of Estimating Best-Fit Hydraulic Gradients Using Head Data from Multiple Wells." Groundwater 41(3):316-320.

DOE Order 5400.5. "Radiation Protection of the Public and the Environment." 
DOE/ORP-2005-01. 2006. Initial Single-Shell Tank System Performance Assessment for the Hanford Site. U.S. Department of Energy, Office of River Protection, Richland, Washington.

DOE/RL-91-32, Draft B. 1991. Expedited Response Action Proposal (EE/CA EE EA) for 200 West Area Carbon Tetrachloride Plume, Appendix B. VJ Rohay and VG Johnson for the U.S. Department of Energy, Richland Operations Office, Richland, Washington.

DOE/RL-91-50. 1991. Environmental Monitoring Plan, United States Department of Energy, U.S. Department of Energy, Richland Operations Office. U.S. Department of Energy, Richland Operations Office, Richland, Washington.

DOE/RL-92-04. 1993. PUREX Source Aggregate Area Management Study Report. U.S. Department of Energy, Richland Operations Office, Richland, Washington.

DOE/RL-92-23, Rev. 0. 1992. Hanford Site Groundwater Background. U.S. Department of Energy, Richland Operations Office, Richland, Washington.

DOE/RL-92-32, Rev. 0. 1992. Expedited Response Action Assessment for 316-5 Process Trenches. U.S. Department of Energy, Richland Operations Office, Richland, Washington.

DOE/RL-92-67, Draft B. 1992. Final Remedial Investigation Study-Environmental Assessment Report for the 1100-EM-1 Operable Unit, Hanford. U.S. Department of Energy, Richland Operations Office, Richland, Washington.

DOE/RL-92-76, Rev. 1, Draft B. 2004. Remedial Investigation/Feasibility Study Work Plan for the 200-UP-1 Groundwater Operable Unit. Prepared by ME Byrnes (Fluor Hanford, Inc.) and MS Miller (Environmental Quality Management) for the U.S. Department of Energy, Richland Operations Office, Richland, Washington.

DOE/RL-93-22. 1994. Phase I and II Feasibility Study Report for the 300-FF-5 Operable Unit. U.S. Department of Energy, Richland Operations Office, Richland, Washington.

DOE/RL-93-73, Rev. 2. 1997. 300 Area Process Trenches Modified Closure/Postclosure Plan. U.S. Department of Energy, Richland Operations Office, Richland, Washington.

DOE/RL-93-88. 1994. Annual Report for RCRA Groundwater Monitoring Projects at Hanford Site Facilities for 1993. Prepared by Geosciences Group, Westinghouse Hanford Company, Environmental Division for U.S. Department of Energy, Richland Operations Office, Richland, Washington.

DOE/RL-94-85, Rev. 0. 1995. Remedial Investigation/Feasibility Study Report for the 300-FF-5 Operable Unit. U.S. Department of Energy, Richland Operations Office, Richland, Washington.

DOE/RL-94-95, Rev. 1. 1995. Hanford Site Groundwater Remediation Strategy. U.S. Department of Energy, Richland Operations Office, Richland, Washington.

DOE/RL-95-73, Rev. 1. 1996. Operation and Maintenance Plan for the 300-FF-5 Operable Unit. Prepared by CH2M HILL Hanford, Inc. for the U.S. Department of Energy, Richland Operations Office, Richland, Washington.

DOE/RL-95-74, Rev. 3. 1996. TWRS System Requirements Review Action Plan. U.S. Department of Energy, Richland Operations Office, Richland, Washington.

DOE/RL-95-83. 1995. The Pilot-Scale Treatability Test Summary for the 100-HR-3 Operable Unit. U.S. Department of Energy, Richland Operations Office, Richland, Washington.

DOE/RL-95-99, Rev. 0. 1996. 100-FR-3 Groundwater/Soil Gas Supplemental Limited Field Investigation Report. U.S. Department of Energy, Richland Operations Office, Richland, Washington.

DOE/RL-95-111. 1997. Corrective Measures Study for the 100-NR-1 and 100-NR-2 Operable Units. U.S. Department of Energy, Richland Operations Office, Richland, Washington. 
DOE/RL-96-39, Rev. 0. 1998. 100-NR-1 Treatment, Storage, and Disposal Units Corrective Measures Study/Closure Plan. U.S. Department of Energy, Richland Operations Office, Richland, Washington.

DOE/RL-96-61. 1997. Hanford Site Background: Part 3, Groundwater Background. U.S. Department of Energy, Richland Operations Office, Richland, Washington.

DOE/RL-96-84, Rev. 0. 1996. Remedial Design Report and Remedial Action Work Plan for the 100-HR-3 and 100-KR-4 Groundwater Operable Units' Interim Action. U.S. Department of Energy, Richland Operations Office, Richland, Washington.

DOE/RL-96-90, Rev. 0. 1997. Interim Action Monitoring Plan for the 100-HR-3 and 100-KR-4 Operable Units. U.S. Department of Energy, Richland Operations Office, Richland, Washington.

DOE/RL-96-105, Rev. 1. 1997. Richland Environmental Restoration Project Baseline, Multi-Year Work Plan. U.S. Department of Energy, Richland Operations Office, Richland, Washington.

DOE/RL-97-1047. 2002. History of the Plutonium Production Facilities at the Hanford Site Historic District, 1943-1990. Prepared by the Hanford Cultural and Historic Resources Program for the U.S. Department of Energy, Richland Operations Office, Richland, Washington.

DOE/RL-99-51. 2000. Remedial Design Report and Remedial Action Work Plan for the 100-HR-3 Groundwater Operable Unit In Situ Redox Manipulation. U.S. Department of Energy, Richland Operations Office, Richland, Washington.

DOE/RL-2000-59, Rev. 0. 2000. Sampling and Analysis Plan for Aquifer Sampling Tubes. U.S. Department of Energy, Richland Operations Office, Richland, Washington.

DOE/RL-2000-72, Rev. 1. 2006. Performance Assessment Monitoring Plan for the Hanford Site Low-Level Burial Grounds. U.S. Department of Energy, Richland Operations Office, Richland, Washington.

DOE/RL-2001-01, Rev. 0, Reissue. 2004. Plutonium/Organic Rich Process condensate/Process Waste Groups OU RI/FS Work Plan: Includes 200-PW-1, 200-PW-3, and 200-PW-6 Operable Units. U. S. Department of Energy, Richland Operations Office, Richland, Washington.

DOE/RL-2001-49, Rev. 1. 2003. Groundwater Sampling and Analysis Plan for the 200-BP-5 Operable Unit. U.S. Department of Energy, Richland Operations Office, Richland, Washington.

DOE/RL-2002-10. 2002. Sampling and Analysis Plan for the 200-UP-1 Groundwater Monitoring Well Network. U.S. Department of Energy, Richland Operations Office, Richland, Washington.

DOE/RL-2002-11, Rev. 1. 2006. 300-FF-5 Operable Unit Sampling and Analysis Plan. Prepared by CH2M HILL Hanford, Inc. for the U.S. Department of Energy, Richland Operations Office, Richland, Washington.

DOE/RL-2002-59. 2003. Hanford Site Groundwater Strategy: Protection, Monitoring, and Remediation. U.S. Department of Energy, Richland Operations Office, Richland, Washington.

DOE/RL-2002-68. 2003. Hanford's Groundwater Management Plan: Accelerated Cleanup and Protection. U.S. Department of Energy, Richland Operations Office, Richland, Washington.

DOE/RL-2003-04, Rev. 0. 2003. Sampling and Analysis Plan for the 200-PO-1 Groundwater Operable Unit. MJ Hartman and JW Lindberg, Pacific Northwest National Laboratory, Richland, Washington.

DOE/RL-2003-04, Rev. 1. 2005. Sampling and Analysis Plan for the 200-PO-1 Groundwater Operable Unit. U.S. Department of Energy, Richland Operations Office, Richland, Washington.

DOE/RL-2003-38, Rev. 1. 2004. 100-BC-5 Operable Unit Sampling and Analysis Plan. U.S. Department of Energy, Richland Operations Office, Richland, Washington. 
DOE/RL-2003-49, Rev. 0. 2003. 100-FR-3 Operable Unit Sampling and Analysis Plan. U.S. Department of Energy, Richland Operations Office, Richland, Washington.

DOE/RL-2003-49, Rev. 1. 2004. 100-FR-3 Operable Unit Sampling and Analysis Plan. U.S. Department of Energy, Richland Operations Office, Richland, Washington.

DOE/RL-2003-55, Rev. 0. 2004. Remedial Investigation/Feasibility Study Work Plan for the 200-2P-1 Groundwater Operable Unit. ME Byrnes (Fluor Hanford, Inc.) for the U.S. Department of Energy, Richland Operations Office, Richland, Washington.

DOE/RL-2005-40, Draft B. 2005. 100-B/C Pilot Project Risk Assessment Report. U.S. Department of Energy, Richland Operations Office, Richland, Washington.

DOE/RL-2005-41, Rev. 0. 2005. Work Plan for Phase III Feasibility Study 300-FF-5 Operable Unit. U.S. Department of Energy, Richland Operations Office, Richland, Washington.

DOE/RL-2005-47, Rev. 0. 2005. 300-FF-5 Operable Unit Limited Field Investigation Plan. U.S. Department of Energy, Richland Operations Office, Richland, Washington.

DOE/RL-2005-76. 2005. Sampling and Analysis Plan for Calendar Year 2005 Well Drilling at the 200-BP-5 Operable Unit. U.S. Department of Energy, Richland Operations Office, Richland, Washington.

DOE/RL-2005-91. 2006. Fiscal Year 2005 Annual Summary Report for 200-UP-1 and 200-ZP-1 Pump-and-Treat Operations. U.S. Department of Energy, Richland Operations Office, Richland, Washington.

DOE/RL-2005-96, Rev. 0, Reissue. May 2006. Strontium-90 Treatability Test Plan for 100-NR-2 Groundwater Operable Unit. U.S. Department of Energy, Richland Operations Office, Richland, Washington.

DOE/RL-2005-97. 2006. Fiscal Year 2005 Annual Summary Report for the In Situ Redox Manipulation Operation. MD Caron and RO Mahood, U.S. Department of Energy, Richland Operations Office, Richland, Washington.

DOE/RL-2006-08. 2006. Calendar Year 2005 Annual Summary Report for the 100-HR-3, 100-KR-4, and 100-NR-2 Operable Unit Pump-and-Treat Operations. RS Edrington, GG Kelty, MG Piepho, and RF Raidl, U.S. Department of Energy, Richland Operations Office, Richland, Washington.

DOE/RL-2006-17, Rev. 0. 2006. Treatability Test Report for Calcium Polysulfide in the 100-K Area. SW Peterson and KA Hedquist, U.S. Department of Energy, Richland Operations Office, Richland, Washington.

DOE/RL-2006-20, Rev. 0. 2006. The Second CERCLA Five-Year Review Report for the Hanford Site. U.S. Department of Energy, Richland Operations Office, Richland, Washington.

DOE/RL-2006-24, Rev. 0. 2006. Remedial Investigation Report for the 200-ZP-1 Groundwater Operable Unit. U.S. Department of Energy, Richland Operations Office, Richland, Washington.

DOE/RL-2006-51. 2006. Remedial Investigation Report for the Plutonium/Organic-Rich Process Condensate/Process Waste Group Operable Unit: Includes the 200-PW-1, 200-PW-3, and 200-PW-6 Operable Units. U.S. Department of Energy, Richland Operations Office, Richland, Washington.

DOE/RL-2006-52, Rev. 1. 2006. The KW Pump and Treat System Remedial Design and Remedial Action Work Plan, Supplement to the 100-KR-4 Groundwater Operable Unit Interim Action. Prepared by RF Raidl, Fluor Hanford, Inc., for U.S. Department of Energy, Richland Operations Office, Richland, Washington.

DOE/RL-2006-58, Rev. 0. 2006. Carbon Tetrachloride Dense Non-Aqueous Phase Liquid (DNAPL) Source Term Interim Characterization Report. WL Bratton, KR Moser, and JD Doughty, U.S. Department of Energy, Richland Operations Office, Richland, Washington. 
DOE/RL-2006-73, Rev. 0. In Press. Fiscal Year 2006 Annual Summary Report for 200-UP-1 and 200-ZP-1 Pump-and-Treat Operations. U.S. Department of Energy, Richland Operations Office, Richland, Washington.

E06-01-20044Q. 2004. 2004 4Q Groundwater Report. EHS\&L Document, AREVA, Richland, Washington.

E06-01-20054Q. 2006. Quarterly Groundwater Monitoring Summary - Fourth Quarter 2005. AREVA, Richland, Washington.

E06-01-2006-1Q. 2006. 2006 1Q Groundwater Report. AREVA, Richland, Washington.

Ecology - Washington State Department of Ecology, U.S. Environmental Protection Agency, and U.S. Department of Energy. 1989. Hanford Federal Facility Agreement and Consent Order. Document No. 89-10, as amended (The Tri-Party Agreement), Olympia, Washington.

Ecology. 1994a. Dangerous Waste Portion of the Resource Conservation and Recovery Act Permit for the Treatment, Storage, and Disposal of Dangerous Waste. Permit Number WA 7890008967, as revised. Washington State Department of Ecology, Olympia, Washington.

Ecology. 1994b. Natural Background Soil Metals Concentrations in Washington State. Publication No. 94-115, Washington State Department of Ecology Toxics Cleanup Program, Olympia, Washington.

Ecology. 2000. State Waste Discharge Permit ST 4500. Washington State Department of Ecology, Kennewick, Washington.

Ecology. 2001. Cleanup Levels and Risk Calculations under the Model Toxics Control Act Cleanup Regulation (CLARC). Publication No. 94-145, Version 3.1, Washington State Department of Ecology, Olympia, Washington.

EPA. 2000. "Explanation of Significant Difference for the 300-FF-5 Record of Decision" (see ROD 1996a). Issued by U.S. Environmental Protection Agency, Region 10, and U.S. Department of Energy, Richland, Washington.

EPA. 2001. USDOE Hanford Site First Five Year Review Report. U.S. Environmental Protection Agency, Region 10, Hanford Project Office, Seattle, Washington.

EPA 822-R-96-001. 1996. Drinking Water Regulations and Health Advisories. U.S. Environmental Protection Agency, Office of Water, Washington, D.C.

Ferris JG. 1952. Cyclic Fluctuations of Water Level as a Basis for Determining Aquifer Transmissibility. U.S. Geological Survey, Ground-Water Hydraulic Section, Contribution No. 1, 17 pp.

Gee GW, ZF Zhang, SW Tyler, WH Albright, and MJ Singleton. 2005. "Chloride-Mass-Balance: Cautions in Predicting Increased Recharge Rates." Vadose Zone Journal 4:72-78.

Hausenbuiller RL. 1972. Soil Science: Principles and Practices. Wm. C. Brown Company Publishers, Dubuque, Iowa.

HEIS. 1994. Hanford Environmental Information System. Environmental Information Systems Department, Fluor Hanford, Inc., Richland, Washington.

HNF-EP-0182, Rev. 131. 1999. Waste Tank Summary Report for Month Ending February 28, 1999. BM Hanlon, CH2M HILL Hanford Group, Inc., Richland, Washington.

HNF-EP-0182, Rev. 142. 2000. Waste Tank Summary Report for Month Ending January 31, 2000. BM Hanlon, CH2M HILL Hanford Group, Inc., Richland, Washington.

HNF-EP-0182, Rev 197. 2004. Waste Tank Summary Report for Month Ending September 30, 2004. BM Hanlon, CH2M HILL Hanford Group, Inc., Richland, Washington. 
HNF-SD-WM-TI-740, Rev. 0. 1990. Standard Inventories of Chemicals and Radionuclides in Hanford Site Tank Wastes. Prepared by MJ Kupfer, AL Boldt, BA Higley, KM Hodgson, LW Shelton, BC Simpson, RA Watrous, MD LeClair, GL Borsheim, RT Winward, RM Orme, NG Colton, SL Lambert, DE Place, and WW Schulz for Lockheed Martin Hanford Corporation, Richland, Washington.

HW-77170. 1963. Status of the Groundwater Beneath Hanford Reactor Areas: January 1962 and January 1963. Hanford Atomic Products Operation, General Electric Company, Richland, Washington.

Murphy EM, TR Ginn, and JL Phillips. 1996. "Geochemical Estimates of Recharge in the Pasco Basin: Evaluation of the Chloride Mass Balance Technique.” Water Resource Res. 32:2853-2868.

National Bureau of Standards. 1963. National Bureau of Standards Handbook 69: National Committee on Radiation Protection. U.S. Department of Commerce, Washington, D.C.

NAVD88. 1988. North American Vertical Datum of 1988.

Peterson JM, MM MacDonell, LA Haroun, FA Monette, and RD Hildebrand. 2002. Summary Fact Sheets for Selected Environmental Contaminants to Support Health Risk Analysis. Environmental Assessment Division, Argonne National Laboratory, Chicago, Illinois. Available at: http://www.ead.anl.gov

PNL-5408. 1985. Ground-Water Monitoring at the Hanford Site, January-December 1984. CS Cline, JT Rieger, JR Raymond, and PA Eddy, Pacific Northwest Laboratory, Richland, Washington.

PNL-7147. 1989. Final Report: Soil Gas Survey at the Solid Waste Landfill. JC Evans, RM Freeland, DW Glover, and C Veverka, Pacific Northwest Laboratory, Richland, Washington.

PNL-8122. 1992. Water-Table Elevations on the Hanford Site and Outlying Areas, 1991. DR Newcomer, KD Pohlod, and JP McDonald, Pacific Northwest Laboratory, Richland, Washington.

PNL-8580. 1993. Water Level Measurements for Modeling Hydraulic Properties in the 300-FF-5 and 100 Aggregate Area Operable Units. MD Campbell, WJ McMahon, and KR Simpson, Pacific Northwest Laboratory, Richland, Washington.

PNL-8869. 1993. Preliminary Potentiometric Map and Flow Dynamic Characteristics for the Upper-Basalt Confined Aquifer System. FA Spane, Jr. and RG Raymond, Pacific Northwest Laboratory, Richland, Washington.

PNL-9437. 1994. Monitoring Groundwater and River Interaction Along the Hanford Reach of the Columbia River. MD Campbell, Pacific Northwest Laboratory, Richland, Washington.

PNL-10817. 1995. Hydrochemistry and Hydrogeologic Conditions Within the Hanford Upper Basalt Confined Aquifer System. FA Spane, Jr. and WD Webber, Pacific Northwest Laboratory, Richland, Washington.

PNNL-11141. 1996. Hanford Site Ground-Water Monitoring for 1995. PE Dresel, JT Rieger, WD Webber, PD Thorne, BM Gillespie, SP Luttrell, SK Wurstner, and TL Liikala, Pacific Northwest National Laboratory, Richland, Washington.

PNNL-11523. 1997. Combination RCRA Groundwater Monitoring Plan for the 216-A-10, 216-A-36B, and 216-A-37-1 PUREX Cribs. JW Lindberg, Pacific Northwest National Laboratory, Richland, Washington.

PNNL-11573. 1997. Groundwater Monitoring Plan for the 183-H Solar Evaporation Basins. MJ Hartman, Pacific Northwest National Laboratory, Richland, Washington.

PNNL-11801. 1997. Three-Dimensional Analysis of Future Groundwater Flow Conditions and Contaminant Plume Transport in the Hanford Site Unconfined Aquifer System: FY 1996 and 1997 Status Report. CR Cole, SK Wurstner, MP Bergeron, MD Williams, and PD Thorne, Pacific Northwest National Laboratory, Richland, Washington. 
PNNL-11810. 1998. Results of Phase I Groundwater Quality Assessment for Single-Shell Tank Waste Management Area S-SX at the Hanford Site. VG Johnson and CJ Chou, Pacific Northwest National Laboratory, Richland, Washington.

PNNL-11826. 1998. Results of Phase I Groundwater Quality Assessment for Single-Shell Tank Waste Management Areas B-BX-BY at the Hanford Site. SM Narbutovskih, Pacific Northwest National Laboratory, Richland, Washington.

PNNL-12023. 1998. Groundwater Monitoring for the 100-K Area Fuel-Storage Basins: July 1996 through April 1998. VG Johnson, CJ Chou, MJ Hartman, and WD Webber, Pacific Northwest National Laboratory, Richland, Washington.

PNNL-12057-ICN-1. 2002. RCRA Assessment Plan for Single-Shell Tank Waste Management Area T at the Hanford Site, Interim Change Notice 1. DG Horton, Pacific Northwest National Laboratory, Richland, Washington.

PNNL-12114. 1999. RCRA Assessment Plan for Single-Shell Tank Waste Management Area S-SX at the Hanford Site. VG Johnson and CJ Chou, Pacific Northwest National Laboratory, Richland, Washington.

PNNL-12114-ICN-4. 2006. RCRA Assessment Plan for Single-Shell Tank Waste Management Area S-SX at the Hanford Site, Interim Change Notice 4. RM Smith, Pacific Northwest National Laboratory, Richland, Washington.

PNNL-12220. 1999. Sampling and Analysis Plan Update for Groundwater Monitoring - 1100-EM-1 Operable Unit. DR Newcomer, Pacific Northwest National Laboratory, Richland, Washington.

PNNL-12261. 2000. Revised Hydrogeology for the Suprabasalt Upper Aquifer System, 200 East Area and Vicinity, Hanford Site Washington. BA Williams, BN Bjornstad, R Schalla, and WD Webber, Pacific Northwest National Laboratory, Richland, Washington.

PNNL-13014. 2000. Groundwater Monitoring Plan for the Solid Waste Landfill. JW Lindberg and CJ Chou, Pacific Northwest National Laboratory, Richland, Washington.

PNNL-13023. 2001. RCRA Groundwater Monitoring Plan for Single-Shell Tank Waste Management Area A-AX at the Hanford Site. SM Narbutovskih, Pacific Northwest National Laboratory, Richland, Washington.

PNNL-13032. 2000. Groundwater Monitoring Plan for the Hanford Site 200 Area Treated Effluent Disposal Facility. DB Barnett, Pacific Northwest National Laboratory, Richland, Washington.

PNNL-13047. 1999. Groundwater Monitoring Plan for the 216-A-29 Ditch. MD Sweeney, Pacific Northwest National Laboratory, Richland, Washington.

PNNL-13078. 1999. Effects of Barometric Fluctuations on Well Water-Level Measurements and Aquifer Test Data. FA Spane, Pacific Northwest National Laboratory, Richland, Washington.

PNNL-13080. 2000. Hanford Site Groundwater: Settings, Sources, and Methods. MJ Hartman (ed.), Pacific Northwest National Laboratory, Richland, Washington.

PNNL-13116. 2000. Hanford Site Groundwater Monitoring for Fiscal Year 1999. MJ Hartman, LF Morasch, and WD Webber (eds.), Pacific Northwest National Laboratory, Richland, Washington.

PNNL-13121. 2000. Groundwater Monitoring and Tritium-Tracking Plan for the 200 Area State-Approved Land Disposal Site. DB Barnett, Pacific Northwest National Laboratory, Richland, Washington.

PNNL-13185. 2000. Groundwater Quality Assessment Plan for Single-Shell Tank Waste Management Area U at the Hanford Site. FN Hodges and CJ Chou, Pacific Northwest National Laboratory, Richland, Washington.

PNNL-13282. 2000. Groundwater Quality Assessment for Waste Management Area U; First Determination. FN Hodges and CJ Chou, Pacific Northwest National Laboratory, Richland, Washington. 
PNNL-13378. 2001. Results of Detailed Hydrologic Characterization Tests - Fiscal Year 1999. FA Spane, Jr., PD Thorne, and DR Newcomer, Pacific Northwest National Laboratory, Richland, Washington.

PNNL-13441. 2000. RCRA Groundwater Quality Assessment Report for Waste Management Area S-SX (November 1997 through April 2000). VG Johnson and CJ Chou, Pacific Northwest National Laboratory, Richland, Washington.

PNNL-13447. 2001. Transient Inverse Calibration of Hanford Site-Wide Groundwater Model to Hanford Operational Impacts - 1943 to 1996. CR Cole, MP Bergeron, SK Wurstner, PD Thorne, S Orr, and MI McKinley, Pacific Northwest National Laboratory, Richland, Washington.

PNNL-13486. 2001. Characterization Activities Conducted at the 183-DR Site in Support of an In Situ Gaseous Reduction Demonstration. EC Thornton, TJ Gilmore, KB Olsen, R Schalla, and KJ Cantrell, Pacific Northwest National Laboratory, Richland, Washington.

PNNL-13612. 2001. Groundwater Quality Assessment Plan for Single-Shell Tank Waste Management Area U. RM Smith, FN Hodges, and BA Williams, Pacific Northwest National Laboratory, Richland, Washington.

PNNL-13645. 2001. 300 Area Process Trenches Groundwater Monitoring Plan. JW Lindberg, and CJ Chou, Pacific Northwest National Laboratory, Richland, Washington.

PNNL-13675. 2001. Measurement of Helium-3/Helium-4 Ratios in Soil Gas at the 618-11 Burial Ground. KB Olsen, PE Dresel, and JC Evans, Pacific Northwest National Laboratory, Richland, Washington.

PNNL-13788. 2002. Hanford Site Groundwater Monitoring for Fiscal Year 2001. MJ Hartman, LF Morasch, and WD Webber (eds.), Pacific Northwest National Laboratory, Richland, Washington.

PNNL-13914. 2002. Groundwater Monitoring Plan for the 1301-N, 1324-N/NA, and 1325-N RCRA Facilities. MJ Hartman, Pacific Northwest National Laboratory, Richland, Washington.

PNNL-14022. 2002. 300 Area Uranium Leach and Adsorption Project. RJ Serne, CF Brown, HT Schaef, EM Price, MJ Lindberg, Z Wang, PL Gassman, and JG Catalano, Pacific Northwest National Laboratory, Richland, Washington.

PNNL-14031. 2002. Evaluation of Potential Sources for Tritium Detected in Groundwater at Well 199-K-111A, 100-K Area. RE Peterson, FA Spane, KB Olsen, and MD Williams, Pacific Northwest National Laboratory, Richland, Washington.

PNNL-14033. 2002. Groundwater Monitoring and Assessment Plan for the 100-K Area Fuel Storage Basins. RE Peterson, Pacific Northwest National Laboratory, Richland, Washington.

PNNL-14049. 2002. Data Quality Objectives Summary Report - Designing a Groundwater Monitoring Network for the 200-BP-5 and 200-PO-1 Operable Units. EC Thornton and JW Lindberg, Pacific Northwest National Laboratory, Richland, Washington.

PNNL-14070. 2002. Groundwater Monitoring Plan for the 216-S-10 Pond and Ditch. BA Williams and CJ Chou, Pacific Northwest National Laboratory, Richland, Washington.

PNNL-14098. 2002. Results of Groundwater Monitoring at the Hanford Site 200 Area Treated Effluent Disposal Site-1999 through FY 2002. JT Rieger, Pacific Northwest National Laboratory, Richland, Washington.

PNNL-14107. 2002. Groundwater Chemistry and Hydrogeology of the Upper Saddle Mountains Basalt-Confined Aquifer South and Southeast of the Hanford Site. DR Newcomer, EC Thornton, and TL Liikala, Pacific Northwest National Laboratory, Richland, Washington.

PNNL-14113. 2002. Results of Detailed Hydrologic Characterization Tests - Fiscal Year 2001. FA Spane, Jr., PD Thorne, and DR Newcomer, Pacific Northwest National Laboratory, Richland, Washington. 
PNNL-14187. 2003. Hanford Site Groundwater Monitoring for Fiscal Year 2002. MJ Hartman, LF Morasch, and WD Webber (eds.), Pacific Northwest National Laboratory, Richland, Washington.

PNNL-14287. 2003. Data Quality Objectives Summary Report - Designing a Groundwater Monitoring and Assessment Network for the 100-BC-5 and 100-FR-3 Operable Units. MD Sweeney and CJ Chou, Pacific Northwest National Laboratory, Richland, Washington.

PNNL-14301-Rev2-ICN-1. 2006. Monitoring Plan for RCRA Groundwater Assessment at the 216-U-12 Crib, Interim Change Notice 1. BA Williams, Pacific Northwest National Laboratory, Richland, Washington.

PNNL-14548. 2004. Hanford Site Groundwater Monitoring for Fiscal Year 2003. MJ Hartman, LF Morasch, and WD Webber (eds.), Pacific Northwest National Laboratory, Richland, Washington.

PNNL-14702, Rev. 1. 2006. Vadose Zone Hydrogeology Data Package for Hanford Assessments. GV Last, EJ Freeman, KJ Cantrell, MJ Fayer, GW Gee, WE Nichols, BN Bjornstad, and DG Horton, Pacific Northwest National Laboratory, Richland, Washington.

PNNL-14744. 2004. Recharge Data Package for the 2005 Integrated Disposal Facility Performance Assessment. MJ Fayer and JE Szecsody, Pacific Northwest National Laboratory, Richland, Washington.

PNNL-14753, Rev. 1. 2006. Groundwater Data Package for Hanford Assessments. PD Thorne, MP Bergeron, MD Williams, and VL Freedman, Pacific Northwest National Laboratory, Richland, Washington.

PNNL-14804. 2004. Results of Detailed Hydrologic Characterization Tests - Fiscal Year 2003. FA Spane and DR Newcomer, Pacific Northwest National Laboratory, Richland, Washington.

PNNL-14859. 2005. Interim Status Groundwater Monitoring Plan for Low-Level Waste Management Areas 1 to 4, RCRA Facilities, Hanford, Washington. P Dresel, Pacific Northwest National Laboratory, Richland, Washington.

PNNL-14898. 2004. Results of Groundwater Modeling for Tritium Tracking at the Hanford Site 200 Area State-Approved Land Disposal Site - 2004. DB Barnett, MP Bergeron, and EJ Freeman, Pacific Northwest National Laboratory, Richland, Washington.

PNNL-15070. 2005. Hanford Site Groundwater Monitoring for Fiscal Year 2004. MJ Hartman, LF Morasch, and WD Webber (eds.), Pacific Northwest National Laboratory, Richland, Washington.

PNNL-15121. 2005. Uranium Geochemistry in Vadose Zone and Aquifer Sediments from the 300 Area Uranium Plume. JM Zachara (ed.), Pacific Northwest National Laboratory, Richland, Washington.

PNNL-15127. 2005. Contaminants of Potential Concern in the 300-FF-5 Operable Unit: Expanded Annual Groundwater Report for Fiscal Year 2004. RE Peterson, EJ Freeman, PD Thorne, MD Williams, JW Lindberg, CJ Murray, MJ Truex, SB Yabusaki, JP McDonald, VR Vermeul, and JM Zachara, Pacific Northwest National Laboratory, Richland, Washington.

PNNL-15262. 2005. Influence of Nitrate on the Hanford 100D Area In Situ Redox Manipulation Barrier Longevity. JE Szecsody, JL Phillips, VR Vermeul, JS Fruchter, and MD Williams, Pacific Northwest National Laboratory, Richland, Washington.

PNNL-15301. 2006. RCRA Assessment Plan for Single-Shell Tank Waste Management Area T. DG Horton, Pacific Northwest National Laboratory, Richland, Washington.

PNNL-15315. 2006. RCRA Assessment Plan for Single-Shell Tank Waste Management Area A-AX at the Hanford Site. SM Narbutovskih and CJ Chou, Pacific Northwest National Laboratory, Richland, Washington. 
PNNL-15417. 2006. Borehole Data Package for One CY 2005 CERCLA Well 699-S20-E10, 300-FF-5 Operable Unit, Hanford Site, Washington. BA Williams, BN Bjornstad, DC Lanigan, JM Keller, and ML Rockhold, Pacific Northwest National Laboratory, Richland, Washington.

PNNL-15443. 2006. Vadose Zone Transport Field Study: Summary Report. AL Ward, ME Conrad, WD Daily, JB Fink, VL Freedman, GW Gee, GM Hoversten, JM Keller, EL Majer, CJ Murray, MD White, SB Yabusaki, and ZF Zhang, Pacific Northwest National Laboratory, Richland, Washington.

PNNL-15479. 2005. Groundwater Monitoring Plan for the Hanford Site 216-B-3 Pond RCRA Facility. DB Barnett, RM Smith, CJ Chou, and JP McDonald, Pacific Northwest National Laboratory, Richland, Washington.

PNNL-15499, Rev. 1. 2005. Effect of Geochemical and Physical Heterogeneity on the Hanford 100 D Area In Situ Redox Manipulation Barrier Longevity. JE Szecsody, JS Fruchter, JL Phillips, ML Rockhold, VR Vermeul, MD Williams, BJ Devary, and Y Liu, Pacific Northwest National Laboratory, Richland, Washington.

PNNL-15503. 2006. Characterization of Vadose Zone Sediments Below the C Tank Farm: Borehole C4297 and RCRA Borehole 299-E27-22. CF Brown, RJ Serne, BN Bjornstad, DG Horton, DC Lanigan, RE Clayton, TS Vickerman, IV Kutnyakov, KN Geiszler, SR Baum, KE Parker, and MJ Lindberg, Pacific Northwest National Laboratory, Richland, Washington.

PNNL-15670. 2006. Hanford Site Groundwater Monitoring for Fiscal Year 2005. MJ Hartman, LF Morasch, and WD Webber (eds.), Pacific Northwest National Laboratory, Richland, Washington.

PNNL-15685. 2006. Quarterly RCRA Groundwater Monitoring Data for the Period July through September 2005. MJ Hartman, Pacific Northwest National Laboratory, Richland, Washington.

PNNL-15782. 2006. STOMP Subsurface Transport Over Multiple Phases, Version 4.0, User's Guide. MD White and M Oostrom, Pacific Northwest National Laboratory, Richland, Washington.

PNNL-15797. 2006. Quarterly RCRA Groundwater Monitoring Data for the Period October through December 2005. MJ Hartman, Pacific Northwest National Laboratory, Richland, Washington.

PNNL-15798. 2006. 100-N Shoreline Groundwater Monitoring Plan. MJ Hartman, Pacific Northwest National Laboratory, Richland, Washington.

PNNL-15892. 2006. Hanford Site Environmental Report for Calendar Year 2005. TM Poston, RW Hanf, RL Dirkes, and LF Morasch (eds.), Pacific Northwest National Laboratory, Richland, Washington.

PNNL-15953. 2006. Quarterly RCRA Groundwater Monitoring Data for the Period January through March 2006. MJ Hartman, Pacific Northwest National Laboratory, Richland, Washington.

PNNL-15954. 2006. Screening of Potential Remediation Methods for the 200-ZP-1 Operable Unit at the Hanford Site. MJ Truex, MJ Nimmons, CD Johnson, PE Dresel, and CJ Murray, Pacific Northwest National Laboratory, Richland, Washington.

PNNL-16008. 2006. Site Characterization Plan: Uranium Stabilization through Polyphosphate Injection. VR Vermeul, JS Fruchter, DM Wellman, BA Williams, and MD Williams, Pacific Northwest National Laboratory, Richland, Washington.

PNNL-16069. 2006. Development of Historical Water Table Maps of the 200 West Area of the Hanford Site (1950-1970). TM Kinney and JP McDonald, Pacific Northwest National Laboratory, Richland, Washington.

PNNL-16103, Rev. 0. 2006. Borehole Geologic Data for the 216-Z-Crib Facilities. A Status of Data Assembled through the Hanford Borehole Geologic Information System (HBGIS). GV Last, RD Mackley, and DC Lanigan, Pacific Northwest National Laboratory, Richland, Washington. 
PNNL-16191. 2006. Quarterly RCRA Groundwater Monitoring Data for the Period April through June 2006. MJ Hartman, Pacific Northwest National Laboratory, Richland, Washington.

PNNL-SA-39825. 2003. A Groundwater Quality Assessment at Single-Shell Tank Farms at the DOE Hanford Site. Presented by SM Narbutovskih at Geologic Society of America, Seattle, Washington.

PNNL-SA-49677. 2006. Low-Flux Measurements in Desert Settings Using Water Fluxmeters. GW Gee, JM Keller, ZF Zhang, AL Ward, and BJ Andraski, Pacific Northwest National Laboratory, Richland, Washington.

PNNL-SA-49780. 2006. The 2002-2003 Fluctuation of the Water-Table Elevation in the 200 East Area and Vicinity: Evaluation of Potential Causes. JP McDonald, Pacific Northwest National Laboratory, Richland, Washington.

PNNL-SA-50098. 2006. Groundwater at Waste Management Area B-BX-BY. Presented by SM Narbutovskih (Invited Speaker) at Workshop with Hanford Contractors, Richland, Washington on May 17, 2006.

Rasmussen TC and LA Crawford. 1997. "Identifying and Removing Barometric Pressure Effects in Confined and Unconfined Aquifers." Ground Water 35(3):502-511.

Repasky TR. 2006. Investigation of Preferential Ground Water Flow Pathways in the 100-NR-2 Area Hanford Site. Confederated Tribes of the Umatilla Indian Reservation, Pendleton, Oregon.

RHO-BWI-LD-5. 1978. Geology of Gable Mountain - Gable Butte Area. KR Fecht, Rockwell Hanford Operations, Richland, Washington.

RHO-BWI-ST-5. 1979. "Pasco Basin Hydrology." In Hydrologic Studies Within the Columbia Plateau, Washington: An Integration of Current Knowledge. RE Gephart, FA Spane, Jr., LS Leonhart, DA Palombo, and SR Strait, Rockwell Hanford Operations, Richland, Washington.

RHO-CD-673. 1979. Handbook 200 Areas Waste Sites. Vols. 1 and 3. HL Maxfield, Rockwell Hanford Operations, Richland, Washington.

RHO-RE-ST-12 P. 1984. An Assessment of Aquifer Intercommunication in the B Pond-Gable Mountain Pond Area of the Hanford Site. MJ Graham, GV Last, and KR Fecht, Rockwell Hanford Operations, Richland, Washington.

ROD. 1993. Record of Decision, USDOE Hanford 1100 Area, Hanford Site, Richland, Washington (1100-EM-1, 1100-EM-2, 1100-EM-3, and 1100-IU-1 Operable Units). Washington State Department of Ecology, U.S. Environmental Protection Agency, and U.S. Department of Energy, Richland Operations Office, Richland, Washington.

ROD. 1995a. Declaration of the Record of Decision for the 200-ZP-1 Operable Unit. Washington State Department of Ecology, U.S. Environmental Protection Agency, and U.S. Department of Energy, Richland Operations Office, Richland, Washington.

ROD. 1995b. Declaration of the Record of Decision for the USDOE Hanford Environmental Restoration Disposal Facility. Washington State Department of Ecology, U.S. Environmental Protection Agency, and U.S. Department of Energy, Richland Operations Office, Richland, Washington.

ROD. 1996a. Declaration of the Record of Decision for the 100-HR-3 and 100-KR-4 Operable Units. Washington State Department of Ecology, U.S. Environmental Protection Agency, and U.S. Department of Energy, Richland Operations Office, Richland, Washington.

ROD. 1996b. Record of Decision for the 300-FF-1 and 300-FF-5 Operable Units. Washington State Department of Ecology, U.S. Environmental Protection Agency, and U.S. Department of Energy, Richland Operations Office, Richland, Washington. 
ROD. 1997. Declaration of the Record of Decision for the 200-UP-1 Operable Unit. Washington State Department of Ecology, U.S. Environmental Protection Agency, and U.S. Department of Energy, Richland Operations Office, Richland, Washington.

ROD. 1999a. Amended Record of Decision, Decision Summary and Responsiveness Summary for the 100-HR-3 Operable Unit. U.S. Environmental Protection Agency, Region 10, Seattle, Washington.

ROD. 1999b. Interim Remedial Action Record of Decision for the 100-NR-1 and-NR-2 Operable Units of the Hanford 100-N Area. Washington State Department of Ecology, Olympia, Washington.

RPP-21895, Rev. 2. 2005. 241-C-103 and 241-C-109 Tanks Waste Retrieval Work Plan. CH2M HILL Hanford Group, Inc., Richland, Washington.

RPP-23748, Rev. 0. 2006. Geology, Hydrogeology, Geochemistry, and Mineralogy Data Package for the Single-Shell Tank Waste Management Areas at the Hanford Site. CH2M HILL Hanford Group, Inc., Richland, Washington.

RPP-26744, Rev. 0. 2005. Hanford Soil Inventory Model, Rev. 1. Prepared by RA Corbin, BC Simpson, MJ Anderson (Nuvotec), WF Danielson III (Advanced Imaging Technologies), JG Field, TE Jones (CH2M HILL Hanford Group, Inc.), and CT Kincaid (Pacific Northwest National Laboratory) for the U.S. Department of Energy, Richland, Washington.

RPP-30121, Rev. 0. 2006. Tank 241-S-102 High-Resolution Resistivity Leak Detection and Monitoring Testing Report. CH2M HILL Hanford Group, Inc., Richland, Washington.

RPP-PLAN-26534, Rev. C. 2005. Integrated Disposal Facility Operational Monitoring Plan to Meet DOE Order 435.1. Prepared by DR Lucas (DRL Technology Services), SP Reidel (Pacific Northwest National Laboratory), and RM Mitchell, (Duratek Federal Services) for the U.S. Department of Energy, Richland, Washington.

RPP-RPT-28955, Rev. 0. 2006. Surface Geophysical Exploration of T Tank Farm at the Hanford Site. D Rucker, M Levitt, C Henderson, and K Williams, CH2M HILL Hanford Group, Inc., Richland, Washington.

RPP-RPT-30976. 2006. Surface Geophysical Exploration of S Tank Farm at the Hanford Site. D Rucker, M Levitt, C Henderson, and K Williams, CH2M HILL Hanford Group, Inc., Richland, Washington.

Sheppard SC, MI Sheppard, MO Gallerand, and B Sanipelli. 2005. "Derivation of Ecotoxicity Thresholds for Uranium." Journal of Environmental Radioactivity 79:55-83.

Sobczyk SM. 2004. Interpreted Extent of Subsurface Contamination Resulting from the 241-BX-102 Tank Leak 200 East Area, Hanford Site, Washington. Prepared for Confederated Tribes of the Umatilla Indian Reservation Department of Science and Engineering, Mission, Oregon.

Sobczyk SM, PD Henwood, RG McCain, and JM Silko. 2003. "Vadose Zone Characterization of the B-BX-BY Waste Management Area and Surrounding Disposal Facilities, Hanford Site, Washington." Proc 2003 NGWA Pacific Northwest Focus Conference, Anchorage, Alaska, June 2003.

Spane FA Jr. 2002. "Considering Barometric Pressure in Groundwater Flow Investigations." Water Resources Research 38(6)14:1-18.

U.S. Department of Commerce. 1959, as amended 1963. "Maximum Permissible Body Burdens and Maximum Permissible Concentrations of Radionuclides in Air and in Water for Occupational Exposure." In National Bureau of Standards Handbook 69, National Bureau of Standards, Washington, D.C. (This document is available from the Hilton M. Briggs Library, South Dakota State University, Brookings, South Dakota.)

WCH-88, Rev. 0. 2006. Groundwater and Leachate Monitoring and Sampling at ERDF Calendar Year 2005. DA St. John and RL Weiss, Washington Closure Hanford, Richland, Washington. 
WHC-EP-0587. 1992. Groundwater Impact Assessment Report for the 400 Area Ponds. DK Tyler, Westinghouse Hanford Company, Richland, Washington.

WHC-EP-0595. 1993. Westinghouse Hanford Company Operational Groundwater Status Report 1990-1992. VG Johnson, Westinghouse Hanford Company, Richland, Washington.

WHC-MR-0415. 1993. Miscellaneous Information Regarding Operation and Inventory of 618-10 Burial Ground. CR Webb, Westinghouse Hanford Company, Richland, Washington.

WHC-SA-1674-VA. 1992. Characterization of a Chromium Plume in Groundwater Along the Columbia River Shoreline, Hanford Site, Washington. RE Peterson and MP Connelly, Westinghouse Hanford Company, Richland, Washington. (Presented at 1992 Fall Meeting, American Geophysical Union, San Francisco, December 7-11, 1992.)

WHC-SD-EN-AP-132, Rev. 0. 1993. Interim-Status Groundwater Quality Assessment Plan for the Single-Shell Tank Waste Management Areas T and TX-TY. JA Caggiano and CJ Chou, Westinghouse Hanford Company, Richland, Washington.

WHC-SD-EN-AP-185. 1995. Groundwater Monitoring Plan for the 300 Area Process Trenches. JW Lindberg, CJ Chou, and VG Johnson, Westinghouse Hanford Company, Richland, Washington.

WHC-SD-EN-EV-003, Rev. 1. 1992. Results of Groundwater Quality Assessment Monitoring at the 1301-N and 1324-N/NA Facilities. MJ Hartman, Westinghouse Hanford Company, Richland, Washington.

WHC-SD-EN-EV-032, Rev. 0. 1995. Results of Groundwater Quality Assessment Program at the 216-A-29 Ditch RCRA Facility. JM Votava, Westinghouse Hanford Company, Richland, Washington.

WHC-SD-EN-TI-023. 1992. Hydrologic Information Summary for the Northern Hanford Site. MJ Hartman and RE Peterson, Westinghouse Hanford Company, Richland, Washington.

WHC-SD-EN-TI-101. 1993. Carbon Tetrachloride Evaporative Losses and Residual Inventory Beneath 200 West Area at the Hanford Site. Prepared by Ebasco Services for Westinghouse Hanford Company, Richland, Washington.

WHC-SD-EN-TI-199. 1993. Nonradioactive Dangerous Waste Landfill Soil-Gas Survey: Final Data Report. ID Jacques, Westinghouse Hanford Company, Richland, Washington.

WHC-SD-EN-TI-239, Rev. 0. 1994. 100-K Area Technical Baseline Report. RW Carpenter and SL Cotè, Westinghouse Hanford Company, Richland, Washington.

WHC-SD-EN-TI-248. 1994. 1994 Conceptual Model of the Carbon Tetrachloride Contamination in the 200 West Area at the Hanford Site. VJ Rohay, KJ Swett, and GV Last, Westinghouse Hanford Company, Richland, Washington.

WHC-SD-EN-TI-302. 1995. Speciation and Transport Characteristics of Chromium in the 100D/H Areas of the Hanford Site. EC Thornton, JE Amonette, JA Olivier, and DL Huang, Westinghouse Hanford Company, Richland, Washington.

WMP-21327, Rev. 0. 2004 Performance Evaluation Report for Soil Vapor Extraction Operations at the 200-PW-1 Carbon Tetrachloride Site, Fiscal Year 2003. PM Gent, Fluor Hanford, Inc., Richland, Washington.

WMP-26178, Rev. 0. 2005. Performance Evaluation Report for Soil Vapor Extraction Operations at the 200-PW-1 Carbon Tetrachloride Site, Fiscal Year 2004. VJ Rohay, Fluor Hanford, Inc., Richland, Washington.

WMP-26264. 2005. Borehole Summary Report for Well 299-W15-46 (C3426) Drilled at the 216-Z-9 Trench. ME Caron, Fluor Hanford, Inc., Richland, Washington.

WMP-27020. 2006. Borehole Summary Report for Characterization Borehole C4545 Drilled at the 216-A-8 Crib. Fluor Hanford, Inc., Richland, Washington. 
WMP-28324, Rev 0. 2006. Data Quality Objectives Summary Report for Defining the Nature and Extent of Deep Groundwater Contamination in the 200-2P-1 Operable Unit in the Vicinity of the Old Laundry Facility. Fluor Hanford, Inc., Richland, Washington.

WMP-28389, Rev. 0. 2007. T-Area Technetium-99 Data Quality Objectives Summary Report. VG Rohay, Fluor Hanford, Inc., Richland, Washington.

WMP-28945. 2006. Data Quality Objectives Summary Report in Support of the 200-BP-5 Groundwater Operable Unit Remedial Investigation/Feasibility Study Process. GS Thomas, Fluor Hanford, Inc. Richland, Washington.

WMP-30426, Rev. 0. 2006. Performance Evaluation Report for Soil Vapor Extraction Operations at the 200-PW-1 Carbon Tetrachloride Site, Fiscal Year 2005. VJ Rohay, Fluor Hanford, Inc., Richland, Washington.

WMP-30566. 2007. Borehole Summary Report for Well 299-W15-48 (C3427) Drilled at the 216-Z-9 Trench. VJ Rohay, Fluor Hanford, Inc., Richland, Washington.

WMP-30847, Rev. 0. 2006. 200-UP-1 Operable Unit Rebound Study Letter Report. DB Erb, Fluor Hanford, Inc., Richland, Washington. 


\section{Appendix A}

\section{Supporting Information for CERCLA Groundwater Operable Units}




\section{Contents}

Supporting Information for CERCLA Groundwater Operable Units .............................................................. A.1

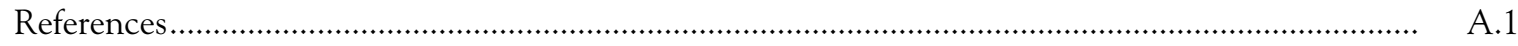

\section{Tables}

A.1 Monitoring Wells and Constituents for 100-BC-5 Operable Unit...................................................... A.2

A.2 Monitoring Wells and Constituents for 100-KR-4 Pump-and-Treat System ...................................... A.3

A.3 Monitoring Wells and Constituents for 100-KR-4 Operable Unit Long-Term Monitoring.................. A.4

A.4 Monitoring Wells and Constituents for 100-NR-2 Interim Action ................................................... A.5

A.5 Monitoring Wells and Constituents for 100-NR-2 Baseline Monitoring............................................ A.6

A.6 Monitoring Wells and Constituents for 100-NR-2 Rebound Monitoring ........................................... A.7

A.7 Monitoring Wells and Constituents for 100-HR-3 Operable Unit In Situ Redox System.................... A. A.8

A.8 Monitoring Wells and Constituents for 100-HR-3 Pump-and-Treat Systems ....................................... A.9

A.9 Monitoring Wells and Constituents for 100-HR-3 Operable Unit Long-Term Monitoring ................. A.10

A.10 Monitoring Wells, Aquifer Tubes, and Constituents for 100-FR-3 Operable Unit ............................. A.12

A.11 Monitoring Wells and Constituents for 200-ZP-1 Operable Unit .................................................... A.14

A.12 Monitoring Wells and Constituents for 200-UP-1 Operable Unit.................................................... A.16

A.13 Monitoring Wells and Constituents for 200-BP-5 Operable Unit ..................................................... A.18

A.14 Monitoring Wells, Aquifer Tubes, and Constituents for 200-PO-1 Operable Unit............................. A.22

A.15 Monitoring Wells, Aquifer Tubes, and Constituents for 300-FF-5 Operable Unit, 300 Area ............... A.26

A.16 Monitoring Wells and Constituents for 300-FF-5 Operable Unit, 618-11 Subregion ........................... A.28

A.17 Monitoring Wells and Constituents for 300-FF-5 Operable Unit, 618-10/316-4 Subregion................. A.28

A.18 Monitoring Wells and Constituents for 1100-EM-1 Operable Unit ...................................................... A.29 


\section{Appendix A}

\section{Supporting Information for CERCLA Groundwater Operable Units}

Under the Comprehensive Environmental Response, Compensation, and Liability Act (CERCLA), the groundwater and vadose zone beneath contaminated portions of the Hanford Site are divided into 11 groundwater operable units. Figure 1.0-1 in Section 1.0 of the main text shows the locations of these units and related groundwater interest areas on the Hanford Site. The interest areas are defined informally to aid in planning, scheduling, and data interpretation.

Tables A.1 through A.18 list the constituents, monitoring wells, and the frequency of sampling for each operable units required by sampling and analysis plans or other documentation. The tables also indicate whether the wells were sampled as scheduled during fiscal year 2006.

In many cases, wells are sampled for additional constituents not strictly required by the plans. Those constituents are not listed in the tables of this appendix, but data files accompanying this report include all required and supplemental data.

\section{References}

Comprehensive Environmental Response, Compensation, and Liability Act. 1980. Public Law 96-510, as amended, 94 Stat. 2767, 42 USC 9601 et seq.

DOE/RL-2001-49, Rev. 1. 2004. Groundwater Sampling and Analysis Plan for the 200-BP-5 Operable Unit. U.S. Department of Energy, Richland Operations Office, Richland, Washington.

DOE/RL-2002-11, Rev. 1. 2006. 300-FF-5 Operable Unit Sampling and Analysis Plan. U.S. Department of Energy, Richland Operations Office, Richland, Washington.

DOE/RL-2003-04, Rev. 1. 2006. Groundwater Sampling and Analysis Plan for the 200-PO-1 Operable Unit. U.S. Department of Energy, Richland Operations Office, Richland, Washington.

DOE/RL-2003-38, Rev. 1. 2003. 100-BC-5 Operable Unit Sampling and Analysis Plan. U.S. Department of Energy, Richland Operations Office, Richland, Washington.

DOE/RL-2003-49, Rev. 1. 2003. 100-FR-3 Operable Unit Sampling and Analysis Plan. U.S. Department of Energy, Richland Operations Office, Richland, Washington.

PNNL-12220. 1999. Sampling and Analysis Plan Update for Groundwater Monitoring - 1100-EM-1 Operable Unit. DR Newcomer, Pacific Northwest National Laboratory, Richland, Washington.

PNNL-15798 (draft). 2006. 100-N Shoreline Groundwater Monitoring Plan. MJ Hartman, Pacific Northwest National Laboratory, Richland, Washington. 
Table A.1. Monitoring Wells and Constituents for 100-BC-5 Operable Unit (adapted from DOE/RL-2003-38)

\begin{tabular}{|c|c|c|c|c|c|c|c|c|c|c|}
\hline Well & 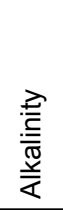 & $\frac{\frac{\pi}{0}}{\frac{0}{\alpha}}$ & $\begin{array}{l}0 \\
\stackrel{0}{0} \\
\frac{0}{5}\end{array}$ & $\underset{\infty}{\mathbb{0}}$ & 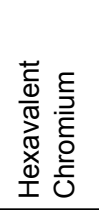 & $\frac{\frac{\infty}{\pi}}{\frac{\pi}{0}} \frac{1}{\Sigma}$ & 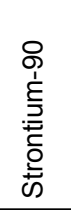 & 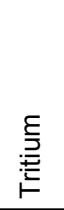 & 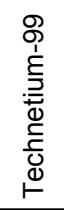 & $\begin{array}{l}\text { Sampled as Scheduled } \\
\text { in FY } 2006\end{array}$ \\
\hline 199-B2-12 & $\mathrm{BO}$ & $\mathrm{BO}$ & BO & $\mathrm{BO}$ & & $\mathrm{BO}$ & $\mathrm{BO}$ & $\mathrm{BO}$ & & Not scheduled \\
\hline 199-B2-13 & A & $\mathrm{BE}$ & A & $\mathrm{BE}$ & & A & $\mathrm{BE}$ & $\mathrm{BE}$ & & Yes \\
\hline 199-B3-1 & A & & A & & A & A & A & A & & Yes \\
\hline 199-B3-46 & $\mathrm{BO}$ & & $\mathrm{BO}$ & & A & $\mathrm{BO}$ & A & A & & Yes \\
\hline 199-B3-47 & A & A & A & A & A & A & A & A & & Yes \\
\hline 199-B4-1 & $\mathrm{BE}$ & $\mathrm{BE}$ & $\mathrm{BE}$ & $\mathrm{BE}$ & $\mathrm{BE}$ & $\mathrm{BE}$ & $\mathrm{BE}$ & $\mathrm{BE}$ & & Yes \\
\hline 199-B4-4 & & $\mathrm{BE}$ & & $\mathrm{BE}$ & & & $\mathrm{BE}$ & $\mathrm{BE}$ & & Yes \\
\hline 199-B4-5 & & & & & & & & & & Water level only \\
\hline 199-B4-6 & & & & & & & & & & Water level only \\
\hline 199-B4-7 & $\mathrm{BO}$ & $\mathrm{BO}$ & $\mathrm{BO}$ & $\mathrm{BO}$ & & $\mathrm{BO}$ & $\mathrm{BO}$ & $\mathrm{BO}$ & & Not scheduled \\
\hline 199-B4-8 & A & $\mathrm{BE}$ & A & $\mathrm{BE}$ & & A & $\mathrm{BE}$ & $\mathrm{BE}$ & & Yes \\
\hline 199-B5-1 & A & A & A & A & A & A & $\mathrm{BE}$ & A & & Yes \\
\hline 199-B5-2 & & BO & & $\mathrm{BO}$ & A & & BO & A & & Yes \\
\hline 199-B8-6 & $\mathrm{BO}$ & BO & BO & $\mathrm{BO}$ & & BO & BO & A & & Yes \\
\hline 199-B9-2 & & $\mathrm{BE}$ & & $\mathrm{BE}$ & & & $\mathrm{BE}$ & $\mathrm{BE}$ & & Yes \\
\hline 199-B9-3 & $\mathrm{BO}$ & $\mathrm{BO}$ & $\mathrm{BO}$ & $\mathrm{BO}$ & & $\mathrm{BO}$ & $\mathrm{BO}$ & BO & & Not scheduled \\
\hline 699-63-90 & $\mathrm{BE}$ & $\mathrm{BE}$ & $\mathrm{BE}$ & $\mathrm{BE}$ & & $\mathrm{BE}$ & & $\mathrm{BE}$ & & Yes \\
\hline $699-65-72$ & $\mathrm{BE}$ & & $\mathrm{BE}$ & & & $\mathrm{BE}$ & & $\mathrm{BE}$ & & Yes \\
\hline $699-65-83$ & & & & & & & & $\mathrm{BE}$ & & Yes \\
\hline 699-66-103 & & & & & & & & $\mathrm{BE}$ & & Yes \\
\hline $699-67-86$ & & & & & & & & $\mathrm{BO}$ & & Not scheduled \\
\hline 699-68-105 & $\mathrm{BO}$ & & $\mathrm{BO}$ & & & $\mathrm{BO}$ & & $\mathrm{BO}$ & & Not scheduled \\
\hline 699-71-77 & $\mathrm{BO}$ & & BO & & & BO & & BO & BO & Not scheduled \\
\hline $699-72-73$ & A & & A & & & A & & A & BO & Yes \\
\hline $699-72-92$ & BO & & BO & & & BO & & BO & & Not scheduled \\
\hline AT-01 & & & & & A & & & A & & Yes \\
\hline AT-03 & & & & & A & & & A & & Yes \\
\hline AT-04 & & & A & & A & & & A & & Yes \\
\hline AT-05 & & A & A & A & A & & A & A & & Yes \\
\hline AT-06 & & A & A & $A$ & A & & A & $A$ & & Yes \\
\hline AT-07 & & A & A & A & A & & & A & & Yes \\
\hline AT-11 & & A & & A & A & & & $A$ & A & Yes \\
\hline AT-12 & & A & & $A$ & A & & & A & A & No \\
\hline AT-B-1 & & & & & A & & & A & & Yes \\
\hline AT-B-2 & & & & & A & & & A & & Yes \\
\hline AT-B-3 & & A & A & A & A & & A & A & & Yes \\
\hline AT-B-4 & & A & A & A & A & & & A & & Yes \\
\hline AT-B-5 & & A & A & A & A & & A & A & A & Yes \\
\hline AT-B-7 & & A & A & A & A & & A & A & & Yes \\
\hline Seep 037-1 & & A & & A & A & & & A & & Yes \\
\hline Seep 039-2 & & A & & A & A & & & A & & $\mathrm{No}^{(\mathrm{a})}$ \\
\hline \multicolumn{11}{|c|}{$\begin{array}{l}\text { (a) Sampling of springs is dependent on flow con } \\
\mathrm{A}=\text { To be sampled annually. } \\
\mathrm{BE}=\text { To be sampled biennially, even fiscal year. } \\
\mathrm{BO}=\text { To be sampled biennially, odd fiscal year. } \\
\mathrm{FY}=\text { Fiscal year. }\end{array}$} \\
\hline
\end{tabular}


Table A.2. Monitoring Wells and Constituents for 100-KR-4 Pump-and-Treat System ${ }^{(a)}$

\begin{tabular}{|l|c|c|}
\hline \multicolumn{1}{|c|}{ Well } & Frequency & $\begin{array}{c}\text { Sampled as Scheduled } \\
\text { in FY 2006 }\end{array}$ \\
\hline $199-\mathrm{K}-117 \mathrm{~A}$ & $\mathrm{M}$ & \\
\hline $199-\mathrm{K}-130$ & $\mathrm{M}$ & Missed 8/2006 \\
\hline $199-\mathrm{K}-131$ & $\mathrm{M}$ & \\
\hline $199-\mathrm{K}-18$ & $\mathrm{M}$ & \\
\hline $199-\mathrm{K}-19$ & $\mathrm{SA}$ & \\
\hline $199-\mathrm{K}-20$ & $\mathrm{M}$ & \\
\hline $199-\mathrm{K}-21$ & $\mathrm{SA}$ & \\
\hline $199-\mathrm{K}-22$ & SA & \\
\hline $199-\mathrm{K}-37$ & SA & \\
\hline
\end{tabular}

(a) Table based on requirements transmitted to the Groundwater Performance Assessment Project via letter FH-0502977 from RG Gallagher (Fluor Hanford, Inc.) to Dr. LK Peters (Pacific Northwest National Laboratory), Tables Specifying Fluor Hanford Performance Sampling

Requirements for Fiscal Year 2006, dated October 12, 2005.

$\mathrm{FY}=$ Fiscal year

$M=$ To be sampled monthly.

$\mathrm{SA}=$ To be sampled semiannually. 
Table A.3. Monitoring Wells and Constituents for 100-KR-4 Operable Unit Long-Term Monitoring ${ }^{(a)}$

\begin{tabular}{|c|c|c|}
\hline Well & Frequency & $\begin{array}{c}\text { Sampled as Scheduled } \\
\text { in FY } 2006\end{array}$ \\
\hline 199-K-106A & $\mathrm{BE}$ & Yes \\
\hline 199-K-107A & Q & Yes \\
\hline 199-K-108A & Q & Yes \\
\hline 199-K-109A & $Q$ & Yes \\
\hline $199-K-11$ & $\mathrm{BO}$ & Not scheduled \\
\hline 199-K-110A & $\mathrm{BE}$ & Yes \\
\hline 199-K-111A & $A$ & Yes \\
\hline $199-K-130$ & $M$ & Yes \\
\hline 199-K-18 & A & Yes \\
\hline 199-K-19 & $A$ & Yes \\
\hline $199-K-20$ & A & Yes \\
\hline $199-K-21$ & A & Yes \\
\hline $199-K-22$ & $A$ & Yes \\
\hline $199-K-23$ & $\mathrm{BO}$ & Not scheduled \\
\hline $199-K-27$ & $Q$ & Yes \\
\hline $199-K-30$ & $Q$ & Yes \\
\hline $199-K-31$ & A & Yes \\
\hline $199-K-32 A$ & $A$ & Yes \\
\hline 199-K-32B & A & Yes \\
\hline $199-K-34$ & $\mathrm{BO}$ & Not scheduled \\
\hline $199-K-35$ & $\mathrm{BO}$ & Not scheduled \\
\hline $199-K-36$ & $Q$ & Yes \\
\hline 199-K-37 & A & Yes \\
\hline $699-70-68$ & $\mathrm{BE}$ & Yes \\
\hline 699-73-61 & $\mathrm{BE}$ & Yes \\
\hline $699-78-62$ & A & Yes \\
\hline SK-057-3 & $A$ & Yes \\
\hline SK-077-1 & $A$ & Yes \\
\hline SK-082-2 & A & Yes \\
\hline \multicolumn{3}{|c|}{$\begin{array}{l}\text { (a) Table based on requirements transmitted to the } \\
\text { Groundwater Performance Assessment Project via letter } \\
\text { FH-0502977 from RG Gallagher (Fluor Hanford, Inc.) to } \\
\text { Dr. LK Peters (Pacific Northwest National Laboratory), } \\
\text { Tables Specifying Fluor Hanford Performance Sampling } \\
\text { Requirements for Fiscal Year 2006, dated October 12, } \\
2005 \text {. } \\
\text { A = To be sampled annually. } \\
\text { BE = To be sampled biennially, even fiscal year. } \\
\text { BO = To be sampled biennially, odd fiscal year. } \\
\text { FY = Fiscal year. } \\
M=\text { To be sampled monthly. } \\
\text { Q = To be sampled quarterly. }\end{array}$} \\
\hline
\end{tabular}


Table A.4. Monitoring Wells and Constituents for 100-NR-2 Interim Action ${ }^{(a)}$

\begin{tabular}{|c|c|c|}
\hline Well & Frequency & $\begin{array}{c}\text { Sampled as Scheduled } \\
\text { in FY } 2006\end{array}$ \\
\hline $199-\mathrm{N}-14$ & SA & Yes \\
\hline $199-\mathrm{N}-16$ & A & Yes \\
\hline $199-\mathrm{N}-18$ & SA & Yes \\
\hline $199-\mathrm{N}-2$ & A & Yes \\
\hline $199-\mathrm{N}-21$ & A & Yes \\
\hline $199-\mathrm{N}-27$ & $A$ & Yes \\
\hline $199-\mathrm{N}-3$ & SA & Yes \\
\hline $199-\mathrm{N}-32$ & SA & Yes \\
\hline $199-N-50$ & A & Yes \\
\hline $199-\mathrm{N}-51$ & $A$ & Delayed until 10/2006 \\
\hline $199-\mathrm{N}-64$ & $A$ & Delayed until 10/2006 \\
\hline $199-N-67$ & SA & Yes \\
\hline $199-\mathrm{N}-70$ & A & Delayed until 10/2006 \\
\hline $199-N-74$ & A & Yes \\
\hline $199-\mathrm{N}-75$ & SA & Yes \\
\hline $199-\mathrm{N}-76$ & SA & Yes \\
\hline $199-\mathrm{N}-80$ & $A$ & Yes \\
\hline $199-\mathrm{N}-81$ & A & Yes \\
\hline $199-N-92 A$ & A & Yes \\
\hline $199-N-96 A$ & A & Yes \\
\hline $199-N-99 A$ & $A$ & Yes \\
\hline \multicolumn{3}{|c|}{$\begin{array}{l}\text { (a) Table based on requirements transmitted to the } \\
\text { Groundwater Performance Assessment Project via letter } \\
\text { FH-0502977 from RG Gallagher (Fluor Hanford, Inc.) to } \\
\text { Dr. LK Peters (Pacific Northwest National Laboratory), } \\
\text { Tables Specifying Fluor Hanford Performance Sampling } \\
\text { Requirements for Fiscal Year 2006, dated October 12, } \\
2005 \text {. } \\
\text { A = To be sampled annually. } \\
\text { FY = Fiscal year. } \\
\text { SA = To be sampled semiannually. }\end{array}$} \\
\hline
\end{tabular}


Table A.5. Monitoring Wells and Constituents for 100-NR-2 Baseline Monitoring ${ }^{(a)}$

\begin{tabular}{|c|c|c|c|c|c|c|c|c|c|}
\hline Well & 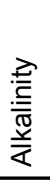 & $\frac{\frac{\pi}{2}}{\frac{0}{2}}$ & $\begin{array}{l}0 \\
\frac{0}{2} \\
\frac{0}{2} \\
\end{array}$ & 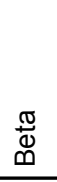 & 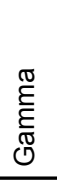 & $\begin{array}{l}\frac{\infty}{\pi} \\
\frac{\omega}{\infty}\end{array}$ & 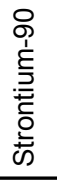 & 营 & $\begin{array}{c}\text { Sampled as Scheduled } \\
\text { in FY } 2006\end{array}$ \\
\hline $199-N-46$ & Q & Q & Q & $\mathrm{M}$ & Q & Q & Q & Q & Yes \\
\hline $199-N-67$ & Q & Q & Q & M & Q & Q & Q & Q & Yes \\
\hline $199-N-92 A$ & $A$ & A & $A$ & $\mathrm{~A}$ & $\mathrm{~A}$ & A & A & A & Yes \\
\hline 199-N-96A & Q & Q & Q & M & Q & Q & Q & Q & Yes \\
\hline 199-N-99A & Q & Q & Q & M & Q & Q & Q & Q & Yes \\
\hline $199-\mathrm{N}-119$ & $Q$ & $Q$ & $Q$ & $M$ & $Q$ & $Q$ & $Q$ & $Q$ & Yes \\
\hline $199-\mathrm{N}-120$ & Q & Q & Q & M & Q & Q & Q & Q & Yes \\
\hline $199-\mathrm{N}-121$ & Q & Q & Q & M & Q & Q & Q & Q & Yes \\
\hline $\mathrm{NS}-2 \mathrm{~A}-23 \mathrm{~cm}$ & $Q$ & $Q$ & $Q$ & $M$ & $Q$ & $Q$ & $Q$ & $Q$ & Yes \\
\hline $\mathrm{NS}-2 \mathrm{~A}-87 \mathrm{~cm}$ & $Q$ & $Q$ & $Q$ & $M$ & $Q$ & $Q$ & $Q$ & $Q$ & Yes \\
\hline NS-2A-168cm & $Q$ & $Q$ & $Q$ & $M$ & $Q$ & $Q$ & $Q$ & $Q$ & Yes \\
\hline NS-3A-10cm & Q & Q & Q & $\mathrm{M}$ & Q & Q & Q & Q & Yes \\
\hline NS-3A-87cm & Q & Q & Q & $\mathrm{M}$ & Q & Q & Q & Q & No; rusted out after $11 / 2005$ \\
\hline NS-3A-176cm & $Q$ & $Q$ & $Q$ & $M$ & $Q$ & $Q$ & $Q$ & $Q$ & $\mathrm{No}^{(\mathrm{b})}$ \\
\hline NS-4A-17cm & Q & Q & Q & M & Q & Q & Q & Q & Yes \\
\hline NS-4A-138cm & Q & Q & Q & M & Q & Q & Q & Q & Yes \\
\hline NS-2 & $Q$ & $Q$ & $Q$ & $M$ & $Q$ & $Q$ & $Q$ & $Q$ & Sampled twice ${ }^{(c)}$ \\
\hline NS-3 & $Q$ & $Q$ & $Q$ & $M$ & $Q$ & $Q$ & $Q$ & $Q$ & Sampled twice ${ }^{(c)}$ \\
\hline NS-4 & $Q$ & $\mathrm{Q}$ & $\mathrm{Q}$ & $\mathrm{M}$ & $Q$ & $Q$ & $\mathrm{Q}$ & $Q$ & Sampled twice ${ }^{(c)}$ \\
\hline \multicolumn{10}{|c|}{$\begin{array}{l}\text { (a) Through April } 2006 \text {. } \\
\text { (b) No alpha, gamma, strontiu } \\
\text { (c) Seep wells cannot be sam } \\
\text { A = To be sampled annually. } \\
\text { FY = Fiscal year. } \\
M=\text { To be sampled monthly. } \\
\text { Q = To be sampled quarterly. }\end{array}$} \\
\hline
\end{tabular}


Table A.6. Monitoring Wells and Constituents for 100-NR-2 Rebound Monitoring ${ }^{(a)}$ (adapted from PNNL-15798)

\begin{tabular}{|c|c|c|c|c|c|c|c|c|c|c|c|}
\hline $\begin{array}{l}\text { Well or Tube } \\
\text { Name }\end{array}$ & 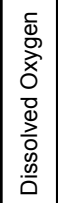 & 跑 & 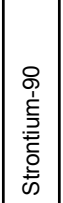 & 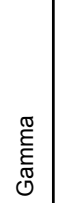 & 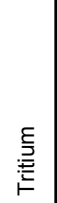 & 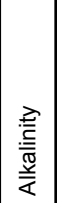 & 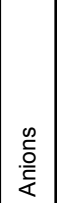 & $\frac{\frac{\infty}{5 \pi}}{\frac{\pi}{0}}$ & 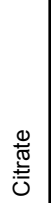 & $\begin{array}{l}I \\
O \\
R \\
0 \\
O \\
O\end{array}$ & Sampled as Scheduled in FY 2006 \\
\hline $199-\mathrm{N}-2$ & SA & & SA & & & & & & & & Yes \\
\hline $199-\mathrm{N}-3$ & SA & & SA & & & & & & & & Yes \\
\hline $199-\mathrm{N}-14$ & SA & & SA & & & & & & & & Yes \\
\hline $199-\mathrm{N}-46$ & M & M & Q & Q & $\mathrm{Q}$ & Q & Q & Q & & & Yes \\
\hline $199-\mathrm{N}-67$ & M & M & Q & Q & Q & $\mathrm{Q}$ & $\mathrm{Q}$ & $\mathrm{Q}$ & & & Yes \\
\hline 199-N-75 & $Q$ & $Q$ & Q & Q & $\mathrm{Q}$ & $Q$ & $Q$ & $Q$ & & & Yes \\
\hline $199-\mathrm{N}-76$ & SA & & SA & & & & & & & & Yes \\
\hline $199-\mathrm{N}-92 \mathrm{~A}$ & SA & SA & SA & SA & SA & SA & SA & SA & & & Yes \\
\hline $199-N-96 A$ & M & M & Q & Q & $Q$ & $Q$ & $Q$ & $Q$ & & $Q$ & Missed 8/2006; September delayed until 10/2006 \\
\hline $199-\mathrm{N}-99 \mathrm{~A}$ & M & M & Q & Q & $\mathrm{Q}$ & $Q$ & $Q$ & $Q$ & & & Yes \\
\hline $199-N-103 A$ & Q & Q & Q & Q & Q & Q & Q & Q & & & Yes \\
\hline $199-\mathrm{N}-105 \mathrm{~A}$ & $\mathrm{Q}$ & Q & Q & Q & Q & Q & Q & Q & & & Yes \\
\hline $199-\mathrm{N}-106 \mathrm{~A}$ & Q & Q & Q & Q & Q & $\mathrm{Q}$ & $\mathrm{Q}$ & $\mathrm{Q}$ & & & Yes \\
\hline $199-\mathrm{N}-119$ & M & M & Q & Q & $\mathrm{Q}$ & $Q$ & $Q$ & Q & & & Yes \\
\hline $199-\mathrm{N}-120$ & SA & SA & SA & SA & SA & SA & SA & SA & & & Yes \\
\hline $199-\mathrm{N}-121$ & SA & SA & SA & SA & SA & SA & SA & SA & & & Yes \\
\hline $199-\mathrm{N}-122$ & $M$ & M & Q & Q & $Q$ & $Q$ & $Q$ & $Q$ & $Q$ & & Began in $7 / 2006$ \\
\hline $199-\mathrm{N}-123$ & M & M & $Q$ & $Q$ & $Q$ & $Q$ & $Q$ & $Q$ & $Q$ & $Q$ & Began in $7 / 2006$ \\
\hline $199-\mathrm{N}-146$ & M & M & Q & Q & Q & Q & Q & Q & Q & & Missed 7/2006; September delayed until 10/2006 \\
\hline $199-\mathrm{N}-147$ & M & M & Q & Q & Q & Q & Q & Q & Q & & Yes \\
\hline NS- $2 A-87 \mathrm{~cm}$ & M & M & Q & Q & $\mathrm{Q}$ & Q & Q & Q & Q & & Yes \\
\hline NS-4A-138cm & M & M & Q & Q & $Q$ & $Q$ & $Q$ & $Q$ & Q & & Missed 9/2006 \\
\hline NVP1-1 & $Q$ & $Q$ & & & & & & & & & Missed 9/2006 \\
\hline NVP1-2 & $Q$ & $Q$ & & & & & & & & & Missed 9/2006 \\
\hline NVP1-3 & $Q$ & $Q$ & & & & & & & & & Missed 9/2006 \\
\hline NVP1-4 & $Q$ & $Q$ & & & & & & & & & Yes \\
\hline NVP1-5 & $\mathrm{Q}$ & $\mathrm{Q}$ & & & & & & & & & Yes \\
\hline NVP2-116.3 & $Q$ & $Q$ & & & & & & & & & Yes \\
\hline NVP2-116.0 & M & M & $Q$ & $Q$ & $Q$ & $Q$ & $Q$ & $Q$ & $Q$ & & Yes \\
\hline NVP2-115.7 & $Q$ & $Q$ & & & & & & & & & Yes \\
\hline NVP2-115.4 & Q & $Q$ & & & & & & & & & Yes \\
\hline NVP2-115.1 & Q & $Q$ & & & & & & & & & Yes \\
\hline APT-1 & M & M & Q & Q & $Q$ & $Q$ & $Q$ & $Q$ & $Q$ & & Added to schedule after apatite emplacement \\
\hline Array-1A & $\mathrm{Q}$ & $\mathrm{Q}$ & Q & A & A & A & A & A & $Q$ & $Q$ & Missed 9/2006 \\
\hline Array-2A & $Q$ & $Q$ & $Q$ & A & A & A & A & A & $Q$ & $Q$ & Yes \\
\hline Array-3A & M & $M$ & $Q$ & $Q$ & $Q$ & $Q$ & $Q$ & $Q$ & $Q$ & & Yes \\
\hline Array-4A & $M$ & $M$ & $Q$ & $Q$ & $Q$ & $Q$ & $Q$ & $Q$ & $Q$ & & Yes \\
\hline Array-6A & $M$ & $M$ & $Q$ & $Q$ & $Q$ & $Q$ & $Q$ & $Q$ & $Q$ & & Yes \\
\hline Array-7A & $Q$ & $Q$ & A & $A$ & $A$ & $A$ & $A$ & $A$ & $Q$ & & Yes \\
\hline Array-8A & $Q$ & $Q$ & A & A & $A$ & $A$ & $A$ & $A$ & & & Yes \\
\hline Array-9A & $Q$ & $Q$ & A & $A$ & $A$ & $A$ & $A$ & $A$ & & & Yes \\
\hline Array-10A & $\mathrm{Q}$ & $\mathrm{Q}$ & A & A & A & A & A & A & & & Yes \\
\hline Array-11A & $Q$ & $Q$ & A & A & $A$ & A & A & A & & & Yes \\
\hline Array-12A & $Q$ & $Q$ & A & A & $A$ & $A$ & $A$ & $A$ & & & Yes \\
\hline Array-13A & $Q$ & $Q$ & A & A & A & A & A & A & & & Yes \\
\hline Array-14A & $Q$ & $Q$ & $A$ & A & $A$ & $A$ & $A$ & $A$ & & & Yes \\
\hline NS-2 & $A$ & $A$ & A & A & $A$ & & & & & & Yes \\
\hline NS-3 & A & A & A & A & $A$ & & & & & & Yes \\
\hline NS-4 & $\mathrm{A}$ & $\mathrm{A}$ & $\mathrm{A}$ & $\mathrm{A}$ & $\mathrm{A}$ & & & & & & Yes \\
\hline \multicolumn{12}{|c|}{$\begin{array}{l}\text { (a) May through September } 2006 . \\
A=\text { To be sampled annually } \\
F Y=\text { Fiscal year. } \\
M=\text { To be sampled monthly. } \\
Q=\text { To be sampled quarterly. } \\
\text { SA }=\text { To be sampled semiannually. } \\
T O C=\text { Total organic carbon. } \\
T P H=\text { Total petroleum hydrocarbons. }\end{array}$} \\
\hline
\end{tabular}


Table A.7. Monitoring Wells and Constituents for 100-HR-3 Operable Unit In Situ Redox System (100-D Area) ${ }^{(a)}$

\begin{tabular}{|c|c|c|}
\hline Well Name & Frequency & $\begin{array}{c}\text { Sampled as Scheduled } \\
\text { in FY } 2006 \\
\end{array}$ \\
\hline 199-D2-6 & Q & Yes \\
\hline 199-D2-8 & Q & Yes \\
\hline 199-D3-2 & $Q$ & Yes \\
\hline 199-D4-1 & $Q$ & Yes \\
\hline 199-D4-15 & $\mathrm{M}$ & Yes \\
\hline 199-D4-20 & Q & Yes \\
\hline 199-D4-22 & Q & Yes \\
\hline 199-D4-23 & Q & Yes \\
\hline 199-D4-26 & Q & Yes \\
\hline 199-D4-31 & Q & Yes \\
\hline 199-D4-32 & $Q$ & Yes \\
\hline 199-D4-36 & Q & Yes \\
\hline 199-D4-38 & Q & Yes \\
\hline 199-D4-39 & Q & Yes \\
\hline 199-D4-4 & Q & Yes \\
\hline 199-D4-48 & Q & Yes \\
\hline 199-D4-5 & Q & Yes \\
\hline 199-D4-6 & Q & Yes \\
\hline 199-D4-62 & Q & Yes \\
\hline 199-D4-7 & Q & Yes \\
\hline 199-D4-78 & Q & Yes \\
\hline 199-D4-83 & Q & Yes \\
\hline 199-D4-84 & Q & Yes \\
\hline 199-D4-85 & Q & Yes \\
\hline 199-D4-86 & Q & Yes \\
\hline 199-D5-36 & Q & Yes \\
\hline 199-D5-38 & $\mathrm{M}$ & Yes \\
\hline 199-D5-39 & $\mathrm{M}$ & Yes \\
\hline 199-D5-43 & $\mathrm{M}$ & Yes \\
\hline \multicolumn{3}{|c|}{$\begin{array}{l}\text { (a) Table based on requirements transmitted to the } \\
\text { Groundwater Performance Assessment Project via letter } \\
\text { FH-0502977 from RG Gallagher (Fluor Hanford, Inc.) to } \\
\text { Dr. LK Peters (Pacific Northwest National Laboratory), } \\
\text { Tables Specifying Fluor Hanford Performance Sampling } \\
\text { Requirements for Fiscal Year 2006, dated October 12, } \\
2005 \text {. } \\
\text { FY = Fiscal year. } \\
\text { M = To be sampled monthly. } \\
\text { Q = To be sampled quarterly. }\end{array}$} \\
\hline
\end{tabular}


Table A.8. Monitoring Wells and Constituents for 100-HR-3 Pump-and-Treat Systems (100-D and 100-H Areas) ${ }^{(a)}$

\begin{tabular}{|c|c|c|}
\hline Well & Frequency & $\begin{array}{c}\text { Sampled as Scheduled } \\
\text { in FY } 2006 \\
\end{array}$ \\
\hline 199-D5-37 & Q & Yes \\
\hline 199-D8-54B & SA & Yes \\
\hline 199-D8-69 & $\mathrm{M}$ & Missed 8/2006 \\
\hline 199-D8-70 & M & Missed 8/2006 \\
\hline 199-D8-71 & SA & Yes \\
\hline 199-D8-73 & $\mathrm{M}$ & Yes \\
\hline 199-D8-88 & $\mathrm{M}$ & Yes \\
\hline 199-Н3-3 & $\mathrm{M}$ & Schedule changed to $Q^{(b)}$ \\
\hline $199-\mathrm{H} 3-4$ & $\mathrm{M}$ & Schedule changed to $Q^{(b)}$ \\
\hline $199-\mathrm{H} 3-5$ & M & Schedule changed to $Q^{(b)}$ \\
\hline $199-\mathrm{H} 4-10$ & SA & Yes \\
\hline $199-\mathrm{H} 4-11$ & $\mathrm{M}$ & Missed 10/2005 \\
\hline 199-H4-12B & SA & Yes \\
\hline $199-\mathrm{H} 4-12 \mathrm{C}$ & SA & Yes \\
\hline $199-\mathrm{H} 4-13$ & SA & Yes \\
\hline $199-\mathrm{H} 4-14$ & $\mathrm{M}$ & Converted to injection wel \\
\hline 199-H4-15B & SA & Yes \\
\hline $199-\mathrm{H} 4-15 \mathrm{CS}$ & SA & Yes \\
\hline $199-\mathrm{H} 4-16$ & SA & Yes \\
\hline $199-\mathrm{H} 4-45$ & SA & Yes \\
\hline $199-\mathrm{H} 4-46$ & SA & Yes \\
\hline $199-\mathrm{H} 4-48$ & SA & Yes \\
\hline $199-\mathrm{H} 4-49$ & SA & Yes \\
\hline $199-\mathrm{H} 4-5$ & M & Missed 8/2006 \\
\hline $199-\mathrm{H} 4-6$ & SA & Yes \\
\hline $199-\mathrm{H} 4-65$ & $\mathrm{M}$ & No; scheduling error \\
\hline $199-\mathrm{H} 4-7$ & Q & Converted to injection wel \\
\hline $199-\mathrm{H} 4-8$ & SA & Yes \\
\hline $199-\mathrm{H} 5-1 \mathrm{~A}$ & SA & Yes \\
\hline
\end{tabular}

(a) Table based on requirements transmitted to the Groundwater Performance Assessment Project via letter FH-0502977 from RG Gallagher (Fluor Hanford, Inc.) to Dr. LK Peters (Pacific Northwest National Laboratory), Tables Specifying Fluor Hanford Performance Sampling Requirements for Fiscal Year 2006, dated October 12, 2005.

(b) Changes to Fluor Hanford, Inc. letter of instruction during FY 2006.

$\mathrm{FY}=$ Fiscal year.

$M=$ To be sampled monthly.

$\mathrm{Q}=$ To be sampled quarterly.

$\mathrm{SA}=$ To be sampled semiannually. 
Table A.9. Monitoring Wells and Constituents for 100-HR-3 Operable Unit Long-Term Monitoring (100-D and 100-H Area) $)^{(a)}$

\begin{tabular}{|c|c|c|}
\hline Well & Frequency & $\begin{array}{c}\text { Sampled as Scheduled } \\
\text { in FY } 2006\end{array}$ \\
\hline 199-D2-6 & Q & Yes \\
\hline 199-D3-2 & Q & Yes \\
\hline 199-D4-13 & Q & Yes \\
\hline 199-D4-14 & Q & Yes \\
\hline 199-D4-15 & $\mathrm{M}$ & Yes \\
\hline 199-D4-19 & Q & Yes \\
\hline 199-D4-20 & Q & Yes \\
\hline 199-D4-22 & Q & Yes \\
\hline 199-D4-23 & Q & Yes \\
\hline 199-D5-13 & Q & Yes \\
\hline 199-D5-14 & Q & Yes \\
\hline 199-D5-15 & $Q$ & Yes \\
\hline 199-D5-16 & Q & Yes \\
\hline 199-D5-17 & A & Yes \\
\hline 199-D5-18 & $\mathrm{BO}$ & Not scheduled \\
\hline 199-D5-19 & $\mathrm{BO}$ & Not scheduled \\
\hline 199-D5-20 & $Q$ & Yes \\
\hline 199-D5-33 & Q & Yes \\
\hline 199-D5-34 & Q & Yes \\
\hline 199-D5-36 & $Q$ & Yes \\
\hline 199-D5-37 & Q & Yes \\
\hline 199-D5-38 & $\mathrm{M}$ & Yes \\
\hline 199-D5-39 & $M$ & Yes \\
\hline 199-D5-40 & Q & Yes \\
\hline 199-D5-41 & Q & Yes \\
\hline 199-D5-43 & $\mathrm{M}$ & Yes \\
\hline 199-D5-44 & Q & Yes \\
\hline 199-D8-4 & A & Yes \\
\hline 199-D8-54B & A & Yes \\
\hline 199-D8-55 & Q & Yes \\
\hline 199-D8-55 & A & Yes \\
\hline 199-H3-2C & $\mathrm{BO}$ & Not scheduled \\
\hline $199-\mathrm{H} 4-10$ & A & Yes \\
\hline $199-\mathrm{H} 4-12 \mathrm{C}$ & $A$ & Yes \\
\hline $199-\mathrm{H} 4-13$ & A & Yes \\
\hline $199-\mathrm{H} 4-14$ & $\mathrm{BO}$ & Not scheduled \\
\hline $199-\mathrm{H} 4-16$ & $\mathrm{BO}$ & Not scheduled \\
\hline $199-\mathrm{H} 4-17$ & $\mathrm{BO}$ & Not scheduled \\
\hline $199-\mathrm{H} 4-45$ & $\mathrm{~A}$ & Yes \\
\hline $199-\mathrm{H} 4-46$ & $\mathrm{BO}$ & Not scheduled \\
\hline $199-\mathrm{H} 4-47$ & $\mathrm{BE}$ & Yes \\
\hline $199-\mathrm{H} 4-48$ & $\mathrm{BE}$ & Yes \\
\hline $199-\mathrm{H} 4-49$ & $\mathrm{BE}$ & Yes \\
\hline
\end{tabular}


Table A.9. (contd)

\begin{tabular}{|c|c|c|}
\hline Well & Frequency & $\begin{array}{l}\text { Sampled as Scheduled } \\
\text { in FY } 2006\end{array}$ \\
\hline $199-\mathrm{H} 4-5$ & A & Yes \\
\hline $199-\mathrm{H} 4-6$ & $\mathrm{BO}$ & Not scheduled \\
\hline $199-\mathrm{H} 4-7$ & $A$ & Yes \\
\hline $199-\mathrm{H} 4-8$ & $\mathrm{BO}$ & Not scheduled \\
\hline $199-\mathrm{H} 4-9$ & $\mathrm{BE}$ & Yes \\
\hline $199-\mathrm{H} 5-1 \mathrm{~A}$ & $\mathrm{BE}$ & Yes \\
\hline $199-\mathrm{H} 6-1$ & $A$ & Yes \\
\hline $699-85-40 \mathrm{~A}$ & $\mathrm{~A}$ & No; dry $^{(b)}$ \\
\hline $699-86-42$ & A & Yes \\
\hline $699-87-42 A$ & $A$ & Yes \\
\hline 699-88-41 & $A$ & Yes \\
\hline 699-90-38 & $A$ & No; dry ${ }^{(b)}$ \\
\hline $699-90-45$ & A & Yes \\
\hline $699-91-46 A$ & $\mathrm{BE}$ & Yes \\
\hline $699-92-49$ & A & No; dry ${ }^{(b)}$ \\
\hline $699-93-48 A$ & $\mathrm{BE}$ & Yes \\
\hline $699-96-43$ & $\mathrm{~A}$ & Not scheduled $^{(\mathrm{c})}$ \\
\hline $699-96-49$ & $A$ & Not scheduled $^{(\mathrm{c})}$ \\
\hline $699-97-51 \mathrm{~A}$ & $A$ & Yes \\
\hline $699-98-49 A$ & $A$ & Yes \\
\hline SD-102-1 & A & Yes \\
\hline SD-110-1 & A & Yes \\
\hline SD-110-2 & A & Yes \\
\hline SD-98-1 & A & Yes \\
\hline $\mathrm{SH}-144-1$ & A & Yes \\
\hline $\mathrm{SH}-145-1$ & A & No \\
\hline $\mathrm{SH}-150-1$ & A & Yes \\
\hline $\mathrm{SH}-152-2$ & A & Yes \\
\hline $\mathrm{SH}-153-1$ & $\mathrm{~A}$ & No \\
\hline \multicolumn{3}{|c|}{$\begin{array}{l}\text { (a) Table based on requirements transmitted to the Groundwater } \\
\text { Performance Assessment Project via letter FH-0502977 from } \\
\text { RG Gallagher (Fluor Hanford, Inc.) to Dr. LK Peters (Pacific } \\
\text { Northwest National Laboratory), Tables Specifying Fluor Hanford } \\
\text { Performance Sampling Requirements for Fiscal Year 2006, dated } \\
\text { October 12, 2005. } \\
\text { (b) Wells not schedule before FY 2006; found to be dry. Not } \\
\text { included in dry well table in document summary. } \\
\text { (c) LOI footnote indicated BO, although frequency listed as A. } \\
\text { A = To be sampled annually. } \\
\text { BE = To be sampled biennially, even fiscal year. } \\
\text { BO = To be sampled biennially, odd fiscal year. } \\
\text { FY = Fiscal year. } \\
\text { LOI = Letter of instruction. } \\
M=\text { To be sampled monthly. } \\
\text { Q = To be sampled quarterly. }\end{array}$} \\
\hline
\end{tabular}


Table A.10. Monitoring Wells, Aquifer Tubes, and Constituents the 100-FR-3 Operable Unit (adapted from DOE/RL-2003-49)

\begin{tabular}{|c|c|c|c|c|c|c|c|c|c|c|}
\hline Well & 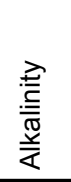 & $\begin{array}{l}\frac{\pi}{0} \\
\frac{0}{2}\end{array}$ & 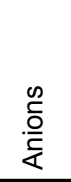 & 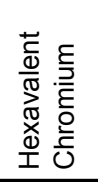 & $\begin{array}{l}\frac{\infty}{\frac{\pi}{\pi}} \\
\frac{\pi}{0} \\
\end{array}$ & 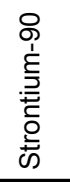 & 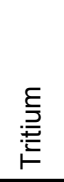 & 山己 & 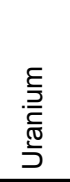 & $\begin{array}{c}\text { Sampled as Scheduled } \\
\text { in FY } 2006\end{array}$ \\
\hline 199-F1-2 & $\mathrm{BO}$ & & $\mathrm{BO}$ & & $\mathrm{BO}$ & & & & & Not scheduled \\
\hline $199-F 5-1$ & A & $\mathrm{BE}$ & A & & A & $\mathrm{BE}$ & $\mathrm{BE}$ & & & Yes \\
\hline $199-F 5-4$ & A & $\mathrm{BO}$ & A & & A & & BO & BO & & Yes \\
\hline 199-F5-42 & $\mathrm{BO}$ & $\mathrm{BO}$ & BO & & BO & BO & BO & & & Not scheduled \\
\hline 199-F5-43A & $\mathrm{BE}$ & $\mathrm{BE}$ & $\mathrm{BE}$ & & $\mathrm{BE}$ & $\mathrm{BE}$ & $\mathrm{BE}$ & & & Yes \\
\hline 199-F5-43B & $\mathrm{BE}$ & $\mathrm{BE}$ & $\mathrm{BE}$ & & $\mathrm{BE}$ & $\mathrm{BE}$ & & & & Yes \\
\hline 199-F5-44 & $\mathrm{BE}$ & $\mathrm{BE}$ & $\mathrm{BE}$ & & $\mathrm{BE}$ & $\mathrm{BE}$ & $\mathrm{BE}$ & & & Yes \\
\hline 199-F5-45 & $\mathrm{BO}$ & $\mathrm{BO}$ & $\mathrm{BO}$ & & BO & $\mathrm{BO}$ & BO & $\mathrm{BO}$ & $\mathrm{BO}$ & Not scheduled \\
\hline 199-F5-46 & $\mathrm{BE}$ & A & $\mathrm{BE}$ & & BE & $\mathrm{BE}$ & A & BE & A & Yes \\
\hline $199-F 5-47$ & A & $\mathrm{BE}$ & A & & $\mathrm{A}$ & & $A$ & $\mathrm{BE}$ & A & Yes \\
\hline 199-F5-48 & $\mathrm{BO}$ & $\mathrm{BO}$ & $\mathrm{BO}$ & & BO & & BO & & $\mathrm{BO}$ & Not scheduled \\
\hline $199-F 5-6$ & A & $\mathrm{BE}$ & A & & A & $\mathrm{BE}$ & $\mathrm{BE}$ & & & Yes \\
\hline 199-F6-1 & $\mathrm{BO}$ & $\mathrm{BO}$ & $\mathrm{BO}$ & & $\mathrm{BO}$ & $\mathrm{BO}$ & BO & & & Not scheduled \\
\hline $199-F 7-1$ & $\mathrm{BE}$ & & $\mathrm{BE}$ & & BE & & & BE & & Yes \\
\hline 199-F7-2 & $\mathrm{BE}$ & $\mathrm{BE}$ & $\mathrm{BE}$ & & $\mathrm{BE}$ & & $\mathrm{BE}$ & $\mathrm{BE}$ & & Yes \\
\hline 199-F7-3 & $\mathrm{BE}$ & $\mathrm{BE}$ & $\mathrm{BE}$ & & $\mathrm{BE}$ & & $\mathrm{BE}$ & $\mathrm{BE}$ & & Yes \\
\hline 199-F8-2 & $\mathrm{BO}$ & $\mathrm{BO}$ & $\mathrm{BO}$ & & BO & & $\mathrm{BO}$ & & $\mathrm{BO}$ & Not scheduled \\
\hline 199-F8-3 & BO & A & BO & & BO & & A & BO & A & Yes \\
\hline 199-F8-4 & $\mathrm{BE}$ & A & $\mathrm{BE}$ & & $\mathrm{BE}$ & & $\mathrm{BE}$ & & A & Yes \\
\hline $699-58-24$ & $\mathrm{BE}$ & & $\mathrm{BE}$ & & $\mathrm{BE}$ & & & & & Yes \\
\hline $699-60-32$ & BO & & BO & & BO & & & & & Not scheduled \\
\hline $699-62-31$ & BO & & BO & & BO & & & & & Not scheduled \\
\hline $699-62-43 F$ & A & & A & & A & & A & & & Yes \\
\hline 699-63-25A & BO & & BO & & BO & & BO & & & Not scheduled \\
\hline 699-63-55 & $\mathrm{BO}$ & & $\mathrm{BO}$ & & BO & & A & & & Yes \\
\hline $699-64-27$ & $\mathrm{BE}$ & & $\mathrm{BE}$ & & $\mathrm{BE}$ & & & & & Yes \\
\hline $699-66-23$ & $\mathrm{BE}$ & & $\mathrm{BE}$ & & BE & & $\mathrm{BE}$ & & & Yes \\
\hline $699-67-51$ & $\mathrm{BO}$ & & $\mathrm{BO}$ & & BO & & BO & & & Not scheduled \\
\hline 699-71-30 & $\mathrm{BO}$ & $\mathrm{BO}$ & $\mathrm{BO}$ & & BO & & BO & & & Not scheduled \\
\hline 699-74-44 & $\mathrm{BO}$ & & $\mathrm{BO}$ & & BO & & & BO & & Not scheduled \\
\hline $699-77-36$ & BE & & $\mathrm{BE}$ & & BE & & & BE & & Yes \\
\hline $699-77-54$ & $\mathrm{BO}$ & & $\mathrm{BO}$ & & BO & & & & & Not scheduled \\
\hline 699-81-38 & $\mathrm{BE}$ & & BE & & BE & & & & & Yes \\
\hline 699-83-47 & BE & & BE & & BE & & & BE & & Yes \\
\hline AT-62 & $\mathrm{A}$ & & A & A & A & & & & & Yes \\
\hline AT-63 & A & & A & A & A & & & & & Yes \\
\hline AT-64 & A & & A & A & A & A & & & & Yes \\
\hline AT-65 & A & & A & A & A & A & & & & Yes \\
\hline AT-66 & A & & A & A & $\mathrm{A}$ & A & & A & & Yes \\
\hline
\end{tabular}


Table A.10. (contd)

\begin{tabular}{|c|c|c|c|c|c|c|c|c|c|c|}
\hline Well & 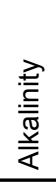 & $\begin{array}{l}\frac{\pi}{0} \\
\frac{0}{2} \\
\end{array}$ & 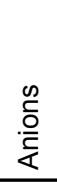 & 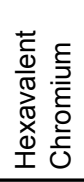 & $\frac{\frac{\omega}{\pi}}{\frac{\pi}{0}}$ & 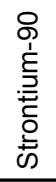 & 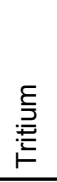 & 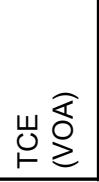 & 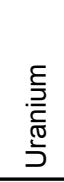 & $\begin{array}{l}\text { Sampled as Scheduled } \\
\text { in FY } 2006\end{array}$ \\
\hline AT-67 & $\mathrm{A}$ & & A & A & A & & & & & Yes \\
\hline AT-68 & A & & A & A & A & & A & & & $\mathrm{No}^{(a)}$ \\
\hline AT-72 & $\mathrm{A}$ & & $\mathrm{A}$ & A & $\mathrm{A}$ & & A & & & Yes \\
\hline AT-73 & A & & A & A & A & & A & & & $\mathrm{No}^{(\mathrm{a})}$ \\
\hline AT-74 & $\mathrm{A}$ & & A & A & A & & A & & & Yes \\
\hline AT-75 & $\mathrm{A}$ & & A & A & A & & $A$ & & & $\mathrm{No}^{(\mathrm{a})}$ \\
\hline AT-76 & $\mathrm{A}$ & & A & A & $\mathrm{A}$ & & $\mathrm{A}$ & & & Yes \\
\hline AT-77 & A & & A & A & A & & & & & $\mathrm{No}^{(\mathrm{a})}$ \\
\hline AT-78 & A & & A & A & A & & & & & $\mathrm{No}^{(\mathrm{a})}$ \\
\hline AT-80 & A & & A & A & A & & & & & $\mathrm{No}^{(\mathrm{a})}$ \\
\hline AT-F-1 & $\mathrm{A}$ & & $\mathrm{A}$ & A & $\mathrm{A}$ & $\mathrm{A}$ & & & & Yes \\
\hline AT-F-2 & A & & A & A & A & & A & A & & Yes \\
\hline AT-F-3 & A & & A & A & A & & A & A & & Yes \\
\hline AT-F-4 & A & & A & A & A & & A & & & Yes \\
\hline SF-187-1 & A & & A & A & A & & A & & & $\mathrm{No}^{(\mathrm{a})}$ \\
\hline SF-190-4 & A & & A & A & A & & $A$ & & & $\mathrm{No}^{(\mathrm{a})}$ \\
\hline SF-207-1 & A & & A & A & A & & A & & & No alkalinity \\
\hline \multicolumn{11}{|c|}{$\begin{array}{l}\text { (a) Sampling of aquifer tubes and springs depen } \\
A=\text { To be sampled annually. } \\
\text { BE = To be sampled biennially, even fiscal year } \\
\text { BO = To be sampled biennially, odd fiscal year } \\
\text { FY = Fiscal year. } \\
\text { TCE = Trichloroethene. } \\
\text { VOA = Volatile organic analyses. }\end{array}$} \\
\hline
\end{tabular}


Table A.11. Monitoring Wells and Constituents for 200-ZP-1 Operable Unit ${ }^{(a)}$

\begin{tabular}{|c|c|c|}
\hline Well & Frequency & $\begin{array}{l}\text { Sampled as Scheduled } \\
\text { in FY } 2006\end{array}$ \\
\hline $299-W 10-1$ & $\bar{A}$ & Yes \\
\hline 299-W10-13 & $\mathrm{BO}$ & No; dry \\
\hline 299-W10-20 & $\mathrm{BO}$ & Not scheduled \\
\hline 299-W10-21 & A & No; dry FY 2005 \\
\hline 299-W10-22 & SA & Yes \\
\hline 299-W10-23 & A & Yes \\
\hline 299-W10-4 & SA & Yes \\
\hline 299-W10-5 & A & Delayed until 11/2006 \\
\hline 299-W11-10 & SA & Yes \\
\hline 299-W11-13 & SA & Second delayed until 11/2006 \\
\hline 299-W11-14 & SA & No; dry \\
\hline 299-W11-18 & A & Yes \\
\hline 299-W11-3 & SA & Second delayed until 10/2006 \\
\hline 299-W11-37 & SA & Yes \\
\hline 299-W11-43 & Q & $\begin{array}{l}\text { Inadvertently not scheduled until 03/2006; } \\
\text { sampled once FY 2006; once 10/06 }\end{array}$ \\
\hline 299-W11-6 & SA & Second delayed until 10/2006 \\
\hline 299-W11-7 & A & Yes \\
\hline 299-W12-1 & A & Delayed until 10/2006 \\
\hline 299-W13-1 & Q & Yes \\
\hline 299-W14-13 & A & Added to schedule ${ }^{(b)}$ \\
\hline 299-W14-14 & A & Yes \\
\hline 299-W14-16 & A & Yes \\
\hline 299-W15-1 & SA & Yes \\
\hline 299-W15-11 & SA & Yes \\
\hline 299-W15-15 & Q & Sampled twice ${ }^{(b)}$ \\
\hline 299-W15-17 & SA & Yes \\
\hline 299-W15-2 & A & Yes \\
\hline 299-W15-30 & SA & Yes \\
\hline 299-W15-31A & Q & Sampled three times ${ }^{(b)}$ \\
\hline 299-W15-34 & Q & Sampled once ${ }^{(b)}$ \\
\hline 299-W15-35 & Q & Sampled twice ${ }^{(b)}$ \\
\hline 299-W15-36 & Q & Sampled once ${ }^{(b)}$ \\
\hline 299-W15-38 & A & No; scheduling error. \\
\hline 299-W15-39 & SA & Second delayed until 10/2006 \\
\hline 299-W15-40 & Q & Sampled twice ${ }^{(b)}$ \\
\hline 299-W15-41 & SA & Yes \\
\hline 299-W15-42 & SA & Yes \\
\hline 299-W15-43 & Q & Sampled once ${ }^{(b)}$ \\
\hline 299-W15-44 & Q & Yes \\
\hline 299-W15-45 & Q & Yes \\
\hline 299-W15-46 & Q & Sampled three times ${ }^{(b)}$ \\
\hline 299-W15-47 & Q & Missed third \\
\hline 299-W15-49 & Q & Yes \\
\hline
\end{tabular}


Table A.11. (contd)

\begin{tabular}{|c|c|c|}
\hline Well & Frequency & $\begin{array}{l}\text { Sampled as Scheduled } \\
\text { in FY } 2006\end{array}$ \\
\hline $299-W 15-50$ & $Q$ & Yes \\
\hline 299-W15-152 & Q & $\begin{array}{c}\text { No; scheduling error. Sampled twice for other } \\
\text { projects. }\end{array}$ \\
\hline 299-W15-60 & A & Added to schedule ${ }^{(b)}$ \\
\hline 299-W15-763 & Q & Yes \\
\hline 299-W15-765 & Q & Yes \\
\hline 299-W15-7 & SA & Yes \\
\hline 299-W17-1 & SA & Yes \\
\hline 299-W18-16 & Q & Yes \\
\hline 299-W18-23 & Q & Yes \\
\hline 299-W6-10 & A & No; dry \\
\hline 299-W7-12 & $\mathrm{BO}$ & Not scheduled \\
\hline 299-W7-4 & A & Delayed until 10/2006 \\
\hline 299-W8-1 & $\mathrm{BE}$ & Delayed until 11/2006 \\
\hline $699-43-89$ & $\mathrm{BO}$ & Not scheduled \\
\hline $699-44-64$ & $\mathrm{BO}$ & Not scheduled \\
\hline $699-45-69 A$ & $\mathrm{BO}$ & Not scheduled \\
\hline $699-47-60$ & $\mathrm{BO}$ & Not scheduled \\
\hline $699-48-71$ & SA & Second delayed until 11/2006 \\
\hline $699-48-77 A$ & $\mathrm{BO}$ & $\begin{array}{l}\text { Sampled even though Fluor Hanford, Inc. } \\
\text { letter specified odd FY }\end{array}$ \\
\hline $699-50-74$ & Q & $\begin{array}{l}\text { New well, sampled once FY 2006; once } \\
\qquad 11 / 2006\end{array}$ \\
\hline $699-55-60 A$ & $\mathrm{BO}$ & Not scheduled \\
\hline \multicolumn{3}{|c|}{$\begin{array}{l}\text { (a) Table based on requirements transmitted to the Groundwater Performance } \\
\text { Assessment Project via letter FH-0502977 from RG Gallagher (Fluor Hanford, } \\
\text { Inc.) to Dr. LK Peters (Pacific Northwest National Laboratory), Tables Specifying } \\
\text { Fluor Hanford Performance Sampling Requirements for Fiscal } \\
\text { Year } 2006 \text {, dated October } 12,2005 \text {. } \\
\text { (b) Changes to Fluor Hanford, Inc. letter of instruction during FY } 2006 . \\
\text { A = To be sampled annually. } \\
\text { BE = To be sampled biennially, even fiscal year. } \\
\text { BO = To be sampled biennially, odd fiscal year. } \\
\text { FY = Fiscal year. } \\
Q=\text { To be sampled quarterly. } \\
\text { SA = To be sampled semiannually. }\end{array}$} \\
\hline
\end{tabular}


Table A.12. Monitoring Wells and Constituents for 200-UP-1 Operable Unit ${ }^{(\mathrm{a})}$

\begin{tabular}{|c|c|c|}
\hline Well & Frequency & $\begin{array}{c}\text { Sampled as Scheduled } \\
\text { in FY } 2006\end{array}$ \\
\hline 299-W15-37 & $\bar{A}$ & Yes \\
\hline 299-W18-15 & SA & Yes \\
\hline 299-W18-21 & A & Yes \\
\hline 299-W18-22 & A & Yes \\
\hline 299-W18-30 & A & Yes \\
\hline 299-W18-33 & A & No; access problem \\
\hline 299-W19-101 & Q & Yes \\
\hline 299-W19-105 & A & Added to schedule; ${ }^{(b)}$ delayed until $10 / 2006$ \\
\hline 299-W19-107 & A & Added to schedule; ${ }^{(\mathrm{b})}$ delayed until FY 2007 \\
\hline 299-W19-18 & SA & Second delayed until 10/2006 \\
\hline 299-W19-34A & A & Yes \\
\hline 299-W19-34B & $\mathrm{BE}$ & No; pump problem \\
\hline 299-W19-35 & SA & Second delayed until 11/2006 \\
\hline 299-W19-36 & SA & Yes \\
\hline 299-W19-37 & SA & Yes \\
\hline 299-W19-39 & SA & Yes \\
\hline 299-W19-4 & $\mathrm{BO}$ & Not scheduled \\
\hline 299-W19-40 & A & No; sample dry \\
\hline 299-W19-43 & SA & Yes \\
\hline 299-W19-46 & SA & Yes \\
\hline 299-W19-48 & Q & Yes \\
\hline 299-W19-49 & Q & Yes \\
\hline 299-W21-2 & Q & New well; sampled once ${ }^{(\mathrm{b})}$ \\
\hline $299-W 22-20$ & A & Yes \\
\hline 299-W22-26 & A & Yes \\
\hline 299-W22-45 & A & Delayed until 11/2006 \\
\hline 299-W22-48 & SA & Second delayed until 10/2006 \\
\hline 299-W22-49 & SA & Second delayed until 10/2006 \\
\hline 299-W22-69 & A & Added to schedule; ${ }^{(b)}$ delayed until $10 / 2006$ \\
\hline 299-W22-72 & A & Added to schedule; ${ }^{(b)}$ delayed until $10 / 2006$ \\
\hline 299-W22-83 & Q & Fourth delayed until $10 / 2006$ \\
\hline 299-W22-86 & A & Added to schedule; ${ }^{(b)}$ delayed until $10 / 2006$ \\
\hline 299-W22-9 & $\mathrm{BO}$ & Not scheduled \\
\hline 299-W23-10 & SA & Sampled once; no water second time \\
\hline 299-W23-14 & A & No; dry FY 2003 \\
\hline 299-W23-15 & SA & Second delayed until 11/2006 \\
\hline 299-W23-21 & Q & Fourth delayed until FY 2007 \\
\hline 299-W23-4 & SA & Yes \\
\hline 299-W23-9 & A & Yes \\
\hline 299-W26-13 & $\mathrm{BO}$ & Not scheduled \\
\hline 299-W26-14 & A & Yes \\
\hline $699-30-66$ & Q & New well; sampled twice in FY 2006 \\
\hline $699-32-62$ & $\mathrm{BO}$ & Not scheduled \\
\hline $699-32-72 A$ & $\mathrm{BO}$ & Not scheduled \\
\hline
\end{tabular}


Table A.12. (contd)

\begin{tabular}{|c|c|c|}
\hline Well & Frequency & $\begin{array}{c}\text { Sampled as Scheduled } \\
\text { in FY } 2006\end{array}$ \\
\hline $699-35-66 \mathrm{~A}$ & $\mathrm{BO}$ & Not scheduled \\
\hline $699-35-70$ & $\mathrm{BO}$ & Not scheduled \\
\hline 699-35-78A & A & Delayed until FY 2007 \\
\hline $699-36-61 \mathrm{~A}$ & A & Added to schedule; ${ }^{(b)}$ delayed until $10 / 2006$ \\
\hline 699-36-61A & $\mathrm{BO}$ & Not scheduled \\
\hline 699-36-70A & A & Yes \\
\hline 699-36-70B & Q & New well; sampled three times \\
\hline $699-38-65$ & A & Delayed until 11/2006 \\
\hline $699-38-68 A$ & $\mathrm{BO}$ & Not scheduled \\
\hline $699-38-70$ & A & Delayed until 11/2006 \\
\hline 699-38-70B & Q & Yes \\
\hline 699-38-70C & Q & Yes \\
\hline $699-40-62$ & $\mathrm{BO}$ & Not scheduled \\
\hline $699-40-65$ & Q & Sampled three times ${ }^{(b)}$ \\
\hline
\end{tabular}

(a) Table based on requirements transmitted to the Groundwater Performance Assessment Project via letter FH-0502977 from RG Gallagher (Fluor Hanford, Inc.) to Dr. LK Peters (Pacific Northwest National Laboratory), Tables Specifying Fluor Hanford Performance Sampling Requirements for Fiscal Year 2006, dated October 12, 2005.

(b) Changes to Fluor Hanford, Inc. letter of instruction during FY 2006.

$A=$ To be sampled annually.

$\mathrm{BE}=$ To be sampled biennially, even fiscal year.

$\mathrm{BO}=$ To be sampled biennially, odd fiscal year.

$\mathrm{FY}=$ Fiscal year

$\mathrm{Q}=$ To be sampled quarterly.

$\mathrm{SA}=$ To be sampled semiannually. 
Table A.13. Monitoring Wells and Constituents for 200-BP-5 Operable Unit (adapted from DOE/RL-2001-49)

\begin{tabular}{|c|c|c|c|c|c|c|c|c|c|c|c|c|c|c|c|c|c|c|}
\hline \multirow[b]{2}{*}{ Well Name } & \multicolumn{10}{|c|}{ Contaminants of Concern } & \multicolumn{7}{|c|}{ Supporting Constituents/Measurements } & \multirow[b]{2}{*}{$\begin{array}{l}\text { Sampled as } \\
\text { Scheduled in } \\
\text { FY } 2006\end{array}$} \\
\hline & 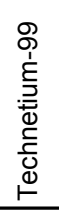 & 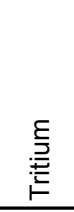 & 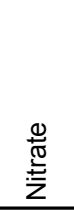 & 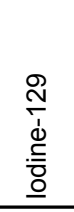 & $\begin{array}{l}\frac{0}{0} \\
\frac{0}{\bar{T}} \\
0 \\
0 \\
0\end{array}$ & $\begin{array}{l}8 \\
\frac{0}{\pi} \\
\frac{1}{0} \\
0 \\
0 \\
\end{array}$ & 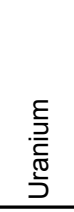 & 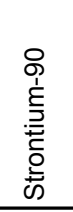 & 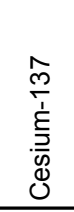 & 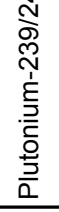 & $\begin{array}{l}\text { 蒿 } \\
\frac{\overline{\bar{E}}}{\bar{\sigma}} \\
\text { 产 } \\
\end{array}$ & 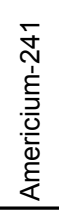 & 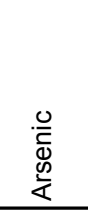 & 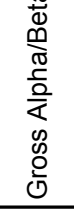 & 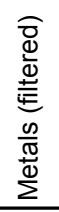 & 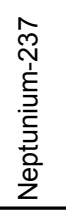 & $\begin{array}{l}x \\
\text { o } \\
\text { S. } \\
\text { o } \\
⺊ \\
\end{array}$ & \\
\hline 299-E24-8 & & $3-07$ & 3-07 & $3-07$ & & $3-07$ & & & $3-07$ & & & & $3-07$ & $3-07$ & & & & Not scheduled \\
\hline 299-E26-10 & & A & A & A & & & & & & & & & & & & & & Yes \\
\hline 299-E26-11 & & $3-07$ & 3-07 & $3-07$ & & & & & & & & & 3-07 & & & & & Not scheduled \\
\hline 299-E27-10 & & $3-07$ & 3-07 & $3-07$ & & & & & & & & & $3-07$ & & & & & Not scheduled \\
\hline 299-E27-14 & A & $A$ & A & $A$ & & & & & & & & & & & & & & Yes \\
\hline 299-E27-15 & A & & A & & & & & & & & A & & & & A & & & Yes \\
\hline 299-E27-17 & & $3-07$ & 3-07 & $3-07$ & & & & & & & & & $3-07$ & & & & & Not scheduled \\
\hline 299-E27-18 & & $3-07$ & 3-07 & $3-07$ & & & & & & & & & $3-07$ & & & & & Not scheduled \\
\hline 299-E27-7 & A & A & A & A & & & & & & & & & A & & & & & Yes \\
\hline 299-E28-13 & & $3-07$ & 3-07 & 3-07 & & & $3-07$ & 3-07 & & & & & & $3-07$ & & & & Not scheduled \\
\hline 299-E28-17 & & & A & & & & A & A & A & A & & & & & & & & Yes \\
\hline 299-E28-18 & & A & A & A & & & A & & & & & & A & A & & & & Yes \\
\hline 299-E28-2 & A & A & A & A & & & & A & A & A & A & & & A & A & & & Yes \\
\hline 299-E28-21 & & & & & & & A & & & & & & & & & & & Yes \\
\hline 299-E28-23 & & & & & & & $A$ & A & $A$ & A & & A & & $A$ & & $\mathrm{~A}$ & & Yes \\
\hline 299-E28-24 & & A & & & & & A & A & A & A & & A & & A & & A & & Yes \\
\hline 299-E28-25 & & A & A & A & & & A & A & A & A & & A & A & A & & A & & Yes \\
\hline 299-E28-26 & A & $3-07$ & A & $3-07$ & & & A & & & & & & $3-07$ & & & & & Yes \\
\hline 299-E28-27 & A & $3-07$ & A & A & & & A & A & A & A & & & & & & & & Yes \\
\hline 299-E28-28 & & $3-07$ & 3-07 & $3-07$ & & & & & & & & & & & & & & Not scheduled \\
\hline 299-E28-5 & & $3-07$ & 3-07 & $3-07$ & & & A & A & A & A & & & $3-07$ & $3-07$ & & & & $\begin{array}{l}\text { Delayed until } \\
10 / 2006^{(a)}\end{array}$ \\
\hline 299-E28-6 & & $3-07$ & 3-07 & $3-07$ & & A & A & A & A & A & & & $3-07$ & $3-07$ & & & & Yes \\
\hline 299-E28-8 & A & & & & & & A & A & A & A & & & & & & & & Yes \\
\hline 299-E32-10 & A & $3-07$ & 3-07 & $3-07$ & A & A & $A$ & & & & & & $3-07$ & & & & & Yes \\
\hline 299-E32-2 & & $3-07$ & 3-07 & $3-07$ & & & & & & & & & & & & & & Not scheduled \\
\hline
\end{tabular}


Table A.13. (contd)

\begin{tabular}{|c|c|c|c|c|c|c|c|c|c|c|c|c|c|c|c|c|c|c|}
\hline \multirow[b]{2}{*}{ Well Name } & \multicolumn{10}{|c|}{ Contaminants of Concern } & \multicolumn{7}{|c|}{ Supporting Constituents/Measurements } & \multirow[b]{2}{*}{$\begin{array}{l}\text { Sampled as } \\
\text { Scheduled in } \\
\text { FY } 2006\end{array}$} \\
\hline & 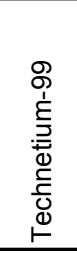 & 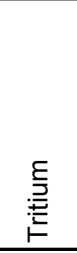 & 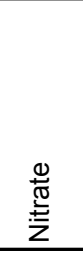 & 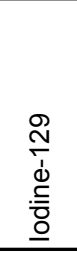 & $\begin{array}{l}\frac{0}{0} \\
\frac{0}{\mathbb{T}} \\
\text { J } \\
\end{array}$ & $\begin{array}{l}8 \\
0 \\
\frac{1}{\pi} \\
\frac{0}{0} \\
0\end{array}$ & 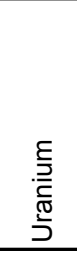 & 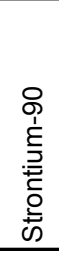 & $\begin{array}{l}\hat{m} \\
\frac{m}{\xi} \\
\frac{5}{D} \\
0 \\
0\end{array}$ & 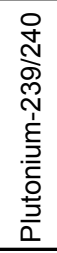 & 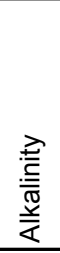 & 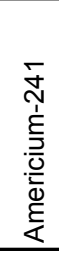 & 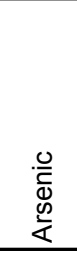 & 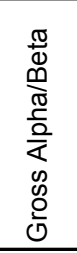 & 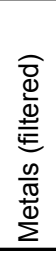 & 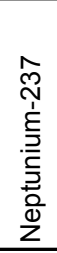 & $\begin{array}{l}\stackrel{一}{O} \\
\stackrel{6}{0} \\
\stackrel{\circ}{-} \\
\end{array}$ & \\
\hline 299-E32-4 & A & A & A & $\mathrm{A}$ & & & & & & & & & & & & & & Yes \\
\hline 299-E32-5 & & $3-07$ & $3-07$ & $3-07$ & & & $3-07$ & & & & & & & & & & & Not scheduled \\
\hline 299-E32-6 & A & $3-07$ & A & $3-07$ & & & $3-07$ & & & & & & & & & & & Yes \\
\hline 299-E32-7 & & $3-07$ & $3-07$ & $3-07$ & & & & & & & & & & & & & & Not scheduled \\
\hline 299-E32-8 & & $3-07$ & $3-07$ & $3-07$ & & & & & & & & & & & & & & Not scheduled \\
\hline 299-E32-9 & & $3-07$ & A & A & $3-07$ & & & & & & & & & & & & & Yes \\
\hline 299-E33-12 & $3-07$ & & & & & & & & & & & & & & & & & Not scheduled \\
\hline 299-E33-13 & & & & & A & & A & & & & & & & & & & & Yes \\
\hline 299-E33-15 & A & & A & & & & & & & & & & & & & & & Yes \\
\hline 299-E33-16 & A & & A & A & & & A & & & & & & & & & & & Yes \\
\hline 299-E33-18 & $A$ & & $A$ & A & & & A & & & & & & & & & & & Yes \\
\hline 299-E33-26 & $A$ & $3-07$ & $3-07$ & $3-07$ & A & A & A & & & & & & & $3-07$ & & & & Yes \\
\hline 299-E33-28 & A & & A & & & & & & & & & & & & & & & Yes \\
\hline 299-E33-29 & $3-07$ & $3-07$ & $3-07$ & $3-07$ & & & & & & & & & & & & & & Not scheduled \\
\hline 299-E33-30 & A & & $A$ & & & & & & & & & & & & & & & Yes \\
\hline 299-E33-32 & $3-07$ & $3-07$ & $3-07$ & $3-07$ & & & & & & & & & & & & & & Not scheduled \\
\hline 299-E33-33 & & $3-07$ & $3-07$ & $3-07$ & & & $3-07$ & & & & & & $3-07$ & & & & & Not scheduled \\
\hline 299-E33-334 & $A$ & & A & & & & $A$ & & & & & & & & & & & Yes \\
\hline 299-E33-335 & A & & & & & & & & & $A$ & & & & & & & & Yes \\
\hline 299-E33-338 & $A$ & & & & & & $A$ & & & & & & & & & & & Yes \\
\hline 299-E33-34 & A & A & A & A & $A$ & A & A & & & & & & & & & & & Yes \\
\hline 299-E33-35 & A & $3-07$ & A & $3-07$ & A & $3-07$ & A & & $3-07$ & & & & & & & & & Yes \\
\hline 299-E33-37 & & $3-07$ & $3-07$ & $3-07$ & & & & & & & & & & & & & & Not scheduled \\
\hline 299-E33-38 & A & A & A & A & A & A & A & A & & A & & & A & A & & & & Yes \\
\hline 299-E33-39 & $A$ & A & $A$ & $A$ & A & & $A$ & & & & & & & & & & & Yes \\
\hline
\end{tabular}


Table A.13. (contd)

\begin{tabular}{|c|c|c|c|c|c|c|c|c|c|c|c|c|c|c|c|c|c|c|}
\hline \multirow[b]{2}{*}{ Well Name } & \multicolumn{10}{|c|}{ Contaminants of Concern } & \multicolumn{7}{|c|}{ Supporting Constituents/Measurements } & \multirow[b]{2}{*}{$\begin{array}{l}\text { Sampled as } \\
\text { Scheduled in } \\
\text { FY } 2006\end{array}$} \\
\hline & 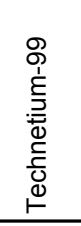 & 点 & 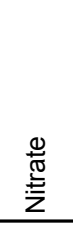 & 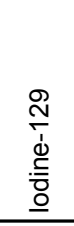 & 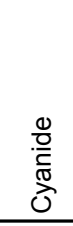 & $\begin{array}{l}8 \\
\frac{0}{\pi} \\
\frac{1}{\pi} \\
0 \\
0 \\
\end{array}$ & 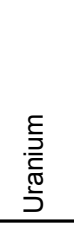 & 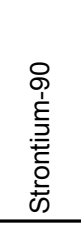 & 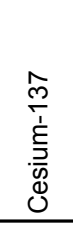 & 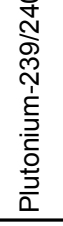 & 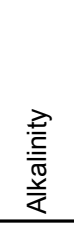 & 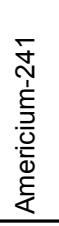 & 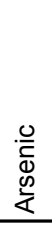 & 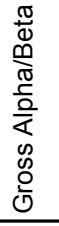 & 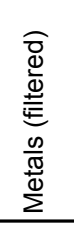 & 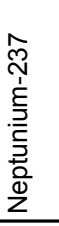 & $\begin{array}{l}x \\
\text { o } \\
\text { 仓ิ } \\
\text { o } \\
\end{array}$ & \\
\hline 299-E33-41 & A & $3-07$ & 3-07 & $3-07$ & 3-07 & 3-07 & A & & $3-07$ & & & & & & & & & Yes \\
\hline 299-E33-42 & A & & & A & & & A & & & & & & & & & & & Yes \\
\hline 299-E33-43 & A & & & A & & & A & & & & & & & & & & & Yes \\
\hline 299-E33-44 & A & & & & & A & A & & & & & & & & & & & Yes \\
\hline 299-E33-7 & A & A & A & A & A & A & A & & A & & & & & A & & & & Yes \\
\hline 299-E34-2 & & A & A & A & & & & & & & & & & & & & & Yes \\
\hline 299-E34-5 & & 3-07 & 3-07 & $3-07$ & & & & & & & & & & & & & & Not scheduled \\
\hline 299-E34-7 & & A & A & & & & & & & & & & & A & & & & No; dry FY 2005 \\
\hline 299-E34-9 & & 3-07 & 3-07 & $3-07$ & & & & & & & & & & & & & & Not scheduled \\
\hline $699-44-39 B$ & & 3-07 & 3-07 & $3-07$ & & & & & & & & & & & & & & Not scheduled \\
\hline $699-45-42$ & & 3-07 & 3-07 & $3-07$ & & & & & & & & & & & & & & Not scheduled \\
\hline $699-47-60$ & A & A & A & A & & & & & & & & & & & & & & $\begin{array}{l}\text { Delayed until } \\
11 / 2006^{(a)}\end{array}$ \\
\hline $699-49-55 A$ & A & A & A & A & A & A & A & A & A & A & & & & A & & & & Yes \\
\hline 699-49-57A & A & A & A & A & A & A & A & & A & & & & A & & & & & Yes \\
\hline 699-49-57B & A & A & A & A & A & A & & & A & & & & & & & & & Yes \\
\hline $699-50-59$ & $3-06$ & & 3-06 & $3-06$ & & $3-06$ & 3-06 & & & & $3-06$ & & & & 3-06 & & & Yes \\
\hline 699-53-47A & & A & A & & & & & A & & & & & & A & & & & Yes \\
\hline 699-53-47B & & & 3-06 & & & & & 3-06 & & & & & & & & & & $\begin{array}{l}\text { Delayed until } \\
11 / 2006^{(a)}\end{array}$ \\
\hline $699-53-48 A$ & & A & A & A & & & & A & & & & & & A & A & & & Yes \\
\hline $699-53-55 \mathrm{~A}$ & A & A & A & & A & A & & & & & & & & & & & & Yes \\
\hline 699-53-55B & A & A & A & & A & A & & & & & & & & & & & & Yes \\
\hline $699-53-55 \mathrm{C}$ & A & A & A & A & A & A & & & & & & & & & & & & Yes \\
\hline $699-54-45 A$ & & & 3-06 & & & & & & & & & & & & & & & $\begin{array}{l}\text { Delayed until } \\
11 / 2006^{(a)}\end{array}$ \\
\hline 699-54-45B & & & 3-06 & & & & & & & & & & & & & & & $\begin{array}{l}\text { Delayed until } \\
12 / 2006^{(a)}\end{array}$ \\
\hline
\end{tabular}


Table A.13. (contd)

\begin{tabular}{|c|c|c|c|c|c|c|c|c|c|c|c|c|c|c|c|c|c|c|}
\hline \multirow[b]{2}{*}{ Well Name } & \multicolumn{10}{|c|}{ Contaminants of Concern } & \multicolumn{7}{|c|}{ Supporting Constituents/Measurements } & \multirow[b]{2}{*}{$\begin{array}{l}\text { Sampled as } \\
\text { Scheduled in } \\
\text { FY } 2006\end{array}$} \\
\hline & 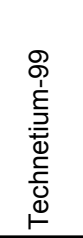 & 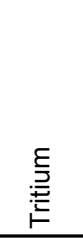 & 养 & 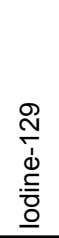 & $\begin{array}{l}\frac{0}{0} \\
\frac{0}{E} \\
\frac{0}{0} \\
0\end{array}$ & $\begin{array}{l}8 \\
0 \\
\frac{1}{\pi} \\
00 \\
0 \\
0\end{array}$ & 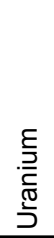 & 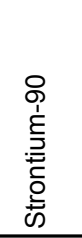 & 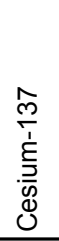 & 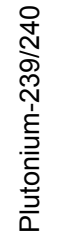 & 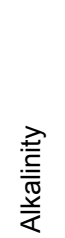 & 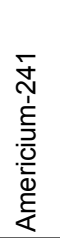 & 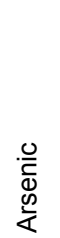 & 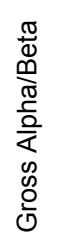 & 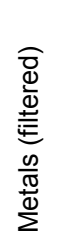 & 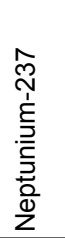 & $\begin{array}{l}\stackrel{x}{o} \\
\stackrel{5}{0} \\
\text { O } \\
⺊\end{array}$ & \\
\hline $699-54-48$ & & & & & & & & $3-06$ & & & & & & & & & & $\begin{array}{l}\text { Delayed until } \\
11 / 2006^{(a)}\end{array}$ \\
\hline $699-54-49$ & & A & A & & & & & A & & & & & & A & & & & $\begin{array}{l}\text { Delayed until } \\
10 / 2006^{(a)}\end{array}$ \\
\hline $699-55-50 \mathrm{C}$ & $A$ & $A$ & A & $A$ & & & & $A$ & & & & & & & & & & Yes \\
\hline $699-55-57$ & $A$ & A & A & A & A & A & & & & & & & & & & & & Yes \\
\hline $699-55-60 \mathrm{~A}$ & $A$ & A & A & A & A & A & & & & & & & & & & & & Yes \\
\hline $699-57-59$ & $A$ & A & A & A & A & A & A & A & $A$ & A & A & & & $A$ & $A$ & & A & Yes \\
\hline $699-59-58$ & A & A & A & $A$ & A & A & $A$ & $A$ & $A$ & $A$ & $A$ & & & $A$ & $A$ & & $A$ & Yes \\
\hline $699-60-60$ & $A$ & A & A & $A$ & A & A & $A$ & A & $A$ & $A$ & $A$ & & & $A$ & $A$ & & A & Yes \\
\hline 699-61-62 & $A$ & $A$ & A & $A$ & $A$ & A & $A$ & $A$ & $A$ & $A$ & $A$ & & & $A$ & $A$ & & $A$ & Yes \\
\hline 699-61-66 & $A$ & $A$ & A & $A$ & A & A & $A$ & $A$ & $A$ & $A$ & $A$ & & & $A$ & $A$ & & $A$ & Yes \\
\hline 699-64-62 & $A$ & $A$ & $A$ & $A$ & $A$ & $A$ & $A$ & $A$ & $A$ & $A$ & $A$ & & & $A$ & $A$ & & $A$ & Yes \\
\hline $699-65-50$ & $3-07$ & & & & & & & & & & & & & & & & & Not scheduled \\
\hline $699-65-72$ & & $3-07$ & & & & & & & & & & & & & & & & Not scheduled \\
\hline $699-66-58$ & $3-07$ & $3-07$ & & & & & & & & & & & & & & & & Not scheduled \\
\hline $699-66-64$ & $3-07$ & $3-07$ & & & & & & & & & & & & & & & & Not scheduled \\
\hline $699-70-68$ & $3-07$ & $3-07$ & & & & & & & & & & & & & & & & Not scheduled \\
\hline $699-72-73$ & $3-07$ & $3-07$ & $3-07$ & & & & & & & & & & & & & & & Not scheduled \\
\hline $699-73-61$ & & $3-07$ & & & & & & & & & & & & & & & & Not scheduled \\
\hline \multicolumn{19}{|c|}{ (a) Off-road sampling delayed because of extreme fire danger. } \\
\hline
\end{tabular}


Table A.14. Monitoring Wells, Aquifer Tubes, and Constituents for 200-PO-1 Operable Unit (adapted from DOE/RL-2003-04)

\begin{tabular}{|c|c|c|c|c|c|c|c|c|c|c|c|c|}
\hline \multirow[b]{2}{*}{ Well Number } & \multicolumn{7}{|c|}{ Contaminants of Concern } & \multicolumn{4}{|c|}{ Supporting Constituents } & \multirow[b]{2}{*}{$\begin{array}{l}\text { Sampled as Scheduled in } \\
\text { FY } 2006\end{array}$} \\
\hline & $\begin{array}{l}.00 \\
\frac{0}{\Phi} \\
\frac{\omega}{2} \\
\frac{\omega}{<}\end{array}$ & 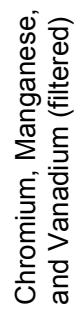 & 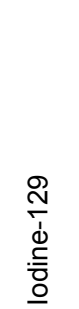 & 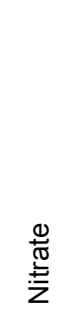 & 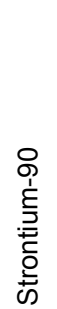 & 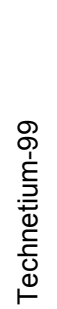 & 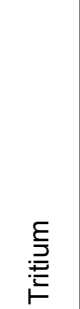 & $\begin{array}{l}\frac{0}{2} \\
\frac{0}{2} \\
\frac{0}{2} \\
0 \\
0 \\
0 \\
0 \\
0\end{array}$ & 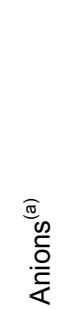 & 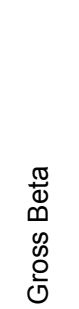 & $\frac{\frac{a}{0}}{\frac{\omega 0}{\pi}}$ & \\
\hline \multicolumn{13}{|c|}{ 200-PO-1 Near-Field Wells } \\
\hline 299-E16-2 & $A$ & $A$ & $A$ & $A$ & $A$ & & $A$ & $A$ & A & $A$ & $A$ & Yes \\
\hline 299-E17-12 & A & A & $A$ & A & $A$ & & A & A & A & A & A & Yes \\
\hline 299-E17-13 & A & A & $A$ & A & $A$ & & A & A & A & $A$ & $A$ & Yes \\
\hline 299-E17-14 & $A$ & A & $A$ & $A$ & $A$ & & A & A & A & A & A & Yes \\
\hline 299-E17-16 & A & A & A & A & $A$ & & A & A & A & A & A & Yes \\
\hline 299-E17-18 & $A$ & A & $A$ & $A$ & $A$ & & $A$ & $A$ & A & $A$ & $A$ & Yes \\
\hline 299-E17-19 & A & A & $A$ & A & $A$ & & A & A & A & A & A & Yes \\
\hline 299-E17-23 & $3-07$ & $3-07$ & $3-07$ & $3-07$ & & & $3-07$ & $3-07$ & $3-07$ & $3-07$ & $3-07$ & Not scheduled \\
\hline 299-E17-25 & $3-07$ & $3-07$ & $3-07$ & $3-07$ & & & $3-07$ & $3-07$ & $3-07$ & $3-07$ & $3-07$ & Not scheduled \\
\hline 299-E18-1 & $3-07$ & $3-07$ & $3-07$ & $3-07$ & & & $3-07$ & $3-07$ & $3-07$ & $3-07$ & $3-07$ & Not scheduled \\
\hline 299-E23-1 & $3-07$ & $3-07$ & $3-07$ & $3-07$ & & & $3-07$ & $3-07$ & $3-07$ & $3-07$ & $3-07$ & Not scheduled \\
\hline 299-E24-18 & $A$ & $A$ & $A$ & $A$ & $A$ & & $A$ & $A$ & $A$ & A & $A$ & Yes \\
\hline 299-E24-20 & $A$ & A & $A$ & $A$ & $A$ & $A$ & $A$ & $A$ & A & A & $A$ & Yes \\
\hline 299-E24-5 & $3-07$ & $3-07$ & $3-07$ & $3-07$ & & & $3-07$ & $3-07$ & $3-07$ & $3-07$ & $3-07$ & Not scheduled \\
\hline 299-E25-17 & $A$ & A & $A$ & $A$ & $A$ & & $A$ & $A$ & A & A & $A$ & Yes \\
\hline 299-E25-18 & A & A & $A$ & A & $A$ & & A & A & A & A & A & Yes \\
\hline 299-E25-19 & A & A & $A$ & A & $A$ & & $A$ & $A$ & A & $A$ & $A$ & Yes \\
\hline 299-E25-20 & $A$ & A & $A$ & $A$ & $A$ & & $A$ & $A$ & A & A & $A$ & Yes \\
\hline 299-E25-22 & $A$ & A & $A$ & $A$ & $A$ & & $A$ & $A$ & A & $A$ & $A$ & Yes \\
\hline 299-E25-28 & $3-07$ & $3-07$ & $3-07$ & $3-07$ & & & $3-07$ & $3-07$ & $3-07$ & $3-07$ & $3-07$ & Not scheduled \\
\hline 299-E25-29P & $3-07$ & $3-07$ & $3-07$ & $3-07$ & & & $3-07$ & $3-07$ & $3-07$ & $3-07$ & $3-07$ & Not scheduled \\
\hline 299-E25-29Q & $3-07$ & $3-07$ & $3-07$ & $3-07$ & & & $3-07$ & $3-07$ & $3-07$ & $3-07$ & $3-07$ & Not scheduled \\
\hline 299-E25-3 & A & A & $A$ & A & $A$ & & A & A & $A$ & $A$ & $A$ & Yes \\
\hline 299-E25-32P & $3-07$ & $3-07$ & $3-07$ & $3-07$ & & & $3-07$ & $3-07$ & $3-07$ & $3-07$ & $3-07$ & Not scheduled \\
\hline 299-E25-32Q & $3-07$ & $3-07$ & $3-07$ & $3-07$ & & & $3-07$ & $3-07$ & $3-07$ & $3-07$ & $3-07$ & Not scheduled \\
\hline 299-E25-34 & $3-07$ & $3-07$ & $3-07$ & $3-07$ & & & $3-07$ & $3-07$ & $3-07$ & $3-07$ & $3-07$ & Not scheduled \\
\hline 299-E25-35 & $3-07$ & $3-07$ & $3-07$ & $3-07$ & & & $3-07$ & $3-07$ & $3-07$ & $3-07$ & $3-07$ & Not scheduled \\
\hline 299-E25-36 & $A$ & A & $A$ & A & $A$ & & A & A & A & A & A & Yes \\
\hline 299-E25-37 & $3-07$ & $3-07$ & $3-07$ & $3-07$ & & & $3-07$ & $3-07$ & $3-07$ & $3-07$ & $3-07$ & Not scheduled \\
\hline 299-E25-41 & A & A & $A$ & A & $A$ & $A$ & A & $A$ & A & A & A & Yes \\
\hline 299-E25-42 & $A$ & A & $A$ & $A$ & $A$ & $A$ & $A$ & $A$ & $A$ & A & A & Yes \\
\hline 299-E25-43 & $3-07$ & $3-07$ & $3-07$ & $3-07$ & & & $3-07$ & $3-07$ & $3-07$ & $3-07$ & $3-07$ & Not scheduled \\
\hline 299-E25-44 & $3-07$ & $3-07$ & $3-07$ & $3-07$ & & & $3-07$ & $3-07$ & $3-07$ & $3-07$ & $3-07$ & Not scheduled \\
\hline 299-E25-47 & $3-07$ & $3-07$ & $3-07$ & $3-07$ & & & $3-07$ & $3-07$ & $3-07$ & $3-07$ & $3-07$ & Not scheduled \\
\hline
\end{tabular}


Table A.14. (contd)

\begin{tabular}{|c|c|c|c|c|c|c|c|c|c|c|c|c|}
\hline \multirow[b]{2}{*}{ Well Number } & \multicolumn{7}{|c|}{ Contaminants of Concern } & \multicolumn{4}{|c|}{ Supporting Constituents } & \multirow[b]{2}{*}{$\begin{array}{l}\text { Sampled as Scheduled in } \\
\text { FY } 2006\end{array}$} \\
\hline & 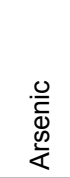 & 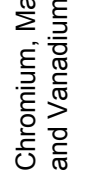 & 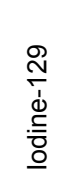 & 䒥 & 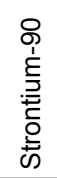 & 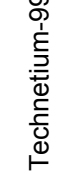 & 舀 & $\begin{array}{l}\frac{\pi}{0} \\
\frac{0}{2} \\
\frac{1}{0} \\
0 \\
0 \\
0 \\
0\end{array}$ & 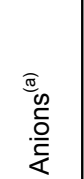 & $\begin{array}{l}\frac{\pi}{0} \\
\infty \\
0 \\
00 \\
0 \\
0\end{array}$ & 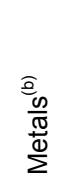 & \\
\hline 299-E25-6 & A & A & A & A & A & & A & A & A & A & A & Yes \\
\hline 299-E26-4 & A & A & A & A & A & & A & A & A & A & A & Yes \\
\hline $699-37-47 A$ & A & A & A & A & A & & A & A & A & A & A & Yes \\
\hline 699-39-39 & 3-07 & 3-07 & $3-07$ & 3-07 & & & 3-07 & $3-07$ & $3-07$ & 3-07 & 3-07 & Not scheduled \\
\hline $699-42-41$ & $3-07$ & $3-07$ & $3-07$ & $3-07$ & & & 3-07 & $3-07$ & 3-07 & 3-07 & 3-07 & Not scheduled \\
\hline $699-42-42 B$ & 3-07 & 3-07 & $3-07$ & 3-07 & & & 3-07 & $3-07$ & $3-07$ & 3-07 & 3-07 & Not scheduled \\
\hline $699-43-43$ & $3-07$ & $3-07$ & $3-07$ & 3-07 & & & $3-07$ & $3-07$ & $3-07$ & $3-07$ & $3-07$ & Not scheduled \\
\hline $699-43-45$ & 3-07 & 3-07 & $3-07$ & 3-07 & & & 3-07 & $3-07$ & $3-07$ & 3-07 & 3-07 & Not scheduled \\
\hline $699-44-39 B$ & $3-07$ & $3-07$ & $3-07$ & & & $3-07$ & $3-07$ & $3-07$ & $3-07$ & $3-07$ & $3-07$ & Not scheduled \\
\hline
\end{tabular}

\begin{tabular}{|c|c|c|c|c|c|c|c|c|c|c|c|c|c|c|c|}
\hline \multirow[b]{2}{*}{$\begin{array}{l}\text { Well or Aquifer } \\
\text { Tube Name }\end{array}$} & \multicolumn{3}{|c|}{$\begin{array}{c}\text { Contaminants of } \\
\text { Concern }\end{array}$} & \multicolumn{11}{|c|}{ Supporting Constituents } & \multirow[b]{2}{*}{$\begin{array}{l}\text { Sampled as Scheduled } \\
\text { in FY } 2006\end{array}$} \\
\hline & 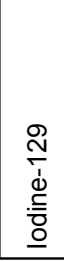 & $\begin{array}{l}\frac{\Phi}{\pi} \\
\frac{\pi}{2} \\
\end{array}$ & 点 & $\begin{array}{l}\frac{\pi}{0} \\
\frac{0}{2} \\
\frac{1}{5} \\
0 \\
0 \\
0 \\
0\end{array}$ & $\begin{array}{l}0 \\
.0 \\
\end{array}$ & 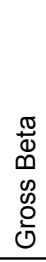 & 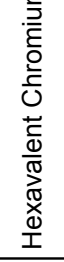 & 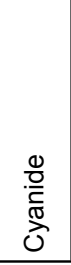 & 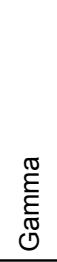 & 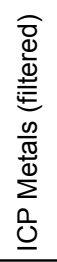 & 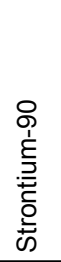 & 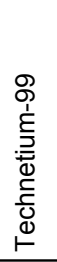 & 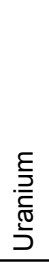 & § & \\
\hline \multicolumn{16}{|c|}{ 200-PO-1 Far Field Wells } \\
\hline \multicolumn{16}{|l|}{ BC Cribs } \\
\hline 299-E13-14 & & A & A & A & A & A & & A & A & A & A & A & A & & Yes \\
\hline 299-E13-5 & & A & A & A & A & A & & A & A & A & A & A & A & & Yes \\
\hline \multicolumn{16}{|c|}{ Southeast Transect } \\
\hline 699-10-54A & & A & A & A & A & A & & & A & A & A & & & A & Yes \\
\hline 699-24-46 & A & A & A & A & A & A & & & A & A & A & & & A & Yes \\
\hline 699-26-33 & A & A & A & A & A & A & & & A & A & A & & & A & Yes \\
\hline $699-31-31$ & A & A & A & $A$ & $A$ & A & & & $A$ & $A$ & $\mathrm{~A}$ & & & $A$ & Yes \\
\hline 699-32-22A & A & A & A & A & A & A & & & A & A & A & & & A & Yes \\
\hline 699-32-43 & A & A & A & A & A & A & & & A & A & A & & & A & Yes \\
\hline $699-41-23$ & A & A & A & $A$ & A & A & & & A & A & A & & & A & Yes \\
\hline 699-46-21B & A & A & A & A & A & A & & & A & A & A & & & A & Yes \\
\hline \multicolumn{16}{|l|}{ River Transect } \\
\hline 699-10-E12 & & A & $\mathrm{A}$ & $A$ & $A$ & A & & & $\mathrm{A}$ & $A$ & $\mathrm{~A}$ & & & $\mathrm{~A}$ & Yes \\
\hline 699-20-E12O & A & A & A & A & A & A & & & A & A & A & & & A & Yes \\
\hline $699-41-1 A$ & A & A & A & A & A & A & & & A & A & A & & & A & Yes \\
\hline 699-46-4 & A & A & A & $A$ & A & A & & & $A$ & A & A & & & $A$ & Yes \\
\hline 699-S3-E12 & & A & A & A & A & A & & & A & A & A & & & A & Yes \\
\hline 699-S19-E13 & & A & A & A & $A$ & A & & & $A$ & $A$ & A & & & $A$ & Yes \\
\hline
\end{tabular}


Table A.14. (contd)

\begin{tabular}{|c|c|c|c|c|c|c|c|c|c|c|c|c|c|c|c|}
\hline \multirow[b]{2}{*}{$\begin{array}{c}\text { Well or Aquifer } \\
\text { Tube Name }\end{array}$} & \multicolumn{3}{|c|}{$\begin{array}{l}\text { Contaminants of } \\
\text { Concern }\end{array}$} & \multicolumn{11}{|c|}{ Supporting Constituents } & \multirow[b]{2}{*}{$\begin{array}{c}\text { Sampled as Scheduled } \\
\text { in FY } 2006\end{array}$} \\
\hline & 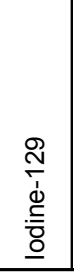 & $\frac{\Phi}{\frac{\Phi}{5}}$ & 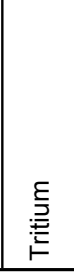 & $\begin{array}{l}\frac{\pi}{0} \\
\frac{0}{0} \\
\frac{0}{2} \\
00 \\
0 \\
0 \\
0\end{array}$ & $\frac{0}{0}$ & $\begin{array}{l}\text { I } \\
0 \\
0 \\
0 \\
0 \\
0 \\
0 \\
0 \\
\end{array}$ & 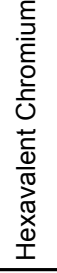 & $\begin{array}{l}\frac{0}{0} \\
\frac{0}{\frac{1}{\pi}} \\
\frac{\pi}{J} \\
0\end{array}$ & $\begin{array}{l}\underset{\mathbb{D}}{E} \\
\stackrel{\mathbb{E}}{\mathbb{V}} \\
\mathbb{O}\end{array}$ & 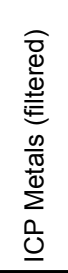 & 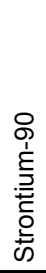 & 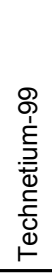 & 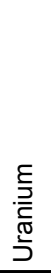 & 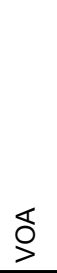 & \\
\hline \multicolumn{16}{|c|}{ Basalt Confined Aquifer } \\
\hline 299-E16-1 & $3-06$ & 3-06 & 3-06 & $3-06$ & $3-06$ & $3-06$ & & & & $3-06$ & & & & & Yes \\
\hline $699-13-1 C$ & & $3-06$ & 3-06 & $3-06$ & $3-06$ & $3-06$ & & & & $3-06$ & & & & & Delayed until $12 / 2006^{(c)}$ \\
\hline 699-24-1P & & 3-06 & 3-06 & 3-06 & 3-06 & 3-06 & & & & $3-06$ & & & & & Yes \\
\hline 699-32-22B & 3-06 & 3-06 & 3-06 & 3-06 & 3-06 & $3-06$ & & & & $3-06$ & & & & & Yes \\
\hline $699-42-40 \mathrm{C}$ & $3-07$ & $3-07$ & $3-07$ & $3-07$ & $3-07$ & $3-07$ & & & & $3-07$ & & & & & Not scheduled \\
\hline $\begin{array}{l}\text { 699-S11- } \\
\text { E12AP }\end{array}$ & & $3-06$ & $3-06$ & 3-06 & $3-06$ & $3-06$ & & & & $3-06$ & & & & & Yes \\
\hline \multicolumn{16}{|c|}{ Far-Field General } \\
\hline 499-S0-7 & & $3-07$ & $3-07$ & & $3-07$ & & & & & & & & & & Not scheduled \\
\hline 699-12-4D & $3-07$ & 3-07 & 3-07 & & 3-07 & & & & & & & & & & Not scheduled \\
\hline $699-13-1 A$ & $3-07$ & $3-07$ & $3-07$ & & $3-07$ & & & & & & & & & & Not scheduled \\
\hline $699-13-3 A$ & & 3-07 & 3-07 & & $3-07$ & & & & & & & & & & Not scheduled \\
\hline 699-14-38 & & $3-07$ & $3-07$ & & $3-07$ & & & & & & & & & & Not scheduled \\
\hline $699-17-5$ & $3-07$ & $3-07$ & 3-07 & & 3-07 & & & & & & & & & & Not scheduled \\
\hline $699-19-43$ & $3-07$ & $3-07$ & $3-07$ & & $3-07$ & & & & & & & & & & Not scheduled \\
\hline $699-20-20$ & $3-07$ & $3-07$ & 3-07 & & $3-07$ & & & & & & & & & & Not scheduled \\
\hline 699-20-E12S & & $3-07$ & 3-07 & & 3-07 & & & & & & & & & & Not scheduled \\
\hline 699-20-E5A & & 3-07 & $3-07$ & & $3-07$ & & & & & & & & & & Not scheduled \\
\hline $699-21-6$ & $3-07$ & $3-07$ & 3-07 & & 3-07 & & & & & & & & & & Not scheduled \\
\hline $699-2-3$ & $3-07$ & $3-07$ & 3-07 & & $3-07$ & & & & & & & & & & Not scheduled \\
\hline 699-22-35 & $3-07$ & $3-07$ & $3-07$ & & $3-07$ & & & & & & & & & & Not scheduled \\
\hline 699-24-34C & $3-07$ & $3-07$ & $3-07$ & & $3-07$ & & & & & & & & & & Not scheduled \\
\hline 699-26-15A & $3-07$ & $3-07$ & 3-07 & & 3-07 & & & & & & & & & & Not scheduled \\
\hline $699-26-33$ & & $3-07$ & 3-07 & & 3-07 & & & & & & & & & & Not scheduled \\
\hline 699-26-35A & $3-07$ & $3-07$ & $3-07$ & & $3-07$ & & & & & & & & & & Not scheduled \\
\hline $699-2-6 A$ & & $3-07$ & 3-07 & & 3-07 & & & & & & & & & & Not scheduled \\
\hline $699-2-7$ & & $3-07$ & $3-07$ & & $3-07$ & & & & & & & & & & Not scheduled \\
\hline $699-28-40$ & $3-07$ & $3-07$ & $3-07$ & & $3-07$ & & & & & & & & & & Not scheduled \\
\hline $699-29-4$ & $3-07$ & $3-07$ & 3-07 & & 3-07 & & & & & & & & & & Not scheduled \\
\hline 699-31-11 & $3-07$ & $3-07$ & $3-07$ & & $3-07$ & & & & & & & & & & Not scheduled \\
\hline 699-33-42 & $3-07$ & 3-07 & $3-07$ & & $3-07$ & & & & & & & & & & Not scheduled \\
\hline 699-33-56 & $3-07$ & $3-07$ & $3-07$ & & $3-07$ & & & & & & & & & & Not scheduled \\
\hline 699-34-41B & $3-07$ & 3-07 & 3-07 & & 3-07 & & & & & & & & & & Not scheduled \\
\hline 699-34-42 & $3-07$ & $3-07$ & $3-07$ & & $3-07$ & & & & & & & & & & Not scheduled \\
\hline $699-35-9$ & $3-07$ & $3-07$ & $3-07$ & & $3-07$ & & & & & & & & & & Not scheduled \\
\hline $699-37-43$ & $3-07$ & $3-07$ & $3-07$ & & $3-07$ & & & & & & & & & & Not scheduled \\
\hline 699-37-E4 & $3-07$ & $3-07$ & $3-07$ & & $3-07$ & & & & & & & & & & Not scheduled \\
\hline 699-38-15 & $3-07$ & $3-07$ & 3-07 & & 3-07 & & & & & & & & & & Not scheduled \\
\hline $699-40-1$ & $3-07$ & $3-07$ & $3-07$ & & $3-07$ & & & & & & & & & & Not scheduled \\
\hline
\end{tabular}


Table A.14. (contd)

\begin{tabular}{|c|c|c|c|c|c|c|c|c|c|c|c|c|c|c|c|}
\hline \multirow[b]{2}{*}{$\begin{array}{l}\text { Well or Aquifer } \\
\text { Tube Name }\end{array}$} & \multicolumn{3}{|c|}{$\begin{array}{c}\text { Contaminants of } \\
\text { Concern }\end{array}$} & \multicolumn{11}{|c|}{ Supporting Constituents } & \multirow[b]{2}{*}{$\begin{array}{l}\text { Sampled as Scheduled } \\
\text { in FY } 2006\end{array}$} \\
\hline & 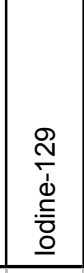 & 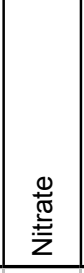 & 点 & $\begin{array}{l}\frac{0}{2} \\
\frac{0}{0} \\
\frac{0}{2} \\
0 \\
0 \\
0 \\
0 \\
0\end{array}$ & $\begin{array}{l}0 \\
\frac{0}{0} \\
\frac{0}{2}\end{array}$ & $\begin{array}{l}\text { 跑 } \\
0 \\
0 \\
0 \\
0 \\
0 \\
0\end{array}$ & 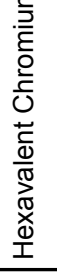 & 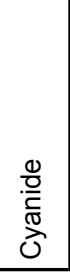 & 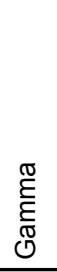 & 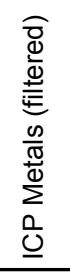 & 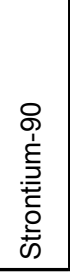 & 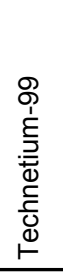 & 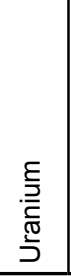 & ఏ & \\
\hline 699-40-33A & $3-07$ & $3-07$ & $3-07$ & & $3-07$ & & & & & & & & & & Not scheduled \\
\hline $699-41-40$ & $3-07$ & $3-07$ & $3-07$ & & $3-07$ & & & & & & & & & & Not scheduled \\
\hline $699-42-12 A$ & $3-07$ & 3-07 & 3-07 & & $3-07$ & & & & & & & & & & Not scheduled \\
\hline $699-42-39 \mathrm{~A}$ & $3-07$ & 3-07 & $3-07$ & & $3-07$ & & & & & & & & & & Not scheduled \\
\hline 699-42-39B & $3-07$ & $3-07$ & $3-07$ & & $3-07$ & & & & & & & & & & Not scheduled \\
\hline 699-43-3 & $3-07$ & 3-07 & $3-07$ & & $3-07$ & & & & & & & & & & Not scheduled \\
\hline $699-43-40$ & $3-07$ & $3-07$ & $3-07$ & & $3-07$ & & & & & & & & & & Not scheduled \\
\hline 699-43-41E & $3-07$ & 3-07 & $3-07$ & & $3-07$ & & & & & & & & & & Not scheduled \\
\hline $699-45-42$ & 3-07 & $3-07$ & 3-07 & & $3-07$ & & & & & & & & & & Not scheduled \\
\hline $699-47-5$ & $3-07$ & $3-07$ & $3-07$ & & $3-07$ & & & & & & & & & & Not scheduled \\
\hline 699-48-7A & & $3-07$ & 3-07 & & $3-07$ & & & & & & & & & & Not scheduled \\
\hline 699-49-13E & $3-07$ & 3-07 & $3-07$ & & $3-07$ & & & & & & & & & & Not scheduled \\
\hline $699-50-28 B$ & $3-07$ & $3-07$ & $3-07$ & & $3-07$ & & & & & & & & & & Not scheduled \\
\hline $699-52-19$ & & $3-07$ & $3-07$ & & $3-07$ & & & & & & & & & & Not scheduled \\
\hline 699-8-17 & $3-07$ & $3-07$ & $3-07$ & & $3-07$ & & & & & & & & & & Not scheduled \\
\hline $699-8-25$ & $3-07$ & $3-07$ & $3-07$ & & $3-07$ & & & & & & & & & & Not scheduled \\
\hline 699-9-E2 & $3-07$ & $3-07$ & $3-07$ & & $3-07$ & & & & & & & & & & Not scheduled \\
\hline 699-S12-3 & & $3-07$ & $3-07$ & & $3-07$ & & & & & & & & & & Not scheduled \\
\hline 699-S19-E14 & & $3-07$ & $3-07$ & & $3-07$ & & & & & & & & & & Not scheduled \\
\hline 699-S2-34B & A & A & A & & A & & & & & A & & & & & Yes \\
\hline 699-S3-25 & & $3-07$ & $3-07$ & & $3-07$ & & & & & & & & & & Not scheduled \\
\hline 699-S6-E14A & & $3-07$ & 3-07 & & $3-07$ & & & & & & & & & & Not scheduled \\
\hline 699-S6-E4A & & $3-07$ & 3-07 & & $3-07$ & & & & & & & & & & Not scheduled \\
\hline 699-S6-E4B & & $3-07$ & 3-07 & & $3-07$ & & & & & & & & & & Not scheduled \\
\hline 699-S8-19 & & 3-07 & 3-07 & & $3-07$ & & & & & & & & & & Not scheduled \\
\hline 81-D, M, S & A & A & A & $A$ & A & A & A & & & & & $\mathrm{A}$ & & & No \\
\hline $82-M, S$ & A & A & A & A & A & A & A & & & & & A & & & No \\
\hline 83-D & A & A & A & $A$ & A & A & A & & & & & A & & & No \\
\hline 84-D, M, S & A & A & A & A & A & A & A & & & & & A & & & No Cr6+ \\
\hline 85-D, M, S & A & A & A & A & A & A & A & & & & & A & & & No Cr6+ \\
\hline 86-D, M, S & A & A & A & $\mathrm{A}$ & A & A & A & & & & & $\mathrm{A}$ & & & No Cr6+ \\
\hline $\begin{array}{l}\text { (a) Anions - Ana } \\
\text { (b) Metals - Ana } \\
\text { (c) Access coor } \\
\text { 3-06 = Sampled } \\
\text { 3-07 = Sampled } \\
\text { A = To be sampl } \\
\text { ICP = Inductively } \\
\text { VOA = Volatile O }\end{array}$ & $\begin{array}{l}\text { alytes ir } \\
\text { lytes in } \\
\text { dinated } \\
\text { triennic } \\
\text { triennic } \\
\text { ed ann } \\
\text { coupl } \\
\text { rganic }\end{array}$ & $\begin{array}{l}\text { nclude } \\
\text { nclude } \\
\text { d with } \\
\text { ally; ne } \\
\text { ally; ne } \\
\text { uaally. } \\
\text { ed plas } \\
\text { analys }\end{array}$ & $\begin{array}{l}\text { but no } \\
\text { but not } \\
\text { Energy } \\
\text { ext sche } \\
\text { xt sche } \\
\text { sma. } \\
\text { ses. }\end{array}$ & di & $\begin{array}{l}\text { for } F Y \\
\text { for } F Y\end{array}$ & $\begin{array}{l}\text { Delay } \\
2006 \\
2007\end{array}$ & & & & & & & & & \\
\hline
\end{tabular}


Table A.15. Monitoring Wells, Aquifer Tubes, and Constituents for 300-FF-5 Operable Unit, 300 Area (adapted from DOE/RL-2002-11)

\begin{tabular}{|c|c|c|c|c|c|c|c|c|c|c|c|c|c|c|c|}
\hline \multirow[b]{2}{*}{ Well } & \multirow[b]{2}{*}{$\begin{array}{l}\text { Hydrologic } \\
\text { Unit } \\
\text { Monitored }\end{array}$} & \multicolumn{3}{|c|}{ Contaminants of Concern } & \multicolumn{5}{|c|}{ Contaminants of Potential Concern } & \multicolumn{5}{|c|}{ Supporting Measurements } & \multirow[b]{2}{*}{ 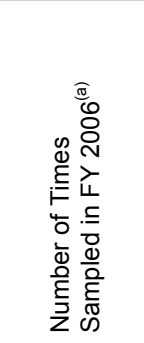 } \\
\hline & & 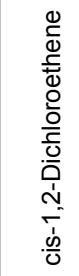 & 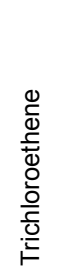 & 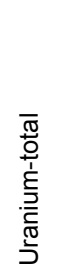 & 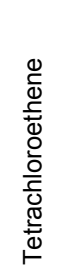 & 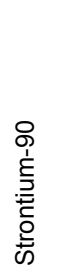 & 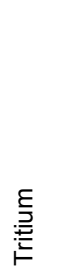 & 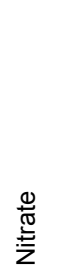 & $\begin{array}{l}\frac{\infty}{0} \\
\frac{0}{2} \\
\frac{1}{2}\end{array}$ & 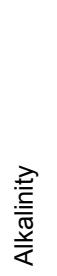 & 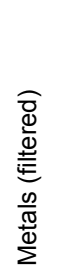 & 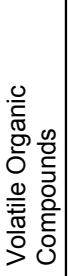 & $\begin{array}{l}\frac{\pi}{0} \\
0 \\
\frac{0}{\pi} \\
\frac{\pi}{0} \\
\frac{0}{\pi} \\
0 \\
0 \\
0 \\
0 \\
0\end{array}$ & 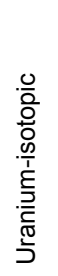 & \\
\hline \multicolumn{16}{|c|}{ Near-River Well Grouping } \\
\hline $399-1-1$ & TU & SA & SA & SA & SA & & & SA & SA & SA & SA & SA & SA & & 2 \\
\hline $399-1-10 A$ & TU & SA & SA & Q & SA & & A & Q & Q & Q & SA & SA & SA & A & 8 \\
\hline $399-1-10 B$ & LU & SA & SA & SA & SA & & & SA & SA & SA & SA & SA & & & 8 \\
\hline $399-1-16 A$ & TU & SA & SA & Q & SA & & A & Q & Q & Q & SA & SA & SA & A & 8 \\
\hline $399-1-16 B$ & LU & SA & SA & SA & SA & & & SA & SA & SA & SA & SA & & & 8 \\
\hline $399-1-16 C$ & $C$ & $A$ & $A$ & A & $A$ & & & A & A & $A$ & $A$ & A & & & 1 \\
\hline $399-2-1$ & TU & SA & SA & Q & SA & & A & $Q$ & Q & $Q$ & SA & SA & SA & A & 2 \\
\hline $399-2-2$ & TU & SA & SA & SA & SA & & & SA & SA & SA & SA & SA & SA & & 2 \\
\hline $399-3-1$ & TU & SA & SA & SA & SA & & & SA & SA & SA & SA & SA & SA & & 2 \\
\hline 399-3-9 & TU & SA & SA & SA & SA & & & SA & SA & SA & SA & SA & SA & & 2 \\
\hline $399-3-10$ & TU & SA & SA & Q & SA & & A & $Q$ & Q & $Q$ & SA & SA & SA & A & 2 \\
\hline $399-3-18$ & TU & $Q$ & $Q$ & Q & $Q$ & & A & $Q$ & Q & $Q$ & $Q$ & Q & $\mathrm{Q}$ & A & 1 (new well) \\
\hline $399-4-7$ & TU & SA & SA & SA & SA & & & SA & SA & SA & SA & SA & SA & & 1 \\
\hline $399-4-9$ & TU & SA & SA & SA & SA & & & SA & SA & SA & SA & SA & SA & & 2 \\
\hline $399-4-10$ & TU & SA & SA & SA & SA & & & SA & SA & SA & SA & $S A$ & SA & & 1 \\
\hline \multicolumn{16}{|c|}{ Central Region-Uranium Plume Transport Corridor Well Grouping } \\
\hline $399-1-2$ & TU & SA & SA & SA & SA & & & SA & SA & SA & SA & SA & SA & & 4 \\
\hline $399-1-6$ & TU & SA & SA & SA & SA & & & SA & SA & SA & SA & SA & SA & & 2 \\
\hline $399-1-7$ & TU & SA & SA & SA & SA & & & SA & SA & SA & SA & SA & SA & & 2 \\
\hline $399-1-8$ & LU & SA & SA & SA & SA & & & SA & SA & SA & SA & SA & SA & & 2 \\
\hline $399-1-9$ & C & $A$ & A & A & A & & & A & A & A & A & A & & & 0 \\
\hline $399-1-11$ & TU & SA & SA & SA & SA & & & SA & SA & SA & SA & SA & SA & & 2 \\
\hline $399-1-12$ & TU & SA & SA & SA & SA & & & SA & SA & SA & SA & SA & SA & & 2 \\
\hline $399-1-17 A$ & TU & SA & SA & Q & SA & & A & $\mathrm{Q}$ & Q & $Q$ & SA & SA & SA & A & 8 \\
\hline 399-1-17B & LU & SA & SA & SA & SA & & & SA & SA & SA & SA & SA & SA & & 8 \\
\hline $399-1-17 C$ & C & $A$ & A & A & A & & & A & A & A & $A$ & A & & & 0 \\
\hline $399-1-21 A$ & TU & SA & SA & Q & SA & & A & Q & Q & Q & SA & SA & SA & A & 2 \\
\hline 399-1-21B & LU & SA & SA & SA & SA & & & SA & SA & SA & SA & SA & SA & & 2 \\
\hline $399-1-23$ & TU & Q & $Q$ & Q & Q & & A & Q & Q & Q & $\mathrm{Q}$ & Q & $\mathrm{Q}$ & A & 9 \\
\hline $399-3-11$ & TU & SA & SA & Q & SA & A & A & Q & Q & Q & SA & SA & SA & A & 2 \\
\hline $399-3-12$ & TU & SA & SA & SA & SA & & & SA & SA & SA & SA & SA & & & 2 \\
\hline $399-3-20$ & TU & Q & Q & Q & Q & & A & $\mathrm{Q}$ & Q & Q & Q & Q & Q & A & 2 (new well) \\
\hline \multicolumn{16}{|c|}{ Northwest Region-Upgradient Conditions Well Group } \\
\hline $399-1-15$ & TU & SA & SA & SA & SA & & & SA & SA & SA & SA & SA & SA & & 2 \\
\hline $399-1-18 A$ & TU & & & SA & & & SA & SA & SA & SA & SA & & & & 7 \\
\hline $399-1-18 B$ & LU & & & SA & & & SA & SA & SA & SA & SA & & & & 7 \\
\hline $399-1-18 C$ & C & & & A & & & & A & A & A & A & & & & 1 \\
\hline $399-8-5 A$ & TU & SA & SA & SA & SA & & & SA & SA & SA & SA & SA & SA & & 2 \\
\hline 699-S20-E10 & TU & & & SA & & & SA & SA & SA & SA & SA & & & & 3 (new well) \\
\hline
\end{tabular}


Table A.15. (contd)

\begin{tabular}{|c|c|c|c|c|c|c|c|c|c|c|c|c|c|c|c|}
\hline \multirow[b]{2}{*}{ Well } & \multirow[b]{2}{*}{$\begin{array}{c}\text { Hydrologic } \\
\text { Unit } \\
\text { Monitored }\end{array}$} & \multicolumn{3}{|c|}{ Contaminants of Concern } & \multicolumn{4}{|c|}{ Contaminants of Potential Concern } & \multicolumn{6}{|c|}{ Supporting Measurements } & \multirow[b]{2}{*}{ 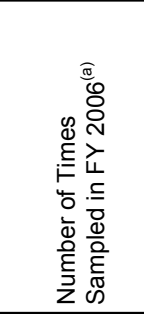 } \\
\hline & & 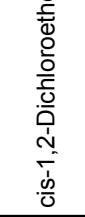 & 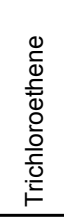 & 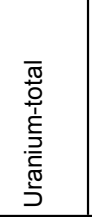 & 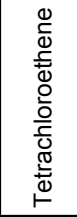 & 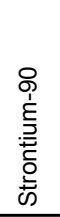 & 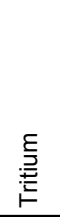 & $\begin{array}{l}\frac{9}{\pi} \\
\frac{\pi}{2}\end{array}$ & $\frac{\mathscr{0}}{\circ}$ & 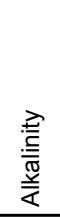 & 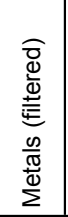 & 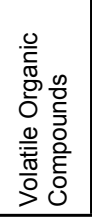 & 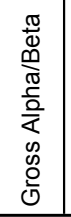 & 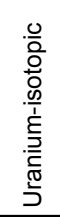 & \\
\hline \multicolumn{16}{|c|}{ Southwest Region-Upgradient Conditions Well Group } \\
\hline $399-3-2$ & TU & SA & SA & SA & SA & & & SA & SA & SA & SA & SA & & & 2 \\
\hline $399-3-6$ & TU & SA & SA & SA & SA & & & SA & SA & SA & SA & SA & & & 2 \\
\hline 399-3-19 & TU & Q & Q & Q & Q & & A & Q & Q & Q & Q & Q & Q & A & 2 (new well) \\
\hline $399-4-1$ & TU & SA & SA & SA & SA & & & SA & SA & SA & SA & SA & & & 2 \\
\hline $399-4-12$ & TU & SA & SA & SA & SA & & & SA & SA & SA & SA & SA & & & 2 \\
\hline $399-5-4 B$ & TU & SA & SA & SA & SA & & & SA & SA & SA & SA & SA & & & 2 \\
\hline \begin{tabular}{|l} 
699-S27- \\
E14
\end{tabular} & TU & A & A & A & A & & & A & A & A & A & A & & & 2 \\
\hline \multicolumn{16}{|c|}{ Shoreline-Aquifer Tubes } \\
\hline AT-3-1-D(1) & TU & & & A & & & & & & & & & & & 1 \\
\hline AT-3-1-M & TU & SA & SA & SA & SA & & & SA & SA & SA & SA & SA & SA & & 2 \\
\hline AT-3-1-S & TU & & & A & & & & & & & & & & & 2 \\
\hline AT-3-2-M & TU & SA & SA & SA & SA & & & SA & SA & SA & SA & SA & SA & & 2 \\
\hline AT-3-2-S & TU & & & A & & & & & & & & & & & 2 \\
\hline AT-3-3-D & TU & & & A & & & & & & & & & & & 3 \\
\hline AT-3-3-M & TU & & & A & & & & & & & & & & & 3 \\
\hline AT-3-3-S & TU & SA & SA & SA & SA & & & SA & SA & SA & SA & SA & SA & & 2 \\
\hline AT-3-4-D & TU & & & A & & & & & & & & & & & 2 \\
\hline AT-3-4-M & TU & & & A & & & & & & & & & & & 2 \\
\hline AT-3-4-S & TU & & & SA & & & & SA & SA & SA & SA & & SA & & 2 \\
\hline AT-3-5-S & TU & & & SA & & & & SA & SA & SA & SA & & SA & & 2 \\
\hline AT-3-6-D & TU & & & A & & & & & & & & & & & 1 \\
\hline AT-3-6-M & TU & & & A & & & & & & & & & & & 1 \\
\hline AT-3-6-S & TU & & & SA & & & & SA & SA & SA & SA & & SA & & 1 \\
\hline AT-3-7-D & TU & & & A & & & & & & & & & & & 2 \\
\hline AT-3-7-M & TU & & & SA & & & & SA & SA & SA & SA & & SA & & 2 \\
\hline AT-3-7-S & TU & & & A & & & & & & & & & & & 2 \\
\hline AT-3-8-D & TU & & & A & & & & & & & & & & & 0 \\
\hline AT-3-8-M & TU & & & A & & & & & & & & & & & 2 \\
\hline AT-3-8-S & TU & & & SA & & & & SA & SA & SA & SA & & SA & & 2 \\
\hline \multicolumn{16}{|c|}{ Shoreline-Riverbank Springs } \\
\hline S3-42-2 & sW & & & A & & & & A & A & A & A & & A & & 1 \\
\hline S3-DR42-2 & sW & & & A & & & & A & A & A & A & & A & & 1 \\
\hline SPRING 10 & sw & & & A & & & & A & A & A & A & & A & & \\
\hline SPRING 11 & sw & & & A & & & & A & A & A & A & & A & & \\
\hline \multicolumn{16}{|c|}{$\begin{array}{l}\text { (a) Project in transition from Rev. } 0 \text { to Rev. } 1 \text { of the sampling and analysis plan, making a direct comparison complex. Not all constituents } \\
\text { analyzed each time the well was sampled. Some wells co-sampled for other projects. } \\
A=\text { To be sampled annually. } \\
C=\text { Uppermost confined aquifer. } \\
\text { LU = Lower unconfined aquifer. } \\
Q=\text { To be sampled quarterly. } \\
\text { SA = To be sampled semiannually. } \\
\text { SW = Surface water. } \\
\text { TU = Top of unconfined aquifer. }\end{array}$} \\
\hline
\end{tabular}


Table A.16. Monitoring Wells and Constituents for 300-FF-5 Operable Unit, 618-11 Subregion (adapted from DOE/RL-2002-11)

\begin{tabular}{|c|c|c|c|c|c|c|c|c|c|c|}
\hline \multirow[b]{2}{*}{ Well } & \multicolumn{6}{|c|}{ Contaminants of Potential Concern } & \multicolumn{3}{|c|}{$\begin{array}{c}\text { Supporting } \\
\text { Measurements }\end{array}$} & \multirow[b]{2}{*}{ 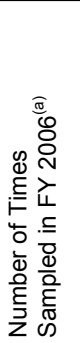 } \\
\hline & 点 & $\begin{array}{l}\text { đँ } \\
\infty \\
0 \\
00 \\
00 \\
0\end{array}$ & 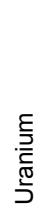 & 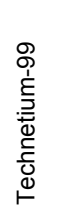 & $\begin{array}{l}\frac{0}{2} \\
\frac{0}{2} \\
0 \\
0 \\
0 \\
\frac{0}{0} \\
0\end{array}$ & 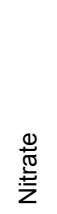 & $\begin{array}{l}\frac{\infty}{0} \\
\text {.0 } \\
\frac{1}{2}\end{array}$ & 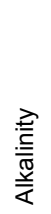 & 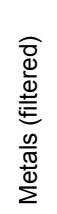 & \\
\hline \multicolumn{11}{|c|}{ Downgradient of 618-11 Burial Ground (Near-Field) } \\
\hline $699-12-2 C$ & Q & Q & SA & SA & Q & SA & SA & SA & SA & 3 \\
\hline $699-13-2 D$ & Q & Q & SA & SA & Q & SA & SA & SA & SA & 3 \\
\hline $699-13-3 A$ & Q & Q & SA & SA & Q & SA & SA & SA & SA & 3 \\
\hline \multicolumn{11}{|c|}{ Upgradient Conditions (Near-Field) } \\
\hline $699-12-4 D$ & A & A & $A$ & A & A & A & A & A & A & 1 \\
\hline \multicolumn{11}{|c|}{ Downgradient of 618-11 Burial Ground (Far-Field) } \\
\hline $699-13-0 A$ & Q & Q & & & Q & SA & SA & SA & SA & 3 \\
\hline 699-13-1E & Q & Q & & & Q & SA & SA & SA & SA & 2 \\
\hline \multicolumn{11}{|c|}{$\begin{array}{l}\text { (a) Project in transition from Rev. } 0 \text { to Rev. } 1 \text { of the sampling and analysis plan, making a } \\
\text { direct comparison complex. Not all constituents analyzed each time the well was sampled } \\
\text { Some wells co-sampled for other projects. } \\
\text { A = To be sampled annually. } \\
Q=\text { To be sampled quarterly. } \\
\text { SA = To be sampled semiannually. }\end{array}$} \\
\hline
\end{tabular}

Table A.17. Monitoring Wells and Constituents for 300-FF-5 Operable Unit, 618-10/316-4 Subregion (adapted from DOE/RL-2002-11)

\begin{tabular}{|c|c|c|c|c|c|c|c|c|c|c|c|c|}
\hline \multirow[b]{2}{*}{ Well } & \multicolumn{5}{|c|}{ Contaminants of Potential Concern } & \multicolumn{6}{|c|}{ Supporting Measurements } & \multirow[b]{2}{*}{ 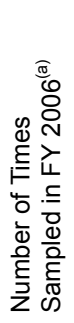 } \\
\hline & 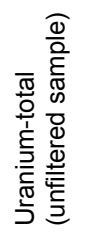 & $\begin{array}{l}\frac{0}{0} \\
\frac{0}{2} \\
\frac{0}{0} \\
0 \\
\frac{0}{0} \\
\frac{1}{2} \\
\frac{1}{3} \\
\frac{0}{2} \\
1=\end{array}$ & $\begin{array}{l}\frac{0}{0} \\
\frac{0}{0} \\
\frac{0}{2} \\
0 \\
0 \\
0 \\
0 \\
0\end{array}$ & 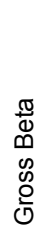 & 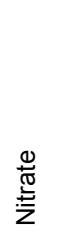 & 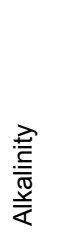 & 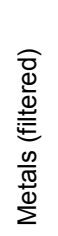 & 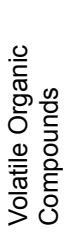 & 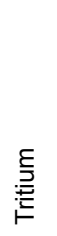 & 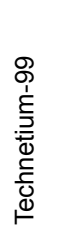 & 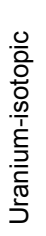 & \\
\hline \multicolumn{13}{|c|}{ Downgradient of $618-10$ Burial Ground (Near-Field) } \\
\hline 699-S6-E4K & SA & SA & SA & SA & SA & SA & SA & SA & SA & SA & A & 2 \\
\hline 699-S6-E4L & Q & SA & Q & Q & Q & SA & SA & SA & SA & SA & A & 3 \\
\hline \multicolumn{13}{|c|}{ Downgradient of 618-10 Burial Ground; Within 316-4 Crib Footprint (Near-Field) } \\
\hline 699-S6-E4A & Q & SA & Q & Q & Q & SA & SA & SA & SA & SA & A & 3 \\
\hline \multicolumn{13}{|c|}{ Background: $618-10$ Burial Ground/316-4 Cribs } \\
\hline 699-S6-E4D & A & & A & A & A & A & A & & A & A & & 1 \\
\hline \multicolumn{13}{|c|}{ Downgradient of 618-10 Burial Ground/316-4 Crib } \\
\hline 699-S6-E4B & SA & & SA & SA & SA & SA & SA & & SA & & & 2 \\
\hline 699-S6-E4E & SA & & SA & SA & SA & SA & SA & & SA & & & 1 \\
\hline \multicolumn{13}{|c|}{$\begin{array}{l}\text { Wells completed at the top of the unconfined aquifer. } \\
\text { (a) Project in transition from Rev. } 0 \text { to Rev. } 1 \text { of the sampling and analysis plan, making a direct comparison } \\
\text { complex. Not all constituents analyzed each time the well was sampled. Some wells co-sampled for other projects. } \\
\text { A = To be sampled annually. } \\
Q=\text { To be sampled quarterly. } \\
\text { SA = To be sampled semiannually. }\end{array}$} \\
\hline
\end{tabular}


Table A.18. Monitoring Wells and Constituents for 1100-EM-1 Operable Unit (adapted from PNNL-12220)

\begin{tabular}{|c|c|c|c|c|}
\hline Well & 号 & 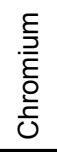 & 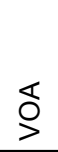 & $\begin{array}{c}\text { Sampled as Scheduled } \\
\text { in FY } 2006\end{array}$ \\
\hline 699-S27-E12A & A & & A & Delayed until 11/2006 \\
\hline 699-S28-E12 & A & & A & Delayed until 11/2006 \\
\hline 699-S28-E13A & A & & $A$ & Yes \\
\hline 699-S29-E10A & A & & $A$ & Delayed until 11/2006 \\
\hline 699-S29-E11 & A & & $A$ & Delayed until FY 2007 \\
\hline 699-S29-E12 & A & & $A$ & Delayed until 11/2006 \\
\hline 699-S29-E13A & A & & $A$ & Delayed until 11/2006 \\
\hline 699-S30-E10A & A & & A & Delayed until 11/2006 \\
\hline 699-S30-E10B & A & & A & Delayed until 11/2006 \\
\hline 699-S30-E11A & A & & A & Delayed until 11/2006 \\
\hline 699-S31-E10A & A & & A & Yes \\
\hline 699-S31-E10C & A & & A & Yes \\
\hline 699-S31-E10D & A & & A & Yes \\
\hline 699-S31-E11 & A & & $A$ & Yes \\
\hline 699-S41-E12 & & $A$ & & Yes \\
\hline \multicolumn{5}{|c|}{$\begin{array}{l}A=\text { To be sampled annually. } \\
F Y=\text { Fiscal year. } \\
\text { VOA = Volatile organic analyses. }\end{array}$} \\
\hline
\end{tabular}




\section{Appendix B}

\section{Supporting Information for Monitored Facilities}




\section{Contents}

Supporting Information for Monitoring Facilities

B.1

References

B.1

\section{Tables}

B.1 Estimates of Groundwater Flow Rates at Hanford Site Facilities

B.6

B.2 Upgradient/Downgradient Comparison Values Used for Statistical Comparisons at RCRA Sites in FY 2006

B.3 Monitoring Wells and Constituents for 100-N Area Units

B.9

B.4 Critical Means for 116-N-1 Liquid Waste Disposal Facility for FY 2007 Comparisons

B. 10

B.5 Critical Means for 120-N-1 and 120-N-2 Liquid Waste Disposal Facilities for FY 2007

Comparisons

B.10

B.6 Critical Means for 116-N-3 Liquid Waste Disposal Facility for FY 2007 Comparisons

B.11

B.7 Monitoring Wells and Constituents for 116-H-6 Evaporation Basins

B.11

B.8 Monitoring Wells and Constituents for 216-A-29 Ditch

B.12

B.9 Critical Means for 216-A-29 Ditch for FY 2007 Comparisons

B.12

B.10 Monitoring Wells and Constituents for 216-B-3 Pond

B.13

B.11 Critical Means for 216-B-3 Pond for FY 2007 Comparisons ............................................................... B.13

B.12 Monitoring Wells and Constituents for 216-B-63 Trench …………................................................. B.14

B.13 Critical Means for 216-B-63 Trench for FY 2007 Comparisons ........................................................... B. 14

B.14 Monitoring Wells and Constituents for 216-S-10 Pond and Ditch …............................................... B.

B.15 Critical Means for 216-S-10 Pond and Ditch for FY 2007 Comparisons ............................................. B.15

B.16 Monitoring Wells and Constituents for 216-U-12 Crib ................................................................ B.

B.17 Monitoring Wells and Constituents for 316-5 Process Trenches ...................................................... B. B.

B.18 Monitoring Wells and Constituents for Integrated Disposal Facility .................................................. B.17

B.19 Monitoring Wells and Constituents for Liquid Effluent Retention Facility ....................................... B.17

B.20 Monitoring Wells and Constituents for Low-Level Waste Management Area 1................................. B.. B

B.21 Critical Means for Low-Level Waste Management Area 1 for FY 2007 Comparisons .......................... B.18 
B.22 Monitoring Wells and Constituents for Low-Level Waste Management Area 2................................. B.19

B.23 Critical Means for Low-Level Waste Management Area 2 for FY 2007 Comparisons .......................... B.19

B.24 Monitoring Wells and Constituents for Low-Level Waste Management Area 3................................... B. B.20

B.25 Monitoring Wells and Constituents for Low-Level Waste Management Area 4.................................. B.21

B.26 Critical Means for Low-Level Waste Management Area 4 for FY 2007 Comparisons ......................... B.21

B.27 Monitoring Wells and Constituents for the Nonradioactive Dangerous Waste Landfill...................... B. B.22

B.28 Critical Means for Nonradioactive Dangerous Waste Landfill for FY 2007 Comparisons...................... B.22

B.29 Monitoring Wells and Constituents for RCRA PUREX Cribs 216-A-10, 216-A-36B, and

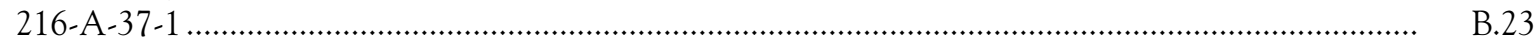

B.30 Monitoring Wells and Constituents for Waste Management Area A-AX …..................................... B..24

B.31 Monitoring Wells and Constituents for Waste Management Area B-BX-BY........................................ B.

B.32 Monitoring Wells and Constituents for Waste Management Area C................................................ B..26

B.33 Critical Means for Waste Management Area C for FY 2007 Comparisons ............................................ B.26

B.34 Monitoring Wells and Constituents for Waste Management Area S-SX ........................................... B. B.27

B.35 Monitoring Wells and Constituents for Waste Management Area T .................................................. B.28

B.36 Monitoring Wells and Constituents for Waste Management Area TX-TY .......................................... B. B.29

B.37 Monitoring Wells and Constituents for Waste Management Area U.................................................. B..30

B.38 Monitoring Wells and Constituents for the KE and KW Basins......................................................... B.31

M.39 Monitoring Wells, Constituents, and Enforcement Limits for 200 Area Treated Effluent
Disposal Facility.................................................................................................................................. B.

B.40 Monitoring Wells and Constituents for Environmental Restoration Disposal Facility ........................ B.32

B.41 Monitoring Wells and Constituents for Solid Waste Landfill ............................................................... B. B.

B.42 Analytical Results for Required Constituents at Solid Waste Landfill ................................................. B. B.

B.43 Results of Shapiro and Francia Test for Normality and Background Threshold Values for

B.44 Monitoring Wells, Constituents, and Enforcement Limits for State-Approved Land Disposal Site 


\section{Figures}

B.1 RCRA Units on the Hanford Site Requiring Groundwater Monitoring ............................................. B.

B.2 Groundwater Monitoring Wells for 100-N Area RCRA Sites........................................................... B.39

B.3 Groundwater Monitoring Wells at 116-H-6 Evaporation Basins ............................................................. B.40

B.4 Groundwater Monitoring Wells at 216-A-29 Ditch, PUREX Cribs, and Waste Management

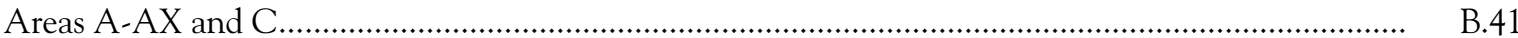

B.5 Groundwater Monitoring Wells at 216-B-3 Pond and 200 Area Treated Effluent Disposal Facility

B.6 Groundwater Monitoring Wells at 216-S-10 Pond and Ditch ............................................................ B.. B.

B.7 Groundwater Monitoring Wells at the 216-U-12 Crib …................................................................... B.44

B.8 Groundwater Monitoring Wells at 316-5 Process Trenches............................................................... B. B.45

B.9 Groundwater Monitoring Wells at Integrated Disposal Facility ........................................................ B..46

B.10 Groundwater Monitoring Wells at Liquid Effluent Retention Facility ............................................. B.47

B.11 Groundwater Monitoring Wells at Low-Level Waste Management Area 1 .......................................... B.48

B.12 Groundwater Monitoring Wells at 216-B-63 Trench and Low-Level Waste Management

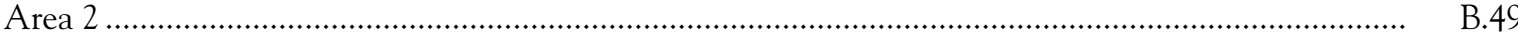

B.13 Groundwater Monitoring Wells at Low-Level Waste Management Area 3 ........................................ B... B

B.14 Groundwater Monitoring Wells at Low-Level Waste Management Area 4 .......................................... B.

B.15 Groundwater Monitoring Wells at Nonradioactive Dangerous Waste Landfill and Solid

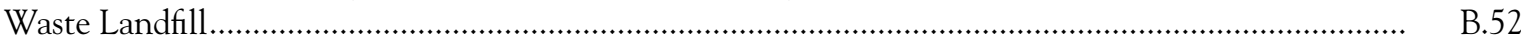

B.16 Groundwater Monitoring Wells at Waste Management Area B-BX-BY …………………………........ B.

B.17 Groundwater Monitoring Wells at Waste Management Areas S-SX and U ....................................... B.54

B.18 Groundwater Monitoring Wells at Waste Management Areas T and TX-TY...................................... B.5.

B.19 Regulated Units on the Hanford Site Requiring Groundwater Monitoring ......................................... B.56

B.20 Groundwater Monitoring Wells at 100-K Basins .................................................................................. B.57

B.21 Groundwater Monitoring Wells at State-Approved Land Disposal Site ........................................... B.58 


\section{Appendix B}

\section{Supporting Information for Monitored Facilities}

This appendix provides supplemental information for Resource Conservation and Recovery Act (RCRA) and other regulated units on the Hanford Site that require groundwater monitoring excluding Comprehensive Environmental Response, Compensation, and Liability Act (CERCLA) units (discussed in Appendix A). Site-specific discussions for each facility in Appendix B are found in the body of the document under the respective operable unit in which the facility lies (see Figure 1.0-1 in the main text for operable units).

RCRA groundwater monitoring continued during fiscal year (FY) 2006 at 26 waste management areas (Figure B.1). Estimates of groundwater velocity, hydrologic properties, and associated references are shown in Table B.1 for all RCRA sites and the Solid Waste Landfill. Table B.2 lists comparison values used for statistical comparisons at RCRA sites monitored under indicator parameter programs in FY 2006. Tables B.3 through B.37 provide supporting information for the RCRA sites and Figures B.2 through B.18 show locations of monitoring wells.

This appendix also provides constituent lists, well network configurations, and other ancillary information for regulated facilities that fall outside of RCRA programs except CERCLA units. Some network wells in these facilities are shared with RCRA facilities. Figure B.19 shows the general locations of these facilities. Locations of monitoring wells are shown in Figures B.15, B.20, and B.21. Tables B.38 through B.44 list the constituents list and/or results summaries for the facilities.

\section{References}

40 CFR 264, Appendix IX. "Ground-Water Monitoring List." U.S. Environmental Protection Agency, U.S. Code of Federal Regulations.

Atomic Energy Act. As amended, Ch. 1073, 68 Stat. 919, 42 USC 2011 et seq.

BHI-00873. 1996. Description of Work for Routine Groundwater Sampling at the Environmental Restoration Disposal Facility. BH Ford, Bechtel Hanford, Inc., Richland, Washington.

BNWL-1709. 1973. Collection and Analysis of Pump Test Data for Transmissivity Values. KL Kipp and RD Mudd, Battelle, Pacific Northwest Laboratory, Richland, Washington.

Comprehensive Environmental Response, Compensation, and Liability Act. 1980. Public Law 96-150, as amended, 94 Stat. 2767, 42 USC 9601 et seq.

DOE Order 435.1. 1999. "Radioactive Waste Management.” U.S. Department of Energy, Washington, D.C.

DOE/RL-2000-72, Rev. 1. 2006. Performance Assessment Monitoring Plan for the Hanford Site Low-Level Burial Grounds. U.S. Department of Energy, Richland Operations Office, Richland, Washington.

DOE/RL-2003-12, Rev. 0. 2003. Hanford Facility Dangerous Waste Permit Application, Integrated Disposal Facility. U.S. Department of Energy, Richland Operations Office, Richland, Washington.

Ecology. 1994. Dangerous Waste Portion of the Resource Conservation and Recovery Act Permit for the Treatment, Storage, and Disposal of Dangerous Waste. Permit Number WA7890008967, as amended. Washington State Department of Ecology, Olympia, Washington.

PNL-5408. 1985. Groundwater Monitoring at the Hanford Site, January-December 1984. CS Cline, JT Rieger, JR Raymond, and PA Eddy, Pacific Northwest Laboratory, Richland, Washington. 
PNL-6716. 1988. Interim Characterization Report for the 300 Area Process Trenches. R Schalla, RW Wallace, RL Aaberg, SP Airhart, DJ Bates, JVM Carlile, CS Cline, DI Dennison, MD Freshley, PR Heller, EJ Jensen, KB Olsen, RG Parkhurst, JT Rieger, and EJ Westergard, Pacific Northwest Laboratory, Richland, Washington.

PNL-6728. 1988. Geohydrologic Characterization of the Area Surrounding the 183-H Solar Evaporation Basins. TL Liikala, RL Aaberg, NJ Aimo, DJ Bates, TJ Gilmore, EJ Jensen, GV Last, PL Oberlander, KB Olsen, KR Oster, LR Roome, JC Simpson, SS Teel, and EJ Westergard, Pacific Northwest Laboratory, Richland, Washington.

PNL-6820. 1989. Hydrogeology for the 200 Areas Low-Level Burial Grounds - An Interim Report. GV Last, BN Bjornstad, MP Bergeron, DW Wallace, DR Newcomer, JA Schramke, MA Chamness, CS Cline, SP Airhart, and JS Wilber, Pacific Northwest Laboratory, Richland, Washington.

PNL-8335. 1992. Applications of Three Aquifer Test Methods for Estimating Hydraulic Properties Within the 100-N Area. TJ Gilmore, FA Spane, Jr., DR Newcomer, and CR Sherwood, Pacific Northwest Laboratory, Richland, Washington.

PNL-10195. 1994. Three-Dimensional Conceptual Model for the Hanford Site Unconfined Aquifer System: FY 1994 Status Report. PD Thorne, MA Chamness, VR Vermeul, QC Macdonald, and SE Schubert, Pacific Northwest Laboratory, Richland, Washington.

PNNL-11523. 1997. Combination RCRA Groundwater Monitoring Plan for the 216-A-10, 216-A-36B, and 216-A-37-1 PUREX Cribs. JW Lindberg, Pacific Northwest National Laboratory, Richland, Washington.

PNNL-11523, Rev. 1. 2005. Interim-Status RCRA Groundwater Monitoring Plan for the 216-A-10, 216-A-36B, and 216-A-37-1 PUREX Cribs. JW Lindberg and RP Elmore, Pacific Northwest National Laboratory, Richland, Washington.

PNNL-11523-ICN-1. 1998. Combination RCRA Groundwater Monitoring Plan for the 216-A-10, 216-A-36B, and 216-A-37-1 PUREX Cribs, Interim Change Notice 1. JW Lindberg, Pacific Northwest National Laboratory, Richland, Washington.

PNNL-11573. 1997. Groundwater Monitoring Plan for the 183-H Solar Evaporation Basins. MJ Hartman, Pacific Northwest National Laboratory, Richland, Washington.

PNNL-11957. 1998. Immobilized Low-Activity Waste Site Borehole 299-E17-21. SP Reidel, KD Reynolds, and DG Horton, Pacific Northwest National Laboratory, Richland, Washington.

PNNL-12072-ICN-1. 2002. RCRA Assessment Plan for Single-Shell Tank Waste Management Area TX-TY at the Hanford Site, Interim Change Notice 1. DG Horton, Pacific Northwest National Laboratory, Richland, Washington.

PNNL-12114-ICN-3. 2006. RCRA Assessment Plan for Single-Shell Tank Waste Management Area S-SX at the Hanford Site, Interim Change Notice 3. RM Smith, Pacific Northwest National Laboratory, Richland, Washington.

PNNL-12227. 1999. Groundwater Monitoring Plan for the Nonradioactive Dangerous Waste Landfill. JW Lindberg and MJ Hartman, Pacific Northwest National Laboratory, Richland, Washington.

PNNL-12227-ICN-1. 2001. Groundwater Monitoring Plan for the Nonradioactive Dangerous Waste Landfill, Interim Change Notice 1. JW Lindberg and MJ Hartman, Pacific Northwest National Laboratory, Richland, Washington.

PNNL-13014. 2000. Groundwater Monitoring Plan for the Solid Waste Landfill. JW Lindberg and CJ Chou, Pacific Northwest National Laboratory, Richland, Washington.

PNNL-13022-ICN-2. 2003. Groundwater Quality Assessment Plan for Single-Shell Waste Management Area B-BX-BY at the Hanford Site, Interim Change Notice 2. SM Narbutovskih, Pacific Northwest National Laboratory, Richland, Washington. 
PNNL-13022-ICN-3. 2006. Groundwater Quality Assessment Plan for Single-Shell Waste Management Area B-BX-BY at the Hanford Site, Interim Change Notice 3. SM Narbutovskih, Pacific Northwest National Laboratory, Richland, Washington.

PNNL-13024-ICN-4. 2004. RCRA Groundwater Monitoring Plan for Single-Shell Tank Waste Management Area C at the Hanford Site, Interim Change Notice 4. SM Narbutovskih, Pacific Northwest National Laboratory, Richland, Washington.

PNNL-13032. 2000. Groundwater Monitoring Plan for the Hanford Site 200 Area Treated Effluent Disposal Facility. DB Barnett, Pacific Northwest National Laboratory, Richland, Washington.

PNNL-13047. 1999. Groundwater Monitoring Plan for the 216-A-29 Ditch. MD Sweeney, Pacific Northwest National Laboratory, Richland, Washington.

PNNL-13121. 2000. Groundwater Monitoring and Tritium-Tracking Plan for the 200 Area State-Approved Land Disposal Site. DB Barnett, Pacific Northwest National Laboratory, Richland, Washington.

PNNL-13378. 2001. Results of Detailed Hydrologic Characterization Tests - Fiscal Year 1999. FA Spane, Jr., PD Thorne, and DR Newcomer, Pacific Northwest National Laboratory, Richland, Washington.

PNNL-13441. 2000. RCRA Groundwater Quality Assessment Report for Waste Management Area S-SX (November 1997 through April 2000). VG Johnson and CJ Chou, Pacific Northwest National Laboratory, Richland, Washington.

PNNL-13514. 2001. Results of Detailed Hydrologic Characterization Tests - Fiscal Year 2000. FA Spane, PD Thorne, and DR Newcomer, Pacific Northwest National Laboratory, Richland, Washington.

PNNL-13612-ICN-2. 2006. Groundwater Quality Assessment Plan for Single-Shell Tank Waste Management Area U, Interim Change Notice 2. RM Smith, Pacific Northwest National Laboratory, Richland, Washington.

PNNL-13652. 2001. Geologic and Wireline Borehole Summary from the Second ILAW Borehole (299-E24-21). SP Reidel, DG Horton, and MM Valenta, Pacific Northwest National Laboratory, Richland, Washington.

PNNL-13914. 2002. Groundwater Monitoring Plan for the 1301-N, 1324-N/NA, and 1325-N RCRA Facilities. MJ Hartman, Pacific Northwest National Laboratory, Richland, Washington.

PNNL-14033. 2002. Groundwater Monitoring and Assessment Plan for the 100-K Area Fuel Storage Basins. RE Peterson, Pacific Northwest National Laboratory, Richland, Washington.

PNNL-14070. 2002. Groundwater Monitoring Plan for the 216-S-10 Pond and Ditch. BA Williams and CJ Chou, Pacific Northwest National Laboratory, Richland, Washington.

PNNL-14070-ICN-1. 2003. Groundwater Monitoring Plan for the 216-S-10 Pond and Ditch, Interim Change Notice 1. BA Williams, Pacific Northwest National Laboratory, Richland, Washington.

PNNL-14112. 2002. Groundwater Monitoring Plan for the 216-B-63 Trench on the Hanford Site. MD Sweeney, Pacific Northwest National Laboratory, Richland, Washington.

PNNL-14113. 2002. Results of Detailed Hydrologic Characterization Tests - Fiscal Year 2001. FA Spane, Jr., PD Thorne, and DR Newcomer, Pacific Northwest National Laboratory, Richland, Washington.

PNNL-14186. 2003. Results of Detailed Hydrologic Characterization Tests - Fiscal Year 2002. FA Spane, DR Newcomer, and PD Thorne, Pacific Northwest National Laboratory, Richland, Washington.

PNNL-14301-Rev2-ICN-1. 2006. Monitoring Plan for RCRA Groundwater Assessment at the 216-U-12 Crib. BA Williams and CJ Chou, Pacific Northwest National Laboratory, Richland, Washington. 
PNNL-14656. 2004. Borehole Data Package for Four CY 2003 RCRA Wells 299-E27-4, 299-E27-21, 299-E27-22, and 299-E27-23 at Single-Shell, Waste Management Area C, Hanford Site, Washington. BA Williams and SM Narbutovskih, Pacific Northwest National Laboratory, Richland, Washington.

PNNL-14753, Rev. 1. 2006. Groundwater Data Package for Hanford Assessments. PD Thorne, MP Bergeron, MD Williams, and VL Freedman, Pacific Northwest National Laboratory, Richland, Washington.

PNNL-14804. 2004. Results of Detailed Hydrologic Characterization Tests - Fiscal Year 2003. FA Spane and DR Newcomer, Pacific Northwest National Laboratory, Richland, Washington.

PNNL-14859-ICN-1. 2006. Interim Status Groundwater Monitoring Plan for Low-Level Waste Management Areas 1 and 4 , RCRA Facilities, Hanford, Washington. P Dresel, Pacific Northwest National Laboratory, Richland, Washington.

PNNL-15301. 2006. RCRA Assessment Plan for Single-Shell Tank Waste Management Area T. D.G. Horton, Pacific Northwest National Laboratory, Richland, Washington.

PNNL-15315. 2006. RCRA Assessment Plan for Single-Shell Tank Waste Management Area A-AX at the Hanford Site. SM Narbutovskih, Pacific Northwest National Laboratory, Richland, Washington.

PNNL-15479. 2005. Groundwater Monitoring Plan for the Hanford Site 216-B-3 Pond RCRA Facility. DB Barnett, RM Smith, CJ Chou, and JP McDonald, Pacific Northwest National Laboratory, Richland, Washington.

PNNL-15670. 2006. Hanford Site Groundwater Monitoring for Fiscal Year 2005. MJ Hartman, LF Morasch, and WD Webber (eds.), Pacific Northwest National Laboratory, Richland, Washington.

Resource Conservation and Recovery Act. 1976. Public Law 94-580, as amended, 90 Stat. 2795, 42 USC 6901 et seq.

RPP-21895, Rev. 3. 2006. 241-C-103 and 241-C-109 Tanks Waste Retrieval Work Plan. JS Schofield, CH2M HILL Hanford Group, Inc., Richland, Washington.

RPP-PLAN-26534, Rev. C. 2005. Integrated Disposal Facility Operational Monitoring Plan to Meet DOE Order 435.1. Prepared by DR Lucas (DRL Technology Services), SP Reidel (Pacific Northwest National Laboratory), and RM Mitchell, (Duratek Federal Services) for the U.S. Department of Energy, Richland, Washington.

Shapiro SS. 1980. "How to Test Normality and Other Distributional Assumptions." In ASQC Basic References in Quality Control: Statistical Techniques, Vol. 3, EJ Dudewicz (ed.), American Society of Quality Control, Milwaukee, Wisconsin.

Shapiro SS and RS Francia. 1972. "Approximate Analysis of Variance Test for Normality." Journal of the American Statistical Association 67:215-216.

WAC 173-160. "Minimum Standards for Construction and Maintenance of Wells." Washington Administrative Code, Olympia, Washington.

WAC 173-304. "Minimum Functional Standards for Solid Waste Handling." Washington Administrative Code, Olympia, Washington.

WAC 173-304-490. "Ground Water Monitoring Requirements." Washington Administrative Code, Olympia, Washington.

WHC-EP-0021. 1987. Interim Hydrogeologic Characterization Report and Groundwater Monitoring System for the Nonradioactive Dangerous Waste Landfill, Hanford Site, Washington. DC Weekes, SP Luttrell, and MR Fuchs, Westinghouse Hanford Company, Richland, Washington.

WHC-MR-0207. 1990. Borehole Completion Data Package for the 216-B-63 Trench--1990. SM Goodwin, Westinghouse Hanford Company, Richland, Washington. 
WHC-SD-EN-AP-024. 1990. Interim Status Groundwater Monitoring Plan for the 200 East Area Liquid Effluent Retention Facility. JS Schmid, Westinghouse Hanford Company, Richland, Washington.

WHC-SD-EN-AP-185. 1995. Groundwater Monitoring Plan for the 300 Area Process Trenches. JW Lindberg, CJ Chou, and VG Johnson, Westinghouse Hanford Company, Richland, Washington.

WHC-SD-EN-DP-047. 1992. Borehole Completion Data Package for the 216-A-29 RCRA Facility Monitoring Wells: Calendar Year 1991. GL Kasza, Westinghouse Hanford Company, Richland, Washington.

WHC-SD-EN-DP-052. 1993. Borehole Completion Data Package for the 216-S-10 Facility, CY-1992. BA Williams and DB Barnett, Westinghouse Hanford Company, Richland, Washington.

WHC-SD-EN-EV-002. 1990. Interim Hydrogeologic Characterization Report for the 216-B-3 Pond. Westinghouse Hanford Company, Richland, Washington. 
Table B.1. Estimates of Groundwater Flow Rates at Hanford Site Facilities

\begin{tabular}{|c|c|c|c|c|c|c|c|}
\hline Site & $\begin{array}{c}\text { Flow } \\
\text { Direction }\end{array}$ & $\begin{array}{l}\text { Flow Rate } \\
(\mathrm{m} / \mathrm{d})\end{array}$ & Method & $\begin{array}{l}\text { Hydraulic Conductivity } \\
\text { (m/d) (source) }\end{array}$ & $\begin{array}{l}\text { Effective } \\
\text { Porosity }{ }^{(\text {) }}\end{array}$ & Gradient $^{(b)}$ & Comments \\
\hline 116-N-1 LWDF & NW & 0.04 to 0.69 & Darcy & $\begin{array}{l}6.1 \text { to } 37 \\
\text { (PNL-8335) }\end{array}$ & & 0.0019 & $\begin{array}{l}\text { Gradient calculated between wells } 199-\mathrm{N}-34 \text { and } \\
199-\mathrm{N}-2 \text {. }\end{array}$ \\
\hline $\begin{array}{l}120-\mathrm{N}-1 \text { and } \\
120-\mathrm{N}-2\end{array}$ & NW & 0.07 to 1.2 & Darcy & $\begin{array}{l}6.1 \text { to } 37 \\
\text { (PNL-8335) }\end{array}$ & & 0.0032 & $\begin{array}{l}\text { Gradient calculated between wells } 199-\mathrm{N}-72 \text { and } \\
199-\mathrm{N}-26 \text {. }\end{array}$ \\
\hline 116-N-3 LWDF & $\mathrm{N}$ & 0.02 to 0.45 & Darcy & $\begin{array}{l}6.1 \text { to } 37 \\
\text { (PNL-8335) }\end{array}$ & & 0.0012 & $\begin{array}{l}\text { Gradient calculated between wells } 199-\mathrm{N}-28 \text { and } \\
199-\mathrm{N}-81 \text {. }\end{array}$ \\
\hline $\begin{array}{l}\text { 116-H-6 } \\
\text { evaporation } \\
\text { basins }\end{array}$ & $\mathrm{E}$ & 0.34 to 9.7 & Darcy & $\begin{array}{l}15 \text { to } 140 \\
\text { (PNL-6728) }\end{array}$ & & 0.0069 & $\begin{array}{l}\text { Gradient calculated between wells } 199-\mathrm{H} 4-9 \text { and } \\
\text { 199-H4-12B. }\end{array}$ \\
\hline 216-A-29 ditch & WSW & 0.0013 & Darcy & $\begin{array}{l}18 \\
\text { (WHC-SD-EN-DP-047) }\end{array}$ & 0.25 & 0.000018 & Gradient calculated from water-table map. \\
\hline 216-B-3 pond & $\begin{array}{l}\text { WSW to } \\
\text { SSE }\end{array}$ & 0.01 & Darcy & $\begin{array}{l}1.0 \\
\text { (WHC-SD-EN-EV-002; } \\
\text { PNL-10195) }\end{array}$ & 0.25 & 0.002 & $\begin{array}{l}\text { Gradient calculated between wells } 699-44-39 B \\
\text { and } 699-42-42 B \text {. }\end{array}$ \\
\hline 216-B-63 trench & SW? & Undetermined & & $\begin{array}{l}182 \\
(\text { WHC-MR-0207) }\end{array}$ & & & $\begin{array}{l}\text { Uncertain of flow direction. Gradient too low to } \\
\text { determine flow rate. }\end{array}$ \\
\hline $216-S-10$ pond & ESE & 0.075 to 2.25 & Darcy & $\begin{array}{l}10 \\
\text { (WHC-SD-EN-DP-052) } \\
12 \text { to } 150 \\
\text { (BNWL-1709) }\end{array}$ & 0.1 to 0.2 & 0.0015 & $\begin{array}{l}\text { Wells are dry. Gradient calculated using regional } \\
\text { water-table maps. }\end{array}$ \\
\hline 216-U-12 crib & ESE & 0.027 to 0.05 & Darcy & $\begin{array}{l}4.2 \text { to } 5.4 \\
\text { (PNNL-13378) }\end{array}$ & 0.1 to 0.2 & 0.001 & $\begin{array}{l}\text { Gradient calculated between wells 299-W22-87 } \\
\text { and 299-W22-79. }\end{array}$ \\
\hline \multirow[t]{2}{*}{$\begin{array}{l}316-5 \text { process } \\
\text { trenches }\end{array}$} & SE & $\begin{array}{c}10.7 \\
(\mathrm{PNL}-5408)\end{array}$ & $\begin{array}{l}\text { Movement of } \\
\text { PCE spill }\end{array}$ & & & & \\
\hline & SE & 0.14 to 14 & Darcy & $\begin{array}{l}150 \text { to } 15,000 \\
\text { (PNL-6716) }\end{array}$ & 0.25 & 0.00023 & $\begin{array}{l}\text { Gradient calculated from December } 2005 \text { water- } \\
\text { table map. }\end{array}$ \\
\hline IDF & SE & $\begin{array}{l}0.002 \text { to } \\
0.0075\end{array}$ & Darcy & $\begin{array}{l}68 \text { to } 75 \\
\text { (PNNL-13652; } \\
\text { PNNL-11957) }\end{array}$ & & 0.00001 & $\begin{array}{l}\text { Uncertainty in gradient and rate of flow. Flow } \\
\text { direction inferred from plume maps. }\end{array}$ \\
\hline LERF & sW & 0.24 & Darcy & $\begin{array}{l}39.8 \\
\text { (PNNL-14804) }\end{array}$ & 0.25 & 0.0016 & Gradient calculated from water-table map. \\
\hline LLWMA 1 & $\mathrm{~N}$ ? & Undetermined & & $\begin{array}{l}2,500 \text { to } 7,500 \\
\text { (PNNL-14753) }\end{array}$ & & & $\begin{array}{l}\text { Uncertain of flow direction. Gradient too low to } \\
\text { determine flow rate. }\end{array}$ \\
\hline LLWMA 2 & W to SW? & Undetermined & & $\begin{array}{l}2,500 \text { to } 7,500 \\
\text { (PNNL-14753) }\end{array}$ & & & $\begin{array}{l}\text { Uncertain of flow direction. Gradient too low to } \\
\text { determine flow rate. }\end{array}$ \\
\hline LLWMA 3 & $75^{\circ} \mathrm{E}$ of $\mathrm{N}$ & 0.015 to 0.18 & Darcy & $\begin{array}{l}2.5 \text { to } 10 \\
\text { (PNNL-14753) }\end{array}$ & & 0.0018 & Flow direction from trend-surface analysis. \\
\hline LLWMA 4 & $\mathrm{E}$ & 0.1 to 1.0 & Darcy & $\begin{array}{l}10 \text { to } 25 \\
\text { (PNNL-14753) }\end{array}$ & & 0.004 & $\begin{array}{l}\text { Flow direction is variable due to effects of pump- } \\
\text { and-treat system. }\end{array}$ \\
\hline NRDWL & $\begin{array}{l}125^{\circ} \mathrm{E} \text { of } \mathrm{N} \\
\text { (based on } \\
\text { plume maps) }\end{array}$ & 0.02 to 0.15 & Darcy & $\begin{array}{l}518 \text { to } 1,524 \\
\text { (WHC-EP-0021) }\end{array}$ & & 0.00001 & $\begin{array}{l}\text { Uncertainty with gradient and rate of flow. Flow } \\
\text { direction inferred from plume maps. }\end{array}$ \\
\hline
\end{tabular}


Table B.1. (contd)

\begin{tabular}{|c|c|c|c|c|c|c|c|}
\hline Site & $\begin{array}{l}\text { Flow } \\
\text { Direction }\end{array}$ & $\begin{array}{l}\text { Flow Rate } \\
(\mathrm{m} / \mathrm{d})\end{array}$ & Method & $\begin{array}{l}\text { Hydraulic Conductivity } \\
(\mathrm{m} / \mathrm{d}) \text { (source) }\end{array}$ & $\begin{array}{l}\text { Effective } \\
\text { Porosity }\end{array}$ & Gradient $^{(b)}$ & Comments \\
\hline PUREX cribs & SE & 0.0006 to 0.3 & Darcy & $\begin{array}{l}18 \text { to } 3,000 \\
\text { (PNNL-11523; } \\
\text { PNNL-11523-ICN-1) }\end{array}$ & & 0.00001 & $\begin{array}{l}\text { Uncertainty with gradient and rate of flow. Flow } \\
\text { direction inferred from plume maps. }\end{array}$ \\
\hline SWL & $\begin{array}{l}125^{\circ} \mathrm{E} \text { of } \mathrm{N} \\
\text { (based on } \\
\text { plume maps) }\end{array}$ & 0.02 to 0.13 & Darcy & $\begin{array}{l}640 \text { to } 1,280 \\
\text { (PNL-6820) }\end{array}$ & & 0.00001 & $\begin{array}{l}\text { Uncertainty with gradient and rate of flow. Flow } \\
\text { direction inferred from plume maps. }\end{array}$ \\
\hline WMAA-AX & SE & 0.74 to 1.0 & Darcy & 1,981 & 0.3 to 0.4 & 0.00015 & $\begin{array}{l}\text { Gradient and flow rate calculated between wells } \\
299-E 24-20 \text { and } 299-E 25-93 \text {. }\end{array}$ \\
\hline WMA B-BX-BY & $\begin{array}{l}\text { WSW? } \\
\text { (north half) } \\
\text { SSE to SE? } \\
\text { (south half) }\end{array}$ & Undetermined & & $\begin{array}{l}73 \text { to } 2,520 \\
\text { (PNNL-6820) }\end{array}$ & & & $\begin{array}{l}\text { Maximum hydraulic conductivity based on aquifer } \\
\text { test data.(c) Uncertain of flow direction. Gradient } \\
\text { too low to determine flow rate. }\end{array}$ \\
\hline WMA C & SW & Undetermined & Darcy & $\begin{array}{l}1,890 \text { to } 6,888 \\
\text { (PNNL-14656) }\end{array}$ & & & Gradient too low to determine flow rate. \\
\hline \multirow[t]{2}{*}{ WMA S-SX } & $E$ to ESE & 0.07 to 0.14 & $\begin{array}{l}\text { Contaminant } \\
\text { travel time } \\
\text { (PNNL-13441) }\end{array}$ & NA & NA & NA & $\begin{array}{l}\text { Based on inferred contaminant travel time } \\
\text { between } 216-\text { S-25 crib and downgradient wells } \\
299-\text { W23-15 and } 299-\text { W22-46, and between } \\
\text { wells } 299-\text { W22-46 and 299-W22-83. }\end{array}$ \\
\hline & & 0.009 to 0.36 & Darcy & $\begin{array}{l}0.58 \text { to } 17.2 \\
\text { (PNNL-13514 and } \\
\text { PNNL-14113) }\end{array}$ & 0.09 to 0.12 & $\begin{array}{l}0.0018 \text { to } \\
0.0019\end{array}$ & \\
\hline WMA T & $\begin{array}{l}85^{\circ} \text { to } 98^{\circ} \mathrm{E} \\
\text { of } \mathrm{N}\end{array}$ & 0.017 to 0.28 & Darcy & 1.69 to 28.1 & 0.1 & 0.001 & $\begin{array}{l}\text { Flow direction based on trend surface analysis: } \\
\text { PNNL-14113, PNNL-13378. }\end{array}$ \\
\hline WMA TX-TY & $\begin{array}{l}\text { Variable (see } \\
\text { text) }\end{array}$ & NA & NA & $\begin{array}{l}14.2 \text { to } 19.9 \\
\text { (PNNL-13378, } \\
\text { PNNL-14113, and } \\
\text { PNNL-14186 }\end{array}$ & NA & NA & $\begin{array}{l}\text { Flow direction and rate influenced by } 200-Z \mathrm{P}-1 \\
\text { pump-and-treat. }\end{array}$ \\
\hline WMA U & E & 0.08 & Darcy & $\begin{array}{l}6.12 \\
\text { (PNNL-13378) }\end{array}$ & 0.17 & 0.0021 & $\begin{array}{l}\text { Average gradient between upgradient and } \\
\text { downgradient wells. }\end{array}$ \\
\hline $\begin{array}{l}\text { (a) Effective por } \\
\text { (b) March } 2006 \\
\text { (c) Letter report } \\
\text { Test/Depth Inten } \\
\text { IDF = Integrated } \\
\text { LERF = Liquid ef } \\
\text { LLWMA = Low-le } \\
\text { LWDF = Liquid } \\
\text { NA = Not applica } \\
\text { NRDWL = Nonra } \\
\text { PCE = Tetrachlo } \\
\text { PUREX = Pluton } \\
\text { SWL = Solid Wa } \\
\text { WMA = Waste m }\end{array}$ & $\begin{array}{l}\text { assumed to be } \\
\text { ss noted othery } \\
\text { n FA Spane and } \\
\text { Conducted Dur } \\
\text { posal Facility. } \\
\text { nt retention faci } \\
\text { waste manager } \\
\text { e disposal facilit } \\
\text { active Dangerol } \\
\text { hene. } \\
\text {-Uranium Extra } \\
\text {-andfill. } \\
\text { gement area. }\end{array}$ & $\begin{array}{l}\text { etween } 0.1 \text { and } \\
\text { Re. } \\
g \text { the Drilling of } \mathrm{P} \\
\text { Waste Landfill. } \\
\text { on (Plant). }\end{array}$ & $\begin{array}{l}.3 \text {, a representati } \\
\text { cific Northwest N } \\
M A B-B X-B Y W e\end{array}$ & $\begin{array}{l}\text { e range for the unconfine } \\
\text { tional Laboratory, to JV E } \\
\text { 299-E33-49 (C4261), da }\end{array}$ & $\begin{array}{l}\text { aquifer system } \\
\text { rghese, Fluor ' } \\
\text { d October } 8,2\end{array}$ & $\begin{array}{l}\text { unless other } \\
\text { anford, Inc., } \\
04 .\end{array}$ & $\begin{array}{l}\text { Nise noted. } \\
\text { Ilug Test Characterization Results for Multi- }\end{array}$ \\
\hline
\end{tabular}


Table B.2. Upgradient/Downgradient Comparison Values ${ }^{(a)}$ Used for Statistical Comparisons at RCRA Sites in FY 2006

\begin{tabular}{|c|c|c|c|c|c|}
\hline Quarter & $\begin{array}{c}\text { Specific } \\
\text { Conductance } \\
\text { Critical Mean, } \\
\mu \mathrm{S} / \mathrm{cm}\end{array}$ & $\begin{array}{l}\text { pH Critical } \\
\text { Range }\end{array}$ & $\begin{array}{c}\text { TOC Critical } \\
\text { Mean }^{(\mathrm{b})} / \mathrm{LOQ} \\
\mu \mathrm{g} / \mathrm{L}\end{array}$ & $\begin{array}{c}\text { TOX Critical } \\
\text { Mean/LOQ, } \mu \mathrm{g} / \mathrm{L}\end{array}$ & Comments \\
\hline \multicolumn{6}{|c|}{$116-\mathrm{N}-1(1301-\mathrm{N})$ Facility } \\
\hline Jan-Mar 2006 & 1,169 & {$[6.49,8.90]$} & $2,001 / 2,740$ & $34.9 / 30.6$ & \\
\hline Jul-Sep 2006 & 1,169 & {$[6.49,8.90]$} & $2,001 / 2,700$ & $34.9 / 29.5$ & \\
\hline \multicolumn{6}{|c|}{$120-\mathrm{N}-1$ and $120-\mathrm{N}-2$ (1324-N/NA) Facilities } \\
\hline Oct-Dec 2005 & 483 & {$[7.57,8.56]$} & $2,160 / 2,780$ & $30.9 / 30.5$ & \\
\hline Apr-Jun 2006 & 491 & {$[7.53,8.60]$} & $2,300 / 2,930$ & $32.7 / 29.7$ & $\begin{array}{l}\text { Critical means revised because } \\
\text { downgradient well } 199-N-59 \text { was } \\
\text { sampled for the first time in several } \\
\text { years. }\end{array}$ \\
\hline \multicolumn{6}{|c|}{$116-\mathrm{N}-3(1325-\mathrm{N})$ Facility } \\
\hline Jan-Mar 2006 & 403 & {$[7.80,8.35]$} & $2,210 / 2,240$ & $21.7 / 30.6$ & \\
\hline Jul-Sep 2006 & 403 & {$[7.80,8.35]$} & $2,210 / 2,700$ & $21.7 / 29.5$ & \\
\hline \multicolumn{6}{|c|}{ 216-A-29 Ditch } \\
\hline Oct-Dec 2005 & 273 & {$[7.02,9.79]$} & $1,690 / 2,780$ & $18.3 / 30.5$ & \\
\hline Apr-Jun 2006 & 273 & {$[7.14,9.65]$} & $2,980 / 2,930$ & $17.1 / 29.7$ & \\
\hline \multicolumn{6}{|c|}{ 216-B-3 Pond } \\
\hline Jan-Mar 2006 & 338 & {$[7.70,8.58]$} & $2,200 / 2,780$ & $27.2 / 30.5$ & \\
\hline Jul-Sep 2006 & 338 & {$[7.70,8.58]$} & $2,200 / 2,700$ & $27.2 / 29.5$ & \\
\hline \multicolumn{6}{|c|}{ 216-B-63 Ditch } \\
\hline Oct-Dec 2005 & 681 & {$[7.70,8.38]$} & $920 / 2,780$ & $19.1 / 30.5$ & \\
\hline Apr-Jun 2006 & 681 & {$[7.70,8.38]$} & $920 / 2,930$ & $19.1 / 29.7$ & \\
\hline \multicolumn{6}{|c|}{ 216-S-10 Pond and Ditch } \\
\hline Oct-Dec 2005 & 296 & {$[7.49,8.73]$} & $1,300 / 2,780$ & $\mathrm{NC}^{(\mathrm{c})} / 30.5$ & \\
\hline Apr-Jun 2006 & 296 & {$[7.49,8.73]$} & $1,300 / 2,930$ & $\mathrm{NC}^{(\mathrm{c})} / 29.7$ & \\
\hline \multicolumn{6}{|c|}{ Low Level Waste Management Area 1} \\
\hline Oct-Dec 2005 & 778 & {$[7.34,8.70]$} & $1,340 / 2,780$ & $19.2 / 30.5$ & \\
\hline Apr-Jun 2006 & 777 & {$[7.34,8.69]$} & $1,341 / 2,930$ & $19.1 / 29.7$ & $\begin{array}{l}\text { Critical means revised because one } \\
\text { downgradient well could not be } \\
\text { sampled this quarter. }\end{array}$ \\
\hline \multicolumn{6}{|c|}{ Low Level Waste Management Area 2} \\
\hline Oct-Dec 2005 & 1,372 & {$[6.83,8.70]$} & $4,370 / 2,780$ & $64.6 / 30.5$ & \\
\hline Apr-Jun 2006 & 1,372 & {$[6.83,8.70]$} & $4,370 / 2,930$ & $64.6 / 29.7$ & \\
\hline \multicolumn{6}{|c|}{ Low Level Waste Management Area 3} \\
\hline \multicolumn{6}{|c|}{ No statistical comparisons until new baseline established } \\
\hline \multicolumn{6}{|c|}{ Low Level Waste Management Area 4} \\
\hline Jan-Mar 2006 & 813 & {$[7.31,8.55]$} & $1,413 / 2,740$ & $43.9 / 30.6$ & \\
\hline Jul-Sep 2006 & 813 & {$[7.31,8.55]$} & $1,413 / 2,700$ & $43.9 / 29.5$ & \\
\hline \multicolumn{6}{|c|}{ Nonradioactive Dangerous Waste Landfill } \\
\hline Jan-Mar 2006 & 599 & {$[6.71,7.71]$} & $1,079 / 2,740$ & $22.1 / 30.6$ & \\
\hline Jul-Sep 2006 & 598 & {$[6.73,7.70]$} & $1,057 / 2,700$ & $21.7 / 29.5$ & $\begin{array}{l}\text { Critical means revised because one } \\
\text { downgradient well could not be } \\
\text { sampled this quarter. }\end{array}$ \\
\hline \multicolumn{6}{|c|}{ Waste Management Area C } \\
\hline Oct-Dec 2005 & 943 & {$[6.77,9.46]$} & $2,860 / 2,780$ & $39.0 / 30.5$ & \\
\hline Apr-Jun 2006 & 943 & {$[6.77,9.46]$} & $2,860 / 2,930$ & $39.0 / 29.7$ & \\
\hline \multicolumn{6}{|c|}{$\begin{array}{l}\text { (a) Upgradient/Downgradient comparison values (in bold) for TOC and TOX are the larger of calculated } \\
\text { quantitation for the respective quarter. } \\
\text { (b) Reported values rounded to the nearest } 10 \mu \mathrm{g} / \mathrm{L} \text {. } \\
\text { (c) Not calculated. Critical mean value could not be calculated because essentially all measurements w } \\
\text { detection limit. } \\
\text { LOQ = Limit of quantitation; based on field blanks collected and analyzed in the previous four quarters. } \\
\text { TOC = Total organic carbon. } \\
\text { TOX = Total organic halides. }\end{array}$} \\
\hline
\end{tabular}


Table B.3. Monitoring Wells and Constituents for 100-N Area Units (adapted from PNNL-13914)

\begin{tabular}{|c|c|c|c|c|c|c|c|c|c|c|c|}
\hline \multirow[b]{2}{*}{ Well Number ${ }^{(a)}$} & \multirow[b]{2}{*}{ Comment } & \multirow[b]{2}{*}{ 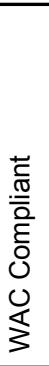 } & \multicolumn{4}{|c|}{$\begin{array}{c}\text { Contamination } \\
\text { Indicator Parameters }\end{array}$} & \multicolumn{4}{|c|}{ Other Parameters } & \multirow[b]{2}{*}{$\begin{array}{c}\text { Sampled as Scheduled } \\
\text { in FY 2006? }\end{array}$} \\
\hline & & & 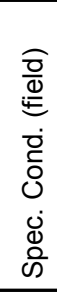 & 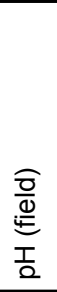 & 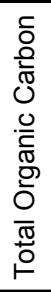 & 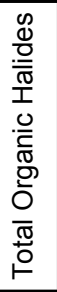 & 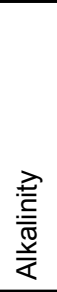 & $\begin{array}{l}\widehat{a} \\
\frac{0}{0} \\
\frac{c}{0} \\
\frac{0}{<}\end{array}$ & 号 & 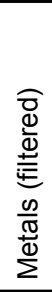 & \\
\hline \multicolumn{12}{|c|}{ 116-N-1 (1301-N) Liquid Waste Disposal Facility } \\
\hline $199-\mathrm{N}-105 \mathrm{~A}$ & Extraction well & $\mathrm{C}$ & $\mathrm{S}$ & $\mathrm{S}$ & $\mathrm{S}$ & $\mathrm{S}$ & $A$ & & A & $\mathrm{A}$ & Yes \\
\hline $199-\mathrm{N}-2$ & & $\mathrm{P}$ & S & $\mathrm{S}$ & $\mathrm{S}$ & $\mathrm{S}$ & A & & A & A & Yes \\
\hline $199-\mathrm{N}-3$ & & $\mathrm{P}$ & $\mathrm{S}$ & $\mathrm{S}$ & $S$ & $\mathrm{~S}$ & A & & A & A & $\begin{array}{l}\text { Second delayed } \\
\text { until } 10 / 2006\end{array}$ \\
\hline $199-N-34$ & & $\mathrm{P}$ & $\mathrm{S}$ & $\mathrm{S}$ & $\mathrm{S}$ & $\mathrm{S}$ & A & & A & A & Yes \\
\hline $199-N-57$ & & $\mathrm{C}$ & $\mathrm{S}$ & $\mathrm{S}$ & $\mathrm{S}$ & $\mathrm{S}$ & A & & A & A & $\begin{array}{c}\text { Second delayed } \\
\text { until } 10 / 2006\end{array}$ \\
\hline \multicolumn{12}{|c|}{ 120-N-1 and 120-N-2 (1324-N/NA) Facilities } \\
\hline $199-\mathrm{N}-59$ & & $\mathrm{C}$ & $\mathrm{S}$ & $\mathrm{S}$ & $\mathrm{S}$ & $\mathrm{S}$ & $A$ & A & A & A & $\begin{array}{c}\text { Sampled once; } \\
\text { insufficient water }\end{array}$ \\
\hline $199-N-71$ & & $\mathrm{C}$ & S & $\mathrm{S}$ & $\mathrm{S}$ & $\mathrm{S}$ & A & & A & A & Yes \\
\hline $199-\mathrm{N}-72$ & & $\mathrm{C}$ & $\mathrm{S}$ & $\mathrm{S}$ & $\mathrm{S}$ & $\mathrm{S}$ & A & & A & A & Yes \\
\hline $199-\mathrm{N}-73$ & & $\mathrm{C}$ & $\mathrm{S}$ & $\mathrm{S}$ & $\mathrm{S}$ & $\mathrm{S}$ & A & & A & A & Yes \\
\hline $199-\mathrm{N}-77$ & $\begin{array}{l}\text { Bottom of } \\
\text { aquifer; no } \\
\text { statistics }\end{array}$ & $\mathrm{C}$ & $\mathrm{S}$ & $\mathrm{S}$ & $\mathrm{S}$ & $\mathrm{S}$ & A & $\mathrm{S}$ & A & A & Yes \\
\hline \multicolumn{12}{|c|}{ 116-N-3 (1325-N) Liquid Waste Disposal Facility } \\
\hline $199-\mathrm{N}-28$ & $\begin{array}{l}\text { Information } \\
\text { only; no } \\
\text { statistics }\end{array}$ & $\mathrm{P}$ & $\mathrm{S}$ & $\mathrm{S}$ & $\mathrm{S}$ & $\mathrm{S}$ & $\mathrm{A}$ & & A & A & Yes \\
\hline $199-\mathrm{N}-32$ & & $\mathrm{P}$ & $\mathrm{S}$ & $\mathrm{S}$ & S & $\mathrm{S}$ & $\mathrm{S}$ & & $\mathrm{S}$ & $S$ & Yes \\
\hline $199-\mathrm{N}-41$ & & $P$ & $S$ & $S$ & $S$ & $S$ & $A$ & & A & A & $\begin{array}{l}\text { Second delayed } \\
\text { until } 11 / 2006\end{array}$ \\
\hline $199-N-74$ & & C & $S$ & $S$ & $S$ & $S$ & $A$ & & $A$ & A & Yes \\
\hline $199-\mathrm{N}-81$ & & C & $S$ & $S$ & $S$ & $\mathrm{~S}$ & $A$ & & A & $\mathrm{A}$ & Yes \\
\hline \multicolumn{12}{|c|}{$\begin{array}{l}\text { Wells completed at the top of the unconfined aquifer unless specified otherwise. } \\
\text { (a) Bold italic = Upgradient well. } \\
\text { (b) Monitored for Atomic Energy Act. } \\
\text { A = To be sampled annually. } \\
\text { C = Well is constructed as a resource protection well under WAC 173-160. } \\
\text { FY = Fiscal year. } \\
P=\text { Constructed prior to WAC requirements. } \\
S=\text { To be sampled semiannually. } \\
\text { Spec. Cond. = Specific conductance. } \\
\text { WAC = Washington Administrative Code. }\end{array}$} \\
\hline
\end{tabular}


Table B.4. Critical Means for 116-N-1 (1301-N) Liquid Waste Disposal Facility for FY 2007 Comparisons ${ }^{(a)}$

\begin{tabular}{|l|c|c|c|c|c|c|c|}
\hline \multicolumn{1}{|c|}{ Constituent, unit } & $\mathrm{n}$ & $\mathrm{df}$ & $\mathrm{t}_{\mathrm{c}}$ & $\begin{array}{c}\text { Average } \\
\text { Background }\end{array}$ & $\begin{array}{c}\text { Standard } \\
\text { Deviation }\end{array}$ & $\begin{array}{c}\text { Critical } \\
\text { Mean }\end{array}$ & $\begin{array}{c}\text { Upgradient/ } \\
\text { Downgradient } \\
\text { Comparison Value }\end{array}$ \\
\hline $\begin{array}{l}\text { Specific conductance, } \\
\mu \mathrm{S} / \mathrm{cm}\end{array}$ & 9 & 8 & 5.0413 & 555.1 & 114.7 & 1,165 & 1,165 \\
\hline Field $\mathrm{pH}$ & 9 & 8 & 5.6174 & 7.67 & 0.242 & {$[6.24,9.10]$} & {$[6.24,9.10]$} \\
\hline $\begin{array}{l}\text { Total organic carbon, } \\
\mu \mathrm{b} / \mathrm{L}\end{array}$ & 9 & 8 & 5.0413 & 502.4 & 296.0 & 2,075 & $2,700^{(\mathrm{c})}$ \\
\hline $\begin{array}{l}\text { Total organic halides, } \\
\mu \mathrm{s} / \mathrm{L}\end{array}$ & $8^{(\mathrm{d})}$ & 7 & 5.4079 & 8.53 & 5.19 & 38.3 & 38.3 \\
\hline
\end{tabular}

(a) Based on semiannual sampling events from September 2004 to March 2006 for upgradient wells $199-\mathrm{N}-57$ and from October 2004 to September 2006 for upgradient well 199-N-34.

(b) For values reported below laboratory's specified method detection limit, one-half of the method detection limit is used in the critical means calculation.

(c) Upgradient/downgradient comparison value is the most recently determined limit of quantitation (updated quarterly).

(d) Excluded suspected values on samples collected in September 2005 from upgradient well 199-N-34.

$\mathrm{df}=$ Degrees of freedom $(n-1)$.

$\mathrm{n}=$ Number of background replicate averages.

$\mathrm{t}_{\mathrm{c}}=$ Bonferroni critical $\mathrm{t}$-value for appropriate $\mathrm{df}$ and 20 comparisons.

Table B.5. Critical Means for 120-N-1 and 120-N-2 (1324-N/NA) Liquid Waste Disposal Facilities for FY 2007 Comparisons ${ }^{(a)}$

\begin{tabular}{|l|c|c|c|c|c|c|c|}
\hline \multicolumn{1}{|c|}{ Constituent, unit } & $\mathrm{n}$ & $\mathrm{df}$ & $\mathrm{t}_{\mathrm{c}}$ & $\begin{array}{c}\text { Average } \\
\text { Background }\end{array}$ & $\begin{array}{c}\text { Standard } \\
\text { Deviation }\end{array}$ & Critical Mean & $\begin{array}{c}\text { Upgradient/ } \\
\text { Downgradient } \\
\text { Comparison Value }\end{array}$ \\
\hline $\begin{array}{l}\text { Specific conductance, } \\
\mu \mathrm{S} / \mathrm{cm}\end{array}$ & 5 & 4 & 7.5288 & 372.0 & 14.3 & 490 & 490 \\
\hline Field $\mathrm{pH}$ & 5 & 4 & 9.0294 & 8.07 & 0.044 & {$[7.63,8.50]$} & {$[7.63,8.50]$} \\
\hline $\begin{array}{l}\text { Total organic carbon, } \\
\mu \mathrm{g} / \mathrm{L} \text { (b) }\end{array}$ & 5 & 4 & 7.5288 & 390.8 & 196.0 & 2,007 & $2,700^{(\mathrm{c})}$ \\
\hline $\begin{array}{l}\text { Total organic halides, } \\
\mu \mathrm{g} / \mathrm{b} \text { (b) }\end{array}$ & 5 & 4 & 7.5288 & 8.3 & 2.59 & 29.6 & 29.6 \\
\hline
\end{tabular}

(a) Based on semiannual sampling events from September 2004 to September 2006 for upgradient well 199-N-71.

(b) For values reported below laboratory's specified method detection limit, one-half of the method detection limit is used in the critical means calculation.

(c) Upgradient/downgradient comparison value is the most recently determined limit of quantitation (updated quarterly).

$\mathrm{df}=$ Degrees of freedom $(n-1)$.

$\mathrm{n}=$ Number of background replicate averages.

$t_{c}=$ Bonferroni critical $t$-value for appropriate $d f$ and 12 comparisons 
Table B.6. Critical Means for 116-N-3 (1325-N) Liquid Waste Disposal Facility for FY 2007 Comparisons ${ }^{(a)}$

\begin{tabular}{|c|c|c|c|c|c|c|c|}
\hline Constituent, unit & $\mathrm{n}$ & df & $t_{c}$ & $\begin{array}{c}\text { Average } \\
\text { Background }\end{array}$ & $\begin{array}{l}\text { Standard } \\
\text { Deviation }\end{array}$ & Critical Mean & $\begin{array}{c}\text { Upgradient/ } \\
\text { Downgradient } \\
\text { Comparison Value }\end{array}$ \\
\hline $\begin{array}{l}\text { Specific conductance, } \\
\mu \mathrm{S} / \mathrm{cm}\end{array}$ & 5 & 4 & 8.1216 & 370.2 & 3.4 & 401 & 401 \\
\hline Field $\mathrm{pH}$ & 5 & 4 & 9.7291 & 8.06 & 0.044 & {$[7.59,8.53]$} & {$[7.59,8.53]$} \\
\hline $\begin{array}{l}\text { Total organic carbon, }{ }^{(b)} \\
\mu \mathrm{g} / \mathrm{L}\end{array}$ & 5 & 4 & 8.1216 & 363.0 & 194.5 & 2,093 & $2,700^{(\mathrm{c})}$ \\
\hline $\begin{array}{l}\text { Total organic halides, }{ }^{(b)} \\
\mu \mathrm{g} / \mathrm{L}\end{array}$ & 5 & 4 & 8.1216 & 5.8 & 2.38 & 27.0 & $29.5^{(\mathrm{c})}$ \\
\hline \multicolumn{8}{|c|}{$\begin{array}{l}\text { (a) Based on semiannual sampling events from September } 2004 \text { to September } 2006 \text { for upgradient well } 199-\mathrm{N}-74 . \\
\text { (b) For values reported below laboratory's specified method detection limit, one-half of the method detection limit is used } \\
\text { in the critical means calculation. } \\
\text { (c) Upgradient/downgradient comparison value is the most recently determined limit of quantitation (updated quarterly). } \\
\mathrm{df}=\text { Degrees of freedom ( } \mathrm{n}-1 \text { ). } \\
\mathrm{n}=\text { Number of background replicate averages. } \\
\mathrm{t}_{\mathrm{c}}=\text { Bonferroni critical t-value for appropriate df and } 16 \text { comparisons. }\end{array}$} \\
\hline
\end{tabular}

Table B.7. Monitoring Wells and Constituents for 116-H-6 (183-H) Evaporation Basins (adapted from PNNL-11573 and 2006 permit modification ${ }^{(a)}$ )

\begin{tabular}{|c|c|c|c|c|c|c|c|c|c|c|}
\hline \multirow[b]{2}{*}{ Well Number } & \multirow[b]{2}{*}{ Comment } & \multirow[b]{2}{*}{ 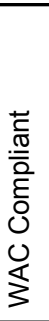 } & \multicolumn{4}{|c|}{ Permit-Specified } & \multicolumn{3}{|c|}{$\begin{array}{c}\text { Other } \\
\text { Parameters } \\
\end{array}$} & \multirow[b]{2}{*}{$\begin{array}{c}\text { Sampled as Scheduled } \\
\text { in FY 2006? }\end{array}$} \\
\hline & & & 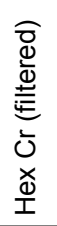 & 恋 & 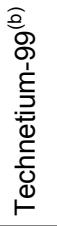 & 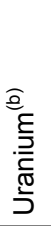 & 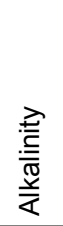 & $\frac{0}{0}$ & 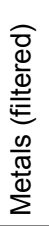 & \\
\hline $199-\mathrm{H} 4-12 \mathrm{~A}$ & Extraction well & $\mathrm{C}$ & $A$ & $\mathrm{~A}$ & $A$ & A & A & $A$ & $A$ & Yes \\
\hline $199-\mathrm{H} 4-12 \mathrm{C}$ & Mid-depth unconfined & C & $A$ & $A$ & $A$ & A & A & $A$ & A & Yes \\
\hline $199-\mathrm{H} 4-3$ & Extraction well & $\mathrm{P}$ & $A$ & $A$ & $A$ & A & A & $A$ & $A$ & Yes \\
\hline $199-\mathrm{H} 4-7$ & $\begin{array}{l}\text { Converted to injection } \\
\text { well } 8 / 2005\end{array}$ & $\mathrm{C}$ & & & & & & & & Removed from network \\
\hline 199-H4-8 & & C & $A$ & $A$ & $A$ & A & A & $A$ & A & Yes \\
\hline \multicolumn{11}{|c|}{$\begin{array}{l}\text { Wells completed at the top of the unconfined aquifer unless specified otherwise. } \\
\text { (a) Hanford Facility RCRA Permit Modification Notification Form, signed by GP Davis (Ecology), January 10, } 2006 . \\
\text { 183-H Solar Evaporation Basins, Part VI, Chapter 2, and Attachment } 37 . \\
\text { (b) Radionuclides not typically subject to RCRA monitoring, but included in the current Hanford Facility RCRA } \\
\text { Permit (Ecology 1994) for this facility. } \\
\text { A = To be sampled annually. } \\
\text { C = Well is constructed as a resource protection well under WAC 173-160. } \\
\text { FY = Fiscal year. } \\
\text { Hex Cr = Hexavalent chromium. } \\
\text { P = Constructed prior to WAC requirements. } \\
\text { RCRA = Resource Conservation and Recovery Act. } \\
\text { WAC = Washington Administrative Code. }\end{array}$} \\
\hline
\end{tabular}


Table B.8. Monitoring Wells and Constituents for 216-A-29 Ditch (adapted from PNNL-13047)

\begin{tabular}{|c|c|c|c|c|c|c|c|c|c|c|c|}
\hline \multirow[b]{2}{*}{ Well Number ${ }^{(a)}$} & \multirow[b]{2}{*}{ Comment } & \multirow[b]{2}{*}{ 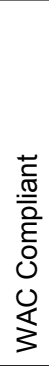 } & \multicolumn{4}{|c|}{$\begin{array}{c}\text { Contamination } \\
\text { Indicator Parameters }\end{array}$} & \multicolumn{4}{|c|}{ Other Parameters } & \multirow[b]{2}{*}{$\begin{array}{c}\text { Sampled as Scheduled } \\
\text { in FY 2006? }\end{array}$} \\
\hline & & & 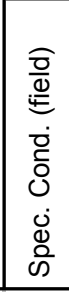 & 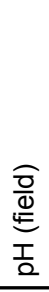 & 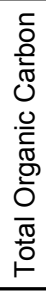 & 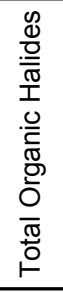 & 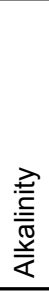 & $\begin{array}{l}0 \\
\stackrel{0}{0} \\
\frac{0}{2} \\
\end{array}$ & 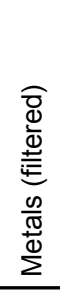 & $\begin{array}{l}\frac{\infty}{0} \\
\frac{C}{\Phi} \\
\frac{D}{\alpha} \\
\end{array}$ & \\
\hline 299-E25-26 & Upper unconfined & $\mathrm{C}$ & $\mathrm{S}$ & $S$ & $\mathrm{~S}$ & $\mathrm{~S}$ & $\mathrm{~S}$ & $\mathrm{~S}$ & $A$ & $A$ & Yes \\
\hline 299-E25-28 & $\begin{array}{l}\text { Deep unconfined; } \\
\text { no statistics }\end{array}$ & $\mathrm{C}$ & $S$ & $S$ & $S$ & $S$ & $S$ & $S$ & $A$ & A & $\begin{array}{l}\text { TOC and TOX } \\
\text { only once }^{(b)}\end{array}$ \\
\hline 299-E25-32P & & C & $S$ & $S$ & $S$ & $S$ & $\mathrm{~S}$ & $\mathrm{~S}$ & A & A & Yes \\
\hline 299-E25-34 & & C & $S$ & $S$ & $S$ & $S$ & $S$ & $\mathrm{~S}$ & A & A & Yes \\
\hline 299-E25-35 & & $\mathrm{C}$ & $S$ & $S$ & $\mathrm{~S}$ & $S$ & $S$ & $\mathrm{~S}$ & $A$ & A & Yes \\
\hline 299-E25-48 & & $\mathrm{C}$ & $S$ & $S$ & $S$ & $S$ & $S$ & $\mathrm{~S}$ & $A$ & A & Yes \\
\hline 299-E26-12 & & $\mathrm{C}$ & $S$ & $S$ & $S$ & $S$ & $S$ & $S$ & $A$ & A & Yes \\
\hline 299-E26-13 & & $\mathrm{C}$ & $S$ & $S$ & $S$ & $S$ & $S$ & $S$ & $A$ & A & Yes \\
\hline $699-43-45$ & & $\mathrm{C}$ & $S$ & $S$ & $S$ & $S$ & $S$ & $S$ & $A$ & $A$ & Yes \\
\hline \multicolumn{12}{|c|}{$\begin{array}{l}\text { Wells completed at the top of the unconfined aquifer unless specified otherwise. } \\
\text { (a) Bold italic = Upgradient well. } \\
\text { (b) Not needed for this supplement well. Interim change notice planned. } \\
\text { A = To be sampled annually. } \\
\text { C = Well is constructed as a resource protection well under WAC 173-160. } \\
\text { FY = Fiscal year. } \\
\text { S = To be sampled semiannually. } \\
\text { Spec. Cond. = Specific conductance. } \\
\text { TOC = Total organic carbon. } \\
\text { TOX = Total organic halides. } \\
\text { WAC = Washinaton Administrative Code }\end{array}$} \\
\hline
\end{tabular}

Table B.9. Critical Means for 216-A-29 Ditch for FY 2007 Comparisons $^{(\mathrm{a})}$

\begin{tabular}{|l|c|c|c|c|c|c|c|}
\hline \multicolumn{1}{|c|}{ Constituent, unit } & $\mathrm{n}$ & $\mathrm{df}$ & $\mathrm{t}_{\mathrm{c}}$ & $\begin{array}{c}\text { Average } \\
\text { Background }\end{array}$ & $\begin{array}{c}\text { Standard } \\
\text { Deviation }\end{array}$ & Critical Mean & $\begin{array}{c}\text { Upgradient/ } \\
\text { Downgradient } \\
\text { Comparison Value }\end{array}$ \\
\hline $\begin{array}{l}\text { Specific conductance, } \\
\mu \mathrm{S} / \mathrm{cm}\end{array}$ & 5 & 4 & 9.7291 & 241.6 & 3.08 & 274 & 274 \\
\hline Field $\mathrm{pH}$ & 7 & 6 & 7.4012 & 8.43 & 0.181 & {$[6.99,9.86]$} & {$[6.99,9.86]$} \\
\hline $\begin{array}{l}\text { Total organic carbon, } \\
\mu \mathrm{g} / \mathrm{L})\end{array}$ & $4^{\text {(c) }}$ & 3 & 15.145 & 302.2 & 121.5 & 2,359 & $2,700^{(\mathrm{d})}$ \\
\hline $\begin{array}{l}\text { Total organic halides, } \\
\mu \mathrm{b} / \mathrm{L}\end{array}$ & 5 & 4 & 9.7291 & 3.51 & 1.55 & 20.0 & $29.5^{(\mathrm{d})}$ \\
\hline
\end{tabular}

(a) Based on semiannual sampling events from April 2005 to April 2006 (October 2004 to April 2006 for pH) for upgradient well 699-43-45.

(b) For values reported below laboratory's specified method detection limit, one-half of the method detection limit is used in the critical means calculation.

(c) Excluded suspected values on samples collected in April 2006.

(d) Upgradient/downgradient comparison value is the most recently determined limit of quantitation (updated quarterly).

$\mathrm{df}=$ Degrees of freedom $(n-1)$.

$\mathrm{n}=$ Number of background replicate averages.

$\mathrm{t}_{\mathrm{c}}=$ Bonferroni critical $\mathrm{t}$-value for appropriate $\mathrm{df}$ and 32 comparisons. 
Table B.10. Monitoring Wells and Constituents for 216-B-3 Pond (adapted from PNNL-15479)

\begin{tabular}{|c|c|c|c|c|c|c|c|c|c|c|c|c|c|}
\hline \multirow[b]{2}{*}{ Well Number ${ }^{(a)}$} & \multirow[b]{2}{*}{ Comment } & \multicolumn{5}{|c|}{$\begin{array}{c}\text { Contamination } \\
\text { Indicator Parameters }\end{array}$} & \multicolumn{6}{|c|}{ Other Parameters } & \multirow[b]{2}{*}{$\begin{array}{l}\text { Sampled as Scheduled } \\
\text { in FY 2006? }\end{array}$} \\
\hline & & 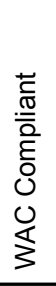 & 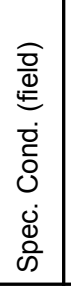 & 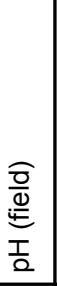 & 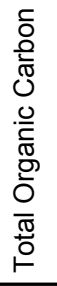 & 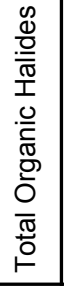 & 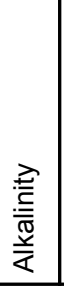 & $\begin{array}{l}\frac{\widehat{a}}{\pi} \\
\frac{\pi}{0} \\
\frac{0}{\alpha}\end{array}$ & $\frac{0}{0}$ & $\begin{array}{l}\text { a } \\
\frac{\pi}{0} \\
\infty \\
\infty\end{array}$ & 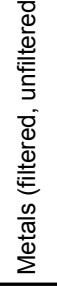 & $\begin{array}{l}\frac{\infty}{0} \\
\frac{0}{\Phi} \\
\frac{\pi}{0}\end{array}$ & \\
\hline $699-42-42 B$ & $\begin{array}{l}\text { Bottom of } \\
\text { aquifer }\end{array}$ & $C$ & $\mathrm{~s}$ & $S$ & $\mathrm{~s}$ & $\mathrm{~s}$ & $\mathrm{~A}$ & $S$ & $\mathrm{~A}$ & $\mathrm{~s}$ & $\mathrm{~A}$ & $A$ & $\begin{array}{l}\text { Second delayed } \\
\text { until } 11 / 2006^{(c)}\end{array}$ \\
\hline 699-43-44 & & C & $\mathrm{s}$ & $S$ & $\mathrm{~s}$ & $\mathrm{~s}$ & A & $S$ & A & $\mathrm{s}$ & A & A & $\begin{array}{l}\text { Second delayed } \\
\text { until } 11 / 2006^{(\mathrm{c})}\end{array}$ \\
\hline $699-43-45$ & & C & $\mathrm{s}$ & $\mathrm{s}$ & $S$ & $\mathrm{~s}$ & $A$ & $S$ & A & $\mathrm{s}$ & A & A & $\begin{array}{l}\text { Second delayed } \\
\text { until } 11 / 2006^{(\mathrm{c})}\end{array}$ \\
\hline $699-44-39 B$ & & C & $\mathrm{s}$ & $\mathrm{s}$ & $\mathrm{S}$ & $\mathrm{s}$ & A & $S$ & A & $\mathrm{s}$ & A & A & $\begin{array}{l}\text { Second delayed } \\
\text { until } 11 / 2006^{(c)}\end{array}$ \\
\hline $\begin{array}{l}\text { Wells completec } \\
\text { (a) Bold italic } \\
\text { (b) Monitored fo } \\
\text { (c) Delayed bec } \\
\mathrm{A}=\text { To be samp } \\
\mathrm{C}=\text { Well is cons } \\
\mathrm{FY}=\text { Fiscal yea } \\
\mathrm{S}=\text { To be samp } \\
\text { Spec. Cond. = } \\
\text { WAC = Washin }\end{array}$ & $\begin{array}{l}\text { t the top of } t \\
\text { Upgradient } \mathrm{u} \\
\text { Atomic Ener } \\
\text { use of fire da } \\
\mathrm{d} \text { annually. } \\
\text { ucted as a re } \\
\mathrm{d} \text { semiannua } \\
\text { ecific conduc } \\
\text { n Administra }\end{array}$ & $\begin{array}{l}\text { e un } \\
\text { ell. } \\
\text { y } A c \\
\text { iger. }\end{array}$ & onfine & $\mathrm{d}$ aqu & ifer 4 & less & specif & ied o & erwi & & & & \\
\hline
\end{tabular}

Table B.11. Critical Means for 216-B-3 Pond for FY 2007 Comparisons $^{(a)}$

\begin{tabular}{|c|c|c|c|c|c|c|c|}
\hline Constituent, unit & $\mathrm{n}$ & df & $t_{c}$ & $\begin{array}{l}\text { Average } \\
\text { Background }\end{array}$ & $\begin{array}{l}\text { Standard } \\
\text { Deviation }\end{array}$ & Critical Mean & $\begin{array}{c}\text { Upgradient/ } \\
\text { Downgradient } \\
\text { Comparison Value }\end{array}$ \\
\hline $\begin{array}{l}\text { Specific conductance, } \\
\mu \mathrm{S} / \mathrm{cm}\end{array}$ & 5 & 4 & 8.1216 & 259.6 & 8.8 & 338 & 338 \\
\hline Field $\mathrm{pH}$ & 5 & 4 & 9.7291 & 8.15 & 0.038 & {$[7.74,8.55]$} & {$[7.74,8.55]$} \\
\hline $\begin{array}{l}\text { Total organic carbon, }{ }^{(b)} \\
\mu \mathrm{g} / \mathrm{L}\end{array}$ & 5 & 4 & 8.1216 & 304.5 & 100.1 & 1,195 & $2,700^{(c)}$ \\
\hline $\begin{array}{l}\text { Total organic halides, }{ }^{(b)} \\
\mu \mathrm{g} / \mathrm{L}\end{array}$ & 5 & 4 & 8.1216 & 2.77 & 2.79 & 27.6 & $29.5^{(\mathrm{c})}$ \\
\hline \multicolumn{8}{|c|}{$\begin{array}{l}\text { (a) Based on semiannual sampling events from January } 2004 \text { to January } 2006 \text { from upgradient well } 699-44-39 B \text {. } \\
\text { (b) For values reported below laboratory's specified method detection limit, one-half of the method detection limit is used } \\
\text { in the critical means calculation. } \\
\text { (c) Upgradient/downgradient comparison value is the most recently determined limit of quantitation (updated quarterly). } \\
\text { df = Degrees of freedom ( } n-1) \text {. } \\
n=\text { Number of background replicate averages. } \\
t_{c}=\text { Bonferroni critical t-value for appropriate df and } 16 \text { comparisons. }\end{array}$} \\
\hline
\end{tabular}


Table B.12. Monitoring Wells and Constituents for 216-B-63 Trench (adapted from PNNL-14112)

\begin{tabular}{|c|c|c|c|c|c|c|c|c|c|c|c|c|}
\hline \multirow[b]{2}{*}{ Well Number ${ }^{(a)}$} & \multirow[b]{2}{*}{ 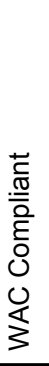 } & \multicolumn{4}{|c|}{$\begin{array}{c}\text { Contamination } \\
\text { Indicator Parameters }\end{array}$} & \multicolumn{6}{|c|}{ Other Parameters } & \multirow[b]{2}{*}{$\begin{array}{c}\text { Sampled as Scheduled } \\
\text { in FY 2006? }\end{array}$} \\
\hline & & 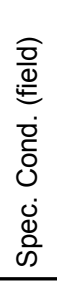 & 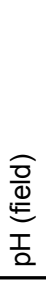 & 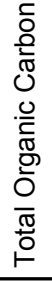 & 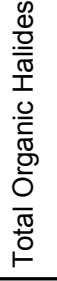 & 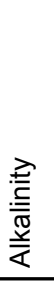 & $\begin{array}{l}\frac{a}{0} \\
\frac{\pi}{0} \\
\frac{0}{2} \\
\end{array}$ & 兄 & $\begin{array}{l}\widehat{a} \\
\bar{\sigma} \\
\overline{0} \\
\infty\end{array}$ & 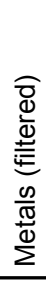 & $\begin{array}{l}\frac{0}{0} \\
\frac{C}{0} \\
\frac{C}{\alpha} \\
\end{array}$ & \\
\hline $299-E 27-8$ & $\mathrm{C}$ & $S$ & $\mathrm{~S}$ & $S$ & $\mathrm{~S}$ & $A$ & $S$ & $A$ & $S$ & $A$ & $A$ & Yes \\
\hline 299-E27-9 & $\mathrm{C}$ & $S$ & $S$ & $S$ & $\mathrm{~S}$ & A & $S$ & A & $S$ & A & $A$ & Yes \\
\hline 299-E27-11 & $\mathrm{C}$ & $S$ & $S$ & $S$ & $S$ & A & $S$ & A & $S$ & A & $A$ & Yes \\
\hline 299-E27-16 & C & $S$ & $S$ & $S$ & $\mathrm{~S}$ & A & $S$ & A & $S$ & A & $A$ & Yes \\
\hline 299-E27-17 & C & $S$ & $S$ & $S$ & $\mathrm{~S}$ & A & $S$ & A & $S$ & A & $A$ & Yes \\
\hline 299-E27-18 & C & $S$ & $\mathrm{~S}$ & $S$ & $\mathrm{~S}$ & A & $S$ & A & $S$ & A & A & Yes \\
\hline 299-E27-19 & C & $S$ & $\mathrm{~S}$ & $S$ & $S$ & $A$ & $S$ & A & $S$ & A & $A$ & Yes \\
\hline 299-E33-33 & C & $S$ & $S$ & $S$ & $S$ & $A$ & $S$ & $A$ & $S$ & A & $A$ & Yes \\
\hline 299-E33-36 & C & $S$ & $S$ & $S$ & $\mathrm{~S}$ & $A$ & $S$ & A & $S$ & A & $A$ & Yes \\
\hline 299-E33-37 & C & $S$ & $S$ & $S$ & $S$ & $A$ & $S$ & $A$ & $S$ & A & $A$ & Yes \\
\hline 299-E34-8 & C & $S$ & $S$ & $S$ & $S$ & $A$ & $S$ & A & $S$ & A & $A$ & Yes \\
\hline 299-E34-10 & C & $S$ & $S$ & $S$ & $\mathrm{~S}$ & $A$ & $S$ & A & $S$ & A & A & Yes \\
\hline \multicolumn{13}{|c|}{$\begin{array}{l}\text { Wells completed at the top of the unconfined aquifer. } \\
\text { (a) Bold italic = Upgradient well. } \\
\text { (b) Monitored for Atomic Energy Act. } \\
\text { A = To be sampled annually. } \\
\text { C = Well is constructed as a resource protection well } \\
\text { FY = Fiscal year. } \\
\text { S = To be sampled semiannually. } \\
\text { Spec. Cond. = Specific conductance. } \\
\text { WAC = Washington Administrative Code. }\end{array}$} \\
\hline
\end{tabular}

Table B.13. Critical Means for 216-B-63 Trench for FY 2007 Comparisons ${ }^{(a)}$

\begin{tabular}{|c|c|c|c|c|c|c|c|}
\hline Constituent, unit & $\mathrm{n}$ & $\mathrm{df}$ & $t_{c}$ & $\begin{array}{c}\text { Average } \\
\text { Background } \\
\end{array}$ & $\begin{array}{l}\text { Standard } \\
\text { Deviation } \\
\end{array}$ & Critical Mean & $\begin{array}{c}\text { Upgradient/ } \\
\text { Downgradient } \\
\text { Comparison Value }\end{array}$ \\
\hline $\begin{array}{l}\text { Specific conductance, } \\
\mu \mathrm{S} / \mathrm{cm}\end{array}$ & 22 & 21 & 4.186 & 451.8 & 67.0 & 739 & 739 \\
\hline Field pH & 22 & 21 & 4.476 & 8.04 & 0.117 & {$[7.51,8.58]$} & {$[7.51,8.58]$} \\
\hline $\begin{array}{l}\text { Total organic carbon, }{ }^{(b)} \\
\mu \mathrm{g} / \mathrm{L}\end{array}$ & 20 & 19 & 4.267 & 425.8 & 158.2 & 1,118 & $2,700^{(c)}$ \\
\hline $\begin{array}{l}\text { Total organic halides, }{ }^{(b)} \\
\mu \mathrm{g} / \mathrm{L}\end{array}$ & $20^{(\mathrm{d})}$ & 19 & 4.267 & 5.0 & 3.52 & 20.4 & $29.5^{(\mathrm{c})}$ \\
\hline \multicolumn{8}{|c|}{$\begin{array}{l}\text { (a) Based on semiannual sampling events from October } 2004 \text { to April } 2006 \text { for upgradient wells } 299-E 27-8,299-E 27-9 \text {, } \\
299-E 27-11 \text {, and } 299-E 27-17 \text { and from January } 2005 \text { to April } 2006 \text { for upgradient well } 299-E 34-10 \text {. } \\
\text { (b) For values reported below laboratory's specified method detection limit, one-half of the method detection limit is used } \\
\text { in the critical means calculation. } \\
\text { (c) Upgradient/downgradient comparison value is the most recently determined limit of quantitation (updated quarterly). } \\
\text { (d) Excluded erroneous analytical results on samples collected in April } 2005 \text { from wells } 299-E 27-9 \text { and } 299-E 34-10 . \\
d f=\text { Degrees of freedom ( } n-1) \text {. } \\
n=\text { Number of background replicate averages. } \\
t_{c}=\text { Bonferroni critical t-value for appropriate df and } 48 \text { comparisons. }\end{array}$} \\
\hline
\end{tabular}


Table B.14. Monitoring Wells and Constituents for 216-S-10 Pond and Ditch (adapted from PNNL-14070 and PNNL-14070-ICN-1)

\begin{tabular}{|c|c|c|c|c|c|c|c|c|c|c|c|c|c|c|}
\hline \multirow[b]{2}{*}{ Well Number } & \multirow[b]{2}{*}{ Comment } & \multirow[b]{2}{*}{ 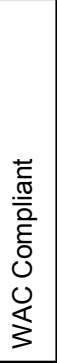 } & \multicolumn{4}{|c|}{\begin{tabular}{c|} 
Contamination \\
Indicator Parameters
\end{tabular}} & \multicolumn{7}{|c|}{ Other Parameters } & \multirow[b]{2}{*}{$\begin{array}{c}\text { Sampled as Scheduled } \\
\text { in FY 2006? }\end{array}$} \\
\hline & & & 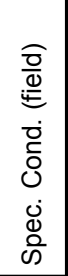 & 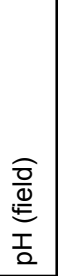 & 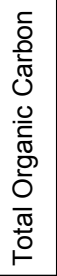 & 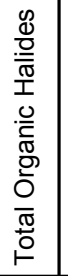 & 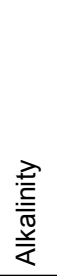 & 号 & 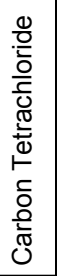 & 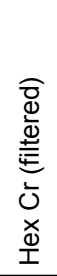 & 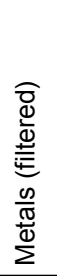 & $\begin{array}{l}\frac{\infty}{0} \\
\frac{0}{\Phi} \\
\frac{c}{\alpha}\end{array}$ & 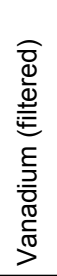 & \\
\hline 299-W26-13 & & $\mathrm{C}$ & $\mathrm{S}$ & $\mathrm{S}$ & $\mathrm{S}$ & $\mathrm{S}$ & $S$ & $A$ & $\mathrm{~S}$ & $\mathrm{~S}$ & $A$ & $A$ & $S$ & $\mathrm{No}^{(\mathrm{a})}$ \\
\hline 299-W26-14 & & C & $S$ & $S$ & $S$ & $S$ & $S$ & A & $S$ & $S$ & A & $A$ & $S$ & Yes \\
\hline 299-W27-2 & $\begin{array}{l}\text { Bottom of aquifer; } \\
\text { no statistics }\end{array}$ & $C$ & $S$ & $S$ & & & $S$ & $A$ & $S$ & $S$ & $A$ & & $S$ & $\mathrm{No}^{(\mathrm{a})}$ \\
\hline \multicolumn{15}{|c|}{$\begin{array}{l}\text { Wells completed at the top of the unconfined aquifer unless specified otherwise. } \\
\text { (a) Carbon tetrachloride and vanadium sampled only once; plan modified for FY } 2007 . \\
A=\text { To be sampled annually. } \\
C=\text { Well is constructed as a resource protection well under WAC 173-160. } \\
\text { FY = Fiscal year. } \\
\text { Hex Cr = Hexavalent chromium. } \\
S=\text { To be sampled semiannually. } \\
\text { Spec. Cond. = Specific conductance. } \\
\text { WAC = Washinaton Administrative Code. }\end{array}$} \\
\hline
\end{tabular}

Table B.15. Critical Means for 216-S-10 Pond and Ditch for FY 2007 Comparisons $^{(a)}$

\begin{tabular}{|l|c|c|c|c|c|c|c|}
\hline \multicolumn{1}{|c|}{ Constituent, unit } & $\mathrm{N}$ & $\mathrm{df}$ & $\mathrm{t}_{\mathrm{c}}$ & $\begin{array}{c}\text { Average } \\
\text { Background }\end{array}$ & $\begin{array}{c}\text { Standard } \\
\text { Deviation }\end{array}$ & Critical Mean & $\begin{array}{c}\text { Upgradient/ } \\
\text { Downgradient } \\
\text { Comparison Value }\end{array}$ \\
\hline $\begin{array}{l}\text { Specific conductance, } \\
\mu \mathrm{S} / \mathrm{cm}\end{array}$ & 4 & 3 & 10.8689 & 269.8 & 2.2 & 296 & 296 \\
\hline Field $\mathrm{pH}$ & 4 & 3 & 13.745 & 8.11 & 0.04 & {$[7.49,8.73]$} & {$[7.49,8.73]$} \\
\hline $\begin{array}{l}\text { Total organic carbon, } \\
\mu \mathrm{g} / \mathrm{L} \text { (b) }\end{array}$ & 4 & 3 & 10.8689 & 195.6 & 90.9 & 1,300 & $2,700^{(\mathrm{c})}$ \\
\hline $\begin{array}{l}\text { Total organic halides, } \\
\mu \mathrm{g} / \mathrm{L}\end{array}$ & 4 & 3 & 10.8689 & $\mathrm{NC}$ & $\mathrm{NC}$ & $\mathrm{NC}$ & $29.5^{(\mathrm{c})}$ \\
\hline
\end{tabular}

(a) Based on semiannual sampling events from December 2001 to June 2003 for upgradient well 299-W26-7, which went dry in 2003. Background levels will be revised when data from a new upgradient well are available.

(b) For values reported below laboratory's specified method detection limit, one-half of the method detection limit is used in the critical means calculation.

(c) Upgradient/downgradient comparison value is the most recently determined limit of quantitation (updater quarterly).

(d) Critical mean cannot be calculated because essentially all measurements are below vendor specified detection limit.

$\mathrm{df}=$ Degrees of freedom $(n-1)$.

$\mathrm{n}=$ Number of background replicate averages.

$\mathrm{NC}=$ Not calculated.

$\mathrm{t}_{\mathrm{c}}=$ Bonferroni critical $\mathrm{t}$-value for appropriate $\mathrm{df}$ and 12 comparisons. 
Table B.16. Monitoring Wells and Constituents for 216-U-12 Crib (adapted from PNNL-14301-Rev2-ICN-1)

\begin{tabular}{|c|c|c|c|c|c|c|c|c|c|}
\hline Well Number ${ }^{(a)}$ & Comment & 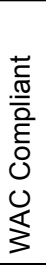 & 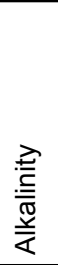 & 足 & 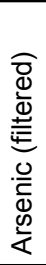 & 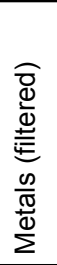 & 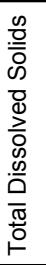 & 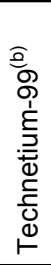 & $\begin{array}{l}\text { Sampled as Scheduled in } \\
\text { FY 2006? }\end{array}$ \\
\hline 299-W21-2 & $\begin{array}{l}\text { Adding to network in } \\
\text { FY } 2006\end{array}$ & $\mathrm{C}$ & $A$ & $Q$ & $A$ & $A$ & $A$ & $Q$ & $\begin{array}{l}\text { Fourth delayed } \\
\text { until } 11 / 2007\end{array}$ \\
\hline 299-W22-79 & & $\mathrm{C}$ & A & Q & A & A & A & Q & $\begin{array}{l}\text { Fourth delayed } \\
\text { until } 10 / 2006\end{array}$ \\
\hline 299-W22-87 & $\begin{array}{l}\text { Adding to network in } \\
\text { FY } 2006\end{array}$ & C & $A$ & Q & $A$ & $A$ & A & Q & $\begin{array}{l}\text { Started June; Sept } \\
\text { delayed to } 10 / 2006\end{array}$ \\
\hline 699-36-70A & & C & A & $Q$ & A & A & A & $\mathrm{Q}$ & Yes \\
\hline \multicolumn{10}{|c|}{$\begin{array}{l}\text { Wells completed at the top of the unconfined aquifer. } \\
\text { (a) Bold italic = Upgradient well. } \\
\text { (b) Monitored for Atomic Energy Act. } \\
\text { A = To be sampled annually. } \\
C=\text { Well is constructed as a resource protection well under WAC 173-160. } \\
\text { FY = Fiscal year. } \\
Q=\text { To be sampled quarterly. } \\
\text { WAC = Washington Administrative Code. }\end{array}$} \\
\hline
\end{tabular}

Table B.17. Monitoring Wells and Constituents for 316-5 Process Trenches (adapted from WHC-SD-EN-AP-185)

\begin{tabular}{|c|c|c|c|c|c|c|c|}
\hline Well Number & Comment & 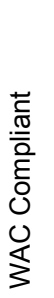 & 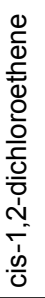 & 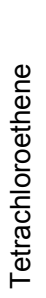 & 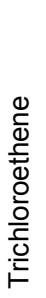 & 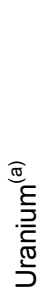 & $\begin{array}{l}\text { Sampled as Scheduled } \\
\text { in FY 2006? }\end{array}$ \\
\hline $399-1-10 A$ & & $\mathrm{C}$ & $S$ & $S$ & $S$ & $S$ & Yes \\
\hline $399-1-10 B$ & Lower unconfined & $\mathrm{C}$ & $S$ & $S$ & $S$ & $S$ & Yes \\
\hline $399-1-16 A$ & & $\mathrm{C}$ & $S$ & $S$ & $S$ & $S$ & Yes \\
\hline $399-1-16 B$ & Lower unconfined & C & $S$ & $S$ & $S$ & S & Yes \\
\hline $399-1-17 A$ & & $C$ & $S$ & $S$ & $S$ & $S$ & Yes \\
\hline $399-1-17 B$ & Lower unconfined & C & $S$ & $S$ & $S$ & $S$ & Yes \\
\hline $399-1-18 A$ & & C & $S$ & $S$ & $S$ & $S$ & Yes \\
\hline $399-1-18 B$ & Lower unconfined & C & $S$ & $S$ & $S$ & $S$ & Yes \\
\hline
\end{tabular}

Wells completed at the top of the unconfined aquifer unless specified otherwise.

(a) Radionuclides not typically subject to RCRA monitoring, but included in the current Hanford Facility RCRA Permit (Ecology 1994) for this facility.

$\mathrm{C}=$ Well is constructed as a resource protection well under WAC 173-160.

$\mathrm{FY}=$ Fiscal year.

RCRA = Resource Conservation and Recovery Act

$\mathrm{S}=$ Sampled four consecutive months, twice per year (semiannually).

WAC $=$ Washington Administrative Code . 
Table B.18. Monitoring Wells and Constituents for Integrated Disposal Facility (adapted from DOE/RL-2003-12 and RPP-PLAN-26534)

\begin{tabular}{|c|c|c|c|c|c|c|c|c|c|c|c|c|c|c|c|}
\hline \multirow[b]{2}{*}{ Well Number ${ }^{(a)}$} & \multirow[b]{2}{*}{ 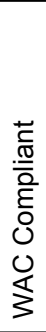 } & \multirow[b]{2}{*}{$\begin{array}{l}\frac{\widehat{a}}{x} \\
\text { x } \\
\frac{x}{0} \\
\frac{0}{d} \\
\frac{0}{2} \\
\frac{1}{4}\end{array}$} & \multicolumn{5}{|c|}{ Indicator Parameters } & \multicolumn{7}{|c|}{ Other Parameters } & \multirow[b]{2}{*}{$\begin{array}{c}\text { Sampled as Scheduled } \\
\text { in FY 2006? }\end{array}$} \\
\hline & & & 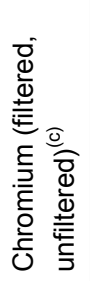 & $\begin{array}{l}\widehat{\partial} \\
\frac{\partial}{0} \\
\dot{0} \\
\dot{0} \\
\dot{0} \\
0 \\
\dot{0} \\
\Phi \\
\text { की }\end{array}$ & 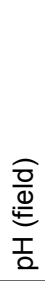 & 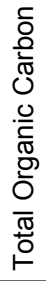 & $\begin{array}{l}\mathscr{0} \\
\frac{d}{0} \\
\frac{0}{\pi} \\
\frac{\pi}{1} \\
.0 \\
\frac{0}{\pi} \\
\frac{\pi}{0} \\
\frac{0}{0} \\
\frac{\pi}{0} \\
\frac{\pi}{0}\end{array}$ & 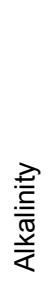 & $\frac{\text { D }}{\frac{0}{c}}$ & 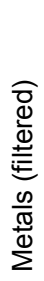 & $\begin{array}{l}\frac{\widehat{0}}{0} \\
\frac{\pi}{0} \\
\frac{0}{\alpha}\end{array}$ & $\begin{array}{l}\widehat{0} \\
\frac{\pi}{0} \\
0 \\
0\end{array}$ & 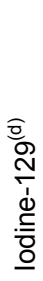 & 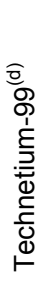 & \\
\hline 299-E17-22 & $\mathrm{C}$ & 1 & (e) & (e) & (e) & (e) & (e) & $\mathrm{S}$ & $S$ & $\mathrm{~S}$ & $S$ & $\mathrm{~S}$ & $\mathrm{~S}$ & $S$ & Yes \\
\hline 299-E17-23 & C & 1 & (e) & (e) & (e) & (e) & (e) & $S$ & $\mathrm{~S}$ & $\mathrm{~S}$ & $S$ & $\mathrm{~S}$ & $\mathrm{~S}$ & $S$ & Yes \\
\hline 299-E17-25 & C & 1 & (e) & (e) & (e) & (e) & (e) & $S$ & $S$ & $S$ & $S$ & $S$ & $\mathrm{~S}$ & $S$ & Missed 7/2006 \\
\hline 299-E17-26 & C & 1 & (e) & (e) & (e) & (e) & (e) & $S$ & $S$ & $S$ & $S$ & $S$ & $S$ & $S$ & Yes \\
\hline 299-E18-1 & C & 1 & (e) & (e) & (e) & (e) & (e) & $S$ & $S$ & $S$ & $S$ & $S$ & $S$ & $S$ & Yes \\
\hline 299-E24-21 & C & 1 & (e) & (e) & (e) & (e) & (e) & $S$ & $S$ & $S$ & $S$ & $S$ & $S$ & $S$ & Yes \\
\hline 299-E24-24 & $\mathrm{C}$ & 1 & (e) & (e) & (e) & (e) & (e) & $S$ & $S$ & $S$ & $S$ & $S$ & $S$ & $S$ & Yes \\
\hline
\end{tabular}

Wells completed at the top of the unconfined aquifer.

(a) Bold italic $=$ Upgradient well.

(b) 40 CFR 264, Appendix IX constituent list, sampled one time per well. See main text

(c) Filtered and unfiltered samples for one year after background established; filtered only thereafter.

(d) Operational parameters monitored for DOE Order 435.1.

(e) Sampled two times per quarter for one year to establish background, then four times semiannually (total of eight times per well per year) thereafter.

$C=$ Well is constructed as a resource protection well under WAC 173-160.

$\mathrm{FY}=$ Fiscal year.

$S=$ To be sampled semiannually.

Spec. . Cond. $=$ Specific conductance. .

WAC $=$ Washington Administrative Code.

Table B.19. Monitoring Wells and Constituents for Liquid Effluent Retention Facility (adapted from WHC-SD-EN-AP-024)

\begin{tabular}{|c|c|c|c|c|c|c|c|c|c|c|}
\hline Well Number ${ }^{(a)}$ & 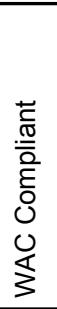 & 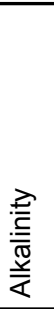 & $\begin{array}{l}\frac{\widehat{a}}{\frac{\pi}{0}} \\
\frac{\bar{c}}{0} \\
\frac{0}{\alpha}\end{array}$ & 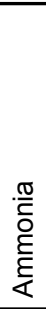 & $\begin{array}{l}0 \\
\stackrel{0}{0} \\
\frac{0}{5} \\
\frac{1}{<}\end{array}$ & $\begin{array}{l}\widehat{a} \\
\frac{\pi}{0} \\
0 \\
\infty\end{array}$ & 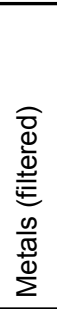 & $\begin{array}{l}\frac{\infty}{0} \\
\frac{0}{\infty} \\
\frac{1}{\alpha}\end{array}$ & 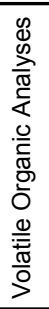 & $\begin{array}{c}\text { Sampled as Scheduled } \\
\text { in FY 2006? }\end{array}$ \\
\hline 299-E26-10 & $C$ & A & $S$ & $S$ & $A$ & $S$ & $A$ & $A$ & $S$ & Yes \\
\hline 299-E26-11 & $\mathrm{C}$ & A & $S$ & $\mathrm{~S}$ & $A$ & $S$ & $A$ & $A$ & $S$ & Yes \\
\hline \multicolumn{11}{|c|}{$\begin{array}{l}\text { Wells completed at the top of the unconfined aquifer. } \\
\text { Statistical evaluations suspended in } 2001 \text { because only one downgradient well is not dry. } \\
\text { (a) Bold italic = Upgradient well. } \\
\text { (b) Monitored for Atomic Energy Act. } \\
\text { A = To be sampled annually. } \\
\text { C = Well is constructed as a resource protection well under WAC 173-160. } \\
\text { FY = Fiscal year. } \\
S=\text { To be sampled semiannually. } \\
\text { WAC = Washington Administrative Code. }\end{array}$} \\
\hline
\end{tabular}


Table B.20. Monitoring Wells and Constituents for Low-Level Waste Management Area 1 (adapted from PNNL-14859-ICN-1 and DOE/RL-2000-72)

\begin{tabular}{|c|c|c|c|c|c|c|c|c|c|c|c|c|c|c|c|c|}
\hline \multirow[b]{2}{*}{ Well Number ${ }^{(a)}$} & \multirow[b]{2}{*}{ 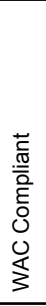 } & \multicolumn{4}{|c|}{$\begin{array}{c}\text { Contamination } \\
\text { Indicator Parameters }\end{array}$} & \multicolumn{6}{|c|}{ Other Chemical Parameters } & \multicolumn{4}{|c|}{ AEA Parameters ${ }^{(\mathrm{b})}$} & \multirow[b]{2}{*}{$\begin{array}{c}\text { Sampled as Scheduled } \\
\text { in FY 2006? }\end{array}$} \\
\hline & & 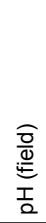 & 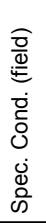 & 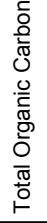 & 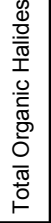 & 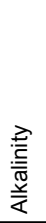 & 号 & 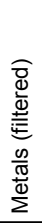 & 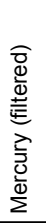 & 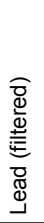 & $\begin{array}{l}\frac{\infty}{0} \\
\frac{0}{\Phi} \\
\frac{\Phi}{L}\end{array}$ & 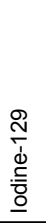 & 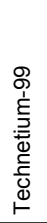 & 点 & 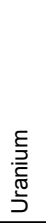 & \\
\hline 299-E28-26 & C & $S$ & $\mathrm{~S}$ & $S$ & $\mathrm{~S}$ & A & $S$ & $S$ & A & A & A & $S$ & $S$ & $S$ & $\mathrm{~S}$ & Yes \\
\hline 299-E28-27 & C & $S$ & $\mathrm{~S}$ & $S$ & $\mathrm{~S}$ & A & $S$ & $\mathrm{~S}$ & A & A & A & $\mathrm{S}$ & S & S & $\mathrm{S}$ & Yes \\
\hline 299-E28-28 & C & $\mathrm{S}$ & $\mathrm{S}$ & $S$ & $\mathrm{~S}$ & A & $\mathrm{S}$ & $\mathrm{S}$ & A & A & A & $\mathrm{S}$ & S & S & $\mathrm{S}$ & Yes \\
\hline $299-E 32-2$ & C & $S$ & $\mathrm{~S}$ & $S$ & $\mathrm{~S}$ & A & $S$ & $\mathrm{~S}$ & A & A & A & $\mathrm{S}$ & $S$ & S & $\mathrm{S}$ & Yes \\
\hline 299-E32-3 & C & $S$ & $S$ & $S$ & $S$ & A & $S$ & $S$ & A & A & A & $S$ & $S$ & $S$ & $S$ & Yes \\
\hline 299-E32-4 & C & $S$ & $S$ & $S$ & $S$ & A & $S$ & $S$ & A & A & A & $S$ & $S$ & $S$ & $S$ & Yes \\
\hline 299-E32-5 & C & $S$ & $S$ & $S$ & $S$ & $A$ & $S$ & $S$ & A & A & A & $S$ & $S$ & $S$ & $S$ & Yes \\
\hline 299-E32-6 & C & $S$ & $S$ & $S$ & $S$ & A & $S$ & $S$ & A & $A$ & A & $S$ & $S$ & $S$ & $S$ & Yes \\
\hline 299-E32-7 & C & $S$ & $S$ & $S$ & $S$ & $A$ & $S$ & $S$ & A & $A$ & A & $S$ & $S$ & $S$ & $S$ & Yes \\
\hline 299-E32-8 & $\mathrm{C}$ & $S$ & $S$ & $S$ & $S$ & A & $S$ & $S$ & A & $A$ & $A$ & $S$ & $S$ & $S$ & $S$ & Yes \\
\hline 299-E32-9 & C & $S$ & $S$ & $S$ & $S$ & A & $S$ & $S$ & A & A & A & $S$ & $S$ & $S$ & $S$ & Yes \\
\hline 299-E32-10 & C & $S$ & $S$ & $S$ & $S$ & A & $S$ & $S$ & A & A & A & $S$ & $S$ & $S$ & $S$ & Yes \\
\hline 299-E33-28 & $\mathrm{C}$ & $S$ & $S$ & $S$ & $S$ & A & $S$ & $S$ & A & A & A & $S$ & $S$ & $S$ & $S$ & Yes \\
\hline 299-E33-29 & $\mathrm{C}$ & $\mathrm{S}$ & $\mathrm{S}$ & $S$ & $\mathrm{~S}$ & A & $\mathrm{S}$ & $\mathrm{S}$ & A & A & A & $\mathrm{S}$ & $S$ & $S$ & $\mathrm{~S}$ & Yes \\
\hline 299-E33-30 & C & $\mathrm{S}$ & $\mathrm{S}$ & $S$ & $\mathrm{~S}$ & A & $S$ & $\mathrm{~S}$ & $A$ & A & A & $S$ & $S$ & $S$ & $S$ & Yes \\
\hline 299-E33-34 & C & $S$ & $\mathrm{~S}$ & $S$ & $\mathrm{~S}$ & A & $S$ & $S$ & A & A & A & $\mathrm{S}$ & $S$ & $S$ & $\mathrm{~S}$ & Yes \\
\hline 299-E33-35 & C & $\mathrm{S}$ & $\mathrm{S}$ & $S$ & $\mathrm{~S}$ & $\mathrm{~A}$ & $\mathrm{~S}$ & $\mathrm{~S}$ & $\mathrm{~A}$ & A & A & $\mathrm{S}$ & $S$ & $S$ & $\mathrm{~S}$ & Yes \\
\hline \multicolumn{17}{|c|}{$\begin{array}{l}\text { Wells completed at the top of the unconfined aquifer unless specified otherwise. } \\
\text { (a) Bold italic = Upgradient well. } \\
\text { (b) Monitored for DOE Order } 435.1 . \\
\text { A = To be sampled annually. } \\
\text { AEA = Atomic Energy Act } \\
C=\text { Well is constructed as a resource protection well under WAC 173-160. } \\
\text { FY = Fiscal year. } \\
S=\text { To be sampled semiannually. } \\
\text { Spec. Cond. = Specific conductance. } \\
\text { WAC = Washington Administrative Code. }\end{array}$} \\
\hline
\end{tabular}

Table B.21. Critical Means for Low-Level Waste Management Area 1 for FY 2007 Comparisons ${ }^{(a)}$

\begin{tabular}{|c|c|c|c|c|c|c|c|}
\hline Constituent, unit & $\mathrm{n}$ & $\mathrm{df}$ & $t_{c}$ & $\begin{array}{l}\text { Average } \\
\text { Background }\end{array}$ & $\begin{array}{l}\text { Standard } \\
\text { Deviation }\end{array}$ & Critical Mean & $\begin{array}{c}\text { Upgradient/ } \\
\text { Downgradient } \\
\text { Comparison Value }\end{array}$ \\
\hline $\begin{array}{l}\text { Specific conductance, } \\
\mu \mathrm{S} / \mathrm{cm}\end{array}$ & 28 & 27 & 4.1540 & 508.9 & 70.8 & 808 & 808 \\
\hline Field pH & 28 & 27 & 4.4137 & 8.00 & 0.126 & {$[7.44,8.57]$} & {$[7.44,8.57]$} \\
\hline $\begin{array}{l}\text { Total organic carbon, }{ }^{(b)} \\
\mu \mathrm{g} / \mathrm{L}\end{array}$ & 28 & 27 & 4.1540 & 701.6 & 489.4 & 2,771 & $2,770^{(c)}$ \\
\hline $\begin{array}{l}\text { Total organic halides, }{ }^{(b)} \\
\mu \mathrm{g} / \mathrm{L}\end{array}$ & 28 & 27 & 4.1540 & 5.11 & 3.16 & 18.5 & $29.5^{(\mathrm{d})}$ \\
\hline \multicolumn{8}{|c|}{$\begin{array}{l}\text { (a) Based on semiannual sampling events from December } 2004 \text { to June } 2006 \text { for upgradient wells } 299-E 28-26 \text {, } \\
299-E 28-27,299-E 28-28,299-E 32-4,299-E 33-28,299-E 33-29 \text {, and } 299-E 33-35 \text {. } \\
\text { (b) For values reported below laboratory's specified method detection limit, one-half of the method detection limit is used } \\
\text { in the critical means calculation. } \\
\text { (c) Upgradient/downgradient comparison value is the calculated critical mean rounded to the nearest } 10 \mu \mathrm{g} / \mathrm{L} \text {. } \\
\text { (d) Upgradient/downgradient comparison value is the most recently determined limit of quantitation (updated quarterly). } \\
\text { df = Degrees of freedom }(n-1) \text {. } \\
n=\text { Number of background replicate averages. } \\
t_{c}=\text { Bonferroni critical t-value for appropriate df and } 68 \text { comparisons. }\end{array}$} \\
\hline
\end{tabular}


Table B.22. Monitoring Wells and Constituents for Low-Level Waste Management Area 2 (adapted from PNNL-14859-ICN-1 and DOE/RL-2000-72)

\begin{tabular}{|c|c|c|c|c|c|c|c|c|c|c|c|c|c|c|c|c|c|c|}
\hline \multirow[b]{2}{*}{ Well Number ${ }^{(a)}$} & \multirow[b]{2}{*}{ Comment } & \multirow[b]{2}{*}{ 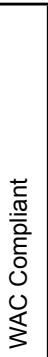 } & \multicolumn{4}{|c|}{\begin{tabular}{c|} 
Contamination \\
Indicator Parameters \\
\end{tabular}} & \multicolumn{7}{|c|}{ Other Chemical Parameters } & \multicolumn{4}{|c|}{ AEA Parameters ${ }^{(b)}$} & \multirow[b]{2}{*}{$\begin{array}{l}\text { Sampled as Scheduled } \\
\text { in FY 2006? }\end{array}$} \\
\hline & & & 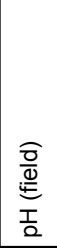 & 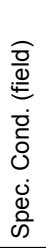 & 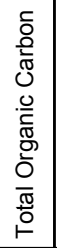 & 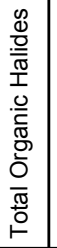 & 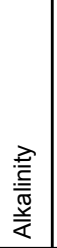 & $\underset{\stackrel{0}{0}}{\frac{0}{c}}$ & 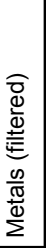 & 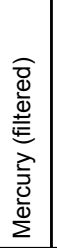 & 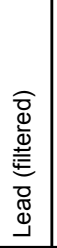 & 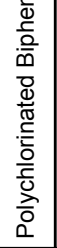 & $\begin{array}{l}\frac{0}{0} \\
\frac{0}{\Phi} \\
\frac{\pi}{\alpha}\end{array}$ & 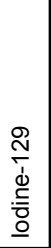 & 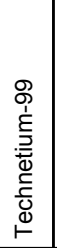 & $\begin{array}{l}\underline{\xi} \\
\stackrel{\underline{E}}{E} \\
\vdash\end{array}$ & 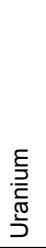 & \\
\hline 299-E27-8 & & $C$ & $S$ & $\mathrm{~s}$ & $\mathrm{~s}$ & $\mathrm{~s}$ & $A$ & $\mathrm{~s}$ & $S$ & $A$ & $A$ & $A$ & $A$ & $\mathrm{~s}$ & $\mathrm{~s}$ & $s$ & $\mathrm{~s}$ & Yes \\
\hline 299-E27-9 & & $C$ & $S$ & $\mathrm{~s}$ & $S$ & $S$ & A & $s$ & $S$ & A & A & A & A & $s$ & $\mathrm{~s}$ & $S$ & $\mathrm{~s}$ & Yes \\
\hline 299-E27-10 & & $\mathrm{C}$ & $S$ & $S$ & S & $S$ & A & S & $S$ & A & A & $A$ & $A$ & 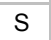 & S & $S$ & $\mathrm{~S}$ & Yes \\
\hline 299-E27-11 & & $\mathrm{C}$ & $S$ & $S$ & S & $S$ & A & $S$ & $S$ & A & $A$ & $A$ & A & 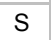 & S & $S$ & $\mathrm{~S}$ & Yes \\
\hline 299-E27-17 & & C & $S$ & $S$ & S & $\mathrm{S}$ & $A$ & S & $S$ & A & A & $A$ & A & $s$ & S & $S$ & $S$ & Yes \\
\hline 299-E34-2 & & C & S & $S$ & S & $S$ & A & $S$ & $S$ & $A$ & A & $A$ & A & $\mathrm{s}$ & S & $S$ & $\mathrm{~S}$ & Yes \\
\hline 299-E34-9 & & $\mathrm{C}$ & $S$ & $S$ & S & $S$ & $A$ & $\mathrm{~S}$ & $S$ & $A$ & $A$ & $A$ & $A$ & $\mathrm{~s}$ & $S$ & $S$ & $S$ & Yes \\
\hline 299-E34-10 & & C & $S$ & $S$ & $S$ & $S$ & $A$ & $S$ & $S$ & $A$ & $A$ & $A$ & $A$ & $\mathrm{~S}$ & $S$ & $S$ & $S$ & Yes \\
\hline 299-E34-12 & & $\mathrm{C}$ & $S$ & $S$ & $S$ & $S$ & $\mathrm{~A}$ & $\mathrm{~S}$ & $S$ & $\mathrm{~A}$ & $\mathrm{~A}$ & $\mathrm{~A}$ & $\mathrm{~A}$ & $\mathrm{~s}$ & $\mathrm{~S}$ & $s$ & $S$ & Yes \\
\hline \multicolumn{19}{|c|}{$\begin{array}{l}\text { Wells completed at the top of the unconfined aquifer. } \\
\text { (a) Bold italic = Upgradient well. } \\
\text { (b) Monitored for DOE Order } 435.1 \text {. } \\
A=\text { To be sampled annually. } \\
\text { AEA = Atomic Energy Act. } \\
C=\text { Well is constructed as a resource protection well under WAC 173-160. } \\
\text { FY = Fiscal year. } \\
S=\text { To be sampled semiannually. } \\
\text { Spec. Cond. = Specific conductance. } \\
\text { WAC = Washington Administrative Code. }\end{array}$} \\
\hline
\end{tabular}

Table B.23. Critical Means for Low-Level Waste Management Area 2 for FY 2007 Comparisons ${ }^{(a)}$

\begin{tabular}{|c|c|c|c|c|c|c|c|}
\hline Constituent, unit & $\mathrm{n}$ & df & $t_{c}$ & $\begin{array}{c}\text { Average } \\
\text { Background }\end{array}$ & $\begin{array}{l}\text { Standard } \\
\text { Deviation }\end{array}$ & Critical Mean & $\begin{array}{c}\text { Upgradient/ } \\
\text { Downgradient } \\
\text { Comparison Value }\end{array}$ \\
\hline $\begin{array}{l}\text { Specific conductance, } \\
\mu \mathrm{S} / \mathrm{cm}\end{array}$ & 6 & 5 & 7.7981 & 951.1 & 52.9 & 1,397 & 1,397 \\
\hline Field $\mathrm{pH}$ & 6 & 5 & 9.0332 & 7.72 & 0.079 & {$[6.95,8.48]$} & {$[6.95,8.48]$} \\
\hline $\begin{array}{l}\text { Total organic carbon, }{ }^{(b)} \\
\mu \mathrm{g} / \mathrm{L}\end{array}$ & 6 & 5 & 7.7981 & 985.6 & 174.9 & 2,459 & $2,700^{(c)}$ \\
\hline $\begin{array}{l}\text { Total organic halides, }{ }^{(b)} \\
\mu \mathrm{g} / \mathrm{L}\end{array}$ & 6 & 5 & 7.7981 & 10.22 & 6.16 & 62.1 & 62.1 \\
\hline \multicolumn{8}{|c|}{$\begin{array}{l}\text { (a) Based on semiannual sampling events from April } 2004 \text { to April } 2006 \text { for upgradient well } 299-E 27-10 . \\
\text { (b) For values reported below laboratory's specified method detection limit, one-half of the method detection limit is used in } \\
\text { the critical means calculation. } \\
\text { (c) Upgradient/downgradient comparison value is the most recently determined limit of quantitation (updated quarterly). } \\
\mathrm{df}=\text { Degrees of freedom }(n-1) \text {. } \\
\mathrm{n}=\text { Number of background replicate averages. } \\
\mathrm{t}_{\mathrm{c}}=\text { Bonferroni critical t-value for appropriate df and } 36 \text { comparisons. }\end{array}$} \\
\hline
\end{tabular}


Table B.24. Monitoring Wells and Constituents for Low-Level Waste Management Area 3 (adapted from PNNL-14859-ICN-1 and DOE/RL-2000-72)

\begin{tabular}{|c|c|c|c|c|c|c|c|c|c|c|c|c|c|c|c|c|c|c|}
\hline \multirow[b]{2}{*}{ Well Number } & \multirow[b]{2}{*}{ Comment } & \multirow[b]{2}{*}{ 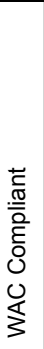 } & \multicolumn{4}{|c|}{$\begin{array}{c}\text { Indicator } \\
\text { Parameters }\end{array}$} & \multicolumn{7}{|c|}{ Other Chemical Parameters } & \multicolumn{4}{|c|}{ AEA Parameters ${ }^{(a)}$} & \multirow[b]{2}{*}{$\begin{array}{c}\text { Sampled as Scheduled } \\
\text { in FY 2006? }\end{array}$} \\
\hline & & & 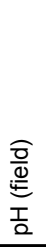 & 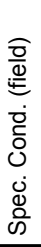 & 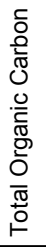 & 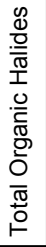 & 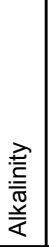 & $\frac{\infty}{\stackrel{0}{0}}$ & 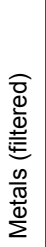 & 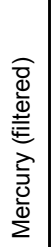 & 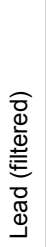 & $\begin{array}{l}\frac{\infty}{0} \\
\frac{0}{0} \\
\frac{C}{\alpha}\end{array}$ & 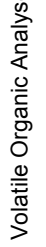 & 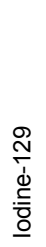 & 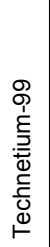 & 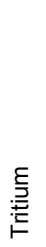 & 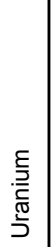 & \\
\hline $299-W 7-3$ & $\begin{array}{l}\text { Deep unconfined; } \\
\text { no statistics }\end{array}$ & $\mathrm{C}$ & $S$ & $\mathrm{~S}$ & $\mathrm{~S}$ & $\mathrm{~S}$ & $A$ & $\mathrm{~S}$ & $\mathrm{~S}$ & $\mathrm{~A}$ & $A$ & $\mathrm{~A}$ & $A$ & $\mathrm{~S}$ & $S$ & $\mathrm{~S}$ & $\mathrm{~S}$ & $\begin{array}{l}\text { Second delayed } \\
\text { until 10/2006 }\end{array}$ \\
\hline 299-W7-4 & & $\mathrm{C}$ & S & $\mathrm{S}$ & $\mathrm{S}$ & $\mathrm{S}$ & $A$ & $S$ & $S$ & A & $A$ & $A$ & A & $S$ & S & S & S & Yes \\
\hline 299-W8-1 & & $\mathrm{C}$ & S & $\mathrm{S}$ & $\mathrm{S}$ & $\mathrm{S}$ & $A$ & $S$ & $S$ & A & A & A & A & S & $S$ & S & S & $\begin{array}{l}\text { Second delayed } \\
\text { until } 10 / 2006\end{array}$ \\
\hline 299-W10-14 & $\begin{array}{l}\text { Deep unconfined; } \\
\text { no statistics }\end{array}$ & $\mathrm{C}$ & $S$ & $\mathrm{~S}$ & $S$ & $\mathrm{~S}$ & $A$ & $S$ & $S$ & A & $A$ & $A$ & A & S & $S$ & $S$ & S & $\begin{array}{l}\text { Second delayed } \\
\text { until 10/2006 }\end{array}$ \\
\hline 299-W10-20 & & $\mathrm{C}$ & $S$ & $S$ & $S$ & $S$ & $A$ & $S$ & $S$ & A & $A$ & $A$ & A & $S$ & $S$ & $S$ & $S$ & $\begin{array}{l}\text { Second unsuccessful; } \\
\text { dry }\end{array}$ \\
\hline 299-W10-29 & Planned & $\mathrm{C}$ & $S$ & $\mathrm{~S}$ & $\mathrm{~S}$ & $S$ & A & $S$ & $S$ & A & $A$ & $A$ & $A$ & $S$ & S & S & $S$ & $\begin{array}{c}\text { New well; sampling } \\
\text { delayed until } 10 / 2006\end{array}$ \\
\hline 299-W10-30 & Planned & $\mathrm{C}$ & $\mathrm{S}$ & $\mathrm{S}$ & $\mathrm{S}$ & $\mathrm{S}$ & $A$ & $\mathrm{~S}$ & $\mathrm{~S}$ & $A$ & $A$ & $A$ & $A$ & $\mathrm{~S}$ & $\mathrm{~S}$ & $S$ & S & $\begin{array}{c}\text { New well; sampling } \\
\text { delayed until } 10 / 2006\end{array}$ \\
\hline 299-W10-31 & & C & $S$ & $\mathrm{~S}$ & $\mathrm{~S}$ & $\mathrm{~S}$ & $A$ & $S$ & $S$ & A & $A$ & $A$ & $A$ & $S$ & S & S & $S$ & $\begin{array}{l}\text { New well; sampling } \\
\text { delayed until 10/2006 }\end{array}$ \\
\hline \multicolumn{19}{|c|}{$\begin{array}{l}\text { Wells completed at the top of the unconfined aquifer unless specified otherwise. } \\
\text { (a) Monitored for DOE Order } 435.1 \text {. } \\
\text { A = To be sampled annually. } \\
\text { AEA = Atomic Energy Act } \\
\text { C = Well is constructed as a resource protection well under WAC 173-160. } \\
\text { FY = Fiscal year. } \\
S=\text { To be sampled semiannually. } \\
\text { Spec. Cond. = Specific conductance. } \\
\text { WAC = Washington Administrative Code. }\end{array}$} \\
\hline
\end{tabular}


Table B.25. Monitoring Wells and Constituents for Low-Level Waste Management Area 4 (adapted from PNNL-14859-ICN-1 and DOE/RL-2000-72)

\begin{tabular}{|c|c|c|c|c|c|c|c|c|c|c|c|c|c|c|c|c|c|c|}
\hline \multirow[b]{2}{*}{ Well Number ${ }^{(a)}$} & \multirow[b]{2}{*}{ Comment } & \multirow[b]{2}{*}{ 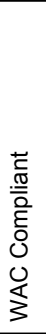 } & \multicolumn{4}{|c|}{$\begin{array}{l}\text { Indicator } \\
\text { Parameters }\end{array}$} & \multicolumn{7}{|c|}{ Other Chemical Parameters } & \multicolumn{4}{|c|}{ AEA Parameters ${ }^{(\mathrm{b})}$} & \multirow[b]{2}{*}{$\begin{array}{l}\text { Sampled as Scheduled } \\
\text { in FY 2006? }\end{array}$} \\
\hline & & & 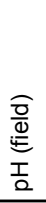 & 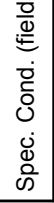 & 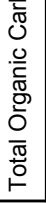 & 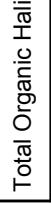 & 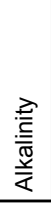 & 号 & 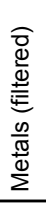 & 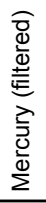 & 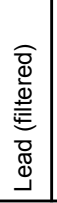 & $\begin{array}{l}\frac{\infty}{0} \\
\frac{0}{0} \\
\frac{c}{0} \\
\end{array}$ & $\begin{array}{l}\frac{0}{5} \\
0 \\
0 \\
\overline{0} \\
0 \\
0 \\
0 \\
0 \\
\overline{0} \\
\frac{\pi}{0} \\
>\end{array}$ & $\begin{array}{l}\stackrel{D}{N} \\
\grave{d} \\
\stackrel{\underline{\delta}}{\overline{0}} \\
\underline{0}\end{array}$ & 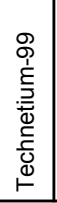 & 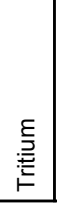 & 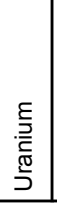 & \\
\hline 299-W15-15 & & $\mathrm{C}$ & $\mathrm{S}$ & $\mathrm{S}$ & $\mathrm{S}$ & $\mathrm{s}$ & A & $\mathrm{S}$ & $\mathrm{S}$ & $A$ & A & $\mathrm{A}$ & $\mathrm{A}$ & $\mathrm{S}$ & $\mathrm{S}$ & $\mathrm{S}$ & $\mathrm{S}$ & Yes \\
\hline 299-W15-17 & $\begin{array}{l}\text { Deep unconfined; } \\
\text { no statistics }\end{array}$ & $\mathrm{C}$ & $S$ & $S$ & $S$ & $S$ & $A$ & $S$ & $S$ & $A$ & A & A & A & $\mathrm{S}$ & S & $S$ & $\mathrm{~S}$ & Yes \\
\hline 299-W15-30 & & $\mathrm{C}$ & $S$ & $S$ & $S$ & $S$ & A & $S$ & $S$ & A & A & A & A & $S$ & S & $S$ & $S$ & Yes \\
\hline 299-W15-83 & & $\mathrm{C}$ & $S$ & $S$ & $S$ & $S$ & A & $S$ & $S$ & A & A & A & A & S & S & S & $S$ & Yes \\
\hline 299-W15-94 & & $\mathrm{C}$ & $S$ & $S$ & $S$ & $S$ & A & $S$ & $S$ & A & A & A & A & S & S & $S$ & $\mathrm{~S}$ & Yes \\
\hline 299-W15-152 & & C & $\mathrm{S}$ & $\mathrm{s}$ & $\mathrm{s}$ & $\mathrm{s}$ & A & $\mathrm{S}$ & $\mathrm{S}$ & A & A & A & A & $\mathrm{S}$ & $\mathrm{S}$ & $\mathrm{S}$ & $\mathrm{s}$ & Yes \\
\hline 299-W15-224 & & $\mathrm{C}$ & $S$ & $\mathrm{~S}$ & $S$ & $S$ & A & $\mathrm{S}$ & $S$ & A & A & A & A & S & S & S & $\mathrm{S}$ & New well; sampled once \\
\hline 299-W18-21 & & $\mathrm{C}$ & $\mathrm{S}$ & $\mathrm{S}$ & $S$ & $S$ & A & $\mathrm{S}$ & $S$ & A & A & A & A & S & S & S & $\mathrm{S}$ & Yes \\
\hline 299-W18-22 & $\begin{array}{l}\text { Deep unconfined; } \\
\text { no statistics }\end{array}$ & $\mathrm{C}$ & $\mathrm{S}$ & $\mathrm{S}$ & $S$ & $S$ & A & $\mathrm{S}$ & $S$ & A & A & A & A & S & S & S & $\mathrm{S}$ & Yes \\
\hline 299-W18-23 & & $\mathrm{C}$ & $\mathrm{S}$ & $\mathrm{s}$ & $S$ & $\mathrm{~S}$ & A & $\mathrm{S}$ & $\mathrm{S}$ & A & A & A & A & S & S & S & $\mathrm{S}$ & Yes \\
\hline $\begin{array}{l}\text { Wells complete } \\
\text { (a) Bold italic } \\
\text { (b) Monitored } \mathrm{f} \\
\mathrm{A}=\text { To be samp } \\
\mathrm{AEA}=\text { Atomic } \\
\mathrm{C}=\text { Well is cons } \\
\mathrm{FY}=\text { Fiscal yea } \\
\mathrm{S}=\text { To be samp } \\
\text { Spec. Cond. = } \\
\text { WAC = Washin }\end{array}$ & $\begin{array}{l}\text { t the top of the unco } \\
\text { Jpgradient well. } \\
\text { DOE Order } 435.1 \text {. } \\
\text { annually. } \\
\text { rgy Act. } \\
\text { ucted as a resource } \\
\text { d semiannually. } \\
\text { ecific conductance. } \\
\text { n Administrative Co }\end{array}$ & fine & aqu & fer un & less & speci & fied o & hern & se. & & & & & & & & & \\
\hline
\end{tabular}

Table B.26. Critical Means for Low-Level Waste Management Area 4 for FY 2007 Comparisons ${ }^{(a)}$

\begin{tabular}{|c|c|c|c|c|c|c|c|}
\hline Constituent, unit & $\mathrm{n}$ & $\mathrm{df}$ & $t_{c}$ & $\begin{array}{c}\text { Average } \\
\text { Background }\end{array}$ & $\begin{array}{l}\text { Standard } \\
\text { Deviation }\end{array}$ & Critical Mean & $\begin{array}{c}\text { Upgradient/ } \\
\text { Downgradient } \\
\text { Comparison Value }\end{array}$ \\
\hline $\begin{array}{l}\text { Specific conductance, } \\
\mu \mathrm{S} / \mathrm{cm}\end{array}$ & 12 & 11 & 4.7244 & 525.6 & 20.4 & 626 & 626 \\
\hline Field $\mathrm{pH}$ & 12 & 11 & 5.1617 & 7.95 & 0.114 & {$[7.34,8.57]$} & {$[7.34,8.57]$} \\
\hline $\begin{array}{l}\text { Total organic carbon, }{ }^{(b)} \\
\mu \mathrm{g} / \mathrm{L}\end{array}$ & 12 & 11 & 4.7244 & 405.1 & 186.9 & 1,324 & $2,700^{(c)}$ \\
\hline $\begin{array}{l}\text { Total organic halides, }{ }^{(b)} \\
\mu \mathrm{g} / \mathrm{L}\end{array}$ & 12 & 11 & 4.7244 & 9.26 & 7.08 & 44.1 & 44.1 \\
\hline
\end{tabular}

(a) Based on semiannual sampling events from January 2005 to July 2006 for upgradient wells 299-W15-15, 299-W18-21, and 299-W18-23.

(b) For values reported below laboratory's specified method detection limit, one-half of the method detection limit is used in the critical means calculation.

(c) Upgradient/downgradient comparison value is the most recently determined limit of quantitation (updated quarterly). $\mathrm{df}=$ Degrees of freedom $(n-1)$.

$n=$ Number of background replicate averages

$t_{c}=$ Bonferroni critical $t$-value for appropriate df and 32 comparisons. 
Table B.27. Monitoring Wells and Constituents for Nonradioactive Dangerous Waste Landfill (adapted from PNNL-12227 and PNNL-12227-ICN-1)

\begin{tabular}{|c|c|c|c|c|c|c|c|c|c|c|c|}
\hline \multirow[b]{2}{*}{ Well Number ${ }^{(a)}$} & \multirow[b]{2}{*}{ Comment } & \multirow[b]{2}{*}{ 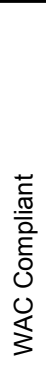 } & \multicolumn{4}{|c|}{$\begin{array}{c}\text { Contamination } \\
\text { Indicator Parameters }\end{array}$} & \multicolumn{4}{|c|}{ Other Parameters } & \multirow[b]{2}{*}{$\begin{array}{c}\text { Sampled as Scheduled } \\
\text { in FY 2006? }\end{array}$} \\
\hline & & & 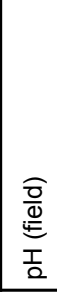 & 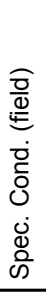 & 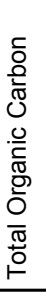 & 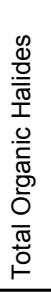 & $\frac{\text { D) }}{\stackrel{0}{\frac{0}{2}}}$ & 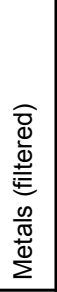 & $\begin{array}{l}\frac{\infty}{0} \\
\frac{0}{\Phi} \\
\frac{1}{\alpha}\end{array}$ & 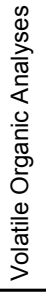 & \\
\hline $699-25-33 A$ & $\begin{array}{l}\text { Top of LPU; } \\
\text { no statistics }\end{array}$ & $\mathrm{C}$ & $\mathrm{S}$ & $\mathrm{S}$ & $\mathrm{S}$ & $\mathrm{S}$ & $\mathrm{S}$ & $A$ & $A$ & $\mathrm{~S}$ & Yes \\
\hline $699-25-34 \mathrm{~A}$ & & $\mathrm{C}$ & S & $S$ & $S$ & $\mathrm{~S}$ & $\mathrm{~S}$ & $A$ & A & $S$ & Yes \\
\hline 699-25-34B & & $\mathrm{C}$ & S & $S$ & $\mathrm{~S}$ & $\mathrm{~S}$ & $S$ & $A$ & $A$ & $S$ & Yes \\
\hline 699-25-34D & & $\mathrm{C}$ & S & $S$ & $S$ & $S$ & $S$ & $A$ & $A$ & $S$ & Yes \\
\hline $699-26-33$ & & C & S & $\mathrm{S}$ & $\mathrm{S}$ & $S$ & $S$ & A & A & $\mathrm{S}$ & Yes \\
\hline 699-26-34A & & $\mathrm{C}$ & S & $S$ & $\mathrm{~S}$ & $\mathrm{~S}$ & $S$ & $A$ & $A$ & $S$ & Yes \\
\hline 699-26-34B & & $\mathrm{C}$ & S & $S$ & $S$ & $\mathrm{~S}$ & $S$ & A & $A$ & $S$ & $\begin{array}{l}\text { Second delayed } \\
\text { until } 11 / 2007\end{array}$ \\
\hline 699-26-35A & & $\mathrm{C}$ & S & $S$ & $S$ & $\mathrm{~S}$ & $S$ & A & $A$ & $S$ & Missed second \\
\hline $699-26-35 C$ & $\begin{array}{l}\text { Top of LPU; } \\
\text { no statistics }\end{array}$ & $\mathrm{C}$ & S & $S$ & $S$ & $\mathrm{~S}$ & $S$ & $A$ & $A$ & $S$ & Yes \\
\hline \multicolumn{12}{|c|}{$\begin{array}{l}\text { Wells completed at the top of the unconfined aquifer unless specified otherwise. } \\
\text { (a) Bold italic = Upgradient well. } \\
\text { A = To be sampled annually. } \\
\text { C = Well is constructed as a resource protection well under WAC 173-160. } \\
\text { FY = Fiscal year. } \\
\text { LPU = Low-permeability in upper Ringold Formation. } \\
\text { S = To be sampled semiannually. } \\
\text { Spec. Cond. = Specific conductance. } \\
\text { WAC = Washington Administrative Code. }\end{array}$} \\
\hline
\end{tabular}

Table B.28. Critical Means for Nonradioactive Dangerous Waste Landfill for FY 2007 Comparisons $^{(a)}$

\begin{tabular}{|c|c|c|c|c|c|c|c|}
\hline Constituent, unit & $\mathrm{n}$ & df & $t_{c}$ & $\begin{array}{c}\text { Average } \\
\text { Background }\end{array}$ & $\begin{array}{l}\text { Standard } \\
\text { Deviation }\end{array}$ & Critical Mean & $\begin{array}{c}\text { Upgradient/ } \\
\text { Downgradient } \\
\text { Comparison Value }\end{array}$ \\
\hline $\begin{array}{l}\text { Specific conductance, } \\
\mu \mathrm{S} / \mathrm{cm}\end{array}$ & 8 & 7 & 5.7282 & 551.6 & 7.0 & 594 & 594 \\
\hline Field $\mathrm{pH}$ & 8 & 7 & 6.4295 & 7.22 & 0.098 & {$[6.55,7.89]$} & {$[6.55,7.89]$} \\
\hline $\begin{array}{l}\text { Total organic carbon, }{ }^{(b)} \\
\mu \mathrm{g} / \mathrm{L}\end{array}$ & $5^{(\mathrm{c})}$ & 4 & 9.3983 & 281.0 & 119.5 & 1,511 & $2,700^{(d)}$ \\
\hline $\begin{array}{l}\text { Total organic halides, }{ }^{(b)} \\
\mu \mathrm{g} / \mathrm{L}\end{array}$ & 8 & 7 & 5.7282 & 5.54 & 3.08 & 24.3 & $29.5^{(\mathrm{d})}$ \\
\hline \multicolumn{8}{|c|}{$\begin{array}{l}\text { (a) Based on most recent sampling events from February } 2005 \text { to September } 2006 \text { for upgradient well } 699-26-34 \mathrm{~A} \text { and } \\
\text { from August } 2004 \text { to February } 2006 \text { for well } 699-26-35 \mathrm{~A} \text {. } \\
\text { (b) For values reported below laboratory's specified method detection limit, one-half of the method detection limit is used } \\
\text { in the critical means calculation. } \\
\text { (c) Excluded suspected total organic carbon values collected in August } 2005 \text { from well } 699-26-34 \mathrm{~A} \text { and in February } 2006 \\
\text { from wells } 699-26-34 \mathrm{~A} \text { and } 699-26-35 \mathrm{~A} \text {. } \\
\text { (d) Upgradient/downgradient comparison value is the most recently determined limit of quantitation (updated quarterly). } \\
\mathrm{df}=\text { Degrees of freedom ( } \mathrm{n}-1 \text { ). } \\
\mathrm{n}=\text { Number of background replicate averages. } \\
\mathrm{t}_{\mathrm{c}}=\text { Bonferroni critical t-value for appropriate df and } 28 \text { comparisons. }\end{array}$} \\
\hline
\end{tabular}


Table B.29. Monitoring Wells and Constituents for RCRA PUREX Cribs 216-A-10, 216-A-36B, and 216-A-37-1 (adapted from PNNL-11523, Rev. 1)

\begin{tabular}{|c|c|c|c|c|c|c|}
\hline \multirow[b]{2}{*}{ Well Number } & \multirow[b]{2}{*}{ Comment } & \multirow[b]{2}{*}{ 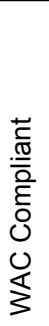 } & \multirow{2}{*}{ 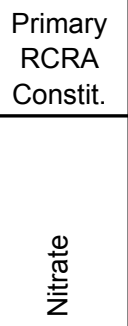 } & \multicolumn{2}{|c|}{$\begin{array}{l}\text { Supporting } \\
\text { Parameters }\end{array}$} & \multirow[b]{2}{*}{$\begin{array}{c}\text { Sampled as Scheduled } \\
\text { in FY 2006? }\end{array}$} \\
\hline & & & & $\frac{\stackrel{n}{c}}{\frac{0}{2}}$ & 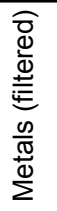 & \\
\hline $299-E 17-1$ & $216-A-10$ & $P$ & $\mathrm{~S}$ & $S$ & $\mathrm{~S}$ & Yes \\
\hline 299-E17-14 & 216-A-36B & C & Q & $Q$ & $Q$ & Yes \\
\hline 299-E17-16 & 216-A-36B & $C$ & S & $S$ & $S$ & Yes \\
\hline 299-E17-18 & 216-A-36B & C & $S$ & $S$ & S & Yes \\
\hline 299-E17-19 & $216-A-10$ & C & $S$ & $S$ & S & Yes \\
\hline 299-E24-16 & $216-A-10$ & C & Q & $Q$ & $Q$ & Yes \\
\hline 299-E24-18 & Upgradient & C & $S$ & $S$ & $S$ & Yes \\
\hline 299-E25-17 & $216-A-37-1$ & $P$ & S & $S$ & $S$ & Yes \\
\hline 299-E25-19 & $216-A-37-1$ & $P$ & Q & $Q$ & $Q$ & Yes \\
\hline 299-E25-31 & Upgradient & C & $\mathrm{S}$ & $S$ & $S$ & Yes \\
\hline $699-37-47 A$ & $216-A-37-1$ & C & S & $S$ & S & Yes \\
\hline 124 Wells & Far-field & & (a) & (a) & & $\begin{array}{l}\text { See Appendix A for } \\
200-P O-1\end{array}$ \\
\hline \multicolumn{7}{|c|}{$\begin{array}{l}\text { Wells completed at the top of the unconfined aquifer. } \\
\text { (a) Far-field wells sampled annually to triennially in conjunction with 200-PO-1 Operable Unit. } \\
C=\text { Well is constructed as a resource protection well under WAC 173-160. } \\
\text { FY = Fiscal year. } \\
P=\text { Constructed prior to WAC requirements. } \\
Q=\text { To be sampled quarterly. } \\
\text { RCRA = Resource Conservation and Recovery Act. } \\
S=\text { To be sampled semiannually. } \\
\text { WAC = Washington Administrative Code. }\end{array}$} \\
\hline
\end{tabular}


Table B.30. Monitoring Wells and Constituents for Waste Management Area A-AX (adapted from PNNL-15315)

\begin{tabular}{|c|c|c|c|c|c|c|c|c|c|c|c|c|}
\hline \multirow[b]{2}{*}{ Well Number ${ }^{(a)}$} & \multirow[b]{2}{*}{ 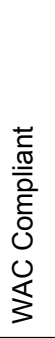 } & \multicolumn{10}{|c|}{ Site-Specific Constituents } & \multirow[b]{2}{*}{$\begin{array}{c}\text { Sampled as Scheduled } \\
\text { in FY 2006? }\end{array}$} \\
\hline & & 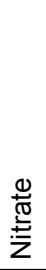 & 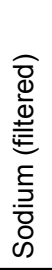 & $\begin{array}{l}\frac{\Phi}{\frac{\pi}{5}} \\
\frac{\omega}{5} \\
\omega\end{array}$ & 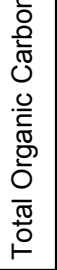 & 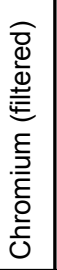 & 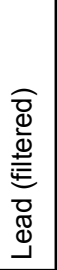 & 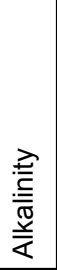 & $\begin{array}{l}0 \\
\frac{2}{0} \\
\frac{0}{2} \\
\frac{1}{4}\end{array}$ & 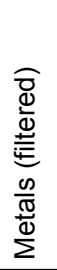 & 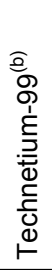 & \\
\hline 299-E24-20 & $\mathrm{C}$ & $\mathrm{Q}$ & $Q$ & $Q$ & $Q$ & $Q$ & $\mathrm{Q}$ & $Q$ & $Q$ & $Q$ & $\mathrm{Q}$ & Yes \\
\hline 299-E24-22 & $\mathrm{C}$ & $Q$ & Q & $Q$ & $Q$ & Q & $Q$ & $Q$ & $Q$ & $Q$ & Q & Yes \\
\hline 299-E24-33 & $\mathrm{C}$ & Q & Q & Q & $Q$ & Q & $\mathrm{Q}$ & $\mathrm{Q}$ & Q & Q & Q & $\begin{array}{l}\text { Fourth delayed } \\
\text { until } 10 / 2006\end{array}$ \\
\hline 299-E25-2 & $\mathrm{P}$ & Q & Q & $Q$ & $Q$ & Q & $Q$ & $Q$ & Q & $Q$ & Q & Yes \\
\hline 299-E25-40 & $\mathrm{C}$ & Q & $Q$ & $Q$ & $Q$ & Q & $Q$ & $Q$ & $Q$ & $Q$ & Q & Yes \\
\hline 299-E25-41 & $\mathrm{C}$ & Q & Q & Q & $Q$ & Q & $Q$ & $\mathrm{Q}$ & $\mathrm{Q}$ & $Q$ & Q & $\begin{array}{l}\text { Fourth delayed } \\
\text { until } 11 / 2006\end{array}$ \\
\hline 299-E25-93 & $\mathrm{C}$ & $Q$ & Q & $Q$ & $Q$ & Q & $Q$ & $Q$ & $\mathrm{Q}$ & $\mathrm{Q}$ & Q & Yes \\
\hline 299-E25-94 & C & Q & Q & $Q$ & $Q$ & Q & $Q$ & $Q$ & Q & $Q$ & Q & $\begin{array}{l}\text { Fourth delayed } \\
\text { until } 10 / 2006\end{array}$ \\
\hline \multicolumn{13}{|c|}{$\begin{array}{l}\text { Wells completed at the top of the unconfined aquifer. } \\
\text { (a) Bold italic = Upgradient well. } \\
\text { (b) Atomic Energy Act parameter. } \\
C=\text { Well is constructed as a resource protection well under WAC 173-160. } \\
\text { FY = Fiscal year. } \\
P=\text { Constructed prior to WAC requirements. } \\
Q=\text { To be sampled quarterly. } \\
\text { WAC = Washington Administrative Code. }\end{array}$} \\
\hline
\end{tabular}


Table B.31. Monitoring Wells and Constituents for Waste Management Area B-BX-BY (adapted from PNNL-13022-ICN-2 and PNNL-13022-ICN-3 ${ }^{\text {(a) }}$ )

\begin{tabular}{|c|c|c|c|c|c|c|c|c|c|c|c|c|}
\hline \multirow[b]{2}{*}{ Well Number ${ }^{(b)}$} & \multirow[b]{2}{*}{ 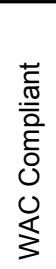 } & \multicolumn{4}{|c|}{ RCRA Parameters } & \multicolumn{6}{|c|}{ AEA Parameters } & \multirow[b]{2}{*}{$\begin{array}{l}\text { Sampled as Scheduled } \\
\text { in FY 2006? }\end{array}$} \\
\hline & & 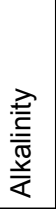 & $\frac{n}{0}$ & 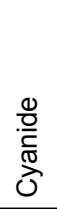 & 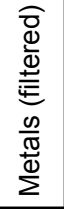 & $\frac{\frac{\pi}{2}}{\frac{0}{4}}$ & 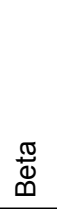 & 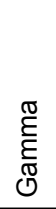 & 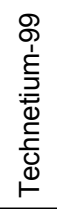 & 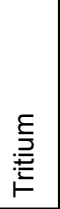 & 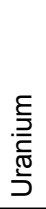 & \\
\hline 299-E28-8 & $P$ & $\mathrm{Q}$ & $Q$ & $S$ & $\bar{Q}$ & & & $\mathrm{~s}$ & $Q$ & $\mathrm{Q}$ & $\mathrm{s}$ & Yes \\
\hline 299-E33-7 & $\mathrm{P}$ & $Q$ & Q & Q & $Q$ & Q & $Q$ & Q & $Q$ & $Q$ & $Q$ & $\begin{array}{l}\text { Fourth delayed } \\
\text { until } 11 / 2007\end{array}$ \\
\hline 299-E33-9 & $\mathrm{P}$ & A & A & A & $A$ & A & $A$ & A & A & A & A & $\begin{array}{l}\text { Sampled twice; }{ }^{(c)} \text { tank farm } \\
\text { access restrictions }\end{array}$ \\
\hline 299-E33-15 & $\mathrm{P}$ & $S$ & $\mathrm{~S}$ & $\mathrm{~S}$ & $S$ & & $\mathrm{~s}$ & $\mathrm{~S}$ & $\mathrm{~S}$ & $\mathrm{~S}$ & $\mathrm{~s}$ & Yes \\
\hline 299-E33-16 & $\mathrm{P}$ & $Q$ & $Q$ & $\mathrm{Q}$ & $Q$ & & $Q$ & $Q$ & $Q$ & $\mathrm{Q}$ & $Q$ & Yes \\
\hline 299-E33-17 & $\mathrm{P}$ & A & A & A & A & & A & & A & A & A & Yes \\
\hline 299-E33-18 & $\mathrm{P}$ & $Q$ & $Q$ & $Q$ & $Q$ & $Q$ & Q & & $Q$ & $Q$ & Q & Yes \\
\hline 299-E33-20 & $\mathrm{P}$ & A & A & A & A & & & & A & A & A & Yes \\
\hline 299-E33-21 & $\mathrm{P}$ & A & A & A & $A$ & & & & A & A & A & Yes \\
\hline 299-E33-26 & C & $Q$ & $Q$ & $\mathrm{Q}$ & $Q$ & $Q$ & $Q$ & $Q$ & $Q$ & $\mathrm{Q}$ & Q & Missed fourth \\
\hline 299-E33-31 & C & $Q$ & Q & $\mathrm{Q}$ & $Q$ & Q & $Q$ & $\mathrm{Q}$ & $\mathrm{Q}$ & Q & $Q$ & Yes \\
\hline 299-E33-32 & C & $Q$ & $Q$ & $Q$ & $Q$ & & $Q$ & $Q$ & $Q$ & $\mathrm{Q}$ & Q & Yes \\
\hline 299-E33-38 & C & $Q$ & Q & Q & $Q$ & $Q$ & Q & Q & $Q$ & $Q$ & Q & Yes \\
\hline 299-E33-39 & C & $\mathrm{Q}$ & Q & Q & $Q$ & & & & $Q$ & $\mathrm{Q}$ & Q & Missed fourth \\
\hline 299-E33-41 & C & $Q$ & Q & $Q$ & $Q$ & $Q$ & $Q$ & Q & $Q$ & $Q$ & $Q$ & Yes \\
\hline 299-E33-42 & C & $Q$ & $Q$ & $Q$ & $Q$ & $Q$ & $Q$ & $Q$ & $Q$ & $\mathrm{Q}$ & Q & Yes \\
\hline 299-E33-43 & C & $Q$ & $Q$ & $Q$ & Q & & Q & & $Q$ & $Q$ & $Q$ & Yes \\
\hline 299-E33-44 & C & $Q$ & $Q$ & $Q$ & $Q$ & $Q$ & $Q$ & $Q$ & $Q$ & $Q$ & $Q$ & Missed fourth \\
\hline 299-E33-47 & $C$ & $Q$ & $Q$ & $Q$ & $Q$ & & & & $Q$ & $Q$ & $Q$ & Yes \\
\hline 299-E33-48 & C & $Q$ & $Q$ & $Q$ & $Q$ & & & & $Q$ & $Q$ & $Q$ & Yes \\
\hline 299-E33-49 & C & $Q$ & Q & $Q$ & Q & & & & $Q$ & $\mathrm{Q}$ & $Q$ & Yes \\
\hline 299-E33-334 & C & $Q$ & $Q$ & $\mathrm{Q}$ & $Q$ & & & & $Q$ & $Q$ & Q & Yes \\
\hline 299-E33-335 & C & $Q$ & Q & $Q$ & $Q$ & & & & $Q$ & $\mathrm{Q}$ & $\mathrm{Q}$ & Yes \\
\hline 299-E33-337 & C & $Q$ & Q & $Q$ & $Q$ & & & & $Q$ & $Q$ & Q & Yes \\
\hline 299-E33-338 & C & $Q$ & Q & Q & $Q$ & & & & $Q$ & $\mathrm{Q}$ & $Q$ & Yes \\
\hline 299-E33-339 & C & Q & Q & $\mathrm{Q}$ & $Q$ & & & & $Q$ & $Q$ & Q & Yes \\
\hline $\begin{array}{l}\text { Wells complete } \\
\text { (a) PNNL-1302 } \\
\text { (b) Bold italic } \\
\text { (c) Quarterly ur } \\
A=\text { To be samp } \\
\text { AEA = Atomic } \\
C=\text { Well is cons } \\
F Y=\text { Fiscal yea } \\
P=\text { Constructec } \\
Q=\text { To be samp } \\
\text { RCRA = Resou } \\
S=\text { To be samp } \\
\text { WAC = Washin }\end{array}$ & $\begin{array}{l}\text { at th } \\
-I C N \\
\text { Ups } \\
\text { ler } \mathrm{P} \\
\text { d an } \\
\text { ergy } \\
\text { ructe }\end{array}$ & $\begin{array}{l}\text { top } \\
3 \text { too } \\
\text { adien } \\
\text { NNL-1 } \\
\text { nually } \\
\text { Act. } \\
\text { tas a }\end{array}$ & $\begin{array}{l}\text { reso } \\
\text { C reo } \\
\text { ition } \\
\text { ually. } \\
\text { trativ }\end{array}$ & $\begin{array}{l}\text { ice } \\
\text { uirem }\end{array}$ & $\begin{array}{l}\text { rotect } \\
\text { ents. }\end{array}$ & quife & II unc & er W & C 17 & -160 & & \\
\hline
\end{tabular}


Table B.32. Monitoring Wells and Constituents for Waste Management Area C (adapted from PNNL-13024-ICN-4 and RPP-21895)

\begin{tabular}{|c|c|c|c|c|c|c|c|c|c|c|c|c|c|c|c|}
\hline \multirow[b]{2}{*}{ Well Number ${ }^{(a)}$} & \multirow[b]{2}{*}{ 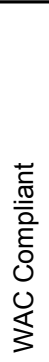 } & \multicolumn{4}{|c|}{$\begin{array}{c}\text { Contamination } \\
\text { Indicator Parameters }\end{array}$} & \multicolumn{5}{|c|}{$\begin{array}{l}\text { Other Chemical } \\
\text { Parameters }\end{array}$} & \multicolumn{4}{|c|}{ AEA Parameters } & \multirow[b]{2}{*}{$\begin{array}{c}\text { Sampled as Scheduled } \\
\text { in FY 2006? }\end{array}$} \\
\hline & & 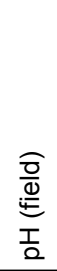 & 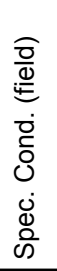 & 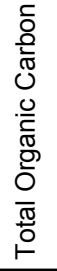 & 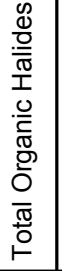 & 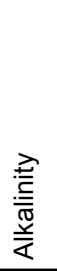 & $\begin{array}{l}\frac{\infty}{c} \\
\frac{0}{\frac{0}{2}} \\
\end{array}$ & $\begin{array}{l}\frac{0}{.0} \\
\frac{0}{\pi} \\
\frac{\pi}{0}\end{array}$ & 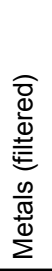 & $\begin{array}{l}\frac{\infty}{0} \\
\frac{0}{\infty} \\
\frac{1}{\alpha}\end{array}$ & $\underset{\infty}{\mathbb{N}}$ & $\begin{array}{l}\underset{\mathbb{\sigma}}{E} \\
\stackrel{E}{E} \\
\mathbb{N} \\
0\end{array}$ & 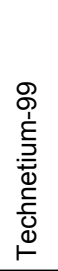 & 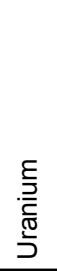 & \\
\hline 299-E27-4 & $\mathrm{C}$ & $\mathrm{Q}$ & $Q$ & $S$ & $\mathrm{~S}$ & $Q$ & $Q$ & $\mathrm{Q}$ & $\mathrm{Q}$ & $A$ & $Q$ & $Q$ & $Q$ & $\mathrm{Q}$ & Yes \\
\hline 299-E27-7 & $\mathrm{P}$ & $Q$ & $Q$ & $S$ & $S$ & $Q$ & $\mathrm{Q}$ & $Q$ & $Q$ & $A$ & $Q$ & $Q$ & $\mathrm{Q}$ & $Q$ & $\begin{array}{l}\text { Fourth delayed } \\
\text { until } 10 / 2006\end{array}$ \\
\hline 299-E27-12 & C & $Q$ & $Q$ & $S$ & $S$ & $Q$ & $\mathrm{Q}$ & $Q$ & $Q$ & $A$ & $Q$ & $Q$ & $\mathrm{Q}$ & $Q$ & $\begin{array}{l}\text { Fourth delayed } \\
\text { until } 10 / 2006\end{array}$ \\
\hline 299-E27-13 & $\mathrm{C}$ & Q & $Q$ & $S$ & $S$ & $Q$ & $Q$ & $Q$ & Q & $A$ & Q & $Q$ & $\mathrm{Q}$ & $\mathrm{Q}$ & Yes \\
\hline 299-E27-14 & $\mathrm{C}$ & $\mathrm{Q}$ & $Q$ & $S$ & $S$ & $Q$ & $Q$ & $Q$ & $Q$ & $A$ & $Q$ & $Q$ & $\mathrm{Q}$ & $\mathrm{Q}$ & Yes \\
\hline 299-E27-15 & $\mathrm{C}$ & Q & $Q$ & $S$ & $S$ & $Q$ & Q & $Q$ & $Q$ & $A$ & $Q$ & $Q$ & $\mathrm{Q}$ & $Q$ & $\begin{array}{l}\text { Fourth delayed } \\
\text { until } 10 / 2006\end{array}$ \\
\hline 299-E27-21 & $\mathrm{C}$ & $Q$ & $Q$ & $S$ & $S$ & $Q$ & $Q$ & $Q$ & $Q$ & $A$ & $Q$ & $Q$ & $\mathrm{Q}$ & $\mathrm{Q}$ & Yes \\
\hline 299-E27-22 & $\mathrm{C}$ & $Q$ & $Q$ & $S$ & $S$ & $Q$ & $Q$ & $Q$ & $Q$ & A & $Q$ & $Q$ & $Q$ & $\mathrm{Q}$ & Yes \\
\hline 299-E27-23 & $\mathrm{C}$ & Q & $Q$ & $S$ & $S$ & $Q$ & Q & $Q$ & Q & A & Q & $\mathrm{Q}$ & Q & $\mathrm{Q}$ & Yes \\
\hline $\begin{array}{l}\text { Wells complete } \\
\text { (a) Bold italic } \\
\mathrm{A}=\text { To be samp } \\
\mathrm{AEA}=\text { Atomic } \\
\mathrm{C}=\text { Well is con } \\
\mathrm{FY}=\text { Fiscal yea } \\
\mathrm{P}=\text { Constructe } \\
\mathrm{Q}=\text { To be sam } \\
\mathrm{S}=\text { To be sam } \\
\text { Spec. Cond. } \\
\text { WAC = Washin }\end{array}$ & $\begin{array}{l}\text { prio } \\
\text { ed } \mathrm{c} \\
\text { ed } \mathrm{s}\end{array}$ & $\begin{array}{l}\text { e top } \\
\text { radie } \\
\text { inual } \\
\text { Act. } \\
\text { d as }\end{array}$ & $\begin{array}{l}\text { C re } \\
\text { y. } \\
\text { ually } \\
\text { ducta }\end{array}$ & unco & fined & aquif & r. & S & C & -16 & & & & & \\
\hline
\end{tabular}

Table B.33. Critical Means for Waste Management Area C for FY 2007 Comparisons $^{(\mathrm{a})}$

\begin{tabular}{|l|c|c|c|c|c|c|c|}
\hline \multicolumn{1}{|c|}{ Constituent, unit } & $\mathrm{n}$ & $\mathrm{df}$ & $\mathrm{t}_{\mathrm{c}}$ & $\begin{array}{c}\text { Average } \\
\text { Background }\end{array}$ & $\begin{array}{c}\text { Standard } \\
\text { Deviation }\end{array}$ & $\begin{array}{c}\text { Critical } \\
\text { Mean }\end{array}$ & $\begin{array}{c}\text { Upgradient/ } \\
\text { Downgradient } \\
\text { Comparison Value }\end{array}$ \\
\hline $\begin{array}{l}\text { Specific conductance, } \\
\mu \mathrm{S} / \mathrm{cm}\end{array}$ & 11 & 10 & 4.8087 & 605.8 & 66.8 & 941 & 941 \\
\hline Field $\mathrm{pH}$ & 11 & 10 & 5.2810 & 8.12 & 0.143 & {$[7.34,8.91]$} & {$[7.34,8.91]$} \\
\hline $\begin{array}{l}\text { Total organic carbon, } \\
\mu \mathrm{b} / \mathrm{L} \text { (b) }\end{array}$ & 8 & 7 & 5.7282 & 667.2 & 298.4 & 2,480 & $2,700^{(\mathrm{c})}$ \\
\hline $\begin{array}{l}\text { Total organic halides, } \\
\mu \mathrm{g} / \mathrm{L}\end{array}$ & $7^{\text {(d) }}$ & 6 & 6.3510 & 8.98 & 4.75 & 41.2 & 41.2 \\
\hline
\end{tabular}

(a) Based on quarterly/semiannual sampling events from December 2004 to June 2006 for upgradient wells 299-E27-22 and 299-E27-7.

(b) For values reported below laboratory's specified method detection limit, one-half of the method detection limit is used in the critical means calculation.

(c) Upgradient/downgradient comparison value is the most recently determined limit of quantitation (updated quarterly).

(d) Excluded suspected values on samples collected in June 2005.

$\mathrm{df}=$ Degrees of freedom $(\mathrm{n}-1)$.

$\mathrm{n}=$ Number of background replicate averages.

$t_{c}=$ Bonferroni critical $t$-value for appropriate $\mathrm{df}$ and 28 comparisons. 
Table B.34. Monitoring Wells and Constituents for Waste Management Area S-SX (adapted from PNNL-12114-ICN-3)

\begin{tabular}{|c|c|c|c|c|c|c|c|c|c|c|c|}
\hline \multirow[b]{2}{*}{ Well Number ${ }^{(a)}$} & \multirow[b]{2}{*}{ 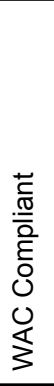 } & \multicolumn{2}{|c|}{$\begin{array}{c}\text { RCRA } \\
\text { Parameters }\end{array}$} & \multicolumn{7}{|c|}{ Supporting Constituents } & \multirow[b]{2}{*}{$\begin{array}{c}\text { Sampled as Scheduled } \\
\text { in FY 2006? }\end{array}$} \\
\hline & & 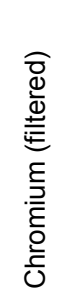 & 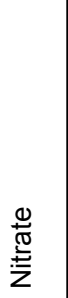 & 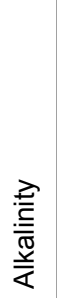 & $\frac{\text { D }}{\frac{0}{2}}$ & 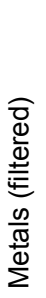 & 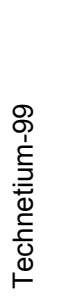 & 营 & 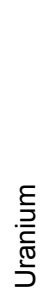 & 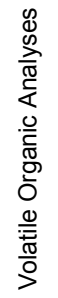 & \\
\hline $299-W 22-44$ & $\mathrm{C}$ & $\bar{Q}$ & $Q$ & $Q$ & $\mathrm{Q}$ & $Q$ & $Q$ & $A$ & $A$ & & $\begin{array}{l}\text { Fourth delayed } \\
\text { until } 10 / 2007\end{array}$ \\
\hline 299-W22-45 & $\mathrm{C}$ & Q & Q & $Q$ & $Q$ & $\mathrm{Q}$ & Q & $A$ & A & & $\begin{array}{l}\text { Fourth delayed } \\
\text { until } 11 / 2007\end{array}$ \\
\hline 299-W22-47 & $\mathrm{C}$ & Q & Q & $Q$ & Q & Q & Q & A & A & Q & $\begin{array}{l}\text { Fourth delayed } \\
\text { until } 10 / 2007\end{array}$ \\
\hline 299-W22-48 & C & Q & Q & $Q$ & $Q$ & Q & Q & $A$ & A & & $\begin{array}{l}\text { Fourth delayed } \\
\text { until } 10 / 2007\end{array}$ \\
\hline 299-W22-49 & $\mathrm{C}$ & Q & Q & $Q$ & Q & Q & Q & $A$ & A & & $\begin{array}{l}\text { Fourth delayed } \\
\text { until } 10 / 2007\end{array}$ \\
\hline 299-W22-50 & C & Q & Q & $Q$ & Q & $Q$ & Q & $A$ & A & & $\begin{array}{l}\text { Fourth delayed } \\
\text { until } 10 / 2007\end{array}$ \\
\hline 299-W22-69 & C & Q & Q & $Q$ & $Q$ & Q & Q & $A$ & A & & (b) \\
\hline 299-W22-72 & $\mathrm{C}$ & Q & Q & Q & Q & $Q$ & Q & A & A & & (b) \\
\hline 299-W22-80 & C & $Q$ & Q & $Q$ & $Q$ & Q & Q & $A$ & A & & $\begin{array}{l}\text { Fourth delayed } \\
\text { until } 10 / 2007\end{array}$ \\
\hline 299-W22-81 & C & Q & Q & $Q$ & Q & $Q$ & $Q$ & A & A & & $\begin{array}{l}\text { Fourth delayed } \\
\text { until } 10 / 2007\end{array}$ \\
\hline 299-W22-82 & C & Q & Q & $Q$ & Q & $Q$ & $Q$ & $A$ & A & & $\begin{array}{l}\text { Fourth delayed } \\
\text { until } 10 / 2007\end{array}$ \\
\hline 299-W22-83 & C & Q & Q & $\mathrm{Q}$ & Q & $Q$ & $\mathrm{Q}$ & A & A & & $\begin{array}{l}\text { Fourth delayed } \\
\text { until } 10 / 2007\end{array}$ \\
\hline 299-W22-84 & C & Q & Q & $Q$ & Q & Q & Q & A & A & & Fourth missed \\
\hline 299-W22-85 & C & Q & Q & $Q$ & Q & $Q$ & $\mathrm{Q}$ & A & A & & $\begin{array}{l}\text { Fourth delayed } \\
\text { until } 10 / 2007\end{array}$ \\
\hline 299-W22-86 & C & $Q$ & Q & $Q$ & $Q$ & $Q$ & Q & $A$ & A & & (b) \\
\hline 299-W23-15 & $C$ & Q & Q & $\mathrm{Q}$ & Q & Q & $\mathrm{Q}$ & A & $A$ & & $\begin{array}{l}\text { Fourth delayed } \\
\text { until } 11 / 2007\end{array}$ \\
\hline 299-W23-19 & C & Q & Q & $Q$ & Q & $Q$ & Q & A & A & & Yes \\
\hline 299-W23-20 & C & $Q$ & Q & $Q$ & Q & $Q$ & $Q$ & $A$ & A & & $\begin{array}{l}\text { Fourth delayed } \\
\text { until } 10 / 2007\end{array}$ \\
\hline 299-W23-21 & C & Q & Q & Q & Q & Q & Q & $\mathrm{A}$ & A & & Fourth missed \\
\hline \multicolumn{12}{|c|}{$\begin{array}{l}\text { Wells completed at the top of the unconfined aquifer } \\
\text { (a) Bold italic = Upgradient well. }\end{array}$} \\
\hline
\end{tabular}


Table B.35. Monitoring Wells and Constituents for Waste Management Area T (adapted from PNNL-15301)

\begin{tabular}{|c|c|c|c|c|c|c|c|c|c|c|c|c|c|c|}
\hline \multirow[b]{2}{*}{ Well Number ${ }^{(a)}$} & \multirow[b]{2}{*}{ Comment } & \multirow[b]{2}{*}{ 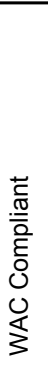 } & \multicolumn{2}{|c|}{$\begin{array}{l}\text { Constituents } \\
\text { of Concern }\end{array}$} & \multicolumn{9}{|c|}{$\begin{array}{l}\text { Constituents of Interest and Supporting } \\
\text { Groundwater Quality Constituents }\end{array}$} & \multirow[b]{2}{*}{$\begin{array}{l}\text { Sampled as Scheduled } \\
\text { in FY 2006? }\end{array}$} \\
\hline & & & 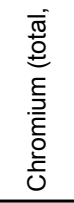 & 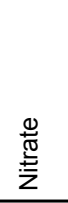 & 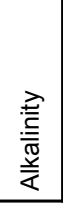 & $\frac{0}{2}$ & 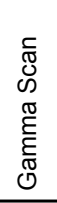 & $\begin{array}{l}\frac{\pi}{0} \\
\frac{c}{2} \\
\frac{2}{2} \\
0 \\
0 \\
0 \\
0 \\
0 \\
0\end{array}$ & $\begin{array}{l}\frac{\pi}{0} \\
0 \\
0 \\
\infty \\
0 \\
0 \\
0\end{array}$ & $\begin{array}{l}\stackrel{D}{N} \\
\stackrel{d}{\Phi} \\
\stackrel{.}{\bar{O}} \\
\underline{O}\end{array}$ & 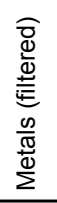 & 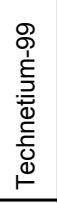 & $\stackrel{E}{\underline{D}}$ & \\
\hline 299-W10-1 & & $P$ & $\mathrm{Q}$ & $Q$ & $\mathrm{Q}$ & $\mathrm{Q}$ & & $A$ & $\mathrm{Q}$ & & $Q$ & $Q$ & $Q$ & Yes \\
\hline 299-W10-4 & & $P$ & Q & Q & $Q$ & $Q$ & $A$ & $A$ & $Q$ & & $Q$ & $Q$ & $Q$ & Yes \\
\hline 299-W10-8 & & $\mathrm{P}$ & Q & Q & Q & Q & & A & Q & & $Q$ & $Q$ & $Q$ & Yes \\
\hline 299-W10-22 & & C & SA & SA & SA & SA & & & $S$ & & SA & SA & SA & Yes \\
\hline 299-W10-23 & & C & Q & Q & Q & Q & & A & Q & & $Q$ & $Q$ & $Q$ & Yes \\
\hline 299-W10-24 & & C & Q & Q & Q & Q & SA & SA & Q & & $Q$ & $Q$ & $Q$ & Yes \\
\hline 299-W10-28 & & C & Q & Q & Q & $Q$ & & A & $Q$ & & $Q$ & $\mathrm{Q}$ & $\mathrm{Q}$ & Yes \\
\hline 299-W11-7 & & $\mathrm{P}$ & SA & SA & SA & SA & & & $S$ & & SA & SA & SA & Yes \\
\hline 299-W11-12 & & $\mathrm{P}$ & Q & Q & Q & Q & & A & Q & & $Q$ & Q & $Q$ & Yes \\
\hline 299-W11-39 & & $\mathrm{C}$ & Q & Q & Q & $Q$ & SA & SA & Q & & $Q$ & $\mathrm{Q}$ & $Q$ & Yes \\
\hline 299-W11-40 & & C & Q & Q & Q & Q & SA & SA & Q & & $Q$ & $Q$ & $Q$ & Yes \\
\hline 299-W11-41 & & C & Q & Q & Q & Q & & A & Q & $A$ & $Q$ & $Q$ & $Q$ & Yes \\
\hline 299-W11-42 & & C & Q & $Q$ & Q & $Q$ & SA & SA & $Q$ & & $Q$ & $Q$ & $Q$ & Yes \\
\hline 299-W11-45 & $\begin{array}{l}\text { Screened } 8.5 \text { to } \\
13 \mathrm{~m} \text { below water } \\
\text { table }\end{array}$ & C & Q & Q & $Q$ & Q & SA & SA & Q & & $Q$ & $Q$ & $Q$ & $\begin{array}{c}\text { New well; first } \\
\text { sampled 05/2006 }\end{array}$ \\
\hline 299-W11-46 & $\begin{array}{l}\text { Screened } 6 \text { to } 12 \mathrm{~m} \\
\text { below water table }\end{array}$ & C & Q & Q & $Q$ & Q & A & A & Q & & $Q$ & $Q$ & $Q$ & Yes \\
\hline 299-W11-47 & $\begin{array}{l}\text { Screened } 9.1 \text { to } \\
18.2 \text { m below water } \\
\text { table }\end{array}$ & $\mathrm{C}$ & Q & Q & $Q$ & Q & SA & SA & SA & $A$ & $Q$ & $Q$ & $Q$ & $\begin{array}{c}\text { New well; first } \\
\text { sampled 05/2006 }\end{array}$ \\
\hline \multicolumn{15}{|c|}{$\begin{array}{l}\text { Wells completed at the top of the unconfined aquifer unless specified otherwise. } \\
\text { (a) Bold italic = Upgradient well. } \\
\text { A = To be sampled annually. } \\
C=\text { Well is constructed as a resource protection well under WAC 173-160. } \\
\text { FY = Fiscal year. } \\
P=\text { Constructed prior to WAC requirements. } \\
Q=\text { To be sampled quarterly. } \\
\text { SA = To be sampled semiannually. } \\
\text { WAC = Washington Administrative Code. }\end{array}$} \\
\hline
\end{tabular}


Table B.36. Monitoring Wells and Constituents for Waste Management Area TX-TY (adapted from PNNL-12072-ICN-1)

\begin{tabular}{|c|c|c|c|c|c|c|c|c|c|c|c|c|c|}
\hline \multirow[b]{2}{*}{ Well Number ${ }^{(a)}$} & \multirow[b]{2}{*}{ Comment } & \multirow[b]{2}{*}{ 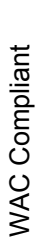 } & \multicolumn{3}{|c|}{ RCRA Parameters } & \multicolumn{7}{|c|}{ AEA Parameters } & \multirow[b]{2}{*}{$\begin{array}{l}\text { Sampled as Scheduled } \\
\text { in FY 2006? }{ }^{(b)}\end{array}$} \\
\hline & & & 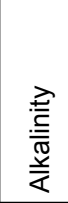 & 号 & 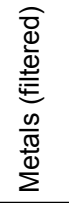 & $\begin{array}{l}\frac{\widehat{a}}{\pi} \\
\frac{0}{0} \\
\frac{0}{\alpha}\end{array}$ & $\begin{array}{l}\widehat{a} \\
\frac{\pi}{0} \\
\infty \\
\infty\end{array}$ & 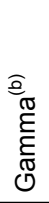 & 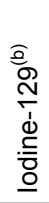 & 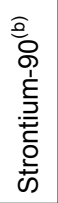 & 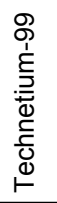 & 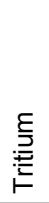 & \\
\hline 299-W10-26 & & $\mathrm{C}$ & $Q$ & $Q$ & 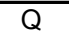 & $A$ & $A$ & $A$ & & & $Q$ & $Q$ & Yes \\
\hline 299-W10-27 & & $\mathrm{C}$ & $Q$ & $Q$ & Q & $A$ & $A$ & $S$ & & & $Q$ & $Q$ & Missed one gamma \\
\hline 299-W14-6 & & $\mathrm{P}$ & Q & Q & $Q$ & $A$ & A & & & & $Q$ & $Q$ & Yes \\
\hline 299-W14-11 & $\begin{array}{l}\text { Screened } 11 \text { to } \\
14.6 \mathrm{~m} \text { below } \\
\text { water table }\end{array}$ & $\mathrm{C}$ & $Q$ & Q & Q & $S$ & $\mathrm{~S}$ & $S$ & $Q$ & A & $Q$ & $Q$ & No strontium-90 \\
\hline 299-W14-13 & & $\mathrm{C}$ & Q & $Q$ & Q & $\mathrm{S}$ & $\mathrm{S}$ & $S$ & Q & A & Q & Q & Yes \\
\hline 299-W14-14 & & $\mathrm{C}$ & Q & Q & Q & A & $A$ & A & & & $Q$ & Q & $\begin{array}{l}\text { Yes; missed alkalinity, } \\
\text { metals and anions once }\end{array}$ \\
\hline 299-W14-15 & & $\mathrm{C}$ & $Q$ & Q & $Q$ & $A$ & $A$ & A & Q & & $Q$ & $Q$ & Yes \\
\hline 299-W14-16 & & $\mathrm{C}$ & Q & Q & Q & & & & Q & & $Q$ & Q & Yes \\
\hline 299-W14-17 & & $\mathrm{C}$ & $Q$ & $Q$ & $Q$ & $S$ & $\mathrm{~S}$ & & $Q$ & & $Q$ & $Q$ & $\begin{array}{c}\text { Yes; missed one alpha and } \\
\text { beta }\end{array}$ \\
\hline 299-W14-18 & & $\mathrm{C}$ & Q & $Q$ & Q & A & A & A & $Q$ & & $Q$ & Q & Yes \\
\hline 299-W14-19 & & $\mathrm{C}$ & Q & $Q$ & Q & A & A & A & & & $Q$ & Q & Yes \\
\hline $299-W 15-40$ & Extraction well & $\mathrm{C}$ & Q & Q & Q & A & A & & & & $\mathrm{Q}$ & Q & Yes \\
\hline 299-W15-41 & & $\mathrm{C}$ & $\mathrm{Q}$ & Q & Q & A & A & A & $S$ & & $Q$ & Q & Yes \\
\hline 299-W15-44 & Extraction well & $\mathrm{C}$ & Q & $Q$ & Q & A & A & A & $S$ & & $Q$ & Q & Yes \\
\hline 299-W15-763 & & $\mathrm{C}$ & Q & $Q$ & Q & A & A & A & & & $Q$ & Q & Yes \\
\hline 299-W15-765 & Extraction well & C & Q & Q & Q & A & A & & $\mathrm{S}$ & & Q & Q & Yes \\
\hline $\begin{array}{l}\text { Wells complete } \\
\text { (a) Bold italic } \\
\text { (b) Constituent } \\
\mathrm{A}=\text { To be samp } \\
\mathrm{AEA}=\text { Atomic } \\
\mathrm{C}=\text { Well is con } \\
\mathrm{FY}=\text { Fiscal yea } \\
\mathrm{P}=\text { Constructe } \\
\mathrm{Q}=\text { To be sam } \\
\mathrm{RCRA}=\text { Resou } \\
\mathrm{S}=\text { To be samp } \\
\text { WAC = Washin }\end{array}$ & $\begin{array}{l}\text { at the top of the ur } \\
\text { Upgradient well. } \\
\text { and frequency cha } \\
\text { d annually. } \\
\text { ergy Act. } \\
\text { ucted as a resour } \\
\text { orior to WAC requi } \\
\text { ed quarterly. } \\
\text { e Conservation an } \\
\text { d semiannually. } \\
\text { on Administrative }\end{array}$ & fine & aquif & unle & speci & fied o & herw & & & hplen & nte & & 2007. \\
\hline
\end{tabular}


Table B.37. Monitoring Wells and Constituents for Waste Management Area U (adapted from PNNL-13612-ICN-2)

\begin{tabular}{|c|c|c|c|c|c|c|c|c|c|}
\hline \multirow[b]{2}{*}{ Well Number ${ }^{(a)}$} & \multirow[b]{2}{*}{ 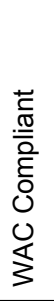 } & \multicolumn{3}{|c|}{$\begin{array}{c}\text { RCRA } \\
\text { Parameters } \\
\end{array}$} & \multicolumn{4}{|c|}{ AEA Parameters } & \multirow[b]{2}{*}{$\begin{array}{c}\text { Sampled as Scheduled } \\
\text { in FY 2006? }\end{array}$} \\
\hline & & 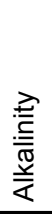 & 足 & 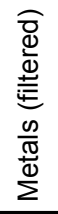 & $\begin{array}{l}\frac{\pi}{2} \\
\frac{2}{2} \\
\frac{0}{4}\end{array}$ & $\begin{array}{l}\frac{\pi}{0} \\
\infty \\
\infty\end{array}$ & $\begin{array}{l}\underset{\mathbb{O}}{E} \\
\stackrel{\mathbb{E}}{\mathbb{N}} \\
\widetilde{O}\end{array}$ & 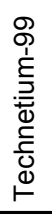 & \\
\hline 299-W18-30 & $\mathrm{C}$ & $Q$ & $Q$ & $Q$ & $A$ & $A$ & $A$ & $Q$ & Yes \\
\hline 299-W18-31 & $\mathrm{C}$ & $Q$ & $Q$ & $Q$ & $A$ & A & $A$ & $Q$ & Yes \\
\hline 299-W18-40 & $\mathrm{C}$ & $Q$ & Q & $Q$ & $A$ & A & $A$ & $Q$ & Yes \\
\hline 299-W19-12 & $\mathrm{C}$ & $Q$ & Q & $\mathrm{Q}$ & $A$ & A & A & Q & Yes \\
\hline 299-W19-41 & C & $Q$ & Q & $\mathrm{Q}$ & $A$ & A & A & $Q$ & Yes \\
\hline 299-W19-42 & C & $Q$ & Q & $\mathrm{Q}$ & A & A & $A$ & $\mathrm{Q}$ & Yes \\
\hline 299-W19-44 & $\mathrm{C}$ & $Q$ & Q & $Q$ & A & A & $A$ & $Q$ & Yes \\
\hline 299-W19-45 & $\mathrm{C}$ & $Q$ & Q & $Q$ & A & A & $A$ & $Q$ & Yes \\
\hline 299-W19-47 & C & $\mathrm{Q}$ & Q & $\mathrm{Q}$ & $\mathrm{A}$ & $\mathrm{A}$ & A & $Q$ & Yes \\
\hline \multicolumn{10}{|c|}{$\begin{array}{l}\text { Wells completed at the top of the unconfined aquifer. } \\
\text { (a) Bold italic = Upgradient well. } \\
\text { A = To be sampled annually. } \\
\text { AEA = Atomic Energy Act. } \\
C=\text { Well is constructed as a resource protection well under WAC 173-160. } \\
\text { FY = Fiscal year. } \\
Q=\text { To be sampled quarterly. } \\
\text { RCRA = Resource Conservation and Recovery Act. } \\
\text { WAC = Washington Administrative Code. }\end{array}$} \\
\hline
\end{tabular}


Table B.38. Monitoring Wells and Constituents for KE and KW Basins (adapted from PNNL-14033(a)

\begin{tabular}{|c|c|c|c|c|c|c|c|c|c|c|c|}
\hline Well Number & Comment & 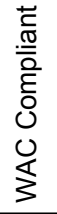 & $\frac{\frac{\pi}{2}}{\frac{\pi}{2}}$ & $\frac{2}{0}$ & $\frac{\pi}{0}$ & $\begin{array}{l}\frac{J}{1} \\
\frac{1}{0} \\
\frac{0}{\mathbb{L}} \\
0\end{array}$ & 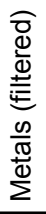 & 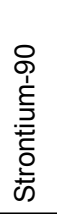 & 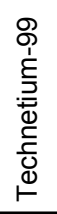 & $\stackrel{\sum}{\underline{E}}$ & $\begin{array}{c}\text { Sampled as Scheduled } \\
\text { in FY 2006? }\end{array}$ \\
\hline \multicolumn{12}{|c|}{ KE Basin } \\
\hline $199-K-27$ & & $\mathrm{P}$ & $Q$ & $Q$ & $Q$ & & $S$ & A & $A$ & $Q$ & Yes \\
\hline $199-K-29$ & & $P$ & $Q$ & $Q$ & $Q$ & $A$ & $A$ & & & $\mathrm{M}$ & Yes \\
\hline $199-K-30$ & & $\mathrm{P}$ & $Q$ & $Q$ & $Q$ & $A$ & $S$ & & & $Q$ & Yes \\
\hline $199-K-32 A$ & & $C$ & $Q$ & $Q$ & $Q$ & $A$ & $A$ & & $A$ & $Q$ & Yes \\
\hline 199-K-109A & & $C$ & $Q$ & Q & $Q$ & A & $S$ & A & A & $Q$ & Yes \\
\hline 199-K-110A & & $C$ & $S$ & $S$ & $S$ & & $A$ & & & $S$ & Yes \\
\hline 199-K-111A & & $C$ & $Q$ & $Q$ & $Q$ & $A$ & A & & $A$ & $Q$ & Yes \\
\hline \multicolumn{12}{|c|}{ KW Basin } \\
\hline $199-K-34$ & & $C$ & $Q$ & $Q$ & $Q$ & $A$ & $S$ & $A$ & $A$ & $Q$ & Yes \\
\hline 199-K-106A & & $C$ & $Q$ & $Q$ & $Q$ & $A$ & $S$ & & & $Q$ & Yes \\
\hline 199-K-107A & & $C$ & $Q$ & $Q$ & $Q$ & $A$ & $S$ & $A$ & $A$ & $Q$ & Yes \\
\hline 199-K-108A & & $C$ & $S$ & $S$ & $S$ & & $S$ & & & $\mathrm{~S}$ & Yes \\
\hline 199-K-132 & & $C$ & $S$ & $S$ & $S$ & $A$ & $S$ & & & $\mathrm{~S}$ & $\begin{array}{l}\text { Yes; new well; replaced } \\
\text { well 199-K-33 }\end{array}$ \\
\hline \multicolumn{12}{|c|}{$\begin{array}{l}\text { Wells completed at the top of the unconfined aquifer. } \\
\text { (a) Selected wells monitored monthly during basin cleanout. } \\
A=\text { To be sampled annually. } \\
C=\text { Well is constructed as a resource protection well under WAC 173-160. } \\
\text { FY = Fiscal year. } \\
P=\text { Constructed prior to WAC requirements. } \\
Q=\text { To be sampled quarterly. } \\
S=\text { To be sampled semiannually. } \\
\text { WAC = Washington Administrative Code. }\end{array}$} \\
\hline
\end{tabular}


Table B.39. Monitoring Wells, Constituents, and Enforcement Limits for 200 Area Treated Effluent Disposal Facility (adapted from PNNL-13032)

\begin{tabular}{l}
\hline \\
\hline
\end{tabular}

Table B.40. Monitoring Wells and Constituents for Environmental Restoration Disposal Facility (adapted from BHI-00873)

\begin{tabular}{|c|c|c|c|c|c|c|c|c|c|c|c|c|c|c|c|}
\hline Well Number ${ }^{(a)}$ & 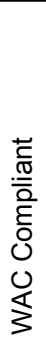 & 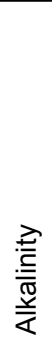 & $\frac{\text { 응 }}{\frac{2}{2}}$ & $\begin{array}{l}\text { n } \\
\text { 을 } \\
\frac{1}{2}\end{array}$ & 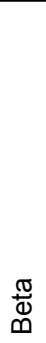 & 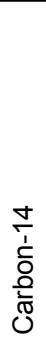 & 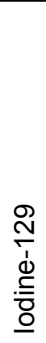 & 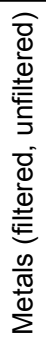 & 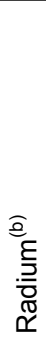 & 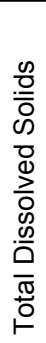 & 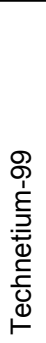 & 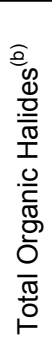 & 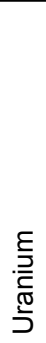 & 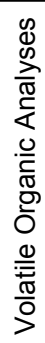 & $\begin{array}{l}\text { Sampled as Scheduled } \\
\text { in FY 2006? }\end{array}$ \\
\hline $699-35-66 \mathrm{~A}$ & $\mathrm{C}$ & $S$ & $S$ & $S$ & $S$ & $\mathrm{~S}$ & $\mathrm{~S}$ & $S$ & $\mathrm{~S}$ & $S$ & $S$ & $S$ & $\mathrm{~S}$ & $\bar{S}$ & $\mathrm{No}^{(\mathrm{b})}$ \\
\hline 699-36-67 & $\mathrm{C}$ & $S$ & $S$ & $S$ & $S$ & $S$ & $S$ & $S$ & $S$ & $S$ & $S$ & $S$ & $S$ & $S$ & $\mathrm{No}^{(\mathrm{b})}$ \\
\hline 699-36-70A & $\mathrm{P}$ & $S$ & $S$ & $S$ & $S$ & $S$ & $S$ & $S$ & $\mathrm{~S}$ & $S$ & $S$ & $S$ & $S$ & $S$ & $\mathrm{No}^{(\mathrm{b})}$ \\
\hline $699-37-68$ & $\mathrm{C}$ & $S$ & $\mathrm{~S}$ & $S$ & $S$ & $S$ & $S$ & $S$ & $S$ & $S$ & $S$ & $S$ & $S$ & $S$ & $\mathrm{No}^{(\mathrm{b})}$ \\
\hline
\end{tabular}

Wells completed at the top of the unconfined aquifer.
(a) Bold italic = Upgradient well.
(b) No radium or total organic halides scheduled in FY 2006.
$\mathrm{C}=$ Well is constructed as a resource protection well under WAC 173-160.
$\mathrm{FY}=$ Fiscal year .
$\mathrm{P}=$ Constructed prior to WAC requirements.
$S=$ To be sampled semiannually.
WAC $=$ Washington Administrative Code. 
Table B.41. Monitoring Wells and Constituents for Solid Waste Landfill (adapted from PNNL-13014)

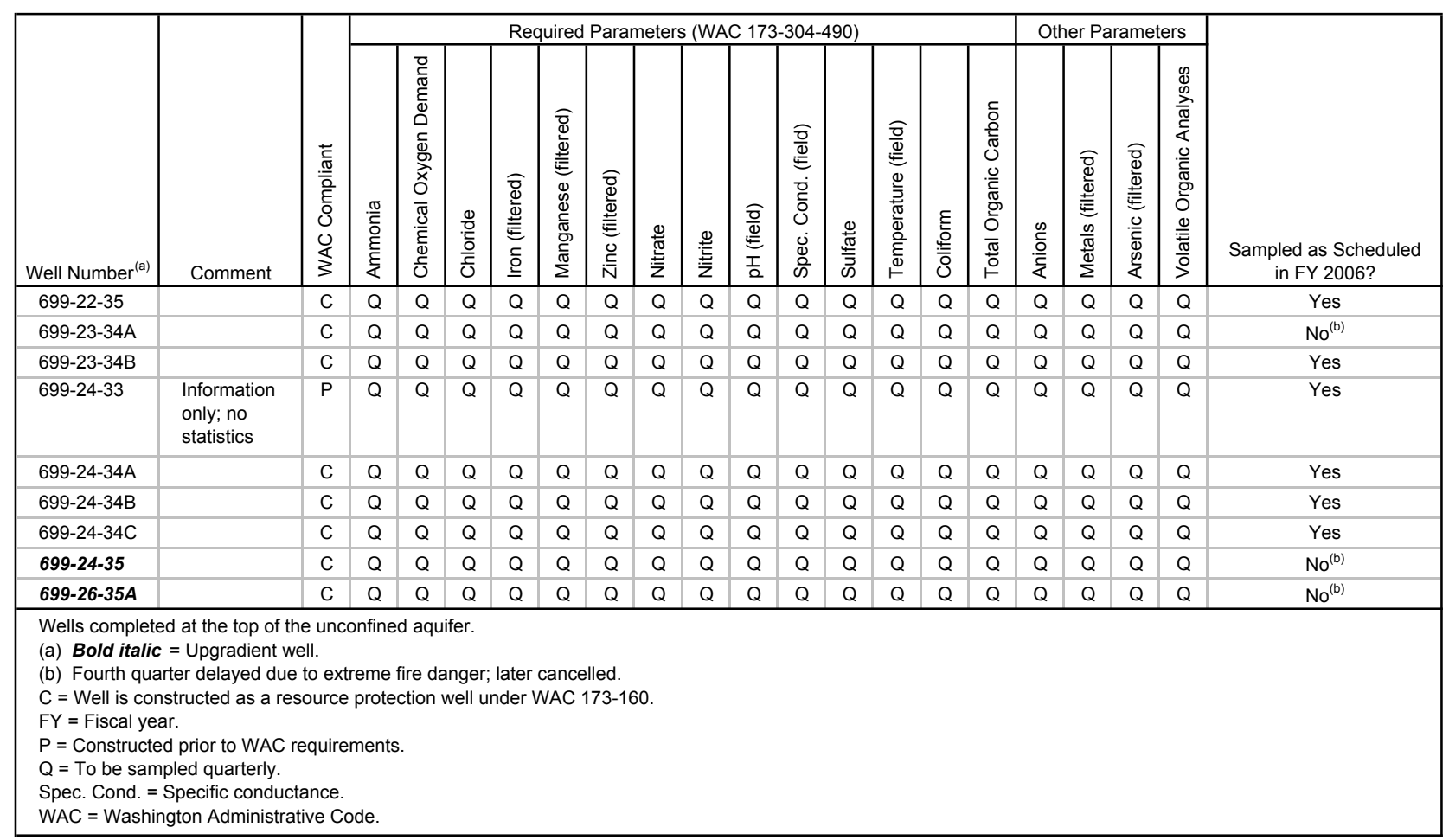


Table B.42. Analytical Results for Required Constituents ${ }^{(a)}$ at Solid Waste Landfill

\begin{tabular}{|c|c|c|c|c|c|c|c|c|c|c|c|}
\hline Constituent, unit & $\begin{array}{c}\begin{array}{c}\text { Background Threshold } \\
\text { Value }\end{array} \\
\end{array}$ & Date & Well 699-22-35 & Well 699-23-34A & Well 699-23-34B & Well 699-24-33 & Well 699-24-34A & Well 699-24-34B & Well 699-24-34C & Well 699-24-35 & Well 699-26-35A \\
\hline \multirow[t]{4}{*}{ Ammonium, $\mu \mathrm{g} / \mathrm{L}$} & $90 \mu \mathrm{g} / \mathrm{L}$ & November 2005 & $<6.69$ & $<6.69$ & $<6.69$ & $<6.69$ & $<6.69$ & $<6.69$ & $<6.69$ & $<6.69$ & $<6.69$ \\
\hline & & February 2006 & $<6.69$ & $<6.69$ & $<6.69$ & $<6.69$ & $<6.69$ & $<6.69$ & $<6.69$ & $<6.69$ & $<6.69$ \\
\hline & & May 2006 & $69.2^{\left({ }^{()}\right.}$ & $<6.69$ & $<6.69$ & $<6.69$ & $<6.69$ & $61^{(c)}$ & $<6.69$ & $<6.69$ & $<6.69$ \\
\hline & & August 2006 & $<6.69$ & (d) & $<6.69$ & $<6.69$ & $<6.69$ & $<6.69$ & $<6.69$ & (d) & (d) \\
\hline \multirow[t]{4}{*}{$\begin{array}{l}\text { Chemical oxygen demand, } \\
\mathrm{mg} / \mathrm{L}\end{array}$} & $10 \mathrm{mg} / \mathrm{L}$ & November 2005 & $<9.2$ & $<9.2$ & 30 & $<9.2$ & $<9.2$ & $<9.2$ & 12 & 52 & 135 \\
\hline & & February 2006 & 62 & $<9.2$ & $<9.2$ & 62 & $<9.2$ & $<9.2$ & 127 & 26 & 10 \\
\hline & & May 2006 & 48 & $<9.2$ & $<9.2$ & $<9.2$ & 12 & 10 & $<9.2$ & $<9.2$ & $<9.2$ \\
\hline & & August 2006 & 17 & (d) & 25 & 27 & 18 & $<9.2$ & $<9.2$ & (d) & (d) \\
\hline \multirow[t]{4}{*}{ Chloride, $\mathrm{mg} / \mathrm{L}$} & $7.8 \mathrm{mg} / \mathrm{L}$ & November 2005 & 7.1 & 7.35 & 7 & 5.4 & $35^{(\mathrm{c})}$ & 7.3 & 7.3 & 25 & 7.5 \\
\hline & & February 2006 & 7 & 6.4 & 6.9 & 6.7 & 7.2 & 6.6 & 5.8 & 6.3 & 7 \\
\hline & & May 2006 & 7.2 & 7.9 & 7.6 & 7.9 & 8.4 & 8 & 8.2 & 7.4 & 7.6 \\
\hline & & August 2006 & 8.4 & (d) & 7.6 & 7.6 & 8.3 & 8.4 & 7.3 & (d) & (d) \\
\hline \multirow[t]{4}{*}{ Coliform bacteria, col/100ml } & $1 \mathrm{col} / 100 \mathrm{ml}$ & November 2005 & $<1$ & 7.4 & $<1$ & $<1$ & $<1$ & $<1$ & 16 & $<1$ & $<1$ \\
\hline & & February 2006 & $<1$ & 6.3 & $<1$ & $<1$ & $<1$ & $<1$ & 7.4 & 13.2 & 2 \\
\hline & & May 2006 & $<1$ & $<1$ & 2 & 3.1 & $<1$ & $<1$ & $<1$ & $<1$ & $<1$ \\
\hline & & August 2006 & $<1$ & (d) & $<1$ & $<1$ & 3.1 & $<1$ & 16 & (d) & (d) \\
\hline \multirow[t]{4}{*}{ Iron, filtered, $\mu \mathrm{g} / \mathrm{L}$} & $160 \mathrm{\mu g} / \mathrm{L}$ & November 2005 & 43.9 & 19 & 21.9 & $<12.6$ & 29.3 & 36.6 & 17.6 & 16.4 & $<12.6$ \\
\hline & & February 2006 & 27.2 & 37.4 & 43.8 & $<25$ & 32.4 & $<25$ & $<25$ & $<25$ & $<25$ \\
\hline & & May 2006 & $158^{(c)}$ & 34.6 & 35.7 & 27.4 & 71.4 & 33.7 & 32.5 & 27 & $<25$ \\
\hline & & August 2006 & 31.6 & (d) & 35 & $<25$ & 40.6 & 31.4 & 26.5 & (d) & (d) \\
\hline \multirow[t]{4}{*}{ Manganese, $\mu \mathrm{g} / \mathrm{L}$} & $10 \mu \mathrm{g} / \mathrm{L}$ & November 2005 & 1.3 & 2.2 & $<0.84$ & $<0.84$ & 1.9 & 2.9 & $<2.5$ & 0.91 & $<0.84$ \\
\hline & & February 2006 & $<2.5$ & $<0.84$ & $<2.5$ & $<2.5$ & $<2.5$ & $<2.5$ & $<2.5$ & $<2.5$ & $<2.5$ \\
\hline & & May 2006 & $<2.5$ & $<2.5$ & 3.6 & $<2.5$ & $<2.5$ & $<2.5$ & $<2.5$ & $<2.5$ & $<2.5$ \\
\hline & & August 2006 & $<2.5$ & (d) & $<2.5$ & $<2.5$ & $<2.5$ & $<2.5$ & 6.4 & (d) & (d) \\
\hline \multirow[t]{4}{*}{ Nitrate, $\mathrm{mg} / \mathrm{L}$} & $29 \mathrm{mg} / \mathrm{L}$ & November 2005 & 15.9 & 15.7 & 15.5 & 14.2 & $46.9^{(c)}$ & 13.7 & 12.4 & $.044^{(\mathrm{c})}$ & 15.5 \\
\hline & & February 2006 & 16.8 & 17.7 & 16.4 & 13.7 & 13.7 & 14.6 & 13.3 & 12.8 & 16.4 \\
\hline & & May 2006 & 16.4 & 17.7 & 15.9 & 13.3 & 13.7 & 15.1 & 13.3 & 12 & 18.1 \\
\hline & & August 2006 & 18.1 & (d) & 16.4 & 14.6 & 13.7 & 16.4 & 13.3 & (d) & (d) \\
\hline \multirow[t]{4}{*}{ Nitrite, $\mu g / L$} & $89 \mu \mathrm{g} / \mathrm{L}$ & November 2005 & $<20$ & $<20$ & $<20$ & $<20$ & $<20$ & $<20$ & $<20$ & $<20$ & $<20$ \\
\hline & & February 2006 & $<20$ & $<20$ & $<20$ & $<20$ & $<20$ & $<20$ & $<20$ & $<20$ & $<20$ \\
\hline & & May 2006 & $154^{(\mathrm{c})}$ & $305^{(c)}$ & $250^{(c)}$ & $273^{(c)}$ & $112^{(c)}$ & $220^{(c)}$ & $266^{(c)}$ & $55.8^{(c)}$ & $78.8^{(c)}$ \\
\hline & & August 2006 & $<13.1$ & (d) & $<13.1$ & $<13.1$ & $<13.1$ & $<13.1$ & $<13.1$ & (d) & (d) \\
\hline
\end{tabular}


Table B.42. (contd)

\begin{tabular}{|c|c|c|c|c|c|c|c|c|c|c|c|}
\hline Constituent, unit & $\begin{array}{c}\begin{array}{c}\text { Background Threshold } \\
\text { Value }^{(b)}\end{array} \\
\end{array}$ & Date & Well 699-22-35 & Well 699-23-34A & Well 699-23-34B & Well 699-24-33 & Well 699-24-34A & Well 699-24-34B & Well 699-24-34C & Well 699-24-35 & Well 699-26-35A \\
\hline \multirow[t]{4}{*}{ Field $\mathrm{pH}$} & $6.68-7.84$ & November 2005 & 6.94 & 6.61 & 6.69 & 6.85 & 6.73 & 6.7 & 6.85 & 6.77 & 7.16 \\
\hline & & February 2006 & 6.94 & 6.6 & 6.67 & 6.84 & 6.66 & 6.69 & 6.88 & 6.73 & 7.15 \\
\hline & & May 2006 & 6.95 & 6.62 & 6.68 & 6.98 & 6.82 & 6.72 & 6.94 & 6.76 & 7.74 \\
\hline & & August 2006 & 7.06 & (d) & 6.65 & 6.85 & 7.13 & 6.68 & 6.89 & (d) & (d) \\
\hline \multirow[t]{4}{*}{ Specific conductance, $\mu \mathrm{S} / \mathrm{cm}$} & $583 \mu \mathrm{S} / \mathrm{cm}$ & November 2005 & 824 & 767 & 787 & 782 & 681 & 720 & 746 & 601 & 556 \\
\hline & & February 2006 & 826 & 765 & 784 & 776 & 694 & 725 & 752 & 599 & 550 \\
\hline & & May 2006 & 817 & 749 & 777 & 759 & 667 & 696 & 728 & 575 & 545 \\
\hline & & August 2006 & 813 & (d) & 777 & 766 & 674 & 758 & 744 & (d) & (d) \\
\hline \multirow[t]{4}{*}{ Sulfate, $\mu \mathrm{g} / \mathrm{L}$} & $47.2 \mathrm{mg} / \mathrm{L}$ & November 2005 & 44.5 & 48.6 & 43.6 & 42.5 & 67.7 & 48.7 & 41.4 & $0.061^{(c)}$ & 37.1 \\
\hline & & February 2006 & 43.8 & 48.2 & 43.7 & 43.4 & 45.6 & 48.5 & 42.1 & 45 & 36.9 \\
\hline & & May 2006 & 43.6 & 48.8 & 43.3 & 43.8 & 46.2 & 51.2 & 42.1 & 44.6 & 47.7 \\
\hline & & August 2006 & 42.9 & (d) & 42.8 & 44.2 & 44.1 & 66.9 & 41.6 & (d) & (d) \\
\hline \multirow[t]{4}{*}{ Temperature, ${ }^{\circ} \mathrm{C}$} & $20.7^{\circ} \mathrm{C}$ & November 2005 & 17.6 & 18.3 & 18.2 & 19.3 & 17.5 & 17 & 17.4 & 17.2 & 19.2 \\
\hline & & February 2006 & 17.4 & 18 & 17.2 & 18.9 & 18.2 & 18.3 & 18.2 & 17.7 & 19 \\
\hline & & May 2006 & 19.3 & 18.7 & 18.6 & 19.9 & $21^{(\mathrm{c})}$ & 19.2 & 19.4 & 18.5 & 20 \\
\hline & & August 2006 & 20.1 & (d) & 18.7 & 19.4 & 19.5 & 19.6 & 19.3 & (d) & (d) \\
\hline \multirow[t]{4}{*}{ Total organic carbon, $\mu \mathrm{g} / \mathrm{L}$} & $2,240 \mu \mathrm{g} / \mathrm{L}$ & November 2005 & $<470$ & 930 & 910 & 820 & 630 & $<470$ & $<470$ & $<470$ & 680 \\
\hline & & February 2006 & $<470$ & $<470$ & 700 & 2,100 & 1,600 & 2,100 & 1,000 & 2,200 & 1,568 \\
\hline & & May 2006 & $<470$ & 510 & 880 & $<470$ & $<470$ & $<470$ & $<470$ & $<470$ & $<470$ \\
\hline & & August 2006 & $<470$ & (d) & $<470$ & 790 & $<470$ & $<470$ & $<470$ & (d) & (d) \\
\hline \multirow[t]{4}{*}{ Zinc, $\mu \mathrm{g} / \mathrm{L}$} & $42.3 \mu \mathrm{g} / \mathrm{L}$ & November 2005 & 3 & 3.3 & 2.8 & 9 & 4 & 5.9 & 12 & 8.7 & 7.5 \\
\hline & & February 2006 & $<5.6$ & 6.9 & $<5.6$ & 14.6 & 7.6 & 6.2 & 18 & 14.7 & 9.3 \\
\hline & & May 2006 & $<9.6$ & $<9.6$ & $<9.6$ & 12 & $<9.6$ & $<9.6$ & 16.6 & 11.7 & $<9.6$ \\
\hline & & August 2006 & 35.1 & (d) & $<9.6$ & 12.3 & $<9.6$ & $<9.6$ & 16.2 & (d) & (d) \\
\hline $\begin{array}{l}\text { Results in bold exceed backgr } \\
\text { (a) WAC 173- } 04 \text {. } \\
\text { (b) Number obtained from Tab } \\
\text { (c) Result not typical of histor } \\
\text { (d) Sample not collected. }\end{array}$ & threshold value. & vater report ( & & & & & & & & & \\
\hline
\end{tabular}


Table B.43. Results of Shapiro and Francia Test for Normality and Background Threshold Values for Solid Waste Landfill

\begin{tabular}{|c|c|c|c|c|c|}
\hline Constituent, ${ }^{(a)}$ unit & $\begin{array}{c}\text { W-test } \\
\text { Statistic, } \\
\text { (log value) }\end{array}$ & $\begin{array}{l}\text { W-test } \\
\text { Statistic, }{ }^{(b)} \\
\text { (raw data) }\end{array}$ & $\begin{array}{l}\text { W-test }{ }^{(\mathrm{b})} \text { Critical } \\
\text { Value, } \mathrm{Wa}^{(\mathrm{c})}\end{array}$ & $\begin{array}{c}\text { Upper } \\
\text { Tolerance Limit }\end{array}$ & $\begin{array}{c}\text { Background } \\
\text { Threshold } \\
\text { Value }\end{array}$ \\
\hline Ammonium (as $\mathrm{NH}_{3}^{-}$), $\mu \mathrm{g} / \mathrm{L}$ & NC & NC & $\mathrm{NC}$ & $\begin{array}{l}90^{(\mathrm{d})} \\
30^{(\mathrm{f})}\end{array}$ & 90 \\
\hline $\begin{array}{l}\text { Chemical oxygen demand, } \\
\mu \mathrm{g} / \mathrm{L}\end{array}$ & NC & NC & NC & $10,000^{(g)}$ & 10,000 \\
\hline Chloride, $\mu \mathrm{g} / \mathrm{L}$ & $0.954 \mathrm{~s}$ & $0.962 \mathrm{~s}$ & 0.963 & $7,820^{(\mathrm{d})}$ & 7,820 \\
\hline $\begin{array}{l}\text { Coliform bacteria, } \\
\text { colonies } / 100 \mathrm{ml}\end{array}$ & NC & $\mathrm{NC}$ & NC & $1^{(\mathrm{g})}$ & 1 \\
\hline Field $\mathrm{pH}$ & $0.988 \mathrm{~ns}$ & NA & 0.963 & {$[6.68,7.84]^{(\mathrm{e})}$} & {$[6.68,7.84]$} \\
\hline Iron, dissolved, $\mu \mathrm{g} / \mathrm{L}$ & $0.960 \mathrm{~s}$ & $0.802 \mathrm{~s}$ & 0.962 & $\begin{array}{l}160^{(\mathrm{d})} \\
113^{(\mathrm{f})}\end{array}$ & 160 \\
\hline Manganese, dissolved, $\mu \mathrm{g} / \mathrm{L}$ & NC & NC & NC & $\begin{array}{l}10^{(\mathrm{d})} \\
11^{(f)}\end{array}$ & 11 \\
\hline Nitrate $\left(\right.$ as $\left.\mathrm{NO}_{3}{ }^{-}\right), \mu \mathrm{g} / \mathrm{L}$ & $0.833 \mathrm{~s}$ & $0.844 \mathrm{~s}$ & 0.963 & $29,000^{(d)}$ & 29,000 \\
\hline Nitrite (as $\mathrm{NO}_{2}^{-}$), $\mu \mathrm{g} / \mathrm{L}$ & $\mathrm{NC}$ & NC & NC & $59^{(f)}$ & 59 \\
\hline Specific conductance, $\mu \mathrm{S} / \mathrm{cm}$ & $0.978 \mathrm{~ns}$ & NA & 0.960 & $583^{(e)}$ & 583 \\
\hline Sulfate, $\mu \mathrm{g} / \mathrm{L}$ & $0.983 \mathrm{~ns}$ & NA & 0.963 & $47,200^{(e)}$ & 47,200 \\
\hline Temperature, ${ }^{\circ} \mathrm{C}$ & $0.953 \mathrm{~s}$ & $0.961 \mathrm{~s}$ & 0.963 & $20.7^{(\mathrm{d})}$ & 20.7 \\
\hline Total organic carbon, $\mu \mathrm{g} / \mathrm{L}$ & NC & NC & $\mathrm{NC}$ & $\begin{array}{l}842^{(\mathrm{d})} \\
2,700^{(f)}\end{array}$ & 2,700 \\
\hline Zinc, dissolved, $\mu \mathrm{g} / \mathrm{L}$ & NC & NC & NC & $\begin{array}{l}42.3^{(\mathrm{d})} \\
43.2^{(\mathrm{f})}\end{array}$ & 43.2 \\
\hline \multicolumn{6}{|c|}{$\begin{array}{l}\text { (a) Constituents are specified in WAC } 173-304-490(2)(d) \text {. Data collected from March } 1993 \text { to May } 2000 \text { from up } \\
699-24-35 \text { and 699-26-35A. } \\
\text { (b) Shapiro and Francia (1972). } \\
\text { (c) Obtained from Table A-9 (Shapiro 1980) for } \alpha=5 \% \text {. } \\
\text { (d) Maximum value reported. } \\
\text { (e) Based on log-normal distribution. } \\
\text { (f) Based on limit of quantitation using results of field blanks (for total organic carbon) or method detection limit. } \\
\text { (g) Based on laboratory lowest detected result. } \\
\text { NA = Not applicable. } \\
\text { NC = Not calculated; insufficient measured values. } \\
\text { ns = Not significant at } 0.05 \text { level of significance. } \\
\text { s = Significant at } 0.05 \text { level of significance. }\end{array}$} \\
\hline
\end{tabular}


Table B.44. Monitoring Wells, Constituents, and Enforcement Limits for State-Approved Land Disposal Site (adapted from PNNL-13121)

\begin{tabular}{|c|c|c|c|c|c|c|c|c|c|c|c|c|c|c|c|c|c|c|}
\hline \multirow[b]{2}{*}{ Well } & \multirow[b]{2}{*}{ Comment } & \multirow[b]{2}{*}{ 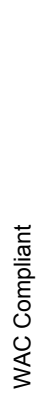 } & \multicolumn{11}{|c|}{ Constituents with Enforcement Limits } & \multicolumn{4}{|c|}{ Other Constituents } & \multirow[b]{2}{*}{$\begin{array}{c}\text { Sampled as Schedulec } \\
\text { in FY 2006? }\end{array}$} \\
\hline & & & $\begin{array}{l}\widehat{n} \\
\infty \\
1 \\
1 \\
0 \\
0 \\
\frac{1}{2} \\
2\end{array}$ & $\begin{array}{l}0 \\
\bar{\partial} \\
0 \\
0 \\
0 \\
0 \\
0 \\
0 \\
0 \\
0 \\
\end{array}$ & 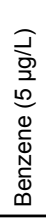 & 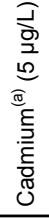 & 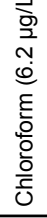 & 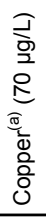 & 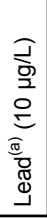 & 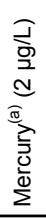 & 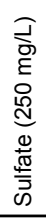 & 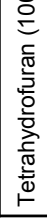 & 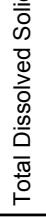 & $\frac{\text { ত }}{\frac{2}{0}}$ & $\begin{array}{l}\frac{\pi}{0} \\
0 \\
\infty\end{array}$ & 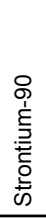 & 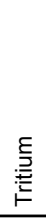 & \\
\hline 299-W6-6 & Bottom of unconfined & $\mathrm{C}$ & & & & & & & & & & & & & & & $\mathrm{A}$ & Yes \\
\hline 299-W6-11 & & $\mathrm{C}$ & & & & & & & & & & & & & & & $\mathrm{A}$ & Yes \\
\hline 299-W6-12 & & $\mathrm{C}$ & & & & & & & & & & & & & & & A & Yes \\
\hline 299-W7-3 & Bottom of unconfined & $\mathrm{C}$ & & & & & & & & & & & & & & & $\mathrm{S}$ & Yes \\
\hline 299-W7-12 & & $\mathrm{C}$ & & & & & & & & & & & & & & & A & Dry FY 2006 \\
\hline 299-W8-1 & & $\mathrm{C}$ & & & & & & & & & & & & & & & $\mathrm{A}$ & Yes \\
\hline $699-48-71$ & Unconfined & $\mathrm{P}$ & & & & & & & & & & & & & & & A & Yes \\
\hline 699-48-77A & Ringold E, upper & $\mathrm{C}$ & Q & Q & Q & Q & Q & Q & Q & Q & Q & Q & $\mathrm{Q}$ & Q & Q & $\mathrm{Q}$ & Q & Yes \\
\hline $699-48-77 \mathrm{C}$ & Ringold E, mid to lower & $\mathrm{C}$ & Q & Q & $\mathrm{Q}$ & Q & Q & $Q$ & Q & $Q$ & $\mathrm{Q}$ & Q & $\mathrm{Q}$ & Q & Q & $\mathrm{Q}$ & $Q$ & Yes \\
\hline 699-48-77D & Ringold E, upper & $\mathrm{C}$ & Q & $Q$ & $\mathrm{Q}$ & Q & Q & Q & Q & Q & $\mathrm{Q}$ & Q & $\mathrm{Q}$ & Q & Q & $\mathrm{Q}$ & $\mathrm{Q}$ & Yes \\
\hline $699-49-79$ & & $\mathrm{P}$ & & & & & & & & & & & & & & & $A$ & Yes \\
\hline $699-51-75$ & & $\mathrm{P}$ & & & & & & & & & & & & & & & $\mathrm{S}$ & Sampled once \\
\hline 699-51-75P & Lower unconfined & $\mathrm{P}$ & & & & & & & & & & & & & & & $A$ & Yes \\
\hline \multicolumn{19}{|c|}{$\begin{array}{l}\text { Wells completed at the top of the unconfined aquifer unless specified otherwise. } \\
\text { (a) Filtered samples. } \\
C=\text { Well is constructed as a resource protection well under WAC 173-160. } \\
\text { FY = Fiscal year. } \\
P=\text { Constructed prior to WAC requirements. } \\
Q=\text { To be sampled quarterly. } \\
S=\text { To be sampled semiannually. } \\
\text { WAC = Washington Administrative Code. }\end{array}$} \\
\hline
\end{tabular}




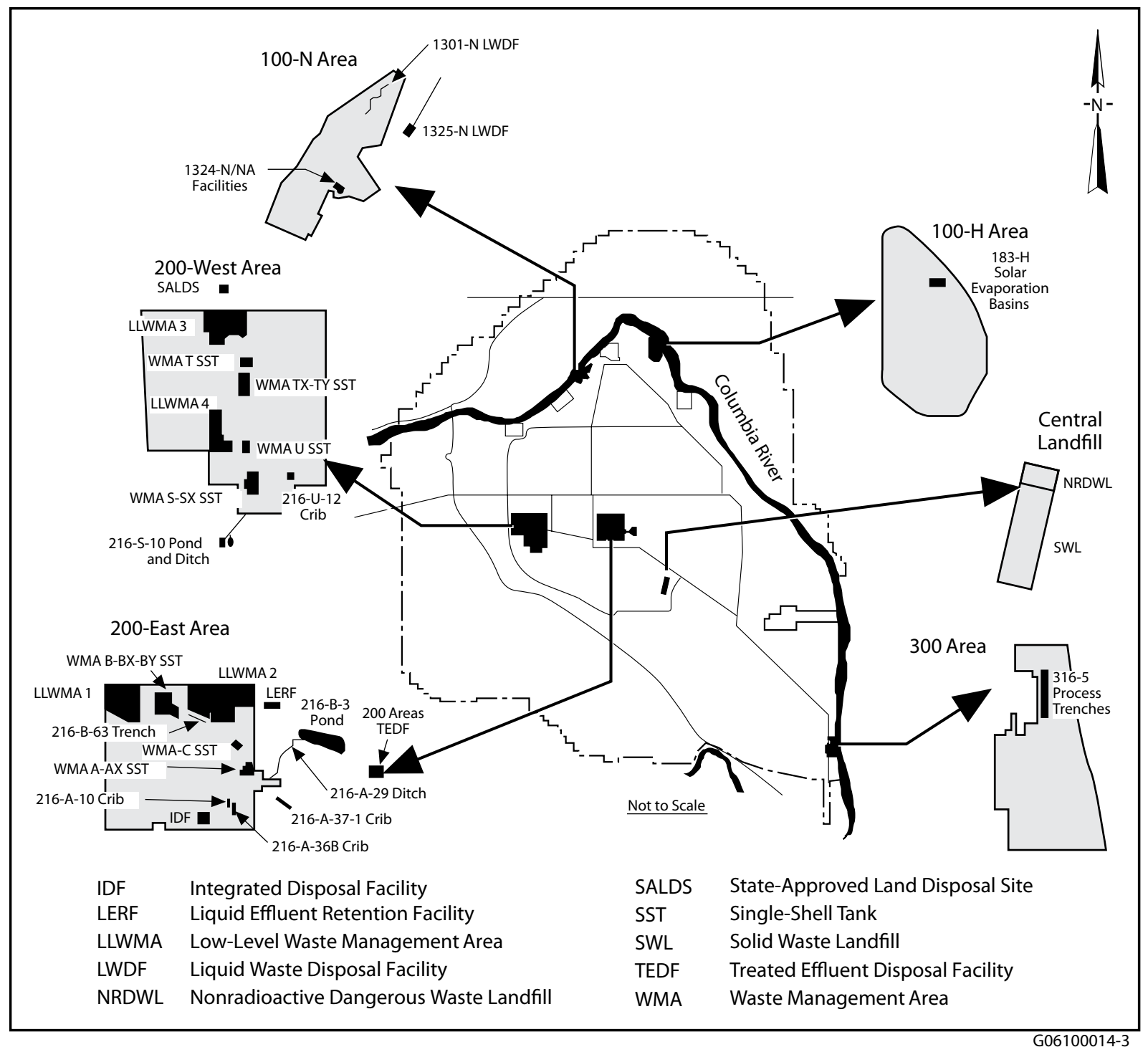

Figure B.1. RCRA Units on the Hanford Site Requiring Groundwater Monitoring (The 216-A-10, 216-A-36B, and 216-A-37-1 cribs are monitored as a single waste management unit, PUREX Cribs.) 


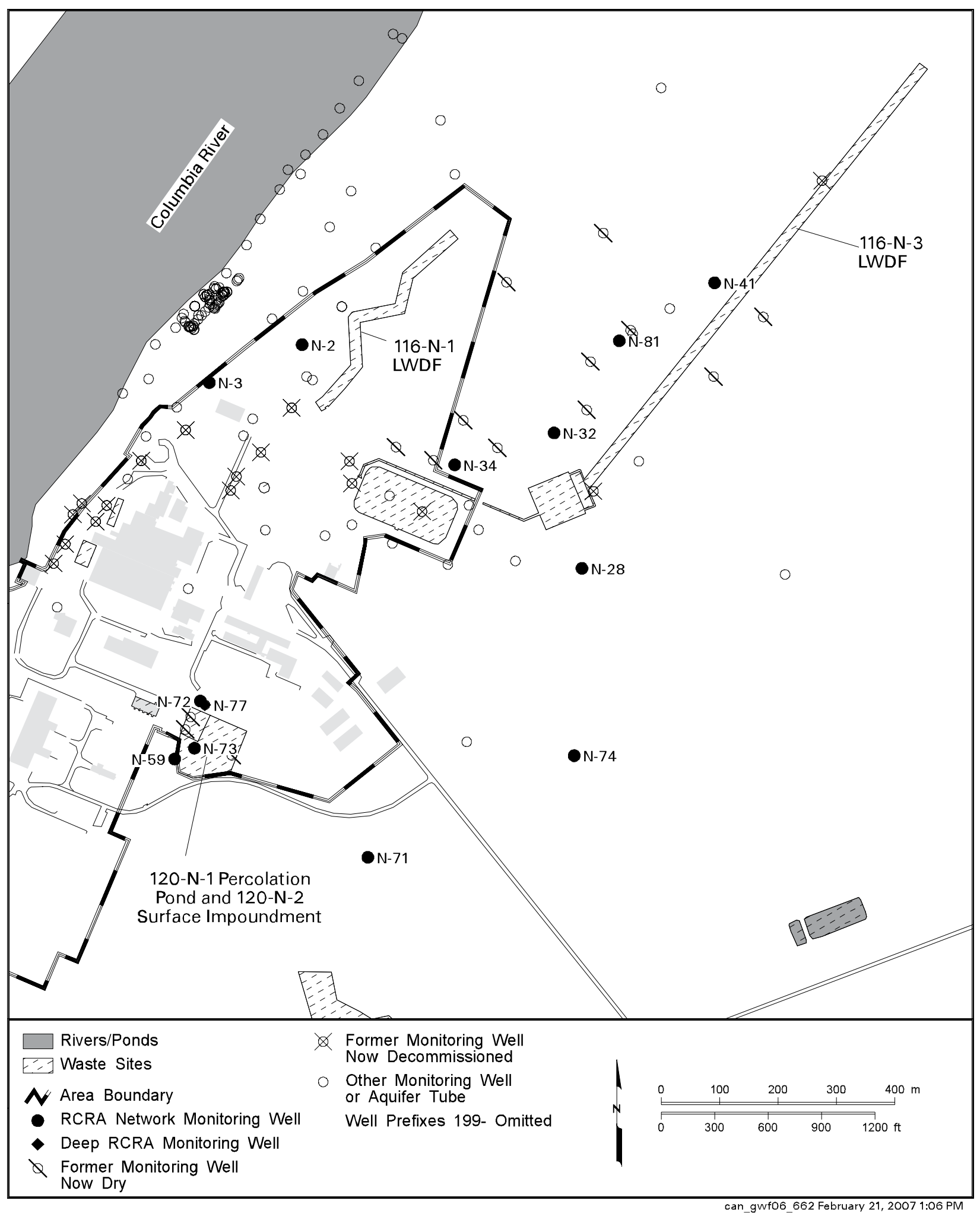

Figure B.2. Groundwater Monitoring Wells for 100-N Area RCRA Sites 


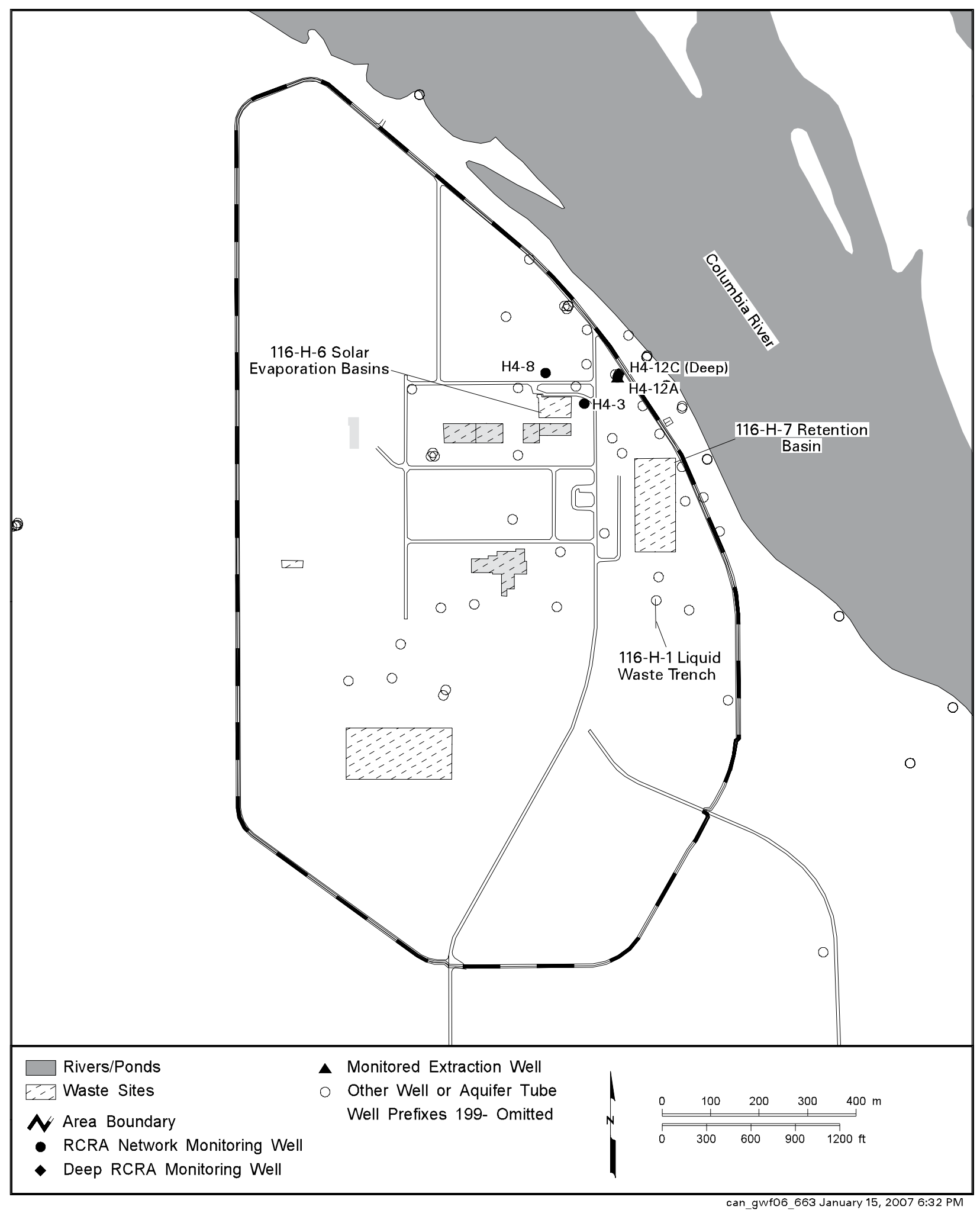

Figure B.3. Groundwater Monitoring Wells at 116-H-6 (183-H) Evaporation Basins 


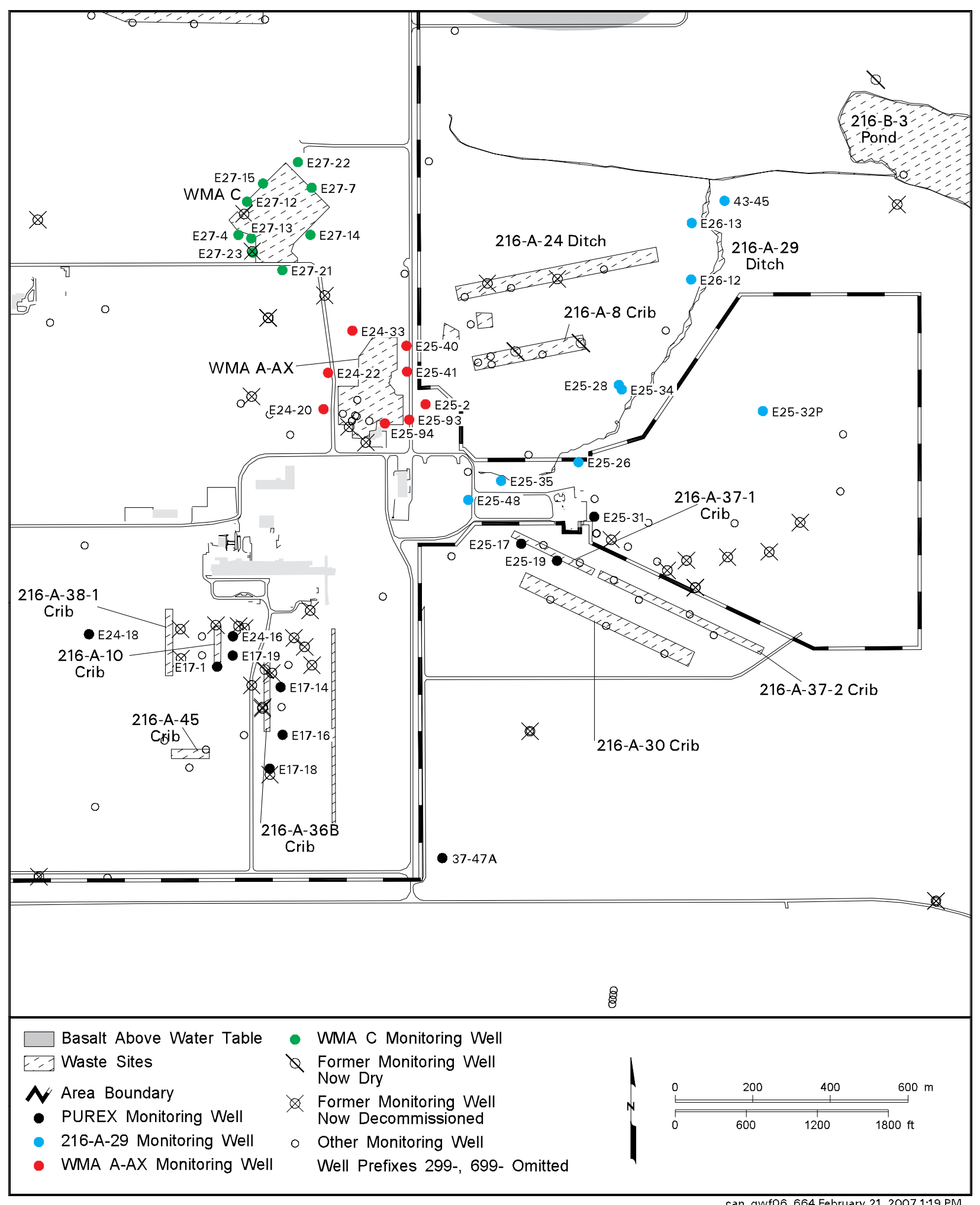

Figure B.4. Groundwater Monitoring Wells at 216-A-29 Ditch, PUREX Cribs, and Waste Management Areas A-AX and C 


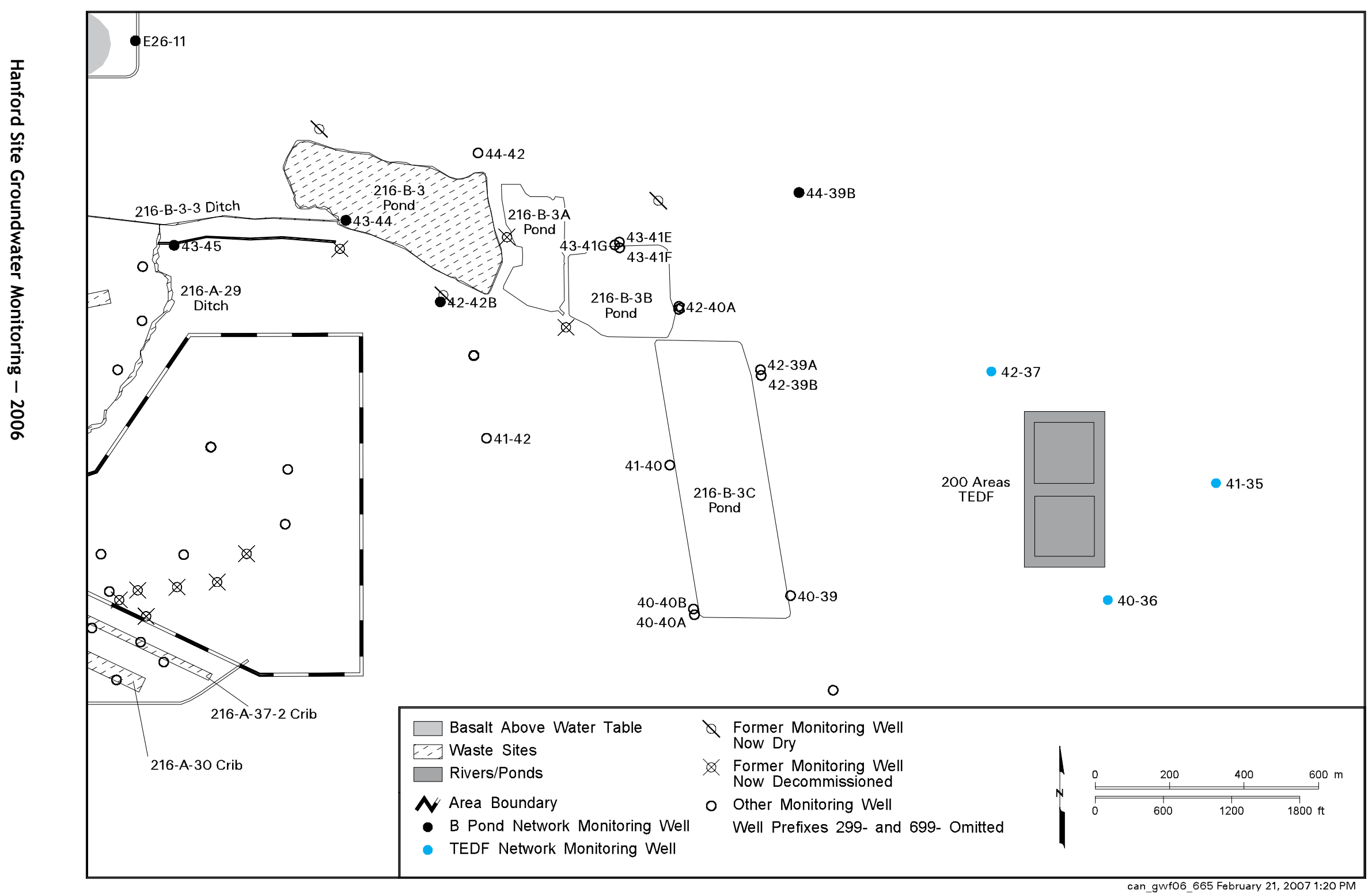

Figure B.5. Groundwater Monitoring Wells at 216-B-3 Pond and 200 Area Treated Effluent Disposal Facility 


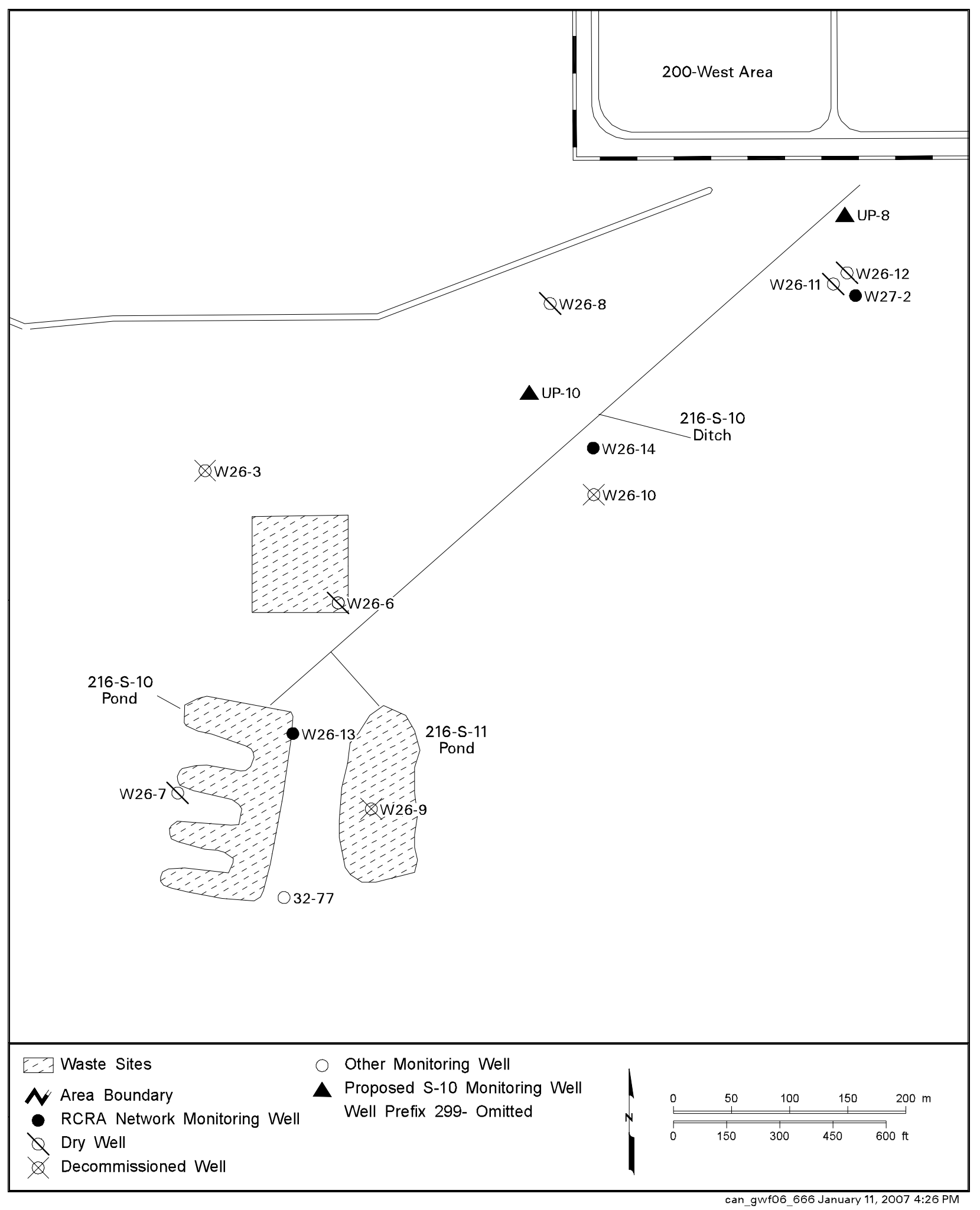

Figure B.6. Groundwater Monitoring Wells at 216-S-10 Pond and Ditch 


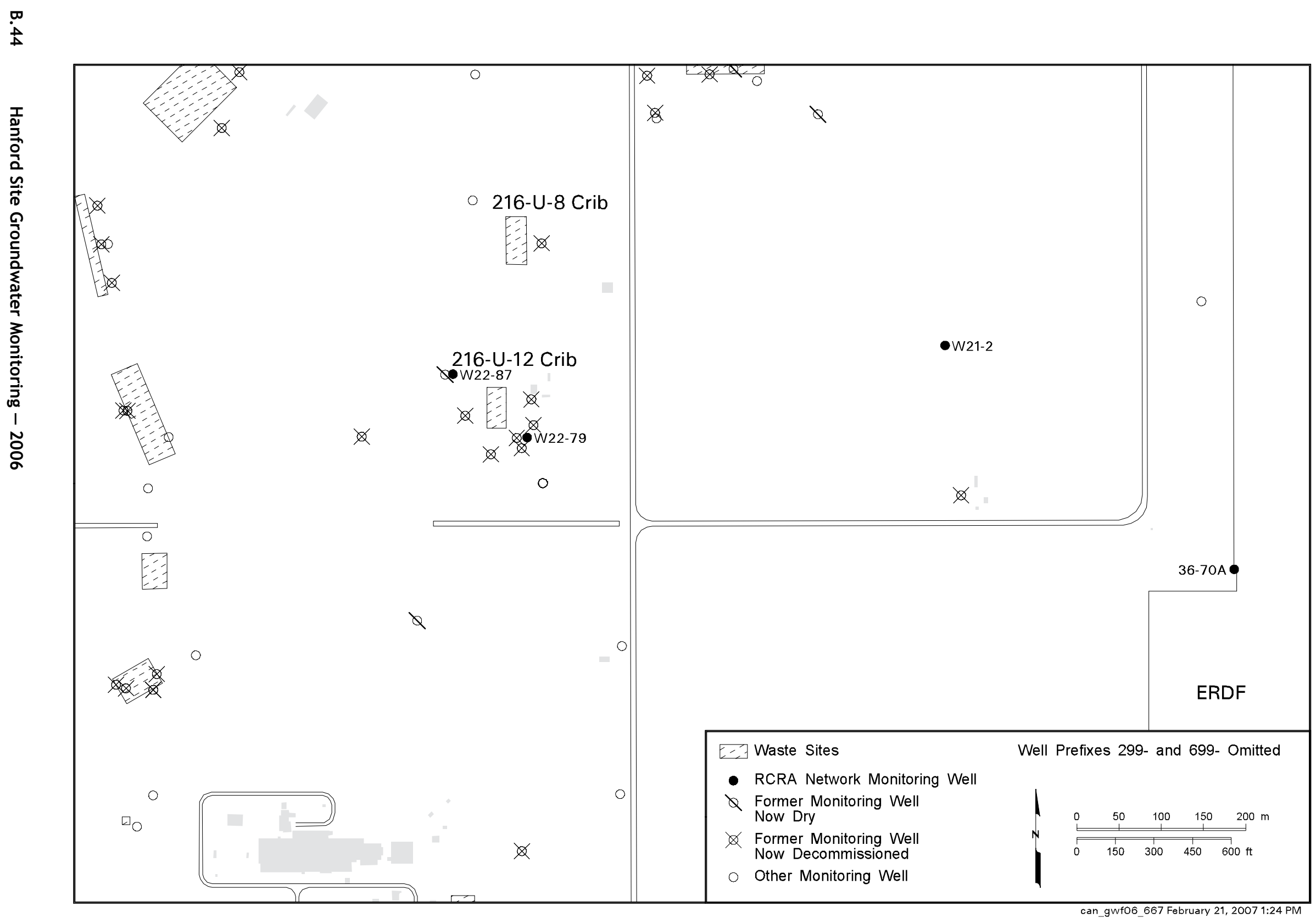

Figure B.7. Groundwater Monitoring Wells at 216-U-12 Crib 


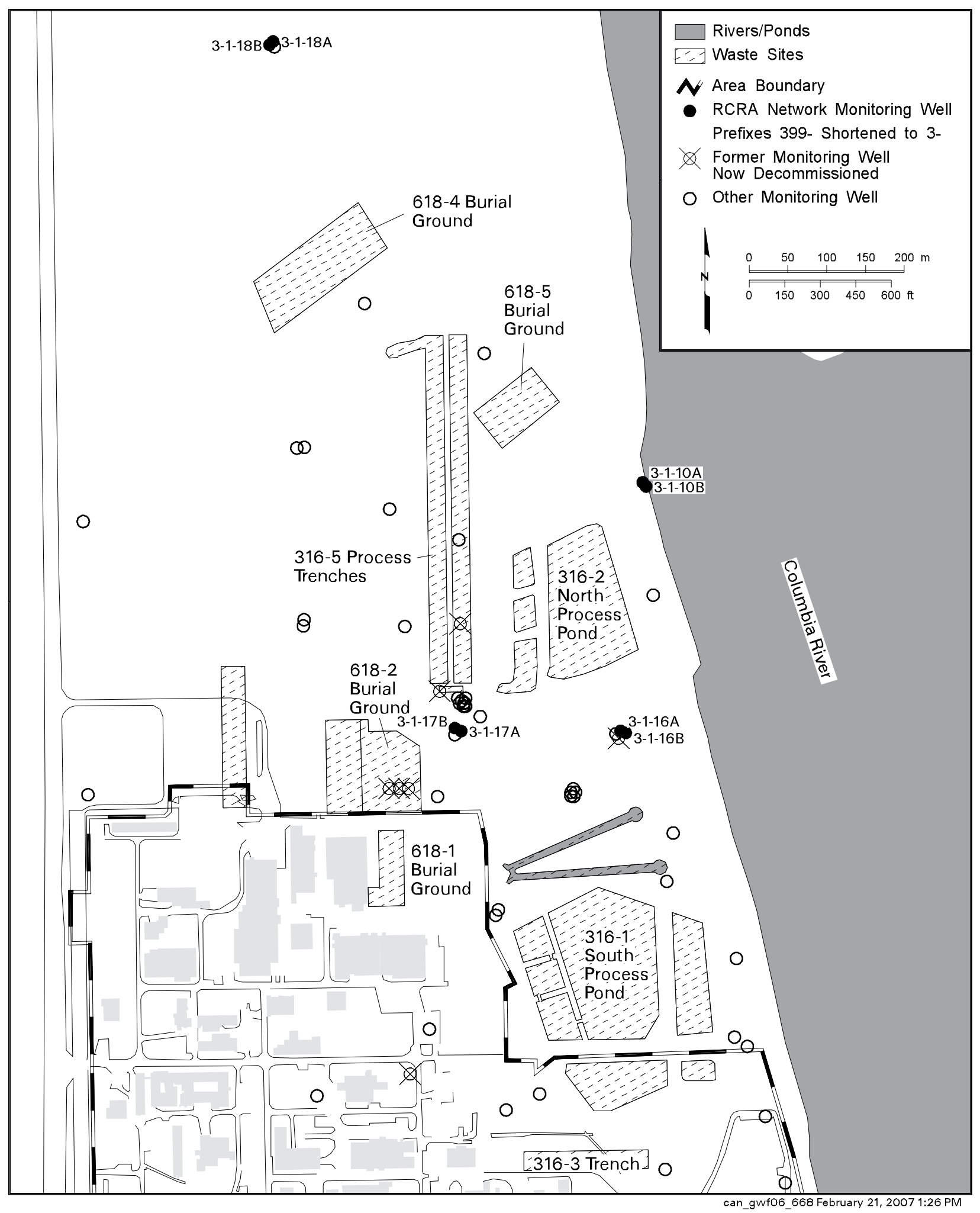

Figure B.8. Groundwater Monitoring Wells at 316-5 Process Trenches 


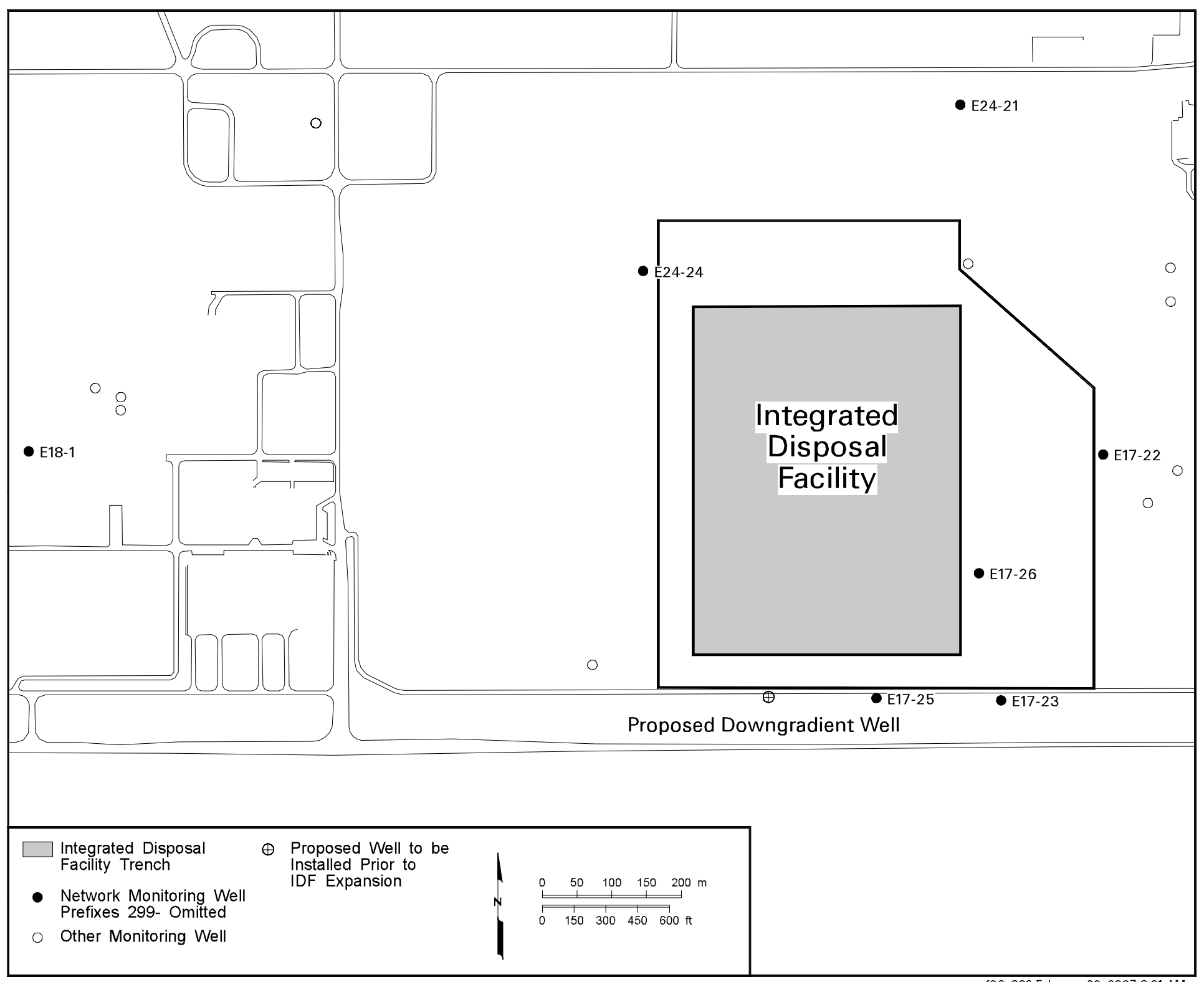

Figure B.9. Groundwater Monitoring Wells at Integrated Disposal Facility 


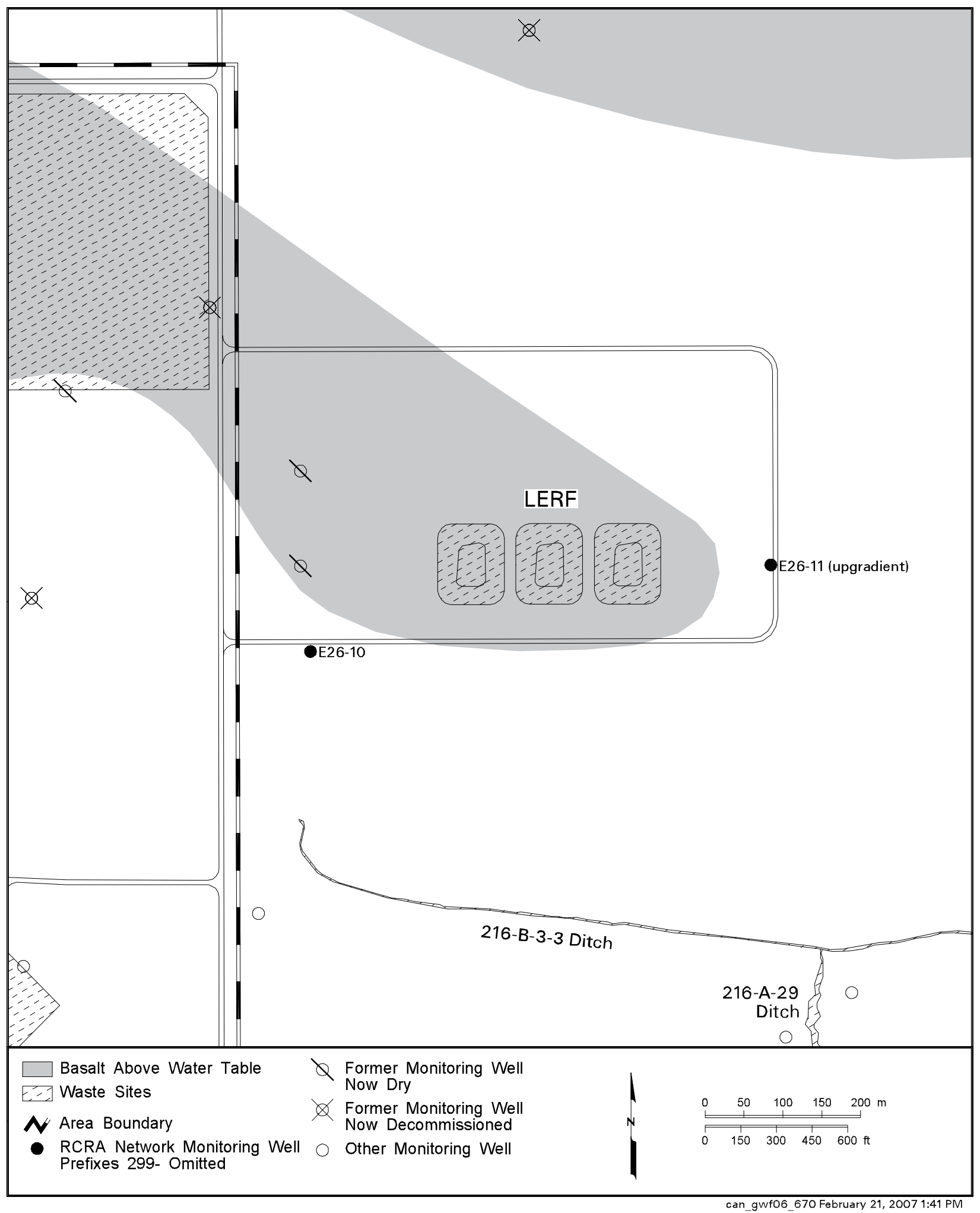

Figure B.10. Groundwater Monitoring Wells at Liquid Effluent Retention Facility 


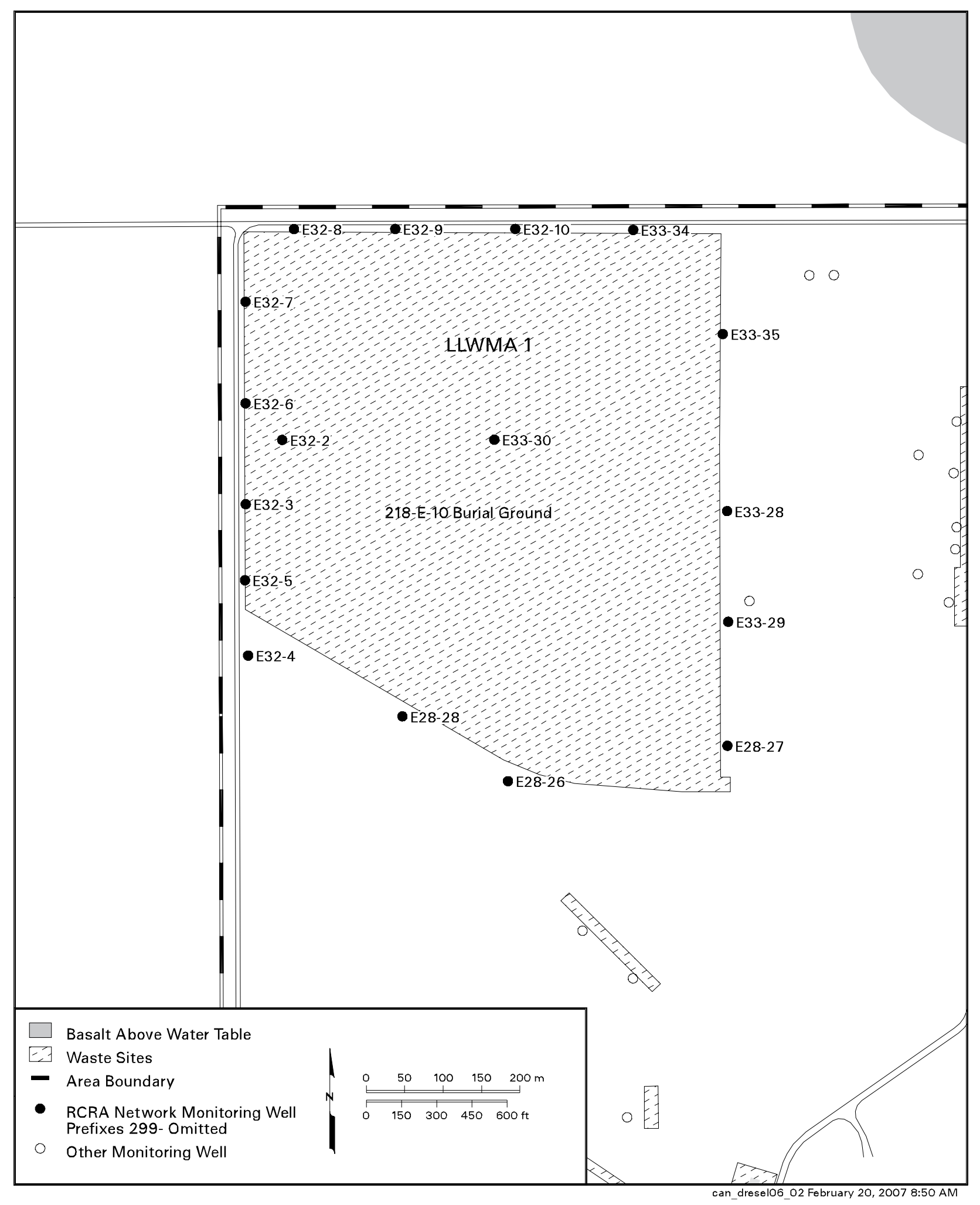

Figure B.11. Groundwater Monitoring Wells at Low-Level Waste Management Area 1 


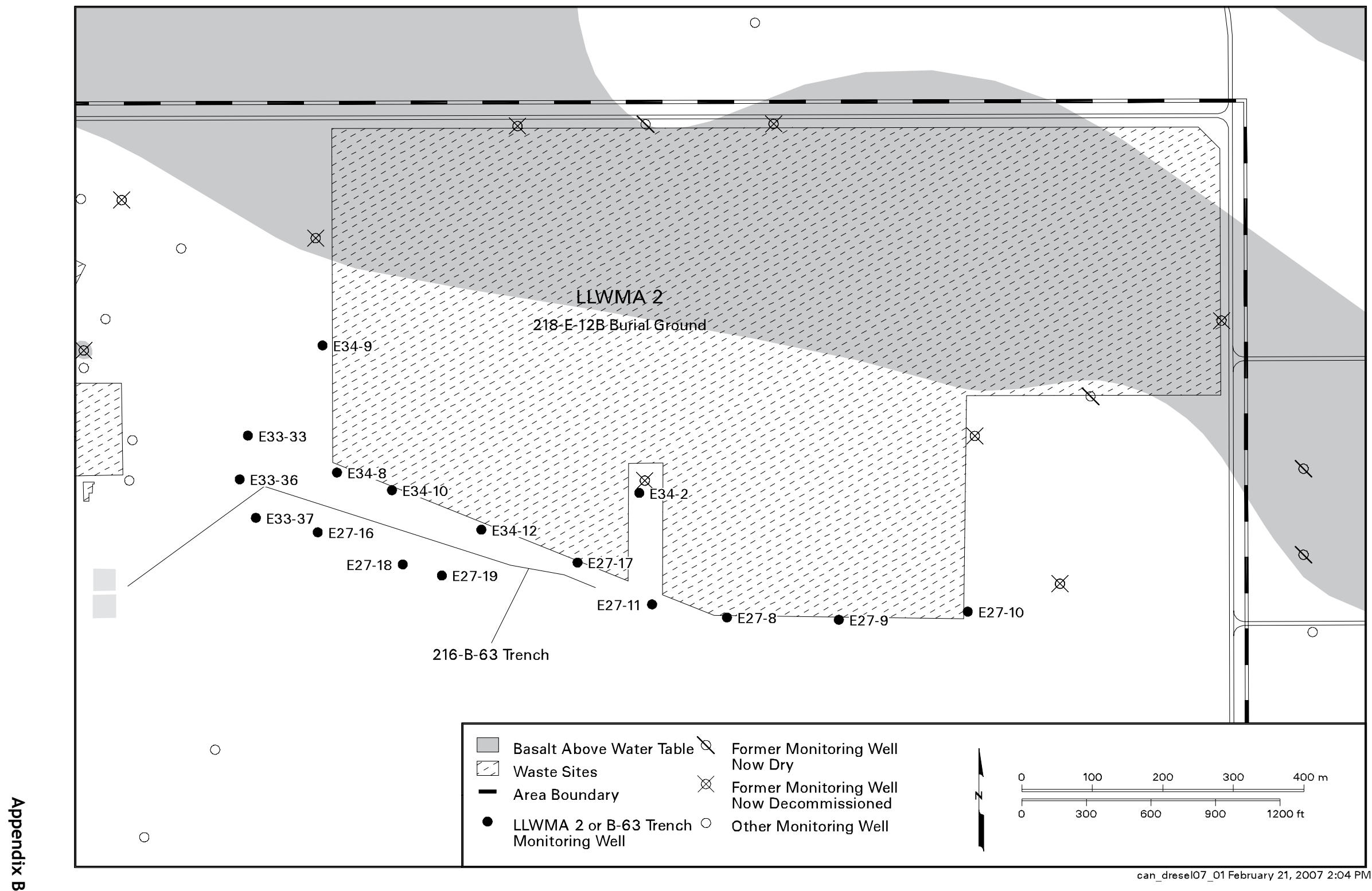

Figure B.12. Groundwater Monitoring Wells at 216-B-63 Trench and Low-Level Waste Management Area 2 


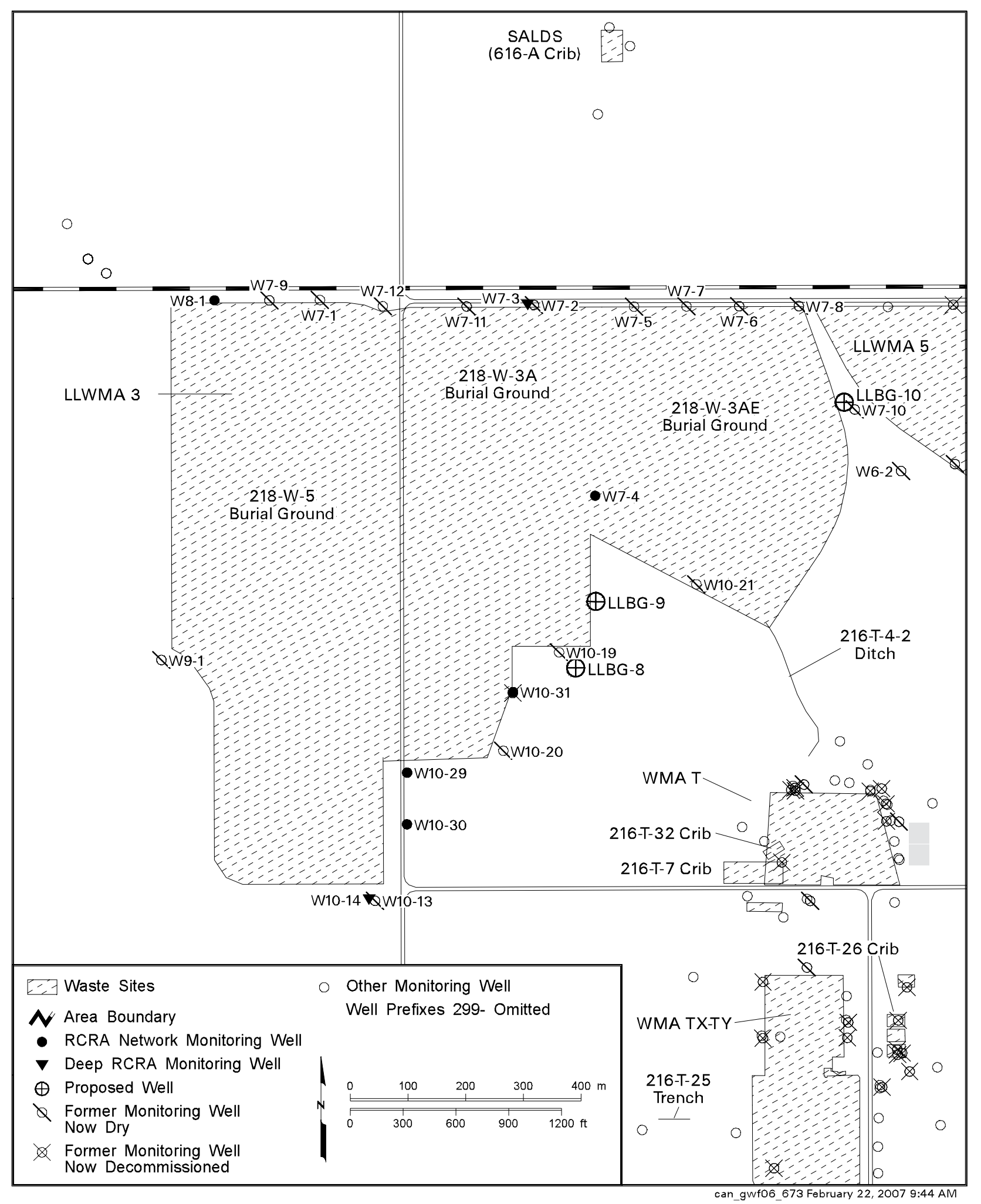

Figure B.13. Groundwater Monitoring Wells at Low-Level Waste Management Area 3 


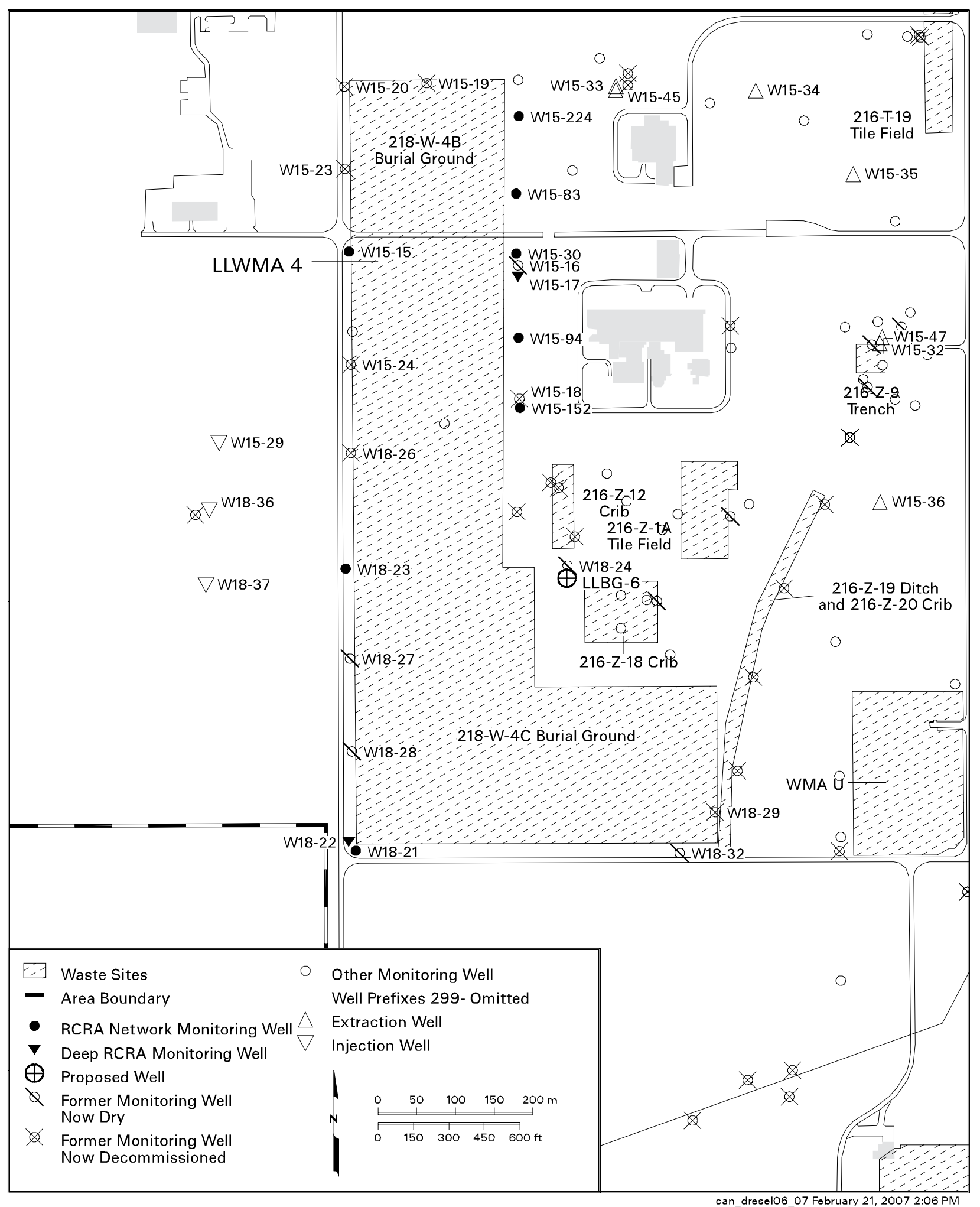

Figure B.14. Groundwater Monitoring Wells at Low-Level Waste Management Area 4 


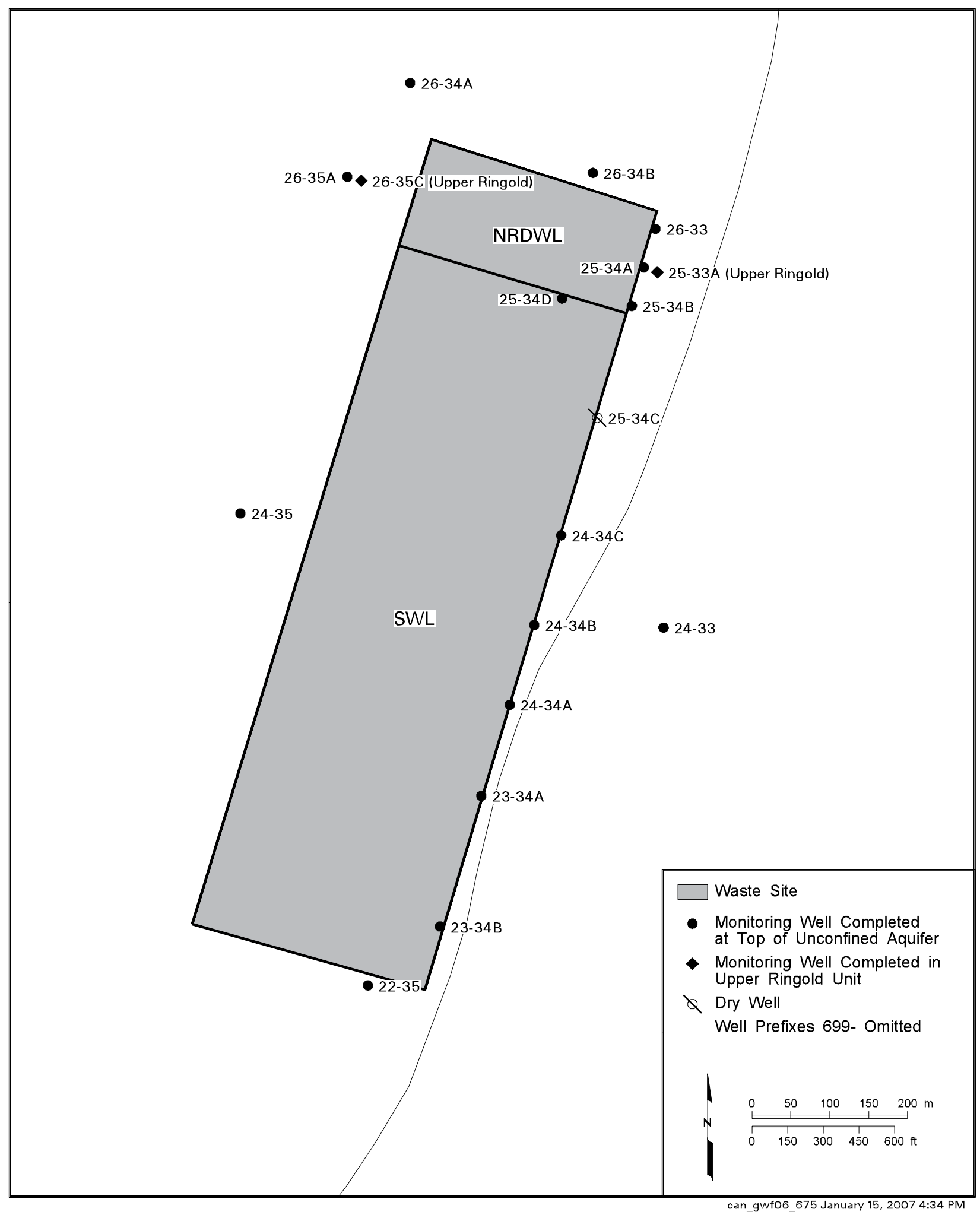

Figure B.15. Groundwater Monitoring Wells at Nonradioactive Dangerous Waste Landfill and Solid Waste Landfill 


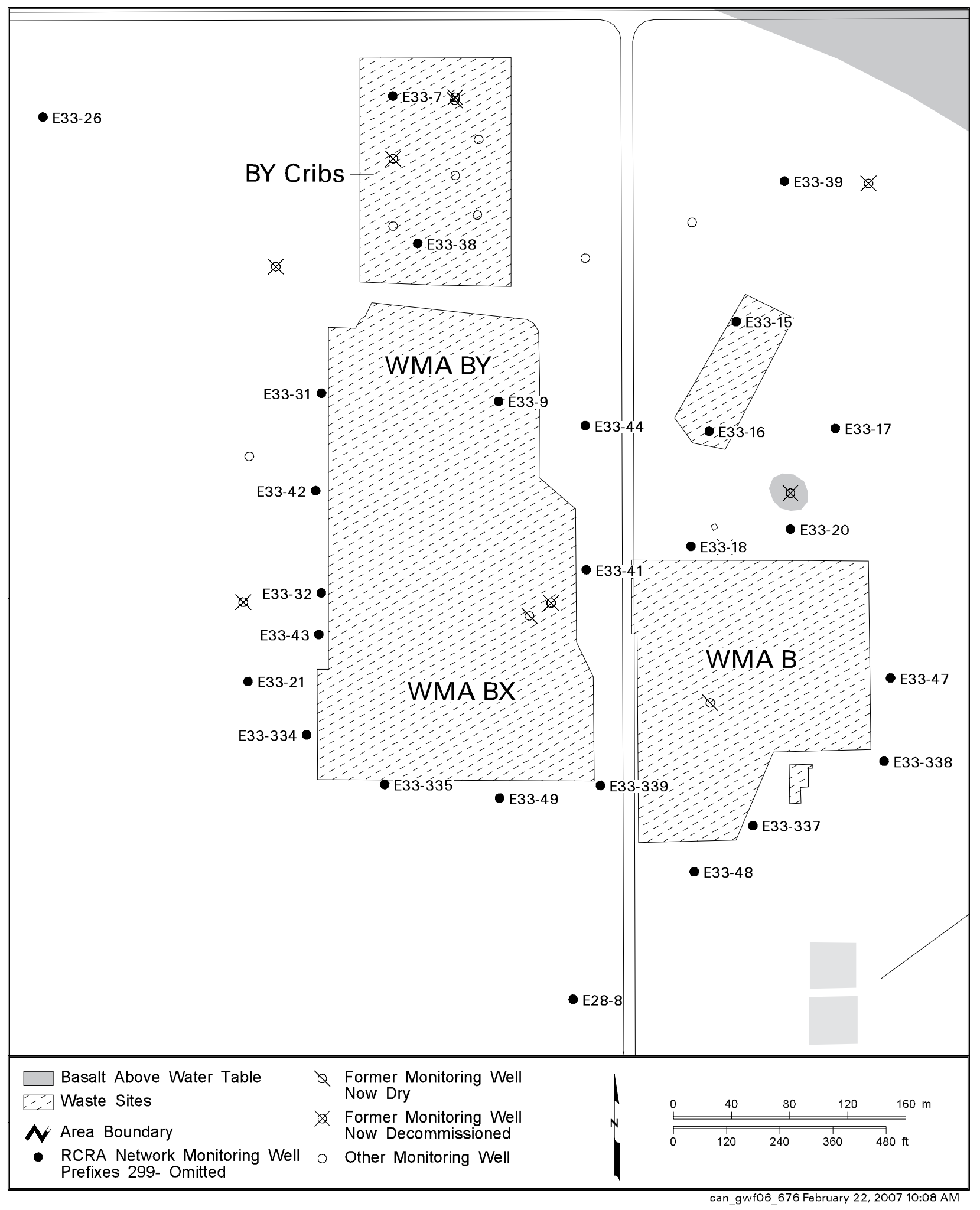

Figure B.16. Groundwater Monitoring Wells at Waste Management Area B-BX-BY 


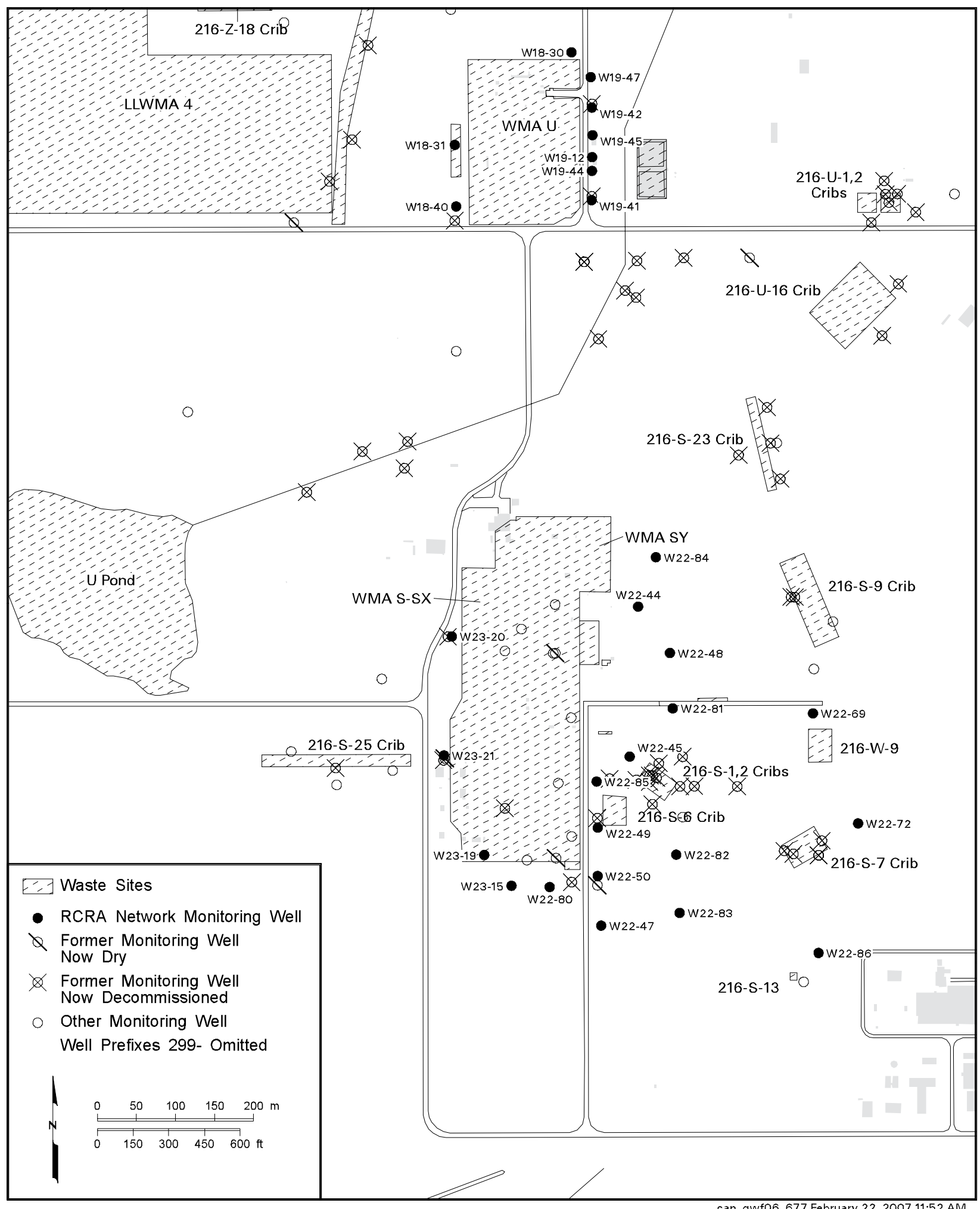

Figure B.17. Groundwater Monitoring Wells at Waste Management Areas S-SX and U 


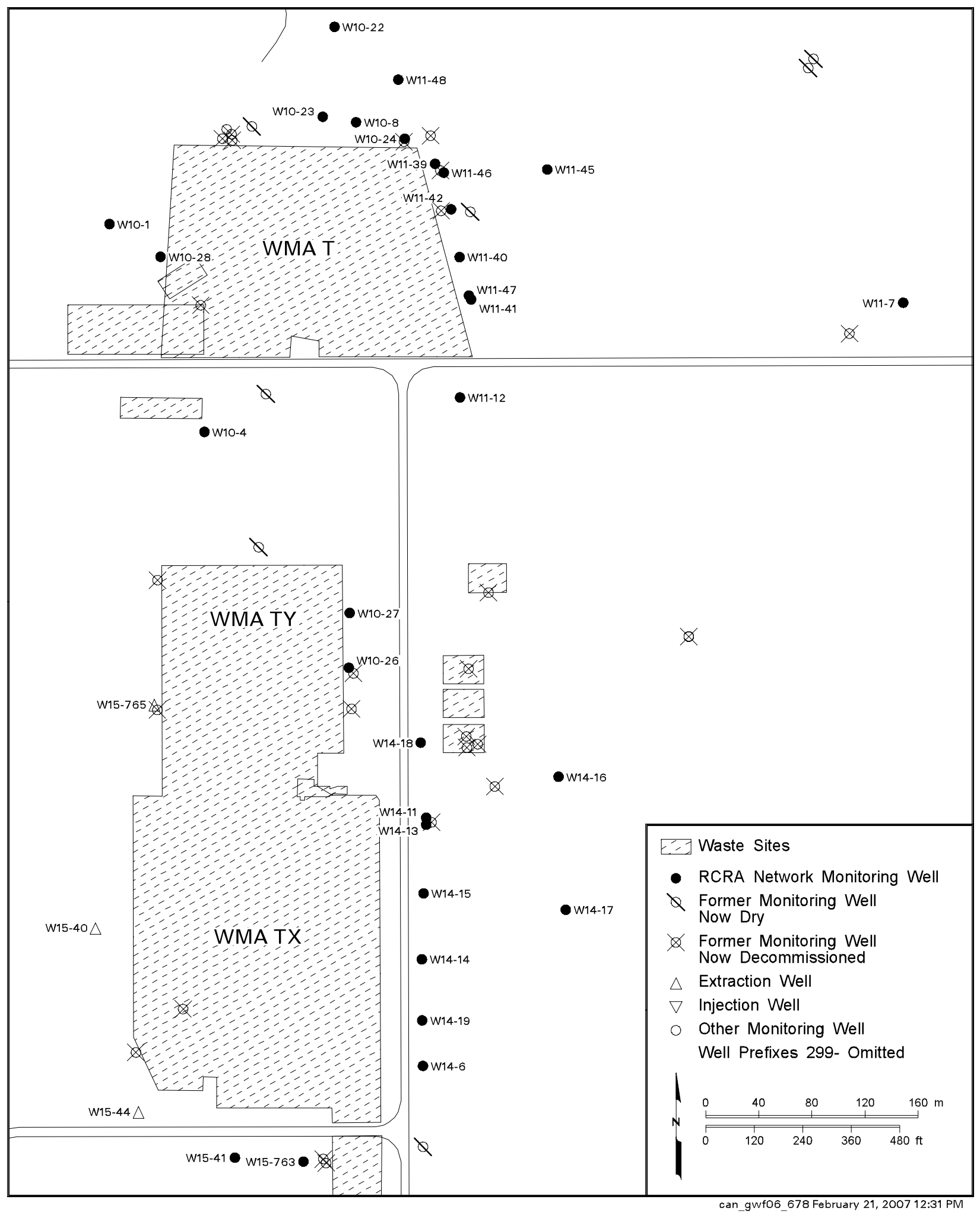

Figure B.18. Groundwater Monitoring Wells at Waste Management Areas T and TX-TY 


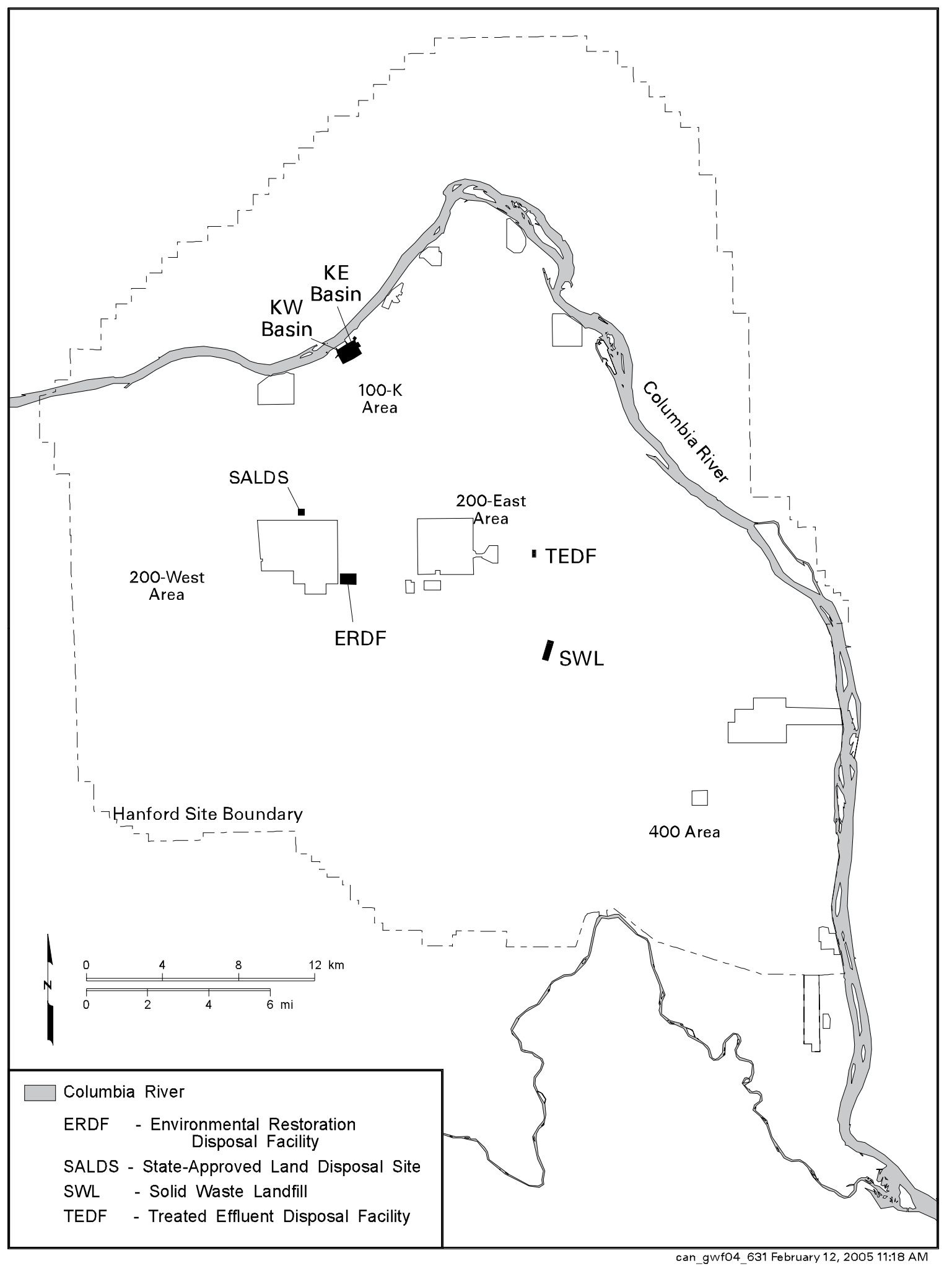

Figure B.19. Regulated Units (other than RCRA units) on the Hanford Site Requiring Groundwater Monitoring 


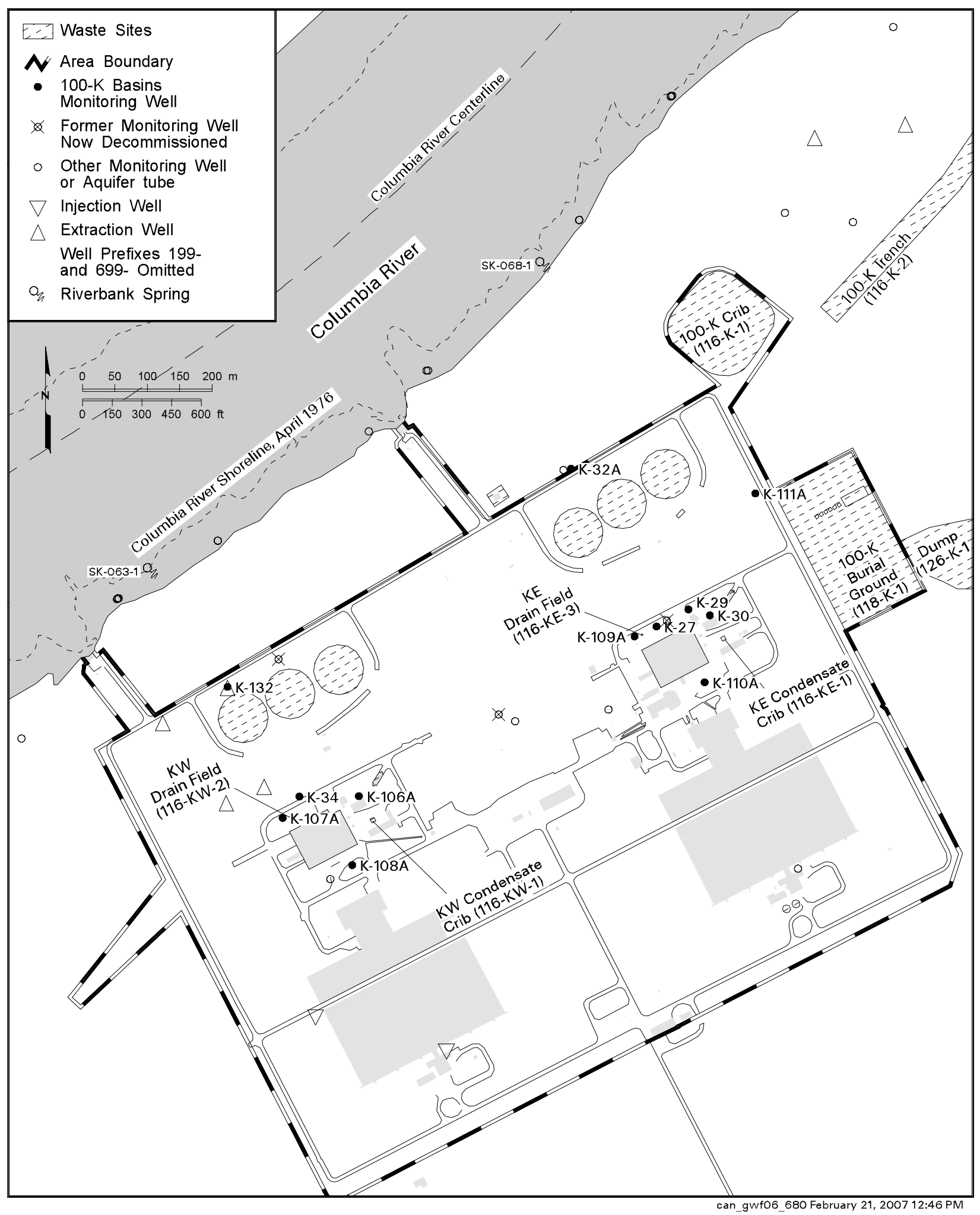

Figure B.20. Groundwater Monitoring Wells at 100-K Basins 


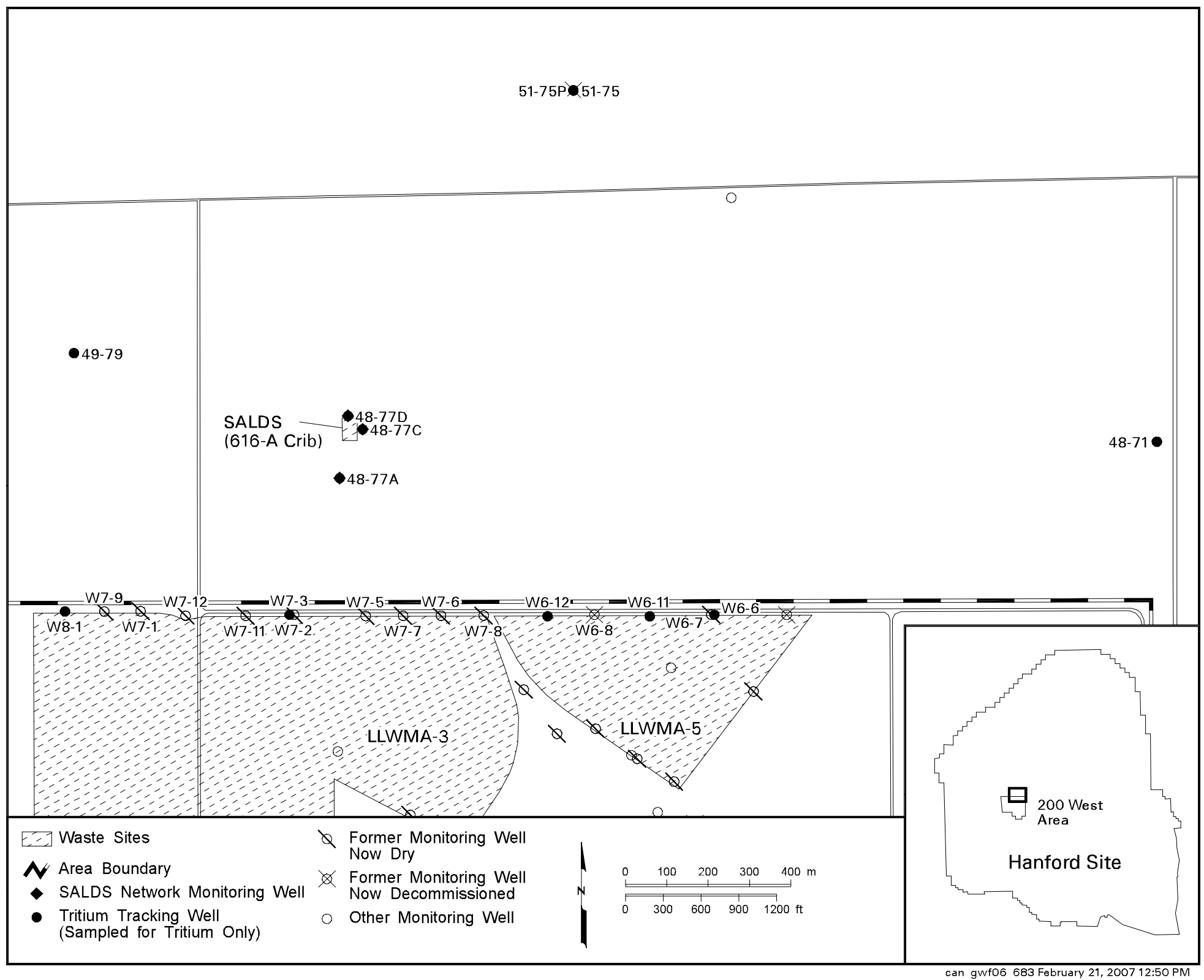

Figure B.21. Groundwater Monitoring Wells at State-Approved Land Disposal Site 


\section{Appendix C}

\section{Quality Assurance and Quality Control}




\section{Contents}

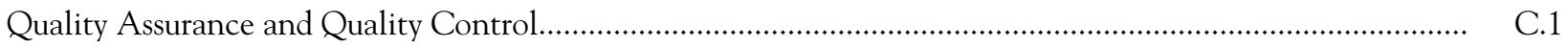

C.1 Sample Collection and Analysis ............................................................................................... C.1

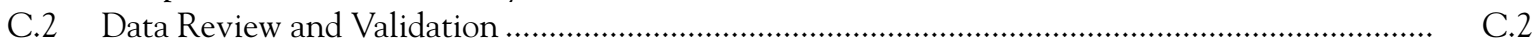

C.2.1 Requests for Data Review ……….................................................................................. C.3

C.3 Data Completeness......................................................................................................... C.

C.4 Field Quality Control Samples.................................................................................................... C.3

C.4.1 Long-Term Monitoring ............................................................................................ C. C.4

C.4.2 Interim Action Monitoring ……………...................................................................... C. C.

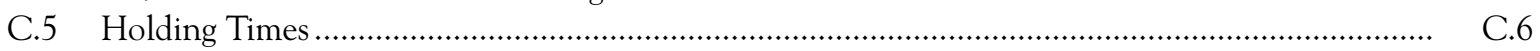

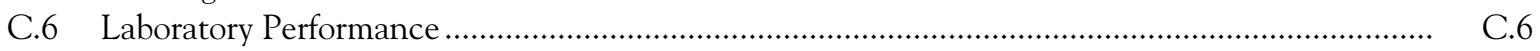

C.6.1 National Performance Evaluation Studies …….............................................................. C.7

C.6.1.1 Water Pollution Studies ................................................................................ C.7

C.6.1.2 DOE Mixed Analyte Performance Evaluation Programs................................... C. C.7

C.6.1.3 InterLaB RadCheM and Multi-Media Radiochemistry Proficiency Testing Program Studies ........................................................................... C. C.

C.6.2 Double-Blind Standard Evaluation ………..................................................................... C. 8

C.6.3 Aluminum Method Comparison ................................................................................. C.10

C.6.4 Laboratory Internal QA/QC Programs........................................................................... C.10

C.6.4.1 Issue Resolution ................................................................................................. C.11

C.6.4.2 Laboratory Audits......................................................................................... C.11

C.6.4.3 Laboratory Assessments........................................................................... C.12

C.7 Limit of Detection, Limit of Quantitation, and Method Detection Limit .................................. C.12

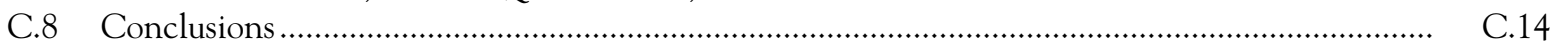

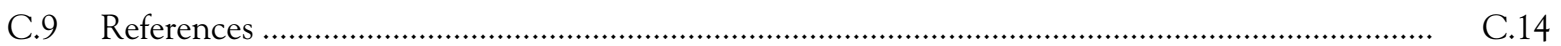

\section{Tables}

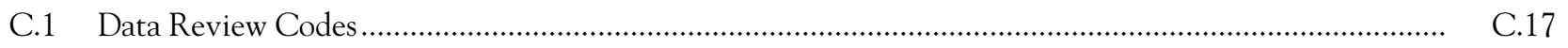

C.2 Requests for Data Review for FY 2006 Data...................................................................................... C.17

C.3 Long-Term Monitoring Full Trip Blanks Exceeding Quality Control Limits ......................................... C.18

C.4 Long-Term Monitoring Field Transfer Blanks Exceeding Quality Control Limits ................................... C. C.19

C.5 Long-Term Monitoring Equipment Blanks Exceeding Quality Control Limits ...................................... C.19

C.6 Long-Term Monitoring Field Duplicates Exceeding Quality Control Limits .......................................... C.20

C.7 Interim Action Monitoring Field Blank Detections ........................................................................... C.21

C.8 Interim Action Monitoring Field Duplicates Exceeding Quality Control Limits .................................... C.. C.21

C.9 Interim Action Monitoring Interlaboratory Splits Exceeding Quality Control Limits........................... C.22

C.10 Hanford Groundwater Monitoring Project Maximum Recommended Holding Times............................. C.22 
C.11 Summary of Severn Trent St. Louis Water Pollution Performance Evaluation Studies

C. 23

C.12 Summary of Lionville Laboratory Water Supply Performance Evaluation Studies .....

C. 23

C.13 Summary of Severn Trent Interlaboratory Performance, FY 2006.

C. 24

C.14 Summary of Eberline Services and Lionville Laboratory Interlaboratory Performance, FY 2006

C. 25

C.15 Summary of Severn Trent Laboratories Double-Blind Spike Determinations.

C.26

C.16 Summary of Lionville Laboratory, Inc. and Eberline Services Double-Blind Spike Determinations........

C.27

C.17 Volatile Organic Compound Interlaboratory Comparison Study

C.27

C.18 Percentage of Out-of-Limit Quality Control Results by Category, Severn Trent Laboratories................ C.28

C.19 Method Blank Results, Severn Trent Laboratories

C.29

C.20 Laboratory Control Samples, Severn Trent Laboratories.....

C.30

C.21 Matrix Spikes and Matrix Spike Duplicates, Severn Trent Laboratories.........

C.32

C.22 Matrix Duplicates, Severn Trent Laboratories

C.35

C.23 Summary of Issue Resolution Forms Received from Severn Trent Laboratories for FY 2006.

C.38

C.24 Results of DOECAP Audits.......

C.25 Summary of Analytical Laboratory Detection/Quantitation Limits Determined from Field Blanks Data, Severn Trent Laboratories......

C.26 Summary of Detection and Quantitation Limits, Severn Trent Laboratory

C. 42 


\section{Appendix C}

\section{Quality Assurance and Quality Control}

\section{J. Thompson}

This appendix presents fiscal year (FY) 2006 quality assurance/quality control (QA/QC) information for longterm and interim action groundwater monitoring at the Hanford Site. The phrase "long-term monitoring" refers to monitoring performed to meet the requirements of the Resource Conservation and Recovery Act (RCRA) and the Atomic Energy Act (AEA). Long-term monitoring also includes monitoring performed at Comprehensive Environmental Response, Compensation, and Liability Act (CERCLA) sites with no active groundwater remediation. Pacific Northwest National Laboratory (PNNL) manages long-term monitoring via the Groundwater Performance Assessment Project (groundwater project). Interim action monitoring encompasses monitoring at sites with active groundwater remediation under CERCLA. Fluor Hanford, Inc. provided oversight for interim action groundwater monitoring during FY 2006. For both categories of groundwater monitoring, PNNL managed sample scheduling, sample collection, analytical work, and entry of associated information into the Hanford Environmental Information System (HEIS) database (HEIS 1994).

The QA/QC practices used by the groundwater project assess and enhance the reliability and validity of field and laboratory measurements conducted to support these programs. Accuracy, precision, and detection are the primary parameters used to assess data quality (Mitchell et al. 1985). Representativeness, completeness, and comparability may also be evaluated for overall quality. These parameters are evaluated through laboratory QC checks (e.g., matrix spikes, laboratory blanks), replicate sampling and analysis, analysis of blind standards and blanks, and interlaboratory comparisons. Acceptance criteria have been established for each of these parameters. When a parameter is outside the criteria, corrective actions are taken to prevent a future occurrence.

The QA/QC practices for RCRA samples are based on guidance from the U.S. Environmental Protection Agency (EPA) (OSWER-9950.1 and SW-846). U.S. Department of Energy (DOE) Orders and internal requirements provide the guidance for the collection and analysis of samples for other long-term monitoring. The QA/QC practices for the groundwater project are described in the project-specific QA plan (PNNL-15014). Guidance for interim action monitoring QA/QC practices is provided in project-specific documents (e.g., DOE/RL-90-08; DOE/RL-91-03; DOE/RL-91-46; DOE/RL-92-76; DOE/RL-96-07; DOE/RL-96-90; DOE/RL-97-36; DOE/RL-2002-10; DOE/RL-2002-17). A glossary of QA/QC terms is provided in PNNL-13080. Additional information about the QA/QC program and FY 2006 data (e.g., results of individual QC samples and/or associated groundwater samples) is available on request.

\section{C.1 Sample Collection and Analysis}

\section{J. Thompson and D. L. Stewart}

Duratek Federal Services, Inc. conducted groundwater sampling for FY 2006. Their tasks included bottle preparation, sample set coordination, field measurements, sample collection, sample shipping, well pumping, and coordination of purgewater containment and disposal. Duratek's statement of work ${ }^{(a)}$ defines quality requirements for sampling activities. Groundwater project staff review all sampling procedures before the procedures are implemented.

Groundwater project staff periodically reviewed sample collection activities performed by nuclear chemical operators from Fluor Hanford, Inc. under the supervision of Duratek Federal Services, Inc. The purpose of the surveillance was to ensure that samples were collected and submitted to the laboratories in accordance with high-quality standards. Five surveillances were conducted in the following areas: sample packaging, shipping, and storage; measurement of groundwater levels; sample collection (two events); and training and associated documentation for the sampling personnel. Minor procedural deviations were identified. Corrective actions for all of these surveillances were received, but corrective

(a) SOW-409744-A-B3. 2001. Statement of Work between Pacific Northwest National Laboratory and Duratek Federal Services, Inc., Richland, Washington. 
actions were not verified because the work scope performed by Duratek Federal Services, Inc. was transferred to Fluor Hanford, Inc. at the direction of the DOE. All surveillances have been closed under the PNNL contract with Duratek Federal Services, Inc. as a result of this transition.

During FY 2006, Severn Trent Laboratories, Incorporated, St. Louis, Missouri (STL St. Louis) performed most of the routine analyses of Hanford groundwater samples for hazardous and non-hazardous chemicals. Lionville Laboratory, Incorporated, Lionville, Pennsylvania (Lionville Laboratory), served as a secondary laboratory for chemical analyses of split samples and blind standards. Severn Trent Laboratories, Incorporated, Knoxville, Tennessee (STL Knoxville), performed dioxin analyses. A limited number of hexavalent chromium and volatile organic analyses were performed by the PNNL Sigma V analytical laboratory and by Fluor Hanford, Inc. at the Waste Sampling and Characterization Facility (WSCF) and a mobile laboratory.

Severn Trent Laboratories, Incorporated, Richland, Washington (STL Richland) performed the majority of radiological analyses on Hanford groundwater samples. Eberline Services, Richmond, California, also analyzed samples for radiological constituents.

Standard methods from EPA and American Society for Testing and Materials (ASTM) were used for the analysis of chemical constituents. Methods employed for radiological constituents were developed by the analyzing laboratories and are recognized as acceptable within the radiochemical industry. Descriptions of the analytical methods used are provided in PNNL-13080.

\section{C.2 Data Review and Validation}

\section{J. Hartman, H. Hampt, and C. J. Thompson}

Groundwater project staff review and validate groundwater data according to an established procedure. Validation produces an electronic data set that is useable by the groundwater project and others, with suspect or erroneous data corrected or flagged. The validation process includes the following activities:

- Review of sampling documents and analytical data verification.

- Quality control evaluation.

- Project scientists' evaluation.

- Statistical evaluation.

- Resolution of data issues that arose during the evaluation.

Sampling documents include the groundwater sampling record, chain-of-custody forms, field logbook pages, and other paperwork associated with sampling and shipping. Project staff review these forms to determine if the documents are filled out completely, signed appropriately, and legible. Staff also verify that analytical data from the laboratories are complete and reported correctly. Moreover, staff review laboratory documents to check the condition of the samples upon receipt at the laboratory and determine if problems arose during analysis that may have affected the data.

A quarterly evaluation of $\mathrm{QC}$ data is conducted as part of the validation process. Groundwater project staff assess the laboratories' internal QC practices and submit field QC samples and blind standards to the laboratories on a regular basis. QC results are then summarized for project scientists, DOE, and other data users.

Data management staff generate a series of routine data reports that project scientists review. Among these are biweekly data reports, which are generated twice each month and include analytical data that were loaded into the HEIS database since the previous reporting period. The tables are organized by groundwater interest area, RCRA site, or special project (e.g., confined aquifer data). As soon as practical after receiving a report, the project scientists review the data, typically by viewing trend plots, to determine (a) if there are significant changes in contaminant concentrations or distribution and (b) if there are data points that appear erroneous.

Project scientists also review quarterly compilations of the data. The quarterly review provides a method for project staff to check whether there were problems with sampling, all requested analyses were received, and the data seem to represent actual groundwater quality. Unlike the biweekly reports, the quarterly reports usually include a full data set (i.e., all the data from the wells sampled during the previous quarter have been received and loaded into HEIS). This review also includes water-level data, preliminary maps of selected analytical data, and a partial listing of sampling 
comments. When specific questions arise regarding field measurements, analytical results, dates of analysis or sampling, or sample or well numbers, the project scientist requests a formal data review. The process for data reviews is described in Section C.2.1.

\section{C.2.1 Requests for Data Review}

Requests for Data Reviews (RDRs) are the formal mechanism used by the groundwater project to resolve specific issues with data that appear to have problems. When potential anomalies are encountered during a review of analytical data or water-level measurements, the project scientist reviewing the data will initiate an RDR. Depending upon the type of data issue, project staff will then do some or all of the following: request a laboratory recheck, recount, or reanalysis, review hard copy laboratory data, review sampling documents for data-entry errors or other problems, and/or flag the affected data with one of the review codes described in Table C.1.

When a laboratory re-analysis or recount is requested, the laboratory re-analyzes or recounts the original sample and reports the new results. If there is a discrepancy between the original and new results, groundwater staff will determine which results appear to be more representative and assign an appropriate review code to the results that are loaded into HEIS. Laboratory rechecks involve an internal laboratory review of the data. When discrepancies are discovered by the laboratory, the data are re-reported. The re-reported data are loaded into HEIS and flagged appropriately. A review of the sampling documents and/or the hard copy data from the laboratory can sometimes provide an explanation for unusual results (e.g., data entry errors or swapped samples in the field).

RDRs are most commonly resolved by assigning $\mathrm{Y}, \mathrm{G}$, or R review codes to the data in HEIS; however, all of the review codes help define limitations on the data. If a review determines that the result is valid, the result is flagged with a $\mathrm{G}$. If there is clear, documented evidence that a result is erroneous, the result is flagged with an R. The Y code is used when a review did not show if a result was valid or invalid, but the result appears suspect. Data flagged with a $\mathrm{Y}$ or $\mathrm{R}$ are typically excluded from statistical evaluations, maps, and other interpretations, but are not deleted from HEIS. Occasionally, an $\mathrm{RDR}$ is submitted on data that are not managed by the groundwater project (e.g., data associated with active remediation projects). In those cases, the data owner is notified, but no further action is taken by the groundwater project.

Table C.2 lists the number of analytical and water-level results that were flagged during FY 2006 as a result of the RDR process. As of December 12, 2006, the resolution of a number of RDRs is pending, and additional RDRs may yet be filed on FY 2006 data. RDRs have been filed on 611 out of 59,679 analytical results ( 1\%). Similarly, 2.8\% (86 out of 3,060) water-level results were associated with RDRs in FY 2006.

\section{C.3 Data Completeness}

\section{H. Hampt and C. J. Thompson}

Data judged to be complete are data that are not suspect, rejected, associated with a missed holding time, out-oflimit field duplicate or field blank, or qualified to indicate laboratory blank contamination. During FY 2006, 93\% of the groundwater data (both long-term and interim action monitoring) were considered complete. The percentages of potentially invalid data were $1.8 \%$ for field QC problems, $0.6 \%$ for exceeded holding times, $0.2 \%$ for rejected results, $0.2 \%$ for suspect values, and $4.1 \%$ for laboratory blank contamination. These values are similar to the percentages observed in FY 2005.

\section{C.4 Field Quality Control Samples}

\section{S. Sklarew, S. J. Trent, and C. J. Thompson}

Field QC samples include field duplicates, split samples, and three types of field blanks. The three types of field blanks are full trip, field transfer, and equipment blanks. Field duplicates are used to assess sampling and measurement precision. Split samples are used to confirm out-of-trend results and for interlaboratory comparisons. Field blanks provide an overall measure of contamination introduced during the sampling and analysis process. 


\section{C.4.1 Long-Term Monitoring (Groundwater Performance Assessment Project)}

The groundwater project's criteria for evaluating the analytical results of field QC samples are as follows:

- Field Duplicates - Results of field duplicates must have precision within 20\%, as measured by the relative percent difference. Only those field duplicates with at least one result greater than five times the method detection limit or minimum detectable activity are evaluated.

- Split Samples - Results must have a relative percent difference $<20 \%$. Only those results that are greater than five times the method detection limit or minimum detectable activity at both laboratories are evaluated.

- Field Blanks - For most chemical constituents, results above two times the method detection limit are identified as suspected contamination. However, for common laboratory contaminants such as acetone, methylene chloride, 2-butanone, toluene, and phthalate esters, the limit is five times the method detection limit. Results for metals are flagged if they exceed two times the method detection limit. For radiological data, blank results are flagged if they are greater than two times the total minimum detectable activity.

If a field blank does not meet the established criteria, it is assumed that there are potential problems with the data for all associated samples. For full-trip and field-transfer blanks, an associated sample is one that was collected on the same day and analyzed by the same method as a full-trip or field-transfer blank. For equipment blanks, an associated sample is one that has all of the following in common with an equipment blank:

- Collection date.

- Collection method/sampling equipment.

- Analysis method.

Data associated with out-of-limit field blanks are flagged with a $Q$ in the database to indicate a potential contamination problem. A $Q$ is also applied to both duplicate results when their precision exceeds the QC limits.

The percentages of acceptable field blank $(4,931 / 5,140=96 \%)$ and duplicate $(1,937 / 1,977=98 \%)$ results evaluated in FY 2006 were high, indicating little problem with contamination and good precision overall. No split samples were collected during the year.

Tables C.3 through C.6 summarize the field blank and field duplicate results that exceeded QC limits. To assist with their evaluation, the tables are divided into the following categories, where applicable: general chemistry parameters, ammonia and anions, metals, volatile organic compounds, semivolatile organic compounds, and radiological parameters. Constituents not listed in the tables had 100\% acceptable field blanks and/or field duplicates.

With the exception of semivolatile organic compounds, all classes of constituents had results that were flagged as potentially contaminated because of out-of-limit field blank results. A few constituents such as alkalinity, specific conductance, chloride, sulfate, barium, calcium, magnesium, and sodium had several quantifiable field blank results, but the concentrations were much lower than the levels of these constituents in almost all groundwater samples.

Compared to FY 2005, the number of elevated field blank results for total organic carbon increased (4\% to 11\%). The unacceptable results were within a factor of 3 of the QC limits. Laboratory blank results were all within limits for total organic carbon.

Relative to FY 2005, the number of field blank results for chloride that exceeded the QC limits increased significantly ( $16 \%$ to $54 \%)$, though the number for nitrogen in nitrate decreased (9\% to $2 \%$ ). The number of elevated laboratory blank results for chloride also increased this year. However, as noted above, since the chloride concentrations in the blanks were lower than those in most groundwater samples, the overall impact on the data is believed to be minor.

Twenty-seven field blank results for metals exceeded the QC limits, which is less than the number (44) from last year. Most of the unacceptable results were within a factor of 3 of the detection limits. Relative to FY 2005, the number of elevated field blank results for zinc decreased this year (31\% to $13 \%)$ and that for magnesium increased (0\% to $7 \%$ ). Several of the metals (aluminum, barium, beryllium, calcium, sodium, and zinc) with out-of-limit field blank results had one or more comparable method blank results, suggesting that some of the elevated field blank values were caused by false detections or laboratory contamination. 
Concentrations of seven volatile organic compounds exceeded the QC limits in one or more field blanks. Methylene chloride was the predominant volatile contaminant, accounting for $47 \%$ of the out-of-limit results. Laboratory contamination is the suspected source of this common contaminant, because similar concentrations were also measured in several method blanks. Three field blanks, however, had concentrations that were more than five times greater than that of the highest laboratory blank. The number of method blanks that were out of limits for acetone decreased significantly this year compared to FY 2005 (11\% to 1\%). Trace levels of several other volatile organic compounds also were measured in field blanks (Tables C.3 and C.4). In general, the frequencies of detection for these compounds were low $(<8 \%)$, with the exception of those constituents that were analyzed in fewer than three field blanks. The overall impact on the data is believed to be minor.

Gross alpha, gross beta, tritium, and uranium were the only radiological constituents with out-of-limit field blank results. Although their field blank concentrations were low, they were greater than levels of these constituents in some of the associated groundwater samples. Gross beta and uranium were also measured in one or more laboratory method blanks at concentrations similar to the field blank values.

Duplicate results were flagged for all constituent classes (Table C.6). Overall, the relative number of flagged duplicate results was very low (2\%), but the percentages of unacceptable results were high for several constituents based on the number of duplicates that met the evaluation criteria. Most of the associated samples in the radiological parameters category were unfiltered; thus, suspended solids in heterogeneous sample fractions may have caused some of the discrepancies in the results. The majority of the out-of-limit duplicate results appear to be anomalous instances of poor precision based on other QC indicators such as the results from the laboratory duplicates. In several cases, the laboratory was asked to re-analyze or investigate duplicate results with a very high relative percent difference, but the checks did not reveal the source of the problem. Especially poor agreement was observed between pairs of results for alkalinity $(44,000$ and 148,000 $\mu \mathrm{g} / \mathrm{L}$ ), nitrogen in ammonia (non-detect and $69.2 \mu \mathrm{g} / \mathrm{L}$ ), arsenic $(1 \mathrm{and} 4.4 \mu \mathrm{g} / \mathrm{L}$ ), and cis-1,2-dichloroethene (non-detect and $140 \mu \mathrm{g} / \mathrm{L}$ ). Swapped samples or procedural deviations at the laboratory may have caused the unmatched results.

\section{C.4.2 Interim Action Monitoring}

Staff collected samples in accordance with approved procedures. In general, field QC samples consisted of field duplicates, splits, equipment blanks, and trip blanks.

Field QC data were examined to monitor laboratory operations and to identify potential problem areas where improvements were necessary. Evaluation criteria were essentially the same as those used for the long-term monitoring program identified in Section C.4.1.

For field blank samples, 91\% of all reviewed results were returned as non-detected, which is the same as the FY 2005 result. Evaluation of field blank sample results showed no evidence of unexpected or excessive contamination of blanks in the field. Blank detects are summarized in Table C.7. This year, metals and anions are the most common blank contaminants, representing over $80 \%$ of the detected blank results. The common metal contaminants include aluminum, calcium, and zinc. Based on analysis batch quality control results, it appears that most of the metal contamination was introduced during the sample analysis at the laboratory. Zinc and aluminum contamination introduced at the laboratory may have biased the results for these constituents in groundwater samples. The calcium contamination introduced at the laboratory has little impact on groundwater sample analysis results for calcium because the level of contamination is minimal when compared to the average concentration of calcium in the groundwater.

The common anion contaminants include chloride and nitrate. Similar to the metals, chloride contamination appears to have been introduced during sample analysis. The contamination introduced at the laboratory has little impact on groundwater sample analysis results for chloride because the level of contamination is minimal when compared to the average concentration of chloride in the groundwater. The nitrate contamination appears to have originated during the sample collection process because there is no indication of significant contamination in the analytical batch quality control results from the laboratory. The contamination introduced during sampling has little impact on groundwater sample analysis results for nitrate because the level of contamination is minimal when compared to the average concentration of nitrate in the groundwater.

Low levels of methylene chloride were detected in all field blanks and are most likely associated with contamination introduced during analysis of the samples. Methylene chloride is a common laboratory organic contaminant that is routinely detected in blanks. 
Field duplicate results showed $6 \%$ exceeding the criteria used for evaluation. This is significantly better than the result for FY 2005 (15\% exceeded criteria). Field duplicate evaluations are summarized in Table C.8. Most of the exceedances $(69 \%)$ are associated with duplicate results for anion and metal constituents. A significant change from last year is the improvement in the radiochemical analysis duplicate results. This year, no radiochemical analysis duplicates exceeded the evaluation criteria. In general, field duplicate QC issues are minimal and do not indicate significant laboratory or sample collection problems.

Approximately $8 \%$ of split sample results were outside the acceptance limits. This is a slight improvement relative to the FY 2005 result. Table C.9 summarizes the out-of-limit results. Similar to last year, the failure rate for the tritium sample splits is among the highest for all monitored constituents. Of the six split sample pairs collected for tritium analysis, the relative percent difference for three pairs fell outside the acceptance limit. The reason for this discrepancy is not readily apparent. Field analytical and laboratory split samples for both hexavalent chromium and sulfate showed the most frequent exceedances of the QC criteria. In most cases, the differences in analyte concentrations are probably associated with differences in analytical protocol and methods between the laboratory and the field test kits. The relative number of field analytical and laboratory split sample pairs exceeding the QC criteria is similar to the FY 2005 result.

It should be noted that the criteria used to evaluate split samples are likely more restrictive than necessary because they are based on similar criteria for laboratory replicate evaluation (i.e., analysis of multiple aliquots from the same sample container by the same laboratory in the same analytical batch). Evaluation of the split sample data show no significant quality problems exist with either the primary or split laboratories.

Overall, field QC results appear to be good. The evaluation indicates no significant issues between procedures and analyses performed by the laboratories providing services to Fluor Hanford, Inc. The general performance for FY 2006 is similar to or better than the previous year.

\section{C.5 Holding Times}

\section{H. Hampt and C. J. Thompson}

Holding time is the elapsed time period between sample collection and analysis. Samples should be analyzed within recommended holding times to minimize the possibility of changes in constituent concentrations caused by volatilization, decomposition, or other chemical alterations. Samples are also refrigerated to slow potential chemical reactions within the sample matrix. Maximum recommended holding times for constituents frequently analyzed for the groundwater project are listed in Table C.10. Radiological constituents do not have recommended maximum holding times because these constituents are not typically lost under ambient temperatures when appropriate preservatives are used. Results of radionuclide analysis are corrected for decay from sampling date to analysis date.

During FY 2006, recommended holding times were exceeded for 388 out of 7,945 (4.9\%) non-radiological sample analysis requests (both long-term and interim action monitoring). A sample analysis request is defined as a sample that is submitted for analysis by a particular analytical method. In general, the missed holding times should not have a significant impact on the data. Results for samples with missed holding times are flagged with an $\mathrm{H}$ in the database. STL St. Louis exceeded the holding times for 356 out of 7,133 (5\%) sample analysis requests, an increase from FY 2005 (2.8\%). The constituents with the most missed holding times were alkalinity (23 samples), anions by EPA Method 300.0 (230 samples), total organic carbon (54 samples), and total organic halides (16 samples). STL Richland exceeded holding times for 4 out of 62 hexavalent chromium analyses, but all 49 of the laboratory's coliform analyses were performed within the recommended 24-hour holding time. Lionville Laboratory missed holding times for 6 out of 103 anion sample analyses. PNNL analyzed 309 samples onsite for hexavalent chromium; 21 analyses missed holding time. Fluor Hanford, Inc. analyzed 338 samples onsite for hexavalent chromium; one of the measurements was performed after the holding time had expired.

\section{C.6 Laboratory Performance}

\section{S. Sklarew, C. J. Thompson, and D. L. Stewart}

Laboratory performance is measured by several indicators, including national performance evaluation studies, double-blind standard analyses, laboratory audits, and internal laboratory QA/QC programs. This section provides a 
detailed discussion of the performance indicators for STL St. Louis and STL Richland. Brief summaries of performance measures for Lionville Laboratory and Eberline Services also are presented throughout this section. The majority of the laboratories' results were within the acceptance limits indicating good performance overall.

\section{C.6.1 National Performance Evaluation Studies}

During FY 2006, Environmental Resources Associates and DOE conducted national studies to evaluate laboratory performance for chemical and radiological constituents. STL St. Louis and Lionville Laboratory participated in the EPA sanctioned Water Pollution and Water Supply Performance Evaluation studies conducted by Environmental Resources Associates. STL Richland and Eberline participated in the Environmental Resources Associates' InterLaB RadCheM Proficiency Testing Program. Eberline participated in the Environmental Resources Associates' Multi-Media Radiochemistry Proficiency Testing. All four laboratories took part in DOE's Mixed Analyte Performance Evaluation Program. Results of those studies related to groundwater monitoring at the Hanford Site are described in this section.

\section{C.6.1.1 Water Pollution Studies}

The purpose of water pollution studies is to evaluate the performance of laboratories in analyzing selected organic and inorganic compounds. An accredited agency such as Environmental Resource Associates distributes standard water samples to participating laboratories. These samples contain specific organic and inorganic analytes at concentrations unknown to the participating laboratories. After analysis, the laboratories submit results to the accredited agency, which uses regression equations to determine acceptance and warning limits for the study participants. The results of these studies, expressed in this report as a percentage of the results that the accredited agency found acceptable, independently verify the level of laboratory performance.

For the two water pollution studies (ERA WP-132 and 138) and one QuikResponse study (090806C) in which STL St. Louis participated this year, the percentage of results within acceptance limits submitted to the groundwater project ranged from $95 \%$ to $100 \%$ (Table C.11). Twenty-two different constituents had unacceptable results, but only fluoride and volatile solids were out of limits in both studies in which they were measured. Several nutrients, total organic halides, and several volatile organic compounds were out of limits in one out of two studies. The laboratory provided information about possible causes for some of the unacceptable results and suggested corrective actions where appropriate. The constituents that were out of limits in more than one study last year, orthophosphate as phosphorus and oil and grease (gravimetric), were out of limits in the first study but within limits in the second study this year. Constituents that were out of limits in only one study during FY 2005 were within limits in FY 2006, except for ammonia as nitrogen, total Kjeldahl nitrogen, total phosphorus as phosphorus, hexavalent chromium, and iron. Analyses for total Kjeldahl nitrogen and total phosphorus as phosphorus are not performed on Hanford groundwater samples, so these unacceptable results should not have a significant impact on the interpretation of Hanford groundwater data.

Lionville Laboratory submitted results to the groundwater project for one water supply study this year (ERA WS-109). Ninety-six percent of Lionville's results were within the acceptance limits (Table C.12). The unacceptable results for three volatile organic compounds would not have a significant impact on the interpretation of Hanford groundwater data since Lionville does not analyze volatile organic compounds for the Hanford groundwater program.

\section{C.6.1.2 DOE Mixed Analyte Performance Evaluation Programs}

DOE's Mixed Analyte Performance Evaluation Program examines laboratory performance in the analysis of soil and water samples containing metals, volatile and semivolatile organic compounds, and radionuclides. This report considers only water samples. The program is conducted at the Radiological and Environmental Sciences Laboratory in Idaho Falls, Idaho. DOE evaluates the accuracy of the Mixed Analyte Performance Evaluation Program results for radiological and inorganic samples by determining if they fall within a 30\% bias of the reference value.

Two studies were available for FY 2006 (MAPEP-06-MaW15\&OrW15\&GrW15 and MAPEP-06MaW16\&OrW16\&GrW16). All results for STL St. Louis were acceptable, though three results were acceptable with warning. One result was unacceptable for STL Richland: nickel-63; two other results were acceptable with warning (Table C.13). STL Richland had unacceptable results for nickel-63 in the previous MAPEP study as well. Two results were unacceptable for Lionville Laboratory: cadmium and copper; one other result was acceptable with warning. One gross beta result was unacceptable for Eberline Services. (Table C.14). 


\section{C.6.1.3 InterLaB RadCheM and Multi-Media Radiochemistry Proficiency Testing Program Studies}

The purpose of the InterLaB RadCheM and Multi-Media Radiochemistry Proficiency Testing Programs, conducted by Environmental Resources Associates, is to evaluate the performance of laboratories in analyzing selected radionuclides. The InterLaB RadCheM program provides blind standards that contain specific amounts of one or more radionuclides in a water matrix to participating laboratories. Environmental Resources Associates standards were prepared for the following radionuclides/parameters: barium-133, cesium-134, cesium-137, cobalt-60, gross alpha, gross beta, iodine-131, radium-226, radium-228, strontium-89, strontium-90, tritium, uranium (natural), uranium (natural) mass, and zinc-65. After sample analysis, the results were forwarded to Environmental Resources Associates for comparison with known values and with results from other laboratories. Environmental Resources Associates bases its control limits on the EPA's National Standards for Water Proficiency Testing Studies Criteria Document (NERL-Ci-0045).

In the two studies in which STL Richland participated this year (RAD-64 and 65), a total of 29 constituents were analyzed. Two results were unacceptable: cesium-134 and radium-226 (Table C.13).

Eberline Services participated in two studies this year (RAD-64 and 66); 14 constituents were analyzed. All of the results were acceptable, although gross alpha was not evaluated in one sample (Table C.14).

The Multi-Media Radiochemistry Proficiency Testing Program provides blind standards that contain specific amounts of one or more radionuclides in water, soil, vegetation, and air filter samples to participating laboratories. This report considers only water samples. Environmental Resources Associates standards were prepared for the following radionuclides/parameters in water: americium-241, cesium-134, cesium-137, cobalt-60, gross alpha, gross beta, iron-55, plutonium-238, plutonium-239, strontium-90, uranium-234, uranium-238, uranium (natural), and uranium (natural) mass. After sample analysis, the results were forwarded to Environmental Resources Associates for comparison with known values and with results from other laboratories. Environmental Resources Associates bases its control limits on a DOE report (EML-564).

In the one study in which Eberline Services participated this year (MRAD-003), 15 constituents were analyzed. Four results were unacceptable: gross alpha, gross beta, plutonium-238, and plutonium-239 (Table C.14). Since Eberline did not perform many analyses for these constituents during FY 2006, these results should not have a significant impact on the interpretation of Hanford groundwater data.

\section{C.6.2 Double-Blind Standard Evaluation}

During FY 2006, the groundwater project forwarded blind QC standards to STL Richland and St. Louis, Lionville Laboratory, Eberline Services, and two onsite laboratories operated by Fluor Hanford, Inc.: the Waste Sample Characterization Facility and a mobile laboratory. Blind spiked standards were generally prepared in triplicate and submitted to the laboratories to check the accuracy and precision of analyses. For most constituents, the standards were prepared in a groundwater matrix from a background well. Standards for specific conductance were commercially prepared in deionized water. In all cases, the standards were submitted to the laboratories in double-blind fashion (i.e., the standards were disguised as regular groundwater samples). After analysis, the laboratory's results were compared with the spiked concentrations, and a set of control limits were used to determine if the data were acceptable. Generally, if a result was out of limits, the data were reviewed for errors. In situations where several results for the same method were unacceptable, the results were discussed with the laboratory, potential problems were investigated, and corrective actions were taken if appropriate.

Tables C.15 and C.16 list the number and types of most of the blind standards used in FY 2006 along with the control limits for each constituent. Additional blind standard results from a volatiles interlaboratory comparison study are summarized in Table C.17. Overall, $85 \%$ of the blind spike determinations were acceptable. This was slightly higher than the percentage from FY 2005 (83\%). A total of 34 results were out of limits for STL Richland and St. Louis. Total organic halides, carbon tetrachloride, chloroform, trichloroethene, gross alpha, and tritium were the constituents with out-of-limit results. Both the Waste Sample Characterization Facility and the mobile laboratory had two unacceptable results for carbon tetrachloride. The Waste Sample Characterization Facility also had out-of-limit results for chloroform (1) and trichloroethene (3). All of the results from Lionville Laboratory and Eberline Services were within the acceptance limits. 
Total organic carbon results were significantly improved compared to last year. All of the results from STL St. Louis and Lionville Laboratory were acceptable. In FY 2005, approximately half of the results from both laboratories were out of limits.

STL St. Louis had fifteen unacceptable results for total organic halides. All of the $1^{\text {st }}$ quarter results were within the QC limits. Beginning with the second quarter, many of the results exhibited a bias that varied with the spiked constituents. Most of the out-of-limit results for the phenolic standards were biased high (134\% to 189\% recoveries), while the volatile standards tended to have low recoveries (44\% to 69\%). The low bias in the latter results is attributed to volatilization or weak retention of the volatile compounds on the charcoal cartridges used in the analysis. In general, the reasons for the phenolic failures are unknown. Three of the high results are probably related to low spiking levels-the third quarter standards were spiked within a factor of 5 of the method detection limit. However, four of the high-biased results were associated with standards that had been spiked at quantifiable levels. Other QC indicators from STL such as the laboratory QC data and WP study results have demonstrated acceptable performance for the total organic halides method. Moreover, since relatively few $(\sim 1 \%)$ total organic halides results for regular groundwater samples were flagged as suspect during FY 2006, the problems with the blind standards are believed to be isolated.

Approximately one-third of STL St. Louis' results for volatile organic compounds were out of limits. Most of the associated recoveries were between $66 \%$ and $74 \%$. Six of the unacceptable results were from the first quarter, and the recoveries were very similar for all three of the spiked compounds (carbon tetrachloride, chloroform, and trichloroethene). A PNNL analysis of a split sample indicated that the standards had been spiked at the correct concentration. Consequently, the problem may have been caused by a procedural error at the laboratory. STL St. Louis also had two high-biased results for carbon tetrachloride during the third quarter. The laboratory performed much better on volatile organics during the fourth quarter; all 15 results were within the acceptance limits, as described next.

A laboratory intercomparison study that focused on volatile organic compounds was conducted in July 2006. The study was requested by Fluor Hanford, Inc. to evaluate the performance of the mobile laboratory relative to that of the WSCF and STL St. Louis. Previous monitoring data indicated that the mobile laboratory's results for carbon tetrachloride were often $\sim 30 \%$ higher than those from other laboratories. Most of the blind standards in this study were spiked with carbon tetrachloride only, although the lowest-concentration samples also contained chloroform and trichloroethene. Standards were submitted to the laboratories in triplicate, except for one group that was submitted to the mobile laboratory to investigate holding times. Table C.17 lists the standards' concentrations and the individual results from the three laboratories. Overall, the laboratories performed well; $84 \%$ of the results were within the $\pm 25 \%$ acceptance limits. All of STL St. Louis' results were acceptable. The WSCF had out-of-limit results for carbon tetrachloride (2), chloroform (1), and trichloroethene (3). All of the unacceptable results were for the standards spiked at the lowest concentrations. The mobile laboratory had two unacceptable results for carbon tetrachloride. The first of these was a non-detected result for a mid-level standard; presumably this was caused by over-dilution of the sample. A minor factor evaluated in this study was whether delays in analysis affect the mobile laboratory's results. This was evaluated with the highest-concentration standards containing carbon tetrachloride. The mobile laboratory was provided with seven of these samples, and the laboratory was asked to analyze four relatively quickly and to analyze the remaining samples near the end of the 14-day holding time. In general, the holding time did not appear to impact the results, although one of the samples analyzed on the fourteenth day had an unacceptably low recovery $(71 \%)$. A final observation from this study is that the mobile laboratory's results tended to be $\sim 10 \%$ to $30 \%$ lower than those from STL St. Louis and WSCF. This contradiction with previous data may be related to the use of new instrumentation and procedures at the mobile laboratory.

In general, STL Richland performed well on the analysis of radiological blind standards. Seven results were outside the QC limits. One of the results was for gross alpha. The low recovery (69\%) may have been caused by an isolated procedural error at the laboratory. The other unacceptable results were for tritium; reported values were approximately three times higher than the expected concentrations. The laboratory reanalyzed the samples and obtained nearly identical results. Additionally, STL Richland had tritium results that were similarly biased last year. However, since the laboratory's performance on tritium analyses in national performance evaluation programs has been acceptable (see Section C.6.1.2), it appears that the tritium standards may have been spiked at a higher concentration than anticipated. The concentration of the tritium spiking solution will be verified before the solution is used to prepare future blind standards.

Eberline Services analyzed 12 blind standards for gross beta, and all of the results were acceptable. 


\section{C.6.3 Aluminum Method Comparison}

Between January and March 2006, the groundwater project had STL St. Louis analyze 20 routine groundwater samples for aluminum by two methods to investigate potential false-detection problems that were discussed in last year's report (PNNL-15670, p. C.5). The techniques used were inductively coupled plasma-optical emission spectroscopy; (ICP-OES; Method 6010C; SW-846) and inductively coupled plasma-mass spectrometry (ICP-MS; Method 6020A; SW-846). Most of the historical data for aluminum had been generated using the less sensitive ICP-OES method. Samples were collected from wells across the Hanford Site. The method detection limits were $8 \mu \mathrm{g} / \mathrm{L}$ for ICP-MS and 17 and $95 \mu \mathrm{g} / \mathrm{L}$ for ICP-OES (the ICP-OES value increased during this study). In most cases, aluminum was not detected by either method. Six samples had detections by ICP-OES but not by ICP-MS. Detected concentrations ranged from 20 to $113 \mu \mathrm{g} / \mathrm{L}$. The ICP-MS results appear to be more reliable based on greater method sensitivity and the expectation that Hanford groundwater should not contain appreciable concentrations of dissolved aluminum. Thus, the results appear to confirm earlier suspicions about false-positive results obtained with the ICP-OES method. Future aluminum analyses will be performed by the ICP-MS method.

\section{C.6.4 Laboratory Internal QA/QC Programs}

STL Richland, STL St. Louis, Eberline Services, and Lionville Laboratory maintain internal QA/QC programs that generate data on analytical performance by analyzing method blanks, laboratory control samples, matrix spikes and matrix spike duplicates, matrix duplicates, and surrogates (see PNNL-13080 for definitions of these terms). This information provides a means to assess laboratory performance and the suitability of a method for a particular sample matrix. Laboratory QC data are not currently used for in-house validation of individual sample results unless the lab is experiencing unusual performance problems with an analytical method. An assessment of the laboratory QC data for FY 2006 is summarized in this section. STL data are discussed in detail first. Table C.18 provides a summary of the STL QC data by listing the percentage of QC results that were out of limits for each analyte category and QC parameter. Additional details are presented in Tables C.19 through C.22. Constituents not listed in these tables did not exceed STL's QC limits. A brief summary of Lionville Laboratory and Eberline Services data is presented at the end of the section.

Most of FY 2006 laboratory QC results were within acceptance limits, suggesting that the analyses were in control and reliable data were generated. Nevertheless, a number of parameters had unacceptable results.

Evaluation of results for method blanks was based on the frequency of detection above the blank QC limits. In general, these limits are two times the method detection limit for chemical constituents and two times the total propagated error for radiochemistry parameters. For common laboratory contaminants such as 2-butanone, acetone, methylene chloride, phthalate esters, and toluene, the QC limit is five times the method detection limit.

Table C.19 summarizes method blank results from STL Richland and St. Louis. The ammonia and anions and metal categories had the greatest percentages of method blank results exceeding the QC limits. The following parameters had $>10 \%$ of method blank results outside the QC limits: conductivity, bromide, chloride, phosphate, aluminum, bismuth, calcium, zinc, and methylene chloride. The out-of-limit method blank results for conductivity, calcium, and strontium (elemental) are not a significant problem because the values are typically much lower than the levels measured in Hanford Site groundwater. Similarly, the highest method blank results for chloride $(0.19 \mathrm{mg} / \mathrm{L})$, sulfate $(0.4 \mathrm{mg} / \mathrm{L})$, barium $(3 \mu \mathrm{g} / \mathrm{L})$, and sodium $(1,060 \mu \mathrm{g} / \mathrm{L})$ are typically lower than the respective levels measured in Hanford groundwater. The percentage of out-of-limit method blanks decreased significantly compared to FY 2005 for fluoride, nitrogen in nitrite, phosphate, arsenic, iron, zinc, acetone, bromomethane, and potassium-40, while the percentage increased for conductivity, chloride, and sulfate.

Table C.20 summarizes results for the laboratory control samples from STL Richland and St. Louis. Only semivolatile organic compounds had $>2 \%$ of their measurements outside the QC limits. The semivolatile organic compound category had a decreased percentage of results outside the QC limits compared to FY 2005 results (5\% to 2\%). Specific compounds with $>10 \%$ of out-of-limit laboratory control samples included phosphate, 1-butanol, acrolein, bromomethane, cyclohexanone, 2-(2,4-dichlorophenoxy)propionic acid, 2-chloronaphthalene, dicamba, heptachlor, hexachlorobutadiene, oil and grease, and uranium-235. In all of these cases except 1-butanol and bromomethane, the number of QC samples analyzed was limited $(<20)$. Many of these constituents are not routinely monitored in Hanford groundwater.

Table C.21 summarizes results for the matrix spikes and matrix spike duplicates from STL Richland and St. Louis. The ammonia and anions category had the greatest percentage of matrix spikes/spike duplicates exceeding the QC limits. 
This represents an increase compared to FY 2005 results that were out of limits for the ammonia and anions category (13\% to $23 \%)$. The general chemistry parameters, metals, and radiochemistry parameters categories also showed an increase in the number of results out of limits compared to FY 2005 results ( $2 \%$ to $5 \%, 0.2 \%$ to $0.7 \%$, and $3 \%$ to $7 \%$, respectively); the volatile organic compounds category showed a decrease relative to FY 2005 ( $7 \%$ to 3\%). The percentage of out-of-limit results increased significantly compared to FY 2005 for total organic carbon; chloride; fluoride; nitrogen in ammonia; nitrogen in nitrate; phosphate; cadmium; calcium; chromium; iron; sodium; 1,4-dioxane; 1-butanol; acrolein; bromomethane; iodomethane; trans-1,4-dichloro-2-butene; vinyl acetate; 2,4-dimethylphenol; and uranium. For FY 2006, 2005, and 2004, less than $1 \%$ of the matrix spikes or matrix spike duplicates for metals were out of limits.

Matrix duplicates were evaluated by comparing the relative percent difference to the QC limit for results that were five times greater than the method detection limit or the minimum detectable activity. Table C.22 lists the constituents that exceeded the relative percent difference limits. The semivolatile organic compound categories had the greatest percentage of matrix duplicates exceeding the QC limits. This represents an increase in this category in the number of results out of limits compared to FY 2005 results (9\% to 13\%). All other categories had fewer than 3\% of their measurements outside the QC limits.

Surrogate data that were out of limits included five compounds for volatile organics and four for semivolatile organics. For volatile organic compounds, 2\% of the surrogate results were outside of QC limits, a decrease compared to FY 2005 results $(5 \%)$. The semivolatile organic surrogates had $2 \%$ of the results out of limits.

QC data for Eberline Services and Lionville Laboratory were limited for FY 2006 because these laboratories did not analyze many samples for routine long-term or interim action groundwater monitoring. Lionville Laboratory analyzed a limited number $(<10$ each) of method blanks, laboratory control samples, matrix spikes, and matrix duplicates for total organic carbon, anions by ion chromatography, and metals by inductively coupled plasma-atomic emission spectroscopy. For several of the metal analyses, the only element of interest was aluminum. All of the QC data for total organic carbon were within limits. Method blanks for a number of metals (barium, beryllium, calcium, cobalt, copper, magnesium, manganese, nickel, sodium, vanadium, and zinc) had some results that were out of limits. The levels for the method blanks for calcium and sodium that were out of limits were much lower than the levels measured in the groundwater samples. Several of the duplicates for three metals (manganese, nickel, zinc) and one anion (chloride) were also out of limits. A matrix spike was out of limits for nitrogen in nitrite. Eberline Services QC data were limited to gross alpha, gross beta, radionuclides by gamma spectroscopy, strontium-90, and tritium. All of the QC data were within limits.

\section{C.6.4.1 Issue Resolution}

Issue resolution forms are documents used to record and resolve problems encountered with sample receipt, sample analysis, missed holding times, and data reporting (e.g., broken bottles or QC problems). The laboratories generate these forms and forward them to the groundwater project as soon as possible after a potential problem is identified. The forms provide a means for the project to give direction to the laboratory on resolution with the issues. The documentation is intended to identify occurrences, deficiencies, and/or issues that may potentially have an adverse effect on data integrity. During FY 2006, 50 issue resolution forms were submitted by STL Richland and St. Louis laboratories. Issue of resolution forms were not received by the secondary or limited use laboratories. Any issues were documented via email and the case narratives.

Table C.23 indicates the specific issues identified this year and the number of analytical requests that were impacted. The number of affected analytical requests was small compared to the total number of analytical requests submitted ( 14,100 , consisting of $\sim 23,400$ bottles). Relative to FY 2005, the frequencies of the individual issues were less than last year's in most categories prior to receipt at the laboratory. However, the frequencies of issues after receipt at the laboratory were slightly higher than the previous year. The number of missed holding times was primarily related to shipping delays. About $30 \%$ of the missed holding time issues were related to laboratory delays. Laboratory QC issues were due to analytical problems that occurred mostly with radiological constituents and phenols.

\section{C.6.4.2 Laboratory Audits}

Laboratory activities are regularly assessed by surveillance and auditing processes to ensure that quality problems are prevented and/or detected. Regular assessment supports continuous process improvement. During FY 2006, five of these audits were conducted on laboratories that routinely analyzed Hanford groundwater samples. These audits were performed by the Department of Energy Consolidated Audit Program (DOECAP). 
The goal of the DOECAP is to design and implement a program to consolidate site audits of commercial and DOE environmental laboratories providing services to DOE Environmental Management. The specific audit objectives of the DOECAP were to assess the ability of the laboratories to produce data of acceptable and documented quality through analytical operations that follow approved methods and the handling of DOE samples and associated waste in a manner that protects human health and the environment. All laboratories were evaluated against the requirements of the DOE's document, DOECAP Quality Systems for Analytical Services, Revision 2.1 (DOECAP 2005).

The DOECAP audits were performed at the following laboratories: STL Knoxville, Tennessee, December 12-14, 2005; STL St. Louis, Missouri, April 4-7, 2006; Eberline Services, Richmond, California, February 4-7, 2006; Lionville Laboratory, Lionville, Pennsylvania, May 23-24, 2006; and STL Richland, Washington, May 23-24, 2006. The assessment scope of the DOECAP audits included the following specific functional areas: (1) QA management systems and general laboratory practices, (2) data quality for organic analyses, (3) data quality for inorganic and wet chemistry analyses, (4) data quality for radiochemistry analysis, (5) hazardous and radioactive materials management, and (6) verification of corrective-action implementation from previous audit findings.

A total of 34 findings and 45 observations were noted for the 5 DOECAP audits. Results of each of these audits are summarized in Table C.24. Corrective actions have been accepted for all audits, and verification of the corrective actions will be performed in future audits. All laboratories have been qualified to continue to provide analytical services for samples generated at DOE sites.

In addition to many of the past audit findings being closed, proficiencies for many of the laboratories were noted this year, indicating that the laboratories are improving their processes and continuing to provide quality analytical services. Continued assessments of the laboratories are planned for the upcoming year to further evaluate performance and to ensure those corrective actions for the past findings and observations have been implemented.

\section{C.6.4.3 Laboratory Assessments}

A technical/management assessment of STL St. Louis was conducted on February 8-9, 2006, by PNNL. The purpose of the assessment was to evaluate the continued support of analytical services for the PNNL groundwater project as specified in the statement of work between Fluor Hanford, Inc. and STL and Eberline Services. ${ }^{\text {(b) }}$ Primary areas of the assessment included: a review of selected analyses (wet chemistry and metals) and procedures performed for the PNNL groundwater project; method detection limit determination and reporting; sample receipt; data review, and data reporting processes; and implementation of STL's QA Management Plan in accordance with Hanford Analytical Services Quality Assurance Document (HASQARD, Volumes 1 and 4, DOE/RL-96-68).

Minor issues were noted in the following areas: data review processes, logbook review, procedure noncompliance, and training of staff to assure that they are certified before performing analyses of samples. The laboratory has responded to those items identified and their corrective actions will be verified during the next assessment or audit. Additionally, improvements were noted in the processes used for managing method detection limits and in the documentation of the internal chain of custody for samples with short hold times.

\section{C.7 Limit of Detection, Limit of Quantitation, and Method Detection Limit}

\section{J. Chou, H. Hampt, and C. J. Thompson}

Detection and quantitation limits are essential to evaluate data quality and usefulness because they provide the limits of a method's measurement. The detection limit is the lower limit at which a measurement can be differentiated from background. The quantitation limit is the lower limit where a measurement becomes quantifiably meaningful. The limit of detection, limit of quantitation, and method detection limit are useful for evaluating groundwater data.

The limit of detection is defined as the lowest concentration level statistically different from a blank (Currie 1988). The concentration at which an analyte can be detected depends on the variability of the blank response. For the purpose of this discussion, the blank is taken to be a method blank.

(b) RFSH-SOW-93-0003, Rev. 6. 1999. Environmental and Waste Characterization of Analytical Services. Statement of Work between Fluor Daniel Hanford, Inc. and Severn Trent Laboratories, Richland, Washington, and Eberline Services, Richmond, California. 
In general, the limit of detection is calculated as the mean concentration in the blank plus three standard deviations of that concentration (EPA/540/P-87/001, OSWER 9355.0-14). The blank-corrected limit of detection is simply three times the blank standard deviation. At three standard deviations from the blank mean, the false-positive and the falsenegative error rates are each $~ 7 \%$ (Miller and Miller 1988). A false-positive error is an instance when an analyte is declared present but is, in fact, absent. A false-negative error is an instance when an analyte is declared absent but is, in fact, present.

The limit of detection for a radionuclide is typically computed from the counting error associated with each reported result (e.g., EPA 520/1-80-012) and represents instrumental or background conditions at the time of analysis. In contrast, the limit of detection and limit of quantitation for the radionuclides shown in Table C. 25 are based on variabilities that result from both counting errors and uncertainties introduced by sample handling. In the latter case, distilled water, submitted as a sample, is processed as if it were an actual sample. Thus, any random cross-contamination of the blank during sample processing will be included in the overall error, and the values shown in Table C.25 are most useful for assessing long-term variability in the overall process.

The limit of quantitation is defined as the level above which quantitative results may be obtained with a specified degree of confidence (Keith 1991). The limit of quantitation is calculated as the blank mean plus 10 standard deviations of the blank (EPA/540/P-87/001, OSWER 9355.0-14). The blank-corrected limit of quantitation is simply 10 times the blank standard deviation. The limit of quantitation is most useful for defining the lower limit of the useful range of concentration measurement technology. When the analyte signal is 10 times larger than the standard deviation of the blank measurements, there is a $95 \%$ probability that the true concentration of the analyte is within $\pm 25 \%$ of the measured concentration.

The method detection limit is defined as the minimum concentration of a substance that can be measured and reported with a $99 \%$ confidence that the analyte concentration is greater than zero. The method detection limit is determined from analysis of a sample in a given matrix containing the analyte (Currie 1988). The method detection limit is 3.14 times the standard deviation of the results of seven replicates of a low-level standard. Note that the method detection limit, as defined above, is based on the variability of the response of low-level standards rather than on the variability of the blank response.

For this report, total organic carbon, total organic halides, and radionuclide field blank data are available for limit of detection and limit of quantitation determinations. The field blanks are $\mathrm{QC}$ samples that are introduced into a process to monitor the performance of the system. The use of field blanks to calculate the limit of detection and the limit of quantitation is preferred over the use of laboratory blanks because field blanks include error contributions from sample preparation and handling, in addition to analytical uncertainties. Methods to calculate the limit of detection and the limit of quantitation are described in detail in Appendix A of DOE/RL-91-03. The results of the limit of detection and limit of quantitation determinations are listed in Table C.25.

Because of the lack of blank data for other constituents of concern, it was necessary to calculate approximate limit of detection and limit of quantitation values by using variability information obtained from low-level standards. The data from the low-level standards are obtained from laboratory method detection limit studies. If low-level standards are used, the variability of the difference between the sample and blank response is increased by a factor of 2 (Currie 1988, p. 84). The formulas are summarized below:

$$
\begin{aligned}
\mathrm{MDL} & =3.14 \cdot \mathrm{s} \\
\mathrm{LOD} & =3(\sqrt{2} \cdot \mathrm{s}) \\
& =4.24 \cdot \mathrm{s} \\
\mathrm{LOQ} & =10(\sqrt{2} \cdot \mathrm{s}) \\
& =14.14 \cdot \mathrm{s}
\end{aligned}
$$

where $s=$ standard deviation from the seven replicates of the low-level standard.

The results of limit of detection, limit of quantitation, and method detection limit calculations for most nonradiological constituents of concern (besides total organic carbon and total organic halides) are listed in Table C.26. The values in the table apply to STL St. Louis only. 
Specific evaluation of detection-limit issues for the interim action groundwater monitoring was not performed for this report. Detection limit issues are primarily assessed as part of site-specific validation activities. No validation activities were performed on interim action groundwater monitoring data in FY 2006.

\section{C.8 Conclusions}

Overall, assessments of FY 2006 QA/QC information indicate that groundwater monitoring data are reliable and defensible. Sampling was conducted in accordance with reviewed procedures. Few contamination or other samplingrelated problems were encountered that affected data integrity. Likewise, laboratory performance was excellent in most respects, based on the large percentages of acceptable field and laboratory QC results. Satisfactory laboratory audits and generally acceptable results in nationally based performance evaluation studies also demonstrated good laboratory performance. However, the following areas of concern were identified and should be considered when interpreting groundwater monitoring results:

- A few QC samples were probably swapped in the field or at the laboratory based on a small number of unusually high field-blank results and duplicate results with poor precision. The same problem likely occurred for a small number of groundwater samples. Mismatched results for key constituents are identified during data review and flagged when appropriate.

- Several indicator parameters, anions, metals, volatile organic compounds, and radiological parameters were detected at low levels in field and/or laboratory method blanks. The most significant contaminants were acetone, aluminum, arsenic, bromide, carbon tetrachloride, fluoride, methylene chloride, nitrogen in nitrate, potassium- 40 , and zinc.

- Maximum recommended holding times were exceeded for $\sim 4.9 \%$ of groundwater monitoring samples that were analyzed by non-radiological methods. Anions were primarily affected, though the data impacts are considered minor.

- Laboratory performance on blind standards was good overall: $85 \%$ of the results were acceptable. Constituents with out-of-limit results from STL (St. Louis and Richland) were carbon tetrachloride, chloroform, gross alpha, total organic halides, trichloroethene, and tritium. All of Lionville Laboratory's and Eberline Services' results were acceptable.

\section{C.9 References}

Atomic Energy Act, as amended, Ch. 1073, 68 Stat. 919, 42 USC 2011 et seq.

APHA/AWWA/WEF. 1998. Standard Methods for the Examination of Water and Wastewater, 20th ed., American Public Health Association, American Water Works Association, and Water Environment Federation, Washington, D.C.

Comprehensive Environmental Response, Compensation, and Liability Act. 1980. Public Law 96-510, as amended, 94 Stat. 2767, 42 USC 9601 et seq

Currie LA (ed.). 1988. "Detection in Analytical Chemistry: Importance, Theory, and Practice." ACS Symposium Series 361, American Chemical Society, Washington, D.C., pp. 17, 79-92.

DOECAP. 2005. DOECAP Quality Systems for Analytical Services, Revision 2.1. U.S. Department of Energy, Washington, D.C.

DOE/RL-90-08. 1992. Remedial Investigation/Feasibility Study Work Plan for the 100-BC-5 Operable Unit, Hanford Site, Richland, Washington. U.S. Department of Energy, Richland Operations Office, Richland, Washington.

DOE/RL-91-03. 1991. Annual Report for RCRA Groundwater Monitoring Projects at Hanford Site Facilities for 1990. Prepared by Geosciences Group, Westinghouse Hanford Company, Environmental Division for U.S. Department of Energy, Richland Operations Office, Richland, Washington.

DOE/RL-91-46. 1996. RCRA Facility Investigation/Corrective Measures Study Work Plan for the 100-NR-2 Operable Unit Hanford Site, Richland, Washington. U.S. Department of Energy, Richland Operations Office, Richland, Washington. 
DOE/RL-92-76. 1994. Remedial Investigation/Feasibility Study Work Plan for the 200-UP-1 Groundwater Operable Unit, Hanford Site, Richland, Washington. U.S. Department of Energy, Richland Operations Office, Richland, Washington.

DOE/RL-96-07. 1996. 200-ZP-1 IRM Phase II and III Remedial Design Report. U.S. Department of Energy, Richland Operations Office, Richland, Washington.

DOE/RL-96-68, Rev. 2. 1998. HASQARD, Volumes 1 and 4. Hanford Analytical Services Quality Assurance Requirements Documents. U.S. Department of Energy, Richland Operations Office, Richland, Washington.

DOE/RL-96-90, Rev. 0. 1997. Interim Action Monitoring Plan for the 100-HR-3 and 100-KR-4 Operable Units. Prepared by CH2M HILL Hanford, Inc. for U.S. Department of Energy, Richland Operations Office, Richland, Washington.

DOE/RL-97-36, Rev. 2. 1997. 200-UP-1 Groundwater Remedial Design/Remedial Action Work Plan. U.S. Department of Energy, Richland Operations Office, Richland, Washington.

DOE/RL-2002-10, Rev. 0. 2002. Sampling and Analysis Plan for the 200-UP-1 Groundwater Monitoring Network. U.S. Department of Energy, Richland Operations Office, Richland, Washington.

DOE/RL-2002-17, Rev. 0. 2002. Sampling and Analysis Plan for the 200-ZP-1 Groundwater Monitoring Network. U.S. Department of Energy, Richland Operations Office, Richland, Washington.

EML-564. January 1995. Analysis of EML QAP Data from 1982-1992: Determination of Operational Criteria and Control Limits for Reformance Evaluation Purposes. V Pan, Environmental Measurements Laboratory, U.S. Department of Energy, New York.

EPA 520/1-80-012. 1980. Upgrading Environmental Radiation Data. Health Physics Report HPSR-1. JE Watson, Office of Radiation Programs, U.S. Environmental Protection Agency, Washington, D.C.

EPA/540/P-87/001, OSWER 9355.0-14. 1987. A Compendium of Superfund Field Operations Methods. U.S. Environmental Protection Agency, Washington, D.C., pp. 16-3 to 16-5.

EPA-600/4-81-004. 1981. Environmental Radioactivity Laboratory Intercomparison Studies Program: Fiscal Year 1980-81. AB Jarvis and L Siu, U.S. Environmental Protection Agency, Las Vegas, Nevada.

EPA Method 300.0. 1991. The Determination of Inorganic Anions in Water by Ion Chromatography. U.S. Environmental Protection Agency, Washington, D.C.

HEIS. 1994. Hanford Environmental Information System. Environmental Information Systems Department, Fluor Hanford, Inc., Richland, Washington.

Keith LH. 1991. Environmental Sampling and Analysis: A Practical Guide. Lewis Publishers, CRC Press, Inc., Boca Raton, Florida, pp. 93-115.

MAPEP-06-MaW15\&OrW15\&GrW15. 2006. Water Sample MAP-06-15 Performance Report. U.S. Department of Energy, Mixed Analyte Performance Evaluation Program, Radiological and Environmental Sciences Laboratory, Idaho Falls, Idaho.

MAPEP-06-MaW16\&OrW16\&GrW16. 2006. Water Sample MAP-06-W16 Performance Report. U.S. Department of Energy, Mixed Analyte Performance Evaluation Program, Radiological and Environmental Sciences Laboratory, Idaho Falls, Idaho.

Miller JC and JN Miller. 1988. Statistics for Analytical Chemistry, Second Edition. Ellis Horwood Limited, Chichester, England, pp. 115-116. 
Mitchell WJ, RC Rhodes, and FF McElroy. 1985. "Determination of Measurement Data Quality and Establishment of Achievable Goals for Environmental Measurements." Quality Assurance for Environmental Measurements, ASTMSTP 867.

NERL-Ci-0045. 1998. National Standards for Water Proficiency Testing Studies Criteria Document. U.S. Environmental Protection Agency, Washington, D.C.

OSWER-9950.1. 1986. Resource Conservation and Recovery Act (RCRA) Groundwater Monitoring Technical Enforcement Guidance Document (TEGD). U.S. Environmental Protection Agency, Washington, D.C.

PNNL-13080. 1999. Hanford Site Groundwater: Setting, Sources and Methods. MJ Hartman (ed.), Pacific Northwest National Laboratory, Richland, Washington.

PNNL-15014. 2005. The Groundwater Performance Assessment Project Quality Assurance Plan. Prepared by Pacific Northwest National Laboratory for U.S. Department of Energy, Richland Operations Office, Richland, Washington.

PNNL-15670. 2006. Hanford Site Groundwater Monitoring for Fiscal Year 2005. MJ Hartman, LF Morasch, and WD Webber (eds.), Pacific Northwest National Laboratory, Richland, Washington.

Resource Conservation and Recovery Act. 1976. Public Law 94 580, as amended, 90 Stat 2795, 42 USC 6901 et seq.

SW-846. 1986. Test Methods for Evaluating Solid Wastes: Physical/Chemical Methods, SW-846, Third Edition. Office of Solid Waste and Emergency Response, U.S. Environmental Protection Agency, Washington, D.C. Online manual available at http://www.epa.gov/epaoswer/hazwaste/test/sw846.htm 
Table C.1. Data Review Codes

\begin{tabular}{|c|l|}
\hline Code & \multicolumn{1}{|c|}{ Definition } \\
\hline D & Result is associated with a documented laboratory nonconformance. \\
\hline F & Result is being reviewed as part of the RDR process. This flag is assigned when an RDR is initiated. \\
\hline G & Result is valid according to further review. \\
\hline H & Laboratory holding time exceeded before the sample was analyzed. \\
\hline P & Potential problem. Collection/analysis circumstances make value questionable. \\
\hline Q & Associated quality control sample is out of limits. \\
\hline R & Result is not valid according to further review. \\
\hline Y & Result is suspect. Review had insufficient evidence to show result valid or invalid. \\
\hline Z & Miscellaneous circumstance exists. See project file. \\
\hline RDR = Request for data review. \\
\hline
\end{tabular}

Table C.2. Requests for Data Review for FY 2006 Data

\begin{tabular}{|c|c|c|c|c|c|c|c|}
\hline Flag G & Flag Y & Flag R & Flag P & Notify Owner & Other Action & Pending & $\begin{array}{c}\text { Number of } \\
\text { Results with an } \\
\text { Assigned RDR }\end{array}$ \\
\hline \multicolumn{7}{|c|}{ Analytical Results } \\
\hline 118 & 169 & 98 & 17 & 137 & 6 & 66 & 611 \\
\hline \multicolumn{7}{|c|}{ Water-Level Measurements } \\
\hline 18 & 31 & 7 & 7 & -- & -- & 23 & 86 \\
\hline
\end{tabular}


Table C.3. Long-Term Monitoring Full Trip Blanks Exceeding Quality Control Limits

\begin{tabular}{|c|c|c|c|c|c|}
\hline Constituent & $\begin{array}{c}\text { Number Out } \\
\text { of Limits }\end{array}$ & $\begin{array}{l}\text { Number of } \\
\text { Analyses }\end{array}$ & $\begin{array}{c}\text { Percent Out } \\
\text { of Limits }\end{array}$ & Range of QC Limits ${ }^{(a)}$ & $\begin{array}{c}\text { Range of Out-of-Limit } \\
\text { Results }\end{array}$ \\
\hline \multicolumn{6}{|c|}{ General Chemistry Parameters } \\
\hline Alkalinity & 2 & 40 & 5.0 & $3,600 \mu \mathrm{g} / \mathrm{L}$ & $5,000-8,000 \mu \mathrm{g} / \mathrm{L}$ \\
\hline Chemical oxygen demand & 2 & 3 & 66.7 & $18,400 \mu \mathrm{g} / \mathrm{L}$ & $30,000-34,000 \mu \mathrm{g} / \mathrm{L}$ \\
\hline Specific conductance & 1 & 1 & 100 & $0.4 \mu \mathrm{S} / \mathrm{cm}$ & $0.8 \mu \mathrm{S} / \mathrm{cm}$ \\
\hline Total organic carbon & 8 & 75 & 10.7 & $860-940 \mu \mathrm{g} / \mathrm{L}$ & $890-2,800 \mu \mathrm{g} / \mathrm{L}$ \\
\hline Total organic halides & 11 & 62 & 17.7 & $5.2-6.4 \mu \mathrm{g} / \mathrm{L}$ & $7-19.5 \mu \mathrm{g} / \mathrm{L}$ \\
\hline \multicolumn{6}{|c|}{ Ammonia and Anions } \\
\hline Chloride & 28 & 52 & 53.8 & $46-50 \mu \mathrm{g} / \mathrm{L}$ & $47-220 \mu \mathrm{g} / \mathrm{L}$ \\
\hline Nitrogen in nitrate & 1 & 52 & 1.9 & $88.6 \mu \mathrm{g} / \mathrm{L}$ & $124 \mu \mathrm{g} / \mathrm{L}$ \\
\hline Phosphate & 1 & 2 & 50.0 & $38 \mu \mathrm{g} / \mathrm{L}$ & $150 \mu \mathrm{g} / \mathrm{L}$ \\
\hline Sulfate & 1 & 52 & 1.9 & $100 \mu \mathrm{g} / \mathrm{L}$ & $180 \mu \mathrm{g} / \mathrm{L}$ \\
\hline \multicolumn{6}{|c|}{ Metals } \\
\hline Aluminum & 3 & 10 & 30.0 & $33.2 \mu \mathrm{g} / \mathrm{L}$ & $34.2-65 \mu \mathrm{g} / \mathrm{L}$ \\
\hline Barium & 2 & 45 & 4.4 & $0.64-1.78 \mu \mathrm{g} / \mathrm{L}$ & $0.68-2.7 \mu \mathrm{g} / \mathrm{L}$ \\
\hline Beryllium & 1 & 45 & 2.2 & $0.36 \mu \mathrm{g} / \mathrm{L}$ & $0.51 \mu \mathrm{g} / \mathrm{L}$ \\
\hline Calcium & 8 & 45 & 17.8 & $21.4-72 \mu \mathrm{g} / \mathrm{L}$ & $28.1-97.4 \mu \mathrm{g} / \mathrm{L}$ \\
\hline Chromium & 1 & 45 & 2.2 & $6.2 \mu \mathrm{g} / \mathrm{L}$ & $10.3 \mu \mathrm{g} / \mathrm{L}$ \\
\hline Magnesium & 3 & 45 & 6.7 & $216 \mu \mathrm{g} / \mathrm{L}$ & $260-342 \mu \mathrm{g} / \mathrm{L}$ \\
\hline Potassium & 1 & 45 & 2.2 & $3,220 \mu \mathrm{g} / \mathrm{L}$ & $3,450 \mu \mathrm{g} / \mathrm{L}$ \\
\hline Sodium & 1 & 45 & 2.2 & $220 \mu \mathrm{g} / \mathrm{L}$ & $228 \mu \mathrm{g} / \mathrm{L}$ \\
\hline Vanadium & 1 & 45 & 2.2 & $11.8 \mu \mathrm{g} / \mathrm{L}$ & $13.2 \mu \mathrm{g} / \mathrm{L}$ \\
\hline Zinc & 6 & 45 & 13.3 & $2.4 \mu \mathrm{g} / \mathrm{L}$ & $2.9-7.1 \mu \mathrm{g} / \mathrm{L}$ \\
\hline \multicolumn{6}{|c|}{ Volatile Organic Compounds } \\
\hline Carbon tetrachloride & 1 & 22 & 4.5 & $0.3 \mu \mathrm{g} / \mathrm{L}$ & $0.45 \mu \mathrm{g} / \mathrm{L}$ \\
\hline Methylene chloride & 12 & 22 & 54.5 & $0.5-0.6 \mu \mathrm{g} / \mathrm{L}$ & $0.85-6.2 \mu \mathrm{g} / \mathrm{L}$ \\
\hline \multicolumn{6}{|c|}{ Radiological Parameters } \\
\hline Gross alpha & 1 & 32 & 3.1 & $1.334 \mathrm{pCi} / \mathrm{L}^{(\mathrm{b})}$ & $1.61 \mathrm{pCi} / \mathrm{L}$ \\
\hline Gross beta & 1 & 36 & 2.8 & $3.66 \mathrm{pCi} / \mathrm{L}^{(\mathrm{b})}$ & $7.98 \mathrm{pCi} / \mathrm{L}$ \\
\hline Tritium & 2 & 38 & 5.3 & $12.18-12.72 \mathrm{pCi} / \mathrm{L}^{(\mathrm{b})}$ & $40.9-74 \mathrm{pCi} / \mathrm{L}$ \\
\hline Uranium & 1 & 27 & 3.7 & $0.1814 \mu \mathrm{g} / \mathrm{L}$ & $0.429 \mu \mathrm{g} / \mathrm{L}$ \\
\hline \multicolumn{6}{|c|}{$\begin{array}{l}\text { (a) Because method detection limits may change throughout the year, the limits are presented as a range. However, each } \\
\text { result was evaluated according to the method detection limit in effect at the time the sample was analyzed. } \\
\text { (b) The limit for radiological analyses is determined by the sample-specific total propagated uncertainty. } \\
\text { QC = Quality control. }\end{array}$} \\
\hline
\end{tabular}


Table C.4. Long-Term Monitoring Field Transfer Blanks Exceeding Quality Control Limits

\begin{tabular}{|l|c|c|c|c|c|}
\hline \multicolumn{1}{|c|}{ Constituent } & $\begin{array}{c}\text { Number Out } \\
\text { of Limits }\end{array}$ & $\begin{array}{c}\text { Number of } \\
\text { Analyses }\end{array}$ & $\begin{array}{c}\text { Percent Out } \\
\text { of Limits }\end{array}$ & $\begin{array}{c}\text { Range of QC } \\
\text { Limits }{ }^{(a)}\end{array}$ & $\begin{array}{c}\text { Range of Out-of-Limit } \\
\text { Results }\end{array}$ \\
\hline Acetone & 1 & 97 & 1.0 & $4 \mu \mathrm{g} / \mathrm{L}$ & $14 \mu \mathrm{g} / \mathrm{L}$ \\
\hline Bromomethane & 1 & 2 & 50.0 & $1 \mu \mathrm{g} / \mathrm{L}$ & $1.2 \mu \mathrm{g} / \mathrm{L}$ \\
\hline Carbon disulfide & 1 & 97 & 1.0 & $0.5 \mu \mathrm{g} / \mathrm{L}$ & $0.81 \mu \mathrm{g} / \mathrm{L}$ \\
\hline Carbon tetrachloride & 8 & 97 & 8.2 & $0.18-0.3 \mu \mathrm{g} / \mathrm{L}$ & $0.23-0.71 \mu \mathrm{g} / \mathrm{L}$ \\
\hline Chloroform & 1 & 97 & 1.0 & $0.38 \mu \mathrm{g} / \mathrm{L}$ & $1.7 \mu \mathrm{g} / \mathrm{L}$ \\
\hline Chloromethane & 1 & 2 & 50.0 & $0.38 \mu \mathrm{g} / \mathrm{L}$ & $0.44 \mu \mathrm{L} / \mathrm{L}$ \\
\hline Methylene chloride & 82 & 97 & 84.5 & $0.5-0.6 \mu \mathrm{g} / \mathrm{L}$ & $0.57-24 \mu \mathrm{g} / \mathrm{L}$ \\
\hline
\end{tabular}

(a) Because method detection limits may change throughout the year, the limits are presented as a range. However, each result was evaluated according to the method detection limit in effect at the time the sample was analyzed. $\mathrm{QC}=$ Quality control.

Table C.5. Long-Term Monitoring Equipment Blanks Exceeding Quality Control Limits

\begin{tabular}{|c|c|c|c|c|c|}
\hline Constituent & $\begin{array}{c}\text { Number Out } \\
\text { of Limits }\end{array}$ & $\begin{array}{l}\text { Number of } \\
\text { Analyses }\end{array}$ & $\begin{array}{l}\text { Percent Out } \\
\text { of Limits }\end{array}$ & $\begin{array}{l}\text { Range of } Q C \\
\text { Limits }^{(a)}\end{array}$ & $\begin{array}{l}\text { Range of Out-of-Limit } \\
\text { Results }\end{array}$ \\
\hline \multicolumn{6}{|c|}{ General Chemistry Parameters } \\
\hline Alkalinity & 1 & 2 & 50.0 & $3,600 \mu \mathrm{g} / \mathrm{L}$ & $130,000 \mu \mathrm{g} / \mathrm{L}$ \\
\hline Total organic halides & 3 & 4 & 75.0 & $5.2 \mu \mathrm{g} / \mathrm{L}$ & $6.5-8 \mu \mathrm{g} / \mathrm{L}$ \\
\hline \multicolumn{6}{|c|}{ Metals } \\
\hline Calcium & 1 & 2 & 50.0 & $50 \mu \mathrm{g} / \mathrm{L}$ & $72 \mu \mathrm{g} / \mathrm{L}$ \\
\hline Zinc & 1 & 2 & 50.0 & $2.4 \mu \mathrm{g} / \mathrm{L}$ & $3.4 \mu \mathrm{g} / \mathrm{L}$ \\
\hline $\begin{array}{l}\text { (a) Because method } \\
\text { each result was evalt } \\
Q C=\text { Quality control. }\end{array}$ & $\begin{array}{l}\text { on limits } \mathrm{m} \\
\text { cording tc }\end{array}$ & $\begin{array}{l}\text { hange } t \mathrm{l} \\
\text { method }\end{array}$ & ction limit & $\begin{array}{l}\text { e limits are } \\
\text { ct at the time }\end{array}$ & $\begin{array}{l}\text { ed as a range. Howev } \\
\text { imple was analyzed. }\end{array}$ \\
\hline
\end{tabular}


Table C.6. Long-Term Monitoring Field Duplicates Exceeding Quality Control Limits

\begin{tabular}{|c|c|c|c|c|c|}
\hline Constituent & $\begin{array}{l}\text { Total Number } \\
\text { of Duplicates }\end{array}$ & $\begin{array}{l}\text { Number of } \\
\text { Duplicates } \\
\text { Evaluated }^{(a)}\end{array}$ & $\begin{array}{c}\text { Number Out } \\
\text { of Limits }\end{array}$ & $\begin{array}{l}\text { Percent Out of } \\
\text { Limits }\end{array}$ & $\begin{array}{c}\text { Range of Out-of-Limit } \\
\text { Relative Percent } \\
\text { Differences }^{\left(b^{b}\right)}\end{array}$ \\
\hline \multicolumn{6}{|c|}{ General Chemistry Parameters } \\
\hline Alkalinity & 42 & 42 & 2 & 4.8 & $23.9-108.3$ \\
\hline Chemical oxygen demand & 2 & 1 & 1 & 100 & 135.7 \\
\hline \multicolumn{6}{|c|}{ Ammonia and Anions } \\
\hline Chloride & 48 & 48 & 1 & 2.1 & 43.0 \\
\hline Cyanide & 9 & 3 & 1 & 33.3 & 38.8 \\
\hline Fluoride & 48 & 47 & 4 & 8.5 & $32.0-136.4$ \\
\hline Nitrogen in ammonia & 5 & 1 & 1 & 100 & 164.7 \\
\hline Nitrogen in nitrate & 48 & 48 & 1 & 2.1 & 150.0 \\
\hline \multicolumn{6}{|c|}{ Metals } \\
\hline Arsenic & 4 & 2 & 2 & 100 & $46.2-125.9$ \\
\hline Iron & 43 & 5 & 2 & 40.0 & $103.1-153.0$ \\
\hline Potassium & 43 & 15 & 6 & 40.0 & $20.7-37.5$ \\
\hline Zinc & 43 & 7 & 4 & 57.1 & $44.2-118.2$ \\
\hline \multicolumn{6}{|c|}{ Volatile Organic Compounds } \\
\hline Acetone & 11 & 1 & 1 & 100 & 36.4 \\
\hline cis-1,2-Dichloroethene & 11 & 2 & 1 & 50.0 & 199.5 \\
\hline Methylene chloride & 11 & 1 & 1 & 100 & 188.9 \\
\hline Trichloroethene & 11 & 6 & 1 & 16.7 & 155.6 \\
\hline \multicolumn{6}{|c|}{ Radiological Parameters } \\
\hline Cobalt-60 & 15 & 3 & 1 & 33.3 & 24.9 \\
\hline Gross alpha & 34 & 9 & 2 & 22.2 & $36.5-43.6$ \\
\hline Gross beta & 35 & 28 & 4 & 14.3 & $21.6-34.7$ \\
\hline lodine-129 & 18 & 4 & 3 & 75.0 & $21.1-25.3$ \\
\hline Technetium-99 & 28 & 16 & 1 & 6.3 & 31.4 \\
\hline $\begin{array}{l}\text { (a) Duplicates with both re } \\
\text { from the evaluation. } \\
\text { (b) In cases where a non-c } \\
\text { detectable activity was use }\end{array}$ & ss than five tin & $\begin{array}{l}\text { the method c } \\
\text { oared with a } n \\
\text { oncentration. }\end{array}$ & $\begin{array}{l}\text { ction limit or } \\
\text { sured value, }\end{array}$ & $\begin{array}{l}\text { nimum detectab } \\
\text { method detect }\end{array}$ & $\begin{array}{l}\text { activity were excluded } \\
\text { limit or minimum }\end{array}$ \\
\hline
\end{tabular}


Table C.7. Interim Action Monitoring Field Blank Detections

\begin{tabular}{|c|c|c|c|c|c|}
\hline Constituent & $\begin{array}{l}\text { Number of } \\
\text { Detects }\end{array}$ & $\begin{array}{l}\text { Number of } \\
\text { Analyses }\end{array}$ & $\begin{array}{l}\text { Percent Out } \\
\text { of Limits }\end{array}$ & $\begin{array}{l}\text { Range of } Q C \text { Limits } \\
\quad(\mu \mathrm{g} / \mathrm{L} \text { or } \mathrm{pCi} / \mathrm{L})\end{array}$ & $\begin{array}{c}\text { Range of Out-of-Limit } \\
\text { Results } \\
(\mu \mathrm{g} / \mathrm{L} \text { or } p C i / L)\end{array}$ \\
\hline \multicolumn{6}{|c|}{ Anions } \\
\hline Chloride & 6 & 8 & 75 & $23-250$ & $28-6,700$ \\
\hline Fluoride & 1 & 8 & 13 & 5.1 & 250 \\
\hline Nitrate & 4 & 8 & 50 & $53.1-12,000$ & $17.7-44.3$ \\
\hline Sulfate & 3 & 8 & 38 & $61-610$ & $100-44,800$ \\
\hline \multicolumn{6}{|c|}{ Metals } \\
\hline Aluminum & 11 & 12 & 92 & 16.6 & $20.6-37.1$ \\
\hline Barium & 1 & 15 & 7 & 0.32 & 0.37 \\
\hline Calcium & 10 & 15 & 67 & $10.7-36$ & $11.9-48.6$ \\
\hline Sodium & 1 & 15 & 7 & 380 & 520 \\
\hline Zinc & 8 & 15 & 53 & 1.2 & $2-6.2$ \\
\hline \multicolumn{6}{|c|}{ Volatile Organic Compounds } \\
\hline Methylene chloride & 9 & 9 & 100 & $0.1-0.12$ & $0.97-5.7$ \\
\hline Trichloroethene & 1 & 9 & 11 & 0.13 & 0.31 \\
\hline
\end{tabular}

Table C.8. Interim Action Monitoring Field Duplicates Exceeding Quality Control Limits

\begin{tabular}{|c|c|c|c|c|c|}
\hline Constituent & $\begin{array}{c}\text { Total } \\
\text { Number of } \\
\text { Duplicates }\end{array}$ & $\begin{array}{c}\text { Number of Duplicates } \\
\text { Evaluated }^{(a)}\end{array}$ & $\begin{array}{c}\text { Number } \\
\text { Out of } \\
\text { Limits }\end{array}$ & $\begin{array}{l}\text { Percent } \\
\text { Out of } \\
\text { Limits }\end{array}$ & $\begin{array}{l}\text { Range of Relative } \\
\text { Percent Differences }\end{array}$ \\
\hline \multicolumn{6}{|c|}{ Wet Chemistry } \\
\hline Chloride & 16 & 16 & 1 & 6 & $0-28.6$ \\
\hline Fluoride & 16 & 16 & 2 & 13 & $0-72.6$ \\
\hline Nitrite & 16 & 1 & 1 & 100 & 8.04 \\
\hline \multicolumn{6}{|c|}{ Metals } \\
\hline Chromium & 21 & 15 & 1 & 7 & $0-49.5$ \\
\hline Iron & 21 & 6 & 5 & 83 & $3.84-63.2$ \\
\hline Sodium & 21 & 21 & 1 & 5 & $0-22.2$ \\
\hline \multicolumn{6}{|c|}{ Volatile Organic Parameters } \\
\hline Carbon disulfide & 13 & 1 & 1 & 100 & 34.8 \\
\hline Carbon tetrachloride & 13 & 10 & 3 & 30 & $0-55.8$ \\
\hline Chloroform & 13 & 10 & 1 & 10 & $0-26.1$ \\
\hline
\end{tabular}


Table C.9. Interim Action Monitoring Interlaboratory Splits Exceeding Quality Control Limits

\begin{tabular}{|c|c|c|c|c|c|}
\hline Constituent & $\begin{array}{l}\text { Total Number } \\
\text { of Splits }\end{array}$ & $\begin{array}{l}\text { Number of Splits } \\
\text { Evaluated }^{(a)}\end{array}$ & $\begin{array}{l}\text { Number Out of } \\
\text { Limits }\end{array}$ & $\begin{array}{l}\text { Percent Out of } \\
\text { Limits }\end{array}$ & $\begin{array}{l}\text { Range of Relative } \\
\text { Percent Differences }\end{array}$ \\
\hline \multicolumn{6}{|c|}{ Anions } \\
\hline Chloride & 8 & 8 & 2 & 25 & $3.65-54.4$ \\
\hline \multicolumn{6}{|c|}{ Radiological Parameters } \\
\hline Tritium & 8 & 6 & 3 & 50 & $17.3-31.8$ \\
\hline Total beta radiostrontium & 5 & 1 & 1 & 100 & 29.2 \\
\hline \multicolumn{6}{|c|}{ Fixed Laboratory-Field Analyses } \\
\hline Hexavalent chromium & 39 & 36 & 8 & 22 & $0-54$ \\
\hline Sulfate & 22 & 22 & 4 & 18 & $0.66-35.9$ \\
\hline
\end{tabular}

Table C.10. Hanford Groundwater Monitoring Project Maximum Recommended Holding Times

\begin{tabular}{|c|c|c|}
\hline Method & Constituent & Holding Time \\
\hline 120.1 (EPA-600/4-81-004) & Conductivity & 28 days \\
\hline 160.1 (EPA-600/4-81-004) & Total dissolved solids & 7 days \\
\hline 300.0 (EPA-600/4-81-004) & Bromide & 28 days \\
\hline 300.0 (EPA-600/4-81-004) & Chloride & 28 days \\
\hline 300.0 (EPA-600/4-81-004) & Fluoride & 28 days \\
\hline 300.0 (EPA-600/4-81-004) & Nitrate & 48 hours \\
\hline 300.0 (EPA-600/4-81-004) & Nitrite & 48 hours \\
\hline 300.0 (EPA-600/4-81-004) & Phosphate & 48 hours \\
\hline 300.0 (EPA-600/4-81-004) & Sulfate & 28 days \\
\hline 310.1 (EPA-600/4-81-004) & Alkalinity & 14 days \\
\hline 350.1 (EPA-600/4-81-004) & Ammonia & 28 days \\
\hline 410.4 (EPA-600/4-81-004) & Chemical oxygen demand & 28 days \\
\hline $6010(S W-846)$ & Inductively coupled plasma metals & 6 months \\
\hline $6020(S W-846)$ & $\begin{array}{l}\text { Inductively coupled plasma-mass } \\
\text { spectrometry metals }\end{array}$ & 6 months \\
\hline 7060 (SW-846) & Arsenic & 6 months \\
\hline $7196(S W-846)$ & Hexavalent chromium & 24 hours \\
\hline $7421(\mathrm{SW}-846)$ & Lead & 6 months \\
\hline $7470(S W-846)$ & Mercury & 28 days \\
\hline 8015M (SW-846) & Total petroleum hydrocarbons & 14 days \\
\hline 8040 (SW-846) & Phenols & $\begin{array}{l}7 \text { days before extraction; } 40 \text { days after } \\
\text { extraction }\end{array}$ \\
\hline $8081(S W-846)$ & Pesticides & $\begin{array}{l}7 \text { days before extraction; } 40 \text { days after } \\
\text { extraction }\end{array}$ \\
\hline $8082(S W-846)$ & Polychlorinated biphenyls & $\begin{array}{l}7 \text { days before extraction; } 40 \text { days after } \\
\text { extraction }\end{array}$ \\
\hline $8260(S W-846)$ & Volatile organics & 14 days \\
\hline 8270 (SW-846) & Semivolatile organics & $\begin{array}{l}7 \text { days before extraction; } 40 \text { days after } \\
\text { extraction }\end{array}$ \\
\hline $9012(S W-846)$ & Cyanide & 14 days \\
\hline $9020(\mathrm{SW}-846)$ & Total organic halides & 28 days \\
\hline $9030(\mathrm{SW}-846)$ & Sulfides & 7 days \\
\hline 9060 (SW-846) & Total organic carbon & 28 days \\
\hline 9223 (APHA/AWWA/WEF) & Coliform & 24 hours \\
\hline
\end{tabular}


Table C.11. Summary of Severn Trent St. Louis Water Pollution (WP) Performance Evaluation Studies

\begin{tabular}{|l|c|c|c|}
\hline & $\begin{array}{c}\text { WP-132 } \\
\text { March 2006 } \\
\text { Accreditation Laboratory }\end{array}$ & $\begin{array}{c}\text { WP-138 } \\
\text { September 2006 } \\
\text { Acceptable Results/Total }\end{array}$ & $\begin{array}{c}\text { QuiK }{ }^{\mathrm{TM}} \text { Response 090806C } \\
\text { September 2006 } \\
\text { Acceptable Results/Total }\end{array}$ \\
\hline $\begin{array}{l}\text { Environmental Resource } \\
\text { Associates }\end{array}$ & $429 / 465^{(\mathrm{a})}$ & $413 / 428^{(\mathrm{b})}$ & $34 / 34$ \\
\hline
\end{tabular}

(a) Unacceptable results were for calcium hardness $\left(\mathrm{CaCO}_{3}\right)$, ammonia as $\mathrm{N}$, nitrate + nitrite as $\mathrm{N}$, orthophosphate as $\mathrm{P}$, total $\mathrm{Kjeldahl}$ nitrogen, total phosphorus as $\mathrm{P}$, oil and grease (gravimetric), total residual chlorine, conductivity at $25^{\circ} \mathrm{C}$, fluoride, total solids at $105^{\circ} \mathrm{C}$, iron, tin, hexavalent chromium, volatile solids, tert-butyl methyl ether, chloromethane, hexachlorobutadiene, 1,2,3-trichloropropane, and acidity as $\mathrm{CaCO}_{3}$.

(b) Unacceptable results were for fluoride, volatile solids, total organic halides, and benzene in gasoline range organics.

WP $=$ Water pollution .

Table C.12. Summary of Lionville Laboratory Water Supply (WS) Performance Evaluation Studies

\begin{tabular}{|l|c|} 
& \multicolumn{1}{|c|}{$\begin{array}{c}\text { WS-109 } \\
\text { Actober } 2005\end{array}$} \\
\hline Environmental Resource Associates & \multicolumn{1}{|c|}{$65 / 68^{(a)}$} \\
\hline $\begin{array}{l}\text { (a) Unacceptable results were for 1,2-dichloroethane, trans-1,2-dichloroethylene, and } \\
\text { total xylenes. } \\
\text { WS }=\text { Water supply. }\end{array}$ \\
\hline
\end{tabular}


Table C.13. Summary of Severn Trent Interlaboratory Performance, FY 2006

\begin{tabular}{|c|c|c|}
\hline Constituent & $\begin{array}{l}\text { Number of Results } \\
\text { Reported for Each }\end{array}$ & $\begin{array}{l}\text { Number Within Acceptable } \\
\text { Control Limits }\end{array}$ \\
\hline \multicolumn{3}{|c|}{$\begin{array}{l}\text { DOE Mixed Analyte Performance Evaluation Program (MAPEP-06-MaW15\&OrW15\&GrW15) } \\
\text { Radiological and Environmental Sciences Laboratory }\end{array}$} \\
\hline $\begin{array}{l}\text { Americium-241, cesium-134, cesium-137, cobalt-57, cobalt-60, iron-55, manganese-54, plutonium-238, } \\
\text { plutonium-239/240, strontium-90, technetium-99, tritium, uranium-234/233, uranium-238, zinc-65, gross alpha, gross } \\
\text { beta }\end{array}$ & $4^{(a, b)}$ & $4^{(\mathrm{c})}$ \\
\hline Nickel-63 & $4^{(a, b)}$ & $3^{(d)}$ \\
\hline $\begin{array}{l}\text { Antimony, arsenic, barium, beryllium, cadmium, chromium, cobalt, copper, lead, mercury, nickel, selenium, silver, } \\
\text { thallium, uranium-total, uranium-235, uranium-238, vanadium, zinc }\end{array}$ & $2^{(\mathrm{b})}$ & $2^{(c)}$ \\
\hline $\begin{array}{l}\text { di-n-Octylphthalate; benzo(b)fluoranthene; benzo(k)fluoranthene; benzo(a)pyrene; indeno(1,2,3-c,d)pyrene; } \\
\text { dibenzo(a,h)anthracene; benzo(g,h,i)perylene; alpha-BHC; beta-BHC; gamma-BHC (lindane); delta-BHC; heptachlor; } \\
\text { aldrin; heptachlor epoxide; endosulfan I; 4,4'-DDE; dieldrin; endrin; 4,4'-DDD; endosulfan II; 4,4'-DDT; } \\
\text { endrin aldehyde; endosulfan sulfate; aniline; phenol; 2-chlorophenol; 1,3-dichlorobenzene; 1,4-dichlorobenzene; } \\
\text { benzyl alcohol; 1,2-dichlorobenzene; hexachloroethane; nitrobenzene; isophorone; 2-nitrophenol; 2,4-dimethylphenol; } \\
\text { 2,4-dichlorophenol; 1,2,4-trichlorobenzene; naphthalene; hexachlorobutadiene; 4-chloro-3-methylphenol; } \\
\text { 2-methvInaphthalene; 2-methylphenol; hexachlorocyclopentadiene; 3+4-methylphenol; 2,4,6-trichlorophel } \\
\text { 2,6-dichlorophenol; o-toluidine; 2-chloronaphthalene; 2-nitroaniline; dimethylphthalate; acenaphthylene; } \\
\text { 2,6-dinitrotoluene; 3-nitroaniline; acenaphthene; 2,4-dinitrotoluene; 2,4-dinitrophenol; 4-chloroaniline; dibenzofuran; } \\
\text { 4-nitrophenol; 2-naphthylamine; 1,4-naphthoquinone; fluorene; diethylphthalate; 4,6-dinitro-2-methylphenol; } \\
\text { 1,2,4,5-tetrachlorobenzene; 2,4,5-trichlorophenol; hexachlorobenzene; pentachlorophenol }\end{array}$ & $1^{(b)}$ & 1 \\
\hline \multicolumn{3}{|c|}{$\begin{array}{c}\text { ERA InterLaB RadCheM Proficiency Testing Program (RAD-64, 65) } \\
\text { Environmental Resource Associates }\end{array}$} \\
\hline Gross alpha & $4^{(\mathrm{a})}$ & $4^{(e)}$ \\
\hline Radium-226 & $4^{(a)}$ & $3^{(e)}$ \\
\hline Barium-133, cesium-134, cobalt-60, gross beta, radium-228, strontium-89, strontium-90, zinc-65 & $2^{(a)}$ & $2^{(e)}$ \\
\hline Cesium-137 & $2^{(a)}$ & $1^{(e)}$ \\
\hline lodine-131, tritium, uranium (natural), uranium (natural) mass & $1^{(\mathrm{a})}$ & $1^{(\mathrm{e})}$ \\
\hline \multicolumn{3}{|c|}{$\begin{array}{l}\text { (a) Results from STL Richland. } \\
\text { (b) Results from STL St. Louis. } \\
\text { (c) Three results for iron- } 55 \text { (two for St. Louis, one for Richland) and one result each for technetium-99 (Richland) and zinc (St. Louis) were acceptable but outside warning limits. } \\
\text { (d) Result from STL Richland was not acceptable. } \\
\text { (e) Control limits from National Standards for Water Proficiency Testing Studies Criteria Document (NERL-Ci-0045) and National Environmental Laboratory Accreditation Conference } \\
\text { PT Field of Testing list. }\end{array}$} \\
\hline
\end{tabular}


Table C.14. Summary of Eberline Services and Lionville Laboratory Interlaboratory Performance, FY 2006

\begin{tabular}{|c|c|c|}
\hline Constituent & $\begin{array}{l}\text { Number of Results } \\
\text { Reported for Each }\end{array}$ & $\begin{array}{l}\text { Number Within Acceptable } \\
\text { Control Limits }\end{array}$ \\
\hline \multicolumn{3}{|c|}{$\begin{array}{l}\text { DOE Mixed Analyte Performance Evaluation Program } \\
\text { (MAPEP-06-MaW15\&OrW15\&GrW15, MAPEP-06-MaW16\&OrW16\&GrW16) } \\
\text { Radiological and Environmental Sciences Laboratory }\end{array}$} \\
\hline $\begin{array}{l}\text { Americium-241, cesium-134, cesium-137, cobalt-57, cobalt-60, iron-55, } \\
\text { manganese-54, nickel-63, plutonium-238, plutonium-239/240, strontium-90, } \\
\text { technetium-99, tritium, uranium-234/233, uranium-238, zinc-65, gross alpha }\end{array}$ & $2^{(a)}$ & 2 \\
\hline Gross beta & $2^{(a)}$ & 1 \\
\hline $\begin{array}{l}\text { Antimony, arsenic, barium, beryllium, chromium, cobalt, lead, nickel, } \\
\text { selenium, silver, thallium, uranium-total, vanadium, zinc }\end{array}$ & $2^{(\mathrm{b})}$ & $2^{(\mathrm{c})}$ \\
\hline Cadmium, copper & $2^{(\mathrm{b})}$ & 1 \\
\hline Mercury & $1^{(\mathrm{b})}$ & 1 \\
\hline $\begin{array}{l}\text { 2-Chlorophenol; 1,3-dichlorobenzene; 1,4-dichlorobenzene; } \\
\text { 1,2-dichlorobenzene; hexachloroethane; nitrobenzene; isophorone; } \\
\text { 2-nitrophenol; 2,4-dichlorophenol; 1,2,4-trichlorobenzene; naphthalene; } \\
\text { hexachlorobutadiene; 4-chloro-3-methylphenol; 2-methylnaphthalene; } \\
\text { 2-methylphenol; hexachlorocyclopentadiene; 3+4-methylphenol; } \\
\text { 2,4,6-trichlorophenol; 2-chloronaphthalene; dimethylphthalate; } \\
\text { acenaphthylene; 2,6-dinitrotoluene; acenaphthene; 2,4-dinitrotoluene; } \\
\text { 2,4-dinitrophenol; dibenzofuran; 4-nitrophenol; fluorene; diethylphthalate; } \\
\text { 4,6-dinitro-2-methylphenol; 2,4,5-trichlorophenol; hexachlorobenzene; } \\
\text { pentachlorophenol; phenanthrene; anthracene; di-n-butylphthalate; } \\
\text { fluoranthene; pyrene; butylbenzylphthalate; benzo(a)anthracene; chrysene }\end{array}$ & $2^{(\mathrm{b})}$ & 2 \\
\hline Phenol, 2,4-dimethylphenol, bis(2-ethylhexyl)phthalate & $1^{(\mathrm{b})}$ & 1 \\
\hline \multicolumn{3}{|c|}{$\begin{array}{c}\text { ERA InterLaB RadCheM Proficiency Testing Program (RAD-64, 66) } \\
\text { Environmental Resource Associates }\end{array}$} \\
\hline $\begin{array}{l}\text { Barium-133, cesium-134, cesium-137, cobalt-60, gross alpha, gross beta, } \\
\text { radium-226, radium-228, strontium-89, strontium-90, tritium, uranium } \\
\text { (natural), uranium (natural) mass, zinc-65 }\end{array}$ & $2^{(\mathrm{a})}$ & $2^{(\mathrm{d})}$ \\
\hline Gross alpha & $2^{(a)}$ & $1^{(\mathrm{d}, \mathrm{e})}$ \\
\hline \multicolumn{3}{|c|}{$\begin{array}{l}\text { ERA Multi-Media Radiochemistry Proficiency Testing Program (MRAD-003) } \\
\text { Environmental Resource Associates }\end{array}$} \\
\hline $\begin{array}{l}\text { Americium-241, cesium-134, cesium-137, cobalt-60, iron-55, strontium-90, } \\
\text { tritium, uranium-234, uranium-238, uranium (natural), uranium (natural) mass }\end{array}$ & $1^{(a)}$ & $1^{(\mathrm{f})}$ \\
\hline Plutonium-238, plutonium-239, gross alpha, gross beta & $1^{(\mathrm{a})}$ & $0^{(f)}$ \\
\hline \multicolumn{3}{|c|}{$\begin{array}{l}\text { (a) Results from Eberline Services. } \\
\text { (b) Results from Lionville Laboratory. } \\
\text { (c) One result for uranium-total was acceptable but outside warning limits. } \\
\text { (d) Control limits fromNational Standards for Water Proficiency Testing Studies Criteria Document (NERL-Ci-0045) and from } \\
\text { National Environmental Laboratory Accreditation Conference PT Field of Testing list. } \\
\text { (e) Gross alpha was not evaluated in one sample. } \\
\text { (f) Control limits from EML-564. }\end{array}$} \\
\hline
\end{tabular}


Table C.15. Summary of Severn Trent Laboratories Double-Blind Spike Determinations

\begin{tabular}{|c|c|c|c|c|c|}
\hline Constituent & Laboratory & $\begin{array}{l}\text { Sample } \\
\text { Frequency }\end{array}$ & $\begin{array}{c}\text { Number of } \\
\text { Results } \\
\text { Reported }^{(a)} \\
\end{array}$ & $\begin{array}{l}\text { Number of Results } \\
\text { Outside QC Limits }^{(b)}\end{array}$ & Control Limits ${ }^{(\mathrm{c})}(\%)$ \\
\hline \multicolumn{6}{|c|}{ General Chemical Parameters } \\
\hline Specific conductance & St. Louis & Quarterly & 12 & 0 & \pm 25 \\
\hline $\begin{array}{l}\text { Total organic carbon (potassium } \\
\text { hydrogen phthalate spike) }\end{array}$ & St. Louis & Quarterly & 16 & 0 & \pm 25 \\
\hline $\begin{array}{l}\text { Total organic halides } \\
\text { (2,4,5-trichlorophenol spike) }\end{array}$ & St. Louis & Quarterly & 13 & 8 & \pm 25 \\
\hline $\begin{array}{l}\text { Total organic halides (carbon } \\
\text { tetrachloride, chloroform, and } \\
\text { trichloroethene spike) }\end{array}$ & St. Louis & Quarterly & 18 & 7 & \pm 25 \\
\hline \multicolumn{6}{|c|}{ Ammonia and Anions } \\
\hline Cyanide & St. Louis & Quarterly & 12 & 0 & \pm 25 \\
\hline Fluoride & St. Louis & Quarterly & 12 & 0 & \pm 25 \\
\hline Nitrate as Nitrogen & St. Louis & Quarterly & 12 & 0 & \pm 25 \\
\hline \multicolumn{6}{|c|}{ Metals } \\
\hline Chromium & St. Louis & Annually & 3 & 0 & \pm 20 \\
\hline \multicolumn{6}{|c|}{ Volatile Organic Compounds } \\
\hline Carbon tetrachloride & St. Louis & Quarterly & 18 & 7 & \pm 25 \\
\hline Chloroform & St. Louis & Quarterly & 12 & 2 & \pm 25 \\
\hline Trichloroethene & St. Louis & Quarterly & 12 & 3 & \pm 25 \\
\hline \multicolumn{6}{|c|}{ Radiological Parameters } \\
\hline Gross alpha (plutonium-239 spike) & Richland & Quarterly & 12 & 1 & \pm 30 \\
\hline Gross beta (strontium-90 spike) & Richland & Quarterly & 12 & 0 & \pm 30 \\
\hline Cesium-137 & Richland & Annually & 3 & 0 & \pm 30 \\
\hline Cobalt-60 & Richland & Annually & 3 & 0 & \pm 30 \\
\hline lodine-129 & Richland & Semiannually & 9 & 0 & \pm 30 \\
\hline Plutonium-239 & Richland & Quarterly & 12 & 0 & \pm 30 \\
\hline Strontium-90 & Richland & Semiannually & 6 & 0 & \pm 30 \\
\hline Technetium-99 & Richland & Quarterly & 12 & 0 & \pm 30 \\
\hline Tritium & Richland & Annually & 6 & 6 & \pm 30 \\
\hline Tritium (low level) & Richland & Semiannually & 6 & 0 & \pm 30 \\
\hline Uranium-238 & Richland & Quarterly & 12 & 0 & \pm 30 \\
\hline \multicolumn{6}{|c|}{$\begin{array}{l}\text { (a) Blind standards were generally submitted in duplicate, triplicate, or quadruplicate. } \\
\text { (b) Quality control limits are given in the Hanford Groundwater Monitoring Project's QA plan. } \\
\text { (c) Each result must be within the specified percentage of the known value to be acceptable. } \\
\text { QA = Quality assurance. } \\
\text { QC = Quality control. }\end{array}$} \\
\hline
\end{tabular}


Table C.16. Summary of Lionville Laboratory, Inc. and Eberline Services Double-Blind Spike Determinations

\begin{tabular}{|c|c|c|c|c|c|}
\hline Constituent & Laboratory & $\begin{array}{l}\text { Sample } \\
\text { Frequency }\end{array}$ & $\begin{array}{l}\text { Number of } \\
\text { Results } \\
\text { Reported }^{(a)}\end{array}$ & $\begin{array}{l}\text { Number of Results } \\
\text { Outside QC Limits }{ }^{(b)}\end{array}$ & Control Limits ${ }^{(\mathrm{c})}(\%)$ \\
\hline \multicolumn{6}{|c|}{ General Chemical Parameters } \\
\hline $\begin{array}{l}\text { Total organic carbon (potassium } \\
\text { hydrogen phthalate spike) }\end{array}$ & Lionville & Quarterly & 13 & 0 & \pm 25 \\
\hline \multicolumn{6}{|c|}{ Radiological Parameters } \\
\hline Gross beta (strontium-90 spike) & Eberline & Quarterly & 12 & 0 & \pm 30 \\
\hline \multicolumn{6}{|c|}{$\begin{array}{l}\text { (a) Blind standards were generally submitted in duplicate, triplicate, or quadruplicate. } \\
\text { (b) Quality control limits are given in the Hanford Groundwater Monitoring Project's QA plan. } \\
\text { (c) Each result must be within the specified percentage of the known value to be acceptable. } \\
\text { QA = Quality assurance. } \\
\text { QC = Quality control. }\end{array}$} \\
\hline
\end{tabular}

Table C.17. Volatile Organic Compound Interlaboratory Comparison Study

\begin{tabular}{|c|c|c|c|c|c|c|c|}
\hline Laboratory & $\begin{array}{l}\text { Spike Concentration } \\
(\mu \mathrm{g} / \mathrm{L})\end{array}$ & $\begin{array}{c}\text { Result } 1 \\
(\mu \mathrm{g} / \mathrm{L})\end{array}$ & Recovery 1 & $\begin{array}{c}\text { Result } 2 \\
(\mu \mathrm{g} / \mathrm{L})\end{array}$ & Recovery 2 & $\begin{array}{c}\text { Result } 3 \\
(\mu \mathrm{g} / \mathrm{L})\end{array}$ & Recovery 3 \\
\hline \multicolumn{8}{|c|}{ Carbon Tetrachloride } \\
\hline \multirow[t]{3}{*}{ St. Louis } & 20.1 & 21 & $105 \%$ & 23 & $114 \%$ & 24 & $119 \%$ \\
\hline & 673 & 660 & $98 \%$ & 670 & $100 \%$ & 650 & $97 \%$ \\
\hline & 2,616 & 3,100 & $119 \%$ & 2,600 & $99 \%$ & 2,600 & $99 \%$ \\
\hline \multirow[t]{3}{*}{ WSCF } & 20.1 & 12 & $60 \%^{(a)}$ & 14 & $70 \%^{(a)}$ & 16 & $80 \%$ \\
\hline & 673 & 660 & $98 \%$ & 670 & $100 \%$ & 630 & $94 \%$ \\
\hline & 2,616 & 2,300 & $88 \%$ & 2,300 & $88 \%$ & 2,200 & $84 \%$ \\
\hline \multirow[t]{4}{*}{ Mobile } & 20.1 & 15 & $75 \%$ & 16.1 & $80 \%$ & 15.2 & $76 \%$ \\
\hline & 673 & $N D^{(b)}$ & - & 570 & $85 \%$ & 590 & $88 \%$ \\
\hline & $2,616^{(\mathrm{c})}$ & 2,048 & $78 \%$ & 2,073 & $79 \%$ & 2,036 & $78 \%$ \\
\hline & $2,616^{(d)}$ & 1,997 & $76 \%$ & 1,862 & $71 \%^{(a)}$ & 2,232 & $85 \%$ \\
\hline \multicolumn{8}{|c|}{ Chloroform } \\
\hline St. Louis & 20.4 & 23 & $113 \%$ & 24 & $118 \%$ & 25 & $122 \%$ \\
\hline WSCF & 20.4 & 15 & $74 \%^{(a)}$ & 18 & $88 \%$ & 17 & $83 \%$ \\
\hline Mobile & 20.4 & 18.7 & $92 \%$ & 19.6 & $96 \%$ & 18.9 & $93 \%$ \\
\hline \multicolumn{8}{|c|}{ Trichloroethene } \\
\hline St. Louis & 12.6 & 13 & $103 \%$ & 14 & $111 \%$ & 14 & $111 \%$ \\
\hline WSCF & 12.6 & 7.2 & $57 \%^{(a)}$ & 8.4 & $67 \%^{(a)}$ & 9.1 & $72 \%^{(\mathrm{a})}$ \\
\hline Mobile & 12.6 & 10.5 & $83 \%$ & 11.2 & $89 \%$ & 10.6 & $84 \%$ \\
\hline \multicolumn{8}{|c|}{$\begin{array}{l}\text { (a) Recovery is outside the acceptance limits. } \\
\text { (b) Non-detected result. } \\
\text { (c) Samples were analyzed within } 2 \text { days of preparation. A fourth result of } 1,997 \mu \mathrm{g} / \mathrm{L} \text { ( } 76 \% \text { recovery) is not shown in the table. } \\
\text { (d) Samples were analyzed } 14 \text { days after preparation. }\end{array}$} \\
\hline
\end{tabular}


Table C.18. Percentage of Out-of-Limit Quality Control Results by Category, Severn Trent Laboratories (Richland and St. Louis)

\begin{tabular}{|l|c|c|c|c|c|c|c|}
\hline \multicolumn{1}{|c|}{ QC Parameter } & $\begin{array}{c}\text { General } \\
\text { Chemistry } \\
\text { Parameters }\end{array}$ & $\begin{array}{c}\text { Ammonia } \\
\text { and Anions }\end{array}$ & Metals & VOC & SVOC & $\begin{array}{c}\text { Radiological } \\
\text { Parameters }\end{array}$ & Total \\
\hline Method Blanks & 0.6 & 10.5 & 2.3 & 1.0 & 0.0 & 0.3 & 2.2 \\
\hline Lab Control Samples & 0.6 & 1.3 & 0.5 & 2.0 & 2.2 & 0.8 & 1.2 \\
\hline Matrix Spikes & 4.7 & 22.7 & 0.7 & 3.0 & 2.2 & 6.7 & 3.4 \\
\hline Matrix Duplicates & 2.2 & 1.4 & 0.2 & 1.5 & 13.1 & 1.4 & 1.8 \\
\hline Surrogates & - & - & - & 2.3 & 1.6 & - & 2.2 \\
\hline $\begin{array}{l}\text { QC = Quality control. } \\
\text { SVOC = Semivolatile organic compounds. } \\
\text { VOC = Volatile organic compounds. }\end{array}$
\end{tabular}


Table C.19. Method Blank Results, Severn Trent Laboratories (Richland and St. Louis)

\begin{tabular}{|c|c|c|c|}
\hline Constituent & Percent Out of Limit ${ }^{(\mathrm{a})}$ & Number of Analyses & $\begin{array}{c}\text { Concentration Range of } \\
\text { Out-of-Limit Results }\end{array}$ \\
\hline \multicolumn{4}{|c|}{ General Chemistry Parameters } \\
\hline Total General Chemistry Parameters & 0.6 & 315 & - \\
\hline Conductivity & 33.3 & 6 & $0.5-0.8 \mu \mathrm{S} / \mathrm{cm}$ \\
\hline \multicolumn{4}{|c|}{ Ammonia and Anions } \\
\hline Total Ammonia and Anions & 10.5 & 1,209 & - \\
\hline Bromide & 14.3 & 7 & $0.081 \mathrm{mg} / \mathrm{L}$ \\
\hline Chloride & 47.5 & 223 & $0.042-0.19 \mathrm{mg} / \mathrm{L}$ \\
\hline Fluoride & 0.5 & 222 & $0.056 \mathrm{mg} / \mathrm{L}$ \\
\hline Nitrogen in nitrate & 0.4 & 223 & $0.035 \mathrm{mg} / \mathrm{L}$ \\
\hline Nitrogen in nitrite & 0.5 & 222 & $0.014 \mathrm{mg} / \mathrm{L}$ \\
\hline Phosphate & 11.8 & 17 & $0.17-0.21 \mathrm{mg} / \mathrm{L}$ \\
\hline Sulfate & 6.7 & 223 & $0.13-0.4 \mathrm{mg} / \mathrm{L}$ \\
\hline \multicolumn{4}{|c|}{ Metals } \\
\hline Total Metals & 2.3 & 3,838 & - \\
\hline Aluminum & 18.9 & 90 & $33.4-99.9 \mu \mathrm{g} / \mathrm{L}$ \\
\hline Arsenic & 5.0 & 60 & $0.65-4.5 \mu \mathrm{g} / \mathrm{L}$ \\
\hline Barium & 2.5 & 199 & $0.72-3.0 \mu \mathrm{g} / \mathrm{L}$ \\
\hline Beryllium & 2.0 & 197 & $0.57-7.7 \mu \mathrm{g} / \mathrm{L}$ \\
\hline Bismuth & 16.7 & 6 & $82.4 \mu \mathrm{g} / \mathrm{L}$ \\
\hline Calcium & 12.8 & 195 & $22.9-234 \mu \mathrm{g} / \mathrm{L}$ \\
\hline Iron & 0.5 & 199 & $84.1 \mu \mathrm{g} / \mathrm{L}$ \\
\hline Manganese & 0.5 & 198 & $1.7 \mu \mathrm{g} / \mathrm{L}$ \\
\hline Mercury & 4.0 & 25 & $0.2 \mu \mathrm{g} / \mathrm{L}$ \\
\hline Sodium & 1.5 & 200 & $225-1,060 \mu \mathrm{g} / \mathrm{L}$ \\
\hline Strontium (elemental) & 0.5 & 200 & $1.3 \mu \mathrm{g} / \mathrm{L}$ \\
\hline Zinc & 14.1 & 192 & $2.5-12.4 \mu \mathrm{g} / \mathrm{L}$ \\
\hline \multicolumn{4}{|c|}{ Volatile Organic Compounds } \\
\hline Total Volatile Organic Compounds & 1.0 & 3,641 & - \\
\hline 1,4-Dioxane & 0.9 & 115 & $30 \mu \mathrm{g} / \mathrm{L}$ \\
\hline Acetone $^{(b)}$ & 0.9 & 116 & $1.2 \mu \mathrm{g} / \mathrm{L}$ \\
\hline Acetonitrile & 5.3 & 19 & $11 \mu \mathrm{g} / \mathrm{L}$ \\
\hline Chlorobenzene & 5.3 & 19 & $0.11 \mu \mathrm{g} / \mathrm{L}$ \\
\hline Methylene chloride $\mathrm{e}^{(b)}$ & 26.7 & 116 & $0.51-2.7 \mu \mathrm{g} / \mathrm{L}$ \\
\hline Trichloroethene & 0.9 & 115 & $0.61 \mu \mathrm{g} / \mathrm{L}$ \\
\hline Xylenes (total) & 1.7 & 116 & $1.0-1.2 \mu \mathrm{g} / \mathrm{L}$ \\
\hline \multicolumn{4}{|c|}{ Semivolatile Organic Compounds } \\
\hline Total Semivolatile Organic Compounds & 0.0 & 1,083 & - \\
\hline \multicolumn{4}{|c|}{ Radiological Parameters } \\
\hline Total Radiochemistry Parameters & 0.3 & 1,963 & - \\
\hline Carbon-14 & 5.9 & 17 & $25.6 \mathrm{pCi} / \mathrm{L}$ \\
\hline Gross beta & 0.9 & 110 & $9.35 \mathrm{pCi} / \mathrm{L}$ \\
\hline Potassium-40 & 1.1 & 90 & $97.4 \mathrm{pCi} / \mathrm{L}$ \\
\hline Uranium & 1.7 & 121 & $0.257-0.378 \mu \mathrm{g} / \mathrm{L}$ \\
\hline
\end{tabular}


Table C.20. Laboratory Control Samples, Severn Trent Laboratories (Richland and St. Louis)

\begin{tabular}{|c|c|c|}
\hline Constituent & Percent Out of Limit & Number of Analyses \\
\hline \multicolumn{3}{|c|}{ General Chemistry Parameters } \\
\hline Total General Chemistry Parameters & 0.6 & 314 \\
\hline Total organic carbon & 2.9 & 70 \\
\hline \multicolumn{3}{|c|}{ Ammonia and Anions } \\
\hline Total Ammonia and Anions & 1.3 & 1,209 \\
\hline Chloride & 0.9 & 223 \\
\hline Fluoride & 0.5 & 222 \\
\hline Nitrogen in nitrate & 0.5 & 223 \\
\hline Nitrogen in nitrite & 4.1 & 222 \\
\hline Phosphate & 11.8 & 17 \\
\hline Sulfate & 0.4 & 223 \\
\hline \multicolumn{3}{|c|}{ Metals } \\
\hline Total Metals & 0.5 & 3,835 \\
\hline Aluminum & 2.2 & 90 \\
\hline Arsenic & 1.7 & 60 \\
\hline Barium & 1.5 & 199 \\
\hline Hexavalent chromium & 2.3 & 44 \\
\hline Potassium & 3.5 & 198 \\
\hline Strontium (elemental) & 2.0 & 199 \\
\hline \multicolumn{3}{|c|}{ Volatile Organic Compounds } \\
\hline Total Volatile Organic Compounds & 2.0 & 3,400 \\
\hline 1,1,1-Trichloroethane & 3.4 & 117 \\
\hline 1,1-Dichloroethene & 1.7 & 116 \\
\hline 1,2-Dichloroethane & 0.9 & 117 \\
\hline 1,4-Dichlorobenzene & 2.5 & 118 \\
\hline 1,4-Dioxane & 4.7 & 43 \\
\hline 1-Butanol & 11.6 & 43 \\
\hline 2-Butanone & 0.9 & 117 \\
\hline Acetone & 2.6 & 117 \\
\hline Acrolein & 37.5 & 8 \\
\hline Allyl chloride & 8.0 & 25 \\
\hline Benzene & 1.7 & 117 \\
\hline Bromoform & 8.0 & 25 \\
\hline Bromomethane & 16.0 & 25 \\
\hline Carbon disulfide & 5.1 & 117 \\
\hline Carbon tetrachloride & 2.4 & 126 \\
\hline cis-1,2-Dichloroethene & 0.8 & 118 \\
\hline cis-1,3-Dichloropropene & 8.0 & 25 \\
\hline Cyclohexanone & 16.7 & 6 \\
\hline Ethylbenzene & 0.9 & 117 \\
\hline Methylene chloride & 0.9 & 117 \\
\hline Styrene & 8.0 & 25 \\
\hline
\end{tabular}


Table C.20. (contd)

\begin{tabular}{|c|c|c|}
\hline Constituent & Percent Out of Limit & Number of Analyses \\
\hline Tetrachloroethene & 7.7 & 117 \\
\hline Toluene & 0.9 & 117 \\
\hline trans-1,2-Dichloroethene & 2.6 & 117 \\
\hline trans-1,3-Dichloropropene & 4.0 & 25 \\
\hline trans-1,4-Dichloro-2-butene & 4.0 & 25 \\
\hline Trichloroethene & 2.6 & 116 \\
\hline \multicolumn{3}{|c|}{ Semivolatile Organic Compounds } \\
\hline Total Semivolatile Organic Compounds & 2.2 & 858 \\
\hline 2-(2,4-Dichlorophenoxy)propionic acid & 50.0 & 2 \\
\hline 2,4,5-Trichlorophenol & 3.3 & 30 \\
\hline 2,4-Dichlorophenol & 2.6 & 39 \\
\hline 2,4-Dimethylphenol & 3.3 & 30 \\
\hline 2,4-Dinitrophenol & 3.2 & 31 \\
\hline 2,6-Dichlorophenol & 3.7 & 27 \\
\hline 2-Chloronaphthalene & 100.0 & 1 \\
\hline 2-Chlorophenol & 3.3 & 30 \\
\hline 2-Methylphenol & 2.6 & 39 \\
\hline 2-Nitrophenol & 2.6 & 39 \\
\hline 3-+4-Methylphenol & 3.0 & 33 \\
\hline 4-Chloro-3-methylphenol & 3.3 & 30 \\
\hline Dicamba & 50.0 & 2 \\
\hline Heptachlor & 25.0 & 4 \\
\hline Hexachlorobutadiene & 11.1 & 9 \\
\hline Oil and grease & 50.0 & 4 \\
\hline Pentachlorophenol & 2.6 & 39 \\
\hline Phenol & 2.3 & 43 \\
\hline \multicolumn{3}{|c|}{ Radiological Parameters } \\
\hline Total Radiochemistry Parameters & 0.8 & 1,431 \\
\hline Gross alpha & 1.8 & 112 \\
\hline Gross beta & 0.9 & 112 \\
\hline lodine-129 & 2.9 & 103 \\
\hline Plutonium-239/240 & 9.1 & 22 \\
\hline Technetium-99 & 1.4 & 140 \\
\hline Uranium & 0.4 & 242 \\
\hline Uranium-235 & 50.0 & 2 \\
\hline
\end{tabular}


Table C.21. Matrix Spikes and Matrix Spike Duplicates, Severn Trent Laboratories (Richland and St. Louis)

\begin{tabular}{|c|c|c|}
\hline Constituent & Percent Out of Limit & Number of Analyses \\
\hline \multicolumn{3}{|c|}{ General Chemistry Parameters } \\
\hline Total General Chemistry Parameters & 4.7 & 407 \\
\hline Alkalinity & 2.4 & 124 \\
\hline Chemical oxygen demand & 21.4 & 14 \\
\hline Conductivity & 12.5 & 8 \\
\hline Total organic carbon & 4.4 & 136 \\
\hline Total organic halides & 4.8 & 125 \\
\hline \multicolumn{3}{|c|}{ Ammonia and Anions } \\
\hline Total Ammonia and Anions & 22.7 & 1,425 \\
\hline Chloride & 16.0 & 263 \\
\hline Cyanide & 37.1 & 62 \\
\hline Fluoride & 15.4 & 260 \\
\hline Nitrogen in ammonia & 35.7 & 28 \\
\hline Nitrogen in nitrate & 16.0 & 263 \\
\hline Nitrogen in nitrite & 49.8 & 263 \\
\hline Phosphate & 46.7 & 15 \\
\hline Sulfate & 10.6 & 263 \\
\hline \multicolumn{3}{|c|}{ Metals } \\
\hline Total Metals & 0.7 & 9,159 \\
\hline Aluminum & 1.4 & 220 \\
\hline Cadmium & 1.7 & 476 \\
\hline Calcium & 1.9 & 476 \\
\hline Chromium & 2.1 & 478 \\
\hline Copper & 0.4 & 476 \\
\hline Hexavalent chromium & 1.1 & 93 \\
\hline Iron & 1.5 & 474 \\
\hline Magnesium & 0.4 & 476 \\
\hline Manganese & 0.8 & 474 \\
\hline Potassium & 0.6 & 476 \\
\hline Silver & 0.6 & 476 \\
\hline Sodium & 2.7 & 476 \\
\hline Strontium (elemental) & 0.4 & 476 \\
\hline \multicolumn{3}{|c|}{ Volatile Organic Compounds } \\
\hline Total Volatile Organic Compounds & 3.0 & 7,883 \\
\hline 1,1,1-Trichloroethane & 4.4 & 275 \\
\hline 1,1-Dichloroethane & 2.2 & 275 \\
\hline 1,1-Dichloroethene & 4.0 & 273 \\
\hline 1,2-Dibromo-3-chloropropane & 1.8 & 56 \\
\hline 1,2-Dichloroethane & 2.2 & 275 \\
\hline 1,4-Dichlorobenzene & 0.7 & 281 \\
\hline 1,4-Dioxane & 5.2 & 97 \\
\hline 1-Butanol & 7.2 & 97 \\
\hline 2-Butanone & 2.5 & 275 \\
\hline 2-Chloro-1,3-butadiene & 5.6 & 18 \\
\hline
\end{tabular}


Table C.21. (contd)

\begin{tabular}{|c|c|c|}
\hline Constituent & Percent Out of Limit & Number of Analyses \\
\hline 2-Hexanone & 1.8 & 56 \\
\hline 4-Methyl-2-pentanone & 1.5 & 275 \\
\hline Acetone & 11.3 & 275 \\
\hline Acrolein & 22.2 & 18 \\
\hline Allyl chloride & 3.6 & 56 \\
\hline Benzene & 2.9 & 275 \\
\hline Bromomethane & 8.9 & 56 \\
\hline Carbon disulfide & 8.7 & 275 \\
\hline Carbon tetrachloride & 7.1 & 239 \\
\hline Chloroethane & 1.8 & 56 \\
\hline Chloroform & 2.9 & 273 \\
\hline Chloromethane & 7.1 & 56 \\
\hline cis-1,2-Dichloroethene & 2.6 & 269 \\
\hline cis-1,3-Dichloropropene & 3.6 & 56 \\
\hline Dichlorodifluoromethane & 3.6 & 56 \\
\hline Ethyl cyanide & 2.1 & 97 \\
\hline Ethyl methacrylate & 3.6 & 56 \\
\hline Ethylbenzene & 2.2 & 275 \\
\hline lodomethane & 27.8 & 18 \\
\hline Styrene & 3.6 & 56 \\
\hline Tetrachloroethene & 2.2 & 275 \\
\hline Tetrahydrofuran & 2.1 & 97 \\
\hline Toluene & 2.2 & 275 \\
\hline TPH Gasoline & 3.3 & 30 \\
\hline trans-1,2-Dichloroethene & 4.4 & 275 \\
\hline trans-1,3-Dichloropropene & 3.6 & 56 \\
\hline trans-1,4-Dichloro-2-butene & 7.1 & 56 \\
\hline Trichloroethene & 0.7 & 271 \\
\hline Vinyl acetate & 27.8 & 18 \\
\hline Vinyl chloride & 1.1 & 275 \\
\hline \multicolumn{3}{|c|}{ Semivolatile Organic Compounds } \\
\hline Total Semivolatile Organic Compounds & 2.2 & 1,729 \\
\hline 2-(2,4-Dichlorophenoxy)propionic acid & 25.0 & 4 \\
\hline 2,4,5-Trichlorophenol & 3.1 & 64 \\
\hline 2,4,6-Trichlorophenol & 3.1 & 64 \\
\hline 2,4-Dichlorophenol & 2.4 & 82 \\
\hline 2,4-Dimethylphenol & 6.3 & 64 \\
\hline 2,4-Dinitrophenol & 1.6 & 64 \\
\hline 2,6-Dichlorophenol & 5.2 & 58 \\
\hline 2-Chlorophenol & 3.1 & 64 \\
\hline 2-Methylphenol & 2.4 & 82 \\
\hline 2-Nitrophenol & 1.2 & 82 \\
\hline 3-+4-Methylphenol & 2.9 & 70 \\
\hline
\end{tabular}


Table C.21. (contd)

\begin{tabular}{|l|c|c|}
\hline \multicolumn{1}{|c|}{ Constituent } & Percent Out of Limit & Number of Analyses \\
\hline 4-Chloro-3-methylphenol & 3.1 & 64 \\
\hline 4-Nitrophenol & 1.6 & 4 \\
\hline Aroclor 1016 & 25.0 & 4 \\
\hline Aroclor 1260 & 25.0 & 4 \\
\hline Endosulfan I & 50.0 & 4 \\
\hline Endosulfan II & 50.0 & 4 \\
\hline Heptachlor & 25.0 & 4 \\
\hline Heptachlor epoxide & 50.0 & 6 \\
\hline Oil and grease & 16.7 & 82 \\
\hline Pentachlorophenol & 1.2 & 86 \\
\hline Phenol & 2.3 & 114 \\
\hline
\end{tabular}


Table C.22. Matrix Duplicates, Severn Trent Laboratories (Richland and St. Louis)

\begin{tabular}{|c|c|c|}
\hline Constituent & Percent Out of Limit & Number of Analyses \\
\hline \multicolumn{3}{|c|}{ General Chemistry Parameters } \\
\hline Total General Chemistry Parameters & 2.2 & 599 \\
\hline Alkalinity & 0.4 & 252 \\
\hline Chemical oxygen demand & 5.0 & 20 \\
\hline Coliform & 16.7 & 18 \\
\hline Total dissolved solids & 50.0 & 4 \\
\hline Total organic carbon & 0.6 & 178 \\
\hline Total organic halides & 4.4 & 114 \\
\hline \multicolumn{3}{|c|}{ Ammonia and Anions } \\
\hline Total Ammonia and Anions & 1.4 & 2,536 \\
\hline Bromide & 9.1 & 11 \\
\hline Chloride & 1.5 & 479 \\
\hline Cyanide & 1.6 & 61 \\
\hline Fluoride & 2.1 & 474 \\
\hline Nitrogen in ammonia & 2.2 & 45 \\
\hline Nitrogen in nitrate & 0.4 & 478 \\
\hline Nitrogen in nitrite & 2.3 & 478 \\
\hline Sulfate & 0.4 & 475 \\
\hline \multicolumn{3}{|c|}{ Metals } \\
\hline Total Metals & 0.2 & 4,625 \\
\hline Antimony & 0.8 & 236 \\
\hline Hexavalent chromium & 5.4 & 92 \\
\hline Iron & 0.4 & 237 \\
\hline Mercury & 3.3 & 30 \\
\hline Potassium & 0.4 & 238 \\
\hline \multicolumn{3}{|c|}{ Volatile Organic Compounds } \\
\hline Total Volatile Organic Compounds & 1.5 & 6,278 \\
\hline 1,1-Dichloroethane & 0.5 & 219 \\
\hline 1,2,3-Trichlorobenzene & 11.1 & 9 \\
\hline 1,2-Dibromo-3-chloropropane & 2.2 & 45 \\
\hline 1,2-Dibromoethane & 2.3 & 44 \\
\hline 1,2-Dichloroethane & 0.5 & 219 \\
\hline 1,4-Dioxane & 14.8 & 88 \\
\hline 1-Butanol & 18.2 & 88 \\
\hline 2-Butanone & 5.0 & 220 \\
\hline 2-Hexanone & 2.2 & 45 \\
\hline 4-Methyl-2-pentanone & 4.1 & 220 \\
\hline Acetone & 6.9 & 217 \\
\hline Bromomethane & 6.7 & 45 \\
\hline Carbon disulfide & 0.5 & 219 \\
\hline Carbon tetrachloride & 1.0 & 208 \\
\hline Chloromethane & 2.2 & 45 \\
\hline Cyclohexanone & 11.1 & 9 \\
\hline
\end{tabular}


Table C.22. (contd)

\begin{tabular}{|c|c|c|}
\hline Constituent & Percent Out of Limit & Number of Analyses \\
\hline Methylene chloride & 0.9 & 220 \\
\hline Tetrahydrofuran & 2.3 & 88 \\
\hline trans-1,3-Dichloropropene & 4.5 & 44 \\
\hline trans-1,4-Dichloro-2-butene & 4.5 & 44 \\
\hline Vinyl chloride & 3.2 & 219 \\
\hline \multicolumn{3}{|c|}{ Semivolatile Organic Compounds } \\
\hline Total Semivolatile Organic Compounds & 13.1 & 919 \\
\hline 1,2,4-Trichlorobenzene & 8.3 & 12 \\
\hline 2,2-Dichloropropionic acid & 50.0 & 2 \\
\hline 2,2'-Oxybis(1-chloropropane) & 33.3 & 3 \\
\hline 2,3,4,6-Tetrachlorophenol & 13.8 & 29 \\
\hline 2,4,5-Trichlorophenol & 12.5 & 32 \\
\hline 2,4,6-Trichlorophenol & 9.4 & 32 \\
\hline 2,4-Dichlorophenol & 12.2 & 41 \\
\hline 2,4-Dimethylphenol & 12.5 & 32 \\
\hline 2,4-Dinitrophenol & 9.1 & 33 \\
\hline 2,4-Dinitrotoluene & 33.3 & 3 \\
\hline 2,6-Dichlorophenol & 13.8 & 29 \\
\hline 2,6-Dinitrotoluene & 33.3 & 3 \\
\hline 2-Chlorophenol & 15.6 & 32 \\
\hline 2-Methylnaphthalene & 33.3 & 3 \\
\hline 2-Methylphenol & 12.2 & 41 \\
\hline 2-Nitroaniline & 33.3 & 3 \\
\hline 2-Nitrophenol & 14.6 & 41 \\
\hline 2-secButyl-4,6-dinitrophenol & 3.2 & 31 \\
\hline 3,3'-Dichlorobenzidine & 33.3 & 3 \\
\hline 3-+4-Methylphenol & 11.4 & 35 \\
\hline 3-Nitroaniline & 33.3 & 3 \\
\hline 4.4'-DDT & 25.0 & 4 \\
\hline 4,6-Dinitro-2-methylphenol & 12.5 & 32 \\
\hline 4-Bromophenylphenyl ether & 33.3 & 3 \\
\hline 4-Chloro-3-methylphenol & 12.5 & 32 \\
\hline 4-Chloroaniline & 33.3 & 3 \\
\hline 4-Chlorophenylphenyl ether & 33.3 & 3 \\
\hline 4-Nitroaniline & 33.3 & 3 \\
\hline 4-Nitrophenol & 18.8 & 32 \\
\hline Acenaphthene & 33.3 & 3 \\
\hline Acenaphthylene & 33.3 & 3 \\
\hline Anthracene & 33.3 & 3 \\
\hline Aroclor 1016 & 50.0 & 2 \\
\hline Aroclor 1260 & 50.0 & 2 \\
\hline Benzo(a)anthracene & 33.3 & 3 \\
\hline Benzo(a)pyrene & 33.3 & 3 \\
\hline
\end{tabular}


Table C.22. (contd)

\begin{tabular}{|c|c|c|}
\hline Constituent & Percent Out of Limit & Number of Analyses \\
\hline Benzo(b)fluoranthene & 33.3 & 3 \\
\hline Benzo(ghi)perylene & 33.3 & 3 \\
\hline Benzo(k)fluoranthene & 33.3 & 3 \\
\hline bis(2-Chloroethoxy)methane & 33.3 & 3 \\
\hline bis(2-Chloroethyl) ether & 33.3 & 3 \\
\hline Chrysene & 33.3 & 3 \\
\hline Dibenz[a,h]anthracene & 33.3 & 3 \\
\hline Dibenzofuran & 33.3 & 3 \\
\hline Diethylphthalate & 33.3 & 3 \\
\hline Dimethylphthalate & 33.3 & 3 \\
\hline Di-n-butylphthalate & 33.3 & 3 \\
\hline Fluoranthene & 33.3 & 3 \\
\hline Fluorene & 33.3 & 3 \\
\hline Heptachlor & 25.0 & 4 \\
\hline Hexachlorobenzene & 33.3 & 3 \\
\hline Hexachlorobutadiene & 16.7 & 12 \\
\hline Hexachlorocyclopentadiene & 33.3 & 3 \\
\hline Hexachloroethane & 33.3 & 3 \\
\hline Indeno(1,2,3-cd)pyrene & 33.3 & 3 \\
\hline Isophorone & 33.3 & 3 \\
\hline Naphthalene & 9.5 & 21 \\
\hline Nitrobenzene & 33.3 & 3 \\
\hline N-Nitroso-di-n-dipropylamine & 33.3 & 3 \\
\hline N-Nitroso-diphenylamine & 33.3 & 3 \\
\hline Pentachlorophenol & 4.9 & 41 \\
\hline Phenanthrene & 33.3 & 3 \\
\hline Phenol & 17.4 & 46 \\
\hline \multicolumn{3}{|c|}{ Radiological Parameters } \\
\hline Total Radiochemistry Parameters & 1.4 & 1,816 \\
\hline Cobalt- 60 & 1.1 & 89 \\
\hline Gross alpha & 1.9 & 105 \\
\hline Gross beta & 4.5 & 111 \\
\hline lodine-129 & 8.4 & 95 \\
\hline Plutonium-239/240 & 10.5 & 19 \\
\hline Potassium-40 & 1.1 & 89 \\
\hline Tritium & 1.5 & 135 \\
\hline Uranium-235 & 17.6 & 17 \\
\hline Uranium-238 & 5.9 & 17 \\
\hline
\end{tabular}


Table C.23. Summary of Issue Resolution Forms Received from Severn Trent Laboratories (Richland and St. Louis) for FY 2006

\begin{tabular}{|l|c|c|}
\hline \multirow{2}{*}{\multicolumn{1}{|c|}{ Issue Category }} & \multicolumn{2}{|c|}{ Number of Analyses Impacted } \\
\cline { 2 - 3 } & $\begin{array}{c}\text { Prior to Receipt at the } \\
\text { Laboratory }\end{array}$ & $\begin{array}{c}\text { After Receipt at the } \\
\text { Laboratory }\end{array}$ \\
\hline Hold Time Missed & 70 & 39 \\
\hline Broken Bottles & 7 & 1 \\
\hline Missing Samples & & \\
\hline Temperature Deviation & 1 & \\
\hline pH Variance & 2 & 28 \\
\hline Bottle size/type (insufficient volume) & 1 & \\
\hline $\begin{array}{l}\text { Chain-of-Custody Forms } \\
\text { Incomplete/SDG Assignment }\end{array}$ & -- & \\
\hline Laboratory QC Out of Limits & -- & \\
\hline Analytical Preparation Deviations & -- & \\
\hline $\begin{array}{l}\text { Method Failures/Discontinued } \\
\text { Analyses }\end{array}$ & & \\
\hline $\begin{array}{l}\text { QC = Quality control. } \\
\text { SDG = Sample delivery group. }\end{array}$ & & \\
\hline
\end{tabular}


Table C.24. Results of DOECAP Audits

\begin{tabular}{|c|c|c|c|}
\hline Laboratory & Findings & Observations & Summary of Results \\
\hline $\begin{array}{l}\text { Severn Trent, Inc. } \\
\text { St. Louis, MO }\end{array}$ & 14 & 22 & $\begin{array}{l}\text { Findings related to insufficient implementation of the corrective } \\
\text { action process as required in the DOECAP QSAS, lack of a } \\
\text { defined process for identification of the root cause for missed PE } \\
\text { samples, procedural noncompliance to either SOPS or DOECAP } \\
\text { QSAS requirements, not calibrating pipettes prior to use, and lack } \\
\text { of current procedures to reflect lab practices. Observations were } \\
\text { related to inconsistent general laboratory practices related } \\
\text { primarily laboratory information system, training, and inadequate } \\
\text { procedures. }\end{array}$ \\
\hline $\begin{array}{l}\text { Eberline Services- } \\
\text { Richmond, CA }\end{array}$ & 2 & 11 & $\begin{array}{l}\text { Findings related to lack of compliance with the method blank } \\
\text { acceptance criteria as defined in the DOECAP QSAS and lack of } \\
\text { SOP to define management of the LIMS and communication of } \\
\text { hardware. Observations related to inconsistent laboratory } \\
\text { practices in the area of documentation, updating procedures with } \\
\text { current information, and tracking of samples from receipt to } \\
\text { disposal. }\end{array}$ \\
\hline $\begin{array}{l}\text { Lionville Laboratory, } \\
\text { Inc.-Lionville, PA }\end{array}$ & 5 & 5 & $\begin{array}{l}\text { Findings related to non compliance of SOPs to the requirements } \\
\text { in the latest version of SW-846, training records not being keep } \\
\text { current, insufficient monitoring of refrigerator and freezer } \\
\text { performance over non work days, missing write protection on } \\
\text { spreadsheets with formulas, and not maintaining the radiation } \\
\text { survey instrument calibration and the calibration records. } \\
\text { Observations related to inconsistent general practices within the } \\
\text { laboratory hazardous and radioactive material management. }\end{array}$ \\
\hline $\begin{array}{l}\text { SevernTrent, Inc. } \\
\text { Richland, WA }\end{array}$ & 8 & 5 & $\begin{array}{l}\text { Findings related to inconsistencies between the Laboratory } \\
\text { Quality Assurance Manual and the Corporate Quality Assurance } \\
\text { program to the requirements in the DOECAP QSAS, lack of } \\
\text { SOPs, and non compliance to SOPs. Observations related to } \\
\text { inconsistent general laboratory practices such as tracking of } \\
\text { samples to disposition, logbook review, incorrect and out of date } \\
\text { references being used, and general cleanliness of the hoods } \\
\text { being use to receive samples. }\end{array}$ \\
\hline $\begin{array}{l}\text { SevernTrent, Inc.- } \\
\text { Knoxville, TN }\end{array}$ & 6 & 2 & $\begin{array}{l}\text { Findings related to the inconsistency of the QA manual with the } \\
\text { elements in the QSAS, lack of documented training of personnel } \\
\text { to latest revision of SOPs, lack of daily verification of the } \\
\text { accuracy of mechanical volumetric dispensers, lack of a process } \\
\text { to generate and report EDDs to clients, lack of elements in Waste } \\
\text { Management Plan to track sample from receipt to disposal, and } \\
\text { lack of implementation of the Radioactive Inventory Program. } \\
\text { Observations were related to maintaining the independence of } \\
\text { the QA Manager and mislabeling a summa canister. }\end{array}$ \\
\hline \multicolumn{4}{|c|}{$\begin{array}{l}\text { DOECAP = Department of Energy Consolidated Assessment Program. } \\
\text { EDD = Electronic data deliverable. } \\
\text { LIMS = Laboratory Information Management System. } \\
\text { PE = Performance evaluation. } \\
\text { QA = Quality assurance. } \\
\text { QSAS = Quality Systems for Analytical Services. } \\
\text { SOP = Standard operating procedure. }\end{array}$} \\
\hline
\end{tabular}


Table C.25. Summary of Analytical Laboratory Detection/Quantitation Limits Determined from Field Blanks Data, Severn Trent Laboratories (Richland and St. Louis)

\begin{tabular}{|c|c|c|c|c|c|}
\hline Period $^{(a)}$ & $\begin{array}{c}\text { Number of } \\
\text { Samples }\end{array}$ & Mean & $\begin{array}{l}\text { Standard } \\
\text { Deviation }\end{array}$ & $\begin{array}{l}\text { Limit of } \\
\text { Detection }\end{array}$ & $\begin{array}{c}\text { Limit of } \\
\text { Quantitation }\end{array}$ \\
\hline \multicolumn{6}{|c|}{ Constituent: Total Organic Carbon, $\mu \mathrm{g} / \mathrm{L}$} \\
\hline $01 / 13 / 05-12 / 30 / 05$ & 75 & 419.7 & 277.7 & $830^{(\mathrm{c})}$ & $2,780^{(\mathrm{c})}$ \\
\hline 04/06/05 - 03/29/06 & $83^{(b)}$ & 376.9 & 273.7 & 820 & 2,740 \\
\hline 07/13/05 - 06/21/06 & $71^{(\mathrm{b})}$ & 415.9 & 292.9 & 880 & 2,930 \\
\hline 10/14/05 - 09/20/06 & $71^{(\mathrm{b})}$ & 344.2 & 269.9 & 810 & 2,700 \\
\hline Summary & $71^{(\mathrm{b})}$ & 344.2 & 269.9 & 810 & 2,700 \\
\hline \multicolumn{6}{|c|}{ Constituent: Total Organic Halides, $\mu g / L$} \\
\hline $01 / 13 / 05-12 / 21 / 05$ & $54^{(\mathrm{b})}$ & 3.17 & 3.05 & $9.2^{(\mathrm{c})}$ & $30.5^{(\mathrm{c})}$ \\
\hline 04/06/05 - 03/23/06 & $68^{(\mathrm{b})}$ & 3.01 & 3.06 & 9.2 & 30.6 \\
\hline 07/13/05 - 06/21/06 & $59^{(\mathrm{b})}$ & 2.46 & 2.97 & 8.9 & 29.7 \\
\hline $10 / 14 / 05-09 / 20 / 06$ & $59^{(\mathrm{b})}$ & 2.34 & 2.95 & 8.8 & 29.5 \\
\hline Summary & $59^{(\mathrm{b})}$ & 2.34 & 2.95 & 8.8 & 29.5 \\
\hline \multicolumn{6}{|c|}{ Constituent: Cesium-137, pCi/L } \\
\hline $11 / 17 / 05-12 / 02 / 05$ & 2 & -0.42 & 1.04 & $3.11^{(\mathrm{c})}$ & $10.36^{(\mathrm{c})}$ \\
\hline $01 / 26 / 06-03 / 21 / 06$ & 6 & 0.05 & 1.59 & 4.76 & 15.86 \\
\hline 04/13/06 - 08/07/06 & 6 & 0.18 & 0.87 & 2.61 & 8.71 \\
\hline Summary & 14 & 0.04 & 1.26 & 3.78 & 12.59 \\
\hline \multicolumn{6}{|c|}{ Constituent: Cobalt-60, pCi/L } \\
\hline $11 / 17 / 05-12 / 02 / 05$ & 2 & 0.23 & 0.80 & $2.40^{(\mathrm{c})}$ & $8.00^{(\mathrm{c})}$ \\
\hline 01/26/06 - 03/21/06 & 6 & 0.01 & 0.40 & 1.21 & 4.02 \\
\hline 04/13/06 - 08/07/06 & 6 & 0.08 & 1.38 & 4.13 & 13.77 \\
\hline Summary & 14 & 0.07 & 1.00 & 2.99 & 9.97 \\
\hline \multicolumn{6}{|c|}{ Constituent: Europium-152, pCi/L } \\
\hline $11 / 17 / 05-12 / 02 / 05$ & 2 & -0.87 & 5.92 & $17.76^{(\mathrm{c})}$ & $59.18^{(\mathrm{c})}$ \\
\hline 01/26/06 - 03/21/06 & 6 & -0.49 & 1.97 & 5.91 & 19.70 \\
\hline 04/13/06 - 08/07/06 & 6 & 0.61 & 1.65 & 4.95 & 16.50 \\
\hline Summary & 14 & -0.07 & 2.49 & 7.46 & 24.87 \\
\hline \multicolumn{6}{|c|}{ Constituent: Europium-154, pCi/L } \\
\hline $11 / 17 / 05-12 / 02 / 05$ & 2 & -3.59 & 1.63 & $4.90^{(\mathrm{c})}$ & $16.33^{(\mathrm{c})}$ \\
\hline $01 / 26 / 06-03 / 21 / 06$ & 6 & 0.10 & 3.72 & 11.15 & 37.16 \\
\hline $04 / 13 / 06-08 / 07 / 06$ & 6 & 0.43 & 1.93 & 5.79 & 19.30 \\
\hline Summary & 14 & -0.28 & 2.87 & 8.60 & 28.65 \\
\hline \multicolumn{6}{|c|}{ Constituent: Europium-155, pCi/L } \\
\hline $11 / 17 / 05-12 / 02 / 05$ & 2 & 2.35 & 0.13 & $0.38^{(\mathrm{c})}$ & $1.27^{(\mathrm{c})}$ \\
\hline 01/26/06 - 03/21/06 & 6 & 1.34 & 2.30 & 6.89 & 22.97 \\
\hline 04/13/06 - 08/07/06 & 6 & -0.51 & 0.91 & 2.73 & 9.10 \\
\hline Summary & 14 & 0.69 & 1.67 & 5.00 & 16.66 \\
\hline \multicolumn{6}{|c|}{ Constituent: Gross Alpha, pCi/L } \\
\hline $10 / 14 / 05-12 / 30 / 05$ & 14 & 0.13 & 0.47 & $1.41^{(\mathrm{c})}$ & $4.71^{(\mathrm{c})}$ \\
\hline 01/05/06 - 03/31/06 & 11 & 0.06 & 0.10 & 0.29 & 0.98 \\
\hline 04/13/06 - 06/13/06 & 6 & 0.06 & 0.20 & 0.60 & 2.00 \\
\hline 07/11/06 - 09/13/06 & 5 & 0.25 & 0.32 & 0.97 & 3.23 \\
\hline Summary & 36 & 0.11 & 0.34 & 1.01 & 3.35 \\
\hline
\end{tabular}


Table C.25. (contd)

\begin{tabular}{|c|c|c|c|c|c|}
\hline Period $^{(\mathrm{a})}$ & $\begin{array}{c}\text { Number of } \\
\text { Samples }\end{array}$ & Mean & $\begin{array}{l}\text { Standard } \\
\text { Deviation }\end{array}$ & $\begin{array}{l}\text { Limit of } \\
\text { Detection }\end{array}$ & $\begin{array}{c}\text { Limit of } \\
\text { Quantitation }\end{array}$ \\
\hline \multicolumn{6}{|c|}{ Constituent: Gross Beta, pCi/L } \\
\hline $10 / 14 / 05-12 / 30 / 05$ & 14 & 1.04 & 0.81 & $2.43^{(\mathrm{c})}$ & $8.08^{(\mathrm{c})}$ \\
\hline 01/05/06 - 03/31/06 & $13^{(b)}$ & 0.69 & 0.60 & 1.79 & 5.96 \\
\hline 04/13/06 - 06/13/06 & 7 & 0.87 & 0.75 & 2.25 & 7.50 \\
\hline 07/11/06 - 09/13/06 & 5 & 1.10 & 0.59 & 1.77 & 5.91 \\
\hline Summary & $39^{(\mathrm{b})}$ & 0.90 & 0.71 & 2.12 & 7.08 \\
\hline \multicolumn{6}{|c|}{ Constituent: lodine-129, pCi/L } \\
\hline $10 / 19 / 05-12 / 16 / 05$ & 4 & -0.02 & 0.06 & $0.17^{(\mathrm{c})}$ & $0.57^{(\mathrm{c})}$ \\
\hline 01/18/06 - 07/21/06 & 9 & -0.05 & 0.12 & 0.37 & 1.22 \\
\hline Summary & 13 & -0.04 & 0.11 & 0.32 & 1.08 \\
\hline \multicolumn{6}{|c|}{ Constituent: Strontium-90, pCi/L } \\
\hline $12 / 02 / 05-03 / 31 / 06$ & 5 & 0.02 & 0.13 & $0.39^{(\mathrm{c})}$ & $1.31^{(\mathrm{c})}$ \\
\hline 04/13/06 - 06/13/06 & 4 & 0.03 & 0.14 & 0.42 & 1.39 \\
\hline Summary & 9 & 0.02 & 0.13 & 0.40 & 1.34 \\
\hline \multicolumn{6}{|c|}{ Constituent: Technetium-99, $\mathrm{pCi} / \mathrm{L}$} \\
\hline $10 / 19 / 05-12 / 30 / 05$ & 7 & 9.12 & 6.94 & $20.8^{(c)}$ & $69.4^{(\mathrm{c})}$ \\
\hline 01/18/06 - 03/23/06 & 8 & -1.15 & 3.76 & 11.3 & 37.6 \\
\hline 04/13/06 - 05/08/06 & 3 & 2.36 & 5.77 & 17.3 & 57.6 \\
\hline 07/11/06 - 08/07/06 & 4 & 3.61 & 2.18 & 6.5 & 21.8 \\
\hline Summary & 22 & 3.46 & 5.10 & 15.3 & 51.0 \\
\hline \multicolumn{6}{|c|}{ Constituent: Technetium-99, Low-Level Method, pCi/L } \\
\hline $11 / 28 / 05-05 / 15 / 06$ & 2 & 2.32 & 1.44 & $4.3^{(\mathrm{c})}$ & $14.4^{(\mathrm{c})}$ \\
\hline \multicolumn{6}{|c|}{ Constituent: Tritium, (pCi/L) } \\
\hline $10 / 14 / 05-12 / 30 / 05$ & 14 & 88.8 & 131.0 & $393^{(c)}$ & $1,310^{(\mathrm{c})}$ \\
\hline 01/05/06 - 03/31/06 & 11 & 39.6 & 135.1 & 405 & 1,351 \\
\hline 04/13/06 - 06/23/06 & 8 & 25.1 & 54.7 & 164 & 547 \\
\hline 07/11/06 - 09/13/06 & 7 & 26.1 & 102.6 & 308 & 1,026 \\
\hline Summary & 40 & 51.6 & 116.6 & 350 & 1,166 \\
\hline \multicolumn{6}{|c|}{ Constituent: Tritium, Low-Level Method, pCi/L } \\
\hline 01/26/06 - 07/24/06 & 2 & 57.4 & 23.4 & $70^{(\mathrm{c})}$ & $234^{(\mathrm{c})}$ \\
\hline \multicolumn{6}{|c|}{ Constituent: Uranium, $\mu \mathrm{g} / \mathrm{L}$} \\
\hline $10 / 19 / 05-12 / 30 / 05$ & 7 & -0.002 & 0.040 & $0.118^{(\mathrm{d})}$ & $0.399^{(d)}$ \\
\hline $01 / 18 / 06-03 / 31 / 06$ & 8 & -0.011 & 0.011 & 0.022 & 0.097 \\
\hline $04 / 13 / 06-06 / 27 / 06$ & $7^{(\mathrm{b})}$ & 0.015 & 0.010 & 0.044 & 0.111 \\
\hline 07/11/06 - 08/10/06 & 4 & 0.010 & 0.003 & 0.018 & 0.037 \\
\hline Summary & $26^{(\mathrm{b})}$ & 0.002 & 0.022 & 0.069 & 0.225 \\
\hline \multicolumn{6}{|c|}{$\begin{array}{l}\text { (a) Time period covered for total organic carbon and total organic halides is a moving average of four quarters. } \\
\text { (b) Excluded outliers. } \\
\text { (c) Limit of detection (blank corrected) equals } 3 \text { times the blank standard deviation; limit of quantitation (blank corrected) } \\
\text { equals } 10 \text { times the blank standard deviation. Numbers are rounded. } \\
\text { (d) Limit of detection equals the mean blank concentration plus } 3 \text { standard deviations; limit of quantitation equals the mean } \\
\text { blank concentration plus } 10 \text { standard deviations. Numbers are rounded. }\end{array}$} \\
\hline
\end{tabular}


Table C.26. Summary of Detection and Quantitation Limits, Severn Trent Laboratory (St. Louis)

\begin{tabular}{|c|c|c|c|c|c|c|c|c|}
\hline Method & Constituent & $\begin{array}{c}\text { Initial MDL }^{(\mathrm{a})} \\
(\mu \mathrm{g} / \mathrm{L})\end{array}$ & $\begin{array}{c}\text { Initial LOD } \\
(\mu \mathrm{g} / \mathrm{L})\end{array}$ & $\begin{array}{c}\text { Initial LOQ } \\
(\mu \mathrm{g} / \mathrm{L})\end{array}$ & $\begin{array}{l}\text { Ending Values, } \\
\text { Effective Date }\end{array}$ & $\begin{array}{c}\text { Ending } \mathrm{MDL}^{(a)} \\
(\mu \mathrm{g} / \mathrm{L})\end{array}$ & $\begin{array}{c}\text { Ending LOD } \\
(\mu \mathrm{g} / \mathrm{L})\end{array}$ & $\begin{array}{c}\text { Ending LOQ } \\
(\mu \mathrm{g} / \mathrm{L})\end{array}$ \\
\hline \multicolumn{9}{|c|}{ General Chemical Parameters } \\
\hline EPA-600/4-81-004, 120.1 & Conductivity (b) & 0.22 & 0.30 & 0.99 & $01 / 04 / 06$ & 0.2 & 0.27 & 0.90 \\
\hline EPA-600/4-81-004, 160.1 & Total dissolved solids & 3,600 & 4,861 & 16,211 & & & & \\
\hline EPA-600/4-81-004, 310.1 & Alkalinity & 1,800 & 2,431 & 8,106 & $12 / 01 / 05$ & 2,500 & 3,376 & 11,258 \\
\hline EPA-600/4-81-004, 410.4 & Chemical oxygen demand & 7,100 & 9,587 & 31,973 & $12 / 02 / 05$ & 9,200 & 12,423 & 41,429 \\
\hline EPA-600/4-81-004, 413.1 & Oil and grease & 5,000 & 6,752 & 22,516 & $03 / 21 / 06$ & 1,800 & 2,431 & 8,106 \\
\hline \multicolumn{9}{|c|}{ Ammonia and Anions } \\
\hline EPA-600/4-81-004, 300.0 $0^{(c)}$ & Bromide & 26 & 35 & 117 & & & & \\
\hline EPA-600/4-81-004, 300.0 $0^{(c)}$ & Chloride & 25 & 34 & 113 & $04 / 28 / 06$ & 23 & 31 & 104 \\
\hline EPA-600/4-81-004, 300.0 $0^{(c)}$ & Fluoride & 5.1 & 7 & 23 & $04 / 28 / 06$ & 20 & 27 & 90 \\
\hline EPA-600/4-81-004, 300.0 $0^{(c)}$ & Nitrate & 44 & 59 & 198 & $04 / 28 / 06$ & 18 & 24 & 81 \\
\hline EPA-600/4-81-004, 300.0 $0^{(c)}$ & Nitrite & 20 & 27 & 90 & $04 / 28 / 06$ & 13 & 18 & 59 \\
\hline EPA-600/4-81-004, 300.0 $0^{(c)}$ & Phosphate & 19 & 26 & 86 & $04 / 28 / 06$ & 100 & 135 & 450 \\
\hline EPA-600/4-81-004, 300.0 $0^{(c)}$ & Sulfate & 61 & 82 & 275 & $04 / 28 / 06$ & 50 & 68 & 225 \\
\hline EPA-600/4-81-004, 350.1 & Ammonia & 7.05 & 9.5 & 31.7 & $11 / 29 / 05$ & 6.69 & 9.0 & 30.1 \\
\hline SW-846, 9012 & Cyanide & 2 & 2.7 & 9.0 & 01/20/06 & 2.4 & 3.2 & 10.8 \\
\hline \multicolumn{9}{|c|}{ Metals } \\
\hline SW-846, 6010 & Aluminum & 16.6 & 22.4 & 74.8 & $01 / 31 / 06$ & 94.8 & 128 & 427 \\
\hline SW-846, 6010 & Antimony & 23 & 31 & 104 & $02 / 01 / 06$ & 44.8 & 60.5 & 201.7 \\
\hline SW-846, 6010 & Barium $^{(d)}$ & 0.32 & 0.4 & 1.4 & $04 / 27 / 06$ & 5 & 6.8 & 22.5 \\
\hline SW-846, 6010 & Beryllium & 0.18 & 0.24 & 0.81 & 01/31/06 & 0.51 & 0.69 & 2.30 \\
\hline SW-846, 6010 & Cadmium & 0.86 & 1 & 4 & 01/31/06 & 2.3 & 3.1 & 10.4 \\
\hline SW-846, 6010 & Calcium $^{(\mathrm{d})}$ & 10.7 & 14 & 48 & $04 / 27 / 06$ & 36 & 49 & 162 \\
\hline SW-846, 6010 & Chromium & 1.9 & 3 & 9 & 01/31/06 & 3.1 & 4.2 & 14.0 \\
\hline SW-846, 6010 & Cobalt ${ }^{(\mathrm{d})}$ & 1.7 & 2 & 8 & $04 / 27 / 06$ & 5 & 6.8 & 22.5 \\
\hline SW-846, 6010 & Copper & 4.3 & 5.8 & 19.4 & 01/31/06 & 2.8 & 3.8 & 12.6 \\
\hline SW-846, 6010 & Iron & 12.6 & 17.0 & 56.7 & 01/31/06 & 25 & 34 & 113 \\
\hline SW-846, 6010 & Magnesium & 137 & 185 & 617 & 01/31/06 & 108 & 146 & 486 \\
\hline SW-846, 6010 & Manganese & 0.84 & 1.1 & 3.8 & 01/31/06 & 2.5 & 3 & 11 \\
\hline SW-846, 6010 & Nickel & 4 & 5 & 18 & 01/31/06 & 7.5 & 10.1 & 33.8 \\
\hline SW-846, 6010 & Potassium & 1,610 & 2,174 & 7,250 & $01 / 31 / 06$ & 1,500 & 2,025 & 6,755 \\
\hline SW-846, 6010 & Silver & 2.2 & 3 & 10 & $02 / 01 / 06$ & 5.2 & 7.0 & 23.4 \\
\hline
\end{tabular}


Table C.26. (contd)

\begin{tabular}{|c|c|c|c|c|c|c|c|c|}
\hline Method & Constituent & $\begin{array}{c}\text { Initial MDL }{ }^{(a)} \\
(\mu \mathrm{g} / \mathrm{L})\end{array}$ & $\begin{array}{c}\text { Initial LOD } \\
(\mu \mathrm{g} / \mathrm{L}) \\
\end{array}$ & $\begin{array}{c}\text { Initial LOQ } \\
(\mu \mathrm{g} / \mathrm{L})\end{array}$ & $\begin{array}{l}\text { Ending Values, } \\
\text { Effective Date }\end{array}$ & $\begin{array}{c}\text { Ending } \mathrm{MDL}^{(\mathrm{a})} \\
(\mu \mathrm{g} / \mathrm{L})\end{array}$ & $\begin{array}{c}\begin{array}{c}\text { Ending LOD } \\
(\mu \mathrm{g} / \mathrm{L})\end{array} \\
\end{array}$ & $\begin{array}{c}\text { Ending LOQ } \\
(\mu \mathrm{g} / \mathrm{L})\end{array}$ \\
\hline SW-846, 6010 & Sodium & 380 & 513 & 1,711 & $01 / 31 / 06$ & 110 & 149 & 495 \\
\hline SW-846, 6010 & Strontium (elemental) & 0.66 & 0.9 & 3.0 & 01/31/06 & 0.56 & 0.76 & 2.52 \\
\hline SW-846, 6010 & Vanadium & 1.4 & 1.9 & 6.3 & 01/31/06 & 5.9 & 8.0 & 26.6 \\
\hline SW-846, 6010 & Zinc $^{(\mathrm{d})}$ & 1.2 & 1.6 & 5.4 & 04/27/06 & 9.6 & 13.0 & 43.2 \\
\hline SW-846, 6020 & Arsenic $^{(d)}$ & 1.8 & 2.4 & 8.1 & 04/20/06 & 2 & 2.70 & 9.01 \\
\hline SW-846, 6020 & Lead & 0.57 & 0.77 & 2.57 & 02/01/06 & 0.49 & 0.66 & 2.21 \\
\hline SW-846, 7470 & Mercury & 0.046 & 0.06 & 0.21 & 02/09/06 & 0.093 & 0.13 & 0.42 \\
\hline \multicolumn{9}{|c|}{ Volatile Organic Compounds } \\
\hline SW-846, 8260 & 1,1,1,2-Tetrachloroethane & 0.09 & 0.12 & 0.41 & $12 / 15 / 05$ & 0.15 & 0.20 & 0.68 \\
\hline SW-846, 8260 & 1,1,1-Trichloroethane & 0.08 & 0.11 & 0.36 & $12 / 15 / 05$ & 0.15 & 0.2 & 0.7 \\
\hline SW-846, 8260 & 1,1,2,2-Tetrachloroethane & 0.08 & 0.11 & 0.36 & $12 / 15 / 05$ & 0.28 & 0.4 & 1.3 \\
\hline SW-846, 8260 & 1,1,2-Trichloroethane & 0.07 & 0.09 & 0.32 & $12 / 15 / 05$ & 0.23 & 0.31 & 1.04 \\
\hline SW-846, 8260 & 1,1-Dichloroethane & 0.07 & 0.1 & 0.3 & $12 / 15 / 05$ & 0.16 & 0.22 & 0.72 \\
\hline SW-846, 8260 & 1,1-Dichloroethylene & 0.04 & 0.05 & 0.18 & $12 / 15 / 05$ & 0.21 & 0.3 & 0.9 \\
\hline SW-846, 8260 & 1,2,3-Trichloropropane & 0.15 & 0.20 & 0.68 & 02/02/06 & 0.27 & 0.36 & 1.22 \\
\hline SW-846, 8260 & 1,2-Dibromoethane & 0.07 & 0.09 & 0.32 & $12 / 15 / 05$ & 0.23 & 0.3 & 1.0 \\
\hline SW-846, 8260 & 1,2-Dichloroethane & 0.09 & 0.1 & 0.4 & $12 / 15 / 05$ & 0.21 & 0.28 & 0.95 \\
\hline SW-846, 8260 & 1,2-Dichloropropane & 0.1 & 0.14 & 0.45 & $12 / 15 / 05$ & 0.16 & 0.22 & 0.72 \\
\hline SW-846, 8260 & 1,4-Dichlorobenzene & 0.09 & 0.12 & 0.41 & $12 / 15 / 05$ & 0.2 & 0.27 & 0.90 \\
\hline SW-846, 8260 & 1,4-Dioxane & 2.6 & 3.5 & 11.7 & $12 / 15 / 05$ & 12 & 16 & 54 \\
\hline SW-846, 8260 & 1-Butanol & 1.1 & 1.49 & 4.95 & $12 / 15 / 05$ & 2.6 & 4 & 12 \\
\hline SW-846, 8260 & 2-Butanone & 0.33 & 0.45 & 1.49 & $12 / 19 / 06$ & 0.56 & 0.8 & 2.5 \\
\hline SW-846, 8260 & 2-Hexanone & 0.2 & 0.27 & 0.90 & $12 / 15 / 05$ & 0.19 & 0.26 & 0.86 \\
\hline SW-846, 8260 & 4-Methyl-2-pentanone & 0.1 & 0.14 & 0.45 & $12 / 15 / 05$ & 0.53 & 0.72 & 2.39 \\
\hline SW-846, 8260 & Acetone & 0.21 & 0.28 & 0.95 & $12 / 15 / 05$ & 0.7 & 0.95 & 3.15 \\
\hline SW-846, 8260 & Acetonitrile & 0.21 & 0.28 & 0.9 & $02 / 02 / 06$ & 3.5 & 4.73 & 15.76 \\
\hline SW-846, 8260 & Acrolein & 2.8 & 3.8 & 12.6 & $02 / 02 / 06$ & 1.4 & 1.9 & 6.3 \\
\hline SW-846, 8260 & Benzene & 0.05 & 0.07 & 0.23 & $12 / 15 / 05$ & 0.17 & 0.23 & 0.77 \\
\hline SW-846, 8260 & Bromodichloromethane & 0.08 & 0.11 & 0.36 & $12 / 15 / 05$ & 0.14 & 0.2 & 0.6 \\
\hline SW-846, 8260 & Bromoform & 0.17 & 0.2 & 0.8 & $12 / 15 / 05$ & 0.21 & 0.3 & 0.9 \\
\hline SW-846, 8260 & Bromomethane & 0.5 & 0.68 & 2.25 & $12 / 15 / 05$ & 0.28 & 0.4 & 1.3 \\
\hline
\end{tabular}


Table C.26. (contd)

\begin{tabular}{|c|c|c|c|c|c|c|c|c|}
\hline Method & Constituent & $\begin{array}{c}\text { Initial MDL }^{(a)} \\
(\mu \mathrm{g} / \mathrm{L})\end{array}$ & $\begin{array}{c}\text { Initial LOD } \\
(\mu \mathrm{g} / \mathrm{L})\end{array}$ & $\begin{array}{c}\text { Initial LOQ } \\
(\mu \mathrm{g} / \mathrm{L})\end{array}$ & \begin{tabular}{|c|} 
Ending Values, \\
Effective Date
\end{tabular} & $\begin{array}{c}\text { Ending } \mathrm{MDL}^{(\mathrm{a})} \\
(\mu \mathrm{g} / \mathrm{L})\end{array}$ & $\begin{array}{c}\text { Ending LOD } \\
(\mu \mathrm{g} / \mathrm{L})\end{array}$ & $\begin{array}{c}\text { Ending LOQ } \\
(\mu \mathrm{g} / \mathrm{L})\end{array}$ \\
\hline SW-846, 8260 & Carbon disulfide & 0.25 & 0.34 & 1.13 & $12 / 15 / 05$ & 0.16 & 0.2 & 0.7 \\
\hline SW-846, 8260 & Carbon tetrachloride & 0.09 & 0.12 & 0.41 & $12 / 15 / 05$ & 0.15 & 0.2 & 0.7 \\
\hline SW-846, 8260 & Chlorobenzene & 0.05 & 0.1 & 0.2 & $12 / 15 / 05$ & 0.2 & 0.27 & 0.90 \\
\hline SW-846, 8260 & Chloroethane & 0.11 & 0.15 & 0.50 & $12 / 15 / 05$ & 0.16 & 0.2 & 0.7 \\
\hline SW-846, 8260 & Chloroform & 0.07 & 0.09 & 0.32 & $12 / 15 / 05$ & 0.19 & 0.26 & 0.86 \\
\hline SW-846, 8260 & Chloromethane & 0.19 & 0.3 & 0.9 & $12 / 15 / 05$ & 0.2 & 0.3 & 0.9 \\
\hline SW-846, 8260 & cis-1,2-Dichloroethene & 0.27 & 0.36 & 1.22 & $12 / 15 / 05$ & 0.19 & 0.3 & 0.9 \\
\hline SW-846, 8260 & cis-1,3-Dichloropropene & 0.13 & 0.18 & 0.59 & $12 / 15 / 05$ & 0.2 & 0.27 & 0.90 \\
\hline SW-846, 8260 & Dichlorodifluoromethane & 0.14 & 0.19 & 0.63 & $12 / 15 / 05$ & 0.27 & 0.4 & 1.2 \\
\hline SW-846, 8260 & Ethyl cyanide & 0.88 & 1.2 & 4.0 & $12 / 19 / 05$ & 1.7 & 2.3 & 7.7 \\
\hline SW-846, 8260 & Ethylbenzene & 0.07 & 0.09 & 0.32 & $12 / 15 / 05$ & 0.22 & 0.3 & 1.0 \\
\hline SW-846, 8260 & Methylenechloride & 0.12 & 0.2 & 0.5 & $12 / 15 / 05$ & 0.1 & 0.14 & 0.45 \\
\hline SW-846, 8260 & Styrene & 0.13 & 0.18 & 0.59 & $12 / 15 / 05$ & 0.14 & 0.19 & 0.63 \\
\hline SW-846, 8260 & Tetrachloroethylene & 0.1 & 0.14 & 0.45 & $12 / 15 / 05$ & 0.19 & 0.3 & 0.9 \\
\hline SW-846, 8260 & Tetrahydrofuran & 1.2 & 1.62 & 5.40 & $12 / 15 / 05$ & 2.9 & 3.9 & 13.1 \\
\hline SW-846, 8260 & Toluene & 0.08 & 0.11 & 0.36 & $12 / 15 / 05$ & 0.2 & 0.3 & 0.9 \\
\hline SW-846, 8260 & trans-1,2-Dichloroethylene & 0.08 & 0.11 & 0.36 & $12 / 15 / 05$ & 0.16 & 0.2 & 0.7 \\
\hline SW-846, 8260 & trans-1,3-Dichloropropene & 0.07 & 0.09 & 0.32 & $12 / 15 / 05$ & 0.23 & 0.31 & 1.04 \\
\hline SW-846, 8260 & Trichloroethene & 0.13 & 0.18 & 0.59 & $12 / 15 / 05$ & 0.2 & 0.3 & 0.9 \\
\hline SW-846, 8260 & Vinyl acetate & 0.2 & 0.3 & 0.9 & $02 / 02 / 06$ & 0.46 & 0.62 & 2.07 \\
\hline SW-846, 8260 & Vinyl chloride & 0.07 & 0.09 & 0.32 & $12 / 15 / 05$ & 0.23 & 0.3 & 1.0 \\
\hline SW-846, 8260 & Xylenes (total) & 0.13 & 0.18 & 0.59 & $12 / 15 / 05$ & 0.58 & 0.78 & 2.61 \\
\hline SW-846, 8015 & TPH, gasoline fraction & 20 & 27.01 & 90.06 & 03/10/06 & 7.9 & 10.668 & 35.58 \\
\hline \multicolumn{9}{|c|}{ Semivolatile Organic Compounds } \\
\hline SW-846, 8015 & TPH, diesel fraction & 50 & 68 & 225 & & & & \\
\hline SW-846, 8040 & 2,3,4,6-Tetrachlorophenol & 2.8 & 3.8 & 12.6 & $12 / 21 / 05$ & 2 & 3 & 9 \\
\hline SW-846, 8040 & 2,4,5-Trichlorophenol & 3 & 4.1 & 13.5 & $12 / 21 / 05$ & 2.2 & 3.0 & 9.9 \\
\hline SW-846, 8040 & 2,4,6-Trichlorophenol & 3.2 & 4.3 & 14.4 & $12 / 21 / 05$ & 2.2 & 3.0 & 9.9 \\
\hline SW-846, 8040 & 2,4-Dichlorophenol & 3.1 & 4.2 & 14.0 & $12 / 21 / 05$ & 2.1 & 2.8 & 9.5 \\
\hline SW-846, 8040 & 2,4-Dimethylphenol & 2.9 & 3.9 & 13.1 & $12 / 21 / 05$ & 2.1 & 2.8 & 9.5 \\
\hline SW-846, 8040 & 2,4-Dinitrophenol & 2.9 & 3.9 & 13.1 & $12 / 21 / 05$ & 2.4 & 3.2 & 10.8 \\
\hline
\end{tabular}


Table C.26. (contd)

\begin{tabular}{|c|c|c|c|c|c|c|c|c|}
\hline Method & Constituent & $\begin{array}{c}\text { Initial MDL }{ }^{(a)} \\
(\mu \mathrm{g} / \mathrm{L})\end{array}$ & $\begin{array}{c}\text { Initial LOD } \\
(\mu \mathrm{g} / \mathrm{L})\end{array}$ & $\begin{array}{c}\text { Initial LOQ } \\
(\mu \mathrm{g} / \mathrm{L})\end{array}$ & $\begin{array}{l}\text { Ending Values, } \\
\text { Effective Date }\end{array}$ & $\begin{array}{c}\text { Ending } \mathrm{MDL}^{(a)} \\
(\mu \mathrm{g} / \mathrm{L})\end{array}$ & $\begin{array}{c}\text { Ending LOD } \\
(\mu \mathrm{g} / \mathrm{L})\end{array}$ & $\begin{array}{c}\text { Ending LOQ } \\
(\mu \mathrm{g} / \mathrm{L})\end{array}$ \\
\hline SW-846, 8040 & 2,6-Dichlorophenol & 3.1 & 4.2 & 14.0 & $12 / 21 / 05$ & 2.1 & 2.8 & 9.5 \\
\hline SW-846, 8040 & 2-Chlorophenol & 2.9 & 3.9 & 13.1 & $12 / 21 / 05$ & 2.2 & 3.0 & 9.9 \\
\hline SW-846, 8040 & 2-Nitrophenol & 3.3 & 4.5 & 14.9 & $12 / 21 / 05$ & 2.3 & 3.1 & 10.4 \\
\hline SW-846, 8040 & 2-secButyl-4,6-dinitrophenol(DNBP) & 3.7 & 5.0 & 16.7 & $12 / 21 / 05$ & 2.4 & 3.2 & 10.8 \\
\hline SW-846, 8040 & 3,4 methyl phenol & 2.9 & 3.9 & 13.1 & $12 / 21 / 05$ & 2.2 & 3.0 & 9.9 \\
\hline SW-846, 8040 & 4,6-Dinitro-2methyl phenol & 2.6 & 3.5 & 11.7 & $12 / 21 / 05$ & 2.2 & 3.0 & 9.9 \\
\hline SW-846, 8040 & 4-Chloro-3-methylphenol & 3.2 & 4.3 & 14.4 & $12 / 21 / 05$ & 2.4 & 3.2 & 10.8 \\
\hline SW-846, 8040 & 4-Nitrophenol & 2.3 & 3.1 & 10.4 & $12 / 21 / 05$ & 2.2 & 3.0 & 9.9 \\
\hline SW-846, 8040 & Pentachlorophenol & 2.8 & 3.8 & 12.6 & $12 / 21 / 05$ & 2.4 & 3.2 & 10.8 \\
\hline SW-846, 8040 & Phenol & 2.8 & 3.8 & 12.6 & $12 / 21 / 05$ & 2.3 & 3.1 & 10.4 \\
\hline SW-846, 8082 & Aroclor-1016 & 0.22 & 0.30 & 0.99 & $11 / 17 / 05$ & 0.31 & 0.42 & 1.40 \\
\hline SW-846, 8082 & Aroclor-1221 & 0.22 & 0.30 & 0.99 & $11 / 17 / 05$ & 0.31 & 0.42 & 1.40 \\
\hline SW-846, 8082 & Aroclor-1232 & 0.22 & 0.30 & 0.99 & $11 / 17 / 05$ & 0.31 & 0.42 & 1.40 \\
\hline SW-846, 8082 & Aroclor-1242 & 0.22 & 0.30 & 0.99 & $11 / 17 / 05$ & 0.31 & 0.4 & 1.4 \\
\hline SW-846, 8082 & Aroclor-1248 & 0.22 & 0.30 & 0.99 & $11 / 17 / 05$ & 0.31 & 0.42 & 1.40 \\
\hline SW-846, 8082 & Aroclor-1254 & 0.14 & 0.19 & 0.63 & $11 / 17 / 05$ & 0.28 & 0.38 & 1.26 \\
\hline SW-846, 8082 & Aroclor-1260 & 0.14 & 0.19 & 0.63 & $11 / 17 / 05$ & 0.28 & 0.38 & 1.26 \\
\hline SW-846, 8270 & 1,2,4,5-Tetrachlorobenzene & 0.4 & 0.5 & 1.8 & 07/19/06 & 1 & 1.4 & 4.5 \\
\hline SW-846, 8270 & 1,2,4-Trichlorobenzene & 0.3 & 0.4 & 1.4 & 02/08/06 & 1 & 1.4 & 4.5 \\
\hline SW-846, 8270 & 1,2-Dichlorobenzene & 0.27 & 0.36 & 1.22 & 02/08/06 & 1 & 1.4 & 4.5 \\
\hline SW-846, 8270 & 1,3-Dichlorobenzene & 0.24 & 0.32 & 1.08 & 02/08/06 & 1 & 1.4 & 4.5 \\
\hline SW-846, 8270 & 2,4,5-Trichlorophenol & 6 & 8.1 & 27.0 & 02/08/06 & 2 & 2.7 & 9.0 \\
\hline SW-846, 8270 & 2,4,6-Trichlorophenol & 5.6 & 7.6 & 25.2 & 02/08/06 & 2 & 2.7 & 9.0 \\
\hline SW-846, 8270 & 2,4-Dichlorophenol ${ }^{(\mathrm{d})}$ & 1.6 & 2.2 & 7.2 & 02/08/06 & 1 & 1.4 & 4.5 \\
\hline SW-846, 8270 & 2,4-Dimethylphenol & 0.24 & 0.3 & 1.1 & 02/08/06 & 1 & 1.4 & 4.5 \\
\hline SW-846, 8270 & 2,4-Dinitrophenol & 6.7 & 9.0 & 30.2 & 07/19/06 & 10 & 14 & 45 \\
\hline SW-846, 8270 & 2,4-Dinitrotoluene & 1.8 & 2.4 & 8.1 & $01 / 11 / 06$ & 1.1 & 1.5 & 5.0 \\
\hline SW-846, 8270 & 2,6-Dinitrotoluene & 1.7 & 2.3 & 7.7 & $01 / 11 / 06$ & 1.1 & 1.5 & 5.0 \\
\hline SW-846, 8270 & 2-Chloronaphthalene & 0.27 & 0.36 & 1.22 & $02 / 08 / 06$ & 1 & 1 & 5 \\
\hline SW-846, 8270 & 2-Chlorophenol & 0.2 & 0.3 & 0.9 & 02/08/06 & 1 & 1 & 5 \\
\hline
\end{tabular}


Table C.26. (contd)

\begin{tabular}{|c|c|c|c|c|c|c|c|c|}
\hline Method & Constituent & $\begin{array}{c}\text { Initial } \mathrm{MDL}^{(\mathrm{a})} \\
(\mu \mathrm{g} / \mathrm{L})\end{array}$ & $\begin{array}{c}\text { Initial LOD } \\
(\mu \mathrm{g} / \mathrm{L})\end{array}$ & $\begin{array}{c}\text { Initial LOQ } \\
(\mu \mathrm{g} / \mathrm{L})\end{array}$ & $\begin{array}{l}\text { Ending Values, } \\
\text { Effective Date }\end{array}$ & $\begin{array}{c}\text { Ending MDL }^{(\mathrm{a})} \\
(\mu \mathrm{g} / \mathrm{L})\end{array}$ & $\begin{array}{c}\text { Ending LOD } \\
(\mu \mathrm{g} / \mathrm{L})\end{array}$ & $\begin{array}{c}\text { Ending LOQ } \\
(\mu \mathrm{g} / \mathrm{L})\end{array}$ \\
\hline SW-846, 8270 & 2-Methylnaphthalene & 0.31 & 0.42 & 1.4 & 02/08/06 & 1 & 1 & 5 \\
\hline SW-846, 8270 & 2-Methylphenol (cresol, o-) ${ }^{(\mathrm{d})}$ & 1.2 & 1.6 & 5.4 & 02/08/06 & 2 & 3 & 9 \\
\hline SW-846, 8270 & 2-Nitroaniline & 5.8 & 7.8 & 26.1 & 02/08/06 & 2 & 3 & 9 \\
\hline SW-846, 8270 & 2-Nitrophenol & 4.9 & 6.6 & 22.1 & 02/08/06 & 1 & 1 & 5 \\
\hline SW-846, 8270 & 3,3'-Dichlorobenzidine & 0.35 & 0.5 & 1.6 & 02/08/06 & 1 & 1 & 5 \\
\hline SW-846, 8270 & 3-Nitroaniline & 1.1 & 1.5 & 5.0 & & & & \\
\hline SW-846, 8270 & 4,6-Dinitro-2methyl phenol & 4.3 & 5.8 & 19.4 & 02/08/06 & 5 & 7 & 23 \\
\hline SW-846, 8270 & 4-Bromophenylphenyl ether & 0.3 & 0.4 & 1.4 & 02/08/06 & 1 & 1 & 5 \\
\hline SW-846, 8270 & 4-Chloro-3-methylphenol & 4.8 & 6.5 & 21.6 & 02/08/06 & 1 & 1 & 5 \\
\hline SW-846, 8270 & 4-Chloroaniline & 0.28 & 0.4 & 1.3 & 02/08/06 & 1 & 1 & 5 \\
\hline SW-846, 8270 & 4-Chlorophenylphenyl ether & 0.32 & 0.4 & 1.4 & 02/08/06 & 1 & 1 & 5 \\
\hline SW-846, 8270 & 4-Methylphenol (cresol, p- $)^{(d)}$ & 1.5 & 2.0 & 6.8 & 07/19/06 & 1 & 1 & 5 \\
\hline SW-846, 8270 & 4-Nitroaniline & 1.9 & 2.6 & 8.6 & 01/11/06 & 1.3 & 1.8 & 5.9 \\
\hline SW-846, 8270 & 4-Nitrophenol & 3.2 & 4.3 & 14.4 & 07/19/06 & 5 & 6.8 & 22.5 \\
\hline SW-846, 8270 & Acenaphthene & 0.26 & 0.35 & 1.17 & 02/08/06 & 1 & 1.4 & 4.5 \\
\hline SW-846, 8270 & Acenaphthylene & 0.23 & 0.31 & 1.04 & 02/08/06 & 1 & 1.4 & 4.5 \\
\hline SW-846, 8270 & Aniline & 0.28 & 0.38 & 1.26 & 02/08/06 & 1 & 1.4 & 4.5 \\
\hline SW-846, 8270 & Anthracene & 2.2 & 3.0 & 9.9 & 01/11/06 & 1.1 & 1.5 & 5.0 \\
\hline SW-846, 8270 & Benzo(a)anthracene & 0.13 & 0.18 & 0.59 & 02/08/06 & 1 & 1 & 5 \\
\hline SW-846, 8270 & Benzo(a)pyrene & 0.34 & 0.5 & 1.5 & 02/08/06 & 1 & 1 & 5 \\
\hline SW-846, 8270 & Benzo(b)fluoranthene & 0.37 & 0.50 & 1.67 & 02/08/06 & 1 & 1 & 5 \\
\hline SW-846, 8270 & Benzo(ghi)perylene & 0.35 & 0.5 & 1.6 & 02/08/06 & 1 & 1 & 5 \\
\hline SW-846, 8270 & Benzo(k)fluoranthene & 0.39 & 0.5 & 1.8 & 02/08/06 & 1 & 1 & 5 \\
\hline SW-846, 8270 & Benzyl alcohol & 0.26 & 0.35 & 1.17 & $01 / 27 / 06$ & 1 & 1 & 5 \\
\hline SW-846, 8270 & Bis(2-Chloroethoxy)methane & 0.3 & 0.4 & 1.4 & 02/08/06 & 1 & 1 & 5 \\
\hline SW-846, 8270 & Bis(2-chloroethyl) ether & 0.25 & 0.34 & 1.13 & 02/08/06 & 1 & 1 & 5 \\
\hline SW-846, 8270 & Bis(2-ethylhexyl) phthalate ${ }^{(d)}$ & 2.6 & 3.5 & 11.7 & 02/08/06 & 1 & 1 & 5 \\
\hline SW-846, 8270 & Butylbenzylphthalate & 0.48 & 0.65 & 2.2 & 02/08/06 & 1 & 1 & 5 \\
\hline SW-846, 8270 & Chrysene & 0.14 & 0.19 & 0.63 & 02/08/06 & 1 & 1 & 5 \\
\hline SW-846, 8270 & Di-n-butylphthalate & 0.14 & 0.19 & 0.63 & 02/08/06 & 1 & 1 & 5 \\
\hline
\end{tabular}


Table C.26. (contd)

\begin{tabular}{|c|c|c|c|c|c|c|c|c|}
\hline Method & Constituent & $\begin{array}{c}\text { Initial } \mathrm{MDL}^{(\mathrm{a})} \\
(\mu \mathrm{g} / \mathrm{L})\end{array}$ & $\begin{array}{c}\text { Initial LOD } \\
(\mu \mathrm{g} / \mathrm{L})\end{array}$ & $\begin{array}{c}\text { Initial LOQ } \\
(\mu \mathrm{g} / \mathrm{L})\end{array}$ & $\begin{array}{l}\text { Ending Values, } \\
\text { Effective Date }\end{array}$ & $\begin{array}{c}\text { Ending MDL }{ }^{(a)} \\
(\mu \mathrm{g} / \mathrm{L})\end{array}$ & $\begin{array}{c}\text { Ending LOD } \\
(\mu \mathrm{g} / \mathrm{L})\end{array}$ & $\begin{array}{c}\text { Ending LOQ } \\
(\mu \mathrm{g} / \mathrm{L})\end{array}$ \\
\hline SW-846, 8270 & Di-n-octylphthalate & 1.2 & 1.6 & 5.4 & $02 / 08 / 06$ & 5 & 7 & 23 \\
\hline SW-846, 8270 & Dibenz[a,h]anthracene & 0.35 & 0.5 & 1.6 & $02 / 08 / 06$ & 1 & 1 & 5 \\
\hline SW-846, 8270 & Dibenzofuran & 0.3 & 0.4 & 1.4 & $02 / 08 / 06$ & 1 & 1 & 5 \\
\hline SW-846, 8270 & Diethylphthalate & 0.13 & 0.18 & 0.59 & $02 / 08 / 06$ & 1 & 1 & 5 \\
\hline SW-846, 8270 & Dimethyl phthalate & 0.27 & 0.36 & 1.22 & $02 / 08 / 06$ & 1 & 1 & 5 \\
\hline SW-846, 8270 & Fluoranthene & 0.32 & 0.43 & 1.44 & $02 / 08 / 06$ & 1 & 1 & 5 \\
\hline SW-846, 8270 & Fluorene & 0.31 & 0.42 & 1.40 & $02 / 08 / 06$ & 1 & 1 & 5 \\
\hline SW-846, 8270 & Hexachlorobenzene & 0.28 & 0.38 & 1.26 & $02 / 08 / 06$ & 1 & 1 & 5 \\
\hline SW-846, 8270 & Hexachlorobutadiene & 4.4 & 5.9 & 19.8 & $02 / 08 / 06$ & 1 & 1 & 5 \\
\hline SW-846, 8270 & Hexachlorocyclopentadiene & 2.5 & 3.4 & 11.3 & & & & \\
\hline SW-846, 8270 & Hexachloroethane & 0.5 & 0.7 & 2.3 & $02 / 08 / 06$ & 1 & 1 & 5 \\
\hline SW-846, 8270 & Indeno(1,2,3-cd)pyrene & 0.48 & 0.65 & 2.2 & $02 / 08 / 06$ & 1 & 1 & 5 \\
\hline SW-846, 8270 & Isophorone & 0.25 & 0.34 & 1.13 & $02 / 08 / 06$ & 1 & 1 & 5 \\
\hline SW-846, 8270 & N-Nitroso-di-n-propylamine & 0.31 & 0.42 & 1.40 & $02 / 08 / 06$ & 1 & 1 & 5 \\
\hline SW-846, 8270 & N-Nitrosodimethylamine & 0.73 & 0.99 & 3.29 & 07/19/06 & 2 & 3 & 9 \\
\hline SW-846, 8270 & N-Nitrosodiphenylamine & 0.23 & 0.31 & 1.04 & 02/08/06 & 1 & 1 & 5 \\
\hline SW-846, 8270 & Naphthalene $e^{(d)}$ & 2 & 3 & 9 & $02 / 08 / 06$ & 1 & 1 & 5 \\
\hline SW-846, 8270 & Pentachlorophenol $^{(\mathrm{d})}$ & 1.4 & 1.9 & 6.3 & $02 / 08 / 06$ & 2 & 3 & 9 \\
\hline SW-846, 8270 & Phenanthrene & 0.12 & 0.16 & 0.54 & $02 / 08 / 06$ & 1 & 1 & 5 \\
\hline SW-846, 8270 & Phenol & 0.52 & 0.70 & 2.34 & $04 / 05 / 06$ & 4 & 5 & 18 \\
\hline SW-846, 8270 & Pyrene & 0.3 & 0.4 & 1.4 & 02/08/06 & 1 & 1 & 5 \\
\hline \multicolumn{9}{|c|}{$\begin{array}{l}\text { (a) MDLs for many constituents changed during the fiscal year. For these constituents, the initial MDL, LOD, and LOQ were in effect until the date the values were updated (ending } \\
\text { values, effective date). In cases where the MDL did not change, no ending values are listed. } \\
\text { (b) } \mu \text { Mhos/cm. } \\
\text { (c) Units for this method are } \mathrm{mg} / \mathrm{L} \text {. } \\
\text { (d) Additional MDLs were used briefly during the year for these compounds. } \\
\text { LOD = Limit of detection. } \\
\text { LOQ = Limit of quantitation. } \\
\text { MDL = Method detection limit. }\end{array}$} \\
\hline
\end{tabular}




\section{Distribution of Printed Full Report}

No. of

Copies

1 B. Moore

U.S. Department of Energy

Forrestal Building, EM-22

1000 Independence Avenue, S.W.

Washington, D.C. 20585

1 T. M. Stoops

Oregon Office of Energy

Nuclear Safety Division

625 Marion Street N.E.

Salem, OR 97303

1 Washington State Department of Ecology

P.O. Box 47600, MS 7600

Olympia, WA 98504-7600

\section{Onsite}

16 DOE Richland Operations Office

B. L. Charboneau (5)

J. P. Hanson

A6-33

R. D. Hildebrand (3)

J. G. Morse

K. M. Thompson (3)

A. C. Tortoso

Public Reading Room (2)

8 Fluor Hanford, Inc.

M. E. Byrnes

E6-35

G. D. Cummins

E6-35

B. H. Ford

A. Miskho

L. C. Swanson

G. S. Thomas

S. H. Worley

C. Wright
E6-35

H8-40

E6-35

E6-35

E6-35

E6-35
No. of

Copies

2 Washington State Department of Ecology

D. Goswami H0-57

J. Lyons HO-57

2 U.S. Environmental Protection Agency

N. Ceto

B1-46

M. Lentz

B1-46

21 Pacific Northwest National Laboratory

D. B. Barnett

K6-75

C. J. Chou

K6-75

P. E. Dresel

K6-96

J. S. Fruchter

M. J. Hartman (3)

K6-96

D. G. Horton

K6-96

J. W. Lindberg

K6-75

K6-75

S. P. Luttrell

J. P. McDonald

K6-96

K6-96

L. F. Morasch

K6-86

S. M. Narbutovskih K6-96

C. A. Newbill K6-96

R. M. Smith

K6-96

D. L. Stewart

K6-96

M. D. Sweeney

K6-75

C. J. Thompson

K6-96

W. D. Webber

K6-96

Hanford Technical Library (2)

P8-55 


\section{Distribution of Summary Booklet with CD Report}

No. of

Copies

Offsite

S. Arlt

City of Richland

P.O. Box 190

Richland, WA 99352

M. Ault

US Ecology, Inc.

P.O. Box 638

Richland, WA 99352

B. Moore

U.S. Department of Energy

Forrestal Building, EM-22

1000 Independence Avenue, S.W.

Washington, D.C. 20585

J. R. Beaver, Mayor

Kennewick City Council

210 West Sixth Avenue

Kennewick, WA 99336

M. E. Benitz, Jr.

Benton County Commissioner

620 Market Street

Prosser, WA 99350

T. D. Bowden

912 N. 48th Street

Seattle, WA 98103

2 Center for Isotope Geochemistry

Lawrence Berkeley National Laboratory

1 Cyclotron Road, Building 70A4418

Berkeley, CA 94720-8179

ATTN: J. N. Christensen

M. Conrad

\section{J. Chasse}

Energy Northwest

P.O. Box 968

Richland, WA 99352
No. of

$\underline{\text { Copies }}$

2 Confederated Tribes of the Umatilla Indian Reservation

Environmental Planning/Rights Protection

P.O. Box 638

Pendleton, OR 97801

ATTN: S. Harris

J. H. Richards

D. Crumpler

8208 W. Deschutes Place

Kennewick, WA 99336

R. A. Danielson

Washington State Department of Health

5508 Englewood Avenue

Yakima, WA 98908

G. De Bruler

Columbia River United

P.O. Box 912

Bingen, WA 98605

T. Friend

SAIC

3250 Port of Benton Boulevard

Richland, WA 99352

A.J.K. Fyall

Benton County Planning Department

P.O. Box 910

Prosser, WA 99350

H. Gucinski, Chair

Pacific Northwest Natural Area Committee 3200 Jefferson Way

Corvallis, OR 97331

A. Haymaker

1721 Cottonwood Drive

Pasco, WA 99301

H. Heacock

TRIDEC

901 N. Colorado

Kennewick, WA 99336 
No. of

Copies

R. E. Isaacson

2106 Lee Boulevard

Richland, Washington 99352

R. E. Jaquish

Washington State Department of Health

1232 Vintage Avenue

Richland, WA 99352

R. Jim

Confederated Tribes and Bands of the Yakama Nation

Environmental Restoration/Waste Management 2808 Main Street

Union Gap, WA 98903

2 Idaho National Engineering and Environmental Laboratory

P.O. Box 1625, MS-2107

Idaho Falls, ID 83415-2107

ATTN: J. M. Hubbell

J. B. Sisson

K. Klaus

Brookhaven National Laboratory

Building 51

Upton, NY 11973

R. J. Leaumont

Lower Columbia Basin Audubon Society

9016 Sunset Terrace

Pasco, WA 99301

S. Lilligren

Environmental Specialist

ERWM, Nez Perce Tribe

P.O. Box 365

Lapwai, ID 83540

J. Loving

U.S. Department of Energy

Forrestal Building, Room 3E094

1000 Independence Avenue, S.W.

Washington, DC 20585

L. Maas

Framatome ANP Richland, Inc.

2101 Horn Rapids Road

Richland, WA 99352
No. of

Copies

S. McDaniel

South Columbia Basin Irrigation District

P.O. Box 1006

Pasco, WA 99301

K. Moser

Vista Engineering Technologies

8203 W. Quinault, Building C, Suite 200

Kennewick, WA 99336

S. McNutt

City of Richland

3102 Twin Bridges Road

Richland, WA 99352

2 Nez Perce Tribe

Environmental Restoration/Waste Management

P.O. Box 365

Lapwai, ID 83540-0365

ATTN: L. Lilligren

P. Sobotta

3 Oregon Office of Energy

625 Marion Street N.E.

Salem, OR 97303

ATTN: K. Niles (2)

T. M. Stoops

P. Orr

Environment Agency

Ghyll Mount, Gillian Way

Penrith 40 Business Park

Penrith

Cumbria CA11 9BP

UK

R. Patt

1655 S. Elm \#405

Canby, OR 97013

G. M. Pollet

Executive Director

Heart of America, NW

1314 56th Street NE, Suite 100

Seattle, WA 98105

D. Postma

Bureau of Reclamation

U.S. Department of the Interior

P.O. Box 815

Ephrata, WA 98823 
No. of Copies

R. K. Price

4200 W. 19th

Kennewick, WA 99338

W. Riggsbee 6304 Collins Road

West Richland, WA 99353

J. A. Riley

Washington State Department of Health

P.O. Box 453

Post Falls, ID 83877-0453

F. J. Schelling

Sandia National Laboratories

P.O. Box 5800, MS-0779

Albuquerque, NM 87185-0779

J. R. Schinner

11382 Canary Drive

Ijamsville, MD 21754

L. Seelatsee

Wanapum People

Grant County P.U.D.

30 "C" Street S.W.

P.O. Box 878

Ephrata, WA 98823

M. Sully

Neptune and Company

1505 15th Street, Suite B

Los Alamos, NM 87544

Technical Services

Walla Walla College Library

104 S. College Avenue

College Place, WA 99324-1159

J. VanLeer

Cascadia Community College

18345 Campus Way NE

Bothell, WA 98011

M. G. Waddell

Earth Sciences and Resources Institute

University of South Carolina

Columbia, SC 29208
No. of

Copies

4 U.S. Department of Energy

Cloverleaf Building

19901 Germantown Road

Germantown, MD 20874-1290

ATTN: D. Gysta, EM-22

K. Juroff, EM-61

B. Rowley, EM-22

A. Wallo III, HS-20

2 U.S. Geological Survey

934 Broadway, Suite 300

Tacoma, WA 98402

ATTN: R. Dinicola

B. Drost

2 Washington State Department of Health

Division of Radiation Protection

P.O. Box 47827

Olympia, WA 98504-7827

ATTN: D. McBaugh

S. VanVerst

\section{Onsite}

69 DOE Richland Operations Office

T. W. Ferns

A5-15

B. L. Foley

A6-38

J. P. Hanson

A5-13

H. B. Hathaway

A3-04

R. D. Hildebrand (20)

A6-38

K. D. Leary

A6-38

J. G. Morse (10)

A6-38

J. P. Sands

A3-04

J. M. Silko

A6-38

G. L. Sinton

A6-38

K. M. Thompson (20)

A6-38

A. C. Tortoso (10)

A6-38

D. C. Ward

A2-17

\section{DOE Office of River Protection}

$\begin{array}{ll}\text { R. W. Lober } & \text { H6-60 } \\ \text { S. Wiegman } & \text { H6-60 }\end{array}$ 
No. of

Copies

7 CH2M HILL Hanford Group, Inc.

D. C. Comstock

J. G. Field

F. Mann

W. J. McMahon

D. A. Myers

H. A. Sydnor

C. D. Wittreich

4 Eberline Federal Services

J. J. Dorian

M. G. Gardner

D. J. Moak

C. J. Perkins

2 Eberline Services Hanford, Inc.

T. W. Fogwell

J. A. Winterhalder

E6-35

E6-35

\section{Fluor Hanford, Inc.}

M. A. Baechler

E6-35

J. V. Borghese

M. E. Byrnes

C. W. Connell

G. D. Cummins

R. A. Daughety

J. L. Day

D. B. Erb

B. H. Ford (20)

J. G. Hogan

R. L. Jackson

G. G. Kelty

R. O. Mahood

K. M. McDonald

B. B. Nelson-Maki

V. J. Rohay

K. K. Schneider

L. C. Swanson (10)

B. Thackaberry

G. S. Thomas

S. J. Trent

J. D. Williams

S. H. Worley

M. I. Wood

H1-11

H1-11

E6-35

E6-35

A $0-21$

E6-35

S2-42

R3-15

E6-35

E6-35

S0-01

E6-35

E6-35

E6-35

T4-10

R3-32

E6-35

E6-35

E6-35

E6-35

E6-35

A $0-21$

E6-35

H1-11

H8-44
No. of

$\underline{\text { Copies }}$

2 Freestone Environment Services

D. K. Tyler

B6-07

M. Serkowski

B6-07

\section{MACTEC ERS}

P. D. Henwood

B2-62

North Wind, Inc.

P. H. Wicks

T4-05

5 U.S. Environmental Protection Agency
A. Boyd
B1-46
C. E. Cameron
B1-46
D. A. Faulk
B1-46
L. E. Gadbois
B1-46
R. Lobos
B1-46

3 Washington Closure Hanford
K. R. Fecht

H4-21

D. A. St. John

H4-21

R. L. Weiss

H4-21

7 Washington State Department of Ecology

B. L. Becker-Khaleel

HO-57

J. A. Caggiano

HO-57

A. D. Huckaby

HO- 57

Z. Maine

$\mathrm{HO}-57$

J. Price

HO- 57

J. Shea

$\mathrm{HO}-57$

D. G. Singleton

$\mathrm{HO}-57$

85 Pacific Northwest National Laboratory

E. V. Arntzen

K6-85

D. H. Bacon

K9-33

M. P. Bergeron

K9-36

C. A. Brandt

K9-04

R. W. Bryce

K6-75

J. W. Buck

R. J. Cameron

K6-52

S. F. Conley

R. L. Dirkes

K6-96

K6-75

P. E. Dresel (5)
K6-75

K6-96 
No. of

$\underline{\text { Copies }}$

W. J. Deutsch

R. P. Elmore

O. T. Farmer

M. J. Fayer

V. L. Freedman

M. D. Freshley

J. S. Fruchter

G. W. Gee

D. R. Geist

R. E. Gephart

T. J Gilmore

S. M. Goodwin

R. W. Hanf

M. J. Hartman (15)

J. M. Keller

E. A. Lepel

S. P. Luttrell

M. D. Johnson

C. T. Kincaid

C. K. Knudson

G. V. Last

T. L. Liikala
No. of

Copies

K6-81

K6-96

P8-08

K9-33

K9-36

K9-33

K6-96

K9-33

K6-85

K8-88

K6-96

P7-07

K6-75

K6-96

BPO

P8-01

K6-96

K6-96

K9-33

K6-52

K6-81

K6-96
D. P. Mendoza

P. D. Meyer

D. R. Newcomer

K. B. Olsen

B. E. Opitz

G. W. Patton

R. E. Peterson

S. P. Reidel

J. T. Rieger

R. G. Riley

K. Rhoads

R. J. Serne

D. S. Sklarew

F. A. Spane, Jr.

P. D. Thorne

V. R. Vermeul

G. Whelan

B. A. Williams

M. D. Williams

S. K. Wurstner

J. M. Zachara

Hanford Technical Library (2)
K6-81

BPO

K6-96

K6-96

K6-75

K6-75

K6-75

K6-75

K6-96

K2-21

K3-54

P7-22

K6-96

K6-96

K6-96

K6-96

K9-36

K6-75

K9-96

K9-36

K8-96

P8-55 